\title{
日本版敗血症診療ガイドライン 2020 \\ The Japanese Clinical Practice Guidelines for Management of Sepsis and Septic Shock 2020 (J-SSCG 2020)
}

\begin{tabular}{|c|c|c|c|c|c|c|}
\hline 盛時 1 ※ & 小倉 & 裕司 $2, ※$ & 矢田部 & 一晃 4 & 茂亮 5 & 敏明 6 \\
\hline 垣花 泰之 ${ }^{7}$ & 川崎 & 達也 8 & 久志本 成樹 9 & 泰弘 10 & 穣治 11 & 伸朗 12 \\
\hline 谷口＼cjkstart巧 13 & 鶴田 & 良介 14 & 土井 研人 15 & 松幸 16 & 孝明 17 & 正樹 18 \\
\hline 島＼cjkstart清太郎 19 & 細川 & 直登 20 & 好樹 21 & 麻子 22 & 直之 23 & 一馬 24 \\
\hline 原 嘉孝3 & 大下 & 慎一郎 12 & 善孝 16 & 麻衣 25 & 梅村 & 佑亮 27 \\
\hline 近藤 豊 28 & 斎藤 & 浩輝 29 & 正明 30 & 俊介 31 & 親宗 32 & 毅郎 33 \\
\hline 東平 日出夫 34 & 橋本 & 英樹 35 & 敬 36 & 一二三 亨 37 & 智也 38 & 龍将 39 \\
\hline 藤井＼cjkstart智子 40 & 三浦 & 慎也 41 & 英人 42 & 阿部 智一 43 & 幸吉 44 & 有輝 45 \\
\hline 石原 唯史 ${ }^{28}$ & 井手 & 健太郎 46 & 健太 47 & 伊藤 雄介 48 & 稲田 & 宇都宮 明美 50 \\
\hline 卯野木＼cjkstart健 51 & 遠藤 & 功二 52 & 大内 & 将之 54 & 小野 & 桂＼cjkstart守弘 56 \\
\hline 川口＼cjkstart敦 57 & 川村 & 雄介 58 & 大介 ${ }^{9}$ & 健児 59 & 清泰 60 & 秀明 53 \\
\hline 下山 哲 42 & 鈴木 & 武志 61 & 秀介 62 & 関野 元裕 63 & 高橋＼cjkstart希 17 & 世 64 \\
\hline 高橋＼cjkstart弘 65 & 田上 & 隆 66 & 吾郎 67 & 巽＼cjkstart博臣 21 & 谷＼cjkstart昌憲 68 & 飛鳥 69 \\
\hline 堤＼cjkstart悠介 69 & 内藤 & 貴基 70 & 正晴 71 & 長澤＼cjkstart俊郎 72 & 中村 謙介 73 & 哲郎 74 \\
\hline 布宮＼cjkstart伸 75 & 則末 & 泰博 76 & 悟 77 & 長谷川 大祐 ${ }^{3}$ & 淳司 78 & 原＼cjkstart直己 79 \\
\hline 東別府 直紀 80 & 古島 & 夏奈 81 & 弘隆 82 & 松石 雄二朗 83 & 匡 84 & 峰松＼cjkstart佑輔 85 \\
\hline 宮下＼cjkstart亮一 86 & 宮武 & 祐士 87 & 恵実 88 & 山田＼cjkstart亨 89 & 博之 90 & 良 91 \\
\hline 吉田＼cjkstart健史 ${ }^{92}$ & 吉田 & 悠平 93 & 旬平 26 & 四本＼cjkstart竜一 94 & 米倉＼cjkstart寛 95 & 剛志 96 \\
\hline 渡邊＼cjkstart栄三 97 & 青木 & 誠 98 & 英樹 99 & 安部 隆国 100 & 五十嵐＼cjkstart豊 101 & 直也 102 \\
\hline 石川 雅巳 103 & 石丸 & 剛 104 & 修太郎 37 & 隆太 105 & 今長谷 尚史 106 & 牛村＼cjkstart春樹 107 \\
\hline 入野田＼cjkstart崇 108 & 上原 & 健司 109 & 典敬 110 & 岳志 111 & 江川＼cjkstart裕子 112 & 有希 113 \\
\hline 太田＼cjkstart浩平 12 & 大地 & 嘉史 100 & 孝則 114 & 大邊＼cjkstart寛幸 115 & 岡 和幸 116 & 信長 117 \\
\hline 岡田 遥平 118 & 岡野 & 弘 119 & 潤 120 & 奥田＼cjkstart拓史 ${ }^{121}$ & 小倉 崇以 ${ }^{122}$ & 小野寺＼cjkstart悠 123 \\
\hline 小山 雄太 ${ }^{124}$ & 貝沼 & 関志 125 & 英介 126 & 正広 42 & 弘美 16 & 金谷 明浩 127 \\
\hline 右子 唯 128 & 金畑 & 圭太 ${ }^{110}$ & 謙一 129 & 河野 浩幸 130 & 知也 12 & 斉 131 \\
\hline 城戸 崇裕 ${ }^{132}$ & 木村 & 翔 68 & 博之 133 & 小橋 大輔 110 & 巌 134 & 堺＼cjkstart正仁 ${ }^{135}$ \\
\hline 坂本 彩香 136 & 佐藤 & 哲哉 108 & 康浩 137 & 学 138 & 伸哉 139 & 知久 140 \\
\hline 莒原＼cjkstart陽 141 & 杉田 & 篤紀 142 & 聡 143 & 鈴木 祐二 ${ }^{144}$ & 朋宏 145 & 健司 146 \\
\hline 高氏＼cjkstart修平 147 & 高島 & 光平 46 & 生 ${ }^{148}$ & 高橋＼cjkstart洋子 149 & 淳 150 & 裕記 151 \\
\hline 保 亜希仁 ${ }^{147}$ & 角山 & 泰一朗 152 & 健一 153 & 健太郎 154 & 義裕 155 & 健太朗 15 \\
\hline 富永＼cjkstart直樹 101 & 豊㠃 & 光信 91 & 幸樹年 157 & 内藤 宏道 158 & 功 159 & 直 160 \\
\hline 中村＼cjkstart嘉 161 & 中森 & 裕毅 95 & 功 162 & 奈良場＼cjkstart啓 73 & 知大 163 & 典宏 164 \\
\hline 西村 朋也 110 & 西山 & 慶 165 & 智久 166 & 芳賀 大樹 167 & 祥弘 168 & 克彦 169 \\
\hline 武志 49 & 浜崎 & 俊明 170 & 林 拓也 68 & 林＼cjkstart実 129 & 速水 宏樹 171 & 剛 172 \\
\hline 洋平 28 & 藤井 & 遼 173 & 藤田＼cjkstart基 ${ }^{14}$ & 藤村 直幸 174 & 拓 175 & 真仁 ${ }^{176}$ \\
\hline 牧 盾 177 & 增永 & 直久 178 & 洋輔 179 & 卓也 180 & 南 啓介 181 & 裕也 182 \\
\hline 本 和幸 183 & 村田 & 哲平 184 & 真知 185 & 隆郎 186 & 浩平 187 & 直樹 188 \\
\hline |本＼cjkstart朋納 4 & 吉廣 & 尚大 189 & 裕 $28, ※ ※$ & 修 $3, ※ ※$ & & \\
\hline
\end{tabular}

日本版敗血症診療ガイドライン 2020 特別委員会 25,190 
要約 : 日本集中治療医学会と日本救急医学会は, 合同の特別委員会を組織し, 2016 年に発表し た日本版敗血症診療ガイドライン (J-SSCG) 2016 の改訂を行った。本ガイドライン (J-SSCG 2020）の目的は, J-SSCG 2016 と同様に, 敗血症・敗血症性ショックの診療において, 医療従 事者が患者の予後改善のために適切な判断を下す支援を行うことである。改訂に際し，一般臨 床家だけでなく多職種医療者にも理解しやすく，かつ質の高いガイドラインとすることによっ て，広い普及を目指した。J-SSCG 2016 ではSSCG 2016 にない新しい領域 [ICU-acquired weakness（ICU-AW）と post-intensive care syndrome（PICS），体温管理など］を取り上げたが， J-SSCG 2020 では新たに注目すべき 4 領域（Patient-and Family-Centered Care, sepsis treatment system, 神経集中治療, ストレス潰瘍) を追加し, 計 22 領域とした。重要な 118 の臨床課題 (clinical question : CQ）をエビデンスの有無にかかわらず抽出した。これらの CQ には，本邦で特に注 目されている CQ も含まれる。多領域にわたる大規模ガイドラインであることから, 委員 25 名 を中心に, 多職種（看護師, 理学療法士, 臨床工学技士, 薬剂師）および患者経験者も含めたワー キンググループメンバー，両学会の公募によるシステマティックレビューメンバーによる総勢 226 名の参加・協力を得た。また, 中立的な立場で横断的に活躍するアカデミックガイドライ ン推進班をJ-SSCG 2016 に引き続き組織した。将来への橋渡しとなることを企図して, 多くの 若手医師をシステマティックレビューチーム・ワーキンググループに登用し, 学会や施設の垣 根を越えたネットワーク構築も進めた。作成工程においては, 質の担保と作業過程の透明化を 図るために様々な工夫を行い, パブリックコメント募集は計 2 回行った。推奨作成には GRADE 方式を取り入れ，修正 Delphi 法を用いて全委員の投票により推奨を決定した。結果，118CQに 対する回答として，79 個の GRADE による推奨，5個の GPS (good practice statement), 18 個の エキスパートコンセンサス, 27 個の BQ（background question）の解説, および敗血症の定義と 診断を示した。新たな試みとして，CQ ごとに診療フローなど時間軸に沿った視覚的情報を取 り入れた。J-SSCG 2020 は, 多職種が関わる国内外の敗血症診療の現場において, ベッドサイ ドで役立つガイドラインとして広く活用されることが期待される。

なお，本ガイドラインは，日本集中治療医学会と日本救急医学会の両機関誌のガイドライン増 刊号として同時掲載するものである。

Keywords: sepsis, septic shock, guidelines, evidence-based medicine, systematic review, Medical Information Network Distribution Service (Minds), GRADE

ガイドライン発行日 2020 年 9 月 28 日

\footnotetext{
※ 委員長

※※ 担当理事

神戸大学大学院医学研究科外科系講座麻酔科学分野

大阪大学医学部附属病院高度救命救急センター

藤田医科大学医学部麻酔・侵襲制御医学講座

奈良県総合医療センター集中治療部

神戸大学医学部災害救急医学分野

6 順天堂大学救急災害医学

7 鹿児島大学大学院医歯学総合研究科救急 - 集中治療医学 分野

静岡県立こども病院小児集中治療センター

東北大学大学院医学系研究科外科病態学講座救急医学分野

香川大学医学部救急災害医学講座

神戸大学大学院医学研究科外科系講座災害・救急医学分野

広島大学大学院医系科学研究科救急集中治療医学

金沢大学医薬保健研究域麻酔・集中治療医学

山口大学大学院医学系研究科救急 - 総合診療医学

東京大学大学院医学系研究科救急科学

浜松医科大学附属病院集中治療部

千葉大学大学院医学研究院救急集中治療医学

山形大学医学部附属病院救急部・高度集中治療センター
}

19 慶應義塾大学医学部総合診療教育センター

20 亀田総合病院感染症科

21 札幌医科大学医学部集中治療医学

22 名古屋市立大学大学院医学研究科先進急性期医療学

3 名古屋大学大学院医学系研究科救急 ·集中治療医学分野

2 大阪医科大学救急医学教室

25 一般社団法人日本救急医学会

26 大阪急性期・総合医療センター救急診療科

27 藤田医科大学病院看護部

28 順天堂大学医学部附属浦安病院救急診療科
JA 広島総合病院救急・集中治療科

広島大学病院診療支援部リハビリテーション部門

京都大学医学部附属病院手術部

防衛医科大学校精神科学講座

Curtin University

日立総合病院救急集中治療科・感染症科

The Feinstein Institutes for Medical Research

聖路加国際病院救急部・救命救急センター

大阪警察病院 $\mathrm{ER} \cdot$ 救命救急科

琉球大学大学院医学研究科救急医学講座 
東京慈恵会医科大学附属病院集中治療部

The Royal Children's Hospital Melbourne

自治医科大学附属さいたま医療センター救急科

筑波記念病院救急科

仙台市立病院麻酔科・集中治療科・救命救急センター

豊橋創造大学保健医療学部

国立成育医療研究センター集中治療科

あいち小児保健医療総合センター総合診療科

尼崎総合医療センター感染症内科

大阪母子医療センター集中治療科

京都大学大学院医学系研究科人間健康科学系専攻

札幌市立大学看護学部

京都大学大学院医学研究科薬剤疫学分野

茨城キリスト教大学看護学部

小牧市民病院救急集中治療科

新久喜総合病院消化器センター

沖縄県立中部病院外科

CHU Sainte Justine, University of Montreal

公立昭和病院リハビリテーション科

日本赤十字社和歌山医療センター感染症内科部・救急科部

国際医療福祉大学医学部麻酔・集中治療医学

東海大学医学部付属病院麻酔科

東京医科大学麻酔科学分野集中治療部

長崎大学大学院医歯薬学総合研究科麻酔集中治療医学分野

福島県立医科大学臨床研究イノベーションセンター

製鉄記念室蘭病院循環器内科

日本医科大学武蔵小杉病院救命救急科

長崎大学病院高度救命救急センター

埼玉県立小児医療センター集中治療科

独立行政法人国立病院機構水戸医療センター救急医療部 救命救急センター

聖マリアンナ医科大学救急医学

神戸大学医学部附属病院集中治療部

東海大学大学院医学研究科

日立総合病院救急集中治療科

大阪市立大学医学研究科救急医学

自治医科大学医学部麻酔科学・集中治療医学講座集中治 療医学部門

東京ベイ・浦安市川医療センター集中治療部門

京都府立医科大学付属病院集中治療部

国立病院機構東京医療センター救命救急センター

横浜労災病院薬剤部

神戸市立医療センター中央市民病院麻酔科

神戸大学医学部附属病院麻酔科

筑波大学附属病院リハビリテーション部/株式会社 Exult

筑波大学大学院人間総合科学研究科疾患制御医学専攻

京都府立医科大学救急医療学教室

大阪大学医学部附属病院臨床工学部

昭和大学医学部集中治療医学講座
87 加古川中央市民病院臨床工学室

88 北里大学病院集中治療センター RST $・$ RRT 室

89 東邦大学医療センター大森病院看護部

90 京都大学大学院医学研究科初期診療・救急医学

91 慶應義塾大学医学部救急医学

92 大阪大学大学院医学系研究科麻酔集中治療医学講座

93 大阪急性期・総合医療センター看護部

94 東邦大学医療センター大森病院

95 三重大学医学部附属病院臨床麻酔部

96 北海道大学大学院医学研究院救急医学教室

97 東千葉メディカルセンター救急科・集中治療部

98 群馬大学大学院医学系研究科救急医学

99 奈良県立医科大学救急医学講座

100 大分大学医学部附属病院麻酔科

101 日本医科大学付属病院高度救命救急センター

102 大阪大学大学院医学系研究科生体統御医学講座麻酔 ·集 中治療医学教室

103 吳共済病院麻酔 $\cdot$ 救急集中治療部

104 草加市立病院総合内科

105 東京都立小览総合医療センター救命・集中治療部集中治 療科

106 東京大学大学院医学系研究科

107 洛和会音羽病院感染症科 / 京都大学大学院医学研究科社会 健康医学系専攻健康情報学分野

108 東北大学病院高度救命救急センター

109 岩国医療センター麻酔科

110 前橋赤十字病院高度救命救急センター集中治療科・救急科

111 関西医科大学麻酔科学講座

112 さいたま赤十字病院高度救命救急センター

113 筑波大学医学医療系救急・集中治療

114 昭和大学藤が丘病院救急診療科

115 東京大学大学院医学系研究科臨床疫学経済学教室大学院

116 島根大学医学部附属病院高度外傷センター

117 京都府立医科大学救急医療学講座

118 京都大学医学研究科初期診療救急医学分野

119 杏林大学麻酔科

120 橋本市民病院救急科

121 東北大学東北メディカル・メガバンク機構地域医療支援 部門

122 済生会宇都宮病院栃木県救命救急センター

123 山形大学医学部麻酔科学講座

124 吉祥寺あさひ病院内科・透析センター

125 稲沢市民病院麻酔・救急集中治療部門

126 名古屋市立大学大学院医学研究科 / 麻酔科学 - 集中治療医 学分野

127 仙台医療センター麻酔科

128 三重大学医学部附属病院救命救急・総合集中治療センター

129 福井県立病院救命救急センター

130 おんが病院外科 
131 聖隷三方原病院救急科

132 筑波大学附属病院小児科

133 University of Texas Health Science Center at Houston

134 東京医科大学麻酔科学分野

135 巨樹の会新武雄病院総合診療科

136 筑波大学附属病院救急・集中治療科

137 千葉大学大学院医学研究院整形外科学先端春椎関節機能 再建医学講座

138 京都大学医学部附属病院初期診療・救急科

139 群馬県立小児医療センター小児集中治療部

140 東京女子医科大学東医療センター救急医療科

141 横浜市立大学附属病院集中治療部

142 日本大学救急医学系救急集中治療医学分野

143 岡山大学病院集中治療部

144 浜松医科大学附属病院麻酔科蘇生科

145 慶應義塾大学医学部麻酔学教室

146 宮城県立こども病院集中治療科

147 旭川医科大学救急医学講座

148 福山市民病院循環器内科

149 古河総合病院内科

150 大阪母子医療センター麻醉科

151 福岡県立精神医療センター太宰府病院

152 帝京大学病院高度救命救急センター

153 九州大学病院救命救急センター小児科

154 熊本大学病院集中治療部

155 医療法人社団東光会戸田中央総合病院（麻酔科/ICU)

156 慶應義塾大学病院小児科

157 済生会横浜市東部病院救命救急センター

158 岡山大学大学院医歯薬学総合研究科救命救急 · 災害医療 学講座

159 横浜市立みなと赤十字病院集中治療部

$160 \mathrm{JCHO}$ 東京山手メディカルセンター感染症内科 (呼吸器内科)

161 日本赤十字社京都第二赤十字病院救急科

162 名古屋第二赤十字病院麻酔集中治療部

163 静岡県立総合病院救命救急科・集中治療科

164 京都大学大学院医学研究科予防医療学

165 新潟大学大学院医歯学総合研究科救命救急医学分野

166 順天堂大学医学部附属練馬病院救急・集中治療科

167 大阪市立総合医療センター小监集中治療部

168 済生会宇都宮病院救急集中治療科

169 福島県立医科大学低侵襲腫瘍制御学講座

170 日本赤十字社和歌山医療センター第一救急科部

171 埼玉県済生会栗橋病院救急医学科

172 日本心臓血圧研究振興会附属㯁原記念病院集中治療部

173 栃木県済生会宇都宮病院救急・集中治療科

174 雪の聖母会聖マリア病院麻酔科・中央手術センター

175 東京ベイ・浦安市川医療センター救急集中治療科

176 京都第一赤十字病院救急科

177 九州大学病院集中治療部
178 京都大学大学院社会健康医学系専攻医療疫学分野

179 千葉県救急医療センター集中治療科

180 金沢市立病院内科

181 石川県立中央病院救命救急センター

182 済生会川口総合病院救急・総合内科

183 昭和大学医学部救急災害医学講座

184 東京都健康長寿医療センター循環器内科

185 神戸市立医療センター中央市民病院救命救急センター

186 宮崎県立延岡病院救急センター

187 防衛医科大学校病院救急部

188 福井大学医学部附属病院救急部

189 JA 広島総合病院薬剤部

190 一般社団法人日本集中治療医学会

付記：

・日本版敗血症診療ガイドライン 2020 特別委員会 全メンバー の利益相反・作成の役割一覧表は巻末に示した。

・本編に揭載しなかった，作成過程における詳細な経緯，文 献検索式と選択過程, 各文献の評価などは, デジタル付録 として日本集中治療医学会および日本救急医学会のホーム ページに掲載した。

・本ガイドラインは, 日本集中治療医学会雑誌と日本救急医 学会雑誌のガイドライン増刊号に同時掲載される。

·代表著者連絡先 :

委員長 江木 盛時 (moriori@tg8.so-net.ne.jp)

委員長 小倉 裕司（ogura@hp-emerg.med.osaka-u.ac.jp）

・両委員長は本ガイドライン作成において均等に貢献した。

謝辞：

アカデミックガイドライン推進班の大下慎一郎先生には日 本語版本編作成リーダーとして，本稿の作成作業において多 大な貢献をいただきました。また，日本集中治療医学会事務 局の吉田有美佳さん，日本救急医学会事務局の福田修太さん には温かいご支援を賜りました。心より感謝申し上げます。 


\section{目次}

はじめに $\cdots \cdots+S 10$

本ガイドラインの基本理念・概要 $\cdots \cdots \cdot S 11$

1. 名称 $\cdots \cdots, S 11$

2. ガイドライン全体の目的 $\cdots \cdots \cdot S 11$

3. 対象とする患者集団 ……S $S 11$

4. 対象とする利用者(本ガイドラインの使用者) …... $S 11$

5. 利用にあたっての注意 $\cdots \cdots S 11$

6. 本ガイドライン作成における組織編成 …… $S 11$

7. 関係する専門家グループの代表者の参加と専 門家による外部評価 ……S 13

8. 対象集団（患者，一般市民など）の価值観を 反映するための工夫 $\cdots \cdots S_{13}$

9. 質と透明性の担保 ……S 13

10. 作成資金 $\cdots \cdots$. S 14

11. ガイドライン普及の方策 $\cdots \cdots . S 14$

12. 改訂予定 $\cdots \cdots S_{14}$

13. 今回のガイドライン作成を通して目指したも う 1 つの意義 $\cdots \cdots S 14$

本ガイドライン作成方法の概略と推奨の解䣋 …... $S 15$

1. $\mathrm{CQ}$ の立案 $\cdots \cdots S 15$

2. システマティックレビューによるエビデンス の検索，収集，統合……S 16

3. 推奨の策定 ……S 18

4. ガイドラインにおける推奨の強さの解釈の注 意点…... $S 19$

CQ1：敗血症の定義と診断 $\cdots \cdots S 21$

CQ1-1： 敗血症の定義 $\cdots \cdots S 21$

CQ1-2：敗血症の診断と重症度分類 $\cdots \cdots S 23$

\section{CQ2 : 感染の診断 $\cdots \cdots \cdot S 27$}

CQ2-1： 血液培養はいつ採取するか？…... $S 28$

CQ2-2：血液培養以外の培養検体は，いつ採取 するか? ……S 30

CQ2-3：抗菌薬投与前のグラム染色は有用 加? ……S 31

CQ2-4-1：一般病棟あるいは救急外来において， 敗血症診断のバイオマーカー検査とし て C 反応性蛋白 (CRP)，プロカルシ トニン (PCT), プレセプシン (P-SEP), インターロイキン 6 （IL-6）の位置づ けは? ……S 33
CQ2-4-2：集中治療室において, 敗血症診断のバ イオマーカー検査として C 反応性蛋 白 (CRP), プロカルシトニン (PCT), プレセプシン (P-SEP)，インターロ イキン 6（IL-6）の位置づけは？…... S 36

CQ3 : 画像診断と感染源のコントロール $\cdots \cdots S 39$

CQ3-1：敗血症を疑う患者に対して，感染源検 索のために画像検査を行うか? …… $S 40$

CQ3-2：感染源が不明な敗血症患者に対して, 全身造影 CT 検査を早期に行うか? …. $S 41$

CQ3-3：腹腔内感染症による敗血症患者に対し て，外科手術/侵襲的ドレナージ術に よる感染源のコントロールを行う か? …...S 43

CQ3-4-1：感染性膵壊死に対して，早期に侵襲的 なインターベンション治療による感染 源のコントロールを行うか? …… $S 45$

CQ3-4-2： 感染性膵壊死に対して，より低侵襲な インターベンション治療で感染源のコ ントロールを行うか? ……S 47

CQ3-5：＼cjkstart尿管閉塞を原因とする急性腎孟腎炎に よる敗血症患者に対して，侵襲的ドレ ナージ術による感染源コントロールを 行うか? ……S 50

CQ3-6：壊死性軟部組織感染症による敗血症患 者に対して，外科的デブリードマン術 による感染源のコントロールを行う か? …... S 52

CQ3-7： カテーテル関連血流感染が疑われる敗 血症患者に対して，カテーテル抜去に よる感染源のコントロールを行う か? ….. S 54

CQ3-8：膿胸による敗血症患者に対して，侵襲 的ドレナージ術による感染源コント ロールを行うか? ……S 56

CQ4 : 抗菌薬治療……S 58

CQ4-1： 経験的抗菌薬はどのようにして選択す るか? …. S 62

CQ4-2：経験的抗菌薬にカルバペネム系抗菌薬 を含めるのはどのような場合か? ….. $S 74$ 
CQ4-3： どのような場合に, MRSA や一般細 菌以外（カンジダ，ウイルス，レジオ ネラ，リケッチア，クロストリジオイ デス ディフィシルなど）に対する経 験的抗微生物薬を選択するか? ….... $S 76$

CQ 4-4：敗血症が疑われて経験的抗菌薬を使用 する患者において，投与前の各種培養 陰性の確認をしたら抗菌薬を中止する か? ……S 80

CQ4-5：感染症専門家あるいは抗菌薬適正使用 支援チームに相談するのはどのような 場合か? ……S 82

CQ4-6：敗血症に対する経験的抗菌薬は，敗血 症認知後 1 時間以内を目標に投与開始 するか? …...S 84

CQ4-7：敗血症に対して $\beta$ ラクタム系薬の持続 投与または投与時間の延長を行う か? …. S 86

CQ4-8：敗血症に対する抗菌薬治療において, デエスカレーションを行うか? ….. $S 89$

CQ4-9：敗血症に対する抗菌薬治療において, プロカルシトニンを指標とした治療終 了を行うか? ……S 92

CQ4-10：敗血症に対して，比較的短期間（7 日 間以内）の抗菌薬治療を行うか? …. $S 95$

CQ4-11： 腎排泄型の抗微生物薬の用量調整に際 して，何が参考になるか? ……S S 98

CQ5 : 免疫グロブリン (IVIG) 療法 ……S 101

CQ5-1： 敗血症に対して免疫グロブリン （IVIG）投与を行うか? ……S 102

CQ5-2-1： 劇症型溶血性レンサ球菌感染症(STSS) に対して免疫グロブリン（IVIG）投与 を行うか? ……S 104

CQ5-2-2：毒素性ショック症候群（TSS）に対し て免疫グロブリン（IVIG）投与を行 うか? ……S 107

\section{CQ6：初期蘇生・循環作動薬 ……S 109}

CQ6-1：敗血症患者に対して心エコーを行う

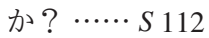

CQ6-2：成人敗血症患者の初期蘇生に対して EGDT を用いるか? …S 115

CQ6-3：成人敗血症患者に対して初期蘇生輸液 と同時または早期（3 時間以内）に血 管収縮薬を使用するか? ……S 117

CQ6-4：成人敗血症患者の初期蘇生の指標とし て乳酸值を用いるか? ……S 120
CQ6-5：成人敗血症患者に対する初期輸液の輸 液速度や輸液量は? ……S 122

CQ 6-6：成人敗血症患者の輸液反応性をどのよ うに評価するか? ……S 124

CQ6-7：成人敗血症患者の初期輸液にアルブミ ン製剂を投与するか? ……S 127

CQ6-8：成人敗血症患者の初期輸液に人工膠質 液を投与するか? ……S 129

CQ6-9-1： 成人敗血症患者に対する血管収縮薬の 第一選択としてノルアドレナリン，ド パミン，フェニレフリンのどれを使用 するか?（ノルアドレナリン vs ドパ ミン) $\cdots \cdots \cdot S 132$

CQ6-9-2：成人敗血症患者に対する血管収縮薬の 第一選択としてノルアドレナリン，ド パミン，フェニレフリンのどれを使用 するか?（ノルアドレナリン vs フェ ニレフリン) $\cdots \cdots S 135$

CQ6-10-1：成人敗血症患者に対する血管収縮薬の 第二選択としてアドレナリンを使用す るか? …S 137

CQ6-10-2：成人敗血症患者に対する血管収縮薬の 第二選択としてバソプレシンを使用す るか?（保険適用外使用）……S 140

CQ6-11： 心原性ショックを伴う成人敗血症患者 に対して強心薬を使用するか？…… $S 143$

CQ6-12：成人敗血症患者に対して $\beta$ 遮断薬を使 用するか? ……S 145

CQ6-13：成人敗血症性ショック患者に対する補 助循環の適応は? $\cdots \cdots S 148$

CQ7 : ステロイド療法 $\cdots \cdots$ S 150

CQ7-1：初期輸液と循環作動薬に反応しない敗 血症性ショック患者に対して，ステロ イド（ヒドロコルチゾン）を投与する か? …S $S 151$

CQ7-2：初期輸液と循環作動薬に反応しない敗 血症性ショック患者に対して，ヒドロ コルチゾンとフルドロコルチゾンを投 与すべきか?（フルドロコルチゾン： 保険適用外使用) ……S 154

CQ7-3： ショックに至っていない敗血症患者に 対して，ステロイド（ヒドロコルチゾ ン）を投与するか? ……S 157

CQ8 : 輸血療法 $\cdots \cdots S 160$

CQ8-1： 敗血症性ショックの初期蘇生におい て，赤血球輸血はどのように行うか？ ….. $S 161$ 
CQ8-2：敗血症で循環動態が安定している場合 に赤血球輸血はどのように行うか? …. $S 164$

CQ8-3：敗血症に対して新鮮凍結血漿の投与は どのように行うか? ……S 166

CQ8-4：敗血症に対して血小板輸血はどのよう に行うか? ……S 168

CQ9 : 呼吸管理 $\cdots \cdots$ S 171

CQ9-1：成人敗血症患者の呼吸管理において, 目標 $\mathrm{SpO}_{2}$ をどの範囲にするか? …... $S 174$

CQ9-2：成人敗血症患者の初期の呼吸不全に対 して, 非侵襲的人工呼吸（NIV）また は経鼻高流量療法 (NHFT) を行うか? …. S 177

CQ9-3：成人敗血症患者の人工呼吸管理におい て, 肺保護換気戦略を行うか? …… $S 184$

CQ9-4：成人敗血症患者の人工呼吸管理におい て, 高 PEEP 設定を行うか? ……S 187

CQ9-5：人工呼吸管理となった成人敗血症患者 に対して，抜管前に自発呼吸トライア ル（SBT）を行うか? ……S 190

CQ9-6：人工呼吸管理となった成人敗血症患者 に対して，抜管後に予防的な非侵襲的 人工呼吸（NIV）または経鼻高流量療 法（NHFT）を行うか? ……S 192

CQ10 : 痛み・不穏・せん妄の管理 $\cdots \cdots \cdot S 199$

CQ10-1：人工呼吸中の成人敗血症患者に対し て，鎮痛優先のプロトコルに基づく管 理を行うか? ……S 201

CQ10-2：人工呼吸中の成人敗血症患者の鎮静薬 として, ベンゾジアゼピンよりもプロ ポフォールやデクスメデトミジンを優 先的に投与するか? ……S 204

CQ10-3：人工呼吸中の敗血症患者の鎮静薬調整 において, 1 日 1 回の鎮静薬中止やプ ロトコルを用いた鎮静薬の調整による light sedation を行うか? ……S 207

CQ10-4：成人敗血症患者のせん妄予防に, 薬物 療法を行うか? ……S 210

CQ10-5：成人敗血症患者のせん妄治療に, 薬物 療法を行うか? ……S 216

CQ10-6：成人敗血症患者のせん妄予防に, 非薬 物療法を行うか? ……S 220

CQ11：急性腎障害 - 血液浄化療法 $\cdots \cdots S 224$

CQ11-1：敗血症性 AKI の予防・治療目的にフ ロセミドの投与は行うか? ……S 226
CQ11-2：敗血症性 AKI の予防・治療目的に心 房性ナトリウム利尿ペプチド（ANP） の投与は行うか?（保険適用外使用） …. S 229

CQ11-3：敗血症性 AKI の予防・治療目的にド パミンの投与は行うか? ……S 231

CQ11-4：敗血症性 AKI に対する腎代替療法で は持続的治療を行うか? ……S 234

CQ11-5-1：敗血症性 AKI 対して, 早期の腎代 替療法を行うか? (Stage 2 vs Stage 3 または古典的絶対適応) ……S 236

CQ11-5-2：敗血症性 AKI に対して, 早期の腎代 替療法を行うか?（Stage 3 vs 古典的 絶対適応) ……S 239

CQ11-6：敗血症性 AKI に対する腎代替療法に おいて, 血液浄化量の増加を行うか? $\cdots \cdots S 241$

CQ11-7：敗血症性ショックに対して, PMX-DHP を行うか? ……S 244

\section{CQ12：栄養療法……S 247}

CQ12-1：敗血症患者への栄養投与は経腸栄養と 経静脈栄養のどちらを行うか? …… $S 249$

CQ12-2：循環動態不安定な敗血症性ショックの 患者において, 経腸栄養を行うか? ……S 252

CQ12-3：敗血症患者では経腸栄養をいつ始める

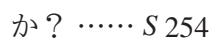

CQ12-4：敗血症患者の治療開始初期では経腸栄 養を消費エネルギーよりも少なく投与 するか? ……S 257

CQ12-5：経腸栄養を行っている敗血症患者に経 静脈栄養を併用するか? ……S 260

CQ12-6：敗血症患者に対する急性期の至適タン パク質投与量はいくらか? ……S 262

CQ12-7-1：敗血症患者に対して，急性期にビタミ ンC投与を行うか? (保険適用外使用) ……S 265

CQ12-7-2：敗血症患者に対して，急性期にビタミ ン D投与を行うか? (保険適用外使用) …. S 268

CQ12-8：敗血症患者における経腸栄養の開始や 耐性の判断方法は? $\cdots \cdots S 271$

CQ12-9：敗血症患者における急性期以降の栄養 投与法は? …S 272

\section{CQ13 : 血糖管理 $\cdots \cdots$ S 273}

CQ13-1：敗血症患者において毛細管血を用いた 簡易血糖測定装置による血糖測定を行 うか? …S S 275 
CQ13-2：敗血症患者の目標血糖值はいくつにす るか? ……S 278

CQ14 : 体温管理 $\cdots \cdots$ S 284

CQ14-1： 発熱を伴う敗血症患者に解熱療法を行 うか? ……S 286

CQ14-2：低体温を伴う敗血症患者に復温療法を 行うか? ……S 289

CQ15：DIC 診断と治療…. S 291

CQ15-1：敗血症性 DIC の診断方法は? …... S 292

CQ15-2：敗血症性 DIC が疑われる症例での鑑 別疾患は? ……S 294

CQ15-3： 敗血症性 DIC にアンチトロンビンの 補充を行うか? ……S 295

CQ15-4：敗血症性 DIC にヘパリン・ヘパリン 類の投与を行うか? ……S 298

CQ15-5： 敗血症性 DIC にリコンビナント・ト ロンボモジュリン投与を行うか? …… $S 300$

CQ15-6：敗血症性 DIC にタンパク分解酵素阻 害薬の投与を行うか? ……S 303

CQ16 : 静脈血栓塞栓症 (venous thromboembolism:

VTE）対策 $\cdots \cdots S 306$

CQ16-1：敗血症における深部静脈血栓症の予防 として機械的予防法（弾性ストッキン グ，間欠的空気圧迫法）を行うか? …... S 307

CQ16-2：敗血症における深部静脈血栓症の予防 として抗凝固療法（未分画ヘパリン, 低分子ヘパリン, ワルファリン, NOAC/ DOAC）を行うか? ……S 309

CQ16-3：敗血症患者のVTE 予防はいつまで行 うか? …S S 311

CQ17 : Post-intensive care syndrome (PICS) と ICU-acquired weakness (ICU-AW) …S S 314

CQ17-1： PICS の予防に早期リハビリテーショ ンを行うか? ……S 316

CQ17-2：敗血症に対して ICU-AW の予防に他 動関節運動療法を行うか? ……S 319

CQ17-3： ICU-AW 予防に神経筋電気刺激を行う か? …S S 322

CQ18：小児 $\cdots \cdots S 325$

CQ18-1： 小児敗血症の初期蘇生に診療アルゴリ ズムを用いるか? ……S 328
CQ18-2：感染巣が推定しにくい小児敗血症に対 する経験的抗菌薬はどのように選択す るか? …S S 331

CQ18-3： 小児敗血症診療において，どのような 場合に経験的治療に抗ヘルペスウイル ス薬を含めるか? ……S 333

CQ18-4： 小児敗血症に対する循環管理の目標血 圧は? ……S 334

CQ18-5：小児敗血症における輸液に対する反応 の評価方法は? ……S 335

CQ18-6： 小児敗血症に対する初期輸液の速度や 量は? ……S 337

CQ18-7： 小児敗血症性ショックに対して，第一 選択の循環作動薬としてドパミンを使 用するか? ……S 338

CQ18-8： 小児敗血症性ショックに対して, 循環 作動薬としてバゾプレシンを使用する か? (保険適用外使用) ……S 342

CQ18-9：初期輸液と循環作動薬に反応しない小 児敗血症性ショックに対して，ステロ イド投与を行うか? ……S 345

CQ18-10：小児敗血症で循環動態が安定している 場合に赤血球輸血はいつ開始する

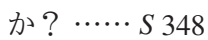

CQ18-11：小児敗血症に対して, 敗血症の治療と して血液浄化療法を行うか?（血漿交 換を含む) $\cdots \cdots \cdot S 351$

CQ18-12：小児敗血症に対して，免疫グロブリン （IVIG）投与を行うか? ……S 354

CQ18-13：小児敗血症に対して, 厳密な血糖管理 を行うか? ……S 357

CQ19 : 神経集中治療 $\cdots \cdots S 360$

CQ19-1：意識障害, 痓攣, 麻㽻などの症状から 脳障害を疑う敗血症患者における鑑別 疾患とその検査方法は？……S 361

CQ20 : Patient- and Family-Centered Care $\cdots \cdots S 363$

CQ20-1：患者と家族に対する, PICS および PICS-Fに関する情報提供の方法は? $\cdots \cdots S 365$

CQ20-2：敗血症患者あるいは集中治療患者に対 して，ICU 日記をつけるか? ……S 366

CQ20-3：集中治療中の身体拘束（抑制）を避け るべきか? ……S 369

CQ20-4-1：睡眠ケアとして換気補助を行うか? ….. $S 374$

CQ20-4-2：睡眠ケアとして非薬物的睡眠管理（耳 栓·アイマスク·音楽療法）を行うか? ……S 376 
CQ20-5： 集中治療室における家族の面会制限を 緩和するべきか? ……S S 379

CQ20-6：患者の価値観・考え方等を尊重した意 思決定支援の方法は? ……S 382

CQ21 : Sepsis treatment system $\cdots \cdots \cdot S 384$

CQ21-1：一般病棟, ER で敗血症を早期発見す る方法は? ……S 386

CQ21-2：一般病棟で敗血症を疑う患者の病状変 化に対応する rapid response system (RRS) の役割とはどのようなものか? ... $S 388$

CQ21-3： 初期輸液蘇生に不応の敗血症はどこで 管理するか? ……S 389

CQ21-4：敗血症初期診療の質評価指標（quality indicator）は何か? ……S 391

CQ 21-5： 敗血症の啓発活動にはどのようなもの があるか? ……S 392

CQ22 : ストレス潰瘍 …S S 394

CQ22-1：敗血症患者に消化管出血の予防を目的 とした抗潰瘍薬の投与を行うか? …... S 395

CQ22-2：敗血症患者に対する抗潰瘍薬の中止の 判断はどのようにするか? ……S S 398

日本版敗血症診療ガイドライン 2020 特別委員会 氏 名 ·所属 · 利益相反 ·作成の役割一覧表 ……S S 400 


\section{はじめに}

世界で数秒に 1 人が敗血症で命を落としている。敗 血症は, あらゆる年齢層が罹患する重篤な疾患であり， その診療支援を行うことを目的とした質の高いガイド ラインを作成することの社会的意義は非常に高い。国 際的な敗血症診療ガイドラインとして, 2004 年から 4 年ごとに改訂を重ねている SSCG ${ }^{1 ）}$ があるが，2012 年, 本邦の臨床の実情を考慮した日本版敗血症診療ガ イドライン（J-SSCG）が日本集中治療医学会によって 初めて発表された2)。2016 年の改訂（J-SSCG 2016） 3,4）に際し，日本集中治療医学会と日本救急医 学会による両学会合同の特別委員会が組織され，単な る改訂版の位置づけではなく, 一般臨床家にも理解し やすく，かつ質の高いガイドラインを作成し，広い普 及を目指した。J-SSCG 2016 では，19名の委員を含む 総勢 73 名の医師が作成に携わり，19 領域 89 に及ぶ 重要臨床課題（clinical question: CQ）を網羅した。日 本医療機能評価機構による AGREE II を用いた J-SSCG 2016 の評価は高く, 特に作成の厳密さ, 推奨提示の 明確さ，編集の独立性などが評価された。J-SSCG 2016 では, SSCG 2016 では取り扱いのない画像診断, 体温管理, ICU-acquired weakness（ICU-AW）と Post-Intensive Care Syndrome（PICS）など斬新な領域 も積極的に取り上げ，診療指針を示した。また， SSCG 2016 と同様の CQ であっても, エビデンスだけ でなく医療水準，医療環境，医療経済，保険制度，日 本人の価值観や希望, 文化など種々の要因が考慮され, 両ガイドラインで推奨が異なるケースもみられた。こ のことは，世界標準をターゲットとしたガイドライン が，諸事情が異なる各国において必ずしも使いやすい とは限らないことを意味している。

今回の改訂（J-SSCG 2020）において，多職種の医 療従事者が敗血症患者の予後改善のために適切な判断 を下す支援を行うことを目的とし，両学会合同の委員 会が結成された。ガイドラインは非常に幅広い領域を カバーする必要があり, 内容も規模も J-SSCG 2016 を 上回る本邦最大級のガイドラインとなった。委員と担 当理事の 26 名に加えて, 多職種（看護師 9 名, 理学 療法士 4 名, 臨床工学技士 2 名, 薬剤師 2 名）および 患者経験者（2名, うち 1 名は看護師）も含めたワー キンググループメンバー 85 名と両学会の公募による システマティックレビューメンバー 115 名による総勢 226 名の参加協力を得た。特に, 多職種および患者経 験者がワーキンググループメンバーとして参加するこ とで視点が広くなり，より柔軟な評価ができたこと
は，J-SSCG 2016 からの大きな進化である。また，シ ステマティックレビューは, ワーキンググループメン バー, システマティックレビューメンバーで行い, 推 奨を策定する委員とは一定の独立性を保つ点でも理想 の形に近づいた。

J-SSCG 2020 では，前述の J-SSCG 2016 で取り上げ た領域に加え, 新たな項目として, 神経集中治療, Patient-and Family-Centered Care, Sepsis Treatment System, ストレス潰瘍の 4 領域を注目すべきテーマと して収載した。さらに，本邦では，小児集中治療室が 少なく, 主に成人敗血症患者の治療にあたる医療従事 者が小児敗血症患者を診療せざるを得ない状況がある ことを鑑み，J-SSCG 2020 においても小児の項目を含 めた。これにより, 合計 22 領域, CQ118 題のガイド ラインとなった。推奨作成には GRADE 方式を取り入 れ，修正 Delphi 法を用いて全委員の投票により推奨 を決定した。CQに対する回答として，79個の GRADEによる推奨, 5 個の GPS (good practice statement), 18 個のエキスパートコンセンサス, 27 個 の BQ（background question）の解説, および敗血症の

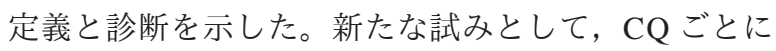
時間軸に沿った視覚的情報を診療フローとして取り入 れ, 各 CQ の臨床的位置づけを行い, アプリケーショ ンとしても配信することにした。J-SSCG 2020 は，多 職種が関わる国内外の敗血症診療の現場において, ベッドサイドで役立つガイドラインとして広く活用さ れることが期待される。

J-SSCG 2020 の作成工程において，中立的な立場で 横断的に活躍するアカデミックガイドライン推進班を J-SSCG 2016 に引き続き組織した。また，質の担保と 作業過程の透明化を図るため, 相互査読制度, 各班内 の討議のオープン化などの工夫を行い, パブリックコ メント募集は計 2 回行った。本ガイドライン作成の意 義の 1 つに, 作成過程を通じ, 学会や施設の垣根を越 えて若手を含むメンバー間の有機的なネットワーク構 築が進んだことが挙げられる。これを基盤に, ガイド ラインとは独立して多施設研究や独自のシステマ ティックレビューを行い論文化するなどの動きが活発 に行われている。本ガイドラインが基盤となり，本邦 の急性期領域からのエビデンス発信のプラットフォー ムが今後も形成されることを願う。

なお，本ガイドラインは，日本集中治療医学会と日 本救急医学会の両機関誌のガイドライン増刊号として 同時掲載するものである。また，同内容は英訳され，

「Journal of Intensive Care」と「Acute Medicine and Surgery」の両学会英文誌に同時掲載される。 


\section{本ガイドラインの基本理念・概要}

\section{1. 名称}

日本版敗血症診療ガイドライン 2020 とした。英語 名称は, The Japanese Clinical Practice Guidelines for Management of Sepsis and Septic Shock 2020 とし，略称 は国際版との対比を重んじ, J-SSCG 2020 とした。

\section{2. ガイドライン全体の目的}

世界で数秒に 1 人が敗血症で命を落としている。あ らゆる年齢層が罹患する重篤な疾患であり，その診療 支援を目的とした質の高いガイドラインを作成するこ との社会的意義は非常に高い。本ガイドラインは, 敗 血症・敗血症性ショックの診療において, 医療従事者 が，患者の予後改善のために適切な判断を下す支援を 行うことを目的とする。

\section{3. 対象とする患者集団}

小児から成人に至るまでの敗血症・敗血症性ショッ ク患者およびその疑いのある患者を対象とする。集中 治療室に限らず, 一般病棟や救急外来で, 診断・治療 を受ける患者を包括するが，敗血症患者は高度な全身 管理を必要とすることから, 敗血症およびその疑いの 強い患者では, 状況が許す限り, 速やかに集中治療室 へ移送しての管理が望ましいことを強調する。

\section{4. 対象とする利用者 (本ガイドラインの使用者)}

敗血症診療に従事または関与する専門医，一般臨床 医, 看護師, 薬剤師, 理学療法士, 臨床工学技士, 管 理栄養士などのすべての医療従事者である。

\section{5. 利用にあたっての注意}

ガイドライン作成とその使用が目指すのは，患者全 体における治療成績の向上である。したがって，個別 の患者の状況や特殊性に応じて, ガイドラインを必ず しも遵守しない治療方法が医師の裁量によって選択さ れることも必要である。また，ガイドラインは，その 作成時点でのエビデンスブックとしての側面もあり, 刻々と積みあがるエビデンスや社会情勢の変化に応じ て, 改訂を重ねていくべきものである。ガイドライン は決して法律ではなく，その領域の専門家が標準より 優れた治療成績を達成しているのであれば, ガイドラ インをすべて遵守する必要はない。「ガイドラインは 三流を二流にするが，一流を二流にする」ともいわれ る。ただし，一流であってもガイドラインを参照し， 日々の診療の見直しを図りながら, 治療成績の向上を
目指すべきであることは当然である。

このような観点から, 一般臨床家, 多職種を含む医 療従事者にも理解しやすい内容とし, CQに取り上げ る重要臨床課題も, 高度に専門的な内容は避けた。全 22 領域の中には, 「PADIS ガイドライン (日本語訳)」, 「集中治療における早期リハビリテーション〜根拠に 基づくエキスパートコンセンサス〜」，「AKI（急性腎 障害）診療ガイドライン」,「ARDS 診療ガイドライ ン」,「日本版重症患者の栄養療法ガイドライン」な ど, 敗血症に特化はしていないが, より専門的な臨床 課題を扱っているガイドラインが本邦に既に存在する ので, 必要に応じてそれらも参照されたい。

ガイドラインは, 医療従事者の治療方針決定を支援 するために何らかの推奨を提供することが原則とされ ているが, 明確な推奨を示し得なかったものもある。 また,「ガイドラインにおける推奨の強さの解釈の注 意点」に詳しく述べているが, 推奨の強さは連続体で あり, 弱い推奨・弱い非推奨の間にはほとんど差がな い場合もある。敗血症は, その病原微生物や感染巣, さらには病態, 病期も多様である。1つのアルゴリズ ムや推奨を単純に当てはめることで功を奏する疾患で はない。さらには, 患者の病状のみならず医療者のマ ンパワーやリソース, 患者・家族の意向などを勘案し て, 臨床家の判断が下されるべきものである。ガイド ラインの内容を理解し遵守していただくことは重要で あるが，ガイドラインにとらわれ過ぎず，状況に応じ て賢明に利用していただければ幸いである。

上記の本ガイドラインの使用にあたっての注意点を 鑑み, 本委員会は, 本ガイドラインを裁判における根 拠として利用することを認めない。また，本邦で保険 適用となり日常的に使用されている治療法が本ガイド ラインにおいて “弱い非推奨” であることは, その存 在価值やすべての患者に対する有益性を否定するもの ではない。弱い非推奨の治療法は, 洗練された集中治 療管理において, 益となる患者を賢明に選択して施行 することで患者予後改善に寄与しうる治療法であるた め, 本委員会は, 本ガイドラインを保険適用の是非の 根拠として利用することを認めない。

また，前述のように，エビデンスは常に蓄積し，更 新されていくものであるため, 本邦において保険適用 外であっても, 日常的に敗血症診療で行われている治 療法に関しては, CQとして取り上げて評価した。

\section{6. 本ガイドライン作成における組織編成}

日本医療機能評価機構内に設置されている EBM 医 療情報部による医療情報サービス事業（Medical 
Information Network Distribution Service: Minds）が推奨 するガイドライン作成のための組織づくりでは，ガイ ドライン統括委員会, ガイドライン作成グループ, シ ステマティックレビューチームを編成することを推奨 している5)。以下に J-SSCG 2020 における組織編成を 示す。

\section{= ガイドライン統括委員会 (J-SSCG 2020 作} 成準備委員会） $=$

本ガイドラインは，本邦の急性期診療に大きな影響 を及ぼす可能性が高く，その作成は公共性の高い事業 である。J-SSCG 2020 作成を中立的な立場で作成する ことが可能な組織編成を行うために，J-SSCG 2016 作 成において中立的な立場で尽力した旧委員を中心に， ガイドライン統括委員会として J-SSCG 2020 作成準備 委員会を編成した。J-SSCG 2020 作成準備委員会では, J-SSCG 2020 作成の目的を明確化し, 組織体制の構築 を行った。後述の通り, 本ガイドラインは 4 年ごとの 改訂を計画しており, 次回は J-SSCG 2024 として改訂 予定である。J-SSCG 2020 の公開, 普及, 導入までは, J-SSCG 2020 のガイドライン統括委員会が行い, その 評価および改訂は J-SSCG 2024 のガイドライン統括委 員会が引き継ぐこととなっている。

= 各領域におけるガイドライン作成グループ, システマティックレビューチーム, ワーキング グループのチーム編成 $=$

ガイドラインを作成する組織は，ガイドライン作成 工程およびシステマティックレビューの作業過程を網 羅的に理解しているものでなければならない。 J-SSCG 2016 の作成工程でシステマティックレビュー を経験し，ガイドライン作成工程を理解した人員は増 加したが，本ガイドラインにおけるすべての領域，す ベての CQ を網羅するという点では，いまだガイドラ イン作成およびシステマティックレビュー実施が可能 な人材に限りがある。これらの状況を考慮し, 全メン バーに対して，システマティックレビューを開始する 前に, ガイドライン作成のための Web 講習会を継続 的に行った。

また，敗血症の定義と診断，感染症の診断，感染源 のコントロール, 抗菌薬治療, 免疫グロブリン (IVIG) 療法, 初期蘇生・循環作動薬, ステロイド療法, 輸血 療法, 人工呼吸管理, 痛み・不稳 - せん妄の管理, 急 性腎障害·急性血液浄化, 栄養療法, 血糖管理, 体温 管理, DIC 診断と治療, 静脈血栓塞栓症対策, $\mathrm{ICU}-\mathrm{AW} \cdot \mathrm{PICS}$ - 早期リハビリテーション, 小児, 神
経集中治療, Patient-and Family-Centered Care, Sepsis Treatment System, ストレス潰瘍の 22 領域ごとの班編 成を行った。ガイドライン作成グループとシステマ ティックレビューチームを独立して配置すると同時 に, システマティックレビューチームを牽引し, ガイ ドライン作成グループを補助する目的にワーキンググ ループを配置した。

\section{= ガイドライン作成グループ（日本版敗血症診} 療ガイドライン 2020 特別委員会） =

ガイドライン作成グループである日本版敗血症診療 ガイドライン 2020 特別委員会（以下，委員会）は, 日本集中治療医学会および日本救急医学会理事会の承 認を受けて設立された。本委員会の委員長および委員 は, ガイドライン統括委員会である J-SSCG 2020 作成 準備委員会が作成した人選基準（30４0\% のメンバー 入れ替え, 特定の施設に偏らない, 実質的な貢献があ る）をもとに，個人の専門性も鑑み，両学会メンバー から最終的に 25 名（1名は担当理事兼任）が選出さ れ，両学会理事会により承認された。

委員会は, システマティックレビューには関与せず, システマティックレビューチームと独立した組織であ る。委員会は, J-SSCG 2020 におけるスコープとして, 疾患の基本的特徵, 網羅する内容, システマティック レビューの方法, 推奨作成から最終確認および公開に 関する事項を協議して決定し, 明確化した。詳細は後 述のガイドライン作成方法に記述するが，委員会は各 領域における診療アルゴリズムを作成し, 重要臨床課 題を決定したうえで, 関連する CQ を PICO 形式で作成 した。システマティックレビューチームによって統合さ れたエビデンスの評価をもとに, 推奨文と診療ガイド ライン草案を作成し，パブリックコメントによる外部評 価を反映させた診療ガイドライン最終版を作成した。 委員全員の氏名, 所属, 利益相反のリストは, 本ガイ ドラインの巻末資料に掲載している。

\section{= システマティックレビューチーム =}

ガイドラインの推奨事項の作成のため, 専門的にシ ステマティックレビューを行う担当としてシステマ ティックレビューチームが編成された。前述の 2 学会 会員から公募のあったメンバー計 115 名から構成され た。本システマティックレビューチームは, システマ ティックレビューにのみ専従し, 推奨作成などの工程 とは独立した組織である。システマティックレビュー チーム全員の氏名, 所属, 利益相反のリストは, 本ガ イドラインの巻末資料に掲載している。 
=ワーキンググループ =

システマティックレビューチームを率引し, ガイド ライン作成グループを補助する目的にワーキンググ ループが編成された。領域ごとに計 85 名の専門家が ワーキンググループメンバーとして選出され，委員会 により承認された。ワーキンググループは，システマ ティックレビューの事前調査, システマティックレ ビュー実施のリード, 推奨文案・草案の作成の補助を 職務とした。メンバー全員の氏名, 所属, 利益相反の リストは, 本ガイドラインの巻末資料に掲載している。

= 領域を横断した大規模ガイドラインを統一し て作成するための水先案内役としてのアカデ ミックガイドライン推進班 $=$

各領域を統合して一貫性のあるガイドラインとする ためには, 各領域班における各作業過程を調整する必 要がある。これらのことを総合的に考えて, 横断的に ガイドライン作成を俯瞰し, 中立的な立場で活動する アカデミックガイドライン推進班をJ-SSCG 2016 と同 様に組織した。アカデミックガイドライン推進班は, 前述の 2 学会会員から選出された 28 名のガイドライ ン作成の有識者によって構成された。アカデミックガ イドライン推進班は, ガイドライン取り扱い範囲決 定, PICO 決定, システマティックレビューの方法論, 推奨文作成の原則, コンセンサス決定法の策定に対し て, 専門家集団として助言を行った。また, 各班の活 動を監査するとともに, システマティックレビューの 質の向上を図るための支援や学術資料の作成など, 様々な局面でガイドライン全体での統一性をもたせる ための活動を行い, 水先案内人としての活動を行っ た。アカデミックガイドライン推進班全員の氏名, 所 属, 利益相反のリストは, 本ガイドラインの巻末資料 に揭載している。

\section{7. 関係する専門家グループの代表者の参加と専 門家による外部評価}

敗血症診療は多職種で行われるため, 医師だけでは なく多くの専門家が参加する。J-SSCG 2020 では, 敗 血症診療に関係する様々な職種の専門グループの代表 者として, 看護師 9 名, 理学療法士 4 名, 臨床工学技 土 2 名, 薬剤師 1 名がワーキンググループとして参加 し, 委員会の作成した診療アルゴリズムや $\mathrm{CQ} へ$ の フィードバック, および, 推奨文や推奨草案の作成に 関与した。さらに薬剤師 1 名がシステマティックレ ビューチームに参加した。

J-SSCG 2020 作成委員会は, 日本医療機能評価機構
内に設置されている EBM 医療情報部における Minds の指導のもと, GRADE システムの原則に則り, ガイ ドライン作成工程の各段階において, 作業工程の査読· 確認を行った。また, Minds 専門官に委員会会議に参 加いただき, ガイドライン作成担当者からの質疑応答 に応じていただくことで直接的に問題解決を図った。

\section{8. 対象集団（患者，一般市民など）の価值観を 反映するための工夫}

患者および患者家族の価値観や希望を反映させるた めに, 敗血症に罹患した医療者・研究者 2 名を患者代 表者として, 委員あるいはワーキンググループに加え た。この点は, 幅広くかつ高度な医学的知識が必要と される敗血症の複雑性, 重篤性および病態の理解を得 たうえで, 患者や家族の立場の価值観や希望をガイド ラインに反映させるうえで有用であると考える。

\section{9. 質と透明性の担保}

アカデミックガイドライン推進班編成以外にも, 質 と透明性の担保を図る工夫としての以下の取り組みを 行った。

\section{(1) 日本医療機能評価機構内 EBM 医療情報部におけ} る Minds の協力と各種講習会

よりエビデンスに基づいたガイドラインとするた めに, 医療情報サービス事業 Minds の指導のもと, GRADE システムに則って, 各作成過程において, 随時指導を仰ぎながら作成し, 委員会会議にも適宜 出席をいただいた。Mindsが開催する診療ガイドラ イン作成の基本コースやシステマティックレビュー の講習会に, 積極的にガイドライン作成メンバーの 参加を呼び掛けた。

(2) ガイドライン作成, システマティックレビュー実 施のための Web 講習

J-SSCG 2020 作成に関わるすべての参加者を対象 に, ガイドライン作成, システマティックレビュー 実施のための Web 講習をシステマティックレ ビュー実施の前に行い, 参加者全員で方法論の確認 と統一を行った。

\section{(3) 相互查読}

各種作業工程の節目において, 他領域班委員によ る相互査読を行い, 修正作業を繰り返し, 修正案を 委員会で議論する形式をとりながら作業を進めた。 


\section{(4) 複数回のパブリックコメント募集}

$\mathrm{CQ}$ 立案時に両学会のホームページおよび Minds のホームページにおいて，さらに最終案策定時に両 学会のホームページにおいて, 計 2 回原則記名式で パブリックコメントを求めた。最終案策定時では, パブリックコメント提出者からも利益相反の開示を お願いした。なお，広く意見を求めるために， m3.com, 日経メディカル Online, メディカルトリ ビューン，日本医事新報社の協力を得て，両学会の パブリックコメント募集の URL を紹介いただいた。

\section{(5) 作業の透明化}

各領域のメンバーは，公式のメーリングリスト （ML）を作成し，メンバー間の議論はできるだけ ML 上で行うこととした。コアメンバーとアカデミッ クガイドライン推進班は，すべての班の ML に ROM （read only member）として加わっている。これによ り，各班でなされている議論を把握することが可能 であり，議論の透明化を図るとともに，節目ごとに 各班でなされた議論のサマリーを提出し，それぞれ の作業過程，議論内容を収録する付録を作成した。

\section{(6) 利益相反 (COI) とメンバーの役割の開示}

経済的 COI と学術的（アカデミック） COI ならび に各メンバーの役割を巻末に開示した。経済的 COI は，2017 年に日本医学会がまとめた診療ガイドラ イン策定参加資格基準ガイダンス ${ }^{6)} に$ 従い，2017 年から 3 年分に適用して開示した。委員相互の学術 的 COI の干渉を避けるために, 推奨草案に対して の委員の投票は匿名化して行った。

\section{0. 作成資金}

本ガイドラインは，日本集中治療医学会と日本救急 医学会の資金で作成した。作成にあたり，すべてのメ ンバーは一切の報酬を受けていない。推奨の作成にあ たり，両学会ならびに協力を得た Minds の意向や利 益は反映されていない。

\section{1. ガイドライン普及の方策}

利用者が利用しやすいように，ダイジェスト版の小 冊子を作成する。また，スマートフォンやタブレット で閲覧できるアプリを作成する。また，世界に向けて 両学会それぞれの英文機関誌に同時掲載する。両学会 での活動の一環として，学術集会や各種セミナーなど において本ガイドラインの普及活動に努めるととも に，普及状況並びに敗血症診療に関するモニタリング
活動を行う。

\section{2. 改訂予定}

本ガイドラインは 4 年ごとの改訂を計画している。 次回は 2024 年に改訂予定である。それまでに内容を 改訂すべき重要な知見が得られた場合は，部分改訂を 行うことを検討する。

\section{3. 今回のガイドライン作成を通して目指した もう 1 つの意義}

国際ガイドラインである SSCG があり，4 年ごとに 改訂がなされているなかで, 本邦独自のガイドライン を作成する意義を問われることも多い。本邦独自の治 療や文化に合わせたガイドラインの必要性は確かに重 要であるが，本邦から発信されているエビデンスが少 ない現状にあって，エビデンスに基づいて作れば作る ほど，国際的なガイドラインと同様な内容になること は否めない。しかしながら，もう 1 つの重要な意義は 作成工程にあると考えている。臨床上の疑問の抽出や システマティックレビューの作業などを通しての人材 育成は，その大きな柱である。当初の狙い以上に，学 会や施設の垣根を越えてメンバー間の有機的なネット ワーク構築が進んだ。このネットワークを基盤として, ガイドラインを離れたところでも多施設研究や独自の システマティックレビューを行い論文化するなどの動 きが生まれ，今なお活発となってきている。また，臨 床上の重要課題でありながらエビデンスの乏しい領域 など，今後の多施設ランダム化比較試験の標的などが 浮き彫りになってきた。また，集中治療医と救急医で は扱う敗血症の背景が異なることも多いが，その点で も，両学会が協力して作成する意義は大きいと考える。 本ガイドラインがマイルストーンとなり, 救急・集中 治療領域における本邦からのエビデンス発信のプラッ トフォームが形成されることを願ってやまない。

\section{文 献}

1) Rhodes A, Evans LE, Alhazzani W, et al: Surviving Sepsis Campaign: International Guidelines for Management of Sepsis and Septic Shock: 2016. Crit Care Med. 2017; 45: 486-552.

2）日本集中治療医学会 Sepsis Registry 委員会: 日本版敗血症診 療ガイドライン The Japanese Guidelines for Management of Sepsis. 日集中医誌. 2013; 20: 124-73.

3）西田修, 小倉裕司, 井上茂亮, 他, 日本版敗血症診療ガイドラ イン 2016 作成特別委員会. 日本版敗血症診療ガイドライン 2016. 日集中医誌. 2017; 24: S1-232.

4）西田修, 小倉裕司, 井上茂亮, 他, 日本版敗血症診療ガイドラ イン 2016 作成特別委員会. 日本版敗血症診療ガイドライン 2016. 日救急医会誌. 2017; 28: S1-232.

5）森實敏夫, 吉田雅博, 小島原典子編: 第 1 章 診療ガイドラ イン総論. Minds 診療ガイドライン作成の手引き 2014. 医学 
書院, 東京, 2014, p1-5.

6）日本医学会利益相反委員会: 診療ガイドライン策定参加資 格基準ガイダンス. 日本医学会, 東京, 2017.

\section{本ガイドライン作成方法の概略と推奨の解釈}

日本版敗血症診療ガイドライン 2020 は， 1. クリニ カルクエスチョン (clinical question: CQ) の立案, 2. システマティックレビューによるエビデンスの検 索, 収集, 統合とその確実性の評価, 3. 推奨の策定, の 3 つの工程を経て作成した。

\section{1. $C Q$ の立案}

診療ガイドラインは，診療の基礎的知識を網羅する とともに，標準的な診療体系の構築に寄与する必要が ある。そのため, 過去のガイドラインで取り上げられ た重要な $\mathrm{CQ}$ は, 最新の知見はなくとも, 本ガイドラ インでも採用した。CQ 立案のルールに基づき, 委員 とワーキンググループメンバーが協働して担当領域に おける CQ の原案を作成し, 委員による相互査読で出 された意見を反映し，ガイドライン作成委員会で CQ のリストを作成した。これらの CQに対し，2018 年 12 月 3 日から 16 日の期間において, web 上でパブ リックコメントを募集した。寄せられたパブリックコ メントを参考にCQの改訂を行い, 委員会にて全 118 題の CQ を最終決定した。

CQ には, background questions（BQ）と foreground questions（FQ）が含まれる。BQ とは, 疾患, 診断, 治 療など，一般的な知識として周知されていることを問う $\mathrm{CQ}$ を指す。例えば，ある疾患の診断方法はどのような ものかといった内容で, 情報提供の役割を担う CQ であ る。一方, FQ とは, 臨床現場における様々な状況に特 化した情報を問う CQ である。例えば，ある特定の疾患 の患者にある特定の治療は有効かといった内容で, 臨 床現場での決定に影響を与えうる。

FQ には, 研究のテーマになりえないほど極めて常 識的ではあるものの, すべての医療者に周知したい CQ である good practice statement (GPS) と, システマ ティックレビューの対象となり推奨策定が行われる CQ がある。後者の CQ において, 対象論文が存在し た場合には The Grading of Recommendations Assessment, Development and Evaluation（GRADE）による推奨を提 示し，対象論文がなかった場合には，エキスパートコ ンセンサスとして推奨を提示した。

本ガイドラインにおける $\mathrm{CQ}$ 立案のルール

1）質の高いエビデンスがないことは，CQ としない 理由とはならない。したがって, 臨床上必要な CQ が存在すると考えれば，質の高いエビデンスの有無 


\begin{tabular}{|c|c|}
\hline \multirow{2}{*}{$\begin{array}{l}\text { バックグラウンドクエスチョン } \\
\text { background questions （BQ） }\end{array}$} & 疾患, 診断, 治療など, 一般的な知識として周知されていることを問う CQ \\
\hline & $\begin{array}{l}\text { ・標準的な知識の提示を行う。 } \\
\text { ・システマティックレビューは必須でない。 } \\
\text { ・推奨は提示しない。 }\end{array}$ \\
\hline \multirow[t]{2}{*}{$\begin{array}{l}\text { フォアグラウンドクエスチョン } \\
\text { foreground questions } \quad(\mathrm{FQ})\end{array}$} & $\begin{array}{l}\text { 臨床現場における様々な状況に特化した情報を問う CQ である。例えば，ある特定の疾患の患者にある特定 } \\
\text { の治療は有効かといた内容で，臨床現場での決定に影響を与えうる。 }\end{array}$ \\
\hline & $\begin{array}{l}\text { ・治療選択の提示を行う。 } \\
\text { ・ GPS 以外 FQ F゙は, システマティックレビューは必須である。 } \\
\text { ・治療選択に関する推奨を提示する。 }\end{array}$ \\
\hline
\end{tabular}

$\mathrm{FQ}$ に対する推奨の分類

\begin{tabular}{|l|l|}
\hline good practice statement (GPS) & 研究のテーマになりえないほど極めて常識的ではあるものの, すべての医療者に周知したい推奨 \\
\hline GRADEによる推奨 (GRADE) & $\begin{array}{l}\text { GRADE システムの原則に則って提示された推奨。システマティックレビューを行い, 得られたエビデンスを } \\
\text { もとに, エビデンスの確実性, 利益と不利益のバランス, 価值観や好み, コストや資源の利用の4 要因を加 } \\
\text { 味し, 委員会での合議により推奨を策定した。 }\end{array}$ \\
\hline $\begin{array}{l}\text { エキスパートコンセンサスによ } \\
\text { る推奨(UnGrade) }\end{array}$ & $\begin{array}{l}\text { システマティックレビューを行うが対象論文がなかった CQにおいて提示されたエキスパートによるコンセ } \\
\text { ンサス。想定される利益と不利益のバランス, 価值観や好み, コストや資源の利用の3要因を加味し, 委員 } \\
\end{array}$ \\
\hline
\end{tabular}

にかかわらず提示する。

2）過去の敗血症ガイドラインや SSCG で扱われた CQのうち, 臨床上重要な CQ は採用し, 必要に応 じて改訂する。

3） $\mathrm{CQ}$ は基本的に質問形式とし, PICO [Patients（対 象患者）; Intervention（評価する介入）; Control（対 照）; Outcome（評価項目）］を決定する。本ガイド ラインの対象は敗血症患者であるため, PICO にお ける対象患者（P）は，敗血症患者あるいは敗血症 性ショック患者とした。しかし，敗血症患者を対象 とした臨床試験の報告がそしいが，集中治療患者や 人工呼吸患者などを対象とした臨床試験の結果が敗 血症患者に適応可能である診療領域に関連する $\mathrm{CQ}$ では，対象患者（P）を集中治療患者や人工呼吸患 者などに設定した。

\section{BQ（background questions）の策定}

前述のように， $\mathrm{BQ}$ は，疾患，診断，治療など，一 般的な知識をまとめた情報提示を目的とした CQ であ る。対象とする患者集団と本ガイドラインの使用者を 鑑み, 必要と思われる情報に関する $\mathrm{CQ}$ 案を立案し, パブリックコメントを経て確定した。確定した CQ に 対する推奨文案を各領域班で作成し，委員会における 賛同率が 95\%を超えるまで修正・改訂を繰り返して, 合意形成に至った。

\section{GPS（good practice statement）の策定}

GPS は，“飛行機から飛び降りる際にパラシュート
を付けるか否か?”1）といった極めて常識的で，かつ， ランダム化比較試験（RCT）が倫理的に不可能なテー マを取り扱った CQに対して提示した。対象とする患 者集団と本ガイドラインの使用者を鑑み，提示が必要 と思われる FQにおいて, CQ を立案し, パブリックコ メントを経て確定した。確定した CQに対する推奨文 案を各領域班で作成し，委員会における賛同率が $95 \%$ を超えるまで修正・改訂を繰り返して，合意形成に 至った。

\section{敗血症の定義と診断の提示}

敗血症の定義と診断は，世界的に広く使用されてい る定義と診断（sepsis-3）を採用することとし，CQ1 はその概説の形態とした。そのため, 担当班で作成の うえ，全委員の合議によって決定した。

\section{2. システマティックレビューによるエビデンス の検索, 収集, 統合}

GPS を除くFQ における各 CQ に対する文献検索を 網羅的に行い，これらの検索された文献から RCT およ びシステマティックレビューを抽出した。その方法論 は原則として GRADEに基づき進めた。

\section{Step 1: 文献検索}

文献検索は, CENTRAL, Pubmed, 医学中央雑誌の 検索エンジンを用いて行った。

検索式は， the Medical Subject Headings (MeSH) terms と自由検索語を用いて, 2 名以上の独立したレビュアー 
によって作成した。Pubmedにおける検索では, RCT を特定する研究デザインのフィルターには, 原則, Cochrane によって作成した Sensitive-maximizing version の Search Strategies を用いた。対象とする論文の出版時 期は制限しなかった。言語は日本語と英語を対象とし た。事前に特定した Key RCTs が含まれていることを 確認したうえで，文献検索式を最終決定し，各検索エ ンジンでの文献検索実施日とヒット論文数を記録した。

\section{Step 2 : 一次スクリーニング}

Step 1 で特定されたすべての文献のタイトルと抄録 をダウンロードした。文献管理ソフトウエア EndNote (Clarivate Analytics, USA) または Mendeley（Mendeley Ltd., UK）の自動重複除去機能を用いて, 重複した文 献を除去したのち，さらに手作業で重複した論文を除 去した。論文スクリーニング作業は, Web上の Rayyan（https://rayyan.qcri.org/welcome）で行った。独 立した 2 名のレビュアーが，文献のタイトルと抄録を レビューし, 研究方法と PICO が明らかに対象となら ない論文を除外した。対象論文である可能性が少しで もあれば，除外しなかった。

\section{Step 3 : 二次スクリーニング}

Step 2 で残った論文の full text を取り寄せ，2名の レビュアーによって, 研究デザインおよびPICO が CQ に一致する論文を選択し, 対象論文として確定し た。2名のレビュー間で意見の一致をみない文献につ いては， 3 人目のレビュアーによってレビューし，3 者間で話し合いを行った。この段階で除外した論文に ついては，除外理由を記録した。文献検索から対象論 文決定までのプロセスは, PRISMA フローダイアグラ ムにまとめた。

\section{ネットワークメタ解析に関する $\mathrm{CQ}$ の扱い}

ネットワークメタ解析に関する CQ は, 頻度論的解析 方法を用いて間接推定值およびネットワーク推定值を 算出した $[\mathrm{R}$ パッケージ netmeta を用いた Confidence in Network Meta-Analysis（CINeMA）を利用]。また，ラ ンキングに関しては surface under the cumulative ranking curve（SUCRA）を用いた（Stataの mvmeta コマンドを 用いて算出)。エビデンスの質の評価はGRADE working groupの手法をもとに行った。本ガイドライン においては, CQ9-2, CQ9-6でネットワークメタ解析を 行った。
質的研究をエビデンスとして用いる $\mathrm{CQ}$ の扱い

質的研究が適切な研究手法と考えられる $\mathrm{CQ}$ に関し ては, GRADE-CERQual approach (Confidence in the Evidence from Reviews of Quality research: CERQual）を エビデンス抽出の手法として適用した。本ガイドライ ンにおいては, CQ20-3「集中治療中の身体拘束（抑 制）を避けるべきか？」に用いた。

エビデンスが存在した $\mathrm{CQ}$ におけるエビデンスの確実 性の評価

システマティックレビューを行った FQ 型の CQ に ついて, 各班が担当 $\mathrm{CQ}$ におけるエビデンスの確実性 （A〜D）をRisk of bias/非直接性/非一貫性/不精確 性/出版バイアスの 5 項目をもとに評価した。本ガイ ドラインで採用している GRADE システムの定めるエ ビデンスの確実性の定義は以下の通りである。

エビデンスの確実性の定義

高 : 効果の推定值に強く確信がある

中 : 効果の推定值に中程度の確信がある

低 : 効果の推定值に対する確信は限定的である 非常に低：効果の推定值がほとんど確信できな い

\section{Step 4 : データ抽出, バイアスリスクの評価}

データ抽出は, 2 人の独立したレビューにより行い, 標準化したデータ抽出フォームを用いた。研究ごとに 以下の項目について詳細情報を抽出した（研究デザイ ン, 研究対象者参入基準, 除外基準, 症例数, 介入と コントロール，アウトカム）。文献に十分な情報の記 載がない場合は，その旨を記載し，著者への問い合わ せは行わなかった。

\section{Step 4-1 : 量的研究}

2 名の独立したレビューにより, 研究・アウトカム ごとに，以下のドメインにおけるバイアスリスクを評 価した。

(RCT)

・ランダム割り付け

- 割り付けの隱蔽化

- 患者・医療者の盲検化

- 評価者の盲検化

・ 不完全なアウトカム

・ 選択アウトカム報告

・その他のバイアス 
（観察研究）（ROBINS-I の手法に則って評価した）

・交絡因子によるバイアス

・患者選択に伴うバイアス

・群分けに関するバイアス

・想定する介入とのずれ

・データ欠損に伴うバイアス

・アウトカム評価段階のバイアス

・選択アウトカム報告

バイアスの潜在性の程度は，high，low，または unclear と判断し，データ抽出フォームと同様に標準 化されたバイアスリスクの表に記載した。バイアスの 潜在性が high と判断された場合は, その判断理由も 記載した。バイアスリスクがhigh であることを理由 に，文献を除外することはしなかった。バイアスリス

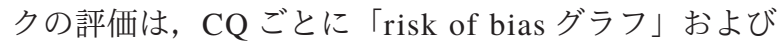
「risk of bias サマリー」に視覚的にまとめた。

\section{Step 4-2 : CERQual}

2 名の独立したレビューにより, 研究・アウトカム ごとに，以下のドメインにおけるバイアスリスクを評 価した。

- 研究目的は明確か

- 質的評価が適切な研究方法か

・研究デザインは適切か

- 研究対象は適切か

・データ収集方法は適切か

- 研究実施者と研究対象者の関係性の考慮は十分か

・ 倫理的問題の考慮は十分か

・データ分析は厳密か

・ 結果提示は明確か

・研究意義は十分か

バイアスの潜在性の程度は, yes, no または cannot tell と判断し, データ抽出フォームと同様に標準化さ れたバイアスリスクの表に記載した。バイアスの潜在 性が yes と判断された場合は，その判断理由も記載し た。バイアスリスクが yes であることを理由に，文献 を除外することはしなかった。

\section{Step 5: メ夕解析とエビデンスの確実性の評価}

採用する文献の定性的評価，定量的評価を行った。 定量的評価では，可能な場合，Revman 5 を用いて， メタ解析を行った。それらを総括してエビデンスの確 実性の評価を各領域班で作成した。

\section{3. 推奨の策定}

推奨の決定に先立ち，委員とワーキンググループは 協㗢して Evidence to Decision テーブル（EtD テーブ ル）を作成した。その後，エビデンスの確実性・効果 のバランス・価值観，そして，コストや資源の利用の 4 要因を加味し, 委員会での合議により推奨を策定し た。GRADE システムで示される推奨の強さは，推 奨・弱い推奨・弱い非推奨・非推奨の 4 つのカテゴ リーに分類される（下表）。

\begin{tabular}{|c|c|c|c|c|}
\hline 推奨の強さ & 推奨 & 弱い推奨 & 弱い非推奨 & 非推奨 \\
\hline 推奨の内容 & $\begin{array}{c}\text { 介入支持の } \\
\text { 強い推奨 }\end{array}$ & $\begin{array}{c}\text { 介入支持の } \\
\text { 条件付き(弱 } \\
\text { い)推奨 }\end{array}$ & $\begin{array}{c}\text { 介入反対の } \\
\text { 条件付き(弱 } \\
\text { い)推奨 }\end{array}$ & $\begin{array}{c}\text { 介入反対の } \\
\text { 強い推奨 }\end{array}$ \\
\hline 推奨の表現 & $\begin{array}{l}\text { 〜すること } \\
\text { を推奨する。 }\end{array}$ & $\begin{array}{l}\text { 〜すること } \\
\text { を弱く推奨 } \\
\text { する。 }\end{array}$ & $\begin{array}{l}\text { 〜しないこ } \\
\text { とを弱く推 } \\
\text { 奨する。 }\end{array}$ & $\begin{array}{l}\text { 〜しないこ } \\
\text { とを推奨す } \\
\text { る。 }\end{array}$ \\
\hline
\end{tabular}

\section{推奨の強さの記載方法}

推奨の強さ「1」: 推奨する。

推奨の強さ「2」: 弱く推奨する。

PICO に沿った文献の網羅的検索によって，十分な エビデンスが得られなかった $\mathrm{FQ}$ 型の $\mathrm{CQ}$ では，委員 とワーキンググループは協働して EtD テーブルを作 成し，その EtD を根拠にエキスパートコンセンサス を提示した。この EtDでは，エキスパートが考える 各介入の望ましい効果, 望ましくない効果と両者のバ ランス，価值観そして，コストや資源の利用の要因を 加味し，委員会での合議により推奨を策定した。本エ キスパートコンセンサスでの推奨は，“弱く推奨する” とし，上記の GRADEに則った推奨と見分けができる よう文末に「エキスパートコンセンサス : エビデンス 不十分」と付記した。

GRADE に則った CQ と，エキスパートコンセンサス を提示するCQ における委員会の合意形成

委員の合意形成は修正 Delphi 法を用いた。

\section{Step 1 : 投票}

各委員は作成された推奨草案に対し 1 から 9 点まで の得点付け（1：同意できない，9点：同意できる）を それぞれ独立して行った。7点未満の得点を付けた委 員は，判断をした理由も併せて提示した。投票はオン ラインかつ匿名で実施した。投票に関わっていない独 立したメンバーが集計を行い,得点の中央值（Median）, パーセンタイル範囲（Interpercentile Range: IPR），対称 
を補正したパーセンタイル範囲（Interpercentile Range Adjusted for Symmetry: IPRAS), 見解不一致指数 （Disagreement Index: DI）を算出した。

\section{Step 2 : パネル会議}

集計結果にもとづき以下のようにパネル会議を行 い，合意形成を行った。

(1) Median < 7.5 かつ DI $\geqq 0.2$ の場合

委員会で議論を行ったのち, EtD と推奨文の改訂を 行い，再投票とした。

(2) Median $\geqq 7.5$ あるいは DI $<0.2$ の場合

A）投票の際に委員より提示されたコメントに, 推奨に対する重大な意見があった場合

委員会で議論を行い，合意形成を図った。委 員会で合意形成ができなかった CQ では, EtD と推奨文の改訂を行い，再投票とした。

B）投票の際に委員より提示されたコメントに, 推奨に対する重大な意見がなかった場合

委員間で投票結果の確認を行い合意形成とし た。

4. ガイドラインにおける推奨の強さの解釈の注 意点

前述のように，本ガイドラインで決定される推奨の 強さは, 推奨·弱い推奨・弱い非推奨・非推奨の 4 つ のカテゴリーに分類される。この際に, 弱い推奨と弱 い非推奨は異なる方向の推奨のように捉える考え方が あるが，これは誤りである（下図）。

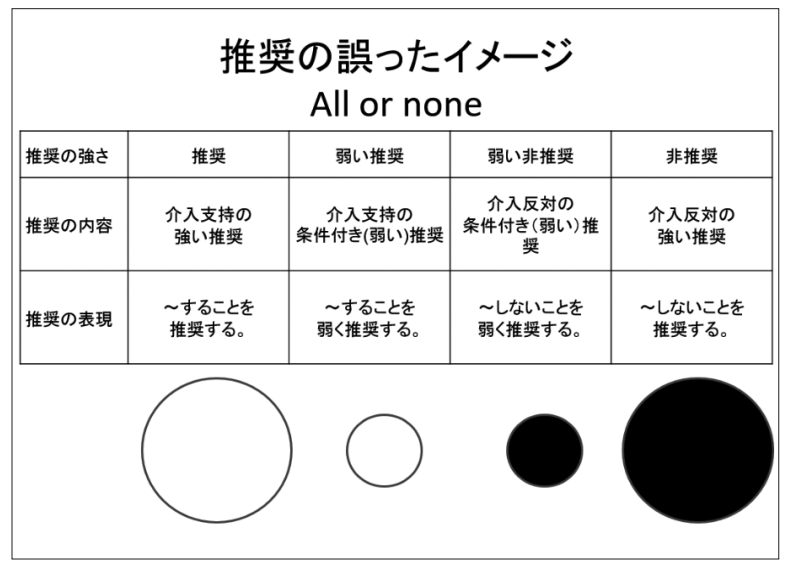

推奨の強さは, エビデンスの質・効果のバランス · 価值観，そして，コストや資源の利用の 4 要因によっ て規定されるため，その推奨度は実質的には連続的で
あり，弱い推奨と弱い非推奨との間に大きな差がない こともありうる(下図)。

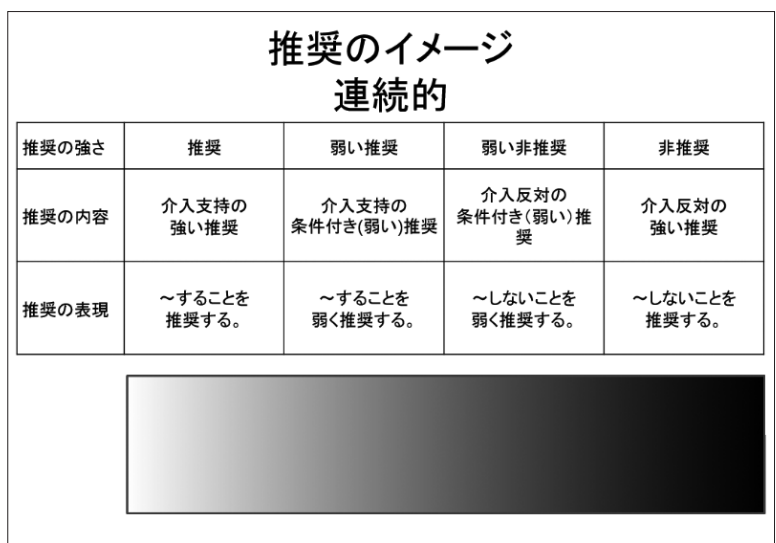

各推奨をより理解しやすく記載すると以下のように 考えられる。

\section{推奨（賛成）}

真白に近い灰色。ほとんどの場合で行うこと が奨められる介入。多くの患者で益が害を上回 る。しかし，少数の患者では害が益を上回るこ ともある。

\section{弱い推奨（賛成）}

白め淡い灰色。行わない場合もあるが，行う ことを奨められることが多い介入。全体でみれ ば，益が害を上回る可能性が高い。しかし，患 者によっては害のほうが強く生じることもあり うる。

\section{弱い非推奨（反対）}

黒め濃い灰色。行う場合もあるが，行なわな いことを奨められることが多い介入。全体でみ れば，害が益を上回る可能性が高い。しかし， 患者によっては益のほうが強く生じることもあ りうる。

\section{非推奨（反対）}

黒に近い灰色，ほとんどの場合で行わないこ とが奨められる介入。多くの患者で，害が益を 上回る。しかし, 少数の患者では害が利益を上 回ることもある。

前述のように，推奨の強さは連続的であり，例え ば, “弱い推奨（賛成）”であっても，“推奨（賛成）” に限りなく近いものもあれば, “弱い非推奨（反対）” 
に限りなく近いものも存在する。

敗血症は, 原因, 重症度, 病期, 併存症や合併症な どによって大きな多様性を生じる病態である。臨床に おいては，患者の病状はもちろんのこと，医療者のマ ンパワーやリソース，患者・家族の意向など，個々の 患者において, 臨床家による適切な判断が必要であ る。その際に，推奨策定の論拠を知ったうえでガイド ラインの推奨を参考としていただくことが，ガイドラ インの賢明な利用法である。

これらのことを考えれば，本ガイドラインで弱く推 奨されている医療介入を行わなかったことで医療裁判 において不利な状況に陥ったり，ガイドライン上の弱 い非推奨の医療介入を熟慮のうえで施行したことを批 判されたりすることは，ガイドラインやエビデンスの 本質が理解されていないことによって生じる悲劇と考 えられる。

ガイドラインの推奨は, 本来的には 4 つのカテゴ リーに当てはめることが困難なものを，一定のルール に基づいて半ば強制的にカテゴリー化している事実を 理解して使用いただきたい。

\section{文 献}

1) Gordon S, Jill P: Parachute use to prevent death and major trauma related to gravitational challenge: systematic review of randomised controlled trials. BMJ. 2003; 327: 1459-61. 


\section{CQ1：敗血症の定義と診断}

\section{CQ1-1：敗血症の定義}

要約 : 敗血症は,「感染症によって重篤な臓器障害が 引き起こされる状態」と定義される。敗血症は, 感染 症に伴う生体反応が生体内で調節不能な状態となった 病態であり, 生命を脅かす臓器障害を引き起こす。ま た, 敗血症性ショックは, 敗血症の中に含まれる 1 区 分であり，「急性循環不全により細胞障害および代謝 異常が重度となり, ショックを伴わない敗血症と比べ て死亡の危険性が高まる状態」と定義する。これら は, 2016 年 2 月に発表された敗血症の定義「The Third International Consensus Definitions for Sepsis and Septic Shock (Sepsis-3) 1)」に準じる。

解説 : 日本版敗血症診療ガイドライン (J-SSCG) 2020 では，J-SSCG 2016 2-5）と同様に，2016 年 2 月に公表 された Sepsis-3 ${ }^{1)}$ に準じて敗血症を定義する。

まず，本邦では 2012 年に公表された J-SSCG 5-7) の策定において，敗血症と菌血症の区分を明確にした 経緯がある。1914 年に Schottmüller ら ${ }^{8)}$ は,「敗血症 は微生物が局所から血流に侵入した病気」として「菌 血症」の概念を広め, 本邦においても, 血液での微生 物の検出が敗血症の確定診断と考えられていた。しか し, 敗血症に類似する病態は血液中に微生物が存在し ない場合でも生じることが明らかにされ，1989年に は Bone ら9)により sepsis syndrome（セプシス症候群） という概念が提唱された。結果として，1992 年に， Sepsis-1 10）の定義が米国集中治療医学会と米国胸部疾 患学会により報告され, 全身性炎症反応症候群 (systemic inflammatory response syndrome: SIRS) (Table 1-1-1）の概念が紹介された。Sepsis-1により，「敗血 症は感染症によるSIRS」と定義され, 菌血症と敗血 症は異なる定義として区分されるようになった。

一方, Sepsis-1 10) による敗血症の定義が広く用いら れるようになった後, Sepsis-1の定義と診断では, 蔵 器障害の進展や生命予後における診断特異性が低いこ とが問題とされた。2001 年に, 米国集中治療医学会, 欧州集中治療医学会などの 5 学会により International Sepsis Definition Conference が開催され, SIRS を有用 な概念としたものの, SIRS に基づく敗血症診断を高め る方策が検討された。そして，2003 年にSepsis-2 ${ }^{11)}$ と して, 敗血症における診断特異度を高めるための 24 項目の補助診断が提案された（Table 1-1-2）。しかし, Sepsis-2 の補助診断は Sepsis-1 と比較して敗血症の診
断特異度を高めるものではなかった ${ }^{12-14) 。 ~}$

このようななかで敗血症は, 集中治療のターゲット となる臓器障害の進展として討議されるようになっ た。Kaukonen ら 15) の豪州・ニュージーランドの報告 では, 感染症による新たな臓器障害として管理した集 中治療症例において，8例に 1 例はSIRS の診断基準 を満たしていないという結果が示された。これらの結 果をもとに, 臓器障害に基づいて敗血症を診断する基 準として Sepsis-3 1) が誕生した。そして, Sepsis-1 10) における SIRS 診断および重症敗血症の重症度区分が 敗血症の定義と診断から削除された。

Sepsis-3 ${ }^{1 ）}$ の定義は, 感染症における臓器障害の進 行に注目したものである。一方で, Sepsis-1 の定義に

Table 1-1-1 SIRS とSepsis-1の定義 10)

体 $\quad$ 温 $>38^{\circ} \mathrm{C}$ あるいは $<36^{\circ} \mathrm{C}$

心 拍 数 $>90$ 回/分

呼吸数 $>20$ 回/分あるいは $\mathrm{PaCO}_{2}<32 \mathrm{mmHg}$

白血球数 $>12,000 / \mathrm{mm}^{3}$ あるいは $<4,000 / \mathrm{mm}^{3}$ あるいは幼若球 $>10 \%$

【解説】上記 4 項目のうち，2 項目以上を満たす場合に，全身性炎症 反応症候群 (systematic inflammatory response syndrome: SIRS) と定義す る。感染症が疑われる状態において, SIRS を満たす場合に, 敗血症 と診断する。

Table 1-1-2 Sepsis-2の定義 11)

感染症の確定もしくは疑いがあり，かつ以下のいくつかを満たす （項目数規定なし）

(1) 全身所見

. 発熱: 核温 $>38.3^{\circ} \mathrm{C}$

. 低体温 : 核温 $<36^{\circ} \mathrm{C}$

·頻脈 : 心拍数 $>90$ 回/分, もしくは > 年齢平均の $2 \mathrm{SD}$

·頻呼吸

・精神状態の変容

・著明な浮腫または体液過剩 : 24 時間で輸液バランス $20 \mathrm{~mL} / \mathrm{kg}$ 以上

・高血糖 : 糖尿病の既往のない状態で血糖值 > $120 \mathrm{mg} / \mathrm{dL}$

(2) 炎症所見

- 白血球上昇 $>12,000 / \mu \mathrm{L}$

·白血球低下 $<4,000 / \mu \mathrm{L}$

·白血球正常で $10 \%$ を超える幼若白血球

・ CRP > 基準值の $2 \mathrm{SD}$

・プロカルシトニン > 基準值の $2 \mathrm{SD}$

(3)循環変動

- 血圧低下 : 収縮期血圧 $<90 \mathrm{mmHg}$, 平均血圧 $<70 \mathrm{mmHg}$, もしく は成人では正常值より $40 \mathrm{mmHg}$ を超える低下, もしくは年齢に対 する正常值の $2 \mathrm{SD}$ 未満

・混合静脈血酸素飽和度 $\left(\mathrm{SvO}_{2}\right)>70 \%$

- 心係数 $(\mathrm{CI})>3.5 \mathrm{~L} /$ 分 $/ \mathrm{m}^{2}$

(4) 臟器障害所見

·低酸素血症 : $\mathrm{PaO}_{2} / \mathrm{F}_{\mathrm{I}} \mathrm{O}_{2}<300 \mathrm{mmHg}$

·急性乏尿 : 尿量 $<0.5 \mathrm{~mL} / \mathrm{kg} /$ 時が少なくとも 2 時間持続

・血中クレアチニン值の増加 : >0.5mg/dL

- 凝固異常 : PT-INR > 1.5, もしくは APTT > 60 秒

・イレウス : 腸蠕動音の消失

·血小板減少 : $<10$ 万 $/ \mu \mathrm{L}$

・高ビリルビン血症 : > $7 \mathrm{mg} / \mathrm{dL}$

(5)組織灌流所見

・高乳酸血症 $>1 \mathrm{mmol} / \mathrm{L}$

. 毛細血管の再灌流減少, もしくは斑状皮膚所見 
おける重症敗血症はSIRS 基準を満たしたうえで蔵器 障害を進展させた敗血症であり，Sepsis-3 の敗血症と は厳密には一致しないことに注意が必要である (Fig.1-1)。

本ガイドラインでは，敗血症は感染症により重篤な 臓器障害が引き起こされた状態とし，また敗血症性 ショックは敗血症に急性循環不全を伴い, 細胞障害お よび代謝異常が重度となる状態として定義される。本 定義は, 感染症に合併する臓器障害に着眼するもので あり, SIRS 基準を満たさない感染症においても臓器 障害の進展を診断するものである。

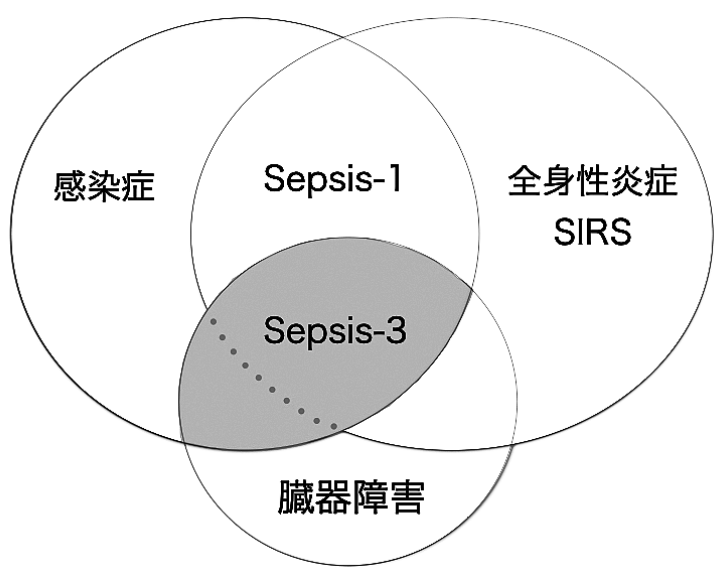

Fig. 1-1 感染症とSIRS と臓器障害の関連性

【解説】Sepsis-3 ${ }^{1 ）}$ の敗血症は，感染症あるいは感染症を疑う状 態において, 臓器障害が進展する状態として定義される。 Sepsis-1 10) では, 感染症あるいは感染症を疑う状態において SIRS を合併した場合に敗血症と診断し，さらに臓器障害を進展 させた場合に重症敗血症と診断した。Sepsis-3における敗血症 と Sepsis-1 における重症敗血症では，以上のように蔵器障害に SIRS を伴うかどうかの違いがあることに注意する。

\section{文 献}

1) Singer M, Deutschman CS, Seymour CW, et al: The third international consensus definitions for sepsis and septic shock (Sepsis-3). JAMA. 2016; 315: 801-10.

2）西田修, 小倉裕司, 井上茂亮, 他, 日本版敗血症診療ガイドラ イン 2016 作成特別委員会. 日本版敗血症診療ガイドライン 2016. 日集中医誌. 2017; 24: S1-232.

3）西田修, 小倉裕司, 井上茂亮, 他, 日本版敗血症診療ガイドラ イン 2016 作成特別委員会. 日本版敗血症診療ガイドライン 2016. 日救急医会誌. 2017; 28: S1-232.

4) Nishida O, Ogura H, Egi M, et al: The Japanese clinical practice guidelines for management of sepsis and septic shock (J-SSCG 2016). J Intensive Care. 2018; 6: 7.

5) Nishida O, Ogura H, Egi M, et al: The Japanese clinical practice guidelines for management of sepsis and septic shock 2016 (J-SSCG 2016). Acute Med Surg. 2018; 5: 3-89.

6）織田成人, 相引眞幸, 池田寿昭, 他: 日本集中治療医学会 Sepsis Registry 委員会. 日本版敗血症治療ガイドライン 2013 . 日集中医誌. 2013; 20 124-73.

7) Oda $S$, Aibiki M, Ikeda $T$, et al: The Japanese guidelines for the management of sepsis. J Intensive Care. 2014; 2: 55.
8) Budelmann G: Hugo Schottmüller, 1867-1936. The problem of sepsis. Internist (Berl). 1969; 10: 92-101.

9) Bone RC, Fisher CJ Jr, Clemmer TP, et al: Sepsis syndrome: a valid clinical entity. Methylprednisolone severe sepsis study group. Crit Care Med. 1989; 17: 389-93.

10) American College of Chest Physicians/Society of Critical Care Medicine Consensus Conference: definitions for sepsis and organ failure and guidelines for the use of innovative therapies in sepsis. Crit Care Med. 1992; 20: 864-74.

11) Levy MM, Fink MP, Marshall JC, et al: 2001 SCCM/ESICM/AC CP/ATS/SIS international sepsis definitions conference. Crit Care Med. 2003; 31: 1250-6.

12) Weiss $M$, Huber-Lang $M$, Taenzer $M$, et al: Different patient case mix by applying the $2003 \mathrm{SCCM} / \mathrm{ESICM} / \mathrm{ACCP} / \mathrm{ATS} / \mathrm{SIS}$ sepsis definitions instead of the $1992 \mathrm{ACCP} / \mathrm{SCCM}$ sepsis definitions in surgical patients: a retrospective observational study. BMC Med Inform Decis Mak. 2009; 9: 25.

13) Zhao H, Heard SO, Mullen MT, et al: An evaluation of the diagnostic accuracy of the 1991 American College of Chest Physicians/Society of Critical Care Medicine and the 2001 Society of Critical Care Medicine/European Society of Intensive Care Medicine/American College of Chest Physicians/American Thoracic Society/Surgical Infection Society sepsis definition. Crit Care Med. 2012; 40: 1700-6.

14) Vincent JL, Opal SM, Marshall JC, et al: Sepsis definitions: time for change. Lancet. 2013; 381: 774-5.

15) Kaukonen KM, Bailey M, Pilcher D, et al: Systemic inflammatory response syndrome criteria in defining severe sepsis. $\mathrm{N}$ Engl $\mathrm{J}$ Med. 2015; 372: 1629-38. 


\section{CQ1-2 : 敗血症の診断と重症度分類}

要約 : 敗血症の診断は, (1)感染症もしくは感染症の疑 いがあり，かつ(2) SOFA (sequential【sepsis-related】 organ failure assessment）スコア（Table 1-2-1）の合計 2 点以上の急上昇として行う。

敗血症診断に至るプロセスは, 病院前救護, 救急外 来，一般病棟における場合と，集中治療室あるいはそ れに準じる場合に分けて行う。病院前救護, 救急外 来, 一般病棟では, 感染症あるいは感染症が疑われる 場合には，敗血症のスクリーニングとして quick SOFA（qSOFA）（Table 1-2-2）を評価する。qSOFA は, (1)意識変容, (2)呼吸数 $\geqq 22$ 回/分, (3)収縮期血圧 $\leqq$ $100 \mathrm{mmHg}$ の 3 項目で構成される。感染症あるいは感 染症が疑われる状態において, qSOFAの 2 項目以上 が満たされる場合に敗血症を疑い，早期治療開始や集 中治療医への紹介のきっかけとする。

一方, 集中治療室あるいはそれに準じる環境では, SOFA スコアを用いる。既に感染症と診断されている 場合や感染症が疑われる状態では, SOFA スコアの推 移を評価し，SOFA スコアの 2 点以上の急上昇により 敗血症と診断する。

敗血症性ショックは，敗血症の中に含まれる重症度 の高い 1 区分であり，「敗血症の中でも急性循環不全 により死亡率が高い重症な状態」として区別する。敗 血症性ショックの診断は，平均動脈血圧 $\geqq 65 \mathrm{mmHg}$ 以上を保つために輸液療法に加えて血管収縮薬を必要 とし，かつ血中乳酸值 $2 \mathrm{mmol} / \mathrm{L} （ 18 \mathrm{mg} / \mathrm{dL} ）$ を超える 場合とする。
以上のように，敗血症の診断においては，感染症の 評価に加えて，集中治療室内外での診断プロセスが異 なる。病院前救護, 救急外来, 一般病棟などの集中治 療室外では, qSOFA を用いて敗血症を疑う。しかし, 敗血症の確定診断は, SOFA スコアの推移の確認が必 要であり，集中治療室あるいはそれに準じる診療環境 における SOFA スコアを用いた最終診断が必要であ る。

解説 : 日本版敗血症診療ガイドライン（J-SSCG） 2020 では, 敗血症の重症度分類は, 敗血症と敗血症性ショッ クの 2 つの区分とする。CQ1-1 で示した敗血症の定義 に従い, 敗血症の治療ターゲットを臓器障害とし, 感 染症による臓器障害の進展として敗血症の診断と治療 にあたる。Sepsis-1 1）および Sepsis-2 2) の定義における 全身性炎症反応症候群 (systemic inflammatory response syndrome: SIRS）の診断にとらわれずに，感染症の増 悪として臓器障害の進行と結びつけ3）て敗血症を診断 し， qSOFA ${ }^{4 ）}$ とSOFA スコア5）を敗血症診断に用い る。この敗血症診断における方策は, J-SSCG 2016 6-9), さらに Surviving Sepsis Campaign 10,11）や国際的動向に 準じている。

qSOFA に関する Seymour らの原著論文 ${ }^{4)}$ では, ペン シルバニア州南西部にある 12 の病院における 2010〜 2012 年の間に記録された約 130 万件の電子カルテより, 感染を疑う 148,907 例を解析している。qSOFA は, 派 生コホート（derivation cohort）より院内死亡に関連し た要因をロジスティック回帰分析で抽出して作成され た。次に，検証コホート（validation cohort）を利用し て, SIRS 診断基準, SOFA スコア, ロジスティック器

Table 1-2-1 SOFAスコア

\begin{tabular}{|c|c|c|c|c|c|}
\hline スコア & 0 & 1 & 2 & 3 & 4 \\
\hline \multicolumn{6}{|l|}{ 意識 } \\
\hline Glasgow coma scale & 15 & $13-14$ & $10-12$ & $6-9$ & $<6$ \\
\hline \multicolumn{6}{|l|}{ 呼吸 } \\
\hline $\mathrm{PaO}_{2} / \mathrm{F}_{\mathrm{I}} \mathrm{O}_{2}(\mathrm{mmHg})$ & $\geqq 400$ & $<400$ & $<300$ & $<200$ および呼吸補助 & $<100$ および呼吸補助 \\
\hline 循環 & 平均血圧 $\geqq 70 \mathrm{mmHg}$ & 平均血圧 $<70 \mathrm{mmHg}$ & $\begin{array}{c}\text { ドパミン }<5 \mu \mathrm{g} / \mathrm{kg} / \text { 分 } \\
\text { あるいはドブタミンの } \\
\text { 併用 } \\
\end{array}$ & \begin{tabular}{|c|} 
ドパミン $5-15 \mu \mathrm{g} / \mathrm{kg} /$ 分 \\
あるいはノルアドレナ \\
リン $\leqq 0.1 \mu \mathrm{g} / \mathrm{kg} /$ 分ある \\
いはアドレナリン \\
$0.1 \mu \mathrm{g} / \mathrm{kg} /$ 分 \\
\end{tabular} & $\begin{array}{c}\text { ドパミン }>15 \mu \mathrm{g} / \mathrm{kg} / \text { 分 } \\
\text { あるいはノルアドレナ } \\
\text { リン }>0.1 \mu \mathrm{g} / \mathrm{kg} / \text { 分ある } \\
\text { いはアドレナリン }> \\
0.1 \mu \mathrm{g} / \mathrm{kg} / \text { 分 }\end{array}$ \\
\hline \multicolumn{6}{|c|}{ 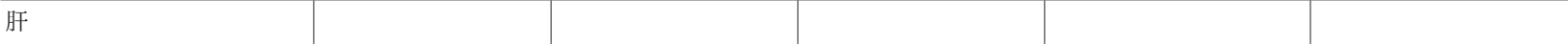 } \\
\hline 血漿ビリルビン值 $(\mathrm{mg} / \mathrm{dL})$ & $<1.2$ & $1.2-1.9$ & $2.0-5.9$ & $6.0-11.9$ & $\geqq 12.0$ \\
\hline \multicolumn{6}{|l|}{ 腎 } \\
\hline 血漿クレアチニン值 & $<1.2$ & $1.2-1.9$ & $2.0-3.4$ & $3.5-4.9$ & $\geqq 5.0$ \\
\hline 尿量 $(\mathrm{mL} /$ 日 $)$ & & & & $<500$ & $<200$ \\
\hline \multicolumn{6}{|l|}{ 凝固 } \\
\hline 血小板数 $\left(\times 10^{3} / \mu \mathrm{L}\right)$ & $\geqq 150$ & $<150$ & $<100$ & $<50$ & $<20$ \\
\hline
\end{tabular}


Table 1-2-2 quick SOFAスコア

意識変容

呼吸数 $\geqq 22$ 回/分

収縮期血圧 $\leqq 100 \mathrm{mmHg}$

感染症あるいは感染症を疑う病態で, quick SOFA(qSOFA)スコアの3 項目中 2 項目以上が存在する場合に敗血症を疑う。

官機能障害スコア (logistic organ dysfunction system score: LODS), qSOFA の院内死亡に対する予測精度が 比較された。その結果, 集中治療室内外にかかわらず qSOFA はSIRSより優れているが, 集中治療室で用い られる SOFAには劣り, 集中治療室外ではLODS と同 等, かつ SOFA や SOFA 変化に勝るという結果となっ た。以上より, 集中治療室外では敗血症を強く疑う初 期スクリーニングとして qSOFA の評価が推奨され，集 中治療室では qSOFA によるスクリーニングは推奨され ないこととなった。本研究では, 検証コホートの約 $89 \%$ の症例は集中治療室外であり, qSOFA 2 項目以上 では, 1 項目以下に比べて院内死亡率が $3 \sim 14$ 倍に増 加するという結果であった。

一方, 本研究4) の集中治療室症例の解析では, SOFA スコア5) と LODS が院内死亡の予測に優れて いるという結果であった。集中治療室症例における後 の前向き臨床研究でも同様の結果が得られている12)。 SOFA スコアは，本邦の集中治療室における特定集中 治療管理の必須評価項目であるため, 集中治療室にお いては感染症あるいは感染症が疑われる状態で SOFA スコアを評価し，合計 2 点以上の急上昇を敗血症と診 断することは可能であると考えられた。以上より本ガ イドラインでも, 集中治療室における敗血症の確定診 断にSOFA スコアを用いる。

一方, 敗血症性ショックは, 敗血症が重症化した 1 区分として敗血症とは別に定義される。敗血症性 ショックは，輸液蘇生だけでは血圧を維持できず，ノ ルアドレナリンなどの血管収縮薬を必要とし，さらに 血中乳酸值が $2 \mathrm{mmoL} / \mathrm{L} （ 18 \mathrm{mg} / \mathrm{dL} ）$ を超える状態と して敗血症と区分する。

Shankar-Hari ら 13）は，敗血症性ショックに関する 臨床研究などをシステマティックレビューし, Delphi 法などを用いて「持続する低血圧」，「血管収縮薬を用 いた治療」,「血中乳酸值」の 3 つの組み合わせにより 新しい敗血症性ショックの診断項目とすることを決定 した。そして, Surviving Sepsis Campaign データベー ス 28,150 例を用いたコホート研究より血中乳酸值を 評価できる 18,840 例を抽出し, 乳酸值 $>2 \mathrm{mmoL} / \mathrm{L}$ $(18 \mathrm{mg} / \mathrm{dL})$ を敗血症性ショックの診断の閾值と定め
た。Sepsis-3 ${ }^{3)}$ では, 敗血症性ショックにおける細胞・ 代謝異常の評価として,「持続する低血圧」,「血管収 縮薬を用いた治療」,「血中乳酸值」を採用し，本ガイ ドラインもこの敗血症性ショックの診断基準に準じる 方針とした。

J-SSCG 2016 6-9) では, Sepsis-1 1) および Sepsis-2 2) を踏襲するか, Sepsis-3 ${ }^{3)}$ に移行するか, また独自に Sepsis の定義と診断基準を策定するかについて討議さ れた。現在も, Sepsis-3 の問題点として, (1) Seymour ら4）の原著論文における評価項目は敗血症発症の予 測ではなく院内死亡の評価基準であること，(2) qSOFA の敗血症診断の感度が低いこと（敗血症診断 におけるSepsis-2 の鋭敏性), (3) SOFA スコア項目の 見直しが必要であること [ショックやDIC（disseminated intravascular coagulation) やAKI (acute kidney injury）などにおける本邦の急性臓器障害の診断基準 と合致しないこと], (4) qSOFA と SOFA との評価基準 に違いがあること（収縮期血圧 $\leqq 100 \mathrm{mmHg}$ もしく

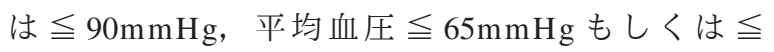
$70 \mathrm{mmHg}$ など), (5)感染症を疑う基準が不明瞭である こと, (6)本邦における乳酸值測定のルーチン化の問題 があること，(7)全身性炎症の新定義の必要性などが残 存する。

以上において, J-SSCG 2016 6-9) および SSCG2016 10, 11) の公表後, 本邦を含めて qSOFA を検証する論文が発 表されている13-17)。qSOFA は，ベッドサイドで簡便か つ迅速に患者の重症度を評価できる利点があるが, 2020 年においても敗血症診断と死亡転帰に対する感度 の低さが課題として指摘されており, 敗血症の early alert system としての評価は十分に定まっていない。ま た，Sepsis-3 3) による診断は，従来の Sepsis-1 1) による 診断より，敗血症と確定する診断数が減少すると予想 されている 18-20)。集中治療室入室日にSepsis-1 もしく はSepsis-3 のクライテリアを満たした 21,491 例のデー タベース検討 18) では, Sepsis-1の診断基準を満たす症 例のうち 13.4\% は Sepsis-3 の基準を満たさず，この 21 日死亡率は $7.0 \%$ と報告されている。既往の臟器障害 をもたない症例に限定すると, Sepsis-1 診断例の $18.4 \%$ がSepsis-3 のクライテリアを満たさず，一方，Sepsis-3 診断例の $6.0 \%$ が Sepsis-1 のクライテリアを満たしてい なかった17)。このように, Sepsis-3による敗血症診断 は, 重症度の高い敗血症をより厳密に診断することに 重きを置いていることに注意する。

また, Australasian Resuscitation in Sepsis Evaluation

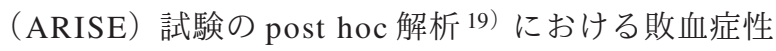
ショックの解析では, Sepsis-1 ${ }^{1)}$ の定義により敗血症 


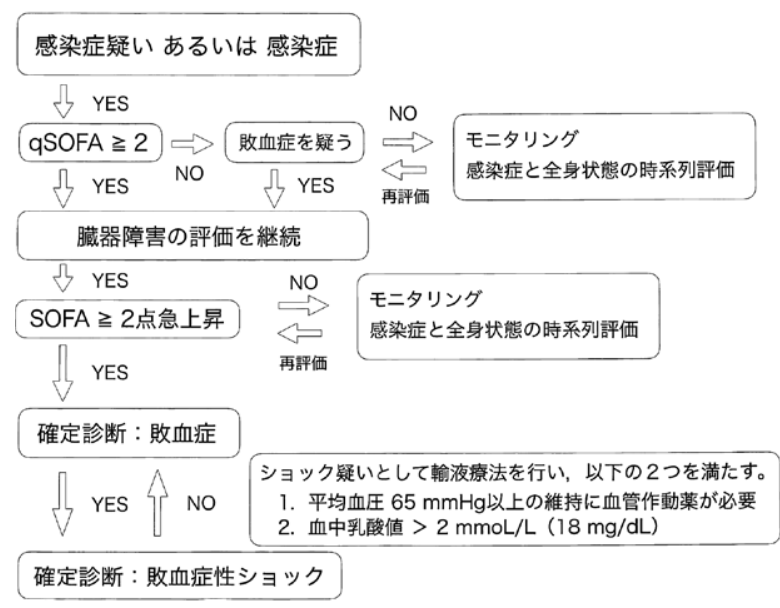

Fig. 1-2 敗血症と敗血症性ショックの診断の流れ

【解説】集中治療室以外の管理では，感染症あるいは感染症の 疑いのある場合, qSOFA (quick sequential sepsis-related organ failure assessment）を評価する。qSOFAの 3 項目である，(1)意 識変容, (2)呼吸数 $\geqq 22$ 回/分, (3)収縮期血圧 $\leqq 100 \mathrm{mmHg}$ を評 価し, 2 項目以上満たす場合には積極的に敗血症を疑う。 qSOFA $\geqq 2$ 点では, 集中治療室またはそれに準じた環境におけ る SOFA スコアの評価に移行させる。集中治療室では, 血液・ 生化学検査, 動脈血ガス分析などより SOFA スコアを時系列で 評価し, SOFA スコアの合計点数が 2 点以上の急上昇となる場 合に敗血症の確定診断とする。敗血症において, 輸液蘇生だけ では平均血圧 $\geqq 65 \mathrm{mmHg}$ を維持できず，ノルアドレナリンな どの血管収縮薬を併用し，さらに血中乳酸值 $>2 \mathrm{mmol} / \mathrm{L}$ $(18 \mathrm{mg} / \mathrm{dL})$ の場合に, 敗血症性ショックと確定診断する。敗血 症と評価できない状況においては, 感染症の徵候や全身状態に 注意し, 集中治療室外では qSOFA, 集中治療室内では SOFA ス コアを適宜再評価する。

性ショックと診断された 1,591 例において, qSOFA を 満たしたのは 1,139 例（約 71.6\%）, qSOFA および SOFA によるSepsis-3 ${ }^{3)}$ の敗血症診断を満たしたもの は 1,010 例（約 63.4\%），さらにSepsis-3 の敗血症性 ショックの診断基準を満たしたものは203例（約 $12.8 \%$ ）と解析されている。フロリダの救急部門を対 象とした 2 つ研究からなる敗血症データベース 470 例の解析 20) においては, Sepsis-3 の診断で敗血症性 ショックが評価されたのは 200 例 $(42.5 \%)$, Sepsis-1 および Sepsis-2 による診断で敗血症性ショックが評価 されたのは 270 例 $(57.4 \%)$ であり, Sepsis-3 の敗血 症性ショックはSOFA スコアと死亡率が統計学的に有 意に高かった。このように, Sepsis-3による敗血症性 ショックの診断は, 重症度の高い敗血症性ショックを 診断していることに注意して対応することになる。

以上より，J-SSCG 2020 では，J-SSCG 2016 6-9）と同 様に，敗血症および敗血症性ショックの診断を Fig. 1-2 として記載した。本定義と診断に準拠し，敗血症 の早期診断と早期治療の一助として頂きたい。

\section{文 献}

1) American College of Chest Physicians/Society of Critical Care Medicine Consensus Conference: definitions for sepsis and organ failure and guidelines for the use of innovative therapies in sepsis. Crit Care Med. 1992; 20: 864-74.

2) Levy MM, Fink MP, Marshall JC, et al: 2001 SCCM/ESICM/ ACCP/ATS/SIS International sepsis definitions conference. Crit Care Med. 2003; 31: 1250-6.

3) Singer M, Deutschman CS, Seymour CW, et al: The Third International consensus definitions for sepsis and septic shock (Sepsis-3). JAMA. 2016; 315: 801-10.

4) Seymour CW, Liu VX, Iwashyna TJ, et al: Assessment of clinical criteria for sepsis: For the third international consensus definitions for sepsis and septic shock (Sepsis-3). JAMA. 2016; 315: 762-74.

5) Vincent JL, Moreno R, Takala J, et al: The SOFA (Sepsis-related Organ Failure Assessment) score to describe organ dysfunction/ failure. On behalf of the Working Group on Sepsis-Related Problems of the European Society of Intensive Care Medicine. Intensive Care Med. 1996; 22: 707-10.

6）西田修, 小倉裕司, 井上茂亮, 他: 日本版敗血症診療ガイドラ イン 2016 作成特別委員会. 日本版敗血症診療ガイドライン 2016. 日集中医誌. 2017; 24: S1-232.

7）西田修, 小倉裕司, 井上茂亮, 他: 日本版敗血症診療ガイドラ イン 2016 作成特別委員会. 日本版敗血症診療ガイドライン 2016. 日救急医会誌. 2017; 28: S1-232.

8) Nishida O, Ogura H, Egi M, et al: The Japanese clinical practice guidelines for management of sepsis and septic shock 2016 (J-SSCG 2016). J Intensive Care. 2018; 6: 7.

9) Nishida O, Ogura H, Egi M, et al: The Japanese clinical practice guidelines for management of sepsis and septic shock 2016 (J-SSCG 2016). Acute Med Surg. 2018; 5: 3-89.

10) Rhodes A, Evans LE, Alhazzani W, et al: Surviving sepsis campaign: international guidelines for management of sepsis and septic shock: 2016. Intensive Care Med. 2017; 43: 304-77.

11) Rhodes A, Evans LE, Alhazzani W, et al: Surviving sepsis campaign: international guidelines for management of sepsis and septic shock: 2016. Crit Care Med. 2017; 45: 486-552.

12) Raith EP, Udy AA, Bailey M, et al: Prognostic accuracy of the SOFA score, SIRS sriteria, and qSOFA score for in-hospital mortality among adults with suspected infection admitted to the intensive care unit. JAMA. 2017; 317: 290-300.

13) Shankar-Hari M, Phillips GS, Levy ML, et al: Developing a new definition and assessing new clinical criteria for septic shock: For the third international consensus definitions for sepsis and septic shock (Sepsis-3). JAMA. 2016; 315: 775-87.

14) Freund Y, Lemachatti N, Krastinova E, et al: Prognostic accuracy of Sepsis-3 criteria for in-hospital mortality among patients with suspected infection presenting to the emergency department. JAMA. 2017; 317: 301-8.

15) Umemura $Y$, Ogura H, Gando $S$, et al: Assessment of mortality by qSOFA in patients with sepsis outside ICU: A post hoc subgroup analysis by the Japanese Association for Acute Medicine Sepsis Registry Study Group. J Infect Chemother. 2017; 23: 757-62.

16) Umemura $Y$, Ogura $H$, Gando $S$, et al: Prognostic Accuracy of Quick SOFA is different according to the severity of illness in infectious patients. J Infect Chemother. 2019; 25: 943-9.

17) Kushimoto $\mathrm{S}$, Gando $\mathrm{S}$, Ogura $\mathrm{H}$, et al: Complementary role of hypothermia identification to the quick sequential organ failure assessment score in predicting patients with sepsis at high risk of mortality: A retrospective analysis from a multicenter, observational study. J Intensive Care Med. 2020; 35: 502-10.

18) Fang $X$, Wang Z, Yang J, et al: Clinical evaluation of Sepsis-1 and Sepsis-3 in the ICU. Chest. 2018; 153: 1169-76.

19) Peake SL, Delaney A, Bailey M, et al: Potential impact of the 
2016 consensus definitions of sepsis and septic shock on future sepsis research. Ann Emerg Med. 2017; 70: 553-61.e1.

20) Sterling SA, Puskarich MA, Glass AF, et al: The impact of the sepsis-3 septic shock definition on previously defined septic shock patients. Crit Care Med. 2017; 45: 1436-42. 


\section{CQ2 : 感染の診断}

敗血症・敗血症性ショックの診療において，その原 因となる感染症の診断は重要である。感染症の診断を 行ううえで，まず検体の採取による病原微生物の同定 が極めて重要であり, 適切な治療にもつながる。病 歴, 身体所見, 画像検査などから可及的速やかに感染 巣を絞り込み, 血液培養とともに推定感染部位から適 切に培養検体を採取する必要がある。培養の中でも, 血液培養は最も重要な検査であり, 菌血症を引き起こ している病原微生物を同定する臨床的意義は大きい。 血液培養の結果から, 感染巣が判明する場合があり, 不明であった感染巣を推測するうえで重要な情報が得 られることもある。また, 培養および抗菌薬の感受性 検査の結果によりデエスカレーションを含む治療の最 適化が可能である。しかしながら，血液を採取する方 法やタイミングをまちがえると, 菌のコンタミネー ションや感受性に対して不正確な情報が得られる場合 もあり, 不必要な治療やコストの増加につながりかね ない。血液培養に関しては，これまでも良質なエビデ ンスの有無にかかわらず重要であると記載されている が，血液を採取する方法やタイミングに関して依然と して周知徹底されていないため, 本ガイドラインでも 取り上げることとした。そこで，CQ2-1 として「血液 培養はいつ採取するか?」を掲げる。

また, 敗血症性ショック患者では血液培養検査の陽 性率は $69 \%$ との報告があるが, 発熱があるからといっ て血液培養検査を行っても陽性率は高くないため, 血 液培養には限界がある ${ }^{1)} 。$ 特に, 尿路感染, 肺炎, 骾
膜炎といった感染症によって生じた敗血症の場合，血 液培養だけで感染臓器および原因微生物を同定するこ とは極めてむずかしい。多くのガイドラインでは, 臨 床像より感染源となっている可能性が否定できない部 位から, 検体をできる限り抗菌薬開始前に採取するこ とは，予後を改善するというエビデンスはないが，エ キスパートコンセンサスの立場で推奨されている。本 ガイドラインでも血液培養以外の各種培養検査に関し て述べることは極めて重要であると考え, CQ2-2 とし て「血液培養以外の培養検体は，いつ採取するか? 」 を掲げる。

臨床の現場では, 血液培養の結果を待たずして抗菌 薬を選択するが，抗菌薬を選択する際にグラム染色所 見を参考にするというプラクティスは広く普及してお り, 病態生理の側面からも一定の妥当性があるといわ れている 1)。また，グラム染色は簡便で迅速に施行す ることができ，しかも安価である。しかしながら，グ ラム染色所見のみで抗菌薬を選択すると, 重症病態に もかかわらず不適切な抗微生物薬が選択されるリスク がある2）。本ガイドラインでもグラム染色が有用であ るか否かを述べることは極めて重要であると考え, CQ2-3 として「抗菌薬投与前のグラム染色は有用か?」 を掲げる。

さらに, 感染症の診断に関して, バイオマーカー検 査の有用性を確認する必要がある。敗血症の診断は, Sepsis-3 の臓器障害を伴う感染症となっている。従来 の全身性炎症性反応を伴う感染症であった際には, 臨 床上急性膵炎のように発熱や炎症反応の増加を認める が非感染症である場合や, 感染症は存在するものの重

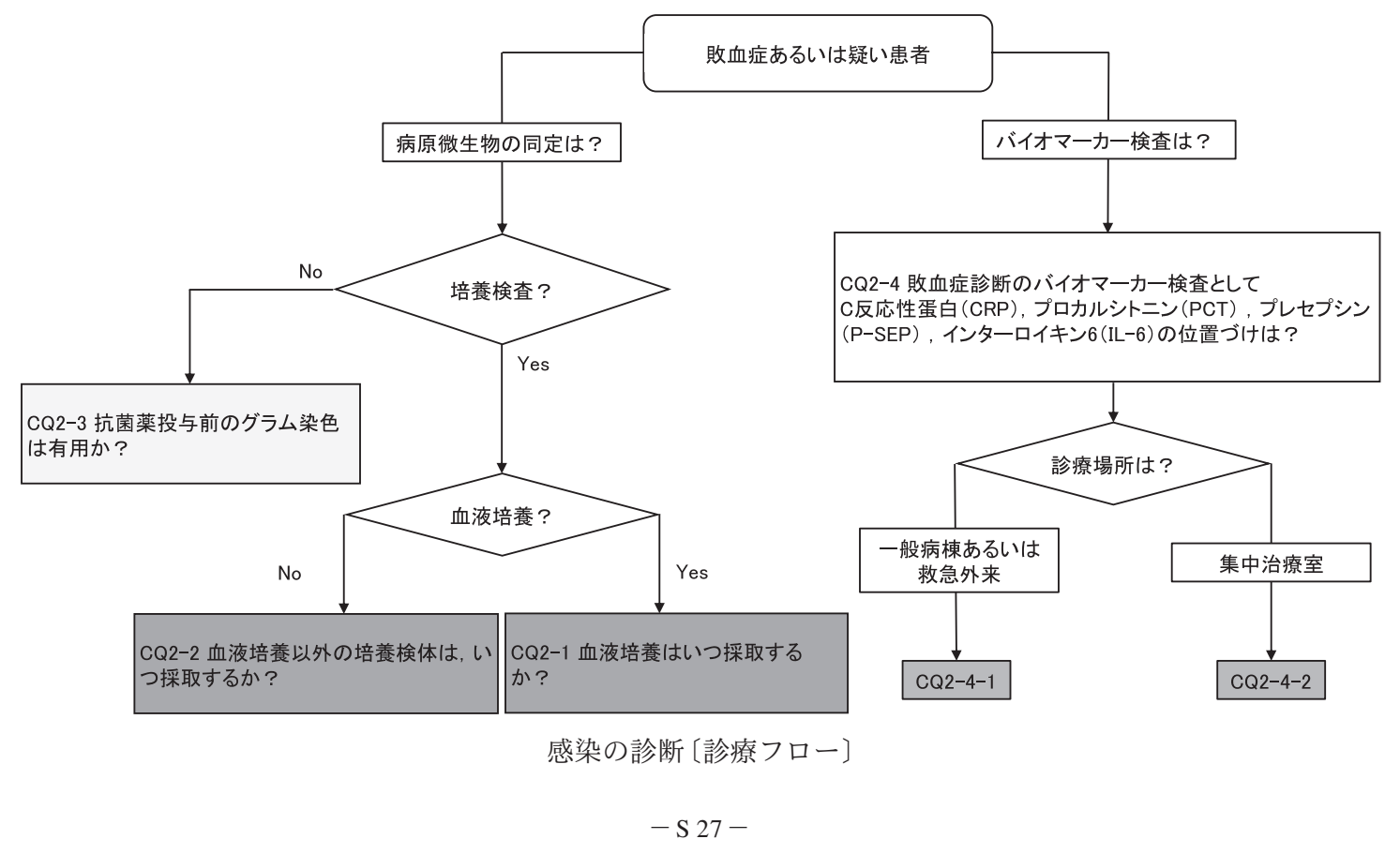


症度を含治療方法の選択に苦慮する場合が少なから ず存在している。その際，敗血症の診断とともにバイ オマーカー検査の結果を参考に治療を行う場合が多々 ある。バイオマーカーとしては, C 反応性蛋白 (CRP), プロカルシトニン (PCT), プレセプシン (P-SEP), インターロイキン 6（IL-6）の 4 種類のバイオマー カーが現在敗血症診断目的で用いられている。これら 4 種類のバイオマーカーに関して, 日本版敗血症診療 ガイドライン（J-SSCG）2016では，救急外来や一般 病棟などの非重症患者と集中治療室に入室する重症患 者とに分けて, 感染症診断の補助検査として非重症患 者ではPCT，P-SEP またはIL-6を日常的には評価し ないことを弱く推奨し，重症患者ではPCT または P-SEP を評価することを弱く推奨した ${ }^{3,4)}$ 。その後, バイオマーカーに関する数多くの報告がなされ，本ガ イドラインにおいても敗血症診断目的で 4 種類のバイ オマーカーの評価を述べることは極めて重要であると 考えた。また, 救急外来や一般病棟などの非重症患者 と集中治療室に入室するような重症患者とでは評価は 異なるため，CQ2-4-1 として「一般病棟あるいは救急 外来において，敗血症診断のバイオマーカー検査とし て C 反応性蛋白 (CRP), プロカルシトニン (PCT), プレセプシン（P-SEP），インターロイキン 6（IL-6） の位置づけは?」, CQ2-4-2 として「集中治療室にお いて，敗血症診断のバイオマーカー検査として C 反 応性蛋白 (CRP), プロカルシトニン (PCT), プレセ プシン（P-SEP），インターロイキン6（IL-6）の位置 づけは?」を掲げる。

\section{文 献}

1) CoburnB, Morris AM, Tomlinson G, et al: Does this adult patient with suspected bacteremia require blood cultures?. JAMA. 2012; 308: 502-11.

2) Metlay JP, Waterer GW, Long AC, et al: Diagnosis and treatment of adults with community-acquired pneumonia. An official clinical practice guideline of the American thoracic society and infectious diseases society of America. Am J Respir Crit Care Med. 2019; 200: e45-67.

3）西田修, 小倉裕司, 井上茂亮, 他: 日本版敗血症診療ガイ ドライン 2016 作成特別委員会. 日本版敗血症診療ガイドラ イン 2016. 日集中医誌. 2017; 24: S1-232.

4）西田修，小倉裕司，井上茂亮，他: 日本版敗血症診療ガイ ドライン 2016 作成特別委員会. 日本版敗血症診療ガイドラ イン 2016. 日救急医会誌. 2017; 28: S1-232.

\section{CQ2-1：血液培養はいつ採取するか？}

Answer : 抗菌薬投与前に 2 セット以上採取する(Good Practice Statement)。

\section{（1）背景および本 $C Q$ の重要度}

敗血症・敗血症性ショックの診療において，原因と なる病原微生物の同定が極めて重要であり, 適切な治 療にもつながる。血液培養に関する一般的な推奨を記 述することは，良質なエビデンスの有無にかかわらず 重要であると記載されているが，依然として周知徹底 されていないため，本ガイドラインでも踏襲す る1,2)。

救急外来などで，未治療の敗血症疑い患者に対し， アルゴリズム的に抗菌薬投与前に血液培養 2 セット以 上を可及的速やかに採取することが重要である。ま た, 術後感染や入院患者の敗血症の場合は, 事前に抗 菌薬が投与されている場合が少なくない。しかしこの ような患者においても, できるだけ早急に血液培養 2 セット以上を採取することが重要である。

\section{（2）解説}

一般的に菌血症は, 心内膜炎, 中心静脈カテーテル 感染, 肺炎, 膿瘍, 骨髄炎, 腹腔内感染症, 尿路感染 症などの感染症で生じ，高い死亡率を来している3)。 各種の迅速診断法が開発されているものの ${ }^{4)}$, 現在で も血液培養は菌血症を診断するうえでの標準的検査法 である。血液培養を採取するタイミングに関する良質 なエビデンスがなく, 本 CQ に対し明確な推奨の提示 はできない。

これまで, 菌血症を疑う症状（発熱，悪寒・戦慄， 低血圧, 頻呼吸など）の出現, 原因不明の低体温, 低 血圧, 意識障害 (特に高齢者), 白血球数増加卢減少, 代謝性アシドーシス，免疫不全患者における呼吸不 全・急性腎障害・急性肝機能障害などが見られた場合 は敗血症を疑い，できるだけ早急に血液培養を 2 セッ 卜以上採取することが推奨されている5)。そのなかで も特に， $38.5^{\circ} \mathrm{C}$ 以上の発熱や戦慄が生じた場合は，早 急に血液培養を 2 セット以上採取することが勧められ ている。しかしながら，菌血症の可能性が低い場合の 発熱や白血球の上昇のみでは，無理に血液培養を採取 しなくてもよいとする報告もある6)。

原則として，抗菌薬治療の開始が遅滞することのな いよう留意しつつ, 抗菌薬投与前に採取することが重 要である。なぜなら, 抗菌薬投与後では検出感度が低 下し，菌を同定できない場合が多いためである7)。抗 
菌薬治療中の場合は，抗菌薬濃度がトラフ付近，すな わち次回の抗菌薬投与直前に採取する。また，治療に 対する反応が乏しく, 抗菌薬を変更する際も改めて採 取することが望ましい。

採血量に関しては，多く採取すればするほど菌を同 定する割合が高くなることが知られている ${ }^{8)}$ 。しかし ながら，採血量が多くなると医原性貧血を引き起こす 可能性があり，一般的には 1 セットあたり 20〜30mL の採血量が推奨されている。本邦では，沉用されてい る血液ボトルが $10 \mathrm{~mL}$ のものが多いため, 1 セットあ たり $20 \mathrm{~mL}$ が一般的である。Cheruvanky らは，医療経 済学的にも $30 \mathrm{~mL}$ に比べて $20 \mathrm{~mL}$ のほうがよいと報告 している9)。

何セット採取するかという問題に関しては，1 セッ トだけでは感度の低下とコンタミネーションを排除で きないことより否定的であり, 少なくとも 2 セット, 可能なら 3 セット採取するのが望ましいとの報告があ る 8,10$)$ 。実際, 血液培養の陽性率は $5 \sim 13 \%$ に過ぎ ず，20〜56\%にコンタミネーションがあるといわれ ている ${ }^{11)}$ 。セットの数を増やせば感度は上昇する（1 セットなら約 80\%，2 2ットなら約 89\%，3 3 セットな ら約 $98 \%$ との報告がある $\left.{ }^{7)}\right)$ 。なお，4 セット以上採 取しても感度の上昇は見込めず，患者負担が多くなる ため避けるべきである。

コンタミネーションの疑いを減らすために，適切な

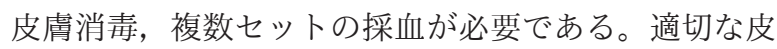
膚消毒として，1\% グルコン酸クロルヘキシジン，ポ ビドンョード, $70 \%$ アルコールのうち, どれが最適 な消毒薬かは依然として不明であるが，これらの薬剤 を用いて正確な無菌操作を遵守することが重要である ことは間違いない12)。

なお，本 $\mathrm{CQ}$ に関して，担当班から「抗菌薬投与前 に 2 セット以上採取する」という意見文が提案され， 委員の全会一致により,「good practice statement (GPS)」 として可決された。

\section{文 献}

1）西田修, 小倉裕司, 井上茂亮, 他: 日本版敗血症診療ガイドラ イン 2016 作成特別委員会. 日本版敗血症診療ガイドライン 2016. 日集中医誌. 2017; 24: S1-232.

2）西田修, 小倉裕司, 井上茂亮, 他: 日本版敗血症診療ガイドラ イン 2016 作成特別委員会. 日本版敗血症診療ガイドライン 2016. 日救急医会誌. 2017; 28: S1-232.

3) Long B, Koyfman A: Best clinical practice: Blood culture utility in the emergency department. J Emerg Med. 2016; 51: 529-39.

4) Huang TD, Melnik E, Bogaerts P, et al: Evaluation of the ePlex blood culture identification panels for detection of pathogens in bloodstream infections. J Clin Microbiol. 2019; 57: e01597-18.

5) Chandrasekar PH, Brown WJ: Clinical issues of blood cultures. Arch Intern Med. 1994; 154: 841-9.
6) Coburn B, Morris AM, Tomlinson G, et al: Does this adult patient with suspected bacteremia require blood culture? JAMA. 2012; 308: 502-11.

7) Phua J, Ngerng W, See K, et al: Characteristics and outcomes of culture-negative versus culture-positive severe sepsis. Crit Care. 2013; 17: R202.

8) Cockerill FR, Wilson JW, Vetter EA, et al: Optimal testing parameters for blood cultures. Clin Infect Dis. 2004; 38: 1724-30. Available online at: http://dx.doi.org/10.1086/421087. Accessed June 1, 2020.

9) Cheruvanky A, Kirn TJ, Weinstein MP: Cost-effectiveness of 30compared to 20-milliliter blood cultures: a retrospective study. J Clin Microbiol. 2016; 54: 64-7.

10) Lee A, Mirrett S, Reller LB, et al: Detection of bloodstream infections in adults: how many blood cultures are needed? J Clin Microbiol. 2007; 45: 3546-8.

11) Lamy B, Dargère $S$, Arendrup MC, et al: How to optimize the use of blood cultures for the diagnosis of bloodstream infections? A state-of-the art. Front Microbiol. 2016; 7: 697.

12) Kiyoyama T, Tokuda Y, Shiiki S, et al: Isopropyl alcohol compared with isopropyl alcohol plus povidone-iodine as skin preparation for prevention of blood culture contamination. J Clin Microbiol. 2009; 47: 54-8. 
CQ2-2：血液培養以外の培養検体は，いつ採取 するか?

Answer : 抗菌薬投与前に必要に応じて血液培養以外 の各種培養検体を採取する（Good Practice Statement）。

\section{（1）背景および本 $C Q$ の重要度}

敗血症・敗血症性ショックの診療において, 感染臟 器および原因微生物の同定は極めて重要である。日本 版敗血症診療ガイドライン（J-SSCG）2016において も, 臨床像より感染源となっている可能性が否定でき ない部位からの検体を抗菌薬開始前に採取しておくこ とは, 感染臟器および原因微生物の同定に極めて重要 であることが述べられており 1,2$)$ ，本 $\mathrm{CQ}$ の重要度は 高い。

\section{（2）解説}

血液培養は血流感染や菌血症を診断する標準的検査 法とみなされている。敗血症性ショック患者では血液 培養検査の陽性率は $69 \%$ との報告があるが，発熱が あるからといって血液培養検査を行っても陽性率は高 くないため，血液培養には限界がある ${ }^{3)}$ 。特に，尿路 感染, 肺炎, 髄膜炎といった感染症によって生じた敗 血症の場合, 血液培養だけで感染臟器および原因微生 物を同定することは極めてむずかしい。多くのガイド ラインでは, 臨床像より感染源となっている可能性が 否定できない部位から，検体をできる限り抗菌薬開始 前に採取することについて，予後を改善するというエ ビデンスはないものの推奨されている 4-6)。

肺炎に関しては，肺炎の病態によって診断や治療は 異なるが，喀痰培養が診断の手助けになる。しかしな がら，喀痰は上気道のコンタミネーションのリスクを 伴っているため, 胸水や血液培養の結果と一致してい ない場合には解釈に注意が必要である。患者が重症 で，人工呼吸管理のために気管挿管されている場合， 気管吸引痰を採取して定量培養を行い, 菌数が $10^{4} \mathrm{CFU} / \mathrm{mL}$ 以上であれば原因菌の可能性が高いと報 告されている（抗菌薬投与前の吸引痰で, 感度 $90 \%$, 特異度 77\%）7。また，人工呼吸器関連肺炎の診断に おいては，気管吸引痰で菌が分離されない場合には原 因菌ではない確率が $94 \%$ であるとの報告がある ${ }^{8)}$ 。 さらに，肺炎が原因または合併している ARDS の場 合にも, 気管支肺胞洗浄液の微生物検索は治療方針決 定のためにも重要であり, 患者の免疫力が低下してい る場合は, ニューモシスチス肺炎や肺真菌症の除外の ためにも有用である99。
尿路感染症の多くは，大腸常在菌による上行性尿路 感染であり，原因菌の証明と薬剤感受性を調べるため に抗菌薬投与前に尿培養検査を施行する。再発性また は難治性の場合には抗菌薬投与が行われているため, 2〜3 日間の休薬を挟んで尿培養検査を施行する 5,10$)$ 。 細菌性髄膜炎に関しては, 血液培養・髄液培養の有 用性を確認したランダム化比較試験（RCT）はない が，頭部 CT や臨床所見より脳ヘルニアが疑われず, 腰椎穿刺が禁忌でない限り, 頭痛, 意識障害などによ り䯣膜炎を疑うすべての患者に抗菌薬投与前に髄液を 採取することが望ましい6)。しかしながら，髄液採取 に時間がかかる場合には抗菌薬投与を優先すべきであ る。髄液培養の陽性率は未治療では 70〜80\%，抗菌 薬治療後では $50 \%$ 以下といわれている ${ }^{11)}$ 。細菌性䯣 膜炎において, 髄液培養の陽性率は採取量が多いほ ど，また遠心（1,500〜2,500× g, 15 分）を行うほど 検出率は高くなる ${ }^{12)}$ 。

なお，本 $\mathrm{CQ}$ に関して，担当班から「抗菌薬投与前 に必要に応じて血液培養以外の各種培養検体を採取す る」という意見文が提案され，委員の全会一致によ り,「good practice statement (GPS)」として可決され た。

\section{文 献}

1）西田修, 小倉裕司, 井上茂亮, 他: 日本版敗血症診療ガイドラ イン 2016 作成特別委員会. 日本版敗血症診療ガイドライン 2016. 日集中医誌. 2017; 24: S1-232.

2）西田修, 小倉裕司, 井上茂亮, 他: 日本版敗血症診療ガイドラ イン 2016 作成特別委員会. 日本版敗血症診療ガイドライン 2016. 日救急医会誌. 2017; 28: S1-232.

3) Coburn B, Morris AM, Tomlinson G, et al: Does this adult patient with suspected bacteremia require blood cultures? JAMA. 2012; 308: 502-11.

4) 日本呼吸器学会成人肺炎診療ガイドライン 2017 作成委員 会: 成人肺炎診療ガイドライン 2017. 日本呼吸器学会, 東京, 2017.

5）山本新吾, 石川清仁, 速見浩士, 他: JAID/JSC 感染症治療ガイ ドライン 2015一尿路感染症・男性性器感染症一. 日化療会 誌. 2015; 64: 1-30.

6）細菌性髄膜炎診療ガイドライン作成委員会: 細菌性髄膜炎 診療ガイドライン 2014. 南江堂, 東京, 2014.

7) El Solh AA, Akinnusi ME, Pineda LA, et al: Diagnostic yield of quantitative endotracheal aspirates in patients with severe nursing home-acquired pneumonia. Crit Care. 2007; 11: R57.

8) Blot F, Raynard B, Chachaty E, et al: Value of gram stain examination of lower respiratory tract secretions for early diagnosis of nosocomial pneumonia. Am J Respir Crit Care Med. 2000; 162: 1731-7.

9）日本集中治療医学会／日本呼吸療法医学会 ARDS 診療ガイ ドライン作成委員会: ARDS 診療ガイドライン 2016. 日集中 医誌. 2017; 24: 57-63.

10) Ishikawa $K$, Matsumoto $T$, Yasuda $M$, et al: The nationwide study of bacterial pathogens associated with urinary tract infections conducted by the Japanese Society of Chemotherapy. J Infect Chemother. 2011; 17: 126-38. 
11) McGill F, Heyderman RS, Panagiotou S, et al: Acute bacterial meningitis in adults. Lancet. 2016; 388: 3036-47.

12) Gray LD, Fedorko DP: Laboratory diagnosis of bacterial meningitis. Clin Microbiol Rev. 1992; 5: 130-45.
CQ2-3 : 抗菌薬投与前のグラム染色は有用か？

Answer : 経験的治療に採用する抗菌薬を選択する際 に，培養検体のグラム染色所見を参考にすることを弱 く推奨する（エキスパートコンセンサス：エビデンス 不十分)。

\section{（1）背景および本 $C Q$ の重要度}

日本版敗血症診療ガイドライン（J-SSCG）2016 ${ }^{1,2)}$ で指摘されたように，経験的治療に採用する抗菌薬を 選択する際に，グラム染色所見を参考にするというプ ラクティスは広く普及しており, 病態生理の側面から も一定の妥当性があると考える。また，実際にグラム 染色は簡便で迅速に施行することができ，しかも安価 である。本ガイドラインにおいても，グラム染色が有 用であるか否かは重要な課題であり, 意見を記述して おくべきであると考える。

(2) PICO

P (患者) : 感染症, 敗血症, 敗血症性ショックを 疑う患者

I（介入）: 血液培養検査判明前にグラム染色を行う

$\mathrm{C}$ (対照) : 非介入

$\mathrm{O}$ (アウトカム $)$ : 院内死亡, ICU 滞在日数, あらゆ る重篤な副作用, 感染性合併症, 血圧低下

\section{（3）エビデンスの要約}

システマティックレビューを行ったが，PICO に合 致するランダム化比較試験（RCT）は存在しなかっ た。

（4）益と害のバランス

望ましい効果 :

- 経験的治療に採用する抗菌薬を選択する際に，参考 になる場合がある。

-市中肺炎，尿路感染，細菌性髄膜炎などで比較的良 好な特異度が報告されている。

$\checkmark$ ATS/IDSA の市中肺炎のガイドライン 20193) で は, 治療前の喀痰のグラム染色と培養は行うべ きとなっている（重症肺炎で挿管した場合, MRSA や緑膿菌のためにエンピリックに治療を 開始する場合, MRSA や緑膿菌の既感染がある 場合, 入院中や 90 日以内に経口抗菌薬を投与さ れている場合には行うべきである)。

$\checkmark$ JAID/JSC 感染症治療ガイドライン 20154) の尿 路感染症・男性性器感染症では, カテーテル関 
連尿路感染症の場合，尿のグラム染色が原因菌 の推定に役立つことが示されている。成人肺炎 患者において, 入院患者の下気道から分離され る菌は定着菌であることも多いため, 好中球領 食像の有無による起炎菌の判定にグラム染色が 有用である。グラム染色所見に基づく抗菌薬選 択は適切な empiric therapyにつながり, definitive therapy につながる場合も多い。

$\checkmark$ 細菌性髄膜炎診療ガイドライン 20145) では，グ ラム染色が簡易で，速やかに結果が得られる検査 であり，感度 50〜90\%，特異度 60〜90\%，最小 検出感度 $10^{5} \mathrm{cfu} / \mathrm{mL}$ であることが報告されてい る。また，菌株により検出感度が高いものもある （肺炎球菌 90\%，インフルエンザ菌 86\%，髄膜炎 菌 75\% など)。

望ましくない効果 :

本検査結果のみで抗菌薬を選択すると，重症病態に もかかわらず不適切な狭域抗微生物薬が選択されるリ スクがある。また，検査施行者により感度・特異度が 影響され，不適切な抗菌薬選択のリスクがある（検者 の不適切な検查手技，不十分な検鏡経験などによる偽 陽性・偽陰性の可能性がある)。また，ATS/IDSAの 市中肺炎のガイドライン 20193) では，抗菌薬投与に より菌株が変化する可能性があるため, 治療後に得ら れた喀痰におけるグラム染色は推奨しないことになっ ている。

\section{益と害のバランス :}

PICO に合致する RCT は存在せず不明であるが，患 者の状態によってそのバランスは異なると考えられ
る。グラム染色は簡便で迅速に施行することができ， しかも安価であることから，その有用性と限界を理解 したうえで行うことは，おそらく益が害を上回るもの と考えられる。

（5）アウトカム全般に関するエビデンスの確実性

システマティックレビューを行ったが，PICOに合 致する RCT は存在しなかった。

\section{（6）価值観}

死亡率が低下することについて患者・家族は一般的 に重視すると考えられ，不確実性やばらつきはないと 考える。

\section{（7）容認性}

グラム染色は簡便で迅速に施行することができ，し かも安価であることから，容認性はおそらく妥当なも のといえる。

\section{（8）実行可能性}

多くの集中治療室では，グラム染色が行えると考え る。

（9）判断の要約（Table 2-3-1）

（10）推奨グレーディング決定の工程

修正 RAND 法を用いた投票によって，中央值 8, 見解不一致指数 0.015 の結果となり，委員会で採択さ れた（7 点以上：91.7\%）。

Table 2-3-1 判断の要約

\begin{tabular}{|c|c|c|c|c|c|c|c|}
\hline & \multicolumn{7}{|c|}{ 判断 } \\
\hline 問題 & いいえ & $\begin{array}{c}\text { おそらく、いい } \\
\text { え }\end{array}$ & おそらく、はい & はい & & さまざま & 分からない \\
\hline 望ましい効果 & わずか & 小さい & 中 & 大きい & & さまざま & 分からない \\
\hline 望ましくない効果 & 大きい & 中 & 小さい & わずか & & さまざま & 分からない \\
\hline エビデンスの確実性 & 非常に低 & 低 & 中 & 高 & & & 採用研究なし \\
\hline 価值钼 & $\begin{array}{c}\text { 重要な不確実性 } \\
\text { またははよらつ } \\
\text { あり }\end{array}$ & $\begin{array}{c}\text { 重要な不確実性 } \\
\text { またはばらつき } \\
\text { の可能性あり }\end{array}$ & $\begin{array}{l}\text { 重要な不確実性 } \\
\text { またはばらつき } \\
\text { はおそらくなし }\end{array}$ & $\begin{array}{c}\text { 重要な不確実性 } \\
\text { またはばらつき } \\
\text { はなし }\end{array}$ & & & \\
\hline 効果のバランス & 比較が優位 & $\begin{array}{c}\text { 比較がおそらく } \\
\text { 優位 }\end{array}$ & $\begin{array}{c}\text { 介入も比較もい } \\
\text { ずれも優位でな } \\
\text { い }\end{array}$ & $\begin{array}{c}\text { おそらく介入が } \\
\text { 優位 }\end{array}$ & 介入が優位 & さまざま & 分からない \\
\hline 容認性 & いいえ & $\begin{array}{c}\text { おそらく、いい } \\
\text { え }\end{array}$ & おそらく、はい & はい & & さまざま & 分からない \\
\hline 実行可能性 & いいえ & $\begin{array}{c}\text { おそらく、いい } \\
\text { え }\end{array}$ & おそらく、はい & はい & & さまざま & 分からない \\
\hline
\end{tabular}


（11）関連する他の診療ガイドラインにおける推奨

市中肺炎, 尿路感染, 細菌性髄膜炎などのガイドラ インにおいて，グラム染色の有用性，欠点に関して指 摘されている。詳細は，（4）益と害のバランスに記載 したとおりである。

\section{（12）実施に関わる検討事項}

検査前に抗菌薬を投与してしまった場合や，抗菌薬 の投与を急ぐ場合，益と害のバランスが異なる可能性 がある。

\section{（13）今後の研究の可能性}

グラム染色の有用性に関する RCT がないことは明 らかであり，グラム染色を行うことによる生存率の改 善や，選択した抗菌薬の有効性などに関する検証を行 う RCT が必要である。

\section{文 献}

1）西田修, 小倉裕司, 井上茂亮, 他: 日本版敗血症診療ガイドラ イン 2016 作成特別委員会. 日本版敗血症診療ガイドライン 2016. 日集中医誌. 2017; 24: S1-232.

2）西田修, 小倉裕司, 井上茂亮, 他: 日本版敗血症診療ガイドラ イン 2016 作成特別委員会. 日本版敗血症診療ガイドライン 2016. 日救急医会誌. 2017; 28: S1-232.

3) Metlay JP, Waterer GW, Long AC, et al: Diagnosis and treatment of adults with community-acquired pneumonia. An official clinical practice guideline of the American thoracic society and infectious diseases society of America. Am J Respir Crit Care Med. 2019; 200: e45-67.

4）山本新吾, 石川清仁, 速見浩士, 他: JAID/JSC 感染症治療ガイ ドライン 2015一尿路感染症・男性性器感染症一. 日化療会 誌. 2015; 64: 1-30.

5）細菌性髄膜炎診療ガイドライン作成委員会: 細菌性髄膜炎 診療ガイドライン 2014. 南江堂, 東京, 2014.
CQ2-4-1：一般病棟あるいは救急外来において, 敗血症診断のバイオマーカー検査として C 反応 性蛋白 (CRP), プロカルシトニン (PCT), プ レセプシン（P-SEP), インターロイキン 6 (IL-6) の位置づけは?

Answer：一般病棟あるいは救急外来において，敗血 症を疑ったときのバイオマーカー検査の感度, 特異度 は, CRPでは $59 \%, 79 \%$, PCT では 74\%, $81 \%$, P-SEPでは 75\%，74\%，IL-6では 78\%，78\% であっ た。したがって，バイオマーカー単独による敗血症診 断は一般的に困難と考えられ，その使用はいずれも全 身状態観察などに加えた補助的な位置づけといえる (BQ に対する情報提示)。

\section{（1）背景および本 $C Q$ の重要度}

敗血症（Sepsis-3）の診断は, 現在, “重篤な臟器障 害を認める感染症”となっている。しかし, 臨床上, 感染症を疑うが確定診断に直ちには至らない場合，治 療方法の選択に苦慮することも少なくない。このよう な場合に，バイオマーカーの利用可能性を確認する価 值がある。バイオマーカーとしては, CRP, PCT, P-SEP，IL-6の 4 種類が用いられている。これらのバ イオマーカーに関して, 前回の日本版敗血症診療ガイ ドライン（J-SSCG）2016では, 救急外来や一般病棟 などの非重症患者において敗血症が疑われる場合，感 染症診断の補助検査として P-SEP またはPCT または IL-6 を日常的には評価しないことを弱く推奨すると 提言した 1,2$)$ 。その後，バイオマーカーに関する数多 くの報告がなされ，一般病棟あるいは救急外来におけ る敗血症診断目的で 4 種類のバイオマーカーを評価す ることが必要であると考え，本ガイドラインにおいて も取り上げた。

（2）本 CQ が background question（BQ）となった経 緯

本 CQ は当初, 『感染症診断にバイオマーカーとし て CRP，PCT，P-SEP，IL-6のいずれを用いるか?』 という GRADEに則った CQ であった。しかし，感染 症診断となると, 対象疾患が非常に広範囲となるため, 本ガイドラインの特性を鑑みて，全身状態に悪影響を 及ぼすような重篤な病態である敗血症に焦点を置くこ ととなった。システマティックレビューは CQ2-4-2 と 合わせて網羅的文献検索を行い，その抽出論文から 「一般病棟あるいは救急外来部門」と「集中治療部門」 に分けて診断精度研究のシステマティックレビューを 
行った。「一般病棟あるいは救急外来部門」で対象と なった論文は計 11 編で, 各バイオマーカーのメタ解 析で統合された論文は, CRP 8 編 ${ }^{3-10)}$, PCT 11 編 3-13)，P-SEP 4 編 8, 9, 12,13)，IL-6 4 編 3, 5, 6, 11) であ る。

その結果をもとにエビデンスプロファイル（EP）， evidence to decision（EtD）をまとめ,『PCT, P-SEP, IL-6 の診断精度は比較的正確であると考えられるが, 患者や家族における重要なアウトカムに対する効果の バランスは拮抗していることから, CRP も含め, い ずれのバイオマーカーも弱い非推奨』として Answer を提示し，委員会での投票が行われた。

2 回の投票の結果，合意形成に至らなかった（同意 中央值 7 点, 不一致指数 0.1826$)$ 。委員からは, これ まで広く日常的に測定している CRP, PCT, P-SEP な どの検査を行わなくて良いと解釈され，バイオマー カー測定が行われなくなることが懸念されるとの意見 が出された。委員会で議論を重ねた結果, 最終的に本 CQ は BQ として扱う方針となった。
（3）解説

以下の解説は，システマティックレビューの結果お よびGRADEの推奨工程として作成した EP（Table 2-4-1-1〜2-4-1-4）を参考に作成した。

本 CQ におけるシステマティックレビューの結果で は，一般病棟あるいは救急外来において，敗血症を 疑った場合のバイオマーカー検査の感度, 特異度は, CRP では 59\%，79\%，PCT では 74\%，81\%，P-SEP で は75\%，74\%，IL-6では78\%，78\%であった。実際 の臨床では，CRPのみしか測定できない施設もあれ ば，複数のバイオマーカーが測定可能な施設もある。 そのため, 敗血症を疑った場合の補助として CRP を 用いるのであれば，PCT，P-SEP，IL-6よりも感度が 劣ることを考慮する必要がある。もしも CRPに加え PCT, P-SEP, IL-6いずれかのバイオマーカーを測定 可能な施設であれば，上記システマティックレビュー の結果から敗血症を疑う補助として，より参考になる 可能性がある。このように，これらのバイオマーカー は一部の症例に対して有意義な結果をもたらす可能性

Table 2-4-1-1 エビデンスプロファイル (一般病棟あるいは救急外来における CRP)

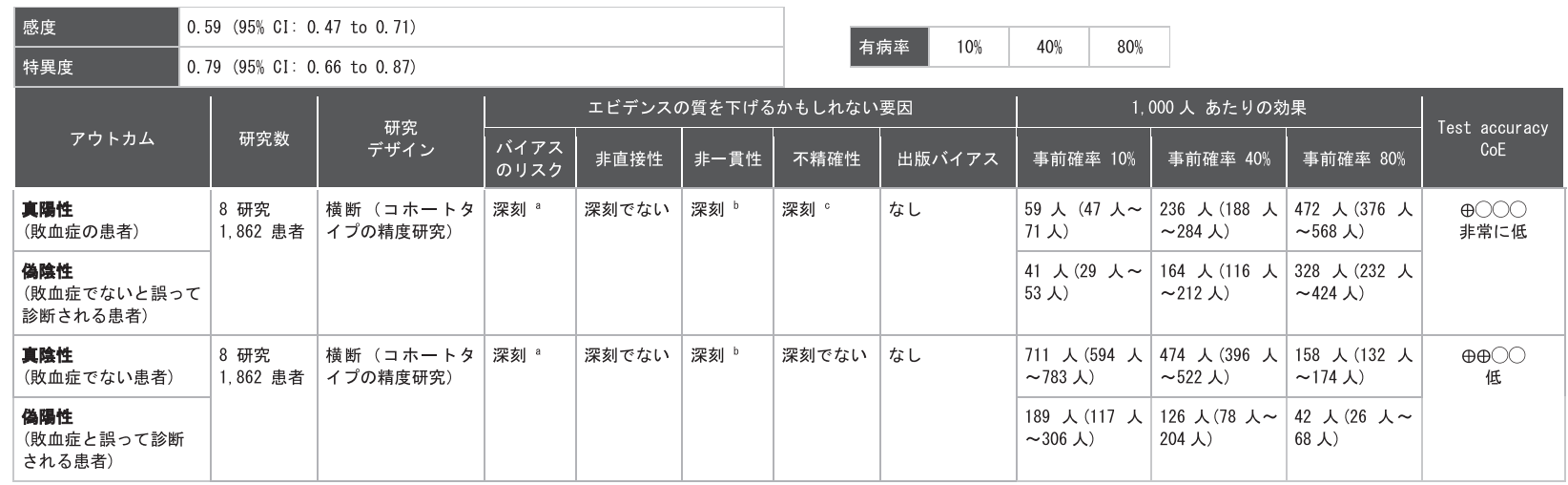

a. 観察研究のみで 8 研究のバイアスがマーカー(インデックス)に対して大きい

b. Q 值の $P$-value $<0.05$ ：異質性あり，95\%CI overlap: insufficient $I^{2}>90$ 。

c. 信頼区間が広く、特に有病率が高い状況での偽陰性の数の幅が広い。

Table 2-4-1-2 エビデンスプロファイル（一般病棟あるいは救急外来における PCT）

\begin{tabular}{|c|c|c|c|c|c|c|c|c|c|c|c|c|}
\hline 感度 & \multicolumn{5}{|c|}{$0.74(95 \% \mathrm{CI}: 0.62$ to 0.83$)$} & \multirow{2}{*}{\multicolumn{2}{|c|}{ 有病率 }} & \multirow{2}{*}{$40 \%$} & \multirow{2}{*}{$80 \%$} & & & \\
\hline 特異度 & $0.81(95 \%$ & $\mathrm{CI}: 0.73$ to 0.88$)$ & & & & & & & & & & \\
\hline \multirow[b]{2}{*}{ アウトカム } & \multirow[b]{2}{*}{ 研究数 } & \multirow{2}{*}{$\begin{array}{l}\text { 研究 } \\
\text { デザイン }\end{array}$} & \multicolumn{5}{|c|}{ エビデンスの質を下げるかもしれない要因 } & \multicolumn{4}{|c|}{ 1,000人 あたりの効果 } & \multirow{2}{*}{$\begin{array}{l}\text { Test accuracy } \\
\text { CoE }\end{array}$} \\
\hline & & & $\begin{array}{l}\text { バイアス } \\
\text { のリスク }\end{array}$ & 非直接性 & 非一貫性 & 不精確性 & 出版パイアス & 事前 & 率 $10 \%$ & 事前確率 40\% & 事前確率 $80 \%$ & \\
\hline $\begin{array}{l}\text { 真陽性 } \\
\text { (敗血症の患者) }\end{array}$ & \multirow{2}{*}{$\begin{array}{l}11 \text { 研究 } \\
3,164 \text { 患 } \\
\text { 者 }\end{array}$} & \multirow[t]{2}{*}{$\begin{array}{l}\text { 横断（コホートタイ } \\
\text { プの精度研究） }\end{array}$} & \multirow[t]{2}{*}{ 深刻 a } & \multirow[t]{2}{*}{ 深刻でない } & \multirow[t]{2}{*}{ 深刻 b } & \multirow[t]{2}{*}{ 深刻でない } & \multirow[t]{2}{*}{$\begin{array}{l}\text { 出版バイアスが } \\
\text { 強く示唆される。 }\end{array}$} & \multicolumn{2}{|c|}{$\begin{array}{l}74 \text { 人 } \\
83 \text { 人) }\end{array}$} & $\begin{array}{l}296 \text { 人(248 } \\
\sim 332 \text { 人) }\end{array}$ & $\mid \begin{array}{l}592 \text { 人(496 人 } \\
\sim 664 \text { 人) }\end{array}$ & \multirow[t]{2}{*}{$\begin{array}{l}\oplus \bigcirc 00 \\
\text { 非常に低 }\end{array}$} \\
\hline $\begin{array}{l}\text { 偽陰性 } \\
\text { (敗血症でないと誤って } \\
\text { 診断される患者) }\end{array}$ & & & & & & & & \multicolumn{2}{|c|}{$\begin{array}{l}26 \text { 人 }(17 \text { 人 } \\
38 \text { 人) }\end{array}$} & $\begin{array}{l}104 \text { 人(68 人 } \\
152 \text { 人) }\end{array}$ & 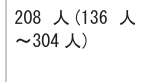 & \\
\hline $\begin{array}{l}\text { 真陰性 } \\
\text { (敗血症でない患者) }\end{array}$ & \multirow{2}{*}{$\begin{array}{l}11 \text { 研究 } \\
3,164 \text { 患 } \\
\text { 者 }\end{array}$} & \multirow[t]{2}{*}{$\begin{array}{l}\text { 横断（コホートタイ } \\
\text { プの精度研究） }\end{array}$} & \multirow[t]{2}{*}{ 深刻 a } & \multirow[t]{2}{*}{ 深刻でない } & \multirow[t]{2}{*}{ 深刻 b } & \multirow[t]{2}{*}{ 深刻でない } & \multirow[t]{2}{*}{$\begin{array}{l}\text { 出版バイアスが } \\
\text { 強く示唆される。 }\end{array}$} & \multicolumn{2}{|c|}{ 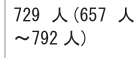 } & $\begin{array}{l}486 \curlywedge(438 \curlywedge \\
\sim 528 \text { 人) }\end{array}$ & $\begin{array}{l}162 \curlywedge(146 \curlywedge \\
\sim 176 \curlywedge)\end{array}$ & \multirow[t]{2}{*}{$\begin{array}{l}\oplus \bigcirc 0 \bigcirc \\
\text { 非常に低 }\end{array}$} \\
\hline $\begin{array}{l}\text { 伪陽性 } \\
\text { (敗血症と誤って診断 } \\
\text { される患者) }\end{array}$ & & & & & & & & \multicolumn{2}{|c|}{$\begin{array}{l}171 \text { 人(108人 } \\
\sim 243 \text { 人 })\end{array}$} & 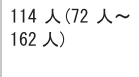 & $\begin{array}{l}38 \curlywedge(24 \curlywedge \sim \\
54 \hat{\curlywedge})\end{array}$ & \\
\hline
\end{tabular}

a. 観察研究のみで 11 研究のバイアスがマーカー (インデックス)に対して大きい。

b. Q 值の $P$-value $\left\langle 0.05\right.$ : 異質性あり, $95 \%$ CI overlap: insufficient $\mathrm{I}^{2}>75$ 。

c. Deeks' Funnel Plot Asymmetry Test で非対称性であった $(P=0,01)$ 
Table 2-4-1-3 エビデンスプロファイル (一般病棟あるいは救急外来における P-SEP)

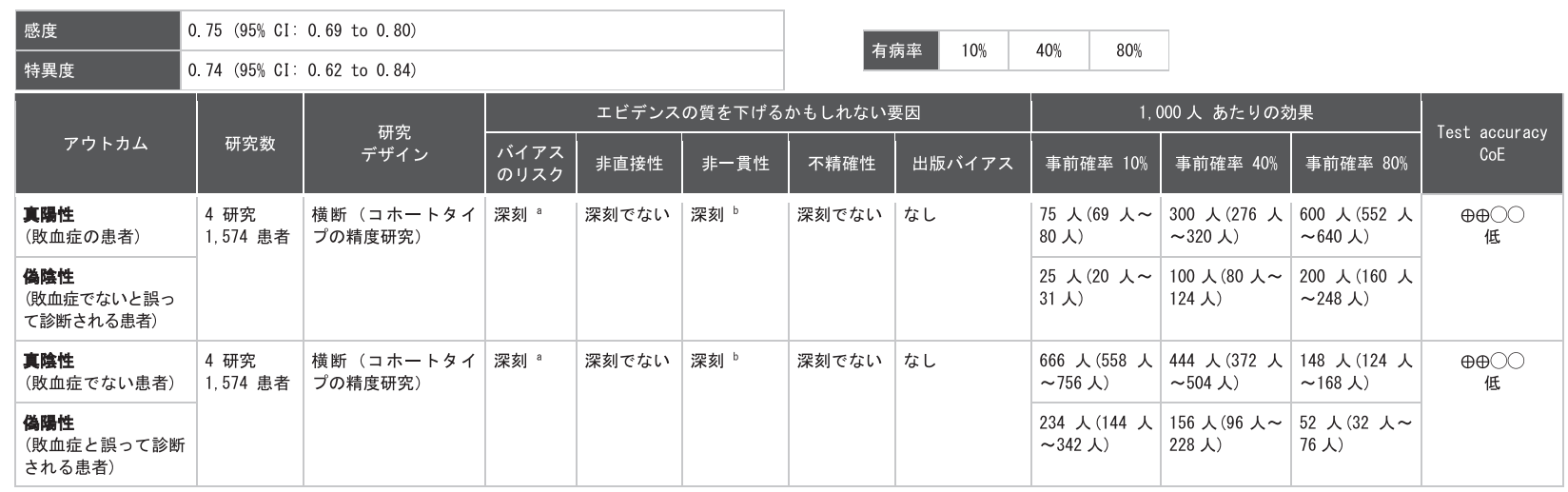

a. 観察研究のみで 4 研究のバイアスがマーカー (インデックス)に対して大きい。

b. $Q$ 値, $\mathrm{I}^{2}$ 值が高く, P-value<0. 05: 異質性あり。

Table 2-4-1-4 エビデンスプロファイル（一般病棟あるいは救急外来における IL-6）

\begin{tabular}{|c|c|c|c|c|c|c|c|c|c|c|c|c|}
\hline \multirow{2}{*}{\begin{tabular}{|l|} 
感度 \\
特異度
\end{tabular}} & \multicolumn{5}{|c|}{$0.78(95 \% \mathrm{CI}: 0.62$ to 0.88$)$} & \multirow{2}{*}{ 有病率 } & \multirow{2}{*}{$10 \%$} & \multirow{2}{*}{$40 \%$} & \multirow{2}{*}{$80 \%$} & & & \\
\hline & $0.78(95 \% \mathrm{CI}: 0$ & to 0.85 ) & & & & & & & & & & \\
\hline \multirow[b]{2}{*}{ アウトカム } & \multirow[b]{2}{*}{ 研究数 } & \multirow{2}{*}{$\begin{array}{l}\text { 研究 } \\
\text { デザイン }\end{array}$} & \multicolumn{5}{|c|}{ エビデンスの質を下げるかもしれない要因 } & \multicolumn{4}{|c|}{ 1,000人 あたりの効果 } & \multirow{2}{*}{$\begin{array}{c}\text { Test accuracy } \\
\text { CoE }\end{array}$} \\
\hline & & & $\begin{array}{l}\text { パイアス } \\
\text { のリスク }\end{array}$ & 非直接性 & 非一貫性 & 不精確性 & 出版パイアス & \multicolumn{2}{|c|}{ 事前確率 $10 \%$} & 事前確率 40\% & 事前確率 $80 \%$ & \\
\hline $\begin{array}{l}\text { 真陽性 } \\
\text { (敗血症の患者) }\end{array}$ & \multirow[t]{2}{*}{$\begin{array}{l}4 \text { 研究 } \\
563 \text { 患者 }\end{array}$} & \multirow[t]{2}{*}{$\begin{array}{l}\text { 横断（コホートタイ } \\
\text { プの精度研究） }\end{array}$} & \multirow[t]{2}{*}{ 深刻a } & \multirow[t]{2}{*}{ 深刻でない } & \multirow[t]{2}{*}{ 深刻 b } & \multirow[t]{2}{*}{ 深刻でない } & \multirow[t]{2}{*}{ なし } & \multicolumn{2}{|c|}{$\begin{array}{l}78 \text { 人 }(62 \curlywedge \sim \\
88 \text { 人) }\end{array}$} & $\begin{array}{l}312 \text { 人(248 人 } \\
\sim 352 \text { 人) }\end{array}$ & $\begin{array}{l}624 \text { 人(496 人 } \\
\sim 704 \text { 人) }\end{array}$ & \multirow[t]{2}{*}{$\underset{\text { 低 }}{\oplus \oplus \bigcirc \bigcirc}$} \\
\hline $\begin{array}{l}\text { 偽陰性 } \\
\text { (敗血症でないと誤って } \\
\text { 診断される患者) }\end{array}$ & & & & & & & & \multicolumn{2}{|c|}{$\begin{array}{l}22 \text { 人(12人 } \\
38 \text { 人) }\end{array}$} & $\begin{array}{l}88 \text { 人(48人 } \\
152 \text { 人) }\end{array}$ & 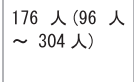 & \\
\hline $\begin{array}{l}\text { 真陰性 } \\
\text { (敗血症でない患者) }\end{array}$ & \multirow[t]{2}{*}{$\begin{array}{l}4 \text { 研究 } \\
563 \text { 患者 }\end{array}$} & \multirow[t]{2}{*}{$\begin{array}{l}\text { 横断（コホートタイ } \\
\text { プの精度研究） }\end{array}$} & \multirow[t]{2}{*}{ 深刻 a } & \multirow[t]{2}{*}{ 深刻でない } & \multirow[t]{2}{*}{ 深刻でない } & \multirow[t]{2}{*}{ 深刻でない } & \multirow[t]{2}{*}{ なし } & \multicolumn{2}{|c|}{$\begin{array}{l}702 \text { 人(630人 } \\
\sim 765 \text { 人) }\end{array}$} & $\begin{array}{l}468 \text { 人(420人 } \\
\sim 510 \text { 人) }\end{array}$ & $\begin{array}{l}156 \text { 人(140人 } \\
\sim 170 \text { 人 })\end{array}$ & \multirow[t]{2}{*}{$\begin{array}{c}\oplus \oplus \oplus \bigcirc \\
\text { 中 }\end{array}$} \\
\hline $\begin{array}{l}\text { 糧陽性 } \\
\text { (敗血症と誤って診断 } \\
\text { される患者) }\end{array}$ & & & & & & & & \multicolumn{2}{|c|}{$\begin{array}{l}198 \text { 人(135人 } \\
\sim 270 \text { 人) }\end{array}$} & $\begin{array}{l}132 \text { 人(90人 } \\
\sim 180 \text { 人) }\end{array}$ & $\begin{array}{l}44 \text { 人( }(30 \text { 人 } \\
60 \text { 人) }\end{array}$ & \\
\hline
\end{tabular}

、観察研究のみで 4 研究のパイアスがマーカー (インデックス)に対して大きい

b. Q 値の $P$-value $<0.05$ : 異質性あり, $95 \%$ CI over lap: insufficient: $I^{2}=91$ 。

もあるが，測定結果の解釈は，患者の状況，採血した 時間, 場所など様々な要因により変化することにも注 意が必要である。そのため, メ久解析から得られた感 度，特異度を具体的に提示したうえで，様々な状況下 に置かれた読者に個々に判断していただくこととし た。

当委員会では, 本 CQ に対して，『バイオマーカー 単独による敗血症診断は一般的に困難と考えられ，そ の使用はいずれも全身状態観察などに加えた補助的な 位置づけといえる』という Answer を提示する。

\section{文 献}

1）西田修, 小倉裕司, 井上茂亮, 他: 日本版敗血症診療ガイドラ イン 2016 作成特別委員会. 日本版敗血症診療ガイドライン 2016. 日集中医誌. 2017; 24: S1-232.

2）西田修, 小倉裕司, 井上茂亮, 他: 日本版敗血症診療ガイドラ イン 2016 作成特別委員会. 日本版敗血症診療ガイドライン 2016. 日救急医会誌. 2017; 28: S1-232.

3) Gaini S, Koldkjaer OG, Pedersen C, et al: Procalcitonin, lipopolysaccharide-binding protein, interleukin-6 and C-reactive protein in community-acquired infections and sepsis: a prospective study. Crit Care. 2006; 10: R53.
4) Jaimes FA, De La Rosa GD, Valencia ML, et al: A latent class approach for sepsis diagnosis supports use of procalcitonin in the emergency room for diagnosis of severe sepsis. BMC Anesthesiol. 2013; 13: 23.

5) Jekarl DW, Lee SY, Lee J, et al: Procalcitonin as a diagnostic marker and IL-6 as a prognostic marker for sepsis. Diagn Microbiol Infect Dis. 2013; 75: 342-7.

6) Jekarl DW, Kim JY, Lee S, et al: Diagnosis and evaluation of severity of sepsis via the use of biomarkers and profiles of 13 cytokines: A multiplex analysis. Clin Chem Lab Med. 2015; 53: 575-81.

7) Oshita H, Sakurai J, Kamitsuna M: Semi-quantitative procalcitonin test for the diagnosis of bacterial infection: Clinical use and experience in Japan. J Microbiol Immunol Infect. 2010; 43: 222-7.

8) de Guadiana Romualdo LG, Torrella PE, González MV, et al: Diagnostic accuracy of presepsin (soluble CD14 subtype) for prediction of bacteremia in patients with systemic inflammatory response syndrome in the emergency department. Clin Biochem. 2014; 47: 505-8

9) de Guadiana Romualdo LG, Torrella PE, Acebes SR, et al: Diagnostic accuracy of presepsin (sCD14-ST) as a biomarker of infection and sepsis in the emergency department. Clin Chim Acta. 2017; 464: 6-11.

10) de Guadiana Romualdo LG, Albaladejo Otón MD, Acebes SR, et al: Diagnostic accuracy of lipopolysaccharide-binding protein for sepsis in patients with suspected infection in the emergency department. Ann Clin Biochem. 2018; 55: 143-8. 
11) Angeletti S, Dicuonzo G, Fioravanti M, et al: Procalcitonin, MR-Proadrenomedullin, and Cytokines Measurement in Sepsis Diagnosis: Advantages from Test Combination. Dis Markers. 2015; 2015: 951532.

12) Liu B, Chen YX, Yin Q, et al: Diagnostic value and prognostic evaluation of Presepsin for sepsis in an emergency department. Crit Care. 2013; 17: R244.

13) Ulla M, Pizzolato E, Lucchiari M, et al: Diagnostic and prognostic value of presepsin in the management of sepsis in the emergency department: A multicenter prospective study. Crit Care. 2013; 17: R168.
CQ2-4-2 : 集中治療室において, 敗血症診断のバ イオマーカー検査としてC 反応性蛋白 (CRP), プロカルシトニン (PCT), プレセプシン (P-SEP), インターロイキン 6（IL-6）の位置づけは？

Answer : 集中治療室において, 敗血症を疑ったとき のバイオマーカー検査の感度, 特異度は, CRP では 71\%，61\%，PCTでは74\%，70\%，P-SEPでは 82\%， $73 \%$, IL-6では 72\%，76\%であった。したがって， バイオマーカー単独による敗血症診断は一般的に困難 と考えられ，その使用はいずれも全身状態観察などに 加えた補助的な位置づけといえる（BQに対する情報 提示)。

\section{（1）背景および本 $C Q$ の重要度}

敗血症（Sepsis-3）の診断は, 現在, “重篤な臓器障 害を認める感染症” となっている。しかし, 臨床上, 感染症を疑うが確定診断に直ちには至らない場合, 治 療方法の選択に苦慮することも少なくない。このよう な場合に，バイオマーカーの利用可能性を確認する価 值がある。バイオマーカーとしては, CRP, PCT, P-SEP，IL-6の 4 種類が集中治療室において診断目的 で用いられている。これらのバイオマーカーに関し て, 前回の日本版敗血症診療ガイドライン（J-SSCG） 2016 では, ICUなどの重症患者において敗血症が疑 われる場合, 感染症診断の補助検査として P-SEP ま たはPCT を評価することを弱く推奨し，IL-6 を日常 的には評価しないことを弱く推奨すると提言し

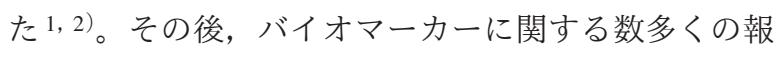
告がなされ，集中治療室における敗血症診断目的で 4 種類のバイオマーカーを評価することが必要であると 考え，本ガイドラインにおいても取り上げた。

（2）本 $C Q$ が background question（BQ）となった経 緯

本 CQ は当初, 『感染症診断にバイオマーカーとして CRP, PCT, P-SEP, IL-6のいずれを用いるか?』とい うGRADEに則った CQ であった。しかし，本ガイド ラインの特性を鑑みて，全身状態に悪影響を及ぼすよ うな重篤な病態である敗血症に焦点を置くこととなっ た。システマティックレビューは CQ2-4-1 と合わせて 網羅的文献検索を行い，その抽出論文から「一般病棟 あるいは救急外来部門」と「集中治療部門」に分けて 診断精度研究のシステマティックレビューを行った。 「集中治療部門」で対象となった論文は計 9 編で，各 バイオマーカーのメタ解析で統合された論文は, CRP 
7 編 ${ }^{3-9)}$, PCT 9 編 ${ }^{3-11), ~ P-S E P ~} 4$ 編3, 7, 8, 10), IL-6 6 編4-7, 9, 11) である。

その結果をもとにエビデンスプロファイル（EP）, evidence to decision（EtD）をまとめ, GRADE で評価 を行い，『集中治療室において敗血症診断のバイオ マーカーとして，CRP，PCT，P-SEPを測定すること を弱く推奨する。IL-6 を測定しないことを弱く推奨 する』という推奨文を提示し，委員会での投票が行わ れた。2 回の投票の結果，合意形成に至らなかった （同意中央值 7 点，不一致指数 0.0184 ）。委員からは, 「感染症ではなく敗血症の診断において，バイオマー カー単独の役割はあくまで補助的である」「CRPが PCT, P-SEP と同じ弱い推奨，IL-6 だけが弱い非推奨 とする評価は，適切とはいえない」などの意見が出さ れた。委員会で議論を重ねた結果，最終的に本 CQ は BQ として扱うほうが適切と判断した。
（3）解説

以下の解説は，システマティックレビューの結果お よびGRADEの推奨工程として作成した EP（Table 2-4-2-1〜2-4-2-4）を参考に作成した。

本 CQ におけるシステマティックレビューの結果で は，集中治療室において，敗血症を疑った場合のバイ オマーカー検査の感度，特異度は，CRPでは $71 \%$, 61\%，PCT では 74\%，70\%，P-SEPでは 82\%，73\%， IL-6では 72\%，76\%であり，この結果は，感度，特 異度ともに十分に高いとも低いともいえないものであ る。

システマティックレビューに用いた個々の論文 $3-5)$ からは，バイオマーカーが敗血症の診断に対して有意 義な結果をもたらす可能性も示唆される。一方で，バ イオマーカー測定結果が，患者の状況，採血した時期 など様々な要因により変化したり, 細菌の種類, 感染 部位によっても影響を受けることにも注意が必要であ る。そのため, メ夕解析から得られた感度, 特異度を

Table 2-4-2-1エビデンスプロファイル（ICUにおけるCRP）

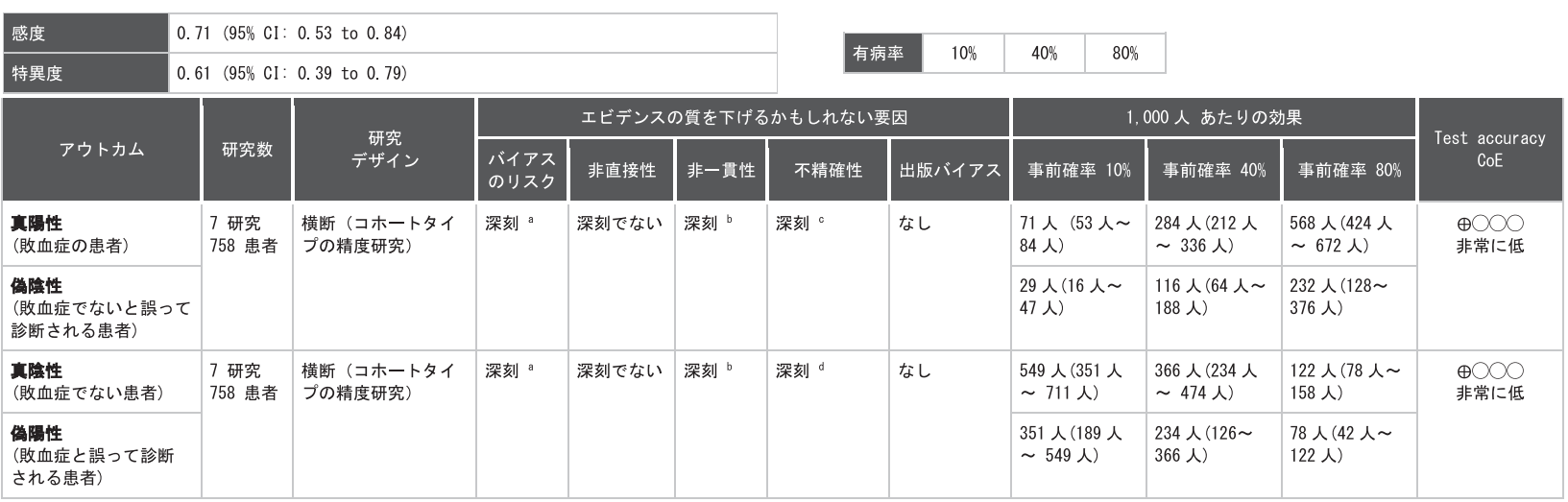

a. 観察研究のみで 7 研究のバイアスがマーカー(インデックス)に対して大きい

b. Q 值の $P$-value $<0.05$ : 異質性あり, $95 \%$ CI overlap:insufficient $I^{2}>85$ 。

c. 信頼区間が広く、特に有病率が高い状況での偽陰性の数の幅が広い。

d. 信頼区間が広く，偽陽性の数の幅が広い。

Table 2-4-2-2エビデンスプロファイル（ICUにおける PCT）

\begin{tabular}{|c|c|c|c|c|c|c|c|c|c|c|c|c|}
\hline 感度 & \multicolumn{5}{|c|}{$0.74(95 \% \mathrm{CI}: 0.64$ to 0.83$)$} & \multirow{2}{*}{ 有病 } & & & \multirow{2}{*}{$80 \%$} & & & \\
\hline 特異度 & $0.70(95 \% \mathrm{CI}:$ & 0.60 to 0.78 ) & & & & & 列 4 & $40 \%$ & & & & \\
\hline \multirow[b]{2}{*}{ アウトカム } & \multirow[b]{2}{*}{ 研究数 } & \multirow{2}{*}{$\begin{array}{l}\text { 研究 } \\
\text { デザイン }\end{array}$} & \multicolumn{5}{|c|}{ エビデンスの質を下げるかもしれない要因 } & \multicolumn{4}{|c|}{ 1,000人 あたりの効果 } & \multirow{2}{*}{$\begin{array}{c}\text { Test accuracy } \\
\text { CoE }\end{array}$} \\
\hline & & & $\begin{array}{l}\text { バイアス } \\
\text { のリスク }\end{array}$ & 非直接性 & 非一貫性 & 不精確性 & 出版バイアス & 事前確率 & $10 \%$ & 事前確率 40\% & 事前確率 80\% & \\
\hline $\begin{array}{l}\text { 真陽性 } \\
\text { (敗血症の患者) }\end{array}$ & \multirow[t]{2}{*}{$\begin{array}{l}9 \text { 研究 } \\
1,142 \text { 患者 }\end{array}$} & \multirow[t]{2}{*}{$\begin{array}{l}\text { 横断（コホートタイ } \\
\text { プの精度研究） }\end{array}$} & \multirow[t]{2}{*}{ 深刻 a } & \multirow[t]{2}{*}{ 深刻でない } & \multirow[t]{2}{*}{ 深刻 b } & \multirow[t]{2}{*}{ 深刻でない } & \multirow[t]{2}{*}{ なし } & $\begin{array}{l}74 \text { 人 } \\
83 \text { 人) }\end{array}$ & 人 & $\begin{array}{l}296 \text { 人(256 人 } \\
332 \text { 人) }\end{array}$ & $\begin{array}{l}592 \text { 人(512 人 } \\
664 \text { 人) }\end{array}$ & \multirow[t]{2}{*}{$\underset{\text { 低 }}{\oplus \oplus \bigcirc}$} \\
\hline $\begin{array}{l}\text { 偽陰性 } \\
\text { (敗血症でないと誤っ } \\
\text { て診断される患者) }\end{array}$ & & & & & & & & $\begin{array}{l}26 \hat{\curlywedge}(17 \\
36 \hat{\curlywedge})\end{array}$ & $\curlywedge \sim$ & 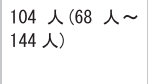 & 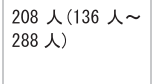 & \\
\hline $\begin{array}{l}\text { 真陰性 } \\
\text { (敗血症でない患者) }\end{array}$ & \multirow[t]{2}{*}{$\begin{array}{l}9 \text { 研究 } \\
1,142 \text { 患者 }\end{array}$} & \multirow[t]{2}{*}{$\begin{array}{l}\text { 横断（コホートタイ } \\
\text { プ精度研究） }\end{array}$} & \multirow[t]{2}{*}{ 深刻 a } & \multirow[t]{2}{*}{ 深刻でない } & \multirow[t]{2}{*}{ 深刻。 } & \multirow[t]{2}{*}{ 深刻でない } & \multirow[t]{2}{*}{ なし } & $\begin{array}{l}630 \text { 人(540 } \\
702 \text { 人) }\end{array}$ & 人 & $\begin{array}{l}420 \text { 人(360人 } \\
468 \text { 人) }\end{array}$ & $\begin{array}{l}140 \text { 人(120 人 } \\
156 \text { 人) }\end{array}$ & \multirow[t]{2}{*}{$\underset{\text { 低 }}{\oplus \oplus \bigcirc \bigcirc}$} \\
\hline $\begin{array}{l}\text { 偽陽性 } \\
\text { (敗血症と誤って診断 } \\
\text { される患者) }\end{array}$ & & & & & & & & $\begin{array}{l}270 \text { 人(198 } \\
360 \text { 人) }\end{array}$ & 人 & $\begin{array}{l}180 \text { 人(132人〜 } \\
240 \text { 人) }\end{array}$ & $\begin{array}{l}60 \text { 人 (44 人 } \\
80 \text { 人) }\end{array}$ & \\
\hline
\end{tabular}

a. 観察研究のみで 9 研究のバイアスがマーカー（インデックス）に対して大きい。

b. Q 值の $P$-value $<0.05$ : 異質性あり, $95 \%$ CI overlap: insufficient $I^{2}=86$ 。

c. $Q$ 值の $P$-value $<0.05$ : 異質性あり, $95 \%$ CI overlap: insufficient $I^{2}=76$ 。 
Table 2-4-2-3 エビデンスプロファイル（ICUにおけるP-SEP）

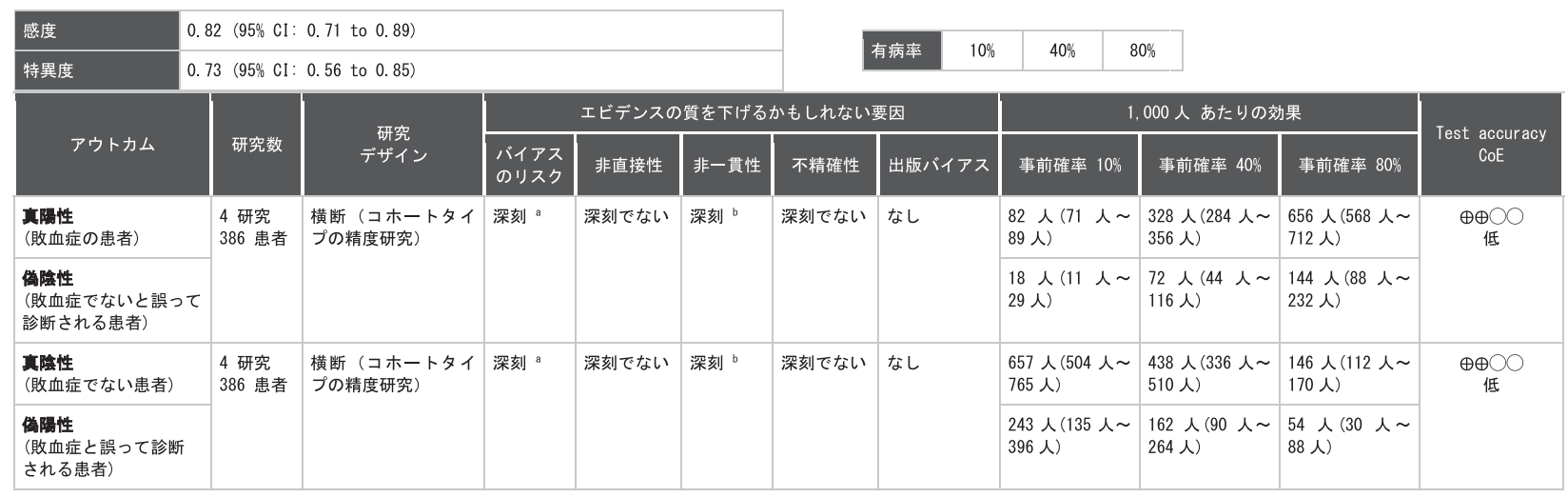

a. 観察研究のみで 4 研究のバイアスがマーカー(インデックス)に対して大きい。

b. Q 値の $P$ value<0. 05: 異質性あり, $95 \%$ CI over lap: sufficient 。

Table 2-4-2-4エビデンスプロファイル (ICUにおける IL-6)

\begin{tabular}{|c|c|c|c|c|c|c|c|c|c|c|c|}
\hline \multirow{2}{*}{$\begin{array}{l}\text { 感度 } \\
\text { 特異度 }\end{array}$} & \multicolumn{5}{|c|}{$0.72(95 \% \mathrm{CI}: 0.49$ to 0.88$)$} & \multirow{2}{*}{ 有病萃 } & \multirow{2}{*}{$10 \%$} & & & & \\
\hline & \multicolumn{5}{|c|}{$0.76(95 \% \mathrm{CI}: 0.62$ to 0.86$)$} & & & $40 \%$ & & & \\
\hline \multirow[b]{2}{*}{ アウトカム } & \multirow[b]{2}{*}{ 研究数 } & \multirow{2}{*}{$\begin{array}{l}\text { 研究 } \\
\text { デザイン }\end{array}$} & \multicolumn{5}{|c|}{ エビデンスの質を下げるかもしれない要因 } & \multicolumn{3}{|c|}{ 1,000人 あたりの効果 } & \multirow{2}{*}{$\begin{array}{l}\text { Test accuracy } \\
\text { CoE }\end{array}$} \\
\hline & & & $\begin{array}{l}\text { バイアス } \\
\text { のリスク }\end{array}$ & 非直接性 & 非一貫性 & 不精確性 & 出版バイアス & 事前確率 10\% & 事前確率 40\% & 事前確率 $80 \%$ & \\
\hline $\begin{array}{l}\text { 真陽性 } \\
\text { (敗血症の患者) }\end{array}$ & \multirow[t]{2}{*}{$\begin{array}{l}6 \text { 研究 } \\
855 \text { 患者 }\end{array}$} & \multirow[t]{2}{*}{$\begin{array}{l}\text { 横断（コホートタイ } \\
\text { プの精度研究） }\end{array}$} & \multirow[t]{2}{*}{ 深刻 a } & \multirow[t]{2}{*}{ 深刻でない } & \multirow[t]{2}{*}{ 深刻 b } & \multirow[t]{2}{*}{ 深刻。 } & \multirow[t]{2}{*}{ なし } & $\begin{array}{l}72 \text { 人(49人 } \\
88 \text { 人) }\end{array}$ & $\begin{array}{l}288 \curlywedge(196 \curlywedge \\
\sim 352 \curlywedge)\end{array}$ & $\begin{array}{l}576 \text { 人(392 ᄉ } \\
\sim 704 \text { 人) }\end{array}$ & \multirow[t]{2}{*}{$\begin{array}{l}\oplus \bigcirc \bigcirc \bigcirc \\
\text { 非常に低 }\end{array}$} \\
\hline $\begin{array}{l}\text { 偽陰性 } \\
\text { (敗血症でないと誤って } \\
\text { 診断される患者) }\end{array}$ & & & & & & & & $\begin{array}{l}28 \curlywedge(12 \curlywedge \sim \\
51 \curlywedge)\end{array}$ & $\begin{array}{l}112 \text { 人(48 人 } \\
204 \text { 人) }\end{array}$ & $\begin{array}{l}224 \text { 人(96人 } \\
408 \text { 人) }\end{array}$ & \\
\hline $\begin{array}{l}\text { 真陰性 } \\
\text { (敗血症でない患者) }\end{array}$ & \multirow[t]{2}{*}{$\begin{array}{l}6 \text { 研究 } \\
855 \text { 患者 }\end{array}$} & \multirow[t]{2}{*}{$\begin{array}{l}\text { 横断(コホートタイ } \\
\text { プの精度研究) }\end{array}$} & \multirow[t]{2}{*}{ 深刻 a } & \multirow[t]{2}{*}{ 深刻でない } & \multirow[t]{2}{*}{ 深刻 b } & \multirow[t]{2}{*}{ 深刻でない } & \multirow[t]{2}{*}{ なし } & $\begin{array}{l}684 \text { 人(558人 } \\
\sim 774 \text { 人) }\end{array}$ & $\begin{array}{l}456 \text { 人(372人 } \\
\sim 516 \text { 人) }\end{array}$ & 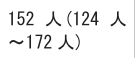 & \multirow[t]{2}{*}{$\underset{\text { 低 }}{\oplus \oplus \bigcirc \bigcirc}$} \\
\hline $\begin{array}{l}\text { 僧陽性 } \\
\text { (敗血症と誤って診断 } \\
\text { される患者) }\end{array}$ & & & & & & & & $\begin{array}{l}216 \curlywedge(126 \curlywedge \\
\sim 342 \curlywedge)\end{array}$ & $\begin{array}{l}144 \text { 人(84 人 } \\
228 \text { 人) }\end{array}$ & $\begin{array}{l}48 \text { 人 }(28 \text { 人 } \\
76 \text { 人) }\end{array}$ & \\
\hline
\end{tabular}

. 観察研究のみで 6 研究のバイアスがマーカー (インデックス)に対して大きい。

b. $Q$ 值の $P$-value $<0.05$ : 異啠性あり, $95 \%$ CI over lap: insufficient $I^{2}>90$ 。

c. 信頼区間が広く、特に有病率が高い状況での领陰性の数の幅が広い。

具体的に提示したうえで, 様々な状沉下に置かれた読 者に個々に判断していただくこととした。

当委員会では，本 $\mathrm{CQ}$ に対して，『バイオマーカー 単独による敗血症診断は一般的に困難と考元られ，そ の使用はいずれも全身状態観察などに加えた補助的な 位置づけといえる』という Answer を提示する。

\section{文 献}

1）西田修, 小倉裕司, 井上茂亮, 他: 日本版敗血症診療ガイドラ イン 2016 作成特別委員会. 日本版敗血症診療ガイドライン 2016. 日集中医誌. 2017; 24: S1-232.

2）西田修, 小倉裕司, 井上茂亮, 他: 日本版敗血症診療ガイドラ イン 2016 作成特別委員会. 日本版敗血症診療ガイドライン 2016. 日救急医会誌. 2017; 28: S1-232.

3) Ali FT, Ali MAM, Elnakeeb MM, et al: Presepsin is an early monitoring biomarker for predicting clinical outcome in patients with sepsis. Clin Chim Acta. 2016; 460: 93-101.

4) Bacli C, Sungurtekin H, Gürses E, et al: Usefulness of procalcitonin for diagnosis of sepsis in the intensive care unit. Critical Care. 2003; 7: 85-90.

5) Du B, Pan J, Cheng D, et al: Serum procalcitonin and interleukin-6 levels may help to differentiate systemic inflammatory response of infectious and non-infectious origin. Chin Med J (Engl). 2003; 116: 538-42.
6) Meynaar IA, Droog W, Batstra M, et al: In critically ill patients, serum procalcitonin is more useful in differentiating between sepsis and SIRS than CRP, Il-6, or LBP. Crit Care Res Pract. 2011; 2011: 594645.

7) Takahashi W, Nakada TA, Yazaki M, et al: Interleukin-6 Levels Act as a Diagnostic Marker for Infection and a Prognostic Marker in Patients with Organ Dysfunction in Intensive Care Units. Shock. 2016; 46: 254-60.

8) Yamamoto T, Nishimura T, Kaga S, et al: Diagnostic accuracy of presepsin for sepsis by the new Sepsis-3 definitions. Am J Emerg Med. 2019; 37: 1936-41.

9) Yang Y, Xie J, Guo F, et al: Combination of C-reactive protein, procalcitonin and sepsis-related organ failure score for the diagnosis of sepsis in critical patients. Ann Intensive Care. 2016; 6: 51.

10) Klouche K, Cristol JP, Devin J, et al: Diagnostic and prognostic value of soluble CD14 subtype (Presepsin) for sepsis and community-acquired pneumonia in ICU patients. Ann Intensive Care. 2016; 6: 59 .

11) Mat-Nor MB, Md Ralib A, Abdulah NZ, et al: The diagnostic ability of procalcitonin and interleukin- 6 to differentiate infectious from noninfectious systemic inflammatory response syndrome and to predict mortality. J Crit Care. 2016; 33: 245-51. 


\section{CQ3 : 画像診断と感染源のコントロール}

敗血症に対して，早期に治療を開始することの重要 性は広く受け入れられている。早期治療の中でも, 感 染源のコントロールは, 敗血症の根源である「感染 巣」を絶ち「コントロールする」ことにより有効性を 発揮する治療法であり, 初期治療の礎をなす。迅速に 適切な感染源のコントロールを行うためには画像診断 は必要不可欠である。したがって画像診断に関する CQ 2 つまず取り上げ，続いて感染源のコントロー ルに関する CQを 7 つ取り上げた。

まず画像診断に関する 1 つ目の CQ として,「CQ 3-1 : 敗血症を疑う患者に対して, 感染源検索のため に画像検査を行うか?」を取り上げた。感染源検索の ための画像検査には，単純 X 線，超音波検査， CT 検 査, MRI 検査があり, 部位により有用性の高い検査 方法は異なる。本 CQ の解説では, 実際の診療現場で 参考にしていただけるように, 各臓器・疾患に特有と 考えられる画像診断法について表も含め解説してい る。

次に画像診断に関する 2 つ目の CQ として，全身造 影 $\mathrm{CT}$ 検査に関する CQ「CQ3-2：感染源が不明な敗 血症患者に対して，全身造影 CT 検査を早期に行う か?」を取り上げた。感染源が不明である場合，早期 に感染源の検索を行うことは治療方針を策定するため
にも必要不可欠である。本邦で普及している画像診断 である CT 検査を行うことは局所診断および感染源の 重症度を判断するためにも重要であるため, CQ とし て取り上げた。

続いて感染源のコントロールに関する CQ の選定に ついて議論を重ね, 特に感染源のコントロールが重要 と考えられる，下記の 6 つの感染源，1）腹腔内感染 症，2）感染性膵壊死，3）尿管閉塞を原因とする急性 腎孟腎炎，4）壊死性軟部組織感染症，5）カテーテル 関連血流感染，6）膿胸を選び，CQ として設定した。 感染源のコントロールの基本方針は「迅速に」「適 切に」であることは誰もが知るところである。手法に 関しては, 低侵襲で, 合併症発生率が低く, 十分な効 果が期待できる手法が最善である。また，基本的に感 染源のコントロールは迅速に行うべきであるが，例外 として, 待機的な介入を考慮するものとして感染性膵 壊死が挙げられることを提示した。

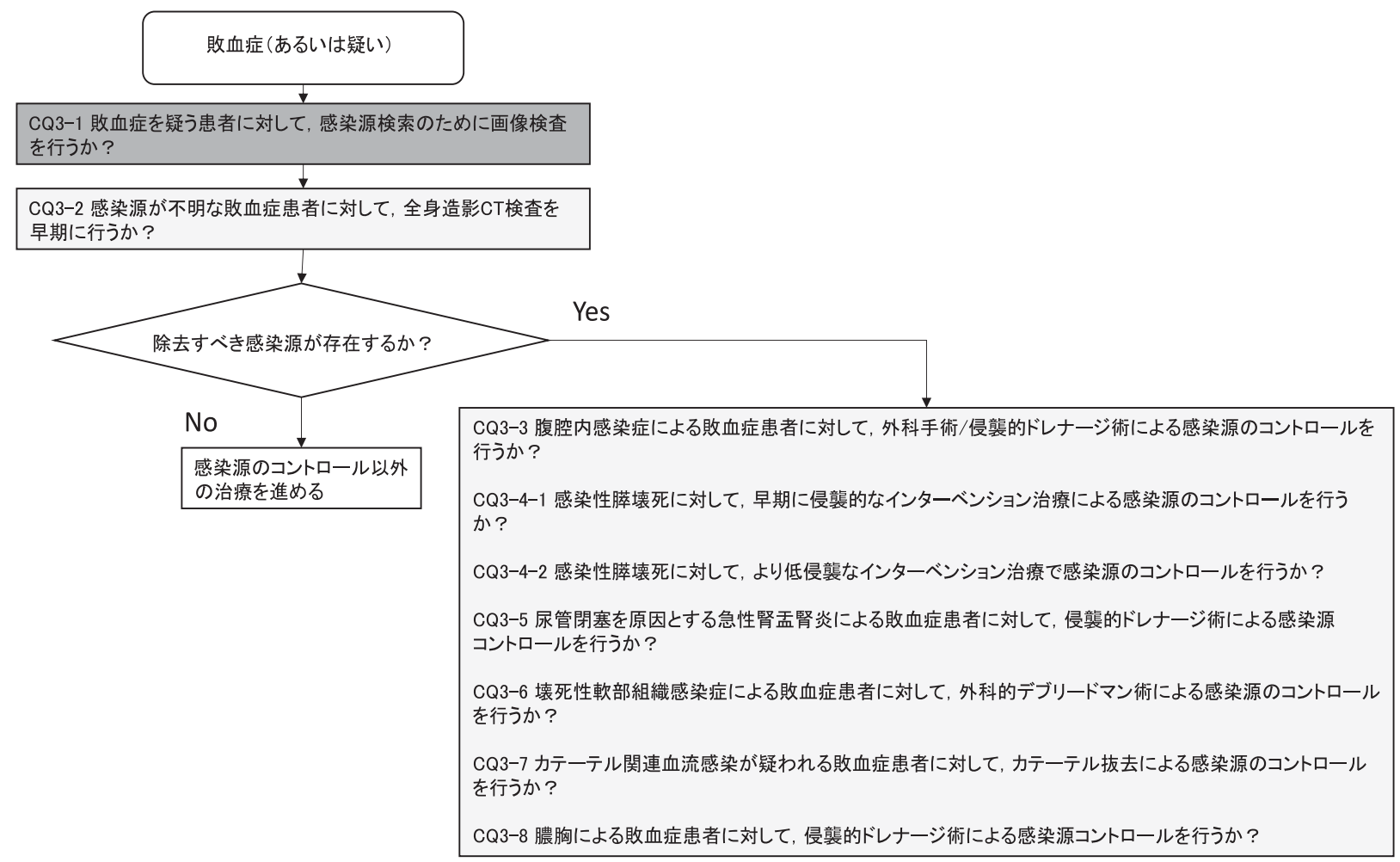

画像診断と感染源のコントロール[診療フロー] 
CQ3-1：敗血症を疑う患者に対して，感染源検 索のために画像検査を行うか?

Answer：感染源が明らかでない場合は，感染源検索 のために画像検査を行う（Good Practice Statement）。

\section{（1）背景および本 $C Q$ の重要度}

早期の感染源のコントロールは，敗血症患者の転帰 改善につながる重要な治療法である。そのため，敗血 症を疑う患者に対して，コントロールが必要な感染源 が存在するかどうかを早期に評価することは重要であ り，その手段として画像検査を考慮する必要があると 考え，本 $\mathrm{CQ}$ の立案に至った。

\section{（2）解説}

感染源検索のための画像検査には，単純 X 線検査， 超音波検査, CT 検査, MRI 検査があり，部位により 有用性の高い検査方法は異なる。以下に各臓器・疾患 に特有と考えられる画像診断法について解説する (Table 3-1-1)。

(1)頭頸部

脳膿瘍・髄膜脳炎 : CT 検査は MRI 検査に比して緊 急検査として施行しやすいため，先行して施行される 場合が多い。造影 MRI 検査は, 膿瘍の被膜や周囲組 織への炎症の波及を検出できるため最も推奨される画 像検査である1)。

頸部膿瘍（降下性縦隔炎）：体表に近い頸部膿瘍は 超音波検査にて検出可能であるが，深頸部の膿瘍の検 出には限界があり, CT 検査が有用である。造影剤を 用いた CT 検査は感染による液体貯留と血管などの構 造物を明瞭に鑑別できるため推奨される検査であ る2)。

(2)胸部

膿胸 : 単純 $X$ 線検査，超音波検査は第 1 選択の検
査である。膿胸を疑う際，造影 CT 検査は感染源のコ ントロールの実施や治療経過の評価を行うための指標 として有用な検査である。

感染性心内膜炎 : 感染性心内膜炎の診断基準（Duke の診断基準) 3) の 2 大項目の 1 つは心臓超音波検査所 見であり，感染性心内膜炎を疑う場合は，全症例に対 して経胸壁心臓超音波検査を first-line として実施す る。経食道心臓超音波検査の感染性心内膜炎に対する 診断精度は, 経胸壁に比べ優れているため, 必要例に 経食道心臓超音波検査を追加することが推奨されてい る4)。

(3)腹部

腸管穿孔・腹膜炎：単純 $\mathrm{X}$ 線検査，超音波検査は 最初に施行される検査である。さらに評価が必要な場 合は, 引き続き $\mathrm{CT}$ 検査を行う。臓器や腸管の虚血の 有無など詳細な評価が必要な場合は，造影 CT 検査が 推奨される (急性腹症診療ガイドライン $\left.2015^{5)}\right)$ 。

胆囊炎・胆管炎 : 超音波検査, CT 検査は最も推奨 される検査である。造影 $\mathrm{CT}$ 検査では有用な所見を描 出できる。また MRI/MRCP も画像検査の選択肢とし て推奨されている6)。

閉塞性尿路感染症 : 超音波検査が first-line として実 施すべき検査である。もし閉塞性尿路感染症を疑う所 見を認めれば，閉塞の原因を精査するために CT 検査 を実施することが推奨されている7)。

(4)その他

壊死性軟部組織感染症 : 造影 CT 検査は軟部組織の 腫脹や軟部組織内の液体貯留を検出可能であり, 施行 すべき検査である。しかしながら，壊死性筋膜炎の確 定診断を造影 CT 検査のみでは行えない。壊死性筋膜 炎の確定診断は，外科的に皮下組織・筋膜を試験開創 し, 筋膜・筋を直接観察することが必要である ${ }^{8)}$ 。

画像検査は，最適な治療法の選択を可能にするとい

Table 3-1-1 感染源のコントロールが必要な疾患と画像検査

\begin{tabular}{|c|c|c|c|c|c|}
\hline & & \multicolumn{4}{|c|}{ 主に想定される検査 } \\
\hline & & 単純 X 線検査 & 超音波検査 & CT 検査 & MRI 検査 \\
\hline \multirow[t]{2}{*}{ 頭頸部 } & 脳膿瘍・髄膜脳炎 & & & ○造影 & ○造影, FLAIR 像(脳炎) \\
\hline & 頸部膿瘍 (降下性縦隔炎) & & $\bigcirc$ & ○造影 & \\
\hline \multirow[t]{2}{*}{ 胸＼cjkstart部 } & 膿胸 & 0 & $\bigcirc$ & ○造影 & \\
\hline & 感染性心内膜炎 & & $\bigcirc^{*}$ & & \\
\hline \multirow[t]{3}{*}{ 腹＼cjkstart部 } & 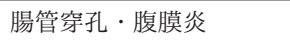 & O & $\bigcirc$ & ○造影 & \\
\hline & 胆囊炎‧胆管炎 & & $\bigcirc$ & ○造影 & O(MRI/MRCP) \\
\hline & 閉塞性尿路感染症 & 0 & 0 & 0 & \\
\hline その他 & 壊死性軟部組織感染症 & & & ○造影 & \\
\hline
\end{tabular}

*感染性心内膜炎の診断精度は経胸壁に比べ，経食道心臟超音波検査の方が優れている。 
う観点で有益である。一方，X 線被曝・造影剂使用の リスク, 特に重症患者の場合は検査室への移動中に急 変のリスクなどの害があることも十分に認識する必要 がある。

\section{文 献}

1) Brouwer MC, Tunkel AR, McKhann GM 2nd, et al: Brain abscess. N Engl J Med. 2014; 371: 447-56.

2) Maroldi R, Farina D, Ravanelli M, et al: Emergency Imaging Assessment of Deep Neck Space Infections. Semin. Ultrasound, CT MR. 2012; 33: 432-42.

3) Li JS, Sexton DJ, Mick N, et al: Proposed modifications to the duke criteria for the diagnosis of infective endocarditis. Clin Infect Dis. 2000; 30: 633-8.

4) Habib G, Lancellotti P, Antunes MJ, et al: 2015 ESC Guidelines for the management of infective endocarditis: The Task Force for the Management of Infective Endocarditis of the European Society of Cardiology (ESC). Eur Heart J. 2015; 36: 3075-128.

5）小豆畑丈夫, 前田重信, 吉田雅博, 他: 急性腹症診療ガイドラ イン 2015. 日腹部救急医会誌. 2017; 37: 551-7.

6) Kiriyama S, Kozaka K, Takada T, et al: Tokyo Guidelines 2018 : diagnostic criteria and severity grading of acute cholangitis (with videos). J Hepatobiliary Pancreat Sci. 2018; 25: 17-3.

7) Wagenlehner FM, Lichtenstern $C$, Rolfes $C$, et al: Diagnosis and management for urosepsis. Int J Urol. 2013; 20: 963-70.

8) Stevens DL, Bisno AL, Chambers HF, et al: Practice guidelines for the diagnosis and management of skin and soft tissue infections: 2014 update by the Infectious Diseases Society of America. Clin Infect Dis. 2014; 59: e10-52.
CQ3-2：感染源が不明な敗血症患者に対して, 全身造影 CT 検査を早期に行うか?

Answer : 感染源が不明な敗血症患者に対して, 可及 的速やかに全身造影 $\mathrm{CT}$ 検査を行うことを弱く推奨す る（エキスパートコンセンサス：エビデンス不十分）。

\section{（1）背景および本 $C Q$ の重要度}

敗血症では, 感染源に対する早期の適切な治療介入 が推奨されている1)。感染源が不明である場合, 早期 に感染源の検索を行うことは，治療方針を策定するた めにも必要不可欠であり, 本邦で普及している画像診 断としての CT 検査を行うことは, 局所診断および感 染源の重症度を判断するためにも重要である。そのた め, 本ガイドラインの CQ として取り上げた。

\section{(2) PICO}

P (患者) : 感染源が不明な敗血症, 敗血症性ショッ ク患者

I（介入）：全身造影 $\mathrm{CT}$ 検査を行う

$\mathrm{C}$ (対照)：全身造影 $\mathrm{CT}$ 検查を行わない

O (アウトカム) : 28 日死亡, 病院死亡, ICU 滞在 日数, 造影剤腎症, 検査移動のリスク

\section{（3）エビデンスの要約}

システマティックレビューの結果, PICO に合致し た敗血症診断基準を満たした患者および集中治療患者 を対象としたランダム化比較試験（RCT）は，過去に 施行されていないことが確認された。

\section{（4）益と害のバランス}

望ましい効果 :

感染源が不明な敗血症では, 標準治療を行っても全 身状態の改善に至らない可能性がある。したがって, 生命予後改善のためには早期に全身造影 $\mathrm{CT}$ 検査を施 行し, 感染源を明らかにする努力が必要であり, その 結果により患者にとって望ましい治療介入が可能とな ると考えられる。

望ましくない効果 :

全身造影 $\mathrm{CT}$ 検査に際しては, 集中治療室や病棟か らの移動が必要である。ショックを合併している場合 など, 移動に伴うさらなる循環動態の不安定化が懸念 される。また，造影剤を使用することから，ヨードア レルギーや造影剂腎症の発症も懸念される。

益と害のバランス :

PICO に合致する RCT は存在せず，不明であるが， 
患者の状態によってそのバランスは異なると考えられ る。少なくとも感染源が不明である場合には, 全身造 影 $\mathrm{CT}$ 検査を施行することにより感染源が判明する可 能性がある。移動に伴う循環動態の不安定化や造影剂 腎症，ヨードアレルギーなどの害との比較では，益が 上回るものと考えられる。

（5）アウトカム全般に関するエビデンスの確実性

システマティックレビューを行ったが，PICOに合 致する RCT は存在しなかった。

\section{（6）価値観}

死亡率が低下することについて患者・家族は一般的 に重視すると考えられ，不確実性やばらつきはないと 考えられる。

\section{（7）容認性}

検査室への移動を伴うため, 医師，看護師などの医 療従事者の仕事量が増大するが，集中治療室での仕事 の範疇であり，特にその影響は少ないと考えられる。 全身造影 $\mathrm{CT}$ 検査に伴うコストの増大があるが，全体 の診療に占める割合は非常に少なく, 容認性は妥当な ものといえる。

\section{（8）実行可能性}

本邦は世界の中で人口あたりの $\mathrm{CT}$ 撮像装置の普及が 最も進んだ地域であり，敗血症診療を行う多くの施設に 装備されているため, 実行可能であると考えられる。
（10）推奨グレーディング決定の工程

修正 RAND 法を用いた投票によって，中央值 8, 見解不一致指数 0.164 の結果となり, 委員会で採択さ れた（7 点以上 : 95.8\%)。

\section{（11）関連する他の診療ガイドラインにおける推奨}

SSCG 2016 では画像診断を行うことを強く推奨して いる2)。

\section{（12）実施に関わる検討事項}

感染源の検索として, すべての臓器に対し造影 CT が有用とは限らない。臟器に特異的な検査方法が優先 される場合もあり, 感染源不明の敗血症における臟器 別の造影 CT の有用性について検討が必要である。

\section{（13）今後の研究の可能性}

感染源を明確にし，重症度評価あるいは的確な介入 計画を立案するためにも造影 $\mathrm{CT}$ は重要である。しか し, 感染源が不明な場合に造影 CT 施行の有無による RCT は存在せず，今後も RCT の実施は困難である。 また，造影剂使用による造影剂腎症やアレルギー発症 のリスクと検査室移動に関する循環動態への影響な ど，今後，さらに検討が必要である。

\section{文 献}

1) De Waele JJ: Early source control in sepsis. Langenbecks Arch Surg. 2010; 395: 489-94.

2) Rhodes A, Evans LE, Alhazzani W, et al: Surviving Sepsis Campaign: International Guidelines for Management of Sepsis and Septic Shock: 2016. Intensive Care Med. 2017; 43: 304-77.

（9）判断の要約（Table 3-2-1）

Table 3-2-1 判断の要約

\begin{tabular}{|c|c|c|c|c|c|c|c|}
\hline & \multicolumn{7}{|c|}{ 半判湆 } \\
\hline 問題 & いいえ & $\begin{array}{c}\text { おそらく、いい } \\
\text { え }\end{array}$ & おそらく、はい & はい & & さまざま & 分からない \\
\hline 望ましい勃果 & わずか & 小さい & 中 & 大きい & & さまざま & 分からない \\
\hline 望ましくない効果 & 大きい & 中 & 小さい & わずか & & さまざま & 分からない \\
\hline エビデンスの確実性 & 非常に低 & 低 & 中 & 高 & & & 採用研究なし \\
\hline 価值钼 & $\begin{array}{c}\text { 重要な不確実性 } \\
\text { またはばらつき } \\
\text { あり }\end{array}$ & $\begin{array}{c}\text { 重要な不確実性 } \\
\text { またはばらつき } \\
\text { の可能性あり }\end{array}$ & $\begin{array}{l}\text { 重要な不確実性 } \\
\text { またはばらつき } \\
\text { はおそらくなし }\end{array}$ & $\begin{array}{c}\text { 重要な不確実性 } \\
\text { またはばらつき } \\
\text { はなし }\end{array}$ & & & \\
\hline 勃果のパランス & 比較が優位 & $\begin{array}{c}\text { 比較がおそらく } \\
\text { 優位 }\end{array}$ & $\begin{array}{c}\text { 介入も比較もい } \\
\text { ずれも優位でな } \\
\text { い }\end{array}$ & $\begin{array}{c}\text { おそらく介入が } \\
\text { 優位 }\end{array}$ & 介入が優位 & さまざま & 分からない \\
\hline 容認性 & いいえ & $\begin{array}{c}\text { おそらく、いい } \\
\text { え }\end{array}$ & おそらく、はい & はい & & さまざま & 分からない \\
\hline 実行可能性 & いいえ & 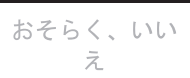 & おそらく、はい & はい & & さまざま & 分からない \\
\hline
\end{tabular}


CQ3-3 : 腹腔内感染症による敗血症患者に対し て, 外科手術/侵襲的ドレナージ術による感染源 のコントロールを行うか?

Answer: 腹腔内感染症による敗血症患者に対して, 可及的速やかに外科手術/侵襲的ドレナージ術（膿瘍 ドレナージ，胆道/胆囊ドレナージを含む）による感 染源のコントロールを行うことを弱く推奨する（エキ スパートコンセンサス : エビデンス不十分)。

\section{（1）背景および本 $C Q$ の重要度}

腹腔内感染症は, 適切な感染源のコントロール（外 科手術または膿瘍ドレナージ, 胆道/胆囊ドレナージ を含むドレナージ術）の必要な病態であり, 重要臨床 課題である。そのため, 本ガイドラインの $\mathrm{CQ}$ として 取り上げた。

(2) PICO

$\mathrm{P}$ (患者) : 腹腔内感染症による敗血症患者

I（介入）：感染源のコントロール［外科手術または 侵襲的ドレナージ術（膿瘍ドレナージ, 胆道/胆 囊ドレナージを含む)］を行う

C (対照)：感染源のコントロール［外科手術または ドレナージ術（膿場ドレナージ, 胆道/胆囊ドレ ナージを含む)］を行わない

$\mathrm{O}$ (アウトカム) : 28 日死亡, 院内死亡, ICU 滞在 日数, 病院滞在日数, 感染源のコントロールに伴 う合併症

\section{（3）エビデンスの要約}

システマティックレビューの結果, PICO に合致し た敗血症診断基準を満たした患者および集中治療患者 を対象としたランダム化比較試験（RCT）は, 過去に 施行されていないことが確認された。

\section{（4）益と害のバランス}

\section{望ましい効果 :}

下部消化管穿孔による沉発性腹膜炎など, 感染源の コントロールを行わない通常の抗菌薬治療のみでは改 善する可能性が非常に乏しい腹腔内感染症による敗血 症では, 迅速な感染源のコントロールを行うことによ り患者に益する可能性が高いと考える。

\section{望ましくない効果 :}

実際の臨床で生じることが予想される害としては, 外科手術または侵襲的ドレナージ術施行に関連し, 出 血・臟器損傷・生体侵襲による全身状態悪化・感染な
どが考えられる。

\section{益と害のバランス :}

$\mathrm{PICO}$ に合致する RCT は存在せず, 効果のバランス は不明である。腹腔内感染症による敗血症は, 外科手 術または侵襲的ドレナージ術（膿瘍ドレナージ, 胆 道/胆囊ドレナージを含む）を行って得られる利益と， 外科手術または侵襲的ドレナージ術に関連する出血・ 臓器損傷・生体侵襲による全身状態悪化・感染などの 害を比較しても，おそらく益が害を上回ると考えられ る。

\section{（5）アウトカム全般に関するエビデンスの確実性}

システマティックレビューを行ったが，PICOに合 致する RCT は存在しなかった。

\section{（6）価值観}

死亡率が低下することについて, 患者・家族は一般 的に重視すると考えられ, 不確実性やばらつきはない と考える。

\section{（7）容認性}

外科手術または侵襲的ドレナージ術（膿瘍ドレナー ジ, 胆道/胆囊ドレナージを含む）は保険診療で認め られた標準的治療法であり, 原因の解消を行わなけれ ば回復する可能性は低く, 迅速な感染源のコントロー ルを行うことは患者にとって益が害を上回る可能性が 高いことから, 容認性はおそらく妥当なものと考え る。

\section{（8）実行可能性}

外科手術または侵襲的ドレナージ術（膿瘍ドレナー ジ, 胆道/胆囊ドレナージを含む）は, 敗血症診療を 行う多くの施設で実行可能であると考えられる。しか しながら, 状況により実行不可能な場合は, 迅速に施 行可能な施設への移送などの負担が生じる。

\section{（9）判断の要約（Table 3-3-1）}

\section{（10）推奨グレーディング決定の工程}

修正 RAND 法を用いた投票によって, 中央值 8, 見解不一致指数 0.292 の結果となり, 委員会で採択さ れた（7 点以上: $91.7 \%) 。$

\section{（11）関連する他の診療ガイドラインにおける推奨}

SSCG 2016 においては, 腹腔内感染症に限定した $\mathrm{CQ}$ は取り上げられていない1)。米国外科感染症学会 
Table 3-3-1 判断の要約

\begin{tabular}{|c|c|c|c|c|c|c|c|}
\hline & \multicolumn{7}{|c|}{ 判䱚 } \\
\hline 問題 & いいえ & $\begin{array}{c}\text { おそらく、いい } \\
\text { え }\end{array}$ & おそらく、はい & はい & & さまざま & 分からない \\
\hline 望ましい勃果 & わずか & 小さい & 中 & 大きい & & さまざま & 分からない \\
\hline 望ましくない勃果 & 大きい & 中 & 小さい & わずか & & さまざま & 分からない \\
\hline エビデンスの確実性 & 非常に低 & 低 & 中 & 高 & & & 採用研究なし \\
\hline 価值観 & $\begin{array}{c}\text { 重要な不確実性 } \\
\text { またはばらつき } \\
\text { あり }\end{array}$ & $\begin{array}{c}\text { 重要な不確実性 } \\
\text { またはばらつき } \\
\text { の可能性あり }\end{array}$ & $\begin{array}{l}\text { 重要な不確実性 } \\
\text { またはばらつき } \\
\text { はおそらくなし }\end{array}$ & $\begin{array}{c}\text { 重要な不確実性 } \\
\text { またはばらつき } \\
\text { はなし }\end{array}$ & & & \\
\hline 効果のバランス & 比較が優位 & $\begin{array}{c}\text { 比較がおそらく } \\
\text { 優位 }\end{array}$ & $\begin{array}{c}\text { 介入も比較もい } \\
\text { ずれも優位でな } \\
\text { い }\end{array}$ & $\begin{array}{c}\text { おそらく介入が } \\
\text { 優位 }\end{array}$ & 介入が優位 & さまざま & 分からない \\
\hline 容認性 & いいえ & $\begin{array}{c}\text { おそらく、いい } \\
\text { え }\end{array}$ & おそらく、はい & はい & & さまざま & 分からない \\
\hline 実行可能性 & いいえ & $\begin{array}{c}\text { おそらく、いい } \\
\text { え }\end{array}$ & おそらく、はい & はい & & さまざま & 分からない \\
\hline
\end{tabular}

のガイドライン 2,3）では迅速な感染源のコントロー ルの重要性が強調されている。

\section{（12）実施に関わる検討事項}

感染巣の部位・大きさ，患者の全身状態により，侵 襲的処置（外科手術とドレナージ術）による益と害の バランスが異なる可能性がある。

\section{（13）今後の研究の可能性}

腹腔内感染症による敗血症患者に対しての感染源の コントロールに関する RCT が存在しないことが明ら かとなった。感染源のコントロール方法は，外科手術 (開腹・腹腔鏡下) や侵襲的ドレナージ術（経皮的・ 内視鏡的）など複数存在するが，患者のエントリー基 準設定や侵襲度の異なる処置を比較する RCT の実施 は困難と思われる。感染源のコントロールの施行のタ イミングに関しても，早期に行うことが有効であるこ とは理論上明らかであり，検証する RCT の実施は困 難と思われる4)。早期に感染源のコントロールを行う ことにつながる因子の研究や，より低侵襲で効果的な 感染源のコントロール方法の開発の研究が必要と考え られる。

\section{文 献}

1) Rhodes A, Evans LE, Alhazzani W, et al: Surviving Sepsis Campaign: International Guidelines for Management of Sepsis and Septic Shock: 2016. Crit Care Med. 2017; 45: 486-552.

2) Solomkin JS, Mazuski JE, Bradley JS, et al: Diagnosis and management of complicated intra-abdominal infection in adults and children: guidelines by the Surgical Infection Society and the Infectious Diseases Society of America. Surg Infect (Larchmt).
2010; 11: 79-109.

3) Mazuski JE, Tessier JM, May AK, et al: The surgical infection society revised guidelines on the management of intra-abdominal infection. Surg Infect (Larchmt). 2017; 18: 1-76.

4) Azuhata $T$, Kinoshita K, Kawano D, et al: Time from admission to initiation of surgery for source control is a critical determinant of survival in patients with gastrointestinal perforation with associated septic shock. Crit Care. 2014; 18: R87. 
CQ3-4-1 : 感染性膵壊死に対して, 早期に侵襲的 なインターベンション治療による感染源のコン トロールを行うか?

Answer : 感染性膵壊死に対して, 早期に侵襲的なイ ンターベンション治療による感染源のコントロールを 行わないことを弱く推奨する (GRADE $2 \mathrm{C}$ : エビデン スの確実性 $=$ 「低」)。

\section{（1）背景および本 $C Q$ の重要度}

壊死組織は感染の原因であり，早期介入が一般原則 である。しかし，膵壊死はこの早期介入の一般原則が 該当しない。また, 低侵襲で効果的な感染源のコント ロール方法に取り組んだランダム化比較試験（RCT） も行われていることから，本疾患の介入タイミングは 重要臨床課題であると考える。

(2) PICO

$P$ (患者)：重症感染性膵壊死患者

I（介入）：早期に侵襲的なインターベンション治療 による感染源のコントロールを行う（48～72 時 間以内）

C (対照)：晚期に侵襲的なインターベンション治療 による感染源のコントロールを行う（発症から 12 日後）

$\mathrm{O}$ (アウトカム $)$ : 死亡

\section{（3）エビデンスの要約（Table 3-4-1-1）}

システマティックレビューの結果, PICO に合致し た 1 つのサンプル数の小さな RCT（早期介入 25 例, 晚期介入 11 例）があることが確認された。死亡は早 期介入 $56.0 \%$ ，晚期介入 $27.3 \%$ ，効果推定值はリスク 差（RD）1,000 人あたり 286 人多い $(95 \%$ CI: 71 人少 ない〜 1,000 人多い）であり，介入群である早期介入 は晚期介入に比べて生命転帰に関する望ましい効果を 認めなかった。
（4）益と害のバランス

望ましい効果 :

1 つの小さなサンプル数の研究において, 早期介入 は晚期介入に比べて生命転帰に関する望ましい効果を 認めなかった。なお，副作用や医療コストなどは検討 されておらず，介入群の望ましい効果はわからない。 望ましくない効果 :

前述のように, 死亡率は早期介入 $56.0 \%$, 晚期介入 $27.3 \%$, 効果推定值は RD 1,000 人あたり 286 人多い ( $95 \%$ CI: 71 人少ない 1,000 人多い) であり, 介入群 である早期介入は，晚期介入に比べて望ましくない効 果は大きい。

益と害のバランス :

早期介入に比べて晚期介入の死亡率の低下が示され ていることから，おそらく晚期介入の益が害を上回る と考えられる。

（5）アウトカム全般に関するエビデンスの確実性

1 つのサンプル数の小さな RCT があるが，治療法 の比較のため隠蔽化はできておらず，95\% CI が 1.25 をまたいでいるため「低」とした。

\section{（6）価值観}

各アウトカムにおける患者・家族の価值観に関する データはない。一般的に, 死亡アウトカムが低下する ことを患者・家族は重視すると考えられ，不確実性や ばらつきはないと考える。

\section{（7）容認性}

晚期介入は入院期間の延長が予想されるが，早期介 入に比べて死亡率の低下が示されていることから，患 者・家族の個人の視点からおそらく益が害を上回ると 考えられる。

\section{（8）実行可能性}

感染源のコントロール介入までの集中治療管理も重 要であり, 適切な施設での施行が求められる。

Table 3-4-1-1エビデンスプロファイル

\begin{tabular}{|c|c|c|c|c|c|c|c|c|c|c|c|c|}
\hline \multicolumn{7}{|c|}{ 確実性の評価 } & \multicolumn{2}{|c|}{ 患者数 } & \multicolumn{2}{|c|}{ 効果 } & \multirow[b]{2}{*}{ 確実性 } & \multirow[b]{2}{*}{ 重要性 } \\
\hline 研究数 & $\begin{array}{l}\text { 研究 } \\
\text { デザイン }\end{array}$ & $\begin{array}{l}\text { バイアス } \\
\text { のリスク }\end{array}$ & 非一貫性 & 非直接性 & 不精確性 & $\begin{array}{l}\text { その他 } \\
\text { の模討 }\end{array}$ & 介入 & 介入なし & $\begin{array}{l}\text { 相対指標 } \\
(95 \% \mathrm{CI})\end{array}$ & $\begin{array}{l}\text { 絶対指標 } \\
(95 \% \mathrm{II})\end{array}$ & & \\
\hline \multicolumn{13}{|l|}{ 死亡 } \\
\hline 1 & RCT & 深刻 a & 深刻でない & 深刻でない & 深刻 b & なし & $\begin{array}{l}14 / 25 \\
(56.0 \%)\end{array}$ & $3 / 11 \quad(27.3 \%)$ & $\begin{array}{c}\text { RR } 2.05 \\
(0.74 \text { to } 5.73)\end{array}$ & \begin{tabular}{|c|} 
1, 000 人あたり \\
286 人多い (71 \\
少ない 1,000人 \\
多い)
\end{tabular} & $\underset{\text { 低 }}{\oplus \oplus \bigcirc \bigcirc}$ & 重大 \\
\hline
\end{tabular}


(9) 判断の要約（Table 3-4-1-2）

\section{（10）推奨グレーディング決定の工程}

修正 RAND 法を用いた投票によって，中央值 8 , 見解不一致指数 0.164 の結果となり，委員会で採択さ れた（7点以上 : $87.5 \%) 。$

\section{（11）関連する他の診療ガイドラインにおける推奨}

感染性膵壊死は早期感染源コントロール介入の一般 原則が該当しない。急性膵炎診療ガイドライン 2015 第 4 版 ${ }^{1)}$ においても，介入タイミングの原則につい ての明確な見解が述べられていない。

\section{（12）実施に関わる検討事項}

感染性膵壊死全例に対する標準的治療として，早期 介入は行わないことが望まれる。ただし，1 つの小さ な RCT の結果に基づいた推奨であるため，感染源の コントロールを行わず全身状態が悪化する場合などで は，早期に侵襲的なインターベンション治療を行うこ とが必要な場合もあるため, 症例や状況に応じた適応 判断を否定するものではない。

\section{（13）今後の研究の可能性}

全身状態の悪化についての評価とインターベンショ ンのタイミングの検証が必要と考えられる。また，感 染性膵壊死に対する感染源のドレナージ方法に関して は，侵襲度の異なるいくつかのアプローチ方法があ り，近年では治療効果に従って段階的に侵襲の強度を 強めていくアプローチ（step-up approach）など，いく
つかの新しい治療戦略も報告されてきており 2,3$)$, 現 状では治療侵襲度と治療効果の関連についての評価は 定まっていない。臨床現場でもドレナージのアプロー チ方法については多様性があり, head-to-head の直接 比較だけでは評価が困難になっている。

$$
\text { 文 献 }
$$

1）急性膵炎診療ガイドライン 2015 改訂出版委員会: 急性膵炎 診療ガイドライン 2015 (第 4 版). 金原出版, 東京, 2015.

2) Hollemans RA, Bakker OJ, Boermeester MA, et al: Superiority of Step-up Approach vs Open Necrosectomy in Long-term Follow-up of Patients With Necrotizing Pancreatitis. Gastroenterology. 2019; 156: 1016-26.

3) van Brunschot $S$, van Grinsven J, van Santvoort HC, et al: Endoscopic or surgical step-up approach for infected necrotising pancreatitis: a multicentre randomised trial. Lancet. 2018; 391: $51-8$.

Table 3-4-1-2 判断の要約

\begin{tabular}{|c|c|c|c|c|c|c|c|}
\hline 問題 & いいえ & $\begin{array}{c}\text { おそらく、いい } \\
\text { え }\end{array}$ & おそらく、はい & はい & & さまざま & 分からない \\
\hline 望ましい効果 & わずか & 小さい & 中 & 大きい & & さまざま & 分からない \\
\hline 望ましくない効果 & 大きい & 中 & 小さい & わずか & & さまざま & 分からない \\
\hline エビデンスの確実性 & 非常に低 & 低 & 中 & 高 & & & 採用研究なし \\
\hline 価值観 & $\begin{array}{c}\text { 重要な不確実性 } \\
\text { またはばらつき } \\
\text { あり }\end{array}$ & $\begin{array}{c}\text { 重要な不確実性 } \\
\text { またはばらつき } \\
\text { の可能性ありり }\end{array}$ & $\begin{array}{l}\text { 重要な不確実性 } \\
\text { またはばらつき } \\
\text { はおそらくなし }\end{array}$ & $\begin{array}{c}\text { 重要な不確実性 } \\
\text { またはばらつつ } \\
\text { はなし }\end{array}$ & & & \\
\hline 効果のパランス & 比較が優位 & $\begin{array}{c}\text { 比較がおそらく } \\
\text { 優位 }\end{array}$ & $\begin{array}{c}\text { 介入も比較もい } \\
\text { ずれも優位でな } \\
\text { い }\end{array}$ & $\begin{array}{c}\text { おそらく介入が } \\
\text { 優位 }\end{array}$ & 介入が優位 & さまざま & 分からない \\
\hline 容認性 & いいえ & $\begin{array}{c}\text { おそらく、いい } \\
\text { え }\end{array}$ & おそらく、はい & はい & & さまざま & 分からない \\
\hline 実行可能性 & いいえ & $\begin{array}{c}\text { おそらく、いい } \\
\text { え }\end{array}$ & おそらく、はい & はい & & さまざま & 分からない \\
\hline
\end{tabular}


CQ3-4-2 : 感染性膵壊死に対して，より低侵襲な インターベンション治療で感染源のコントロー ルを行うか?

Answer：感染性膵壊死による敗血症患者に対して, より低侵襲なインターベンション治療による感染源の コントロールを行うことを推奨する（GRADE 2B：エ ビデンスの確実性 =「中」)。

\section{（1）背景および本 CQ の重要度}

感染性膵壊死は，何らかのインターベンション治療 で感染源を除去することが必要な疾患である。近年, ドレナージ手技としては，(1)手術的ドレナージ，(2)内 視鏡的ドレナージ，(3)経皮的ドレナージ（主に後腹膜 経路), (4)治療効果に従って段階的に侵襲の強度を強 めていくアプローチ（step-up approach）など， いくつ かの治療戦略が報告されてきており, 治療侵襲度と治 療効果の関連については重要臨床課題である。

\section{(2) PICO}

$\mathrm{P}$ (患者)：感染性膵壊死による敗血症患者

I（介入）：より低侵襲的な方法で感染源のコント ロールを行う

C (対照) : 侵襲的な方法で感染源のコントロールを 行う

$\mathrm{O}$ (アウトカム ) : 死亡（6 か月， 3 年，10 年), ICU 滞在日数, 病院滞在日数, 感染源のコントロール に伴う合併症

\section{（3）エビデンスの要約}

システマティックレビューの結果, PICO に合致し た 2 つのラン゙ム化比較試験（RCT）があることが確 認された（より低侵襲的な方法 94 例，侵襲的な方法 92 例)。

死亡アウトカムに関しては，6 か月死亡アウトカム の効果推定值は，リスク差（RD） 1,000人あたり 40 人多い $(48$ 人少ない〜 211 人多い) であり，ICU 滞 在日数および病院滞在日数については, 効果推定值は それぞれ，平均（MD）19.74日多い（20.84 日少な い〜60.31 日多い) · MD 7.76 日少ない（27.86日少な い〜12.34 日多い) であった。効果推定值の幅が広く, 侵襲的なインターベンション治療に比ベてより低侵襲 的なインターベンション治療が感染源のコントロール に及ぼす効果はわからない。

一方，より低侵襲的な方法（ドレナージ手技）で感 染源のコントロールを行うと，侵襲的な方法に比べて
合併症の発生は低い $[R D 1,000$ 人あたり 187 人少な い $(95 \% \mathrm{CI}: 305$ 人少ない〜 55 人多い)] という結果 となり，より低侵襲的なインターベンション治療の効 果が認められた。

(4) 益と害のバランス（Table 3-4-2-1）

望ましい効果 :

2 つの RCT のデータでは, より低侵襲的な方法（ド レナージ手技）で感染源のコントロールを行うと，侵 襲的な方法に比べて合併症の発生は低い [RD 1,000 人あたり 187 人少ない $(95 \% \mathrm{CI}: 305$ 人少ない〜 55 人 多い)］。以上の結果から, より低侵襲的なインターベ ンション治療の望ましい効果は「中」と考えられる。 望ましくない効果 :

死亡アウトカムに関しては，短期 $(6$ か月) · 中期 (3 年) ・長期（10 年）の 3 つの時間軸で検討した。 ICU 帯在日数および病院滞在日数も合わせて検討し た。

6 か月死亡のみで 2 つの RCT のデータ（より低侵 襲的な方法 94 例，侵襲的な方法 92 例）を pool でき, 死亡アウトカムの効果推定值は, RD 1,000人あたり 40 人多い（48人少ない〜 211 人多い）であった。ま た, ICU 滞在日数・病院滞在日数の効果推定值はそれ ぞれ，MD 19.74 日多い（20.84 日少ない〜60.31 日多 い)・MD 7.76 日少ない（27.86 日少ない〜12.34 日多 い)であった。

効果推定值の幅が広く, 侵襲的なインターベンショ ン治療に比ベてより低侵襲的なインターベンション治 療で感染源のコントロールを行うことによる望ましく ない効果はわからない。

益と害のバランス :

本 CQ の介入における望ましい効果は「中」であり, 望ましくない効果は効果量の幅が広く, わからないと 判断した。その効果のバランスは介入あるいは比較対 照のいずれも支持しない。

（5）アウトカム全般に関するエビデンスの確実性

今回採用したすべてのアウトカムの効果推定值の方 向性は一致している（効果なし）ため, 全体としては 一番高いアウトカムの確実性を採用した。アウトカム 全体にわたるエビデンスの確実性は「中」である。

\section{（6）価値観}

各アウトカムにおける患者・家族の価值観に関する データはない。一般的に, 死亡アウトカムが低下する ことについて患者・家族は重視すると考えられ，不確 
Table 3-4-2-1エビデンスプロファイル

\begin{tabular}{|c|c|c|c|c|c|c|c|c|c|c|c|c|}
\hline \multicolumn{7}{|c|}{ 確実性の評価 } & \multicolumn{2}{|c|}{ 患者数 } & \multicolumn{2}{|c|}{ 効果 } & \multirow[b]{2}{*}{ 確実性 } & \multirow[b]{2}{*}{ 重要性 } \\
\hline 研究数 & $\begin{array}{l}\text { 研究 } \\
\text { デザイン }\end{array}$ & $\begin{array}{l}\text { パイアス } \\
\text { のリスク }\end{array}$ & 非一貫性 & 非直接性 & 不精確性 & $\begin{array}{l}\text { その他 } \\
\text { の検討 }\end{array}$ & $\begin{array}{l}\text { より低侵襲的な } \\
\text { 方法 }\end{array}$ & 侵襲的な方法 & $\begin{array}{l}\text { 相対指標 } \\
(95 \% \text { CI })\end{array}$ & $\begin{array}{l}\text { 絶対指標 } \\
(95 \% \mathrm{CI})\end{array}$ & & \\
\hline \multicolumn{13}{|c|}{ 死亡（6 か月） } \\
\hline 2 & RCT & 深刻 a & 深刻でない & 深刻でない & 非常に深刻 b & なし & $17 / 94 \quad(18.1 \%)$ & $13 / 92 \quad(14.1 \%)$ & $\begin{array}{c}\text { RD } 0.04 \\
(-0.06 \text { to } 0.15)\end{array}$ & $\begin{array}{l}1,000 \text { 人あたり } 40 \\
\text { 人多い (48 人少な } \\
\text { い 211 人多い) }\end{array}$ & $\begin{array}{l}\oplus \bigcirc 00 \\
\text { 非常に低 }\end{array}$ & 重大 \\
\hline \multicolumn{13}{|c|}{ 死亡（3 年） } \\
\hline 1 & RCT & 深刻 a & 深刻でない & 深刻でない & 非常に深刻 b & なし & $8 / 43 \quad(18.6 \%)$ & $7 / 45 \quad(15.6 \%)$ & $\begin{array}{c}\text { RD } 0.03 \\
(-0.16 \text { to } 0.19)\end{array}$ & $\begin{array}{l}1,000 \text { 人あたり } 31 \\
\text { 人多い (82 人少な } \\
\text { い 313 人多い) }\end{array}$ & $\begin{array}{l}\oplus \bigcirc 00 \\
\text { 非常に低 }\end{array}$ & 重大 \\
\hline \multicolumn{13}{|c|}{ 死亡（10 年） } \\
\hline 1 & RCT & 深刻 a & 深刻でない & 深刻でない & 非常に深刻 b & なし & $13 / 43 \quad(30.2 \%)$ & $9 / 45 \quad(20.0 \%)$ & $\begin{array}{c}\text { RR } 0.10 \\
(-0.08 \text { to } 0.28)\end{array}$ & $\begin{array}{l}1,000 \text { 人あたり } 102 \\
\text { 人多い (56人少な } \\
\text { い 434 人多い) }\end{array}$ & $\begin{array}{l}\oplus \bigcirc 00 \\
\text { 非常に低 }\end{array}$ & 重大 \\
\hline
\end{tabular}

a. 治療法の比較のため, 㩊蔽化はできない。

b. 不精確性は 1.25 と0.75 を両方ともまたいでいるため，2段階ダウン(非常に深刻)とした。

\begin{tabular}{|c|c|c|c|c|c|c|c|c|c|c|c|c|}
\hline \multicolumn{7}{|c|}{ 確実性の評価 } & \multicolumn{2}{|c|}{ 患者数 } & \multicolumn{2}{|c|}{ 勃果 } & \multirow[b]{2}{*}{ 確実性 } & \multirow[b]{2}{*}{ 重要性 } \\
\hline 研究数 & $\begin{array}{l}\text { 研究 } \\
\text { デザイン }\end{array}$ & $\begin{array}{l}\text { バイアス } \\
\text { のリスク }\end{array}$ & 非一貫性 & 非直接性 & 不精確性 & $\begin{array}{l}\text { その他 } \\
\text { の検討 }\end{array}$ & $\begin{array}{c}\text { より低侵襲的な } \\
\text { 方法 }\end{array}$ & 侵豐的な方法 & $\begin{array}{l}\text { 相対指標 } \\
(95 \% \text { cI })\end{array}$ & $\begin{array}{l}\text { 絶対指標 } \\
(95 \% \mathrm{CI})\end{array}$ & & \\
\hline \multicolumn{13}{|c|}{ 合併症（6か月） } \\
\hline 2 & RCT & 深刻a & 深刻 b & 深刻でない & 深刻 c & なし & $22 / 94 \quad(23.4 \%)$ & $39 / 92 \quad(42.4 \%)$ & $\begin{array}{c}\mathrm{RD}-0.19 \\
(-0.45 \text { to } 0.06)\end{array}$ & $\begin{array}{c}1,000 \text { 人あたり } \\
187 \text { 人少ない } \\
(305 \text { 人少ない } \\
55 \text { 人多い) }\end{array}$ & $\begin{array}{l}\oplus \bigcirc 0 \bigcirc \\
\text { 非常に低 }\end{array}$ & 重大 \\
\hline \multicolumn{13}{|c|}{ ICU 滞在日数 } \\
\hline 2 & RCT & 深刻 a & 深刻 d & 深刻でない & 深刻でない & なし & 94 & 92 & - & $\begin{array}{c}\text { 平均 } 19.74 \text { 日長い } \\
\text { (20.84 日短い } \\
60.31 \text { 日長い) }\end{array}$ & $\underset{\text { 低 }}{\oplus \oplus \bigcirc \bigcirc}$ & 重大 \\
\hline \multicolumn{13}{|c|}{ 病院滞在日数 } \\
\hline 2 & $\mathrm{RCT}$ & 深刻 a & 深刻 e & 深刻でない & 深刻でない & なし & 94 & 92 & - & $\begin{array}{c}\text { 平均 } 7.76 \text { 日短い } \\
\text { (27. } 86 \text { 日短い } \\
\text { 12.34 日長い) }\end{array}$ & $\underset{\text { 低 }}{\oplus \oplus \bigcirc}$ & 重要 \\
\hline
\end{tabular}

a. 治療法の比較のため，㩊蔽化はできない。

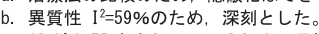

c. CI が 0.75 をまたいでいるため, 深刻とした。

d. 異質性 $\mathrm{I}^{2}=92 \%$ のため, 非一貫性は深刻とした。

e. 異質性 I²=45\%であり，非一貫性は深刻とした。

実性やばらつきはないと考える。

\section{（7）容認性}

より低侵襲的なインターベンション治療で感染源の コントロールを行う場合，ドレナージ手技の回数が増 す可能性があり，医師，看護師など，医療従事者の仕 事量が増大することも考えられるが，集中治療に伴う 一連の仕事の範疇であり, 特にその影響は少ないと考 えられる。有害事象に関しては，有意差は認めなかっ た。

介入に伴うコストは，手技回数や入院期間が延長す るとコストが増大する可能性もあるが，その個人負担 額を考えると, 患者・家族の個人の視点からおそらく 許容できると考えられる。

\section{（8）実行可能性}

より低侵襲的なインターベンション治療で感染源の コントロールを行うことは, 敗血症診療を行う多くの 施設で実行可能であると考えられるが，施設のハード
面およびソフト面の技量を要する。

（9）判断の要約（Table 3-4-2-2）

（10）推奨グレーディング決定の工程

修正 RAND 法を用いた投票によって，中央值 7, 見解不一致指数 0.164 の結果となり，委員会で採択さ れた（7 点以上 : 83.3\%)。

（11）関連する他の診療ガイドラインにおける推奨 急性膵炎診療ガイドライン 2015 1) では，低侵襲ド レナージである，経皮的（後腹膜経路），あるいは内 視鏡的経消化管的ドレナージを最初に行うことを推奨 している。

\section{（12）実施に関わる検討事項}

感染源のコントロールとして，手技の侵襲度，手技 のタイミング，デブリードマン術を行う範囲，繰り返 すデブリードマン術の必要性などについて，患者の全 
日本版敗血症診療ガイドライン 2020

Table 3-4-2-2 判断の要約

\begin{tabular}{|c|c|c|c|c|c|c|c|}
\hline & \multicolumn{7}{|c|}{ 半㲘 } \\
\hline 問題 & いいえ & $\begin{array}{c}\text { おそらく、いい } \\
\text { え }\end{array}$ & おそらく、はい & はい & & さまざま & 分からない \\
\hline 望ましい勃果 & わずか & 小さい & 中 & 大きい & & さまざま & 分からない \\
\hline 望ましくない勃果 & 大きい & 中 & 小さい & わずか & & さまざま & 分からない \\
\hline エビデンスの確実性 & 非常に低 & 低 & 中 & 高 & & & 採用研究なし \\
\hline 価值観 & $\begin{array}{l}\text { 重要な不確実性 } \\
\text { またはばらつき } \\
\text { あり }\end{array}$ & $\begin{array}{c}\text { 重要な不確実性 } \\
\text { またはばらつき } \\
\text { の可能性あり }\end{array}$ & $\begin{array}{l}\text { 重要な不確実性 } \\
\text { またはばらつき } \\
\text { はおそらくなし }\end{array}$ & $\begin{array}{c}\text { 重要な不確実性 } \\
\text { またはばらつき } \\
\text { はなし }\end{array}$ & & & \\
\hline 効果のバランス & 比較が優位 & $\begin{array}{c}\text { 比較がおそらく } \\
\text { 優位 }\end{array}$ & $\begin{array}{c}\text { 介入も比較もい } \\
\text { ずれも優位でな } \\
\text { い }\end{array}$ & $\begin{array}{c}\text { おそらく介入が } \\
\text { 優位 }\end{array}$ & 介入が優位 & さまざま & 分からない \\
\hline 容認性 & いいえ & $\begin{array}{c}\text { おそらく、いい } \\
\text { え }\end{array}$ & おそらく、はい & はい & & さまざま & 分からない \\
\hline 実行可能性 & いいえ & $\begin{array}{c}\text { おそらく、いい } \\
\text { え }\end{array}$ & おそらく、はい & はい & & さまざま & 分からない \\
\hline
\end{tabular}

身状態と合わせての検討が必要であり，全例に対する 標準的治療としての推奨ではない。

\section{（13）今後の研究の可能性}

感染性膵壊死に対するドレナージ手技は，(1)手術的 ドレナージ，(2)内視鏡的ドレナージ，(3)経皮的ドレ ナージ (主に後腹膜経路), (4)治療効果に従って段階 的に侵襲の強度を強めていくアプローチ（step-up approach）など，近年，異なるいくつかの治療戦略が 報告されてきている。

また， step-up approachの中でも，内視鏡的 step-up approach（内視鏡的経消化管的ドレナージと，それに 引き続く内視鏡的ネクロセクトミー）と，低侵襲外科 的 step-up approach（経皮的ドレナージと，それに引 き続く video-assisted retroperitoneal debridement）の 2 種類の報告がある。2018 年に報告された TENSION trial $^{2 ）}$ では, 内視鏡的 step-up approach と低侵襲外科 的 step-up approach での生命予後に差はなかったもの の, ICU 滞在日数や膵液瘻などの合併症は前者で有意 に少なかった。このように，より低侵襲なインターベ ンションによる治療介入が推奨される可能性がある が，それぞれの手技を行う際の麻酔方法や鎮静方法に も違いがあり，患者の全身状態やそれぞれの手技に伴 う循環動態への影響が考えられるため，デブリードマ ン手技の選択やタイミング，アプローチ方法の組み合 わせなどについては，今後さらに検討が必要である。

\section{文 献}

1）急性膵炎診療ガイドライン 2015 改訂出版委員会: 急性膵炎
診療ガイドライン 2015 (第 4 版). 金原出版, 東京, 2015.

2) van Brunschot $S$, van Grinsven J, van Santvoort HC, et al: Endoscopic or surgical step-up approach for infected necrotising pancreatitis: a multicentre randomised trial. Lancet. 2018; 391: 51-8. 
CQ3-5：尿管閉塞を原因とする急性腎孟腎炎に よる敗血症患者に対して, 侵襲的ドレナージ術 による感染源コントロールを行うか?

Answer：尿管閉塞を原因とする急性腎孟腎炎による 敗血症患者に対して，可及的速やかに経尿道的尿管ス テント留置術あるいは経皮的腎ろう造設術による感染 源のコントロールを行うことを弱く推奨する（エキス パートコンセンサス：エビデンス不十分)。

\section{（1）背景および本 $C Q$ の重要度}

尿管閉塞に起因する急性腎孟腎炎は感染源のコント ロールが必要な疾患である。尿路感染の兆候を伴う尿 管閉塞は泌尿器科領域における緊急対応を要する病態 であり，尿管ステント留置術・腎ろう造設術などを用 いた緊急の減圧術は, 感染を伴う水腎症に起因するさ らなる合併症を予防する目的でしばしば必要な処置で ある。したがって，尿管閉塞を原因とする急性腎孟腎 炎に対し, 感染源コントロールを行うか否かは重要な 問題と考えられる。

\section{(2) PICO}

$\mathrm{P}$ (患者)：尿管閉塞に起因する急性腎孟腎炎による 敗血症患者

I（介入）：感染源のコントロール（尿管ステント留 置術・腎ろう造設術）を行う

C (対照)：感染源のコントロール（尿管ステント留 置術・腎ろう造設術）を行わない

O (アウトカム) : 28 日死亡, 病院死亡, ICU 滞在 日数, 病院滞在日数, 感染源のコントロールに伴 う合併症

\section{（3）エビデンスの要約}

システマティックレビューの結果, PICO に合致す るランダム化比較試験（RCT）は存在しないことが確 認された。

\section{（4）益と害のバランス}

望ましい効果 :

尿管閉塞に起因する急性腎孟腎炎は，経尿道的尿管 ステント留置術あるいは経皮的腎ろう造設術を行い, 原因の解消を行わなければ, 敗血症から回復する可能 性は低く, 迅速な感染源のコントロールを行うことは 患者に益する可能性が高いと考える。

望ましくない効果 :

侵襲的な処置に伴う害として, 出血, 臓器損傷や後
腹膜（腔）への感染の波及などが考えられる。

益と害のバランス :

PICO に合致する RCT は存在せず，効果のバランス は不明であるが，尿管閉塞に起因する急性腎孟腎炎は 経尿道的尿管ステント留置術あるいは経皮的腎ろう造 設術を行って得られる利益と, 出血などの合併症や専 門施設への移送費用などの害を考慮しても益が害を上 回ると考えられる。

（5）アウトカム全般に関するエビデンスの確実性 システマティックレビューを行ったが，PICOに合 致する RCT は存在しなかった。

\section{（6）価值観}

一般的に，死亡が低下することについて患者・家族 は重視すると考えられ，不確実性やばらつきはないと 考える。

\section{（7）容認性}

本介入（経尿道的尿管ステント留置術あるいは経皮 的腎ろう造設術）は保険診療で認められた標準的治療 法であり，原因の解消を行わなければ，敗血症から回 復する可能性は低く，迅速な感染源のコントロールを 行うことは患者にとって益が害を上回る可能性が高い と考えることから，容認性はおそらく妥当なものと考 える。

\section{（8）実行可能性}

本介入（経尿道的尿管ステント留置術あるいは経皮 的婜ろう造設術）は保険診療で認められた標準的治療 法であるため, 実效性は高いといえる。しかしなが ら, 迅速に専門性のある処置（経尿道的尿管ステント 留置術あるいは経皮的腎ろう造設術）を行うために は，施行可能な施設への移送などの負担が生じる可能 性がある。

（9）判断の要約（Table 3-5-1）

\section{（10）推奨グレーディング決定の工程}

修正 RAND 法を用いた投票によって, 中央值 8, 見解不一致指数 0.164 の結果となり，委員会で採択さ れた（7 点以上 : 95.8\%)。

（11）関連する他の診療ガイドラインにおける推奨 米国泌尿器科学会ガイドライン1) では，尿管閉塞 に起因する腎孟腎炎や膿腎症において迅速な閉塞の解 
日本版敗血症診療ガイドライン 2020

Table 3-5-1 判断の要約

\begin{tabular}{|c|c|c|c|c|c|c|c|}
\hline & \multicolumn{7}{|c|}{ 判畋 } \\
\hline 問題 & いいえ & $\begin{array}{c}\text { おそらく、いい } \\
\text { え }\end{array}$ & おそらく、はい & はい & & さまざま & 分からない \\
\hline 望ましい効果 & わずか & 小さい & 中 & 大きい & & さまざま & 分からない \\
\hline 望ましくない効果 & 大きい & 中 & 小さい & わずか & & さまざま & 分からない \\
\hline エビデンスの確実性 & 非常に低 & 低 & 中 & 高 & & & 採用研究なし \\
\hline 価値覞 & $\begin{array}{c}\text { 重要な不確実性 } \\
\text { またはばらつき } \\
\text { あり }\end{array}$ & $\begin{array}{c}\text { 重要な不確実性 } \\
\text { またはばらつき } \\
\text { の可能性ありり }\end{array}$ & $\begin{array}{l}\text { 重要な不確実性 } \\
\text { またはばらつき } \\
\text { はおそらくなし }\end{array}$ & $\begin{array}{c}\text { 重要な不確実性 } \\
\text { またはばらつき } \\
\text { はなし }\end{array}$ & & & \\
\hline 効果のバランス & 比較が優位 & $\begin{array}{c}\text { 比較がおそらく } \\
\text { 優位 }\end{array}$ & $\begin{array}{c}\text { 介入も比較もい } \\
\text { ずれも優位でな } \\
\text { い }\end{array}$ & $\begin{array}{c}\text { おそらく介入が } \\
\text { 優位 }\end{array}$ & 介入が優位 & さまざま & 分からない \\
\hline 容認性 & いいえ & $\begin{array}{c}\text { おそらく、いい } \\
\text { え }\end{array}$ & おそらく、はい & はい & & さまざま & 分からない \\
\hline 実行可能性 & いいえ & $\begin{array}{c}\text { おそらく、いい } \\
\text { え }\end{array}$ & おそらく、はい & はい & & さまざま & 分からない \\
\hline
\end{tabular}

除が推奨されている（強い推奨エビデンスレベル GRADE C)。後方視的研究であるが, Borofsky ら 2) は，2007〜2009 年の尿路結石による敗血症を対象と した 1,712 名について多変量解析を行った結果，外科 的閉塞解除を行わなかった群は, 閉塞解除を行った群 と比較し, 死亡率が有意に高かった（19.2\% vs. 8.82\%, $P<0.001)$ と報告し, 米国泌尿器科学会ガイドライ ンでもこの報告が支持されている。EAU ガイドライ ン3）においても，速やかな閉塞の解除が強く推奨さ れている (GRADE A)。また，尿管閉塞の緊急解除の 方法である経皮的腎瘻造設術と経尿道的尿管ステント 留置術には有意な差は認められない。敗血症患者では なく結石性尿管閉塞による感染患者での研究である が，Pearle らの小規模 RCT ${ }^{4 ）}$ (1998 年，対象者数計 42 名）ではいずれの方法も同等に効果的であると報 告し，前述のガイドライン 1,3$)$ でもこの結果が支持 されている。

\section{（12）実施に関わる検討事項}

感染源のコントロールが行われたタイミングにより 結果が異なる可能性がある。本ガイドラインでは，可 及的速やかに感染源のコントロールを行うことを弱く 推奨する。

\section{（13）今後の研究の可能性}

尿管閉塞を原因とする急性腎孟腎炎による敗血症の 感染源のコントロールに関する RCT がないことが明 らかとなった。感染源のコントロールが死亡率に与え る影響や，感染源に伴う出血や炎症の波及などを検証
する RCT の実施が望まれる。しかしながら，感染源 のコントロールを施行することの益が害を上回ること が予想されることから，今後も RCT の実施は困難で あると思われる。今後は，感染源のコントロールの方 法やタイミングに関する検討が新たなエビデンスの構 築に不可欠と思われる。

\section{文 献}

1) Assimos D, Krambeck A, Miller NL, et al: Surgical Management of Stones: American Urological Association/Endourological Society Guideline, PART I. J Urol. 2016; 196: 1153-60.

2) Borofsky MS, Walter $D$, Shah $O$, et al: Surgical decompression is associated with decreased mortality in patients with sepsis and ureteral calculi. J Urol. 2013; 189: 946-51.

3) Türk C, Petř́ík A, Sarica K, et al: EAU Guidelines on Interventional Treatment for Urolithiasis. Eur Urol. 2016; 69: 475-82.

4) Pearle MS, Pierce HL, Miller GL, et al: Optimal method of urgent decompression of the collecting system for obstruction and infection due to ureteral calculi. J Urol. 1998; 160: 1260-4. 
CQ3-6：壊死性軟部組織感染症による敗血症患 者に対して，外科的デブリードマン術による感 染源のコントロールを行うか?

Answer : 壊死性軟部組織感染症による敗血症患者に 対して，可及的速やかに外科的デブリードマン術によ る感染源のコントロールを行うことを弱く推奨する (エキスパートコンセンサス：エビデンス不十分)。

\section{（1）背景および本 CQ の重要度}

壊死性軟部組織感染症は，早期の感染源の外科的コ ントロールが必要な疾患である。デブリードマン術の 必要性の有無が画像検査では困難であることなども知 られており, 重要臨床課題であるため, 本ガイドライ ンの CQとして取り上げた。

\section{(2) PICO}

$\mathrm{P}$ (患者)：壊死性軟部組織感染症による敗血症患者

I（介入）：外科的デブリードマン術を行う

$\mathrm{C}$ (対照)：外科的デブリードマン術を行わない

O (アウトカム ) : 28 日死亡, 病院死亡, ICU 滞在 日数, 病院滞在日数, 感染源のコントロールに伴 う合併症

\section{（3）エビデンスの要約}

システマティックレビューの結果，PICO に合致し たランダム化比較試験（RCT）は存在しなかった。

\section{（4）益と害のバランス}

望ましい効果 :

敗血症の原因となっている壊死組織（軟部組織）に 対し，外科的デブリードマン術を行うことで，感染源 の確実なコントロールが可能となり，生命予後や治療 日数の短縮などの望ましい効果が得られる可能性が高 いと考えられる。

\section{望ましくない効果：}

多くは全身麻酔下での手術が必要である。循環動態 の不安定例では麻酔導入によるさらなる不安定化も懸 念される。また，出血などによる循環動態への影響も 懸念される。外科的デブリードマン術により，新たな 臓器虚血を来し, 追加の外科的デブリードマン術が必 要となることもある。

\section{益と害のバランス :}

PICO に合致する RCT は存在せず不明であるが，感 染源を外科的に除去することは，外科的治療を行わな い場合よりも益が害を上回るものと考えられる。
（5）アウトカム全般に関するエビデンスの確実性 システマティックレビューを行ったが，PICO に合 致する RCT は存在しなかった。

\section{（6）価値観}

一般的に，死亡が低下することについて患者・家族 は重視すると考えられ，不確実性やばらつきはないと 考える。

\section{（7）容認性}

手術室への移動を伴うため，医師，看護師など医療 従事者の仕事量が増大するが，集中治療室での仕事の 範疇であり，特にその影響は少ないと考えられる。外 科的治療に伴うコストの増大はあるが，全体の診療に 占める割合は小さく容認性は妥当なものといえる。

\section{（8）実行可能性}

外科的デブリードマン術は, 敗血症診療を行う多く の施設で実行可能であると考えられる。しかしなが ら, 状況により実行不可能な場合は, 迅速に施行可能 な施設への移送などの負担が生じる。

(9) 判断の要約（Table 3-6-1）

\section{（10）推奨グレーディング決定の工程}

修正 RAND 法を用いた投票によって，中央值 8, 見解不一致指数 0.178 の結果となり, 委員会で採択さ れた（7点以上 : $87.5 \%) 。$

\section{（11）関連する他の診療ガイドラインにおける推奨}

SSCG 2016 では，敗血症や敗血症性ショックの患者 においては，緊急で感染源のコントロールを要する特 定の解剖学的部位がないかどうかの診断を速やかに行 うことが推奨されており, 診断後は可能な限り速やか に感染源のコントロールのためのインターベンション を行うことを推奨する「best practice statement」となっ ている1)。

筋膜や筋区画などの深部感染を来しているかどうか の判断が重要となるが, IDSA（Infectious Diseases Society of America) のガイドラインにおいては，CT や MRI などの画像診断が有用ではあるが，画像診断 のために治療介入が遅れる可能性がある場合には, 早 期に外科的デブリードマン術を行って筋膜組織まで感 染が及んでいるかどうかを直接目視にて確認すること が推奨されている2)。 
Table 3-6-1 判断の要約

\begin{tabular}{|c|c|c|c|c|c|c|c|}
\hline 問題 & いいえ & $\begin{array}{c}\text { おそらく、いい } \\
\text { え }\end{array}$ & おそらく、はい & はい & & さまざま & 分からない \\
\hline 望ましい効果 & わずか & 小さい & 中 & 大きい & & さまざま & 分からない \\
\hline 望ましくない効果 & 大きい & 中 & 小さい & わずか & & さまざま & 分からない \\
\hline エビデンスの確実性 & 非常に低 & 低 & 中 & 高 & & & 採用研究なし \\
\hline 価值钼 & $\begin{array}{c}\text { 重要な不確実性 } \\
\text { またはははらつき } \\
\text { あり }\end{array}$ & $\begin{array}{c}\text { 重要な不確実性 } \\
\text { またはばらつき } \\
\text { の可能性ありり }\end{array}$ & $\begin{array}{l}\text { 重要な不確実性 } \\
\text { またはははらつき } \\
\text { はおそらくなし }\end{array}$ & $\begin{array}{c}\text { 重要な不確実性 } \\
\text { またはばらつき } \\
\text { はなし }\end{array}$ & & & \\
\hline 効果のパランス & 比較が優位 & $\begin{array}{c}\text { 比較がおそらく } \\
\text { 優位 }\end{array}$ & $\begin{array}{c}\text { 介入も比較もい } \\
\text { ずれも優位でな } \\
\text { い }\end{array}$ & $\begin{array}{c}\text { おそらく介入が } \\
\text { 優位 }\end{array}$ & 介入が優位 & さまざま & 分からない \\
\hline 容認性 & いいえ & $\begin{array}{c}\text { おそらく、いい } \\
\text { え }\end{array}$ & おそらく、はい & はい & & さまざま & 分からない \\
\hline 実行可能性 & いいえ & $\begin{array}{c}\text { おそらく、いい } \\
\text { え }\end{array}$ & おそらく、はい & はい & & さまざま & 分からない \\
\hline
\end{tabular}

\section{（12）実施に関わる検討事項}

一度に広範囲に外科的デブリードマン術を行う場合 と，段階的に外科的デブリードマン術を行う場合と

で，益と害のバランスが異なる可能性がある。

\section{（13）今後の研究の可能性}

壊死性軟部組織感染症による敗血症患者に対して, 外科的デブリードマン術による感染源のコントロール に関する RCT が存在しないことが明らかとなった。 壊死性軟部組織感染症は，時に急速に進行するため （溶連菌感染症などでは急速に進行することがある）, 外科的デブリードマン術が遅れると致死的となる可能 性がある ${ }^{3)}$ 。そのため，外科的デブリードマン術を行 わないという選択を強要することは難しく, 今後も RCT の実施は困難ではないかと考える。また，全身 麻酔に伴う循環動態への影響が考えられるため，外科 的デブリードマン術を行うタイミングや， 1 回の外科 的デブリードマン術を行う処置の範囲などについて は，今後さらに検討が必要である。

\section{文 献}

1) Rhodes A, Evans LE, Alhazzani W, et al: Surviving Sepsis Campaign: International Guidelines for Management of Sepsis and Septic Shock: 2016. Crit Care Med. 2017; 45: 486-552.

2) Stevens DL, Bisno AL, Chambers HF, et al: Practice guidelines for the diagnosis and management of skin and soft tissue infections: 2014 update by the infectious diseases society of America. Clin Infect Dis. 2014; 59: 147-59.

3) Nawijn F, Smeeing DPJ, Houwert RM, et al: Time is of the essence when treating necrotizing soft tissue infections: A systematic review and meta-analysis. World J Emerg Surg. 2020; 15: 4 
CQ3-7 : カテーテル関連血流感染が疑われる敗 血症患者に対して, カテーテル抜去による感染 源のコントロールを行うか?

Answer : カテーテル関連血流感染が疑われる敗血症 患者に対して, 可及的速やかにカテーテル抜去による 感染源のコントロールを行うことを弱く推奨する（エ キスパートコンセンサス：エビデンス不十分)。

\section{（1）背景および本 $C Q$ の重要度}

カテーテル関連血流感染（CRBSI）では，覚知と対 処の遅れは転帰悪化につながりうる。CRBSI 予防が 重要であることは周知の事実であるが，カテーテルの 留置期間や抜去のタイミングについては, 最終的なコ ンセンサスを得られていない。そのため，本ガイドラ インの CQ として取り上げた。

(2) PICO

$\mathrm{P}$ (患者)：血管カテーテル感染による敗血症を疑う 患者

I（介入）：感染源のコントロール（カテーテル抜 去）を行う

$C$ (対照)：感染源のコントロール（カテーテル抜 去）を行わない

O (アウトカム)：28 日死亡, 病院死亡, ICU 滞在 日数, 病院滞在日数, 感染源のコントロールに伴 う合併症

（3）エビデンスの要約

システマティックレビューの結果, PICO に合致し たランダム化比較試験（RCT）は存在しなかった。

\section{（4）益と害のバランス}

望ましい効果 :

血管カテーテル感染は, 感染源のコントロールを行 わない通常の抗菌薬治療のみでは改善しない可能性が ある。原因の解消を行わなければ，予後や死亡率の悪 化につながる症例があるため, 迅速な感染源のコント ロールを行うことは患者に益する可能性が高いと考え る。この望ましい効果はカテーテル感染診断の正確性 の影響を受ける。

望ましくない効果 :

血管カテーテルが必要な患者は, 感染源のコント ロールとして血管カテーテルを抜去するのみではな く, 血管カテーテルの再挿入が必要であり, 血管カ テーテル挿入に関連する合併症が考えられ，再挿入に
関する状況に影響を受ける。頻回なルート交換は，コ スト・作業負担を増加させる。

益と害のバランス :

$\mathrm{PICO}$ に合致する RCT は存在せず，効果のバランス は不明である。血管カテーテル感染の場合, 感染源の コントロール（カテーテル抜去）を行って得られる利 益と，血管カテーテル㨂入に関連する合併症による害 を比較しても，おそらく益が害を上回ると考えられ る。

（5）アウトカム全般に関するエビデンスの確実性

システマティックレビューを行ったが，PICO に合 致する RCT は存在しなかった。

\section{（6）価值観}

一般的に，死亡が低下することについて患者・家族 は重視すると考えられ，不確実性やばらつきはないと 考える。

\section{（7）容認性}

感染源のコントロール（カテーテル抜去）は標準的 治療法であり，原因の解消を行わなければ，敗血症か ら回復する可能性は低く, 迅速な感染源のコントロー ルを行うことは患者にとって益が害を上回る可能性が 高いと考えることから，容認性はおそらく妥当なもの と考える。カテーテルの再㨂入に関連する負担が存在 する。

\section{（8）実行可能性}

感染源のコントロール（カテーテル抜去）は，敗血 症診療を行う多くの施設で実行可能であると考えられ る。

（9）判断の要約（Table 3-7-1）

（10）推奨グレーディング決定の工程

修正 RAND 法を用いた投票によって，中央值 8, 見解不一致指数 0.178 の結果となり，委員会で採択さ れた（7 点以上 : $87.5 \%) 。$

\section{（11）関連する他の診療ガイドラインにおける推奨}

SSCG 2016 においては，敗血症や敗血症性ショック の感染源の可能性がある血管カテーテルは, 他の血管 カテーテルを挿入後直ちに抜去することを推奨する 「best practice statement」となっている1)。 
Table 3-7-1 判断の要約

\begin{tabular}{|c|c|c|c|c|c|c|c|}
\hline & \multicolumn{7}{|c|}{ 判断 } \\
\hline 問題 & いいえ & $\begin{array}{c}\text { おそらく、いい } \\
\text { え }\end{array}$ & おそらく、はい & はい & & さまざま & 分からない \\
\hline 望ましい效果 & わずか & 小さい & 中 & 大きい & & さまざま & 分からない \\
\hline 望ましくない勃果 & 大きい & 中 & 小さい & わずか & & さまざま & 分からない \\
\hline エビデンスの確実性 & 非常に低 & 低 & 中 & 高 & & & 採用研究なし \\
\hline 価值観 & $\begin{array}{c}\text { 重要な不確実性 } \\
\text { またはばらつき } \\
\text { あり }\end{array}$ & $\begin{array}{c}\text { 重要な不確実性 } \\
\text { またはばらつ } \\
\text { の可能性あり }\end{array}$ & $\begin{array}{l}\text { 重要な不確実性 } \\
\text { またはばらつき } \\
\text { はおそらくなし }\end{array}$ & $\begin{array}{c}\text { 重要な不確実性 } \\
\text { またはばらつき } \\
\text { はなし }\end{array}$ & & & \\
\hline 効果のパランス & 比較が優位 & $\begin{array}{c}\text { 比較がおそらく } \\
\text { 優位 }\end{array}$ & $\begin{array}{c}\text { 介入も比較もい } \\
\text { ずれも優位でな } \\
\text { い }\end{array}$ & $\begin{array}{c}\text { おそらく介入が } \\
\text { 優位 }\end{array}$ & 介入が優位 & さまざま & 分からない \\
\hline 容認性 & いいえ & $\begin{array}{c}\text { おそらく、いい } \\
\text { え }\end{array}$ & おそらく、はい & はい & & さまざま & 分からない \\
\hline 実行可能性 & いいえ & $\begin{array}{c}\text { おそらく、いい } \\
\text { え }\end{array}$ & おそらく、はい & はい & & さまざま & 分からない \\
\hline
\end{tabular}

\section{（12）実施に関わる検討事項}

血管カテーテル留置の必要度や, 再留置の難易度に

より，益と害のバランスが異なる可能性がある。

\section{（13）今後の研究の可能性}

血管カテーテル感染を迅速に高精度に診断する方法

のさらなる研究が必要と考えられる。

$$
\text { 文 献 }
$$

1) Rhodes A, Evans LE, Alhazzani W, et al: Surviving Sepsis Campaign: International Guidelines for Management of Sepsis and Septic Shock: 2016. Crit Care Med. 2017; 45: 486-552. 
CQ3-8：膿胸による敗血症患者に対して，侵襲 的ドレナージ術による感染源コントロールを行 うか?

Answer：膿胸による敗血症患者に対して, 可及的速 やかに開胸ドレナージまたは経皮的胸腔ドレナージに よる感染源のコントロールを行うことを弱く推奨する (エキスパートコンセンサス：エビデンス不十分）。

\section{（1）背景および本 $C Q$ の重要度}

膿胸は感染源のコントロールが必要な病態であり, 開胸ドレナージ，または経皮的胸腔ドレナージによる 感染源のコントロールが行われる。臨床現場において は，タイミングや処置法について最終的なコンセンサ スを得ていない。また，感染源のコントロール処置を いつ行うべきか, 適切な方法は何かについて科学的根 拠を明示しているガイドラインはない。侵襲的処置 （開胸・経皮的ドレナージ術）の有効性，有害性の評 価は定まっておらず，侵襲的処置に関する本 $\mathrm{CQ}$ の優 先度は高いと考える。

\section{(2) PICO}

$\mathrm{P}$ (患者) : 膿胸, 気管支断端瘻, 胸膜炎, 肺炎随伴 性胸水を伴う敗血症患者

I（介入）：感染源のコントロール（開胸・経皮的ド レナージ術）を行う

C (対照)：感染源のコントロール（開胸・経皮的ド レナージ術）を行わない

O (アウトカム) : 28 日死亡, 病院死亡, ICU 滞在 日数, 病院滞在日数, 感染源のコントロールに伴 う合併症

\section{（3）エビデンスの要約}

システマティックレビューの結果，PICO に合致す るランダム化比較試験（RCT）は存在しないことが確 認された。

\section{（4）益と害のバランス}

望ましい効果 :

被包化を伴った膿胸は通常の抗菌薬治療では改善し ないため，原因の解消を行わなければ，敗血症から回 復する可能性は低いと考えられる。したがって, 迅速 な感染源のコントロールを行うことは患者に益する可 能性が高いと考える。

望ましくない効果 :

侵襲的な処置に伴う害として, 出血や肺損傷，創部
やドレーンの痛みなどが考えられる。開胸術は経皮的 ドレナージ術に比して侵襲が大きく，望ましくない効 果の程度は大きいと考えられる。

益と害のバランス :

PICO に合致する RCT は存在せず，効果のバランス は不明であるが，膿胸による敗血症では，開胸・経皮 的ドレナージ術を行って得られる利益と, 出血や肺損 傷などの合併症を考慮しても，おそらく益が害を上回 ると考えられる。

（5）アウトカム全般に関するエビデンスの確実性

システマティックレビューを行ったが，PICO に合 致する RCT は存在しなかった。

\section{（6）価值観}

一般的に，死亡が低下することについて患者および 患者家族は重視すると考えられ，不確実性やばらつき はないと思われる。

\section{（7）容認性}

本介入（開胸・経皮的ドレナージ術）は保険診療で 認められた標準的治療法であり，原因の解消を行わな ければ，敗血症から回復する可能性は低く，迅速な感 染源のコントロールを行うことは患者にとって益が害 を上回る可能性が高いと考えることから，容認性はお そらく妥当なものと考える。組織の癒着などによりド レナージの経路に実質臟器が存在し, 経皮的ドレナー ジが困難な場合には，開胸ドレナージも考虑して迅速 に施行可能な施設への移送などの負担が生じる。

\section{（8）実行可能性}

開胸・経皮的ドレナージ術の実行可能性は高い。施 設により実行できない場合は，実行可能な施設への移 送により実行可能と考えられる。

\section{（9）判断の要約（Table 3-8-1)}

\section{（10）推奨グレーディング決定の工程}

修正 RAND 法を用いた投票によって，中央值 8, 見解不一致指数 0.014 の結果となり, 委員会で採択さ れた（7 点以上 : 95.8\%)。

\section{（11）関連する他の診療ガイドラインにおける推奨}

英国胸部疾患学会ガイドライン1）や米国胸部疾患 学会ガイドライン 2) では, 膿胸の患者には経皮的胸 腔ドレナージを施行し，胸部 X 線や全身状態を観察 
Table 3-8-1 判断の要約

\begin{tabular}{|c|c|c|c|c|c|c|c|}
\hline & \multicolumn{7}{|c|}{ 判河 } \\
\hline 問題 & いいえ & $\begin{array}{c}\text { おそらく、いい } \\
\text { え }\end{array}$ & おそらく、はい & はい & & さまざま & 分からない \\
\hline 望ましい效果 & わずか & 小さい & 中 & 大きい & & さまざま & 分からない \\
\hline 望ましくない効果 & 大きい & 中 & 小さい & わずか & & さまざま & 分からない \\
\hline エビデンスの確実性 & 非常に低 & 低 & 中 & 高 & & & 採用研究なし \\
\hline 価値観 & $\begin{array}{c}\text { 重要な不確実性 } \\
\text { またははよらつき } \\
\text { あり }\end{array}$ & $\begin{array}{c}\text { 重要な不確実性 } \\
\text { またはばらつき } \\
\text { の可能性あり }\end{array}$ & $\begin{array}{l}\text { 重要な不確実性 } \\
\text { またはばらつき } \\
\text { はおそらくなし }\end{array}$ & $\begin{array}{c}\text { 重要な不確実性 } \\
\text { またはばらつき } \\
\text { はなし }\end{array}$ & & & \\
\hline 効果のバランス & 比較が優位 & $\begin{array}{c}\text { 比較がおそらく } \\
\text { 優位 }\end{array}$ & $\begin{array}{c}\text { 介入も比較もい } \\
\text { ずれも優位でな } \\
\text { い }\end{array}$ & $\begin{array}{c}\text { おそらく介入が } \\
\text { 優位 }\end{array}$ & 介入が優位 & さまざま & 分からない \\
\hline 容認性 & いいえ & $\begin{array}{c}\text { おそらく、いい } \\
\text { え }\end{array}$ & おそらく、はい & はい & & さまざま & 分からない \\
\hline 実行可能性 & いいえ & $\begin{array}{c}\text { おそらく、いい } \\
\text { え }\end{array}$ & おそらく、はい & はい & & さまざま & 分からない \\
\hline
\end{tabular}

することが推奨されている。英国胸部疾患学会ガイド ライン 1) では, 厚さ $10 \mathrm{~mm}$ を超える胸水または胸水 の増量を認める場合や症状が軽快しない場合は，診断 のためのサンプリングを推奨している。膿胸の診断に は画像所見のみならず検体をサンプリングし，細菌培 養, グラム染色, 生化学的検査 ( $\mathrm{pH}$ や血糖值) から の総合的診断が有用である。胸膜感染患者では血液培 養以外に細菌を認めない場合もあることから，血液培 養の施行も重要である。抗菌薬の投与とドレナージに て 5〜7 日以内に改善がみられない（胸水の増量や症 状が軽快しない）場合には，外科的手術も考慮す る1)。

膿胸に対する侵襲的処置である経皮的ドレナージと 開胸ドレナージについて, Redden らはシステマティッ クレビュー（2017 年, 対象者数計 391 名）を行い, いずれの方法も合併症に有意差を認めなかったことを 報告している3)。

\section{（12）実施に関わる検討事項}

膿胸の形状 (単房性, 多房性)，大きさや肺実質の 胸膜への癒着，ならびに患者の重篤度による，侵襲的 処置（開胸・経皮的ドレナージ）により，益と害のバ ランスが異なる可能性がある。

\section{（13）今後の研究の可能性}

膿胸による敗血症患者の侵襲的処置（開胸・経皮的 胸腔ドレナージ）に関する RCT がないことが明らか になり，侵襲的処置が死亡率に与える影響について検 証する RCT の実施が望まれるが，患者の病態 [膿胸
の形状 (単房性, 多房性), 大きさや肺実質の胸膜へ の癒着，ならびに患者の重篤度など］は均一ではな く, RCT の実施は困難と思われる。今後は，実施の タイミングや方法がアウトカムに及ぼす影響について 検証する RCT の早期実施が望まれる。

\section{文 献}

1) Davies HE, Davies RJO, Davies CWH, et al: Management of pleural infection in adults: British Thoracic Society Pleural Disease Guideline 2010. Thorax. 2010; 65: ii41-53.

2) Colice GL, Curtis A, Deslauriers J, et al: Medical and surgical treatment of parapneumonic effusions : an evidence-based guideline. Chest. 2000; 118: 1158-71.

3) Redden MD, Chin TY, van Driel ML: Surgical versus non-surgical management for pleural empyema. Cochrane Database Syst Rev. 2017; 3: CD010651. 


\section{CQ4：抗菌薬治療}

はじめに

本項では，抗菌薬投与の開始から中止に関する臨床 課題の中で, 特に敗血症診療において重要と思われる $11 \mathrm{CQ}$ を取り上げた。内容はエビデンスの有無により， GRADE 評価を導入したもの, GRADE 評価を試みるも 叶わずエキスパートコンセンサスとしたもの，BQ とし て情報提供にとどめたものがあり，留意のうえうまく 活用していただきたい。研究の乏しい領域では，今後 の知見集積に伴い考え方が変化する可能性がある。

抗菌薬治療は, 敗血症診療における原疾患に対する 必須の根本治療である。抗菌薬治療のむずかしさは, その介入が直接転帰に関わることだけでなく，世界的 に深刻化する抗菌薬耐性（antimicrobial resistance: AMR）の問題とも関係しており，過剩な治療が将来 の有効な治療薬を失うリスクと関係している点にあ る。敗血症に対する不十分な治療は避ける必要がある が，同時に過剩な治療も慎む必要がある。いわゆる antimicrobial stewardship (AS) の考え1)を十分に取り 入れた分別のある抗菌薬治療が求められる。

本ガイドラインは，敗血症診療に特化したガイドラ インであるため，抗菌薬選択の各論には言及しない。 敗血症における抗菌薬選択の原則は, 一般的な感染症 診療と同様である。すなわち，患者背景，疑わしい感 染臟器, 地域や施設の疫学情報, 最近の抗菌薬使用歴 などから，可能な限り具体的な微生物や薬剂而性を想 定したうえで投与すべき抗菌薬を選択する。ただし， 敗血症患者では, 非重症患者の場合に比べて，原因微 生物に対して有効な抗菌薬を速やかに投与することが 重要である。また, 可能な施設においては, 感染症専 門医へのコンサルテーションも重要である。以下，各 $\mathrm{CQ}$ ごとに概説する。

CQ4-1：経験的抗菌薬はどのようにして選択するか？ 適切な経験的抗菌薬治療の選択は，適切な外科的感 染巣コントロールと並ぶ敗血症の根本治療であり, 患 者予後に関連する重要な治療介入である2)。抗菌薬選 択に関する原則は敗血症においても一般的な感染症診 療と同様であるが，一刻を争う敗血症診療では抗菌薬 選択に必要な情報収集に割ける時間に制約があり，し ばしば困難を伴う。個別の状況を考慮せずに画一的な 第一選択薬を決めておくと迅速な投与はしやすくなる が，個々の患者にとっては不十分なもしくは過剩な治 療になるリスクを伴う。

敗血症患者に対する経験的抗菌薬の選択の方法につ
いて，CQ として設定し，各感染症別の選択肢一覧と 共に示すことは, 臨床現場の意思決定にとって重要と 考えた。経験的抗菌薬は原因微生物の想定のもとに選 択し, 原因微生物が確定した後には標的抗菌薬へ最適 化されることが前提の治療であり, 最初の段階でいか に原因微生物を想定するかが重要である ${ }^{3-5)}$ 。疑わし い感染巣ごとに, 患者背景, 疫学や迅速微生物診断法 に基づいて原因微生物を推定し, 臟器移行性と耐性菌 の可能性も考慮して選択する方法がある（詳細は本文 参照)。選択薬リスト作成にあたっては，2012 年日本 版敗血症診療ガイドライン（J-SSCG）（初版）に示さ れた表と, 各感染症のガイドラインおよび抗菌薬感受 性試験のための標準検査法を参照して作成した（Table 4-1-1，4-1-2 参照) 6-8)。

CQ4-2 : 経験的抗菌薬にカルバペネム系抗菌薬を含め るのはどのような場合か？

広域抗菌薬の中で，カルバペネム系薬剤（以下，カ ルバペネム）は最も広域のスペクトラムを有する薬剤 であり，治療の適切性を高める目的で，敗血症の経験 的抗菌薬として比較的よく選択さ机うる。しかし，カ ルバペネムの過剩使用は, カルバペネム耐性菌の増加 のほか，抗菌薬関連の副作用やコストを高放険性 を伴っている9)。カルバペネムを遍く使用するのでは なく, 適切な症例に対して選択的に使用することは, 抗菌薬スチュワードシップの観点から望ましいと考え られる。よって，臨床現場においてカルバペネムを使 用したほうがよい適応病態をまとめておくことには意 義があると考え，具体的な情報提供を行うこととし た。

CQ4-3 : どのような場合に, MRSA や一般細菌以外 （カンジダ， ウイルス，レジオネラ, リヶッチア，ク ロストリジオイデス ディフィシルなど）に対する経 験的抗微生物薬を選択するか?

敗血症に対する経験的抗微生物薬を適切に選択する ことは，患者予後に関連し，非常に重要である2)。通 常用いられる広域 $\beta$ ラクタム系抗菌薬以外の抗微生物 薬が必要な病原体について，どのような場合に想起す べきかを知っておくことは, 迅速な対応が求められる 敗血症診療における臨床現場の意思決定に有用である と考え，CQ として設定した。

経験的抗微生物薬は原因微生物の想定のもとに選択 し，原因微生物が確定した後には標的抗微生物薬へ最 適化されることが前提の治療であり, 最初の段階でい かに原因微生物を想定するかが重要である ${ }^{3)}$ 。患者背 
景や検查結果などから，それぞれの微生物が原因とし て想定される場合を作成し，Table 4-3-1にまとめた。

CQ4-4：敗血症が疑われて経験的抗菌薬を使用する患 者において, 投与前の各種培養陰性の確認をしたら抗 菌薬を中止するか?

臨床的に敗血症と診断し，しかるべき培養検査を 行っても, その約 30〜 60\% は培養陰性となり “culture negative sepsis” と称される ${ }^{10)}$ 。敗血症の診断にもと づき経験的抗菌薬を開始した後，培養が陰性であった 場合, 安全に抗菌薬を終了可能かどうかは明らかでは なく, culture negative sepsisの疫学や予後をまとめた 知見は少ない。敗血症と診断した最大半数の患者が遭 遇しうる状況であり，本ガイドラインに取り上げるべ き重要臨床課題であると考え $\mathrm{CQ}$ として設定した。シ ステマティックレビューの結果, 本 CQ にこたえるラ ンダム化比較試験（RCT）は存在せず，エビデンス不 十分として，エキスパートコンセンサスとした。

CQ4-5: 感染症専門家あるいは抗菌薬適正使用支援 チームに相談するのはどのような場合か？

抗菌薬適正使用支援チーム (antimicrobial stewardship team: AST) は, 感染症専門の薬剤師や医 師を中心として臨床検査技師や看護師，事務職員で構 成され，医療機関において抗菌薬適正使用を実践する チームである。

敗血症の診療において, 抗菌薬の選択や投与経路, 投与間隔，投与期間の決定は患者の予後に影響を与え る重要な介入である2)。そのため, 敗血症診療におい ては, 想定される原因微生物を十分カバーする抗菌薬 の選択が求められる。しかしながら, 敗血症の初期抗 菌薬として何を選択するべきかに関しては，画一的な 回答はなく, 実際には個々の症例に応じて抗菌薬を選 択する必要があるため, 対応する医師の大きな負担と なりうる。ASTに相談することで, 適切な感染巣の 評価や抗菌薬選択, 抗菌薬の投与期間設定の援助がな され，医師の負担を軽減すると共に，適切な感染症治 療遂行が期待できる 11 。具体的にどのような場合に 相談すべきかについて，情報提供した。

CQ4-6 : 敗血症に対する経験的抗菌薬は, 敗血症認知 後 1 時間以内を目標に投与を開始するか?

敗血症における抗菌薬投与のタイミングに関して は，RCT の施行がむずかしいが，可及的速やかに抗 菌薬投与を開始する有益性は, 理論的に受け入れやす く, それを支持する観察研究が複数報告されてい
る 12-14)。Kumar らの観察研究では敗血症性ショック 患者において, 抗菌薬投与が 1 時間遅れるごとに死亡 率が $7.6 \%$ 増加すると報告されている ${ }^{15) 。 し か し ， 1 ~}$ 時間以内の抗菌薬投与に固執した場合, 原因微生物診 断の推定が不十分となり, 不必要かつ過剩に広域・多 剂の抗菌薬投与が増える可能性がある。そのため, 現 時点のエビデンスを再精査し, RCT と観察研究を含 めたシステマティックレビューを行い, 推奨文を作成 した。

\section{CQ4-7：敗血症に対して $\beta$ ラクタム系薬の持続投与ま} たは投与時間の延長を行うか?

本 CQ は抗菌薬のPK-PD (pharmachokinetics/ pharmachodynamics）理論にもとづき, 既存の抗菌薬 の治療効果を高められないかを検討した臨床課題であ る。 $\beta$ ラクタム系薬は敗血症治療に最も広く選択され る抗菌薬であり 16), その殺菌作用と治療効果は, 血 中濃度が治療対象となる細菌の最小発育阻止濃度 （MIC）を超えている時間に相関する。この特性を考 慮すると, 点滴時間を延長するかもしくは持続投与す ることは, time above MIC (24 時間の中で抗菌薬の血 中濃度が MIC を超えている時間の割合）を延長し， より優れた臨床効果が期待できる可能性がある ${ }^{17) 。}$ しかし，これまで本邦において抗菌薬は間欠的投与さ れることが多かった。近年, この疑問に答える RCT が報告されており，これらの RCT を対象としたシス テマティックレビューを行い, 推奨文を作成した。

CQ 4-8：敗血症に対する抗菌薬治療において, デェ スカレーションを行うか?

デエスカレーションとは, 経験的治療として投与開 始された広域ないし多剤の抗菌薬が適切で, かつ必要 なソースコントロールができている場合において, 原 因菌の同定/抗菌薬感受性が判明したのちに, 可及的 速やかに狭域・単剂の抗菌薬へと変更する戦略のこと である ${ }^{18)}$ 。デエスカレーションは, AMR 対策, 感染 管理, そして医療経済的な視点から理にかなった戦略 である。J-SSCG 2016 では4,5), 敗血症, 敗血症性 ショックの患者に対する抗菌薬治療において, デエス カレーションを実施することが弱く推奨（2D）され ており, SSCG 20163) でも best practice statement とし て推奨されていた。

しかし，デエスカレーションという介入を直接的に 評価する RCT を企図することは容易ではなく, 過去 の報告は観察研究が多い。今回は RCT および観察研 究の双方においてエビデンスを評価し, 推奨を作成し 
た。とりわけ，デエスカレーションは現在広く普及し ている診療手法であること，かつ，抗菌薬スチュワー ドシップの観点が世界的にも国内でも強調されている という背景も踏まえ，推奨文を作成した。

CQ4-9：敗血症に対する抗菌薬治療において，プロカ ルシトニンを指標とした治療終了を行うか?

感染症における抗菌薬の中止基準に関する質の高い 科学的根拠は少ない。敗血症の経過におけるプロカル シトニンの低下は死亡リスクの減少と関連しているこ とが報告されている19,20)。そこで，プロカルシトニ ンをガイドに用いて抗菌薬中止を行うことにより患者 の転帰を悪化させることなく抗菌薬日数を短縮できる のではないかという研究が近年活発に行われてきた。
今回，敗血症および敗血症性ショックを対象にプロカ ルシトニンを指標とした抗菌薬の中止を検討した $\mathrm{RCT}$ を対象にシステマティックレビューを行い，推 奨文を作成した。

CQ4-10：敗血症に対して，比較的短期間（7 日間以 内）の抗菌薬治療を行うか?

敗血症に対する抗菌薬治療に伴う害として，投与期 間が長いほど常在菌叢の中で耐性菌やClostridioides difficile，真菌が定着・増殖するリスクが高まり，次 の新たな敗血症のリスクになる 21,22$)$ 。近年，抗菌薬 耐性の問題は世界的な脅威となっており ${ }^{23)}$, 肺炎な どの各種感染症における抗菌薬の治療期間について, 短期間治療は長期間治療と比較して死亡率や臨床的治

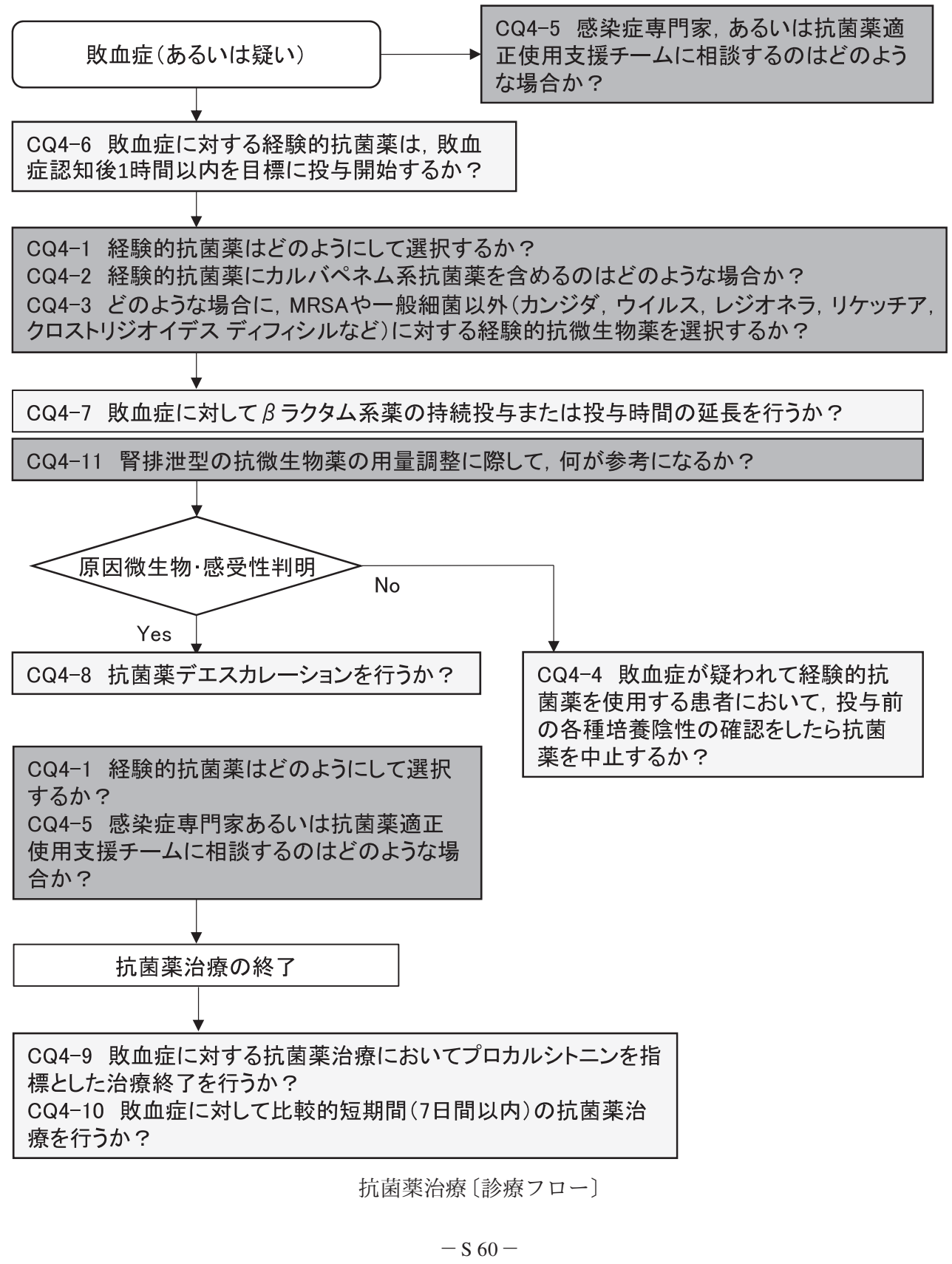


癒率に差がない報告が増えてきた ${ }^{24,25)}$ 。しかし，敗 血症における抗菌薬の治療期間に関する知見は確立し ていない。そこで，敗血症または集中治療を要する感 染症のうち 4 週間以上の長期治療を要するもの（心内 膜炎，化膿性脊椎炎）を除いて，1 週間（8日）以内 の抗菌薬治療を 1 週間（8日）以上の抗菌薬治療と比 較した RCT を対象にシステマティックレビューを行 い，推奨文を作成した。

\section{CQ4-11：腎排泄型の抗微生物薬の用量調整に際し て，何が参考になるか？}

敗血症患者では臓器障害として腎障害を生じること が多く, 腎障害時には腎排泄型の抗微生物薬は用量調 整を行う必要がある15,26-28)。この観点から, 腎排泄 型の抗微生物薬の用量調整に際して参考とすべき指標 について BQ として記述した。特に，1）腎機能の指 標，2）分布容積の増加と血漿や細胞外液における抗 微生物薬の希䣋，3）腎クリアランスや体液量の変動,

4）体外膜型肺（extracorporeal membrane oxygenation: ECMO）や腎代替療法による影響に関する情報提供を 行った。

\section{文 献}

1) Pollack LA, van Santen KL, Weiner LM: Antibiotic stewardship programs in U.S. acute care hospitals: Findings from the 2014 national healthcare safety network annual hospital survey. Clin Infect Dis. 2016; 63: 443-9.

2) Paul M, Shani V, Muchtar E, et al: Systematic review and metaanalysis of the efficacy of appropriate empiric antibiotic therapy for sepsis. Antimicrob Agents Chemother. 2010; 54: 4851-63.

3) Rhodes A, Evans LE, Alhazzani W, et al: Surviving Sepsis Campaign: International Guidelines for Management of Sepsis and Septic Shock: 2016. Intensive Care Med. 2017; 43: 304-77.

4）西田修，小倉裕司，井上茂亮，他，日本版敗血症診療ガイド ライン 2016 作成特別委員会. 日本版敗血症診療ガイドライ ン 2016. 日集中医誌. 2017; 24: S1-232.

5）西田修，小倉裕司，井上茂亮，他，日本版敗血症診療ガイド ライン 2016 作成特別委員会. 日本版敗血症診療ガイドライ ン 2016. 日救急医会誌. 2017; 28: S1-232.

6) Oda S, Aibiki M, Ikeda T, et al: The Japanese guidelines for the management of sepsis. J Intensive Care. 2014; 2:55

7）織田成人，相引眞幸，池田寿昭，他: 日本集中治療医学会 Sepsis Registry 委員会. 日本版敗血症治療ガイドライン 2013. 日集中医誌. 2013; 20 124-73.

8) CLSI M100-S27: Performance Standards for Antimicrobial Susceptibility Testing, 27th Edition. Available online at: https:// webstore.ansi.org/standards/clsi/clsim100s27. Accessed November 29, 2020.

9) Patrier J, Timsit JF: Carbapenem use in critically ill patients. Curr Opin Infect Dis. 2020; 33: 86-91.

10) Sigakis MJG, Jewell E, Maile MD, et al: Culture-Negative and Culture-Positive Sepsis: A Comparison of Characteristics and Outcomes. Anesth Analg. 2019; 129: 1300-9.

11) Raineri E, Pan A, Mondello P, et al: Role of the infectious diseases specialist consultant on the appropriateness of antimicrobial therapy prescription in an intensive care unit. Am J Infect
Control. 2008; 36: 283-90

12) Gaieski DF, Mikkelsen ME, Band RA, et al: Impact of time to antibiotics on survival in patients with severe sepsis or septic shock in whom early goal-directed therapy was initiated in the emergency department. Crit Care Med. 2010; 38: 1045-53.

13) Yokota PK, Marra AR, Martino MD, et al: Impact of appropriate antimicrobial therapy for patients with severe sepsis and septic shock - A quality improvement study. PLoS One. 2014; 9: e104475.

14) Ferrer R, Artigas A, Suarez D, et al: Effectiveness of treatments for severe sepsis: A prospective, multicenter, observational study. Am J Respir Crit Care Med. 2009; 180: 861-6.

15) Kumar A, Roberts D, Wood KE, et al: Duration of hypotension before initiation of effective antimicrobial therapy is the critical determinant of survival in human septic shock. Crit Care Med. 2006; 34: 1589-96.

16) Roberts JA, Abdul-Aziz MH, Lipman J, et al: Individualised antibiotic dosing for patients who are critically ill: Challenges and potential solutions. Lancet Infect Dis. 2014; 14: 498-509.

17) Abdul-Aziz MH, Sulaiman H, Mat-Nor MB, et al: Beta-Lactam Infusion in Severe Sepsis (BLISS) : a prospective, two-centre, open-labelled randomised controlled trial of continuous versus intermittent beta-lactam infusion in critically ill patients with severe sepsis. Intensive Care Med. 2016; 42: 1535-45.

18) De Waele JJ, Schouten J, Beovic B, et al: Antimicrobial de-escalation as part of antimicrobial stewardship in intensive care: no simple answers to simple questions - a viewpoint of experts. Intensive Care Med. 2020; 46: 236-44.

19) Charles PE, Tinel C, Barbar S, et al: Procalcitonin kinetics within the first days of sepsis: Relationship with the appropriateness of antibiotic therapy and the outcome. Crit Care. 2009; 13: R38.

20) Karlsson S, Heikkinen M, PettiläV, et al: Predictive value of procalcitonin decrease in patients with severe sepsis: A prospective observational study. Crit Care. 2010; 14: R205.

21) Micek S, Johnson MT, Reichley R, et al: An institutional perspective on the impact of recent antibiotic exposure on length of stay and hospital costs for patients with gram-negative sepsis. BMC Infect Dis. 2012; 12: 56.

22) Baggs J, Jernigan JA, Halpin AL, et al: Risk of Subsequent Sepsis Within 90 Days After a Hospital Stay by Type of Antibiotic Exposure. Clin Infect Dis. 2018; 66: 1004-12.

23) The Government of Japan: National Action Plan on Antimicrobial Resistance (AMR) 2016-2020. 2016. Available online at: https:// www.mhlw.go.jp/file/06-Seisakujouhou-10900000-Kenkoukyoku/ 0000138942.pdf. Accessed November 29, 2020.

24) Royer S, Demerle KM, Dickson RP, et al: Shorter versus longer courses of antibiotics for infection in hospitalized patients: A systematic review and meta-analysis. J Hosp Med. 2018; 13: 336-42.

25) Onakpoya IJ, Walker AS, Tan PS, et al: Overview of systematic reviews assessing the evidence for shorter versus longer duration antibiotic treatment for bacterial infections in secondary care. PLoS One. 2018; 13: e0194858.

26) Godin M, Murray P, Mehta RL: Clinical approach to the patient with AKI and sepsis. Semin Nephrol. 2015; 35: 12-22.

27) Sime FB, Roberts MS, Roberts JA: Optimization of dosing regimens and dosing in special populations. Clin Microbiol Infect. 2015; $21: 886-93$.

28) Lewis SJ, Mueller BA: Antibiotic dosing in patients with acute kidney injury: 'Enough But Not Too Much'. J Intensive Care Med. 2016; 31: 164-76. 
CQ4-1：経験的抗菌薬はどのようにして選択す るか?

Answer : 疑わしい感染巣ごとに, 患者背景, 疫学や 迅速微生物診断法に基づいて原因微生物を推定し, 臓 器移行性と而性菌の可能性も考慮して選択する方法が ある（Table 4-1-1 参照）（BQ に対する情報提示）。

\section{（1）背景および本 $C Q$ の重要度}

適切な経験的抗菌薬治療の選択は, 適切な外科的感 染巣コントロールと並んで敗血症の根本治療であり, 患者予後に関連する重要な治療介入である ${ }^{1)}$ 。経験的 抗菌薬は原因微生物の想定のもとに選択し，原因微生 物が確定した後には標的抗菌薬へ最適化されることが 前提の治療であり, 最初の段階でいかに原因微生物を 想定するかが重要となる 2,3$)$

抗菌薬選択に関する原則は, 敗血症においても一般 的な感染症診療と同様であるが，一刻を争う敗血症診 療では抗菌薬選択に必要な情報収集に割ける時間に制 約があり困難を伴う。個別の状況を考慮せずに画一的 な第 1 選択薬を決めておくと迅速な投与はしやすくな るが，個々の患者にとっては不十分な，もしくは過剩 な治療になるリスクを伴う。

これまでの国際版および日本版敗血症診療ガイドラ イン（J-SSCG）では, 適切な経験的抗菌薬の選択は 重要であるという記載はあるものの, 具体的な選択に ついては各感染症別のガイドラインに委ねる形で記載 していないものが多かった 2-5)。しかし，各感染症別 ガイドラインの主な対象は一般病棟であり, 敗血症に 関する記載がないものが多い6-14)。

そこで, 敗血症患者に対する経験的抗菌薬の選択の 方法について, CQ として設定し, 各感染症別の選択 肢一覧とともに示すことは, 臨床現場の意思決定に とって重要と考えた。選択薬りスト作成にあたって は, 2012 年の J-SSCG に示された類似の表と, 各感染 症に関するガイドラインおよび抗菌薬感受性試験のた めの標準検査法を参照して作成した $4,5,15)$ 。

\section{（2）解説}

経験的抗菌薬の選択は, 疑われる感染巣ごとに, 患 者背景, 疫学に基づいて原因微生物を想定し, 利用可 能な範囲で迅速微生物診断法を用いてその確認をした うえで, 臟器移行性やスペクトラム（耐性菌の可能性 を含む)，および臨床的なエビデンスを踏まえて行う。

Table 4-1-1（各感染症別の経験的治療薬）は, 頻度 の高い感染巣と患者背景の組み合わせごとに, 敗血症
を前提とした経験的抗菌薬の選択肢リストを専門家の 意見として示した。本表は, 個別の状況や地域の疫学 などの情報を加味し, 各地域・施設における抗菌薬ガ イドラインと共に利用することで, 意思決定の参考に なることを想定している。また，各地域・施設におけ る抗菌薬ガイドラインが存在しなければ，本表をベー スとして作成することも可能である。

原因微生物は, 感染巣ごとの疫学により想定され る。したがって, 感染巣の同定は, 感染巣からの検体 採取や外科的ドレナージのためだけではなく，抗菌薬 の選択のために重要である。敗血症の原因になりうる 感染巣は, 本邦の 2 つの疫学研究 $(2010 \sim 11$ 年 : 15 施設, $2016 \sim 17$ 年 : 59 施設）によると, 呼吸器感染 症, 腹腔内感染症, 尿路感染症, 軟部組織感染症が多

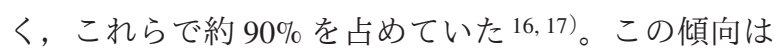
海外の複数の研究でも同様の結果であった 18-22)。一 方, 敗血症患者の約 $1 / 6$ は感染巣が同定されないとも 報告されている 18-22)。感染巣の特異的な所見を認め ない場合に考慮すべき感染症として, 感染巣はあるが 特異的な所見を捉えにくい感染症（感染性心内膜炎, カテーテル関連血流感染症など), 感染巣を形成しな い/ 不明の全身感染症（劇症型脾摘後感染症, 電撃性 紫斑病, リケッチア感染症, 感染巣のない発熱性好中 球減少症など）がある。人工物関連感染症（カテーテ 儿関連血流感染症, 人工弁心内膜炎, 脳室腹腔シャン 卜関連骾膜炎, 人工関節感染症など）は特異的所見が 得られにくいため注意する6-9)。

原因微生物は, 患者背景によっても想定される。(1) 外的因子としての患者周囲環境からの曝露歴（医療関 連, 渡航歴を含む) と, (2)内的因子としての患者自身 の状態（年齢, 性別, 基礎疾患を含む) の 2 つがあ る。抗菌薬選択の際にどの患者背景因子で分類するか は, 感染巣ごとに異なっている。一般的に, 市中感染 症は医療関連感染症と異なる微生物が原因になること が多く, 緑膿菌は例外を除いて市中感染症でルーチン にカバーする必要はない。医療関連感染症の危険因子 となる曝露には, 侵襲的手技またはデバイス（手術, 移植, 血管内カテーテル, 尿道留置カテーテル, 気管 チューブ，経管栄養チューブ，その他の人工物）や, 抗菌薬治療歷がある。海外渡航歷のある敗血症患者で は, マラリアや髄膜炎菌感染症, ウイルス性出血熱, レプトスピラ症, リケッチア症などの全身性感染症 や，薬剂耐性菌による感染症を考虑する必要があ る 23,24)。国内でもダ二媒介感染症流行地への旅行歴 があれば，リケッチア感染症（日本紅斑熱，ツツガム シ病）や重症熱性血小板減少症候群（SFTS）による 
敗血症を鑑別に含める 25)。また，宿主である患者の 要因として年齢は重要であり, 髄膜炎の原因菌は 50 歳以上か否かで異なる 10)。肺炎の原因としてのレジ オネラ症の約 $90 \%$ は 50 歳以上で発生している ${ }^{26) 。}$ 糖尿病患者では, 尿路感染症, 軟部組織感染症が多 (27)。好中球減少患者の敗血症では, 緑膿菌や, 状 況によって MRSA（methicillin-resistant Staphylococcus aureus）などを想定する11)。細胞性免疫不全患者 [HIV（human immunodeficiency virus）を含む］の肺 炎ではニューモシスチスを鑑別に含める 12 。

感染巣と患者背景に関連する疫学情報から原因微生 物を想定した後, 可能であれば迅速微生物診断法を実 施する。迅速微生物診断法としてグラム染色は, 採取 検体の白血球の有無により局所炎症があるかどうか, 有意な微生物が存在するかを確認できる。グラム染色 を実施した場合，検体の質を踏まえたうえで経験的抗 菌薬によるカバーの過不足がないかを検討することが 重要である13)。

原因微生物の想定・確認ができれば，臟器移行性や スペクトラム（耐性菌の可能性を含む），および臨床 的なエビデンスを踏まえて抗菌薬を選択する。抗菌薬 の藏器移行性と到達部位での活性に関して注意すべき ものを以下に示す。䯣膜炎に対する $\beta$ ラクタム系薬と してセフトリアキソン, セフェピム, メロペネムは使 用できるが，髄液移行性の観点からセファゾリンは避 けるべきである。心内膜炎に頭蓋内への播種として脳 膿瘍を合併した場合は，同様に髄液移行性に注意を要 する。肺炎に対してのダプトマイシンは, 肺胞のサー ファクタントで不活化されるため避ける ${ }^{14) 。}$

世界的に薬剤耐性の問題が大きくなってきており, 敗血症診療においても耐性菌の増加は脅威であ る 28-32)。抗菌薬の感受性率は, 時と場所（国, 地域, 施設, 病棟）によって変化するため, 各地域・施設の ローカル・データ（アンチバイオグラムを含む）の把 握が重要である4,5)。なお，アンチバイオグラムは 様々な目的で提出された検体の集計のため, 抗菌薬開 始前の検体のみを集めた実際の感受性率よりも耐性度 が高く示されることが報告されており，注意して使用 する ${ }^{33)}$ 。また, 患者自身の細菌検查歷も重要である。 過去の保菌（定着菌）や感染症の検出菌は, 必ずしも 敗血症の原因微生物になるとは限らないが，耐性菌の 検出歷がある場合には危険因子であり，カバーするこ とを考虑する。

経験的抗菌薬は, 想定される原因微生物のカバー漏 れを少なくするように選択するが，原因微生物が確定 すれば標的抗菌薬に移行することが前提の治療であ
る。もしカバーができていないことが判明した場合 は, 速やかな変更を要する。標的抗菌薬は, 治療効果 を最大限引き出し, 副作用および菌交代に伴うコラテ ラルダメージ（常在微生物叢に対する悪影響）を最小 限にするものがよい 34)。例えば，頭蓋内播種のない メチシリン感受性黄色ブドウ球菌（MSSA）菌血症に 対する第 1 選択薬は本邦ではセファゾリンであり, メ チシリン耐性が判明していない段階で頻用されるバン コマイシンよりもMSSA 菌血症に対する治療成績が

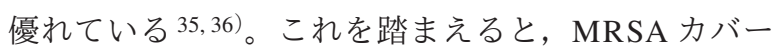
目的で経験的抗菌薬としてバンコマイシンを使用する 際に, MSSAの可能性が高いと判断した場合は, バン コマイシンとセファゾリンの併用も考慮される。この ように, 経験的抗菌薬の選択に際しては, 後に移行す る予定の標的抗菌薬の選択肢を事前に把握しておくこ とが有用である。Table 4-1-2（原因微生物別の標的治 療薬）には，敗血症診療で遭遇する可能性が高い標的 抗菌薬リストを感受性パターン別に示した。なお, 経 験的抗菌薬から標的抗菌薬に移行する際にスペクトラ ムのみに焦点をあてた考え方として，広域抗菌薬を狭 域抗菌薬に変更する場合はデエスカレーションと表現 し，その反対はエスカレーションと表現する 23,37)。 敗血症においてデエスカレーションが有効な戦略かに ついては CQ4-8を参照する。

敗血症に対する抗菌薬選択を最適化することで予後 を改善しようとする種々の検討がなされてきた。2016 年の J-SSCG では, 経験的抗菌薬治療におけるルーチ ンの併用療法は, 予後を改善せず腎障害を含む治療の 害が問題になるため, 行わないことが推奨された (1B) 3)。また, 敗血症診療ではカルバペネムが比較 的よく選択されるが, 薬剤耐性の脅威が世界的な課題 となるなかで, カルバペネムの過剩使用を控えるレジ メン (carbapenem-sparing regimen) を戦略的に採用す る取り組みがなされてきた。本邦では, 2018 年から は抗菌薬適正使用支援加算が新設され, 感染症専門家 や抗菌薬適正使用支援チームへの相談体制の整備が推 進されている。これらを踏まえて, 経験的抗菌薬を選 択する際には, CQ4-2(経験的抗菌薬にカルバペネム 系抗菌薬を含めるのはどのような場合か? ), CQ4-3 [どのような場合に, MRSA や一般細菌以外（カンジ ダ, ウイルス, レジオネラ, リケッチア, クロストリ ジオイデスディフィシルなど）に対する経験的抗微 生物薬を選択するか], CQ4-5（感染症専門家あるい は抗菌薬適正使用支援チームに相談するのはどのよう な場合か？）も参考になる。

最後に, 敗血症の原因となる感染症の種類が多岐に 
わたることに加えて，薬剤耐性の世界的な脅威，抗菌 薬の開発・供給制限に関する課題，感受性試験の検査 基準の近年の度重なる改訂など，抗菌薬治療を取り巻 く専門的知見は複雑さを増す一方である。また，しか るべき培養検査を行っても 3〜 5 割は培養陰性となり “culture-negative sepsis”と称されるように（CQ4-4）,
限界もある。限られた抗菌薬を有効に利用して敗血症 に対応していくためには，「疑われる感染巣ごとに， 患者背景, 疫学や迅速微生物診断法に基づいて原因微 生物を推定し，臓器移行性と耐性菌の可能性も考慮し て選択する」という感染症診療の原則を，忠実に実践 していくことが重要である。

Table 4-1-1＼cjkstart各感染症別の経験的治療薬

【利用にあたって】本表は, 各種感染症に関するガイドラインおよび日本感染症学会/日本化学療法学会感染症治療ガイドを参照し, 下記の考え方を加味して, 敗血症に関係するものを一覧にまとめたものである。実践的にするために，代表的な選択肢を提示した。 経験的治療薬は, その性格上，唯一絶対的な選択肢として提示することはむずかしく，各種ガイドラインにおいてもエビデンスと 専門家の意見による提案として提示されるが，作成された年代および地域のアンチバイオグラムや，各施設で利用可能な採用抗菌 薬の種類によっても左右される。本表は, 各施設の敗血症および抗菌薬適性使用支援チームの専門家が, 施設ごとの抗菌薬ガイド ラインを作成する際の参考にできる。

\begin{tabular}{|c|c|c|c|c|c|}
\hline 感染巣 & \multicolumn{2}{|c|}{ 患者背景·病態 } & 主に想定される原因菌 & 薬剂の例（VCM の用量は注釈 k）を参照） & 備考 \\
\hline \multirow[t]{4}{*}{ 肺炎 a) } & \multirow{2}{*}{ 市中 } & 下記以外 & $\begin{array}{l}\text { 肺炎球菌, インフルエンザ } \\
\text { 桿菌, クレブシエラ, マイ } \\
\text { コプラズマ, レジオネラ }\end{array}$ & $\begin{array}{l}\text { CTRX 2g } 24 \text { 時間毎 } 38) \\
\pm \text { AZM 500mg } 24 \text { 時間毎 38) }\end{array}$ & $\begin{array}{l}\text { レジオネラリスクはCQ4-3を } \\
\text { 参照。 }\end{array}$ \\
\hline & & $\begin{array}{l}\text { インフルエンザ } \\
\text { 後, 壊死性肺炎 }\end{array}$ & $\begin{array}{l}\text { 上記＋黄色ブドウ球菌(市 } \\
\text { 中型 MRSA を含む) }\end{array}$ & $\begin{array}{l}\text { CTRX 2g } 24 \text { 時間毎 38, 39) } \\
\pm \text { VCM 38,39) k) }\end{array}$ & MRSA リスクは CQ4-3 を参照。 \\
\hline & \multicolumn{2}{|c|}{$\begin{array}{l}\text { 医療関連·人工呼吸 } \\
\text { 器関連 }\end{array}$} & $\begin{array}{l}\text { 肺炎球菌, 大腸菌, 緑膿菌, } \\
\text { 黄色ブドウ球菌 }\end{array}$ & $\begin{array}{l}\lceil\mathrm{CFPM} 2 \mathrm{~g} 8 \text { 時間毎 or } \\
\text { TAZ/PIPC 4.5g } 8 \text { 時間毎」 } \\
\pm \text { VCM } 38) \mathrm{k} \text { ) }\end{array}$ & $\begin{array}{l}\text { 早期あるいは耐性菌リスクがな } \\
\text { い場合には市中肺炎の選択肢が } \\
\text { 適用可能。 } \\
\text { MRSA リスクは CQ4-3 を参照。 }\end{array}$ \\
\hline & \multicolumn{2}{|c|}{$\begin{array}{l}\text { 細胞性免疫低下 }+ \\
\text { ニューモシスチス予 } \\
\text { 防なし＋両側陰影 }\end{array}$} & ニューモシスチス & $\begin{array}{l}\text { ST : トリメトプリムとして 240〜320mg } 8 \text { 時間毎 } \\
\text { or ペンタミジン } 4 \mathrm{mg} / \mathrm{kg} 24 \text { 時間毎 } 38)\end{array}$ & $\begin{array}{l}\mathrm{ST}: \text { トリメトプリムとして } \\
15 \mathrm{mg} / \mathrm{kg} / \text { 日 } \fallingdotseq \text { 本邦の ST 合剂 }(1 \\
\text { 錠または } 1 \mathrm{~g} \text { 中のトリメトプリ } \\
\text { ムは } 80 \mathrm{mg}) \text { で } 1 \text { 回 } 3 \sim 4 \text { 錠また } \\
\text { は 3〜 } 4 \mathrm{~g} 8 \text { 時間毎。 }\end{array}$ \\
\hline \multirow[t]{3}{*}{$\begin{array}{l}\text { 尿路 } \\
\text { 感染症 b) }\end{array}$} & \multicolumn{2}{|c|}{$\begin{array}{l}\text { 市中(ESBL 産生菌リ } \\
\text { スク低い) }\end{array}$} & 大腸菌 & CTRX 1～2g 24 時間毎 38) & \multirow[t]{2}{*}{$\begin{array}{l}\text { ESBL 産生菌リスクは CQ4-2 参 } \\
\text { 照。 }\end{array}$} \\
\hline & \multicolumn{2}{|c|}{$\begin{array}{l}\text { 市中(ESBL 産生菌リ } \\
\text { スク高い) }\end{array}$} & & $\begin{array}{l}\text { CMZ 1 2g } 8 \text { 時間毎 } 40,41) \text { or } \\
\text { TAZ/PIPC 4.5g } 8 \text { 時間毎 }{ }^{42)} \text { or } \\
\text { MEPM 1g } 8 \text { 時間毎 }{ }^{38)}\end{array}$ & \\
\hline & \multicolumn{2}{|c|}{ 医療関連 } & $\begin{array}{l}\text { 大腸菌, クレブシエラ, エ } \\
\text { ンテロバクター, 緑膿菌, } \\
\text { 腸球菌 }\end{array}$ & $\begin{array}{l}\lceil T A Z / P I P C ~ 4.5 \mathrm{~g} 8 \text { 時間毎 or } \\
\text { MEPM 1g } 8 \text { 時間毎」 } \\
\pm \text { VCM }^{38)} \text { k) }\end{array}$ & $\begin{array}{l}\mathrm{VCM} \text { はグラム染色で連鎖状グ } \\
\text { ラム陽性球菌を認める場合など } \\
\text { に追加。 }\end{array}$ \\
\hline \multirow{3}{*}{$\begin{array}{l}\text { 胆道· } \\
\text { 腹腔内 } \\
\text { 感染症 c) }\end{array}$} & \multicolumn{2}{|c|}{$\begin{array}{l}\text { 市中(ESBL 産生菌リ } \\
\text { スク低い) }\end{array}$} & \multirow[t]{2}{*}{$\begin{array}{l}\text { 大腸菌, バクテロイデス等 } \\
\text { の嫌気性菌 }\end{array}$} & $\begin{array}{l}\text { SBT/ABPC 3g } 6 \text { 時間毎 }{ }^{43)} \text { or } \\
\text { 「CTRX 2g } 24 \text { 時間毎+ MNZ 500mg } 8 \text { 時間毎」 43) }\end{array}$ & \multirow{2}{*}{$\begin{array}{l}\text { ESBL 産生菌リスクは CQ4-2 参 } \\
\text { 照。 } \\
\text { SBT/ABPC を選択肢にしてよ } \\
\text { いか, 施設・地域のアンチバイ } \\
\text { オグラムを確認する。 } \\
\end{array}$} \\
\hline & \multicolumn{2}{|c|}{$\begin{array}{l}\text { 市中(ESBL 産生菌リ } \\
\text { スク高い) }\end{array}$} & & $\begin{array}{l}\text { CMZ 1 2 2 } 8 \text { 時間毎 }{ }^{43)} \text { or } \\
\text { TAZ/PIPC 4.5g } 8 \text { 時間毎 } 38 \text { ) }\end{array}$ & \\
\hline & \multicolumn{2}{|c|}{ 医療関連 } & $\begin{array}{l}\text { 大腸菌, バクテロイデス等 } \\
\text { の嫌気性菌, エンテロバク } \\
\text { ター, 緑膿菌, 腸球菌 } \\
\text { 土カンジダ }\end{array}$ & $\begin{array}{l}\text { 「TAZ/PIPC 4.5g } 8 \text { 時間毎 or } \\
\text { (CFPM 2g } 8 \text { 時間毎 }+ \text { MNZ 500mg } 8 \text { 時間毎) or } \\
\text { MEPM 1g } 8 \text { 時間毎」38,43) } \\
\pm \text { MCFG 100mg } 24 \text { 時間毎 } 38)\end{array}$ & $\begin{array}{l}\text { カンジダリスクは CQ4-3 を参 } \\
\text { 照。 }\end{array}$ \\
\hline \multirow[t]{3}{*}{$\begin{array}{l}\text { 壊死性軟部 } \\
\text { 組 織 感 染 } \\
\text { 症 d) }\end{array}$} & \multicolumn{2}{|c|}{$\begin{array}{l}\text { 単一菌疑い } \\
\text { （グラム陽性球菌ある } \\
\text { いはグラム陽性桿菌） }\end{array}$} & $\begin{array}{l}\beta \text { 溶血性レンサ球菌, クロ } \\
\text { ストリジウム, } \\
\text { 稀に黄色ブドウ球菌(市中 } \\
\text { 型 MRSA を含む) }\end{array}$ & $\begin{array}{l}\lceil\mathrm{CTRX} 2 \mathrm{~g} 24 \text { 時間毎 or } \\
\text { SBT/ABPC 3g } 6 \text { 時間毎」 } \\
\pm \text { VCM 38) k) } \\
\pm \text { CLDM 600mg } 8 \text { 時間毎 }{ }^{38)}\end{array}$ & \multirow[t]{2}{*}{$\begin{array}{l}\text { MRSA リスクはCQ4-3 を参照。 } \\
\text { CLDM は, トキシックショッ } \\
\text { ク症候群におけるトキシン産生 } \\
\text { の抑制目的。 }\end{array}$} \\
\hline & \multicolumn{2}{|c|}{$\begin{array}{l}\text { 複数菌疑い(糖尿病 } \\
\text { 性, フルニ工壊疽) }\end{array}$} & $\begin{array}{l}\text { 黄色ブドウ球菌，大腸菌， } \\
\text { 嫌気性菌 }\end{array}$ & $\begin{array}{l}\text { TAZ/PIPC 4.5g } 8 \text { 時間毎 } 38 \text { ) } \\
\pm \text { VCM }{ }^{38) k} \text { k) }\end{array}$ & \\
\hline & \multicolumn{2}{|c|}{ 海水·淡水への曝露 } & エロモナス, ビブリオ & $\begin{array}{l}\text { CTRX 2g } 24 \text { 時間毎 } \\
+ \text { MINO 100mg } 12 \text { 時間毎 38) }\end{array}$ & \\
\hline
\end{tabular}


日本版敗血症診療ガイドライン 2020

Table 4-1-1 各感染症別の経験的治療薬 (つづき)

\begin{tabular}{|c|c|c|c|c|}
\hline 感染巣 & 患者背景·病態 & 主に想定される原因菌 & 薬剂の例（VCM の用量は注釈 $\mathrm{k}$ )を参照） & 備考 \\
\hline \multirow[t]{2}{*}{ 脊椎炎 e) } & 市中 & $\begin{array}{l}\text { MSSA, レンサ球菌, } \\
\text { 稀に肺炎球菌, グラム陰性 } \\
\text { 桿菌 }\end{array}$ & $\begin{array}{l}\text { CEZ 2g } 8 \text { 時間毎 38) or } \\
\text { CTRX 2g } 24 \text { 時間毎 } 38)\end{array}$ & \multirow[t]{2}{*}{ MRSA リスクは CQ4-3 を参照。 } \\
\hline & 医療関連 & $\begin{array}{l}\text { 黄色ブドウ球菌, グラム陰 } \\
\text { 性桿菌 }\end{array}$ & $\begin{array}{l}\text { CFPM 2g } 12 \text { 時間毎 } \\
+\mathrm{VCM}^{38)} \text { k) }\end{array}$ & \\
\hline \multirow[t]{3}{*}{ 心内膜炎f) } & $\begin{array}{l}\text { 自己弁 : } \\
\text { MRSA リスクなし }\end{array}$ & $\begin{array}{l}\text { MSSA, レンサ球菌, 腸球 } \\
\text { 菌 }\end{array}$ & $\begin{array}{l}\text { SBT/ABPC } 3 g \text { 6 時間毎 }{ }^{38)} \text { or } \\
\text { 「CTRX 2g } 24 \text { 時間毎 } \\
+ \text { ABPC 2g } 4 \text { 時間毎」38,44) }\end{array}$ & $\begin{array}{l}\text { 腸球菌の可能性が高い場合は } \\
\lceil\mathrm{CTRX}+\mathrm{ABPC} \text { を選択。 } \\
\text { 頭蓋内播種病変がある場合は } \\
\mathrm{CTRX} \text { は } 2 \mathrm{~g} 12 \text { 時間毎。 }\end{array}$ \\
\hline & $\begin{array}{l}\text { 自己弁 : } \\
\text { MRSA リスクあり }\end{array}$ & 上記 + MRSA & $\begin{array}{l}\text { CTRX 2g } 24 \text { 時間毎 } \\
\left.+\operatorname{VCM}^{38,44)} \mathrm{k}\right)\end{array}$ & $\begin{array}{l}\text { 頭蓋内播種病変がある場合は } \\
\text { CTRX は } 2 \mathrm{~g} 12 \text { 時間毎。 } \\
\text { MRSA リスクは CQ4-3 を参照。 }\end{array}$ \\
\hline & $\begin{array}{l}\text { 人工弁 or } \\
\text { ペースメーカー }\end{array}$ & $\begin{array}{l}\text { 上記＋表皮ブドウ球菌，グ } \\
\text { ラム陰性桿菌 }\end{array}$ & $\begin{array}{l}\lceil\mathrm{CTRX} 2 \mathrm{~g} 24 \text { 時間毎 or } \\
\text { CFPM 2g } 12 \text { 時間毎」 } \\
+ \text { VCM } 38,44) \mathrm{k})\end{array}$ & \\
\hline \multirow[t]{2}{*}{$\begin{array}{l}\text { 感染性動脈 } \\
\text { 瘤 } \mathrm{g})\end{array}$} & 市中 & $\begin{array}{l}\text { 黄色ブドウ球菌, サルモネ } \\
\text { ラ, グラム陰性桿菌 }\end{array}$ & $\begin{array}{l}\lceil\text { CFPM 2g } 12 \text { 時間毎 or } \\
\text { TAZ/PIPC 4.5g } 8 \text { 時間毎」 } \\
\pm \text { VCM k) }\end{array}$ & MRSA リスクは CQ4-3 を参照。 \\
\hline & 人工血管 & $\begin{array}{l}\text { 黄色ブドウ球菌, 表皮ブド } \\
\text { ウ球菌, 緑膿菌 }\end{array}$ & $\begin{array}{l}\lceil\text { CFPM 1g } 8 \text { 時間毎 or } \\
\text { TAZ/PIPC 4.5g } 8 \text { 時間毎 or } \\
\text { MEPM 1g } 8 \text { 時間毎」 } \\
+ \text { VCM k) }\end{array}$ & \\
\hline $\begin{array}{l}\text { カテーテル } \\
\text { 関連血流感 } \\
\text { 染症 } h)\end{array}$ & 血管内カテーテル & $\begin{array}{l}\text { 表皮ブドウ球菌, 黄色ブド } \\
\text { ウ球菌(MRSA 含む), 大腸 } \\
\text { 菌, 緑膿菌, } \\
\text { 土カンジダ }\end{array}$ & $\begin{array}{l}\text { VCM k) } \\
+ \text { CFPM 2g 8〜12 時間毎 } \\
\pm \text { MCFG 100mg 24 時間毎 } 38)\end{array}$ & $\begin{array}{l}\text { カンジダリスクはCQ4-3 を参 } \\
\text { 照。 }\end{array}$ \\
\hline \multirow[t]{3}{*}{ 髄膜炎 i) } & 市中 (50 歳未満) & 肺炎球菌, 髄膜炎菌 & $\begin{array}{l}\text { CTRX 2g } 12 \text { 時間毎 } \\
+\mathrm{VCM} 38,45) \mathrm{k})\end{array}$ & \\
\hline & $\begin{array}{l}\text { 市 中 (50 歳 以上, 細 } \\
\text { 胞性免疫不全) }\end{array}$ & $\begin{array}{l}\text { 肺炎球菌, 骾膜炎菌, リス } \\
\text { テリア }\end{array}$ & $\begin{array}{l}\text { ABPC 2g } 4 \text { 時間毎 } \\
+ \text { CTRX 2g } 12 \text { 時間毎 } \\
+ \text { VCM } 38,45) \text { k) }\end{array}$ & \\
\hline & $\begin{array}{l}\text { 脳外科術後 or シャン } \\
\text { 卜関連髄膜炎 }\end{array}$ & MRSA, 緑膿菌 & $\begin{array}{l}\lceil\mathrm{CAZ} \text { or CFPM or MEPM } \\
(2 \mathrm{~g} 8 \text { 時間毎 }) 」 \\
\left.+\mathrm{VCM}^{38,45)} \mathrm{k}\right)\end{array}$ & \\
\hline \multirow{7}{*}{$\begin{array}{l}\text { 感染巣不明 } \\
\text { または全身 } \\
\text { 性j) }\end{array}$} & $\begin{array}{l}\text { 市中(下記のいずれで } \\
\text { もない) }\end{array}$ & $\begin{array}{l}\text { 肺炎球菌, 髄膜炎菌, } \beta \text { 溶 } \\
\text { 血性レンサ球菌, 大腸菌 }\end{array}$ & CTRX 2g 24 時間毎 38) & \begin{tabular}{|l} 
䯣膜炎の可能性がある場合は, \\
髄膜炎の項目を参照。
\end{tabular} \\
\hline & $\begin{array}{l}\text { 医療関連(下記のいず } \\
\text { れでもない) }\end{array}$ & 緑膿菌, MRSA & $\begin{array}{l}\lceil\text { CFPM 2g } 8 \text { 時間毎 or } \\
\text { TAZ/PIPC } 4.5 \mathrm{~g} 8 \text { 時間毎 or } \\
\text { MEPM 2g } 8 \text { 時間毎」 } \\
\left.+ \text { VCM }{ }^{k}\right)\end{array}$ & \\
\hline & $\begin{array}{l}\text { トキシックショック } \\
\text { 症候群 }\end{array}$ & $\begin{array}{l}\text { 黄色ブドウ球菌, } \beta \text { 溶血性 } \\
\text { レンサ球菌, クロストリジ } \\
\text { ウム }\end{array}$ & $\begin{array}{l}\lceil\mathrm{CTRX} 2 \mathrm{~g} 24 \text { 時間毎 or SBT/ABPC } 3 \mathrm{~g} 6 \text { 時間毎」 } \\
+\mathrm{CLDM} 600 \mathrm{mg} 8 \text { 時間毎 } \\
\pm \mathrm{VCM} \text { k }\end{array}$ & MRSA リスクは CQ4-3 を参照。 \\
\hline & リケッチア流行地 & 日本紅斑熱, ツツガムシ病 & MINO 100mg 12 時間毎 46) & \\
\hline & 発熱性好中球減少症 & 緑膿菌, MRSA & 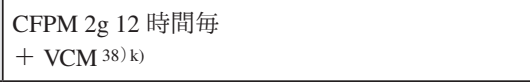 & $\begin{array}{l}\text { 抗緑膿菌薬の併用は CQ4-2 } \\
\text { 参照。 }\end{array}$ \\
\hline & 脾摘後 & $\begin{array}{l}\text { 肺炎球菌, 髄膜炎菌, イン } \\
\text { フルエンザ桿菌, カプノサ } \\
\text { イトファーガ }\end{array}$ & $\begin{array}{l}\text { 髄膜炎の可能性がない場合 : } \\
\text { CTRX 2g } 24 \text { 時間毎 } 38)\end{array}$ & $\begin{array}{l}\text { 髄膜炎の可能性がある場合は, } \\
\text { 髄膜炎の項目を参照。 }\end{array}$ \\
\hline & ショック＋発疹 & $\begin{array}{l}\text { 電撃性紫斑病 (髄膜 炎菌, } \\
\text { 肺炎球菌), リケッチア }\end{array}$ & $\begin{array}{l}\text { CTRX 2g } 12 \text { 時間毎 } \\
+ \text { VCM } 38) \text { k) } \\
\text { + MINO 100mg } 12 \text { 時間毎 46,47) }\end{array}$ & $\begin{array}{l}\text { 心内膜炎の可能性がある場合 } \\
\text { は, 心内膜炎の項目を参照。 }\end{array}$ \\
\hline
\end{tabular}

【略語】 ABPC : アンピシリン, AZM : アジスロマイシン, CAZ：セフタジジム, CFPM : セフェピム, CLDM : クリンダマイシン, CMZ : セフメタ ゾール, CTRX : セフトリアキソン, GM : ゲンタマイシン, MCFG : ミカファンギン, MEPM : メロペネム, MINO : ミノサイクリン, MNZ：メトロ ニダゾール, SBT/ABPC : スルバクタム/アンピシリン, ST : スルファメトキサゾール/トリメトプリム, TAZ/PIPC : タゾバクタム/ピペラシリン, VCM : バンコマイシン。（抗菌薬の略語は JAID/JSC 感染症治療ガイドに準じた）

a）肺炎：インフルエンザウイルス感染後や壊死性肺炎は，通常の市中肺炎の原因に加えて黄色ブドウ球菌（MRSA を含む）が問題になるため，別項 を作成して記載した。 
b）尿路感染症 : 本邦の ESBL 産生菌の疫学および治療の報告を加味して提示した。

c）胆道・腹腔内感染症 : 本邦の ESBL 産生菌の疫学および治療の報告を加味して提示した。

d）壞死性軟部組織感染症 : 患者背景（曝露歴，基礎疾患）や経過などから（場合によっては試験切開検体の迅速検査結果も加味する）原因菌を推定 できる場合の選択肢として 3 種類を提示した。

e）春椎炎：血行動態的および神経学的に安定している脊椎炎では経験的治療薬は控えることが推奨されているが，敗血症を合併した場合は経験的治 療の適応である 48)。経験的治療のレジメンは確立してはいないが，JAID/JSC 感染症治療ガイドを参考に選択肢を提示した ${ }^{38) 。}$

f） 心内膜炎：自然弁の心内膜炎における GM の併用は，黄色ブドウ球菌の場合以前は推奨されていた ${ }^{38)}$ が，近年推奨されなくなっている44)。腸球 菌の場合には, GM の代わりにCTRX を ABPC と併用するレジメンが示された。これらのことを加味して, 経験的治療として GM を併用しないレ ジメン提示した ${ }^{44)}$ 。また，心内膜炎で高率に合併する頭蓋内播種を有する場合について，JAID/JSC 感染症治療ガイドに記載がなかったが，本表 では骾液移行性を加味して提示した。人工弁の心内膜炎では, GM の腎毒性を考虑して, 原因菌が未確定な段階での経験的治療としては GM を含 まない選択肢を提示した。

g）感染性動脈瘤：JAID/JSC 感染症治療ガイド等に記載がなく確立した推奨はない 38,49) が，選択肢として提示した。

h）カテーテル関連血流感染症：JAID/JSC 感染症治療ガイドを参考に選択肢を提示した ${ }^{38)}$ 。

i） 骾膜炎：JAID/JSC 感染症治療ガイド等を参考に選択肢を提示した ${ }^{38,45)}$

j）感染巣不明または全身性：JAID/JSC 感染症治療ガイド等に記載がないが，敗血症では感染巣不明の場合が少なくないため，想定される病態ごとの 選択肢を提示した。

k）VCM の用量は，抗菌薬 TDM ガイドライン 2016 等の記載（初回ローディング : $25 \sim 30 \mathrm{mg} / \mathrm{kg}$ 静注，その後，維持量（腎機能正常）：15〜20mg/kg 静注 12 時間ごと）が参考になる ${ }^{50)}$

Table 4-1-2 原因微生物別の標的治療薬

【利用にあたって】本表は, 各種感染症に関するガイドラインおよび日本感染症学会/日本化学療法学会感染症治療ガイドを参照し, 感受性検査の基準 $\left.{ }^{51}\right)$ および抗菌薬適性使用の考え方 52$)$ を加味して，敗血症に関係するものを一覧にまとめたものである。実践的 にするために，代表的な選択肢を提示した。

各施設の敗血症および抗菌薬適性使用支援チームの専門家は，デエスカレーションを推進する際に，各施設の状況（利用可能な採 用抗菌薬など）を加味して本表を利用できる。

\begin{tabular}{|c|c|c|c|c|c|}
\hline 原因微生物 & 感染巣 & 感受性結果 & 選択肢 & 代替薬 & 備考 \\
\hline \multicolumn{6}{|c|}{ グラム陽性球菌(ブドウ状）〈GPC in clusters〉 } \\
\hline \multirow[t]{10}{*}{$\begin{array}{l}\text { Staphylococcus } \\
\text { aureus } \\
\text { 黄色ブドウ球菌 }\end{array}$} & \multirow{3}{*}{$\begin{array}{l}\text { カテーテル関連 } \\
\text { 血流感染症, 脊 } \\
\text { 椎炎·関節炎· } \\
\text { 腸腰筋膿瘍, 自 } \\
\text { 己弁心内膜炎 } \\
\text { (頭蓋内播種の } \\
\text { 合併なし), } \\
\text { 肺炎 }\end{array}$} & $\begin{array}{l}\text { MSSA(PCG: S \& CEZ: S) } \\
\text { ※ PCG : S とは, ペニシ } \\
\text { リナーゼ非産生が確認で } \\
\text { きた場合 }\end{array}$ & $\begin{array}{l}\text { PCG } 400 \text { 万単位 } 4 \sim 6 \text { 時間毎 } 53-55 \text { ) or } \\
\text { ABPC } 2 \mathrm{~g} \text { 4 6 時間毎 38) } \\
\text { (心内膜炎 : } 4 \text { 時間毎, 他 : } 4 \sim 6 \text { 毎) }\end{array}$ & CEZ & \\
\hline & & MSSA(PCG: R \& CEZ: S) & CEZ 2g 8 時間毎 38, 44, 56) & & GM 併用は推奨されない44)。 \\
\hline & & MRSA(CEZ: R \& VCM: S) & $\begin{array}{l}\mathrm{VCM} \text { 初回 25〜30mg/kg, その後 15〜 } \\
20 \mathrm{mg} / \mathrm{kg} 12 \text { 時間毎 } 6,38,44,50,56,57)\end{array}$ & $\begin{array}{l}\mathrm{DAP}(\text { 肺炎は除 } \\
く \text { ) or TEIC or } \\
\mathrm{LZD}^{38,44,50,57)}\end{array}$ & $\begin{array}{l}\mathrm{VCM} \text { 目 標 トラフ 值 } 15 \sim \\
20 \mu \mathrm{g} / \mathrm{mL}^{44,50,57) 。}\end{array}$ \\
\hline & \multirow{3}{*}{$\begin{array}{l}\text { 自己弁心内膜炎 } \\
\text { (頭蓋内播種の } \\
\text { 合併あり), 術 } \\
\text { 後髄膜炎 (髄液 } \\
\text { シャント感染症 } \\
\text { を含む) }\end{array}$} & $\begin{array}{l}\text { MSSA(PCG: S \& CEZ: S) } \\
\text { ※ PCG : S とは, ペニシ } \\
\text { リナーゼ非産生が確認で } \\
\text { きた場合 }\end{array}$ & $\begin{array}{l}\text { PCG } 400 \text { 万単位 } 4 \sim 6 \text { 時間毎 }{ }^{53-55)} \text { or } \\
\text { ABPC } 2 \mathrm{~g} 4 \sim 6 \text { 時間毎 } 38 \text { ) } \\
\text { (心内膜炎 : } 4 \text { 時間毎, 他 : } 4 \sim 6 \text { 時 } \\
\text { 間毎) }\end{array}$ & CEZ は避ける & \\
\hline & & MSSA(CEZ: S) & $\begin{array}{l}\text { CTRX 2g } 12 \text { 時間毎 or CFPM 2g } 8 \\
\text { 時間毎 or MEPM 2g } 8 \text { 時間毎 } 8,44)\end{array}$ & CEZ は避ける & $\begin{array}{l}\text { ESC2015 では CTX の記載あ } \\
\text { り 56)。 }\end{array}$ \\
\hline & & MRSA(CEZ: R \& VCM: S) & $\begin{array}{l}\mathrm{VCM} \text { 初回 } 25 \sim 30 \mathrm{mg} / \mathrm{kg} \text {, その後 15〜 } \\
20 \mathrm{mg} / \mathrm{kg} 12 \text { 時間毎 } 6,38,44,50,56,57)\end{array}$ & $\begin{array}{l}\text { DAP or TEIC or } \\
\text { LZD } 44,50,57)\end{array}$ & $\begin{array}{l}\mathrm{VCM} \text { 目標トラフ值は } 15 \text { } \\
20 \mu \mathrm{g} / \mathrm{mL} 44,50,57) 。 \\
\mathrm{BSAC} 2012 \text { では VCM+RFP な } \\
\text { ど58)。 }\end{array}$ \\
\hline & \multirow[t]{2}{*}{ 人工弁心内膜炎 } & GM: S \& RFP: S & $\begin{array}{l}\text { 自己弁心内膜炎の各レジメン(上 } \\
\text { 記) + GM 2 3mg/kg } 24 \text { 時間毎 } \\
\text { RFP 600mg 経口 } 1 \text { 日 } 1 \text { 回(3 剤併 } \\
\text { 用) 6,44,56,57)。 }\end{array}$ & & 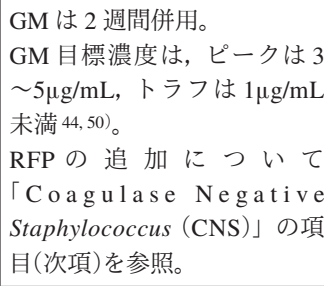 \\
\hline & & GM: R, AMK or LVFX: S & $\begin{array}{l}\text { 前項の GM の代わり：AMK or } \\
\text { LVFX }\end{array}$ & & \\
\hline & \multirow[t]{2}{*}{$\begin{array}{l}\text { トキシック } \\
\text { ショック症候群 }\end{array}$} & CLDM: S & $\begin{array}{l}\text { 上記各レジメン＋CLDM 600mg } \\
8 \text { 時間毎 59) }\end{array}$ & & \\
\hline & & CLDM: R \& LZD: S & $\begin{array}{l}\text { 上記各レジメン＋CLDM 600mg } \\
8 \text { 時間毎 or 上記各レジメン＋ LZD } \\
600 \mathrm{mg} 12 \text { 時間毎 } 59)\end{array}$ & & $\begin{array}{l}\text { CLDM はトキシン産生抑制 } \\
\text { 目的(R でも抑制できる) 60)。 }\end{array}$ \\
\hline
\end{tabular}


Table 4-1-2 原因微生物別の標的治療薬 (つづき)

\begin{tabular}{|c|c|c|c|c|c|}
\hline 原因微生物 & 感染巣 & 感受性結果 & 選択肢 & 代替薬 & 備考 \\
\hline $\begin{array}{l}\text { Coagulase Negative } \\
\text { Staphylococcus } \\
\text { (CNS) } \\
\text { コアグラーゼ陰性 } \\
\text { ブドウ球菌 }\end{array}$ & $\begin{array}{l}\text { カテーテル関連 } \\
\text { 血流感染症, 人 } \\
\text { 工弁心内膜 炎, } \\
\text { 人工関節感染症 }\end{array}$ & \multicolumn{4}{|c|}{$\begin{array}{l}\text { ·感受性別の選択は Staphylococcus aureus と同様。 } \rightarrow 「 \text { Staphylococcus aureus」の項目 }(\text { 上記)を参照。 } \\
\text { 人工弁心内膜炎や, 人工関節感染症で温存療法を行う場合は, RFP の追加を考慮する。 } \rightarrow \text { RFP は耐性化しや } \\
\text { すいため単剤で使用しない。菌量が多い時は避けたほうがよいとする専門家の意見がある。感受性検査結果 } \\
\text { が参考になる } 6,38,44,56 \text { 。 }\end{array}$} \\
\hline \multicolumn{6}{|c|}{ グラム陽性球菌(レンサ状) 〈GPC in chains〉 } \\
\hline \multirow{5}{*}{$\begin{array}{l}\text { Streptococcus } \\
\text { pneumoniae } \\
\text { 肺炎球菌 } \\
\text { ※ PCG の感受性 } \\
\text { 基準は, 髄膜炎と } \\
\text { 非髄膜炎で異なる } \\
\text { ので注意 }\end{array}$} & \multirow[t]{2}{*}{$\begin{array}{l}\text { 髄膜炎以外 } \\
\text { （肺炎など） }\end{array}$} & PCG: $\mathrm{S}(\mathrm{MIC} \leqq 2 \mu \mathrm{g} / \mathrm{mL})$ & $\begin{array}{l}\text { PCG } 200 \text { 万単位 } 4 \text { 時間毎 or } \\
\text { ABPC } 2 \mathrm{~g} \text { 6 } 8 \text { 時間毎 38) } \\
\text { (心内膜炎・侵襲性感染症は, PCG } \\
400 \text { 万単位 } 4 \text { 時間毎 or ABPC } 2 \mathrm{~g} 4 \\
\text { 時間毎) }\end{array}$ & CTRX & \\
\hline & & $\begin{array}{l}\text { PCG: I or } \mathrm{R}(\mathrm{MIC} \geqq \\
4 \mu \mathrm{g} / \mathrm{mL})\end{array}$ & CTRX 2g 24 時間毎 38) & $\begin{array}{l}\text { VCM or } \\
\operatorname{LVFX}(\mathrm{S} \text { なら })\end{array}$ & \\
\hline & \multirow[t]{3}{*}{ 髄膜炎 } & PCG: $\mathrm{S}(\mathrm{MIC} \leqq 0.06 \mu \mathrm{g} / \mathrm{mL})$ & $\begin{array}{l}\text { PCG } 400 \text { 万単位 } 4 \text { 時間毎 } 38,45) \text { or } \\
\text { ABPC } 2 \mathrm{~g} 4 \text { 時間毎 } 38,61 \text { ) }\end{array}$ & CTRX & \\
\hline & & $\begin{array}{l}\text { P C G : R ( M I C } \geqq \\
0.12 \mu \mathrm{g} / \mathrm{mL}) \quad \& \text { CTRX: S } \\
(\mathrm{MIC} \leqq 0.5 \mu \mathrm{g} / \mathrm{mL})\end{array}$ & CTRX 2g 12 時間毎 38,45) & CFPM ${ }^{8)}$ & \\
\hline & & $\begin{array}{l}\text { P C G : R ( M I C } \geqq \\
0.12 \mu \mathrm{g} / \mathrm{mL}) \& \text { CTRX: I or } \\
\mathrm{R}(\mathrm{MIC} \geqq 1.0 \mu \mathrm{g} / \mathrm{mL})\end{array}$ & $\begin{array}{l}\mathrm{VCM} \text { 初 回 } 25 \sim 30 \mathrm{mg} / \mathrm{kg}, \text { その 後 } \\
15 \sim 20 \mathrm{mg} / \mathrm{kg} 12 \text { 時間毎 }+\mathrm{CTRX} 2 \mathrm{~g} \\
12 \text { 時間毎 } 38,45,50) \\
\text { (CTRX MIC > } 2 \mu \mathrm{g} / \mathrm{mL} \& \text { RFP: S } \\
\text { で, RFP の追加を考慮) } 38,61)\end{array}$ & & $\begin{array}{l}\text { VCM 目 標トラフ 值 } 15 \sim \\
20 \mu \mathrm{g} / \mathrm{mL} 45,50) 。\end{array}$ \\
\hline \multirow{2}{*}{$\begin{array}{l}\text { Group A, B, C, F, } \\
\text { G Streptococcus } \\
\beta \text { 溶血性レンサ球 } \\
\text { 菌 }\end{array}$} & $\begin{array}{l}\text { 菌血症, } \\
\text { 軟部組織感染症 }\end{array}$ & PCG: S & $\begin{array}{l}\text { PCG 200 400 万単位 } 4 \text { 時間毎 }{ }^{38)} \text { or } \\
\text { ABPC } 2 g \text { } 4 \sim 6 \text { 時間毎 }\end{array}$ & CEZ or CTRX & $\begin{array}{l}\text { CLDM はトキシン産生抑制目 } \\
\text { 的(R でもよく使用される)。 }\end{array}$ \\
\hline & $\begin{array}{l}\text { トキシ シ ク } \\
\text { ショック症候群 }\end{array}$ & PCG: S & $\begin{array}{l}\text { 上記各レジメン＋CLDM 600mg } \\
8 \text { 時間毎38,62) }\end{array}$ & & \\
\hline \multirow[t]{6}{*}{$\begin{array}{l}\text { Viridans } \\
\text { Streptococcus, } \\
\text { S. gallolyticus } \\
\text { (S. bovis) }\end{array}$} & \multirow[t]{3}{*}{ 心内膜炎 } & $\begin{array}{l}\text { PCG の MIC } \\
\leqq 0.12 \mu \mathrm{g} / \mathrm{mL}\end{array}$ & $\begin{array}{l}\text { PCG } 400 \text { 万単 位. } 4 \text { 時 間 毎 38) or } \\
\text { ABPC } 2 \mathrm{~g} \text { 4 6 時間毎 } 44)\end{array}$ & CTRX 38$)$ & $\begin{array}{l}\text { PCG は, } 24 \text { 時 間 持 続 静 注 } \\
\text { や38), } 6 \text { 時間毎に分割する方 } \\
\text { 法もあり 6,56)。 } \\
\text { PCG 200 300 万単位 } 4 \text { 時間 } \\
\text { 毎も選択肢(自然弁 } 6,56), 人 \\
\text { 工弁 } 56) \text { ) }\end{array}$ \\
\hline & & $\begin{array}{l}\text { PCG の MIC } \\
=0.25 \mu \mathrm{g} / \mathrm{mL}\end{array}$ & $\begin{array}{l}\lceil\mathrm{PCG} 400 \text { 万単位 } 4 \text { 時間毎 or ABPC } \\
2 \mathrm{~g} 4 \text { 時間毎」 } \\
+\mathrm{GM} 3 \mathrm{mg} / \mathrm{kg} 24 \text { 時間毎( or } 1 \mathrm{mg} / \mathrm{kg} \\
1 \text { 日 } 2 \sim 3 \text { 回) } 6,38,44,50,56)\end{array}$ & $\begin{array}{l}\mathrm{CTRX}(\mathrm{MIC} \\
\leqq 0.5 \mu \mathrm{g} / \mathrm{mL} \text { な } \\
\text { ら })+\mathrm{GM}\end{array}$ & $\begin{array}{l}\text { PCG は, } 24 \text { 時間持続静注す } \\
\text { る方法もあり } 38 \text { )。 } \\
\mathrm{GM} \text { 目標濃度は, ピークは } 3 \\
\sim 5 \mu \mathrm{g} / \mathrm{mL}, \quad \text { トフは } 1 \mu \mathrm{g} / \mathrm{mL} \\
\text { 未満 } 44,50) 。 \\
\mathrm{GM} \text { は自然弁 } 2 \text { 週間, 人工弁 } \\
6 \text { 週間併用。 }\end{array}$ \\
\hline & & PCG の MIC $\geqq 0.5$ & 感染症専門家に相談 6, 44, 56)。 & & \\
\hline & \multirow{3}{*}{$\begin{array}{l}\text { 心内膜炎以外 } \\
\text { (肺炎, 菌血症, } \\
\text { 発熱性好中球減 } \\
\text { 少症など) }\end{array}$} & PCG: S & $\begin{array}{l}\text { PCG 200 300 万単位 4 6 時間毎 or } \\
\text { ABPC } 2 \mathrm{~g} \text { 6 } 8 \text { 時間毎 } 38,63 \text { ) }\end{array}$ & CTRX & $\begin{array}{l}\mathrm{PCG} \text { は, } 1 \text { 日量を } 24 \text { 時間持 } \\
\text { 続静注する方法もあり }{ }^{38) 。}\end{array}$ \\
\hline & & PCG: I/R \& CTRX: S & CTRX 2g 24 時間毎 63) & & \\
\hline & & $\begin{array}{l}\text { PCG: I/R \& CTRX: R \& } \\
\text { VCM: S }\end{array}$ & $\begin{array}{l}\mathrm{VCM} \text { 初 回 } 25 \sim 30 \mathrm{mg} / \mathrm{kg}, \text { その後 } \\
15 \sim 20 \mathrm{mg} / \mathrm{kg} 12 \text { 時間毎 } 63)\end{array}$ & & \\
\hline \multirow[t]{2}{*}{ Enterococcus sp. } & \multirow[t]{2}{*}{ 心内膜炎 } & PCG: S & 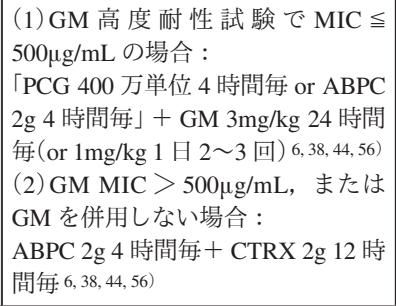 & & 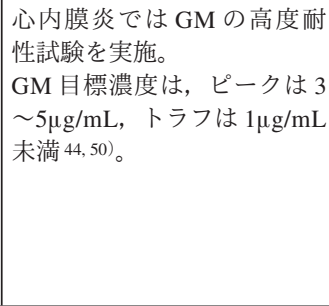 \\
\hline & & $\begin{array}{l}\text { PCG: } \mathrm{R}(\mathrm{MIC} \geqq 16 \mu \mathrm{g} / \mathrm{mL}) \\
\text { \& VCM: } \mathrm{S}\end{array}$ & $\begin{array}{l}\mathrm{GM} \text { 高度 耐性 試 験 で } \mathrm{MIC} \leqq \\
500 \mu \mathrm{g} / \mathrm{mL} \text { の場合: } \\
\mathrm{VCM} \text { 初回 } 25 \sim 30 \mathrm{mg} / \mathrm{kg}, \text { その後 } \\
15 \sim 20 \mathrm{mg} / \mathrm{kg} 12 \text { 時 間 毎 } 50)+\mathrm{GM} \\
3 \mathrm{mg} / \mathrm{kg} 24 \text { 時間毎 }(\text { or } 1 \mathrm{mg} / \mathrm{kg} 1 \text { 日 } \\
2 \sim 3 \text { 回) } 38,44)\end{array}$ & $\begin{array}{l}\text { SBT/ABPC: S } \\
\text { なら } \\
\text { SBT/ABPC+ } \\
\text { GM 6,56) }\end{array}$ & 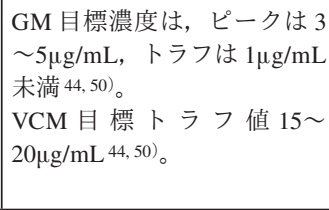 \\
\hline
\end{tabular}


日集中医誌 J Jpn Soc Intensive Care Med Vol. 28 Suppl

Table 4-1-2 原因微生物別の標的治療薬 (つづき)

\begin{tabular}{|c|c|c|c|c|c|c|}
\hline 原因微生物 & 感染巣 & \multicolumn{2}{|c|}{ 感受性結果 } & 選択肢 & 代替薬 & 備考 \\
\hline \multirow[t]{3}{*}{$\begin{array}{l}\text { Enterococcus sp. } \\
\text { (続き) }\end{array}$} & $\begin{array}{l}\text { 心内膜炎 } \\
\text { (続き) }\end{array}$ & \multicolumn{2}{|c|}{ VCM: R(VRE) } & $\mathrm{DAP}+\mathrm{ABPC}^{6,56,64)}$ & & 感染症専門家に相談も必要。 \\
\hline & \multirow[t]{2}{*}{ 心内膜炎以外 } & \multicolumn{2}{|l|}{ PCG: S } & $\begin{array}{l}\text { PCG } 300 \text { 万単位 } 4 \text { 時間毎 or ABPC } \\
2 \mathrm{~g} 4 \sim 6 \text { 時間毎 } 38)\end{array}$ & & \\
\hline & & \multicolumn{2}{|c|}{ PCG: R \& VCM: S } & $\begin{array}{l}\mathrm{VCM} \text { 初回 } 25 \sim 30 \mathrm{mg} / \mathrm{kg}, \text { その後 } \\
15 \sim 20 \mathrm{mg} / \mathrm{kg} 12 \text { 時間毎 } 50)\end{array}$ & & \\
\hline \multicolumn{7}{|c|}{ グラム陽性桿菌 〈GPR〉 } \\
\hline $\begin{array}{l}\text { Bacillus sp. } \\
\text { (Bacillus anthracis } \\
\text { 以外) }\end{array}$ & $\begin{array}{l}\text { カテーテル関連 } \\
\text { 血流感染症など }\end{array}$ & \multicolumn{2}{|l|}{ VCM: S } & $\begin{array}{l}\mathrm{VCM} \text { 初回 } 25 \sim 30 \mathrm{mg} / \mathrm{kg}, \text { その後 } \\
15 \sim 20 \mathrm{mg} / \mathrm{kg} 12 \text { 時間毎 } 38,50)\end{array}$ & CLDM $\left.{ }^{38}\right)$ & \\
\hline $\begin{array}{l}\text { Corynebacterium } \\
\text { sp. }\end{array}$ & $\begin{array}{l}\text { カテーテル関連 } \\
\text { 血流感染症, 人 } \\
\text { 工物感染症など }\end{array}$ & \multicolumn{2}{|l|}{ VCM: S } & $\begin{array}{l}\mathrm{VCM} \text { 初回 } 25 \sim 30 \mathrm{mg} / \mathrm{kg}, \text { その後 } \\
15 \sim 20 \mathrm{mg} / \mathrm{kg} 12 \text { 時間毎 } 38,50)\end{array}$ & $\begin{array}{l}\mathrm{PCG}(\mathrm{S} \text { なら }) \text { or } \\
\mathrm{TEIC} \text { or } \\
\mathrm{LZD}(\mathrm{S} \text { なら })^{38)}\end{array}$ & \\
\hline $\begin{array}{l}\text { Listeria } \\
\text { monocytogenes }\end{array}$ & 髄膜炎 & \multicolumn{2}{|l|}{ ABPC: $\mathrm{S}$} & $\begin{array}{l}\text { ABPC } 2 \mathrm{~g} 4 \text { 時間毎 }{ }^{38)} \pm \mathrm{GM} 1.7 \mathrm{mg} / \mathrm{kg} \\
8 \text { 時間毎 }\end{array}$ & $\begin{array}{l}\mathrm{ST} \text { or }\lceil\mathrm{ABPC}+ \\
\mathrm{ST}\rfloor\end{array}$ & $\begin{array}{l}\text { 併用などは感染症専門家に相 } \\
\text { 談も必要。 }\end{array}$ \\
\hline Nocardia sp. & $\begin{array}{l}\text { 重症肺炎· } \\
\text { 脳膿瘍· } \\
\text { 播種性感染症 }\end{array}$ & \multicolumn{2}{|c|}{$\begin{array}{l}\text { (ルーチンの感受性検査実 } \\
\text { 施は困難なので, nocardia } \\
\text { 疑いでの重症例における } \\
\text { 抗菌薬選択肢を示す) }\end{array}$} & $\begin{array}{l}\text { 「STトリメトプリムとして } 240 \sim \\
320 \mathrm{mg} 8 \text { 時間毎＋ IPM/CS 0.5g } 6 \text { 時 } \\
\text { 間毎」 or「IPM/CS 0.5g } 6 \text { 時間毎＋ } \\
\text { AMK } 15 \mathrm{mg} / \mathrm{kg} 24 \text { 時間毎」38, 65) }\end{array}$ & $\begin{array}{l}\text { LZD, MEPM, } \\
\text { CTRX, MINO }\end{array}$ & $\begin{array}{l}\text { 感染症専門家に相談も必要。 } \\
\text { LZD は基本的に S。 } \\
\text { ST は稀に R だが, 感受性結果 } \\
\text { と臨床効果の相関は議論あり。 } \\
\text { ST : トリメトプリムとして } \\
15 \mathrm{mg} / \mathrm{kg} / \text { / } \fallingdotseq \text { 本邦の ST 合剂 }(1 \\
\text { 錠または } 1 \mathrm{~g} \text { 中のトリメトプリ } \\
\text { ムは } 80 \mathrm{mg} \text { )で } 1 \text { 回 } 3 \sim 4 \text { 錠また } \\
\text { は } 3 \sim 4 \mathrm{~g} 8 \text { 時間毎。 }\end{array}$ \\
\hline \multicolumn{7}{|c|}{ グラム陰性球菌 〈GNC〉 } \\
\hline \multirow[t]{2}{*}{$\begin{array}{l}\text { Neisseria } \\
\text { meningitidis }\end{array}$} & \multirow[t]{2}{*}{$\begin{array}{l}\text { 髄膜炎, } \\
\text { 菌血症 }\end{array}$} & \multicolumn{2}{|c|}{$\begin{array}{l}\text { PCG: } \mathrm{S} \\
(\mathrm{MIC}<0.1 \mathrm{mg} / \mathrm{mL})\end{array}$} & $\begin{array}{l}\text { PCG } 400 \text { 万単位 } 4 \text { 時間毎 or } \\
\text { ABPC } 2 \mathrm{~g} 4 \text { 時間毎 38,61) }\end{array}$ & CTRX & \\
\hline & & \multicolumn{2}{|l|}{ PCG: R } & CTRX 2g 12 時間毎 38, 61) & & \\
\hline \multicolumn{7}{|c|}{ グラム陰性桿菌(腸内細菌科) 〈GNR (1)〉 } \\
\hline \multirow{8}{*}{$\begin{array}{l}\text { Escherichia coli, } \\
\text { Proteus mirabilis } \\
\text { 注 : Proteus } \\
\text { vulgaris は } \\
\text { Enterobacter の項目 } \\
\text { を参照 }\end{array}$} & \multirow{5}{*}{$\begin{array}{l}\text { 尿路感染症, } \\
\text { 菌血症など } \\
\text { （髄膜炎は除く） }\end{array}$} & \multicolumn{2}{|l|}{ ABPC: $\mathrm{S}$} & ABPC 1 2g 6 時間毎 66) & $\mathrm{CPFX}(\mathrm{S}$ なら $)$ or & \\
\hline & & \multicolumn{2}{|c|}{ ABPC: R \& CEZ: S } & CEZ 2g 8 時間毎 38, 51, 67) & $\mathrm{ST}(\mathrm{S}$ なら $)$ & \\
\hline & & \multicolumn{2}{|c|}{$\begin{array}{l}\text { ABPC: R \& CEZ: R \& } \\
\text { CTRX }(\mathrm{CTX}): S\end{array}$} & CTRX 1～2g 24 時間毎 38,51, 68) & & \\
\hline & & \multicolumn{2}{|c|}{$\begin{array}{l}\text { ESBL 産生菌 } \\
\lceil\mathrm{CTRX}(\mathrm{CTX}): \mathrm{R} \text { or } \\
\text { CAZ: R」\&「MEPM:S \& } \\
\text { TAZ/PIPC: S \& CMZ: S」 }\end{array}$} & $\begin{array}{l}\text { CMZ 1 2g } 8 \text { 時間毎 40,41, 69) } \\
\text { TAZ/PIPC 4.5g 6〜8 時間毎 42, 70) } \\
\text { MEPM 1g } 8 \text { 時間毎 38, 51, 68) }\end{array}$ & & $\begin{array}{l}\text { CMZ, TAZ/PIPC は臨床的安 } \\
\text { 定, 腎孟腎炎などで選択肢に } \\
\text { なるという報告あり。 }\end{array}$ \\
\hline & & \multicolumn{2}{|c|}{$\begin{array}{l}\text { MEPM or IPM/CS のいず } \\
\text { れかが S でない。 }\end{array}$} & 感染症専門家に相談。 & & \\
\hline & \multirow[t]{3}{*}{ 髄膜炎 } & \multicolumn{2}{|l|}{ CTRX: S } & CTRX 2g 12 時間毎 8,38) & & 骾膜炎では CEZ は避ける。 \\
\hline & & \multicolumn{2}{|c|}{ CTRX: R \& MEPM: S } & MEPM 2g 8 時間毎 8) & & \\
\hline & & \multicolumn{2}{|c|}{$\begin{array}{l}\text { MEPM or IPM/CS のいず } \\
\text { れかがS でない。 }\end{array}$} & 感染症専門家に相談。 & & \\
\hline Klebsiella sp. & $\begin{array}{l}\text { 尿路感染症, } \\
\text { 肺炎, } \\
\text { 肝膿瘍など }\end{array}$ & \multicolumn{5}{|c|}{$\begin{array}{l}\cdot \mathrm{ABPC}: \mathrm{S} \text { でも自然耐性なので ABPC は選択しない。 } \\
\cdot \text { ABPC 以外は, Escherichia coli と同様なので, 上記「Escherichia coli, Proteus mirabilis」の項目を参照。 } \\
\cdot \text { ·侵襲性肝膿瘍症候群では, CEZ: S であっても, CEZより CTRX のほうが成績がよいとする観察研究あり 71)。 }\end{array}$} \\
\hline \multirow{4}{*}{$\begin{array}{l}\text { Enterobacter sp., } \\
\text { Citrobacter } \mathrm{sp} . \\
\text { Serratia } \\
\text { marcescens, } \\
\text { Proteus vulgaris, } \\
\text { Morganella sp. }\end{array}$} & \multirow[t]{4}{*}{$\begin{array}{l}\text { 菌血症, } \\
\text { 肺炎など } \\
\text { (髄膜炎は除く） }\end{array}$} & \multicolumn{2}{|c|}{$\begin{array}{l}\lceil\mathrm{CTRX}(\mathrm{CTX}): S \quad \& \\
\text { CAZ:S」\& CFPM: S }\end{array}$} & $\begin{array}{l}\text { CFPM (1g } 8 \text { 時間毎 or } 2 \mathrm{~g} 8 \sim 12 \text { 時 } \\
\text { 間毎) } 38,51,68,72) \\
\text { TAZ/PIPC } 4.5 \mathrm{~g} 6 \sim 8 \text { 時 間 毎 }{ }^{68)} \text { or } \\
\text { CTRX } 1 \sim 2 \mathrm{~g} 24 \text { 時間毎 } 38,51,68)\end{array}$ & $\begin{array}{l}\text { MEPM or } \\
\mathrm{CPFX}(\mathrm{S} \text { なら }) \text { or } \\
\mathrm{ST}(\mathrm{S} \text { なら })\end{array}$ & \multirow{3}{*}{$\begin{array}{l}\text { ABPC は自然耐性。 } \\
\text { CTRX, CAZ, TAZ/PIPC は } \\
\text { 治療中に AmpC 型セファ } \\
\text { スポリナーゼ産生により耐性 } \\
\text { 化する可能性がある。胆道系 } \\
\text { 悪性腫瘍に伴う胆管炎などで } \\
\text { は注意73)。 }\end{array}$} \\
\hline & & $\begin{array}{l}\text { 「CTRX } \\
(\mathrm{CTX}):\end{array}$ & $\begin{array}{l}\text { CFPM: S \& } \\
\text { MEPM: S }\end{array}$ & $\begin{array}{l}\text { CFPM (1g } 8 \text { 時間毎 or } 2 \mathrm{~g} 8 \sim 12 \text { 時 } \\
\text { 間毎) } 38,51,68)\end{array}$ & $\begin{array}{l}\mathrm{CPFX}(\mathrm{S} \text { なら }) \text { or } \\
\mathrm{ST}(\mathrm{S} \text { なら })\end{array}$ & \\
\hline & & $\begin{array}{l}\text { R or } \\
\text { CAZ: R」 }\end{array}$ & $\begin{array}{l}\text { CFPM: R \& } \\
\text { MEPM: S }\end{array}$ & MEPM 1g 8 時間毎 38,51,68) & & \\
\hline & & $\begin{array}{l}\text { MEPM o } \\
\text { れかがS }\end{array}$ & $\begin{array}{l}\text { IPM/CS のいず } \\
\text { ごない。 }\end{array}$ & 感染症専門家に相談。 & & $\begin{array}{l}\text { Serratia はコリスチンに自然 } \\
\text { 耐性。 }\end{array}$ \\
\hline
\end{tabular}


日本版敗血症診療ガイドライン 2020

Table 4-1-2 原因微生物別の標的治療薬 (つづき)

\begin{tabular}{|c|c|c|c|c|c|}
\hline 原因微生物 & 感染巣 & 感受性結果 & 選択肢 & 代替薬 & 備考 \\
\hline \multirow{3}{*}{$\begin{array}{l}\text { Enterobacter } \mathrm{sp} . \\
\text { Citrobacter } \mathrm{sp} . \\
\text { Serratia } \\
\text { marcescens, } \\
\text { Proteus vulgaris, } \\
\text { Morganella } \mathrm{sp} . \\
\text { (続き) }\end{array}$} & \multirow[t]{3}{*}{ 髄膜炎 } & CFPM: S & CFPM 2g 8 時間毎 8) & & \multirow{2}{*}{$\begin{array}{l}\text { 感染症専門家に相談も必要。 } \\
\text { C. koseri は CTRX も選択肢。 }\end{array}$} \\
\hline & & MEPM: S & MEPM 2g 8 時間毎 8,74) & & \\
\hline & & $\begin{array}{l}\text { MEPM or IPM/CS のいず } \\
\text { れかがS でない。 }\end{array}$ & 感染症専門家に相談。 & & $\begin{array}{l}\text { Serratiaはコリスチンに自然 } \\
\text { 耐性。 }\end{array}$ \\
\hline \multirow{3}{*}{$\begin{array}{l}\text { Salmonella sp. } \\
\text { (腸チフス以外) }\end{array}$} & \multirow{3}{*}{$\begin{array}{l}\text { 菌血症, } \\
\text { 腸管外感染症 } \\
\text { (感染性大動脈 } \\
\text { 瘤など） }\end{array}$} & ABPC: $\mathrm{S}$ & ABPC 2g 6 時間毎 74) & \multirow[t]{3}{*}{$\mathrm{CPFX}(\mathrm{S}$ なら $)$} & \\
\hline & & ABPC: R \& CTRX: S & CTRX 2g 24 時間毎 74) & & 䯣膜炎では 2g 12 時間毎 \\
\hline & & $\begin{array}{l}\text { ABPC: R \& CTRX: R \& } \\
\text { MEPM: S }\end{array}$ & MEPM 1g 8 時間毎 74) & & 髄膜炎では 2g 8 時間毎 \\
\hline \multicolumn{2}{|c|}{ グラム陰性桿菌(ブドウ糖非発酵菌) } & \multicolumn{4}{|l|}{$\langle$ GNR (2) $\rangle$} \\
\hline \multirow{7}{*}{$\begin{array}{l}\text { Pseudomonas } \\
\text { aeruginosa } \\
\text { (緑膿菌) }\end{array}$} & \multirow{5}{*}{$\begin{array}{l}\text { 肺炎, } \\
\text { 尿路感染症, } \\
\text { 菌血症, } \\
\text { 発熱性好中球減 } \\
\text { 少症など } \\
\text { (䯟膜炎は除く) }\end{array}$} & CAZ: S & $\begin{array}{l}\text { CAZ 2g } 8 \text { 時間 毎( or } 1 \mathrm{~g} 6 \text { 時間 } \\
\text { 毎) } 38,51 \text { ) }\end{array}$ & \multirow{3}{*}{$\begin{array}{l}\mathrm{MEPM}(\mathrm{S} \text { なら }) \text { or } \\
\mathrm{CPFX}(\mathrm{S} \text { なら })\end{array}$} & \\
\hline & & CFPM: S & $\begin{array}{l}\text { CFPM 2g 8～12 時間毎(or } 1 \mathrm{~g} 8 \text { 時 } \\
\text { 間毎) 38,51) }\end{array}$ & & \\
\hline & & PIPC: S & PIPC 4g 6 時間毎 38) & & $\begin{array}{l}\text { PIPC の感受性基準は最低 } 3 \mathrm{~g} \\
6 \text { 時間毎以上用いた場合で設 } \\
\text { 定されている51)。 }\end{array}$ \\
\hline & & $\begin{array}{l}\text { 上記いずれも R \& MEPM: } \\
\mathrm{S}\end{array}$ & MEPM 1g 8 時間毎 38,51) & $\mathrm{CPFX}(\mathrm{S}$ なら $)$ & \\
\hline & & $\begin{array}{l}\text { MEPM or IPM/CS のいず } \\
\text { れかがS でない。 }\end{array}$ & 感染症専門家に相談。 & & \\
\hline & \multirow[t]{2}{*}{ 髄膜炎 } & CAZ: S or CFPM: S & $\begin{array}{l}\text { CAZ 2g } 8 \text { 時間毎 or CFPM 2g } 8 \text { 時 } \\
\text { 間毎 } 8 \text { ) }\end{array}$ & & \\
\hline & & MEPM: S & MEPM 2g 8 時間毎 8) & & \\
\hline \multirow{4}{*}{$\begin{array}{l}\text { Acinetobacter } \\
\text { baumannii }\end{array}$} & \multirow{4}{*}{$\begin{array}{l}\text { 院内肺炎·人工 } \\
\text { 呼吸器関連肺 } \\
\text { 炎, } \\
\text { 創傷感染 }\end{array}$} & CFPM: S & CFPM 2g 8 時間毎 38) & \multirow{4}{*}{$\begin{array}{l}\mathrm{CPFX}(\mathrm{S} \text { なら }) \text { or } \\
\mathrm{MINO}(\mathrm{S} \text { なら })\end{array}$} & \\
\hline & & SBT/ABPC: S & $\begin{array}{l}\text { SBT/ABPC } 3 g \text { 時間毎以上(重症 } \\
\text { 例は用量を感染症専門家に相 } \\
\text { 談) } 38,75)\end{array}$ & & $\begin{array}{l}\text { SBT の部分が抗菌作用を発 } \\
\text { 揮。 }\end{array}$ \\
\hline & & MEPM: S & MEPM 1g 8 時間毎 51) & & \\
\hline & & $\begin{array}{l}\text { MEPM or IPM/CS のいず } \\
\text { れかがS でない。 }\end{array}$ & 感染症専門家に相談。 & & \\
\hline $\begin{array}{l}\text { Stenotrophomonas } \\
\text { maltophilia }\end{array}$ & $\begin{array}{l}\text { 菌血症, } \\
\text { 肺炎 }\end{array}$ & ST: S & $\begin{array}{l}\text { ST : トリメトプリムとして } 240 \sim \\
320 \mathrm{mg} 8 \text { 時間毎 } 38)\end{array}$ & $\begin{array}{l}\text { MINO }{ }^{38)} \text { or } \\
\operatorname{CPFX}(\mathrm{S} \text { なら })\end{array}$ & $\begin{array}{l}\text { カルバペネム系に自然耐性。 } \\
\mathrm{ST}: \text { トリメトプリムとして } \\
15 \mathrm{mg} / \mathrm{kg} / \text { 㫜本邦の ST 合剂 }(1 \\
\text { 錠または } 1 \mathrm{~g} \text { 中のトリメトプ } \\
\text { リムは } 80 \mathrm{mg} \text { ) で } 1 \text { 回 } 3 \sim 4 \text { 錠 } \\
\text { または } 3 \sim 4 \mathrm{~g} 8 \text { 時間毎。 }\end{array}$ \\
\hline \multicolumn{6}{|c|}{ グラム陰性桿菌(その他) 〈GNR (3)〉 } \\
\hline \multirow{5}{*}{$\begin{array}{l}\text { Haemophilus } \\
\text { influenzae }\end{array}$} & \multirow[t]{2}{*}{ 髄膜炎 } & ABPC: $\mathrm{S}$ & ABPC 2g 4 時間毎 45, 61) & $\mathrm{CTRX}^{8)}$ & \\
\hline & & $\begin{array}{l}\text { ABPC: } R \& \\
\text { CTRX }(C T X): S\end{array}$ & CTRX 2g 12 時間毎 38, 61) & CFPM ${ }^{8)}$ & \\
\hline & \multirow{3}{*}{$\begin{array}{l}\text { 肺炎, } \\
\text { 喉頭蓋炎 }\end{array}$} & ABPC: $\mathrm{S}$ & ABPC 2g 6 時間毎 38) & & \\
\hline & & $\begin{array}{l}\text { ABPC: } R \text { \& } \\
\text { SBT/ABPC: S }\end{array}$ & SBT/ABPC 3g 6 時間毎 38) & & \\
\hline & & $\begin{array}{l}\text { ABPC: } R \& \\
\text { CTRX }(C T X): S\end{array}$ & CTRX 1～2g 24 時間毎 38) & & \\
\hline \multirow{2}{*}{$\begin{array}{l}\text { Pasteurella } \\
\text { multocida, } \\
\text { Capnocytophaga } \\
\text { canimorsus }\end{array}$} & \multirow[t]{2}{*}{ 動物咬傷 } & PCG: S & SBT/ABPC 3g 6 時間毎 62) & CTRX & $\begin{array}{l}\text { 単一菌による感染症では } \\
\text { PCG } 400 \text { 万単位 } 4 \text { 時間毎。 }\end{array}$ \\
\hline & & PCG: R \& SBT/ABPC: S & SBT/ABPC 3g 6 時間毎 62) & CTRX & \\
\hline Aeromonas sp. & $\begin{array}{l}\text { 軟 部 組 織 感 染 } \\
\text { 症, } \\
\text { 菌血症 }\end{array}$ & CTRX: S or MINO: S & $\begin{array}{l}\text { CTRX 2g } 24 \text { 時間毎＋MINO 100mg } \\
12 \text { 時間毎 62) }\end{array}$ & $\begin{array}{l}\text { CPFX+MINO, } \\
\text { LVFX }\end{array}$ & \\
\hline Vibrio vulnificus & $\begin{array}{l}\text { 軟 部 組 織 感 染 } \\
\text { 症, } \\
\text { 菌血症 }\end{array}$ & CTRX: S \& MINO: S & $\begin{array}{l}\text { CTRX 2g } 24 \text { 時間毎＋MINO 100mg } \\
12 \text { 時間毎 62) }\end{array}$ & $\begin{array}{l}\text { C T X + CPFX, } \\
\text { LVFX }\end{array}$ & $\begin{array}{l}\beta \text { ラクタム単剂は併用療法よ } \\
\text { り死亡率が高かったとする観 } \\
\text { 察研究あり } 76 \text { 。 }\end{array}$ \\
\hline
\end{tabular}


日集中医誌 J Jpn Soc Intensive Care Med Vol. 28 Suppl

Table 4-1-2 原因微生物別の標的治療薬 (つづき)

\begin{tabular}{|c|c|c|c|c|c|c|}
\hline 原因微生物 & 感染巣 & \multicolumn{2}{|c|}{ 感受性結果 } & 選択肢 & 代替薬 & 備考 \\
\hline \multicolumn{7}{|c|}{ 偏性嫌気性菌(C. difficile 以外) } \\
\hline 偏性嫌気性菌 & 複数菌感染症 & \multicolumn{5}{|c|}{ 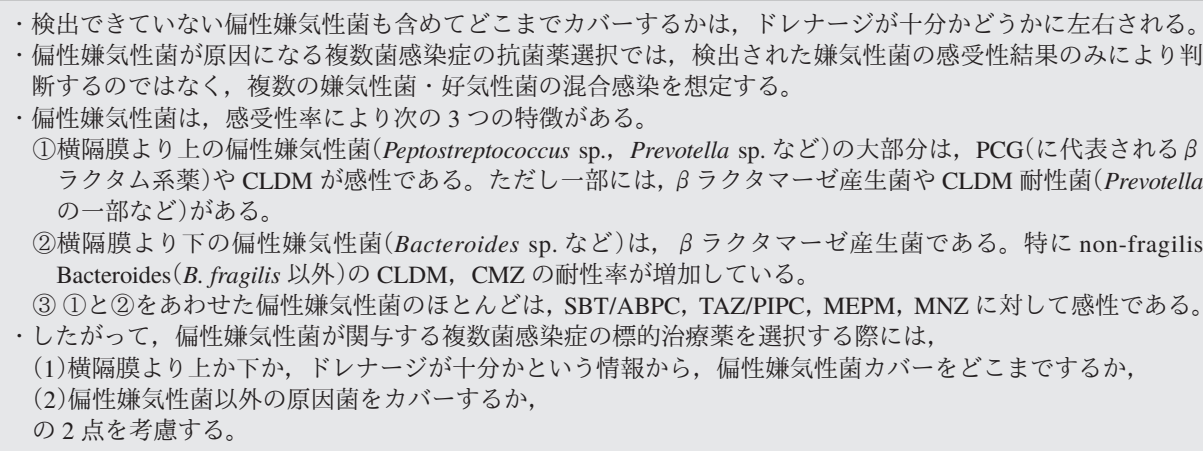 } \\
\hline \multirow[t]{2}{*}{$\begin{array}{l}\text { Peptostreptococcus } \\
\text { sp., } \\
\text { Prevotella sp. } \\
\text { (横隔膜より上の } \\
\text { 偏性嫌気性菌） }\end{array}$} & \multicolumn{2}{|l|}{$\begin{array}{l}\text { 肺化膿症, } \\
\text { 深頸部感染症など }\end{array}$} & \multirow{2}{*}{$\begin{array}{l}\text { 右記では代 } \\
\text { 表的な選択 } \\
\text { 肢を示す。 } \\
\text { 偏性嫌気性 } \\
\text { 菌以外に検 } \\
\text { 出されている } \\
\text { 細菌の感受 } \\
\text { 性結果も, 選 } \\
\text { 択の参考に } \\
\text { なる。 }\end{array}$} & $\begin{array}{l}\text { SBT/ABPC } 3 g \text { } 6 \text { 時間毎 or } \\
\text { CLDM 600mg } 8 \text { 時間毎 or } \\
\lceil\mathrm{MNZ} 500 \mathrm{mg} 8 \text { 時 間 毎 }+ \text { (PCG } \\
200 \sim 300 \text { 万単位 } 4 \text { 時間毎 or CTRX } \\
2 \mathrm{~g} 24 \text { 時間毎 }) 」 77)\end{array}$ & TAZ/PIPC & \\
\hline & 脳膿瘍 & & & \begin{tabular}{|l|}
$($ PCG 400 万 単 位 4 時間 毎 or \\
CTRX 2g 12 時間毎 or CFPM 2g 8 \\
時 間 毎 $)+$ MNZ 500mg 8 時間 \\
毎」 78$)$
\end{tabular} & & \\
\hline \multirow[t]{2}{*}{$\begin{array}{l}\text { Bacteroides sp. } \\
\text { （横隔膜より下の } \\
\text { 偏性嫌気性菌） }\end{array}$} & \multirow[t]{2}{*}{$\begin{array}{l}\text { 腹腔内の複数菌 } \\
\text { 感染症 } \\
\text { (二次性腹膜炎, } \\
\text { 腹腔内膿瘍, } \\
\text { 胆管炎 })\end{array}$} & \begin{tabular}{|l} 
ドレナー \\
ジ不十分
\end{tabular} & \multirow{2}{*}{$\begin{array}{l}\text { 右記では代 } \\
\text { 表的な選択 } \\
\text { 肢を示す。 } \\
\text { 偏性嫌気性 } \\
\text { 菌以外に検 } \\
\text { 出されている } \\
\text { 細菌の感受 } \\
\text { 性結果も, 選 } \\
\text { 択の参考に } \\
\text { なる。 }\end{array}$} & $\begin{array}{l}\text { SBT/ABPC 3g } 8 \text { 時間毎 or } \\
\text { TAZ/PIPC 4.5g } 8 \text { 時間毎 or } \\
\text { 「MNZ 500mg } 8 \text { 時間毎 }+(\text { CEZ 2g } \\
8 \text { 時間毎 or CTRX 2g } 24 \text { 時間毎 or } \\
\text { CFPM 2g } 12 \text { 時間毎 or CPFX 400mg } \\
12 \text { 時間毎)」 } 38 \text { ) }\end{array}$ & MEPM & $\begin{array}{l}\text { CMZ: R, CLDM: R が増えて } \\
\text { いる38)。 }\end{array}$ \\
\hline & & $\begin{array}{l}\text { ドレナー } \\
\text { ジ十分 }\end{array}$ & & $\begin{array}{l}\text { CMZ 1g } 8 \text { 時間毎 or } \\
\text { 「CLDM 600mg } 8 \text { 時間毎 + (CEZ 2g } \\
8 \text { 時間毎 or CTRX 2g } 24 \text { 時間毎 or } \\
\text { CFPM 2g } 12 \text { 時間毎 or CPFX 400mg } \\
12 \text { 時間毎)」 or } \\
\text { 前項の「ドレナージ不十分」の選択 } \\
\text { 肢38) }\end{array}$ & & \\
\hline $\begin{array}{l}\text { Clostridium } \mathrm{sp} .(\mathrm{C} . \\
\text { perfringens など) }\end{array}$ & ガス壊疽 & \multicolumn{2}{|l|}{ PCG: S } & $\begin{array}{l}\text { PCG } 400 \text { 万単位 } 4 \text { 時間毎 } \\
\text { + CLDM 600mg } 8 \text { 時間毎 38, 62) }\end{array}$ & & $\begin{array}{l}\text { CLDM はトキシン産生抑制 } \\
\text { 目的(Rでもよく使用され } \\
\text { る) }{ }^{38)} \text { 。 }\end{array}$ \\
\hline \multicolumn{7}{|c|}{ Clostridioides (Clostridium) difficile } \\
\hline \multirow[t]{3}{*}{$\begin{array}{l}\text { Clostridioides } \\
\text { (Clostridium) } \\
\text { difficile }\end{array}$} & \multirow[t]{3}{*}{$\begin{array}{l}\text { Clostridioides } \\
\text { difficile 感染症 } \\
(\mathrm{CDI})\end{array}$} & \multicolumn{2}{|l|}{ 初発 } & $\begin{array}{l}\text { VCM 125mg } 1 \text { 日 } 4 \text { 回(経口または } \\
\text { 経鼻胃管) 38,79) }\end{array}$ & $\begin{array}{l}\text { 非 重 症 : MNZ } \\
\text { 経口 }\end{array}$ & \multirow[t]{3}{*}{ VCM 静注は無効。 } \\
\hline & & \multicolumn{2}{|l|}{ 再発 } & $\begin{array}{l}\text { VCM 漸減レジメン (125mg } 1 \text { 日 } 4 \\
\text { 回から開始) or FDX 200mg } 1 \text { 日 } 2 \\
\text { 回 79) }\end{array}$ & $\begin{array}{l}\text { 初 発 治 療 が } \\
\text { MNZ } \\
\text { VCM 時: }\end{array}$ & \\
\hline & & \multicolumn{2}{|c|}{$\begin{array}{l}\text { ショック, 低血圧, 巨大 } \\
\text { 結腸症, イレウス, VCM } \\
\text { 125mg レジメン不応の時 }\end{array}$} & $\begin{array}{l}\text { 「VCM 500mg } 6 \text { 時間毎(経口 or 経 } \\
\text { 鼻胃管) or イレウスでは } 500 \mathrm{mg} / \text { 生 } \\
\text { 食 } 100 \mathrm{~mL} \text { 停留浣腸として経肛門注 } \\
\text { 入」 } \\
\pm \text { MNZ 500mg 静注 } 8 \text { 時間毎 }{ }^{79)}\end{array}$ & & \\
\hline \multicolumn{7}{|l|}{ その他の細菌 } \\
\hline Legionella sp. & 肺炎 & & & $\begin{array}{l}\text { LVFX 500 750mg } 24 \text { 時間毎 38) or } \\
\text { AZM 500mg } 24 \text { 時間毎 38) }\end{array}$ & MINO 38) & \\
\hline $\begin{array}{l}\text { Mycoplasma } \\
\text { pneumoniae }\end{array}$ & 肺炎 & & & MINO 100mg 12 時間毎 38) & AZM or LVFX & \\
\hline Rickettsia japonica & 日本紅斑熱 & & & MINO 100mg 12 時間毎 46) & CPFX & \\
\hline $\begin{array}{l}\text { Orientia } \\
\text { tsutsugamushi }\end{array}$ & ツツガムシ病 & & & MINO 100mg 12 時間毎 46) & AZM & CPFX は無効。 \\
\hline
\end{tabular}


日本版敗血症診療ガイドライン 2020

Table 4-1-2 原因微生物別の標的治療薬 (つづき)

\begin{tabular}{|c|c|c|c|c|c|}
\hline 原因微生物 & 感染巣 & 感受性結果 & 選択肢 & 代替薬 & 備考 \\
\hline $\begin{array}{l}\text { Leptospira } \\
\text { interrogans }\end{array}$ & レプトスピラ症 & & PCG 150 万単位 6 時間毎 80 ) & $\begin{array}{l}\text { CTRX or } \\
\text { MINO }\end{array}$ & \\
\hline \multicolumn{6}{|l|}{ 真菌 } \\
\hline Candida & $\begin{array}{l}\text { カンジダ血症, } \\
\text { 播種性カンジダ } \\
\text { 症 } \\
\text { (発熱性好中球 } \\
\text { 減少症を含む) }\end{array}$ & \multicolumn{4}{|c|}{ 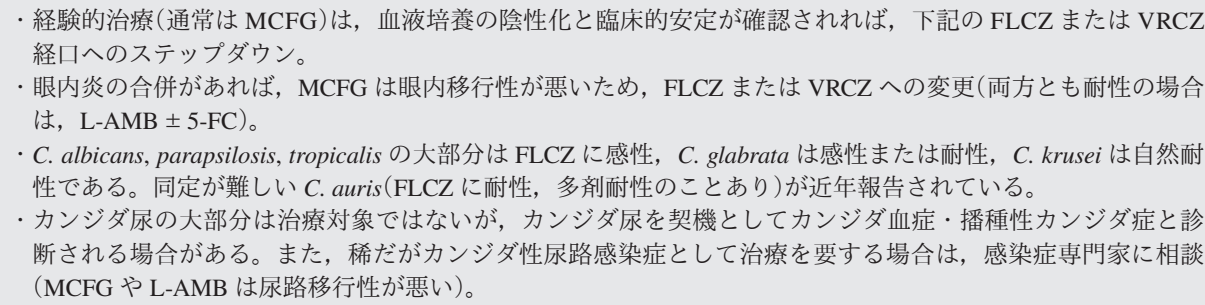 } \\
\hline $\begin{array}{l}\text { Candida albicans, } \\
\text { C. parapsilosis, } \\
\text { C. tropicalis }\end{array}$ & \multirow[t]{4}{*}{$\begin{array}{l}\text { カンジダ血症の } \\
\text { 安定後 }\end{array}$} & FLCZ: S & $\begin{array}{l}\text { FLCZ 初回 800mg } \\
\text { (その後 400mg) } 24 \text { 時間毎 } 81 \text { ) }\end{array}$ & & \\
\hline \multirow[t]{2}{*}{ C. glabrata } & & FLCZ: S & $\begin{array}{l}\text { FLCZ 初回 800mg } \\
\text { (その後 400mg) } 24 \text { 時間毎 } 81)\end{array}$ & & \multirow{3}{*}{$\begin{array}{l}\text { MCFG のまま治療を完遂す } \\
\text { るのも選択肢。 } \\
\text { 感染症専門家に相談。 }\end{array}$} \\
\hline & & FLCZ: R \& VRCZ: S & $\begin{array}{l}\text { VRCZ 初日 } 6 \mathrm{mg} / \mathrm{kg} 12 \text { 時間毎(その } \\
\text { 後 } 4 \mathrm{mg} / \mathrm{kg} 12 \text { 時間毎) } 81 \text { ) }\end{array}$ & & \\
\hline C. krusei & & FLCZ: R \& VRCZ: S & $\begin{array}{l}\text { VRCZ 初日 } 6 \mathrm{mg} / \mathrm{kg} 12 \text { 時間毎(その } \\
\text { 後 } 4 \mathrm{mg} / \mathrm{kg} 12 \text { 時間毎) } 81 \text { ) }\end{array}$ & & \\
\hline Aspergillus sp. & $\begin{array}{l}\text { 侵襲性肺アスペ } \\
\text { ルギルス症 }\end{array}$ & & $\begin{array}{l}\text { VRCZ 初日 } 6 \mathrm{mg} / \mathrm{kg} 12 \text { 時間毎(その) } \\
\text { 後 } 4 \mathrm{mg} / \mathrm{kg} 12 \text { 時間毎) } 38,81 \text { ) }\end{array}$ & L-AMB ${ }^{38)}$ & \\
\hline $\begin{array}{l}\text { Pneumocystis } \\
\text { jirovecii }\end{array}$ & $\begin{array}{l}\text { ニューモシスチ } \\
\text { ス肺炎 }\end{array}$ & & $\begin{array}{l}\mathrm{ST}: \text { トリメトプリムとして } 240 〜 \\
320 \mathrm{mg} 8 \text { 時間毎 } 38)\end{array}$ & $\begin{array}{l}\text { ペンタミジン点 } \\
\text { 滴静注 }{ }^{38)}\end{array}$ & $\begin{array}{l}\mathrm{ST}: \text { トリメトプリムとして } \\
15 \mathrm{mg} / \mathrm{kg} / \text { 日 } \fallingdotseq \text { 本邦の ST 合剤 }(1 \\
\text { 錠または } 1 \mathrm{~g} \text { 中のトリメトプ } \\
\text { リムは } 80 \mathrm{mg} \text { )で } 1 \text { 回 } 3 \sim 4 \text { 錠 } \\
\text { または } 3 \sim 4 \mathrm{~g} 8 \text { 時間毎。 }\end{array}$ \\
\hline Cryptococcus sp. & $\begin{array}{l}\text { 髄膜炎 } \\
\text { (非 HIV) }\end{array}$ & & $\begin{array}{l}\mathrm{L}-\mathrm{AMB} 3 \sim 4 \mathrm{mg} / \mathrm{kg} 24 \text { 時間 毎 }+ \\
5-\mathrm{FC} 25 \mathrm{mg} / \mathrm{kg} \text { 経口 } 6 \text { 時間毎 } 81 \text { ) }\end{array}$ & FLCZ(高用量) & \\
\hline Mucor sp. など & ムコール症 & & L-AMB 5～10mg/kg 24 時間毎 81) & & \\
\hline \multicolumn{6}{|l|}{ ウイルス } \\
\hline インフルエンザ & 肺炎など & & $\begin{array}{l}\text { オセルタミビル } 75 \mathrm{mg} \text { 経口 } 1 \text { 日 } 2 \\
\text { 回 } 82 \text { ) }\end{array}$ & ペラミビル & \\
\hline SFTS & $\begin{array}{l}\text { 重症熱性血小板 } \\
\text { 減少症候群 }\end{array}$ & & 研究中 83) & & \\
\hline CMV & 肺炎など & & $\begin{array}{l}\text { ガンシクロビル } 5 \mathrm{mg} / \mathrm{kg} 12 \text { 時間 } \\
\text { 毎38) }\end{array}$ & ホスカルネット & \\
\hline HSV & 脳炎など & & アシクロビル 10mg/kg 8 時間毎 84) & & \\
\hline
\end{tabular}

【略語】 ABPC : アンピシリン, AMK : アミカシン, AZM : アジスロマイシン, CAZ : セフタジジム, CEZ : セファゾリン, CFPM : セフェピム, CLDM : クリンダマイシン, CMV : サイトメガロウイルス, CMZ : セフメタゾール, CPFX : シプロフロキサシン, CTRX : セフトリアキソン, CTX : セフォタキシム, DAP : ダプトマイシン, 5-FC : フルシトシン, FDX : フィダキソマイシン, FLCZ : フルコナゾール, GM : ゲンタマイシン, HSV : 単純ヘルペスウイルス, IPM/CS : イミペネム/シラスタチン, L-AMB：リポソーマル・アムホテリシン B, LVFX : レボフロキサシン, LZD : リネゾリド, MCFG : ミカファンギン, MEPM : メロペネム, MINO : ミノサイクリン, MNZ : メトロニダゾール, PCG : ペニシリン G, PIPC : ピペ ラシリン, RFP：リファピシン, SBT/ABPC : スルバクタム/アンピシリン, SFTS : 重症熱性血小板減少症候群, ST : スルファメトキサゾール/トリ メトプリム, TAZ/PIPC : タゾバクタム/ピペラシリン, TEIC : テイコプラニン, VCM : バンコマイシン, VRCZ : ボリコナゾール。（抗菌薬の略語は JAID/JSC 感染症治療ガイドに準じた）

$\mathrm{S}$ : 感性, I : 中間, $\mathrm{R}$ : 耐性

\section{文 献}

1) Paul M, Shani V, Muchtar E, et al: Systematic review and metaanalysis of the efficacy of appropriate empiric antibiotic therapy for sepsis. Antimicrob Agents Chemother. 2010; 54: 4851-63.

2) Rhodes A, Evans LE, Alhazzani W, et al: Surviving Sepsis Campaign: International Guidelines for Management of Sepsis and Septic Shock: 2016. Crit Care Med. 2017; 45: 486-552.

3) Nishida O, Ogura H, Egi M, et al: The Japanese Clinical Practice Guidelines for Management of Sepsis and Septic Shock 2016
(J-SSCG 2016). Acute Med Surg. 2018; 5: 3-89.

4) Oda $S$, Aibiki M, Ikeda $T$, et al: The Japanese guidelines for the management of sepsis. J Intensive Care. 2014; 2: 55.

5）日本集中治療医学会 Sepsis Registry 委員会: 日本版敗血症治 療ガイドライン.日集中医誌. 2013; 20: 124-73.

6) Baddour LM, Wilson WR, Bayer AS, et al: Infective endocarditis in adults: Diagnosis, antimicrobial therapy, and management of complications: A scientific statement for healthcare professionals from the American Heart Association. Circulation. 2015; 132: 1435-86.

7) Zou H, Li G: Clinical practice guidelines for the diagnosis and 
management of intravascular catheter-related infection: 2009 update by the Infectious Diseases Society of America. Chinese J Infect Chemother. 2010; 2010: 81-4.

8) Tunkel AR, Hasbun R, Bhimraj A, et al: 2017 Infectious Diseases Society of America's Clinical Practice Guidelines for HealthcareAssociated Ventriculitis and Meningitis. Clin Infect Dis. 2017; 64: e34-65.

9) Osmon DR, Berbari EF, Berendt AR, et al: Diagnosis and management of prosthetic joint infection: Clinical practice guidelines by the infectious diseases Society of America. Clin Infect Dis. 2013; 56: 1-10.

10) van de Beek D, Cabellos C, Dzupova O, et al: ESCMID guideline: diagnosis and treatment of acute bacterial meningitis. Clin Microbiol Infect. 2016; 22: S37-62.

11) Freifeld AG, et al: Idsa Fiebre Y Neutropenia. 2011; 52.

12) Maschmeyer G, Helweg-Larsen J, Pagano L, et al: ECIL guidelines for treatment of Pneumocystis jirovecii pneumonia in non-HIV-infected haematology patients. J Antimicrob Chemother. 2016; 71: 2405-13.

13) Stevens DL, Bisno AL, Chambers HF, et al: Executive summary: Practice guidelines for the diagnosis and management of skin and soft tissue infections: 2014 update by the infectious diseases society of America. Clin Infect Dis. 2014; 59: 147-59.

14) Kalil AC, Metersky ML, Klompas M, et al: Management of Adults with Hospital-acquired and Ventilator-associated Pneumonia: 2016 Clinical Practice Guidelines by the Infectious Diseases Society of America and the American Thoracic Society. Clin Infect Dis. 2016; 63: e61-111.

15) CLSI M100-S27: Performance Standards for Antimicrobial Susceptibility Testing, 27th Edition. Available online at: https:// webstore.ansi.org/standards/clsi/clsim100s27. Accessed November 29, 2020.

16) Ogura H, Gando S, Saitoh D, et al: Epidemiology of severe sepsis in Japanese intensive care units: A prospective multicenter study. J Infect Chemother. 2014; 20: 157-62.

17) Abe T, Ogura H, Kushimoto $S$, et al: Variations in infection sites and mortality rates among patients in intensive care units with severe sepsis and septic shock in Japan. J Intensive Care. 2019; 7 : 28.

18) Angus DC, Linde-Zwirble WT, Lidicker J, et al: Epidemiology of severe sepsis in the United States: Analysis of incidence, outcome, and associated costs of care. Crit Care Med. 2001; 29: 1303-10.

19) Finfer S, Bellomo R, Lipman J, et al: Adult-population incidence of severe sepsis in Australian and New Zealand intensive care units. Intensive Care Med. 2004; 30: 589-96.

20) Vincent JL, Sakr Y, Sprung CL, et al: Sepsis in European intensive care units: Results of the SOAP study. Crit Care Med. 2006; 34: 344-53

21) van Vught LA, Klein Klouwenberg PMC, Spitoni C, et al: Incidence, Risk Factors, and Attributable Mortality of Secondary Infections in the Intensive Care Unit After Admission for Sepsis. JAMA. 2016; 315: 1469-79.

22) Leligdowicz A, Dodek PM, Norena M, et al: Association between source of infection and hospital mortality in patients who have septic shock. Am J Respir Crit Care Med. 2014; 189: 1204-13.

23) Hayakawa K, Mezaki K, Sugiki Y, et al: High rate of multidrugresistant organism colonization among patients hospitalized overseas highlights the need for preemptive infection control. Am J Infect Control. 2016; 44: e257-9.

24) Southeast Asia Infectious Disease Clinical Research Network: Causes and outcomes of sepsis in southeast Asia: a multinational multicentre cross-sectional study. Lancet Glob Heal. 2017; 5: e157-67.

25) Yamaji K, Aonuma H, Kanuka H: Distribution of tick-borne diseases in Japan: Past patterns and implications for the future. $\mathrm{J}$
Infect Chemother. 2018; 24: 499-504.

26) NIID: Legionellosis, January 2008-December 2012. IASR. 2013; 34: 155-7. Available online at: https://www.niid.go.jp/niid/en/iasrvol33-e/865-iasr/4237-tpc400.html. Accessed November 29, 2020.

27) Koh GCKW, Peacock SJ, van der Poll T, et al: The impact of diabetes on the pathogenesis of sepsis. Eur J Clin Microbiol Infect Dis. 2012; 31: 379-88.

28) Bretonnière $C$, Leone $M$, Milési $C$, et al: Strategies to reduce curative antibiotic therapy in intensive care units (adult and paediatric). Intensive Care Med. 2015; 41: 1181-96.

29) Ammerlaan HSM, Harbarth S, Buiting AGM, et al: Secular trends in nosocomial bloodstream infections: antibiotic-resistant bacteria increase the total burden of infection. Clin Infect Dis. 2013; 56: 798-805.

30) Saito H, Noda H, Takakura S, et al: First major practical step toward appropriate antimicrobial use by the government of Japan. Jpn J Infect Dis. 2019; 72: 56-7.

31) The Government of Japan: National Action Plan on Antimicrobial Resistance (AMR) 2016-2020. Available online at: https://www. mhlw.go.jp/file/06-Seisakujouhou-10900000-Kenkoukyoku/ 0000138942.pdf. Accessed November 29, 2020.

32) Collignon PC, Conly JM, Andremont A, et al: World Health Organization Ranking of Antimicrobials According to Their Importance in Human Medicine: A Critical Step for Developing Risk Management Strategies to Control Antimicrobial Resistance from Food Animal Production. Clin Infect Dis. 2016; 63: 1087-93.

33) Ti TY, Kumarasinghe G, Taylor MB, et al: What is true community-acquired urinary tract infection? Comparison of pathogens identified in urine from routine outpatient specimens and from community clinics in a prospective study. Eur J Clin Microbiol Infect Dis. 2003; 22: 242-5.

34) Paterson DL: 'Collateral damage' from cephalosporin or quinolone antibiotic therapy. Clin Infect Dis. 2004; 38: S341-5.

35) Schweizer ML, Furuno JP, Harris AD, et al: Comparative effectiveness of nafcillin or cefazolin versus vancomycin in methicillinsusceptible Staphylococcus aureus bacteremia. BMC Infect Dis. 2011; 11: 279.

36) McDanel JS, Perencevich EN, Diekema DJ, et al: Comparative Effectiveness of Beta-Lactams Versus Vancomycin for Treatment of Methicillin-Susceptible Staphylococcus aureus Bloodstream Infections among 122 Hospitals. Clin Infect Dis. 2015; 61: 361-7.

37) Leone M, Bechis C, Baumstarck K, et al: De-escalation versus continuation of empirical antimicrobial treatment in severe sepsis: a multicenter non-blinded randomized noninferiority trial. Intensive Care Med. 2014; 40: 1399-408.

38）日本感染症学会, 日本化学療法学会, JAID/JSC 感染症治療力゙ イド・ガイドライン作成委員会: JAID/JSC 感染症治療ガイド 2019. ライフサイエンス出版, 東京, 2019.

39) Chertow DS, Memoli MJ: Bacterial coinfection in influenza: A grand rounds review. JAMA. 2013; 309: 275-82.

40) Matsumura Y, Yamamoto M, Nagao M, et al: Multicenter Retrospective Study of Cefmetazole and Flomoxef for Treatment of Extended-Spectrum- $\beta$-Lactamase-Producing Escherichia Coli Bacteremia. Antimicrob Agents Chemother. 2015; 59: 5107-13.

41) Doi A, Shimada T, Harada S, et al: The efficacy of cefmetazole against pyelonephritis caused by extended-spectrum betalactamase-producing Enterobacteriaceae. Int J Infect Dis. 2013; 17: e159-63.

42) Harris PNA, Tambyah PA, Lye DC, et al: Effect of piperacillintazobactam vs meropenem on 30-day mortality for patients with e coli or Klebsiella pneumoniae bloodstream infection and ceftriaxone resistance. JAMA. 2018; 320: 984-94.

43) Gomi H, Solomkin JS, Schlossberg D, et al: Tokyo Guidelines 2018: antimicrobial therapy for acute cholangitis and cholecystitis. J Hepatobiliary Pancreat Sci. 2018; 25: 3-16. 
44) 日本循環器学会, 日本心臓病学会, 日本心エコー図学会, 他: 感染性心内膜炎の予防と治療に関するガイドライン（2017 年改訂版). 2017.

45) 細菌性髄膜炎診療ガイドライン作成委員会: 細菌性䯣膜炎 診療ガイドライン 2014. 南江堂, 東京, 2014.

46）山藤栄一郎: リケッチア感染症一日本紅斑熱とッッガムシ 病をどのように疑い, 診断・治療するか. Hospitalist. 2017; 5 519-28.

47）IASR 31-5 日本紅斑熱, Rickettsia japonica, 急性感染性電撃性 紫斑病の合併, DIC, 間接蛍光抗体法, PCR. Available online at: http://idsc.nih.go.jp/iasr/31/363/dj363b.html. Accessed November $29,2020$.

48) Berbari EF, Kanj SS, Kowalski T, et al: 2015 Infectious Diseases Society of America (IDSA) Clinical Practice Guidelines for the Diagnosis and Treatment of Native Vertebral Osteomyelitis in Adults. Clin Infect Dis. 2015; 61: e26-46.

49) Wilson WR, Bower TC, Creager MA, et al: Vascular Graft Infections, Mycotic Aneurysms, and Endovascular Infections: A Scientific Statement from the American Heart Association. Circulation. 2016; 134: e412-60.

50）日本化学療法学会抗菌薬 TDM ガイドライン作成委員会: 抗 菌薬 TDM ガイドライン 2016. 日本化学療法学会/日本 TDM 学会. 2016. Available online at: http://www.chemotherapy. or.jp/guideline/tdm_es.html. Accessed November 29, 2020.

51) Patel JB, Clinical and Laboratory Standards Institute: Performance standards for antimicrobial susceptibility testing. CLSI. M100; S27.

52）8学会合同抗微生物薬適正使用推進検討委員会: 抗菌薬適正 使用支援プログラム実践のためのガイダンス. 2017.

53) Fraimow HS: Systemic Antimicrobial Therapy in Osteomyelitis. Semin Plast Surg. 2009; 23: 90-9.

54) Bille J: Medical treatment of staphylococcal infective endocarditis. Eur Heart J. 1995; 16: 80-3.

55) Infectious Disease and Antimicrobial Agents: Penicillins. Available online at: http://www.antimicrobe.org/d24.asp. Accessed November 29, 2020.

56) Habib G, Lancellotti P, Antunes MJ, et al: 2015 ESC Guidelines for the management of infective endocarditis: The task force for the management of infective endocarditis of the European society of cardiology (ESC): Endorsed by: European association for cardio-thoracic surgery (EACTS), the European association of nuclear medicine (EANM). Russ J Cardiol. 2016; 133: 65-116.

57）日本化学療法学会, 日本感染症学会, MRSA 感染症の治療ガ イドライン作成委員会: MRSA 感染症の治療ガイドラインー 改訂版-2019. 2019.

58) Gould FK, Denning DW, Elliott TSJ, et al: Guidelines for the diagnosis and antibiotic treatment of endocarditis in adults: A report of the working party of the british society for antimicrobial chemotherapy. J Antimicrob Chemother. 2012; 67: 269-89.

59) Lappin E, Ferguson AJ: Gram-positive toxic shock syndromes. Lancet Infect Dis. 2009; 9: 281-90.

60) Schlievert PM, Kelly JA: Clindamycin-Induced Suppression of Toxic-Shock Syndrome--Associated Exotoxin Production. J Infect Dis. 1984; 149: 471.

61) Tunkel AR, Hartman BJ, Kaplan SL, et al: Practice Guidelines for the Management of Bacterial Meningitis. Clin Infect Dis. 2004; 39: $1267-84$.

62) Stevens DL, Bisno AL, Chambers HF, et al: Practice Guidelines for the Diagnosis and Management of Skin and Soft Tissue Infections: 2014 Update by the Infectious Diseases Society of America. Clin Infect Dis. 2014; 59: e10-52.

63) Han SB, Bae EY, Lee JW, et al: Clinical characteristics and antimicrobial susceptibilities of viridans streptococcal bacteremia during febrile neutropenia in patients with hematologic malignancies: a comparison between adults and children. BMC Infect
Dis. 2013; 13: 273.

64) Nigo M, Munita JM, Arias CA, et al: What's new in the treatment of enterococcal endocarditis?. Curr Infect Dis Rep. 2014; 16: 431.

65) Restrepo A, Clark NM, Infectious Diseases Community of Practice of the American Society of Transplantation: Nocardia infections in solid organ transplantation: Guidelines from the Infectious Diseases Community of Practice of the American Society of Transplantation. Clin Transplant. 2019; 33: e13509.

66) NICE: Pyelonephritis (acute): antimicrobial prescribing guideline Evidence review. NICE guideline 111. 2018.

67) Wang KC, Liu MF, Lin CF, et al: The impact of revised CLSI cefazolin breakpoints on the clinical outcomes of Escherichia coli bacteremia. J Microbiol Immunol Infect. 2016; 49: 768-74.

68) European Association of Urology: EAU Guidelines on Urological Infections. 2018.

69) Fukuchi T, Iwata K, Kobayashi S, et al: Cefmetazole for bacteremia caused by ESBL-producing enterobacteriaceae comparing with carbapenems. BMC Infect Dis. 2016; 16: 427.

70) Harris PNA, Tambyah PA, Paterson DL: $\beta$-lactam and $\beta$ -lactamase inhibitor combinations in the treatment of extendedspectrum $\beta$-lactamase producing Enterobacteriaceae: Time for a reappraisal in the era of few antibiotic options? Lancet Infect Dis. 2015; 15: 475-85.

71) Cheng HP, Siu LK, Chang FY: Extended-spectrum cephalosporin compared to cefazolin for treatment of Klebsiella pneumoniaecaused liver abscess. Antimicrob Agents Chemother. 2003; 47 : 2088-92.

72) Tamma PD, Girdwood SCT, Gopaul R, et al: The use of cefepime for treating AmpC $\beta$-lactamase-producing enterobacteriaceae. Clin Infect Dis. 2013; 57: 781-8.

73) Choi SH, Lee JE, Park SJ, et al: Emergence of antibiotic resistance during therapy for infections caused by Enterobacteriaceae producing AmpC $\beta$-lactamase: Implications for antibiotic use. Antimicrob Agents Chemother. 2008; 52: 995-1000.

74) Pegues DV, Miller SI: Salmonella Species. Mandell, Douglas, and Bennett's Principles and Practice of Infectious Diseases. Elsevier Inc., Amsterdam, 2019.

75) Chu H, Zhao L, Wang M, et al: Sulbactam-based therapy for Acinetobacter baumannii infection: A systematic review and meta-analysis. Braz J Infect Dis. 2013; 17: 389-94.

76) Wong KC, Brown AM, Luscombe GM, et al: Antibiotic use for Vibrio infections: important insights from surveillance data. BMC Infect Dis. 2015; 15: 226.

77) Desai H, Agrawal A: Pulmonary emergencies: Pneumonia, acute respiratory distress syndrome, lung abscess, and empyema. Med Clin North Am. 2012; 96: 1127-48.

78) Brouwer MC, Tunkel AR, McKhann GM, et al: N Engl J Med. 2014; 371: 447-56.

79）日本化学療法学会・日本感染症学会 CDI 診療ガイドライン 作成委員会: Clostridioides（Clostridium） difficile 感染症診療 ガイドライン. 2018.

80) Haake DA, Levett PN: Leptospirosis in humans. Curr Top Microbiol Immunol. 2015; 387: 65-97.

81）日本医真菌学会侵襲性カンジダ症の診断・治療ガイドライ ン作成委員会: 日本医真菌学会侵襲性カンジダ症の診断・ 治療ガイドライン 2013. 日本医真菌学会, 東京, 2013.

82) IDSA: Clinical Practice Guidelines by the Infectious Diseases Society of America: 2018 Update on Diagnosis, Treatment, Chemoprophylaxis, and Institutional Outbreak Management of Seasonal Influenza. Clin Infect Dis. 2019; 30: 97-8.

83）加藤康幸: 重症熱性血小板減少症（SFTS）診療の手引き改 訂版 (第 4 版). 国立国際医療センター, 東京, 2016.

84）日本神経感染症学会, 日本神経学会, 日本神経治療学会, 単純 ヘルペス脳炎診療ガイドライン作成委員会: 単純ヘルペス 脳炎診療ガイドライン 2017. 南江堂, 東京, 2017. 
CQ4-2：経験的抗菌薬にカルバペネム系抗菌薬 を含めるのはどのような場合か？

Answer : ESBL 産生菌，あるいはカルバペネムのみに 感受性を持つ耐性緑膿菌, 耐性アシネトバクターな ど，カルバペネム系薬剤が特に有効と考えられる微生 物が原因として想定される場合である（BQに対する 情報提示)。

\section{（1）背景および本 $C Q$ の重要度}

敗血症の抗菌療法において, 経験的治療の適切性が 死亡率低下に関連するとの観察研究が多数存在す る1)。このため, SSCG2016においては, “敗血症あ るいは敗血症性ショック患者には，想定されるすべて の病原体（細菌，真菌やウイルス感染まで考慮する） をカバーするため, 経験的選択に基づく広域スペクト ラム抗菌薬の単剤あるいは併用をすることを推奨する (強い推奨, 中等度のエビデンスレベル)” と記述され ていた2)。

広域抗菌薬の中で，カルバペネム系薬剂（以下，カ ルバペネム) は最も広域のスペクトラムを有する薬剤 であり, 治療の適切性を高める目的で, 敗血症の経験 的抗菌薬として比較的よく選択されうる。しかし，力 ルバペネムの過剩使用は, カルバペネム耐性菌の増加 のほか, 抗菌薬関連の副作用やコストを高める危険性 を伴っている。カルバペネムを日常的に使用するので はなく, 適切な症例に対して選択的に使用すること は，抗菌薬スチュワードシップの観点から望ましいと 考えられるため, 本ガイドラインの $\mathrm{CQ}$ として取り上 げた。

\section{（2）解説}

現時点で，本邦において使用可能な経静脈カルバペ ネムには, メロペネム, ドリペネム, イミペネム/シ ラスタチン, パニペネム/ベタミプロン, ビアペネム がある。いずれの薬剤も抗菌スペクトラムはほぼ同様 であり,グラム陽性菌から陰性菌まで幅広い。ただ し, メチシリン耐性ブドウ球菌あるいは腸球菌群や, ステノトロホモナス・マルトフィリア，真菌などには 感受性を有さない。

2001 年頃までの研究を集めたレビューで, 敗血症 に対して経験的/標的治療を区別せず行われた，カル バペネムと他の広域 $\beta$ ラクタム系薬剂の効果を比較し たランダム化比較試験（RCT）では，カルバペネムの 治療効果は $\beta$ ラクタム系薬剤単剤あるいは $\beta$ ラクタム 系薬剤十アミノグリコシドまたはメトロニダゾール
の併用と同等であった ${ }^{3)}$ 。重症感染症患者を対象とし た RCTにおいても，カルバペネムは肺炎においてタ ゾバクタム/ピペラシリン4-6), 腹腔内感染症において タゾバクタム/ピペラシリン7) やキノロン ${ }^{8)}$ ，あるい は髄膜炎において第 3 世代セフェム 9 , 10) といずれも 同等の効果であった。つまり現時点では, 敗血症患者 に対してカルバペネムを日常的に使用することの優位 性は示されていない。

ある特定の微生物が原因と考えられる際に，カルバ ペネムを選択的に使用するという考えがある。近年， 腸内細菌科グラム陰性桿菌群の中で, 基質拡張型 $\beta$ ラ クタマーゼ（ESBL）を産生する株の増加が問題と なっている ${ }^{11)}$ 。ESBL 産生菌に対する治療選択肢に は，カルバペネム系薬剤の他に， $\beta$ ラクタマーゼ阻害 薬配合広域ペニシリン，セファマイシン，アミノグリ コシドなどがある。観察研究ではカルバペネムとの非 劣性を示唆する結果もあるが12)，RCT ではカルバペ ネムの優位性が指摘されており 13,14$)$, 特に敗血症/敗 血症性ショックなどの重症病態では, 少なくとも経験 的治療の段階ではカルバペネムが第 1 選択となりう る。また，緑膿菌やアシネトバクターは耐性化しやす く, $\beta$ ラクタム系薬剤の中でカルバペネムのみに感受 性を有する耐性パターンの菌株が存在する。これら微 生物が想定される時に，カルバペネム系薬剂を選択す ることは理にかなっている。ただし，現時点の本邦の 臨床現場においてこのような耐性株に出会うことは稀 である。

一方，他の薬剤と同様に，カルバペネムには而性菌 が存在する。カルバペネム耐性のグラム陰性桿菌群の 存在は, 現在, 全世界的に問題となっている。特に, 抗菌薬治療に伴う緑膿菌の耐性獲得率はカルバペネム が最も高い 15,16$)$ 。カルバペネムの使用は多剂耐性緑 膿菌, あるいは多剤耐性アシネトバクターの最も大き な危険因子である ${ }^{17)}$ 。メ久解析では, カルバペネム 使用によるカルバペネム耐性緑膿菌感染症発生のオッ ズ比は 7.09 (95\% CI: 5.43〜9.25）である 18）。そして, 本邦の JANIS サーベイランスにおいてカルバペネム

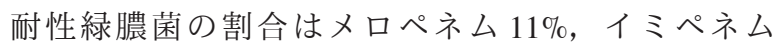
17\% と高い 19)。また, カルバペネムはカルバペネマー ゼ産生菌を含めたカルバペネム耐性腸内細菌科グラム 陰性桿菌の危険因子でもある20)。この耐性菌は, 全 世界的には, 特に発展途上国においてその増加が問題 となっており，本邦における分離頻度は $0.5 \%$ 未満と まだ低いが ${ }^{19)}$, グローバリゼーションのなかで今後 分離頻度が増加することが予測される。而性菌は経験 的抗菌薬の不適切性を高め, 不良な転帰に影響するこ 


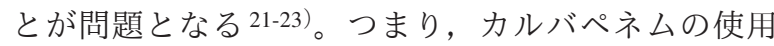
に際しては耐性菌選択の危険性を意識した適正使用の 観点が欠かせない。

カルバペネムの適正使用に重きを置けば，カルバペ ネムは他の薬剤では代替しがたい上記の微生物が病原 菌であると想定されるような稀な状況においてのみ使 用する，という戦略が成り立つ。これは，カルバペネ 厶使用にかかる最も保守的な選択肢だが，抗菌薬ス チュワードシップを重視する観点や，本邦においてカ ルバペネムが頻用されているという現状を踏まえて, 本ガイドラインはこの保守的選択を支持する。具体的 には, “ESBL 産生菌, あるいはカルバペネムのみに 感受性を持つ耐性緑膿菌, 耐性アシネトバクターなど が想定される場合”に，カルバペネムを選択する。

問題は，上記の微生物の可能性をどのような方法で 評価するのかである。体系的レビューを含む複数の研 究が, ESBL 産生菌 ${ }^{11,24,25)}$, 第 3 世代セフェム耐性 腸内細菌科 26)， あるいは而性緑膿菌感染症 20) の危険 因子について報告している。微生物ごとに差違はある ものの, 多くの研究に共通する最も主要な危険因子 は, (1)抗菌薬の投与歴, (2)耐性菌の保菌/定着, であ る。

Rottier ら 26) は, 腸内細菌科グラム陰性桿菌群によ る菌血症患者を対象に, 第 3 世代セフェム而性腸内細 菌科グラム陰性桿菌群の危険因子を評価し, 耐性菌の 保菌/定着が存在する場合のみにカルバペネムを使用 するとの想定の場合に, 適切率を下げることなくカル バペネムやアミノグリコシドの過剩使用を回避できる とした。

Lambregts ら 27) は, グラム陰性桿菌菌血症におい て第 2 世代セフェム+アミノグリコシド耐性菌の危 険因子を耐性菌保菌＋抗菌薬使用歴で抽出し，選択 的にカルバペネムを投与した場合にカルバペネム使用 を削減でき, 経験的治療の適切性が高まるとした。

これらの研究結果を参考にすれば, (1)各耐性菌の保 菌/定着あるいは感染/分離既往, に加えて, (2)抗菌薬 の投与歴を, “ESBL 産生菌, あるいはカルバペネム のみに感受性を持つ耐性緑膿菌, 而性アシネトバク ターなどが想定される場合”の危険因子として設定 し，カルバペネムを経験的治療に用いることを考慮す る。

ただし，カルバペネムの代替として使用できる薬剤 や, 想定する耐性菌の頻度や耐性度は, 国や地域, あ るいは施設や部署ごとに異なり, 本邦においても臨床 現場における解析が必要である。

\section{文 献}

1) Paul M, Shani V, Muchtar E, et al: Systematic review and metaanalysis of the efficacy of appropriate empiric antibiotic therapy for sepsis. Antimicrob Agents Chemother. 2010; 54: 4851-63.

2) Rhodes A, Evans LE, Alhazzani W, et al: Surviving Sepsis Campaign : International Guidelines for Management of Sepsis and Septic Shock : 2016. Intensive Care Med. 2017; 43: 304-77.

3) Bochud P, Bonten M, Marchetti O, et al: Antimicrobial therapy for patients with severe sepsis and septic shock: An evidencebased review. Crit Care Med. 2004; 32: S495-512.

4) Trouillet JL, Vuagnat A, Combes A, et al: Pseudomonas aeruginosa Ventilator-Associated Pneumonia: Comparison of Episodes Due to Piperacillin-Resistant versus PiperacillinSusceptible Organisms. Clin Infect Dis. 2002; 34: 1047-54.

5) Schmitt DV, Leitner E, Welte T, et al: Piperacillin / Tazobactam vs Imipenem / Cilastatin in the Treatment of Nosocomial Pneumonia-a Double Blind Prospective Multicentre Study. Infection. 2006; 34:127-34.

6) Joshi M, Metzler M, Mccarthy M, et al: Comparison of piperacillin / tazobactam and imipenem / cilastatin, both in combination with tobramycin, administered every $6 \mathrm{~h}$ for treatment of nosocomial pneumonia. Respir Med. 2006; 100: 1554-65.

7) Erasmo AA, Crisostomo AC, Yan L, et al: Randomized Comparison of Piperacillin / Tazobactam Versus Imipenem / Cilastatin in the Treatment of Patients with Intra-abdominal Infection. Asian J Surg. 2004; 27: 227-35.

8) Solomkin JS, Wilson SE, Christou NV, et al: Results of a Clinical Trial of Clinafloxacin Versus Imipenem / Cilastatin for Intraabdominal Infections. Ann Surg. 2001; 233: 79-87.

9) Klugman KP, Dagan R: Randomized Comparison of Meropenem with Cefotaxime for Treatment of Bacterial Meningitis. Meropenem Meningitis Study Group. Antimicrob Agents Chemother. 1995; 39: 1140-6.

10) Schmutzhard E, Williams KJ, Vukmirovitsf G, et al: A randomised comparison of meropenem with cefotaxime or ceftriaxone for the treatment of bacterial meningitis in adults. Meropenem Meningitis Study Group. J Antimicrob Chemother. 1995; 36: 85-97.

11) Goodman KE, Lessler J, Cosgrove SE, et al: A Clinical Decision Tree to Predict Whether a Bacteremic Patient is Infected with an Extended-Spectrum $\beta$-Lactamase-Producing Organism. Clin Infect Dis. 2016; 63: 896-903.

12) Palacios-Baena ZR, Gutiérrez-Gutiérrez B, Calbo E, et al: Empiric Therapy with Carbapenem-Sparing Regimens for Bloodstream Infections due to Extended-Spectrum $\beta$-LactamaseProducing Enterobacteriaceae: Results from the INCREMENT Cohort. Clin Infect Dis. 2017; 65: 1615-23.

13) Tamma PD, Rodriguez-Bano J: The use of noncarbapenem $\beta$-lactams for the treatment of extended-spectrum $\beta$-lactamase infections. Clin Infect Dis. 2017; 64: 972-80.

14) Tamma PD, Han JH, Rock C, et al: Carbapenem therapy is associated with improved survival compared with piperacillintazobactam for patients with extended-spectrum $\beta$-lactamase bacteremia. Clin Infect Dis. 2015; 60: 1319-25.

15) Harris AD, Smith D, Johnson JA, et al: Risk Factors for Imipenem-Resistant Pseudomonas aeruginosa among Hospitalized Patients. Clin Infect Dis. 2002; 34: 340-5.

16) Owens Jr RC: An overview of harms associated with $\beta$-lactam antimicrobials: Where do the carbapenems fit in? Crit Care. 2008; 12 Suppl 4: S3.

17) Falagas ME, Kopterides P: Risk factors for the isolation of multidrug-resistant Acinetobacter baumannii and Pseudomonas aeruginosa : a systematic review of the literature. 2006; 64: 7-15.

18) Voor AF, Severin JA, Lesaffre EMEH, et al: A Systematic 
Review and Meta-Analyses Show that Carbapenem Use and Medical Devices Are the Leading Risk Factors for CarbapenemResistant Pseudomonas aeruginosa. 2014; 58: 2626-37.

19）厚生労働省: 院内感染対策サーベイランス検査部門. 2018.

20) Liu P, Li X, Luo M, et al: Risk Factors for Carbapenem-Resistant Klebsiella Pneumoniae Infection: A Meta-Analysis. Microb Drug Resist. 2018; 24: 190-8.

21) Micek ST, Welch EC, Khan J, et al: Resistance to empiric antimicrobial treatment predicts outcome in severe sepsis associated with gram-negative bacteremia. J Hosp Med. 2011; 6 : 405-10.

22) Zilberberg MD, Nathanson BH, Sulham K, et al: Carbapenem resistance, inappropriate empiric treatment and outcomes among patients hospitalized with Enterobacteriaceae urinary tract infection, pneumonia and sepsis. BMC Infect Dis. 2017; 17: 279.

23) Kohler PP, Volling C, Green K, et al: Carbapenem Resistance, Initial Antibiotic Therapy, and Mortality in Klebsiella pneumoniae Bacteremia: A Systematic Review and Meta-Analysis. Infect Control Hosp Epidemiol. 2017; 38: 1319-28.

24) Kang C, Wi YM, Lee MY, et al: Epidemiology and Risk Factors of Community Onset Infections Caused by Extended-Spectrum $\beta$-Lactamase-Producing Escherichia coli Strains. J Clin Microbiol. 2012; 50: 312-7.

25) Rodríguez-Baño J, Picón E, Gijón P, et al: Community-Onset Bacteremia Due to Extended-Spectrum Beta-LactamaseProducing Escherichia coli : Risk Factors and Prognosis. Clin Infect Dis. 2010; 50: 40-8.

26) Rottier WC, Bamberg YRP, Dorigo-Zetsma JW, et al: Predictive value of prior colonization and antibiotic use for third-generation cephalosporin-resistant enterobacteriaceae bacteremia in patients with sepsis. Clin Infect Dis. 2015; 60: 1622-30.

27) Lambregts MMC, Hendriks BJC, Visser LG, et al: Using local clinical and microbiological data to develop an institution specific carbapenem-sparing strategy in sepsis: A nested case-control study. Antimicrob Resist Infect Control. 2019; 8: 19.
CQ4-3：どのような場合に, MRSA や一般細菌 以外（カンジダ， ウイルス，レジオネラ, リケッ チア，クロストリジオイデス ディフィシルなど） に対する経験的抗微生物薬を選択するか?

Answer : 感染巣, 患者背景および検査結果などから, それぞれの微生物が原因として想定される場合である

（Table 4-3-1）（BQ に対する情報提示）。

\section{（1）背景および本 $C Q$ の重要度}

敗血症の抗菌療法において, 経験的治療の適切性が 死亡率低下に関連するとの観察研究が多数存在す る1)。このため, SSCG2016においては, “敗血症あ るいは敗血症性ショック患者には, 想定されるすべて の病原体 (細菌, 真菌やウイルス感染まで考慮する) をカバーするため, 経験的選択に基づく広域スペクト ラム抗菌薬の単剤あるいは併用投与をすることを推奨 する (強い推奨, 中等度のエビデンスレベル)”と記 述されていた2)。

メチシリン耐性黄色ブドウ球菌（methicillin-resistant Staphylococcus aureus: MRSA) や, Legionella pneumophila, リケッチア，クロストリジオイデス ディフィシルなどの細菌, またCandida 属, さらにウ イルスは，一般的な細菌感染症診療で用いられる抗菌 療法では治療がむずかしい。治療の適切性を高める目 的で，これらすべての病原体を考慮した経験的抗微生 物薬を選択した場合，副作用やコストを高める危険性 を伴うだけでなく，耐性微生物の選択を助長しうる。 適切な症例に対し，適切な抗微生物薬を選択的に使用 することは，抗菌薬スチュワードシップの観点からも 望ましいと考え, 本ガイドラインの $\mathrm{CQ}$ として取り上 げた。

\section{（2）解説}

MRSA や一般細菌以外に対して, 経験的抗微生物 薬を選択する際に考慮するべき感染症発症のリスク, 重症化のリスクを記載する。

\section{1) MRSA について}

黄色ブドウ球菌（Staphylococcus aureus）は，およ そ $50 \%$ の成人が一時的 $(30 \%)$ または永続的 $(20 \%)$ に保菌しているとの報告がある（日本人では $36 \%)^{3,4)}$ 。特に永続的な保菌者は菌量が多く, S. aureusによる感染症を発症するリスクが高い5)。そし て, インスリン依存性の糖尿病, 血液透析, 腹膜透 析，アトピー性皮膚炎，医療曝露，繰り返すS. aureus 皮膚感染症, HIV 感染症, 麻薬常習者は保菌リスク 
が高い6)。多剂耐性菌である MRSAの保菌リスクも 糖尿病, COPD (chronic obstructive pulmonary disease), 心不全などの医療曝露である7)。

S. aureusによる感染症としては, 皮膚軟部組織感染 症, 骨髄炎, 関節炎, 手術部位感染症, インフルエン ザウイルス感染症後の市中肺炎, 院内肺炎/人工呼吸 器関連肺炎, 菌血症, カテーテル関連血流感染症, 感 染性心内膜炎, トキシックショック症候群など幅広 い8)。そして, S. aureusによるこれらの感染症を起こ すリスクは，血液透析 [リスク比（RR）：257～291］, 腹膜透析（RR 150 204），糖尿病（RR 7)，心疾患 （RR 20.6），脳卒中（RR 6.4），担癌患者（RR 7.1～ 12.9), SLE (systemic lupus erythematosus) (RR 2.4), 関節リウマチ（RR 2.2）, HIV 感染症（RR 23.7）, 固形 臓器移植後 (RR 20.7), アルコール依存症（RR 8.2） が知られている ${ }^{8)}$ 。皮膚軟部組織感染症において，皮 下膿瘍やリンパ節膿瘍などを穿刺して集簇するグラム 陽性球菌を認めた場合も，S. aureus が原因菌である可 能性を考慮する9)。

\section{2) Legionella pneumophila について}

レジオネラ症は, 臨床的に細菌性肺炎との区別は難 しい 10)。L. pneumophila は水系の環境に存在するグラ 厶陰性桿菌であり，25～ $40^{\circ} \mathrm{C}$ の暖水でよく発育する。 污染した水がエアロゾル化した場合, レジオネラ症の 最も重要な供給源となる11,12)。発症リスクが高いの は, 男性, 喫煙, 慢性心疾患, 肺疾患, 糖尿病, 未期 腎不全, 固形臓器移植, 免疫不全, 担癌, 50 歳以上 である ${ }^{12)}$ 。

水系懪露がある肺炎患者で上述したような危険因子 がある場合にL. pneumophilaによる感染症を考慮する。

\section{3）リケッチア属について}

本邦で報告されているリケッチア症は, Orientia tsutsugamushi によるツツガムシ病とRickettsia japonica による日本紅斑熱である。共にダニ媒介性疾患であ り, 前者はツツガムシの幼虫, 後者はマダニ (Haemaphysalis 属, Ixodes 属の一部) に咬まれること により感染する。

ツツガムシ病では発熱 $(95 \%)$, 発疹 $(86 \%)$, 黒色

Table 4-3-1 成人における各病原体の感染巣とリスクとなる患者背景

\begin{tabular}{|c|c|c|}
\hline 病原体 & 感染巣と症状‧所見 & リスク患者背景 \\
\hline \multirow[t]{2}{*}{$\begin{array}{l}\text { Staphylococcus aureus } \\
\text { (MRSA) }\end{array}$} & \multirow{2}{*}{$\begin{array}{l}\text { 皮膚軟部組織感染症, 骨髄炎, 関節炎, 手術部位感染症, } \\
\text { インフルエンザウルス感染症後の市中肺炎, 院内肺 } \\
\text { 炎/人工呼吸器関連肺炎, 菌血症, カテーテル関連血流 } \\
\text { 感染症, 感染性心内膜炎, トキシックシック症候群 }\end{array}$} & $\begin{array}{l}\text { 血液透析, 腹膜透析, 糖尿病, 心疾患, 脳卒中, 担癌患者, } \\
\text { SLE, 関節リウマチ, HIV 感染症, 固形臟器移植後, アル } \\
\text { コール依存症 }\end{array}$ \\
\hline & & 90 日以内の抗菌薬治療歴，MRSA の保菌 \\
\hline $\begin{array}{c}\text { クロストリジオイデス ディ } \\
\text { フィシル }\end{array}$ & 偽膜性腸炎，中毒性巨大結腸症 & $\begin{array}{l}\text { 抗菌薬曝露※, 制酸薬, ヒスタミン } \mathrm{H}_{2} \text { 受容体拮抗薬, 高齢, } \\
\text { 入院のー既往, 基礎疾患の重症度が高い, 腹部手術後, 経鼻 } \\
\text { カテーテル留置, 長期入院 }\end{array}$ \\
\hline Legionella pneumophila & 水系曝露のある患者の肺炎 & $\begin{array}{l}\text { 水系曝露, 男性, } 50 \text { 歳以上, 喫煙, 慢性肺疾患, 慢性心 } \\
\text { 疾患, 肺疾患, 糖尿病, 未期腎不全, 固形臟移植, 免 } \\
\text { 疫不全, 担癌患者 }\end{array}$ \\
\hline $\begin{array}{l}\text { Rickettsia japonica } \\
\text { Orientia tsutsugamushi }\end{array}$ & $\begin{array}{l}\text { 発熱, 皮疹, 肝脾腫, リンパ節腫脹, 筋肉痛, 意識障 } \\
\text { 害などの症状, 血小板減少を来す敗血症 }\end{array}$ & $\begin{array}{l}\text { 流行地においてダニ咬傷, 自然曝露や黒色痂皮/刺し口 } \\
\text { (eschar)がある }\end{array}$ \\
\hline Candida spp. & $\begin{array}{l}\text { 菌血症, カテーテル関連血流感染症, 感染性心内膜炎, } \\
\text { 固形臓器膿瘍, 䯣膜炎, 眼内炎 }\end{array}$ & $\begin{array}{l}\text { 広域抗菌薬使用, 血管内カテーテル留置, 人工物留置, 絶 } \\
\text { 食/経静脈栄養, 抗がん剂使用, 固形藏器移植後, カンジ } \\
\text { ダ定着 }\end{array}$ \\
\hline $\begin{array}{l}\text { インフルエンザ } \\
\text { ウイルス }\end{array}$ & $\begin{array}{l}\text { 肺炎, 脳炎, 脳症, 臓器障害を伴う意識障害, 心筋炎, } \\
\text { Reye 症候群 }\end{array}$ & 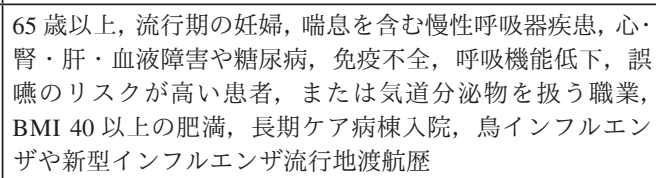 \\
\hline $\begin{array}{l}\text { 単純ヘルペス } \\
\text { ウイルス(HSV) } \\
\end{array}$ & 脳炎, 脳症, 多臟器不全 & $\begin{array}{l}30 \text { 歳未満, } 50 \text { 歳以上, 免疫不全, 固形藏器移植後, 骨䯣 } \\
\text { 䅦後, HIV 症 }\end{array}$ \\
\hline $\begin{array}{l}\text { サイトメガロ } \\
\text { ウイルス }\end{array}$ & 脳炎, 網脈絡膜炎, 腸炎, 肺炎 & 固形臟器移植後, 骨髄移植後, HIV 感染症 \\
\hline $\begin{array}{l}\text { 重症熱性血小板減少症候群 } \\
\text { (SFTS) ウイルス }\end{array}$ & $\begin{array}{l}\text { 発熱, 消化器症状, 意識障害, 㽷攣, 昏睡, リンパ節 } \\
\text { 腫脹, 皮下出血や下血などの出血症状, 呼吸不全, 白 } \\
\text { 血球減少, 血小板減少 }\end{array}$ & 流行地においてダ二咬傷, 自然曝露, 野生動物との接触 \\
\hline
\end{tabular}

※ Clostridioides difficile 感染症発症リスク別抗菌薬表

\begin{tabular}{|c|c|c|}
\hline 高リスク & 中リスク & 低リスク \\
\hline $\begin{array}{l}\text { クリンダマイシン, キノロン, } \\
2 \text { 世代以上のセファロスポリン }\end{array}$ & $\begin{array}{l}\text { ペニシリン, マクロライド, } \beta \text { ラクタマーゼ配合剤, } \\
\text { カルバペネム, バンコマイシン, メトロニダゾール }\end{array}$ & $\begin{array}{l}\text { アミノグリコシド, テトラサイクリン, トリメトプリム, } \\
\text { スルフォナミド, リファンピシン }\end{array}$ \\
\hline
\end{tabular}

基本的に種類が多いほど, 期間が多いほどリスクが高まる。 
の痂皮/刺し口（eschar）（85\%）が 3 主徵である ${ }^{13) 。 ~}$ 痂皮は四肢よりも体幹にできることが多く，疑わなけ れば見つけることは困難である。治療介入が遅くなる と肝逸脱酵素の上昇や血小板減少などの症状が出現 し，死亡率は $0.5 \%$ である。

日本紅斑熱は, 発熱 $(99 \%)$, 皮疹 $(94 \%)$ を高率 に認めるが，ツッガムシ病に比べ，痂皮を伴う頻度は 少なく $66 \%$ に過ぎない。肝逸脱酵素の上昇 $(73 \%)$, 頭痛 $(31 \%)$ ，播種性血管内凝固（DIC）（20\%）を多 く認め, 死亡率は $0.9 \%$ である ${ }^{13)}$ 。

ダニの生息地での野外活動歴やダ二咬傷歴，痂皮は 重要な所見だが，必ずしも認められないことがあり， 治療が遅れた場合は臟器不全から致死的になりうる。 敗血症の原因として疑った場合は保健所と相談して検 体採取を行い，結果を待たずに経験的治療を開始する べきとの意見もある。また，海外渡航後などでは， Q 熱, アナプラズマ, エーリキア, ロッキー山紅斑熱, 発疹チフスなどのリケッチアにも注意する。敗血症の 原因として疑った場合, 保健所と相談し検体採取のう えで結果を待たずに経験的治療を開始する。

4）クロストリジオイデス ディフィシルについて

C. difficile は, 土袞や水, 食物など, 環境に遍在す る微生物である。毒素産生型の C. difficile による感染 症（C. difficile infection: CDI）では，下㾥のみで自然 軽快する軽症から重症まで幅広い重症度の症例が報告 されている。生命予後に関わる重症例では, 高熱, 腹 痛, 高白血球血症 $(\geqq 25,000 / \mu \mathrm{L})$, 低アルブミン血症, 腎不全, ショック, 中毒性巨大結腸症などの所見がみ られる14)。

抗菌薬曝露は, 最も重要な CDI 発症のリスク因子 であり, 抗菌薬治療中および終了後 1 か月以内に発症 するリスクが高い。抗菌薬の種類によってもリスクは 異なり 15)（Table 4-3-1），プロトンポンプ阻害薬や， ヒスタミン $\mathrm{H}_{2}$ 受容体拮抗薬などの制酸薬も CDI 発症 のリスクとして知られている16)。その他，高齢，入 院の既往, 基礎疾患の重症度, 腹部手術後, 経鼻力 テーテル留置, 長期入院なども CDI の発症リスクで ある ${ }^{17) 。 ~}$

抗菌薬曝露歴があり, 腹部症状やショックの患者に 上記リスクがある場合に CDI を考慮する。

\section{5）Candida 属について}

Candida 属は酵母様真菌の一種であり, 人体に遍在 する微生物である。通常は感染症を起こすことはない が，免疫抑制状態では眚口瘡や食道カンジダなどの表 層感染症だけでなく, 菌血症やカテーテル関連血流感 染症, 感染性心内膜炎, 固形臟器膿瘍, 髄膜炎, 眼内
炎などの侵襲性感染症を起こすことがある18)。侵襲 性Candida 感染症の発症リスクは，広域抗菌薬の使 用, 血管内カテーテル留置, 人工物留置, 絶食/経静 脈栄養的高カロリ一輸液, 細胞毒性のある抗がん剂使 用, 固形臟器移植後, カンジダ定着などである。早期 の適切な抗真菌薬投与は死亡率を最大 $50 \%$ 減らすと いう報告があり，これらのリスク因子がある患者にお いて敗血症の診療を行う際には，抗真菌薬の併用を検 討するという意見もある19)。しかし，カンジダの定 着のみで抗真菌薬を投与する方法は不適切との意見も あり，その他の臨床情報と併せて検討する必要がある と考えられている20)。

6）ウイルス感染症について

(1)インフルエンザウイルス

季節性インフルエンザは，急激な高熱，悪寒，筋肉 痛, 悪心などで発症し, 多くは合併症なく自然軽快す るが，一部で肺炎，心筋炎や脳炎・脳症を合併し重篤 化する症例もある 21 )。輸入感染症として鳥インフル エンザ（H7N9 など）は急性呼吸窮迫症候群を発症し, 死亡率は約 30\% と非常に高い 22)。インフルエンザ感 染症の重症化リスクとして，65歳以上，流行期の妊 婦, 喘息を含む慢性呼吸器疾患, 心 - 腎 - 肝 - 血液障 害や糖尿病, 免疫不全, 呼吸機能低下, 誤嬹のリスク が高い患者または気道分泌物を扱う職業，BMI 40 以 上の肥満, 長期ケア病棟入院, 鳥インフルエンザや新 型インフルエンザ流行地への渡航歴などが報告されて いる ${ }^{23)}$ 。診断に際して，インフルエンザ抗原迅速検 査の感度は低いため $(62 \%){ }^{24)}$, 季節性インフルエン ザの流行期や, 鳥インフルエンザの流行地への渡航歴 がある患者の呼吸不全や心筋炎, 脳炎・脳症を疑った 場合には，抗インフルエンザ薬の投与を考虑するとい う意見もある 23$) 。$

(2)単純ヘルペスウイルス

単純ヘルペスウイルス（herpes simplex virus: HSV) は DNA ウイルスであり，HSV 1 型は成人のおよそ $90 \%$ 以上が既感染と報告されている25)。通常は繰り 返す口唇ヘルペスなどを起こすが，免疫不全状態の患 者では脳炎や播種性感染症などの致死的な感染症を起 こすことがある。

脳炎は, 30 歳未満と 50 歳以上の二峰性の年齢分布 を示し, 免疫能が低下していない状態での発症も報告 されている26)。他のウイルス性脳炎と比較して側頭 葉の神経巣症状を伴うことが特徵であるが，区別はむ ずかしい27)。

固形臟器移植後, 骨髄移植後, HIV 感染症などの 免疫抑制状態では再活性化により重症 HSV 感染症を 
起こし，広範な粘膜疹や，肝不全などの内臟の障害を 伴う致死性播種性感染症となりうる。重症 HSV 感染 症の発症リスクが高いのは, 藏器移植患者では $\mathrm{T}$ 細 胞への免疫抑制が最も強い移植後 30 日以内 28$)$, 骨䯣 移植では, HSV 1 陽性レシピエントがHSV 1 陰性ド ナーから移植を受けた場合である29)。また，妊婦で はHSV 2 の初感染が播種性感染症となる危険性があ る 25)。

診断については, 血清抗体価検査は時間がかかるう えに, 免疫不全患者では結果の解釈がむずかしいた め, 血清や骾液, 水疮内容液などの検体で PCR 検查 を行う。しかし, これらの検査も迅速に結果を得るこ とが困難であるため, 重症 HSV 感染症の発症リスク が高い患者では, HSV 感染症を疑ったら治療の開始 を考慮するという意見がある。

(3)サイトメガロウイルス

サイトメガロウイルスは DNA ウイルスであり, 先 進国に在住の成人では $50 \%$ 以上が既感染であると報 告されている30)。通常は致死的な感染症を起こさな いが, 固形臟器移植後, 骨骾移植後, HIV 感染症な どの免疫抑制状態の患者では, 脳炎, 網脈絡膜炎, 腸 炎, 肺炎など cytomegalovirus (CMV) disease を起こ し致死的となる。そのため, 免疫抑制状態の患者では ウイルス迅速同定 (シェルバイアル法), CMV 抗原 血症検査 (CMVアンチゲネミア法), 定量 PCR 法な どで, 定期的に血液中のサイトメガロウイルス量をモ ニタリングして, 症状が出現した時に速やかに治療を 開始できるようにしておくことが望ましいとの意見が ある31)。

(4)重症発熱性血小板減少症候群（SFTS）ウイルス

SFTS ウイルスは 2010 年に中国で見つかったウイ ルスで, 中国および本邦や韓国から感染症の報告があ る32)。ダ二媒介性疾患であり, 中間宿主であるフタ トゲチマダニ (Haemaphysalis longicornis) に咬まれる ことで感染する。本邦では西日本を中心に報告があ り, 2019 年 6 月時点で 402 例が報告されている33)。 症状は発熱, 消化器症状, 頭痛, 筋肉痛など非特異的 であるが，SFTS では意識障害などの中枢神経症状， 出血症状, 肝逸脱酵素の上昇を認める場合がある。 1〜2 週間程度で自然軽快するが，27\% が死亡してお り，死亡例では悪性腫場の合併が多かったと報告され

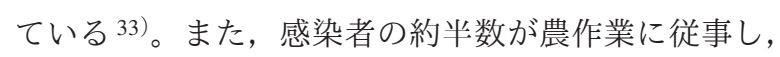
発症前に屋外活動を行っていたとの報告もある ${ }^{33)}$ 。 SFTS に対する有効な薬剤は開発途中であり, 現在, 抗ウイルス薬（ファビピラビル）の医師主導治験が行 わ机ている ${ }^{34)}$

\section{文 献}

1) Paul M, Shani V, Muchtar E, et al: Systematic review and metaanalysis of the efficacy of appropriate empiric antibiotic therapy for sepsis. Antimicrob Agents Chemother. 2010; 50: 4851-63.

2) Rhodes A, Evans LE, Alhazzani W, et al: Surviving Sepsis Campaign: International Guidelines for Management of Sepsis and Septic Shock: 2016. Crit Care Med. 2017; 45: 486-552.

3) Kluytmans J, Van Belkum A, Verbrugh H: Nasal carriage of Staphylococcus aureus: Epidemiology, underlying mechanisms, and associated risks. Clin Microbiol Rev. 1997; 10: 505-20.

4) Uemura E, Kakinohana S, Higa N, et al: Comparative characterization of Staphylococcus aureus isolates from throats and noses of healthy volunteers. Jpn J Infect Dis. 2004; 57: 21-4.

5) Wertheim HFL, Melles DC, Vos MC, et al: The role of nasal carriage in Staphylococcus aureus infections. Lancet Infect Dis. 2005; 5: 751-62.

6) Sollid JUE, Furberg AS, Hanssen AM, et al: Staphylococcus aureus: Determinants of human carriage. Infect Genet Evol. 2014; 21: 531-41.

7) McKinnell JA, Miller LG, Eells SJ, et al: A Systematic Literature Review and Meta-Analysis of Factors Associated with Methicillin-Resistant Staphylococcus aureus Colonization at Time of Hospital or Intensive Care Unit Admission. Infect Control Hosp Epidemiol. 2013; 34: 1077-86.

8) Que YA, Moreillon P: Staphylococcus aureus (Including Staphylococcal Toxic Shock Syndrome). 9th Edit. Mandell, Douglas, and Bennett's Principles Practice of Infectious Diseases. Elsevier Inc., Amsterdam, 2019, p2393-431.e9.

9) Stevens DL, Bisno AL, Chambers HF, et al: Practice guidelines for the diagnosis and management of skin and soft tissue infections: 2014 update by the infectious diseases society of America. Clin Infect Dis. 2014; 59: 147-59.

10) Roig J, Aguilar X, Ruiz J, et al: Comparative study of Legionella pneumophila and other nosocomial- acquired pneumonias. Chest. 1991; 99: 344-50.

11) Fields BS, Benson RF, Besser RE: Legionella and Legionnaires' Disease: 25 Years of Investigation. Clin Microbiol Rev. 2002; 15 : 506-26.

12) Paul HE, Craig RR: Legionnaires' disease and pontiac fever. 9th Edit. US Pharm. Douglas, and Bennett's Principles Practice of Infectious Diseases. Elsevier Inc., Amsterdam, 2019, p2807-17. e5.

13) National Institute of Infectious Diseases: Scrub typhus and Japanese spotted fever in Japan 2007-2016. IASR. 2017; 38 : 109-12.

14) Formerly $C$, Infection $C$, Gerding DN, et al: Clostridioides difficile (Formerly Clostridium difficile) Infection. 9th Edit. Mandell, Douglas, and Bennett's Principles Practice of Infectious Diseases. Elsevier Inc., Amsterdam, 2019, p2933-47.e4.

15) Stevens V, Dumyati G, Fine LS, et al: Cumulative antibiotic exposures over time and the risk of clostridium difficile infection. Clin Infect Dis. 2011; 53: 42-8.

16) Janarthanan S, Ditah I, Adler DG, et al: Clostridium difficileassociated diarrhea and proton pump inhibitor therapy: A metaanalysis. Am J Gastroenterol. 2012; 107: 1001-10.

17) Loo VG, Bourgault A-M, Poirier L, et al: Host and Pathogen Factors for Clostridium difficile Infection and Colonization. $\mathrm{N}$ Engl J Med. 2011; 365: 1693-703.

18) Lionakis MS, Jr JEE: Candida Species. 9th Edit. Mandell, Douglas, and Bennett's Principles Practice of Infectious Diseases. Elsevier Inc., Amsterdam, 2019, p3087-102.e3.

19) Pappas PG, Kauffman CA, Andes DR, et al: Clinical Practice Guideline for the Management of Candidiasis: 2016 Update by the Infectious Diseases Society of America. Clin Infect Dis. 2015; 
62: e1-50.

20) Troughton JA, Browne G, McAuley DF, et al: Prior colonisation with Candida species fails to guide empirical therapy for candidaemia in critically ill adults. J Infect. 2010; 61: 403-9.

21) Treanor JJ: Influenza Viruses, Including Avian Influenza and Swine Influenza. 9th Edit. Mandell, Douglas, and Bennett's Principles Practice of Infectious Diseases. Elsevier Inc., Amsterdam, 2019, p2143-68.e7.

22) Gao HN, Lu HZ, Cao B, et al: Clinical findings in 111 cases of influenza A (H7N9) virus infection. N Engl J Med. 2013; 368 : 2277-85.

23) Uyeki TM, Bernstein HH, Bradley JS, et al: Clinical Practice Guidelines by the Infectious Diseases Society of America: 2018 Update on Diagnosis, Treatment, Chemoprophylaxis, and Institutional Outbreak Management of Seasonal Influenza. Clin Infect Dis. 2019; 68: e1-47.

24) Chartrand C, Leeflang MMG, Minion J, et al: Accuracy of rapid influenza diagnostic tests: A meta-analysis. Ann Intern Med. 2012; 156: 500-11.

25) Schiffer JT, Corey L: Herpes Simplex Virus. 9th Edit. Mandell, Douglas, and Bennett's Principles Practice of Infectious Diseases. Elsevier Inc., Amsterdam, 2019, p1828-48.e7.

26) Whitley RJ, Lakeman F: Herpes Simplex Virus Infections of the Central Nervous System. : Therapeutic and Diagnostic Considerations. Clin Infect Dis. 1995; 20: 414-20.

27) Whitley RJ, Cobbs CG, Alford Jr CA, et al: Diseases that mimic herpes simplex encephalitis. Diagnosis, presentation, and outcome. NIAD Collaborative Antiviral Study Group. JAMA. 1989; 262: 234-9

28) Kusne S, Schwartz M, Breinig MK, et al: Herpes simplex virus hepatitis after solid organ transplantation in adults. J Infect Dis. 1991; 163: 1001-7.

29) Nichols WG, Boeckh M, Carter RA, et al: Transferred Herpes Simplex Virus Immunity after Stem - Cell Transplantation: Clinical Implications. J Infect Dis. 2003; 187: 801-8.

30) William JB: Cytomegalovirus. Mandell, Douglas, and Bennett's Principles Practice of Infectious Diseases. Elsevier Inc., Amsterdam, 2019, p1857-71.

31) Ljungman P, de la Camara R, Robin C, et al: Guidelines for the management of cytomegalovirus infection in patients with haematological malignancies and after stem cell transplantation from the 2017 European Conference on Infections in Leukaemia (ECIL 7). Lancet Infect Dis. 2019; 19: e260-72.

32) Liu Q, He B, Huang SY, et al: Severe fever with thrombocytopenia syndrome, an emerging tick-borne zoonosis. Lancet Infect Dis. $2014 ;$ 14: 763-72.

33） National Institute of Infectious Diseases: 重症熱性血小板減少症 候群（SFTS）2019 年 6 月現在. IASR. 2019; 40: 111-2.

34）安川正貴, 西條政幸: SFTS に対するファビピラビル治療効 果を調べるための医師主導型臨床研究. IASR. 2019; 40: 121.
CQ 4-4: 敗血症が疑われて経験的抗菌薬を使用 する患者において, 投与前の各種培養陰性の確 認をしたら抗菌薬を中止するか?

Answer : 敗血症が疑われて経験的抗菌薬を使用する 患者において，投与前の各種培養陰性の確認をした ら，臨床経過を慎重に考慮したうえで抗菌薬を中止す ることを弱く推奨する（エキスパートコンセンサス： エビデンス不十分)。

\section{（1）背景および本 CQの重要度}

臨床的に敗血症と診断し，しかるべき培養を行って も，3〜6 割は培養陰性となり “culture-negative sepsis” と称される 1)。敗血症の診断にもとづき経験的抗菌薬 を開始した後, 培養が陰性であった場合, 安全に抗菌 薬を終了可能かどうか評価したランダム化比較試験 （RCT）はなく, culture-negative sepsis の疫学や予後を 評価した観察研究は少ない。敗血症と診断した多くの 患者が遭遇しうる状況であり，本ガイドラインに取り 上げるべき重要臨床課題であると考える。

\section{(2) PICO}

$$
\begin{aligned}
& \text { P (患者) : 成人敗血症あるいは敗血症性ショック, } \\
& \text { またはそれに準じる重症感染症疑い患者 } \\
& \text { I (介入 }): \text { 培養陰性判明時に抗菌薬治療を中止する } \\
& \text { C (対照) : 培養陰性判明時に抗菌薬治療を中止しな } \\
& \text { い } \\
& \text { O (アウトカム }): \text { 死亡, 入院日数, 新たな感染症発生 }
\end{aligned}
$$

\section{（3）エビデンスの要約}

システマティックレビューの結果， 1 件の RCT が 検索された 2)。本研究は, 集中治療室で全身性炎症反 応症候群の基準に合致し，明らかな感染巣は不明だが 抗菌薬を使用すべきと判断された患者を対象に, 抗菌 薬を 48 時間で終了する群を介入群とし, 7 日間投与 する群をコントロール群として行われたオープンラベ ル，単施設の小規模（対象患者計 46 名）パイロット 研究である2)。この研究では 48 時間以内の短時間投 与が生命予後を悪化させることなく, 広域抗菌薬の投 与削減に寄与する可能性を示唆している。しかし, 本 研究は培養陰性かどうかで抗菌薬治療の中止を決定し ているわけではなく, 正確には PICO に合致せず，本 $\mathrm{CQ}$ に直接的に答える内容の RCT ではなかった。し たがって, 本 CQにおけるシステマティックレビュー において該当する研究はないとした。

Sepsis-3 以前の全身性炎症反応症候群を用いた敗血 
症診断基準（Sepsis-1, 2）では，当初敗血症と診断し 抗菌薬を開始しても, 結果として敗血症や感染症です らない症例が多く含まれていた ${ }^{3)}$ 。一方, culturenegative sepsis と culture-positive sepsis を比較した観察 研究では, 生命予後に関して, 両群に差はないか, や や culture-positive sepsis のほうが悪いと報告されてい る ${ }^{4,5)}$ 。また，敗血症と臨床的に診断した当初は培養 結果に関しては予想がつかないため，血液培養など各 種培養を採取した後で抗菌薬を開始するプラクティス は普遍的に行われている。培養結果が陰性と確認でき た時点で, 臨床的に敗血症ではないと総合的に判断さ れた場合，可及的速やかに抗菌薬投与の終了を考慮す ることは，抗微生物薬耐性（antimicrobial resistance: AMR）対策としても重要であると考えた。

\section{（4）益と害のバランス}

望ましい効果 :

抗菌薬の中止により，耐性菌の発生リスクおよび続 発性感染症や Clostridioides difficile の発生リスクを減 少できる可能性があり，入院期間短縮あるいは死亡率 減少に関与するかもしれない。

\section{望ましくない効果 :}

経験的抗菌薬が有効な感染症が存在した場合には, 死亡率や入院期間増加などの予後悪化が生じる可能性 がある。しかし，適切に採取された培養の陰性結果と 共に，臨床経過を考慮して感染症が存在しないことを 慎重に判断すれば，抗菌薬中止に伴う望ましくない効 果はわずかと考えられる。

\section{益と害のバランス :}

望ましい効果は小さく，望ましくない効果はわずか であり，おそらく介入が優位と評価した。

（5）アウトカム全般に関するエビデンスの確実性 システマティックレビューでは，最終的にPICOに 合致する RCT は認めなかった。

\section{（6）価値観}

培養陰性時の抗菌薬中止における，各アウトカムに おける患者・家族の価值観に関するデータはない。一 般的に，死亡アウトカムに対して置く相対的価值は高 く，そのばらつきは少ないことが予想される。

\section{（7）容認性}

培養陰性時に抗菌薬を中止するという介入は，患者 の状態をモニタリングした状況においては可能であ り，医療者にとっての容認性は高い。介入に伴う広域 抗菌薬投与量の変化, およびこれに伴うコストへの影 響は評価できていないが，個人負担額を考えると，患 者・家族の個人の視点からも問題なく許容できる。

\section{（8）実行可能性}

介入は抗菌薬の中止のみであり, 多くの医療施設に おいて問題なく実行可能である。

(9) 判断の要約（Table 4-4-1）

Table 4-4-1 判断の要約

\begin{tabular}{|c|c|c|c|c|c|c|c|}
\hline & \multicolumn{7}{|c|}{ 半判断 } \\
\hline 問題 & いいえ & $\begin{array}{c}\text { おそらく、いい } \\
\text { え }\end{array}$ & おそらく、はい & はい & & さまざま & 分からない \\
\hline 望ましい効果 & わずか & 小さい & 中 & 大きい & & さまざま & 分からない \\
\hline 望ましくない効果 & 大きい & 中 & 小さい & わずか & & さまざま & 分からない \\
\hline エビデンスの確実性 & 非常に低 & 低 & 中 & 高 & & & 採用研究なし \\
\hline 価值䘽 & $\begin{array}{c}\text { 重要な不確実性 } \\
\text { またははららつ } \\
\text { あり }\end{array}$ & $\begin{array}{c}\text { 重要な不確実性 } \\
\text { またはばらつき } \\
\text { の可能性あり }\end{array}$ & $\begin{array}{l}\text { 重要な不確実性 } \\
\text { またはばらつき } \\
\text { はおそらくなし }\end{array}$ & $\begin{array}{c}\text { 重要な不確実性 } \\
\text { またはばらつき } \\
\text { はなし }\end{array}$ & & & \\
\hline 効果のパランス & 比較が優位 & $\begin{array}{c}\text { 比較がおそらく } \\
\text { 優位 }\end{array}$ & $\begin{array}{c}\text { 介入も比較もい } \\
\text { ずれも優位でな } \\
\text { い }\end{array}$ & $\begin{array}{c}\text { おそらく介入が } \\
\text { 優位 }\end{array}$ & 介入が優位 & さまざま & 分からない \\
\hline 容認性 & いいえ & 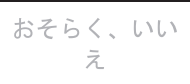 & おそらく、はい & はい & & さまざま & 分からない \\
\hline 実行可能性 & いいえ & $\begin{array}{c}\text { おそらく、いい } \\
\text { え }\end{array}$ & おそらく、はい & はい & & さまざま & 分からない \\
\hline
\end{tabular}


（10）推奨グレーディング決定の工程

修正 RAND 法を用いた投票によって，中央值 7, 見解不一致指数 0.018 の結果となり, 委員会で採択さ れた（7点以上 : 79.2\%)。

\section{（11）関連する他の診療ガイドラインにおける推奨}

SSCG 2016 においては，本 CQ は取り上げられてい ない。

\section{（12）実施に関わる検討事項}

評価対象となる微生物検体は，経験的抗菌薬投与開 始前に適切に採取された検体であることが前提であ る。培養困難微生物や嫌気性菌の関与，あるいは抗菌 薬の先行投与などにより培養陽性とならない可能性に ついて注意し, 臨床的な感染症の蓋然性を合わせて評 価する必要がある。培養陰性にもとづき抗菌薬を中止 した場合に，患者の状態が悪化しないかを適切に把握 できる環境も必要である。感染性心内膜炎や骨髄炎な ど，培養陰性のみをもって抗菌薬を即時中止すること が危険な感染症が存在することにも留意する。

\section{（13）今後の研究の可能性}

介入の害と益が正確に評価できる洗練された方法論 による質の高い RCT の遂行が望まれる。

\section{文 献}

1) Sigakis MJG, Jewell E, Maile MD, et al: Culture-Negative and Culture-Positive Sepsis: A Comparison of Characteristics and Outcomes. Anesth Analg. 2019; 129: 1300-9.

2) Scawn N, Saul D, Pathak D, et al: A pilot randomised controlled trial in intensive care patients comparing 7 days' treatment with empirical antibiotics with 2 days' treatment for hospital-acquired infection of unknown origin. Health Technol Assess. 2012; 16: i-xiii, 1-70.

3) Churpek MM, Zadravecz FJ, Winslow C, et al: Incidence and prognostic value of the systemic inflammatory response syndrome and organ dysfunctions in ward patients. Am J Respir Crit Care Med. 2015; 192: 958-64.

4) Phua J, Ngerng W, See K, et al: Characteristics and outcomes of culture-negative versus culture-positive severe sepsis. Crit Care. 2013; 17: R202

5) Gupta S, Sakhuja A, Kumar G, et al: Culture-Negative Severe Sepsis: Nationwide Trends and Outcomes. Chest. 2016; 150: 1251-9.
CQ4-5：感染症専門家あるいは抗菌薬適正使用 支援チームに相談するのはどのような場合か？

Answer：敗血症の原因が不明の場合，高度薬剂耐性 菌の関与が疑われる場合，新興・再興あるいは輸入感 染症を疑う場合, 黄色ブドウ球菌菌血症およびカンジ ダ血症と判明した場合などである（BQに対する情報 提示)。

\section{（1）背景および本 $C Q$ の重要度}

抗菌薬適正使用支援チーム (Antimicrobial Stewardship Team: AST）は，感染症専門の薬剤師や医 師を中心として臨床検査技師や看護師，事務職員で構 成され，医療機関において抗菌薬適正使用を実践する チームである。

敗血症の診療において，抗菌薬の選択や投与経路， 投与間隔，投与期間の決定は患者の予後に影響を与え る重要な介入である。そのため，敗血症診療において は, 想定される原因微生物を十分カバーする抗菌薬の 選択が求められる。一方で，一律にすべての病原体を 考慮した経験的抗菌薬の選択や治療期間の決定を行っ た場合, 薬剤耐性菌の出現（または瞢延）を助長し, 副作用やコストを高める危険性が伴う。また，一部の 菌血症においては，その他の菌血症とは区別した治療 期間や感染巣の精査が必要となることが知られている が，敗血症を診療するすべての診療部門において十分 な知識や経験が備わっているとはいえないのが現状で ある。感染症専門家あるいはASTへの相談は, 敗血 症診療における抗菌薬の適正使用において重要である ため，本ガイドラインの CQ として取り上げた。

\section{（2）解説}

敗血症診療において，適切な初期抗菌薬の選択と患 者の死亡率低下の関連が報告されており，想定される 微生物を十分にカバーする抗菌薬の選択が重要とな る1)。しかしながら，敗血症の初期抗菌薬として何を 選択するべきかに関しては，画一的な回答はなく，実 際には個々の症例に応じて抗菌薬を選択する必要があ るため, 対応する医師の大きな負担となりうる。 Raineri らは, 感染症専門医への抗菌薬選択の相談を 開始する前後での集中治療患者の感染症治療を比較 し，相談によって適切な抗菌薬の選択率とガイドライ ン遵守率が上昇し，死亡率が低下すると報告した ${ }^{2)}$ 。 特に敗血症の原因が特定できない場合，高度薬剤耐性 菌の関与が疑われる場合，診療機会が少ない新興・再 興あるいは輸入感染症を疑う場合は，抗菌薬選択がよ 
りむずかしくなるため, 感染症専門家あるいは AST へ相談することで, 抗菌薬選択を行う医師の負担を軽 減すると共に, 適切な抗菌薬を選択できる頻度の向上 が期待できる。

敗血症患者では菌血症を呈することが多いが，一部 の菌血症では, 菌種に応じた感染巣の精査が必要とな ることが知られている。黄色ブドウ球菌菌血症であれ ば, 心エコー検査による感染性心内膜炎合併の評価 ${ }^{3)}$ が，カンジダ血症では，眼内炎合併の評価が必要とな る4)。さらに, 血液培養の陰性化の確認や前述の感染 巣の有無に応じて抗菌薬投与期間を設定する必要があ る。しかしながら，敗血症を診療するすべての診療部 門において，これらの診療に関する十分な知識や経験 が備わっているとはいえないのが現状である。これま で黄色ブドウ球菌菌血症を対象としたいくつかの観察 研究において, 感染症専門家あるいはASTに相談す ることで, ガイドラインに基づく診療（血液培養の再 検, 心エコー検查) の遵守率の向上と, 患者の予後の 改善が報告された 5,6 。 した観察研究においても, 同様にガイドライン遵守率 の向上と患者予後の改善が報告されている7-9)。これ らの研究結果から, 黄色ブドウ球菌菌血症やカンジダ 血症と診断された敗血症患者に対しては, 感染症専門 家あるいはASTに相談し, 適切な感染巣の評価と抗 菌薬の投与期間を設定することが妥当であろう。

\section{文 献}

1) Paul M, Shani V, Muchtar E, et al: Systematic review and metaanalysis of the efficacy of appropriate empiric antibiotic therapy for sepsis. Antimicrob Agents Chemother. 2010; 54: 4851-63.

2) Raineri E, Pan A, Mondello P, et al: Role of the infectious diseases specialist consultant on the appropriateness of antimicrobial therapy prescription in an intensive care unit. Am J Infect Control. 2008; 36: 283-90.

3) Zou H, Li G: Clinical practice guidelines for the diagnosis and management of intravascular catheter-related infection: 2009 update by the Infectious Diseases Society of America. Chinese J Infect chemother. 2010; 10: 81-4.

4) Pappas PG, Kauffman CA, Andes DR, et al: Clinical Practice Guideline for the Management of Candidiasis: 2016 Update by the Infectious Diseases Society of America. Clin Infect Dis. 2016; 62: e1-e50.

5) Vogel M, Schmitz RPH, Hagel S, et al: Infectious disease consultation for Staphylococcus aureus bacteremia - A systematic review and meta-analysis. J Infect. 2016; 72: 19-28.

6) Bai AD, Showler A, Burry L, et al: Impact of infectious disease consultation on quality of care, mortality, and length of stay in staphylococcus aureus bacteremia: Results from a large multicenter cohort study. Clin Infect Dis. 2015; 60: 1451-61.

7) Ishikane $\mathrm{M}$, Hayakawa $\mathrm{K}$, Kutsuna $\mathrm{S}$, et al: The impact of infectious disease consultation in candidemia in a tertiary care hospital in Japan over 12 years. PLoS One. 2019; 14: e0215996. Available online at: https://doi.org/10.1371/journal.pone.0215996. Accessed November 29, 2020.
8) Mejia-Chew C, O'Halloran JA, Olsen MA, et al: Effect of infectious disease consultation on mortality and treatment of patients with candida bloodstream infections: a retrospective, cohort study. Lancet Infect Dis. 2019; 19: 1336-44.

9) Lee RA, Zurko JC, Camins BC, et al: Impact of infectious disease consultation on clinical management and mortality in patients with candidemia. Clin Infect Dis. 2019; 68: 1585-7. 
CQ4-6：敗血症に対する経験的抗菌薬は, 敗血 症認知後 1 時間以内を目標に投与開始するか?

Answer : 敗血症あるいは敗血症性ショックと認知し た後, 抗菌薬は可及的早期に開始するが，必ずしも 1 時間以内という目標は用いないことを弱く推奨する (GRADE 2C : エビデンスの確実性 $=「$ 低」)。

\section{（1）背景および本 $C Q$ の重要度}

敗血症に対する抗菌薬投与のタイミングについて は, 多くの観察研究の結果から, SSCG 2016, 日本版 敗血症診療ガイドライン（J-SSCG）2016 共に 1 時間 以内の投与が推奨されており，世界的にも受け入れら れた投与開始目標となっている。米国で行われた州レ ベルの大規模コホート研究では, 発症から経験的抗菌 薬投与開始までの時間に応じて, 死亡リスクは線形に 増加すると報告されている ${ }^{1)}$ 。そのため, 敗血症認知 から 1 時間以内の抗菌薬投与がどの程度推奨できるか 評価する必要があり, 本ガイドラインの CQ として取 り上げた。

\section{(2) PICO}

P (患者)：成人敗血症あるいは敗血症性ショック患 者

I（介入）：敗血症あるいは敗血症性ショック認知 後, 抗菌薬開始が 1 時間以内

C (対照)：敗血症あるいは敗血症性ショック認知 後, 抗菌薬開始が 1 時間より遅い

$\mathrm{O}$ (アウトカム) : 死亡

\section{（3）エビデンスの要約}

システマティックレビューの結果，PICO に合致し たランダム化比較試験（RCT）は認めなかった。観察 研究については 7 件 2-8) 試行されており, 観察研究を 用いたメタ解析を行った。
（4）益と害のバランス（Table 4-6-1）

望ましい効果 :

7 つの観察研究から得られる全死亡に関する効果推 定值は，リスク差（RD）10 少ない/1,000（95\% CI： 23 少ない〜7多い）であり, 望ましい効果は限定的で あった。

望ましくない効果 :

抗菌薬の早期投与による望ましくないアウトカムに ついては，評価し得た範囲で発生しなかった。抗菌薬 の早期投与によって, 薬剤が不要な患者に十分な評価 がなされる前に抗菌薬投与が行われる可能性がある が，それによる望ましくない効果は評価できていな い。

\section{益と害のバランス :}

本 $\mathrm{CQ}$ においては，死亡率に関する $\mathrm{RD}$ の推定効果 值が小さく，95\% CI は 0 をまたいでいる。介入によ る重大または重要な害や，想定される望ましくない効 果は評価できていないため, 介入も比較対象もいずれ も優位でないと判断した。

（5）アウトカム全般に関するエビデンスの確実性

今回採用したアウトカムのうち, 効果推定值を評価 できたものは死亡率のみであった。同アウトカムの確 実性は「低」であったため，アウトカム全体にわたる エビデンスの確実性は「低」である。

\section{（6）価値観}

敗血症患者に対する抗菌薬を， 1 時間以内を目標に 投与を開始するかに関して，各アウトカムにおける患 者・家族の価值観に関するデータはない。一般的に死 亡アウトカムに対する相対価值は高く，そのばらつき は少ないことが予想される。

\section{（7）容認性}

介入による有害事象のリスクは低い可能性が高い。 介入に伴う抗菌薬の総投与量の変化，およびこれに伴 うコストへの影響は評価できていないが，個人負担額

Table 4-6-1エビデンスプロファイル

\begin{tabular}{|c|c|c|c|c|c|c|c|c|c|c|c|c|}
\hline \multicolumn{7}{|c|}{ 碓怢性の評価 } & \multicolumn{2}{|c|}{ 患者数 } & \multicolumn{2}{|c|}{ 効果 } & \multirow[b]{2}{*}{ 確夹性 } & \multirow[b]{2}{*}{ 重要性 } \\
\hline 研究数 & $\begin{array}{l}\text { 研究 } \\
\text { デザイン }\end{array}$ & $\begin{array}{l}\text { パイアス } \\
\text { のリスク }\end{array}$ & 非一貫性 & 非直接性 & 不精碓性 & $\begin{array}{l}\text { その他 } \\
\text { の橹討 }\end{array}$ & $\begin{array}{c}1 \text { 時間以内の抗 } \\
\text { 生剂投与 }\end{array}$ & $\begin{array}{c}1 \text { 時間以隆の抗生 } \\
\text { 耾投与 }\end{array}$ & 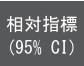 & $\begin{array}{l}\text { 總対指摽 } \\
(95 \% \text { CI })\end{array}$ & & \\
\hline \multicolumn{13}{|l|}{ 死亡 } \\
\hline 7 & 観察研究 & 非常1深刻 a & 深刻でない & 深刻でない & 深刻でない & なし & $\begin{array}{l}\text { 1, } 994 / 6,458 \\
(30.9 \%)\end{array}$ & $\begin{array}{l}5,411 / 16,556 \\
(32.78)\end{array}$ & $\begin{array}{l}\text { RR 0.97 } \\
(0.93 \text { to } \\
1.02)\end{array}$ & $\begin{array}{c}1,000 \text { 人あたり } \\
10 \text { 人少ない } \\
\text { (23 人少ない } \\
\sim 7 \text { 人多い) }\end{array}$ & $\underset{\text { 低 }}{\oplus \oplus \bigcirc \bigcirc}$ & 重大 \\
\hline
\end{tabular}

a. 採用研究のすべてにおいて患者選択に関する記載が不十分である。 
が大きく変化する可能性は低く, 患者・家族の個人の 視点から容認できると考える。一方で，1時間に拘泥 した抗菌薬の早期投与企図によって原因微生物診断の 推定が不十分となり, 不必要かつ過剩に広域・多剤の 抗菌薬投与が増えるという潜在的な害が否定できず, これは抗菌薬適正使用の観点からの容認性が低い。

\section{（8）実行可能性}

国内外における観察研究結果からは, 多くの施設に おいてその実行可能性は高くない。

\section{（9）判断の要約（Table 4-6-2）}

\section{（10）推奨グレーディング決定の工程}

修正 RAND 法を用いた投票によって，中央值 7, 見解不一致指数 0.164 の結果となり, 委員会で採択さ れた（7点以上 : 83.3\%)。

\section{（11）関連する他の診療ガイドラインにおける推奨}

J-SSCG 2016 9,10) においては，1 時間以内の抗菌薬 開始をエキスパートコンセンサス/エビデンスなしと して推奨している（同意率 100\%）。SSCG 2016 ${ }^{11)}$ で も，敗血症または敗血症性ショックを認識してから 1 時間以内の抗生剤投与を推奨している。これらは, メ 夕解析では抗菌薬の速やかな投与による死亡率の低下 を証明することができなかったが，大規模で質の高い 研究において速やかな抗菌薬投与の有効性が示唆され たためであった $4,5,12-14) 。$

\section{（12）実施に関わる検討事項}

予想される標的微生物をカバーする適切な抗菌薬を 選択し，これを可及的速やかに投与する方向性そのも のを否定するものではないことに注意が必要である。

\section{（13）今後の研究の可能性}

敗血症あるいは敗血症性ショックと認知した後, 1 時間以内に抗微生物薬を投与することを目標とした診 療について, より質の高い研究データに基づくさらな る情報の集積が必要である。

\section{文 献}

1) Seymour CW, Gesten F, Prescott HC, et al: Time to treatment and mortality during mandated emergency care for sepsis. N Engl J Med. 2017; 376: 2235-44.

2) Andersson M, Östholm-Balkhed $\AA ̊$, Fredrikson M, et al: Delay of appropriate antibiotic treatment is associated with high mortality in patients with community-onset sepsis in a Swedish setting. Eur J Clin Microbiol Infect Dis. 2019; 38: 1223-34.

3) Ferrer R, Artigas A, Suarez D, et al: Effectiveness of treatments for severe sepsis: A prospective, multicenter, observational study. Am J Respir Crit Care Med. 2009; 180: 861-6.

4) Ferrer R, Martin-Loeches I, Phillips G, et al: Empiric antibiotic treatment reduces mortality in severe sepsis and septic shock from the first hour: Results from a guideline-based performance improvement program. Crit Care Med. 2014; 42: 1749-55.

5) Gaieski DF, Mikkelsen ME, Band RA, et al: Impact of time to antibiotics on survival in patients with severe sepsis or septic shock in whom early goal-directed therapy was initiated in the emergency department. Crit Care Med. 2010; 38: 1045-53.

6) Puskarich MA, Trzeciak S, Shapiro NI, et al: Association between timing of antibiotic administration and mortality from septic shock in patients treated with a quantitative resuscitation protocol. Crit Care Med. 2011; 39: 2066-71.

7) Ryoo SM, Kim WY, Sohn CH, et al: Prognostic value of timing of antibiotic administration in patients with septic shock treated with early quantitative resuscitation. Am J Med Sci. 2015; 349:

Table 4-6-2 判断の要約

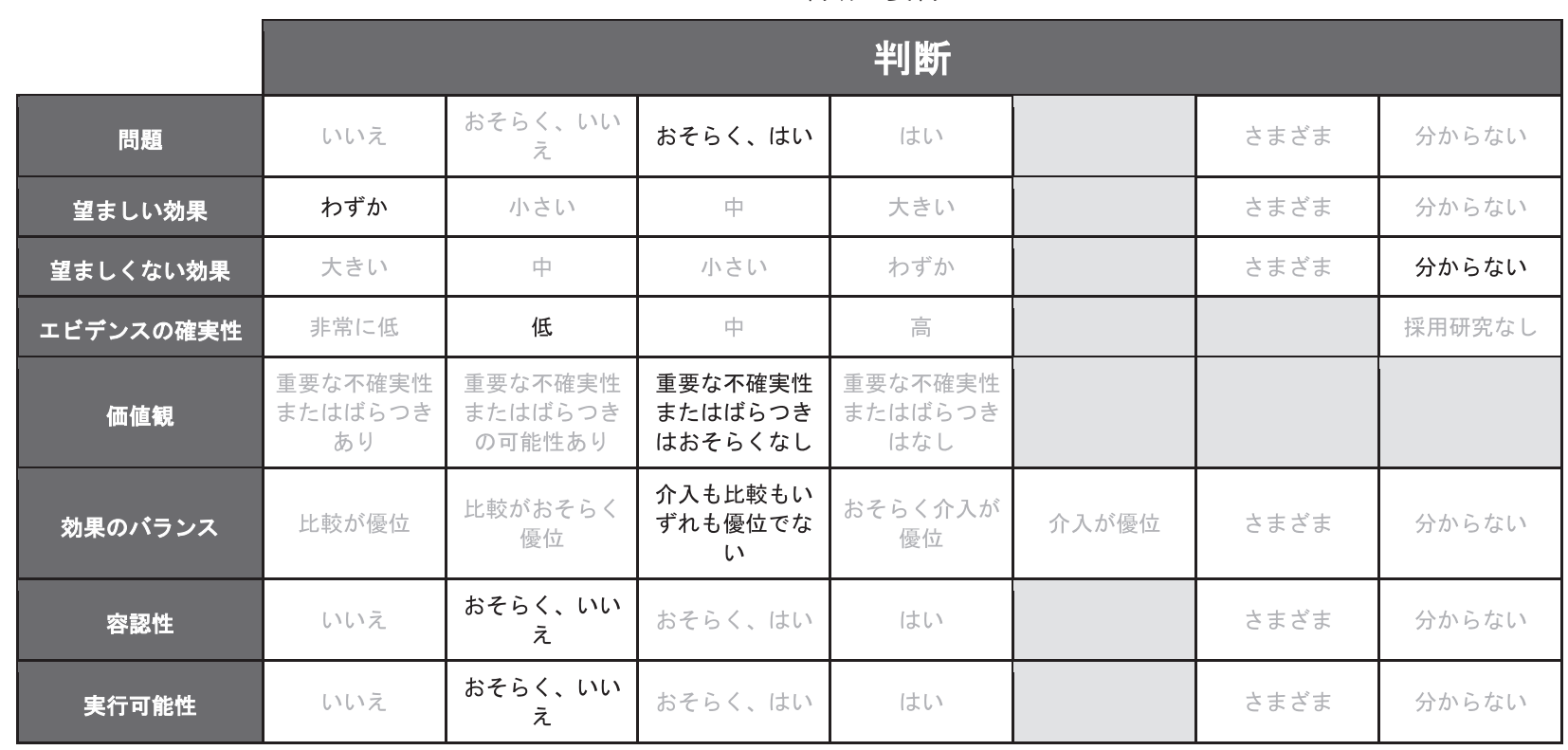


328-33.

8) Yokota PK, Marra AR, Martino MD, et al: Impact of appropriate antimicrobial therapy for patients with severe sepsis and septic shock - A quality improvement study. PLoS One. 2014; 9 : e104475.

9）西田修, 小倉裕司, 井上茂亮, 他, 日本版敗血症診療ガイドラ イン 2016 作成特別委員会. 日本版敗血症診療ガイドライン 2016. 日集中医誌. 2017; 24: S1-232.

10）西田修, 小倉裕司, 井上茂亮, 他, 日本版敗血症診療ガイドラ イン 2016 作成特別委員会. 日本版敗血症診療ガイドライン 2016. 日救急医会誌. 2017; 28: S1-232.

11) Rhodes A, Evans LE, Alhazzani W, et al: Surviving Sepsis Campaign: International Guidelines for Management of Sepsis and Septic Shock: 2016. Intensive Care Med. 2017; 43: 304-77.

12) Barie PS, Hydo LJ, Shou J, et al: Influence of antibiotic therapy on mortality of critical surgical illness caused or complicated by infection. Surg Infect (Larchmt). 2005; 6: 41-54.

13) Barochia AV, Cui X, Vitberg D, et al: Bundled care for septic shock: An analysis of clinical trials. Crit Care Med. 2010; 38: 668-78.

14) Kumar A, Roberts D, Wood KE, et al: Duration of hypotension before initiation of effective antimicrobial therapy is the critical determinant of survival in human septic shock. Crit Care Med. 2006; 34: 1589-96.
CQ4-7：敗血症に対して $\beta$ ラクタム系薬の持続 投与または投与時間の延長を行うか?

Answer : 敗血症に対する $\beta$ ラクタム系抗菌薬治療に おいて，抗菌薬の持続投与もしくは投与時間の延長を 行うことを弱く推奨する（GRADE 2B：エビデンスの 確実性 $=「$ 中」)。

\section{（1）背景および本 $C Q$ の重要度}

敗血症患者の致死率は依然として高く，治療成績を 向上させる介入法の確立は急務である。抗菌薬の投与 は，これまで間欠投与で行われることが多かったが, $\mathrm{PK} / \mathrm{PD}$ の観点からは時間依存性の $\beta$ ラクタム薬は持 続投与もしくは投与時間の延長において有効性が高い かもしれない。 $\beta$ ラクタム薬の持続投与の有効性を検 証することは, 敗血症のアウトカムの改善につながる 可能性があり，重要な臨床課題の 1 つと考える。

(2) PICO

P (患者) : 敗血症あるいは敗血症性ショック患者

$\mathrm{I}$ (介入) : $\beta$ ラクタム系薬の持続投与または投与時 間の延長

$\mathrm{C}$ (対照) : $\beta$ ラクタム系薬の間欠投与

$\mathrm{O}$ (アウトカム) : 死亡, 臨床的治癒, 副作用, 薬剂 而性菌の検出（CDI, MRSA, 耐性グラム陰性桿 菌など)，ターゲット血中濃度達成

\section{（3）エビデンスの要約}

システマティックレビューの結果，PICO に合致し たランダム化比較試験（RCT）が 13 件施行されてお り，これらを用いたメタ解析を実施した ${ }^{1-13)}$ 。

\section{（4）益と害のバランス（Table 4-7-1）}

死亡（9 RCT, $\mathrm{n}=844 ）$ に対する効果推定值はリス ク差（RD）1,000 人あたり 69 人少ない（95\% CI: 135 人少ない〜 32 人多い）であり，臨床的治癒（9 RCT, $\mathrm{n}=886 ）$ に対する効果推定值は，RD 1,000 人あたり 113 人多い $(95 \% \mathrm{CI}: 9$ 人多い〜241 人多い) である。 副作用（3 RCT, n=691）に対する効果推定值は，RD 1,000 人あたり 0 人 $(95 \% \mathrm{CI}: 41$ 人少ない〜 59 人多い) であり，副作用の上昇は認められなかった。また薬剤 耐性菌の検出（1 RCT, $\mathrm{n}=198 ） に$ 対する効果推定值 は, RD 1,000 人あたり 18 人少ない（35人少ない〜 72 人多い）である。 
Table 4-7-1 エビデンスプロファイル

\begin{tabular}{|c|c|c|c|c|c|c|c|c|c|c|c|c|}
\hline \multicolumn{7}{|c|}{ 確実性の評価 } & \multicolumn{2}{|c|}{ 患者数 } & \multicolumn{2}{|c|}{ 効果 } & \multirow[b]{2}{*}{ 確夷性 } & \multirow[b]{2}{*}{ 重要性 } \\
\hline 研究数 & $\begin{array}{c}\text { 研究 } \\
\text { デサン }\end{array}$ & $\begin{array}{l}\text { パイアス } \\
\text { のリスク }\end{array}$ & 非一貫性 & 非直接性 & 不精碓性 & $\begin{array}{l}\text { その他 } \\
\text { の検討 }\end{array}$ & Continuous & Intermittent & $\begin{array}{l}\text { 相対指標 } \\
(95 \% \text { CI) }\end{array}$ & $\begin{array}{l}\text { 綂対指標 } \\
(95 \% \text { II) }\end{array}$ & & \\
\hline \multicolumn{13}{|l|}{ 死亡 } \\
\hline 9 & RCT & 深刻 & 深刻でない & 深刻てない & 深刻 & なし & $88 / 420 \quad(21.0 \%)$ & 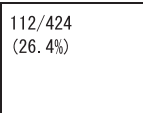 & $\begin{array}{l}\text { RR } 0.74 \\
\text { (0.49 to } 1.12)\end{array}$ & $\begin{array}{l}\text { 1, } 000 \text { 人あたり } \\
69 \text { 人少ない } \\
\text { 人少ない } 135 \text { 人多 } \\
\text { () }\end{array}$ & $\begin{array}{l}\oplus \oplus \bigcirc \bigcirc \\
\text { 低 }\end{array}$ & 重大 \\
\hline \multicolumn{13}{|c|}{ 臨床的治撚 } \\
\hline 9 & RCT & 深刻 & 深刻てない & 深刻てない & 深刻てない & \begin{tabular}{|l} 
出版人゙イア \\
スが強く示 \\
唆される
\end{tabular} & $\begin{array}{l}245 / 443 \\
(55.3 \%)\end{array}$ & $\begin{array}{l}209 / 443 \\
(47.2 \%)\end{array}$ & $\begin{array}{l}\text { RR } 1.24 \\
\text { (1.02 to } 1.51)\end{array}$ & $\begin{array}{l}\text { 1, 000 人あたり } \\
113 \text { 人多い } 9 \text { (9人 } \\
\text { 多い 241 人多 } \\
\text { い) }\end{array}$ & \begin{tabular}{|l|}
$\oplus \oplus \bigcirc \bigcirc$ \\
低
\end{tabular} & 重大 \\
\hline \multicolumn{13}{|l|}{ 副作用 } \\
\hline 3 & RCT & 深刻 & 深刻でない & 深刻でない & 深刻でない & なし & $42 / 342(12.3 \%)$ & $43 / 349$ (12. 3\%) & $\begin{array}{l}\text { RR } 1.00 \\
(0.67 \text { to } 1.48)\end{array}$ & $\begin{array}{l}\text { 1,000人あたり } 0 \\
\text { 人少ない } 411 \text { } \\
\text { 少ない 59人多 } \\
\text { い) }\end{array}$ & $\begin{array}{l}\oplus \oplus \oplus \bigcirc \\
\text { 中 }\end{array}$ & 重大 \\
\hline \multicolumn{13}{|c|}{ 薬绪耐性菌の検出 } \\
\hline 1 & RCT & 深刻 & 深刻てない & 深刻てない & 深刻 & なし & $2 / 96(2.1 \%)$ & $4 / 102(3.9 \%)$ & $\begin{array}{l}\text { RR } 0.53 \\
\text { (0.10 to } 2.83)\end{array}$ & $\begin{array}{l}1,000 \text { 人あたり } \\
18 \text { 人少ない } 35 \\
\text { 人少ない 72人 } \\
\text { 多い) }\end{array}$ & $\begin{array}{l}\oplus \oplus \oplus \bigcirc) \\
\text { 低 }\end{array}$ & 重大 \\
\hline \multicolumn{13}{|c|}{ ターゲット血中濃度達成 } \\
\hline 2 & RCT & 深刻 & 深刻でない & 深刻でない & 深刻でない & なし & $71 / 90(78.9 \%)$ & $29 / 87$ (33. 3\%) & \begin{tabular}{|l|} 
RR 2.35 \\
(1.71 to 3.22$)$
\end{tabular} & $\begin{array}{l}\text { 1, 000人 人あたり } \\
450 \text { 人多い (237 } \\
\text { 人多い 740人多 } \\
\text { い) }\end{array}$ & $\begin{array}{l}\oplus \oplus \oplus \oplus \bigcirc \\
\text { 中 }\end{array}$ & 重要 \\
\hline
\end{tabular}

バイアスのリスクはー部High と unknown riskが多く1グレードダウン，不正確性は薬剤耐性菌の検出はサンプルサイズが小さくダウン，不正確性は死亡に関して 1 をまたいでおり 1 グレードダウン， 臨床的治㓐はその他で publication bias で 1 グレードダウン。

（5）アウトカム全般に関するエビデンスの確実性

望ましい帰結に関与するターゲット血中濃度達成率 は「中」のエビデンス，望ましくない帰結に関与する 副作用は「中」のエビデンスとなった。今回採用した すべてのアウトカムの効果推定值の方向性は概ね一致 しており，最高のエビデンスを採用すると，アウトカ ム全体にわたるエビデンスの確実性は「中」である。

\section{（6）価値観}

敗血症患者に対する抗菌薬の持続投与もしくは投与 時間延長に関して，各アウトカムにおける患者・家族 の価值観に関するデータはない。しかしながら, ター ゲット血中濃度達成は高く，医師，薬剤師などの医療 者からの価值観は高いと考えられる。また医療者と患 者の両方において, 一般的に死亡, 臨床的治癒に対し て置く相対的価值は高く, そのばらつきは少ないこと が予想される。

\section{（7）容認性}

抗菌薬の持続投与や投与時間の延長に際しては，特 別な手技は求められない。シリンジポンプが必要とな るものの，集中治療室においてその施行は比較的容易 であり，医療者にとっての容認性は高いと考えられ る。コストの面では個人負担額は変わらず, 患者・家 族の個人の視点からもおそらく許容できる。しかしな がら, 一般病棟においては, 介入群は長期間のシリン
ジポンプを必要とするため, 歩行リハビリテーション の妨げとなる可能性もある。

（8）実行可能性

介入は多くの医療施設において実行可能であると考 えられる。

（9）判断の要約 (Table 4-7-2)

（10）推奨グレーディング決定の工程

修正 RAND 法を用いた投票によって，中央值 8 , 見解不一致指数 0.164 の結果となり, 委員会で採択さ れた（7 点以上 : $83.3 \%) 。$

\section{（11）関連する他の診療ガイドラインにおける推奨}

J-SSCG 2016 ではターゲット血中濃度達成に差がな く(オッズ比 1.88; CI: 0.89 3.98, P=0.10), 副作用 の評価ができなかったことから， $\beta$ ラクタム薬の持続 投与もしくは投与時間の延長を行わないことを弱く推 奨している。

その後, 新たに複数の RCT がシステマティックレ ビューに組み込まれ, ターゲット血中濃度の改善が認 められたこと, 副作用は増えないことが確認されたた め, 現在の推奨に至った。 
Table 4-7-2 判断の要約

\begin{tabular}{|c|c|c|c|c|c|c|c|}
\hline & \multicolumn{7}{|c|}{ 判梓 } \\
\hline 問題 & いいえ & $\begin{array}{c}\text { おそらく、いい } \\
\text { え }\end{array}$ & おそらく、はい & はい & & さまざま & 分からない \\
\hline 望ましい効果 & わずか & 小さい & 中 & 大きい & & さまざま & 分からない \\
\hline 望ましくない効果 & 大きい & 中 & 小さい & わずか & & さまざま & 分からない \\
\hline エビデンスの確実性 & 非常に低 & 低 & 中 & 高 & & & 採用研究なし \\
\hline 価値覞 & $\begin{array}{c}\text { 重要な不確実性 } \\
\text { またはばらつき } \\
\text { あり }\end{array}$ & $\begin{array}{c}\text { 重要な不確実性 } \\
\text { またはばらつき } \\
\text { の可能性ありり }\end{array}$ & $\begin{array}{l}\text { 重要な不確実性 } \\
\text { またはばらつき } \\
\text { はおそらくなし }\end{array}$ & $\begin{array}{c}\text { 重要な不確実性 } \\
\text { またはばらつき } \\
\text { はなし }\end{array}$ & & & \\
\hline 効果のバランス & 比較が優位 & $\begin{array}{c}\text { 比較がおそらく } \\
\text { 優位 }\end{array}$ & $\begin{array}{c}\text { 介入も比較もい } \\
\text { ずれも優位でな } \\
\text { い }\end{array}$ & $\begin{array}{c}\text { おそらく介入が } \\
\text { 優位 }\end{array}$ & 介入が優位 & さまざま & 分からない \\
\hline 容認性 & いいえ & $\begin{array}{c}\text { おそらく、いい } \\
\text { え }\end{array}$ & おそらく、はい & はい & & さまざま & 分からない \\
\hline 実行可能性 & いいえ & $\begin{array}{c}\text { おそらく、いい } \\
\text { え }\end{array}$ & おそらく、はい & はい & & さまざま & 分からない \\
\hline
\end{tabular}

\section{（12）実施に関わる検討事項}

抗菌薬の持続投与または投与時間の延長を実践して いる施設は少なく，実施前に各医療機関において看護 師への教育, 薬剂部の協力や監視, 院内のコンセンサ スが必要となる可能性がある。また，持続投与に必要 な医療資源（輸液ポンプ，シリンジポンプなど）の使 用時間が増加すると考えられる。

\section{（13）今後の研究の可能性}

以下の内容に関する検討が求められる。

・ $\beta$ ラクタム系抗菌薬だけでなく, 他の種類の抗菌薬 に対する検討

・一般病棟において，抗菌薬の間欠的投与を持続投与 または投与時間の延長に変更した場合，患者の離床 や QOL への影響

\section{文 献}

1) Abdul-Aziz $M H$, Sulaiman $H$, Mat-Nor MB, et al: Beta-Lactam Infusion in Severe Sepsis (BLISS): a prospective, two-centre, open-labelled randomised controlled trial of continuous versus intermittent beta-lactam infusion in critically ill patients with severe sepsis. Intensive Care Med. 2016; 42: 1535-45.

2) Angus BJ, Smith MD, Suputtamongkol Y, et al: Pharmacokineticpharmacodynamic evaluation of ceftazidime continuous infusion vs intermittent bolus injection in septicaemic melioidosis. Br J Clin Pharmacol. 2000; 49: 445-52.

3) Chytra I, Stepan M, Benes J, et al: Clinical and microbiological efficacy of continuous versus intermittent application of meropenem in critically ill patients: a randomized open-label controlled trial. Crit Care. 2012; 16: R113.

4) Dulhunty JM, Roberts JA, Davis JS, et al: Continuous infusion of beta-lactam antibiotics in severe sepsis: a multicenter doubleblind, randomized controlled trial. Clin Infect Dis. 2013; 56 : 236-44.
5) Georges B, Conil JM, Cougot P, et al: Cefepime in critically ill patients: continuous infusion vs. an intermittent dosing regimen. Int J Clin Pharmacol Ther. 2005; 43: 360-9.

6) Laterre PF, Wittebole $X$, Van de Velde $S$, et al: Temocillin (6g daily) in critically ill patients: continuous infusion versus three times daily administration. J Antimicrob Chemother. 2015; 70: 891-8.

7) Lau WK, Mercer D, Itani KM, et al: Randomized, open-label, comparative study of piperacillin-tazobactam administered by continuous infusion versus intermittent infusion for treatment of hospitalized patients with complicated intra-abdominal infection. Antimicrob Agents Chemother. 2006; 50: 3556-61.

8) Fahimi F, Ghafari S, Jamaati H, et al: Continuous versus intermittent administration of piperacillin-tazobactam in intensive care unit patients with ventilator-associated pneumonia. Indian J Crit Care Med. 2012; 16: 141-7.

9) Dulhunty JM, Roberts JA, Davis JS, et al: A Multicenter Randomized Trial of Continuous versus Intermittent $\beta$-Lactam Infusion in Severe Sepsis. Am J Respir Crit Care Med. 2015; 192: 1298-305.

10) Rafati MR, Rouini MR, Mojtahedzadeh M, et al: Clinical efficacy of continuous infusion of piperacillin compared with intermittent dosing in septic critically ill patients. Int J Antimicrob Agents. 2006; 28: 122-7.

11) Roberts JA, Boots R, Rickard CM, et al: Is continuous infusion ceftriaxone better than once-a-day dosing in intensive care? A randomized controlled pilot study. J Antimicrob Chemother. 2007; 59: 285-91.

12) Roberts JA, Kirkpatrick CM, Roberts MS, et al: Meropenem dosing in critically ill patients with sepsis and without renal dysfunction: intermittent bolus versus continuous administration? Monte Carlo dosing simulations and subcutaneous tissue distribution. J Antimicrob Chemother. 2009; 64: 142-50.

13) Zhao HY, Gu J, Lyu J, et al: Pharmacokinetic and Pharmacodynamic Efficacies of Continuous versus Intermittent Administration of Meropenem in Patients with Severe Sepsis and Septic Shock: A Prospective Randomized Pilot Study. Chin Med J. 2017; 130: 1139-45. 
CQ4-8：敗血症に対する抗菌薬治療において, デエスカレーションを行うか?

Answer : 敗血症に対する抗菌薬治療において，デエ スカレーションを行うことを弱く推奨する（GRADE 2D : エビデンスの確実性 $=$ 「非常に低」)。

\section{（1）背景および本 $C Q$ の重要度}

敗血症診療では初期に広域抗菌薬が使用されること が多いが，広域抗菌薬の使用は世界的に問題になって いる抗菌薬耐性（antimicrobial resistance: AMR）を助 長し，医療コストの上昇に関与する。この広域抗菌薬 を狭域抗菌薬に変更すること（デエスカレーション） は，広域抗菌薬の適正使用を通じ，AMR 対策や医療 経済に貢献する重要な診療戦略である。患者の安全性 を損なうことなくデエスカレーションが可能であるか どうかについて検討する価值がある。安全にデエスカ レーションが可能であれば, AMR 対策, 感染管理, そして医療経済的な視点からすべきプラクティスに位 置づけることが可能である。そのため, 本ガイドライ ンの CQ として取り上げた。
(2) PICO

$\mathrm{P}$ (患者)：成人敗血症あるいは敗血症性ショック患 者

I（介入）: 培養結果に基づいた抗菌薬デエスカレー ション

$\mathrm{C}$ (対照) : 抗菌薬デエスカレーションを行わない

$\mathrm{O}$ (アウトカム) : 死亡 (90日死亡, 28 日死亡, 最 長観察期間の死亡), 重複感染

（3）エビデンスの要約

システマティックレビューの結果，敗血症患者のみ を対象としたランダム化比較試験（RCT）は過去に 1 件施行されており 1$)$ ，この 1 論文と，別途 13 件の観 察研究 2-14)を用いたメ夕解析を行った。

（4）益と害のバランス（Table 4-8-1） 望ましい効果 :

広域抗菌薬の使用量減少, AMR 減少, コス卜減少 などの望ましい効果については検討できていない。以 上より，望ましい効果はわからない。

望ましくない効果 :

1つの $\mathrm{RCT}(\mathrm{n}=116)$ では，90 日死亡は 1,000 人あ

Table 4-8-1エビデンスプロファイル

ORCT

\begin{tabular}{|c|c|c|c|c|c|c|c|c|c|c|c|c|}
\hline \multicolumn{7}{|c|}{ 確実性の評価 } & \multicolumn{2}{|c|}{ 患者数 } & \multicolumn{2}{|c|}{ 効果 } & \multirow[b]{2}{*}{ 確実性 } & \multirow[b]{2}{*}{ 重要性 } \\
\hline 研究数 & $\begin{array}{l}\text { 研究 } \\
\text { デザイン }\end{array}$ & $\begin{array}{l}\text { パイアス } \\
\text { のリスク }\end{array}$ & 非一貫性 & 非直接性 & 不精確性 & $\begin{array}{l}\text { その他 } \\
\text { の検討 }\end{array}$ & De-escalation & $\begin{array}{l}\text { No de- } \\
\text { escalation }\end{array}$ & $\begin{array}{l}\text { 相対指標 } \\
(95 \% \text { CI })\end{array}$ & $\begin{array}{l}\text { 絶対指標 } \\
(95 \% \text { CI })\end{array}$ & & \\
\hline \multicolumn{13}{|c|}{90 日死亡 } \\
\hline 1 & RCT & 深刻 a & 深刻でない & 深刻でない & 非常に深刻 b & なし & $18 / 59(30.5 \%)$ & $13 / 57 \quad(22.8 \%)$ & $\begin{array}{c}\text { RR } 1.34 \\
(0.72 \text { to } 2.47)\end{array}$ & $\begin{array}{l}1,000 \text { 人あたり } 78 \\
\text { 人多い } 64 \text { 人少な } \\
\text { い 335人多い) }\end{array}$ & $\begin{array}{l}\oplus \bigcirc \bigcirc \bigcirc \\
\text { 非常に低 }\end{array}$ & 重大 \\
\hline \multicolumn{13}{|l|}{ 重複感染 } \\
\hline 1 & RCT & 深刻 a & 深刻でない & 深刻でない & 深刻。 & なし & $16 / 59 \quad(27.1 \%)$ & $6 / 57 \quad(10.5 \%)$ & $\begin{array}{c}\text { RR } 2.58 \\
\text { (1.08 to } 6.12)\end{array}$ & $\begin{array}{c}1,000 \text { 人あたり } 166 \\
\text { 人多い(8人多い } \\
539 \text { 人多い) }\end{array}$ & $\underset{\text { 低 }}{\oplus \oplus \bigcirc}$ & 重大 \\
\hline
\end{tabular}

a. 採用研究は盲検化またはアウトカム報告に関する記載が不十分である。

b. 相対リスク減少を 20 30\%とした場合の最適情報量（OIS）を満たさず，信頼区間が効果なし（RR=1）を含み，かつ重篤な利益（RR=0.75）と重篤な害（RR=1.25）の双方を含む

c．相対リスク減少を20 30\%とした場合の最適情報量（OIS）を満たさず，かつ重篤な害（RR=1.25）を含む。

○観察研究

\begin{tabular}{|c|c|c|c|c|c|c|c|c|c|c|c|c|}
\hline \multicolumn{7}{|c|}{ 確実性の評価 } & \multicolumn{2}{|c|}{ 患者数 } & \multicolumn{2}{|c|}{ 勃果 } & \multirow[b]{2}{*}{ 確実性 } & \multirow[b]{2}{*}{ 重要性 } \\
\hline 研究数 & $\begin{array}{l}\text { 研究 } \\
\text { デザイン }\end{array}$ & $\begin{array}{l}\text { バイアス } \\
\text { のリスク }\end{array}$ & 非一貫性 & 非直接性 & 不精確性 & $\begin{array}{l}\text { その他 } \\
\text { の唡討 }\end{array}$ & De-escalation & $\begin{array}{c}\text { No de- } \\
\text { escalation }\end{array}$ & $\begin{array}{l}\text { 相対指標 } \\
(95 \% \mathrm{CI})\end{array}$ & $\begin{array}{l}\text { 絶対指標 } \\
(95 \% \text { CI })\end{array}$ & & \\
\hline \multicolumn{13}{|c|}{ 最長観察期間の死亡 } \\
\hline 13 & 観察研究 & 深刻 a & 深刻 b & 深刻でない & 深刻でない & なし & $\begin{array}{l}229 / 1337 \\
(17.1 \%)\end{array}$ & $\begin{array}{c}544 / 2298 \\
(23.7 \%)\end{array}$ & $\begin{array}{c}\text { RR } 0.66 \\
\text { (0. } 52 \text { to } 0.83 \text { ) }\end{array}$ & $\begin{array}{c}1,000 \text { 人あたり } 80 \\
\text { 人少ない }(114 \text { 人少 } \\
\text { ない } 40 \text { 人少な } \\
\text { (1) }\end{array}$ & $\begin{array}{l}\oplus \bigcirc \bigcirc \bigcirc \\
\text { 非常に低 }\end{array}$ & 重大 \\
\hline
\end{tabular}

\begin{tabular}{|c|c|c|c|c|c|c|c|c|c|c|c|c|}
\hline 2 & 観察研究 & 深刻 a & 深刻。 & 深刻でない & 深刻 d & なし & $15 / 244(6.1 \%)$ & $45 / 261$ (17. 2\%) & $\begin{array}{c}\text { RR } 0.48 \\
\text { (0. } 12 \text { to } 1.84)\end{array}$ & $\begin{array}{l}\text { 1, } 000 \text { 人あたり } 90 \\
\text { 人少ない (152人少 } \\
\text { ない 145人多い) }\end{array}$ & $\begin{array}{l}\oplus \bigcirc 00 \\
\text { 非常に低 }\end{array}$ & 重大 \\
\hline
\end{tabular}

a. 採用研究の多くにおいて患者選択に関する記載が不十分である。

b. $I^{2}=56 \% ， P=0.007$ と異質性がある。

c. 点推定值が研究間で異なり, その相違がかなり大きい。

d. 相対リスク減少を 20 30\%とした場合の最道情報量（OIS）を满たさず，信頼区間が効果なし（RR=1）を含み，かつ重篤な利益（RR=0.75）と重篤な害（RR=1.25）の双方を含む。

重複感染についてはアウトカムの報告がなかった。 
たり 78 人多い（64人少ない〜 335 人多い）である。 13 の観察研究 $(\mathrm{n}=3,635)$ において長期フォロー アップによる死亡は 1,000 人あたり 80 人少ない（114 人少ない〜 40 人少ない）である。エビデンスの質は いずれも非常に低い。重複感染の発生は, RCT では 1,000 人あたり 166 人多い（8 人多い〜 539 人多い） が，観察研究において同アウトカムを評価した論文は なく, 解析はなされていない。以上より, 望ましくな い効果はわずかである。

益と害のバランス :

本 CQ において，デエスカレーション介入による望 ましい効果は評価できておらず，望ましくない効果は 死亡率に関しては評価が困難で, 重感染率を高める可 能性があり, 効果のバランスはどちらかといえばわず かに望ましくない方向性を示す。アウトカム全般にわ たるエビデンスの確実性は「非常に低」である。重感 染率を評価した 1 つの小規模 RCT では，重複感染の 発生率は介入群 16/59（27\%），対照群 6/57（11\%）で あるが，これは介入群において抗菌薬の総投与期間が 延長したためと考察されている。つまり, 重感染率の 上昇がデエスカレーションによるものか投与期間延長 によるものかが正確に評価できていない。加えて, 重 複感染は死亡など重要転帰に影響しなかったと記載さ れている。抗菌薬デエスカレーションにより投与日数 が延長することは, 標準的な臨床実践とは乘離してい る。また, デエスカレーションは抗菌薬スチュワード シップの観点より推奨され，広く普及している実践で ある。以上を踏まえると，このエビデンス総体のみで デエスカレーションを推奨しないとする方向づけを行 うことは困難と評価する。

\section{（5）アウトカム全般に関するエビデンスの確実性}

望ましくない効果について, RCT と観察研究の方 向性は相反している。アウトカムの確実性はいずれも 非常に低い。アウトカム全体にわたるエビデンスの確 実性は「非常に低」である。

\section{（6）価値観}

抗菌薬デエスカレーションに関して, 各アウトカム における患者・家族の価值観に関するデータはない。 一般的に, 死亡アウトカムに対する相対的価值は高 く，そのばらつきは少ないことが予想される。

\section{（7）容認性}

デエスカレーションは一般的に普及した常識的な診 療手法で，その施行は容易であり，医療者にとっての
容認性は高い。介入に伴う広域抗菌薬投与量の変化, およびこれに伴うコストへの影響は評価できていない が，個人負担額を考えると，患者・家族の個人の視点 からは問題なく許容できる。耐性菌感染症の問題につ いて，患者・家族の個人の視点で利害を判断すること は不可能と考える。

\section{（8）実行可能性}

介入は抗菌薬の変更のみであり, 多くの医療施設に おいて問題なく実行可能である。

\section{（9）判断の要約（Table 4-8-2）}

\section{（10）推奨グレーディング決定の工程}

修正 RAND 法を用いた投票によって，中央值 7, 見解不一致指数 0.164 の結果となり, 委員会で採択さ れた（7 点以上 : $83.3 \%) 。$

\section{（11）関連する他の診療ガイドラインにおける推奨}

J-SSCG 2016 15,16) においては，デエスカレーショ ンの実施は本ガイドラインと同様「弱い推奨」となっ ている。SSCG 2016 ${ }^{17)}$ では, best practice statement と して行うことを推奨されている。

\section{（12）実施に関わる検討事項}

デエスカレーションを行った場合に，抗菌薬の総投 与期間が延長しないように留意する必要がある。

\section{（13）今後の研究の可能性}

デエスカレーションの益が評価可能な，洗練された 方法論による質の高い RCT の遂行が望まれる。

\section{文 献}

1) Leone $\mathrm{M}$, Bechis $\mathrm{C}$, Baumstarck $\mathrm{K}$, et al: De-escalation versus continuation of empirical antimicrobial treatment in severe sepsis: a multicenter non-blinded randomized noninferiority trial. Intensive Care Med. 2014; 40: 1399-408.

2) Carugati M, Franzetti F, Wiemken T, et al: De-escalation therapy among bacteraemic patients with community-acquired pneumonia. Clin Microbiol Infect. 2015; 21: 936. e11-8.

3) Garnacho-Montero J, Gutiérrez-Pizarraya A, Escoresca-Ortega A, et al: De-escalation of empirical therapy is associated with lower mortality in patients with severe sepsis and septic shock. Intensive Care Med. 2014; 40: 32-40.

4) Gonzalez L, Cravoisy A, Barraud D, et al: Factors influencing the implementation of antibiotic de-escalation and impact of this strategy in critically ill patients. Crit Care. 2013; 17: R140.

5) Heenen S, Jacobs F, Vincent JL: Antibiotic strategies in severe nosocomial sepsis: Why do we not de-escalate more often? Crit Care Med. 2012; 40: 1404-9.

6) Lee CC, Lee NY, Chen PL, et al: Impact of antimicrobial 
日本版敗血症診療ガイドライン 2020

Table 4-8-2 判断の要約

\begin{tabular}{|c|c|c|c|c|c|c|c|}
\hline & \multicolumn{7}{|c|}{ 判梓 } \\
\hline 問題 & いいえ & $\begin{array}{c}\text { おそらく、いい } \\
\text { え }\end{array}$ & おそらく、はい & はい & & さまざま & 分からない \\
\hline 望ましい効果 & わずか & 小さい & 中 & 大きい & & さまざま & 分からない \\
\hline 望ましくない効果 & 大きい & 中 & 小さい & わずか & & さまざま & 分からない \\
\hline エビデンスの確実性 & 非常に低 & 低 & 中 & 高 & & & 採用研究なし \\
\hline 価值覞 & $\begin{array}{c}\text { 重要な不確実性 } \\
\text { またはばらつき } \\
\text { あり }\end{array}$ & $\begin{array}{l}\text { 重要な不確実性 } \\
\text { またはばらつき } \\
\text { の可能性ありり }\end{array}$ & $\begin{array}{l}\text { 重要な不確実性 } \\
\text { またはばらつき } \\
\text { はおそらくなし }\end{array}$ & $\begin{array}{c}\text { 重要な不確実性 } \\
\text { またはばらつき } \\
\text { はなし }\end{array}$ & & & \\
\hline 勃果のバランス & 比較が優位 & $\begin{array}{c}\text { 比較がおそらく } \\
\text { 優位 }\end{array}$ & $\begin{array}{c}\text { 介入も比較もい } \\
\text { ずれも優位でな } \\
\text { い }\end{array}$ & $\begin{array}{c}\text { おそらく介入が } \\
\text { 優位 }\end{array}$ & 介入が優位 & さまざま & 分からない \\
\hline 容認性 & いいえ & $\begin{array}{c}\text { おそらく、いい } \\
\text { え }\end{array}$ & おそらく、はい & はい & & さまざま & 分からない \\
\hline 実行可能性 & いいえ & 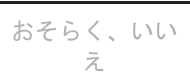 & おそらく、はい & はい & & さまざま & 分からない \\
\hline
\end{tabular}

strategies on clinical outcomes of adults with septic shock and community-onset Enterobacteriaceae bacteremia: De-escalation is beneficial. Diagn Microbiol Infect Dis. 2015; 82: 158-64.

7) Lee CC, Wang JL, Lee $\mathrm{CH}$, et al: Clinical benefits of antimicrobial de-escalation in adults with community-onset monomicrobial Escherichia coli, Klebsiella species and Proteus mirabilis bacteremia. Int J Antimicrob Agents. 2017; 50: 371-6.

8) Mokart D, Slehofer G, Lambert J, et al: De-escalation of antimicrobial treatment in neutropenic patients with severe sepsis: Results from an observational study. Intensive Care Med. 2014; 40: 41-9.

9) Moraes RB, Guillén JAV, Zabaleta WJC, et al: De-escalation, adequacy of antibiotic therapy and culture positivity in septic patients: An observational study. Rev Bras Ter Intensiva. 2016; 28: 315-22.

10) Morel J, Casoetto J, Jospé R, et al: De-escalation as part of a global strategy of empiric antibiotherapy management. A retrospective study in a medico-surgical intensive care unit. Crit Care. 2010; 14: R225.

11) Niimura T, Zamami Y, Imai $T$, et al: Evaluation of the benefits of de-escalation for patients with sepsis in the emergency intensive care unit. J Pharm Pharm Sci. 2018; 21: 54-9.

12) Oshima T, Kodama Y, Takahashi W, et al: Empiric antibiotic therapy for severe sepsis and septic shock. Surg Infect (Larchmt). 2016; 17: 210-6.

13) Salahuddin N, Amer L, Joseph M, et al: Determinants of Deescalation Failure in Critically Ill Patients with Sepsis: A Prospective Cohort Study. Crit Care Res Pract. 2016; 2016 : 6794861.

14) Viasus D, Simonetti AF, Garcia-Vidal C, et al: Impact of antibiotic de-escalation on clinical outcomes in communityacquired pneumococcal pneumonia. J Antimicrob Chemother. 2017; 72: 547-53.

15）西田修, 小倉裕司, 井上茂亮, 他, 日本版敗血症診療ガイドラ イン 2016 作成特別委員会. 日本版敗血症診療ガイドライン 2016. 日集中医誌. 2017; 24: S1-232.

16）西田修, 小倉裕司, 井上茂亮, 他, 日本版敗血症診療ガイドラ イン 2016 作成特別委員会. 日本版敗血症診療ガイドライン 2016. 日救急医会誌. 2017; 28: S1-232.

17) Rhodes A, Evans LE, Alhazzani W, et al: Surviving Sepsis Campaign: International Guidelines for Management of Sepsis and Septic Shock : 2016. Intensive Care Med. 2017; 43: 304-77. 
CQ4-9：敗血症に対する抗菌薬治療において, プロカルシトニンを指標とした治療終了を行う か?

Answer：敗血症に対する抗菌薬治療において，プロ カルシトニンを指標とした治療終了を行うことを弱く 推奨する $($ GRADE 2B：エビデンスの確実性＝「中」）。

\section{（1）背景および本 $C Q$ の重要度}

抗菌薬総使用量は，薬剂而性菌の出現と関連してお り，抗菌薬懪露歴は次の新たな敗血症のリスクになり うることが報告されている ${ }^{1,2)}$ 。一方で，多くの感染 症において抗菌薬の中止基準に関する質の高い科学的 根拠は少なく，抗菌薬の投与期間を短縮できる可能性 が指摘されてきた。また，敗血症の経過におけるプロ カルシトニンの低下は，死亡リスクの減少と関連して いることが報告されている3 ${ }^{3,4)}$ 。したがって, “プロ カルシトニンを指標とした抗菌薬中止の意思決定を行 うことにより，患者の転帰を悪化させることなく抗菌 薬日数を短縮できるか”という臨床的疑問は，重要な 臨床課題である。現在，敗血症における抗菌薬の中止 基準として明確なものはなく，抗菌薬の適切な中止基 準は感染対策，薬剂耐性菌発生の防止などにつながる ため，本 CQ の貢献度は高いと考えられる。

\section{(2) $\mathrm{PICO}$}

$\mathrm{P}$ (患者)：成人の敗血症あるいは敗血症性ショック
患者

I（介入）：プロカルシトニンをガイドとした抗菌薬 終了

$C$ (対照) : 担当医の判断，あるいはプロカルシトニ ンを含まないプロトコルに準じた抗菌薬終了

$\mathrm{O}$ (アウトカム) : 28 日死亡, 院内死亡, 敗血症の 再燃, 抗菌薬投与日数

\section{（3）エビデンスの要約}

システマティックレビューの結果，PICO に合致し たランダム化比較試験（RCT）が 12 件施行されてお り 5-16)，これらを用いたメタ解析を実施した。その結 果, 28 日死亡および院内死亡は介入群で対照群と比 較して低く，抗菌薬投与日数が短かった。

\section{（4）益と害のバランス（Table 4-9-1）}

望ましい効果 :

介入における 28 日死亡のアウトカム $(5 \mathrm{RCT}: \mathrm{n}=$ 2,867）の効果推定值とその信頼区間は，1,000 人あた り 42 人少ない（69人少ない〜 11 人少ない）であり, 院内死亡のアウトカム (9 RCT: $\mathrm{n}=2,422)$ の効果推 定值とその信頼区間は，1,000 人あたり 50 人少ない （79人少ない 18 人少ない）であった。抗菌薬投与日 数のアウトカム（3 RCT: $\mathrm{n}=231)$ の効果推定值とそ の信頼区間は，介入により平均（MD）1.16日短い （2.33 日短い〜 0 日短い)。なお，それぞれに不完全な アウトカム報告の懸念のある研究がみられた。

Table 4-9-1エビデンスプロファイル

\begin{tabular}{|c|c|c|c|c|c|c|c|c|c|c|c|c|}
\hline \multicolumn{7}{|c|}{ 確実性の評価 } & \multicolumn{2}{|c|}{ 患者数 } & \multicolumn{2}{|c|}{ 効果 } & \multirow[b]{2}{*}{ 確実性 } & \multirow[b]{2}{*}{ 重要性 } \\
\hline 研究数 & $\begin{array}{c}\text { 研究 } \\
\text { デサン }\end{array}$ & $\begin{array}{l}\text { パイアス } \\
\text { のリスク }\end{array}$ & 非一貫性 & 非直接性 & 不精碓性 & $\begin{array}{l}\text { その他 } \\
\text { の㛟討 }\end{array}$ & РСT & non-PCT & $\begin{array}{l}\text { 相対指標 } \\
(95 \% \text { CI })\end{array}$ & $\begin{array}{l}\text { 絶対指標 } \\
(95 \% \text { CI })\end{array}$ & & \\
\hline \multicolumn{13}{|l|}{28 日死亡 } \\
\hline 5 & RCT & 深刻 a & 深刻でない & 深刻てない & 深刻でない & なし & $\begin{array}{l}320 / 1434 \\
(22.3 \%)\end{array}$ & $\begin{array}{c}379 / 1433 \\
(26.4 \%)\end{array}$ & $\begin{array}{c}\text { RR } 0.84 \\
(0.74 \text { to } 0.96)\end{array}$ & $\begin{array}{l}1 \text { 1, 000 人あたり } 42 \\
\text { 少ない } 69 \text { 人少 } \\
\text { ない〜11 人少な } \\
\text { (い) }\end{array}$ & $\begin{array}{c}\oplus \oplus \oplus \oplus \bigcirc \\
\text { 中 }\end{array}$ & 重大 \\
\hline \multicolumn{13}{|l|}{ 院内死亡 } \\
\hline 9 & RCT & 深刻 b & 深刻でない & 深刻てない & 深刻でない & なし & $\begin{array}{l}256 / 1197 \\
(21.4 \%)\end{array}$ & $\begin{array}{l}321 / 1225 \\
(26.2 \%)\end{array}$ & $\begin{array}{c}\text { RR } 0.81 \\
(0.70 \text { to } 0.93)\end{array}$ & $\begin{array}{c}1,000 \text { 人あたり } 50 \\
\text { 人少ない (79人少 } \\
\text { ない 18 人少な } \\
\text { (い) }\end{array}$ & $\begin{array}{c}\oplus \oplus \oplus \oplus \bigcirc \\
\text { 中 }\end{array}$ & 重大 \\
\hline \multicolumn{13}{|c|}{ 敗血症の再燃 } \\
\hline 4 & RCT & 深刻 b & 深刻でい & 深刻てない & 深刻。 & なし & $7 / 126(5.6 \%)$ & $6 / 135(4.4 \%)$ & $\begin{array}{c}\text { RR } 1.19 \\
\text { (0. } 40 \text { to } 3.55)\end{array}$ & $\begin{array}{l}1,000 \text { 人あたり } \\
\text { 人多い(27人少な } \\
\text { い 113人多い) }\end{array}$ & $\underset{\text { 低 }}{\oplus \oplus \bigcirc O}$ & 重大 \\
\hline \multicolumn{13}{|c|}{ 抗菌薬投与日数 } \\
\hline 3 & RCT & 深刻 d & 深刻。 & 深刻てない & 深刻 1 & なし & 120 & 111 & - & $\begin{array}{c}\text { 平均 } 1.16 \text { 日短い } \\
\text { (2.33日短い } \\
\text { 日短い) }\end{array}$ & $\begin{array}{l}\oplus \text { 翡常に低 } \\
\end{array}$ & $\begin{array}{l}\text { 重大 } \\
\end{array}$ \\
\hline
\end{tabular}

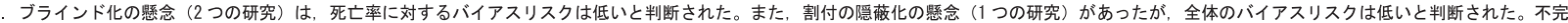
全なアウトカム報告の懸念（2つの研究）があったため,1 1 レベルグレードダウンとした。

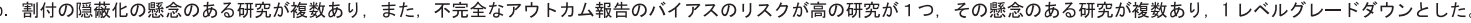

c. 信頼区間が臨床的決断の閾值をまたいでいる。

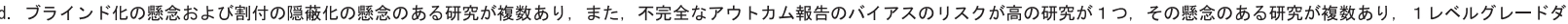
ウンとした。

e. 異質性が非常に大きいため, 1レベルグレードダウンとした。

f，信頼区間が臨床的決断の閾值をまたいでいる。 
望ましくない効果 :

介入における敗血症再然アウトカム $(4 \mathrm{RCT}: \mathrm{n}=$ 261）の効果推定值とその信頼区間は，1,000人あたり 8 人の再燃の増加 $(27$ 人減少 $~ 113$ 人増加）であった。 信頼区間が臨床的決断の閾值をまたいでいたため，望 ましくない効果はわずかとした。

益と害のバランス :

望ましくない効果はわずかであり，また死亡率に関 しては 28 日死亡および院内死亡ともに中程度の確実 性を持ちながら望ましい効果を示したことから，価值 観によらず介入を支持できると考えられる。

（5）アウトカム全般に関するエビデンスの確実性

28 日死亡および院内死亡ともに望ましい効果を示 す方向性は同一であり，割付の隠蔽化の懸念および不 完全なアウトカム報告の懸念がある研究はあったもの の，全体としてのバイアスリスクは低く，結果として 確実性は「中」と判断した。

\section{（6）価値観}

一般的に，死亡アウトカムに対する相対的価值は高 く，そのばらつきは少ないことが予想される。

\section{（7）容認性}

プロカルシトニンの測定頻度が増加することは検査 技師の負担増加に寄与しうると考えられる。また，診 断群分類包括評価（DPC）を採用しない医療機関で は，測定費用が影響する可能性がある。ただし，連日 測定と非連日測定による違いもあることや，DPC 採
用病院では包括医療費に含まれることから，利害関係 者にとっての容認性は一概には決定できない。

\section{（8）実行可能性}

プロカルシトニンの測定が院内で施行され，速やか に結果が得られるかどうかについては施設間差があ る。本邦においてプロカルシトニンを院内測定してい る機関の割合は不明であるが，十分ではないと想定さ れる。

一方で，院内測定を導入している場合には測定頻度 を増やすことの敷居は高くないため，実行可能性は 様々と考えられる。

\section{(9) 判断の要約（Table 4-9-2）}

（10）推奨グレーディング決定の工程

修正 RAND 法を用いた投票によって, 中央值 8, 見解不一致指数 0.164 の結果となり，委員会で採択さ れた（7点以上 : 100\%)。

\section{（11）関連する他の診療ガイドラインにおける推奨}

SSCG 2016 17) では “We suggest that measurement of procalcitonin levels can be used to support shortening the duration of antimicrobial therapy in sepsis patients (weak recommendation, low quality of evidence).”としている。 これは抗菌薬の投与中止よりもデエスカレーションに 主眼を置いたものであった。さらに日本版敗血症診療 ガイドライン（J-SSCG）2016 18）では，「抗菌薬はプ ロカルシトニンを指標に中止してよいか?」という

Table 4-9-2 判断の要約

\begin{tabular}{|c|c|c|c|c|c|c|c|}
\hline & \multicolumn{7}{|c|}{ 半判漳 } \\
\hline 問題 & いいえ & $\begin{array}{c}\text { おそらく、いい } \\
\text { え }\end{array}$ & おそらく、はい & はい & & さまざま & 分からない \\
\hline 望ましい効果 & わずか & 小さい & 中 & 大きい & & さまざま & 分からない \\
\hline 望ましくない効果 & 大きい & 中 & 小さい & わずか & & さまざま & 分からない \\
\hline エビデンスの確実性 & 非常に低 & 低 & 中 & 高 & & & 採用研究なし \\
\hline 価值锥 & $\begin{array}{c}\text { 重要な不確実性 } \\
\text { またはばらつき } \\
\text { あり }\end{array}$ & $\begin{array}{c}\text { 重要な不確実性 } \\
\text { またはばらつき } \\
\text { の可能性あり }\end{array}$ & $\begin{array}{l}\text { 重要な不確実性 } \\
\text { またはばらつき } \\
\text { はおそらくなし }\end{array}$ & $\begin{array}{c}\text { 重要な不確実性 } \\
\text { またはばらつき } \\
\text { はなし }\end{array}$ & & & \\
\hline 効果のバランス & 比較が優位 & $\begin{array}{c}\text { 比較がおそらく } \\
\text { 優位 }\end{array}$ & $\begin{array}{c}\text { 介入も比較もい } \\
\text { ずれも優位でな } \\
\text { い }\end{array}$ & $\begin{array}{c}\text { おそらく介入が } \\
\text { 優位 }\end{array}$ & 介入が優位 & さまざま & 分からない \\
\hline 容認性 & いいえ & $\begin{array}{c}\text { おそらく、いい } \\
\text { え }\end{array}$ & おそらく、はい & はい & & さまざま & 分からない \\
\hline 実行可能性 & いいえ & $\begin{array}{c}\text { おそらく、いい } \\
\text { え }\end{array}$ & おそらく、はい & はい & & さまざま & 分からない \\
\hline
\end{tabular}


$\mathrm{CQ}$ に対して, 当初は「敗血症, 敗血症性ショックに おける抗菌薬治療で, プロカルシトニン值を指標に抗 菌薬の中止を行わないことを弱く推奨する」としてい た。これはメタ解析の結果, 死亡率に有意差がみられ なかったためであった。しかし，その後に新たに RCT 1 件 7) を追加してメタ解析を再度行ったところ, 介入群では対照群と比較して 28 日死亡が有意に低下 し，抗菌薬投与日数も有意に短縮する結果となった。 このことから「敗血症において，プロカルシトニンを 利用した抗菌薬の中止を行うことを弱く推奨する」に 変更となった。

\section{（12）実施に関わる検討事項}

プロカルシトニンの測定結果を迅速に得られる施設 が限られることに留意する必要がある。

\section{（13）今後の研究の可能性}

以下の内容に関する検討が求められる。

・測定費用を考慮した医療経済的効果

・抗菌薬投与日数に関する質の高い RCT

\section{文 献}

1) Micek S, Johnson MT, Reichley R, et al: An institutional perspective on the impact of recent antibiotic exposure on length of stay and hospital costs for patients with gram-negative sepsis. BMC Infect Dis. 2012; 12: 56.

2) Baggs J, Jernigan JA, Halpin AL, et al: Risk of Subsequent Sepsis Within 90 Days after a Hospital Stay by Type of Antibiotic Exposure. Clin Infect Dis. 2018; 66: 1004-12.

3) Charles PE, Tinel C, Barbar S, et al: Procalcitonin kinetics within the first days of sepsis: Relationship with the appropriateness of antibiotic therapy and the outcome. Crit Care. 2009; 13: R38.

4) Karlsson S, Heikkinen M, PettiläV, et al: Predictive value of procalcitonin decrease in patients with severe sepsis: A prospective observational study. Crit Care. 2010; 14: R205.

5) Annane D, Maxime V, Faller JP, et al: Procalcitonin levels to guide antibiotic therapy in adults with non-microbiologically proven apparent severe sepsis: A randomised controlled trial. BMJ Open. 2013; 3: e002186.

6) Bloos F, Trips E, Nierhaus A, et al: Effect of sodium selenite administration and procalcitonin-guided therapy on mortality in patients with severe sepsis or septic shock: A randomized clinical trial. JAMA Intern Med. 2016; 176: 1266-76.

7) de Jong E, van Oers JA, Beishuizen A, et al: Efficacy and safety of procalcitonin guidance in reducing the duration of antibiotic treatment in critically ill patients: A randomised, controlled, open-label trial. Lancet Infect Dis. 2016; 16: 819-27.

8) Deliberato RO, Marra AR, Sanches PR, et al: Clinical and economic impact of procalcitonin to shorten antimicrobial therapy in septic patients with proven bacterial infection in an intensive care setting. Diagn Microbiol Infect Dis. 2013; 76: 266-71.

9) Hochreiter M, Köhler T, Schweiger AM, et al: Procalcitonin to guide duration of antibiotic therapy in intensive care patients: A randomized prospective controlled trial. Crit Care. 2009; 13: R83.

10) Kip MMA, van Oers JA, Shajiei A, et al: Cost-effectiveness of procalcitonin testing to guide antibiotic treatment duration in critically ill patients: Results from a randomised controlled multicentre trial in the Netherlands 11 Medical and Health Sciences 1117 Public Health and Health Services. Crit Care. 2018; 22: 293.

11) Najafi A, Khodadadian A, Sanatkar M, et al: The comparison of procalcitonin guidance administer antibiotics with empiric antibiotic therapy in critically ill patients admitted in intensive care unit. Acta Med Iran. 2015; 53: 562-7.

12) Nobre V, Harbarth S, Graf JD, et al: Use of procalcitonin to shorten antibiotic treatment duration in septic patients: A randomized trial. Am J Respir Crit Care Med. 2008; 177: 498-505.

13) Oliveira CF, Botoni FA, Oliveira CRA, et al: Procalcitonin versus C-reactive protein for guiding antibiotic therapy in sepsis: A randomized trial. Crit Care Med. 2013; 41: 2336-43.

14) Schroeder S, Hochreiter M, Koehler T, et al: Procalcitonin (PCT) guided algorithm reduces length of antibiotic treatment in surgical intensive care patients with severe sepsis: Results of a prospective randomized study. Langenbecks Arch Surg. 2009; 394: 221-6.

15) Shehabi Y, Sterba M, Garrett PM, et al: Procalcitonin algorithm in critically ill adults with undifferentiated infection or suspected sepsis. A randomized controlled trial. Am J Respir Crit Care Med. 2014; 190: 1102-10.

16) Svoboda P, Kantorová I, Scheer P, et al: Can procalcitonin help us in timing of re-intervention in septic patients after multiple trauma or major surgery? Hepatogastroenterology. 2007; 54: 359-63.

17) Rhodes A, Evans LE, Alhazzani W, et al: Surviving Sepsis Campaign: International Guidelines for Management of Sepsis and Septic Shock: 2016. Intensive Care Med. 2017; 43: 304-77.

18) Nishida O, Ogura H, Egi M, et al: The Japanese Clinical Practice Guidelines for Management of Sepsis and Septic Shock 2016 (J-SSCG 2016). J Intensive Care. 2018; 6: 7. 
CQ4-10：敗血症に対して，比較的短期間（7日 間以内）の抗菌薬治療を行うか?

Answer : 敗血症に対して，比較的短期間（7 日間以 内）の抗菌薬治療を行うことを弱く推奨する (GRADE 2D : エビデンスの確実性 $=$ 「非常に低」)。

コメント：短期投与が必要な感染症のうち, エビデン スがあるのは肺炎および腹腔内感染症に限られている ことから，本推奨は条件付き推奨である。なお，長期 投与が必要な感染症（心内膜炎, 化膿性脊椎炎）は本 $\mathrm{CQ}$ の対象ではない。

\section{（1）背景および本 $C Q$ の重要度}

敗血症に対する抗菌薬治療に伴う害として，投与期 間が長いほど常在菌叢の中で耐性菌や Clostridioides difficile, 真菌が定着・増殖するリスクが高まり, 次 の新たな敗血症のリスクになることが考えられ る 1,2$)$ 。世界的には新規抗菌薬の開発が減少する一方 で, 不適切な使用を背景とした薬剤耐性（antimicrobial resistance: AMR）の問題が脅威となっている3)。近年, 肺炎などの各種感染症における抗菌薬の治療期間につ いて, 短期間治療は長期間治療と比較して死亡率や臨 床的治癒率に差がない報告が増えてきた ${ }^{4,5)}$ 。そこで 敗血症診療においても，患者の転帰を悪化させること なく抗菌薬レジメン期間を短縮できるかという臨床的 疑問は重要と判断し，CQ として取り上げた。

\section{(2) PICO}

P (患者) : 成人敗血症あるいは敗血症性ショック, または集中治療を要する感染症患者 $(※ 1,2)$

※1 敗血症あるいは敗血症性ショックに限定し たランダム化比較試験（RCT）はほとんどな いため，本 CQ では集中治療を要する感染症 を対象に含めた。

$※ 24$ 週間以上の投与が必要な感染症（心内膜 炎, 化膿性脊椎炎) を対象外とするために, (1)市中肺炎, (2)院内肺炎/人工呼吸器関連肺炎, (3)急性腎孟腎炎/敗血症性尿路感染症, (4)腹腔 内感染症/腹膜炎, (5)胆管炎, (6)菌血症を本 $\mathrm{CQ}$ の対象感染症に指定した。

I（介入）：1 週間（8日）以内の短期間抗菌薬治療

C (対照) : 1 週間を超える長期間抗菌薬治療

O (アウトカム ) : 死亡 (28日, 最長観察期間), 臨 床的治癒，敗血症の再燃，薬剂耐性菌の検出

\section{（3）エビデンスの要約}

システマティックレビューの結果， RCT は, PICO に示す各感染症のうち, (2)院内肺炎/ 人工呼吸器関連 肺炎に関して 3 件， (4)腹腔内感染症に関して 1 件施行 されていた 6-9)。それ以外の(1)市中肺炎，(3)急性腎孟 腎炎/敗血症性尿路感染症，(5)胆管炎，(6)菌血症に関

しては，該当研究を認めなかった。

この 4 論文を用いたメタ解析の結果，28 日死亡は 3 つの RCT で評価され，死亡に対する効果推定值は 1,000 人あたり 12 人多い $(95 \% \mathrm{CI}: 34$ 人少ない〜 78 人多い）であり，最長観察期間における死亡は 4 つの RCT で評価され，リスク差（RD）は 1,000 人あたり 11 人多い $(95 \%$ CI: 27 人少ない 62 人多い) であっ た。臨床的治癒は 2 つの RCT で評価され, 効果推定 值は 1,000 人あたり 50 人少ない $(95 \%$ CI: 202 人少な い〜144 人多い) であり, 敗血症の再燃は 3 つの RCT で評価され，RDは 1,000 人あたり 77 人多い $(95 \%$ CI: 0 人少ない〜 185 人多い) であった。薬剤耐性菌 の検出については 2 つの RCT で評価され，効果推定 值は 1,000 人あたり 132 人少ない $(95 \%$ CI: 292 人少 ない〜166人多い) であった。

\section{（4）益と害のバランス（Table 4-10-1）}

望ましい効果 :

死亡, 臨床的治癒, 薬剂耐性菌の検出はわずかで, 短期間治療と長期間治療の成績に差は認められなかっ た。

望ましくない効果 :

敗血症の再燃はわずかで, 短期間治療のほうが敗血 症の再燃が有意に増加することはなかった。

益と害のバランス :

本 CQ において，短期間治療による死亡減少，臨床 的治瘾増加, 薬剂耐性菌の検出低下という望ましい効 果はわずかである。敗血症の再燃増加という望ましく ない効果も同様にわずかである。

全体的なエビデンスの確実性は「非常に低」以上 より, 効果のバランスは介入も比較もいずれも優位で ない。

（5）アウトカム全般に関するエビデンスの確実性

アウトカムごとに効果の方向性は同一ではなく, 確 実性は「非常に低」から「中」であった。全体的なエ ビデンスの確実性は, 最も低いものを採用し「非常に 低」とした。 
Table 4-10-1エビデンスプロファイル

\begin{tabular}{|c|c|c|c|c|c|c|c|c|c|c|c|c|}
\hline \multicolumn{7}{|c|}{ 確実性の評価 } & \multicolumn{2}{|c|}{ 患者数 } & \multicolumn{2}{|c|}{ 効果 } & \multirow{2}{*}{ 確実性 } & \multirow{2}{*}{ 重要性 } \\
\hline 研究数 & $\begin{array}{l}\text { 研究 } \\
\text { デザイン }\end{array}$ & $\begin{array}{l}\text { パイアス } \\
\text { のリスク }\end{array}$ & 非一貫性 & 非直接性 & 不精確性 & $\begin{array}{l}\text { その他 } \\
\text { の検討 }\end{array}$ & Short & Long & $\begin{array}{l}\text { 相対指標 } \\
(95 \% \text { CI })\end{array}$ & $\begin{array}{l}\text { 絶対指標 } \\
(95 \% \text { CI })\end{array}$ & & \\
\hline \multicolumn{13}{|c|}{28 日死亡 } \\
\hline 3 & RCT & 深刻でない & 深刻でない & 深刻でない & 深刻 b & なし & $63 / 396(15.9 \%)$ & $61 / 408(15.0 \%)$ & $\begin{array}{c}\text { RR } 1.08 \\
(0.77 \text { to } 1.52)\end{array}$ & $\begin{array}{l}1,000 \text { 人あたり } 12 \\
\text { 人多い (34人少な } \\
\text { い 78 人多い) }\end{array}$ & $\begin{array}{c}\oplus \oplus \oplus \bigcirc \\
\text { 中 }\end{array}$ & 重大 \\
\hline \multicolumn{13}{|c|}{ 最大観察期間における死亡 } \\
\hline 4 & RCT & 深刻 ${ }^{f}$ & 深刻でない & 深刻でない & 深刻 b & なし & $73 / 512(14.3 \%)$ & $70 / 517(13.5 \%)$ & $\begin{array}{c}\text { RR } 1.08 \\
(0.80 \text { to } 1.46)\end{array}$ & $\begin{array}{l}1,000 \text { 人あたり } 11 \\
\text { 人多い (27人少な } \\
\text { い 62 人多い) }\end{array}$ & $\underset{\text { 低 }}{\oplus \oplus \bigcirc \bigcirc}$ & 重大 \\
\hline \multicolumn{13}{|c|}{ 臨床的治癒 } \\
\hline 2 & RCT & 深刻 a & 深刻でない & 深刻でない & 深刻 b & なし & $\begin{array}{l}135 / 195 \\
(69.2 \%)\end{array}$ & $\begin{array}{l}142 / 197 \\
(72.1 \%)\end{array}$ & $\begin{array}{c}\text { RR } 0.93 \\
(0.72 \text { to } 1.20)\end{array}$ & $\begin{array}{l}\text { 1,000 人あたり } 50 \\
\text { 人少ない }(202 \text { 人少 } \\
\text { ない 144 人多い) }\end{array}$ & $\underset{\text { 低 }}{\oplus \oplus \bigcirc \bigcirc}$ & 重大 \\
\hline \multicolumn{13}{|c|}{ 敗血症の再燃 } \\
\hline 3 & $\mathrm{RCT}$ & 深刻。 & 深刻 d & 深刻でない & 深刻 b & なし & $\begin{array}{l}120 / 433 \\
(27.7 \%)\end{array}$ & $89 / 429 \quad(20.7 \%)$ & $\begin{array}{c}\text { RR } 1.37 \\
\text { (1. } 00 \text { to } 1.89)\end{array}$ & 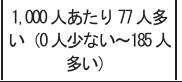 & $\begin{array}{l}\oplus \bigcirc \bigcirc \bigcirc \\
\text { 非常に低 }\end{array}$ & 重大 \\
\hline \multicolumn{13}{|c|}{ 薬剤耐性菌の検出 } \\
\hline 2 & $\mathrm{RCT}$ & 深刻・ & 深刻でない & 深刻でない & 深刻 b & なし & $49 / 127 \quad(38.6 \%)$ & $58 / 119(48.7 \%)$ & $\begin{array}{c}\text { RR } 0.73 \\
(0.40 \text { to } 1.34)\end{array}$ & $\begin{array}{l}1,000 \text { 人あたり } 132 \\
\text { 人少ない }(292 \text { 人少 } \\
\text { ない 166 人多い) }\end{array}$ & $\underset{\text { 低 }}{\oplus \oplus \bigcirc \bigcirc}$ & 重大 \\
\hline
\end{tabular}

a.アアウトカム評価者のブランド化は，臨床的治癒の判定においては極めて重要と考えられた。

b. 信頼区間が臨床的決断の闒値をまたいでいる。

c. アウトカム評価者のブランド化は，敗血症の再燃 の判定においては極めて重要と考えられた。

㥜質性あり

選択的報告，すなわち事前プロトコールによる網羅的報告は，薬剤耐性菌の検出の判定においては極めて重要と考えられた。

最大観察期間における死亡においては，不完全なアウトカムデータは，極めて重要と考えられた。

（6）価値観

抗菌薬治療期間において，各アウトカムにおける患 者・家族の価值観に関するデータはない。一般的に， 死亡アウトカムや臨床的治癒，新たなイベント，薬剤 耐性菌の検出に対する相対的価值は高く，そのばらつ きは少ないことが予想される。

\section{（7）容認性}

抗菌薬治療期間について 1 週間を超えるものから 1 週間以内に短縮するという介入は，患者の状態をモニ タリングした状況において施行は可能であり，医療者 の仕事量および患者侵襲を減らすことから，医療者お よび患者にとっての容認性は高い。介入に伴う広域抗 菌薬投与量の変化，およびこれに伴うコストへの影響 は評価できていないが，個人負担額を考えると，患 者・家族の個人の視点からは問題なく許容できる。ま た，抗菌薬の短期間治療により医療施設における AMR 対策につながり，結果的に敗血症患者自身の薬 剂耐性菌感染リスクを低下させるのであれば，患者・ 家族の個人の視点からも許容できる。ただし，敗血症 の死亡率や治癒率，再発率を悪化させることがないこ とが前提となる。

\section{（8）実行可能性}

介入は抗菌薬の治療期間短縮であり，多くの医療施 設において問題なく実行可能である。
(9) 判断の要約（Table 4-10-2）

（10）推奨グレーディング決定の工程

修正 RAND 法を用いた投票によって，中央值 7, 見解不一致指数 0.018 の結果となり, 委員会で採択さ れた（7点以上：75\%）。

\section{（11）関連する他の診療ガイドラインにおける推奨}

日本版敗血症診療ガイドライン（J-SSCG）2016に おいては，抗菌薬の治療期間に関する CQ はない 10)。 SSCG 2016 においては，敗血症と敗血症性ショックを 伴うほとんどの重症感染症で抗菌薬治療期間は 7〜 10 日間で適切であることが「弱い推奨」となってい た ${ }^{11)}$ 。

\section{（12）実施に関わる検討事項}

敗血症または集中治療を要する状況に特化したエビ デンスがあるのは，肺炎と腹腔内感染症に限られてい る。CQ 設定時に対象としていた尿路感染症，胆管炎， 菌血症に関するエビデンスは不足している。また，長 期投与が必要な感染症（心内膜炎，化膿性脊椎炎）は 本 CQ の対象ではない。実際，敗血症または集中治療 を要する状況に特化したエビデンスがない領域では, 各種一般感染症に対する抗菌化学療法の治療期間を参 考にする必要がある。

敗血症に対して短期間治療とする場合はこれらの条 件を考慮して実施したうえで，再発/再燃リスクに注 
日本版敗血症診療ガイドライン 2020

Table 4-10-2 判断の要約

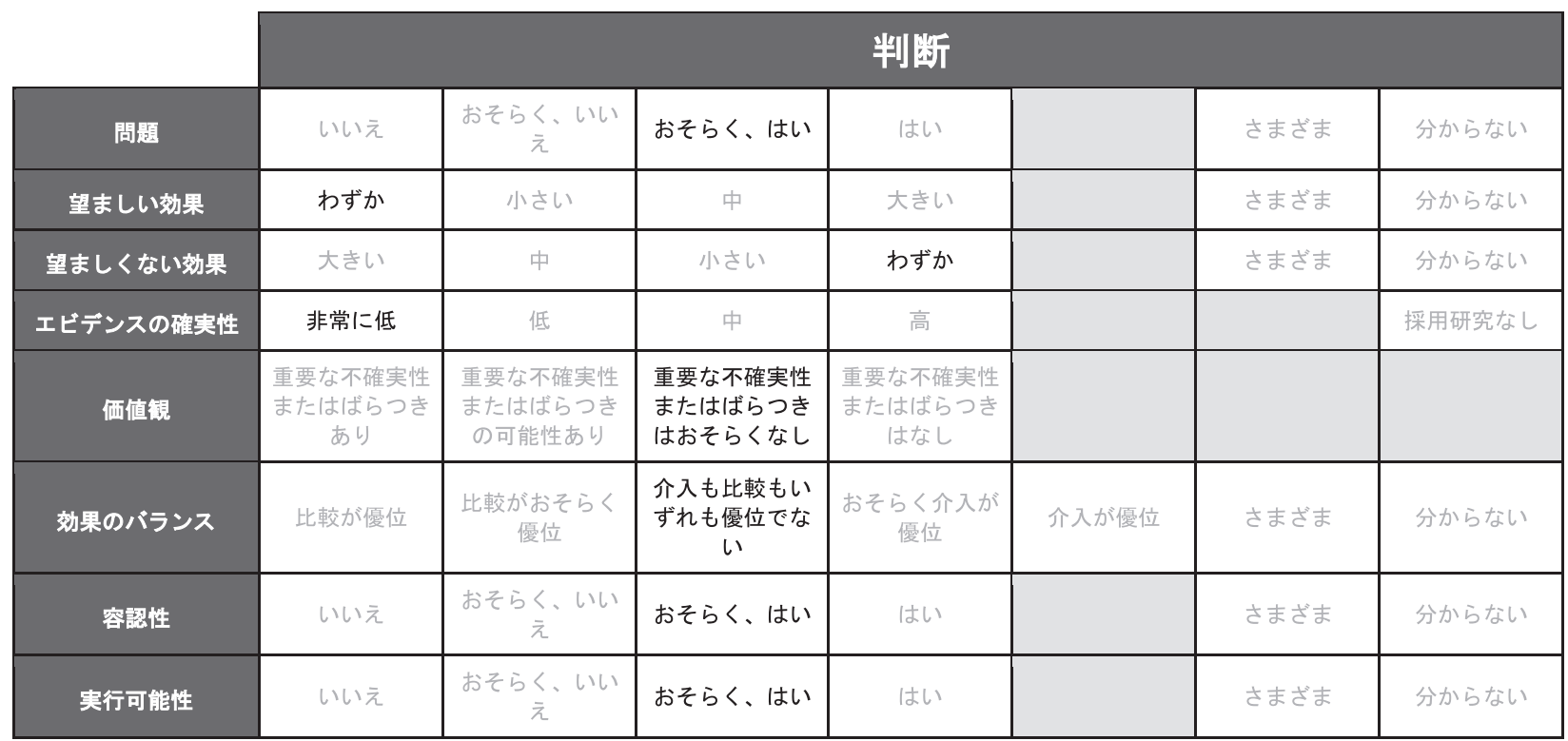

\section{意する必要がある。}

\section{（13）今後の研究の可能性}

以下の内容に関する検討が求められる。

・敗血症または集中治療を要する感染症を対象とし た，抗菌薬投与日数に関する質の高い RCT

- 抗菌薬治療期間と, 薬剤耐性菌の検出や敗血症の再 燃（短期間治療による再発率の増加，長期間治療に よる薬剤而性菌検出の増加による新たな二次感染の 増加）の関係性の検証

\section{文 献}

1) Micek S, Johnson MT, Reichley R, et al: An institutional perspective on the impact of recent antibiotic exposure on length of stay and hospital costs for patients with gram-negative sepsis. BMC Infect Dis. 2012; 12: 56.

2) Baggs J, Jernigan JA, Halpin AL, et al: Risk of Subsequent Sepsis Within 90 Days After a Hospital Stay by Type of Antibiotic Exposure. Clin Infect Dis. 2018; 66: 1004-12.

3) The Government of Japan: National Action Plan on Antimicrobial Resistance (AMR). 2016.

4) Royer S, DeMerle KM, Dickson RP, et al: Shorter versus longer courses of antibiotics for infection in hospitalized patients: A systematic review and meta-analysis. J Hosp Med. 2018; 13: 336-42.

5) Onakpoya IJ, Walker AS, Tan PS, et al: Overview of systematic reviews assessing the evidence for shorter versus longer duration antibiotic treatment for bacterial infections in secondary care. PLoS One. 2018; 13: e0194858.

6) Capellier G, Mockly H, Charpentier C, et al: Early-Onset Ventilator-Associated Pneumonia in Adults Randomized Clinical Trial: Comparison of 8 versus 15 Days of Antibiotic Treatment. PLoS One. 2012; 7: e41290.

7) Chastre J, Wolff M, Fagon JY, et al: Comparison of 8 vs 15 Days of Antibiotic Therapy for Ventilator-Associated Pneumonia in Adults: A Randomized Trial. JAMA. 2003; 290: 2588-98.
8) Kollef $\mathrm{MH}$, Chastre J, Clavel M, et al: A randomized trial of 7-day doripenem versus 10-day imipenem-cilastatin for ventilatorassociated pneumonia. Crit Care. 2012; 16: R218.

9) Montravers P, Tubach F, Lescot T, et al: Short-course antibiotic therapy for critically ill patients treated for postoperative intraabdominal infection: the DURAPOP randomised clinical trial. Intensive Care Med. 2018; 44: 300-10.

10) Nishida O, Ogura H, Egi M, et al: The Japanese Clinical Practice Guidelines for Management of Sepsis and Septic Shock 2016 (J-SSCG 2016). J Intensive Care. 2018; 6: 7.

11) Rhodes A, Evans LE, Alhazzani W, et al: Surviving Sepsis Campaign: International Guidelines for Management of Sepsis and Septic Shock: 2016. Intensive Care Med. 2017; 43: 304-77. 


\section{CQ4-11：腎排泄型の抗微生物薬の用量調整に際 して，何が参考になるか?}

Answer : 複数の時点で測定された腎機能検査值（血 清 $\mathrm{Cr}$ 值, eGFR 值など）に加えて, 体液量の変動, 腎代替療法や他の体外循環治療の有無などが参考にな る（BQ に対する情報提示）。

\section{（1）背景および本 CQ の重要度}

敗血症あるいは敗血症性ショックの治療において, 適切な抗微生物薬の投与設計を行うことは極めて重要 である。敗血症患者では臓器障害として腎障害を生じ ることが多く, 集中治療室において KDIGO（Kidney Disease: Improving Global Outcome）基準で急性腎障害 とされる症例の約半数は敗血症が原因とされる 1-5)。 腎障害時に腎排泄型の抗微生物薬は用量調整を行う必 要があると考えられるが, 一方で敗血症の初期には体 液量の変動や分布容積（volume of distribution: Vd）の 変化が起こるほか, 腎代替療法などの体外循環治療が 導入されることも多く, 用量調整に影響する因子は多 岐にわたる。不適切な抗微生物薬投与は患者の不良な 転帰に関連するため 2, 6-9), 本 CQ の重要度は高い。

\section{（2）解説}

腎排泄型の抗微生物薬では腎障害時にクリアランス が低下し血中濃度が上昇するため，敗血症による腎障 害においても抗微生物薬投与量の調整が必要と考えら れる10-13)。この場合，一般的な腎障害のために作成 された腎機能別の推奨用量では, 特に敗血症の初期に おいて抗微生物薬濃度が不十分となりうるため, 注意 が必要である14,15)。

腎機能の指標として血清 $\mathrm{Cr}$ 值や, $\mathrm{Cr}$ 值に加えて年 齢・性別などを考慮して算出される eGFR 值が一般的 に使用されている。一方, 急激な糸球体濾過量の変化 から 24〜48 時間遅れて Cr 值が変化することが知られ ており, 急性期の病態では真の腎機能を正確に反映し ない可能性が高いため，複数回の測定による $\mathrm{Cr}$ 值の 変動を参考に GFR 值を予想する必要がある。すなわ ち, $\mathrm{Cr}$ 值が上昇傾向であれば真の GFR 值は eGFR 值 よりも小さく, Cr 值が低下傾向であれば真の GFR 值 は eGFR 值よりも大きいことを想定する必要があ る 16)。

また，敗血症患者では抗微生物薬の投与に関連して 以下(1)と (2)に示すような変化から, Cr 值や e GFR 值 による腎機能評価に基づく薬剤投与量では不十分とな る可能性があるため, 特に水溶性抗微生物薬（抗菌
薬； $\beta$-ラクタム系, アミノグリコシド系, グリコペ プチド系, リネゾリド, コリスチン, 抗真菌薬; トリ アゾール系, エキノキャンディン系, ポリエンマクロ ライド系）の投与に際しては，体液量の変動の把握が 重要である 17-27)。

(1)毛細血管漏出およびそれによる浮腫, 輸液療法, 胸腹水，体液ドレナージ，低アルブミン血症，蛋白結 合率低下などに伴う $\mathrm{Vd}$ の増加と, 血漿や細胞外液に おける抗微生物薬の希釈

(2)心拍出量増加, 腎血流増加, 血管拡張 - 毛細血管 漏出・低アルブミン血症による腎クリアランスの増加 (augmented renal clearance)

体外循環によっても抗微生物薬の濃度は影響を受け る24)。体外膜型肺 (extracorporeal membrane oxygenation: ECMO）では回路における抗微生物薬の捕捉や, ECMO による炎症の惹起が原因となり, $\mathrm{Vd}$ や抗微生 物薬クリアランスが変化する可能性が指摘されてい る28-30)。

また，腎代替療法が導入された場合も抗微生物薬の

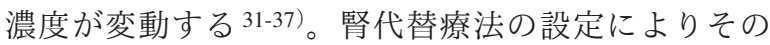
変化は異なるが38-41), 多くの場合は推奨されている 腎代替療法中の抗菌薬投与方法では不十分となる可能 性が指摘されている39,42-48)。なお，これらの海外の 論文で用いられている腎代替療法の濾過量は, 本邦の 保険診療における上限量（16L/日）よりも多いことに 注意が必要である。

\section{文 献}

1) Uchino $S$, Kellum JA, Bellomo R, et al: Acute renal failure in critically ill patients: a multinational, multicenter study. JAMA. 2005; 294: 813-8.

2) Bagshaw SM, George C, Bellomo R, et al: Early acute kidney injury and sepsis: a multicentre evaluation. Crit Care. 2008; 12: R47.

3) Bagshaw SM, Lapinsky S, Dial S, et al: Acute kidney injury in septic shock: clinical outcomes and impact of duration of hypotension prior to initiation of antimicrobial therapy. Intensive Care Med. 2009; 35: 871-81.

4) Lagu T, Rothberg MB, Shief MS, et al: Hospitalizations, costs, and outcomes of severe sepsis in the United States 2003 to 2007. Crit Care Med. 2012; 40: 754-61.

5) Schortgen F, Asfar P: Update in sepsis and acute kidney injury 2014. Am J Respir Crit Care Med. 2015; 191: 1226-31.

6) Kollef MH, Sherman G, Ward S, et al: Inadequate antimicrobial treatment of infections: a risk factor for hospital mortality among critically ill patients. Chest. 1999; 115: 462-74.

7) Ibrahim EH, Sherman G, Ward S, et al: The influence of inadequate antimicrobial treatment of bloodstream infections on patient outcomes in the ICU setting. Chest. 2000; 118: 146-55.

8) Shorr AF, Micek ST, Welch EC, et al: Inappropriate antibiotic therapy in Gram-negative sepsis increases hospital length of stay. Crit Care Med. 2011; 39: 46-51.

9) Roberts JA, Paul SK, Akova M, et al: DALI: defining antibiotic levels in intensive care unit patients: Are current $\beta$-lactam 
antibiotic doses sufficient for critically ill patients? Clin Infect Dis. 2014; 58: 1072-83.

10) Roberts JA, Abdul-Aziz MH, Lipman J, et al: Individualised antibiotic dosing for patients who are critically ill: challenges and potential solutions. Lancet Infect Dis. 2014; 14: 498-509.

11) Godin M, Murray P, Mehta RL: Clinical approach to the patient with AKI and sepsis. Semin Nephrol. 2015; 35: 12-22.

12) Sime FB, Roberts MS, Roberts JA: Optimization of dosing regimens and dosing in special populations. Clin Microbiol Infect. 2015; $21: 886-93$.

13) Lewis SJ, Mueller BA: Antibiotic dosing in patients with acute kidney injury: 'Enough But Not Too Much'. J Intensive Care Med. 2016; 31: 164-76.

14) Blot S, Lipman J, Roberts DM, et al: The influence of acute kidney injury on antimicrobial dosing in critically ill patients: Are dose reductions always necessary? Diagn Microbiol Infect Dis. 2014; 79: 77-84.

15) De Waele JJ, Lipman J, Akova M, et al: Risk factors for target non-attainment during empirical treatment with $\beta$-lactam antibiotics in critically ill patients. Intensive Care Med. 2014; 40: 1340-51.

16) Bernier-Jean A, Beaubien-Souligny W, Goupil R, et al: Diagnosis and outcomes of acute kidney injury using surrogate and imputation methods for missing preadmission creatinine values. BMC Nephrol. 2017; 18: 141.

17) Hoste EAJ, Daman J, Vanholder RC, et al: Assessment of renal function in recently admitted critically ill patients with normal serum creatinine. Nephrol Dial Transplant. 2005; 20: 747-53.

18) Herrera-Gutiérrez ME, Seller-Pérez G, Banderas-Bravo E, et al: Replacement of 24-h creatinine clearance by 2 -h creatinine clearance in intensive care unit patients: a single-center study. Intensive Care Med. 2007; 33: 1900-6.

19) Baptista JP, Udy AA, Sousa E, et al: A comparison of estimates of glomerular filtration in critically ill patients with augmented renal clearance. Crit Care. 2011; 15: R139.

20) Martin JH, Fay MF, Udy A, et al: Pitfalls of using estimations of glomerular filtration rate in an intensive care population. Intern Med J. 2011; 41: 537-43.

21) Gonçalves-Pereira J, Póvoa P: Antibiotics in critically ill patients: a systematic review of the pharmacokinetics of $\beta$-lactams. Crit Care. 2011; 15: R206.

22) Udy AA, Varghese JM, Altulroni M, et al: Subtherapeutic initial $\beta$-lactam concentrations in select critically ill patients: association between augmented renal clearance and low trough drug concentrations. Chest. 2012; 142: 30-9.

23) Grootaert V, Willems L, Debaveye Y, et al: Augmented Renal Clearance in the Critically Ill: How to Assess Kidney Function. Ann Pharmacother. 2012; 46: 952-9.

24) Udy AA, Roberts JA, Lipman J: Clinical implications of antibiotic pharmacokinetic principles in the critically ill. Intensive Care Med. 2013; 39: 2070-82.

25) Udy AA, Roberts JA, Shorr AF, et al: Augmented renal clearance in septic and traumatized patients with normal plasma creatinine concentrations: identifying at-risk patients. Crit Care. 2013; 17 R35.

26) Udy AA, Baptista JP, Lim NL, et al: Augmented renal clearance in the ICU: results of a multicenter observational study of renal function in critically ill patients with normal plasma creatinine concentrations*. Crit Care Med. 2014; 42: 520-7.

27) Carlier M, Carrette S, Roberts JA, et al: Meropenem and piperacillin/tazobactam prescribing in critically ill patients: does augmented renal clearance affect pharmacokinetic/pharmacodynamic target attainment when extended infusions are used? Crit Care. 2013; 17: R84.

28) Shekar K, Fraser JF, Smith MT, et al: Pharmacokinetic changes in patients receiving extracorporeal membrane oxygenation. J Crit Care. 2012; 27: 741.e9-18.

29) Shekar K, Roberts JA, Mcdonald CI, et al: Sequestration of drugs in the circuit may lead to therapeutic failure during extracorporeal membrane oxygenation. Crit Care. 2012; 16: R194.

30) Dzierba AL, Abrams D, Brodie D: Medicating patients during extracorporeal membrane oxygenation: the evidence is building. Crit Care. 2017; 21: 66.

31) Heintz BH, Matzke GR, Dager WE: Antimicrobial dosing concepts and recommendations for critically ill adult patients receiving continuous renal replacement therapy or intermittent hemodialysis. Pharmacotherapy. 2009; 29: 562-77.

32) Choi G, Gomersall CD, Tian Qi, et al: Principles of antibacterial dosing in continuous renal replacement therapy. Crit Care Med. 2009; 37: 2268-82.

33) Bogard KN, Peterson NT, Plumb TJ, et al: Antibiotic dosing during sustained low-efficiency dialysis: special considerations in adult critically ill patients. Crit Care Med. 2011; 39: 560-70.

34) Eyler RF, Mueller BA, Medscape: Antibiotic dosing in critically ill patients with acute kidney injury. Nat Rev Nephrol. 2011; 7: 226-35.

35) Scoville BA, Mueller BA: Medication dosing in critically ill patients with acute kidney injury treated with renal replacement therapy. Am J Kidney Dis. 2013; 61: 490-500.

36) Ulldemolins M, Vaquer S, Llauradó-Serra M, et al: Beta-lactam dosing in critically ill patients with septic shock and continuous renal replacement therapy. Crit Care. 2014; 18: 227.

37) Veiga RP, Paiva JA: Pharmacokinetics-pharmacodynamics issues relevant for the clinical use of beta-lactam antibiotics in critically ill patients. Crit Care. 2018; 22: 233.

38) Churchwell MD, Mueller BA: Drug dosing during continuous renal replacement therapy. Semin Dial. 2009; 22: 185-8.

39) Roberts DM, Roberts JA, RobertsMS, et al: Variability of antibiotic concentrations in critically ill patients receiving continuous renal replacement therapy: a multicentre pharmacokinetic study. Crit Care Med. 2012; 40: 1523-8.

40) Jamal JA, Udy AA, Lipman J, et al: The impact of variation in renal replacement therapy settings on piperacillin, meropenem, and vancomycin drug clearance in the critically ill: an analysis of published literature and dosing regimens*. Crit Care Med. 2014; 42: $1640-50$.

41) Roberts DM, Liu X, Roberts JA, et al: A multicenter study on the effect of continuous hemodiafiltration intensity on antibiotic pharmacokinetics. Crit Care. 2015; 19: 84.

42) Fiaccadori E, Maggiore U, Rotelli C, et al: Removal of linezolid by conventional intermittent hemodialysis, sustained low-efficiency dialysis, or continuous venovenous hemofiltration in patients with acute renal failure. Crit Care Med. 2004; 32: 2437-42.

43) Kielstein JT, Czock D, Schöpke T, et al: Pharmacokinetics and total elimination of meropenem and vancomycin in intensive care unit patients undergoing extended daily dialysis. Crit Care Med. 2006; 34: 51-6.

44) Burkhardt O, Joukhadar C, Traunmüller F, et al: Elimination of daptomycin in a patient with acute renal failure undergoing extended daily dialysis. J Antimicrob Chemother. 2008; 61: 224-5.

45) Seyler L, Cotton F, Taccone FS, et al: Recommended $\beta$-lactam regimens are inadequate in septic patients treated with continuous renal replacement therapy. Crit Care. 2011; 15: R137.

46) Wilson FP, Berns JS: Vancomycin levels are frequently subtherapeutic during continuous venovenous hemodialysis (CVVHD). Clin Nephrol. 2012; 77: 329-31.

47) Zoller M, Maier B, Hornuss C, et al: Variability of linezolid concentrations after standard dosing in critically ill patients: a prospective observational study. Crit Care. 2014; 18: R148. 


\section{日集中医誌 J Jpn Soc Intensive Care Med Vol. 28 Suppl}

48) Euteneuer JC, Kamatkar S, Fukuda T, et al: Suggestions for Model-Informed Precision Dosing to Optimize Neonatal Drug Therapy. J Clin Pharmacol. 2019; 59: 168-76. 


\section{CQ5 : 兔疫グロブリン（IVIG）療法}

敗血症には様々な補助療法（adjunctive therapies）が 試みられている。多クローン性免疫グロブリンには, 病原微生物・毒素の中和作用, 補体活性化による領 食・溶菌促進作用, オプソニン効果, 抗体依存性細胞 傷害作用, 非特異的抗炎症作用, 炎症性サイトカイン 産生抑制作用などがあり 1,2)，臨床では特発性血小板 減少性紫斑病, 重症筋無力症, 慢性炎症性脱髄性多発 神経炎, Guillain-Barre 症候群，川崎病などへの免疫 グロブリン（IVIG）がガイドラインで推奨されてい る。また，上記作用および低免疫グロブリン血症の合 併頻度が高いことから感染症への効果も期待され ${ }^{3)}$, 特に重症例に対し投与されてきた。本邦では正岡らの 臨床研究結果に基づき重症感染症が保険適用となって おり 4)，2010 年〜2011 年にかけて日本救急医学会が 実施した前向き観察研究では, 重症敗血症 624 人の $34.6 \%$ ，うちショック合併 282 人の $44.0 \%$ に投与され ていた5)。

しかし, 各種敗血症診療ガイドラインにおける推奨 は必ずしも一貫しておらず, SSCG 2016 においては弱 い非推奨であったが，日本版敗血症診療ガイドライン （J-SSCG）2016では弱い推奨とする担当班からの案に 対して委員会の同意率が低く，推奨に関する提示は見 送られた。一方で, 特に死亡率の高い劇症型溶血性レ ンサ球菌感染症 (STSS), 毒素性ショック症候群 (TSS), 壊死性軟部組織感染症などの特殊感染症に対 する投与を推奨する文献が複数あり，検討の必要性が 出ている。そこで今回のガイドライン改訂に当たり, 我々は従来の「CQ5-2-1：劇症型溶血性レンサ球菌感 染症（STSS）に対して免疫グロブリン（IVIG）投与 を行うか?」に加えて,「CQ5-2-2 : 毒素性ショック
症候群（TSS）に対して免疫グロブリン（IVIG）投与 を行うか?」の CQ を立案し，両者に対しそれぞれ GRADEに基づくシステマティックレビューを行い, 推奨を決定した。

CQ5-1 においては, low quality of evidence も含むシ ステマティックレビュー, high quality of evidence のみ のシステマティックレビューの両者を実施し, 事前設 定により後者を採用し推奨に用いた。結果的に, 前述 の正岡論文が採用システマティックレビューに含まれ ず, 推奨の方向性が J-SSCG 2016 担当班の草案とは異 なり, 弱い非推奨となった。今回は委員会の同意が得 られ，推奨に関する提示に至った。また，CQ5-2にお いては, 臨床研究が少ないことが予想されたため, シ ステマティックレビューの対象を観察研究に拡げて検 討を行った。

\section{文 献}

1) Nimmerjahn F, Ravetch JV: Anti-inflammatory actions of intravenous immunoglobulin. Annu Rev Immunol. 2008; 26: 513-33.

2) Shankar-Hari M, Spencer J, Sewell WA, et al: Bench-to-bedside review: Immunoglobulin therapy for sepsis - biological plausibility from a critical care perspective. Crit Care. 2012; 16: 206.

3) Shankar-Hari M, Culshaw N, Post B, et al: Endogenous IgG hypogammaglobulinaemia in critically ill adults with sepsis: systematic review and meta-analysis. Intensive Care Med. 2015; 41: 1393-401.

4）正岡徹, 長谷川廣文, 高久史麿, 他: 重症感染症に対する抗菌 薬との併用療法における静注用ヒト免疫グロブリンの効果. 日化療会誌. 2000; 48: 199-217.

5）小谷穣治, 齋藤大蔵, 丸藤哲, 他: 日本救急医学会 Sepsis Registry 特別委員会報告 Severe Sepsis 治療データ解析結果. 日救急医会誌. 2013; 24: 291-6.

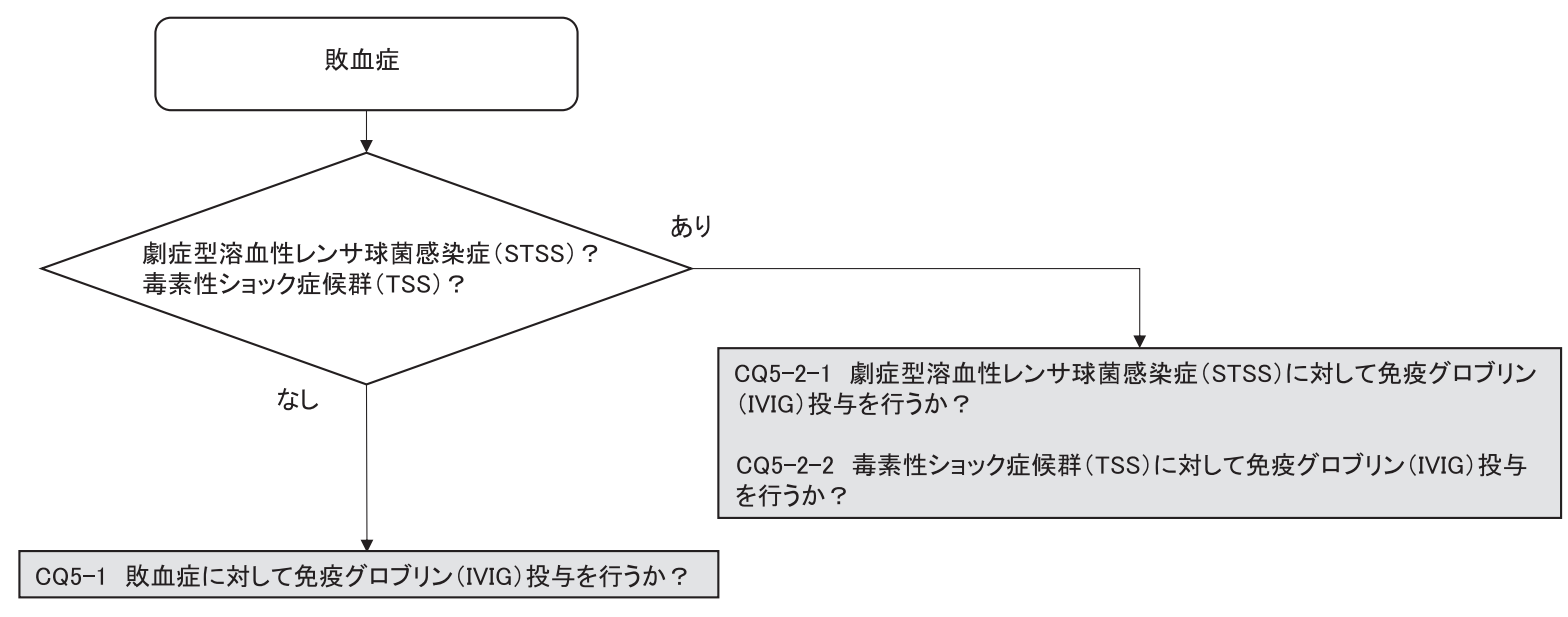

免疫グロブリン (IVIG）〔診療フロー〕 
CQ5-1：敗血症に対して免疫グロブリン（IVIG） 投与を行うか?

Answer : 敗血症に対して，免疫グロブリン（IVIG） 投与を行わないことを弱く推奨する（GRADE 2B：エ

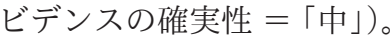

\section{（1）背景および本 $C Q$ の重要度}

IVIG には種々の病原微生物や毒素に対する特異抗 体が含まれ，抗原と結合するとオプソニン効果や補体 の活性化の他，毒素・ウイルスの中和作用，炎症性サ イトカインの産生抑制作用を有する 1)。敗血症患者で は, 産生抑制や漏出・消耗により発症早期から血清 $\mathrm{IgG}$ は低值となるため, 適切な循環管理と抗菌薬の早 期投与と共に，IVIG 投与が予後を改善する可能性が ある。

敗血症患者の致死率は依然として高く，治療成績を 向上させる介入法の確立は急務である。現状では, IVIG 投与の有効性・有害性の評価は定まっておらず, 臨床現場でもその投与判断については多様性がある。 以上より，本 CQ は重要度の高いものと考えられる。
(2) PICO

$\mathrm{P}$ (患者)：感染症，敗血症あるいは敗血症性ショッ ク患者

I（介入）：IVIG 投与

C (対照)：プラセボ投与あるいは IVIG 非投与

$\mathrm{O}$ (アウトカム ) : 全原因死亡（バイアスリスクの低 い研究限定), 全原因死亡 [全ランダム化比較試 験（RCT）対象]，ICU 滞在日数，あらゆる重篤 な副作用

\section{（3）エビデンスの要約}

システマティックレビューの結果，PICO に合致し

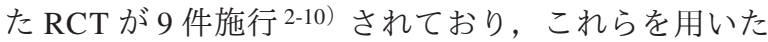
メタ解析を実施した。

\section{（4）益と害のバランス（Table 5-1-1）}

望ましい効果：

今回，死亡アウトカムに関しては事前設定に基づい て検索した全 RCT を対象としたものならびに，バイ アスリスクが低い RCT に限定したもの，の 2 通りを 行った。エビデンスの確実性が高いほうの解析を用い ることを事前に設定していたため，低いバイアスのリ

Table 5-1-1エビデンスプロファイル

\begin{tabular}{l|c|c|c|c|c|c|}
\multicolumn{9}{c|}{ 確実性の評価 } \\
\hline 研究数 & $\begin{array}{c}\text { 研究 } \\
\text { デザイン }\end{array}$ & $\begin{array}{c}\text { バイアス } \\
\text { のリスク }\end{array}$ & 非一貫性 & 非直接性 & 不精確性 & $\begin{array}{l}\text { その他 } \\
\text { の検討 }\end{array}$ \\
\hline
\end{tabular}

\begin{tabular}{|l|l|}
\multicolumn{2}{|c|}{ 患者数 } \\
\hline IVIG 群 & Control 群
\end{tabular}

\begin{tabular}{|l|l|}
\hline \multicolumn{2}{|c|}{ 就果 } \\
\hline $\begin{array}{l}\text { 相刘指標 } \\
(95 \% \mathrm{Cl})\end{array}$ & $\begin{array}{l}\text { 紋対指標 } \\
(95 \% \mathrm{Cl})\end{array}$ \\
\hline
\end{tabular}

全原因死亡（全 RCT 対象）

\begin{tabular}{|c|c|c|c|c|c|c|c|c|c|c|c|c|}
\hline 9 & RCT & 深刻 a & 深刻でないb & 深刻 c & 深刻でない & なし & $\begin{array}{l}232 / 769 \\
(30.2 \%)\end{array}$ & $\begin{array}{l}271 / 709 \\
(38.2 \%)\end{array}$ & $\begin{array}{c}\text { RR } 0.72 \\
\text { (0.58 to } 0.90 \text { ) }\end{array}$ & $\begin{array}{c}1,000 \text { 人あたり } 107 \text { 人少 } \\
\text { ない } \\
(161 \text { 人少ない } 38 \text { 人少 } \\
\text { ない })\end{array}$ & $\begin{array}{c}\oplus \oplus \bigcirc \bigcirc \\
\text { 低 }\end{array}$ & 重大 \\
\hline
\end{tabular}

全原因死亡 (バイアスリスクの低い研究限定)

\begin{tabular}{|c|c|c|c|c|c|c|c|c|c|c|c|c|}
\hline 3 & RCT & 深刻でない & 深刻でない & 深刻c & 深刻でない & なし & $\begin{array}{l}139 / 381 \\
(36.5 \%)\end{array}$ & $\begin{array}{c}131 / 364 \\
(36.0 \%)\end{array}$ & $\begin{array}{c}\text { RR } 1.02 \\
\text { (0.84 to } 1.23 \text { ) }\end{array}$ & $\begin{array}{c}\text { 1,000 人あたり } 7 \text { 人多い } \\
(58 \text { 人少ない } 83 \text { 人多 } \\
\text { い) }\end{array}$ & $\begin{array}{c}\oplus \oplus \oplus \bigcirc \\
\text { 中 }\end{array}$ & 重大 \\
\hline
\end{tabular}

ICU 滞在日数

\begin{tabular}{|c|c|c|c|c|c|c|c|c|c|c|c|c|}
\hline 4 & RCT & 深刻 a & 深刻でない & 深刻 c & 深刻でない & なし & 233 & 202 & - & $\begin{array}{c}\text { 平均 } 1.1 \text { 日少ない } \\
(5.44 \text { 日少ない to } 3.25 \\
\text { 日多い) }\end{array}$ & $\begin{array}{c}\oplus \oplus \bigcirc \bigcirc \\
\text { 低 }\end{array}$ & 重大 \\
\hline
\end{tabular}

あらゆる重篤な副作用

\begin{tabular}{|c|c|c|c|c|c|c|c|c|c|c|c|c|}
\hline 2 & RCT & 深刻でない & 深刻でない & 深刻 c & 非常に深刻 d & なし & $\begin{array}{l}15 / 371 \\
(4.0 \%)\end{array}$ & $\begin{array}{c}15 / 353 \\
(4.2 \%)\end{array}$ & $\begin{array}{c}\text { RR } 0.97 \\
\text { (0.45 to } 2.08 \text { ) }\end{array}$ & $\begin{array}{c}\text { 1,000 あたり } 1 \text { 人少ない } \\
(23 \text { 人少ない } 46 \text { 人多 } \\
\text { い) }\end{array}$ & $\begin{array}{l}\oplus \bigcirc 0 \bigcirc \\
\text { 非常に低 }\end{array}$ & 重大 \\
\hline
\end{tabular}

※事前設計の PICO フォームでは以下の通り定めていた : 死亡アウトカムについてはバイアスリスクの低い研究に限定したサブグループ解析を行い，推采の決定においては，エビデンスの確信性が最も高い 解析結果を優先する。その結果，推奖に用いる死亡アウトカムは，『全原因死亡（バイアスリスクの低い研究に限定）』とした。

a. 多くの研究をバイアスリスクが高いと判断した。

b. 異質性は $2^{2}=49 \%$ 高く，非一貫性に関する深刻なバイアスが示唆される。ただし，この異質性は各研究のバイアスのリスクから説明可能であるため, バイアスのリスクならびに非一貫性の両面での 1 段階のダウングレードで妥当であると判断した。

c. 海外で実施された多くの研究が，国内保険用量を超える大量投与を検証したものである。介入に関する非直接性があると判断した。

d. 信頼区間は, “効果なし”と“相当な利益（RR 0.75）・相当な害（RR1.25）”の双方を含んでいる。 
スクの死亡アウトカムを採用した。

バイアスリスクの低い3つの RCT から得られる全 死亡に関する効果推定值は, リスク差（RD）1,000人 あたり 7 人多い $(95 \% \mathrm{CI}: 58$ 人少ない〜 83 人多い) であり，IVIG 投与による望ましい効果は限定的であ る。ICU 滞在日数に関する効果推定值は, 平均 (MD) 1.1 日短い（95\% CI: 5.44 日短い〜3.25 日長い）と， 同様に望ましい効果は限定的である。

望ましくない効果 :

あらゆる重篤な副作用に関する効果推定值は，RD 1,000 人あたり 1 人少ない $(95 \% \mathrm{CI}: 23$ 人少ない〜 46 人多い）であり，望ましくない効果も増えない可能性 が高い。

\section{益と害のバランス :}

本 CQ においては，すべてのアウトカムがIVIG の 効果なしを示す結果であったため，患者・家族が置く 相対的価值の設定によらず，その効果のバランスは介 入あるいは比較対象のいずれも支持しない。

\section{（5）アウトカム全般に関するエビデンスの確実性}

今回採用したすべてのアウトカムの効果推定值の方 向性は一致している（効果なし）ため，一番高いアウ トカムの確実性を全体としては採用した。アウトカム 全体にわたるエビデンスの確実性は「中」である。

\section{（6）価値観}

敗血症患者に対するIVIG 投与における，各アウト カムに置く患者・家族の価值観に関するデータはな い。一般的に，死亡アウトカムに対して置く相対的価
值は高く，そのばらつきは少ないことが予想される。

\section{（7）容認性}

有害事象はリスクが低い可能性が高い。介入に伴う コストは約 126,000 円（IVIG $5 \mathrm{~g}=$ 平均的な薬価約 42,000 円を 3 日間投与の場合）である。その個人負担 額を考えると，患者・家族の個人の視点からおそらく 許容できるであろう。また, IVIG 投与に伴う医療者 の仕事量増加はわずかであると考えられる。

（8）実行可能性

介入は多くの医療施設において実行可能である。

（9）判断の要約（Table 5-1-2）

（10）推奨グレーディング決定の工程

修正 RAND 法を用いた投票によって，中央值 8, 見解不一致指数 0.178 の結果となり，委員会で採択さ れた（7 点以上 : $87.5 \%) 。$

（11）関連する他の診療ガイドラインにおける推奨

SSCG 2016 では弱い非推奨である。一方，日本版敗 血症診療ガイドライン（J-SSCG）2016 では IVIG 担当 班の推奨文草案「成人の敗血症患者に対して IVIG を 投与することを弱く推奨する（推奨 $2 \mathrm{C}$ )」が 2 度の投 票でいずれも 3 分の 2 以上の合意が得られず，明確な 推奨を提示していない。

Table 5-1-2 判断の要約

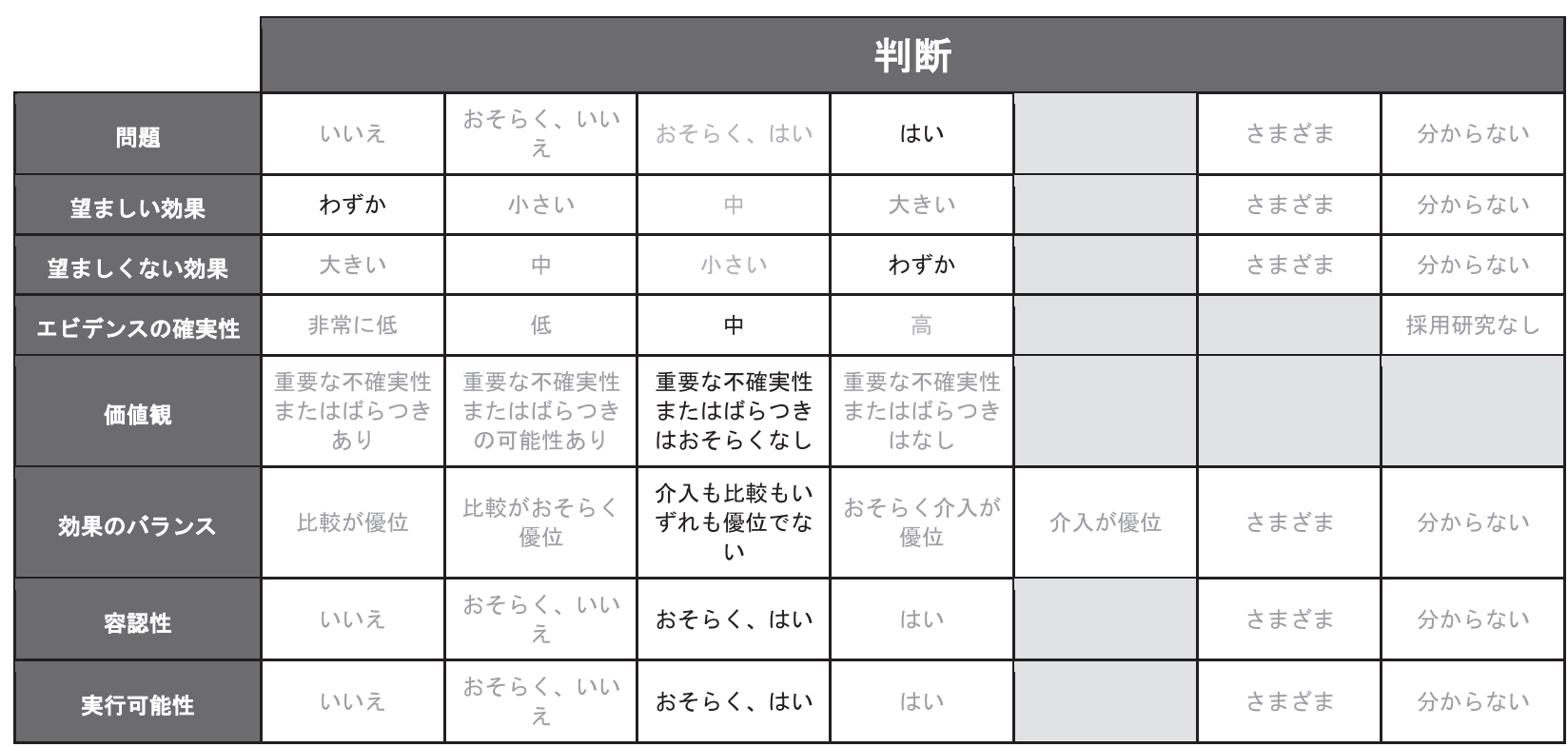




\section{（12）実施に関わる検討事項}

標準的治療として IVIG 投与を行うことは好ましくな いが，症例に応じた適応判断を否定するものではない。

\section{（13）今後の研究の可能性}

以下の内容に関する検討が求められるであろう。

・本邦で認可された投与量（IVIG $5 \mathrm{~g} /$ 日 $\times 3$ 日間）

\section{による有効性の検証}

・大量長期投与による有効性の検証

・低ガンマグロブリン血症合併敗血症に対する有効 性の検証

・壊死性軟部組織感染症，毒素性ショック症候群 （toxic shock syndrome: TSS）などの特殊な感染症 に対する有効性の検証

\section{文 献}

1) Aubron $C$, Berteau F, Sparrow RL: Intravenous immunoglobulin for adjunctive treatment of severe infections in ICUs. Curr Opin Crit Care. 2019; 25: 417-22.

2) Masaoka $T$, Hasegawa $H$, Takaku F, et al: The efficacy of intravenous immunogloblin in combination thrapy with antibiotics for severe infections. Japanese J Chemother. 2000; 48: 199-217.

3) Madsen MB, Hjortrup PB, Hansen MB, et al: Immunoglobulin G for patients with necrotising soft tissue infection (INSTINCT): a randomised, blinded, placebo-controlled trial. Intensive Care Med. 2017; 43: 1585-93.

4) Werdan K, Pilz G, Bujdoso O, et al: Score-based immunoglobulin G therapy of patients with sepsis: the SBITS study. Crit Care Med. 2007; 35: 2693-701.

5) Grundmann R, Hornung M: Immunoglobulin therapy in patients with endotoxemia and postoperative sepsis - a prospective randomized study. Prog Clin Biol Res. 1988; 272: 339-49.

6) Darenberg J, Ihendyane N, Sjolin J, et al: Intravenous immunoglobulin $\mathrm{G}$ therapy in streptococcal toxic shock syndrome: a European randomized, double-blind, placebo-controlled trial. Clin Infect Dis. 2003; 37: 333-40.

7) De Simone C, Delogu G, Corbetta G: Intravenous immunoglobulins in association with antibiotics: a therapeutic trial in septic intensive care unit patients. Crit Care Med. 1988; 16: 23-6.

8) Burns ER, Lee V, Rubinstein A: Treatment of septic thrombocytopenia with immune globulin. J Clin Immunol. 1991; 11: 363-8.

9) Marenovic T, Filipovic D, Lukic Z, et al: High doses of immunoglobulins decrease mortality rate of surgical patients with severe intraabdominal infections and sepsis. Vojnosanit Pregl. 1998; 55 : 71-4.

10) Lorenzo D, Valentina B, Andrea I, et al: High-Dose Intravenous IgG for Treatment of Severe Surgical Infections. Dig Surg. 1996; 13: 430-4.
CQ5-2-1 : 劇症型溶血性レンサ球菌感染症 (STSS) に対して免疫グロブリン（IVIG）投与を行うか？

Answer：劇症型溶血性レンサ球菌感染症（STSS）に 対して，免疫グロブリン（IVIG）投与を行うことを 弱く推奨する（GRADE 2D：エビデンスの確実性 $=$ 「非常に低」)。

\section{（1）背景および本 $C Q$ の重要度}

敗血症は，病原微生物の種類に依存しない重症感染 症であるが，特定の感染症では病原菌が産生する毒素 により特有の重症病態を呈する。 $\mathrm{A}$ 群・ $\mathrm{G}$ 群レンサ球 菌による劇症型溶血性レンサ球菌感染症（severe invasive streptococcal infection，または streptococcal toxic shock syndrome: STSS）の病態には，菌が産生する外毒 素が関与するとされ，毒素中和やサイトカイン産生抑 制の作用を持つ IVIG が，両病態を改善する可能性が 指摘されている。

STSS は急激に多臓器不全を呈し，死亡率は 40〜 50\%を超えるとされる。そのため，治療成績を向上 させる介入法の確立は急務である。欧米の診療指針な どでは，観察研究などの結果を基に IVIG 投与を推奨 しているものもある1-5)。しかし，現状では，IVIG 投 与の有効性・有害性の評価は定まっておらず，臨床現 場でもその投与判断については多様性がある。以上よ り，本 CQ は重要度の高いものと考えられる。

(2) PICO

P (患者)：レンサ球菌性敗血症（STSS を含む）の 患者

I（介入）：IVIG 投与

C (対照) : プラセボ投与あるいは IVIG 非投与

$\mathrm{O}$ (アウトカム ) : 全原因死亡（全 RCT ・観察研究 対象)，全原因死亡 [クリンダマイシン（CLDM） 投与限定症例]，ICU 滞在日数，あらゆる重篤な 副作用

\section{（3）エビデンスの要約}

システマティックレビューの結果，PICO に合致し た RCT が 1 件，観察研究が 4 件施行 6-9) されており, これらを別々に用いたメタ解析を実施した。

\section{(4) 益と害のバランス（Table 5-2-1-1）}

望ましい効果：

死亡アウトカムに関しては，事前設定に基づき全症 例を対象としたもの，ならびに CLDM 投与症例に限 
Table 5-2-1-1エビデンスプロファイル

\begin{tabular}{|c|c|c|c|c|c|c|c|c|c|c|c|c|}
\hline \multicolumn{7}{|c|}{ 碓夷性の評価 } & \multicolumn{2}{|c|}{ 㭧者数 } & \multicolumn{2}{|r|}{ 奻果 } & \multirow{2}{*}{ 確夷性 } & \multirow[b]{2}{*}{ 重要性 } \\
\hline 研究数 & $\begin{array}{l}\text { 研究 } \\
\text { デサイン }\end{array}$ & $\begin{array}{l}\text { パイアス } \\
\text { のリスク }\end{array}$ & 非一而性 & 非直接性 & 不橉碓性 & $\begin{array}{l}\text { その他 } \\
\text { の㛟时 }\end{array}$ & IVIG 群 & Control 群 & 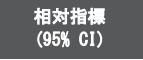 & 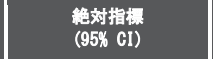 & & \\
\hline \multicolumn{13}{|c|}{ STSS 全原因死亡 } \\
\hline 1 & RCT & 深刻でない & 深刻でない & 深刻。 & 非常に深刻 d & なし & $\begin{array}{l}2 / 10 \\
(20.0 \%)\end{array}$ & $4 / 11(36.4 \%)$ & $\begin{array}{c}\text { RR } 0.55 \\
\text { (0.13 to } 2.38 \text { ) }\end{array}$ & $\begin{array}{c}1,000 \text { あたり } 164 \text { 人少 } \\
\text { ない } \\
\text { (316 人少ない } 502 \text { 人い) } \\
\text { 多い) }\end{array}$ & $\begin{array}{l}\oplus \bigcirc \bigcirc \bigcirc \\
\text { 非常に低 }\end{array}$ & 重大 \\
\hline 3 & 観察研究 & 非常に深刻 a & 深刻でない & 深刻。 & 深刻。 & なし & $\begin{array}{l}11 / 58 \\
(19.0 \%)\end{array}$ & $50 / 115(43.5 \%)$ & $\begin{array}{c}\mathrm{RR} 0.42 \\
(0.25 \text { to } 0.73)\end{array}$ & $\begin{array}{c}1,000 \text { 人あたり } 252 \text { 人少 } \\
\text { ない } \\
\text { (326 少ないい } 117 \text { 人少 } \\
\text { ないい) }\end{array}$ & $\begin{array}{l}\oplus \bigcirc \bigcirc \bigcirc \\
\text { 非常に低 }\end{array}$ & 重大 \\
\hline \multicolumn{13}{|c|}{ 全原因死亡（CLDM 投与症例限定） } \\
\hline 1 & RCT & 深刻でない & 深刻でない & 深刻。 & 非常に深刻 d & なし & $1 / 8(12.5 \%)$ & $3 / 10 \quad(30.0 \%)$ & $\begin{array}{c}\mathrm{RR} 0.42 \\
\text { (0.05 to } 3.28)\end{array}$ & $\begin{array}{c}1,000 \text { あたり } 174 \text { 人少な } \\
\text { (285人少ない 684人 } \\
\text { 多い) }\end{array}$ & $\begin{array}{l}\oplus \bigcirc \bigcirc \bigcirc \\
\text { 非常に低 }\end{array}$ & 重大 \\
\hline 4 & 観察研究 & 深刻 ${ }^{b}$ & 深刻でない & 深刻。 & 深刻。 & なし & $\begin{array}{l}13 / 80 \\
(16.3 \%)\end{array}$ & $29 / 95(30.5 \%)$ & $\begin{array}{c}\text { RR } 0.53 \\
(0.30 \text { to } 0.94)\end{array}$ & $\begin{array}{c}1,000 \text { 人あたり } 143 \text { 人少 } \\
\text { ない } \\
(214 \text { 人少ない } 18 \text { 人少 } \\
\text { ない }\end{array}$ & $\begin{array}{l}\oplus \bigcirc \bigcirc \bigcirc \\
\text { 非常に低 }\end{array}$ & 重大 \\
\hline \multicolumn{13}{|c|}{ あらゆる重篤な副作用 } \\
\hline 1 & RCT & 深刻でない & 深刻でない & 深刻。 & 非常に深刻 d & なし & $\begin{array}{l}8 / 50 \\
(16.0 \%)\end{array}$ & $11 / 50 \quad(22.0 \%)$ & $\begin{array}{c}\text { RR } 0.73 \\
\text { (0.32 to } 1.65)\end{array}$ & $\mid \begin{array}{c}1,000 \text { 人あたり } 59 \text { 人少 } \\
\text { ない } \\
(150 \text { 人少ない 143 } \\
\text { 多い) }\end{array}$ & $\begin{array}{l}\oplus \bigcirc \bigcirc \bigcirc \\
\text { 非常に低 }\end{array}$ & 重大 \\
\hline
\end{tabular}

a. すべての研究において，ROBINS-Iにおける「交絡因子によるバイアス」を「重大」と判定したため「非常に深刻」と判断した。 b. すべての研究において，ROBINS-Iにおける「交絡因子によるバイアス」を「深刻」と判定したため「深刻」と判断した。

c. 海外で実施された多くの研究が，国内保隃用量を超える大量投与を梌証したものである。介入に関する非直接性があると判断した。

d. 信頼区間は, “効果なし”と“相当な利益（RR 0.75）・相当な害（RR1.25）”の双方を含んでいるため「非常に深刻」と判断した。

最適情報量を満たさないため「深刻」と判断した。

定したもの，の 2 通りを行い，よりバイアスリスクの 低いCLDM 投与症例に限定したものを採用した。 RCT から得られる全死亡に関する効果推定值は, リ スク差（RD）1,000人あたり 174 人少ない（95\% CI: 285 人少ない〜 684 人多い）であり，IVIG 投与による 望ましい効果は限定的である。一方，観察研究から得 られる全死亡に関する効果推定值は，RD 1,000人あ たり 143 人少ない $(95 \% \mathrm{CI}: 214$ 人少ない〜 18 人少な い）であり，IVIG 投与による望ましい効果が認めら れた。

STSS を対象にした RCT は，観察対象が 18 例の 1 研究のみであり, 疾患頻度や重篤性を考えると, 今後 も大規模 RCT が実施される可能性は低いと思われる。 したがって，例外的ではあるが観察研究のシステマ ティックレビューを実施し，その結果を踏まえて小さ いながらも望ましい効果を期待できると判断した。

望ましくない効果 :

RCT，観察研究共に評価は不可能であったが，敗血 症の結果（CQ5-1）を踏まえ望ましくない効果はあっ たとしてもわずかと判断した。

益と害のバランス :

CLDM 投与症例限定の観察研究において，死亡ア ウトカムはIVIG 投与により改善している。また, IVIG 投与に関連する重篤な副作用に関してはわずか であると考えられる。以上より，介入がおそらく優位 であると考えられる。
（5）アウトカム全般に関するエビデンスの確実性

アウトカム全体にわたるエビデンスの確実性は, 「非常に低い」である。

\section{（6）価値観}

STSS に対するIVIG 投与における，各アウトカム に置く患者・家族の価值観に関するデータはない。一 般的に死亡アウトカムに対して置く相対的価值は高 く，そのばらつきは少ないことが予想される。

\section{（7）容認性}

有害事象のリスクが低い可能性が高い。本邦の保険 適用量を遵守した場合，介入に伴うコストは約 126,000 円（IVIG 5g = 平均的な薬価約 42,000 円を 3 日間投与の場合）であり，疾患の重篤性に鑑みると， 医療経済学的および患者・家族の視点からおそらく許 容できるであろう。また，IVIG 投与に伴う医療者の 仕事量増加はわずかであると考えられる。

（8）実行可能性

介入は多くの医療施設において実行可能である。

（9）判断の要約（Table 5-2-1-2）

（10）推奨グレーディング決定の工程

修正 RAND 法を用いた投票によって, 中央值 7.5, 
見解不一致指数 0.164 の結果となり, 委員会で採択さ れた（7 点以上 : $75 \%)$ 。

\section{（11）関連する他の診療ガイドラインにおける推奨}

S SCG 2016, 日本版敗血症診療ガイドライン （J-SSCG）2016 のいずれにも推奨の記載はない。

\section{（12）実施に関わる検討事項}

レンサ球菌性敗血症への標準的治療としては, IVIG 投与を推奨するものではない。

本邦の保険適用量での有効性に関しては不明であ る。加えて, 多くの研究で使用されている IVIG 量 （計 $2 \mathrm{~g} / \mathrm{kg}$ 前後）を使用した場合，コストを誰がどの ように負担するかについては検討する必要がある。

\section{（13）今後の研究の可能性}

STSS に対するRCT の実施が強く望まれる。 また，以下の内容に関する検討が求められるであろ う。

・本邦で認可された投与量（IVIG $5 \mathrm{~g} /$ 日 $\times 3$ 日間） による有効性の検証

・大量長期投与による有効性の検証

\section{文 献}

1) Prairie Collaborative Immune Globulin Utilization Management Framework Project: Criteria for the clinical use of immune globulin. Alberta Ministry of Health, Shared Health Manitoba, and Saskatchewan Ministry of Health; 2018.

2) National Blood Authority Australia: Criteria for the clinical use of intravenous immunoglobul in Australia Version 3; 2018.

3) Gilbert DN, Chambers HF, Eliopoulos GM, et al: The Sanford Guide to Antimicrobial Therapy 2019. Antimicrobial Therapy,
Inc. 2019.

4) Parks T, Wilson C, Curtis N, et al: Polyspecific intravenous immunoglobulin in clindamycin-treated patients with streptococcal toxic shock syndrome: A systematic review and metaanalysis. Clin Infect Dis. 2018; 67:1434-6.

5) Darenberg J, Ihendyane N, Sjölin J, et al: Intravenous Immunoglobulin G Therapy in Streptococcal Toxic Shock Syndrome: A European Randomized, Double-Blind, PlaceboControlled Trial. Clin Infect Dis. 2003; 37: 333-40.

6) Linner A, Darenberg J, Sjölin J, et al: Clinical efficacy of polyspecific intravenous immunoglobulin therapy in patients with streptococcal toxic shock syndrome: a comparative observational study. Clin Infect Dis. 2014; 59: 851-7.

7) Carapetis JR, Jacoby P, Carville K, et al: Effectiveness of clindamycin and intravenous immunoglobulin, and risk of disease in contacts, in invasive group a streptococcal infections. Clin Infect Dis. 2014; 59: 358-65.

8) Kaul R, McGeer A, Norrby-Teglund A, et al: Intravenous immunoglobulin therapy for streptococcal toxic shock syndrome-a comparative observational study. The Canadian Streptococcal Study Group. Clin Infect Dis. 1999; 28: 800-7.

9) Kadri SS, Swihart BJ, Bonne SL, et al: Impact of Intravenous Immunoglobulin on Survival in Necrotizing Fasciitis With Vasopressor-Dependent Shock: A Propensity Score-Matched Analysis From 130 US Hospitals. Clin Infect Dis. 2017; 64: 877-85.

Table 5-2-1-2 判断の要約

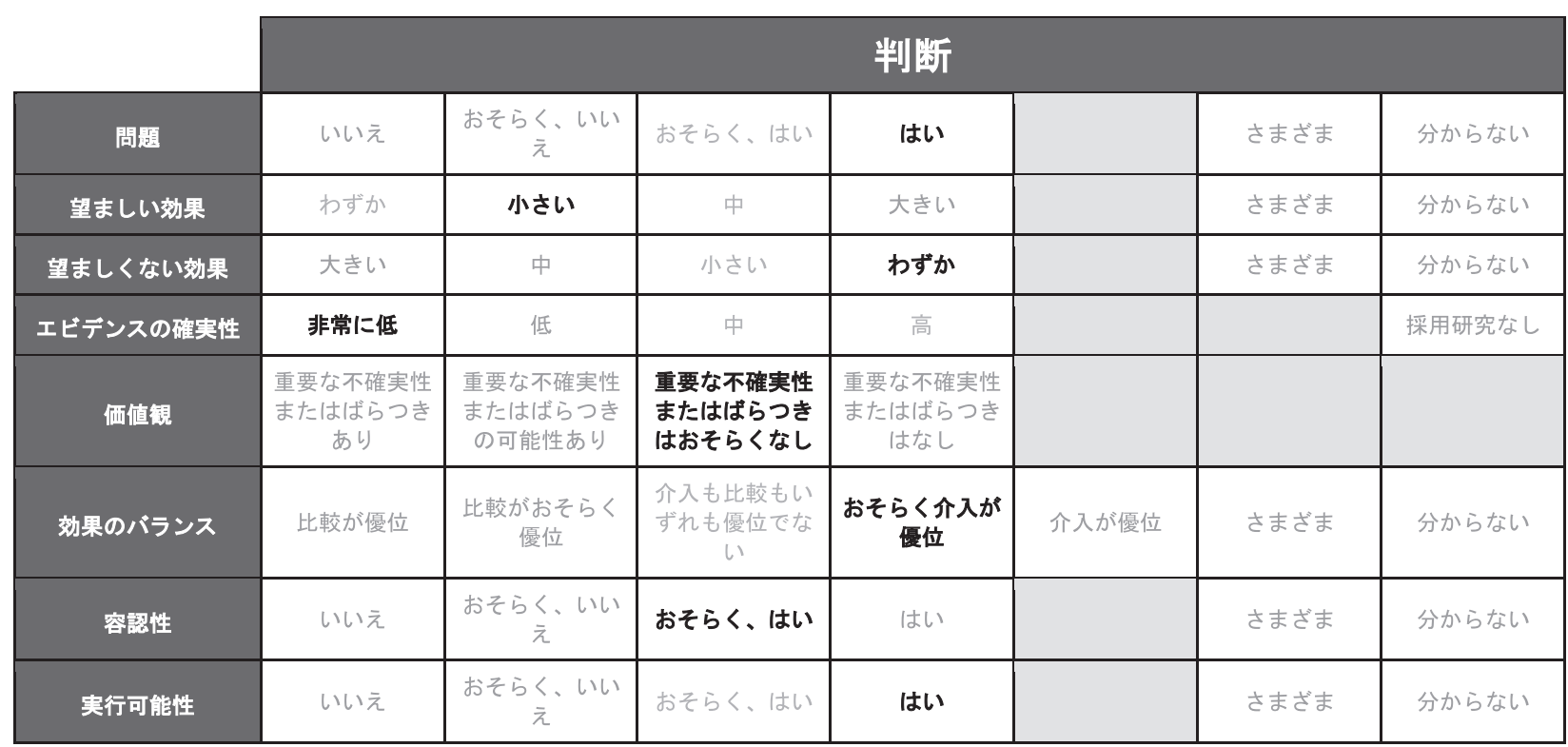


CQ5-2-2：毒素性ショック症候群（TSS）に対し て免疫グロブリン（IVIG）投与を行うか?

Answer : 毒素性ショック症候群（TSS）に対して, 免疫グロブリン（IVIG）投与を行わないことを弱く 推奨する（エキスパートコンセンサス：エビデンス不 十分）。

\section{（1）背景および本 $C Q$ の重要度}

敗血症は, 病原微生物の種類に依存しない重症感染 症であるが，特定の感染症では病原菌が産生する毒素 により特有の重症病態を呈する。黄色ブドウ球菌によ る毒素性ショック症候群（toxic shock syndrome: TSS） の病態には, 同菌が産生する外毒素が関与するとさ れ，毒素中和やサイトカイン産生抑制の作用を持つ IVIG が，両病態を改善する可能性が指摘されている。

TSS は急激に多藏器不全を呈し, 時に致死的とな る。そのため, 治療成績を向上させる介入法の確立は 急務である。欧米の診療指針などでは, STSSに対す る観察研究などの結果を基に TSS においても IVIG 投 与を推奨しているものもある1-3)。しかし, 現状では, IVIG 投与の有効性・有害性の評価は定まっておらず, 臨床現場でもその投与判断については多様性がある。 以上より, 本 $\mathrm{CQ}$ は重要度の高いものと考えられる。

(2) PICO

P (患者) : 黄色ブドウ球菌性敗血症（TSS を含む） の患者

I（介入）: IVIG 投与

C (対照)：プラセボ投与あるいは IVIG 非投与

$\mathrm{O}$ (アウトカム) : 全原因死亡 (全 RCT ・ 観察研究 対象), 全原因死亡 [クリンダマイシン (CLDM) 投与症例限定 $],$ ICU 滞在日数, あらゆる重篤な 副作用

（3）エビデンスの要約

システマティックレビューの結果, PICO に合致し た RCT，観察研究共に認めなかった。

（4）益と害のバランス

望ましい効果 :

TSS については, RCT, 観察研究共に認めなかった。 しかし, STSS と同様に細菌が産生する毒素が重症病 態の主要な原因であるため, IVIG が有効であると考 える専門家も多く, 効果はわずかにあると判断した。
望ましくない効果：

TSS における評価は不可能であったが，STSS の結 果を踏まえ，望ましくない効果はあったとしてもわず かと判断した。

益と害のバランス :

TSS については, RCT, 観察研究共に認めず，望ま しい効果を評価できなかった。望ましくない効果に関 しても同様に評価は不可能であったが，敗血症の結果 （CQ5-1）を踏まえ，望ましくない効果はあったとし てもわずかと考えられる。以上の結果より，効果のバ ランスは介入も比較対象もいずれも優位でないと判断 した。

（5）アウトカム全般に関するエビデンスの確実性 システマティックレビューを行ったが PICO に合致 する RCT, 観察研究は存在せず, 確実性の評価はで きなかった。

\section{（6）価值観}

TSS に対するIVIG 投与における, 各アウトカムに 置く患者・家族の価值観に関するデータはない。一般 的に死亡アウトカムに対して置く相対的価值は高く, そのばらつきは少ないことが予想される。

\section{（7）容認性}

有害事象のリスクが低い可能性が高い。本邦の保険 適用量を遵守した場合，介入に伴うコストは約 126,000 円（IVIG $5 \mathrm{~g}=$ 平均的な薬価約 42,000 円を 3 日間投与の場合）であり, 疾患の重篤性に鑑みると, 医療経済学的および患者・家族の視点からおそらく許 容できるであろう。また, IVIG 投与に伴う医療者の 仕事量増加はわずかであると考えられる。

\section{（8）実行可能性}

介入は多くの医療施設において実行可能である。

(9) 判断の要約（Table 5-2-2-1）

\section{（10）推奨グレーディング決定の工程}

修正 RAND 法を用いた投票によって, 中央值 7, 見解不一致指数 0.164 の結果となり, 委員会で採択さ れた（7 点以上 : $75 \%) 。$

（11）関連する他の診療ガイドラインにおける推奨

SSCG 2016, 日本版敗血症診療ガイドライン （J-SSCG）2016 のいずれにも推奨の記載はない。 
Table 5-2-2-1 判断の要約

\begin{tabular}{|c|c|c|c|c|c|c|c|}
\hline & \multicolumn{7}{|c|}{ 判断 } \\
\hline 問題 & いいえ & $\begin{array}{c}\text { おそらく、いい } \\
\text { え }\end{array}$ & おそらく、はい & はい & & さまざま & 分からない \\
\hline 望ましい勃果 & わずか & 小さい & 中 & 大きい & & さまざま & 分からない \\
\hline 望ましくない勃果 & 大きい & 中 & 小さい & わずか & & さまざま & 分からない \\
\hline エビデンスの確実性 & 非常に低 & 低 & 中 & 高 & & & 採用研究なし \\
\hline 価值観 & $\begin{array}{c}\text { 重要な不確実性 } \\
\text { またはばらつき } \\
\text { あり }\end{array}$ & $\begin{array}{c}\text { 重要な不確実性 } \\
\text { またはばらつき } \\
\text { の可能性あり }\end{array}$ & $\begin{array}{l}\text { 重要な不確実性 } \\
\text { またはばらつき } \\
\text { はおそらくなし }\end{array}$ & $\begin{array}{c}\text { 重要な不確実性 } \\
\text { またはばらつき } \\
\text { はなし }\end{array}$ & & & \\
\hline 効果のバランス & 比較が優位 & $\begin{array}{c}\text { 比較がおそらく } \\
\text { 優位 }\end{array}$ & $\begin{array}{c}\text { 介入も比較もい } \\
\text { ずれも優位でな } \\
\text { い }\end{array}$ & $\begin{array}{c}\text { おそらく介入が } \\
\text { 優位 }\end{array}$ & 介入が優位 & さまざま & 分からない \\
\hline 容認性 & いいえ & $\begin{array}{c}\text { おそらく、いい } \\
\text { え }\end{array}$ & おそらく、はい & はい & & さまざま & 分からない \\
\hline 実行可能性 & いいえ & おそらく、いい & おそらく、はい & はい & & さまざま & 分からない \\
\hline
\end{tabular}

\section{（12）実施に関わる検討事項}

TSS に対して標準的治療として IVIG 投与を行うこ とは好ましくないが，担当医の判断による重症患者へ の投与を否定するものではない。欧米の診療指針など で推奨されている IVIG 量（計 $2 \mathrm{~g} / \mathrm{kg}$ 前後）を使用し た場合，コストを誰がどのように負担するかについて は検討する必要がある。

\section{（13）今後の研究の可能性}

本病態に対する RCT の実施が望まれる。

また，以下の内容に関する検討が求められるであろ う。

・TSS に対する有効性の検証

・本邦で認可された投与量（IVIG $5 \mathrm{~g} /$ 日 $\times 3$ 日間） による有効性の検証

・大量長期投与による有効性の検証

\section{文 献}

1) Prairie Collaborative Immune Globulin Utilization Management Framework Project. Criteria for the clinical use of immune globulin. Alberta Ministry of Health, Shared Health Manitoba, and Saskatchewan Ministry of Health; 2018.

2) National Blood Authority Australia: Criteria for the clinical use of intravenous immunoglobul in Australia Version 3. 2018.

3) Gilbert DN, Chambers HF, Eliopoulos GM, et al: The Sanford Guide to Antimicrobial Therapy 2019. Antimicrobial Therapy Inc., 2019. 


\section{CQ6 : 初期蘇生 ·循環作動薬}

感染症に罹患すると, 生体防御反応として種々のメ ディエータが放出され, そのメディエータの働きによ り初期には末梢血管拡張に伴う相対的循環血液量の減 少が起こる。しかし, 敗血症性ショック症例の約半数 にびまん性左室壁運動低下（敗血症性心筋障害）が認 められるとの報告もあり ${ }^{1)}$, 敗血症性ショックは, 単 に末梢血管拡張に伴う血液分布異常性ショックだけで はなく, 循環血液量減少や心機能低下によるショック （循環血液量減少性ショック，心原性ショック）も合 併する複雑な病態を形成する。従来の敗血症性ショッ クに対する初期の治療戦略は, 相対的な循環血液量減 少に対する急速大量輸液が推奨されてきた2-4) が，心 機能低下症例に対する急速輸液負荷は病態を悪化させ る可能性がある。したがって, 敗血症性ショックに対 する, 迅速かつ適切な治療戦略を遂行するには初期蘇 生時において, 治療開始と同時に心機能・血行動態評 価を行う必要があると考え,「CQ6-1 : 敗血症患者に 対して心エコーを行うか?」を提示し検討を行った。

Rivers ら 5) が提唱した早期目標達成指向型管理法 （early goal-directed therapy: EGDT）とは，敗血症性 ショックに対して早期に組織酸素代謝バランスを改善 させる画期的なプロトコルである。EGDT の有用性に 関しては, 3 つの大規模ランダム化比較試験 (RCT) 6-8) において否定されたが，その後も多くの検証が引き続 き行われている。したがって, 敗血症性ショック治療 の根幹である初期蘇生法としての EGDT の有用性を 再検証する意義は大きいと考え，「CQ6-2：成人敗血 症患者の初期蘇生に対してEGDTを用いるか?」を 提示した。システマティックレビューを行う際の PICO の I（intervention）に関しては, Rivers ら5）が提 唱したオリジナルのEGDT [中心静脈血圧（central venous pressure: CVP) 8〜 $12 \mathrm{mmHg}$, 平均血圧 $\geqq$ $65 \mathrm{mmHg}$ を目標に, 大量輸液と血管収縮薬投与を行 い, 尿量 $\geqq 0.5 \mathrm{~mL} / \mathrm{kg} / \mathrm{hr}$, 中心静脈酸素飽和度 $\left(\mathrm{ScvO}_{2}\right)$ $\geqq 70 \%$ を 時間以内に達成する]に限定して検証を 行った。例えば, 輸液負荷の指標として CVPの代わ りに 1 回拍出量変動や, 組織酸素代謝の指標である $\mathrm{ScvO}_{2}$ の代わりに乳酸值を用いるような modified EGDTは含まれていない。一方, 3つの大規模 $\mathrm{RCT}^{6-8)}$ の結果は, EGDTによる死亡率の低下を示さ なかったが, EGDT の介入による有害事象は報告され ていない。つまり, 高い死亡率を示す敗血症性ショッ ク症例にどのようにアプローチすれば良いのかの指針 を必要とする臨床医に対しては, 施設の治療レベル,
敗血症性ショック例に対する経験度, 主治医やスタッ フの知識やスキルに合わせて EGDT や modified EGDT の使用を考慮してもさしつかえないと考える。

敗血症性ショックにおいて，急性期の臓器灌流を保 つために初期蘇生輸液は重要な位置を占めている。し かし, 敗血症性ショックに対し CVPを指標に輸液負 荷を行った臨床研究において, 輸液量が多い症例で予 後不良となることが報告され ${ }^{9)}$, 敗血症性ショックに 対する大量輸液療法は, 肺水腫などの合併症を増や し, 死亡率と関連していることも報告されている。日 本版敗血症診療ガイドライン（J-SSCG）2016 2,3) で は, 敗血症性ショックの初期蘇生輸液で目標とする臓 器灌流圧を維持できない場合には, 血管収縮薬の投与 を推奨しているが, どのタイミングで血管収縮薬を開 始すべきかについては, 一定の見解が得られていな い。そこで,「CQ6-3：成人敗血症患者に対して初期 蘇生輸液と同時または早期（3 時間以内）に血管収縮 薬を使用するか?」を提示した。しかし, 敗血症性 ショック症例に対しては, 低下した臓器血流や酸素供 給量を改善することが主要な治療戦略であるため, 循 環血液量が減少している状況での血管収縮薬の安易な 使用は厳に慎むべきである。

敗血症性ショックは,「敗血症により循環不全と細 胞機能や代謝の異常を呈する状態」であると定義さ れ, 細胞機能や代謝異常の評価は, 血清乳酸值で行う ことが示されている10)。一方, $\mathrm{ScvO}_{2}$ は組織酸素需 給バランスを示す指標であり, 血清乳酸值は, 嫌気的 代謝の指標として一般的に用いられてきた。敗血症に よる低灌流は, 血圧低下, 血清乳酸值の上昇からある 程度把握できる場合もあるが, 臓器灌流を維持できて いることを確認する指標として何が優れているかは, 一定の見解がない。そこで，「CQ6-4：成人敗血症患 者の初期蘇生の指標として乳酸值を用いるか?」を提 示した。

J-SSCG 2016 2,3) では,「敗血症による組織低灌流 と血管内容量減少のある患者に対し, 初期輸液は晶質 液を $30 \mathrm{~mL} / \mathrm{kg}$ 以上投与する」と記載されている。し かし, 3 つの大規模 RCT の結果において, 初期蘇生 輸液を積極的に推奨するEGDT 群では予後改善効果 が認められなかった。また, 輸液過剰の有害性9）も 報告されている。一方, 初期輸液の輸液速度や輸液量 を提示しておくことで, 臨床医は敗血症患者の診察を 行っている間や, 循環動態の評価をしている間でも, 遅れることなく初期治療を進めることができる。敗血 症性ショックの治療戦略において時間の概念は極めて 重要であるため, 初期輸液の輸液速度や輸液量を支持 
する正確なデータを示す文献はほとんどないが，成人 敗血症患者に対する初期輸液の輸液速度や輸液量を提 示することは重要と考え，「CQ6-5：成人敗血症患者 に対する初期輸液の輸液速度や輸液量は?」を BQ と して提示した。

初期の急速大量輸液療法の問題点は, 心機能低下症 例に対する急速輸液負荷が病態悪化を惹起させること である。そのため, 治療開始と同時に心エコーによる 心機能・血行動態評価を行い，さらなる輸液負荷を継 続する際には輸液反応性を評価することが重要であ る。輸液反応性とは $250 \sim 500 \mathrm{~mL}$ の輸液を投与した際 に心拍出量が有意（10～15\% 以上）に増加すること である ${ }^{11)}$ 。輸液反応性の予測モニタリングは静的指 標と動的指標に分けられ，静的指標とはある 1 点にお ける生体情報で, CVP, 肺動脈揳入圧, 経肺熱希釈法 による心臟拡張末期容量や胸腔内血液容量などがあ る。動的指標とは, 何らかの介入による変動を評価す る方法であり, 受動的下肢挙上法 (PLR) や輸液チャ レンジによる心拍出量の変化, 人工呼吸によって引き 起こされる前負荷の呼吸性変動を用いた脈圧変動や 1 回拍出量変動，エコーを用いた下大静脈径や上大静脈 径の変動, EEO (end - expiratory occlusion) test による 1 回拍出量の変化などがある。動的指標は, 静的指標 よりも輸液反応性の予測に優れている ${ }^{12)}$ が，自発呼 吸, 不整脈, 腹腔内圧上昇や右心不全がある場合や, 頻脈や肺コンプライアンスが低い場合は，变動が小さ くなることも報告されている13)。つまり，それぞれ のモニタリングの特徴を理解し, 適切なモニタリング を選択したうえで, 必要に応じて複数のモニタリング を使用することが望ましい。このような観点から， 「CQ 6-6：成人敗血症患者の輸液反応性をどのように

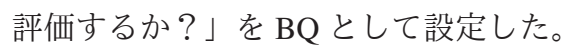

SSCG 20164) では, 敗血症または敗血症性ショック 患者の初期蘇生において相当量の晶質液輸液を必要と する場合には, 晶質液に加えアルブミンを使用するこ とが弱く提案されている。J-SSCG 2016 2,3) では, 敗 血症患者の初期蘇生において，アルブミンをルーチン に使用しないことを推奨しているが，初期蘇生におい て多量の晶質液を必要とする場合や，低アルブミン血 症が認められる場合には，アルブミン使用を考慮する としている。しかし, 敗血症の初期蘇生輸液としての アルブミン使用については，一定の見解がないため, 敗血症/敗血症性ショックにおいて, 初期蘇生輸液の 標準的な輸液製剂としてアルブミンを用いるべきかを 明らかにするため,「CQ6-7：成人敗血症患者の初期 輸液にアルブミン製剤を投与するか?」を提示した。
また，標準的な輸液として人工膠質液を用いるかに関 しては, 「CQ6-8 : 成人敗血症患者の初期輸液に人工 膠質液を投与するか?」」を提示した。

J-SSCG 2016"2３）およびSSCG 20164）では，敗血症 の初期蘇生における血管収縮薬の第一選択薬はノルア ドレナリンが推奨されているが，それはノルアドレナ リンがドパミンより血管収縮作用が強く, 敗血症性 ショック患者における低血圧からの回復に効果的であ ることや，ドパミンと比較して頻脈や不整脈を起こし

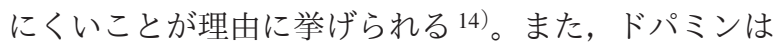
視床下部一下垂体系を介して内分泌の応答に影響を与 え，免疫抑制作用を示すことなども報告されてい る15)。一方，SSCG 20164）では頻脈を呈していない患 者に限ってはドパミンの使用も弱く推奨している。ま た，J-SSCG 20162，3）は十分なエビデンスがなく推奨 を見送られた純粋な $\alpha_{1}$ アドレナリン受容体アゴニス トであるフェニレフリンに関しては, そこで,「CQ6-9： 成人敗血症患者に対する血管収縮薬の第一選択として ノルアドレナリン，ドパミン，フェニレフリンのどれ を使用するか?」をを提示した。J-SSCG 2016 2, 3) およ びSSCG 20164) では, 敗血症の初期蘇生においてノル アドレナリンの昇圧効果が十分でない場合の第二選択 としてアドレナリンおよびバソプレシンが推奨されて いる。しかし，アドレナリン，バソプレシンとも十分 なエビデンスはなく, 第二選択薬についてのコンセン サスは得られていないため,「CQ6-10-1：成人敗血症 患者に対する血管収縮薬の第二選択としてアドレナリ ンを使用するか?」」を提示した。また，「CQ6-10-2： 成人敗血症患者に対する血管収縮薬の第二選択として バソプレシンを使用するか?」を提示した。

敗血症性ショックでは sepsis induced myocardial dysfunction（SIMD）と呼ばれる心機能障害が約 40\% の患者に合併し, 重症化との関連が示唆されてい る16)。SIMD を合併している敗血症性ショックでは, 血管収縮薬のノルアドレナリンに加え, 強心薬である ドブタミンやアドレナリンの投与が行われてきたが, その効果に対してはまだ議論も多い。J-SSCG $2016^{2,3)}$ では敗血症性ショックの心機能不全に対し てドブタミンを推奨し，SSCG 20164）でも十分な輸液 と昇圧薬の投与によっても循環動態が改善しない敗血 症に対してドブタミンを推奨するとしているが，いず れも十分なエビデンスに基づいた推奨ではなく, 敗血 症性ショックの心機能不全に対する強心薬の使用の可 否は敗血症の初期蘇生において重要であるため, 「CQ6-11：心原性ショックを伴う成人敗血症患者に対 して強心薬を使用するか?」を提示した。 
敗血症性ショックにおける従来の治療戦略は，主に 初期輸液とカテコラミンを含む血管収縮薬, 強心薬の 投与であった。近年，敗血症性ショックの頻脈（頻 拍）に対して心拍数のコントロールを目的に $\beta_{1}$ アド レナリン受容体遮断薬投与の効果を検討した複数の研 究があり, 初期蘇生における循環動態の改善や必要輸 液量の減少，短期死亡の減少などの報告がある 17, 18)。 これは従来の治療戦略を見直すきっかけともなり, 将 来の標準治療ともなりうるため,「CQ6-12：成人敗血 症患者に対して $\beta$ 遮断薬を使用するか?」を提示し た。最近，本邦から $\beta$ 遮断薬に関する多施設 RCT が 報告された19）が，今回のシステマティックレビュー およびメタ解析には含まれていない。

敗血症性ショックでは, SIMD と呼ばれる心機能障 害を発症し，心拍出量が低下する病態を呈することが 知られている1）。最近, 重篤な心機能低下を呈する成 人敗血症患者に対して補助循環装置 [veno-arterial extracorporeal membrane oxygenation (V-A ECMO), intra-aortic balloon pumping (IABP) など] の使用が効 果的であったとする報告 20 , 21）が散見されるが，有効 性に関するエビデンスは明確ではないため, 「CQ6-13：成人敗血症性ショック患者に対する補助循

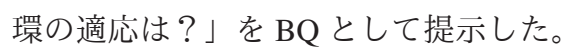

本ガイドラインで示した敗血症性ショックに対する 初期蘇生・循環作動薬に関する推奨度やエキスパート コンセンサスは，これまで報告された RCT からシス
テマティックレビューし, そのメタ解析の結果をもと に示した一般的な指針である。しかし，それは施設の 治療経験, 主治医やスタッフの知識やスキルの程度で 大いに変わることもある。そのことも理解したうえ で，本ガイドラインで示した初期蘇生・循環作動薬の Clinical question \& Answer を診療フローとともにうま く活用していただきたい。治療において時間の概念は 重要であり, “Sepsis is an emergency”を理解し，常に スピード感をもって初期蘇生・循環作動薬を使いこな すことが重要である。

\section{文 献}

1) Vieillard-Baron A: Septic cardiomyopathy. Ann Intensive Care. 2011; $1: 6$.

2）西田修, 小倉裕司, 井上茂亮, 他, 日本版敗血症診療ガイドラ イン 2016 作成特別委員会. 日本版敗血症診療ガイドライン 2016. 日集中医誌. 2017; 24: S1-232.

3）西田修, 小倉裕司, 井上茂亮, 他, 日本版敗血症診療ガイドラ イン 2016 作成特別委員会. 日本版敗血症診療ガイドライン 2016. 日救急医会誌. 2017; 28: S1-232.

4) Rhodes A, Evans LE, Alhazzani W, et al: Surviving Sepsis Campaign: International Guidelines for Management of Sepsis and Septic Shock: 2016. Intensive Care Med. 2017; 43: 304-77.

5) Rivers E, Nguyen B, Havstad S, et al: Early goal-directed therapy in the treatment of severe sepsis and septic shock. N Engl J Med. 2001; 345: 1368-77.

6) Yealy DM, Kellum JA, Huang DT, et al: A randomized trial of protocol-based care for early septic shock. N Engl J Med. 2014; 370: $1683-93$

7) Peake SL, Delaney A, Bailey M, et al: Goal-directed resuscitation for patients with early septic shock. N Engl J Med. 2014; 371: 1496-506.

8) Mouncey PR, Osborn TM, Power GS, et al: Trial of early,

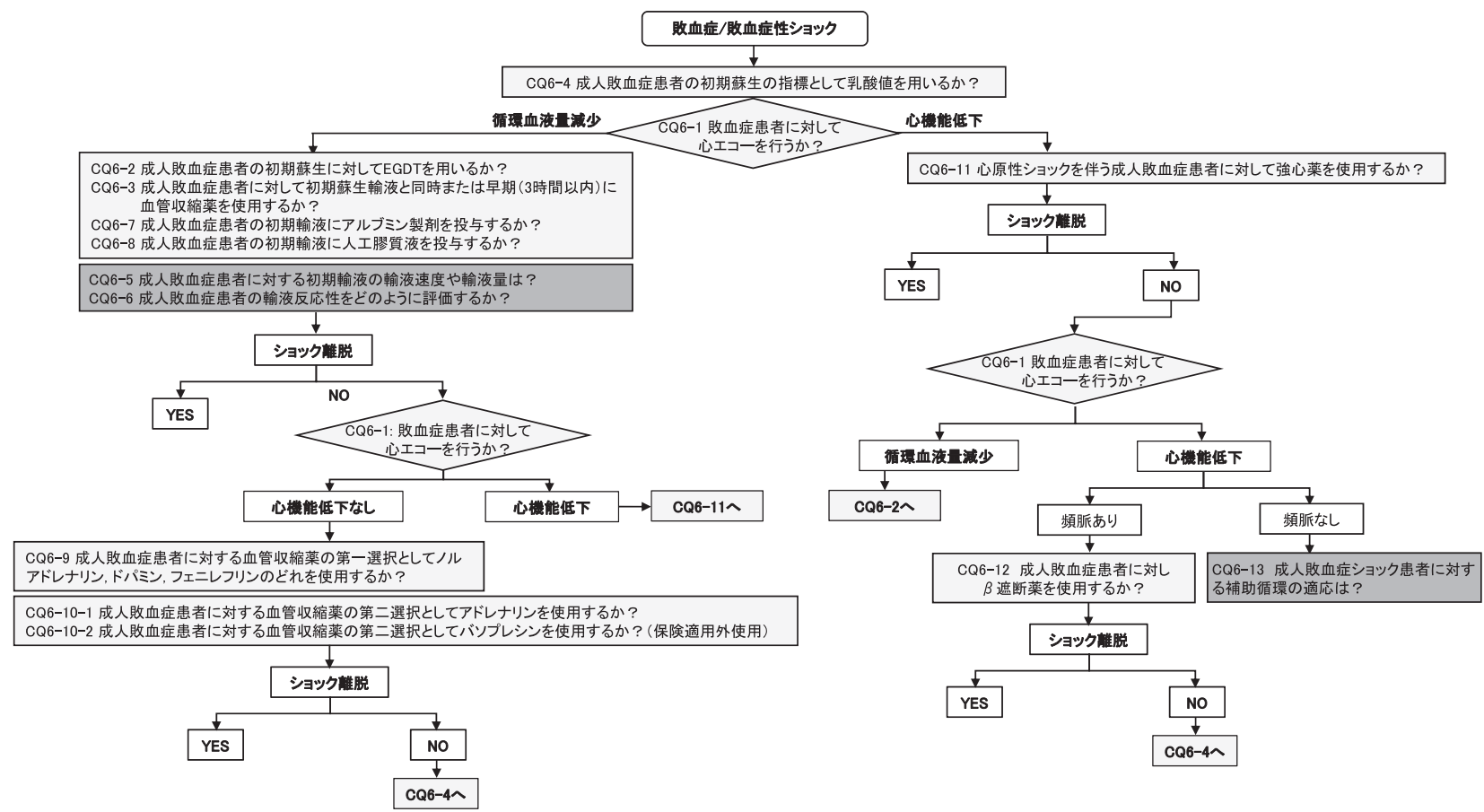

初期蘇生・循環作動薬〔診療フロー〕 
goal-directed resuscitation for septic shock. N Engl J Med. 2015; 372: 1301-11.

9) Boyd JH, Forbes J, Nakada TA, et al: Fluid resuscitation in septic shock: a positive fluid balance and elevated central venous pressure are associated with increased mortality. Crit Care Med. 2011; 39: 259-65.

10) Singer M, Deutschman CS, Seymour CW, et al: The Third International Consensus Definitions for Sepsis and Septic Shock (Sepsis-3). JAMA. 2016; 315: 801-10.

11) Cecconi M, De Backer D, Antonelli M, et al: Consensus on circulatory shock and hemodynamic monitoring. Task force of the European Society of Intensive Care Medicine. Intensive Care Med. 2014; 40: 1795-815.

12) Vincent JL, Weil MH: Fluid challenge revisited. Crit Care Med. 2006; 34: 1333-7.

13) Eskesen TG, Wetterslev M, Perner A: Systematic review including re-analyses of 1148 individual data sets of central venous pressure as a predictor of fluid responsiveness. Intensive Care Med. 2016; 42: 324-32.

14) De Backer D, Biston P, Devriendt J, et al: Comparison of dopamine and norepinephrine in the treatment of shock. N Engl J Med. 2010; 362: 779-89.

15) Beck GCh, Brinkkoetter P, Hanusch C, et al: Clinical review: immunomodulatory effects of dopamine in general inflammation. Crit Care. 2004; 8: 485-91..

16) Kakihana $Y$, Ito $T$, Nakahara $M$, et al: Sepsis-induced myocardial dysfunction: pathophysiology and management. J Intensive Care. 2016; 4: 22

17) Morelli A, Ertmer C, Westphal M, et al: Effect of heart rate control with esmolol on hemodynamic and clinical outcomes in patients with septic shock: a randomized clinical trial. JAMA. 2013; 310: 1683-91.

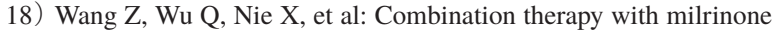
and esmolol for heart protection in patients with severe sepsis: a prospective, randomized trial. Clin Drug Investig. 2015; 35: 707-16.

19) Kakihana $Y$, Nishida $O$, Taniguchi $T$, et al: Efficacy and safety of landiolol, an ultra-short-acting $\beta_{1}$-selective antagonist, for treatment of sepsis-related tachyarrhythmia (J-Land 3S): a multicentre, open-label, randomised controlled trial. Lancet Respir Med. 2020; 8: 863-72

20) Bréchot N, Luyt CE, Schmidt M, et al: Venoarterial extracorporeal membrane oxygenation support for refractory cardiovascular dysfunction during severe bacterial septic shock. Crit Care Med. 2013; 41: 1616-26.

21) Falk L, Hultman J, Broman LM: Extracorporeal membrane oxygenation for septic shock. Crit Care Med. 2019; 47: 1097-105.
CQ6-1：敗血症患者に対して心エコーを行う か?

Answer : 敗血症/敗血症性ショック患者に対して, 初 期蘇生中に心エコーを用いた心機能・血行動態評価を 行うことを弱く推奨する（GRADE 2D : エビデンスの 確実性 $=\lceil$ 非常に低」)。

\section{（1）背景および本 $C Q$ の重要度}

敗血症/敗血症性ショックは, 未梢血管拡張に伴う 血液分布異常性ショックが本態をなす疾患である。そ の一方で, 循環血液量減少, 心機能低下によるショッ ク（循環血液量減少性ショック，心原性ショック）も 合併し, 複雑な病態を形成しうる。したがって, 初期 蘇生時において心エコーを用いた心機能・血行動態評 価を行うことは臨床的に重要なことであるため, 重要 臨床課題として取り上げた。

(2) PICO

P (患者) : 成人, 敗血症/敗血症性ショック患者

I (介入) : 初期蘇生時に心エコーを用いた心機能・ 血行動態評価を行う

C (対照) : 初期蘇生時に心エコーを用いた心機能・ 血行動態評価を行わない

O (アウトカム ) : 短期死亡（28 日死亡)，ICU 滞在 日数

\section{（3）エビデンスの要約}

システマティックレビューの結果，PICO に合致し た研究は 1 本の feasibility study であるランダム化比較 試験（RCT）が 1 件 1）あり，これを用いたメタ解析 を実施した。本研究の内容は心エコーを用いた特定の プロトコルによる介入の有効性を検討している。サン プル数も小さく，結論を裏づけるエビデンスには乏し い。

\section{（4）益と害のバランス（Table 6-1-1）}

\section{望ましい効果 :}

短期死亡のアウトカム（1 RCT: $\mathrm{n}=30 ）$ の効果推 定值とその信頼区間は，1,000 人あたり 134 人多い （104 人少ない 952人多い）であり，ICU 滞在日数の アウトカム（1 RCT: $\mathrm{n}=30 ）$ の効果推定値とその信 頼区間は，平均（MD） 0.3 日短い（4.46日短い〜3.86 日長い）であった。ただし，対象となった研究の数も サンプル数も不十分であるため, 効果判定はできない と判断した。 
Table 6-1-1エビデンスプロファイル

\begin{tabular}{|c|c|c|c|c|c|c|c|c|c|c|c|c|}
\hline \multicolumn{7}{|c|}{ 確実性の評価 } & \multicolumn{2}{|c|}{ 患者数 } & \multicolumn{2}{|c|}{ 効果 } & \multirow[b]{2}{*}{ 確実性 } & \multirow[b]{2}{*}{ 重要性 } \\
\hline 研究数 & $\begin{array}{c}\text { 研究 } \\
\text { デザイン }\end{array}$ & $\begin{array}{l}\text { バイアス } \\
\text { のリスク }\end{array}$ & 非一貫性 & 非直接性 & 不精確性 & $\begin{array}{l}\text { その他 } \\
\text { の検討 }\end{array}$ & [介入]Echo & [比較] other & $\begin{array}{c}\text { 相対指標 } \\
(95 \% \mathrm{CI})\end{array}$ & $\begin{array}{l}\text { 絶対指標 } \\
(95 \% \mathrm{CI})\end{array}$ & & \\
\hline \multicolumn{13}{|c|}{28 日死亡 } \\
\hline 1 & RCT & 深刻 a & 深刻でないb & 深刻でない & 非常に深刻。 & なし & $5 / 15 \quad(33.3 \%)$ & $3 / 15 \quad(20.0 \%)$ & $\begin{array}{c}\text { RR } 1.67 \\
(0.48 \text { to } 5.76)\end{array}$ & $\begin{array}{c}1,000 \text { 人あたり } 134 \\
\text { 人多い (104 人少 } \\
\text { ない 952 人多 } \\
\text { い) }\end{array}$ & $\begin{array}{l}\oplus \bigcirc \bigcirc \bigcirc \\
\text { 非常に低 }\end{array}$ & 重大 \\
\hline \multicolumn{13}{|c|}{ ICU 滞在日数 } \\
\hline 1 & $\mathrm{RCT}$ & 深刻 a & 深刻でないb & 深刻でない & 非常に深刻 c & なし & 15 & 15 & - & $\begin{array}{c}\text { 平均 } 0.3 \text { 日短い } \\
\text { (4.46 日短い } \\
3.86 \text { 日長い) }\end{array}$ & $\begin{array}{l}\oplus \bigcirc \bigcirc \bigcirc \\
\text { 非常に低 }\end{array}$ & 重大 \\
\hline
\end{tabular}

a. 1 本のサンプルサイズの小さいRCT の可能性試験のため。

b. 1 本の可能性試験のため評価困難。

c. サンプルサイズ，信頼区間。

* 長期死亡，あら中る重篤な副作用に関する報告なし。

\section{望ましくない効果 :}

今回，検索で得られた 1 本の RCT では望ましくな い効果に対する検討は行われていないため, 効果判定 はできないと判断した。

益と害のバランス :

本 CQ において，短期死亡に関しては比較対照が優 位な傾向を示し，ICU 滞在日数に関しては介入が優位 な傾向を示した。しかし，今回，検索で得られた研究 はサンプル数が少ない 1 本の RCT のみであり, 効果 のバランスは判定できない。

\section{（5）アウトカム全般に関するエビデンスの確実性}

今回, 検索で得られた研究はサンプル数が少ない 1 本の RCT のみである。今回報告されたアウトカムの 確実性がいずれも非常に低いため，エビデンスの確実 性は「非常に低」と判断した。

\section{（6）価値観}

心エコーを用いた初期蘇生に関して患者・家族の価 值観に関するデータはない。一般的に，死亡アウトカ ムに対して置く相対的価值は高く，そのばらつきは少 ないことが予想される。

\section{（7）容認性}

心エコーは非侵襲的・簡便な検査であり, 患者への 負担は小さい。心エコーの機器が必要であり, 機器を 有さない施設での施行は, 高額な機器の購入を要す る。心エコーに不慣れな施設や医療従事者には, 教育 やトレーニングが必要であり, 初期蘇生の段階で心エ コーを行うことは医療従事者に若干の負担となる。

（8）実行可能性

本邦の多くの医療施設では心エコーが可能な機器を
有している。心エコーを用いた心機能や循環の評価 は，集中治療を行う本邦の医療施設では広く行われて おり，介入の実施は可能である。

（9）判断の要約（Table 6-1-2）

（10）推奨グレーディング決定の工程

修正 RAND 法を用いた投票によって, 中央值 8, 見解不一致指数 0.164 の結果となり，委員会で採択さ れた（7 点以上 : $83.3 \%) 。$

\section{（11）関連する他の診療ガイドラインにおける推奨}

SSCG 20162）では，初期および治療への継続的な評 価を推奨しており，その方法の1つとしてベッドサイ ドでのエコー検査施行を best practice statement として 提示している。

\section{（12）実施に関わる検討事項}

心エコーを実施する医療従事者の技量によって，結 果にばらつきが出る恐れがあるため，実施に際しては 一定のトレーニングや教育を要する。

\section{（13）今後の研究の可能性}

以下の内容に関する検討が求められると考えられる。

・RCT によるエビデンスの蓄積

・ 心エコーを用いた特定のプロトコルの有効性

\section{文 献}

1) Lanspa MJ, Burk RE, Wilson EL, et al: Echocardiogram-guided resuscitation versus early goal-directed therapy in the treatment of septic shock: A randomized, controlled, feasibility trial. J Intensive Care. 2018; 6: 50.

2) Rhodes A, Evans LE, Alhazzani W, et al: Surviving Sepsis Campaign: International Guidelines for Management of Sepsis and Septic Shock: 2016. Intensive Care Med. 2017; 43: 304-77. 
日集中医誌 J Jpn Soc Intensive Care Med Vol. 28 Suppl

Table 6-1-2 判断の要約

\begin{tabular}{|c|c|c|c|c|c|c|c|}
\hline & \multicolumn{7}{|c|}{ 判断 } \\
\hline 問題 & いいえ & $\begin{array}{c}\text { おそらく、いい } \\
\text { え }\end{array}$ & おそらく、はい & はい & & さまざま & 分からない \\
\hline 望ましい効果 & わずか & 小さい & 中 & 大きい & & さまざま & 分からない \\
\hline 望ましくない勃果 & 大きい & 中 & 小さい & わずか & & さまざま & 分からない \\
\hline エビデンスの確実性 & 非常に低 & 低 & 中 & 高 & & & 採用研究なし \\
\hline 価值観 & $\begin{array}{c}\text { 重要な不確実性 } \\
\text { またはばらつき } \\
\text { あり }\end{array}$ & $\begin{array}{c}\text { 重要な不確実性 } \\
\text { またはばらつき } \\
\text { の可能性ありり }\end{array}$ & $\begin{array}{l}\text { 重要な不確実性 } \\
\text { またはばらつき } \\
\text { はおそらくなし }\end{array}$ & $\begin{array}{c}\text { 重要な不確実性 } \\
\text { またはばらつき } \\
\text { はなし }\end{array}$ & & & \\
\hline 効果のバランス & 比較が優位 & $\begin{array}{c}\text { 比較がおそらく } \\
\text { 優位 }\end{array}$ & $\begin{array}{c}\text { 介入も比較も } \\
\text { いずれも優位で } \\
\text { ない }\end{array}$ & $\begin{array}{c}\text { おそらく介入が } \\
\text { 優位 }\end{array}$ & 介入が優位 & さまざま & 分からない \\
\hline 容認性 & いいえ & $\begin{array}{c}\text { おそらく、いい } \\
\text { え }\end{array}$ & おそらく、はい & はい & & さまざま & 分からない \\
\hline 実行可能性 & いいえ & $\begin{array}{c}\text { おそらく、いい } \\
\text { え }\end{array}$ & おそらく、はい & はい & & さまざま & 分からない \\
\hline
\end{tabular}


CQ6-2：成人敗血症患者の初期蘇生に対して EGDTを用いるか?

Answer：敗血症/敗血症性ショック患者に対して，初 期蘇生としてEGDTを行わないことを弱く推奨する (GRADE 2C：エビデンスの確実性 $=「$ 低」）。

\section{（1）背景および本 CQの重要度}

敗血症/敗血症性ショックにおいて, 急性期の藏器 灌流を保つために初期蘇生は重要な役割を担ってい る。初期蘇生において EGDTに従った管理方法は, 通常の管理方法と比較して必ずしも優れていない可能 性が 3 つの大規模ランダム化比較試験（RCT）で示さ れたが，その後も EGDTの有用性に関しては多くの 検証が引き続き行われている。したがって，敗血症治 療の根幹を示す初期蘇生の具体的方法を設定する EGDT の有用性を検証する意義は大きいと考える。

\section{(2) PICO}

P (患者) : 成人, 敗血症/敗血症性ショック患者

I（介入）：EGDTによる初期蘇生（Rivers らが提唱 したオリジナルEGDTのみを対象とする。 Modified EGDT は含まない)

C (対照) : 標準治療による初期蘇生

$\mathrm{O}$ (アウトカム ) : 短期死亡（28 日もしくは 30 日死 亡)，長期死亡（90日死亡；90日死亡がない場合 は最長を用いることを考慮する), ICU 滞在日数, あらゆる重篤な副作用

\section{（3）エビデンスの要約}

システマティックレビューの結果，PICO に合致し た RCT が 4 件施行 ${ }^{1-4)}$ されており，これらを用いた メタ解析を実施した。Riversらの RCT は，オリジナ ルの EGDT ${ }^{1)}$ の臨床効果を検証した RCTである。 ProMISe 試験 2）およびARISE 試験 4）は，EGDT 施行 群と通常治療群の比較であるのに対し, ProCESS 試 験3）は EGDT 施行群，EGDT ほどの厳格ではないプ ロトコルを遵守した標準治療群，および通常治療群の 3 群比較試験である。短期死亡はすべての RCT で, 長期死亡, ICU 滞在日数, 重篤な副作用は ProMISe 試験 2), ARISE 試験 4), ProCESS 試験 3）で評価され ていた。その結果，EGDTにおける望ましい効果と望 ましくない効果は対照と比べて, 共に限定的であっ た。

(4) 益と害のバランス（Table 6-2-1）

望ましい効果：

短期死亡のアウトカム（4 RCT: $\mathrm{n}=3,993 ）$ の効果 推定值とその信頼区間は， 1,000 人あたり 8 人少ない (32 人少ない〜 17 人多い), 長期死亡のアウトカム $(3$ RCT: $\mathrm{n}=3,648 ）$ の効果推定值とその信頼区間は, 1,000 人あたり 5 人少ない（31 人少ない〜26人多い), $\mathrm{ICU}$ 帯在日数のアウトカム（3 RCT: $\mathrm{n}=3,737 ）$ の効 果推定值とその信頼区間は，平均（MD）0.22 日長い （0.13 日短い〜0.58 日長い）であり，EGDTによる初 期蘇生の望ましい効果は限定的であると判断した。

Table 6-2-1エビデンスプロファイル

\begin{tabular}{|c|c|c|c|c|c|c|c|c|c|c|c|c|}
\hline \multicolumn{7}{|c|}{ 確実性の評価 } & \multicolumn{2}{|c|}{ 患者数 } & \multicolumn{2}{|c|}{ 効果 } & \multirow[b]{2}{*}{ 確荑性 } & \multirow[b]{2}{*}{ 重要性 } \\
\hline 研究数 & $\begin{array}{c}\text { 研究 } \\
\text { デザイン }\end{array}$ & $\begin{array}{l}\text { ハイイアス } \\
\text { のリスク }\end{array}$ & 非一貫性 & 非直接性 & 不精確性 & $\begin{array}{l}\text { その他 } \\
\text { の检討 }\end{array}$ & EGDT [介入] & $\begin{array}{c}\text { Usual Care } \\
\text { [比較] }\end{array}$ & $\begin{array}{l}\text { 相対指標 } \\
(95 \% \text { cI) }\end{array}$ & $\begin{array}{l}\text { 緢対指標 } \\
(95 \% \text { CI }\end{array}$ & & \\
\hline \multicolumn{13}{|c|}{ 短期死亡（28 もしくは 30 日死亡） } \\
\hline 4 & $\mathrm{RCT}$ & 深刻でない & 深刻a & 深刻でない & 深刻でない & なし & $\begin{array}{c}403 / 1,986 \\
(20.3 \%)\end{array}$ & $\begin{array}{c}425 / 2,007 \\
(21.2 \%)\end{array}$ & $\begin{array}{l}\text { RR } 0.96 \\
(0.85 \text { to } \\
1.08)\end{array}$ & $\begin{array}{c}1,000 \text { 人あた } \\
\text { り } 8 \text { 人少ない } \\
\text { (32 少ない } \\
17 \text { 人多い) }\end{array}$ & $\begin{array}{c}\oplus \oplus \oplus \bigcirc \\
\text { 中 }\end{array}$ & 重大 \\
\hline \multicolumn{13}{|c|}{ 長期死亡（90 日死亡） } \\
\hline 3 & RCT & 深刻でない & 深刻でない & 深刻でない & 深刻でない & なし & $\begin{array}{c}460 / 1,820 \\
(25.3 \%)\end{array}$ & $\begin{array}{c}470 / 1,828 \\
(25.7 \%)\end{array}$ & $\begin{array}{c}\text { RR } 0.98 \\
(0.88 \text { to } \\
1.10)\end{array}$ & $\begin{array}{c}1,000 \text { 人あた } \\
\text { り } 5 \text { 人少ない } \\
(31 \text { 人少ない } \\
26 \text { 人多い) }\end{array}$ & 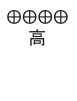 & 重大 \\
\hline
\end{tabular}

ICU 滞在日数

\begin{tabular}{|c|c|c|c|c|c|c|c|c|c|c|c|c|}
\hline 3 & RCT & 深刻でない & 深刻a & 深刻でない & 深刻でない & なし & 1,857 & 1,880 & - & $\begin{array}{c}\text { 平均 } 0.22 \text { 日 } \\
\text { 長い } \\
(0.13 \text { 日短い } \\
0.58 \text { 日長い }\end{array}$ & $\begin{array}{c}\oplus \oplus \oplus \bigcirc \\
\text { 中 }\end{array}$ & 重大 \\
\hline \multicolumn{13}{|c|}{ あらゆる重篤な副作用 } \\
\hline 3 & RCT & 深刻でない & 深刻 a & 深刻でない & 深刻 b & なし & $\begin{array}{c}109 / 1,856 \\
(5.9 \%)\end{array}$ & $\begin{array}{c}105 / 1,878 \\
(5.6 \%)\end{array}$ & $\begin{array}{l}\text { RR } 1.02 \\
(0.66 \text { to } \\
1.57)\end{array}$ & $\begin{array}{c}1,000 \text { 人あた } \\
\text { り } 1 \text { 人多い } \\
\text { (19人少ない } \\
32 \text { 人多い) }\end{array}$ & $\underset{\text { 低 }}{\oplus \oplus \bigcirc \bigcirc}$ & 重大 \\
\hline
\end{tabular}

a. 異質性あり，点推定值も異なる研究あり。

b. イベント数が少なく、95\%CI も広く、臨床的決断の閾值をまたいでいる。 
望ましくない効果 :

あらゆる重篤な副作用（3 RCT: $\mathrm{n}=3,734 ）$ の効果 推定值とその信頼区間は，1,000 人あたり 1 人の増加 （19人少ない 32 人多い）であり，EGDTによる初期 蘇生の望ましくない効果は限定的であると判断した。

益と害のバランス :

望ましい効果と望ましくない効果の正味のバランス は 1,000 人あたり 12 人，介入が優位であり，短期死 亡および長期死亡のアウトカムに対する相対的価值を 考慮すると，効果のバランスは EGDTによる介入が わずかに比較を上回る可能性がある。しかし，死亡ア ウトカムの不確実性を考慮し，信頼区間の最も悪い值 を採用すると 1,000 人あたり 44 人，害のほうが大き くなる。以上より, 効果のバランスとしては介入も比 較対照もいずれも優位でないとした。

\section{（5）アウトカム全般に関するエビデンスの確実性}

今回採用したすべてのアウトカムの効果推定值の方 向性は一致していないため, 一番低い確実性を全体の 確実性として採用した。以上より，アウトカム全体に わたるエビデンスの確実性は「低」とした。

\section{（6）価値観}

EGDT による初期蘇生に対する価值観や意向に対す るエビデンスはない。一般的に患者や家族の死亡に対 する相対的価值は高いと考えられ，そのばらつきは少 ないことが予想される。

\section{（7）容認性}

オリジナルの EGDT を行うためには，中心静脈カ テーテルを挿入して中心静脈圧と中心静脈血酸素飽和 度をモニタリングすることや，赤血球輸血が必要と なってくる。より侵襲や負担が少ない modified EGDT が提唱される現在，中心静脈カテーテルを挿入し，中 心静脈圧と中心静脈血酸素飽和度をモニタリングする ことは医療従事者への負担，患者への負担となるた め, 容認され難いと考える。赤血球輸血についても患 者・家族の考え方は様々であり，容認されないことも ありうる。

\section{（8）実行可能性}

EGDT は本邦の多くの集中治療室で実行可能と考え られるが，中心静脈血酸素飽和度のモニタリング機器 がない施設では実行は困難であることが予想される。

(9) 判断の要約（Table 6-2-2）

（10）推奨グレーディング決定の工程

修正 RAND 法を用いた投票によって，中央值 7.5, 見解不一致指数 0.164 の結果となり，委員会で採択さ れた（7 点以上: $95.8 \%) 。$

\section{（11）関連する他の診療ガイドラインにおける推奨} SSCG 2016 5) においては上記の ProMISe 試験 2), ARISE 試験 ${ }^{4)}$ ，ProCESS 試験3) の結果を受けて, 解 説中に EGDT に従ってはならないわけではないと記 載しつつも，推奨から削除されている。日本版敗血症

Table 6-2-2 判断の要約

\begin{tabular}{|c|c|c|c|c|c|c|c|}
\hline & \multicolumn{7}{|c|}{ 半判断 } \\
\hline 問題 & いいえ & $\begin{array}{c}\text { おそらく、いい } \\
\text { え }\end{array}$ & おそらく、はい & はい & & さまざま & 分からない \\
\hline 望ましい効果 & わずか & 小さい & 中 & 大きい & & さまざま & 分からない \\
\hline 望ましくない効果 & 大きい & 中 & 小さい & わずか & & さまざま & 分からない \\
\hline エビデンスの確実性 & 非常に低 & 低 & 中 & 高 & & & 採用研究なし \\
\hline 価值䘽 & $\begin{array}{c}\text { 重要な不確実性 } \\
\text { またははららつ } \\
\text { あり }\end{array}$ & $\begin{array}{c}\text { 重要な不確実性 } \\
\text { またはばらつき } \\
\text { の可能性あり }\end{array}$ & $\begin{array}{l}\text { 重要な不確実性 } \\
\text { またはばらつき } \\
\text { はおそらくなし }\end{array}$ & $\begin{array}{c}\text { 重要な不確実性 } \\
\text { またはばらつき } \\
\text { はなし }\end{array}$ & & & \\
\hline 勃果のバランス & 比較が優位 & $\begin{array}{c}\text { 比較がおそらく } \\
\text { 優位 }\end{array}$ & $\begin{array}{c}\text { 介入も比較もい } \\
\text { ずれも優位でな } \\
\text { い }\end{array}$ & $\begin{array}{c}\text { おそらく介入が } \\
\text { 優位 }\end{array}$ & 介入が優位 & さまざま & 分からない \\
\hline 容認性 & いいえ & $\begin{array}{c}\text { おそらく、いい } \\
\text { え }\end{array}$ & おそらく、はい & はい & & さまざま & 分からない \\
\hline 実行可能性 & いいえ & $\begin{array}{c}\text { おそらく、いい } \\
\text { え }\end{array}$ & おそらく、はい & はい & & さまざま & 分からない \\
\hline
\end{tabular}


診療ガイドライン (J-SSCG) 2016 6,7) においても「敗 血症, 敗血症性ショックの初期蘇生に EGDT を実施 しないことを弱く推奨する（2A)」とされている。

\section{（12）実施に関わる検討事項}

オリジナルの EGDTに代わる初期蘇生プロトコル の導入, または慎重なモニタリングと評価による初期 蘇生を行うことが必要である。

\section{（13）今後の研究の可能性}

今後, modified EGDT の有効性の検証, 初期輸液製 剂の最適な使用方法の検証, 輸血製剂の初期輸液にお ける最適な使用方法の検証, 輸液反応性の最適な方法 の検証が行われることが望まれる。

\section{文 献}

1) Rivers E, Nguyen B, Havstad S, et al: Early goal-directed therapy in the treatment of severe sepsis and septic shock. N Engl J Med. 2001; 345: 1368-77.

2) Mouncey PR, Osborn TM, Power GS, et al: Trial of early, goaldirected resuscitation for septic shock. N Engl J Med. 2015; 372 1301-11.

3) ProCESS Investigators, Yealy DM, Kellum JA, et al: A randomized trial of protocol-based care for early septic shock. N Engl J Med. 2014; 370: 1683-93.

4) ARISE Investigators, ANZICS Clinical Trials Group, Peake SL, et al: Goal-directed resuscitation for patients with early septic shock. N Engl J Med. 2014; 371: 1496-506.

5) Rhodes A, Evans LE, Alhazzani W, et al: Surviving Sepsis Campaign: International Guidelines for Management of Sepsis and Septic Shock: 2016. Intensive Care Med. 2017; 43: 304-77.

6）西田修, 小倉裕司, 井上茂亮, 他, 日本版敗血症診療ガイドラ イン 2016 作成特別委員会. 日本版敗血症診療ガイドライン 2016. 日集中医誌. 2017; 24: S1-232.

7）西田修, 小倉裕司, 井上茂亮, 他, 日本版敗血症診療ガイドラ イン 2016 作成特別委員会. 日本版敗血症診療ガイドライン 2016. 日救急医会誌. 2017; 28: S1-232.
CQ6-3：成人敗血症患者に対して初期蘇生輸液 と同時または早期（3 時間以内）に血管収縮薬を 使用するか？

Answer : 循環動態の維持が困難な敗血症/敗血症性 ショック患者に対して, 初期蘇生輸液と同時または早 期（3 時間以内）に血管収縮薬を投与することを弱く 推奨する (GRADE $2 \mathrm{C}$ : エビデンスの確実性 $=\lceil$ 低」)。

\section{（1）背景および本 $C Q$ の重要度}

敗血症/敗血症性ショックにおいて, 急性期の藏器 灌流を保つために初期蘇生輸液は重要な位置を占めて いる。初期蘇生輸液のみで目標とする臓器灌流圧を維 持できない場合は，血管収縮薬の投与が必要である。 しかし，どのタイミングから血管収縮薬を開始すべき かについては，一定の見解が得られていない。過剩輸 液は肺水腫などの合併症を増やし, 死亡とも関連して いる。早期に血管収縮薬を投与することで，過剩輸液 を減らし予後を改善する可能性があるため, この疑問 を明らかにすることは重要である。

\section{(2) PICO}

$\mathrm{P}$ (患者) : 成人, 敗血症/敗血症性ショック患者

I (介入) : 初期蘇生輸液と同時または早期（3 時間 以内）に血管収縮薬を使用

$\mathrm{C}$ (対照) : 初期蘇生輸液のみ

$\mathrm{O}$ (アウトカム) : 短期死亡 (28 日死亡), 長期死亡 (90 日もしくは最長期間死亡), 重篤な有害事象 （肺水腫，心筋虚血に関連する合併症）

\section{（3）エビデンスの要約}

システマティックレビューの結果, PICO に合致した ランダム化比較試験（RCT）が 2 件施行 ${ }^{1,2}$ 2) れてい た。Macdonald ら 1) の RCT は血管収縮薬を用いて輸 液量を制限するレジメンを検討した非盲検の多施設 RCT であり, Permpikul ら2) の RCT は発症 1 時間以内 の敗血症性ショック患者を対象に,ノルアドレナリン $0.05 \mu \mathrm{g} / \mathrm{kg} / \mathrm{min}$ 持続投与とプラゼボを比較検討した単施 設盲検化 RCT である。これら $2 つ の \mathrm{RCT}$ を用いたメ タ解析を実施した。

\section{（4）益と害のバランス（Table 6-3-1）}

\section{望ましい効果 :}

短期死亡のアウトカム（2 RCT: $\mathrm{n}=408 ）$ の効果推 定值とその信頼区間は，1,000人あたり 39 人少ない （88 人少ない 38 人多い), 長期死亡のアウトカム $(2$ 
Table 6-3-1エビデンスプロファイル

\begin{tabular}{|c|c|c|c|c|c|c|c|c|c|c|c|c|}
\hline \multicolumn{7}{|c|}{ 碓夷性の評価 } & \multicolumn{2}{|c|}{ 患者数 } & \multicolumn{2}{|c|}{ 奻果 } & \multirow[b]{2}{*}{ 確実性 } & \multirow[b]{2}{*}{ 重要性 } \\
\hline 研究数 & $\begin{array}{c}\text { 研究 } \\
\text { デザイン }\end{array}$ & $\begin{array}{l}\text { バイアス } \\
\text { のリスク }\end{array}$ & 非一貫性 & 非直接性 & 不精確性 & $\begin{array}{l}\text { その他 } \\
\text { の検討 }\end{array}$ & $\begin{array}{c}\text { 早期血管収 } \\
\text { 縮薬使用 }\end{array}$ & $\begin{array}{l}\text { 従来の補液 } \\
\text { による容至 } \\
\text { 負荷を主体 } \\
\text { とした治療 }\end{array}$ & $\begin{array}{l}\text { 相対指標 } \\
(95 \% \text { Cl) }\end{array}$ & $\begin{array}{l}\text { 絶対指標 } \\
(95 \% \text { I })\end{array}$ & & \\
\hline \multicolumn{13}{|c|}{ 短期死亡（28 日死亡） } \\
\hline 2 & RCT & 深刻でない & 深刻 a & 深刻でない & 深刻 b & なし & $\begin{array}{l}27 / 204 \\
(13.2 \%)\end{array}$ & $\begin{array}{l}35 / 204 \\
(17.2 \%)\end{array}$ & $\begin{array}{c}\text { RR } 0.77 \\
\text { (0.49 to } 1.22)\end{array}$ & $\begin{array}{c}1,000 \text { 人あた } \\
\text { り } 39 \text { 人少な } \\
\text { い } \\
\text { (88 人少ない } \\
38 \text { 人多い) }\end{array}$ & $\begin{array}{c}\oplus \oplus \bigcirc \bigcirc \\
\text { 低 }\end{array}$ & 重大 \\
\hline
\end{tabular}

長期死亡（90日もしくは最長期間死亡）

\begin{tabular}{|c|c|c|c|c|c|c|c|c|c|c|c|c|}
\hline 2 & RCT & 深刻でない & 深刻でない & 深刻でない & 深刻 c & なし & $\begin{array}{l}39 / 203 \\
(19.2 \%)\end{array}$ & $\begin{array}{l}41 / 202 \\
(20.3 \%)\end{array}$ & $\begin{array}{c}\text { RR } 0.95 \\
\text { (0.64 to } 1.40)\end{array}$ & $\begin{array}{c}1,000 \text { 人あた } \\
\text { り } 10 \text { 人少な } \\
\text { い } \\
\text { (73 人少ない } \\
81 \text { 人多い) }\end{array}$ & $\begin{array}{c}\oplus \oplus \bigcirc \bigcirc \\
\text { 低 }\end{array}$ & 重大 \\
\hline
\end{tabular}

\begin{tabular}{|c|c|c|c|c|c|c|c|c|c|c|c|c|}
\hline 2 & RCT & 深刻でない & 深刻でない & 深刻でない & 深刻 b & なし & $\begin{array}{l}23 / 205 \\
(11.2 \%)\end{array}$ & $\begin{array}{l}44 / 204 \\
(21.6 \%)\end{array}$ & $\begin{array}{c}\text { RR } 0.52 \\
(0.33 \text { to } 0.82)\end{array}$ & $\begin{array}{c}1,000 \text { 人あた } \\
\text { り } 104 \text { 人少な } \\
\text { い } \\
\text { (145 人少ない } \\
39 \text { 人少ない) }\end{array}$ & $\begin{array}{c}\oplus \oplus \oplus \bigcirc \\
\text { 中 }\end{array}$ & 重大 \\
\hline
\end{tabular}

心筋虚血に関連する合併症

\begin{tabular}{|c|c|c|c|c|c|c|c|c|c|c|c|}
\hline 2 & RCT & 深刻でない & 深刻でない & 深刻でない & 非常に深刻 & なし & $\begin{array}{c}7 / 205 \\
(3.4 \%)\end{array}$ & $\begin{array}{c}4 / 204 \\
(2.0 \%)\end{array}$ & $\begin{array}{c}\text { RR } 1.74 \\
(0.52 \text { to 5.86) }\end{array}$ & $\begin{array}{c}1,000 \text { 人あた } \\
\text { り 15 人多い } \\
\text { (9人少ない } \\
95 \text { 人多い) }\end{array}$ & $\begin{array}{c}\oplus \oplus O 0 \\
\text { 低 }\end{array}$ \\
\hline
\end{tabular}

a. I が 36\%と中等度の異質性があり，点推定値との相違が大きい。

b. 最適情報量を満たさない。

c. 最適情報量を满たしておらず, $95 \% \mathrm{Cl}$ が臨床決断の閾值を跨ぐため, 2 段階グレードダウンした。

RCT: $\mathrm{n}=405 ）$ の効果推定值とその信頼区間は，1,000 人あたり 10 人少ない（73 人少ない〜 81 人多い）だっ た。有害事象として, 肺水腫のアウトカム（2 RCT: n =409）の効果推定值とその信頼区間は，1,000人あ たり 104 人少ない（145人少ない〜39人少ない）で あった。以上より，介入による望ましい効果は「中」 と判断した。

望ましくない効果 :

有害事象として，心筋虚血のアウトカム（2 RCT: n =409）の効果推定值とその信頼区間は，1,000人あ たり 15 人多い（9人少ない〜95人多い）であり，望 ましくない効果はわずかと判断した。

益と害のバランス :

正味の効果は 1,000 人あたり 138 人，介入の望まし い効果が上回る。死亡アウトカムの相対的価值を 3 倍 とし，短期死亡に関する不確実性を考慮して信頼区間 の最悪值（1,000人あたり 38 人多い）で検討した場 合， 1,000 人あたり 15 人，害が上回る。以上より，効 果のバランスは「おそらく介入が優位」と判断した。

（5）アウトカム全般に関するエビデンスの確実性

各アウトカムで効果は異なる方向性を示していたた め，最も低いエビデンスである「低」を採用した。

\section{（6）価値観}

各アウトカムに置く患者・家族の価值観に関する データはない。一般的に死亡アウトカムに対して置く 相対的価值は高く，ばらつきは少ないことが予想され る。

\section{（7）容認性}

敗血症患者の初期蘇生において，血管収縮薬を投与 することは, 既に広く行われている治療であり，投与 のタイミングを初期蘇生輸液と同時または早期（3 時 間以内）にすることは容認されると考えるが，同時に 行う処置や薬剤の準備を増やすため，医療従事者に とっては負担が増す可能性がある。

\section{（8）実行可能性}

本邦の集中治療室であれば，介入は問題なく実行可 能であると考えるが, 初期蘇生輸液を開始するのが集 中治療室以外の場合には困難が予想される。

(9) 判断の要約 (Table 6-3-2)

（10）推奨グレーディング決定の工程

修正 RAND 法を用いた投票によって，中央值 8, 見解不一致指数 0.014 の結果となり委員会で採択と 
Table 6-3-2 判断の要約

\begin{tabular}{|c|c|c|c|c|c|c|c|}
\hline & \multicolumn{7}{|c|}{ 半彞 } \\
\hline 問題 & いいえ & $\begin{array}{c}\text { おそらく、いい } \\
\text { え }\end{array}$ & おそらく、はい & はい & & さまざま & 分からない \\
\hline 望ましい効果 & わずか & 小さい & 中 & 大きい & & さまざま & 分からない \\
\hline 望ましくない効果 & 大きい & 中 & 小さい & わずか & & さまざま & 分からない \\
\hline エビデンスの確実性 & 非常に低 & 低 & 中 & 高 & & & 採用研究なし \\
\hline 価值覞 & $\begin{array}{c}\text { 重要な不確実性 } \\
\text { またはばらつき } \\
\text { あり }\end{array}$ & $\begin{array}{c}\text { 重要な不確実性 } \\
\text { またはばらつき } \\
\text { の可能性あり }\end{array}$ & $\begin{array}{l}\text { 重要な不確実性 } \\
\text { またはばらつき } \\
\text { はおそらくなし }\end{array}$ & $\begin{array}{c}\text { 重要な不確実性 } \\
\text { またはばらつき } \\
\text { はなし }\end{array}$ & & & \\
\hline 効果のパランス & 比較が優位 & $\begin{array}{c}\text { 比較がおそらく } \\
\text { 優位 }\end{array}$ & $\begin{array}{c}\text { 介入も比較もい } \\
\text { ずれも優位でな } \\
\text { い }\end{array}$ & $\begin{array}{c}\text { おそらく介入が } \\
\text { 優位 }\end{array}$ & 介入が優位 & さまざま & 分からない \\
\hline 容認性 & いいえ & $\begin{array}{c}\text { おそらく、いい } \\
\text { え }\end{array}$ & おそらく、はい & はい & & さまざま & 分からない \\
\hline 実行可能性 & いいえ & 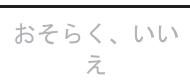 & おそらく、はい & はい & & さまざま & 分からない \\
\hline
\end{tabular}

なった（7 点以上 : $95.8 \%) 。$

\section{（11）関連する他の診療ガイドラインにおける推奨}

日本版敗血症診療ガイドライン（J-SSCG）2016 3 ,4) では，敗血症性ショックにおいて血管内容量減少のあ る患者の初期輸液は, 細胞外液補充液を $30 \mathrm{~mL} / \mathrm{kg}$ 以 上投与することを推奨しており，SSCG 2016 5) では, 低灌流を認める敗血症患者に対して 3 時間以内に $30 \mathrm{~mL} / \mathrm{kg}$ 以上の晶質液の投与を推奨しているが，輸液 量と昇圧薬開始の時期に関する記載はない。また，昇 圧薬の投与を必要とする敗血症患者では, 初期の目標 平均血圧として $65 \mathrm{mmHg}$ を推奨するとしているが, どのタイミングから血管収縮薬を開始すべきかについ ての記載はない。

\section{（12）実施に関わる検討事項}

早期に血管収縮薬を投与した場合の薬剤投与量およ び輸液速度と量は，検討を要する。また，血管内用量 が不足している場合は，十分な初期蘇生輸液を投与す る必要があり，輸液開始を優先する。

\section{（13）今後の研究の可能性}

血管収縮薬の選択，投与量，タイミングなどは不明 であり，これらを明らかにするための研究が必要であ る。また, 有害事象として, 心筋以外の蔵器虚血は評 価できていない。

\section{文 献}

1) Macdonald SPJ, Keijzers G, Taylor DM, et al: Restricted fluid resuscitation in suspected sepsis associated hypotension (REFRESH): a pilot randomised controlled trial. Intensive Care Med. 2018; 44: 2070-8.

2) Permpikul C, Tongyoo S, Viarasilpa $T$, et al: Early use of norepinephrine in septic shock resuscitation (CENSER) a randomized trial. Am J Respir Crit Care Med. 2019; 199: 1097-105.

3）西田修, 小倉裕司, 井上茂亮, 他, 日本版敗血症診療ガイドラ イン 2016 作成特別委員会. 日本版敗血症診療ガイドライン 2016. 日集中医誌. 2017; 24: S1-232.

4）西田修, 小倉裕司, 井上茂亮, 他, 日本版敗血症診療ガイドラ イン 2016 作成特別委員会. 日本版敗血症診療ガイドライン 2016. 日救急医会誌. 2017; 28: S1-232.

5) Rhodes A, Evans LE, Alhazzani W, et al: Surviving Sepsis Campaign: International Guidelines for Management of Sepsis and Septic Shock: 2016. Crit Care Med. 2017; 45: 486-552. 
CQ6-4：成人敗血症患者の初期蘇生の指標とし て乳酸値を用いるか?

Answer: 敗血症/敗血症性ショックの患者に対して, 初期蘇生の指標として乳酸值を用いることを弱く推奨 する（GRADE 2C: エビデンスの確実性 $=「$ 低」）。

\section{（1）背景および本 $C Q$ の重要度}

敗血症/敗血症性ショックにおいて, 急性期の臟器 灌流を保つために初期蘇生は重要な役割を担ってい る。しかし, 臟器灌流を維持できていることを確認す る指標として何が優れているかは，一定の見解がな い。このため, 最適な評価指標を探索することは臨床 現場において重要な課題である。

\section{(2) PICO}

P (患者) : 成人, 敗血症/敗血症性ショック患者

I（介入）: 乳酸值，乳酸クリアランスを指標とする

$\mathrm{C}$ (対照): 乳酸值以外 (平均血圧, 尿量, $\mathrm{ScvO}_{2} / \mathrm{SvO}_{2}$ のいずれか 1 つ以上）を指標とする

$\mathrm{O}$ (アウトカム ) : 短期死亡（28日もしくは 30 日死 亡), 長期死亡 (90 日死亡), ICU 滞在日数, 重 篤な副作用（72 時間後の SOFA スコア）

\section{（3）エビデンスの要約}

システマティックレビューの結果，PICO に合致し たランダム化比較試験（RCT）が 5 件施行 ${ }^{1-5)}$ されて いた。Hernández ら 1) の RCT は, 成人の早期敗血症 性ショック患者の初期蘇生において, 乳酸值と末梢循
環のいずれを指標とするのが死亡率を改善するかを評 価した RCT である。Jansen ら 2) の RCT は，集中治療 室入室時に高乳酸血症（3.0mEq/L 以上）を呈する患 者において, 乳酸值を指標とした初期蘇生と, 中心静 脈血酸素飽和度 $\left(\mathrm{ScvO}_{2}\right)$ や未梢循環など乳酸值以外 を指標とした初期蘇生のいずれが死亡率を改善するか を評価した RCT である。Jones ら3) の RCT は，末梢 循環障害を呈する重症敗血症/敗血症性ショック患者 において，乳酸クリアランスと $\mathrm{ScvO}_{2}$ のいずれを指 標とした初期蘇生が院内死亡率を改善するかを評価し た RCT である。Puskarich ら 4) の RCT は，敗血症患 者の初期蘇生において, 乳酸クリアランスと $\mathrm{ScvO}_{2}$ のいずれを指標とするのが死亡率を改善するかを評価 したRCT である。Zhou ら5)の RCT は，敗血症によ る高乳酸血症を呈する患者において, 乳酸クリアラン スと $\mathrm{ScvO}_{2}$ のいずれを指標とした初期蘇生が死亡率 を改善するかを評価した RCT である。これら 5 つの RCT を用いたメタ解析を実施した。

\section{（4）益と害のバランス（Table 6-4-1）}

望ましい効果 :

短期死亡のアウトカム（5 RCT: $\mathrm{n}=1,479 ）$ の効果 推定値とその信頼区間は， 1,000 人あたり 62 人少ない (133人少ない 43 人多い), 長期死亡のアウトカム （2 RCT: $\mathrm{n}=772 ）$ の効果推定值とその信頼区間は, 1,000 人あたり 21 人少ない（147 人少ない〜 159 人多 い), ICU 滞在日数のアウトカム (3 RCT: $\mathrm{n}=1,084)$ の効果推定值とその信頼区間は，平均（MD）0.03日 長い（0.66日短い〜 0.72 日長い）であった。このた

Table 6-4-1エビデンスプロファイル

\begin{tabular}{|c|c|c|c|c|c|c|c|c|c|c|c|c|}
\hline \multicolumn{7}{|c|}{ 確実性の評価 } & \multicolumn{2}{|c|}{ 患者数 } & \multicolumn{2}{|c|}{ 奻果 } & \multirow[b]{2}{*}{ 碓奏性 } & \multirow[b]{2}{*}{ 重要性 } \\
\hline 研究数 & $\begin{array}{l}\text { 研究 } \\
\text { テザイン }\end{array}$ & $\begin{array}{l}\text { パイアス } \\
\text { のリスク }\end{array}$ & 非一面性 & 非直接性 & 不精破性 & $\begin{array}{l}\text { その他 } \\
\text { の榙討 }\end{array}$ & 眊酸值を指槽 & $\begin{array}{l}\text { 孚酸值以外を } \\
\text { 指塂 }\end{array}$ & $\begin{array}{l}\text { 相対指檈 } \\
(95 \% \text { CI }\end{array}$ & $\begin{array}{l}\text { 䋓対指摫 } \\
(95 \% \text { (I) }\end{array}$ & & \\
\hline \multicolumn{13}{|c|}{ 短期死亡（28 日もしくは 30 日死亡） } \\
\hline 5 & RCT & 深刻でない & 深刻 a & 深刻でない & 深刻 b & なし & $204 / 738(27.6 \%)$ & $\begin{array}{l}230 / 741 \\
(31.0 \%)\end{array}$ & $\begin{array}{l}\text { RR } 0.80 \\
(0.57 \text { to } \\
1.14)\end{array}$ & \begin{tabular}{|c|}
1,000 人あたり \\
62 人少ない \\
$(133$ 人少ない \\
$\sim 43$ 人多い
\end{tabular} & $\underset{\text { 低 }}{\oplus \oplus \bigcirc}$ & 重大 \\
\hline \multicolumn{13}{|c|}{ 長期死亡 (90 日死亡) } \\
\hline 2 & RCT & 深刻でない & 深刻 & 深刻でない & 深刻 b & なし & $156 / 383(40.7 \%)$ & $\begin{array}{l}163 / 389 \\
(41.9 \%)\end{array}$ & $\begin{array}{l}\text { RR } 0.95 \\
(0.65 \text { to } \\
1.38)\end{array}$ & \begin{tabular}{|c|}
1,000 人あたり \\
21 人少ない \\
$(147$ 人少ない \\
$\sim 159$ 人多い) \\
\end{tabular} & $\underset{\text { 低 }}{\oplus \oplus \bigcirc O}$ & 重大 \\
\hline \multicolumn{13}{|c|}{ ICU 滞在日数 } \\
\hline 3 & RCT & 深刻でない & 深刻でない & 深刻でない & 深刻 b & なし & 542 & 542 & - & $\begin{array}{c}\text { 平均 } 0.03 \text { 日 } \\
\text { 長い } \\
(0.66 \text { 日短い } \\
\sim 0.72 \text { 日長 } \\
\text { ( ) }\end{array}$ & $\begin{array}{c}\oplus \oplus \oplus \bigcirc \\
\text { 中 }\end{array}$ & 重大 \\
\hline \multicolumn{13}{|c|}{ 重篤な副作用（72 時間後のSOFA スコア） } \\
\hline 3 & RCT & 深刻てない & 深刻 a & 深刻でない & 深刻 b & なし & 487 & 492 & - & \begin{tabular}{|c|} 
平均 0.04 高い \\
$(0.88$ 低い \\
0.96 高(い) \\
\end{tabular} & $\underset{\text { 低 }}{\oplus \oplus \bigcirc O}$ & 重大 \\
\hline
\end{tabular}

a. $I^{2}$ 高値。

b. 効果推定值の $95 \%$ CI に効果なしと相当の利益/害の両方を含む。 
め，乳酸值を指標とした初期蘇生の望ましい効果は小 さいと判断した。

望ましくない効果 :

重篤な副作用（72 時間後の SOFA スコア）のアウ トカム（3 RCT: $\mathrm{n}=979 ）$ の効果推定值とその信頼区 間は, MD 0.04 高い（0.88 低い〜0.96 高い）であった。 このため, 乳酸值を指標とした初期蘇生の望ましくな い効果はわずかと判断した。

益と害のバランス :

死亡アウトカムに対する相対的価值が高いことを考 慮すると, 効果のバランスは「おそらく介入が優位」 と判断した。

（5）アウトカム全般に関するエビデンスの確実性

今回採用したすべてのアウトカムの効果推定值の方 向性は一致していないため, 一番低い確実性を全体の 確実性として採用した。アウトカム全体にわたるエビ デンスの確実性は「低」である。

\section{（6）価値観}

初期蘇生に対する患者・家族の価值観に関するエビ デンスはない。一般的に死亡に対する相対的価值は高 いと考えられ, そのばらつきは少ないことが予想される。

\section{（7）容認性}

乳酸值の測定ができない施設では，実施に際して検 査機器と試薬の準備が必要になる。医療者の仕事量も 増加するが, わずかであり, 容認されると考えた。

\section{（8）実行可能性}

乳酸值の測定は, 本邦の多くの医療施設において実 行可能である。

(9) 判断の要約 (Table 6-4-2)

（10）推奨グレーディング決定の工程

修正 RAND 法を用いた投票によって，中央值 8, 見解不一致指数 0.146 の結果となり, 委員会で採択さ れた（7 点以上 : 100\%)。

\section{（11）関連する他の診療ガイドラインにおける推奨}

SSCG 2016 6) では, 組織灌流障害の指標である乳酸 值が上昇している患者には, 乳酸值の正常化を図る蘇 生治療をすることを弱く推奨している。日本版敗血症 診療ガイドライン（J-SSCG）20167,8）では，敗血症患 者における初期蘇生において, 経時的に乳酸值を測定 することを弱く推奨している。

\section{（12）実施に関わる検討事項}

乳酸值の測定に必要な血液はわずかであるが，頻繁 な採血による貧血には配慮が必要である。

\section{（13）今後の研究の可能性}

今後, 乳酸值を指標にする際の適切なカットオフ值 の設定, 乳酸值と他の検査法を組み合わせた場合の有 効性, 乳酸值を低下させるための介入方法の探索など を行うことが望まれる。

Table 6-4-2 判断の要約

\begin{tabular}{|c|c|c|c|c|c|c|c|}
\hline & \multicolumn{7}{|c|}{ 半判济 } \\
\hline 問題 & いいえ & $\begin{array}{c}\text { おそらく、いい } \\
\text { え }\end{array}$ & おそらく、はい & はい & & さまざま & 分からない \\
\hline 望ましい效果 & わずか & 小さい & 中 & 大きい & & さまざま & 分からない \\
\hline 望ましくない効果 & 大きい & 中 & 小さい & わずか & & さまざま & 分からない \\
\hline エビデンスの確実性 & 非常に低 & 低 & 中 & 高 & & & 採用研究なし \\
\hline 価值钼 & $\begin{array}{c}\text { 重要な不確実性 } \\
\text { またははらつつき } \\
\text { あり }\end{array}$ & $\begin{array}{c}\text { 重要な不確実性 } \\
\text { またはばらつき } \\
\text { の可能性ありり }\end{array}$ & $\begin{array}{l}\text { 重要な不確実性 } \\
\text { またはばらつき } \\
\text { はおそらくなし }\end{array}$ & $\begin{array}{c}\text { 重要な不確実性 } \\
\text { またはばらつき } \\
\text { はなし }\end{array}$ & & & \\
\hline 勃果のパランス & 比較が優位 & $\begin{array}{c}\text { 比較がおそらく } \\
\text { 優位 }\end{array}$ & $\begin{array}{c}\text { 介入も比較もい } \\
\text { ずれも優位でな } \\
\text { い }\end{array}$ & $\begin{array}{c}\text { おそらく介入が } \\
\text { 優位 }\end{array}$ & 介入が優位 & さまざま & 分からない \\
\hline 容認性 & いいえ & $\begin{array}{c}\text { おそらく、いい } \\
\text { え }\end{array}$ & おそらく、はい & はい & & さまざま & 分からない \\
\hline 実行可能性 & いいえ & $\begin{array}{c}\text { おそらく、いい } \\
\text { え }\end{array}$ & おそらく、はい & はい & & さまざま & 分からない \\
\hline
\end{tabular}




\section{文 献}

1) Hernández G, Ospina-Tascón GA, Damiani LP, et al: Effect of a Resuscitation Strategy Targeting Peripheral Perfusion Status vs Serum Lactate Levels on 28-Day Mortality among Patients with Septic Shock: The ANDROMEDA-SHOCK Randomized Clinical Trial. JAMA. 2019; 321: 654-64.

2) Jansen TC, van Bommel J, Schoonderbeek FJ, et al: Early lactateguided therapy in intensive care unit patients: A multicenter, open-label, randomized controlled trial. Am J Respir Crit Care Med. 2010; 182: 752-61.

3) Jones AE, Shapiro NI, Trzeciak S, et al: Lactate clearance vs central venous oxygen saturation as goals of early sepsis therapy: A randomized clinical trial. JAMA. 2010; 303: 739-46.

4) Puskarich MA, Trzeciak S, Shapiro NI, et al: Prognostic value and agreement of achieving lactate clearance or central venous oxygen saturation goals during early sepsis resuscitation. Acad Emerg Med. 2012; 19: 252-8.

5) Zhou X, Liu D, Su L, et al: Use of stepwise lactate kineticsoriented hemodynamic therapy could improve the clinical outcomes of patients with sepsis-associated hyperlactatemia. Crit Care. 2017; 21: 33.

6) Rhodes A, Evans L, Alhazzani W, et al: Surviving Sepsis Campaign: International Guidelines for Management of Sepsis and Septic Shock: 2016. Intensive Care Med. 2017; 43: 304-77.

7）西田修, 小倉裕司, 井上茂亮, 他, 日本版敗血症診療ガイドラ イン 2016 作成特別委員会. 日本版敗血症診療ガイドライン 2016. 日集中医誌. 2017; 24: S1-232.

8）西田修, 小倉裕司, 井上茂亮, 他, 日本版敗血症診療ガイドラ イン 2016 作成特別委員会. 日本版敗血症診療ガイドライン 2016. 日救急医会誌. 2017; 28: S1-232.
CQ6-5：成人敗血症患者に対する初期輸液の輸 液速度や輸液量は?

Answer：血管内容量減少のある敗血症患者の初期輸 液は，循環血液量を適正化することを目標とし，晶質 液 $30 \mathrm{~mL} / \mathrm{kg}$ 以上を 3 時間以内に投与することが必要 との意見がある。初期輸液の最中はバイタルサインを 注意深く観察し，乳酸クリアランスや心エコーなどを 用いて組織酸素代謝や血行動態評価を行いながら過剩 な輸夜負荷を避けることが重要である（BQ に対する 情報提示)。

\section{（1）背景および本 $C Q$ の重要度}

日本版敗血症診療ガイドライン (J-SSCG) 2016 1,2) では, 「敗血症による組織低灌流と血管内容量減少の ある患者に対し, 初期輸液は晶質液を $30 \mathrm{~mL} / \mathrm{kg}$ 以上投 与する」と記載されている。しかし，2014 年，2015 年 に相次いで報告された 3 つの大規模ランダム化比較試 験（RCT）（ProCESS $\left.{ }^{3)}, \mathrm{ARISE}^{4)}, \mathrm{ProMISe}^{5)}\right)$ の結果 において, 初期蘇生輸液を積極的に推奨する EGDT 群 では予後改善効果が認められず，さらに，輸液過剩の 有害性 6) が報告されている。このように, 初期蘇生輸 液や過剩輸液の問題が注目される状沉において, 成人 敗血症患者に対する初期輸液の輸液速度や輸液量を提 示することは重要と考え, 本ガイドラインの $\mathrm{CQ}$ とし て取り上げた。

\section{（2）解説}

J-SSCG 2016 1,2) において，「敗血症による組織低灌 流と血管内容量減少のある患者に対し, 初期輸液は晶 質液を $30 \mathrm{~mL} / \mathrm{kg}$ 以上投与する」と記載され, SSCG 20167）では，「敗血症に惹起された低灌流状態からの 蘇生には, 最初の 3 時間以内に晶質液を最低 $30 \mathrm{~mL} / \mathrm{kg}$ 投与することを推奨する」と記載されている。近年行

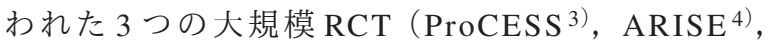
ProMISe ${ }^{5)}$ ) の結果において, 初期蘇生輸液を積極的 に推奨するEGDT群の予後改善効果は認められなかっ たが，実はプロトコル開始前（無作為化前）に ProCESS trial では 2.1〜2.3L, ARISE trial では 2.5〜 2.6L, ProMISe trial では 1.9〜2.0L の初期蘇生輸液（約 $30 \mathrm{~mL} / \mathrm{kg}$ ）が既に施行されていた。このように，ガイ ドラインの普及などに伴い, 敗血症性ショックに対す る初期大量輸液療法 $(30 \mathrm{~mL} / \mathrm{kg})$ の概念は既に常識化 しており，大規模 RCTにおいても初期蘇生輸液に追 加する形で行われた EGDTは，その有用性を示すこ とができなかったものと思われる。一方，Boydら6) 


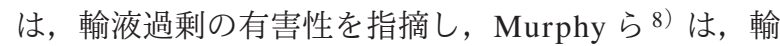
液制限が予後改善につながることを報告している。敗 血症性ショックを対象とした 15 研究 $(\mathrm{n}=31,443)$ のシステマティックレビュー9）は，過剰な輸液バラ ンスは死亡リスクを 70\% 増加（pooled RR 1.70，95\% CI: $1.20,2.41, P=0.003)$ させるが, 敗血症発症か ら 3 時間以内に限定すると大量輸液を行ったほう $(2,085 \mathrm{~mL}$ vs. $1,600 \mathrm{~mL}, P=0.007)$ が院内死亡の改善 （OR 0.34，95\% CI: 0.15〜0.75，P=0.008）につなが ることを示唆している。Kuttabら 10）は，1,032人の 敗血症性ショック患者の観察研究から, 敗血症発症か ら 3 時間以内に $30 \mathrm{~mL} / \mathrm{kg}$ の初期蘇生輸液を達成でき ない場合には，院内死亡が有意に増加（OR 1.52, 95\% CI: 1.03〜2.24）することを報告している。一方, Wardi ら 11）は，駆出率 $40 \%$ 以下の心不全を合併した 敗血症性ショック症例の初期輸液に関しては, $30 \mathrm{~mL} / \mathrm{kg}$ よりも少ない輸液量が推奨されるとしてい る。敗血症/敗血症性ショックに対する初期蘇生輸液 の輸液速度や輸液量に関する質の高いエビデンスはな いが，相対的に減少した循環血液量を補い，組織の低 灌流を改善し，酸素需給バランスをできるだけ早い段 階で適正化しようとする概念を否定するエビデンスも 現時点では存在しない。

以上より，敗血症性ショックにおいて輸液反応性を 評価した後, 血管内容量減少のある患者の初期輸液と して, 晶質液 $30 \mathrm{~mL} / \mathrm{kg}$ 以上を 3 時間以内に投与する ことが敗血症の予後を改善する可能性はある。しか し, 重要な原則は治療の効果を継続的に評価すること であり, 初期輸液の最中はバイタルサインを注意深く 観察し，乳酸クリアランスや心エコーなどを用いて組 織酸素代謝や血行動態の評価を行いながら過剩な輸液 負荷を避けることが重要である。

\section{文 献}

1）西田修, 小倉裕司, 井上茂亮, 他, 日本版敗血症診療ガイドラ イン 2016 作成特別委員会. 日本版敗血症診療ガイドライン 2016. 日集中医誌. 2017; 24: S1-232.

2）西田修, 小倉裕司, 井上茂亮, 他, 日本版敗血症診療ガイドラ イン 2016 作成特別委員会. 日本版敗血症診療ガイドライン 2016. 日救急医会誌. 2017; 28: S1-232.

3) ProCESS Investigators, Yealy DM, Kellum JA, et al: A randomized trial of protocol-based care for early septic shock. N Engl J Med. 2014; 370: 1683-93.

4) ARISE Investigators, ANZICS Clinical Trials Group, Peake SL, et al: Goal-directed resuscitation for patients with early septic shock. N Engl J Med. 2014; 371: 1496-506.

5) Mouncey PR, Osborn TM, Power GS, et al: Trial of early, goaldirected resuscitation for septic shock. N Engl J Med. 2015; 372: 1301-11.

6) Boyd JH, Forbes J, Nakada T, et al: Fluid resuscitation in septic shock: a positive fluid balance and elevated central venous pressure are associated with increased mortality. Crit Care Med. 2011; 39: 259-65.

7) Rhodes A, Evans LE, Alhazzani W, et al: Surviving Sepsis Campaign: International Guidelines for Management of Sepsis and Septic Shock: 2016. Crit Care Med. 2017; 45: 486-552.

8) Murphy CV, Schramm GE, Doherty JA, et al: The importance of fluid management in acute lung injury secondary to septic shock. Chest. 2009; 136: 102-9.

9) Tigabu BM, Davari M, Kebriaeezadeh A, et al: Fluid volume, fluid balance and patient outcome in severe sepsis and septic shock: A systematic review. J Crit Care. 2018; 48: 153-9.

10) Kuttab HI, Lykins JD, Hughes MD, et al: Evaluation and Predictors of Fluid Resuscitation in Patients With Severe Sepsis and Septic Shock. Crit Care Med. 2019; 47: 1582-90.

11) Wardi G, Joel I, Villar J, et al: Equipoise in Appropriate Initial Volume Resuscitation for Patients in Septic Shock With Heart Failure: Results of a Multicenter Clinician Survey. J Intensive Care Med. 2019; 885066619871247. 
CQ6-6：成人敗血症患者の輸液反応性をどのよ うに評価するか?

Answer : 輸液反応性とは, 輸液を行うことで 1 回拍 出量 (SV) の有意な増加が見込まれることであり, 静的指標や動的指標など複数の指標を必要に応じて組 み合わせて評価するという意見がある。静的指標と は，ある 1 点における生体情報で中心静脈圧（central venous pressure: CVP), 肺動脈楔入圧（pulmonary capillary wedge pressure: PCWP）などがあり，動的指 標には受動的下肢挙上（passive leg raising: PLR）や輸 液チャレンジによる心拍出量の変化, 人工呼吸によっ て引き起こされる前負荷の呼吸性変動を用いた脈圧変 動 (pulse pressure variation: PPV), 1 回拍出量変動 (stroke volume variation: SVV) などがある（BQに対 する情報提示)。

\section{（1）背景および本 $C Q$ の重要度}

敗血症患者のショックには, 脱水による絶対的な血 管内容量減少と血管拡張による相対的な血管内容量減 少に加えて, 敗血症性心筋障害 (sepsis-induced myocardial dysfunction: SIMD）による心機能低下も影 響している。血管内容量減少に対する輸液投与は心拍 出量を増加させる介入としては理にかなっているが, 一方で, 肺水腫や腹部コンパートメント症候群など過 剩輸液による害も指摘されている1,2)。そのため, 輸 液投与を行う前に，もしくは輸液を行いながら，輸液 負荷によって得られる益（輸液反応性）を評価するこ とが望ましい。

日本版敗血症診療ガイドライン（J-SSCG）2016で は，「初期蘇生における輸液反応性のモニタリング方 法として何を用いるか？」という臨床上の疑問に対し て,「敗血症, 敗血症性ショックの初期蘇生において は, 用いる指標の限界を考慮して, 必要に応じて複数 のモニタリングを組み合わせて輸液反応性を評価する ことを推奨する」と記載されている ${ }^{3,4)}$ 。本推奨は, 輸液反応性を評価するモニタリングが予後を改善する かシステマティックレビューを行い，特定のモニタリ ングが死亡などの予後を改善しなかったことに基づい ており，輸液反応性の診断精度について検討したもの ではない。輸液反応性を評価することは輸液投与を行 う意思決定に重要であるため BQ として設定し，複数 のモニタリングを組み合わせて使用するためにも，そ れぞれの特徴や限界について解説することとした。

\section{（2）解説}

低灌流の所見を認める敗血症や敗血症性ショック患 者の初期蘇生において, 早期に十分な輸液投与を行 い，その後は輸液を制限した管理を行うことが死亡率 を減少させると報告されている5-8)。しかしながら， 輸液投与により低灌流の改善が期待されるものの, 過 剩輸夜は肺水腫や腹部コンパートメント症候群を来し 敗血症患者の死亡率を上昇させる ${ }^{1,2)}$ ため，至適な 輸液投与量は未だ不明である。過剩輸液を総体重の $10 \%$ 以上の増加と定義した場合，いかなる時期にお いても過剩輸液は集中治療患者の予後不良因子となり

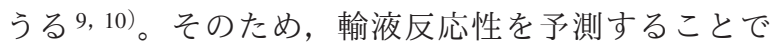
不必要な輸液を回避し, 過剩輸液を防ぐことができれ ば，患者予後を改善できる可能性がある。

輸液反応性とは，250～500mL の輸液を投与した際 に心拍出量や SV が有意に増加することであり，少な くとも 10〜15\% 以上の上昇と定義される $\left.{ }^{11} 112\right)$ 。輸液 反応性の予測のために使用されるモニタリングは，静 的指標と動的指標に分けられる。静的指標とはある 1 点における生体情報で, 中心静脈圧 (CVP), 肺動脈 楔入圧 (PCWP)，経肺熱希釈法による心臟拡張末期容 量（global end-diastolic volume: GEDV）や胸腔内血液 容量（intra-thoracic blood volume: ITBV）などがある。 動的指標とは，何らかの介入による変動を評価する方 法であり，受動的下肢挙上（PLR）や輸液チャレンジ による心拍出量の変化, EEO (end-expiratory occlusion) test による 1 回拍出量の変化, 人工呼吸によって引き 起こされる前負荷の呼吸性変動を用いた脈圧変動 (PPV), 1 回拍出量変動（SVV), 下大静脈径（inferior vena cava diameter: IVCD）や上大静脈径（superior vena cava diameter: SVCD）の変動などがある（Table 6-6-1）。

静的指標である CVP や PCWP は, CVP 8mmHg 以 下や PCWP $12 \mathrm{mmHg}$ 以下の場合に輸液反応性ありと 評価されてきたが，その信頼性は低い。特に，CVP が 8〜 12mmHg 以上の場合には, 輸液反応性を評価す ることは困難である13)。肺動脈カテーテルは侵襲が 大きく，輸液管理の目的でルーチンに使用することは 推奨されていない11)。経肺熱希釈法は, 冷水の急速 注入により GEDV や ITBV などを測定でき，前負荷の 指標として使用できる ${ }^{14)}$ 。さらに, 肺血管外水分量, 肺血管透過性係数などの, 輸液管理に有益な情報を得 ることができる。しかし，輸液反応性の評価について の信頼性は低い 15)。

動的指標は, 静的指標よりも輸液反応性の予測に優 れている16)。しかし，臨床で適応できる状況はそれ ほど多くはない。PPVやSVVは，自発呼吸がなく, 
Table 6-6-1 動的指標の閾值と限界 (文献 27 より引用，一部改変）

\begin{tabular}{|c|c|c|}
\hline 方法 & 閾値 & 主な限界 \\
\hline $\mathrm{PPV}($ pulse pressure variation $) \cdot \mathrm{SVV}($ stroke volume variation $)$ & $12 \%$ & $\begin{array}{l}\text { 下記の症例では使用困難 } \\
\text { 自発呼吸がある症例，不整脈のある症例，1回換気量制限のある } \\
\text { 症例，低肺コンプライアンスの症例 }\end{array}$ \\
\hline IVCD (inferior vena cava diameter) 径の変動 & $12 \%$ & $\begin{array}{l}\text { 下記の症例では使用困難 } \\
\text { 自発呼吸がある症例，1回換気量制限のある症例，低肺コンプラ } \\
\text { イアンスの症例 }\end{array}$ \\
\hline SVCD (superior vena cava diameter) 径の変動 & $12 \sim 40 \%$ & $\begin{array}{l}\text { 経食道心エコーを必要とする。 } \\
\text { 下記の症例では使用困難 } \\
\text { 自発呼吸がある症例，1回換気量制限のある症例，低肺コンプラ } \\
\text { イアンスの症例 }\end{array}$ \\
\hline $\operatorname{PLR}$ (passive leg raising) & $10 \%$ & $\begin{array}{l}\text { 心拍出量を直接測定すること。 } \\
\text { 下記の症例では使用困難 } \\
\text { 下肢欠損症例, 妊婦, 循環作動薬を使用している症例, 腹腔内圧 } \\
\text { が上昇している症例 }\end{array}$ \\
\hline EEO(end-expiratory occlusion) test & $5 \%$ & $\begin{array}{l}\text { 下記の症例では使用困難 } \\
\text { 非㨂管症例， } 15 \text { 秒以上息留めができない症例 }\end{array}$ \\
\hline 少量輸液チャレンジ $(100 \mathrm{~mL})$ & $6 \sim 10 \%$ & 心拍出量を直接, 正確に測定する必要がある。 \\
\hline 輸液チャレンジ $(500 \mathrm{~mL})$ & $15 \%$ & $\begin{array}{l}\text { 繰り返すと過剩輸液の恐れがある。 } \\
\text { 心拍出量を直接測定する必要がある。 }\end{array}$ \\
\hline
\end{tabular}

1 回換気量が $8 \mathrm{~mL} / \mathrm{kg}$ 以上である場合, 陽圧換気に よって $12 \%$ 以上の変動を認めれば輸液反応性がある と評価する。しかし, 自発呼吸, 不整脈, 腹腔内圧上 昇や右心不全がある場合, 変動は大きくなる可能性が あり, 一方で, 頻脈や肺保護換気で管理されている患 者では変動は小さくなりうる17)。また, 肺コンプラ イアンスが低い場合は, 変動が小さくなることも報告 されている18)。エコーを用いた輸液反応性の評価に は, IVCや SVC の径の呼吸性変動があり, CVPより は輸液反応性の予測に優れている19)。SVCのほうが IVCよりも良い指標であるという報告もある20）が, $\mathrm{SVC}$ の径の呼吸性変動の評価には経食道心エコーが 必要であるため侵襲が大きく, また, エコーによる評 価は施行者によって結果のばらつきがあることも他の モニタリングとの相違点である。さらには, SVCDの 径の呼吸性変動には, PEEP, 1 回換気量, 自発呼吸, 右心不全, 腹腔内圧, 血栓などの様々な要因が影響を 与え ${ }^{21)}$, 低左心機能患者においても信頼性がそしい といわれている22)。IVCDの径の呼吸性変動は, PPV やSVVと比較すると信頼性が低く ${ }^{23)}, \mathrm{PPV}$ や SVV が使用可能な場合は優先すべき指標ではないと考えら れる。PLRは下肢挙上による心拍出量の増加を評価 するものであり，下肢挙上による前負荷は，250〜 $350 \mathrm{~mL}$ の輸液に相当する 24$)$ 。下肢挙上により心拍出 量が $10 \%$ 以上増加すれば，輸液反応性があると評価 する。また, PLR は自発呼吸や不整脈を認める患者 においても有用である25)。しかし，その手技はやや 煩雑であり, 具体的な手順は, (1)頭位挙上 $45^{\circ}$ をベー スラインとし, (2)仰臥位で下肢を $45^{\circ}$ 挙上し, (3)血圧
だけではなく心拍出量を直接測定（効果は 1 分程度で 消失), (4)心拍出量をリアルタイムに測定, (5)ベース ラインに戻した時に心拍出量が戻るかを評価，の 5 段 階から成る 26)。下肢挙上による前負荷の増加は, 静 脈系の血管抵抗に依存するため, 循環作動薬や腹腔内 圧上昇などにより影響を受ける27)。EEO は機械換気 の呼気終末に気道を一時的に閉塞する試験であり, 吸 気時の胸腔内圧が上昇しなくなるため，その間は静脈 灌流量が増加する。EEOの時間が十分に長ければ, 増加した右心系の前負荷が左心系にも移行し, 心拍出 量が増加する。15 秒間の EEO を行い, $5 \%$ 以上の心 拍出量の増加が確認できれば輸液反応性があると評価 する28)。PLR と同様に, 心拍出量を直接評価するこ とが望ましい。体位変換を必要としないが，気管挿管 および人工呼吸管理中で，さらに呼気中に 15 秒間以 上の EEO ができる患者でないと測定できない29)。肺 コンプライアンスが低下している患者では, PPVよ りも信頼できるという報告もある ${ }^{30)}$ 。ただし，腹臥 位療法中の信頼性は確認されていない31)。上記のい ずれも使用できない場合は，輸液負荷を行い，その前 後で心拍出量を評価する。輸液量が少なければ測定誤 差による影響を受けやすく，多ければ過剩輸液の恐れ がある。また, 輸液投与により輸液反応性を認めた患 者の約半数が循環動態の改善は一過性と報告されてお り ${ }^{32)}$, 低灌流の所見を確認しつつ, さらなる輸液投 与が必要か継続して評価を行う必要がある。

それぞれのモニタリングの特徵を理解し, 適切なモ ニタリングを選択したうえで, 必要に応じて複数のモ ニタリングを使用することが望ましい。低灌流を認め 
る場合に輸液投与の必要性を検討し，動的指標が利用 可能な状沉であれば，輸液反応性の予測に動的指標を 用いる。動的指標が信頼できない状況であれば，少な くとも輸液負荷を行った前後で血圧以外に心拍出量を 評価するのが良い。心拍出量が増加せず，CVP など の静的指標が上昇する場合は, さらなる輸液負荷は有 害となる可能性がある。

\section{文 献}

1) Vincent JL, Sakr Y, Sprung CL, et al: Sepsis in European intensive care units: results of the SOAP study. Crit Care Med. 2006; 34: 344-53

2) Sakr Y, Rubatto Birri PN, Kotfis K, et al: Higher fluid balance increases the risk of death from sepsis: results from a large international audit. Crit Care Med. 2017; 45: 386-94.

3）西田修, 小倉裕司, 井上茂亮, 他, 日本版敗血症診療ガイドラ イン 2016 作成特別委員会. 日本版敗血症診療ガイドライン 2016. 日集中医誌. 2017; 24: S1-232.

4）西田修, 小倉裕司, 井上茂亮, 他, 日本版敗血症診療ガイドラ イン 2016 作成特別委員会. 日本版敗血症診療ガイドライン 2016. 日救急医会誌. 2017; 28: S1-232.

5) Murphy CV, Schramm GE, Doherty JA, et al: The importance of fluid management in acute lung injury secondary to septic shock. Chest. 2009; 136: 102-9.

6) Hjortrup PB, Haase N, Bundgaard H, et al: Restricting volumes of resuscitation fluid in adults with septic shock after initial management: the CLASSIC randomised, parallel-group, multicentre feasibility trial. Intensive Care Med. 2016; 42: 1695-705.

7) Cordemans C, De Laet I, Van Regenmortel N, et al: Fluid management in critically ill patients: the role of extravascular lung water, abdominal hypertension, capillary leak and fluid balance. Ann Intensive Care. 2012; 2(Suppl 1) : S1.

8) Cordemans C, De Laet I, Van Regenmortel N, et al: Aiming for a negative fluid balance in patients with acute lung injury and increased intra-abdominal pressure: a pilot study looking at the effects of PAL-treatment. Ann Intensive Care. 2012; 2(Suppl 1) : S15.

9) O'Connor ME, Prowle JR: Fluid overload. Crit Care Clin. 2015; 31: 803-21.

10) Vaara ST, Korhonen AM, Kaukonen KM, et al: Fluid overload is associated with an increased risk for 90-day mortality in critically ill patients with renal replacement therapy: data from the prospective FINNAKI study. Crit Care. 2012; 16: R197.

11) Cecconi M, De Backer D, Antonelli M, et al: Consensus on circulatory shock and hemodynamic monitoring. Task force of the European Society of Intensive Care Medicine. Intensive Care Med. 2014; 40: 1795-815.

12) Vincent JL, Weil MH: Fluid challenge revisited. Crit Care Med. 2006; 34: 1333-7.

13) Eskesen TG, Wetterslev M, Perner A: Systematic review including re-analyses of 1148 individual data sets of central venous pressure as a predictor of fluid responsiveness. Intensive Care Med. 2016; 42: 324-32.

14) Sakka SG, Bredle DL, Reinhart K, et al: Comparison between intrathoracic blood volume and cardiac filling pressures in the early phase of hemodynamic instability of patients with sepsis or septic shock. J Crit Care. 1999; 14: 78-83.

15) Muller L, Louart G, Bengler C, et al: The intrathoracic blood volume index as an indicator of fluid responsiveness in critically ill patients with acute circulatory failure: a comparison with central venous pressure. Anesth Analg. 2008; 107: 607-13.

16) Marik PE, Cavallazzi R, Vasu $T$, et al: Dynamic changes in arterial waveform derived variables and fluid responsiveness in mechanically ventilated patients: a systematic review of the literature. Crit Care Med. 2009; 37: 2642-7.

17) Biais M, Ehrmann S, Mari A, et al: Clinical relevance of pulse pressure variations for predicting fluid responsiveness in mechanically ventilated intensive care unit patients: the grey zone approach. Crit Care. 2014; 18: 587.

18) Monnet $X$, Bleibtreu A, FerréA, et al: Passive leg-raising and end-expiratory occlusion tests perform better than pulse pressure variation in patients with low respiratory system compliance. Crit Care Med. 2012; 40: 152-7.

19) Barbier $C$, Loubières $Y$, Schmit $C$, et al: Respiratory changes in inferior vena cava diameter are helpful in predicting fluid responsiveness in ventilated septic patients. Intensive Care Med. 2004; 30: 1740-6.

20) Vignon P, Repessé X, Bégot E, et al: Comparison of echocardiographic indices used to predict fluid responsiveness in ventilated patients. Am J Respir Crit Care Med. 2017; 195: 1022-32.

21) Via G, Tavazzi G, Price S: Ten situations where inferior vena cava ultrasound may fail to accurately predict fluid responsiveness: a physiologically based point of view. Intensive Care Med. 2016; 42: 1164-7.

22) Zhang H, Zhang $Q$, Chen $X$, et al: Respiratory variations of inferior vena cava fail to predict fluid responsiveness in mechanically ventilated patients with isolated left ventricular dysfunction. Ann Intensive Care. 2019; 9: 113.

23) de Oliveira OH, Freitas FG, Ladeira RT, et al: Comparison between respiratory changes in the inferior vena cava diameter and pulse pressure variation to predict fluid responsiveness in postoperative patients. J Crit Care. 2016; 34: 46-9.

24) Lafanechère A, Pène $F$, Goulenok $C$, et al: Changes in aortic blood flow induced by passive leg raising predict fluid responsiveness in critically ill patients. Crit Care. 2006; 10: R132.

25) Cavallaro F, Sandroni C, Marano C, et al: Diagnostic accuracy of passive leg raising for prediction of fluid responsiveness in adults: systematic review and meta-analysis of clinical studies. Intensive Care Med. 2010; 36: 1475-83.

26) Monnet X, Teboul JL: Passive leg raising: five rules, not a drop of fluid! Crit Care. 2015; 19: 18.

27) Monnet X, Marik PE, Teboul JL. Prediction of fluid responsiveness: an update. Ann Intensive Care. 2016; 6: 111.

28) Monnet X, Osman D, Ridel C, et al: Predicting volume responsiveness by using the end-expiratory occlusion in mechanically ventilated intensive care unit patients. Crit Care Med. 2009; 37 : 951-6.

29) Gavelli F, Teboul JL, Monnet X: The end-expiratory occlusion test: please, let me hold your breath! Crit Care. 2019; 23: 274.

30) Monnet X, Bleibtreu A, FerréA, et al: Passive leg-raising and end-expiratory occlusion tests perform better than pulse pressure variation in patients with low respiratory system compliance. Crit Care Med. 2012; 40: 152-7.

31) Yonis H, Bitker L, Aublanc M, et al: Change in cardiac output during Trendelenburg maneuver is a reliable predictor of fluid responsiveness in patients with acute respiratory distress syndrome in the prone position under protective ventilation. Crit Care. 2017; 21: 295.

32) Roger C, Zieleskiewicz L, Demattei C, et al: Time course of fluid responsiveness in sepsis: the fluid challenge revisiting (FCREV) study. Crit Care. 2019; 23: 179. 
CQ6-7 : 成人敗血症患者の初期輸液にアルブミ ン製剤を投与するか?

Answer : 敗血症患者に対して, 初期蘇生輸液の開始 時に標準治療としてアルブミン製剤の投与を行わない ことを弱く推奨する（GRADE 2C：エビデンスの確実 性 $=$ 「低」)。晶質液を用いた標準治療に反応せず，大 量の晶質液を必要とする場合には，アルブミン製剤の 投与を考慮してもよい（エキスパートコンセンサス： エビデンス不十分）。

\section{（1）背景および本 $C Q$ の重要度}

敗血症/敗血症性ショックにおいて, 初期蘇生輸液 は重要な介入である。しかし，標準的な輸液製剤とし てアルブミンを用いるかどうかについては，一定の見 解がない。このため, 初期蘇生輸液の標準的な輸液製 剂としてアルブミンを用いるべきかを明らかにするの は，重要な臨床課題である。

\section{(2) PICO}

P (患者) : 成人, 敗血症/敗血症性ショック患者

I（介入）: 初期輸液に晶質液とアルブミンを用いる

C (対照) : 初期輸液にアルブミンを用いず晶質液の みを用いる

$\mathrm{O}$ (アウトカム ) : 短期死亡（28 日もしくは 30 日死 亡), ICU 滞在日数, 重篤な副作用（肺傷害スコ ア)

\section{（3）エビデンスの要約}

システマティックレビューの結果，PICO に合致し たランダム化比較試験（RCT）が 3 件施行 1-3）されて いた。Rackow ら 1) は，循環血液量減少性ショック・
敗血症性ショック患者の初期蘇生において，5\%アル ブミン，6\%へタスターチ，生理食塩水の有効性を, Finfer ら 2) は, 重症敗血症患者の初期蘇生において, 4\%アルブミンと生理食塩水の有効性を, van der Heijden ら 3) は, 循環血液量減少を伴う敗血症性/非敗 血症性重症患者において，5\% アルブミン，6\% ヒド ロキシエチルスターチ， $4 \%$ ゼラチン，生理食塩水の 有効性を RCT で比較した。これら 3 つの RCTを用い たメタ解析を実施した。

（4）益と害のバランス（Table 6-7-1）

望ましい効果 :

短期死亡のアウトカム（3 RCT: $\mathrm{n}=1,253 ） に$ 関す る効果推定值とその信頼区間は，1,000 人あたり 45 人 少ない (91 人少ない〜 7 人多い), ICU 滞在日数のア ウトカム（1 RCT: $\mathrm{n}=1,218 ）$ の効果推定値とその信 頼区間は，平均（MD） 0.7 日長い（0.1 日短い〜 1.5 日長い）であった。このため, 初期蘇生輸夜にアルブ ミン製剤を使用することの望ましい効果はわずかであ る。

望ましくない効果：

重篤な副作用のアウトカム（肺傷害スコア）（1 $\mathrm{RCT}: \mathrm{n}=24 ）$ の効果推定值とその信頼区間は，MD 0.75 高い $(0.22$ 高い〜 1.28 高い) であった。なお，肺 傷害スコアは $0 \sim 4$ 点で示されるスコアで, 2.5 点以上 で高度の肺傷害があると判定される。以上から，初期 蘇生輸液にアルブミン製剂を使用することの望ましく ない効果はわずかと判断した。

益と害のバランス :

初期蘇生輸液にアルブミン製剤を使用することの望 ましい効果も，望ましくない効果もわずかであること より, 効果のバランスは介入も比較対照もいずれも優

Table 6-7-1 エビデンスプロファイル

\begin{tabular}{|c|c|c|c|c|c|c|c|c|c|c|c|c|}
\hline \multicolumn{7}{|c|}{ 確実性の評価 } & \multicolumn{2}{|c|}{ 患者数 } & \multicolumn{2}{|c|}{ 勃果 } & \multirow[b]{2}{*}{ 確実性 } & \multirow[b]{2}{*}{ 重要性 } \\
\hline 研究数 & $\begin{array}{l}\text { 研究 } \\
\text { テザイン }\end{array}$ & $\begin{array}{l}\text { パイアス } \\
\text { のリスク }\end{array}$ & 非一面性 & 非直接性 & 不精確性 & $\begin{array}{l}\text { その他 } \\
\text { の椟討 }\end{array}$ & Albumin & Grystal loid & $\begin{array}{l}\text { 相対指檈 } \\
(95 \% \text { CI) }\end{array}$ & 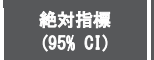 & & \\
\hline \multicolumn{13}{|c|}{ 短期死亡（28 日もしくは 30 日死亡） } \\
\hline 3 & RCT & 深刻でない & 深刻でい & 深刻でない & 深刻 a & なし & $\begin{array}{l}187 / 622 \\
(30.1 \%)\end{array}$ & $\begin{array}{l}220 / 631 \\
(34.9 \%)\end{array}$ & $\begin{array}{c}\operatorname{RR} 0.87 \\
(0.74 \text { to } 1.02)\end{array}$ & $\begin{array}{c}1,000 \text { 人あたり } \\
45 \text { 人少ない } \\
(91 \text { 人少ない 7 } \\
\text { 人多い) }\end{array}$ & $\begin{array}{c}\oplus \oplus \oplus \bigcirc \\
\text { 中 }\end{array}$ & 重大 \\
\hline \multicolumn{13}{|c|}{$\mathrm{ICU}$ 滞在日数 } \\
\hline 1 & RCT & 深刻てない & 深刻でい & 深刻てない & 非常に深刻 0.0 & なし & 603 & 615 & - & \begin{tabular}{|c|} 
平均 0.7 日長い \\
$(0.1$ 日短い \\
1.5 長い)
\end{tabular} & $\underset{\text { 低 }}{\oplus \oplus \circ O}$ & 重大 \\
\hline \multicolumn{13}{|c|}{ 重篤な副作用（肺稘害スコア） } \\
\hline 1 & RCT & 深刻でない & 深刻でない & 深刻でない & 深刻 & なし & 12 & 12 & - & $\begin{array}{c}\text { 平均 } 0.75 \text { 高い } \\
(0.22 \text { 高い } \\
1.28 \text { 高(い) }\end{array}$ & $\begin{array}{c}\oplus \oplus \oplus \oplus \bigcirc \\
\text { 中 }\end{array}$ & 重大 \\
\hline
\end{tabular}


位でないと判断した。

（5）アウトカム全般に関するエビデンスの確実性

今回採用したすべてのアウトカムの効果推定值の方 向性は一致していない（益も害も示さないアウトカム 2 つ，害を示すアウトカム 1 つ）ため，1 番低い確実 性を全体の確実性として採用した。アウトカム全体に わたるエビデンスの確実性は「低」である。

\section{（6）価値観}

初期蘇生輸液に対する患者・家族の価值観に関する エビデンスはない。一般的に死亡に対する相対的価值 は高いと考えられ，そのばらつきは少ないことが予想 される。

\section{（7）容認性}

アルブミン製剤のコストは約 4,000～5,000 円/50mL/瓶 であり，医療経済に与える影響は小さくはない。ま た，アルブミン製剤は血漿分画製剤であるため，感染 症などの危険性を完全には除外できない。患者・家族 の視点からは，効果のバランスが不確かな当該介入を おそらく許容できないと考えられる。医療者の仕事量 増加はごくわずかである。

\section{（8）実行可能性}

アルブミン製剂は多くの医療施設において使用可能 である。
(9) 判断の要約 (Table 6-7-2)

（10）推奨グレーディング決定の工程

修正 RAND 法を用いた投票によって，中央值 7, 見解不一致指数 0.164 の結果となり，委員会で採択さ れた（7 点以上 : $87.5 \%) 。$

（11）関連する他の診療ガイドラインにおける推奨

SSCG 20164）では，敗血症または敗血症性ショック 患者の初期蘇生において相当量の晶質液輸液を必要と する場合には，晶質液に加えアルブミンを使用するこ とが弱く提案されている。日本版敗血症診療ガイドラ イン（J-SSCG）2016 5,6）では，敗血症患者の初期蘇 生において，アルブミンをルーチン使用しないことを 推奨している。ただし，初期蘇生で多量の晶質液を必 要とする場合や，低アルブミン血症が認められる場合 には，アルブミン使用を考慮してもよいかもしれない としている。しかし，敗血症の初期蘇生における標準 的な輸液としてアルブミンを用いるかについては，一 定の見解がない。

\section{（12）実施に関わる検討事項}

アルブミン製剤は，血圧上昇，血管内水分量増加を 期待して使用されることが多い。その一方で，コスト や感染症リスクを懸念されることも多い。本 CQでは, これらをアウトカムとした検討は行われていないた め, 実際の初期蘇生輸液の際には，アルブミン製剤が 有益あるいは有害となる患者群が存在することも否定 できない。

Table 6-7-2 判断の要約

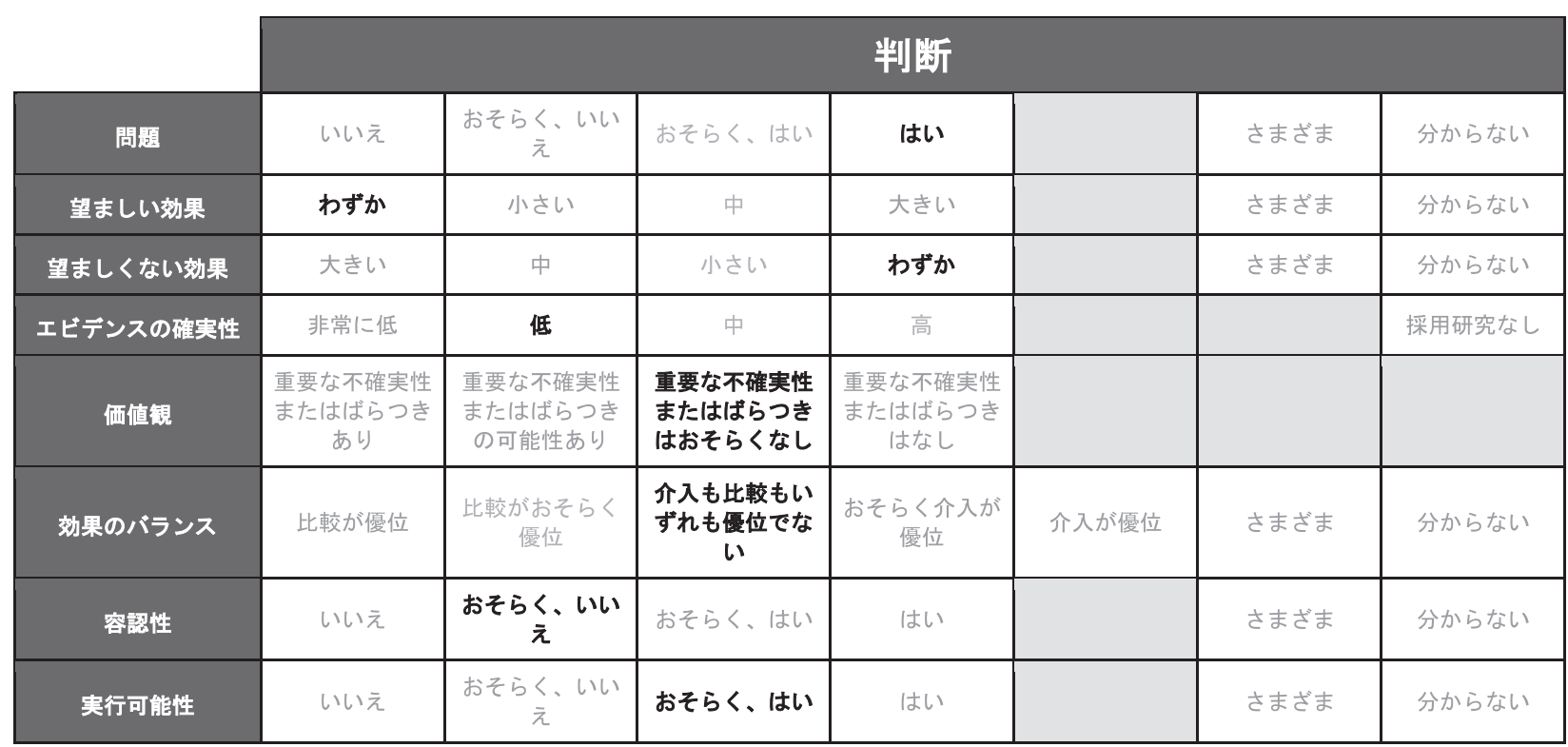




\section{（13）今後の研究の可能性}

今後，アルブミン製剤が血圧・血管内水分量に与え る影響の評価，アルブミン製剤とコスト・感染症リス クの評価，アルブミン製剤を使用する時期に関する研 究が行われることが望まれる。

\section{文 献}

1) Rackow EC, Falk JL, Fein IA, et al: Fluid resuscitation in circulatory shock: a comparison of the cardiorespiratory effects of albumin, hetastarch, and saline solutions in patients with hypovolemic and septic shock. Crit Care Med. 1983; 11: 839-50.

2) Finfer $S$, McEvoy $S$, Bellomo R, et al: Impact of albumin compared to saline on organ function and mortality of patients with severe sepsis. Intensive Care Med. 2011; 37: 86-96.

3) van der Heijden M, Verheij J, van Nieuw Amerongen GP, et al: Crystalloid or colloid fluid loading and pulmonary permeability, edema, and injury in septic and nonseptic critically ill patients with hypovolemia. Crit Care Med. 2009; 37: 1275-81.

4) Rhodes A, Evans LE, Alhazzani W, et al: Surviving Sepsis Campaign: International Guidelines for Management of Sepsis and Septic Shock: 2016. Intensive Care Med. 2017; 43: 304-77.

5）西田修, 小倉裕司, 井上茂亮, 他, 日本版敗血症診療ガイドラ イン 2016 作成特別委員会. 日本版敗血症診療ガイドライン 2016. 日集中医誌. 2017; 24: S1-232.

6）西田修, 小倉裕司, 井上茂亮, 他, 日本版敗血症診療ガイドラ イン 2016 作成特別委員会. 日本版敗血症診療ガイドライン 2016. 日救急医会誌. 2017; 28: S1-232.
CQ6-8：成人敗血症患者の初期輸液に人工膠質 液を投与するか?

Answer : 敗血症/敗血症性ショック患者に対して，人 工膠質液の投与を行わないことを弱く推奨する (GRADE 2D : エビデンスの確実性 $=$ 「非常に低」)。

\section{（1）背景および本 $C Q$ の重要度}

敗血症性ショックにおいて，初期蘇生輸液に何を用 いるかは非常に重要な問題である。標準的な輸液とし て人工膠質液を用いるかどうかについては一定の見解 がない。したがって，初期輸液の標準的な輸液として 人工膠質液を用いるかを明らかにするのは重要であ り，重要臨床課題として取り上げた。

(2) PICO

$\mathrm{P}$ (患者) : 成人, 初期輸液の必要な敗血症性ショッ ク患者

I（介入）: 初期輸液に晶質液と人工膠質液を用いる

$\mathrm{C}$ (対照) : 初期輸液に人工膠質液を用いず晶質液の みを用いる

$\mathrm{O}$ (アウトカム) : 短期死亡（28日もしくは30日死 亡), 長期死亡 (90 日死亡, 90 日がない場合は最 長を用いることを考虑する), ICU 滞在日数, 重 篤な副作用 (透析使用), 重篤な副作用（重篤な 出血）

\section{（3）エビデンスの要約}

システマティックレビューの結果，PICO に合致し たランダム化比較試験（RCT）が 4 件施行 ${ }^{1-4)}$ されて おりここれらを用いたメタ解析を実施した。

\section{（4）益と害のバランス（Table 6-8-1）}

\section{望ましい効果 :}

短期死亡のアウトカム（4 RCT: $\mathrm{n}=2,586 ）$ の効果 推定值とその信頼区間は，1,000 人あたり 9 人多い （25人少ない 46 人多い）であり, 長期死亡のアウト カム（3 RCT: $n=2,545 ）$ の効果推定值とその信頼区 間は，1,000 人あたり 19 人多い（62人少ない〜 123 人 多い）である。ICU 滞在日数のアウトカム（2 RCT: $\mathrm{n}=214 ）$ の効果推定值とその信頼区間は, 平均（MD） 1,000 人あたり 1.13 日短い (8.28 日短い〜 6.03 日長い) である。以上より，人工膠質液投与による望ましい効 果はわずかであると判断した。

望ましくない効果 :

急性腎障害に伴う透析使用のアウトカム（4 RCT: n 
日集中医誌 J Jpn Soc Intensive Care Med Vol. 28 Suppl

Table 6-8-1エビデンスプロファイル

\begin{tabular}{|c|c|c|c|c|c|c|c|c|c|c|c|c|}
\hline \multicolumn{7}{|c|}{ 確実性の評価 } & \multicolumn{2}{|c|}{ 患者数 } & \multicolumn{2}{|c|}{ 奻果 } & \multirow[b]{2}{*}{ 確実性 } & \multirow[b]{2}{*}{ 重要性 } \\
\hline 研究数 & $\begin{array}{l}\text { 研究 } \\
\text { デザイン }\end{array}$ & $\begin{array}{l}\text { バイアス } \\
\text { のリスク }\end{array}$ & 非一貫性 & 非直接性 & 不精確性 & $\begin{array}{l}\text { その他 } \\
\text { の検討 }\end{array}$ & colloid & placebo & $\begin{array}{l}\text { 相対指標 } \\
(95 \% \text { Cl) }\end{array}$ & $\begin{array}{l}\text { 䋓対指標 } \\
(95 \% \text { Cl) }\end{array}$ & & \\
\hline \multicolumn{13}{|c|}{ 短期死亡（28 日もしくは 30 日死亡） } \\
\hline 4 & RCT & 深刻 a & 深刻でない & 深刻でない & 深刻でない & なし & $\begin{array}{c}409 / 1,293 \\
(31.6 \%)\end{array}$ & $\begin{array}{c}400 / 1,293 \\
(30.9 \%)\end{array}$ & $\begin{array}{c}\text { RR } 1.03 \\
\text { (0.92 to } 1.15)\end{array}$ & $\begin{array}{c}1,000 \text { 人あた } \\
\text { り } 9 \text { 人多い } \\
(25 \text { 人少ない } \\
46 \text { 人多い) }\end{array}$ & $\begin{array}{c}\oplus \oplus \oplus \bigcirc \\
\text { 中 }\end{array}$ & 重大 \\
\hline \multicolumn{13}{|c|}{ 長期死亡（90 日死亡もしくは最長観察期間死亡） } \\
\hline 3 & RCT & 深刻 a & 深刻 c & 深刻でない & 深刻でない & なし & $\begin{array}{c}493 / 1,271 \\
(38.8 \%)\end{array}$ & $\begin{array}{c}490 / 1,274 \\
(38.5 \%)\end{array}$ & $\begin{array}{c}\text { RR } 1.05 \\
\text { (0.84 to } 1.32)\end{array}$ & $\begin{array}{c}1,000 \text { 人あた } \\
\text { り } 19 \text { 人多い } \\
\text { (62人少ない } \\
123 \text { 人多い) }\end{array}$ & $\begin{array}{c}\oplus \oplus \bigcirc \bigcirc \\
\text { 低 }\end{array}$ & 重大 \\
\hline \multicolumn{13}{|c|}{ ICU 滞在日数 } \\
\hline 2 & RCT & 深刻でない & 深刻。 & 深刻でない & 非常に深刻 b & なし & 109 & 105 & - & $\begin{array}{c}\text { 平均 } 1.13 \text { 日短 } \\
\text { 俨 } \\
(8.28 \text { 日短い } \\
6.03 \text { 日長い) }\end{array}$ & $\begin{array}{l}\oplus \bigcirc \bigcirc \bigcirc \\
\text { 非常に低 }\end{array}$ & 重大 \\
\hline \multicolumn{13}{|c|}{ 透析使用 } \\
\hline 4 & RCT & 深刻でない & 深刻でない & 深刻 d & 深刻でない & なし & $\begin{array}{c}268 / 1,933 \\
(13.9 \%)\end{array}$ & $\begin{array}{c}264 / 1,958 \\
(13.5 \%)\end{array}$ & $\begin{array}{c}\text { RR } 1.12 \\
\text { (0.82 to } 1.53)\end{array}$ & $\begin{array}{c}1,000 \text { 人あた } \\
\text { り } 16 \text { 人多い } \\
\text { (24人少ない } \\
71 \text { 人多い) }\end{array}$ & $\begin{array}{c}\oplus \oplus \oplus \bigcirc \\
\text { 中 }\end{array}$ & 重大 \\
\hline \multicolumn{13}{|c|}{ 重篤な出血 } \\
\hline 2 & RCT & 深刻でない & 深刻でない & 深刻 d & 非常に深刻 b & なし & $\begin{array}{l}67 / 498 \\
(13.5 \%)\end{array}$ & $\begin{array}{c}45 / 496 \\
(9.1 \%)\end{array}$ & $\begin{array}{c}\text { RR } 1.46 \\
\text { (1.03 to } 2.07)\end{array}$ & $\begin{array}{c}1,000 \text { 人あた } \\
\text { り } 42 \text { 人多い } \\
\text { (3人多い 97 } \\
\text { 人多い) }\end{array}$ & $\begin{array}{l}\oplus \bigcirc \bigcirc \bigcirc \\
\text { 非常に低 }\end{array}$ & 重大 \\
\hline
\end{tabular}

a. 最大症例数の研究で実行バイアスのリスクが存在する。

b. サンプルサイズが小さい。

c. $I^{2}$ 高値。

d. 一部代替アウトカム。

$=3,891 ）$ の効果推定值とその信頼区間は, 1,000人 あたり 16 人多い $(24$ 人少ない〜 71 人多い）であり， 重篤な出血のアウトカム（2 RCT: $\mathrm{n}=994 ）$ の効果推 定值とその信頼区間は， 1,000 人あたり 42 人多い（3 人多い〜97 人多い）である。以上より，人工膠質液 投与による望ましくない効果は「中」と判断した。

益と害のバランス :

益と害の正味のバランスは 1,000 人あたり 86 人, 害が上回る。短期死亡に関する不確実性を考慮し，信 頼区間の最小值（1,000人あたり 25 人少ない）を用い て, 死亡に関連するアウトカムの相対価值を他のアウ トカムの 3 倍としても， 1,000 人あたり 2 人，害が上 回る。以上より, 効果のバランスは「比較がおそらく 優位」と判断した。

\section{（5）アウトカム全般に関するエビデンスの確実性}

今回採用したアウトカムの効果推定值の方向性は一 致していないため，エビデンスの確実性は最も低いア ウトカムの結果を採用し，「非常に低」とした。

\section{（6）価值観}

一般的に，死亡アウトカムに対して置く相対的価值 は高く，そのばらつきは少ないことが予想される。

\section{（7）容認性}

介入による害が大きく，患者には容認されないと考 えられる。人工膠質液（約 700 円 $/ 500 \mathrm{mL）のほうが,}$ 晶質液（約 150 円 $/ 500 \mathrm{~mL}$ ）よりも高価であるが，い ずれも医療経済に与える負担は大きくはない。医療従 事者への負担はどちらの輸液を投与しても変わりはな く，介入は容認されると考える。

\section{（8）実行可能性}

人工膠質液の投与は，本邦の多くの医療施設におい て実行可能である。

(9) 判断の要約 (Table 6-8-2)

（10）推奨グレーディング決定の工程

修正 RAND 法を用いた投票によって，中央值 8, 見解不一致指数 0.029 の結果となり，委員会で採択さ れた（7 点以上：91.7\%）。

\section{（11）関連する他の診療ガイドラインにおける推奨}

SSCG 20165) では，敗血症/敗血症性ショックの患 者で，血管内容量の補充目的で，人工膠質液（ヒドロ キシエチルスターチ製剤）の投与を行わないことを推 奨している。 
Table 6-8-2 判断の要約

\begin{tabular}{|c|c|c|c|c|c|c|c|}
\hline & \multicolumn{7}{|c|}{ 判溇 } \\
\hline 問題 & いいえ & $\begin{array}{c}\text { おそらく、いい } \\
\text { え }\end{array}$ & おそらく、はい & はい & & さまざま & 分からない \\
\hline 望ましい勃果 & わずか & 小さい & 中 & 大きい & & さまざま & 分からない \\
\hline 望ましくない勃果 & 大きい & 中 & 小さい & わずか & & さまざま & 分からない \\
\hline エビデンスの確実性 & 非常に低 & 低 & 中 & 高 & & & 採用研究なし \\
\hline 価值覞 & $\begin{array}{c}\text { 重要な不確実性 } \\
\text { またはばらつき } \\
\text { あり }\end{array}$ & $\begin{array}{l}\text { 重要な不確実性 } \\
\text { またはばらつき } \\
\text { の可能性ありり }\end{array}$ & $\begin{array}{l}\text { 重要な不確実性 } \\
\text { またはばらつき } \\
\text { はおそらくなし }\end{array}$ & $\begin{array}{c}\text { 重要な不確実性 } \\
\text { またはばらつき } \\
\text { はなし }\end{array}$ & & & \\
\hline 効果のバランス & 比較が優位 & $\begin{array}{c}\text { 比較がおそらく } \\
\text { 優位 }\end{array}$ & $\begin{array}{c}\text { 介入も比較もい } \\
\text { ずれも優位でな } \\
\text { い }\end{array}$ & $\begin{array}{c}\text { おそらく介入が } \\
\text { 優位 }\end{array}$ & 介入が優位 & さまざま & 分からない \\
\hline 容認性 & いいえ & $\begin{array}{c}\text { おそらく、いい } \\
\text { え }\end{array}$ & おそらく、はい & はい & & さまざま & 分からない \\
\hline 実行可能性 & いいえ & $\begin{array}{c}お そ ら く 、 い い ~ \\
\text { え }\end{array}$ & おそらく、はい & はい & & さまざま & 分からない \\
\hline
\end{tabular}

\section{（12）実施に関わる検討事項}

ヒドロキシエチルスターチ製剤（hydroxyethyl starch: HES）は，濃度，分子量，置換度などにより異 なり，今回の検討では，6\% HES (130/0.4）（商品名： ボルベン）のような第 3 世代 HES に関する RCT がほ とんどであり，実施の際には注意が必要である。本邦 で他に使用可能な HESには，生食溶媒の $6 \% \mathrm{HES}$ （70/0.5）（商品名：サリンヘス）, リンゲル液が溶媒 の $6 \% \mathrm{HES}(70 / 0.5)$ （商品名：ヘスパンダー）がある。

\section{（13）今後の研究の可能性}

今後, 人工膠質液の種類，投与量に関する検証，人 工膠質液の持続投与の有効性に関する検証などが行わ れることが望まれる。

$$
\text { 文 献 }
$$

1) Perner $\mathrm{A}$, Haase $\mathrm{N}$, Guttormsen $\mathrm{AB}$, et al: Hydroxyethyl starch $130 / 0.42$ versus Ringer's acetate in severe sepsis. N Engl J Med. 2012; 367: 124-34.

2) Annane D, Siami $S$, Jaber $S$, et al: Effects of fluid resuscitation with colloids vs crystalloids on mortality in critically ill patients presenting with hypovolemic shock: The CRISTAL randomized trial. JAMA. 2013; 310: 1809-17.

3) Guidet B, Martinet O, Boulain T, et al: Assessment of hemodynamic efficacy and safety of $6 \%$ hydroxyethylstarch $130 / 0.4$ vs. $0.9 \% \mathrm{NaCl}$ fluid replacement in patients with severe sepsis: The CRYSTMAS study. Crit Care. 2012; 16: R94.

4) McIntyre LA, Fergusson D, Cook DJ, et al: Fluid resuscitation in the management of early septic shock (FINESS): a randomized controlled feasibility trial. Can J Anaesth. 2008; 55: 819-26.

5) Rhodes A, Evans LE, Alhazzani W, et al: Surviving Sepsis Campaign: International Guidelines for Management of Sepsis and Septic Shock: 2016. Intensive Care Med. 2017; 43: 304-77. 
CQ6-9-1：成人敗血症患者に対する血管収縮薬 の第一選択としてノルアドレナリン，ドパミン， フェニレフリンのどれを使用するか?（ノルア ドレナリン vs ドパミン)

Answer : 成人敗血症患者に対する血管収縮薬の第一 選択として，ノルアドレナリンとドパミンのうち，， ルアドレナリンを投与することを弱く推奨する （GRADE 2D : エビデンスの確実性＝「非常に低」）。

\section{（1）背景および本 CQ の重要度}

日本版敗血症診療ガイドライン（J-SSCG）2016 1,2) およびSSCG 20163) では, 敗血症の初期蘇生におけ る血管収縮薬の第一選択薬はノルアドレナリンが推奨 された。しかし，SSCG 2016 では頻脈を呈さない患者 においてはドパミンの使用も弱く推奨されている。ま た，J-SSCG 2016 1,2) は十分なエビデンスがなく推奨 を見送られているフェニレフリンも選択肢の 1 つとし て検討されている。血管収縮薬の選択は敗血症の初期 蘇生に重要であり，第一選択として何を使用するかに ついて, J-SSCG 2020 でも改めて課題として取り上げ ることは重要であり, 重要臨床課題として取り上げ た。

\section{(2) PICO}

$\mathrm{P}$ (患者) : 成人, 初期輸液によっても目標平均血圧 まで血圧を上げることができない敗血症性ショッ ク，かつ血管収縮薬を投与していない状態の患 者。既に何らかの血管収縮薬を投与されている場 合や心機能低下の患者は対象としない

I（介入）：血管収縮薬の第一選択薬としてノルアド レナリンを使用する

C (対照)：血管収縮薬の第一選択薬としてドパミン を使用する

$\mathrm{O}$ (アウトカム) : 短期死亡（28日または 30 日死 亡), 長期死亡 (90日死亡, 90 日の評価がない場 合は最長の評価日を用いることを考慮する)， ショック離脱期間, 臟器虚血, 不整脈

\section{（3）エビデンスの要約}

システマティックレビューの結果, PICO に合致し たランダム化比較試験（RCT）が 5 件施行 ${ }^{4-8)}$ されて いた。De Backer ら ${ }^{8)}$ が行った RCT のみ敗血症以外 のショック患者も含まれていたが，その他は敗血症性 ショック患者を対象にノルアドレナリンとドパミンを 比較した RCT であった。これらを用いたメタ解析を
実施した。

（4）益と害のバランス（Table 6-9-1-1）

望ましい効果 :

短期死亡のアウトカム（5 RCT: $\mathrm{n}=1,397 ）$ の効果 推定值とその信頼区間は， 1,000 人あたり 54 人少ない （102 人少ない 0 人多い）であった。長期死亡および ショック離脱期間に関する報告はなかった。不整脈 （2 RCT: $\mathrm{n}=1,931 ）$ の効果推定值とその信頼区間は, 1,000 人あたり 110 人少ない（138 人少ない 80 人少 ない), 心筋虚血（1 RCT: $\mathrm{n}=1,679 ）$ の効果推定值と その信頼区間は，1,000 人あたり 20 人少ない（21人 少ない〜 12 人少ない）であった。以上より，ノルア ドレナリンによる望ましい効果は「中」と判断した。

望ましくない効果 :

四肢虚血（1 RCT: $\mathrm{n}=1,679 ）$ の効果推定值とその 信頼区間は，1,000 人あたり 3 人多い（6 人少ない〜 23 人多い), 腸間膜虚血（1 RCT: $n=1,679 ）$ の効果 推定值とその信頼区間は，1,000 人あたり 6 人少ない （10人少ない〜7人多い）であった。以上より，ノル アドレナリンによる望ましくない効果はわずかと判断 した。

益と害のバランス :

ノルアドレナリンによる正味の利益は，1,000 人あ たり 187 人望ましい効果が上回り, 死亡アウトカムに 関する不精確性を考慮して，信頼区間で最も悪い值で 検討を行っても, 正味の利益は 1,000 人あたり 133 人 望ましい効果が大きかった。以上より, 効果のバラン スは「介入が優位」と判断した。

（5）アウトカム全般に関するエビデンスの確実性

今回採用したアウトカムの効果推定值の方向性は一 致していないため, エビデンスの確実性は最も低いア ウトカムの結果を採用し,「非常に低」とした。

\section{（6）価値観}

一般的に，死亡アウトカムに対して置く相対的価值 は高く，そのばらつきは少ないことが予想される。

\section{（7）容認性}

ノルアドレナリンのコストは約 100 円 $/ 1 \mathrm{mg}$, ドパミン は約 100 円/100mg であるため，医療経済への影響は少 ないと考える。患者・家族の視点からは本介入を許容 できる。医療従事者にとっては，いずれの薬剤であっ てもシリンジポンプによる投与と循環動態のモニタリ ングが必要であるが，その負担は敗血症を診療する集 
Table 6-9-1-1エビデンスプロファイル

\begin{tabular}{|c|c|c|c|c|c|c|c|c|c|c|c|c|}
\hline \multicolumn{7}{|c|}{ 確実性の評価 } & \multicolumn{2}{|c|}{ 患者数 } & \multicolumn{2}{|c|}{ 効果 } & \multirow[b]{2}{*}{ 確実性 } & \multirow[b]{2}{*}{ 重要性 } \\
\hline 研究数 & $\begin{array}{l}\text { 研究 } \\
\text { デザイン }\end{array}$ & $\begin{array}{l}\text { ハイアス } \\
\text { のリスク }\end{array}$ & 非一其性 & 非直接性 & 不精確性 & $\begin{array}{l}\text { その他 } \\
\text { の検討 }\end{array}$ & Noradrenal ine & Dopamine & $\begin{array}{l}\text { 相対指楆 } \\
(95 \% \text { cI) }\end{array}$ & $\begin{array}{l}\text { 絶対指㗚 } \\
(95 \% \text { CI) }\end{array}$ & & \\
\hline \multicolumn{13}{|c|}{ 短期死亡（28 日もしくは 30 日死亡） } \\
\hline 5 & RCT & 深刻 a & 深刻でない & 深刻でない & 深刻 b & なし & $\begin{array}{l}326 / 670 \\
(48.7 \%)\end{array}$ & $\begin{array}{l}390 / 727 \\
(53.6 \%)\end{array}$ & $\begin{array}{l}\text { RR } 0.90 \\
(0.81 \text { to } \\
1.00)\end{array}$ & $\begin{array}{c}1,000 \text { 人あた } \\
\text { り } 54 \text { 人少な } \\
\text { い } \\
(102 \text { 人少な } \\
\text { い 0 人少な } \\
\text { ( })\end{array}$ & $\underset{\text { 低 }}{\oplus \oplus \bigcirc \bigcirc}$ & 重大 \\
\hline \multicolumn{13}{|l|}{ 不整脈 } \\
\hline 2 & RCT & 深刻a & 深刻でない & 深刻。 & 深刻でない & なし & $\begin{array}{l}153 / 939 \\
(16.3 \%)\end{array}$ & $\begin{array}{l}274 / 992 \\
(27.6 \%)\end{array}$ & $\begin{array}{l}\text { RR } 0.60 \\
(0.50 \text { to } \\
0.71)\end{array}$ & $\begin{array}{c}1,000 \text { 人あた } \\
\text { り } 110 \text { 人少な } \\
\text { い } \\
(138 \text { 人少な } \\
\text { い 80 人少 } \\
\text { ない) }\end{array}$ & $\underset{\text { 低 }}{\oplus \oplus \bigcirc \bigcirc}$ & 重大 \\
\hline \multicolumn{13}{|c|}{ 心筋虚血 } \\
\hline 1 & RCT & 深刻でない & 深刻でない & 深刻。 & 深刻 b & なし & $2 / 821(0.2 \%)$ & $\begin{array}{l}19 / 858 \\
(2.2 \%)\end{array}$ & $\begin{array}{l}\text { RR } 0.11 \\
(0.03 \text { to } \\
0.47)\end{array}$ & $\begin{array}{c}1,000 \text { 人あた } \\
\text { り } 20 \text { 人少な } \\
\text { い } \\
(21 \text { 人少ない } \\
12 \text { 人少ない) }\end{array}$ & $\underset{\text { 低 }}{\oplus \oplus \bigcirc \bigcirc}$ & 重要 \\
\hline \multicolumn{13}{|c|}{ 四肢虚血 } \\
\hline 1 & RCT & 深刻でない & 深刻でない & 深刻。 & 非常に深刻 d & なし & $\begin{array}{l}14 / 821 \\
(1.7 \%)\end{array}$ & $\begin{array}{l}12 / 858 \\
(1.4 \%)\end{array}$ & $\begin{array}{l}\text { RR } 1.22 \\
(0.57 \text { to } \\
2.62)\end{array}$ & $\begin{array}{c}1,000 \text { 人あた } \\
\text { り } 3 \text { 人多い } \\
\text { (6人少ない } \\
23 \text { 人多い) }\end{array}$ & $\begin{array}{l}\oplus \bigcirc 0 \bigcirc \\
\text { 非常に低 }\end{array}$ & 重要 \\
\hline \multicolumn{13}{|c|}{ 腸間膜虚血 } \\
\hline 1 & RCT & 深刻でない & 深刻でない & 深刻。 & 非常に深刻 d & なし & $6 / 821(0.7 \%)$ & $\begin{array}{l}11 / 858 \\
(1.3 \%)\end{array}$ & $\begin{array}{l}\text { RR } 0.57 \\
(0.21 \text { to } \\
1.53)\end{array}$ & $\begin{array}{c}1,000 \text { 人あた } \\
\text { り } 6 \text { 人少ない } \\
\text { (10人少ない } \\
7 \text { 人多い) }\end{array}$ & $\begin{array}{l}\oplus \bigcirc 0 \bigcirc \\
\text { 非常に低 }\end{array}$ & 重要 \\
\hline
\end{tabular}

ショック離脱期間は報告がなかった。

a. 盲検化がされていない研究が含まれている。

b. 最適情報量基準を满たしていない。

c. 敗血症性以外の患者が含まれている。

d. イベント発生数が少なく，臨床決断の閾値をまたいでいる。

中治療室やそれに準じた施設であれば容認される。

\section{（8）実行可能性}

本邦では多くの病院で採用，使用されている薬剤で ある。投与に際して，シリンジポンプを用いること， 循環動態をモニタリングすることが必要であるが，本 邦において敗血症性ショックを診療する集中治療室ま たはそれに準じた施設であれば，実行可能性に関して 問題ないと考える。

\section{（9）判断の要約（Table 6-9-1-2）}

\section{（10）推奨グレーディング決定の工程}

修正 RAND 法を用いた投票によって，中央值 8 , 見解不一致指数 0.015 の結果となり，委員会で採択さ れた（7点以上：95.8\%）。

\section{（11）関連する他の診療ガイドラインにおける推奨}

J-SSCG $2016^{1,2)}$ では，初期輸液に反応しない敗血 症性ショックに対して，第一選択薬としてドパミンよ りもノルアドレナリンの投与が推奨されている（1B）。
SSCG 2016 ${ }^{3 ）}$ でも同様に，第一選択薬としてノルアド レナリンが推奨されている（強い推奨, 中等度のエビ デンスレベル）。

\section{（12）実施に関わる検討事項}

患者の基礎疾患などによりノルアドレナリンによる 臓器虚血の合併症が増すことが予想される場合には, 注意を要する。

\section{（13）今後の研究の可能性}

今後，ノルアドレナリンの投与を開始するタイミン グ，ノルアドレナリンの最大投与量を含む投与量，ノ ルアドレナリンを減量・中止するタイミングなどに関 する研究が望まれる。

\section{文 献}

1）西田修, 小倉裕司, 井上茂亮, 他, 日本版敗血症診療ガイドラ イン 2016 作成特別委員会. 日本版敗血症診療ガイドライン 2016. 日集中医誌. 2017; 24: S1-232.

2）西田修, 小倉裕司, 井上茂亮, 他, 日本版敗血症診療ガイドラ イン 2016 作成特別委員会. 日本版敗血症診療ガイドライン 2016. 日救急医会誌. 2017; 28: S1-232.

3) Rhodes A, Evans LE, Alhazzani W, et al: Surviving Sepsis 
Table 6-9-1-2 判断の要約

\begin{tabular}{|c|c|c|c|c|c|c|c|}
\hline 問題 & いいえ & $\begin{array}{c}\text { おそらく、いい } \\
\text { え }\end{array}$ & おそらく、はい & はい & & さまざま & 分からない \\
\hline 望ましい効果 & わずか & 小さい & 中 & 大きい & & さまざま & 分からない \\
\hline 望ましくない勃果 & 大きい & 中 & 小さい & わずか & & さまざま & 分からない \\
\hline エビデンスの確実性 & 非常に低 & 低 & 中 & 高 & & & 採用研究なし \\
\hline 価值钼 & $\begin{array}{c}\text { 重要な不確実性 } \\
\text { またはばらつき } \\
\text { あり }\end{array}$ & $\begin{array}{c}\text { 重要な不確実性 } \\
\text { またはばらつき } \\
\text { の可能性ありり }\end{array}$ & $\begin{array}{l}\text { 重要な不確実性 } \\
\text { またはばらつき } \\
\text { はおそらくなし }\end{array}$ & $\begin{array}{c}\text { 重要な不確実性 } \\
\text { またはばらつき } \\
\text { はなく }\end{array}$ & & & \\
\hline 勃果のパランス & 比較が優位 & $\begin{array}{c}\text { 比較がおそらく } \\
\text { 優位 }\end{array}$ & $\begin{array}{c}\text { 介入も比較もい } \\
\text { ずれも優位でな } \\
\text { い }\end{array}$ & $\begin{array}{c}\text { おそらく介入が } \\
\text { 優位 }\end{array}$ & 介入が優位 & さまざま & 分からない \\
\hline 容認性 & いいえ & $\begin{array}{c}\text { おそらく、いい } \\
\text { え }\end{array}$ & おそらく、はい & はい & & さまざま & 分からない \\
\hline 実行可能性 & いいえ & $\begin{array}{c}\text { おそらく、いい } \\
\text { え }\end{array}$ & おそらく、はい & はい & & さまざま & 分からない \\
\hline
\end{tabular}

Campaign: International Guidelines for Management of Sepsis and Septic Shock: 2016. Intensive Care Med. 2017; 43: 304-77.

4) Ruokonen E, Takala J, Kari A, et al: Regional blood flow and oxygen transport in septic shock. Crit Care Med. 1993; 21: 1296-303.

5) Martin C, Papazian L, Perrin G, et al: Norepinephrine or dopamine for the treatment of hyperdynamic septic shock? Chest. 1993; 103: 1826-31.

6) Marik PE, Mohedin M: The Contrasting Effects of Dopamine and Norepinephrine on Systemic and Splanchnic Oxygen Utilization in Hyperdynamic Sepsis. JAMA. 1994; 272: 1354-7.

7) Mathur SK, Dhunna R, Chakraborty A: Comparison of norepinephrine and dopamine in the management of septic shock using impedance cardiography. Indian J Crit Care Med. 2007; 11: 186-91.

8) De Backer D, Biston P, Devriendt J, et al: Comparison of dopamine and norepinephrine in the treatment of shock. N Engl J Med. 2010; 362: 779-89. 
CQ6-9-2：成人敗血症患者に対する血管収縮薬 の第一選択としてノルアドレナリン，ドパミン， フェニレフリンのどれを使用するか？（ノルア ドレナリン vs フェニレフリン)

Answer：成人敗血症患者に対する血管収縮薬の第一 選択として，ノルアドレナリン，フェニレフリンのう ち，ノルアドレナリンを投与することを弱く推奨する （GRADE 2D : エビデンスの確実性 $=$ 「非常に低」）。

\section{（1）背景および本 CQの重要度}

日本版敗血症診療ガイドライン（J-SSCG）2016 1,2) およびSSCG 20163) では, 敗血症の初期蘇生におけ る血管収縮薬の第一選択薬はノルアドレナリンが推奨 された。しかし，SSCG 2016 ではフェニレフリンも第 一選択薬として検討されている。血管収縮薬の選択は 敗血症の初期蘇生に重要であり, 重要臨床課題として 取り上げた。

\section{(2) $\mathrm{PICO}$}

$\mathrm{P}$ (患者) : 成人, 初期輸液によっても目標平均血圧 まで血圧を上げることができない敗血症性ショッ ク，かつ血管収縮薬を投与していない状態の患 者。既に何らかの血管収縮薬を投与されている場 合や心機能低下の患者は対象としない

I（介入）：血管収縮薬の第一選択薬としてノルアド レナリンを使用する

C (対照) : 血管収縮薬の第一選択薬としてフェニレ フリンを使用する

$\mathrm{O}$ (アウトカム ) : 短期死亡（28日または30日死 亡), 長期死亡（90 日死亡，90日の評価がない場 合は最長の評価日を用いることを考慮する), ショック離脱期間, 臓器虚血, 不整脈

\section{（3）エビデンスの要約}

システマティックレビューの結果, PICO に合致し たランダム化比較試験（RCT）が 3 件施行 4-6）されて いたが,このうち Keriwalaらの $\mathrm{RCT}^{6}{ }^{6)}$ の結果は ClinicalTrials.gov で公表（NCT02203630）されており， 出版はされていない。いずれの RCT でも, 敗血症性 ショック患者に対して, ノルアドレナリンとフェニレ フリンが比較されていた。これらを用いたメタ解析を 実施した。

（4）益と害のバランス（Table 6-9-2-1）

望ましい効果 :

短期死亡のアウトカム（3 RCT: $\mathrm{n}=103 ）$ の効果推 定值とその信頼区間は， 1,000 人あたり 27 人少ない （181 人少ない〜 198 人多い）であった。長期死亡およ びショック離脱期間のアウトカムに関する報告はな かった。以上より，ノルアドレナリンによる望ましい 効果はわずかと判断した。

望ましくない効果 :

不整脈のアウトカム（1 RCT: $\mathrm{n}=17 ）$ の効果推定 值とその信頼区間は，1,000人あたり 98 人多い（100 人少ない〜 1,000 人多い）であった。評価対象の $\mathrm{n}$ 数 が非常に少なく，ノルアドレナリンによる望ましくな い効果は分からないと判断した。

益と害のバランス :

ノルアドレナリンによる望ましい効果は限定的であ り，望ましくない効果も $\mathrm{n}$ 数が少ない 1 本の RCT か らの結果である。以上より, 効果のバランスは介入も 比較もいずれも優位でないと判断した。

（5）アウトカム全般に関するエビデンスの確実性

今回採用したアウトカムの効果推定值の方向性は一 致していないため, エビデンスの確実性は最も低いア

Table 6-9-2-1エビデンスプロファイル

\begin{tabular}{|c|c|c|c|c|c|c|c|c|c|c|c|c|}
\hline \multicolumn{7}{|c|}{ 確実性の評価 } & \multicolumn{2}{|c|}{ 患者数 } & \multicolumn{2}{|c|}{ 勃果 } & \multirow[b]{2}{*}{ 確夷性 } & \multirow[b]{2}{*}{ 重要性 } \\
\hline 研究数 & $\begin{array}{c}\text { 研究 } \\
\text { デザイン }\end{array}$ & $\begin{array}{l}\text { パイアス } \\
\text { のリスク }\end{array}$ & 非一貫性 & 非直接性 & 不精踓性 & $\begin{array}{l}\text { その他 } \\
\text { の検討 }\end{array}$ & Noradrenal ine & Pheny lephr ine & $\begin{array}{l}\text { 相対指標 } \\
(95 \% \text { CI }\end{array}$ & $\begin{array}{l}\text { 絶対指標 } \\
(95 \% \mathrm{CI})\end{array}$ & & \\
\hline \multicolumn{13}{|c|}{ 短期死亡（28 日もしくは 30 日死亡） } \\
\hline 3 & RCT & 深刻 a & 深刻でない & 深刻でない & 非常に深刻 b & なし & $27 / 52(51.9 \%)$ & $28 / 51 \quad(54.9 \%)$ & $\begin{array}{l}\text { RR } 0.95 \\
(0.67 \text { to } \\
1.36)\end{array}$ & $\begin{array}{c}1,000 \text { 人あたり } \\
27 \text { 人少ない } \\
\text { (181 人少ない } \\
\sim 198 \text { 人多い) }\end{array}$ & $\begin{array}{l}\oplus \bigcirc \bigcirc \bigcirc \\
\text { 非常に低 }\end{array}$ & 重大 \\
\hline \multicolumn{13}{|l|}{ 不整脈 } \\
\hline 1 & RCT & 深刻 a & 深刻でない & 深刻でない & 非常に深刻 b & なし & $2 / 9(22.2 \%)$ & $1 / 8(12.5 \%)$ & $\begin{array}{l}\text { RR } 1.78 \\
(0.20 \text { to } \\
16.10)\end{array}$ & $\begin{array}{c}1,000 \text { 人あたり } \\
98 \text { 人多い } \\
(100 \text { 人少ない } \\
\sim 1,000 \text { 人多 } \\
\text { (1) }\end{array}$ & $\begin{array}{l}\oplus \bigcirc \bigcirc \bigcirc \\
\text { 非常に低 }\end{array}$ & 重大 \\
\hline
\end{tabular}


ウトカムの結果を採用し，「非常に低」とした。

（6）価値観

死亡に対する相対的価值は高いと考えられ，そのば らつきは少ないことが予想される。

（7）容認性

ノルアドレナリンのコストは約 100 円/1mg, フェ ニレフリンは約 60 円/1mg であるため, 医療経済への 影響は少ないと考える。患者・家族の視点からは本介 入を許容できる。医療従事者にとっては，いずれの薬 剤であってもシリンジポンプによる投与と循環動態の モニタリングが必要であるが，その負担は敗血症を診 療する集中治療室やそれに準じた施設であれば容認さ れる。フェニレフリンを集中治療室で使用する経験が 少ない施設においては，第一選択薬として容認できな い可能性がある。

\section{（8）実行可能性}

両剂共に，本邦では多くの病院で採用，使用されて いる薬剤である。また，両剤いずれにおいても，投与 に際して，シリンジポンプを用いること，循環動態を モニタリングすることが必要であるが，本邦において 敗血症性ショックを診療する集中治療室またはそれに 準じた施設であれば，実行可能性に関して問題ないと 考える。J-SSCG 2016 および SSCG 2016 ではノルアド レナリンが第一選択薬として推奨されており，医療従 事者によってはフェニレフリンを用いた初期蘇生の経 験が少ないことが予想される。したがって, フェニレ
フリンを集中治療室で使用する経験が少ない施設にお いては，第一選択薬としての実行可能性が低いかもし れない。

(9) 判断の要約 (Table 6-9-2-2)

（10）推奨グレーディング決定の工程

修正 RAND 法を用いた投票によって，中央值 8, 見解不一致指数 0.164 の結果となり, 委員会で採択さ れた（7 点以上 : 91.7\%)。

\section{（11）関連する他の診療ガイドラインにおける推奨}

J-SSCG 2016 1,2) では，ノルアドレナリンとドパミ ンの比較はあるものの, フェニレフリンとの比較はさ れていない。SSCG 20163）においてもフェニレフリン に関する推奨はなく，より多くの臨床試験の結果が得 られるまでは使用を制限すべきであると記載されてい る。

\section{（12）実施に関わる検討事項}

ノルアドレナリンの使用により，不整脈がわずかに 増加する可能性があり, 注意を要する。

\section{（13）今後の研究の可能性}

今後，フェニレフリンとドパミンとの比較，ノルア ドレナリンの投与を開始するタイミング，ノルアドレ ナリンの最大投与量を含む投与量，ノルアドレナリン を減量・中止するタイミングなどに関する研究が行わ れることが望まれる。

Table 6-9-2-2 判断の要約

\begin{tabular}{|c|c|c|c|c|c|c|c|}
\hline & \multicolumn{7}{|c|}{ 判断 } \\
\hline 問題 & いいえ & $\begin{array}{c}\text { おそらく、いい } \\
\text { え }\end{array}$ & おそらく、はい & はい & & さまざま & 分からない \\
\hline 望ましい効果 & わずか & 小さい & 中 & 大きい & & さまざま & 分からない \\
\hline 望ましくない効果 & 大きい & 中 & 小さい & わずか & & さまざま & 分からない \\
\hline エビデンスの確実性 & 非常に低 & 低 & 中 & 高 & & & 採用研究なし \\
\hline 価值钼 & $\begin{array}{c}\text { 重要な不確実性 } \\
\text { またはばらつき } \\
\text { あり }\end{array}$ & $\begin{array}{c}\text { 重要な不確実性 } \\
\text { またはばらつき } \\
\text { の可能性ありり }\end{array}$ & $\begin{array}{l}\text { 重要な不確実性 } \\
\text { またははばらつき } \\
\text { はおそらくなし }\end{array}$ & $\begin{array}{c}\text { 重要な不確実性 } \\
\text { またはばらつき } \\
\text { はなし }\end{array}$ & & & \\
\hline 効果のバランス & 比較が優位 & $\begin{array}{c}\text { 比較がおそらく } \\
\text { 優位 }\end{array}$ & $\begin{array}{c}\text { 介入も比較もい } \\
\text { ずれも優位でな } \\
\text { い }\end{array}$ & $\begin{array}{c}\text { おそらく介入が } \\
\text { 優位 }\end{array}$ & 介入が優位 & さまざま & 分からない \\
\hline 容認性 & いいえ & $\begin{array}{c}\text { おそらく、いい } \\
\text { え }\end{array}$ & おそらく、はい & はい & & さまざま & 分からない \\
\hline 実行可能性 & いいえ & $\begin{array}{c}\text { おそらく、いい } \\
\text { え }\end{array}$ & おそらく、はい & はい & & さまざま & 分からない \\
\hline
\end{tabular}




\section{文 献}

1）西田修, 小倉裕司, 井上茂亮, 他, 日本版敗血症診療ガイドラ イン 2016 作成特別委員会. 日本版敗血症診療ガイドライン 2016. 日集中医誌. 2017; 24: S1-232.

2）西田修, 小倉裕司, 井上茂亮, 他, 日本版敗血症診療ガイドラ イン 2016 作成特別委員会. 日本版敗血症診療ガイドライン 2016. 日救急医会誌. 2017; 28: S1-232.

3) Rhodes A, Evans LE, Alhazzani W, et al: Surviving Sepsis Campaign: International Guidelines for Management of Sepsis and Septic Shock: 2016. Intensive Care Med. 2017; 43: 304-77.

4) Morelli A, Ertmer C, Rehberg S, et al: Phenylephrine versus norepinephrine for initial hemodynamic support of patients with septic shock: A randomized, controlled trial. Crit Care. 2008; 12 R143.

5) Jain G, Singh DK: Comparison of phenylephrine and norepinephrine in the management of dopamine-resistant septic shock. Indian J Crit Care Med. 2010; 14: 29-34.

6) Vanderbilt University Medical, NCRR, NCATS: Phenylephrine Versus Norepinephrine for Septic Shock in Critically Ill Patients. ClinicalTrials.gov. (2014).
CQ6-10-1：成人敗血症患者に対する血管収縮薬 の第二選択としてアドレナリンを使用するか?

Answer：敗血症/敗血症性ショック患者に対する，血 管収縮薬の第二選択としてアドレナリンを使用しない ことを弱く推奨する（GRADE 2D：エビデンスの確実 性 $=$ 「非常に低」)。

\section{（1）背景および本 $C Q$ の重要度}

日本版敗血症診療ガイドライン（J-SSCG）2016 1,2) および SSCG 2016 3) では, 敗血症の初期蘇生におい てノルアドレナリンの昇圧効果が十分でない場合の第 二選択としてバソプレシンおよびアドレナリンが推奨 されている。しかし，バソプレシン，アドレナリンの いずれにも十分なエビデンスはなく，血管収縮薬の第 二選択薬についてのコンセンサスは得られていない。 血管収縮薬の選択は敗血症の初期蘇生に重要であり, 第二選択として何を使用するかについては, 重要臨床 課題であるといえる。

(2) $\mathrm{PICO}$

$\mathrm{P}$ (患者) : 成人, 初期輸液と血管収縮薬によっても 循環動態が改善しない敗血症性ショック患者

I（介入）：第二選択薬として，アドレナリンを使用 する

$\mathrm{C}$ (対照) : 第二選択薬として, アドレナリンを使用 しない

$\mathrm{O}$ (アウトカム $)$ : 短期死亡 (28 日死亡), 長期死亡 (90 日死亡), ショック離脱期間, 不整脈, 臓器 虚血

\section{（3）エビデンスの要約}

システマティックレビューの結果, PICO に合致し たランダム化比較試験（RCT）が 2 件施行 ${ }^{4,5)}$ されて おり，いずれの RCT も血管収縮薬を使用している敗 血症性ショック患者を対象とし, 対照群ではドブタミ ンが使用されていた。これらを用いたメタ解析を実施 した。

(4) 益と害のバランス（Table 6-10-1-1）

望ましい効果 :

ショック離脱期間の代理アウトカムとして，ICU 滞 在日数を用いた。ICU 滞在日数アウトカム (2 RCT: n =390）の効果推定值とその信頼区間は，平均（MD） 1 日短い（2.98 日短い〜0.98 日長い）だった。以上よ り, 望ましい効果はわずかと判断した。 
日集中医誌 J Jpn Soc Intensive Care Med Vol. 28 Suppl

Table 6-10-1-1エビデンスプロファイル

\begin{tabular}{|c|c|c|c|c|c|c|c|c|c|c|c|c|}
\hline \multicolumn{7}{|c|}{ 確実性の評価 } & \multicolumn{2}{|c|}{ 患者数 } & \multicolumn{2}{|c|}{ 勃果 } & \multirow[b]{2}{*}{ 確実性 } & \multirow[b]{2}{*}{ 重要性 } \\
\hline 研究数 & $\begin{array}{l}\text { 研究 } \\
\text { デザイ }\end{array}$ & $\begin{array}{l}\text { パイアス } \\
\text { のリスク }\end{array}$ & 非一贯性 & 非直接性 & 不精確性 & $\begin{array}{l}\text { その他 } \\
\text { の検討 }\end{array}$ & Adrenal ine & $\begin{array}{c}\text { Noradrenal ine } \\
\text { with } \\
\text { Dobutamine }\end{array}$ & $\begin{array}{l}\text { 相対指檟 } \\
(95 \% \text { CI }\end{array}$ & $\begin{array}{l}\text { 絶対指檟 } \\
(95 \% \text { CI }\end{array}$ & & \\
\hline \multicolumn{13}{|c|}{ 短期死亡（28 日死亡） } \\
\hline 2 & RCT & 深刻でない & 深刻でない & 深刻 a & 非常に深刻 b,c & なし & $\begin{array}{l}80 / 191 \\
(41.9 \%)\end{array}$ & $\begin{array}{l}73 / 199 \\
(36.7 \%)\end{array}$ & $\begin{array}{l}\text { RR } 1.13 \\
(0.89 \text { to } \\
1.45)\end{array}$ & $\begin{array}{l}1,000 \text { 人あた } \\
\text { り } 48 \text { 人多い } \\
\text { (40人少ない } \\
165 \text { 人少ない) }\end{array}$ & $\begin{array}{l}\oplus \bigcirc \bigcirc \bigcirc \\
\text { 非常に低 }\end{array}$ & 重大 \\
\hline \multicolumn{13}{|c|}{ 長期死亡（90 日死亡） } \\
\hline 1 & RCT & 深刻でない & 深刻でない & 深刻 a & 非常に深刻 b.c & なし & $\begin{array}{l}84 / 161 \\
(52.2 \%)\end{array}$ & $\begin{array}{l}85 / 169 \\
(50.3 \%)\end{array}$ & $\begin{array}{l}\text { RR } 1.04 \\
(0.84 \text { to } \\
1.28)\end{array}$ & $\begin{array}{c}1,000 \text { 人あた } \\
\text { り } 20 \text { 人多い } \\
\text { (80人少ない } \\
141 \text { 人多い) }\end{array}$ & $\begin{array}{l}\oplus \bigcirc \bigcirc \bigcirc \\
\text { 非常に低 }\end{array}$ & 重大 \\
\hline \multicolumn{13}{|c|}{ ICU 滞在日数 } \\
\hline 2 & RCT & 深刻でない & 深刻でない & 非常に深刻 a.d & 深刻 b & なし & 191 & 199 & - & $\begin{array}{l}\text { 平均 } 1 \text { 日短い } \\
\text { (2.98 日短い } \\
0.98 \text { 日長い) }\end{array}$ & $\begin{array}{l}\oplus \bigcirc \bigcirc \bigcirc \\
\text { 非常に低 }\end{array}$ & 重大 \\
\hline \multicolumn{13}{|l|}{ 不整脈 } \\
\hline 2 & RCT & 深刻でない & 深刻でない & 深刻 a & 非常に深刻 b.o & なし & $\begin{array}{l}37 / 191 \\
(19.4 \%)\end{array}$ & $\begin{array}{l}34 / 199 \\
(17.1 \%)\end{array}$ & $\begin{array}{l}\text { RR } 1.13 \\
(0.74 \text { to } \\
1.73)\end{array}$ & $\begin{array}{c}1,000 \text { 人あた } \\
\text { り } 22 \text { 人多い } \\
\text { (44人少ない } \\
125 \text { 人多い) }\end{array}$ & $\begin{array}{l}\oplus \bigcirc \bigcirc \bigcirc \\
\text { 非常に低 }\end{array}$ & 重大 \\
\hline \multicolumn{13}{|c|}{ 四肢虚血 } \\
\hline 2 & RCT & 深刻でない & 深刻でない & 深刻 a & 非常に深刻 b.c & なし & $5 / 191 \quad(2.6 \%)$ & $8 / 199 \quad(4.0 \%)$ & $\begin{array}{l}\text { RR } 0.70 \\
(0.17 \text { to } \\
2.91)\end{array}$ & $\begin{array}{c}1,000 \text { 人あた } \\
\text { り } 12 \text { 人少ない } \\
\text { (33人少ない } \\
77 \text { 人多い) }\end{array}$ & $\begin{array}{l}\oplus \bigcirc \bigcirc \bigcirc \\
\text { 非常に低 }\end{array}$ & 重要 \\
\hline
\end{tabular}

a. ドブタミンとの比較など，強心薬として使用したRCT を含んでいる。

b. 最適情報量の基準を満たしていない

d. ショック離脱期間の報告がなく，代理のアウトカムとして採用した。

望ましくない効果 :

28 日死亡のアウトカム（2 RCT: $\mathrm{n}=390 ）$ の効果推 定值とその信頼区間は， 1,000 人あたり 48 人多い $(40$ 人少ない〜 165 人多い), 90 日死亡のアウトカム（1 RCT: $\mathrm{n}=330 ）$ の効果推定值とその信頼区間は，1,000 人あたり 20 人多い（80人少ない〜 141 人多い）だっ た。不整脈のアウトカム（2 RCT: $\mathrm{n}=390 ）$ の効果推 定值とその信頼区間は，1,000人あたり 22 人多い (44 人少ない〜 125 人多い), 四肢虚血のアウトカム $(2$ RCT: $\mathrm{n}=390 ）$ の効果推定值とその信頼区間は，1,000 人あたり 12 人少ない（33 人少ない〜 77 人多い）だっ た。以上より，介入による望ましくない効果は小さい と判断した。

益と害のバランス :

正味の害は 1,000 人あたり 78 人，害のほうが大き い。したがって，「比較がおそらく優位」と判断した。

（5）アウトカム全般に関するエビデンスの確実性

採用されたすべてのアウトカムについて，益と害が 異なる方向性を示していたため, 最も低いエビデンス である「非常に低」を採用した。

（6）価値観

各アウトカムに置く患者・家族の価值観に関する
データはない。一般的に死亡アウトカムに対する相対 的価値は高く，ばらつきは少ないことが予想される。

\section{（7）容認性}

アドレナリンによる介入は効果が明らかではなく， 不整脈が増える可能性があり，患者・家族にとって容 認できない可能性がある。アドレナリン（商品名：ア ドレナリン）は 153 円（1管）であり，医療経済に与 える影響は小さい。医療従事者への負担は介入も対照 も変わらない。

\section{（8）実行可能性}

本邦の集中治療施設であれば，介入は問題なく実行 可能である。集中治療施設以外では介入も対照も実施 は困難が予想される。

（9）判断の要約（Table 6-10-1-2）

（10）推奨グレーディング決定の工程

修正 RAND 法を用いた投票によって，中央值 8 , 見解不一致指数 0.164 の結果となり，委員会で採択さ れた（7 点以上 : 87.5\%)。 
日本版敗血症診療ガイドライン 2020

Table 6-10-1-2 判断の要約

\begin{tabular}{|c|c|c|c|c|c|c|c|}
\hline & \multicolumn{7}{|c|}{ 判溇 } \\
\hline 問題 & いいえ & $\begin{array}{c}\text { おそらく、いい } \\
\text { え }\end{array}$ & おそらく、はい & はい & & さまざま & 分からない \\
\hline 望ましい効果 & わずか & 小さい & 中 & 大きい & & さまざま & 分からない \\
\hline 望ましくない勃果 & 大きい & 中 & 小さい & わずか & & さまざま & 分からない \\
\hline エビデンスの確実性 & 非常に低 & 低 & 中 & 高 & & & 採用研究なし \\
\hline 価值覞 & $\begin{array}{c}\text { 重要な不確実性 } \\
\text { またはばらつき } \\
\text { あり }\end{array}$ & $\begin{array}{c}\text { 重要な不確実性 } \\
\text { またはばらつき } \\
\text { の可能性あり }\end{array}$ & $\begin{array}{l}\text { 重要な不確実性 } \\
\text { またはばらつき } \\
\text { はおそらくなし }\end{array}$ & $\begin{array}{c}\text { 重要な不確実性 } \\
\text { またはばらつき } \\
\text { はなし }\end{array}$ & & & \\
\hline 効果のバランス & 比較が優位 & $\begin{array}{c}\text { 比較がおそらく } \\
\text { 優位 }\end{array}$ & $\begin{array}{c}\text { 介入も比較もい } \\
\text { ずれも優位でな } \\
\text { い }\end{array}$ & $\begin{array}{c}\text { おそらく介入が } \\
\text { 優位 }\end{array}$ & 介入が優位 & さまざま & 分からない \\
\hline 容認性 & いいえ & $\begin{array}{c}\text { おそらく、いい } \\
\text { え }\end{array}$ & おそらく、はい & はい & & さまざま & 分からない \\
\hline 実行可能性 & いいえ & $\begin{array}{c}\text { おそらく、いい } \\
\text { え }\end{array}$ & おそらく、はい & はい & & さまざま & 分からない \\
\hline
\end{tabular}

\section{（11）関連する他の診療ガイドラインにおける推奨}

J-SSCG 2016 1,2) では，十分な輸液とノルアドレナ リン投与を行っても循環動態の維持が困難な敗血症性 ショックには, アドレナリンの使用が弱く推奨されて いる（エキスパートコンセンサス）。また, SSCG 2016 ${ }^{3)}$ では, 目標平均血圧まで上げるために，ノル アドレナリンに加えてアドレナリンを併用することが 提案されている（弱い推奨，低いエビデンスレベル）。 これらは, 心機能低下症例における強心薬としての効 果を期待した推奨と考えられる。

\section{（12）実施に関わる検討事項}

今回の検討は，アドレナリンの血管収縮薬としての 効果を検証したものであり，強心薬としての効果は検 討していないことを留意して推奨を利用する（心機能 が低下した患者に対する強心薬としての検討は CQ6-11 を参照)。

\section{（13）今後の研究の可能性}

今後，アドレナリンの投与のタイミングや投与量, アドレナリンとバソプレシンの直接比較の検討に関す る研究が行われることが望まれる。

\section{文 献}

1）西田修, 小倉裕司, 井上茂亮, 他, 日本版敗血症診療ガイドラ イン 2016 作成特別委員会. 日本版敗血症診療ガイドライン 2016. 日集中医誌. 2017; 24: S1-232.

2）西田修, 小倉裕司, 井上茂亮, 他, 日本版敗血症診療ガイドラ イン 2016 作成特別委員会. 日本版敗血症診療ガイドライン 2016. 日救急医会誌. 2017; 28: S1-232.

3) Rhodes A, Evans LE, Alhazzani W, et al: Surviving Sepsis
Campaign: International Guidelines for Management of Sepsis and Septic Shock: 2016. Intensive Care Med. 2017; 43: 304-77.

4) Annane D, Vignon P, Renault A, et al: Norepinephrine plus dobutamine versus epinephrine alone for management of septic shock: a randomised trial. Lancet. 2007; 370: 676-84.

5) Mahmoud KM, Ammar AS: Norepinephrine supplemented with dobutamine or epinephrine for the cardiovascular support of patients with septic shock. Indian J Crit Care Med. 2012; 16: 75-80. 
CQ6-10-2：成人敗血症患者に対する血管収縮薬 の第二選択としてバソプレシンを使用するか? （保険適用外使用）

Answer：敗血症/敗血症性ショック患者に対する，血 管収縮薬の第二選択としてバソプレシンを使用するこ とを弱く推奨する（GRADE 2D：エビデンスの確実性 =「非常に低」)。

\section{（1）背景および本 $C Q$ の重要度}

日本版敗血症診療ガイドライン（J-SSCG）2016 1,2) およびSSCG 20163) では, 敗血症の初期蘇生におい てノルアドレナリンの昇圧効果が十分でない場合の第 二選択としてバソプレシンおよびアドレナリンが推奨 されている。しかし，バソプレシン，アドレナリンと も十分なエビデンスはなく，血管収縮薬の第二選択薬 についてのコンセンサスは得られていない。血管収縮 薬の選択は敗血症の初期蘇生に重要であり, 第二選択 薬として何を使用するかについて，本ガイドラインで も改めて課題として取り上げることは重要であり, 重 要臨床課題であるといえる。

(2) PICO

$\mathrm{P}$ (患者) : 成人, 初期輸液と血管収縮薬によっても 循環動態が改善しない敗血症性ショック患者

I（介入）：第二選択薬として, バソプレシンを使用 する

$\mathrm{C}$ (対照)：第二選択薬として, バソプレシンを使用 しない

$\mathrm{O}$ (アウトカム) : 短期死亡 (28 日死亡), 長期死亡 (90 日死亡), ショック離脱期間, 不整脈, 臟器 虚血

\section{（3）エビデンスの要約}

システマティックレビューの結果, PICO に合致し たランダム化比較試験（RCT）が 4 件施行 ${ }^{4-7}$ ) されて いた。いずれの RCT も血管収縮薬が必要な敗血症性 ショック患者に対して，ノルアドレナリンとバソプレ シンを比較しており，目標血圧が保てない場合には open label の血管収縮薬を使用することができた。 Gordon らが行った VANISH trial ${ }^{7)}$ は, バソプレシン とノルアドレナリンの比較および，低用量コルチコス テロイドとプラセボの比較も加え, 4 群に分けた RCT であった。これらを用いたメタ解析を実施した。
（4）益と害のバランス（Table 6-10-2-1）

望ましい効果 :

28 日死亡のアウトカム（4 RCT: $\mathrm{n}=1,260 ）$ の効果 推定値とその信頼区間は， 1,000 人あたり 10 人少ない (56 人少ない 45 人多い), 90 日死亡のアウトカム (1 RCT: $\mathrm{n}=792 ）$ の効果推定值とその信頼区間は，1,000 人あたり 54 人少ない $(114$ 人少ない 20 人多い）で あった。

ICU 滞在日数（3 RCT: $\mathrm{n}=1,217 ）$ の効果推定値と その信頼区間は平均（MD）0.16日長い（1.84日短 い〜2.17 日長い）だった。以上より，望ましい効果は 小さいと判断した。

望ましくない効果 :

不整脈（3 RCT: $\mathrm{n}=1,217 ）$ の効果推定値とその信 頼区間は，1,000 人あたり 5 人少ない（16 人少ない〜 19 人多い), 心筋虚血（2 RCT: $n=1,187 ）$ の効果推 定値とその信頼区間は，1,000 人あたり 10 人多い（7 人少ない〜 61 人多い), 四肢虚血 ( $3 \mathrm{RCT}: \mathrm{n}=1,217$ ) の効果推定值とその信頼区間は，1,000 人あたり 22 人 多い（4人多い〜69人多い）だった。以上ょり，望ま しくない効果はわずかと判断した。

益と害のバランス :

正味の効果は 1,000 人あたり 37 人, 介入が優位で ある。以上より，効果のバランスは「おそらく介入が 優位」と判断した。

（5）アウトカム全般に関するエビデンスの確実性 益と害の各アウトカムは異なる方向性を示していた ため, 最も低いエビデンスである「非常に低」を採用 した。

\section{（6）価值観}

各アウトカムに置く患者・家族の価値観に関する データはない。一般的に死亡アウトカムに対して置く 相対的価值は高く, ばらつきは少ないことが予想され る。

\section{（7）容認性}

有害事象として, 四肢虚血が増える可能性がある。 バソプレシン（商品名：ピトレシン）は， 668 円（1 管）と医療経済に与える影響は小さい。バソプレシン は, 循環動態の補助に対して保険適用が得られていな いため, 使用に際しては注意を要する。既に臨床現場 で広く使用されており，容認性は「おそらく，はい」 とした。 
Table 6-10-2-1エビデンスプロファイル

\begin{tabular}{|c|c|c|c|c|c|c|c|c|c|c|c|c|}
\hline \multicolumn{7}{|c|}{ 確実性の評価 } & \multicolumn{2}{|c|}{ 患者数 } & \multicolumn{2}{|c|}{ 効果 } & \multirow[b]{2}{*}{ 確実性 } & \multirow[b]{2}{*}{ 重要性 } \\
\hline 研究数 & $\begin{array}{l}\text { 研究 } \\
\text { デザイン }\end{array}$ & $\begin{array}{l}\text { バイアス } \\
\text { のリスク }\end{array}$ & 非一貫性 & 非直接性 & 不精確性 & $\begin{array}{l}\text { その他 } \\
\text { の梌討 }\end{array}$ & Vasopressin & $\begin{array}{l}\text { Noradrenaline } \\
\text { alone }\end{array}$ & $\begin{array}{l}\text { 相対指標 } \\
(95 \% \text { Cl) }\end{array}$ & $\begin{array}{l}\text { 絶対指標 } \\
(95 \% \text { II) }\end{array}$ & & \\
\hline \multicolumn{13}{|c|}{ 短期死亡（28 日死亡） } \\
\hline 4 & RCT & 深刻 a & 深刻でない & 深刻 b & 深刻 c & なし & $\begin{array}{c}217 / 636 \\
(34.1 \%)\end{array}$ & $\begin{array}{c}218 / 624 \\
(34.9 \%)\end{array}$ & $\begin{array}{c}\text { RR } 0.97 \\
(0.84 \text { to } \\
1.13)\end{array}$ & $\begin{array}{c}1,000 \text { 人あた } \\
\text { り } 10 \text { 人少な } \\
\text { い } \\
\text { (56人少ない } \\
45 \text { 人多い) }\end{array}$ & $\begin{array}{l}\oplus \bigcirc \bigcirc \bigcirc \\
\text { 非常に低 }\end{array}$ & 重大 \\
\hline
\end{tabular}

長期死亡 (90 日死亡)

\begin{tabular}{|c|c|c|c|c|c|c|c|c|c|c|c|c|}
\hline 1 & RCT & 深刻でない & 深刻でない & 深刻 b & 深刻 c & なし & $\begin{array}{c}177 / 400 \\
(44.3 \%)\end{array}$ & $\begin{array}{c}194 / 392 \\
(49.5 \%)\end{array}$ & $\begin{array}{c}\text { RR } 0.89 \\
(0.77 \text { to } \\
1.04)\end{array}$ & $\begin{array}{c}1,000 \text { 人あた } \\
\text { り } 54 \text { 人少な } \\
\text { い } \\
(114 \text { 人少な } \\
\text { い〜20人多 } \\
\text { () }\end{array}$ & $\begin{array}{c}\oplus \oplus \bigcirc \bigcirc \\
\text { 低 }\end{array}$ & 重大 \\
\hline
\end{tabular}

$\mathrm{ICU}$ 滞在日数

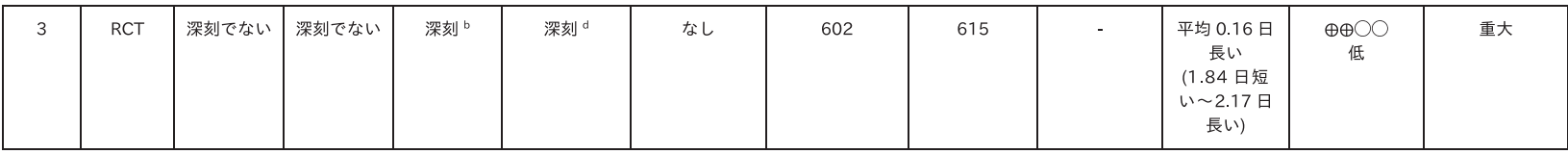

不整脈

\begin{tabular}{|c|c|c|c|c|c|c|c|c|c|c|c|c|}
\hline 3 & RCT & 深刻でない & 深刻でない & 深刻 b & 非常に深刻 c,e & なし & $11 / 616(1.8 \%)$ & $\begin{array}{c}14 / 601 \\
(2.3 \%)\end{array}$ & $\begin{array}{c}\text { RR } 0.77 \\
(0.33 \text { to } \\
1.81)\end{array}$ & $\begin{array}{c}1,000 \text { 人あた } \\
\text { り } 5 \text { 人少な } \\
\text { い } \\
\text { (16 人少ない } \\
19 \text { 人多い) }\end{array}$ & $\begin{array}{l}\oplus \bigcirc \bigcirc \bigcirc \\
\text { 非常に低 }\end{array}$ & 重大 \\
\hline
\end{tabular}

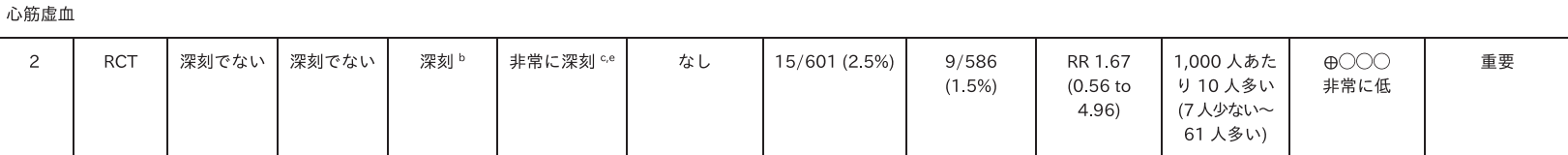

四肢虚血

\begin{tabular}{|c|c|c|c|c|c|c|c|c|c|c|c|c|}
\hline 3 & RCT & 深刻でない & 深刻でない & 深刻 b & 深刻 c & なし & $20 / 616(3.2 \%)$ & $\begin{array}{l}5 / 601 \\
(0.8 \%)\end{array}$ & $\begin{array}{c}\text { RR } 3.66 \\
(1.44 \text { to } \\
9.30)\end{array}$ & $\begin{array}{c}1,000 \text { 人あた } \\
\text { り } 22 \text { 人多い } \\
\text { (4 人多い〜 } \\
69 \text { 人多い) }\end{array}$ & $\underset{\text { 低 }}{\oplus \oplus \bigcirc \bigcirc}$ & 重要 \\
\hline
\end{tabular}

a. 盲検化が不十分な RCT を含んでいる。

b. 第二選択ではなく，第一選択として使用した患者が一部いたり，バゾプレシンへの切替や併用した RCTを含んでいる。

c. 最適情報量の基準を満たしていない。

d. サンプルサイズが十分ではない。

e. 臨床決断の閾值をまたぐ。

（8）実行可能性

本邦の集中治療施設であれば，介入は問題なく実行 可能である。集中治療施設以外では介入も対照も実施 は困難が予想される。

（9）判断の要約（Table 6-10-2-2）

（10）推奨グレーディング決定の工程

修正 RAND 法を用いた投票によって，中央值 7, 見解不一致指数 0.164 の結果となり，委員会で採択さ れた（7 点以上：75\%)。

（11）関連する他の診療ガイドラインにおける推奨

J-SSCG $2016^{1,2)}$ では，十分な輸液とノルアドレナ

リン投与を行っても昇圧効果が不十分な敗血症性 ショック患者に対して, バソプレシンを追加で使用す ることが弱く推奨されている（エキスパートコンセン
サス)。また，SSCG 20163）では，目標平均血圧まで 上げるために，ノルアドレナリンに加えてバソプレシ ンを併用すること（弱い推奨, 中等度のエビデンスレ ベル）や，ノルアドレナリンを減量する目的でバソプ レシンを併用することが提案されている（弱い推奨, 中等度のエビデンスレベル)。

\section{（12）実施に関わる検討事項}

バソプレシンは循環動態の補助に対して保険適用が 得られていないため, 使用に際しては注意を要する。 2 単位/時間を超える高用量投与では虚血性合併症が 増える可能性があることが報告されていることに留意 して推奨を利用する。

（13）今後の研究の可能性

今後，バソプレシンの投与のタイミングや投与量に ついては，さらなる検討が必要である。 
Table 6-10-2-2 判断の要約

\begin{tabular}{|c|c|c|c|c|c|c|c|}
\hline & \multicolumn{7}{|c|}{ 判溇 } \\
\hline 問題 & いいえ & $\begin{array}{c}\text { おそらく、いい } \\
\text { え }\end{array}$ & おそらく、はい & はい & & さまざま & 分からない \\
\hline 望ましい勃果 & わずか & 小さい & 中 & 大きい & & さまざま & 分からない \\
\hline 望ましくない勃果 & 大きい & 中 & 小さい & わずか & & さまざま & 分からない \\
\hline エビデンスの確実性 & 非常に低 & 低 & 中 & 高 & & & 採用研究なし \\
\hline 価值钼 & $\begin{array}{c}\text { 重要な不確実性 } \\
\text { またはばらつき } \\
\text { あり }\end{array}$ & $\begin{array}{c}\text { 重要な不確実性 } \\
\text { またはばらつき } \\
\text { の可能性ありり }\end{array}$ & $\begin{array}{l}\text { 重要な不確実性 } \\
\text { またはばらつき } \\
\text { はおそらくなし }\end{array}$ & $\begin{array}{c}\text { 重要な不確実性 } \\
\text { またはばらつき } \\
\text { はなし }\end{array}$ & & & \\
\hline 勃果のバランス & 比較が優位 & $\begin{array}{c}\text { 比較がおそらく } \\
\text { 優位 }\end{array}$ & $\begin{array}{c}\text { 介入も比較もい } \\
\text { ずれも優位でな } \\
\text { い }\end{array}$ & $\begin{array}{c}\text { おそらく介入が } \\
\text { 優位 }\end{array}$ & 介入が優位 & さまざま & 分からない \\
\hline 容認性 & いいえ & $\begin{array}{c}\text { おそらく、いい } \\
\text { え }\end{array}$ & おそらく、はい & はい & & さまざま & 分からない \\
\hline 実行可能性 & いいえ & $\begin{array}{c}\text { おそらく、いい } \\
\text { え }\end{array}$ & おそらく、はい & はい & & さまざま & 分からない \\
\hline
\end{tabular}

\section{文 献}

1）西田修, 小倉裕司, 井上茂亮, 他, 日本版敗血症診療ガイドラ イン 2016 作成特別委員会. 日本版敗血症診療ガイドライン 2016. 日集中医誌. 2017; 24: S1-232.

2）西田修, 小倉裕司, 井上茂亮, 他, 日本版敗血症診療ガイドラ イン 2016 作成特別委員会. 日本版敗血症診療ガイドライン 2016. 日救急医会誌. 2017; 28: S1-232.

3) Rhodes A, Evans LE, Alhazzani W, et al: Surviving Sepsis Campaign: International Guidelines for Management of Sepsis and Septic Shock: 2016. Intensive Care Med. 2017; 43: 304-77.

4) Lauzier F, Lévy B, Lamarre P, et al: Vasopressin or norepinephrine in early hyperdynamic septic shock: A randomized clinical trial. Intensive Care Med. 2006; 32: 1782-9.

5) Russell JA, Walley KR, Singer J, et al: Vasopressin versus norepinephrine infusion in patients with septic shock. N Engl J Med. 2008; 358: 877-87.

6) Barzegar E, Ahmadi A, Mousavi S, et al: The therapeutic role of vasopressin on improving lactate clearance during and after vasogenic shock: Microcirculation, Is it the black box? Acta Med Iran. 2016; 54: 15-23.

7) Gordon AC, Mason AJ, Thirunavukkarasu N, et al: Effect of early vasopressin vs norepinephrine on kidney failure in patients with septic shock: The VANISH randomized clinical trial. JAMA. 2016; 316: 509-18. 


\section{CQ6-11：心原性ショックを伴う成人敗血症患者 に対して強心薬を使用するか?}

Answer : 心機能低下を呈する成人敗血症性ショック 患者に対して, 強心薬（アドレナリン, ドブタミン) の投与を弱く推奨する（エキスパートコンセンサス： エビデンス不十分)。

\section{（1）背景および本 $C Q$ の重要度}

敗血症性ショックでは, sepsis-induced myocardial dysfunction（SIMD）と呼ばれる心機能障害が約 40\% の患者に合併し, 重症化との関連が示唆されてい る1,2)。SIMD を合併している敗血症性ショックでは, 血管収縮薬のノルアドレナリンに加え, 強心薬である ドブタミンやアドレナリンの投与が行われてきたが, その効果に対してはまだ議論も多い。日本版敗血症診 療ガイドライン（J-SSCG）2016では, 敗血症性ショッ クの心機能不全に対してドブタミンを推奨した ${ }^{3,4)}$ 。 SSCG 2016 でも，十分な輸液と昇圧薬の投与によって も循環動態が改善しない敗血症に対してドブタミンを 推奨するとしている5)。いずれも十分なエビデンスに 基づいた推奨ではなく, 敗血症性ショックの心機能不 全に対する強心薬の使用の可否は敗血症の初期蘇生に おいて重要であり, 重要臨床課題として取り上げた。

(2) PICO

$\mathrm{P}$ (患者): 成人，心機能低下を呈する敗血症性 ショック患者

I (介入) : 強心薬（ドブタミン，アドレナリン, PDE III 阻害薬，Ca 感受性増強薬）を使用する

$\mathrm{C}$ (対照): 強心薬（ドブタミン, アドレナリン, PDE III 阻害薬, Ca 感受性増強薬）を使用しない

$\mathrm{O}$ (アウトカム $)$ : 短期死亡 (28 日死亡), 長期死亡 (90日死亡), ショック離脱期間, 合併症（臓器 障害, 不整脈)

\section{（3）エビデンスの要約}

システマティックレビューの結果, PICO に合致す るランダム化比較試験（RCT） は認めなかった。心機 能が正常または低下している敗血症性ショックを対象 とした RCT は, アドレナリン投与を対照群, ドブタミ ン+ノルアドレナリン投与を介入群として比較検討し た報告と，アドレナリン+ノルアドレナリン投与を対 照群, ドブタミン十ノルアドレナリン投与を介入群と して比較検討した報告がある 6,7)。いずれの報告にお いても死亡や合併症の発生に差は認められていない。

\section{（4）益と害のバランス}

望ましい効果 :

PICO に合致する RCT は認めなかった。心機能が低 下している敗血症性ショックにおいては, その死亡率 が極めて高いことを鑑みると, 強心薬としてドブタミ ンまたはアドレナリンなどの強心薬を投与すること は，投与しない場合に比べて益があると考える。

望ましくない効果 :

PICO に合致するエビデンスはなかった。アドレナ リン，ドブタミンでは不整脈などの合併症が発生する ため，心機能によっては致死的な合併症となりうる。

益と害のバランス :

PICO に合致する RCT は存在せず不明であるが，心 機能が低下している敗血症性ショックにおいては, そ の死亡率が極めて高いことを鑑みると, 強心薬を投与 することの望ましい効果は望ましくない効果を上回る と考える。ただし, 心機能によっては強心薬の投与に より, 重篤な不整脈の出現が懸念され, 望ましくない 効果が上回る場合もある。

（5）アウトカム全般に関するエビデンスの確実性

システマティックレビューでは，PICO に合致する RCT は認めなかった。

\section{（6）価値観}

死亡率が低下することは, 患者・家族は一般的に重 視すると考えられる。

\section{（7）容認性}

強心薬のドブタミンにかかる薬価は約 230 円/100 $\mathrm{mg}$ であり, アドレナリンは約 100 円/1mg, ミルリノ ンは約 1,700 円/10mg であるため, 医療経済への影響 は少ないと考える。これらの薬剤は循環動態をモニタ リングしながらシリンジポンプで投与するため, 医療 従事者への負担がやや増加する。Ca 感受性増強薬に ついては, 注射用レボシメンダンは本邦での保険適用 はなく, 経口薬（ピモベンダン）のみ保険適用となっ ており, 敗血症性ショック患者への投与は現段階では むずかしい。

\section{（8）実行可能性}

ドブタミン，アドレナリンは本邦では多くの病院で 採用, 使用されている薬剂である。投与に際して, シ リンジポンプを用いること, 循環動態をモニタリング することが必要であるが, 本邦において敗血症性 ショックを診療する集中治療室またはそれに準じた施 
設であれば，実行可能性に関して問題ないと考える。

（9）判断の要約（Table 6-11-1）

\section{（10）推奨グレーディング決定の工程}

修正 RAND 法を用いた投票によって，中央值 7, 見解不一致指数 0.164 の結果となり, 委員会で採択さ れた（7点以上 : 79.2\%)。

\section{（11）関連する他の診療ガイドラインにおける推奨}

SSCG 20165) では, “We suggest using dobutamine in patients who show evidence of persistent hypoperfusion despite adequate fluid loading and the use of vasopressor agents (weak recommendation, low quality of evidence)." とドブタミンの推奨が示されている。J-SSCG 2016 では，「十分な輸液とノルアドレナリン投与を行って も循環動態の維持が困難であり，心機能が低下してい る敗血症性ショックにおいては，ドブタミンを使用す ることを弱く推奨する（エキスパートコンセンサ ス/エビデンスの質「C」)」とドブタミンの推奨が示 されている。

\section{（12）実施に関わる検討事項}

心機能が低下した敗血症性ショック患者の一部に は，強心薬の投与により，重篤な不整脈を発症する可 能性があり，慎重な投与または直ちに投与を中止する ことが必要となる場合がある。

\section{（13）今後の研究の可能性}

今後, 本推奨の根拠となるような心機能が低下した 敗血症性ショックに対する強心薬の有効性を検討する $\mathrm{RCT}$ や, 最適な強心薬の種類, 投与量, 投与のタイ ミングなどの検討に関する研究が行われることが望ま れる。

\section{文 献}

1) Bouhemad B, Nicolas-Robin A, Arbelot C, et al: Acute left ventricular dilatation and shock-induced myocardial dysfunction. Crit Care Med. 2009; 37: 441-7.

2) Romero-Bermejo FJ, Ruiz-Bailen M, Gil-Cebrian J, et al: Sepsisinduced cardiomyopathy. Curr Cardiol Rev. 2011; 7: 163-83.

3）西田修, 小倉裕司, 井上茂亮, 他, 日本版敗血症診療ガイドラ イン 2016 作成特別委員会. 日本版敗血症診療ガイドライン 2016. 日集中医誌. 2017; 24: S1-232.

4）西田修, 小倉裕司, 井上茂亮, 他, 日本版敗血症診療ガイドラ イン 2016 作成特別委員会. 日本版敗血症診療ガイドライン 2016. 日救急医会誌. 2017; 28: S1-232.

5) Rhodes A, Evans LE, Alhazzani W, et al: Surviving Sepsis Campaign: International Guidelines for Management of Sepsis and Septic Shock: 2016. Intensive Care Med. 2017; 43: 304-77.

6) Annane D, Vignon P, Renault A, et al: Norepinephrine plus dobutamine versus epinephrine alone for management of septic shock: a randomised trial. Lancet. 2007; 370: 676-84.

7) Mahmoud KM, Ammar AS: Norepinephrine supplemented with dobutamine or epinephrine for the cardiovascular support of patients with septic shock. Indian J Crit Care Med. 2012; 16: 75-80.

Table 6-11-1 判断の要約

\begin{tabular}{|c|c|c|c|c|c|c|c|}
\hline 問題 & いいえ & $\begin{array}{c}\text { おそらく、いい } \\
\text { え }\end{array}$ & おそらく、はい & はい & & さまざま & 分からない \\
\hline 望ましい勃果 & わずか & 小さい & 中 & 大きい & & さまざま & 分からない \\
\hline 望ましくない効果 & 大きい & 中 & 小さい & わずか & & さまざま & 分からない \\
\hline エビデンスの確実性 & 非常に低 & 低 & 中 & 高 & & & 採用研究なし \\
\hline 価值锥 & $\begin{array}{c}\text { 重要な不確実性 } \\
\text { またはばらつき } \\
\text { あり }\end{array}$ & $\begin{array}{c}\text { 重要な不確実性 } \\
\text { またはば情うき } \\
\text { の可能性あり }\end{array}$ & $\begin{array}{l}\text { 重要な不確実性 } \\
\text { またはばらつき } \\
\text { はおそらくなし }\end{array}$ & 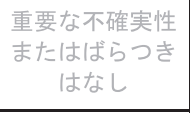 & & & \\
\hline 勃果のバランス & 比較が優位 & $\begin{array}{c}\text { 比較がおそらく } \\
\text { 優位 }\end{array}$ & $\begin{array}{c}\text { 介入も比較もい } \\
\text { ずれも優位でな } \\
\text { い }\end{array}$ & $\begin{array}{c}\text { おそらく介入が } \\
\text { 優位 }\end{array}$ & 介入が優位 & さまざま & 分からない \\
\hline 容認性 & いいえ & $\begin{array}{c}\text { おそらく、いい } \\
\text { え }\end{array}$ & おそらく、はい & はい & & さまざま & 分からない \\
\hline 実行可能性 & いいえ & $\begin{array}{c}\text { おそらく、いい } \\
\text { え }\end{array}$ & おそらく、はい & はい & & さまざま & 分からない \\
\hline
\end{tabular}


CQ6-12：成人敗血症患者に対して $\beta$ 遮断薬を使 用するか?

Answer : 敗血症/敗血症性ショック患者に対して, 初 期蘇生輸液などの標準治療でコントロールできない頻 拍（頻脈）の管理目的に, 短時間作用型 $\beta_{1}$ アドレナ リン受容体遮断薬をモニター監視下で投与することを 弱く推奨する (GRADE 2D：エビデンスの確実性 $=$ 「非常に低」)。

コメント：短時間作用型 $\beta_{1}$ アドレナリン受容体遮断 薬の投与は循環動態の変動を来す恐れがあるため, 集 中治療室で循環管理に熟練した医師のもとで投与する ことが望ましい。

\section{（1）背景および本 $C Q$ の重要度}

敗血症性ショックにおける従来の治療戦略は, 主に 初期輸夜とカテコラミンを含む血管収縮薬, 強心薬の 投与であった。近年, 敗血症性ショックの頻拍に対し て心拍数のコントロールを目的に $\beta_{1}$ アドレナリン受 容体遮断薬投与の効果を検討した複数の研究があり, 初期蘇生における循環動態の改善や必要輸液量の減 少，短期死亡率の減少などの報告がある。これは，従 来の治療戦略を見直すきっかけとなり，将来の標準治 療になりうるため, 重要臨床課題であるといえる。

\section{(2) PICO}

P (患者) : 成人, 敗血症/敗血症性ショック患者

I（介入）：心拍数の管理目的の $\beta_{1}$ アドレナリン受 容体遮断薬を投与する

C (対照)：従来治療（標準治療）

$\mathrm{O}$ (アウトカム ) : 短期死亡（28日もしくは 30 日死 亡), 長期死亡 (90 日死亡, 90 日がない場合は最 長を用いることを考慮する），入院日数（もしく は, 非入院日数), ICU 滞在日数（もしくは, ICU 管理を要した日数), あらゆる重篤な有害事 象（徐拍, 低血圧, 不整脈, 臟器障害の進行）

\section{（3）エビデンスの要約}

システマティックレビューの結果, PICO に合致し たランダム化比較試験（RCT）が 2 件施行 ${ }^{1,2}$ 2) されて いた。Morelli らの研究 1) は, 十分な補液とノルアド レナリンにより平均動脈圧 $65 \mathrm{mmHg}$ 以上に維持され, 心拍数が 95/分以上の患者を対象に，エスモロールの 持続静注を $25 \mathrm{mg} /$ 時間で開始し，心拍数 80〜 94/分を 目標に $2,000 \mathrm{mg} /$ 時間を上限として 96 時間以上使用し た非盲検の単施設 RCT である。一方, Wang らの研
究2）は，SIRS 診断基準の 2 項目を満たし，十分な補 液後にもかかわらず心拍数 $95 /$ 分以上の患者を対象に, 従来通りの治療を継続したコントロール群，ミルリノ ンを追加使用した群，ミルリノンとエスモロールを併 用した群の 3 群で比較した単施設盲検化 RCT である。 これら $2 つ の \mathrm{RCT}$ を用いたメタ解析を実施した。

\section{（4）益と害のバランス（Table 6-12-1）}

\section{望ましい効果 :}

短期死亡のアウトカム（2 RCT: $\mathrm{n}=244 ）$ の効果推 定值とその信頼区間は，1,000 人あたり 304 人少ない （395 人少ない 190 人少ない）であった。生存患者の ICU 滞在日数（1 RCT: $\mathrm{n}=42 ）$ の効果推定值とその 信頼区間は，平均（MD）4 日短い（18.06日短い〜 10.06 日長い)，ICU 管理を要した日数（1 RCT: $\mathrm{n}=$ 60）はMD 4.1 日長い（1.8 長い〜 6.4 長い）であった。 以上より，望ましい効果は大きいと判断した。

望ましくない効果 :

重篤な有害事象として徐拍, 臟器障害の進展として 腎代替療法の施行が報告されていた。徐拍（1 RCT: $\mathrm{n}=60$ ）は，介入群で 30 人中 2 人に認め, 対照群で は発生がなかった。介入群で増加するが, 対照群のイ ベント発生が 0 であったため, 効果推定值を求めるこ とができなかった。腎代替療法（1 RCT: $\mathrm{n}=154 ）$ の 効果推定值とその信頼区間は，1,000 人あたり 12 人少 ない（141 人少ない〜175人多い）であった。以上よ り，望ましくない効果はわずかと判断した。 益と害のバランス :

望ましい効果は大きく, 望ましくない効果について はわずかである。以上より，介入が優位とした。

\section{（5）アウトカム全般に関するエビデンスの確実性}

益と害の各アウトカムは異なる方向性を示していた ため, 最も低いエビデンスである「非常に低」を採用 した。

\section{（6）価値観}

敗血症における頻拍の管理に対する価值観のエビデ ンスはない。一般的に死亡に対する相対的価值は高 く,そのばらつきは少ないことが予想される。

\section{（7）容認性}

エビデンスとして採用した RCT は 2 本とも海外でエ スモロールを使用した研究である。本邦において使用 可能な $\beta$ 遮断薬であるランジオロールの薬価は 4,730 円 $/ 50 \mathrm{mg}$ ，プロプラノロールの薬価は 83 円 $/ 2 \mathrm{mg}$, エス 
Table 6-12-1 エビデンスプロファイル

\begin{tabular}{|c|c|c|c|c|c|c|c|c|c|c|c|c|}
\hline \multicolumn{7}{|c|}{ 確実性の評価 } & \multicolumn{2}{|c|}{ 患者数 } & \multicolumn{2}{|c|}{ 勃果 } & \multirow[b]{2}{*}{ 確実性 } & \multirow[b]{2}{*}{ 重要性 } \\
\hline 研究数 & $\begin{array}{c}\text { 研究 } \\
\text { デザイン }\end{array}$ & $\begin{array}{l}\text { パイアス } \\
\text { のリスク }\end{array}$ & 非一貫性 & 非直接性 & 不精確性 & $\begin{array}{l}\text { その他 } \\
\text { の検討 }\end{array}$ & $\begin{array}{c}\beta_{1} \text { アドレナ } \\
\text { リン受容体遮 } \\
\text { 断韮 }\end{array}$ & プラセボ & $\begin{array}{l}\text { 相対指償 } \\
(95 \% \mathrm{CI})\end{array}$ & $\begin{array}{l}\text { 絶対指標 } \\
(95 \% \text { Cl) }\end{array}$ & & \\
\hline \multicolumn{13}{|c|}{ 短期死亡（28 日死亡） } \\
\hline 2 & RCT & 深刻 a & 深刻でない & 非常に深刻 b.c & 深刻 d & なし & $\begin{array}{l}50 / 107 \\
(46.7 \%)\end{array}$ & $\begin{array}{l}104 / 137 \\
(75.9 \%)\end{array}$ & $\begin{array}{l}\text { RR } 0.60 \\
(0.48 \text { to } \\
0.75)\end{array}$ & $\begin{array}{c}\text { 1,000 人あたり } \\
304 \text { 人少ない } \\
(395 \text { 人少ない } \\
190 \text { 人少ない) }\end{array}$ & $\begin{array}{l}\oplus \bigcirc \bigcirc \bigcirc \\
\text { 非常に低 }\end{array}$ & 重大 \\
\hline \multicolumn{13}{|c|}{ ICU 滞在日数 } \\
\hline 1 & RCT & 深刻 a & 深刻でない & 深刻でない & 深刻 d & なし & 33 & 9 & - & $\begin{array}{c}\text { 平均 } 4 \text { 日短い } \\
(18.06 \text { 日短い } \\
\text { 10.06 日長い) }\end{array}$ & $\underset{\text { 低 }}{\oplus \oplus \bigcirc}$ & 重大 \\
\hline \multicolumn{13}{|c|}{ ICU 管理を要した日数 } \\
\hline 1 & RCT & 深刻 a & 深刻でない & 深刻 b & 深刻 d & なし & 30 & 30 & - & $\begin{array}{c}\text { 平均 } 4.1 \text { 日長い } \\
(1.8 \text { 日長い } 6.4 \\
\text { 日長い) }\end{array}$ & $\begin{array}{l}\oplus \bigcirc \bigcirc \bigcirc \\
\text { 非常に低 }\end{array}$ & 重大 \\
\hline \multicolumn{13}{|c|}{ 重篤な有害事象（徐拍） } \\
\hline 1 & RCT & 深刻 a & 深刻でない & 深刻 b & 非常に深刻 d,e & なし & $2 / 30(6.7 \%)$ & $0 / 30 \quad(0.0 \%)$ & $\begin{array}{l}\text { RR } 5.00 \\
(0.25 \text { to } \\
99.95)\end{array}$ & $\begin{array}{c}1,000 \text { 人あたり } 0 \\
\text { 人少ない } \\
(0 \text { 人少ない 0 } \\
\text { 人少ない })^{f}\end{array}$ & $\begin{array}{l}\oplus \bigcirc \bigcirc \bigcirc \\
\text { 非常に低 }\end{array}$ & 重大 \\
\hline \multicolumn{13}{|c|}{ 重篤な有害事象（繊器障害の進展：腎代替療法の施行） } \\
\hline 1 & RCT & 深刻 a & 深刻でない & 深刻でない & 非常に深刻 d.e & なし & $\begin{array}{c}31 / 77 \\
(40.3 \%)\end{array}$ & $\begin{array}{c}32 / 77 \\
(41.6 \%)\end{array}$ & $\begin{array}{l}\text { RR } 0.97 \\
(0.66 \text { to } \\
1.42)\end{array}$ & $\begin{array}{c}1,000 \text { 人あたり } \\
12 \text { 人少ない } \\
(141 \text { 人少ない } \\
175 \text { 人多い) }\end{array}$ & $\begin{array}{c}\oplus \bigcirc \bigcirc \bigcirc \\
\text { 非常に低 }\end{array}$ & 重大 \\
\hline
\end{tabular}

a. 盲検化されていない。

b. Wang 20152)の介入群がミルリノンを併用している。

c. Wang 2015²)の対照群がミルリノンの併用が含まれる。

d. 最適情報量基準を満たしていない。

. 信頼区間が臨床決断の閾値をまたぐ

f. 今回採用したRCTにおける対照群のイベント発生が 0 であり，計算できない。

モロールの薬価は 3,208 円/100mg であり，医療経済へ の影響はあまり大きくないと考える。ただし，エスモ ロールの適応は本邦では手術時の上室性頻脈性不整脈 に対する使用に限定されており，使用に際しては注意 を要する。

\section{（8）実行可能性}

本邦の集中治療施設であれば，実行可能である。集 中治療施設以外では，実行は困難が予想される。

(9) 判断の要約 (Table 6-12-2)

（10）推奨グレーディング決定の工程

修正 RAND 法を用いた投票によって，中央值 7.5, 見解不一致指数 0.164 の結果となり，委員会で採択さ れた（7点以上 : 87.5\%)。

\section{（11）関連する他の診療ガイドラインにおける推奨}

敗血症または敗血症性ショック患者における初期蘇 生輸液などの標準治療でコントロールできない頻拍 (頻脈) への短時間作用型 $\beta_{1}$ アドレナリン受容体遮 断薬の使用について, 日本版敗血症診療ガイドライン (J-SSCG）2016 3，4）と SSCG 20165）ではCQ として取
り上げていない。

（12）実施に関わる検討事項

$\beta_{1}$ アドレナリン受容体遮断薬の投与は循環動態の 変動を来す恐れがある。モニタ一監視下で従来の治療 （標準治療）が十分に行われたうえで， $\beta_{1}$ アドレナ リン受容体遮断薬を投与することが望ましい。本 CQ では，“短時間作用型 $\beta_{1}$ アドレナリン受容体遮断薬 の投与は循環動態の変動を来す恐れがあるため, 集中 治療室で循環管理に熟練した医師のもとで投与するこ とが望ましい”というエキスパートコンセンサスを加 えて提示することとした。

ランジオロールやプロプラノロールについては，採 用した RCT で検討されておらず，使用に際しては注 意を要する。

\section{（13）今後の研究の可能性}

今後，確実な二重盲検下での多施設参加型 RCT に よる評価， $\beta_{1}$ アドレナリン受容体遮断薬を使用する 時期，投与量の検証，ミルリノン併用の有無に関する 検証, 本邦で使用可能な $\beta_{1}$ アドレナリン受容体遮断 薬の検証に関する研究が行われることが望まれる。 
Table 6-12-2 判断の要約

\begin{tabular}{|c|c|c|c|c|c|c|c|}
\hline 問題 & いいえ & $\begin{array}{c}\text { おそらく、いい } \\
\text { え }\end{array}$ & おそらく、はい & はい & & さまざま & 分からない \\
\hline 望ましい勃果 & わずか & 小さい & 中 & 大きい & & さまざま & 分からない \\
\hline 望ましくない効果 & 大きい & 中 & 小さい & わずか & & さまざま & 分からない \\
\hline エビデンスの確実性 & 非常に低 & 低 & 中 & 高 & & & 採用研究なし \\
\hline 価值钼 & $\begin{array}{c}\text { 重要な不確実性 } \\
\text { またはばらつき } \\
\text { あり }\end{array}$ & $\begin{array}{c}\text { 重要な不確実性 } \\
\text { またはばらつき } \\
\text { の可能性ありり }\end{array}$ & $\begin{array}{l}\text { 重要な不確実性 } \\
\text { またはばらつき } \\
\text { はおそらくなし }\end{array}$ & $\begin{array}{c}\text { 重要な不確実性 } \\
\text { またははばらつき } \\
\text { はなし }\end{array}$ & & & \\
\hline 効果のバランス & 比較が優位 & $\begin{array}{c}\text { 比較がおそらく } \\
\text { 優位 }\end{array}$ & $\begin{array}{c}\text { 介入も比較もい } \\
\text { ずれも優位でな } \\
\text { い }\end{array}$ & $\begin{array}{c}\text { おそらく介入が } \\
\text { 優位 }\end{array}$ & 介入が優位 & さまざま & 分からない \\
\hline 容認性 & いいえ & $\begin{array}{c}\text { おそらく、いい } \\
\text { え }\end{array}$ & おそらく、はい & はい & & さまざま & 分からない \\
\hline 実行可能性 & いいえ & $\begin{array}{c}\text { おそらく、いい } \\
\text { え }\end{array}$ & おそらく、はい & はい & & さまざま & 分からない \\
\hline
\end{tabular}

\section{文 献}

1) Morelli A, Ertmer C, Westphal M, et al: Effect of heart rate control with esmolol on hemodynamic and clinical outcomes in patients with septic shock: A randomized clinical trial. JAMA. 2013; 310: 1683-91

2) Wang Z, Wu Q, Nie X, et al: Combination Therapy with Milrinone and Esmolol for Heart Protection in Patients with Severe Sepsis: A Prospective, Randomized Trial. Clin Drug Investig. 2015; 35: 707-16.

3）西田修, 小倉裕司, 井上茂亮, 他, 日本版敗血症診療ガイドラ イン 2016 作成特別委員会. 日本版敗血症診療ガイドライン 2016. 日集中医誌. 2017; 24: S1-232.

4）西田修, 小倉裕司, 井上茂亮, 他, 日本版敗血症診療ガイドラ イン 2016 作成特別委員会. 日本版敗血症診療ガイドライン 2016. 日救急医会誌. 2017; 28: S1-232.

5) Rhodes A, Evans LE, Alhazzani W, et al: Surviving Sepsis Campaign: International Guidelines for Management of Sepsis and Septic Shock: 2016. Intensive Care Med. 2017; 43: 304-77. 


\section{CQ6-13：成人敗血症性ショック患者に対する補 助循環の適応は?}

Answer : 敗血症性ショック患者における心機能不全 に対して, 静脈-動脈膜型人工肺 (veno-arterial extracorporeal membrane oxygenation: V-A ECMO）や大動脈 内バルーンパンピング (intra-aortic balloon pumping: IABP）などの補助循環の効果に関するエビデンスは 十分ではなく，適応は検討段階である（BQ に対する 情報提示)。

\section{（1）背景および本 $C Q$ の重要度}

敗血症性ショックでは，血管拡張に伴う相対的血管 内容量減少によるショックだけでなく, sepsis-induced myocardial dysfunction（SIMD）と呼ばれる心機能障害 を発症し，心拍出量が低下する病態を呈することも知 られている。最近, 重篤な心機能低下を呈する成人敗 血症患者に対して補助循環装置（V-A ECMO, IABP など）の使用が効果的であったとする報告が散見され るが，有効性に関するエビデンスは明確ではない。敗 血症性ショックにおける心機能不全に対する補助循環 の適用を提示することは重要と考え, 本ガイドライン の CQ として取り上げた。

\section{（2）解説}

敗血症性ショックは，血管拡張に伴う相対的血管内 容量減少によるショックだけでなく，SIMD あるいは 敗血症性心筋症（septic cardiomyopathy）と呼ばれる心 機能障害による心原性ショックを呈することもあ る1,2)。心原性ショック症例を対象とした IABP のラ ンダム化比較試験（RCT）（IABP-SHOCK II trial） ${ }^{3,4}$ では, IABP の使用は心原性ショックの予後を改善し ておらず，心原性ショックにおける（V-A ECMO）と IABP を比較したメタ解析 ${ }^{5)}$ では, V-A ECMO は安全 に使用可能で血行動態を改善したものの，30 日生存 率に有意差はなく，出血に関する合併症が多かったと 報告されている。一方, 本邦の急性・慢性心不全診療 ガイドライン（2017 年改訂版）6）では，「IABP のルー チンでの使用は推奨されないものの，一般に内科治療 に反応しない重症心不全の場合，使用が考慮される」 と記載されている。SIMD を呈した敗血症性ショック 症例に関して，IABP の使用を検討した報告は極めて 少なく, Hiromi ら 7) は, 敗血症患者 2 症例に IABP を導入し救命できたと報告しているが，Takahashi ら 8$)$ の 10 症例の検討では, IABP 導入により循環動 態は改善するものの 28 日生存率は $30 \%$ であった。
SIMD を呈した敗血症性ショック症例に対するV-A ECMO 使用の症例報告や観察研究は散見されるが, 生存率に関しては 15〜70\% と大きく異なっている。 Huang ら 9) は, V-A ECMO を導入した 52 症例を検討 し，生存率は $15 \%$ （8 症例）であったと報告している が，うち 40\%（21 症例）の症例で V-A ECMO 導入前 に心停止に陥っており, 導入時期の問題が予後に大き く影響している可能性がある。Cheng ら 10) は V-A ECMO を導入した 151 症例の成人敗血症患者の検討 から, 生存退院率は $29.8 \%$ であるが, 75 歳以上，進 行性悪性腫瘍患者, 未期の心不全・腎不全患者, 免疫 抑制患者（計 67 名）を除いて解析すると, 生存退院 率は $42 \%$ であったと報告しており，年齢や免疫不全 などの病態が予後に大きく影響する可能性を示唆して いる。一方, Bréchot ら ${ }^{11)}$ は, 14 症例の敗血症性 ショック患者 (平均駆出率 $16 \%$, 平均心係数 $\left.1.3 \mathrm{~L} / \mathrm{min} / \mathrm{m}^{2}\right)$ に $-\mathrm{A}$ ECMO を導入し, 生存退院率は $71.4 \%$ で 1 年以上の経過観察でも良好な QOL であっ たと報告している。彼らの報告には比較的若年症例が 多く含まれていること（平均年齢 45 歳）に留意する 必要はあるが，V-A ECMO の有効性を示す結果となっ ている。Falk ら ${ }^{12)}$ は, V-A ECMO が導入された 37 症例（平均年齢 54.7 歳）のうち, 左室機能低下（平 均駆出率 $25 \%$ ）の 20 症例に限定して検討すると, 病 院生存率 90\%, 長期生存率は $75 \%$ であったと報告し, Vogel ら 13) も, 敗血症性心筋症（12 例）に対して veno-arterio-venous（VAV） ECMO を導入し，6か月後 の生存率は $75 \%$ であったと報告している。特に Vogel らの報告では, ECMO 導入前に心停止に陥った 5 症 例 $(41.7 \%$ ）も加えた検討であり, ECMO 使用の有効 性を十分に示す結果だと思われる。高氏ら ${ }^{14)}$ は，本 邦で 2011〜2013 年の間に行われた The Japan Septic Disseminated Intravascular Coagulation (JSEPTIC DIC) 研究のサブ解析から, V-A ECMO を導入した 30 症例 の予後検討を行ったところ, 生存退院率が $20 \%$ であっ たと報告している。この結果は, 世界の報告と比較す ると若干低值である。しかし，本邦の ARDS に対す る V-V ECMO 使用例の生存率は，36\%（2009 年）か ら 79\%（2016 年）と 2 倍以上に改善しており ${ }^{15)}$, 重 篤な心機能低下を呈する成人敗血症患者に対する V-A ECMO 使用に関しても, 今後, 成績の向上が期待で きると思われる。これまでの先行研究から，V-A ECMO を導入した成人敗血症性ショック症例の予後 因子として, 年齢9), 重症心筋障害 ${ }^{16)}$, ECMO 導入 前の心停止 ${ }^{16)}$, ショックから ECMO 導入までの時 間 17) などがあげられているが，それ以外に ECMO 装 
置の改良や医療スタッフの ECMO 装置に対する習熟 度なども重要であり，それらを考慮した治療戦略が必 要になると思われる。しかし, 成人敗血症患者に対す る V-A ECMOの報告は未だ十分とはいえず，多くが 単一施設での後ろ向き観察研究である。治療の有効性 を検討した RCT は未だ行われておらず，現時点で重 篤な心機能低下を呈する成人敗血症に対するV-A ECMO や IABP の有効性については，依然検討段階で ある。

\section{文 献}

1) Parker MM, Shelhamer JH, Bacharach SL, et al: Profound but reversible myocardial depression in patients with septic shock. Ann Intern Med. 1984; 100: 483-90.

2) Landesberg G, Gilon D, Meroz Y, et al: Diastolic dysfunction and mortality in severe sepsis and septic shock. Eur Heart J. 2012; 33: 895-903.

3) Thiele H, Zeymer U, Neumann FJ, et al: IABP-SHOCK II Trial In- vestigators: Intraaortic balloon support for myocardial infarction with cardiogenic shock. N Engl J Med. 2012; 367: 1287-96.

4) Thiele H, Zeymer U, Neumann FJ, et al: Intra-aortic balloon pump in cardiogenic shock II (IABP-SHOCK II) trial investigators. Intraaortic balloon counterpulsation in acute myocardial infarction complicated by cardiogenic shock (IABP-SHOCK II) : final 12 month results of a randomised, open-label trial. Lancet. 2013; 382: 1638-45

5) Cheng JM, den Uil CA, Hoeks SE, et al: Percutaneous left ventricular assist devices vs. intra-aortic balloon pump counterpulsation for treatment of cardiogenic shock: a meta-analysis of controlled trials. Eur Heart J. 2009; 30: 2102-8.

6) 日本循環器学会, 日本心不全学会, 日本胸部外科学会, 他: 急 性・慢性心不全診療ガイドライン（2017 年改訂版）. Available online at: http://www.asas.or.jp/jhfs/pdf/ topics20180323.pdf.

7) Hiromi $T$, Toida $C$, Muguruma $T$, et al: Two cases with intraaortic balloon pumping use for severe septic cardiomyopathy. Acute Med Surg. 2017; 4: 446-50.

8) Takahashi $Y$, Sonoo $T$, Naraba H, et al: Effect of Intra-arterial balloon pumping for refractory septic cardiomyopathy: A Case Series. Indian J Crit Care Med. 2019; 23: 182-5.

9) Huang CT, Tsai YJ, Tsai PR, et al: Extracorporeal membrane oxygenation resuscitation in adult patients with refractory septic shock. J Thorac Cardiovasc Surg. 2013; 146: 1041-6.

10) Cheng A, Sun HY, Tsai MS, et al: Predictors of survival in adults undergoing extracorporeal membrane oxygenation with severe infections. J Thorac Cardiovasc Surg. 2016; 152: 1526-36. e1.

11) Bréchot N, Luyt CE, Schmidt M, et al: Venoarterial extracorporeal membrane oxygenation support for refractory cardiovascular dysfunction during severe bacterial septic shock. Crit Care Med. 2013; 41: 1616-26.

12) Falk L, Hultman J, Broman LM: Extracorporeal membrane oxygenation for septic shock. Crit Care Med. 2019; 47: 1097-105.

13) Vogel DJ, Murray J, Czapran AZ, et al: Veno-arterio-venous ECMO for septic cardiomyopathy: a single-centre experience. Perfusion. 2018; 33(1_suppl) : 57-64.

14）高氏修平, 早川峰司, 大野浩太, 他: 成人重症敗血症 - 敗血症 ショックに対するV-A ECMO についての後ろ向き研究. 日 救急医会誌. 2017; 28: 904-9.

15) Ohshimo $S$, Shime N, Nakagawa $S$, et al: Comparison of extracorporeal membrane oxygenation outcome for influenza-associated acute respiratory failure in Japan between 2009 and 2016. J Intensive Care. 2018; 6: 38.

16) Park TK, Yang JH, Jeon K, et al: Extracorporeal membrane oxygenation for refractory septic shock in adults. Eur J Cardiothorac Surg. 2015; 47: e68-74.

17) Choi MJ, Ha SO, Kim HS, et al: The simplified acute physiology score II as a predictor of mortality in patients who underwent extracorporeal membrane oxygenation for septic shock. Ann Thorac Surg. 2017; 103: 1246-53. 


\section{CQ7 : ステロイド療法}

敗血症は未だ予後不良の病態であり, 敗血症バンド ルの基本的診療に加えて様々な補助療法（adjunctive therapies）が試みられている。副腎皮質ステロイドは 生理的量で抗ストレス作用, 高用量では様々な抗炎症 作用を発揮することから，特に重症病態の改善を期待 して投与されてきた1,2)。

2008 年には敗血症などの重症病態下で認められる コルチゾール分泌不全 (相対的副腎不全), 糖質コル チコイド受容体の減少や組織反応性の低下による糖質 コルチコイド活性の低下に対し,「重症関連コルチコ ステロイド障害 (critical illness-related corticosteroid insufficiency: CIRCI)」という概念が提唱され，以後定 期的にガイドラインが作成されている3)。

敗血症に対するステロイド療法は高用量と低用量に 二分される。前者に関しては, 1980 年代にメチルプ レドニゾロン大量投与のランダム化比較試験（RCT） が実施されたが，有効性を示せなかった ${ }^{4}$, 5)。一方後 者（低用量ヒドロコルチゾン投与）は，2002年に Annane らが相対的副腎不全患者に対する有効性を RCT で報告 6) して以降注目され，2004 年の SSCG 初 版では, 初期輸液負荷に不応性で循環作動薬の投与を 要する患者への 7 日間投与が推奨された。しかし, 2008 年の大規模 RCT（CORTICUS study）では, ショックからの離脱日数が短縮されたものの, 死亡率 に差がなく7), SSCG 第 2 版以降は推奨を初期輸液負 荷および循環作動薬に不応性の敗血症性ショックに限 定していた。その後新規 RCT がない状況が続いたが, 2018 年に死亡率改善効果なし（ADRENAL trial）, お
よびより重症例に対し改善効果あり（APROCCHSS trial）とする2つの大規模 RCT が同時に公表さ れ 8,9$)$, 本療法が再び脚光を浴びている。今回のガイ ドライン改定に当たり, 我々は「CQ7-1：初期輸液と 循環作動薬に反応しない敗血症性ショック患者に対し てステロイド（ヒドロコルチゾン）を投与するか？」 「CQ7-2 : 初期輸液と循環作動薬に反応しない敗血症 性ショック患者に対して, ヒドロコルチゾンとフルド ロコルチゾンを投与するか?」「CQ7-3：ショックに 至っていない敗血症患者に対して，ステロイド（ヒド ロコルチゾン）を投与するか？」の $3 \mathrm{CQ}$ を立案し， 各々 GRADE にもとづくシステマティックレビューを 行い, 推奨を決定した。

\section{文 献}

1) Ronchetti S, Migliorati G, Bruscoli S, et al: Defining the role of glucocorticoids in inflammation. Clin Sci (Lond). 2018; 132: 1529-43.

2) Cain DW, Cidlowski JA: Immune regulation by glucocorticoids. Nat Rev Immunol. 2017; 17: 233-47.

3) Pastores SM, Annane D, Rochwerg B, et al: Guidelines for the Diagnosis and Management of Critical Illness-Related Corticosteroid Insufficiency (CIRCI) in Critically Ill Patients (Part II): Society of Critical Care Medicine (SCCM) and European Society of Intensive Care Medicine (ESICM) 2017. Crit Care Med. 2018; 46: 146-8.

4) Veterans Administration Systemic Sepsis Cooperative Study Group: Effect of high-dose glucocorticoid therapy on mortality in patients with clinical signs of systemic sepsis. N Engl J Med. 1987; 317: 659-65.

5) Bone RC, Fisher CJ Jr, Clemmer TP, et al: A controlled clinical trial of high-dose methylprednisolone in the treatment of severe sepsis and septic shock. N Engl J Med. 1987; 317: 653-8.

6) Annane D, Sébille V, Charpentier C, et al: Effect of treatment with low doses of hydrocortisone and fludrocortisone on mortality in patients with septic shock. JAMA. 2002; 288: $862-71$.

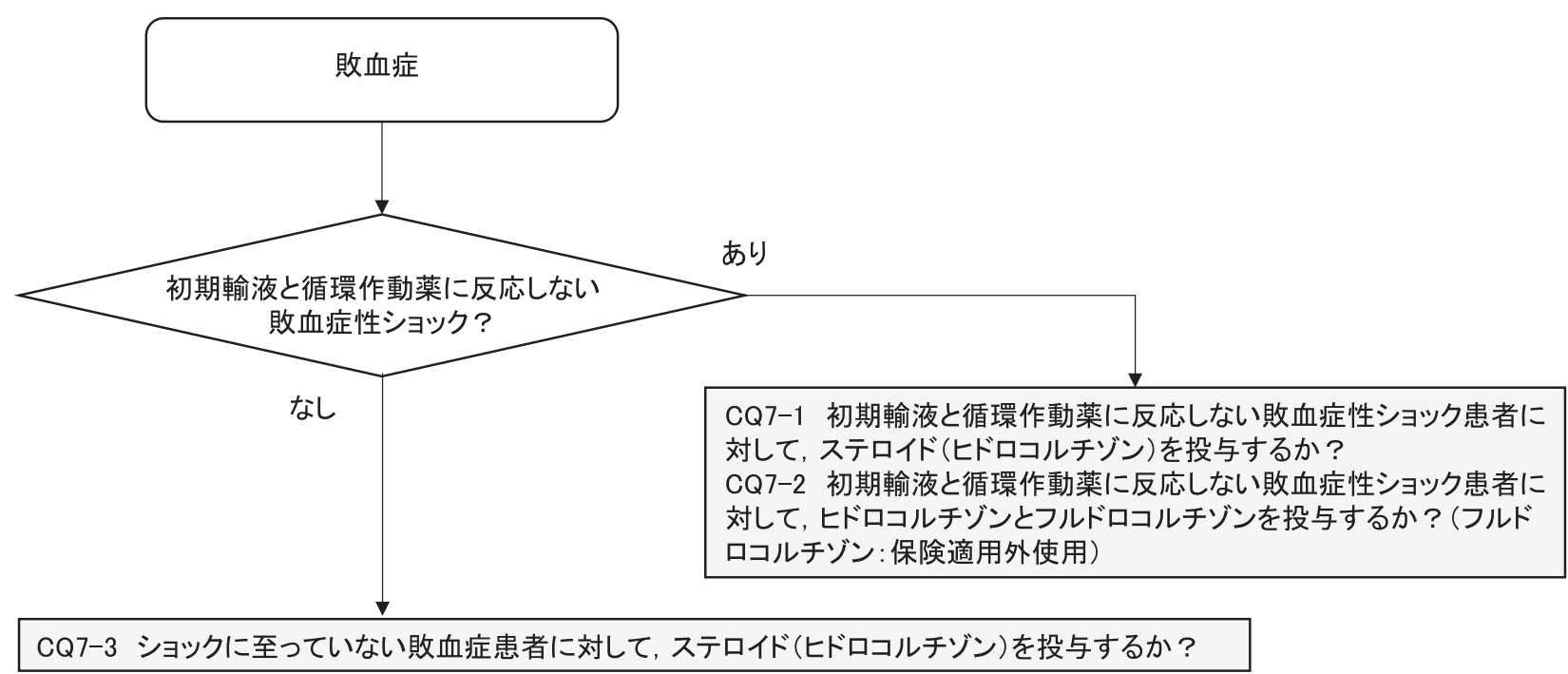

ステロイド療法〔診療フロー〕 
7) Sprung CL, Annane D, Keh D, et al: Hydrocortisone therapy for patients with septic shock. N Engl J Med. 2008; 358: 111-24.

8) Venkatesh B, Finfer S, Cohen J, et al: Adjunctive Glucocorticoid Therapy in Patients with Septic Shock. N Engl J Med. 2018; 378 : 797-808.

9) Annane D, Renault A, Brun-Buisson C, et al: Hydrocortisone plus Fludrocortisone for Adults with Septic Shock. N Engl J Med. 2018; 378: 809-18.
CQ7-1：初期輸液と循環作動薬に反応しない敗 血症性ショック患者に対して, ステロイド（ヒ ドロコルチゾン) を投与するか？

Answer : 初期輸液と循環作動薬に反応しない成人の 敗血症性ショック患者に対して, ショックからの離脱 を目的として，低用量ステロイド（ヒドロコルチゾ ン）を投与することを弱く推奨する（GRADE 2D：エ ビデンスの確実性 $=$ 「非常に低」)。

\section{（1）背景および本 $C Q$ の重要度}

循環作動薬に反応しない敗血症性ショック患者で は，相対的副腎不全がショックの遷延に関与している 可能性がある。副腎皮質ステロイドであるヒドロコル チゾンの投与は, 相対的副腎不全の改善, 抗炎症作 用, 血管収縮作用, 昇圧薬への反応性改善などの作用 により, ショックからの離脱を補助することが期待さ れる。

敗血症性ショックに対するステロイド投与の有用性 については,これまで多数のランダム化比較試験 (RCT)，システマティックレビューが発表されている が, 対象患者・セッティング, 使用するステロイドの 種類・投与量 - 投与方法, アウトカム・有害事象設 定, 解析手法などの差異もあり, 研究結果は必ずしも 一致していない。ショックからの離脱が期待される一 方で合併症の増加の可能性があり, その益と害のバラ ンスについても定まっておらず，個々の患者における 使用の適否は, 主治医の判断にゆだねられている現状 がある。

敗血症性ショックの死亡は高く, 生命予後を改善し うる治療法の確立が急務であることから, 本 $\mathrm{CQ}$ は重 要度の高いものと考えられる。

(2) PICO

$\mathrm{P}$ (患者) : 初期輸液と循環作動薬に反応しない敗血 症性ショック患者

I（介入）：ステロイド（ヒドロコルチゾン）を投与 する

C (対照)：ステロイド（ヒドロコルチゾン）を投与 しない

$\mathrm{O}$ (アウトカム) : 全原因死亡, ショック離脱, あら ゆる重篤な副作用, あらゆる軽微な副作用

\section{(3) エビデンスの要約}

システマティックレビューの結果, PICO に合致し た RCT が 11 件施行 ${ }^{1-11)}$ されており，これらを用い 
たメタ解析を実施した。

（4）益と害のバランス（Table 7-1-1）

望ましい効果 :

今回, 死亡アウトカムは middle term mortality（28 日死亡), long term mortality（90 日以降の死亡）につ いて解析を行った。Middle term mortality（9 RCT: $\mathrm{n}=$ 6,424）に関する効果推定值は 1,000 人あたり 21 人少 ない $(95 \%$ CI: 40 人少ない〜3人多い), long term mortality（5 RCT: $\mathrm{n}=5,716 ） に$ 関する効果推定值は 1,000 人あたり 23 人少ない $(95 \% \mathrm{CI}: 45$ 人少ない〜 4 人多い), と望ましい効果は限定的であった。一方, ショックを離脱するまでに要する時間（5 RCT: $\mathrm{n}=$ 4,661）に関する効果推定值は平均（MD）31.53 時間 短い（95\% CI: 36.6 時間短い〜26.46 時間短い）と望 ましい効果を認めた。この 2 つアアウトカムを考慮 し，望ましい効果は小さいながらあると判断された。

Table 7-1-1エビデンスプロファイル

\begin{tabular}{|c|c|c|c|c|c|c|c|c|c|c|c|c|}
\hline \multicolumn{7}{|c|}{ 確実性の評価 } & \multicolumn{2}{|c|}{ 患者数 } & \multicolumn{2}{|c|}{ 奻果 } & \multirow[b]{2}{*}{ 確実性 } & \multirow[b]{2}{*}{ 重要性 } \\
\hline 研究数 & $\begin{array}{c}\text { 研究 } \\
\text { デザイン }\end{array}$ & $\begin{array}{l}\text { バイアス } \\
\text { のリスク }\end{array}$ & 非一貫性 & 非直接性 & 不精確性 & $\begin{array}{l}\text { その他 } \\
\text { の検討 }\end{array}$ & $\begin{array}{l}\text { ヒドロコル } \\
\text { チゾン }\end{array}$ & プラセボ & $\begin{array}{l}\text { 相対指標 } \\
(95 \% \text { Cl) }\end{array}$ & $\begin{array}{l}\text { 絶対指標 } \\
(95 \% \text { Cl) }\end{array}$ & & \\
\hline \multicolumn{13}{|c|}{28 日死亡 } \\
\hline 9 & RCT & 深刻でない & 深刻でない & 非常に深刻 a & 深刻でない & なし & $\begin{array}{c}917 / 3,208 \\
(28.6 \%)\end{array}$ & $\begin{array}{c}982 / 3,216 \\
(30.5 \%)\end{array}$ & $\begin{array}{c}\text { RR } 0.93 \\
(0.87 \text { to } 1.01)\end{array}$ & $\mid \begin{array}{c}1,000 \text { 人あたり } \\
21 \text { 人少ない } \\
(40 \text { 人少ない } \\
3 \text { 人多い) }\end{array}$ & $\begin{array}{c}\oplus \oplus \bigcirc \bigcirc \\
\text { 低 }\end{array}$ & 重大 \\
\hline
\end{tabular}

長期死亡（90日以降）

\begin{tabular}{|c|c|c|c|c|c|c|c|c|c|c|c|c|}
\hline 5 & RCT & 深刻でない & 深刻でない & 深刻 b & 深刻でない & なし & \begin{tabular}{|c|}
$1,019 / 2,859$ \\
$(35.6 \%)$
\end{tabular} & \begin{tabular}{|c|}
$1,079 / 2,857$ \\
$(37.8 \%)$
\end{tabular} & $\begin{array}{c}\text { RR } 0.94 \\
\text { (0.88 to } 1.01 \text { ) }\end{array}$ & $\begin{array}{c}1,000 \text { 人あたり } \\
23 \text { 人少ない } \\
(45 \text { 人少ない } \\
4 \text { 人多い) }\end{array}$ & $\begin{array}{c}\oplus \oplus \oplus \bigcirc \\
\text { 中 }\end{array}$ & 重大 \\
\hline \multicolumn{13}{|c|}{ ショック離脱 } \\
\hline 5 & RCT & 深刻でない & 非常に深刻 c & 深刻 d & 深刻でない & なし & 2,323 & 2,338 & - & $\begin{array}{c}\text { 平均 } 31.53 \text { 時 } \\
\text { 間短い } \\
(36.6 \text { 時問短い } \\
\sim 26.46 \text { 時間短 } \\
\text { () }\end{array}$ & $\begin{array}{l}\oplus \bigcirc \bigcirc \bigcirc \\
\text { 非常に低 }\end{array}$ & 重大 \\
\hline
\end{tabular}

重篤な合併症

\begin{tabular}{|c|c|c|c|c|c|c|c|c|c|c|c|c|}
\hline 3 & RCT & 深刻でない & 深刻でない & 深刻 e & 深刻でない & なし & $\begin{array}{c}350 / 2,651 \\
(13.2 \%)\end{array}$ & $\begin{array}{c}384 / 2,662 \\
(14.4 \%)\end{array}$ & $\begin{array}{c}\text { RR } 0.93 \\
\text { (0.84 to } 1.03)\end{array}$ & $\begin{array}{c}\text { 1,000 人あたり } \\
10 \text { 人少ない } \\
(23 \text { 人少ない } \\
4 \text { 人多い) }\end{array}$ & $\begin{array}{c}\oplus \oplus \oplus \bigcirc \\
\text { 中 }\end{array}$ & 重大 \\
\hline
\end{tabular}

感染症

\begin{tabular}{|c|c|c|c|c|c|c|c|c|c|c|c|c|}
\hline 7 & RCT & 深刻でない & 深刻でない & 深刻 ' & 深刻でない & なし & $\begin{array}{c}584 / 2,914 \\
(20.0 \%)\end{array}$ & $\begin{array}{c}559 / 2,911 \\
(19.2 \%)\end{array}$ & $\begin{array}{c}\text { RR } 1.04 \\
\text { (0.94 to } 1.16)\end{array}$ & $\begin{array}{c}\text { 1,000 人あたり } \\
8 \text { 人多い } \\
\text { (12人少ない } \\
31 \text { 人多い }\end{array}$ & $\begin{array}{c}\oplus \oplus \oplus \bigcirc \\
\text { 中 }\end{array}$ & 重大 \\
\hline
\end{tabular}

消化管出血

\begin{tabular}{|c|c|c|c|c|c|c|c|c|c|c|c|c|}
\hline 6 & RCT & 深刻でない & 深刻でない & 深刻 : & 深刻でない & なし & $\begin{array}{c}80 / 1,079 \\
(7.4 \%)\end{array}$ & $\begin{array}{c}73 / 1,082 \\
(6.7 \%)\end{array}$ & $\begin{array}{c}\text { RR } 1.09 \\
(0.80 \text { to } 1.48)\end{array}$ & $\begin{array}{c}1,000 \text { 人あたり } \\
6 \text { 人多い } \\
(13 \text { 人少ない } \\
32 \text { 人多い) }\end{array}$ & $\begin{array}{c}\oplus \oplus \oplus \bigcirc \\
\text { 中 }\end{array}$ & 重大 \\
\hline
\end{tabular}

高血糖

\begin{tabular}{|c|c|c|c|c|c|c|c|c|c|c|c|c|}
\hline 4 & RCT & 深刻でない & 深刻でない & 深刻 h & 深刻でない & なし & $\begin{array}{c}773 / 2,722 \\
(28.4 \%)\end{array}$ & $\begin{array}{c}709 / 2,723 \\
(26.0 \%)\end{array}$ & $\begin{array}{c}\text { RR } 1.10 \\
\text { (1.05 to } 1.15)\end{array}$ & $\begin{array}{c}1,000 \text { 人あたり } \\
26 \text { 人多い } \\
(13 \text { 人多い〜 } 39 \\
\text { 人多い) }\end{array}$ & $\begin{array}{c}\oplus \oplus \oplus \bigcirc \\
\text { 中 }\end{array}$ & 重要 \\
\hline
\end{tabular}

a. 1. 対象集団の違い(Patients or populations) Sepsis, septic shockの定義が研究ごとで異なる Arabi2010：旰硬変患者の敗血症性ショック Venkatesh 2018 : 人工呼吸器管理中 2. 介入(や対 照)の違い(Intervension or comparison) 投与方法（用量用法，ボーラスかどうか，日数）に関しては研究ごとで異なる Annane2002，Annane2018：ヒドロコルチゾントフルドロコルチゾン Gordon2016 : vasopressin + hydrocortisone vs vasopressin + placebo, norepinephrine + hydrocortisone vs norepinephrine + placebo の 4 群比較

b. 1. 対象集団の違い(Patients or populations) Sepsis, septic shockの定義が研究ごとで異なる Venkatesh 2018 : 人工呼吸器管理中 2.介入(や対照)の違い(Intervension or comparison) 投与 方法（用量用法，ボーラスかどうか，日数）に関しては研究ごとで異なる Annane2002, Annane2018: ヒドロコルチゾン+フルドロコルチゾン

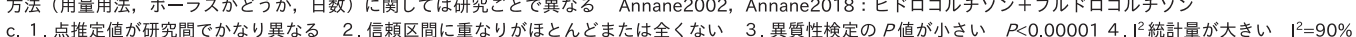

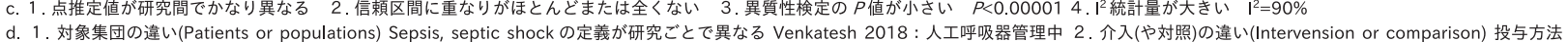
d. 1. 対象集団の違い(Patients or populations) Sepsis, septic shock の定義が研究ごとで異なる Venkatesh 2018 : 人工呼吸器管理中 2. 介入(や対照)の違い(Intervension or comparison) 投与方法
(用量用法, ボーラスが゙う, 日数）に関しては研究ごとで異なる Gordon2016: vasopessin + hydrocortisone vs vasopressin + placebo, norepinephrine + hydrocortisone vs norepinephrine + (用量用法, ボーラスかどうか, 日数) に関しては研究ごとで異なる Gordon2016: vasopressin + hydrocortisone vs vasopressin + placebo, norepinephrine + hydrocortisone vs norepinephrine +
placebo の 4 群比較 3. アウトカのの違い(outcome : 代用アウトカムど) Oppert2005: time to cessation of vasopressor support(median IQR) 単位 : 時間 Gordon2016: time to shock reversal(median IQR) 単位: 時間 Sprung2008: The median time until reversal of shock(median 95\%Cl) 単位 : 日 Venkatesh2018: The median time to resolusion of shock(median IQR) 単 位: 日 4 . 間接比較

e. 1. 対象集団の違い(Patients or populations) Sepsis, septic shock の定義が研究ごとで異なる Venkatesh 2018 : 人工呼吸器管理中 2. 介入(や対照)の違い(Intervension or comparison) 投与方法 (用量用法,ボーラスかどうか，日数）に関しては研究ごとで異なる Annane2018:ヒドロコルチゾン+フルドロコルチゾン Gordon2016: vasopressin + hydrocortisone vs vasopressin + placebo, norepinephrine + hydrocortisone vs norepinephrine + placebo の 4 群比較 3. アウトカムの違い(outcome : 代用アウトカムなど) ：詳細な定義が確認できず 4. 間接比較

f. 1. 対象集団の違い(Patients or populations) Sepsis, septic shock の定義が研究ごとで異なる Arabi2010：盰硬変患者の敗血症性ショック Venkatesh 2018：人工呼吸器管理中 2.介价入(や対照)の違 い(Intervension or comparison) 投与方法 (用量用法,ボーラスかどうか, 日数) に関しては研究ごとで異なる Annane2002,Annane2018:ヒドロコルチゾントフルドロコルチゾン 3.アウトカムの

違い(outcome : 代用アウトカムなど) superinfection, new sepsis, new septic shock, 真菌感染など混在 4 . 間接比較
g. 1. 対象集団の違い(Patients or populations) Sepsis, septic shock の定義が研究ごとで異なる Arabi2010 : 肝硬変患者の敗血症性ショック 2. 介入(や対照)の違い(Intervension or comparison) 投与 方法 (用量用法, ボーラスかどうか, 日数) に関しては研究ごとで異なる Annane2002, Annane2018:ヒドロコルチゾン+フルドロコルチゾン 3.アゥトトカムの違い(outcome : 代用アウトカムな ど) 詳細な定義のないものが多い 4 . 間接比較

h. 1. 対象集団の違い(Patients or populations) Sepsis, septic shock の定義が研究ごとで異なる Arabi2010: 肝硬変患者の敗血症性ショック Venkatesh 2018 : 人工呼吸器管理中 2.介入(や対照)の違 い(Intervension or comparison) 投与方法（用量用法, ボーラスかどうか, 日数）に関しては研究ごとで異なる Annane2018：ヒドロコルチゾン+フルドロコルチゾン 3 . アゥトカムの違い (outcome : 代用アウトカムなど) ）定義は異なる 4 . 間接比較 


\section{望ましくない効果 :}

重篤な副作用に関する効果推定值は, severe adverse

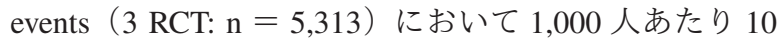
人少ない $(95 \% \mathrm{CI}: 23$ 人少ない〜 4 人多い), 感染症 （7 RCT: $\mathrm{n}=5,825 ）$ において 1,000 人あたり 8 人多い ( $95 \%$ CI：12人少ない〜31 人多い)，消化管出血（6 RCT: $\mathrm{n}=2,161 ）$ において 1,000 人あたり 6 人多い ( $95 \%$ CI: 13 人少ない〜32人多い) であり，望ましく ない効果が増える可能性はわずかである。

益と害のバランス :

本 CQ においては「ショック離脱」以外のアウトカ ムに関して望ましい効果は限定的である。一方，望ま しくない効果についても, 重篤な副作用のアウトカム に差は認めなかった。ショックから離脱するのに要す る時間が，低く見積もっても 24 時間短縮することが 期待できるという結果であり，患者・家族の個人の視 点から，その効果のバランスは，おそらく介入が優位 とした。

\section{（5）アウトカム全般に関するエビデンスの確実性}

今回採用した重大なアウトカムについて，望ましい 効果（効果あり）と，望ましくない効果（効果なし） の両方向のアウトカムが見られるため，アウトカム全 体にわたるエビデンスの確実性については，アウトカ ムの中で最も低い確実性を全体として採用し「非常に 低」とした。

（6）価値観

敗血症性ショック患者に対するステロイド（ヒドロ
コルチゾン）投与において，各アウトカムにおける患 者・家族の価值観に関するデータはない。一般的に, 死亡アウトカムに対して置く相対的価值は高く，その ばらつきは少ないことが予想される。

\section{（7）容認性}

望ましくない効果のエビデンスは少なく，ステロイ ド（ヒドロコルチゾン）投与に伴う費用は投与量・投 与期間により異なるものの，高額ではなく保険適用で ある。その個人負担額を考えると，患者・家族の個人 の視点からおそらく許容できるであろう。道義的・倫 理的な観点からも許容されるものと考える。

\section{（8）実行可能性}

介入は多くの医療施設において実行可能である。

（9）判断の要約（Table 7-1-2）

（10）推奨グレーディング決定の工程

修正 RAND 法を用いた投票によって，中央值 8, 見解不一致指数 0.132 の結果となり，委員会で採択さ れた（7 点以上 : $87.5 \%) 。$

\section{（11）関連する他の診療ガイドラインにおける推奨}

SSCG 2016 においては，適切な輸液蘇生と血管作動 薬投与により血行動態の安定が得られなかった場合の み，1 日 200mg のヒドロコルチゾン経静脈投与を「弱 く推奨」している。日本版敗血症診療ガイドライン （J-SSCG）2016 でも同様の病態に対し「ショックの離

Table 7-1-2 判断の要約

\begin{tabular}{|c|c|c|c|c|c|c|c|}
\hline & \multicolumn{7}{|c|}{ 半粰 } \\
\hline 問題 & いいえ & $\begin{array}{c}\text { おそらく、いい } \\
\text { え }\end{array}$ & おそらく、はい & はい & & さまざま & 分からない \\
\hline 望ましい効果 & わずか & 小さい & 中 & 大きい & & さまざま & 分からない \\
\hline 望ましくない効果 & 大きい & 中 & 小さい & わずか & & さまざま & 分からない \\
\hline エビデンスの確実性 & 非常に低 & 低 & 中 & 高 & & & 採用研究なし \\
\hline 価值钼 & $\begin{array}{c}\text { 重要な不確実性 } \\
\text { またはばらつき } \\
\text { あり }\end{array}$ & $\begin{array}{c}\text { 重要な不確実性 } \\
\text { またははばつう } \\
\text { の可能性あり } \\
\end{array}$ & $\begin{array}{l}\text { 重要な不確実性 } \\
\text { またははばらつき } \\
\text { はおそらくなし }\end{array}$ & $\begin{array}{c}\text { 重要な不確実性 } \\
\text { またはばらつき } \\
\text { はなし } \\
\text { は地 }\end{array}$ & & & \\
\hline 勃果のバランス & 比較が優位 & $\begin{array}{c}\text { 比較がおそらく } \\
\text { 優位 }\end{array}$ & $\begin{array}{c}\text { 介入も比較もい } \\
\text { ずれも優位でな } \\
\text { い }\end{array}$ & $\begin{array}{c}\text { おそらく介入が } \\
\text { 優位 }\end{array}$ & 介入が優位 & さまざま & 分からない \\
\hline 容認性 & いいえ & $\begin{array}{c}\text { おそらく、いい } \\
\text { え }\end{array}$ & おそらく、はい & はい & & さまざま & 分からない \\
\hline 実行可能性 & いいえ & $\begin{array}{c}\text { おそらく、いい } \\
\text { え }\end{array}$ & おそらく、はい & はい & & さまざま & 分からない \\
\hline
\end{tabular}


脱を目的として」投与することが「弱く推奨」されて いる。今回，新たな RCT を加えてシステマティック レビューを行った結果，前版とほぼ同じ推奨となっ た。

\section{（12）実施に関わる検討事項}

すべての敗血症あるいは敗血症性ショック患者に対 する標準的治療としては行わないことが望まれる。ま た，今回解析に選択された RCT はすべて低用量ステ ロイドを用いており, 本推奨は低用量ステロイドの使 用を前提としている。

\section{（13）今後の研究の可能性}

今後, 確実に効果が得られる患者亜群の特定と有効 かつ安全な投与方法，投与量の確立が必要であろう。

\section{文 献}

1) Gordon AC, Mason AJ, Thirunavukkarasu N, et al: Effect of Early Vasopressin vs Norepinephrine on Kidney Failure in Patients With Septic Shock: The VANISH Randomized Clinical Trial. JAMA. 2016; 316: 509-18.

2) Annane D, Renault A, Brun-Buisson $C$, et al: Hydrocortisone plus Fludrocortisone for Adults with Septic Shock. N Engl J Med. 2018; 378: 809-18.

3) Annane D, Sébille V, Charpentier C, et al: Effect of treatment with low doses of hydrocortisone and fludrocortisone on mortality in patients with septic shock. JAMA. 2002; 288: 862-71.

4) Arabi YM, Aljumah A, Dabbagh O, et al: Low-dose hydrocortisone in patients with cirrhosis and septic shock: a randomized controlled trial. CMAJ. 2010; 182: 1971-7.

5) Bollaert PE, Charpentier C, Levy B, et al: Reversal of late septic shock with supraphysiologic doses of hydrocortisone. Crit Care Med. 1998; 26: 645-50.

6) Briegel J, Forst H, Haller M, et al: Stress doses of hydrocortisone reverse hyperdynamic septic shock: a prospective, randomized, double-blind, single-center study. Crit Care Med. 1999; 27: 723-32.

7) Gordon AC, Mason AJ, Perkins GD, et al: The interaction of vasopressin and corticosteroids in septic shock: a pilot randomized controlled trial. Crit Care Med. 2014; 42: 1325-33.

8) Lv QQ, Gu XH, Chen QH, et al: Early initiation of low-dose hydrocortisone treatment for septic shock in adults: A randomized clinical trial. Am J Emerg Med. 2017; 35: 1810-4.

9) Oppert M, Schindler R, Husung C, et al: Low-dose hydrocortisone improves shock reversal and reduces cytokine levels in early hyperdynamic septic shock. Crit Care Med. 2005; 33: 2457-64.

10) Sprung CL, Annane D, Keh D, et al: Hydrocortisone therapy for patients with septic shock. N Engl J Med. 2008; 358: 111-24.

11) Venkatesh B, Finfer $S$, Cohen J, et al: Adjunctive Glucocorticoid Therapy in Patients with Septic Shock. N Engl J Med. 2018; 378 : 797-808.
CQ7-2 : 初期輸液と循環作動薬に反応しない敗 血症性ショック患者に対して，ヒドロコルチゾ ンとフルドロコルチゾンを投与するか？（フル ドロコルチゾン：保険適用外使用）

Answer : 初期輸液と循環作動薬に反応しない成人の 敗血症性ショック患者に対して，ヒドロコルチゾンと フルドロコルチゾンの併用投与を弱く推奨する (GRADE 2C: エビデンスの確実性 $=「$ 低」)。

\section{（1）背景および本 $C Q$ の重要度}

循環作動薬に反応しない敗血症性ショック患者で は，相対的副腎不全がショックの遷延に関与している 可能性がある。CQ7-1に記載したように, 副腎皮質ス テロイドであるヒドロコルチゾン投与により，ショッ クからの離脱が期待される。一方, 鉱質コルチコイド 受容体は各種の重要臟器に発現し, 動物研究において は鉱質コルチコイド投与によるインターロイキン 6 （IL-6）值の低下, ショックからの離脱促進, 生存率 の改善が報告されている1)。

初期輸液と循環作動薬に反応しない敗血症に対しヒ ドロコルチゾンを投与する際には，ヒドロコルチゾン 単独投与が一般的であり，強い鉱質コルチコイド作用 を有する合成コルチコステロイド経口薬のフルドロコ ルチゾンの併用は一部の施設で行われているにすぎな い。現状では，ヒドロコルチゾンとフルドロコルチゾ ンの併用投与の有効性・有害性の評価は定まっておら ず，臨床現場でもその併用投与の判断については多様 性がある。

敗血症性ショックの死亡率は高く, 生命予後を改善 しうる治療法の確立が急務であることから，本 $\mathrm{CQ}$ は 重要度の高いものと考えられる。

(2) PICO

$\mathrm{P}$ (患者) : 初期輸液と循環作動薬に反応しない敗血 症性ショック患者

I（介入）：ヒドロコルチゾンとフルドロコルチゾン の併用投与

$\mathrm{C}$ (対照)：ヒドロコルチゾンの単独投与あるいはプ ラセボの投与

$\mathrm{O}$ (アウトカム $)$ : 全原因死亡, ショック離脱, あら ゆる重篤な合併症, あらゆる軽微な副作用

\section{（3）エビデンスの要約}

システマティックレビューの結果，PICO に合致し たランダム化比較試験（RCT）が 3 件施行 ${ }^{2-4)}$ されて 
おり,これらを用いたメタ解析を実施した 5)。

（4）益と害のバランス（Table 7-2-1）

望ましい効果 :

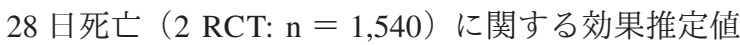
は，1,000 人あたり 52 人少ない $(95 \%$ CI: 4 人少ない ９5 人少ない）であり，低いバイアスのリスクの 3 つの RCT から得られる長期死亡（3 RCT: $\mathrm{n}=2,049$ ) に関する効果推定值は，1,000 人あたり 53 人少ない （95\% CI: 11 人少ない〜90 人少ない）であった。また， ショックからの離脱（1 RCT: $\mathrm{n}=299 ） に$ 関する効果 推定值は 1,000 人あたり 124 人多い (95\% CI: 9 人多 い〜271 人多い）であり，これらの結果から，ヒドロ コルチゾンとフルドロコルチゾンの併用投与による望 ましい効果は大きいと判断される。
望ましくない効果 :

あらゆる重篤な副作用に関する効果推定值は，新規

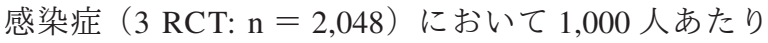
33 人多い (95\% CI: 35 人少ない 119 人多い), 消化

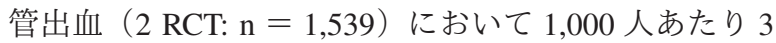
人少ない $(95 \%$ CI: 23 人少ない 27 人多い）であり, ヒドロコルチゾンとフルドロコルチゾンの併用投与に よる望ましくない効果はわずかである。

益と害のバランス :

ヒドロコルチゾンとフルドロコルチゾンの併用投与 による望ましい効果は大きく，一方，望ましくない効 果はわずかである。したがって，おそらく介入が優位 と考えた。これは, 最思の場合（望ましい効果で CI 下限，望ましくない効果で CI 上限）を想定しても同 様の判断となる。

Table 7-2-1エビデンスプロファイル

\begin{tabular}{|c|c|c|c|c|c|c|c|c|c|c|c|c|}
\hline \multicolumn{7}{|c|}{ 確荚性の評価 } & \multicolumn{2}{|c|}{ 患者数 } & \multicolumn{2}{|c|}{ 奻果 } & \multirow[b]{2}{*}{ 碓夷性 } & \multirow[b]{2}{*}{ 重要性 } \\
\hline 研究数 & 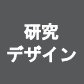 & $\begin{array}{l}\text { ハイアス } \\
\text { のリスク }\end{array}$ & 非一面性 & 非直接性 & 不制磼性 & $\begin{array}{l}\text { その他 } \\
\text { の塔村 }\end{array}$ & 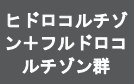 & Control 群 & $\begin{array}{l}\text { 相対指㩖 } \\
(95 \% \text { CI) }\end{array}$ & $\begin{array}{l}\text { 絶対指䍒 } \\
(95 \% \text { GI) }\end{array}$ & & \\
\hline
\end{tabular}

28 日死亡

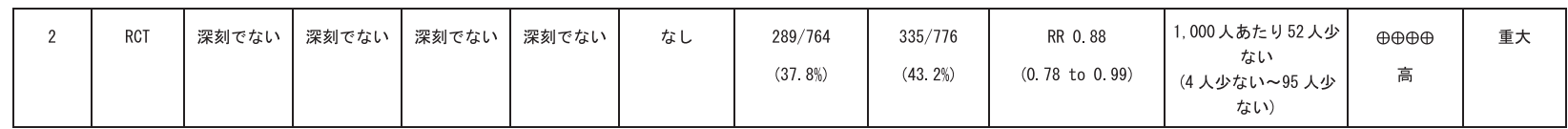

長期死亡

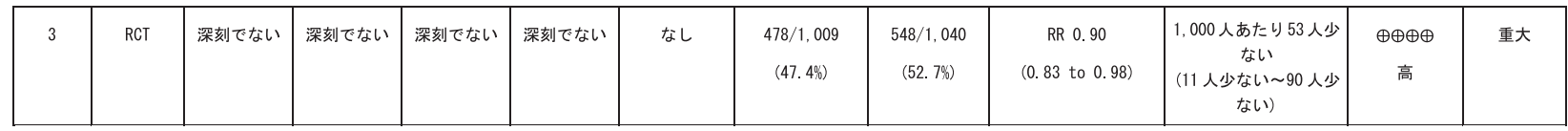

ショックからの回復

\begin{tabular}{|c|c|c|c|c|c|c|c|c|c|c|c|c|}
\hline 1 & RCT & 深刻でない & 深刻でない & 深刻でない & 深刻a & なし & $83 / 150 \quad(55.3 \%)$ & $\begin{array}{l}64 / 149 \\
(43.0 \%)\end{array}$ & $\begin{array}{c}\text { RR } 1.29 \\
\text { (1. } 02 \text { to } 1.63)\end{array}$ & $\begin{array}{c}1,000 \text { 人あたり } 124 \text { 人 } \\
\text { 多い } \\
(9 \text { 人多い 271 人多 } \\
\text { ( ) }\end{array}$ & $\begin{array}{c}\oplus \oplus \oplus \bigcirc \\
\text { 中 }\end{array}$ & 重大 \\
\hline
\end{tabular}

二次感染

\begin{tabular}{|c|c|c|c|c|c|c|c|c|c|c|c|c|}
\hline 3 & RCT & 深刻でない & 深刻 ${ }^{b}$ & 深刻でない & 深刻 ${ }^{\circ}$ & なし & $\begin{array}{c}266 / 1,009 \\
(26.4 \%)\end{array}$ & $\begin{array}{c}242 / 1,039 \\
(23.3 \%)\end{array}$ & $\begin{array}{c}\text { RR } 1.14 \\
(0.85 \text { to } 1.51)\end{array}$ & $\begin{array}{c}1,000 \text { 人あたり } 33 \text { 人多 } \\
\text { い } \\
\text { (35 人少ない 119人 } \\
\text { 多い) }\end{array}$ & $\begin{array}{c}\oplus \oplus \bigcirc \bigcirc \\
\text { 低 }\end{array}$ & 重大 \\
\hline
\end{tabular}

消化管出血

\begin{tabular}{|c|c|c|c|c|c|c|c|c|c|c|c|c|}
\hline 2 & RCT & 深刻でない & 深刻でない & 深刻でない & 非常に深刻 d & なし & $\begin{array}{l}50 / 764 \\
(6.5 \%)\end{array}$ & $53 / 775 \quad(6.8 \%)$ & $\begin{array}{c}\text { RR } 0.96 \\
(0.66 \text { to } 1.39)\end{array}$ & $\begin{array}{c}1,000 \text { 人あたり } 3 \text { 人少 } \\
\text { ない } \\
(23 \text { 人少ない 27 人多 } \\
\text { い) }\end{array}$ & $\begin{array}{c}\oplus \oplus \bigcirc \bigcirc \\
\text { 低 }\end{array}$ & 重大 \\
\hline
\end{tabular}

高血糖

\begin{tabular}{|c|c|c|c|c|c|c|c|c|c|c|c|c|}
\hline 3 & RCT & 深刻でない & 深刻でない & 深刻でない & 深刻でない & なし & $\begin{array}{l}547 / 614 \\
(89.1 \%)\end{array}$ & $520 / 626(83.1 \%)$ & $\begin{array}{c}\text { RR } 1.07 \\
\text { (1.03 to } 1.12)\end{array}$ & $\begin{array}{c}1,000 \text { 人あたり } 58 \text { 人多 } \\
\text { い } \\
(25 \text { 人多い 100人多 } \\
\text { () }\end{array}$ & $\begin{array}{c}\oplus \oplus \oplus \oplus \\
\text { 高 }\end{array}$ & 重要 \\
\hline
\end{tabular}

\section{精神障害}

\begin{tabular}{|c|c|c|c|c|c|c|c|c|c|c|c|c|}
\hline 3 & RCT & 深刻でない & 深刻でない & 深刻でない & 非常に深刻 d & なし & $0 / 150 \quad(0 \%)$ & $1 / 149 \quad(0.7 \%)$ & $\begin{array}{c}\text { RR } 0.33 \\
\text { (0.01 to } 8.06)\end{array}$ & $\begin{array}{c}1,000 \text { 人あたり } 4 \text { 人少 } \\
\text { ない } \\
(6 \text { 人少ない 47 人多 } \\
\text { (い) }\end{array}$ & $\begin{array}{c}\oplus \oplus \bigcirc \bigcirc \\
\text { 低 }\end{array}$ & 重要 \\
\hline
\end{tabular}

a. 最適情報量を満たさないため，深刻とした。

b. I $I^{2}$ 統計量が中程度の異質性となっており，深刻と判断した。

c. $95 \%$ CI が1をまたいでいるため, 深刻とした。

d. 最適情報量を满たさず, $95 \%$ CI が1をまたいで幅広いため，非常に深刻の評価とした。 
（5）アウトカム全般に関するエビデンスの確実性

望ましい効果の効果推定值の方向性は “利益あり” であるが，望ましくない効果の効果推定值の $95 \%$ CI の上限は“害あり”であるため, 利益と害のバランス は不確実である。よって一番低いアウトカムの確実性 を全体としては採用した。エビデンスの確実性が一番 低い重篤な副作用の「低」を採用し，アウトカム全体 にわたるエビデンスの確実性は「低」とした。

\section{（6）価値観}

敗血症性ショック患者に対するヒドロコルチゾンと フルドロコルチゾンの併用投与において，各アウトカ ムにおける患者・家族の価值観に関するデータはな い。一般的に，死亡アウトカムに対して置く相対的価 值は高く，そのばらつきは少ないことが予想される。

\section{（7）容認性}

望ましくない効果のエビデンスは少なく，ステロイ ド（ヒドロコルチゾン）投与に伴う費用は，投与量・ 投与期間により異なるものの，高額ではなく保険適用 である。その個人負担額を考えると，患者・家族の個 人の視点からおそらく許容できるであろう。道義的・ 倫理的な観点からも許容されるものと考える。

\section{（8）実行可能性}

介入は多くの医療施設において実行可能である。
(9) 判断の要約（Table 7-2-2）

（10）推奨グレーディング決定の工程

修正 RAND 法を用いた投票によって，中央值 8, 見解不一致指数 0.164 の結果となり，委員会で採択さ れた（7 点以上 : 83.3\%）。

（11）関連する他の診療ガイドラインにおける推奨

SSCG 2016 には推奨の記載がない。日本版敗血症診 療ガイドライン（J-SSCG）2016では推奨の記載はな いが，フルドロコルチゾン併用投与について検討した RCT において，ヒドロコルチゾン単独投与と比較し 予後を改善せず，尿路感染症などの感染症罹患率を有 意に増加させたため投与すべきではないとしている。

\section{（12）実施に関わる検討事項}

本介入は初期輸液と循環作動薬に反応しない敗血症 性ショックに対してのみ行うことが望まれる。また， フルドロコルチゾンの保険適用が塩喪失型先天性副腎 皮質過形成症，アジソン病に限定されていることに考 慮を要する。

\section{（13）今後の研究の可能性}

ヒドロコルチゾン単独投与と本介入の比較（ヒドロ コルチゾンに対するフルドロコルチゾンの上乗せ効 果）に関して，検討が求められるであろう。

\section{文 献}

1) Hicks CW, Sweeney DA, Danner RL, et al: Efficacy of selective mineralocorticoid and glucocorticoid agonists in canine septic

Table 7-2-2 判断の要約

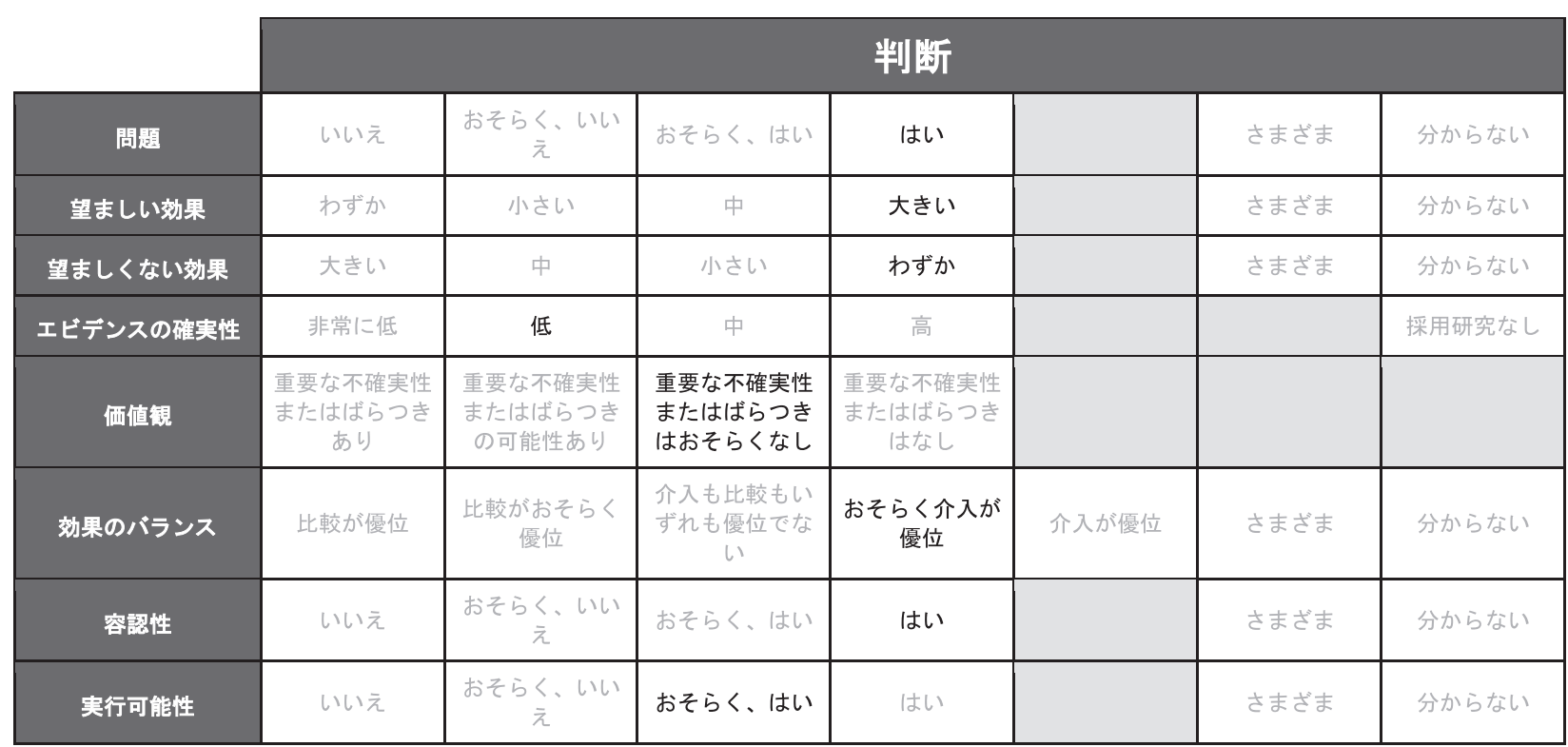


shock. Crit Care Med. 2012; 40: 199-207.

2) Annane $D$, Renault $A$, Brun-Buisson $C$, et al: Hydrocortisone plus Fludrocortisone for Adults with Septic Shock. N Engl J Med. 2018; 378: 809-18.

3) Annane D, Sébille V, Charpentier C, et al: Effect of treatment with low doses of hydrocortisone and fludrocortisone on mortality in patients with septic shock. JAMA. 2002; 288: 862-71.

4) Annane D, Cariou A, Maxime V, et al: Corticosteroid treatment and intensive insulin therapy for septic shock in adults: a randomized controlled trial. JAMA. 2010; 303: 341-8.

5) Yamamoto R, Nahara I, Toyosaki M, et al: Hydrocortisone with fludrocortisone for septic shock: a systematic review and metaanalysis. Acute Med Surg. 2020; 7: e563.
CQ7-3 : ショックに至っていない敗血症患者に 対して，ステロイド（ヒドロコルチゾン）を投 与するか?

Answer : ショックに至っていない敗血症患者に対し て，ヒドロコルチゾンの投与を行わないことを弱く推 奨する（GRADE 2D：エビデンスの確実性 $=$ 「非常に 低」)。

\section{（1）背景および本 CQ の重要度}

ショックに至っていない敗血症患者においても，ス テロイド投与はショックへの進展を予防できる可能性 がある。一方で，ステロイドは免疫機能を抑制し，感 染症, 消化管出血, 高血糖などの合併症を起こすリス クも有する。ショックを伴わない敗血症患者に対する ステロイド投与の益と害のバランス評価は定まってお らず，同薬の使用は主治医の判断にゆだねられている 現状がある。

敗血症は重症化した場合は予後が不良であり，重症 化を防ぐ治療法は有益であることから, 本 CQ は重要 と考えられる。

(2) PICO

$\mathrm{P}$ (患者) : ショックに至っていない敗血症患者

I (介入) : ステロイド（ヒドロコルチゾン）投与

C (対照)：ステロイド（ヒドロコルチゾン）の非投 与あるいはプラセボの投与

$\mathrm{O}$ (アウトカム ) : 全原因死亡, ショックヘの進展, あらゆる重篤な合併症，あらゆる軽微な副作用

\section{（3）エビデンスの要約}

システマティックレビューの結果, PICO に合致し たランダム化比較試験（RCT）が 3 件施行 1-3）されて おり，これらを用いたメタ解析を実施した。

\section{（4）益と害のバランス（Table 7-3-1）}

望ましい効果 :

28 日死亡（3 RCT: $\mathrm{n}=437 ）$ に関する効果推定值は, 1,000 人あたり 2 人少ない $(95 \% \mathrm{CI}: 48$ 人少ない〜 74 人多い）であった。また，ショックへの進展（1 RCT: $\mathrm{n}=349 ）$ に関する効果推定值は 1,000 人あたり 27 人 少ない $(95 \%$ CI: 94 人少ない〜 71 人多い) であり, これらの結果からヒドロコルチゾンの投与による望ま しい効果はわずかと判断される。

望ましくない効果 :

長期死亡（2 RCT: $\mathrm{n}=382 ）$ に関する効果推定值は, 
Table 7-3-1エビデンスプロファイル

\begin{tabular}{|c|c|c|c|c|c|c|c|c|c|c|c|c|}
\hline \multicolumn{7}{|c|}{ 確夷性の評傮 } & \multicolumn{2}{|c|}{ 患者数 } & \multicolumn{2}{|c|}{ 奻果 } & \multirow{2}{*}{ 確夷性 } & \multirow{2}{*}{ 重要性 } \\
\hline 研究数 & $\begin{array}{l}\text { 研究 } \\
\text { デサイン }\end{array}$ & $\begin{array}{l}\text { パイアス } \\
\text { のリスク }\end{array}$ & 非一買性 & 非直接性 & 不䧗確性 & $\begin{array}{l}\text { その他 } \\
\text { の模扵 }\end{array}$ & $\begin{array}{l}\text { ヒドロコル } \\
\text { チソン群 }\end{array}$ & Control群 & $\begin{array}{l}\text { 相対指標 } \\
(95 \% \text { Cl) }\end{array}$ & $\begin{array}{l}\text { 䋓対指標 } \\
(95 \% \text { Cl) }\end{array}$ & & \\
\hline
\end{tabular}

28 日死亡

\begin{tabular}{|c|c|c|c|c|c|c|c|c|c|c|c|c|}
\hline 3 & RCT & 深刻 a & 深刻でない & 深刻でない & 非常に深刻 b & なし & $\begin{array}{l}25 / 217 \\
(11.5 \%)\end{array}$ & $\begin{array}{l}26 / 220 \\
(11.8 \%)\end{array}$ & $\begin{array}{c}\text { RR } 0.98 \\
\text { (0.59 to } 1.63 \text { ) }\end{array}$ & $\begin{array}{c}1,000 \text { 人あたり } 2 \text { 人少 } \\
\text { ない (48 人少ない〜 } 74 \\
\text { 人多い) }\end{array}$ & $\begin{array}{l}\oplus \bigcirc 0 \bigcirc \\
\text { 非常に低 }\end{array}$ & 重大 \\
\hline
\end{tabular}

長期死亡

\begin{tabular}{|c|c|c|c|c|c|c|c|c|c|c|c|c|}
\hline 2 & RCT & 深刻でない & 深刻でない & 深刻でない & 深刻 ${ }^{b}$ & なし & $\begin{array}{l}38 / 191 \\
(19.9 \%)\end{array}$ & $\begin{array}{l}33 / 191 \\
(17.3 \%)\end{array}$ & $\begin{array}{c}\text { RR } 1.15 \\
\text { (0.76 to } 1.76 \text { ) }\end{array}$ & $\begin{array}{c}1,000 \text { 人あたり } 26 \text { 人多 } \\
\text { い } \\
(42 \text { 人少ない } 131 \text { 人 } \\
\text { 多い) }\end{array}$ & $\begin{array}{c}\oplus \oplus \oplus \bigcirc \\
\text { 中 }\end{array}$ & 重大 \\
\hline
\end{tabular}

ショックヘの進行

\begin{tabular}{|c|c|c|c|c|c|c|c|c|c|c|c|c|}
\hline 1 & RCT & 深刻でない & 深刻でない & 深刻でない & 非常に深刻 b & なし & $\begin{array}{l}36 / 179 \\
(20.1 \%)\end{array}$ & $\begin{array}{l}39 / 170 \\
(22.9 \%)\end{array}$ & $\begin{array}{c}\text { RR } 0.88 \\
\text { (0.59 to } 1.31 \text { ) }\end{array}$ & $\begin{array}{c}1,000 \text { 人あたり } 27 \text { 人少 } \\
\text { ない } \\
(94 \text { 人少ない } 71 \text { 人多 } \\
\text { い) }\end{array}$ & $\begin{array}{c}\oplus \oplus \bigcirc \bigcirc \\
\text { 低 }\end{array}$ & 重大 \\
\hline
\end{tabular}

感染症

\begin{tabular}{|c|c|c|c|c|c|c|c|c|c|c|c|c|}
\hline 1 & $\mathrm{RCT}$ & 深刻でない & 深刻でない & 深刻でない & 深刻 b & なし & $\begin{array}{l}40 / 186 \\
(21.5 \%)\end{array}$ & $\begin{array}{l}32 / 189 \\
(16.9 \%)\end{array}$ & $\begin{array}{c}\text { RR } 1.27 \\
\text { (0.84 to } 1.93)\end{array}$ & $\begin{array}{c}1,000 \text { 人あたり } 46 \text { 人多 } \\
\text { 人 } \\
(27 \text { 人少ない } 157 \text { 人 } \\
\text { 多い })\end{array}$ & $\begin{array}{c}\oplus \oplus \oplus \bigcirc \\
\text { 中 }\end{array}$ & 重大 \\
\hline
\end{tabular}

消化管出血

\begin{tabular}{|c|c|c|c|c|c|c|c|c|c|c|c|c|}
\hline 1 & RCT & 深刻でない & 深刻でない & 深刻でない & 非常に深刻 b & なし & $\begin{array}{l}3 / 186 \\
(1.6 \%)\end{array}$ & $\begin{array}{l}2 / 189 \\
(1.1 \%)\end{array}$ & $\begin{array}{c}\text { RR } 1.52 \\
(0.26 \text { to } 9.02)\end{array}$ & $\begin{array}{c}1,000 \text { 人あたり } 6 \text { 人多 } \\
\text { い } \\
\text { (8 人少ない 85 人多 } \\
\text { () }\end{array}$ & $\begin{array}{c}\oplus \oplus \bigcirc \bigcirc \\
\text { 低 }\end{array}$ & 重大 \\
\hline
\end{tabular}

高ナトリウム血症

\begin{tabular}{|c|c|c|c|c|c|c|c|c|c|c|c|c|}
\hline 1 & RCT & 深刻でない & 深刻でない & 深刻でない & 非常に深刻 b & なし & $\begin{array}{c}10 / 186 \\
(5.4 \%)\end{array}$ & $\begin{array}{l}10 / 189 \\
(5.3 \%)\end{array}$ & $\begin{array}{c}\text { RR } 1.02 \\
\text { (0.43 to } 2.38 \text { ) }\end{array}$ & $\begin{array}{c}\text { 1,000 人あたり } 1 \text { 人多 } \\
\text { い } \\
\text { (30 人少ない〜 } 73 \text { 人多 } \\
\text { い) }\end{array}$ & $\begin{array}{c}\oplus \oplus \bigcirc \bigcirc \\
\text { 低 }\end{array}$ & 重大 \\
\hline
\end{tabular}

高血糖

\begin{tabular}{|c|c|c|c|c|c|c|c|c|c|c|c|c|}
\hline 1 & RCT & 深刻でない & 深刻でない & 深刻でない & 深刻でない & なし & $\begin{array}{l}169 / 186 \\
(90.9 \%)\end{array}$ & $\begin{array}{l}154 / 189 \\
(81.5 \%)\end{array}$ & $\begin{array}{c}\text { RR } 1.12 \\
\text { (1.03 to } 1.21)\end{array}$ & $\begin{array}{c}1,000 \text { 人あたり } 98 \text { 人 } \\
\text { 多い } \\
\text { (24 人少ない } 171 \text { 人 } \\
\text { 多い) }\end{array}$ & $\begin{array}{c}\oplus \oplus \oplus \oplus \\
\text { 高 }\end{array}$ & 重要 \\
\hline
\end{tabular}

a.3つの RCT 含んでいるが，全体の $28.7 \%$ \%のェイトをしめているRinaldi らの論文 2)において，不完全なアウトカムデータが認められ，それが高いバイアスのリスクの評価となっている。それを受けて 深刻とした。

b. $95 \% \mathrm{Cl}$ が 1 をまたざながら, かつ, かなり幅広いため, 唯一Clの最小が 0.76 の 28 日死亡は深刻，その他のアウトカムは非常に深刻との評価とした。

1,000 人あたり 26 人多い $(95 \% \mathrm{CI}: 42$ 人少ない〜 131 人多い）であった。また，あらゆる重篤な副作用に関 する効果推定值は，新規感染症（1 RCT: $\mathrm{n}=375 ） に$ おいて 1,000人あたり 46 人多い $(95 \% \mathrm{CI}: 27$ 人少な い〜157 人多い)，消化管出血（1 RCT: $n=375 ） に お ~$ いて 1,000 人あたり 6 人多い $(95 \% \mathrm{CI}: 8$ 人少ない〜 85 人多い）であり，ヒドロコルチゾンの投与による 望ましくない効果は小さい。

益と害のバランス :

本 CQ においては，すべてのアウトカムがヒドロコ ルチゾン投与の効果なしを示す結果であったため，患 者・家族が置く相対的価值の設定によらず，その効果 のバランスは介入も比較もいずれも優位でない。

（5）アウトカム全般に関するエビデンスの確実性

今回採用した重大なアウトカムについて, 望ましい
効果と, 望ましくない効果で効果推定值の方向が異 なっているため, アウトカム全体にわたるエビデンス の確実性については，アウトカムの中で最も低い確実 性を全体として採用し「非常に低」とした。

\section{（6）価値観}

敗血性患者に対するヒドロコルチゾンの投与におい て，各アウトカムにおける患者・家族の価值観に関す るデータはない。一般的に, 死亡アウトカムに対する 相対的価值は高く，そのばらつきは少ないことが予想 される。

\section{（7）容認性}

有害事象はリスクが低い可能性が高い。介入に伴う コストを考慮し, 患者・家族の個人の視点を考慮して も，許容できる介入であると考えられる。 
Table 7-3-2 判断の要約

\begin{tabular}{|c|c|c|c|c|c|c|c|}
\hline & \multicolumn{7}{|c|}{ 判数 } \\
\hline 問題 & いいえ & $\begin{array}{c}\text { おそらく、いい } \\
\text { え }\end{array}$ & おそらく、はい & はい & & さまざま & 分からない \\
\hline 望ましい効果 & わずか & 小さい & 中 & 大きい & & さまざま & 分からない \\
\hline 望ましくない効果 & 大きい & 中 & 小さい & わずか & & さまざま & 分からない \\
\hline エビデンスの確実性 & 非常に低 & 低 & 中 & 高 & & & 採用研究なし \\
\hline 価值観 & $\begin{array}{c}\text { 重要な不確実性 } \\
\text { またはばらつき } \\
\text { あり }\end{array}$ & $\begin{array}{c}\text { 重要な不確実性 } \\
\text { またはばらつき } \\
\text { の可能性あり }\end{array}$ & $\begin{array}{l}\text { 重要な不確実性 } \\
\text { またはばらつき } \\
\text { はおそらくなし }\end{array}$ & $\begin{array}{c}\text { 重要な不確実性 } \\
\text { またはばらつき } \\
\text { はなし }\end{array}$ & & & \\
\hline 効果のバランス & 比較が優位 & $\begin{array}{c}\text { 比較がおそらく } \\
\text { 優位 }\end{array}$ & $\begin{array}{c}\text { 介入も比較もい } \\
\text { ずれも優位でな } \\
\text { い }\end{array}$ & $\begin{array}{c}\text { おそらく介入が } \\
\text { 優位 }\end{array}$ & 介入が優位 & さまざま & 分からない \\
\hline 容認性 & いいえ & $\begin{array}{c}\text { おそらく、いい } \\
\text { え }\end{array}$ & おそらく、はい & はい & & さまざま & 分からない \\
\hline 実行可能性 & いいえ & $\begin{array}{c}\text { おそらく、いい } \\
\text { え }\end{array}$ & おそらく、はい & はい & & さまざま & 分からない \\
\hline
\end{tabular}

\section{（8）実行可能性}

介入は多くの医療施設において実行可能である。

（9）判断の要約（Table 7-3-2）

（10）推奨グレーディング決定の工程

修正 RAND 法を用いた投票によって，中央值 8, 見解不一致指数 0.014 の結果となり，委員会で採択さ れた（7点以上 : 91.7\%)。

（11）関連する他の診療ガイドラインにおける推奨 S SCG 2016, 日本版敗血症診療ガイドライン （J-SSCG）2016のいずれにおいても，適切な輸液蘇生 と血管作動薬投与により血行動態の安定が得られた患 者への投与は非推奨となっている。

\section{（12）実施に関わる検討事項}

重症化前からステロイド投与が行われていた患者に 対するステロイド継続（慢性疾患に対するステロイド の継続投与) に関しては，本推奨は適応されない。

（13）今後の研究の可能性

なし。

\section{文 献}

1) Keh D, Trips E, Marx G, et al: Effect of Hydrocortisone on Development of Shock Among Patients With Severe Sepsis: The HYPRESS Randomized Clinical Trial. JAMA. 2016; 316: 1775-85.

2) Rinaldi S, Adembri C, Grechi S, et al: Low-dose hydrocortisone during severe sepsis: effects on microalbuminuria. Crit Care Med. 2006; 34: 2334-9.

3) Tongyoo S, Permpikul C, Mongkolpun W, et al: Hydrocortisone treatment in early sepsis-associated acute respiratory distress syndrome: results of a randomized controlled trial. Crit Care. 2016; $20: 329$ 


\section{CQ8：輸血療法}

輸血療法は, 出血や慢性貧血に対する赤血球の補 充，出血傾向に対する止血の促進および出血の予防の ための凝固因子や血小板の補充として行われる。人体 の一部かつ有限で貴重な資源である血液を原料とする 血液製剂による輸血療法は, その効果と感染症やアレ ルギーなどの有害事象, 医療資源の視点から適応を慎 重に判断することが重要である。本邦の保険診療にお いては，厚生労働省の「血液製剂の使用指針 平成 31 年改訂版」（以下，厚労省指針）に沿うことが求め られている 1)。厚労省指針の中で, 赤血球輸血につい ては日本版敗血症診療ガイドライン（J-SSCG）2016 が引用されており「敗血症患者の貧血に対して, トリ ガー值を $\mathrm{Hb}$ 值 $7 \mathrm{~g} / \mathrm{dL}$ とすることを強く推奨する」と 記載されている2）が，新鮮凍結血漿，血小板濃厚液 に関しては敗血症患者を対象とした項目はない1)。

敗血症では，貧血や凝固障害など輸血療法が必要と なる病態を伴うことは稀ではないが，敗血症患者を対 象とした輸血療法のエビデンスは限られており，その 適応については未だ議論が多い。

赤血球輸血について，J-SSCG 2016 では循環動態が 安定した状態における赤血球輸血は CQ の対象とせ ず，敗血症性ショックを対象として「敗血症性ショッ クの初期蘇生において, 赤血球輸血はへモグロビン值 $7 \mathrm{~g} / \mathrm{dL}$ 未満で開始することを推奨する（1B)」として いる2,3)。SSCG 2016 では，対象を敗血症性ショック に限定せず，敗血症で集中治療を要する患者を対象と して, 赤血球輸血はへモグロビン值 $7 \mathrm{~g} / \mathrm{dL}$ 未満で開始 することを推奨している4,5)。この推奨は the transfusion requirements in septic shock（TRISS）trial を始め とするランダム化比較試験（RCT）からの推奨であ り，心血管系の基礎疾患をもたない比較的若年の集中 治療患者においては, ヘモグロビン值 $7 \mathrm{~g} / \mathrm{dL}$ 未満で赤 血球輸血を開始することは一定のコンセンサスを得て
いる。一方，実際の臨床においては，高齢者や心血管 系の基礎疾患を有する患者も多く，己れらの患者背景 やショックの有無を考慮した赤血球輸血を行う必要が あるとの考えもある ${ }^{6)}$ 。そこで今回，赤血球輸血に関 しては,「CQ8-1：敗血症性ショックの初期蘇生にお いて，赤血球輸血はどのように行うか?」および 「CQ8-2 : 敗血症で循環動態が安定している場合に赤 血球輸血はどのように行うか?」を立案し，敗血症の 病態ごとに適切な赤血球輸血の開始基準を検討した。

新鮮凍結血漿と血小板濃厚液輸血については, J-SSCG 2016 では「出血傾向がなく外科的処置も要し ない場合, 凝固異常值を補正する目的では新鮮凍結血 漿の投与は行わないことを弱く推奨する（エキスパー トコンセンサス/エビデンスなし)」「敗血症において, 出血傾向が出現した場合または外科的処置が必要な場 合は，本邦の血液製剤の使用指針に沿って血小板輸血 を行うことを弱く推奨する（エキスパートコンセンサ ス/エビデンスなし)」としている2,3)。SSCG 2016 の 記載も同様であり, 敗血症において出血傾向がなく外 科的処置を要しない場合には, 新鮮凍結血漿や血小板 濃厚液輸血を行わないことは一定のコンセンサスを得 たと考えられる ${ }^{3)}$ 。しかし，敗血症患者を対象とした 新鮮凍結血漿や血小板濃厚液輸血に関しては, J-SSCG 2016, SSCG 2016 とも十分な根拠に基づく推 奨の提示ではない。敗血症患者では全身の炎症反応に より凝固障害が発生しやすく, DIC（disseminated intravascular coagulation）を合併した場合の予後は不 良であり，凝固障害の病態に応じた適切な凝固因子や 血小板を補充するべきという考えもある7）。そこで今 回は,「CQ8-3 : 敗血症に対して新鮮凍結血漿の投与 はどのように行うか?」「CQ8-4：敗血症に対して血 小板輸血はどのように行うか?」を立案し，敗血症患 者における新鮮凍結血漿および血小板輸血の投与基準 と投与の考え方について検討した。

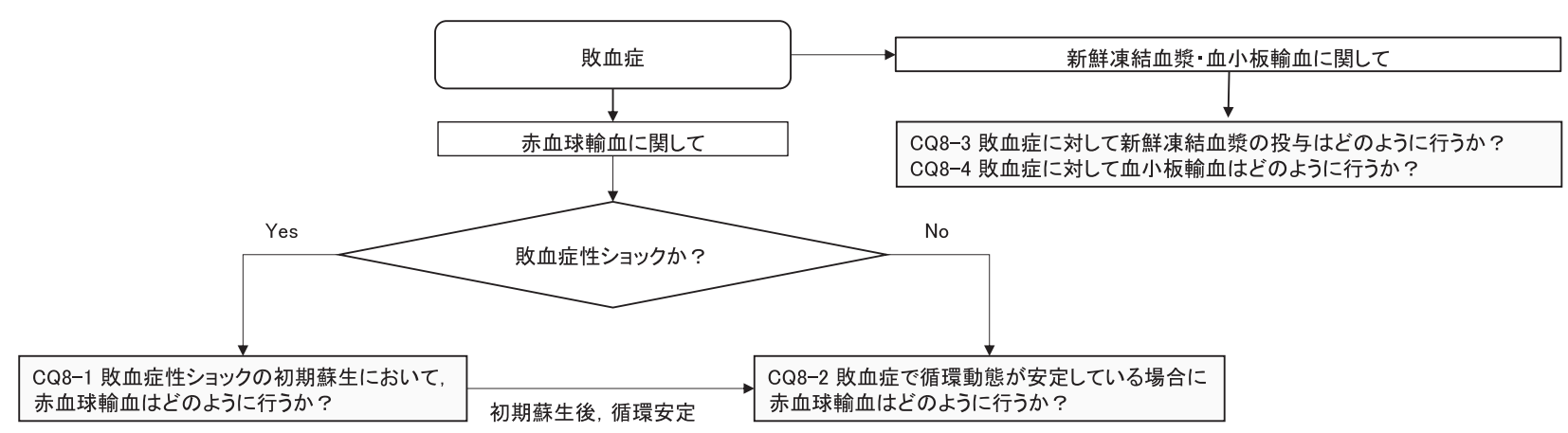

輸血療法 [診療フロー] 


\section{文 献}

1）厚生労衝省医薬・生活衛生局: 血液製剂の使用指針平成 31 年3月. 2019.

2）西田修, 小倉裕司, 井上茂亮, 他, 日本版敗血症診療ガイドラ イン 2016 作成特別委員会. 日本版敗血症診療ガイドライン 2016. 日集中医誌. 2017; 24: S1-232.

3）西田修, 小倉裕司, 井上茂亮, 他, 日本版敗血症診療ガイドラ イン 2016 作成特別委員会. 日本版敗血症診療ガイドライン 2016. 日救急医会誌. 2017; 28: S1-232.

4) Rhodes A, Evans LE, Alhazzani W, et al: Surviving Sepsis Campaign: International Guidelines for Management of Sepsis and Septic Shock: 2016. Intensive Care Med. 2017; 43: 304-77.

5) Holst LB, Haase N, Wetterslev J, et al: Lower versus higher hemoglobin threshold for transfusion in septic shock. N Engl J Med. 2014; 371: 1381-91.

6) Docherty A, Walsh TS: Should blood transfusion be individualised? We are not sure. Intensive Care Med. 2015; 41: 1980-2.

7) Lyons PG, Micek ST, Hampton N, et al: Sepsis-associated coagulopathy severity predicts hospital mortality. Crit Care Med. 2018; 46: 736-42.
CQ8-1：敗血症性ショックの初期蘇生において, 赤血球輸血はどのように行うか?

Answer : 敗血症性ショック患者の初期蘇生において, 赤血球輸血はへモグロビン值 $7 \mathrm{~g} / \mathrm{dL}$ 未満で開始するこ とを弱く推奨する (GRADE 2C : エビデンスの確実性 $=$ 「低」)。

\section{（1）背景および本 CQ の重要度}

敗血症性ショック期には, 組織の低酸素血症や心筋 障害を考慮し, より高いへモグロビン值で組織に十分 な酸素を供給したほうが良いという考えもある。一 方, 日本版敗血症診療ガイドライン (J-SSCG) 初 版1）および J-SSCG 2016 2,3) では, 敗血症性ショック の初期蘇生において, へモグロビン值 $7 \mathrm{~g} / \mathrm{dL}$ 未満で赤 血球輸血を開始することを推奨している。また，厚生 労働省の「血液製剂の使用指針」平成 31 年改訂版 4$)$ および SSCG 20165) でも，ショック期あるいはショッ ク離脱後などの病態への言及はないが, 引用文献より ショック期に関するものと推測される状態において, ヘモグロビン值 $7 \mathrm{~g} / \mathrm{dL}$ 未満での輸血開始を推奨してい る。一方で，へモグロビン值が不十分な場合に生じる と考えられる組織の低酸素血症による虚血性臟器障害 のリスクも考慮する必要がある。以上より, 敗血症性 ショック患者の初期蘇生における赤血球輸血の開始時 期は重要な臨床上の課題であり, 本ガイドラインにお いて, 再度 $\mathrm{CQ}$ として取り上げた。本 $\mathrm{CQ}$ の優先度は 高いと考える。

\section{(2) PICO}

$\mathrm{P}$ (患者)：敗血症性ショック患者

I（介入）：へモグロビン值 $7 \mathrm{~g} / \mathrm{dL}$ 未満で赤血球輸血 を行う

$\mathrm{C}$ (対照)：ヘモグロビン值 $10 \mathrm{~g} / \mathrm{dL}$ 未満で赤血球輸 血を行う

O (アウトカム) : 90 日死亡, 虚血性臟器障害

\section{（3）エビデンスの要約}

システマティックレビューの結果, PICO に合致し たランダム化比較試験（RCT）は 1 件 6) のみであっ た。

\section{（4）益と害のバランス（Table 8-1-1）}

\section{望ましい効果 :}

システマティックレビューにより対象となった RCT は 1 件だけであった。この RCT（n=998）にお 
Table 8-1-1エビデンスプロファイル

\begin{tabular}{|c|c|c|c|c|c|c|c|c|c|c|c|c|}
\hline \multicolumn{7}{|c|}{ 確実性の評価 } & \multicolumn{2}{|c|}{ 患者数 } & \multicolumn{2}{|c|}{ 効果 } & \multirow[b]{2}{*}{ 確実性 } & \multirow[b]{2}{*}{ 重要性 } \\
\hline 研究数 & $\begin{array}{c}\text { 研究 } \\
\text { デザイン }\end{array}$ & $\begin{array}{l}\text { バイアス } \\
\text { のリスク }\end{array}$ & 非一貫性 & 非直接性 & 不精確性 & $\begin{array}{l}\text { その他 } \\
\text { の検討 }\end{array}$ & Hb $7.0 \mathrm{~g} / \mathrm{dL}$ & $\mathrm{Hb} 10.0 \mathrm{~g} / \mathrm{dL}$ & $\begin{array}{l}\text { 相対指標 } \\
(95 \% \text { GI })\end{array}$ & $\begin{array}{l}\text { 絶対指標 } \\
(95 \% \text { CI })\end{array}$ & & \\
\hline \multicolumn{13}{|c|}{90 日死亡 } \\
\hline 1 & RCT & 深刻 a & 深刻でない & 深刻でない & 深刻 b & なし & $216 / 502$ & $223 / 496$ & $\begin{array}{c}R R 0.96 \\
(0.83 \text { to } 1.10)\end{array}$ & $\begin{array}{l}1,000 \text { 人あたり } 18 \\
\text { 人少ない (76 人少 } \\
\text { ない 45 人多い) }\end{array}$ & $\underset{\text { 低 }}{\oplus \oplus \bigcirc \bigcirc}$ & 重大 \\
\hline \multicolumn{13}{|c|}{ 虚血性イベント } \\
\hline 1 & RCT & 深刻 a & 深刻でない & 深刻でない & 深刻 b & なし & $35 / 488$ & $39 / 489$ & $\begin{array}{l}R R=.90 \\
\text { (0. } 58 \text { to } 1.39)\end{array}$ & $\begin{array}{l}\text { 1, } 000 \text { 人あたり } 8 \\
\text { 人少ない (33人少 } \\
\text { ない 31 人多い) }\end{array}$ & $\underset{\text { 低 }}{\oplus \oplus \bigcirc \bigcirc}$ & 重大 \\
\hline
\end{tabular}

a. 患者医療者の盲検化：輸血の閾値を盲検化できない。バイアスのリスクが高い。

b. 95\% CI が臨床的意義のある闒値をまたいでいる。

28 日死亡に関しては, アウトカムの報告がなかった。

ける 90 日死亡に関する効果推定值とその信頼区間は, 1,000 人あたり 18 人少ない（76人少ない〜 45 人多い） であり，へモグロビン值 $7 \mathrm{~g} / \mathrm{dL}$ 未満で赤血球輸血を開 始することによる望ましい効果はわずかである。

望ましくない効果 :

システマティックレビューにより対象となった RCT は 1 件だけであった。この RCT（n=977）にお ける虚血性イベントに関する効果推定值とその信頼区 間は， 1,000 人あたり 8 人少ない（33 人少ない〜 31 人 多い）であり，へモグロビン值 $7 \mathrm{~g} / \mathrm{dL}$ 未満で赤血球輸 血を開始することによる望ましくない効果は増えない 可能性があり，望ましくない効果はわずかである。

益と害のバランス :

1 つの RCT では, 赤血球輸血の開始をへモグロビ ン值 $7.0 \mathrm{~g} / \mathrm{dL}$ に制限することが，アウトカム（90日死 亡および虚血性イベント）に対して効果なしを示す結 果であったため, その効果のバランスは介入あるいは 比較対象のいずれも支持しない。

（5）アウトカム全般に関するエビデンスの確実性

システマティックレビューにより対象となった $\mathrm{RCT}$ は 1 件だけであった。2つのアウトカム（90日 死亡および虚血性イベント）のエビデンスの確実性は 「低」である。2つのアウトカムの方向性（効果なし） は同一方向であるため, アウトカムの中で最も高い確 実性を全体として採用し「低」とした。

\section{（6）価値観}

輸血に対する考え方は個人により様々であり，宗教 上などの理由により輸血を拒む患者・家族もいるが, 必要最小限の輸血を行い, 輸血の合併症を避けること については，患者・家族は一般的に重視すると考えら れる。

\section{（7）容認性}

赤血球輸血のためには，施設と地域の体制整備が必 要である。また，血液型判定や投与までの管理など， 輸血を行うことによる医療従事者の仕事量は増加する ことが予想される。また，赤血球輸血は，約 8,400 円/血液 $200 \mathrm{~mL}$ 相当に由来する赤血球（140mL）であ り，赤血球輸血を行うことにより医療コストが増加す る。このため, 赤血球輸血の開始をへモグロビン值 $7.0 \mathrm{~g} / \mathrm{dL}$ に制限することは，これらの負荷を軽減する ことになる。

\section{（8）実行可能性}

赤血球輸血は供給体制の整備が必要であるが，ほぼ すべての集中治療室において利用可能であると考えら れる。赤血球輸血の開始をへモグロビン值 $7.0 \mathrm{~g} / \mathrm{dL} に$ 制限することは可能であるが，急な出血や貧血が進行 した場合に，夜間・休日の緊急輸血が困難な医療機関 や地域では, ヘモグロビン值 $7.0 \mathrm{~g} / \mathrm{dL}$ 以上でも赤血球 輸血を開始することが必要かもしれない。

\section{(9) 判断の要約 (Table 8-1-2)}

\section{（10）推奨グレーディング決定の工程}

修正 RAND 法を用いた投票によって，中央值 8, 見解不一致指数 0.178 の結果となり，委員会で採択さ れた（7 点以上 : 91.7\%)。

\section{（11）関連する他の診療ガイドラインにおける推奨}

SSCG 20165）では，成人敗血症患者（初期蘇生時や 敗血症性ショックなどの記載はない）に対して，心筋 虚血, 重度の低酸素血症あるいは急性出血などの考慮 するべき病態がない場合は, へモグロビン值が $7.0 \mathrm{~g} / \mathrm{dL}$ 未満となったときのみ赤血球輸血を行うことを推奨し ている（強い推奨/質の高いエビデンス）。J-SSCG 
Table 8-1-2 判断の要約

\begin{tabular}{|c|c|c|c|c|c|c|c|}
\hline & \multicolumn{7}{|c|}{ 判河 } \\
\hline 問題 & いいえ & $\begin{array}{c}\text { おそらく、いい } \\
\text { え }\end{array}$ & おそらく、はい & はい & & さまざま & 分からない \\
\hline 望ましい勃果 & わずか & 小さい & 中 & 大きい & & さまざま & 分からない \\
\hline 望ましくない勃果 & 大きい & 中 & 小さい & わずか & & さまざま & 分からない \\
\hline エビデンスの確実性 & 非常に低 & 低 & 中 & 高 & & & 採用研究なし \\
\hline 価值覞 & $\begin{array}{c}\text { 重要な不確実性 } \\
\text { またははららつき } \\
\text { あり }\end{array}$ & $\begin{array}{l}\text { 重要な不確実性 } \\
\text { またはばらつき } \\
\text { の可能性あり }\end{array}$ & $\begin{array}{l}\text { 重要な不確実性 } \\
\text { またはばらつき } \\
\text { はおそらくなし }\end{array}$ & $\begin{array}{c}\text { 重要な不確実性 } \\
\text { またはばらつき } \\
\text { はなし }\end{array}$ & & & \\
\hline 効果のバランス & 比較が優位 & $\begin{array}{c}\text { 比較がおそらく } \\
\text { 優位 }\end{array}$ & $\begin{array}{c}\text { 介入も比較もい } \\
\text { ずれも優位でな } \\
\text { い }\end{array}$ & $\begin{array}{c}\text { おそらく介入が } \\
\text { 優位 }\end{array}$ & 介入が優位 & さまざま & 分からない \\
\hline 容認性 & いいえ & $\begin{array}{c}\text { おそらく、いい } \\
\text { え }\end{array}$ & おそらく、はい & はい & & さまざま & 分からない \\
\hline 実行可能性 & いいえ & 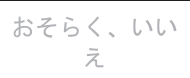 & おそらく、はい & はい & & さまざま & 分からない \\
\hline
\end{tabular}

$2016^{2,3)}$ では，敗血症性ショックの初期蘇生におい て, 赤血球輸血はへモグロビン值 $7.0 \mathrm{~g} / \mathrm{dL}$ 未満で開始 することを推奨している（強い推奨/中程度のエビデ ンスレベル)。

\section{（12）実施に関わる検討事項}

推奨の実施においては，虚血性合併症の有無を評価 することが望まれる。右左シャントの存在など慢性的 な低酸素血症の存在に伴い，代償的に高へモグロビン 血症を呈している患者などでは本推奨は適応となら ず，個別対応が望まれる。

\section{（13）今後の研究の可能性}

敗血症性ショック患者に対する，赤血球輸血に関す る有効性を評価した RCT が 1 件のみであることが明 らかとなった。敗血症性ショック患者に対する赤血球 輸血の有効性や有害事象などを検証するさらなる RCT の実施が望まれる。

\section{文 献}

1）日本集中治療医学会 Sepsis Registry 委員会: 日本版敗血症診 療ガイドライン.日集中医誌. 2013; 20: 124-73.

2）西田修, 小倉裕司, 井上茂亮, 他, 日本版敗血症診療ガイドラ イン 2016 作成特別委員会. 日本版敗血症診療ガイドライン 2016. 日集中医誌. 2017; 24: S1-232.

3）西田修, 小倉裕司, 井上茂亮, 他, 日本版敗血症診療ガイドラ イン 2016 作成特別委員会. 日本版敗血症診療ガイドライン 2016. 日救急医会誌. 2017; 28: S1-232.

4）厚生労働省医薬 - 生活衛生局: 血液製剂の使用指針. 2017.

5) Rhodes A, Evans LE, Alhazzani W, et al: Surviving Sepsis Campaign: International Guidelines for Management of Sepsis and Septic Shock: 2016. Intensive Care Med. 2017; 43: 304-77.

6) Holst LB, Haase N, Wetterslev J, et al: Lower versus higher hemoglobin threshold for transfusion in septic shock. N Engl J Med. 2014; 371: 1381-91. 


\section{CQ8-2 : 敗血症で循環動態が安定している場合 に赤血球輸血はどのように行うか?}

Answer : 循環動態が安定している敗血症患者におい て, 赤血球輸血はへモグロビン值 $7 \mathrm{~g} / \mathrm{dL}$ 未満で開始す ることを弱く推奨する（エキスパートコンセンサス : エビデンス不十分)。

\section{（1）背景および本 $C Q$ の重要度}

貧血に伴う組織の低酸素障害は，臨床的に重要な問 題となることがある。赤血球輸血は, これらへの対応 と予防のために行うが, 必要以上の輸血は血液製剂投 与に伴うアレルギーや感染症のリスクを高める。さら に血液製剂投与に伴う循環への負荷, 輸血関連急性肺 障害（transfusion-related acute lung injury: TRALI）の発 症（赤血球輸血による致死的 TRALI の頻度 1 : 25,002,000 products）1）などの危険性もある。このた め, 貧血に伴う障害を防ぐ最小限の輸血を行うことが 重要と考えられる。

循環動態が安定した敗血症患者に対する赤血球輸血 開始基準について, 日本版敗血症診療ガイドライン （J-SSCG）初版 ${ }^{2 ） お よ ひ ゙ S S C G ~ 20123 ） て ゙ は ， へ モ ク ゙ ロ ~}$ ビン值 $7 \mathrm{~g} / \mathrm{dL}$ 未満での輸血開始を推奨した。しかし, この当時は敗血症に対象を限定した臨床研究がなかっ たため, 集中治療を要する患者全体を対象とした研究 結果を参考に推奨度を決定した。その後の J-SSCG $2016^{4,5)}$ では, 循環動態が安定した状態における赤血 球輸血は一定のコンセンサスが得られていると判断 し，CQとして取り上げなかったが，敗血症性ショッ クの患者に対する赤血球輸血の開始基準を示し, 循環 動態が安定した敗血症患者に対する赤血球輸血の開始 基準を示していないことに対する疑問も出されてい た。赤血球輸血の開始基準について，循環動態が安定 した状態における開始基準も明確にすることは重要な 臨床課題と考え，本ガイドラインで取り上げた。

循環動態が安定した敗血症患者に対する赤血球輸血 の開始基準やへモグロビンの目標值については明確な 基準がなく, 有効性や有害性の評価も定まっていない ため，本 CQ の優先度は高いと考える。

\section{(2) PICO}

$\mathrm{P}$ (患者) : 敗血症患者（敗血症性ショック患者は除 外)

I（介入）: ヘモグロビン值 $7 \mathrm{~g} / \mathrm{dL}$ 未満で赤血球輸血 を行う

$\mathrm{C}$ (対照)：ヘモグロビン值 $10 \mathrm{~g} / \mathrm{dL}$ 未満で赤血球輸
血を行う

$\mathrm{O}$ (アウトカム ) : 病院死亡, ICU 滞在日数, 感染性 合併症，輸血関連急性肺障害やアナフィラキシー などを含むあらゆる重篤な副作用

\section{（3）エビデンスの要約}

システマティックレビューを行ったが, PICO に合致 するランダム化比較試験（RCT）は存在しなかった。

\section{（4）益と害のバランス}

望ましい効果 :

貧血に伴う組織の低酸素障害は，臨床的に重要な問 題となることがあり, 赤血球輸血は, これらへの対応 と予防のために行うが, 必要以上の輸血は, 輸血に伴 う合併症のリスクを高める。貧血に伴う障害を防ぐ最 小限の輸血を行うことは, 輸血の効果を得ながら合併 症を最小限に抑えることになり，患者に益する可能性 が高いと考える。

望ましくない効果 :

赤血球輸血の開始をへモグロビン值 $7.0 \mathrm{~g} / \mathrm{dL}$ に制限 することは, 虚血性心疾患や心不全を有する一部の患 者には, より心臓への負荷を増し有害となる可能性が ある。

益と害のバランス :

PICO に合致する RCT は存在せず不明であるが，患 者の状態によってそのバランスは異なると考えられ る。高度の心不全や虚血性心疾患がなければ, 赤血球 輸血の開始をへモグロビン $7.0 \mathrm{~g} / \mathrm{dL}$ に制限することは, 益が害を上回るものと考えられる。

（5）アウトカム全般に関するエビデンスの確実性

システマティックレビューを行ったが，PICO に合 致する RCT は存在しなかった。

\section{（6）価値観}

輸血に対する考え方は個人により様々であり，宗教 上などの理由により輸血を拒む患者・家族もいるが, 必要最小限の輸血を行い, 輸血の合併症を避けること については, 患者・家族は一般的に重視すると考えら れる。

\section{（7）容認性}

赤血球輸血のためには，施設と地域の体制整備が必 要である。また, 血液型判定や投与までの管理など, 輸血を行うことによる医療従事者の仕事量は増加する ことが予想される。また, 赤血球輸血は, 約 8,400 
円/血液 $200 \mathrm{~mL}$ 相当に由来する赤血球（140mL）であ り，赤血球輸血を行うことにより医療コストが増加す る。このため, 赤血球輸血の開始をへモグロビン $7.0 \mathrm{~g} / \mathrm{dL}$ に制限することは，これらの負荷を軽減する ことになる。

\section{（8）実行可能性}

赤血球輸血は供給体制の整備が必要であるが，ほぼ すべての集中治療室において利用可能であると考えら れる。赤血球輸血の開始をへモグロビン $7.0 \mathrm{~g} / \mathrm{dL}$ に制 限することは可能であるが, 急な出血や貧血が進行し た場合に，夜間・休日の緊急輸血が困難な医療機関や 地域では, ヘモグロビン $7.0 \mathrm{~g} / \mathrm{dL}$ 以上でも赤血球輸血 を開始することが必要かもしれない。

（9）判断の要約（Table 8-2-1）

\section{（10）推奨グレーディング決定の工程}

修正 RAND 法を用いた投票によって，中央值 8, 見解不一致指数 0.164 の結果となり，委員会で採択さ れた（7点以上 : $87.5 \%) 。$

\section{（11）関連する他の診療ガイドラインにおける推奨}

SSCG 2016 6) では, 成人敗血症患者（循環動態が安定, 不安定などの記載はない）に対して, 心筋虚血, 重度の 低酸素血症あるいは急性出血などの考慮するべき病態 がない場合は, ヘモグロビン值が $7.0 \mathrm{~g} / \mathrm{dL}$ 未満となった ときのみ赤血球輸血を行うことを推奨している（強い推 奨/質の高いエビデンス)。J-SSCG $2016^{4,5)}$ では, 循環
動態が安定した後の輸血に関する推奨の記載はない。

\section{（12）実施に関わる検討事項}

推奨の実施においては，虚血性合併症の有無を評価 することが望まれる。右左シャントの存在など慢性的 な低酸素血症の存在に伴い，代償的に高へモグロビン 血症を呈している患者などでは本推奨は適応となら ず，個別対応が望まれる。

\section{（13）今後の研究の可能性}

循環動態が安定した敗血症患者に対する，赤血球輸 血に関する有効性を評価した RCT がないことが明ら かとなり, 循環動態が安定した状態における赤血球輸 血の有効性や有害事象などを検証する RCT の実施が 望まれる。

\section{文 献}

1) Shaz BH, Stowell SR, Hillyer CD: Transfusion-related acute lung injury: From bedside to bench and back. Blood. 2011; 117: 1463-71.

2）日本集中治療医学会 Sepsis Registry 委員会: 日本版敗血症診 療ガイドライン. 日集中医誌. 2013; 20: 124-73.

3) Dellinger RP, Levy MM, Rhodes A, et al: Surviving sepsis campaign: International guidelines for management of severe sepsis and septic shock: 2012. Crit Care Med. 2013; 41: 580-637.

4）西田修, 小倉裕司, 井上茂亮, 他, 日本版敗血症診療ガイドラ イン 2016 作成特別委員会. 日本版敗血症診療ガイドライン 2016. 日集中医誌. 2017; 24: S1-232.

5）西田修, 小倉裕司, 井上茂亮, 他, 日本版敗血症診療ガイドラ イン 2016 作成特別委員会. 日本版敗血症診療ガイドライン 2016. 日救急医会誌. 2017; 28: S1-232.

6) Rhodes A, Evans LE, Alhazzani W, et al: Surviving Sepsis Campaign: International Guidelines for Management of Sepsis and Septic Shock: 2016. Intensive Care Med. 2017; 43: 304-77.

Table 8-2-1 判断の要約

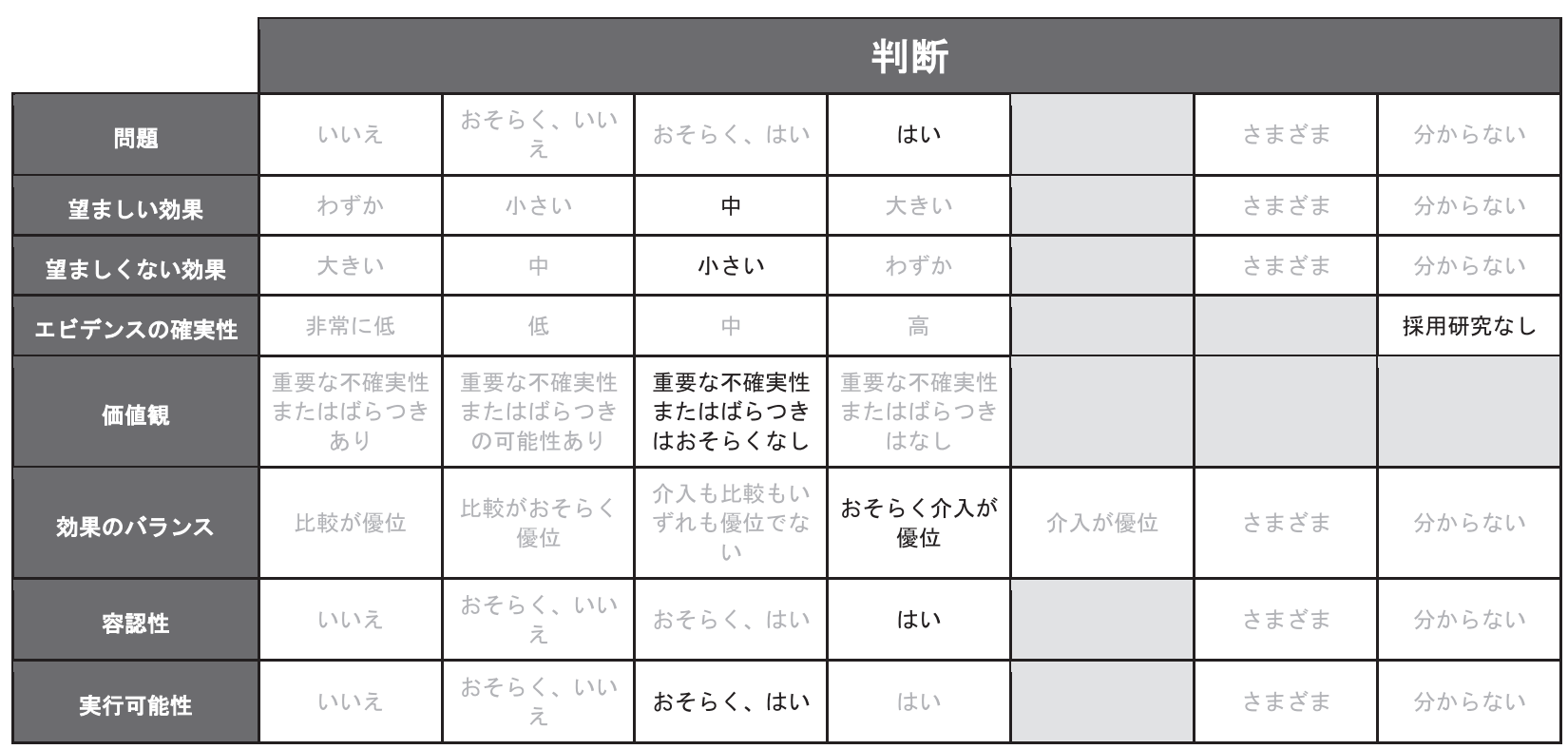




\section{CQ8-3：敗血症に対して新鮮凍結血漿の投与は どのように行うか?}

Answer : 敗血症患者において, 出血傾向を認める, あるいは外科的・侵襲的処置を要するときには，PT・ APTT の延長（PT は INR 2.0 以上または活性值 30\% 以下，APTT は各医療機関における基準の上限の 2 倍 以上または活性值 $25 \%$ 以下）やフィブリノゲン值 $150 \mathrm{mg} / \mathrm{dL}$ 未満の場合に, 新鮮凍結血漿を投与するこ とを弱く推奨する（エキスパートコンセンサス：エビ デンス不十分)。

\section{（1）背景および本 CQ の重要度}

敗血症患者において凝固障害は高率に合併し，凝固 障害を合併した敗血症患者の予後は不良であるとの報 告がある 1)。敗血症患者において, 出血傾向がある, または外科的処置が必要な場合，凝固異常の改善を目 的として新鮮凍結血漿の投与が行われることがある。 しかし，観血的処置時を含めて，新鮮凍結血漿の有用 性は明らかではない2,3)。敗血症患者に対する凝固異 常の改善を目的とした新鮮凍結血漿の有効性，有害性 の評価は定まっておらず，臨床現場でもその投与判断 には多様性がある。以上により，本ガイドラインに取 り上げるべき重要臨床課題であると考える。

(2) PICO

$P$ (患者) : 敗血症患者

I（介入）：あらゆる新鮮凍結血漿の投与（投与開始 值，目標值，投与量，タイミングなどの制限はな い)

$\mathrm{C}$ (対照)：非介入

O (アウトカム ) : 病院死亡, ICU 滞在日数，感染性 合併症，輸血関連肺障害やアナフィラキシーなど を含むあらゆる重篤な副作用

（3）エビデンスの要約

システマティックレビューを行ったが，PICOに合 致するランダム化比較試験（RCT）は存在しなかっ た。

\section{（4）益と害のバランス}

望ましい効果 :

凝固障害に伴う出血症状や，凝固障害が存在する状 態で行う侵襲的介入に伴う出血は，臨床的に重要な問 題となることがある。これらへの対応と予防をするた めに新鮮凍結血漿の投与を行うことは，患者に益する
可能性が高いと考える。

望ましくない効果 :

出血傾向がなく外科的処置も要しない場合に，新鮮 凍結血漿を投与することの害は証明されていないが, 血液製剤投与に伴うアレルギーや感染症のリスクは高 まる。血液製剤投与に伴い循環への負荷, TRALI の 発症（新鮮凍結血漿による致死的 TRALI の頻度 1 : 2〜300,000 products）4）などの危険性がある。

益と害のバランス :

PICO に合致する RCT は存在せず益と害のバランス は不明であるが，患者の状態によってそのバランスは 異なると考えられる。少なくとも高度の凝固障害によ る出血症状を伴う場合や侵襲的介入による出血が予想 される場合は，新鮮凍結血漿の投与に伴う益が害を上 回るものと考えられる。

（5）アウトカム全般に関するエビデンスの確実性 システマティックレビューを行ったが，PICOに合 致する RCT は存在しなかった。

\section{（6）価值観}

死亡率が低下することは, 患者・家族は一般的に重 視すると考えられる。しかし，輸血に対する考え方は 個人により様々であり，宗教上などの理由により輸血 を拒む患者・家族もいる。

\section{（7）容認性}

新鮮凍結血漿の投与のためには，施設と地域の体制 整備が必要である。また，血液型判定や投与までの管 理など，医療従事者の仕事量が増加することが予想さ れるが，その影響は小さいと考えられる。また，新鮮 凍結血漿製剂は，約 9,000 円/血液 $200 \mathrm{~mL}$ 相当に由来 する血漿 $(120 \mathrm{~mL})$ である。出血傾向がなく外科的処 置も要しない場合に，新鮮凍結血漿を投与することに より医療コストが増加する。

\section{（8）実行可能性}

新鮮凍結血漿は供給体制の整備が必要であるが，ほ ぼすべての集中治療室において利用可能であると考え られる。しかし, 夜間・休日の緊急輸血が困難な医療 機関や地域もある。また，実施に際しては献血由来で あることを考慮する必要がある。

(9) 判断の要約（Table 8-3-1） 
日本版敗血症診療ガイドライン 2020

Table 8-3-1 判断の要約

\begin{tabular}{|c|c|c|c|c|c|c|c|}
\hline & \multicolumn{7}{|c|}{ 判溇 } \\
\hline 問題 & いいえ & $\begin{array}{c}\text { おそらく、いい } \\
\text { え }\end{array}$ & おそらく、はい & はい & & さまざま & 分からない \\
\hline 望ましい勃果 & わずか & 小さい & 中 & 大きい & & さまざま & 分からない \\
\hline 望ましくない効果 & 大きい & 中 & 小さい & わずか & & さまざま & 分からない \\
\hline エビデンスの確実性 & 非常に低 & 低 & 中 & 高 & & & 採用研究なし \\
\hline 価值覞 & $\begin{array}{c}\text { 重要な不確実性 } \\
\text { またはばらつき } \\
\text { あり }\end{array}$ & $\begin{array}{c}\text { 重要な不確実性 } \\
\text { またはばらつき } \\
\text { の可能性あり }\end{array}$ & $\begin{array}{l}\text { 重要な不確実性 } \\
\text { またはばらつき } \\
\text { はおそらくなし }\end{array}$ & $\begin{array}{c}\text { 重要な不確実性 } \\
\text { またはばらつき } \\
\text { はなし }\end{array}$ & & & \\
\hline 効果のバランス & 比較が優位 & $\begin{array}{c}\text { 比較がおそらく } \\
\text { 優位 }\end{array}$ & $\begin{array}{c}\text { 介入も比較もい } \\
\text { ずれも優位でな } \\
\text { い }\end{array}$ & $\begin{array}{c}\text { おそらく介入が } \\
\text { 優位 }\end{array}$ & 介入が優位 & さまざま & 分からない \\
\hline 容認性 & いいえ & $\begin{array}{c}\text { おそらく、いい } \\
\text { え }\end{array}$ & おそらく、はい & はい & & さまざま & 分からない \\
\hline 実行可能性 & いいえ & $\begin{array}{c}お そ ら く 、 い い ~ \\
\text { え }\end{array}$ & おそらく、はい & はい & & さまざま & 分からない \\
\hline
\end{tabular}

（10）推奨グレーディング決定の工程

修正 RAND 法を用いた投票によって，中央值 7, 見解不一致指数 0 の結果となり，委員会で採択された (7 点以上 : 75\%)。

\section{（11）関連する他の診療ガイドラインにおける推奨}

日本版敗血症診療ガイドライン（J-SSCG）2016で は，CQ9-2において「出血傾向がなく外科的処置も要 しない場合，凝固異常值を補正する目的では新鮮凍結 血漿の投与は行わないことを弱く推奨する（エキス パートコンセンサス/エビデンスなし)」を示し，不随 するコメントとして，「出血傾向が出現した場合また は外科的処置が必要な場合は，本邦の血液製剤の使用 指針に沿って新鮮凍結血漿の投与を考慮する」と記載 されている5-7)。

SSCG 2016 では,「We suggest against the use of fresh frozen plasma to correct clotting abnormalities in the absence of bleeding or planned invasive procedures (weak recommendation, very low quality of evidence).」の記載 がある ${ }^{8)}$ 。

\section{（12）実施に関わる検討事項}

凝固障害の重症度とこれに伴う症状の重篤度によ

り，新鮮凍結血漿の投与による益と害のバランスが異 なる可能性がある。

\section{（13）今後の研究の可能性}

敗血症患者に対する，新鮮凍結血漿の投与に関する 有効性を評価した RCT がないことが明らかとなり，
新鮮凍結血漿が死亡率に与える影響や，出血症状への 影響，有害事象などを検証する RCT の早期実施が望 まれる。

\section{文 献}

1) Lyons PG, Micek ST, Hampton N, et al: Sepsis-associated coagulopathy severity predicts hospital mortality. Crit Care Med. 2018; 46: 736-42.

2) Yang L, Stanworth $S$, Hopewell $S$, et al: Is fresh-frozen plasma clinically effective? An update of a systematic review of randomized controlled trials (CME). Transfusion. 2012; 52: 1673-86.

3) Murad MH, Stubbs JR, Gandhi MJ, et al: The effect of plasma transfusion on morbidity and mortality: A systematic review and meta-analysis. Transfusion. 2010; 50: 1370-83.

4) Shaz BH, Stowell SR, Hillyer CD: Transfusion-related acute lung injury: From bedside to bench and back. Blood. 2011; 117: 1463-71.

5）西田修, 小倉裕司, 井上茂亮, 他, 日本版敗血症診療ガイドラ イン 2016 作成特別委員会. 日本版敗血症診療ガイドライン 2016. 日集中医誌. 2017; 24: S1-232.

6）西田修, 小倉裕司, 井上茂亮, 他, 日本版敗血症診療ガイドラ イン 2016 作成特別委員会. 日本版敗血症診療ガイドライン 2016. 日救急医会誌. 2017; 28: S1-232.

7）厚生労衝省医薬 ·生活衛生局: 血液製剂の使用指針. 2017.

8) Rhodes A, Evans LE, Alhazzani W, et al: Surviving Sepsis Campaign: International Guidelines for Management of Sepsis and Septic Shock: 2016. Intensive Care Med. 2017; 43: 304-77. 


\section{CQ8-4：敗血症に対して血小板輸血はどのよう} に行うか?

Answer：血小板数 1 万/ $\mu \mathrm{L}$ 未満，あるいは出血症状 を伴う血小板数 5 万 $/ \mu \mathrm{L}$ 未満の敗血症患者に対して, 血小板輸血を行うことを弱く推奨する（エキスパート コンセンサス：エビデンス不十分）。活動性出血を認 める, あるいは外科的・侵襲的処置を要するときに は, 血小板数 5 万/ $\mu \mathrm{L}$ 以上を維持するように血小板輸 血を行うことを弱く推奨する（エキスパートコンセン サス : エビデンス不十分)。

\section{（1）背景および本 $C Q$ の重要度}

血小板減少は敗血症患者に高率に合併し，SOFA ス コアにも含まれる臓器障害の 1 つである。血小板低下 を呈した敗血症患者は, ショック, 急性腎障害, 出血 性有害イベントの合併が高率であり，予後は不良であ るとの報告がある 1,2$)$ 。本邦における敗血症患者を対 象とした前向き研究においても，血小板減少（＜

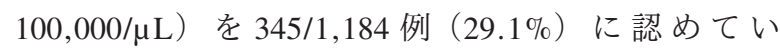
る3）。一方，血小板を投与することによる害としては， TRALI な゙の危険性がある（血小板による致死的 TRALI の頻度 $1: 3 \sim 400,000$ products) ${ }^{4)}$ 。

本邦では, 出血傾向がある, または血小板減少を伴 い外科的処置が必要な敗血症患者に対して血小板の投 与が行われていることが多いが，その有用性は明らか ではない。以上より，敗血症患者に対する血小板輸血 は本ガイドラインに取り上げるべき重要な臨床課題で あると思われる。

血小板輸血の開始基準，目標値と共に，その有効 性，有害性の評価は定まっておらず，血小板輸血に関 する本 CQ の優先度は高いと考える。

\section{(2) PICO}

$P$ (患者)：敗血症患者

I (介入) : あらゆる血小板輸血（投与開始值, 目標 值，投与量，タイミングなどの制限はない）

$\mathrm{C}$ (対照)：非介入

O (アウトカム ) : 病院死亡, ICU 滞在日数, 感染性 合併症, 輸血関連肺障害やアナフィラキシーなど を含むあらゆる重篤な副作用

\section{（3）エビデンスの要約}

システマティックレビューを行ったが PICO に合致 するランダム化比較試験（RCT）は存在しなかった。

\section{(4) 益と害のバランス}

望ましい効果 :

血小板減少に伴う出血症状や血小板減少時における 侵襲的介入に伴う出血は, 臨床的に重大な問題となる ことがある。これらへの対応と予防をするために血小 板輸血を行うことは, 患者に益する可能性が高いと考 える。

望ましくない効果 :

出血傾向がなく外科的処置も要しない場合に, 血小 板輸血をすることの害は証明されていないが，血液製 剂投与に伴うアレルギーや感染症のリスクは高まる。 他の血液製剤と異なり，室温 $\left(20 \sim 24^{\circ} \mathrm{C}\right)$ で保存され ており, 細菌混入による感染症などに留意する必要が ある。また, 血液製剤投与に伴う循環への負荷, TRALI（血小板による致死的 TRALI の頻度 ; $1: 3 \sim$ 400,000 products）4）などの危険性がある。

\section{益と害のバランス :}

PICO に合致する RCT は存在せず不明であるが，患 者の状態によってそのバランスは異なると考えられ る。少なくとも高度血小板数低下による出血症状を伴 う場合や侵襲的介入による出血が予想される場合は, 血小板輸血に伴う益が害を上回るものと考えられる。

（5）アウトカム全般に関するエビデンスの確実性

システマティックレビューを行ったが，PICO に合 致する RCT は存在しなかった。

\section{（6）価値観}

死亡率が低下することは，患者・家族は一般的に重 視すると考えられる。しかし，輸血に対する考え方は 個人により様々であり, 宗教上などの理由により輸血 を拒む患者・家族もいる。

\section{（7）容認性}

血小板輸血のためには, 施設と地域の体制整備が必 要である。また，血液型判定や交差適合試験，投与ま での管理など, 医療従事者の仕事量が増加することが 予想されるが，その影響は小さいと考えられる。ま た，血小板製剤は約 80,000 円/10 単位（200mL）であ る。出血傾向がなく外科的処置も要しない場合に, 血 小板を投与することにより医療コストが増加する。

\section{（8）実行可能性}

血小板輸血には供給体制の整備が必要であるが，ほ ぼすべての集中治療室において利用可能であると考え られる。しかし, 夜間・休日の緊急輸血が困難な医療 
機関や地域もある。また，実施に際しては献血由来で あるとともに，使用期限が短期間の限られた製剤であ ることを考慮する必要がある。

\section{（9）判断の要約（Table 8-4-1）}

\section{（10）推奨グレーディング決定の工程}

修正 RAND 法を用いた投票によって，中央值 8, 見解不一致指数 0.164 の結果となり, 委員会で採択さ れた（7点以上 : 83.3\%)。

\section{（11）関連する他の診療ガイドラインにおける推奨}

SSCG 2016 5) では，敗血症患者において，血小板 投与は明らかな出血がない場合は 1 万/ $\mu \mathrm{L}$ 未満，深刻 な出血のリスクがある場合は 2 万/ $\mu \mathrm{L}$ 未満であれば予 防的投与を行うことが提案されている。また，活動性 の出血がある手術や侵襲的な処置をする場合は 5 万/ $/ \mathrm{LL}$ 以上にすることが提案されている（弱い推 奨/非常に低いエビデンスレベル)。

日本版敗血症診療ガイドライン（J-SSCG）2016 ${ }^{6,7}$ では，本邦の血液製剂の使用指針（平成 28 年一部改 正版） ${ }^{8)}$ に記されている “出血傾向の強く現れる可能 性のある DIC（基礎疾患が白血病，癌，産科的疾患， 重症感染症など）で，血小板数が急速に 5 万/ $\mu \mathrm{L}$ 未満 へと低下し，出血症状を認める場合には，血小板輸血 の適応（血栓による臟器症状が強く現れる DICでは, 血小板輸血には慎重であるべきである)”を引用し， “出血傾向が出現した場合または外科的処置が必要な 場合は，本邦の血液製剤の使用指針に沿って血小板輸
血を行うことを弱く推奨する（エキスパートコンセン サス/エビデンスなし)”としている。

\section{（12）実施に関わる検討事項}

血小板減少の重症度とこれに伴う症状の重篤度によ り，血小板輸血による益と害のバランスが異なる可能 性がある。

\section{（13）今後の研究の可能性}

血小板輸血の有効性を評価する敗血症患者に関する RCT がないことが明らかとなり，血小板輸血が死亡 率に与える影響, 出血症状への影響, 有害事象などを 検証する RCT の早期実施が望まれる。

\section{文 献}

1) Anderson R, Feldman C: Review manuscript: Mechanisms of platelet activation by the pneumococcus and the role of platelets in community-acquired pneumonia. J Infect. 2017; 75: 473-85.

2) Chen M, Zuo X, Tan Y, et al: Six amino acids of VP1 switch along with pandemic of CV-A6-associated HFMD in Guangxi, southern China, 2010-2017. J Infect. 2019; 78: 323-37.

3) Abe T, Ogura H, Shiraishi A, et al: Characteristics, management, and in-hospital mortality among patients with severe sepsis in intensive care units in Japan: The FORECAST study. Crit Care. 2018; 22: 322.

4) Shaz BH, Stowell SR, Hillyer CD: Transfusion-related acute lung injury: From bedside to bench and back. Blood. 2011; 117: 1463-71.

5) Rhodes A, Evans LE, Alhazzani W, et al: Surviving Sepsis Campaign: International Guidelines for Management of Sepsis and Septic Shock: 2016. Intensive Care Med. 2017; 43: 304-77.

6）西田修, 小倉裕司, 井上茂亮, 他, 日本版敗血症診療ガイドラ イン 2016 作成特別委員会. 日本版敗血症診療ガイドライン 2016. 日集中医誌. 2017; 24: S1-232.

7）西田修, 小倉裕司, 井上茂亮, 他, 日本版敗血症診療ガイドラ イン 2016 作成特別委員会. 日本版敗血症診療ガイドライン

Table 8-4-1 判断の要約

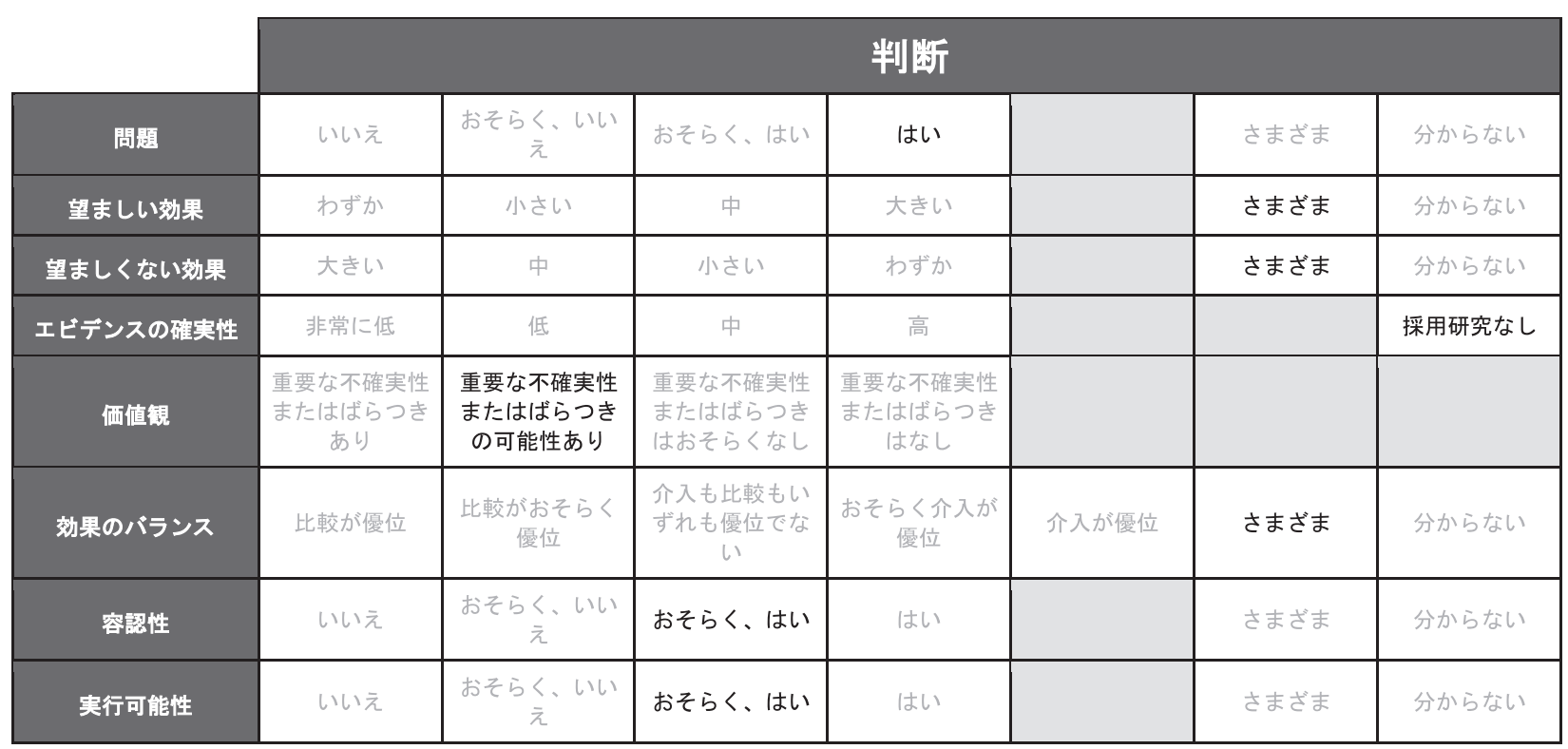




\section{日集中医誌 J Jpn Soc Intensive Care Med Vol. 28 Suppl}

2016. 日救急医会誌. 2017; 28: S1-232.

8）厚生労衝省医薬・生活衛生局: 血液製剂の使用指針. 2017. 


\section{CQ9：呼吸管理}

敗血症は急性呼吸窮迫症候群 (acute respiratory distress syndrome: ARDS）を発症する主因の 1 つであ り，敗血症による呼吸不全の多くはARDS の発症メ カニズムによって引き起こされると考えられる1)。新 たな定義である Sepsis-3 での敗血症患者を母集団とし た呼吸不全やARDS の発症率など疫学的データを正 確に把握するには至っていないが，本邦においては Sepsis-2 で診断された 1,184 例の重症敗血症患者のう ち集中治療室入室初日に ARDS と診断されたのは 193 例（18\%）であり2)，米国の施設で 2015２017 年に 集中治療室に入室し ICD-10 で敗血症と診断された 1,641 例のうち人工呼吸療法を受けたのは 657 例 (40\%) であった ${ }^{3)}$ 。今後は, Sepsis-3 の定義に基づい た臓器不全の程度に従った死亡率のデータが示され, 敗血症患者の呼吸不全においても重症度ごとの予後が 示されることが期待される。

敗血症においては代謝がえ進し高熱を生じて酸素需 要が高まっている状況にあるため, 単純無気肺などに よる低酸素性の呼吸不全と異なり, 呼吸だけでなく循 環にも大きな負担が生じる。したがって, 敗血症患者 の呼吸管理においても循環不全の状態に常に配慮しな がら個々の治療選択をしていかなければならない。こ れは, 人工呼吸療法における陽圧換気や高すぎる PEEP の設定が循環抑制の原因となりうることと大い に関係しており, 循環が不安定になりやすい敗血症患 者の全身管理においては常に注意を要する点である。

CQ9 呼吸管理においては, 敗血症診療における酸 素療法から人工呼吸療法まで幅広く, 呼吸管理に関す る科学的知見の検討を行った。日本版敗血症診療ガイ ドライン（J-SSCG）2016では, 本邦の 3 学会が合同 で作成した「ARDS 診療ガイドライン 2016」から, 人工呼吸管理を対象とした肺保護換気戦略に関する CQ4つをそのまま抜粋したが，今回の J-SSCG 2020 では CQ9 の診療フローに示したように，一般臨床医 が治療を進めるうえで重要と考えられる呼吸管理の $\mathrm{CQ}$ を敗血症診療の見地から新たに設定し推奨を提示 した。

生体の恒常性を維持するためには, 全身の細胞への 酸素供給が必要十分になされなければならないが，急 性期の重症患者におけるいくつかの病態では, 過剰な 酸素投与が弊害となる危険性が指摘されている4)。敗 血症診療においても, 酸素療法や人工呼吸療法での最 適な目標 $\mathrm{SpO}_{2}$ や $\mathrm{PaO}_{2}$ などの指標が示されれば理想 的な呼吸管理が可能となるが，未だ確固たるエビデン
スは示されていない。敗血症患者においても，低酸素 血症が持続することは好ましくなく, 早急に改善さ せ，避けるべき病態と考えられるが，日常臨床におい て過剰な酸素投与の弊害に注意すべきかどうか，未だ 不明である。そこで，「成人敗血症患者の呼吸管理に おいて, 目標 $\mathrm{SpO}_{2}$ をどの範囲にするか?」という CQ9-1 を提示した。

呼吸不全の初期においては低酸素血症を回避するた め酸素投与が開始されるが, 病状の悪化に伴って酸素 の必要量は低流量から高流量へと移行し, 酸素投与で 不十分となれば，陽圧を用いる非侵襲的人工呼吸 (noninvasive ventilation: NIV) が選択されうる。NIV は, 呼吸障害による負担を軽減するだけでなく，心原 性肺水腫への適用のように，同時に心臓への負担も軽 減しうる有効な呼吸循環の治療法として, 昨今まで多 くの臨床研究がなされ, 有効な病態, 適応から注意点 まで, その方法論が確立されてきた5)。加えて最近で は, 死腔洗い出し効果や二次的な PEEP 効果が期待さ れる高流量鼻カニューレを用いた経鼻高流量療法 （nasal high-flow therapy: NHFT）も呼吸管理の選択肢 の 1 つとして注目されている6,7)。そのため, CQ9-2 として「成人敗血症患者の初期の呼吸不全に対して, 非侵襲的人工呼吸（NIV）または経鼻高流量療法 （NHFT）を行うか?」という疑問を重要課題として 提示し，ネットワークメタ解析 (network metaanalysis: NMA）の手法を用いて推奨提示を行った。

敗血症に伴う急性呼吸不全に対して酸素療法やNIV で限界となれば，気管挿管を用いた侵襲的人工呼吸が 選択される。この際には, 陽圧換気によって生じうる 人工呼吸器関連肺傷害 $\left.{ }^{8}\right)$ や患者の自発呼吸による強 い吸気陰圧で惹起される肺傷害である P-SILI（patient self-inflicted lung injury) 9，10）を最小限にするような呼 吸管理が重要と考えられている。肺保護換気と PEEP の選択に関しては, 多くの臨床医が関心をもっている テーマであるため, CQ9-3 として「成人敗血症患者の 人工呼吸管理において, 肺保護換気戦略を行うか? 」, CQ9-4 として「成人敗血症患者の人工呼吸管理におい て, 高 PEEP 設定を行うか?」といった2つの CQを 重要課題として挙げた。

敗血症治療が奏効すれば, 生体における酸素需要は 低下し, 同時に肺傷害も軽減してくるため, 呼吸状態 が改善に転じる。人工呼吸からの離脱を試みる際に, どのように設定変更を行い，どのような基準で離脱可 能と判断すべきか, という臨床疑問に対する明確な答 えはない。人工呼吸を離脱可能かどうか判断する手法 の 1 つとして自発呼吸トライアル (spontaneous 
breathing trial: SBT）があり ${ }^{11)}$, SBTを含めて離脱の プロセスをプロトコル化するのか，それともプロトコ ル化しないのかを比較検討することには，臨床判断と しては大いに意義がある12）そこで，CQ9-5 として 「人工呼吸管理となった成人敗血症患者に対して，抜 管前に自発呼吸トライアル（SBT）を行うか？」を重 要課題として挙げた。一方, 抜管を安全に成功させ, 再插管を回避するためには, 抜管後の気道クリアラン ス能力を予測したり ${ }^{13)}$ ，人工気道が取り除かれた後 の気道開通性を予測するカフリークテストによる評価 をしたり14）といったプロセスも無視できず，陽圧換 気による呼吸サポートの必要性の評価と合わせて, 気
道開通性の評価も同時に行っていくことが重要であ る。

抜管後の再扦管は患者の臨床転帰を悪化させること が報告されているため, 抜管後の呼吸不全の発生や再 挿管を減らせることができる呼吸管理にはどのような ものがあるのかが考慮されるが，その代表が抜管後の 呼吸管理としての予防的 NIV ${ }^{15 ）}$ と予防的 NHFT ${ }^{16)}$ となる。そこで, CQ9-6 として「人工呼吸管理となっ た成人敗血症患者に対して，抜管後に予防的な非侵襲 的人工呼吸（NIV）または経鼻高流量療法（NHFT） を行うか?」という疑問を重要課題として提示し, NMA の手法を用いて推奨提示を行った。

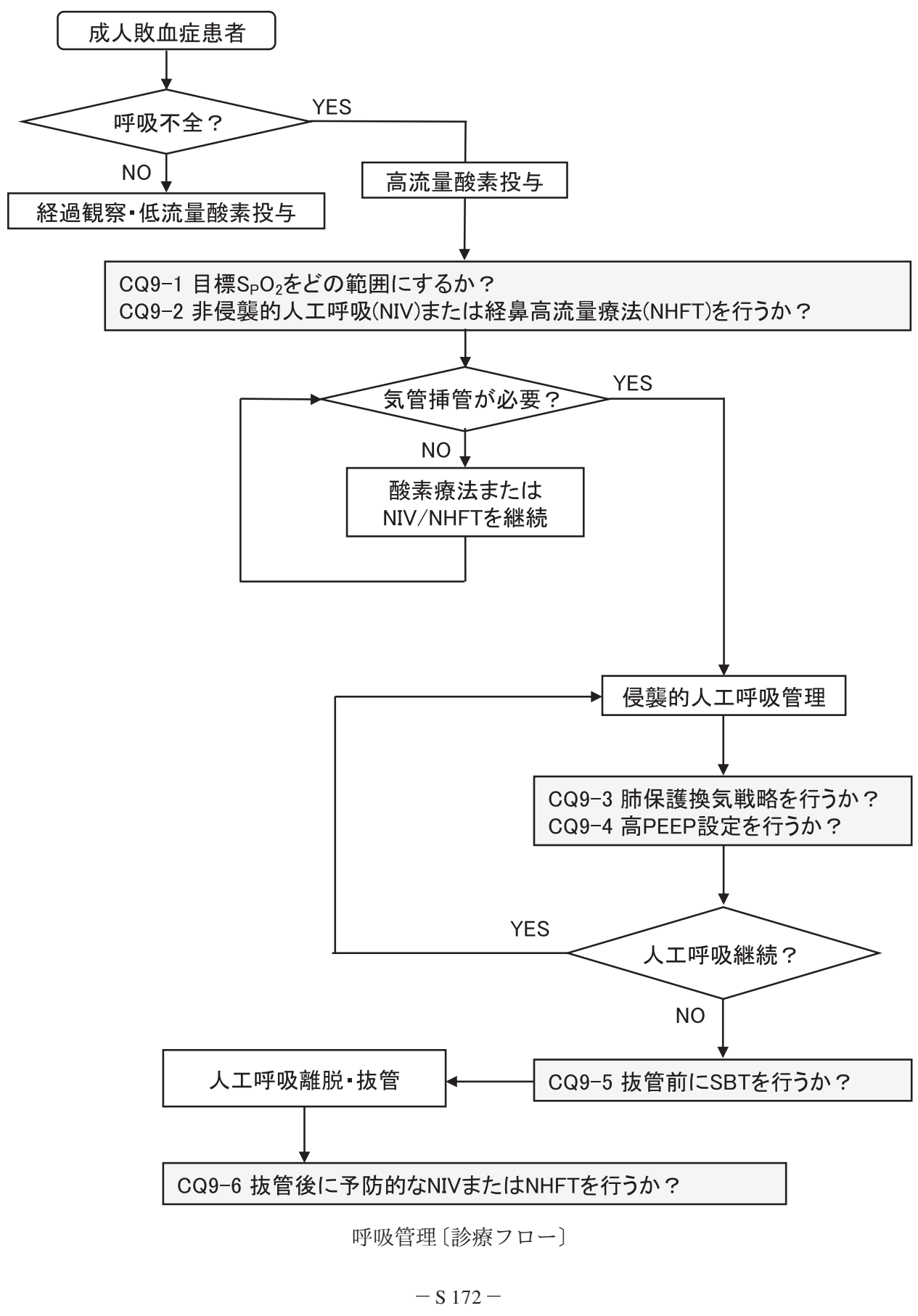




\section{人工呼吸器の設定以外での治療オプションについて} も，呼吸管理班による議論の未にいくつかの臨床疑問 が提案され，その中には，肺胞リクルートメント手技 を行うか，筋弛緩薬を用いるか，腹臥位療法を行う か，低用量ステロイド投与を行うか，輸液制限を行う か, の 5 つが挙げられていた。しかしながら，これら の治療オプションは敗血症患者の呼吸管理に特異的な ものばかりではなく，ARDS 患者を対象とした研究が ほとんどであるため, 委員会での議論の結果, 本ガイ ドラインで検討する CQ からは割愛することとした。 本邦において改訂が予定されている ARDS 診療ガイ ドラインの中で検討される項目と想定されており，今 後の進捗に期待がもたれる。その他にも, 早期リハビ リテーションの効果, 気管切開のタイミング, ECMO (extracorporeal membrane oxygenation) の効果なども, 臨床医が興味を抱く重要な臨床疑問であると考えられ る。

\section{文 献}

1) Fan E, Brodie D, Slutsky AS: Acute Respiratory Distress Syndrome: Advances in Diagnosis and Treatment. JAMA. 2018; 319: 698-710

2) Abe T, Ogura H, Shiraishi A, et al: Characteristics, management, and in-hospital mortality among patients with severe sepsis in intensive care units in Japan: the FORECAST study. Crit Care. 2018; 22: 322.

3) Brown RM, Wang L, Coston TD, et al: Balanced Crystalloids versus Saline in Sepsis. A Secondary Analysis of the SMART Clinical Trial. Am J Respir Crit Care Med. 2019; 200: 1487-95.

4) Chu DK, Kim LHY, Young PJ, et al: Mortality and Morbidity in Acutely Ill Adults Treated with Liberal Versus Conservative Oxygen Therapy (IOTA): A Systematic Review and Meta-Analysis. Lancet. 2018; 391: 1693-705.

5) MacIntyre NR: Physiologic Effects of Noninvasive Ventilation. Respir Care. 2019; 64: 617-28.

6) Drake MG: High-Flow Nasal Cannula Oxygen in Adults: An Evidence-based Assessment. Ann Am Thorac Soc. 2018; 15: 145-55.

7) Ischaki E, Pantazopoulos I, Zakynthinos S: Nasal High Flow Therapy: A Novel Treatment Rather Than a More Expensive Oxygen Device. Eur Respir Rev. 2017; 26: 170028.

8) Curley GF, Laffey JG, Zhang H, et al: Biotrauma and VentilatorInduced Lung Injury: Clinical Implications. Chest. 2016; 150: 1109-17.

9) Yoshida T, Amato MBP, Kavanagh BP, et al: Impact of spontaneous breathing during mechanical ventilation in acute respiratory distress syndrome. Curr Opin Crit Care. 2019; 25: 192-8.

10) Spinelli E, Mauri T, Beitler JR, et al: Respiratory drive in the acute respiratory distress syndrome: pathophysiology, monitoring, and therapeutic interventions. Intensive Care Med. 2020; 46: 606-18.

11) Pellegrini JA, Moraes RB, Maccari JG, et al: Spontaneous Breathing Trials With T-Piece or Pressure Support Ventilation. Respir Care. 2016; 61: 1693-703.

12) Wielenga JM, van den Hoogen A, van Zanten HA, et al: Protocolized versus non-protocolized weaning for reducing the duration of invasive mechanical ventilation in newborn infants.
Cochrane Database Syst Rev. 2016; 3: CD011106.

13) Jiang C, Esquinas A, Mina B: Evaluation of cough peak expiratory flow as a predictor of successful mechanical ventilation discontinuation: a narrative review of the literature. J Intensive Care. 2017; 5: 33

14) Ochoa ME, Marín Mdel C, Frutos-Vivar F, et al: Cuff-leak test for the diagnosis of upper airway obstruction in adults: a systematic review and meta-analysis. Intensive Care Med. 2009; 35: 1171-9.

15) Hess DR: The role of noninvasive ventilation in the ventilator discontinuation process. Respir Care. 2012; 57: 1619-25.

16) Ni YN, Luo J, Yu H, et al: Can high-flow nasal cannula reduce the rate of reintubation in adult patients after extubation? A metaanalysis. BMC Pulm Med. 2017; 17: 142. 
CQ9-1：成人敗血症患者の呼吸管理において, 目標 $\mathrm{SpO}_{2}$ をどの範囲にするか?

Answer : 成人敗血症患者の呼吸管理において, 目標 $\mathrm{SpO}_{2}$ を高め（98～100\%）に設定しないことを弱く推 奨する（GRADE 2B：エビデンスの確実性＝「中」）。 コメント : 循環動態が安定していない場合, 重度の貧 血，あるいは感染症による代謝六進などで酸素需給バ ランスが崩れている可能性が存在する状況ではこの限 りではない。

\section{（1）背景および本 $C Q$ の重要度}

成人敗血症患者では高率に呼吸不全を発症してお り，時にARDS 乞と進展し，酸素療法はもちろんの こと人工呼吸管理をも必要とすることが少なくない。 心筋梗塞や脳卒中では高濃度の酸素投与に否定的な研 究成果が集積されてきているが，敗血症における至適 な動脈血酸素飽和度については明確にされていない。 敗血症患者の転帰が最善となる酸素療法の指標を探求 することは重要な臨床課題となりうる。

\section{(2) PICO}

$\mathrm{P}$ (患者) : 成人敗血症患者

I（介入）：目標 $\mathrm{SpO}_{2}$ を高めに設定する

$\mathrm{C}$ (対照)：目標 $\mathrm{SpO}_{2}$ を低めに設定する

$\mathrm{O}$ (アウトカム) : 死亡, 臟器障害, 感染

\section{（3）エビデンスの要約}

システマティックレビューにおいては,「酸素投与 を必要とする重症患者」を対象として論文検索が行わ れた。その結果，PICOに合致したランダム化比較試
験（RCT）が過去に 3 件 1-3）施行されており, これら 3 編を用いたメ夕解析を実施した。これらの研究にお ける治療方針は敗血症と大きな違いがないことから, エビデンスプロファイルにおける非直接性の評価では すべてのアウトカムにおいて「深刻ではない」と判断 した。

（4）益と害のバランス（Table 9-1-1）

望ましい効果 :

目標 $\mathrm{SpO}_{2}$ を高めに設定することで，呼吸状態の悪 化時や気管吸引の際などにおける低酸素の程度や頻度 を少なくできるかもしれないが，そのようなアウトカ ムを検討した報告はないため「分からない」とした。 望ましくない効果 :

短期死亡（3 RCT, $\mathrm{n}=673$ ）に関する効果推定値 は，目標 $\mathrm{SpO}_{2}$ を高めに設定することによりリスク差 （RD） 1,000 人あたり 42 人多い $(95 \% \mathrm{CI}: 38$ 人少ない 〜156人多い）と示されている。また，高い $\mathrm{SpO}_{2}$ を 目標とすることは，低い $\mathrm{SpO}_{2}$ を目標とすることに比 べて, 臟器障害 $(1 \mathrm{RCT}, \mathrm{n}=434)$ に関する効果推 定值は RD 1,000 人あたり 66 人多い $(95 \%$ CI: 11 人少 ない 175 人多い), 感染症発生 $(1 \mathrm{RCT}, \mathrm{n}=434)$ に関する効果推定值は RD 1,000 人あたり 49 人多 い( $95 \%$ CI: 22 人少ない 153 人多い) と示されてい る。望ましくない効果は「中」と考えられた。エビデ ンスの確実性はいずれのアウトカムでも「中」であっ た。

益と害のバランス :

検討したすべてのアウトカムについて，介入（目標 $\mathrm{SpO}_{2}$ を高めに設定する）を支持しない方向であった ので，「比較（目標 $\mathrm{SpO}_{2}$ を低めに設定する）がおそ

Table 9-1-1 エビデンスプロファイル（メタ解析）

\begin{tabular}{|c|c|c|c|c|c|c|c|c|c|c|c|c|}
\hline \multicolumn{7}{|c|}{ 碓実性の評価 } & \multicolumn{2}{|c|}{ 患者数 } & \multicolumn{2}{|c|}{ 効果 } & \multirow[b]{2}{*}{ 碓実性 } & \multirow[b]{2}{*}{ 重要性 } \\
\hline 研究数 & $\begin{array}{l}\text { 研究 } \\
\text { テザイン }\end{array}$ & $\begin{array}{l}\text { バイアス } \\
\text { のリスク }\end{array}$ & 非一貫性 & 非直接性 & 不精䂠性 & $\begin{array}{l}\text { その他 } \\
\text { の檢討 }\end{array}$ & 目標 $\mathrm{SpO}_{2}$ 高め & 目標 $\mathrm{SpO}_{2}$ 低め & $\begin{array}{l}\text { 相対指摽 } \\
(95 \% \text { CI) }\end{array}$ & $\begin{array}{l}\text { 䋓対指搮 } \\
(95 \% \text { CI }\end{array}$ & & \\
\hline \multicolumn{13}{|l|}{ 死亡 } \\
\hline 3 & RCT & 深刻でない & 深刻でない & 深刻でない a & 深刻 b & なし & $\begin{array}{l}94 / 337 \\
(27.9 \%)\end{array}$ & $75 / 336(22.3 \%)$ & $\begin{array}{l}\text { RR } 1.19 \\
(0.83 \text { to } \\
1.70)\end{array}$ & $\begin{array}{l}\text { 1,000人あたり } \\
42 \text { 人多い } 38 \text { } \\
\text { 少ない } 156 \text { 人 } \\
\text { 多い) }\end{array}$ & $\underset{\text { 中 }}{\oplus \oplus \oplus \bigcirc}$ & 重大 \\
\hline \multicolumn{13}{|c|}{ 臓器障害 } \\
\hline 1 & RCT & 深刻でない & 深刻でない & 深刻でない a & 深刻 b & なし & $\begin{array}{l}56 / 218 \\
(25.7 \%)\end{array}$ & $41 / 216 \quad(19.0 \%)$ & $\begin{array}{l}\text { RR } 1.35 \\
(0.94 \text { to } \\
1.92)\end{array}$ & $\begin{array}{c}\text { 1,000人あたり } \\
66 \text { 人多い (11 } \\
\text { 少ない 175人多 } \\
\text { (1) }\end{array}$ & $\underset{\text { 中 }}{\oplus \oplus \oplus \bigcirc}$ & 重大 \\
\hline \multicolumn{13}{|l|}{ 感染 } \\
\hline 1 & RCT & 深刻でない & 深刻でい & 深刻でない & 深刻 b & なし & $\begin{array}{l}50 / 218 \\
(22.9 \%)\end{array}$ & $39 / 216 \quad(18.1 \%)$ & $\begin{array}{l}\text { RR } 1.27 \\
(0.88 \text { to } \\
1.85)\end{array}$ & $\begin{array}{c}1,000 \text { 人あたり } \\
49 \text { 人多い (22人 } \\
\text { 少ない 153人多 } \\
\text { い) }\end{array}$ & $\underset{\text { 中 }}{\oplus \oplus \oplus \bigcirc}$ & 重大 \\
\hline
\end{tabular}

a. CQ とシステマティックレビュ一の対象疾患が同一ではないが，治療方針が同様であるため深刻でないとした。 b. 閾值を相対リスク比 $25 \%$ と設定した場合，信頼区間における下限が臨床決断の閾值をまたぐと判断する。 
らく優位」と判断した。

くシステマティックレビュー期間後に発表された論文 について〉

本 CQ のテーマは最近のホットトピックスであるた め, システマティックレビュー期間後にもいくつかの 研究結果が報告されていた。今回のシステマティック レビュー期間後から 2020 年 2 月までに発表された論 文を，本システマティックレビューで使用された検索 式を用いて PubMed で簡易スクリーニングを施行した ところ，3 編の論文が確認された。そのうちの 1 つは もう 1 つの大規模研究の post hoc study であったため, これを除いた 2 編 4 , 5) の研究内容が今回のシステマ ティックレビューにどの程度の影響を与えるか追加で 検討した。計 5 編のメタ解析を施行したところ, 高い $\mathrm{SpO}_{2}$ を目標とすることにより, 短期死亡（5 RCT, $\mathrm{n}=1,833)$ に関する効果推定值は, RD 1,000 人あた り 12 人少ない $(95 \% \mathrm{CI}: 81$ 人少ない〜 81 人多い), 臓 器障害（3 RCT, $\mathrm{n}=1,600 ）$ に関しては RD 1,000人 あたり 12 人多い $(95 \% \mathrm{CI}: 51$ 人少ない〜102 人多い), 感染症発生（2 RCT, $\mathrm{n}=635 ）$ に関しては RD 1,000 人あたり 48 人多い $(95 \% \mathrm{CI}: 12$ 人少ない〜 129 人多 い）という結果であった。高い $\mathrm{SpO}_{2}$ を目標とするこ とで短期死亡は若干少なくなる傾向であったが，臓器 障害と感染症発生に関してはもとのシステマティック レビューの結果と同様に増加する傾向が見受けられ た。以上より, 最近の研究結果を含めて益と害を検討 したとしても，本 CQ に対する推奨が大きく変わるこ とにはならないと判断した。
（5）アウトカム全般に関するエビデンスの確実性 エビデンスの確実性はすべてのアウトカムについて 「中」であった。

\section{（6）価値観}

敗血症患者の目標 $\mathrm{SpO}_{2}$ においては, 各アウトカム に置く患者や家族の価值観に関するデータはない。一 般的に, 死亡アウトカムに対する相対的価值は高く, そのばらつきは少ないことが予想される

\section{（7）容認性}

$\mathrm{SpO}_{2}$ を低めに管理することは多くの医療者に受け 入れ可能と考えられるが, 突然の気道トラブルや循環 変動を理由に $\mathrm{SpO}_{2}$ を低く管理することに対して拒否 的な意見が出るかもしれない。また, 酸素流量や $\mathrm{F}_{\mathrm{I}} \mathrm{O}_{2}$ の調節のためにスタッフの仕事量が若干増える かもしれない。酸素使用量が節約されるため酸素にか かるコストは減るであろう。アラームを適切に設定し ながら $\mathrm{SpO}_{2}$ 低下に対処することで，患者や家族の受 け入れへの影響は最小限であると考えられる。

\section{（8）実行可能性}

$\mathrm{SpO}_{2}$ を低めに管理することは, 吸入気酸素濃度や 投与酸素流量を微調整することにより施行可能であ る。

（9）判断の要約（Table 9-1-2）

Table 9-1-2 判断の要約

\begin{tabular}{|c|c|c|c|c|c|c|c|}
\hline & \multicolumn{7}{|c|}{ 判断 } \\
\hline 問題 & いいえ & $\begin{array}{c}\text { おそらく、いい } \\
\text { え }\end{array}$ & おそらく、はい & はい & & さまざま & 分からない \\
\hline 望ましい勃果 & わずか & 小さい & 中 & 大きい & & さまざま & 分からない \\
\hline 望ましくない勃果 & 大きい & 中 & 小さい & わずか & & さまざま & 分からない \\
\hline エビデンスの確実性 & 非常に低 & 低 & 中 & 高 & & & 採用研究なし \\
\hline 価值锥 & $\begin{array}{c}\text { 重要な不確実性 } \\
\text { またはばらつき } \\
\text { あり }\end{array}$ & $\begin{array}{c}\text { 重要な不確実性 } \\
\text { またはばらつき } \\
\text { の可能性あり }\end{array}$ & $\begin{array}{l}\text { 重要な不確実性 } \\
\text { またはばらつき } \\
\text { はおそらくなし }\end{array}$ & $\begin{array}{c}\text { 重要な不確実性 } \\
\text { またはばらつき } \\
\text { はなし }\end{array}$ & & & \\
\hline 効果のパランス & 比較が優位 & $\begin{array}{c}\text { 比較がおそらく } \\
\text { 優位 }\end{array}$ & $\begin{array}{c}\text { 介入も比較もい } \\
\text { ずれも優位でな } \\
\text { い }\end{array}$ & $\begin{array}{c}\text { おそらく介入が } \\
\text { 優位 }\end{array}$ & 介入が優位 & さまざま & 分からない \\
\hline 容認性 & いいえ & $\begin{array}{c}\text { おそらく、いい } \\
\text { え }\end{array}$ & おそらく、はい & はい & & さまざま & 分からない \\
\hline 実行可能性 & いいえ & $\begin{array}{c}\text { おそらく、いい } \\
\text { え }\end{array}$ & おそらく、はい & はい & & さまざま & 分からない \\
\hline
\end{tabular}




\section{（10）推奨グレーディング決定の工程}

修正 RAND 法を用いた投票によって，中央值 7.0, 見解不一致指数 0.164 の結果となり, 委員会で採択さ れた（7 点以上 : $75.0 \%) 。$

\section{（11）関連する他の診療ガイドラインにおける推奨}

本 CQ と類似した成人敗血症患者を対象とした酸素 療法に関する推奨を示したガイドラインは見当たらな いが，国内では日本呼吸器学会と日本呼吸ケア・リハ ビリテーション学会で作成された酸素療法マニュアル （旧酸素療法ガイドライン，メディカルレビュー社， 2017 年）において，海外では BTS guideline for oxygen use in adults (British Thoracic Society) 6)において，い ずれも急性期患者における酸素投与の目標を，酸素飽 和度モニタリング下に $\mathrm{SpO}_{2}$ 94〜 98\%， $\mathrm{CO}_{2}$ ナルコー シスに陥るリスクのある COPD (chronic obstructive pulmonary disease）患者では 88〜92\% とすることが推 奨されている [best practice statement（エキスパート オピニオン）。最近報告された集中治療室入室患者の 大規模データベースを用いた後方視的観察研究7)で は，死亡率は $\mathrm{SpO}_{2}$ 94 98\% で最も低くなる U 字型の カーブを示し，94\% 以下で明らかに高くなるだけで なく，98\% 以上に長くとどまった場合でも死亡リス クは 1.2 1.3 倍に増加することが示されており，これ らの推奨を支持するデータとなっている。

\section{（12）実施に関わる検討事項}

避けるべき高い $\mathrm{SpO}_{2}$ が具体的にどの程度高い值と 解釈するかは個人によって様々であるため，推奨には 高めの $\mathrm{SpO}_{2}$ をあえて具体的な数值として 98〜 100\% と記した。しかし，どの程度高い $\mathrm{SpO}_{2}$ がアウトカム に悪影響を及ぼしているのかを検討した報告はなく， 適切な目標 $\mathrm{SpO}_{2}$ の範囲に関しては今後のさらなる検 討が必要である。また，低酸素血症に至る頻度やそれ による弊害に関しては, 報告されている研究がなかっ たため検討できておらず，こちらに関しても今後のさ らなる検討が必要である。

現代の集中治療室ではほぼルーチンに $\mathrm{SpO}_{2}$ が測定 されているため, $\mathrm{SpO}_{2}$ の值を指標に投与酸素流量や $\mathrm{F}_{\mathrm{I}} \mathrm{O}_{2}$ を漫然と高い状態にしないよう調整することは 比較的容易である。ただし，敗血症管理においては敗 血症性ショックのように循環動態が安定していない場 合には，重度の貧血，あるいは感染症による代謝え進 などで酸素需給バランスが崩れている可能性が存在す る状況に遭遇することも少なくない。そのような，過 度に酸素需要が高まっている状態や酸素供給が低下し
ている状態が予想される場合においては，循環動態が 安定化し酸素需給バランスが立ち直るまでの間，酸素 投与を多くまたは酸素濃度を高くするといったことは 緊急時において一般的に行われている対処法であり， 本推奨はこれを否定するものではない。なお，非侵襲 的モニタリングの特性として $\mathrm{SpO}_{2}$ 值に影響を与える 病態や干渉物質がいくつか存在するため, 連続モニタ されている $\mathrm{SpO}_{2}$ が正しく $\mathrm{SaO}_{2}$ を反映しているかど うかを確認する必要がある。

\section{（13）今後の研究の可能性}

今後は，重症度・気管挿管のリスク・呼吸不全の原 因別に関する検討を行うことが望まれる。今回のメタ 解析では十分な数の RCT がなく, 合計のサンプル数 も足りなかった。一方，本 $\mathrm{CQ}$ は最近のトピックスで あるためシステマティックレビュー期間後にもいくつ かの報告がなされており，システマティックレビュー 結果への影響が懸念される。そのため, 2020 年 2 月 までの簡易追加検索を行い，新たな RCT 2 編（NEJM 2020）を加えたメタ解析を施行した。結果は，高い $\mathrm{SpO}_{2}$ を目標とすることで短期死亡は若干少なくなる 傾向であったが，臟器障害と感染症発生に関してはも とのシステマティックレビューの結果と同様に増加す る傾向が見受けられた（詳細は益と害のバランスの項 を参照)。同様のリサーチクエスチョンの研究がさら に必要である。

\section{文 献}

1) Girardis M, Busani S, Damiani E, et al: Effect of Conservative vs Conventional Oxygen Therapy on Mortality Among Patients in an Intensive Care Unit: The Oxygen-ICU Randomized Clinical Trial. JAMA. 2016; 316: 1583-9.

2) Panwar R, Hardie M, Bellomo R, et al: Conservative versus Liberal Oxygenation Targets for Mechanically Ventilated Patients. A Pilot Multicenter Randomized Controlled Trial. Am J Respir Crit Care Med. 2016; 193: 43-51.

3) Ranchord AM, Argyle R, Beynon R, et al: High-concentration versus titrated oxygen therapy in ST-elevation myocardial infarction: a pilot randomized controlled trial. Am Heart J. 2012; 163: 168-75.

4) ICU-ROX Investigators the Australian and New Zealand Intensive Care Society Clinical Trials Group, Mackle D, Bellomo R, et al: Conservative Oxygen Therapy during Mechanical Ventilation in the ICU. N Engl J Med. 2020; 382: 989-98.

5) Barrot L, Asfar P, Mauny F, et al: Liberal or Conservative Oxygen Therapy for Acute Respiratory Distress Syndrome. N Engl J Med. 2020; 382: 999-1008.

6) O'Driscoll BR, Howard LS, Earis J, et al: BTS guideline for oxygen use in adults in healthcare and emergency settings. Thorax. 2017; 72(Suppl 1): iil-90.

7) van den Boom W, Hoy M, Sankaran J, et al: The Search for Optimal Oxygen Saturation Targets in Critically Ill Patients: Observational Data From Large ICU Databases. Chest. 2020; 157: 566-73. 
CQ9-2 : 成人敗血症患者の初期の呼吸不全に対 して, 非侵襲的人工呼吸（NIV）または経鼻高流 量療法（NHFT）を行うか?

Answer : 成人敗血症患者の初期の呼吸不全に対して, 非侵襲的人工呼吸（NIV）もしくは経鼻高流量療法 （NHFT）を行うことを弱く推奨する（GRADE 2A： エビデンスの確実性 $=「$ 高」)。

\section{（1）背景および本 $C Q$ の重要度}

種々の原因疾患に伴う急性呼吸不全に対する非侵襲 的人工呼吸 (non-invasive ventilation: NIV) や経鼻高流 量療法 (nasal high flow therapy: NHFT) の施行は, 世 界中で行われているが，敗血症患者における有効性は 十分に解明されていない。敗血症患者の初期の呼吸管 理では，酸素需給バランスの崩れを補うための酸素化 の改善, 分時換気量増加に伴う呼吸仕事量の負担軽減 などが，人工呼吸を行う目的となりうる。NIVや NHFT の使用により，插管に伴う不利益を回避するこ とで患者の予後改善につながる可能性がある点で, 成 人敗血症患者の初期の呼吸不全に対してNIVや NHFT を行うかどうかは重要な臨床課題と考える。

(2) PICO

$P$ (患者) : 成人敗血症患者

I（介入)/ C (対照)：急性低酸素性呼吸不全患者に 以下の呼吸管理デバイスのいずれかを使用

1. NIV : マスク，モード，NIV 時間，ウィーニ ング方法は問わない

2. NHFT : 流量, $\mathrm{F}_{\mathrm{I}} \mathrm{O}_{2}$ は問わない

3. 通常の酸素療法 (conventional oxygen therapy: $\mathrm{COT})$ : 鼻カニュラ, フェイスマスク, ベン チュリーマスク : 流量は問わない

$\mathrm{O}$ (アウトカム) : 短期死亡 (ICU 死亡 or 院内死亡 or 研究終了 or 90 日以内死亡。最大のものを採 択)，気管扱管，気管挿管までの時間（hour），感 染，インターフェイスによる皮膚障害，不快感

\section{（3）エビデンスの要約}

システマティックレビューの結果, PICO に合致し たランダム化比較試験（RCT）が 24 件 1-24）施行され ており,これらを用いたメタ解析およびネットワーク メタ解析（network meta-analysis: NMA）を実施した。
（4）益と害のバランス（Table 9-2-1，9-2-2）

望ましい効果 :

本 CQ はNMA を用いて検討した。

短期死亡に関するネットワーク効果推定値（Table 9-2-2）は, COTと比べて, NHFT でリスク差（RD） 1,000 人あたり 65 人少ない $(95 \% \mathrm{CI}: 95$ 人少ない〜 28 人多い）[エビデンスの確実性は「中」］（5 RCT, $\mathrm{n}=$ 1,463)，NIVでRD 1,000 人あたり 30 人少ない $(95 \%$ CI: 60 人少ない〜 3 人多い） [エビデンスの確実性は 「低」]（14 RCT, n= 2,359), そしてNHFT と比べて, NIV でRD 1,000 人あたり 8 人少ない $(95 \%$ CI: 35 人少 ない〜25人多い）[エビデンスの確実性は「低」]（3 $\mathrm{RCT}, \mathrm{n}=338$ ) であった。

気管挿管の施行に関するネットワーク効果推定值 は, COT と比べて, NHFT でRD 1,000 人あたり 65 人 少ない（95\% CI: 95 人少ない 28 人少ない） [エビデ ンスの確実性は「中」]（6 RCT, $\mathrm{n}=1,563), \mathrm{NIV}$ で $\mathrm{RD} 1,000$ 人あたり 60 人少ない $(95 \% \mathrm{CI}: 92$ 人少ない〜 29 人少ない）［エビデンスの確実性は「低」］(17 RCT, $\mathrm{n}=2,506)$, そしてNHFT と比べて, NIVで RD 1,000 人あたり 5 人多い $(95 \%$ CI: 32 人少ない 46 人多い）[エビデンスの確実性は「低」]（5 RCT, n =584）であった。

気管挿管までの時間に関するネットワーク効果推定 值は, COT と比べて, NHFT で平均（MD） 1.15 時間 長い (95\% CI: 0.21 時間短い〜2.09 時間長い) [エビ デンスの確実性は「高」]（1 RCT, $\mathrm{n}=200), \mathrm{NIV}$ で MD 0.53 時間長い $(95 \%$ CI: 0.27 時間短い 0.80 時間 長い）［エビデンスの確実性は「高」］（2 RCT, n = 284), そして NHFT と比べて, NIVで MD 0.62 時間 長い（95\% CI: 1.52 時間短い 0.28 時間長い） [エビ

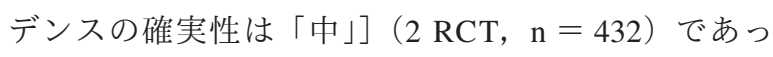
た。

また，短期死亡における surface under the cumulative ranking（SUCRA）は NIV 77.3, NHFT 64.4, COT 8.3 であり，気管挿管における SUCRA は NIV 74.5, NHFT 74.7, COT 0.8 であり，気管挿管までの時間における SUCRA は NIV 40.3，NHFT 85.2，COT 24.5 であった。 望ましくない効果 :

今回の検討では，望ましくない効果として検討した アウトカムはすべて「重大」ではなく「重要」との評 価であったため，本 EtD には含まれなかった。

益と害のバランス :

NIVやNHFT を適用することにより，挿管に伴う 不利益は回避できる可能性がある。しかし, 望ましく ない効果に関しては検討できていない。インターフェ 
日集中医誌 J Jpn Soc Intensive Care Med Vol. 28 Suppl

Table 9-2-1 エビデンスプロファイル（メタ解析）

(a) NIV vs. COT

\begin{tabular}{|c|c|c|c|c|c|c|c|c|c|c|c|c|}
\hline \multicolumn{7}{|c|}{ 確実性の評価 } & \multicolumn{2}{|c|}{ 患者数 } & \multicolumn{2}{|c|}{ 効果 } & \multirow[b]{2}{*}{ 確実性 } & \multirow[b]{2}{*}{ 重要性 } \\
\hline 研究数 & $\begin{array}{l}\text { 研究 } \\
\text { デザイン }\end{array}$ & $\begin{array}{l}\text { バイアス } \\
\text { のリスク }\end{array}$ & 非一貫性 & 非直接性 & 不精確性 & $\begin{array}{l}\text { その他 } \\
\text { の榆討 }\end{array}$ & NIV & СOT & $\begin{array}{l}\text { 相対指標 } \\
(95 \% \mathrm{Cl})\end{array}$ & $\begin{array}{l}\text { 絶対指標 } \\
(95 \% \text { Cl) }\end{array}$ & & \\
\hline \multicolumn{13}{|l|}{ 短期死亡 } \\
\hline 14 & RCT & 深刻でない & 深刻でない & 深刻でない & 深刻 a & $\begin{array}{c}\text { 出版バイアス } \\
\text { が強く示唆さ } \\
\text { れる }\end{array}$ & $\begin{array}{c}265 / 1,366 \\
(19.4 \%)\end{array}$ & $\begin{array}{c}247 / 993 \\
(24.9 \%)\end{array}$ & $\begin{array}{c}\text { RR } 0.80 \\
\text { (0.63 to } 1.01)\end{array}$ & $\mid \begin{array}{l}1,000 \text { 人あたり } 50 \\
\text { 人少ない (92 人少 } \\
\text { ない〜2 人多い) }\end{array}$ & $\underset{\text { 低 }}{\oplus \oplus \bigcirc \bigcirc}$ & 重大 \\
\hline \multicolumn{13}{|c|}{ 気管挿管 } \\
\hline 17 & RCT & 深刻でない & 深刻でないc & 深刻でない & 深刻でない & $\begin{array}{c}\text { 出版バイアス } \\
\text { が強く示唆さ } \\
\text { れる }\end{array}$ & $\begin{array}{c}250 / 1,443 \\
(17.3 \%)\end{array}$ & $\begin{array}{c}337 / 1,063 \\
(31.7 \%)\end{array}$ & $\begin{array}{c}\text { RR } 0.57 \\
(0.42 \text { to } 0.78)\end{array}$ & $\begin{array}{c}1,000 \text { 人あたり } \\
136 \text { 人少ない } \\
(184 \text { 人少ない〜 } \\
70 \text { 人少ない })\end{array}$ & $\begin{array}{c}\oplus \oplus \oplus \bigcirc \\
\text { 中 }\end{array}$ & 重大 \\
\hline \multicolumn{13}{|c|}{ 気管挿管までの時間 } \\
\hline 2 & RCT & 深刻でない & 深刻でないd & 深刻でない & 深刻e & なし & 164 & 120 & - & 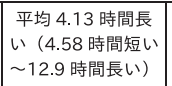 & $\begin{array}{c}\oplus \oplus \oplus \bigcirc \\
\text { 中 }\end{array}$ & 重大 \\
\hline \multicolumn{13}{|c|}{ 皮虐障害 } \\
\hline 1 & RCT & 深刻でない & 深刻でない & 深刻でない & 非常に深刻 f & なし & $2 / 62(3.2 \%)$ & $0 / 61(0.0 \%)$ & $\begin{array}{c}\text { RR } 4.92 \\
\text { (0.24 to } 100.43)\end{array}$ & $\begin{array}{c}1,000 \text { 人あたり } 0 \\
\text { 人少ない (0人少 } \\
\text { ない〜0 人少な } \\
\text { い) }\end{array}$ & $\begin{array}{c}\oplus \oplus \bigcirc \bigcirc \\
\text { 低 }\end{array}$ & 重要 \\
\hline \multicolumn{13}{|l|}{ 感染 } \\
\hline 2 & RCT & 深刻でない & 深刻でない & 深刻でない & 非常に深刻 f & なし & $48 / 253(19.0 \%)$ & $47 / 244(19.3 \%)$ & $\begin{array}{c}\text { RR } 0.99 \\
(0.70 \text { to } 1.40)\end{array}$ & $\begin{array}{l}1,000 \text { 人あたり } 2 \\
\text { 人少ない }(58 \text { 人少 } \\
\text { ない 77 人多い) }\end{array}$ & $\begin{array}{c}\oplus \oplus \bigcirc \bigcirc \\
\text { 低 }\end{array}$ & 重要 \\
\hline
\end{tabular}

a. 閾値を相対リスク比 $25 \%$ と設定した場合，信頼区間における下限が臨床決断の閾值をまたぐと判断する。

b. ファンネルプロットにおける左右非対称性を認める。

c. $\left.\right|^{2}=75 \%$ であるが，効果推定值の方向性は一致している。

d. $\left.\right|^{2}=80 \%$ であるが, 効果推定值の方向性は一致している。

e. 最適情報量の基準を满たしていない。

f. 闘值を相対リスク比 $25 \%$ と設定した場合，信頼区間における上限および下限が臨床決断の閾值をまたぐと判断する。

非一貫性に関しては 2 人の評価者で評価して相違はなかった。

非直接性は, 急性呼吸不全として検索し，敗血症による呼吸不全と治療方針に差がないと判断した。

不快感については，アウトカムの報告がなかった。

(b) NHFT vs. COT

\begin{tabular}{|c|c|c|c|c|c|c|c|c|c|c|c|c|}
\hline \multicolumn{7}{|c|}{ 確実性の評価 } & \multicolumn{2}{|c|}{ 患者数 } & \multicolumn{2}{|c|}{ 効果 } & \multirow[b]{2}{*}{ 確実性 } & \multirow[b]{2}{*}{ 重要性 } \\
\hline 研究数 & $\begin{array}{c}\text { 研究 } \\
\text { デザイン }\end{array}$ & $\begin{array}{l}\text { バィアス } \\
\text { のリスク }\end{array}$ & 非一貫性 & 非直接性 & 不精碓性 & $\begin{array}{l}\text { その他 } \\
\text { の梌討 }\end{array}$ & NHFT & СОT & $\begin{array}{l}\text { 相対指標 } \\
(95 \% \text { CI) }\end{array}$ & $\begin{array}{l}\text { 絶対指標 } \\
(95 \% \text { Cl) }\end{array}$ & & \\
\hline \multicolumn{13}{|l|}{ 死亡 } \\
\hline 5 & RCT & 深刻でない & 深刻でない & 深刻でない & 深刻 a & なし & $\begin{array}{c}213 / 748 \\
(28.5 \%)\end{array}$ & $\begin{array}{c}219 / 715 \\
(30.6 \%)\end{array}$ & $\begin{array}{c}\text { RR } 0.86 \\
\text { (0.60 to } 1.23 \text { ) }\end{array}$ & $\begin{array}{c}1,000 \text { 人あたり } 43 \\
\text { 人少ない (123人少 } \\
\text { ない〜 70 人多い) }\end{array}$ & $\begin{array}{c}\oplus \oplus \oplus \bigcirc \\
\text { 中 }\end{array}$ & 重大 \\
\hline \multicolumn{13}{|l|}{ 気管挿管 } \\
\hline 6 & RCT & 深刻でない & 深刻でない & 深刻でない & 深刻でない & なし & $\begin{array}{c}205 / 800 \\
(25.6 \%)\end{array}$ & $\begin{array}{c}234 / 763 \\
(30.7 \%)\end{array}$ & $\begin{array}{c}\text { RR } 0.86 \\
(0.74 \text { to } 0.99)\end{array}$ & $\mid \begin{array}{c}1,000 \text { 人あたり } 43 \\
\text { 人少ない }(80 \text { 人少な } \\
\text { い〜3 } 3 \text { 人少ない) }\end{array}$ & 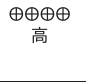 & 重大 \\
\hline \multicolumn{13}{|c|}{ 気管挿管までの時間 } \\
\hline 1 & RCT & 深刻でない & 深刻でない & 深刻でない & 深刻 b & なし & 106 & 94 & - & $\begin{array}{c}\text { 平均 } 7.3 \text { 時間長い } \\
\text { (0.09 時間短い〜 } \\
14.69 \text { 時間長い) }\end{array}$ & $\begin{array}{c}\oplus \oplus \oplus \bigcirc \\
\text { 中 }\end{array}$ & 重大 \\
\hline \multicolumn{13}{|l|}{ 感染 } \\
\hline 1 & RCT & 深刻でない & 深刻でない & 深刻でない & 非常に深刻 c & なし & $39 / 388(10.1 \%)$ & $41 / 388(10.6 \%)$ & $\begin{array}{c}\text { RR } 0.95 \\
\text { (0.63 to } 1.44 \text { ) }\end{array}$ & $\mid \begin{array}{c}1,000 \text { 人あたり } 5 \text { 人 } \\
\text { 少ない (39人少ない〜 } \\
46 \text { 人多い) }\end{array}$ & $\underset{\text { 低 }}{\oplus \oplus \bigcirc \bigcirc}$ & 重要 \\
\hline \multicolumn{13}{|l|}{ 不快感 } \\
\hline 2 & RCT & 深刻でない & 深刻でない & 深刻でない & 深刻でない & なし & 9/83 (10.8\%) & $0 / 85(0.0 \%)$ & $\begin{array}{c}\text { RR } 9.74 \\
(1.27 \text { to } 74.51)\end{array}$ & $\mid \begin{array}{c}1,000 \text { 人あたり } 0 \text { 人 } \\
\text { 少ない (0人少ない 0 } \\
\text { 人少ない) }\end{array}$ & 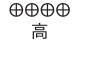 & 重要 \\
\hline
\end{tabular}

a. 閭值を相对リスク比 $25 \%$ と設定した場合，信頼区間における下限が臨床決断の閾值をまたぐと判断する。

b. 最適情報量の基準を満たさない。

c. 閧值を相対リスク比 $25 \%$ と設定した場合，信頼区間における上限および下限が臨床決断の閾值をまたぐと判断する。

非一貫性に関しては 2 人の評価者で評価して相違はなかった。

非直接性は，急性呼吸不全として検索し，敗血症による呼吸不全と治療方針に差がないと判断した。

皮膚障害については, アウトカムの報告がなかった。 


\begin{tabular}{|c|c|c|c|c|c|c|c|c|c|c|c|c|}
\hline \multicolumn{7}{|c|}{ 確実性の評価 } & \multicolumn{2}{|c|}{ 患者数 } & \multicolumn{2}{|c|}{ 奻果 } & \multirow[b]{2}{*}{ 碓実性 } & \multirow[b]{2}{*}{ 重要性 } \\
\hline 研究数 & $\begin{array}{l}\text { 研究 } \\
\text { デザイン }\end{array}$ & $\begin{array}{l}\text { バイアス } \\
\text { のリスク }\end{array}$ & 非一貫性 & 非直接性 & 不精確性 & $\begin{array}{l}\text { その他 } \\
\text { の朲討 }\end{array}$ & NIV & NHFT & $\begin{array}{l}\text { 相対指標 } \\
(95 \% \mathrm{Cl})\end{array}$ & $\begin{array}{l}\text { 絶対指摽 } \\
(95 \% \text { CI) }\end{array}$ & & \\
\hline \multicolumn{13}{|l|}{ 死亡 } \\
\hline 3 & RCT & 深刻でない & 深刻でない & 深刻でない & 深刻でない & なし & $53 / 172(30.8 \%)$ & $26 / 166(15.7 \%)$ & $\begin{array}{c}\text { RR } 1.90 \\
\text { (1.15 to } 3.12)\end{array}$ & $\begin{array}{c}\text { 1,000 人あたり } \\
141 \text { 人多い (23 } \\
\text { 多い 332 人多 } \\
\text { い) }\end{array}$ & 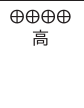 & 重大 \\
\hline \multicolumn{13}{|c|}{ 気管㨉管 } \\
\hline 5 & RCT & 深刻でない & 深刻でない & 深刻でない & 深刻でない & なし & 99/288 (34.4\%) & $68 / 296(23.0 \%)$ & $\begin{array}{c}\text { RR } 1.41 \\
\text { (1.09 to } 1.82 \text { ) }\end{array}$ & $\begin{array}{c}1,000 \text { 人あたり } 94 \\
\text { 人多い (21 人多い } \\
188 \text { 人多い) }\end{array}$ & 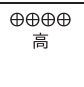 & 重大 \\
\hline \multicolumn{13}{|c|}{ 気管揸管までの時間 } \\
\hline 2 & RCT & 深刻でない & 深刻でない & 深刻でない & 深刻a & なし & 210 & 222 & & \begin{tabular}{|l}
$\mid$ 平均 0.54 時間短い \\
$(1.44$ 時間短い \\
0.37 持間長い)
\end{tabular} & $\underset{\text { 中 }}{\oplus \oplus \oplus \bigcirc}$ & 重大 \\
\hline
\end{tabular}

a. 最適情報量の基準を満たしていない。

非一貫性に関しては 2 人の評価者で評価して相違はなかった。

非直接性は，急性呼吸不全として桧索し，敗血症による呼吸不全と治療方針に差がないと判断した。

皮膚障害と感染, 不快感についてはアウトカムの報告がなかった。

イスによる皮膚障害や不快感などの望ましくない効果 が可能性として挙げられるが，重要度は低いため，効 果のバランスは比較（COTを行う）よりも「おそら く介入（NIVまたはNHFTを行う）が優位」と判断 した。

\section{（5）アウトカム全般に関するエビデンスの確実性}

エビデンスの方向性としては，短期死亡率と気管挿 管までの時間ではすべての比較群において優劣を判断 することはできず，気管扦管のアウトカムのみ COT に対してNIV と NHFT で気管挿管を減少させる望ま しい効果があった。望ましくない効果に関しては評価 できていない。よって，NIVと NHFTの両者を合わ せて推奨する方針とした。SUCRAの数值を参考にエ ビデンスの方向性を判断すると, COTと“NIV また は NHFT”の 2 群においてエビデンスの方向性は一致 していると考え，アウトカム全体にわたるエビデンス の確実性は「高」と判断した。

\section{（6）価値観}

敗血症患者に対するNIVやNHFTによる呼吸管理 では，各アウトカムに置く患者や家族の価值観に関す るデータはない。一般的に, 死亡アウトカムに対して 置く相対的価值は高く，そのばらつきは少ないことが 予想される。

\section{（7）容認性}

呼吸管理を行うために必要となる要素は, デバイス の有無，デバイスや酸素のコスト，デバイスに対する 容認性が挙げられる。NIV，NHFT，COTでは一般的 な呼吸管理デバイスが用いられており，国内のどの病
院においても既に導入されていることが多く，新たな コストは発生しないことが予想される。しかし，デバ イスに関わる消耗品に関しては, NIV と NHFTに使 用される回路費用として約 5,000 円/個が必要となる ため, 医療経済の観点からはCOTのほうがコストを 抑えられると考えられる。また, 医療従事者の仕事量 に関しては, COTに比してNHFT, NHFT に比して NIV において，それぞれの呼吸管理を維持するため の仕事量は増大すると考えられる。さらに，デバイス の容認性に関しては, 皮膚障害や患者不快感が関与す ると考えられるが，どちらも今回の検討では「重大」 アウトカムとしては評価できておらず, 結論には至っ ていない。

\section{（8）実行可能性}

人工呼吸管理が可能な病院であれば，これらの治療 は一般的な呼吸管理方法であり, どの病院においても 実行可能性は高いと考えられる。しかし，デバイスが ない施設では実施できない。

\section{(9) 判断の要約（Table 9-2-3）}

\section{（10）推奨グレーディング決定の工程}

修正 RAND 法を用いた投票によって，中央值 8 , 見解不一致指数 0.164 の結果となり, 委員会で採択さ れた（7 点以上 : $83.3 \%) 。$

\section{（11）関連する他の診療ガイドラインにおける推奨} 本 CQ と類似したテーマを扱っている他のガイドラ インは検索する限り見当たらなかった。 
(a) 死亡

Table 9-2-2 エビデンスプロファイル（ネットワークメタ解析）

\begin{tabular}{|c|c|c|c|c|c|c|c|}
\hline \multicolumn{8}{|c|}{ 急性呼吸不全を伴う敗血症患者における酸素療法のエビデンスの効果の試算, 信頼区間, 確実性 } \\
\hline \multicolumn{5}{|c|}{$\begin{array}{l}\text { 患者群: 酸素療法を必要とする急性呼吸不全を伴う敗血症患者 } \\
\text { 介入: NIV（非侵襲的人工呼吸）, NHFT（経鼻高流量療法）, or COT（従来酸素療法）のうちどれかひとつ } \\
\text { 比較（参照）：介入に含まれる治療法以外の他の治療法のうちひとつ } \\
\text { 結果: 死亡 } \\
\text { 状況: 院内 }\end{array}$} & \multirow{3}{*}{\multicolumn{3}{|c|}{ 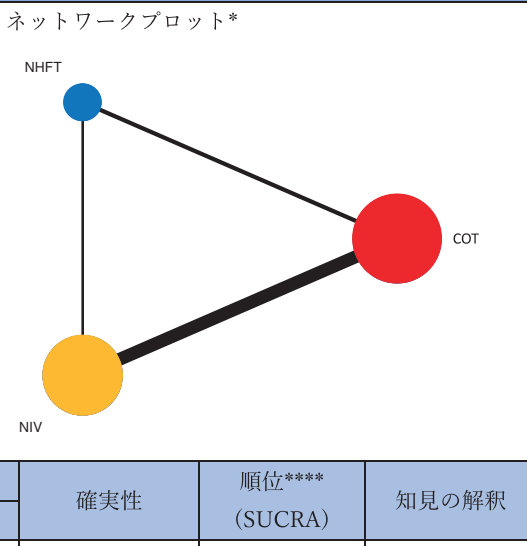 }} \\
\hline \multirow{2}{*}{$\begin{array}{l}\text { 総研究数: } 19 \text { 編 } \\
\text { 総患者数: } 4,837 \text { 人 }\end{array}$} & \multirow{2}{*}{$\begin{array}{l}\text { 相対効果 } \\
(95 \% \mathrm{CI})^{* *}\end{array}$} & \multicolumn{3}{|c|}{ 絶対効果 $(95 \% \mathrm{CI})^{* * *}$} & & & \\
\hline & & 介入なし & 介入あり & 差異 & & & \\
\hline $\begin{array}{l}\text { NIV } \\
(\text { RCT } 14 \text { 編, } \\
\text { 患者数 } 2,359 \text { 人) }\end{array}$ & $\begin{array}{c}0.88 \\
(0.76 \text { to } 1.01) \\
\text { ネットワーク推定 } \\
\text { 値 }\end{array}$ & 249 per 1,000 & 219 per 1,000 & $\begin{array}{c}1,000 \text { 人あたり } 30 \text { 人少 } \\
\text { ない } \\
(60 \text { 人少ない〜 } 3 \text { 人多 } \\
\text { い) }\end{array}$ & $\begin{array}{l}\oplus \oplus \bigcirc \bigcirc \\
\text { 低 }^{1}\end{array}$ & $\begin{array}{c}2 \\
(64.4)\end{array}$ & - \\
\hline $\begin{array}{l}\text { NHFT } \\
\text { (RCT } 5 \text { 編, } \\
\text { 患者数 } 1,463 \text { 人) }\end{array}$ & $\begin{array}{c}0.92 \\
\begin{array}{c}\text { (0.80 to } 1.07) \\
\text { ネットワーク推定 } \\
\text { 值 }\end{array} \\
\end{array}$ & 306 per 1,000 & 242 per 1,000 & $\begin{array}{c}1,000 \text { 人あたり } 65 \text { 人 } \\
\text { 少ない } \\
(95 \text { 人少ない〜 } 28 \text { 人多 } \\
\text { い) }\end{array}$ & $\begin{array}{c}\oplus \oplus \oplus \bigcirc \\
\text { 中 }^{2}\end{array}$ & $\begin{array}{c}1 \\
(77.3)\end{array}$ & - \\
\hline COT & 比較参照 & - & - & - & - & $\begin{array}{c}3 \\
(8.3)\end{array}$ & - \\
\hline $\begin{array}{l}\text { NIV } \\
(\mathrm{RCT} 3 \text { 編, 患者 } \\
\text { 数 } 338 \text { 人) }\end{array}$ & $\begin{array}{c}0.95 \\
\begin{array}{c}\text { (0.78 to } 1.16) \\
\text { ネットワーク推定 } \\
\text { 値 }\end{array}\end{array}$ & 157 per 1,000 & 149 per 1,000 & $\begin{array}{c}1,000 \text { 人あたり } 8 \text { 人少 } \\
\text { ない } \\
(35 \text { 人少ない〜 } 25 \text { 人多 } \\
\text { い) }\end{array}$ & $\begin{array}{l}\oplus \oplus \bigcirc \bigcirc \\
\text { 低 }^{1}\end{array}$ & - & - \\
\hline NHFT & 比較参照 & - & - & - & - & - & - \\
\hline $\begin{array}{l}\text { NIV, non-invasive po } \\
\text { ネットワークメタ解 } \\
\text { *直線は直接比較を表 } \\
\text { **推定値はリスク比 } \\
\text { ***予想される絶対的 } \\
\text { ****有効性の順位 : 順 } \\
\text { 最も有効性の低い治光 }\end{array}$ & $\begin{array}{l}\text { itive; NHFT, nasal } \\
\text { の結果要約テーブ, } \\
\text { す。 } \\
\text { Cl:信頼区間として } \\
\text { な効果 : 予想される } \\
\text { 位統計は, ネットワ } \\
\text { 文で続く。 }\end{array}$ & $\begin{array}{l}\text {-flow therapy; C } \\
\text { 定義 } \\
\text { 吉される。 } \\
\text { 寸的効果は, 介入 } \\
\text { メタ解析におけ }\end{array}$ & $\begin{array}{l}\text { スクと対照群のリ } \\
\text { の治療のうち } 1 \text { 區 }\end{array}$ & $\begin{array}{l}\text { スクとの差を計算するこ } \\
\text { の治療が最も有効である }\end{array}$ & $\begin{array}{l}\text { とによって2 } \\
\text { 確率として定亲 }\end{array}$ & $\begin{array}{l}\text { スクを比較す } \\
2 \text { 番目, } 3 \text { 番 }\end{array}$ & というように, \\
\hline \multicolumn{8}{|c|}{$\begin{array}{l}\text { 中 : 効果の推定值にはやや確信がある。実際の効果は推定值に近い可能性があるが，大きく異なる可能性がある。 } \\
\text { 低 : 効果の推定值に対する信頼性は限られており，真の効果は効果の推定值とは実質的に異なる可能性がある。 } \\
\text { 非常に低 : 効果の推定值にほとんど確信がない。真の効果は推定効果と実質的に異なる可能性が高い。 }\end{array}$} \\
\hline $\begin{array}{l}\text { 備考 } \\
\text { 1. 非一貫性の } P \text { 值 } \\
\text { 2. 非一貫性の } P \text { 值 }\end{array}$ & $\begin{array}{l}05 \text { 未満。 } \\
.1 \text { 未満。 }\end{array}$ & & & & & & \\
\hline
\end{tabular}


（b）気管挿管

Table 9-2-2 エビデンスプロファイル（ネットワークメタ解析）（つづき）

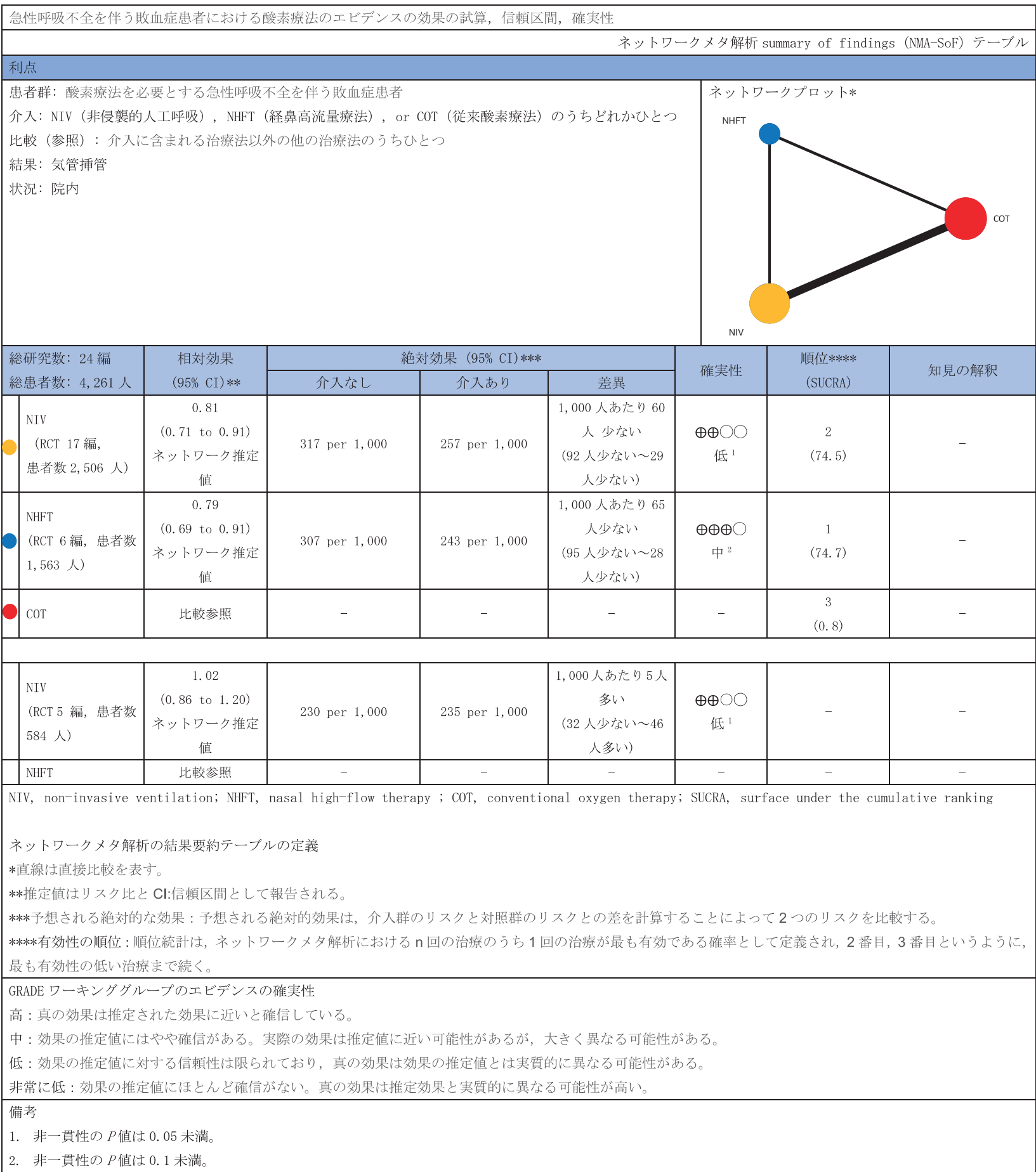


（c）気管挿管までの時間

Table 9-2-2 エビデンスプロファイル（ネットワークメタ解析）（つづき）

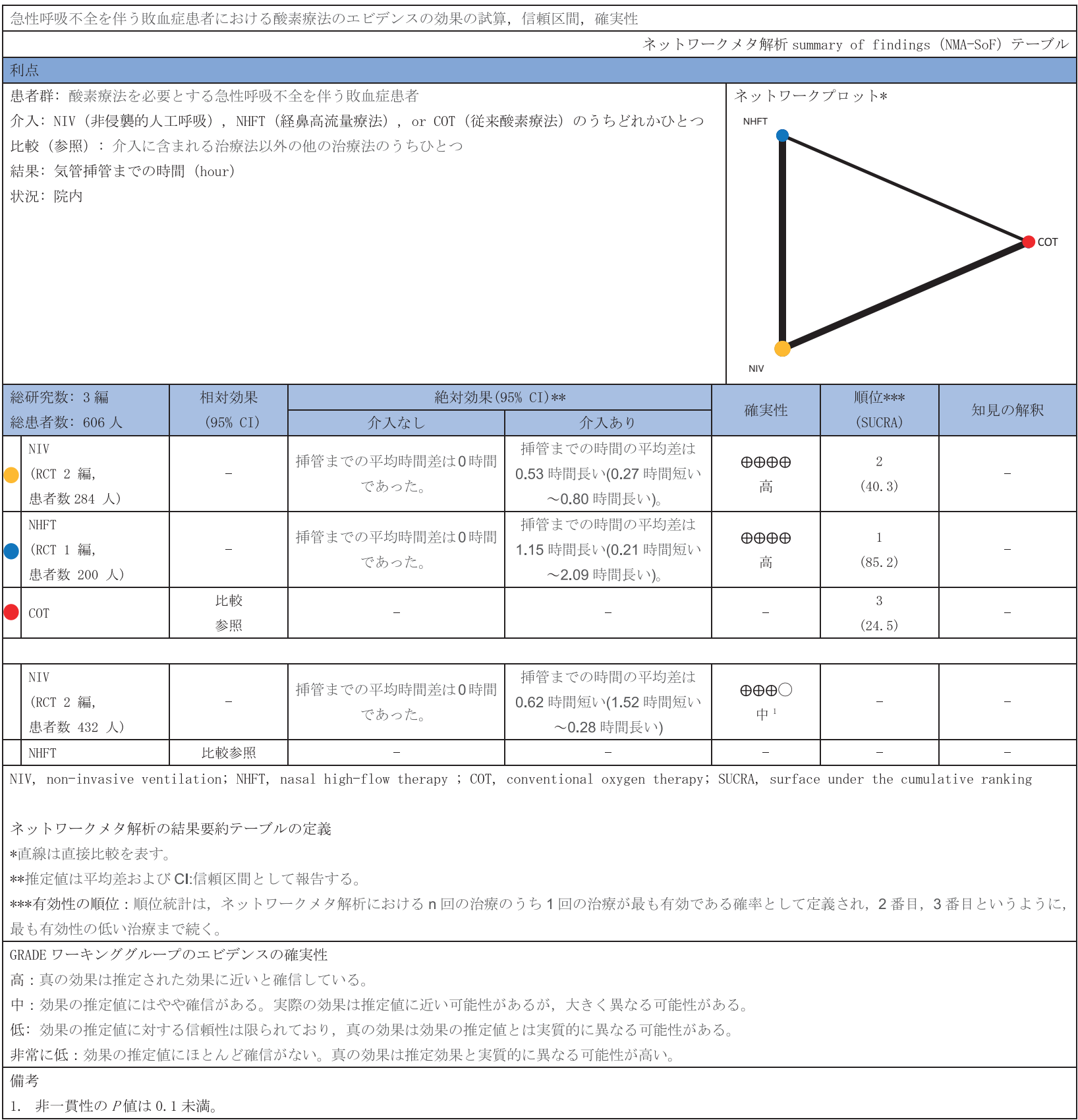


Table 9-2-3 判断の要約

\begin{tabular}{|c|c|c|c|c|c|c|c|}
\hline & \multicolumn{7}{|c|}{ 半楼 } \\
\hline 問題 & いいえ & $\begin{array}{c}\text { おそらく、いい } \\
\text { え }\end{array}$ & おそらく、はい & はい & & さまざま & 分からない \\
\hline 望ましい効果 & わずか & 小さい & 中 & 大きい & & さまざま & 分からない \\
\hline 望ましくない効果 & 大きい & 中 & 小さい & わずか & & さまざま & 分からない \\
\hline エビデンスの確実性 & 非常に低 & 低 & 中 & 高 & & & 採用研究なし \\
\hline 価值観 & $\begin{array}{c}\text { 重要な不確実性 } \\
\text { またはばらつき } \\
\text { あり }\end{array}$ & $\begin{array}{c}\text { 重要な不確実性 } \\
\text { またはばらつき } \\
\text { の可能性あり }\end{array}$ & $\begin{array}{l}\text { 重要な不確実性 } \\
\text { またはばらつき } \\
\text { はおそらくなし }\end{array}$ & $\begin{array}{c}\text { 重要な不確実性 } \\
\text { またはばらつき } \\
\text { はなし }\end{array}$ & & & \\
\hline 勃果のパランス & 比較が優位 & $\begin{array}{c}\text { 比較がおそらく } \\
\text { 優位 }\end{array}$ & $\begin{array}{c}\text { 介入も比較もい } \\
\text { ずれも優位でな } \\
\text { い }\end{array}$ & $\begin{array}{c}\text { おそらく介入が } \\
\text { 優位 }\end{array}$ & 介入が優位 & さまざま & 分からない \\
\hline 容認性 & いいえ & $\begin{array}{c}\text { おそらく、いい } \\
\text { え }\end{array}$ & おそらく、はい & はい & & さまざま & 分からない \\
\hline 実行可能性 & いいえ & $\begin{array}{c}\text { おそらく、いい } \\
\text { え }\end{array}$ & おそらく、はい & はい & & さまざま & 分からない \\
\hline
\end{tabular}

\section{（12）実施に関わる検討事項}

急性呼吸不全患者の初期呼吸管理として, 呼吸不全 に至った原因ごとに最適な酸素療法デバイスは異なる 可能性があるが，本検討では原因別や重症度別での評 価はできていない。実臨床では，それらを加味しなが ら症例に応じた方法を選択するのが良いと考えられ る。

\section{（13）今後の研究の可能性}

今後は，重症度，気管挿管のリスク，呼吸不全の原 因などで分けた検討を行うことが望まれる。

\section{文 献}

1) Antonelli M, Conti G, Bufi M, et al: Noninvasive ventilation for treatment of acute respiratory failure in patients undergoing solid organ transplantation: a randomized trial. JAMA. 2000; 283: 235-41.

2) Azoulay E, Lemiale V, Mokart D, et al: Effect of High-Flow Nasal Oxygen vs Standard Oxygen on 28-Day Mortality in Immunocompromised Patients With Acute Respiratory Failure: The HIGH Randomized Clinical Trial. JAMA. 2018; 320: 2099-107.

3) Bersten $\mathrm{AD}$, Holt $\mathrm{AW}$, Vedig $\mathrm{AE}$, et al: Treatment of severe cardiogenic pulmonary edema with continuous positive airway pressure delivered by face mask. N Engl J Med. 1991; 325: 1825-30.

4) Brambilla AM, Aliberti S, Prina E, et al: Helmet CPAP vs. oxygen therapy in severe hypoxemic respiratory failure due to pneumonia. Intensive Care Med. 2014; 40: 942-9.

5) Cosentini R, Brambilla AM, Aliberti $S$, et al: Helmet continuous positive airway pressure vs oxygen therapy to improve oxygenation in community-acquired pneumonia: a randomized, controlled trial. Chest. 2010; 138: 114-20.

6) Delclaux C, L'Her E, Alberti C, et al: Treatment of acute hypoxemic nonhypercapnic respiratory insufficiency with continuous positive airway pressure delivered by a face mask: A randomized controlled trial. JAMA. 2000; 284: 2352-60

7) Doshi P, Whittle JS, Bublewicz M, et al: High-Velocity Nasal Insufflation in the Treatment of Respiratory Failure: A Randomized Clinical Trial. Ann Emerg Med. 2018; 72: 73-83.e5.

8) Shebl E, Embarak S: High-flow nasal oxygen therapy versus noninvasive ventilation in chronic interstitial lung disease patients with acute respiratory failure. Egypt J Chest Dis Tuberc. 2018; 67: 270-5.

9) Ferrer M, Esquinas A, Leon M, et al: Noninvasive ventilation in severe hypoxemic respiratory failure: a randomized clinical trial. Am J Respir Crit Care Med. 2003; 168: 1438-44.

10) Frat JP, Ragot $S$, Girault $C$, et al: Effect of non-invasive oxygenation strategies in immunocompromised patients with severe acute respiratory failure: a post-hoc analysis of a randomised trial. Lancet Respir Med. 2016; 4: 646-52.

11) Frat JP, Thille AW, Mercat A, et al: High-flow oxygen through nasal cannula in acute hypoxemic respiratory failure. $\mathrm{N}$ Engl $\mathrm{J}$ Med. 2015; 372: 2185-96.

12) Gray A, Goodacre $S$, Newby DE, et al: Noninvasive ventilation in acute cardiogenic pulmonary edema. N Engl J Med. 2008; 359: $142-51$

13) Hilbert G, Gruson D, Vargas F, et al: Noninvasive ventilation in immunosuppressed patients with pulmonary infiltrates, fever, and acute respiratory failure. $\mathrm{N}$ Engl J Med. 2001; 344: 481-7.

14) Jones PG, Kamona S, Doran O, et al: Randomized Controlled Trial of Humidified High-Flow Nasal Oxygen for Acute Respiratory Distress in the Emergency Department: The HOT-ER Study. Respir Care. 2016; 61: 291-9.

15) L'Her E, Duquesne F, Girou E, et al: Noninvasive continuous positive airway pressure in elderly cardiogenic pulmonary edema patients. Intensive Care Med. 2004; 30: 882-8.

16) Lemiale V, Mokart D, Mayaux J, et al: The effects of a 2-h trial of high-flow oxygen by nasal cannula versus Venturi mask in immunocompromised patients with hypoxemic acute respiratory failure: a multicenter randomized trial. Crit Care. 2015; 19: 380.

17) Lemiale V, Mokart D, Resche-Rigon M, et al: Effect of Noninvasive Ventilation vs Oxygen Therapy on Mortality Among Immunocompromised Patients With Acute Respiratory Failure: A Randomized Clinical Trial. JAMA. 2015; 314: 1711-9.

18) Levitt MA: A prospective, randomized trial of BiPAP in severe acute congestive heart failure. J Emerg Med. 2001; 21: 363-9. 
19) Makdee O, Monsomboon A, Surabenjawong U, et al: High-Flow Nasal Cannula Versus Conventional Oxygen Therapy in Emergency Department Patients With Cardiogenic Pulmonary Edema: A Randomized Controlled Trial. Ann Emerg Med. 2017; 70: 465-72.e2.

20) Masip J, Betbesé AJ, Páez J, et al: Non-invasive pressure support ventilation versus conventional oxygen therapy in acute cardiogenic pulmonary oedema: a randomised trial. Lancet. 2000; 356: 2126-32.

21) Park M, Sangean MC, Volpe Mde S, et al: Randomized, prospective trial of oxygen, continuous positive airway pressure, and bilevel positive airway pressure by face mask in acute cardiogenic pulmonary edema. Crit Care Med. 2004; 32: 2407-15.

22) Rittayamai N, Tscheikuna J, Praphruetkit N, et al: Use of High-Flow Nasal Cannula for Acute Dyspnea and Hypoxemia in the Emergency Department. Respir Care. 2015; 60: 1377-82.

23) Wysocki M, Tric L, Wolff MA, et al: Noninvasive pressure support ventilation in patients with acute respiratory failure. A randomized comparison with conventional therapy. Chest. 1995; 107: 761-8.

24) Zhan Q, Sun B, Liang L, et al: Early use of noninvasive positive pressure ventilation for acute lung injury: a multicenter randomized controlled trial. Crit Care Med. 2012; 40: 455-60.
CQ9-3：成人敗血症患者の人工呼吸管理におい て, 肺保護換気戦略を行うか?

Answer：成人敗血症患者の人工呼吸管理において, 肺保護換気戦略を行うことを弱く推奨する（GRADE 2B : エビデンスの確実性 $=\lceil$ 「」)。

\section{（1）背景および本 $C Q$ の重要度}

重症患者における人工呼吸管理において，人工呼吸 器関連肺傷害を来さない管理が患者予後改善のために 必須である。人工呼吸器関連肺傷害を引き起こす可能 性のある因子として 1 回換気量とプラトー圧が示唆さ れており，それらをある一定基準以内に抑えて呼吸管 理を行う肺保護換気の重要性が示唆されているが，成 人敗血症患者における有効性は十分に解明されていな い。それらの目標值を具体的に検討することは，敗血 症診療の専門家だけでなく, 非専門家にとっても重要 な臨床課題と考えられる。

\section{(2) PICO}

$P$ (患者)：成人敗血症患者

I (介入) : 肺保護換気 $[$ 低 1 回換気量もしくは低プ ラトー圧，もしくはその両者によりプラトー圧が ある基準未満となった場合で，PEEP は問わない。 Day 1 のみ : 1 回換気量はおおよそ 4〜 $8 \mathrm{~mL} / \mathrm{kg}$ 理 想体重（ideal body weight: IBW)]

C (対照) : Conventional（上記以外，プラトー圧が ある基準以上となっている場合で，PEEPは問わ

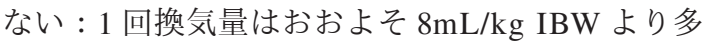
()

$\mathrm{O}$ (アウトカム ) : 短期死亡 (ICU 死亡 or 院内死亡 or 研究終了 or 90 日以内死亡。最大のものを採 択), 人工呼吸離脱日数 (ventilator-free days: VFD, 28 日以内), 圧損傷（各論文の定義に従う, 気胸も含む。両者がある場合は発生数が多いほう を採択), 人工呼吸器関連肺炎（各論文の定義に 従う)

\section{（3）エビデンスの要約}

システマティックレビューの結果, PICO に合致し たランダム化比較試験（RCT）が 9 件 1-9）施行されて おり，これらを用いたメタ解析を実施した。

（4）益と害のバランス（Table 9-3-1）

望ましい効果 :

短期死亡（9 RCT, $\mathrm{n}=2,422 ）$ に関する効果推定值 
Table 9-3-1エビデンスプロファイル

\begin{tabular}{|c|c|c|c|c|c|c|c|c|c|c|c|c|}
\hline \multicolumn{7}{|c|}{ 確実性の評価 } & \multicolumn{2}{|c|}{ 患者数 } & \multicolumn{2}{|c|}{ 効果 } & \multirow[b]{2}{*}{ 確実性 } & \multirow[b]{2}{*}{ 重要性 } \\
\hline 研究数 & $\begin{array}{l}\text { 研究 } \\
\text { デザイン }\end{array}$ & $\begin{array}{l}\text { バイアス } \\
\text { のリスク }\end{array}$ & 非一貫性 & 非直接性 & 不精確性 & $\begin{array}{l}\text { その他 } \\
\text { の梌討 }\end{array}$ & 肺保請換气 & $\begin{array}{l}\text { 肺保讙換気 } \\
\text { 以外 }\end{array}$ & $\begin{array}{l}\text { 相狽指標 } \\
(95 \% \mathrm{CI})\end{array}$ & $\begin{array}{l}\text { 緢对指禋 } \\
(95 \% \mathrm{CI})\end{array}$ & & \\
\hline \multicolumn{13}{|c|}{ 短期死亡 } \\
\hline 9 & RCT & $\begin{array}{c}\text { 深刻でな } \\
\text { い }\end{array}$ & $\begin{array}{c}\text { 深刻でな } \\
\text { い }\end{array}$ & 深刻 a & 深刻でない & なし & $\begin{array}{c}446 / 1,217 \\
(36.6 \%)\end{array}$ & $\begin{array}{c}482 / 1,205 \\
(40.0 \%)\end{array}$ & $\begin{array}{c}\text { RR } 0.91 \\
\text { (0.78 to } 1.06)\end{array}$ & $\begin{array}{l}1,000 \text { 人あたり } 36 \\
\text { 人少ない ( } 88 \text { 人少 } \\
\text { ない } 24 \text { 人多い) }\end{array}$ & $\underset{\text { 中 }}{\oplus \oplus \oplus \bigcirc}$ & 重大 \\
\hline \multicolumn{13}{|c|}{ 人工呼吸離脱日数（28 日以内） } \\
\hline 3 & RCT & $\begin{array}{c}\text { 深刻でな } \\
\quad \text { い }\end{array}$ & 深刻 b & 深刻 & 深刻 c & なし & 958 & 953 & - & $\begin{array}{c}\text { 平均 } 1.79 \text { 日長い } \\
(0.62 \text { 日短い } \\
4.2 \text { 日長い) }\end{array}$ & $\begin{array}{l}\oplus \bigcirc \bigcirc \bigcirc \\
\text { 非常に低 }\end{array}$ & 重大 \\
\hline \multicolumn{13}{|l|}{ 压損傷 } \\
\hline 7 & RCT & $\begin{array}{c}\text { 深刻でな } \\
\text { い }\end{array}$ & $\begin{array}{c}\text { 深刻でな } \\
\text { い }\end{array}$ & 深刻 & 非常に二深刻 & なし & $\begin{array}{c}71 / 1,093 \\
(6.5 \%)\end{array}$ & $\begin{array}{c}79 / 1,089 \\
(7.3 \%)\end{array}$ & $\begin{array}{c}\text { RR } 0.89 \\
(0.57 \text { to } 1.38)\end{array}$ & $\begin{array}{l}1,000 \text { 人あたり } 8 \\
\text { 人少ない (31 人少 } \\
\text { ない } 28 \text { 人多い) }\end{array}$ & $\begin{array}{l}\oplus \bigcirc \bigcirc \bigcirc \\
\text { 非常に低 }\end{array}$ & 重大 \\
\hline \multicolumn{13}{|c|}{ 人工呼吸器関連肺炎 } \\
\hline 1 & RCT & 深刻。 & $\begin{array}{c}\text { 深刻でな } \\
\quad い\end{array}$ & 非常に深刻 千 & 非常に深刻d & なし & $\begin{array}{c}9 / 15 \\
(60.0 \%)\end{array}$ & $\begin{array}{c}6 / 13 \\
(46.2 \%)\end{array}$ & $\begin{array}{c}\text { RR } 1.30 \\
\text { (0.63 to } 2.67)\end{array}$ & $\begin{array}{c}1,000 \text { 人あたり } \\
138 \text { 人多い (171 } \\
\text { 人少ない〜 } 771 \text { 人 } \\
\text { 多い) }\end{array}$ & $\begin{array}{l}\oplus \bigcirc \bigcirc \bigcirc \\
\text { 非常に低 }\end{array}$ & 重要 \\
\hline
\end{tabular}

a. 対象集団の差異がある (ARDSを対象とした研究が多い)。

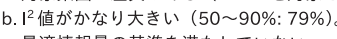

c. 最適情報量の基準を满たしていない。

d. 閾值を相対リスク比 $25 \%$ と設定した場合，信頼区間における上限および下限が臨床決断の閾值をまたぐと判断する。

e. バイアスのリスクが高または不明が多く含まれる。

f. 対象集団の差異がある (ARDS を対象とした研究のみである)。

は, conventional と比較し, 肺保護換気でリスク差 （RD）1,000 人あたり 36 人少ない $(95 \% \mathrm{CI}: 88$ 人少な い〜24 人多い）であった。VFD（3 RCT, $\mathrm{n}=1,911 ）$ に関しては平均（MD）1.79 日長い（95\%CI: 0.62 日短 い〜4.2 日長い）であった。望ましい効果は小さいと 判断した。短期死亡のエビデンスの確実性は「中」, VFD のエビデンスの確実性は「非常に低」であった。 望ましくない効果 :

圧損傷（7 RCT， $\mathrm{n}=2,182 ） に$ 関する効果推定値 は, conventional と比較し, 肺保護換気で RD 1,000人 あたり 8 人少ない $(95 \% \mathrm{CI}: 31$ 人少ない 28 人多い) であった。望ましくない効果はわずかと判断した。結 果の確実性は「非常に低」であった。

益と害のバランス :

肺保護換気はVFDに関しては同等，死亡および圧 損傷に関しては減少する傾向を示し，検討したアウト カムについては介入を支持する方向であったため，効 果のバランスは対照よりも「おそらく介入（肺保護換 気）が優位」と判断した。

\section{（5）アウトカム全般に関するエビデンスの確実性}

すべての望ましい効果と望ましくない効果の方向性 は一致しており，確実性は「中」あるいは「非常に 低」であった。そのため，アウトカム全体にわたるエ ビデンスの確実性は「中」と判断した。

\section{（6）価值観}

敗血症患者に対する肺保護換気においては，各アウ トカムに置く患者や家族の価值観に関するデータはな い。一般的に，死亡アウトカムに対して置く相対的価 值は高く，そのばらつきは少ないことが予想される。

\section{（7）容認性}

一般的な人工呼吸の設定の違いであり，すべての人 工呼吸器で実践できるため, 新たな資源は必要としな い。コストは増加しないため, 患者や家族の個人の視 点からもおそらく許容できると判断した。また，医療 従事者にとっても肺保護換気は人工呼吸設定の重要な 要素であり, 大きく仕事量が増加することもないた め，おそらく許容できると判断した。

\section{（8）実行可能性}

肺保護換気のためのパラメータは人工呼吸で一般的 に設定できる項目であり，多くの医療施設において実 行可能である。新たに人工呼吸器を購入しなければな らない医療施設においては，実行可能性のハードルが 上がる可能性がある。

（9）判断の要約（Table 9-3-2）

（10）推奨グレーディング決定の工程

修正 RAND 法を用いた投票によって，中央值 8, 見解不一致指数 0.164 の結果となり，委員会で採択さ 
Table 9-3-2 判断の要約

\begin{tabular}{|c|c|c|c|c|c|c|c|}
\hline & \multicolumn{7}{|c|}{ 判畋 } \\
\hline 問題 & いいえ & $\begin{array}{c}\text { おそらく、いい } \\
\text { え }\end{array}$ & おそらく、はい & はい & & さまざま & 分からない \\
\hline 望ましい効果 & わずか & 小さい & 中 & 大きい & & さまざま & 分からない \\
\hline 望ましくない効果 & 大きい & 中 & 小さい & わずか & & さまざま & 分からない \\
\hline エビデンスの確実性 & 非常に低 & 低 & 中 & 高 & & & 採用研究なし \\
\hline 価值覞 & $\begin{array}{c}\text { 重要な不確実性 } \\
\text { またはばらつき } \\
\text { あり }\end{array}$ & $\begin{array}{l}\text { 重要な不確実性 } \\
\text { またはばらつき } \\
\text { の可能性ありり }\end{array}$ & $\begin{array}{l}\text { 重要な不確実性 } \\
\text { またはばらつき } \\
\text { はおそらくなし }\end{array}$ & $\begin{array}{c}\text { 重要な不確実性 } \\
\text { またはばらつき } \\
\text { はなし }\end{array}$ & & & \\
\hline 勃果のパランス & 比較が優位 & $\begin{array}{c}\text { 比較がおそらく } \\
\text { 優位 }\end{array}$ & $\begin{array}{c}\text { 介入も比較もい } \\
\text { ずれも優位でな } \\
\text { い }\end{array}$ & $\begin{array}{c}\text { おそらく介入が } \\
\text { 優位 }\end{array}$ & 介入が優位 & さまざま & 分からない \\
\hline 容認性 & いいえ & $\begin{array}{c}\text { おそらく、いい } \\
\text { え }\end{array}$ & おそらく、はい & はい & & さまざま & 分からない \\
\hline 実行可能性 & いいえ & $\begin{array}{c}\text { おそらく、いい } \\
\text { え }\end{array}$ & おそらく、はい & はい & & さまざま & 分からない \\
\hline
\end{tabular}

れた（7点以上 : 100\%）。

\section{（11）関連する他の診療ガイドラインにおける推奨} SSCG 2016 10) では, 敗血症に起因する ARDS（acute respiratory distress syndrome）の患者では, 1 回換気量 の目標を $12 \mathrm{~mL} / \mathrm{kg} \mathrm{IBW}$ ではなく， $6 \mathrm{~mL} / \mathrm{kg}$ IBW に設定 することが強く推奨されている。また，敗血症に起因 する重症 ARDS 患者では, プラトー圧の上限は $30 \mathrm{cmH}_{2} \mathrm{O}$ を超えない設定を使用することが強く推奨 されている。いずれも具体的数值を示したうえでの強 い推奨である。

\section{（12）実施に関わる検討事項}

今回は，プラトー圧と 1 回換気量に関して検討を 行ったが，近年では駆動圧（driving pressure）や経肺 圧（transpulmonary pressure）もアウトカムに影響を来 すことが示されている。しかし，本メタ解析ではそれ らの圧に関しては検討できていないため, 自発呼吸を 伴う患者や胸郭コンプライアンスが高い患者において は十分に検討できていないことにも注意を要する。

\section{（13）今後の研究の可能性}

今後は，プラトー圧と 1 回換気量のみならず，駆動 圧や経肺圧も加味した検討を行うことが望まれる。

\section{文 献}

1) Amato MB, Barbas CS, Medeiros DM, et al: Effect of a protective ventilation strategy on mortality in the acute respiratory distress syndrome. N Engl J Med. 1998; 338: 347-54.

2) The Acute Respiratory Distress Syndrome Network: Ventilation
With Lower Tidal Volumes As Compared With Traditional Tidal Volumes for Acute Lung Injury and the Acute Respiratory Distress Syndrome. N Engl J Med. 2000; 342: 1301-8.

3) Brochard L, Roudot-Thoraval F, Roupiev E, et al: Tidal volume reduction for prevention of ventilator-induced lung injury in acute respiratory distress syndrome. Am J Respir Crit Care Med. 1998; 158: $1831-8$.

4) National Heart, Lung, and Blood Institute PETAL Clinical Trials Network, Moss M, Huang DT, et al: Early Neuromuscular Blockade in the Acute Respiratory Distress Syndrome. N Engl J Med. 2019; 380: 1997-2008.

5) Determann RM, Royakkers A, Wolthuis EK, et al: Ventilation with lower tidal volumes as compared with conventional tidal volumes for patients without acute lung injury: a preventive randomized controlled trial. Crit Care. 2010; 14: R1.

6) de Oliveira PR, Hetzel MP, dos Anjos Silva M, et al: Mechanical ventilation with high tidal volume induces inflammation in patients without lung disease. Crit Care. 2010; 14: R39.

7) Simonis FD, Serpa Neto A, Binnekade JM, et al: Effect of a Low vs Intermediate Tidal Volume Strategy on Ventilator-Free Days in Intensive Care Unit Patients Without ARDS: A Randomized Clinical Trial. JAMA. 2018; 320: 1872-80.

8) Stewart TE, Meade MO, DJ Cook, et al: Evaluation of a ventilation strategy to prevent barotrauma in patients at high risk for acute respiratory distress syndrome. N Engl J Med. 1998; 338: 355-61.

9) Villar J, Kacmarek RM, Pérez-Méndez L, et al: A high positive end-expiratory pressure, low tidal volume ventilatory strategy improves outcome in persistent acute respiratory distress syndrome: a randomized, controlled trial. Crit Care Med. 2006; 34: 1311-8.

10) Rhodes A, Evans LE, Alhazzani W, et al: Surviving Sepsis Campaign: International Guidelines for Management of Sepsis and Septic Shock: 2016. Intensive Care Med. 2017; 43: 304-77. 
CQ9-4：成人敗血症患者の人工呼吸管理におい て, 高 PEEP 設定を行うか?

Answer : 成人敗血症患者の人工呼吸管理の初期にお いては高 PEEP 設定（PEEP $12 \mathrm{cmH}_{2} \mathrm{O}$ 以上）を用いな いことを弱く推奨する（GRADE 2D：エビデンスの確 実性 $=$ 「非常に低」)。

\section{（1）背景および本 $C Q$ の重要度}

重症患者における人工呼吸管理において，人工呼吸 器関連肺傷害を来さない管理は患者予後改善のために 必須である。人工呼吸器関連肺傷害を引き起こす可能 性のある因子として，1 回換気量とプラト一圧のほか に無気肺も示唆されており, 無気肺を改善, つまり機 能的残気量を増加させるために付与する PEEP が患者 予後改善に寄与することが示唆されている。しかし, 高い PEEP は気胸の発生や循環抑制などの有害事象発 生の一因ともなるため, PEEP 設定が本当に予後改善 に寄与するのか，特に人工呼吸管理の初期においては どれくらいの PEEP が適切なのかを知ることは重要な 臨床課題と考えられる。

(2) PICO

$P$ (患者) : 敗血症で人工呼吸管理を必要とする重症
患者

I（介入）：高 PEEP 設定

$\mathrm{C}$ (対照)：低 PEEP 設定

$\mathrm{O}$ (アウトカム) : 短期死亡（ICU 死亡 or 院内死亡 or 研究終了 or 90 日以内死亡。最大のものを採 択), 人工呼吸離脱日数 (VFD, 28 日以内), 圧 損傷, $\mathrm{PaO}_{2} / \mathrm{F}_{1} \mathrm{O}_{2}$ (Day 1 3 の最大值), PEEP に よる循環不全

（3）エビデンスの要約

システマティックレビューの結果，PICO に合致し たランダム化比較試験（RCT）が７件 1-7) 施行されて おり,これらを用いたメタ解析を実施した。

\section{（4）益と害のバランス（Table 9-4-1）}

望ましい効果 :

短期死亡（7 RCT, $\mathrm{n}=3,657 ） に$ 関する効果推定值 とその信頼区間は，低い PEEP と比べて高 PEEPでは, リスク差（RD）1,000 人あたり 8 人少ない $95 \%$ CI: 54 人少ない〜 47 人多い) であった。一方, VFD（3 $\mathrm{RCT}, \mathrm{n}=1,654)$ に関する効果推定值は平均（MD） 0.45 日長い (95\% CI: 2.02 日短い〜2.92 日長い) で あった。望ましい効果はわずかであると判断した。短 期死亡のエビデンスの確実性は「中」, VFD のエビデ

Table 9-4-1エビデンスプロファイル

\begin{tabular}{|c|c|c|c|c|c|c|c|c|c|c|c|c|}
\hline \multicolumn{7}{|c|}{ 碓実性の誰価 } & \multicolumn{2}{|c|}{ 患者数 } & \multicolumn{2}{|c|}{ 効果 } & \multirow[b]{2}{*}{ 確実性 } & \multirow[b]{2}{*}{ 重要性 } \\
\hline 研究数 & $\begin{array}{l}\text { 研究 } \\
\text { デサイン }\end{array}$ & $\begin{array}{l}\text { パイアス } \\
\text { のリスク }\end{array}$ & 非一貫性 & 非直接性 & 不精磼性 & $\begin{array}{l}\text { その他 } \\
\text { の楛討 }\end{array}$ & 高 PEEP & 低 PEEP & $\begin{array}{l}\text { 相対指標 } \\
(95 \% \text { ) }\end{array}$ & $\begin{array}{l}\text { 緦対指標 } \\
(95 \% \text { CI }\end{array}$ & & \\
\hline \multicolumn{13}{|c|}{ 短期死亡 } \\
\hline 7 & RCT & 深刻でない & 深刻てない & 深刻 a & 深刻でない & なし & $\begin{array}{c}706 / 1,815 \\
(38.9 \%)\end{array}$ & $\begin{array}{c}717 / 1,842 \\
(38.9 \%)\end{array}$ & $\begin{array}{l}\text { RR } 0.98 \\
(0.86 \text { to } \\
1.12)\end{array}$ & $\begin{array}{c}\text { 1, 000人あたり } \\
\text { 少ない } 54 \text { (54 } \\
\text { 少ない〜 } 47 \text { 人多 } \\
\text { い) }\end{array}$ & $\underset{\text { 中 }}{\oplus \oplus \oplus \bigcirc}$ & 重大 \\
\hline \multicolumn{13}{|c|}{ 人工呼吸離脱日数 } \\
\hline 3 & RCT & 深刻でない & 非常|=深刻 b & 深刻 a & 深刻でない & なし & 827 & 827 & - & $\begin{array}{l}\text { 平均 } 0.45 \text { 日長い } \\
(2.02 \text { 日短い } \\
2.92 \text { 日長い) }\end{array}$ & $\begin{array}{l}\oplus \bigcirc \bigcirc \bigcirc \\
\text { 非常に低 }\end{array}$ & 重大 \\
\hline \multicolumn{13}{|l|}{ 压損傷 } \\
\hline 6 & RCT & 深刻でない & 深刻。 & 深刻 a & 非常に深刻 d & なし & $\begin{array}{c}122 / 1,716 \\
(7.1 \%)\end{array}$ & $\begin{array}{c}101 / 1,741 \\
(5.8 \%)\end{array}$ & $\begin{array}{l}\text { RR } 1.08 \\
(0.61 \text { to } \\
1.91)\end{array}$ & 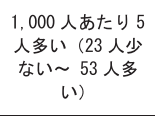 & $\begin{array}{l}\oplus \bigcirc \bigcirc \bigcirc \\
\text { 非常に低 }\end{array}$ & 重大 \\
\hline \multicolumn{13}{|c|}{$\mathrm{PaO}_{2} / \mathrm{F}_{1} \mathrm{O}_{2}$} \\
\hline 6 & RCT & 深刻でない & 深刻てない & 深刻。 & 深刻でい & なし & 1,135 & 1,174 & - & $\begin{array}{l}\text { 平均 } 57.71 \text { 高い } \\
(35.13 \text { 高い } \\
80.3 \text { 高い }\end{array}$ & $\underset{\text { 中 }}{\oplus \oplus \oplus \bigcirc}$ & 重要 \\
\hline \multicolumn{13}{|c|}{ PEEPによる循環不全 } \\
\hline 1 & RCT & 深刻 ${ }^{f}$ & 深刻でない & 深刻 ${ }^{a}$ & 深刻てない & なし & $\begin{array}{l}174 / 501 \\
(34.7 \%)\end{array}$ & $\begin{array}{l}144 / 509 \\
(28.3 \%)\end{array}$ & $\begin{array}{l}\text { RR } 1.23 \\
(1.02 \text { to } \\
1.47)\end{array}$ & $\begin{array}{l}\text { 1,000人あたり } \\
65 \text { 人多い(6人 } \\
\text { 多い133人多 } \\
\text { い) }\end{array}$ & $\underset{\text { 低 }}{\oplus \oplus \bigcirc \bigcirc}$ & 重大 \\
\hline
\end{tabular}

、対象とされている研究の大半は ARDS 患者を対象をしているため，PEEP の効果が非 ARDS 患者とは異なる可能性がある。 b. $I^{2}=81 \%$ ，かつ結果の方向性が各研究で異なる。

c. $I^{2}=70 \%$ ，かつ結果の方向性が各研究で異なる。

d. 閔値を相対リスク比 $25 \%$ と設定した場合，信頼区間における上限および下限が臨床決断の閾値をまたぐと判断する。

e. $I^{2}=96 \%$ あるが各研究の結果の方向性が一致しているため, グレードは下げなかった

f,バイアスのリスクが高または不明が多く含まれる。 
ンスの確実性は「非常に低」であった。

望ましくない効果 :

圧損傷発生率（6 RCT, $\mathrm{n}=3,457 ）$ に関する効果推 定值は低 PEEP と比べて高 PEEPでは RD 1,000人あ たり 5 人多い $(95 \% \mathrm{CI}: 23$ 人少ない〜 53 人多い）で あった。また，循環不全発生（1 RCT, $\mathrm{n}=1,010 ） に$ 対する効果推定值は高 PEEP で RD 1,000 人あたり 65 人多い $(95 \% \mathrm{CI}: 6$ 人多い〜133 人多い) であった。し たがって，望ましくない効果は小さいと判断した。圧 損傷発生のエビデンスの確実性は「非常に低」，循環 不全発生のエビデンスの確実性は「低」であった。

\section{益と害のバランス :}

望ましい効果としての短期死亡と VFD では，いず れも優劣がつけられなかった。望ましくない効果とし ての圧損傷には優劣は認めなかったが，循環不全発生 に関しては増加する方向性を認めた。1 論文しか対象 となっていない循環不全発生のアウトカムの結果だけ をもって比較（低 PEEP）が介入（高 PEEP）と比較 して優位とは断定できないが，望ましくない効果と望 ましい効果の全体のバランスに鑑みて，望ましくない 効果が若干大きいと判断した。なお，エビデンスにお ける不正確さは圧損傷においては非常に深刻であった が，そのほかの重大なアウトカムでは深刻ではなかっ た。以上より, 効果のバランスは介入（高 PEEP 設定） よりも「比較（低 PEEP 設定）がおそらく優位」と判 断した。

\section{（5）アウトカム全般に関するエビデンスの確実性}

望ましい効果は「わずか」，望ましくない効果は 「小さい」であり，各アウトカムが異なる方向を示す ため，アウトカム全体にわたるエビデンスの確実性は
「非常に低」とした。

\section{（6）価値観}

敗血症患者の人工呼吸においては，各アウトカムに 置く患者や家族の価值観に関するデータはない。一般 的に，望ましい効果として死亡アウトカムやVFDに 対して置く相対的価值や，望ましくない効果として， 圧外傷に対して置く相対的価值は高くそのばらつきは 少ないことが予想される。特に循環不全に関しては敗 血症性ショックを助長させる可能性があり，相対的価 值は高いと考えられる。

\section{（7）容認性}

人工呼吸設定において PEEP を調整することによる コストの増加はなく，患者や家族の個人および病院経 営者や医療政策に関わる人々の視点から，おそらく許 容できると判断した。また，PEEPの設定によって， 医療従事者の仕事量が大きく増加することがないた め,おそらく許容できると判断した。

\section{（8）実行可能性}

PEEPは人工呼吸で一般的に設定できる項目であり， 多くの医療施設において実行可能である。新たに人工 呼吸器を購入しなければならない医療施設において は，実行可能性のハードルが上がる可能性がある。

（9）判断の要約（Table 9-4-2）

（10）推奨グレーディング決定の工程

修正 RAND 法を用いた投票によって, 中央值 7, 見解不一致指数 0.164 の結果となり，委員会で採択さ

Table 9-4-2 判断の要約

\begin{tabular}{|c|c|c|c|c|c|c|c|}
\hline & \multicolumn{7}{|c|}{ 判㽧 } \\
\hline 問題 & いいえ & おそらく、いいえ & おそらく、はい & はい & & さまざま & 分からない \\
\hline 望ましい効果 & わずか & 小さい & 中 & 大きい & & さまざま & 分からない \\
\hline 望ましくない効果 & 大きい & 中 & 小さい & わずか & & さまざま & 分からない \\
\hline エビデンスの確実性 & 非常に低 & 低 & 中 & 高 & & & 採用研究なし \\
\hline 価值観 & $\begin{array}{c}\text { 重要な不確実性 } \\
\text { またはばらつき } \\
\text { あり }\end{array}$ & $\begin{array}{c}\text { 重要な不確実性ま } \\
\text { たはばらつきの可 } \\
\text { 能性ありり }\end{array}$ & $\begin{array}{l}\text { 重要な不確実性 } \\
\text { またはばらつき } \\
\text { はおそらくなし }\end{array}$ & \begin{tabular}{|c} 
重要な不確実性 \\
またははばらつき \\
はなし
\end{tabular} & & & \\
\hline 効果のバランス & 比較が優位 & $\begin{array}{c}\text { 比較がおそらく } \\
\text { 優位 }\end{array}$ & $\begin{array}{c}\text { 介入も比較もい } \\
\text { ずれも優位でな } \\
\text { い }\end{array}$ & \begin{tabular}{|l|} 
おそそくく入が \\
優位
\end{tabular} & 介入が優位 & さまざま & 分からない \\
\hline 容認性 & いいえ & おそらく、いいえ & おそらく、はい & はい & & さまざま & 分からない \\
\hline 実行可能性 & いいえ & おそらく、いいえ & おそらく、はい & はい & & さまざま & 分からない \\
\hline
\end{tabular}


れた（7点以上 : 87.5\%）。

\section{（11）関連する他の診療ガイドラインにおける推奨}

SSCG 2016 ${ }^{8)}$ では，敗血症に起因する中等度から重 症の ARDS 患者では，低い PEEPよりも高い PEEP の 使用が弱く推奨されている。これは, 中等度から重症 の ARDS 患者では，より高い PEEPにより死亡率が低 下するとのメタ解析の結果に基づく。PEEPを上げる ことで酸素化が改善する，または，駆動圧が低下する 症例では，PEEPの恩恵を受ける可能性がある。ただ し，今回の解析とは対象が若干異なることに留意され たい。

\section{（12）実施に関わる検討事項}

PEEP の効果は敗血症の重症度により異なる可能性 があるが，重症度の低い患者における高 PEEP の有効 性と害に関しては検討できていない。よって，ARDS に陥った場合には，ARDS の重症度に応じて PEEPを 上げることを検討する必要がある。ただし，敗血症性 ショックの状態では，高 PEEPによる循環抑制が強調 されると思われるため，特に循環不全を伴う患者では 注意を要する。

なお，呼吸不全に至ってから介入までの時間も PEEPによる効果と害に影響を与えることが考えられ， 実際に本推奨を患者に適用する際には注意する必要が ある。また，本推奨は，循環動態が比較的安定してお り，酸素化が悪化している患者において，医療者の判 断により高めの PEEP を使用することを妨げるもので はない。

\section{（13）今後の研究の可能性}

今後は, 単なる PEEP 值の高低のみならず, APRV （airway pressure release ventilation）などの PEEP 付加 の様式による違いやリクルートメント手技併用の有無 が，アウトカムに影響を与える可能性を検討すること が望まれる。

\section{文 献}

1) Amato MBP, Barbas CSV, Medeiros DM, et al: Effect of a protective ventilation strategy on mortality in the acute respiratory distress syndrome. Pneumologie. 1998; 52: 285.

2) The National Heart, Lung, and Blood Institute PETAL Clinical Trials Network: Early Neuromuscular Blockade in the Acute Respiratory Distress Syndrome. N Engl J Med. 2019; 380: 1997-2008.

3) Writing Group for the Alveolar Recruitment for Acute Respiratory Distress Syndrome Trial (ART) Investigators, Cavalcanti AB, SuzumuraÉA, et al: Effect of lung recruitment and titrated Positive End-Expiratory Pressure (PEEP) vs low PEEP on mortality in patients with acute respiratory distress syndrome: A randomized clinical trial. JAMA. 2017; 318: 1335-45.

4) Kacmarek RM, Villar J, Sulemanji D, et al: Open lung approach for the acute respiratory distress syndrome: A pilot, randomized controlled trial. Crit Care Med. 2016; 44: 32-42.

5) Meade MO, Cook DJ, Guyatt GH, et al: Ventilation strategy using low tidal volumes, recruitment maneuvers, and high positive end-expiratory pressure for acute lung injury and acute respiratory distress syndrome: A randomized controlled trial. JAMA. 2008; 299: 637-45.

6) Mercat A, Richard JC, Vielle B, et al: Positive end-expiratory pressure setting in adults with acute lung injury and acute respiratory distress syndrome: A randomized controlled trial. JAMA. 2008; 299: 646-55.

7) Villar J, Kacmarek RM, Pérez-Méndez L, et al: A high positive end-expiratory pressure, low tidal volume ventilatory strategy improves outcome in persistent acute respiratory distress syndrome: A randomized, controlled trial. Crit Care Med. 2006; 34: 1311-8.

8) Rhodes A, Evans LE, Alhazzani W, et al: Surviving Sepsis Campaign: International Guidelines for Management of Sepsis and Septic Shock: 2016. Intensive Care Med. 2017; 43: 304-77. 
CQ9-5：人工呼吸管理となった成人敗血症患者 に対して，抜管前に自発呼吸トライアル（SBT） を行うか?

Answer：人工呼吸管理となった成人敗血症患者に対 して，抜管前に自発呼吸トライアル（SBT）を含めた 人工呼吸器からのウィーニングのプロトコルを用いる ことを弱く推奨する（GRADE 2D：エビデンスの確実 性 $=$ 「非常に低」)。

\section{（1）背景および本 $C Q$ の重要度}

敗血症患者の致死率は依然として高く，治療成績を 向上させる介入法の確立は急務である。人工呼吸管理 においては, 人工呼吸器関連肺炎や人工呼吸器関連肺 傷害を来さないように早期離脱を試みることが患者の 転帰改善のために重要である。日常臨床において, 臨 床医は抜管後の呼吸状態を過小評価しがちであり，主 観的な方法に頼ると離脱が遅れ，人工呼吸が長期化す る危険性がある。日々の自発呼吸トライアル（spontaneous breathing trial: SBT) の実施が，人工呼吸器の設 定を徐々に変更する方法よりも抜管までの期間を短縮 することが報告されているが，現状では SBT を含め た人工呼吸器からのウィーニングのプロトコルの有効 性・有害性の評価は定まっておらず，臨床現場でもそ の判断については多様性がある。そのため, SBTを 含めた人工呼吸器からのウィーニングのためのプロト コルの有用性や具体的な方法を検討することは，敗血 症診療の専門家だけでなく, 非専門家にとっても重要 な臨床課題であると考えられる。
(2) PICO

P (患者) : 人工呼吸管理を必要とする患者

I（介入）：プロトコル化されたウィーニング（SBT を含んだウィーニング)

$\mathrm{C}$ (対照)：プロトコル化されていないウィーニング (SBT 実施なし)

$\mathrm{O}$ (アウトカム) : 短期死亡（ICU 死亡 or 院内死亡 or 研究終了 or 90 日以内死亡。最大のものを採 択）, 再挿管（抜管後 48～72 時間以内, NIV 装 着を含む)，人工呼吸器離脱期間（VFD，28 日以 内), ICU 滞在日数

\section{（3）エビデンスの要約}

システマティックレビューの結果，PICO に合致し たランダム化比較試験（RCT）が 10 件 1-10）施行され ており,これらを用いたメタ解析を実施した。

\section{（4）益と害のバランス（Table 9-5-1）}

望ましい効果 :

短期死亡（8 RCT, $\mathrm{n}=1,282 ）$ に関する効果推定値 は，プロトコルなしと比べて，プロトコルありでリス ク差（RD）1,000 人あたり 10 人少ない（95\% CI: 52 人少ない〜 45 人多い) であった。VFDについては該 当文献がなかった。再挿管（7 RCT, $\mathrm{n}=1,081 ）$ に関 する効果推定值は, プロトコルなしと比べて, プロト コルありでRD 1,000 人あたり 24 人少ない $(95 \% \mathrm{CI}$ : 61 人少ない 41 人多い）であった。短期死亡も再挿 管も減少させる方向性を示したが，その効果はそれほ ど大きいとはいえないため,「小さい」と判断した。 短期死亡，再挿管のエビデンスの確実性はいずれも

Table 9-5-1 エビデンスプロファイル（メタ解析）

\begin{tabular}{|c|c|c|c|c|c|c|c|c|c|c|c|c|}
\hline \multicolumn{7}{|c|}{ 確実性の評価 } & \multicolumn{2}{|c|}{ 恵者数 } & \multicolumn{2}{|c|}{ 効果 } & \multirow[b]{2}{*}{ 確实性 } & \multirow[b]{2}{*}{ 重要性 } \\
\hline 研究数 & $\begin{array}{l}\text { 研究 } \\
\text { デザイン }\end{array}$ & $\begin{array}{l}\text { パイアス } \\
\text { のリスク }\end{array}$ & 非一貫性 & 非直接性 & 不精確性 & $\begin{array}{l}\text { その他 } \\
\text { の模討 }\end{array}$ & $\begin{array}{c}\text { プロトコル化さ } \\
\text { れだィーニン } \\
\text { グ }\end{array}$ & $\begin{array}{l}\text { プロトコル化され } \\
\text { ていない゙ィーニ } \\
\text { ング }\end{array}$ & $\begin{array}{l}\text { 相対指標 } \\
(95 \% \text { (I) }\end{array}$ & $\begin{array}{l}\text { 總対指標 } \\
(95 \% \text { I }\end{array}$ & & \\
\hline \multicolumn{13}{|c|}{ 短期死亡（ICU 死亡 or 院内死亡 or 研究終了 or 90 日以内死亡。最大のものを採択） } \\
\hline 8 & RCT & 深刻 a & 深刻でい & 深刻てない & 非常に深刻 b & なし & $\begin{array}{l}104 / 640 \\
\left(16.33^{*}\right)\end{array}$ & $111 / 642(17.3 \%)$ & $\begin{array}{l}\text { RR } 0.94 \\
(0.70 \text { to } \\
1.26)\end{array}$ & $\begin{array}{c}\text { 1,000人あたり } \\
10 \text { 人少ない } \\
\text { 人少ない } 52 \\
\text { 多い) }\end{array}$ & $\begin{array}{l}\oplus \circ \bigcirc \bigcirc \\
\text { 非常に二低 }\end{array}$ & 重大 \\
\hline \multicolumn{13}{|c|}{ 再掩管（抜管後 $48 \sim 72$ 時間以内，NIV 装着も含む） } \\
\hline 7 & RCT & 深刻。 & 深刻でない & 深刻てない & 非常|深刻 b & なし & $\begin{array}{l}50 / 542 \\
(11.1 \%)\end{array}$ & $59 / 539(11.0 \%)$ & $\begin{array}{l}\text { RR } 0.78 \\
(0.45 \text { to } \\
1.37)\end{array}$ & $\begin{array}{c}\text { 1, 000 人あたり } \\
24 \text { 人少ない }(61 \\
\text { 人少ない 41 } \\
\text { 多い) }\end{array}$ & $\begin{array}{l}\oplus \bigcirc \bigcirc \bigcirc \\
\text { 非常に低 }\end{array}$ & 重大 \\
\hline \multicolumn{13}{|c|}{ ICU 滞在日数 } \\
\hline 5 & RCT & 深刻 a & 深刻でない & 深刻でない & 深刻。 & なし & 348 & 354 & - & $\begin{array}{c}\text { 平均 } 0.89 \text { 日短い } \\
(2.73 \text { 日短い } \\
0.95 \text { 日長い) }\end{array}$ & $\underset{\text { 低 }}{\oplus \oplus O O}$ & 重要 \\
\hline
\end{tabular}

a. バイアスのリスクが高または不明の研究が複数あるが，全体への寄与度は高くないため。

c. 最適情報量の基準を満たしていない。 
「非常に低」であった。ICU 滞在日数の評価も行った がアウトカムの重要度は「重要」であったため, 今回 の EtD の検討には加えていない。

\section{望ましくない効果 :}

今回の検討では，望ましくない効果を示すアウトカ ムは採用されなかったため評価はできず，「分からな いよと判断した。

益と害のバランス :

$\mathrm{SBT}$ を含めた人工呼吸器からのウィーニングのプ ロトコルは，短期死亡と再指管いずれに関しても減少 させる方向性を示した。望ましくない効果については 該当アウトカムがなく評価できていないが，効果バラ ンスは対照（プロトコル化されていないウィーニン グ）よりも「おそらく介入（プロトコル化された ウィーニング）が優位」であると判断した。

\section{（5）アウトカム全般に関するエビデンスの確実性}

すべての望ましい効果の方向性は一致しており, 確 実性はいずれも「非常に低」であった。以上より，ア ウトカム全体にわたるエビデンスの確実性は「非常に 低」と判断した。

\section{（6）価値観}

敗血症患者に対する SBT を含めた人工呼吸器から のウィーニングのプロトコルにおける，各アウトカム に置く患者・家族の価值観に関するデータはない。一 般的に, 死亡アウトカムに対して置く相対的価值は高 く，そのばらつきは少ないことが予想される。

\section{（7）容認性}

抜管前の非侵襲的な試験を行うかどうかであり，す べての挿管患者で抜管前に実践できる試験であるた め, 新たな資源は必要としない。呼吸器設定の変更と いう単純かつ簡単な介入のため，看護師や医師の労力 はそれほど増加しない。コストも増加しないので患 者・家族の個人の視点からもおそらく許容できる。

\section{（8）実行可能性}

人工呼吸管理における一般的な操作ならびに評価方 法であるため, どの病院においても実行可能性は高い といえる。

（9）判断の要約（Table 9-5-2）

（10）推奨グレーディング決定の工程

修正 RAND 法を用いた投票によって，中央值 7.5, 見解不一致指数 0.164 の結果となり, 委員会で採択さ れた（7 点以上：87.5\%）。

（11）関連する他の診療ガイドラインにおける推奨 本 $\mathrm{CQ}$ と類似したテーマを扱っている他のガイドラ インは検索する限り見当たらなかった。

\section{（12）実施に関わる検討事項}

今回は，初回の SBTを含めた人工呼吸器からの ウィーニングに関して検討を行った。よって，複数回 にわたり SBTを失敗している患者に対しては，本メ 夕解析では検討できていないことに注意を要する。ま た，抜管後呼吸不全を来すリスクなどでの層別解析も

Table 9-5-2 判断の要約

\begin{tabular}{|c|c|c|c|c|c|c|c|}
\hline & \multicolumn{7}{|c|}{ 判断 } \\
\hline 問題 & いいえ & おそらく、いいえ & おそらく、はい & はい & & さまざま & 分からない \\
\hline 望ましい効果 & わずか & 小さい & 中 & 大きい & & さまざま & 分からない \\
\hline 望ましくない効果 & 大きい & 中 & 小さい & わずか & & さまざま & 分からない \\
\hline エビデンスの確実性 & 非常に低 & 低 & 中 & 高 & & & 採用研究なし \\
\hline 価值襀 & $\begin{array}{c}\text { 重要な不確実性 } \\
\text { またははよらつき } \\
\text { あり }\end{array}$ & $\begin{array}{c}\text { 重要な不確実性ま } \\
\text { たはばらつきの可 } \\
\text { 能性あり }\end{array}$ & $\begin{array}{l}\text { 重要な不確実性 } \\
\text { またははばらつ } \\
\text { はおそらくなし }\end{array}$ & $\begin{array}{c}\text { 重要な不確実性 } \\
\text { またははららつき } \\
\text { はなし }\end{array}$ & & & \\
\hline 効果のパランス & 比較が優位 & $\begin{array}{c}\text { 比較がおそらく } \\
\text { 優位 }\end{array}$ & $\begin{array}{c}\text { 介入も比較もい } \\
\text { ずれも優位でな } \\
\text { い }\end{array}$ & $\begin{array}{c}\text { おそらく介入が } \\
\text { 優位 }\end{array}$ & 介入が優位 & さまざま & 分からない \\
\hline 容認性 & いいえ & おそらく、いいえ & おそらく、はい & はい & & さまざま & 分からない \\
\hline 実行可能性 & いいえ & おそらく、いいえ & おそらく、はい & はい & & さまざま & 分からない \\
\hline
\end{tabular}


できていないことから，すべての患者において本推奨 を適用できるかは慎重に判断する必要がある。

\section{（13）今後の研究の可能性}

今後は, 患者の重症度別, 抜管後呼吸不全を来すリ スク別, 病態別の SBTを含めた人工呼吸器からの ウィーニングプロトコルの効果を検討することが望ま れる。

\section{文 献}

1) Kollef MH, Shapiro SD, Silver P, et al: A randomized, controlled trial of protocol-directed versus physician-directed weaning from mechanical ventilation. Crit Care Med. 1997; 25: 567-74.

2) Marelich GP, Murin S, Battistella F, et al: Protocol weaning of mechanical ventilation in medical and surgical patients by respiratory care practitioners and nurses: effect on weaning time and incidence of ventilator-associated pneumonia. Chest. 2000; 118 : 459-67.

3) Namen AM, Ely EW, Tatter SB, et al: Predictors of successful extubation in neurosurgical patients. Am J Respir Crit Care Med. 2001; 163: 658-64.

4) Ma YM, Liu YN, Pan L: The effect of spontaneous breathing trial on weaning from ventilators. Zhonghua Jie $\mathrm{He} \mathrm{He} \mathrm{Hu} \mathrm{Xi} \mathrm{Za}$ Zhi. 2010; 33: 179-82.

5) Piotto RF, Maia LN, Machado MN, et al: Effects of the use of mechanical ventilation weaning protocol in the Coronary Care Unit: randomized study. Rev Bras Cir Cardiovasc. 2011; 26: 213-21.

6) Roh JH, Synn A, Lim CM, et al: A weaning protocol administered by critical care nurses for the weaning of patients from mechanical ventilation. J Crit Care. 2012; 27: 549-55.

7) Wang J, Ma Y, Fang Q: Extubation with or without spontaneous breathing trial. Crit Care Nurse. 2013; 33: 50-5.

8) Fan L, Su Y, Elmadhoun OA, et al: Protocol-directed weaning from mechanical ventilation in neurological patients: a randomised controlled trial and subgroup analyses based on consciousness. Neurol Res. 2015; 37: 1006-14.

9) Chaiwat O, Sarima N, Niyompanitpattana K, et al: Protocoldirected vs. physician-directed weaning from ventilator in intraabdominal surgical patients. J Med Assoc Thai. 2010; 93: 930-6.

10) Ely EW, Baker AM, Dunagan DP, et al: Effect on the duration of mechanical ventilation of identifying patients capable of breathing spontaneously. N Engl J Med. 1996; 335: 1864-9.
CQ9-6：人工呼吸管理となった成人敗血症患者 に対して，抜管後に予防的な非侵襲的人工呼吸 （NIV）または経鼻高流量療法（NHFT）を行う か?

Answer：人工呼吸管理となった成人敗血症患者に対 して，抜管後に通常の酸素療法よりは予防的な非侵襲 的人工呼吸 (NIV) もしくは経鼻高流量療法（NHFT） を行うことを弱く推奨する（GRADE 2B：エビデンス の確実性 $=\lceil$ 中」)。

\section{（1）背景および本 $C Q$ の重要度}

抜管後の呼吸不全の原因には，上気道閉塞や不十分 な気道浄化, 過剰な気道分泌物, 肺水腫, 心不全など がある。このような抜管後の呼吸不全が生じると，再 挿管を要する可能性がある。抜管後呼吸不全による再 挿管では, 緊急気管扦管による誤嚥性肺炎の発症や再 鎮静による影響などの合併症が生じる可能性があり, 人工呼吸期間や ICU 滞在日数の延長と関連するため, 抜管後の呼吸不全を予防する必要がある。抜管後の呼 吸不全の予防のためには, NIVやNHFT などの使用 が知られている。抜管後の呼吸不全予防のための呼吸 管理を明らかにすることは, 敗血症診療の専門家のみ ならず，非専門家にとっても重要な臨床課題であると 考えられる。

(2) PICO

P (患者)：急性呼吸不全で人工呼吸管理を 12 時間 以上必要とし，SBT をクリアした患者

I（介入)/C（対照）：抜管直後に予防的に以下の呼 吸管理デバイスのいずれかを使用

1. NIV（マスク，モード，NIV 時間，ウィーニ ング方法は問わない)

2. NHFT（流量, $\mathrm{F}_{\mathrm{I}} \mathrm{O}_{2}$ は問わない)

3. COT (conventional oxygen therapy) : 鼻カニュ ラ, フェイスマスク, ベンチュリーマスク，流 量は問わない

$\mathrm{O}$ (アウトカム)：再挿管（24～72 時間以内の再挿 管), 短期死亡 (ICU 死亡 or 院内死亡 or 研究終 了 or 90 日以内死亡。最大のものを採択)，抜管 後呼吸不全（各文献ごとの定義）, 皮膚障害, 機 器による不快感, 乾燥による不快感

\section{（3）エビデンスの要約}

システマティックレビューの結果，PICO に合致し たランダム化比較試験（RCT）が 13 件 1-13）施行され 
ており，これらを用いたメタ解析およびネットワーク メタ解析（NMA）を実施した。

（4）益と害のバランス（Table 9-6-1，9-6-2） 望ましい効果 :

本 CQ はNMA を用いて検討した。

短期死亡に関するネットワーク効果推定值（Table 9-6-2）は, COTと比べて, NHFTでリスク差（RD） 1,000 人あたり 12 人少ない $(95 \% \mathrm{CI}: 32$ 人少ない〜 16 人多い) [エビデンスの確実性は「中」]（4 RCT, n $=802)$, NIV でRD 1,000 人あたり 31 人少ない $(95 \%$ CI: 53 人少ない〜 1 人多い) [エビデンスの確実性は 「中」] (5 RCT, $\mathrm{n}=784)$, そして NHFT と比べて, NIV でRD 1,000 人あたり 43 人少ない (95\% CI: 102 人少ない〜32人多い) [エビデンスの確実性は「中」] （1 RCT, n=604）であった。

再挿管に関するネットワーク効果推定值は, COT と比べて, NHFT でRD 1,000人あたり 69 人少ない ( $95 \%$ CI: 99 人少ない〜 12 人少ない) [エビデンスの 確実性は「低」]（5 RCT， n=862）, NIV で RD 1,000 人あたり 66 人少ない $(95 \% \mathrm{CI}: 99$ 人少ない〜 1 人少 ない）［エビデンスの確実性は「中」］（4 RCT， n = 664)，そして NHFT と比べて, NIV でRD 1,000人あ たり 16 人多い $(95 \% \mathrm{CI}: 109$ 人少ない〜271 人多い) [エビデンスの確実性は非常に「低」]（1 RCT， n = 604）であった。

また，短期死亡における surface under the cumulative ranking（SUCRA）は NIV 91.8, NHFT 46.3, COT 11.8 であり, 再挿管における SUCRA は NIV 69.8, NHFT 77.8, COT 2.8 であった。

望ましくない効果 :

今回の検討では, 望ましくない効果として検討した アウトカム（皮膚障害, 機器による不快感, 乾燥によ る不快感）の重要度は「重要」との評価であったた め, 本 EtD には含まれなかった。

益と害のバランス :

NIVやNHFT を適用すれば，挿管に伴う不利益は 回避できる可能性がある。しかし，望ましくない効果 に関しては検討できていない。インターフェイスによ る皮膚障害や不快感などの望ましくない効果が可能性 として挙げられるが, 重要度は低いために, 効果のバ ランスは比較対照（COTを行う）よりも「おそらく 介入（NIVまたはNHFTを行う）が優位」と判断し た。
（5）アウトカム全般に関するエビデンスの確実性 エビデンスの方向性としては，気管抻管のアウトカ ムにおいてのみ COT に対して NIV と NHFT において 再挿管を減少させる方向であった。望ましくない効果 に関しては評価できていない。よって, NIV と NHFT に優劣はつけられず，両者を合わせて推奨する方針と した。そのような状況において, SUCRAの数值を参 考にエビデンスの方向性を判断すると, COT と NIV またはNHFTの 2 群においてエビデンスの方向性は 一致していると判断でき, エビデンスの確実性は「重 大なアウトカムに関するエビデンスの確実性の中で最 も高いグレード」を全体的なエビデンスの確実性とし た。したがって，アウトカム全体にわたるエビデンス の確実性は「中」と判断した。

\section{（6）価値観}

抜管後の呼吸管理デバイスの選択では, 各アウトカ ムに置く患者や家族の価值観に関するデータはない。 一般的に，死亡や再挿管アウトカムに対して置く相対 的価值は高く, そのばらつきは少ないことが予想され る。

\section{（7）容認性}

呼吸管理に必要な要素は, デバイスの有無, デバイ スや酸素のコスト，デバイスに対する容認性が挙げら れる。NIV, NHFT, COTでは一般的な呼吸管理デバ イスが用いられており, 国内のどの病院においても既 に導入されていることが多く, 新たなコストは発生し ないことが予想される。しかし，デバイスに関わる消 耗品に関しては, NIV と NHFTに使用される回路費 用として約 5,000 円/個が必要となるため, 医療経済 の観点から COT のほうがコストを抑えられると考え られる。また, 医療従事者の仕事量に関しては, COT に比して NHFT, NHFT に比して NIV において, その 呼吸管理を維持するための仕事量は増大すると考えら れる。さらに, デバイスの容認性に関しては, 皮膚障 害や患者不快感が関与すると考えられるが，どちらも 今回の検討では「重大」アウトカムとしては評価でき ておらず，結論には至っていない。

\section{（8）実行可能性}

人工呼吸管理が可能な病院であれば，これらの治療 は一般的な呼吸管理方法であり, どの病院においても 実行可能性は高いと考えられる。しかし，デバイスが ない施設では実施できない。 
日集中医誌 J Jpn Soc Intensive Care Med Vol. 28 Suppl

Table 9-6-1 エビデンスプロファイル (メタ解析)

(a) NHFT vs. COT

\begin{tabular}{|c|c|c|c|c|c|c|c|c|c|c|c|c|}
\hline \multicolumn{7}{|c|}{ 確実性の評価 } & \multicolumn{2}{|c|}{ 患者数 } & \multicolumn{2}{|c|}{ 効果 } & \multirow[b]{2}{*}{ 確実性 } & \multirow[b]{2}{*}{ 重要性 } \\
\hline 研究数 & $\begin{array}{l}\text { 研究 } \\
\text { デザイン }\end{array}$ & $\begin{array}{l}\text { バイアス } \\
\text { のリスク }\end{array}$ & 非一貫性 & 非直接性 & 不精確性 & $\begin{array}{l}\text { その他 } \\
\text { の検討 }\end{array}$ & NHFT & cot & $\begin{array}{l}\text { 相対指標 } \\
(95 \% \mathrm{CI})\end{array}$ & $\begin{array}{l}\text { 絶対指標 } \\
(95 \% \mathrm{CI})\end{array}$ & & \\
\hline \multicolumn{13}{|l|}{ 短期死亡 } \\
\hline 4 & RCT & 深刻でない & 深刻でない & 深刻でない & 深刻 a & なし & $28 / 403 \quad(6.9 \%)$ & $30 / 399 \quad(7.5 \%)$ & $\begin{array}{c}\text { RR } 0.93 \\
(0.57 \text { to } 1.52)\end{array}$ & $\begin{array}{l}\text { 1, } 000 \text { 人あたり } 5 \\
\text { 人少ない }(32 \text { 人少 } \\
\text { ない 39 人多い) }\end{array}$ & $\begin{array}{c}\oplus \oplus \oplus \bigcirc \\
\text { 中 }\end{array}$ & 重大 \\
\hline \multicolumn{13}{|l|}{ 再挿管 } \\
\hline 5 & RCT & 深刻でない & 深刻でない & 深刻でない & 深刻 a & なし & $25 / 433 \quad(5.8 \%)$ & $58 / 429(13.5 \%)$ & $\begin{array}{c}\text { RR } 0.45 \\
(0.27 \text { to } 0.73)\end{array}$ & \begin{tabular}{|c|}
1,000 人あたり 74 \\
人少ない 99 人少 \\
ない 37 人少な \\
い)
\end{tabular} & $\begin{array}{c}\oplus \oplus \oplus \bigcirc \\
\text { 中 }\end{array}$ & 重大 \\
\hline \multicolumn{13}{|c|}{ 抜管後呼吸不全 } \\
\hline 2 & RCT & 深刻でない & 深刻でない & 深刻でない & 深刻 a & なし & $38 / 342(11.1 \%)$ & $59 / 340(17.4 \%)$ & $\begin{array}{c}\text { RR } 0.65 \\
(0.44 \text { to } 0.94)\end{array}$ & $\begin{array}{c}1,000 \text { 人あたり } 61 \\
\text { 人少ない } 97 \text { 人少 } \\
\text { ない 10 人少な } \\
\text { ( })\end{array}$ & $\begin{array}{c}\oplus \oplus \oplus \bigcirc \\
\text { 中 }\end{array}$ & 重要 \\
\hline \multicolumn{13}{|l|}{ 皮虚障害 } \\
\hline 1 & RCT & 深刻 b & 深刻でない & 深刻でない & 非常に深刻 b & なし & $0 / 264 \quad(0.0 \%)$ & $0 / 263 \quad(0.0 \%)$ & 推定不可 & & $\begin{array}{l}\oplus \bigcirc \bigcirc \bigcirc \\
\text { 非常に低 }\end{array}$ & 重要 \\
\hline \multicolumn{13}{|c|}{ 機器による不快感 } \\
\hline 4 & RCT & 深刻 o.d & 深刻でない & 深刻でない & 深刻 a & なし & 132 & 109 & - & $\begin{array}{c}\text { 平均 } 2.84 \text { 低い } \\
(3.7 \text { 低い 1.98 } \\
\text { 低い) }\end{array}$ & $\underset{\text { 低 }}{\oplus \oplus \bigcirc \bigcirc}$ & 重要 \\
\hline \multicolumn{13}{|c|}{ 乾燥による不快感 } \\
\hline 4 & RCT & 深刻 c.d & 深刻でない & 深刻でない & 深刻 a & なし & 132 & 109 & - & $\begin{array}{l}\text { 平均 } 2.34 \text { 低い (3 } \\
\text { 低い 1.68 低い) }\end{array}$ & $\underset{\text { 低 }}{\oplus \oplus \bigcirc \bigcirc}$ & 重要 \\
\hline
\end{tabular}

a. イベント, サンプルが少ない。

b. イベントが両群で0。

c. 高いバイアスのリスクの文献を含む。

d. アウトカムが欠けている。

(b) NIV vs. COT

\begin{tabular}{|c|c|c|c|c|c|c|c|c|c|c|c|c|}
\hline \multicolumn{7}{|c|}{ 確実性の評価 } & \multicolumn{2}{|c|}{ 患者数 } & \multicolumn{2}{|c|}{ 効果 } & \multirow[b]{2}{*}{ 確実性 } & \multirow[b]{2}{*}{ 重要性 } \\
\hline 研究数 & $\begin{array}{c}\text { 研究 } \\
\text { デザイン }\end{array}$ & $\begin{array}{l}\text { バイアス } \\
\text { のリスク }\end{array}$ & 非一貫性 & 非直接性 & 不精確性 & $\begin{array}{l}\text { その他 } \\
\text { の蚞討 }\end{array}$ & NIV & сот & $\begin{array}{l}\text { 相対指標 } \\
(95 \% \mathrm{CI})\end{array}$ & $\begin{array}{l}\text { 絶対指標 } \\
(95 \% \text { CI }\end{array}$ & & \\
\hline \multicolumn{13}{|l|}{ 短期死亡 } \\
\hline 5 & RCT & 深刻でない & 深刻でない & 深刻でない & 深刻 a & なし & $24 / 390 \quad(6.2 \%)$ & $\begin{array}{l}41 / 394 \\
(10.4 \%)\end{array}$ & $\begin{array}{c}\text { RR } 0.64 \\
(0.40 \text { to } 1.02)\end{array}$ & $\begin{array}{l}\text { 1, } 000 \text { 人あたり } 37 \\
\text { 人少ない }(62 \text { 人少 } \\
\text { ない 2人多い) }\end{array}$ & $\begin{array}{c}\oplus \oplus \oplus \bigcirc \\
\text { 中 }\end{array}$ & 重大 \\
\hline \multicolumn{13}{|l|}{ 再㧴管 } \\
\hline 4 & RCT & 深刻でない & 深刻 b & 深刻でない & 深刻 a & なし & $31 / 330$ (9. 4\%) & $\begin{array}{l}46 / 334 \\
(13.8 \%)\end{array}$ & $\begin{array}{c}\text { RR } 0.50 \\
(0.18 \text { to } 1.38)\end{array}$ & \begin{tabular}{|c|} 
1, 000 人あたり 69 \\
人少ない (113 人 \\
少ない 52人多 \\
(い)
\end{tabular} & $\underset{\text { 低 }}{\oplus \oplus \bigcirc \bigcirc}$ & 重大 \\
\hline \multicolumn{13}{|c|}{ 抜管後呼吸不全 } \\
\hline 2 & RCT & 深刻でない & 深刻。 & 深刻でない & 深刻 a & なし & $\begin{array}{l}43 / 281 \\
(15.3 \%)\end{array}$ & $\begin{array}{l}54 / 287 \\
(18.8 \%)\end{array}$ & $\begin{array}{c}\text { RR } 0.77 \\
(0.35 \text { to } 1.67)\end{array}$ & \begin{tabular}{|c|}
1,000 人あたり 43 \\
人少ない (122人 \\
少ない 126人多 \\
(1)
\end{tabular} & $\underset{\text { 低 }}{\oplus \oplus \bigcirc \bigcirc}$ & 重要 \\
\hline
\end{tabular}

a. イベント，サンプル数少ない。

b. $I^{2}=68 \%$

(c) NIV vs. NHFT

\begin{tabular}{|c|c|c|c|c|c|c|c|c|c|c|c|c|}
\hline \multicolumn{7}{|c|}{ 確実性の評価 } & \multicolumn{2}{|c|}{ 患者数 } & \multicolumn{2}{|c|}{ 効果 } & \multirow[b]{2}{*}{ 確実性 } & \multirow[b]{2}{*}{ 重要性 } \\
\hline 研究数 & $\begin{array}{l}\text { 研究 } \\
\text { デザイン }\end{array}$ & $\begin{array}{l}\text { バイアス } \\
\text { のリスク }\end{array}$ & 非一貫性 & 非直接性 & 不精確性 & $\begin{array}{l}\text { その他 } \\
\text { の検討 }\end{array}$ & NIV & NHFT & $\begin{array}{l}\text { 相対指標 } \\
(95 \% \text { CI })\end{array}$ & $\begin{array}{l}\text { 絶対指標 } \\
(95 \% \mathrm{CI})\end{array}$ & & \\
\hline \multicolumn{13}{|l|}{ 短期死亡 } \\
\hline 1 & RCT & 深刻でない & 深刻でない & 深刻でない & 深刻 a & なし & $\begin{array}{l}56 / 314 \\
(17.8 \%)\end{array}$ & $\begin{array}{l}78 / 290 \\
(26.9 \%)\end{array}$ & $\begin{array}{c}\text { RR } 0.66 \\
\text { (0. } 0.49 \text { to } 0.90)\end{array}$ & $\begin{array}{c}\text { 1,000 人あたり } 91 \\
\text { 人少ない (137 人少 } \\
\text { ない〜 } 27 \text { 人少な } \\
\text { (1) }\end{array}$ & $\begin{array}{c}\oplus \oplus \oplus \bigcirc \\
\text { 中 }\end{array}$ & 重大 \\
\hline \multicolumn{13}{|l|}{ 再掩管 } \\
\hline 1 & RCT & 深刻でない & 深刻でない & 深刻でない & 深刻 a & なし & $\begin{array}{l}60 / 314 \\
(19.1 \%)\end{array}$ & $\begin{array}{l}66 / 290 \\
(22.8 \%)\end{array}$ & $\begin{array}{c}\text { RR } 0.84 \\
(0.62 \text { to } 1.15)\end{array}$ & $\begin{array}{l}\text { 1, } 000 \text { 人あたり } 36 \\
\text { 人少ない }(86 \text { 人少 } \\
\text { ない } 34 \text { 人多い) }\end{array}$ & $\begin{array}{c}\oplus \oplus \oplus \bigcirc \\
\text { 中 }\end{array}$ & 重大 \\
\hline \multicolumn{13}{|c|}{ 抜管後呼吸不全 } \\
\hline 1 & RCT & 深刻でない & 深刻でない & 深刻でない & 深刻 a & なし & $\begin{array}{l}125 / 314 \\
(39.8 \%)\end{array}$ & $\begin{array}{l}78 / 290 \\
(26.9 \%)\end{array}$ & $\begin{array}{c}\operatorname{RR} 1.48 \\
\text { (1. } 17 \text { to } 1.87)\end{array}$ & $\begin{array}{c}1,000 \text { 人あたり } 129 \\
\text { 人多い (46人多い } \\
\sim 234 \text { 人多い) }\end{array}$ & $\begin{array}{c}\oplus \oplus \oplus \bigcirc \\
\text { 中 }\end{array}$ & 重要 \\
\hline \multicolumn{13}{|l|}{ 皮䖉障害 } \\
\hline 1 & RCT & 深刻でない & 深刻でない & 深刻でない & 深刻 a & なし & $\begin{array}{l}135 / 314 \\
(43.0 \%)\end{array}$ & $\begin{array}{l}0 / 290 \\
(0.0 \%)\end{array}$ & $\begin{array}{l}\text { RR } 250.35 \\
(15.65 \text { to } \\
4004.64)\end{array}$ & $\begin{array}{l}1,000 \text { 人あたり } 0 \text { 人 } \\
\text { 少ない (0人少な } \\
\text { い〜0人少ない) }\end{array}$ & $\begin{array}{c}\oplus \oplus \oplus \bigcirc \\
\text { 中 }\end{array}$ & 重要 \\
\hline
\end{tabular}

a. 総イベント数，サンプル数が少ない。 
(a) 短期死亡

Table 9-6-2 エビデンスプロファイル (ネットワークメタ解析)

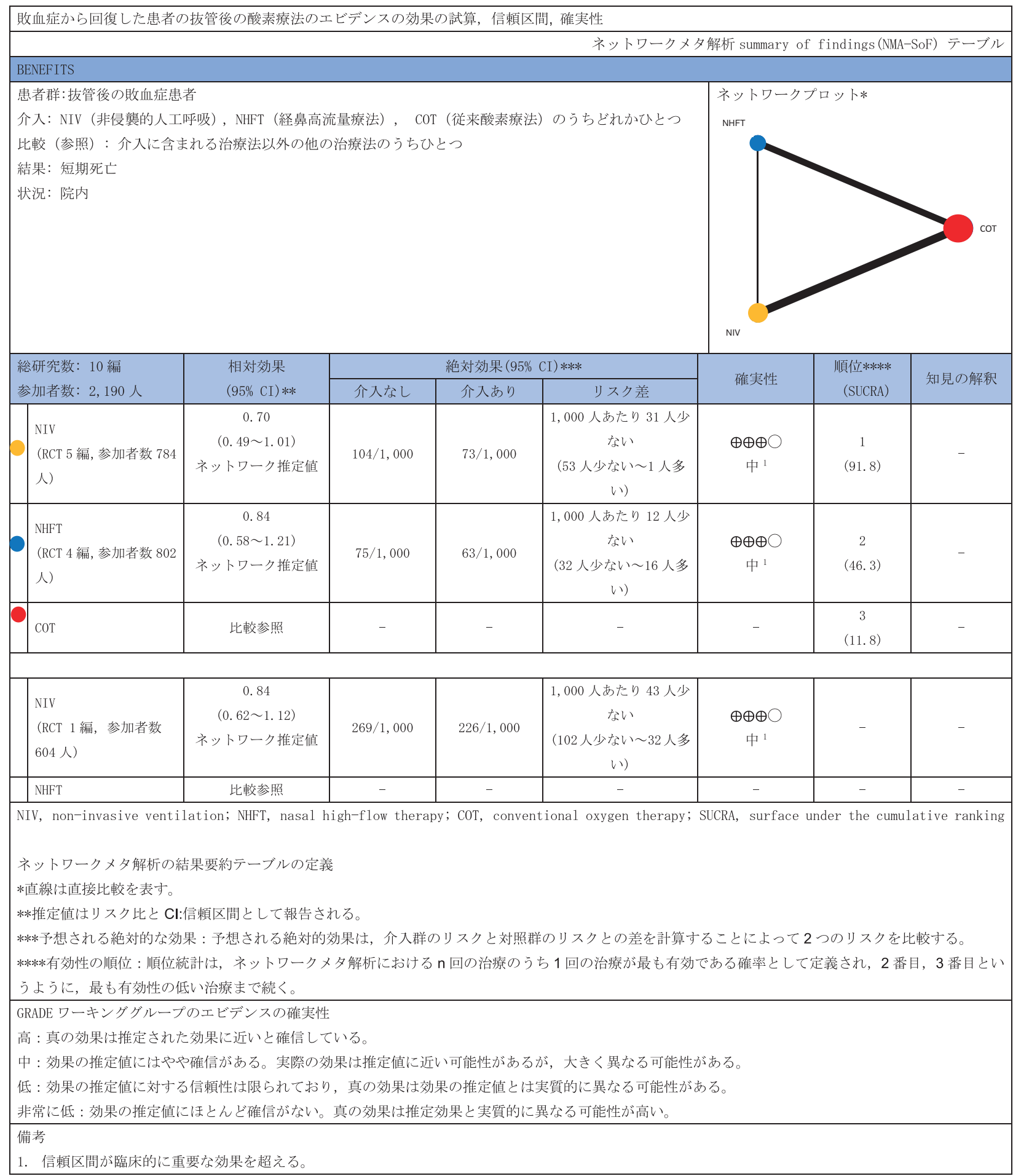


（b）再挿管

Table 9-6-2 エビデンスプロファイル（ネットワークメタ解析）（つづき）

\begin{tabular}{|c|c|c|c|c|c|c|c|}
\hline \multicolumn{8}{|c|}{ 敗血症から回復した患者の抜管後の酸素療法のエビデンスの効果の試算, 信頼区間, 確実性 } \\
\hline \multicolumn{8}{|c|}{ ネットワークメタ解析 summary of findings (NMA-SoF) テーブル } \\
\hline \multicolumn{7}{|c|}{$\begin{array}{l}\text { 患者群：抜管後の敗血症患者 } \\
\text { 介入：NIV（非侵襲的人工呼吸），NHFT（経鼻高流量療法），COT（従来酸素療法）のうちどれか } \\
\text { ひとつ } \\
\text { 比較（参照）：介入に含まれる治療法以外の他の治療法のうちひとつ } \\
\text { 結果：再挿管率 } \\
\text { 状況：院内 }\end{array}$} & \\
\hline \multirow{2}{*}{$\begin{array}{l}\text { 総研究数： } 10 \text { 編 } \\
\text { 総患者数： } 2,130 \text { 人 }\end{array}$} & \multirow{2}{*}{$\begin{array}{l}\text { 相対効果 } \\
(95 \% \text { CI }) * *\end{array}$} & \multicolumn{3}{|c|}{ 絶対効果 (95\% CI) **** } & \multirow{2}{*}{ 確実性 } & \multirow{2}{*}{$\begin{array}{c}\text { 順位***** } \\
\text { (SUCRA) }\end{array}$} & \multirow{2}{*}{ 知見の解釈 } \\
\hline & & 介入なし & 介入あり & リスク差 & & & \\
\hline $\begin{array}{l}\text { NIV } \\
\text { (RCT } 4 \text { 編, 患者数 } \\
664 \text { 人) }\end{array}$ & $\begin{array}{c}0.52 \\
(0.28 \sim 0.99) \\
\text { ネットワーク推 } \\
\text { 定值 } \\
\end{array}$ & $138 / 1,000$ & $72 / 1,000$ & $\begin{array}{c}1,000 \text { 人あたり } 66 \\
\text { 人少ない } \\
(99 \text { 人少ない〜 } 1 \text { 人 } \\
\text { 少ない) }\end{array}$ & $\begin{array}{c}\oplus \oplus \oplus \bigcirc \\
\text { 中 }^{1}\end{array}$ & $\begin{array}{c}2 \\
(69.8)\end{array}$ & - \\
\hline $\begin{array}{l}\text { NHFT } \\
\text { (RCT } 5 \text { 編, 患者数 } \\
862 \text { 人) }\end{array}$ & $\begin{array}{c}0.49 \\
(0.27 \sim 0.91) \\
\text { ネットワーク推 } \\
\text { 定值 }\end{array}$ & $135 / 1,000$ & $66 / 1,000$ & $\begin{array}{c}1,000 \text { 人あたり } 69 \\
\text { 人少ない } \\
(99 \text { 人少ない〜 } 12 \text { 人 } \\
\text { 少ない) }\end{array}$ & $\begin{array}{c}\oplus \oplus \bigcirc \bigcirc \\
\text { 低 }^{2}\end{array}$ & $\begin{array}{c}1 \\
(77.8)\end{array}$ & - \\
\hline $\mathrm{COT}$ & 比較参照 & - & - & - & - & $\begin{array}{c}3 \\
(2.8) \\
\end{array}$ & - \\
\hline $\begin{array}{l}\text { NIV } \\
\text { (RCT } 1 \text { 編, 患者数 } \\
604 \text { 人) }\end{array}$ & $\begin{array}{c}1.07 \\
(0.52 \sim 2.19) \\
\text { ネットワーク推 } \\
\text { 定值 } \\
\end{array}$ & $228 / 1,000$ & $244 / 1,000$ & $\begin{array}{c}1,000 \text { 人あたり } 16 \\
\text { 人多い } \\
(109 \text { 人少ない〜 } 271 \\
\text { 人多い) }\end{array}$ & $\begin{array}{l}\oplus \bigcirc \bigcirc \bigcirc \\
\text { 非常に低 }^{3}\end{array}$ & - & - \\
\hline NHFT & 比較参照 & - & - & - & - & - & - \\
\hline \multicolumn{8}{|c|}{$\begin{array}{l}\text { ネットワークメタ解析の結果要約テーブルの定義 } \\
\text { *直線は直接比較を表す。 } \\
\text { **推定值はリスク比とCl:信頼区間として報告される。 } \\
\text { ***予想される絶対的な効果：予想される絶対的効果は, 介入群のリスクと対照群のリスクとの差を計算することによって } 2 \text { つのリスクを比較 } \\
\text { する。 } \\
\text { ****有効性の順位 : 順位統計は, ネットワークメ夕解析における } \mathrm{n} \text { 回の治療のうち } 1 \text { 回の治療が最も有効である確率として定義され, } 2 \text { 番目, } \\
3 \text { 番目というように, 最も有効性の低い治療まで続く。 }\end{array}$} \\
\hline $\begin{array}{l}\text { GRADE ワーキンググル } \\
\text { 高 : 真の効果は推定 } \\
\text { 中 : 効果の推定値に } \\
\text { 低 : 効果の推定值に文 } \\
\text { 非常に低 : 効果の推只 }\end{array}$ & $\begin{array}{l}\text { ープのエビデンス } \\
\text { れた効果に近いと } \\
\text { やや確信がある。 } \\
\text { する信頼性は限ら } \\
\text { 值にほとんど確信 }\end{array}$ & 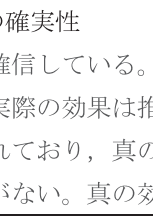 & $\begin{array}{l}\text { 直に近い可能 } \\
\text { 果は効果の推 } \\
\text { よ推定効果と }\end{array}$ & $\begin{array}{l}\text { があるが，大きく異な } \\
\text { 直とは実質的に異なる } \\
\text { 質的に異なる可能性カ }\end{array}$ & $\begin{array}{l}\text { 万可能性があ } \\
\text { 可能性がある } \\
\text { 高い。 }\end{array}$ & & \\
\hline $\begin{array}{l}\text { 備考 } \\
\text { 1. 非一貫性のP 值が } \\
\text { 2. 非一貫性のP 值が } \\
\text { 3. 信頼区間が臨床的 }\end{array}$ & $\begin{array}{l}0.1 \text { 以下。 } \\
0.05 \text { 以下。 } \\
\text { こ重要な効果を超 }\end{array}$ & 。非整合性 & が 0.05 上 & & & & \\
\hline
\end{tabular}


（c）抜管後呼吸不全

Table 9-6-2 エビデンスプロファイル（ネットワークメタ解析）（つづき）

\begin{tabular}{|c|c|c|c|c|c|c|c|c|}
\hline \multicolumn{9}{|c|}{$\begin{array}{r}\text { 敗血症から回復した患者の抜管後の酸素療法のエビデンスの効果の試算，信頼区間，確実性 } \\
\text { ネットワ }\end{array}$} \\
\hline \multicolumn{9}{|l|}{ BENEFITS } \\
\hline \multicolumn{5}{|c|}{$\begin{array}{l}\text { 患者群：拔管後の敗血症患者 } \\
\text { 介入：NIV（非侵襲的人工呼吸），NHFT（経鼻高流量療法），COT（従来酸素療法）のうちどれかひ } \\
\text { とつ } \\
\text { 比較（参照）：介入に含まれる治療法以外の他の治療法のうちひとつ } \\
\text { 結果：抜管後呼吸不全 } \\
\text { 状況：院内 }\end{array}$} & \multirow{3}{*}{\multicolumn{3}{|c|}{ 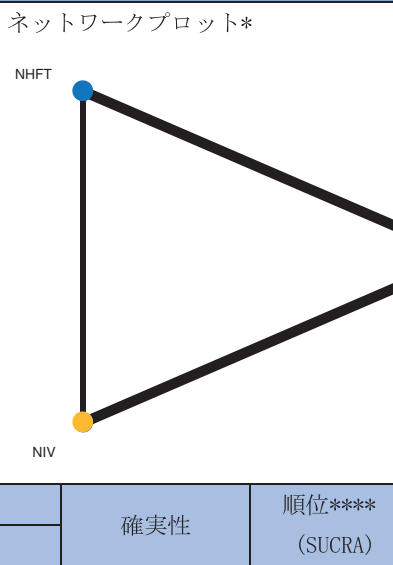 }} & \\
\hline \multirow{2}{*}{$\begin{array}{l}\text { 総研究数： } 5 \text { 編 } \\
\text { 総患者数： } 1,854 \text { 人 }\end{array}$} & \multirow{2}{*}{$\begin{array}{l}\text { 相対効果 } \\
(95 \% \mathrm{CI}) * *\end{array}$} & \multicolumn{3}{|c|}{ 絶対効果 $(95 \%$ CI) *** } & & & & \multirow{2}{*}{ 知見の解釈 } \\
\hline & & 介入なし & 介入あり & リスク差 & & & & \\
\hline $\begin{array}{l}\text { NIV } \\
\text { (RCT 2 編, 患者数 } 568 \\
\text { 人) }\end{array}$ & $\begin{array}{c}0.85 \\
(0.58 \sim 1.24) \\
\text { ネットワーク推定値 }\end{array}$ & $188 / 1,000$ & $160 / 1,000$ & \multicolumn{2}{|c|}{$\begin{array}{c}1,000 \text { 人あたり } 28 \text { 人少な } \\
\text { い } \\
\text { (79 人少ない〜 } 45 \text { 人多い) }\end{array}$} & $\begin{array}{c}\oplus \oplus \oplus \bigcirc \\
\text { 中 }^{1}\end{array}$ & $\begin{array}{c}1 \\
(97.1)\end{array}$ & - \\
\hline $\begin{array}{l}\text { NHFT } \\
\text { (RCT 2 編, 患者数 } 682 \\
\text { 人) }\end{array}$ & $\begin{array}{c}0.61 \\
(0.42 \sim 0.89) \\
\text { ネットワーク推定值 }\end{array}$ & $174 / 1,000$ & $106 / 1,000$ & \multicolumn{2}{|c|}{$\begin{array}{c}1,000 \text { 人あたり } 68 \text { 人少な } \\
\text { い } \\
(101 \text { 人少ない〜 } 19 \text { 人少な } \\
\text { い) }\end{array}$} & $\begin{array}{c}\oplus \oplus \oplus \bigcirc \\
\text { 中 }^{1}\end{array}$ & $\begin{array}{c}2 \\
(42.1)\end{array}$ & - \\
\hline сот & 比較参照 & 評価不可 & 評価不可 & \multicolumn{2}{|l|}{ 評価不可 } & - & $\begin{array}{c}3 \\
(10.6)\end{array}$ & - \\
\hline \multirow{2}{*}{\begin{tabular}{|l} 
\\
NIV \\
(RCT 1 編, 患者数 \\
604 人)
\end{tabular}} & $\begin{array}{c}1.39 \\
(0.95 \sim 2.02) \\
\text { ネットワーク推定値 }\end{array}$ & $269 / 1,000$ & $374 / 1,000$ & \multicolumn{2}{|c|}{$\begin{array}{c}\text { 1, } 000 \text { 人あたり } 105 \text { 人多い } \\
(13 \text { 人少ない〜 } 274 \text { 人多 } \\
\text { い) }\end{array}$} & $\begin{array}{l}\oplus \oplus \oplus \bigcirc \\
\text { 中 }^{1}\end{array}$ & - & - \\
\hline & 比較参照 & 評価不可 & 評価不可 & 評価不可 & & - & - & - \\
\hline \multicolumn{9}{|c|}{ 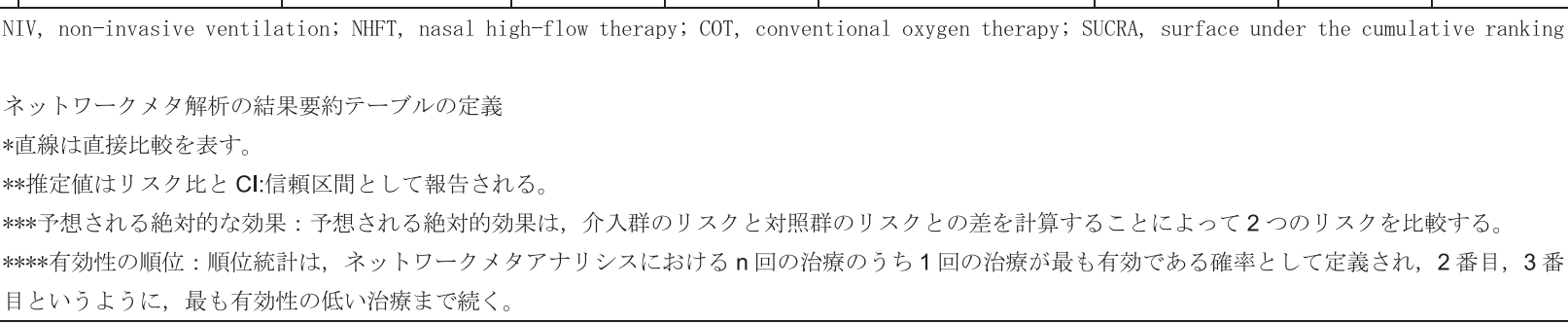 } \\
\hline \multicolumn{9}{|c|}{$\begin{array}{l}\text { 高 : 真の効果は推定された効果に近いと確信している。 } \\
\text { 中 : 効果の推定值にはやや確信がある。実際の効果は推定值に近い可能性があるが，大きく異なる可能性がある。 } \\
\text { 非常に効果の抵 : 効定值に対する信頼性は限られてお定値にほとんど確信がない。真の効果は推定効果と実質的に異なる可能性が高い。 }\end{array}$} \\
\hline
\end{tabular}


（9）判断の要約（Table 9-6-3）

\section{（10）推奨グレーディング決定の工程}

修正 RAND 法を用いた投票によって，中央值 7.5, 見解不一致指数 0.164 の結果となり，委員会で採択さ れた（7 点以上：91.7\%）。

\section{（11）関連する他の診療ガイドラインにおける推奨}

本 $\mathrm{CQ}$ と類似したテーマを扱っている他のガイドラ インは検索する限り見当たらなかった。

\section{（12）実施に関わる検討事項}

抜管後にルーチンにどのような酸素療法デバイスを 使用するかに関しては，患者の年齢，重症度，挿管り スクの有無も影響する可能性があるが，本検討では抜 管後呼吸不全や再挿管のリスク別での評価はなされて いない。実臨床では，それらを加味しながら慎重に判 断することが望まれる。

\section{（13）今後の研究の可能性}

今後は, 抜管後呼吸不全, 再挿管のリスク, 呼吸不 全の原因などで分けた検討を行うことが望まれる。

\section{文 献}

1) Antonicelli F, Cataldo A, Festa R, et al: High-flow oxygen therapy through nasal cannulae versus low-flow oxygen therapy via Venturi mask after extubation in adult, critically ill patients. Crit Care. 2011; 15: 165.

2) Idone FA, Festa R, Antonicelli F, et al: Nasal high-flow oxygen therapy vs. standard oxygen therapy via Venturi mask after extubation: preliminary results of randomized, controlled trial. Intensive Care Med. 2010; 36: S112.

3) Fernandez R, Subira C, Frutos-Vivar F, et al: High-flow nasal cannula to prevent postextubation respiratory failure in high-risk non-hypercapnic patients: a randomized multicenter trial. Ann Intensive Care. 2017; 7: 47.

4) Ferrer M, Valencia M, Nicolas JM, et al: Early noninvasive ventilation averts extubation failure in patients at risk: a randomized trial. Am J Respir Crit Care Med. 2006; 173: 164-70.

5) Hernández G, Vaquero C, Colinas L, et al: Effect of Postextubation High-Flow Nasal Cannula vs Noninvasive Ventilation on Reintubation and Postextubation Respiratory Failure in High-Risk Patients: A Randomized Clinical Trial. JAMA. 2016; 316: 1565-74.

6) Hernández G, Vaquero C, González P, et al: Effect of Postextubation High-Flow Nasal Cannula vs Conventional Oxygen Therapy on Reintubation in Low-Risk Patients: A Randomized Clinical Trial. JAMA. 2016; 315: 1354-61.

7) Mohamed KAE, Abdalla MH: Role of non invasive ventilation in limiting re-intubation after planned extubation. Egypt J Chest Dis Tuberc. 2013; 62, 669-74.

8) Maggiore SM, Idone FA, Vaschetto R, et al: Nasal high-flow versus Venturi mask oxygen therapy after extubation. Effects on oxygenation, comfort, and clinical outcome. Am J Respir Crit Care Med. 2014; 190: 282-8.

9) Ornico SR, Lobo SM, Sanches HS, et al: Noninvasive ventilation immediately after extubation improves weaning outcome after acute respiratory failure: a randomized controlled trial. Crit Care. 2013; 17: R39.

10) Arman PD, Varn MN, Povian S, et al: Effects Of Direct Extubation To High-Flow Nasal Cannula Compared To Standard Nasal Cannula In Patients In The Intensive Care Unit. Am J Respir Crit Care Med. 2017; 195: A1887.

11) Song HZ, Gu JX, Xiu HQ, et al: The value of high-flow nasal cannula oxygen therapy after extubation in patients with acute respiratory failure. Clinics (Sao Paulo). 2017; 72: 562-7.

12) Su CL, Chiang LL, Yang SH, et al: Preventive use of noninvasive ventilation after extubation: a prospective, multicenter randomized controlled trial. Respir Care. 2012; 57: 204-10.

13) Thanthitaweewat V, Muntham D, Chirakalwasan N: TargetedVolume Noninvasive Ventilation Reduces Extubation Failure in Postextubated Medical Intensive Care Unit Patients: A Randomized Controlled Trial. Indian J Crit Care Med. 2018; 22: $639-45$

Table 9-6-3 判断の要約

\begin{tabular}{|c|c|c|c|c|c|c|c|}
\hline & \multicolumn{7}{|c|}{ 判疃 } \\
\hline 問題 & いいえ & おそらく、いいえ & おそらく、はい & はい & & さまざま & 分からない \\
\hline 望ましい効果 & わずか & 小さい & 中 & 大きい & & さまざま & 分からない \\
\hline 望ましくない効果 & 大きい & 中 & 小さい & わずか & & さまざま & 分からない \\
\hline エビデンスの確実性 & 非常に低 & 低 & 中 & 高 & & & 採用研究なし \\
\hline 価值钼 & $\begin{array}{c}\text { 重要な不確実性 } \\
\text { またはばらつき } \\
\text { あり }\end{array}$ & $\begin{array}{c}\text { 重要な不確実性ま } \\
\text { たはばらつの可 } \\
\text { 能性ありり }\end{array}$ & $\begin{array}{l}\text { 重要な不確実性 } \\
\text { またはばつき } \\
\text { はおそらくなし }\end{array}$ & $\begin{array}{l}\text { 重要な不確実 } \\
\text { 性またはばら } \\
\text { つきはなし }\end{array}$ & & & \\
\hline 効果のバランス & 比較が優位 & $\begin{array}{c}\text { 比較がおそらく優 } \\
\text { 位 }\end{array}$ & $\begin{array}{c}\text { 介入も比較もい } \\
\text { ずれも優位でな } \\
\text { い }\end{array}$ & $\begin{array}{c}\text { おそらく介入 } \\
\text { が優位 }\end{array}$ & 介入が優位 & さまざま & 分からない \\
\hline 容認性 & いいえ & おそらく、いいえ & おそらく、はい & はい & & さまざま & 分からない \\
\hline 実行可能性 & いいえ & おそらく、いいえ & おそらく、はい & はい & & さまざま & 分からない \\
\hline
\end{tabular}




\section{CQ10 : 痛み・不穏・せん妄の管理}

成人重症患者に対する鎮痛・鎮静に関して 2013 年 に米国集中治療医学会から公表された「Clinical practice guidelines for the management of pain, agitation, and delirium in adult patients in the intensive care unit」 ${ }^{1)}$ は, 痛み・不穏・せん妄の病態管理を目的とした内容 で作成されており，それぞれの頭文字（Pain， Agitation, Delirium）から 2013 PAD guidelines と略称さ れる。日本集中治療医学会は, 2013 PAD guidelines の 流れを受けつつも, 本邦の状況に合わせた「日本版・ 集中治療室における成人重症患者に対する痛み・不 穏・せん妄管理のための臨床ガイドライン（J-PAD ガ イドライン)」2） 2014 年に公表した。2013PAD guidelines は, 2018 年に「Clinical practice guidelines for the management of pain, agitation/sedation, delirium, immobility, and sleep disruption in adult patients in the ICU (PADIS guidelines)」3）として改訂された。PADIS guidelines は, 不動と睡眠障害の管理の領域が追加さ れたものの, 痛み・不穏・せん妄管理に関しては 2013 PAD guidelines を踏襲している。

日本版敗血症診療ガイドライン (J-SSCG) 2016 4, 5) の「鎮痛・鎮静・せん妄管理」の内容は, J-PAD ガイ ドラインの抜粋として作成された。J-SSCG 2020 では, 敗血症患者の痛み (pain), 不穏 (agitation), せん妄 （delirium）の管理について 6つの CQ を設定して，新 たにGRADE システムに従ってシステマティックレ ビュー, メタ解析を実施した。本 CQ でも敗血症以外 の重症患者も含めた研究に拡げて文献を検索した。

痛みの管理に関して本ガイドラインでは「人工呼吸 中の成人敗血症患者に対して鎮痛優先のプロトコルに 基づく管理を行うことを弱く推奨する」とした。痛み の管理の出発点はルーチンの痛み評価であり, numerical rating scale (NRS), behavioral pain scale (BPS) ${ }^{6)}$ や critical-care pain observation tool (CPOT) ${ }^{7)}$ などの鎮痛スケールを用いて痛みを数值化できる。鎮 痛スケールの詳細については, J-PAD ガイドライン ${ }^{2)}$ を参照されたい。最近の本邦の調査では, 鎮痛薬の第 一選択薬として $89 \%$ の施設でフェンタニルが使用さ れていた ${ }^{8)}$ 。オピオイドには消化管抑制（腸蠕動運動 低下や便秘など）や免疫細胞抑制の副作用があるの で，過量投与を避けて適正な鎮痛効果に調節すること が重要である。鎮痛優先の鎮静法の実践には，短時間 作用性の鎮痛薬が適しているので, 海外諸国ではレミ フェンタニルが選択される報告が多い9）。本邦ではレ ミフェンタニルの適応は全身麻酔の鎮痛のみである
が，集中治療での人工呼吸中の鎮痛に適応を拡大する 治験が現在進行中である。

不穏の管理に関して，本ガイドラインでは「敗血症 患者の人工呼吸管理中の鎮静薬調整において, 1 日 1 回の鎮静薬中止やプロトコルを用いた鎮静薬の調整に よって light sedation を行うことを弱く推奨する」とし た。過剰な鎮静は早期リハビリテーションの妨げとも なる。鎮静・不穏の評価スケールとしては，本邦では Richmond agitation sedation scale (RASS) 10) が97\%の 施設で広く使用されている ${ }^{8)}$ 。RASS の詳細について はJ-PAD ガイドライン2)を参照されたい。1 日 1 回 の鎮静薬中断とプロトコルによる鎮静薬の調整との間 の優劣については明らかではないが, 過剩な鎮静を防 ぐことができれば両者に大きな差はないとされる。浅 い鎮静の至適レベルについてのエビデンスは多くない が，最近の報告では RASS - 2 または -3 の浅い鎮静管 理は無鎮静と比べて血栓症が多かったものの，90日 死亡率, 人工呼吸期間, ICU 滞在日数, せん妄発生率 に差を認めなかった ${ }^{11)}$ 。患者の状態が許す限り深い 鎮静レベルを避けることが肝要である。

不穏に対処するための鎮静薬に関して，本ガイドラ インでは「敗血症患者における人工呼吸管理中の鎮静 薬として, ベンゾジアゼピンよりもプロポフォールや デクスメデトミジンを使用することを弱く推奨する」 とした。これまでの研究では, ベンゾジアゼピンとし て作用時間が長いロラゼパムやミダゾラムが使用され ているので, 鎮静作用の遷延が原因の可能性もある。 現在は全身麻酔のみが保険適用であるが超短時間作用 性のレミマゾラムを用いて検討すれば, 集中治療領域 での鎮静薬としてベンゾジアゼピンの適否を考察する 資料となる。プロポフォールは強い血管拡張作用や propofol infusion syndromeによる小児への投与禁忌, デクスメデトミジンは強い心刺激伝導系抑制など敗血 症診療での問題点もあるので, 敗血症患者へのベンゾ ジアゼピンの選択について引き続き検討する必要があ る。

せん妄は, 敗血症患者の中枢神経系臓器障害の表現 型の 1 つである。せん妄は, 何らかの身体疾患や全身 状態の変化に伴って種々の精神症状 (意識, 注意, 知 覚の障害）を呈し，原因となった身体疾患が改善すれ ば精神症状も回復する4)。時間単位もしくは日単位で 比較的急速に発症し症状が変動することが特徵とさ れ, 精神医学的には軽度の意識混濁に種々の程度の意 識変容を伴う意識障害の一型で多様な症状を呈する症 候群である。人工呼吸管理下の重症患者に発生するせ ん妄は, 患者予後を悪化させる独立危険因子であ 
る 12)。せん妄に対する診療の第一歩は, せん妄診断 ツールを用いた定期的な評価である。本邦でのせん妄 診断ツールの利用頻度は, confusion assessment method for the ICU (CAM-ICU) ${ }^{12)} 60 \%$, intensive care delirium screening checklist (ICDSC) 13) 31\% であり，この 2 者 が広く利用されている。CAM-ICU，ICDSC の詳細に ついてはJ-PAD ガイドライン2）を参照されたい。

薬物療法によるせん妄の予防に関して，本ガイドラ インでは「成人敗血症患者のせん妄予防にデクスメデ トミジンを投与することを弱く推奨するが，ハロペリ ドール，非定型抗精神病薬，スタチンを投与しないこ とを弱く推奨する」とした。PADIS guidelines ${ }^{3)}$ J-PAD ガイドライン ${ }^{2)}$ では, 薬物療法によるせん妄 予防はすべて否定的であったが，デクスメデトミジン のみはせん妄予防効果を支持する報告もある14,15)。 せん妄予防効果についてデクスメデトミジンは有望で あるが, 予防効果が高い患者の状況や病態, 発症予防 に伴う予後改善の有無, 適切な投与速度や投与期間な どについてさらに検討を進める必要がある。

薬物療法によるせん妄の治療に関して, 本ガイドラ インでは「成人敗血症患者のせん妄治療にデクスメデ トミジン，八ロペリドール，非定型抗精神病薬を投与 しないことを弱く推奨する」とした。本ガイドライン ではせん妄に対する薬物療法について予防と治療に分 けて CQ を設定したが，予防に比べて治療に関する質 の高い臨床研究の数が少なく，せん妄の治療効果を明 確に推奨できる薬物は今のところ存在しない。過活動 型せん妄患者で不穏により安全が確保できない場合な ど，十分なエビデンスはないが，症状を緩和する目的 でデクスメデトミジンや非定型抗精神病薬が有効なこ ともある。
非薬物療法によるせん妄の予防に関して，本ガイド ラインでは「成人敗血症患者のせん妄予防に非薬物療 法を行うことを弱く推奨する」とした。アイマスクや 耳栓による睡眠の改善, 眼鏡や補聴器による覚醒の促 進, 音楽や映像によるリラクゼーションなどを単独ま たは組み合わせて施行することにより，せん妄を予防 する効果が報告されている。非薬物療法のせん妄予防 効果には十分なエビデンスはないが，重大な副作用も 想定されないので医療者の仕事量として許容される範 囲で実施することを推奨する。

敗血症患者を含む重症患者管理の原則は，「十分な 痛み対策を基盤とした必要最低限の鎮静管理と頻回の せん妄評価, 可及的速やかなリハビリテーションの実 施」4,5）と総括されている。本稿では 6 つの CQ を設 定して最新の論文まで網羅したシステマティックレ ビューを実施したが，内容が不足する場合はこの領域 の診療ガイドラインである PADIS guidelines ${ }^{3)} や$ J-PAD ガイドライン2)をご参照いただきたい。

$$
\text { 文 献 }
$$

1) Barr J, Fraser GL, Puntillo K, et al: Clinical practice guidelines for the management of pain, agitation, and delirium in adult patients in the intensive care unit. Crit Care Med. 2013; 41: 263-306.

2) Committee for the development of Japanese guidelines for the management of Pain, Agitation, and Delirium in intensive care unit, Japanese Society of Intensive Care Medicine: Japanese guidelines for the management of Pain, Agitation, and Delirium in intensive care unit (J-PAD). J Jpn Soc Intensive Care Med. 2014; 21: 539-79.

3) Devlin JW, Skrobik Y, Gélinas C, et al: Clinical Practice Guidelines for the Prevention and Management of Pain, Agitation/Sedation, Delirium, Immobility, and Sleep Disruption in Adult Patients in the ICU. Crit Care Med. 2018; 46: e825-73.

4）西田修, 小倉裕司, 井上茂亮, 他, 日本版敗血症診療ガイドラ イン 2016 作成特別委員会. 日本版敗血症診療ガイドライン

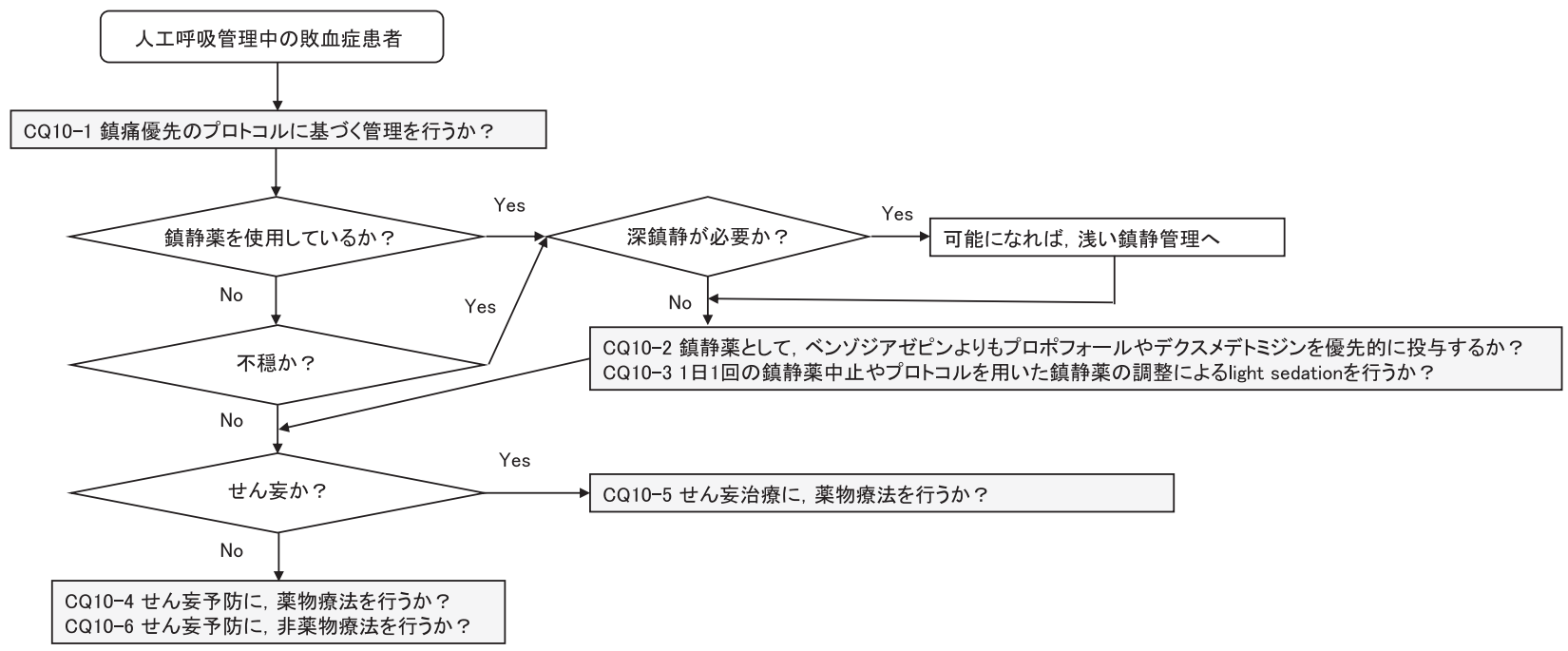

PAD管理〔診療フロー〕 
2016. 日集中医誌. 2017; 24: S1-232.

5）西田修, 小倉裕司, 井上茂亮, 他, 日本版敗血症診療ガイドラ イン 2016 作成特別委員会. 日本版敗血症診療ガイドライン 2016. 日救急医会誌. 2017; 28: S1-232.

6) Payen JF, Bru O, Bosson JL, et al: Assessing pain in critically ill sedated patients by using a behavioral pain scale. Crit Care Med. 2001; 29: 2258-63.

7) Gélinas C, Fillion L, Puntillo KA, et al: Validation of the criticalcare pain observation tool in adult patients. Am J Crit Care. 2006; 15: 420-7.

8）日本集中治療医学会J-PAD ガイドライン検討委員会: 集中 治療領域における痛み・不穏・せん妄管理の現状調査（2019 年). 日集中医誌. 2020; 27: 150-8.

9) Zhu Y, Wang Y, Du B, et al: Could remifentanil reduce duration of mechanical ventilation in comparison with other opioids for mechanically ventilated patients? A systematic review and metaanalysis. Crit Care. 2017; 21: 206.

10) Sessler CN, Gosnell MS, Grap MJ, et al: The Richmond Agitation-Sedation Scale: Validity and reliability in adult intensive care unit patients. Am J Respir Crit Care Med. 2002; 166: 1338-44.

11) Olsen HT, Nedergaard HK, Strøm T, et al: Nonsedation or light sedation in critically ill, mechanically ventilated patients. N Engl J Med. 2020; 382: 1103-11.

12) Ely EW, Inouye SK, Bernard GR, et al: Delirium in mechanically ventilated patients: Validity and reliability of the Confusion Assessment Method for the intensive care unit (CAM-ICU). JAMA. 2001; 286: 2703-10.

13) Bergeron N, Dubois MJ, Dumont M, et al: Intensive care delirium screening checklist: Evaluation of a new screening tool. Intensive Care Med. 2001; 27: 859-64.

14) Flükiger J, Hollinger A, Speich B, et al: Dexmedetomidine in prevention and treatment of postoperative and intensive care unit delirium: a systematic review and meta-analysis. Ann Intensive Care. 2018; 8: 92.

15) Duan X, Coburn M, Rossaint R, et al: Efficacy of perioperative dexmedetomidine on postoperative delirium: systematic review and meta-analysis with trial sequential analysis of randomised controlled trials. Br J Anaesth. 2018; 121: 384-97.
CQ10-1：人工呼吸中の成人敗血症患者に対し て，鎮痛優先のプロトコルに基づく管理を行う か?

Answer : 人工呼吸中の成人敗血症患者に対して, 鎮 痛優先のプロトコルに基づく管理を行うことを弱く推 奨する（GRADE 2C：エビデンスの確実性 $=「$ 低」）。

\section{（1）背景および本 $C Q$ の重要度}

重症患者において不適切な鎮痛管理は患者に負の影 響を与えることが示されている。評価ツールを利用し た鎮痛優先のプロトコルによる鎮痛管理によって, ICU アウトカムおよび臨床アウトカムを改善する可能 性が示唆されている。鎮痛による利益とリスクのバラ ンスをとることを目的にプロトコル管理を行うか否か は, 敗血症診療でも重要臨床課題であるといえる。そ のため, 本ガイドラインの $\mathrm{CQ}$ として取り上げた。

(2) PICO

P (患者): 敗血症, 呼吸不全, 心不全, 熱傷, 大侵 襲手術後などで人工呼吸中の成人重症患者

I（介入）：鎮痛優先のプロトコル管理

C (対照)：プロトコル化されていない従来の管理 or 催眠優先のプロトコル管理

$\mathrm{O}$ (アウトカム ) : 全原因死亡, 人工呼吸期間, 28 日間の人工呼吸器非使用日数, ICU 滞在日数, 重 症合併症, せん妄, 不穏

\section{（3）エビデンスの要約}

システマティックレビューの結果, PICO に合致し たランダム化比較試験（RCT）が７件 1-7) 施行されて おり，これらを用いたメタ解析を実施した。

\section{（4）益と害のバランス（Table 10-1-1）}

\section{望ましい効果 :}

鎮痛優先のプロトコル管理により全原因死亡（5 RCT: $\mathrm{n}=1,012)$ は 1,000 人あたり 18 人少ない（63 人少ない 35 人多い), 人工呼吸期間 (6 RCT: $\mathrm{n}=$ 1,090）は平均（MD） 8.99 時間短い（20.66 時間短い $\sim 2.68$ 時間長い), 28 日間の人工呼吸器非使用日数（1 RCT: $\mathrm{n}=113$ ）は MD 4.2 日長い（0.32 日長い 8.08 日長い), ICU 滞在日数（6 RCT: $\mathrm{n}=1,090 ）$ は MD 15.15 時間短い（26.08 時間短い〜 4.22 時間短い）。望 ましい効果は「中」であると考えた。

望ましくない効果 :

鎮痛優先のプロトコル管理により重症合併症（7 
Table 10-1-1エビデンスプロファイル

\begin{tabular}{|c|c|c|c|c|c|c|c|c|c|c|c|c|}
\hline \multicolumn{7}{|c|}{ 確実性の評価 } & \multicolumn{2}{|c|}{ 患者数 } & \multicolumn{2}{|c|}{ 効果 } & \multirow[b]{2}{*}{ 碓実性 } & \multirow[b]{2}{*}{ 重要性 } \\
\hline 研究数 & $\begin{array}{l}\text { 研究 } \\
\text { デザイン }\end{array}$ & $\begin{array}{l}\text { バイアス } \\
\text { のリスク }\end{array}$ & 非一貫性 & 非直接性 & 不精確性 & $\begin{array}{l}\text { その他 } \\
\text { の検討 }\end{array}$ & $\begin{array}{c}\text { 鎮痛優先のプロ } \\
\text { トコル管理 }\end{array}$ & $\begin{array}{c}\text { プロトコル化さ } \\
\text { れていない管理 } \\
\text { or 催眠優先のプ } \\
\text { ロトコル管理 }\end{array}$ & $\begin{array}{l}\text { 相対指摽 } \\
(95 \% \mathrm{CI})\end{array}$ & $\begin{array}{l}\text { 絶対指標 } \\
(95 \% \mathrm{CI})\end{array}$ & & \\
\hline \multicolumn{13}{|c|}{ 全原因死亡 } \\
\hline 5 & RCT & 深刻でない & 深刻でない & 深刻 a & 深刻 b & なし & $\begin{array}{l}119 / 511 \\
(23.3 \%)\end{array}$ & $126 / 501 \quad(25.1 \%)$ & $\begin{array}{c}\text { RR } 0.93 \\
(0.75 \text { to } 1.14)\end{array}$ & $\begin{array}{l}1,000 \text { 人あたり } 18 \\
\text { 人少ない (63 人少 } \\
\text { ない 35 人多い) }\end{array}$ & $\underset{\text { 低 }}{\oplus \oplus \bigcirc}$ & 重大 \\
\hline \multicolumn{13}{|c|}{ 人工呼吸期間 } \\
\hline 6 & RCT & 深刻。 & 深刻 d & 深刻 a & 深刻。 & なし & 554 & 536 & - & $\begin{array}{c}\text { 平均 } 8.99 \text { 日短い } \\
\text { (20.66 日短い } \\
2.68 \text { 日長い) }\end{array}$ & $\begin{array}{l}\oplus \bigcirc \bigcirc \bigcirc \\
\text { 非常に低 }\end{array}$ & 重大 \\
\hline \multicolumn{13}{|c|}{28 日間の人工呼吸器非使用日数 } \\
\hline 1 & $\mathrm{RCT}$ & 深刻でない & 深刻でない & 深刻 a & 深刻。 & なし & 55 & 58 & - & $\begin{array}{c}\text { 平均 } 4.2 \text { 日長い } \\
\text { (0.32 日長い } \\
8.08 \text { 日長い) }\end{array}$ & $\underset{\text { 低 }}{\oplus \oplus \bigcirc}$ & 重大 \\
\hline \multicolumn{13}{|c|}{ ICU 滞在日数 } \\
\hline 6 & RCT & 深刻。 & 深刻でない & 深刻 a & 深刻 e & なし & 554 & 536 & - & $\begin{array}{c}\text { 平均 } 15.15 \text { 日短い } \\
\text { (26.08 日短い } \\
4.22 \text { 日短い) }\end{array}$ & $\begin{array}{l}\oplus \bigcirc \bigcirc \bigcirc \\
\text { 非常に低 }\end{array}$ & 重大 \\
\hline \multicolumn{13}{|c|}{ 重症合併症 } \\
\hline 7 & RCT & 深刻でない & 深刻でない & 深刻a & 深刻 e & なし & $47 / 647 \quad(7.3 \%)$ & $55 / 649(8.5 \%)$ & $\begin{array}{c}\text { RR } 0.85 \\
(0.58 \text { to } 1.23)\end{array}$ & $\begin{array}{l}1,000 \text { 人あたり } 13 \\
\text { 人少ない ( } 36 \text { 人少 } \\
\text { ない 19 人多い) }\end{array}$ & $\underset{\text { 低 }}{\oplus \oplus \bigcirc}$ & 重大 \\
\hline \multicolumn{13}{|l|}{ せん妄 } \\
\hline 1 & RCT & 深刻 " & 深刻でない & 深刻 a & 深刻 e & なし & $7 / 40 \quad(17.5 \%)$ & $9 / 39 \quad(23.1 \%)$ & $\begin{array}{c}\text { RR } 0.76 \\
(0.31 \text { to } 1.84)\end{array}$ & $\begin{array}{l}\text { 1,000 人あたり } 55 \\
\text { 人少ない (159人少 } \\
\text { ない 194 人多い) }\end{array}$ & $\begin{array}{l}\oplus \bigcirc \bigcirc \bigcirc \\
\text { 非常に低 }\end{array}$ & 重大 \\
\hline
\end{tabular}

a. 今回集まった研究の $P$ 値は敗血症ではなく，集中治療室で人工呼吸中の重症患者であるため, 1 段階グレードダウンした。

b. 最適情報量を満たさず， 0.75 の臨床決断の閾值をぎりぎりまたいでいるため, 1ランクグレードダウンした。

c. 各項目に不明な/高いバイアスのリスクが多いため, 1段階グレードダウンした。

d. I I $=64 \%$ と高く異質性が高いと判定し，1段階グレードダウンした。

・サンプルサイズが最適情報量を満たさないため, 1 段階グレードダウンした。

事前設定したアウトカム「バイアスのリスク」については報告した研究がなかった。

$\mathrm{RCT}: \mathrm{n}=1,296)$ は 1,000 人あたり 13 人少ない $(36$ 人少ない〜 19 人多い)，せん妄（1 RCT: $\mathrm{n}=79 ）$ は 1,000 人あたり 55 人少ない（159人少ない〜194 人多 い)。望ましくない効果はわずかであると考えた。 益と害のバランス :

望ましい効果として ICU 滞在日数，人工呼吸期間, 28 日間の人工呼吸器非使用日数のいずれも介入が優 位であった。一方，望ましくない効果の発現頻度に関 しても，せん妄は介入によって減少する可能性があっ た。益と害のバランスとしてはおそらく介入が優位と 判断した。

\section{（5）アウトカム全般に関するエビデンスの確実性}

今回採用したすべてのアウトカムの効果推定值の方 向性は介入群優位で一致しているため，一番高いエビ デンスの確実性「低」を採用した。

\section{（6）価値観}

敗血症患者に対する鎮痛優先のプロトコルに基づく 管理における，各アウトカムに係る患者・家族の価值 観に関するデータはない。一般的に，死亡，ICU 滞在 日数，人工呼吸期間に対する相対的価值は高く，その ばらつきは少ないことが予想される。

\section{（7）容認性}

鎮痛薬の増量と催眠薬の削減とによりコストは相殺 され，個人負担額への影響は容認できる程度である。 プロトコル管理により医療者の負担は増加する可能性 があるが，こちらも敗血症の鎮痛鎮静管理として望ま れる水準の医療であり, ある程度は容認可能である。

\section{（8）実行可能性}

介入は多くの医療施設において実行可能である。

（9）判断の要約（Table 10-1-2）

（10）推奨グレーディング決定の工程

修正 RAND 法を用いた投票によって，中央值 8, 見解不一致指数 0.164 の結果となり, 委員会で採択さ れた（7 点以上 : 100\%)。

\section{（11）関連する他の診療ガイドラインにおける推奨}

日本版敗血症診療ガイドライン（J-SSCG）2016 ${ }^{8)}$ では，人工呼吸中の成人患者では，鎮痛を優先に行う 鎮静法（analgesia-first sedation）を行うことを弱く推 奨している（2B）。PADIS ガイドライン9）では，「成 人 ICU 患者の痛み管理はルーチンの痛み評価のもと 
日本版敗血症診療ガイドライン 2020

Table 10-1-2 判断の要約

\begin{tabular}{|c|c|c|c|c|c|c|c|}
\hline & \multicolumn{7}{|c|}{ 判溇 } \\
\hline 問題 & いいえ & $\begin{array}{c}\text { おそらく、いい } \\
\text { え }\end{array}$ & おそらく、はい & はい & & さまざま & 分からない \\
\hline 望ましい効果 & わずか & 小さい & 中 & 大きい & & さまざま & 分からない \\
\hline 望ましくない効果 & 大きい & 中 & 小さい & わずか & & さまざま & 分からない \\
\hline エビデンスの確実性 & 非常に低 & 低 & 中 & 高 & & & 採用研究なし \\
\hline 価值覞 & $\begin{array}{c}\text { 重要な不確実性 } \\
\text { またはばらつき } \\
\text { あり }\end{array}$ & $\begin{array}{c}\text { 重要な不確実性 } \\
\text { またはばらつき } \\
\text { の可能性あり }\end{array}$ & $\begin{array}{l}\text { 重要な不確実性 } \\
\text { またはばらつき } \\
\text { はおそらくなし }\end{array}$ & $\begin{array}{c}\text { 重要な不確実性 } \\
\text { またはばらつき } \\
\text { はなし }\end{array}$ & & & \\
\hline 効果のバランス & 比較が優位 & $\begin{array}{c}\text { 比較がおそらく } \\
\text { 優位 }\end{array}$ & $\begin{array}{c}\text { 介入も比較もい } \\
\text { ずれも優位でな } \\
\text { い }\end{array}$ & $\begin{array}{c}\text { おそらく介入が } \\
\text { 優位 }\end{array}$ & 介入が優位 & さまざま & 分からない \\
\hline 容認性 & いいえ & $\begin{array}{c}\text { おそらく、いい } \\
\text { え }\end{array}$ & おそらく、はい & はい & & さまざま & 分からない \\
\hline 実行可能性 & いいえ & 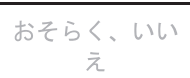 & おそらく、はい & はい & & さまざま & 分からない \\
\hline
\end{tabular}

に行われるべきで，鎮静薬が考慮される以前に痛みの 治療が行われるべきである（Good Practice Statement）」 と記述している。また，「成人重症患者における鎮痛 鎮静管理は，評価をもとにしたプロトコルに基づく， 段階的な手法で行うことを提案する（条件付き推奨, 中等度の質のエビデンス)」と記述している。

\section{（12）実施に関わる検討事項}

プロトコルの内容に関して明確な提示はできず，各 施設の実情に合わせたプロトコルを作成する必要があ る。

\section{（13）今後の研究の可能性}

鎮痛優先のプロトコルによりアウトカムが改善する 病態や重症度を検証する必要がある。特に敗血症患者 を対象とした研究が期待される。

鎮痛優先のプロトコルに適した鎮痛薬として, J-PAD ガイドライン 10), PADIS ガイドライン9）では オピオイドを第一選択としているが，オピオイドの特 定薬剂を推奨するには至っていない。本邦では，人工 呼吸中のオピオイドとしてフェンタニルが大多数の症 例で使用されている。そこでJ-SSCG 2020 の作成にあ たり，「人工呼吸中の成人敗血症患者の痛みに対して， オピオイドの中でもフェンタニルを優先的に投与する か?」を CQに選定し，介入を「オピオイドとして フェンタニルを用いた鎮痛管理」, 比較対象を「フェ ンタニル以外 (レミフェンタニル，モルヒネ) のオピ オイドによる鎮痛管理」としてシステマティックレ ビューを実施した。5つの $\mathrm{RCT}^{4,11-14)}$ が抽出されメ
夕解析を行った結果, 死亡, 人工呼吸期間, ICU 滞在 日数, 重症合併症のアウトカムにおいてフェンタニル の優位性は認められず，せん妄の発生が増える可能性 が示唆された。しかし，標準薬であるフェンタニルの 使用を推奨しない根拠も得られなかったため, ガイド ラインとして明確な指針を示すことが困難と判断し， この CQ を取り下げることとなった。

レミフェンタニルを介入とし，フェンタニル，モル ヒネ，アルフェンタニル，スフェンタニルを比較対照 としたシステマティックレビュー・メタ解析の報 告 15) では, 人工呼吸時間の短縮と鎮静薬投与終了か ら抜管までの時間短縮によりレミフェンタニル優位と されているが, 広く合意されるまでには至っていな い。本邦では，レミフェンタニルは人工呼吸中の鎮痛 薬として認可されていないが, 現在, 適応拡大の治験 が実施されている。本邦の診療環境において，フェン タニルとレミフェンタニルの効果を比較する介入研究 の実施が期待される。

\section{文 献}

1) Breen D, Karabinis A, Malbrain M, et al: Decreased duration of mechanical ventilation when comparing analgesia-based sedation using remifentanil with standard hypnotic-based sedation for up to 10 days in intensive care unit patients: a randomised trial [ISRCTN47583497]. Crit Care. 2005; 9: R200-10.

2) Brook AD, Ahrens TS, Schaiff R, et al: Effect of a nursing-implemented sedation protocol on the duration of mechanical ventilation. Crit Care Med. 1999; 27: 2609-15.

3) Bucknall TK, Manias E, Presneill JJ: A randomized trial of protocol-directed sedation management for mechanical ventilation in an Australian intensive care unit. Crit Care Med. 2008; 36: 1444-50.

4) Karabinis A, Mandragos K, Stergiopoulos S, et al: Safety and 
efficacy of analgesia-based sedation with remifentanil versus standard hypnotic-based regimens in intensive care unit patients with brain injuries: a randomised, controlled trial [ISRCTN 50308308]. Crit Care. 2004; 8: R268-80.

5) Muellejans B, Matthey T, Scholpp J, et al: Sedation in the intensive care unit with remifentanil/propofol versus midazolam/fentanyl: a randomised, open-label, pharmacoeconomic trial. Crit Care. 2006; 10: R91.

6) Rozendaal FW, Spronk PE, Snellen FF, et al: Remifentanilpropofol analgo-sedation shortens duration of ventilation and length of ICU stay compared to a conventional regimen: a centre randomised, cross-over, open-label study in the Netherlands. Intensive Care Med. 2009; 35: 291-8.

7) Strøm T, Martinussen T, Toft P: A protocol of no sedation for critically ill patients receiving mechanical ventilation: a randomised trial. Lancet. 2010; 375: 475-80.

8) Nishida O, Ogura H, Egi M, et al: The Japanese Clinical Practice Guidelines for Management of Sepsis and Septic Shock 2016 (J-SSCG 2016). J Intensive Care. 2018; 6: 7.

9) Devlin JW, Skrobik Y, Gélinas C, et al: Clinical Practice Guidelines for the Prevention and Management of Pain, Agitation/Sedation, Delirium, Immobility, and Sleep Disruption in Adult Patients in the ICU. Crit Care Med. 2018; 46: e825-73.

10）日本集中治療医学会 J-PAD ガイドライン作成委員会: 日本 版・集中治療室における成人重症患者に対する痛み・不穞・ せん妄管理のための臨床ガイドライン. 日集中医誌. 2014; 21: 539-79.

11) Liu D, Lyu J, Zhao H, et al: The influence of analgesic-based sedation protocols on delirium and outcomes in critically ill patients: A randomized controlled trial. PLoS ONE. 2017; 12: e0184310.

12) Muellejans B, López A, Cross MH, et al: Remifentanil versus fentanyl for analgesia based sedation to provide patient comfort in the intensive care unit: a randomized, double-blind controlled trial [ISRCTN43755713]. Crit Care. 2004; 8: R1-11.

13) Oliver WC Jr, Nuttall GA, Murari T, et al: A prospective, randomized, double-blind trial of 3 regimens for sedation and analgesia after cardiac surgery. J Cardiothorac Vasc Anesth. 2011; 25: 110-9.

14) Spies C, Macguill M, Heymann A, et al: A prospective, randomized, double-blind, multicenter study comparing remifentanil with fentanyl in mechanically ventilated patients. Intensive Care Med. 2011; 37: 469-76.

15) Zhu Y, Wang Y, Du B, et al: Could remifentanil reduce duration of mechanical ventilation in comparison with other opioids for mechanically ventilated patients? A systematic review and metaanalysis. Crit Care. 2017; 21: 206.
CQ10-2 : 人工呼吸中の成人敗血症患者の鎮静薬 として, ベンゾジアゼピンよりもプロポフォー ルやデクスメデトミジンを優先的に投与する か?

Answer : 敗血症患者における人工呼吸管理中の鎮静 薬として, ベンゾジアゼピンよりもプロポフォールや デクスメデトミジンを使用することを弱く推奨する (GRADE 2D : エビデンスの確実性 $=$ 「非常に低」)。

\section{（1）背景および本 $C Q$ の重要度}

人工呼吸管理中の鎮静薬の選択によって不穏が低下 する可能性が示唆されている。不穏の予防は, 人工呼 吸期間や ICU 滞在日数の短縮につながり, 患者予後 に直結する可能性があるため, 重要である。したがっ て，人工呼吸管理中の鎮静薬として何を優先的に使用 するかは, 敗血症診療においても重要な臨床課題と考 えられ，本ガイドラインの CQ として取り上げた。

\section{(2) PICO}

$\mathrm{P}$ (患者) : 人工呼吸管理中の 18 歳以上の成人

I（介入）: プロポフォールまたはデクスメデトミジ ンによる鎮静

$\mathrm{C}$ (対照) : ベンゾジアゼピン系鎮静薬による鎮静

$\mathrm{O}$ (アウトカム) : 不穏, 人工呼吸期間, ICU 滞在日 数, 死亡, 計画外抜管

\section{（3）エビデンスの要約}

システマティックレビューの結果, PICO に合致し たランダム化比較試験（RCT）が 14 件 1-14）施行され ており，これらを用いたメタ解析を実施した。

\section{(4) 益と害のバランス（Table 10-2-1）}

\section{望ましい効果：}

プロポフォールやデクスメデトミジンによる鎮静の 実践により，死亡（10 RCT: $\mathrm{n}=1,573 ）$ は 1,000 人あ たり 4 人多い $(32$ 人少ない〜 50 人多い), 不穏 $(2$ RCT: $n=632 ）$ は 1,000 人あたり 66 人少ない（119人 少ない〜 3 人多い), 人工呼吸期間 (7 RCT: $n=1,214)$ は平均（MD）1.56日短い（2.46日短い〜0.67日短 い), ICU 滞在日数（11 RCT: $\mathrm{n}=1,514 ）$ は MD 2.06 日短い（2.72 日短い〜 1.39 日短い）。介入による望ま しい効果は「中」であると判断した。

望ましくない効果 :

重大な合併症に関する検討は行われていないが，計 画外抜管（3 RCT: $\mathrm{n}=359 ）$ は 1,000 人あたり 31 人多 
Table 10-2-1エビデンスプロファイル

\begin{tabular}{|c|c|c|c|c|c|c|c|c|c|c|c|c|}
\hline \multicolumn{7}{|c|}{ 確実性の評価 } & \multicolumn{2}{|c|}{ 患者数 } & \multicolumn{2}{|c|}{ 効果 } & \multirow[b]{2}{*}{ 確実性 } & \multirow[b]{2}{*}{ 重要性 } \\
\hline 研究数 & $\begin{array}{l}\text { 研究 } \\
\text { デザイン }\end{array}$ & $\begin{array}{l}\text { パイアス } \\
\text { のリスク }\end{array}$ & 非一貫性 & 非直接性 & 不精確性 & $\begin{array}{l}\text { その他 } \\
\text { の検討 }\end{array}$ & $\begin{array}{c}\text { Propofol or } \\
\text { Dexmedetomidine }\end{array}$ & Benzodiazepine & $\begin{array}{l}\text { 相対指標 } \\
(95 \% \mathrm{II})\end{array}$ & $\begin{array}{l}\text { 絶対指標 } \\
(95 \% \mathrm{CI})\end{array}$ & & \\
\hline \multicolumn{13}{|l|}{ 不穏 } \\
\hline 2 & $\mathrm{RCT}$ & 深刻 a & 深刻でない & 深刻でない & 深刻 b & なし & $78 / 317 \quad(24.6 \%)$ & $99 / 315 \quad(31.4 \%)$ & $\begin{array}{l}\text { RR } 0.79 \\
(0.62 \text { to } \\
1.01)\end{array}$ & $\begin{array}{c}\text { 1,000 人あたり } \\
66 \text { 人少ない (119 } \\
\text { 人少ない 3 } 1 \text { 人多 } \\
\text { (1) }\end{array}$ & $\underset{\text { 低 }}{\oplus \oplus \bigcirc \bigcirc}$ & 重大 \\
\hline \multicolumn{13}{|c|}{ 人工呼吸期間 } \\
\hline 7 & RCT & 深刻。 & 深刻 d & 深刻でない & 深刻e & なし & 668 & 546 & - & $\begin{array}{c}\text { 平均 } 1.56 \text { 日短い } \\
\text { (2.46日短い } \\
0.67 \text { 日短い) }\end{array}$ & $\begin{array}{l}\oplus \bigcirc 00 \\
\text { 非常に低 }\end{array}$ & 重大 \\
\hline \multicolumn{13}{|c|}{ ICU 滞在日数 } \\
\hline 11 & RCT & 深刻 c & 深刻でない & 深刻でない & 深刻 ${ }^{e}$ & なし & 816 & 698 & - & $\begin{array}{c}\text { 平均 } 2.06 \text { 日短い } \\
\text { (2.72 日短い } \\
1.39 \text { 日短い) }\end{array}$ & $\underset{\text { 低 }}{\oplus \oplus \bigcirc \bigcirc}$ & 重大 \\
\hline \multicolumn{13}{|l|}{ 死亡 } \\
\hline 10 & RCT & 深刻 $^{\dagger}$ & 深刻でない & 深刻でない & なしg & なし & $190 / 848 \quad(22.4 \%)$ & $157 / 725(21.7 \%)$ & $\begin{array}{l}\text { RR } 1.02 \\
(0.85 \text { to } \\
1.23)\end{array}$ & $\begin{array}{c}1,000 \text { 人あたり } 4 \\
\text { 人多い }(32 \text { 人少 } \\
\text { ない 50人多 } \\
\text { い) }\end{array}$ & $\begin{array}{l}\oplus \bigcirc 00 \\
\text { 非常に低 }\end{array}$ & 重大 \\
\hline \multicolumn{13}{|c|}{ 計画外拢管 } \\
\hline 3 & RCT & 深刻 h & 深刻でない & 深刻でない & 深刻 b & なし & $20 / 179 \quad(11.2 \%)$ & $15 / 180$ & $\begin{array}{l}\text { RR } 1.37 \\
(0.74 \text { to } \\
2.54)\end{array}$ & $\begin{array}{c}\text { 1, } 000 \text { 人あたり } \\
31 \text { 人多い }(22 \text { 人 } \\
\text { 少ない 128人多 } \\
\text { (1) }\end{array}$ & $\underset{\text { 低 }}{\oplus \oplus \bigcirc \bigcirc}$ & 重大 \\
\hline
\end{tabular}

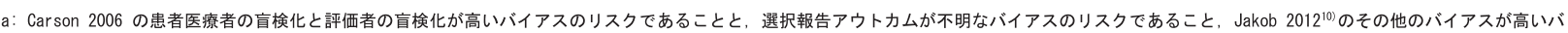
イアスのリスクであることから 1 段階グレードを下げた。

b: リスク比の $95 \%$ 信頼区間が 1 を含むため 1 段階グレードを下げた。

c：60\%以上の weight を占める研究で患者医療者の盲検化が高いバイアスのリスクや不明のバイアスのリスクであり，選択アウトカム報告やその他のバイアスもほとんどの研究で高いバイアスのリスク や不明のバイアスのリスクであることから 1 段階グレードを下げた。

$\mathrm{d}: \mathrm{I}^{2}=79 \%$ あり異質性が大きいため, 1段階グレードを下げた。

：対象者数が十分でないため, 1段階グレードを下げた。

: 全体の 3 分の 1 の weight を占める研究で患者医療者の盲検化が高いバイアスのリスクであり，選択アウトカム報告やその他のバイアスもほとんどの研究で高いバイアスのリスクや不明のバイアスの リスクであることから 1 段階グレードを下げた。

$\mathrm{g}$ : 両群の治療により死亡率には差が出ないと考えられるため, 対象者数が十分ではないが, 結果が不精確ではないと判断した。

h: $85 \%$ weight を占める研究で患者医療者の盲検化が高いバイアスのリスクであり，不完全なアウトカム報告が $78 \%$ weight を占める研究で高いバイアスのリスクであることから 1 段階グレードを下 げた。

い（22 人少ない〜 128 人多い）。介入による望ましく ない効果はわずかであると判断した。

益と害のバランス :

望ましい効果と望ましくない効果のバランスから， おそらく介入が優位と判断した。

\section{（5）アウトカム全般に関するエビデンスの確実性}

不穏, 人工呼吸期間, ICU 滞在日数については介入 を支持する方向で一致している。死亡はわずかに増 加，計画外抜管は増加する傾向であり，各アウトカム が異なる方向を示しているため，各アウトカムのエビ デンスの確実性の中で最も低い「非常に低」とした。

\section{（6）価值観}

人工呼吸管理中の鎮静薬の選択に対する，患者・家 族の価值観に関するデータはないが，不穏，死亡，人 工呼吸期間や ICU 滞在日数は，患者予後に直結する アウトカムであることから，その価值観は高く，ばら つきは少ないものと推察できる。

\section{（7）容認性}

介入における鎮静薬は，比較対象となる鎮静薬より
もコストは高いものの（1,821～4,890 円/1V)，不穏の 軽減，人工呼吸期間や ICU 滞在日数の短縮などの効 果による患者への有益性とそれにより予測できる医療 費の削減効果を考慮すれば，医療従事者の観点からだ けではなく，患者・家族の視点からもおそらく許容さ れるものと推察できる。

\section{（8）実行可能性}

既に多くの患者に対して頻繁に使用されている鎮静 薬であり，安全性も確立されていることから，どの医 療施設においても実行可能と判断される。

(9) 判断の要約 (Table 10-2-2)

（10）推奨グレーディング決定の工程

修正 RAND 法を用いた投票によって，中央值 8 , 見解不一致指数 0.164 の結果となり，委員会で採択さ れた（7 点以上 : 91.7\%）。

（11）関連する他の診療ガイドラインにおける推奨 SSCG 2016 ${ }^{15)}$ ，日本版敗血症診療ガイドライン （J-SSCG）2016 16，17）では，どの鎮静薬を用いるべき 
Table 10-2-2 判断の要約

\begin{tabular}{|c|c|c|c|c|c|c|c|}
\hline & \multicolumn{7}{|c|}{ 判溇 } \\
\hline 問題 & いいえ & $\begin{array}{c}\text { おそらく、いい } \\
\text { え }\end{array}$ & おそらく、はい & はい & & さまざま & 分からない \\
\hline 望ましい効果 & わずか & 小さい & 中 & 大きい & & さまざま & 分からない \\
\hline 望ましくない効果 & 大きい & 中 & 小さい & わずか & & さまざま & 分からない \\
\hline エビデンスの確実性 & 非常に低 & 低 & 中 & 高 & & & 採用研究なし \\
\hline 価值覞 & $\begin{array}{c}\text { 重要な不確実性 } \\
\text { またはばらつき } \\
\text { あり }\end{array}$ & $\begin{array}{c}\text { 重要な不確実性 } \\
\text { またはばらつき } \\
\text { の可能性あり }\end{array}$ & $\begin{array}{l}\text { 重要な不確実性 } \\
\text { またはばらつき } \\
\text { はおそらくなし }\end{array}$ & $\begin{array}{c}\text { 重要な不確実性 } \\
\text { またはばらつき } \\
\text { はなし }\end{array}$ & & & \\
\hline 効果のバランス & 比較が優位 & $\begin{array}{c}\text { 比較がおそらく } \\
\text { 優位 }\end{array}$ & $\begin{array}{c}\text { 介入も比較もい } \\
\text { ずれも優位でな } \\
\text { い }\end{array}$ & $\begin{array}{c}\text { おそらく介入が } \\
\text { 優位 }\end{array}$ & 介入が優位 & さまざま & 分からない \\
\hline 容認性 & いいえ & $\begin{array}{c}\text { おそらく、いい } \\
\text { え }\end{array}$ & おそらく、はい & はい & & さまざま & 分からない \\
\hline 実行可能性 & いいえ & $\begin{array}{c}お そ ら く 、 い い ~ \\
\text { え }\end{array}$ & おそらく、はい & はい & & さまざま & 分からない \\
\hline
\end{tabular}

かに関する記載はない。PADIS ガイドライン 18) にお いては, ベンゾジアゼピン系鎮静薬と比較して, プロ ポフォールによる鎮静は人工呼吸期間短縮につなが り，デクスメデトミジンによる鎮静は人工呼吸期間短 縮のみならずせん妄発症を抑える可能性があるとし て，プロポフォールやデクスメデトミジンによる鎮静 を提案している（条件付き推奨，低い質）。

\section{（12）実施に関わる検討事項}

鎮静薬を選択する際にプロポフォールとデクスメデ トミジンのどちらを優先して使用するのか，併用する ほうが良いのかについて，常に考慮する必要がある。 デクスメデトミジンには血圧低下，徐脈などの循環器 系副作用が存在し，その使用の際には注意を要する。 また，プロポフォールについても血圧低下，PRIS (propofol infusion syndrome) などの副作用が存在し, その使用の際には注意を要する。

\section{（13）今後の研究の可能性}

今後は敗血症患者のみを対象として，どの鎮静薬を 優先的に使用すべきかに関する検討を行う必要があ る。また, プロポフォール単独, デクスメデトミジン 単独, 両薬剤の併用のなかではどの鎮静方法が最も良 いのか，併用する場合にはどちらの薬剤を主として使 用するのが良いのかに関する検討が必要である。

\section{文 献}

1) Chamorro C, de Latorre FJ, Montero A, et al: Comparative study of propofol versus midazolam in the sedation of critically ill patients: results of a prospective, randomized, multicenter trial.
Crit Care Med. 1996; 24: 932-9.

2) Weinbroum AA, Halpern P, Rudick V, et al: Midazolam versus propofol for long-term sedation in the ICU: a randomized prospective comparison. Intensive Care Med. 1997; 23: 1258-63.

3) Sanchez-Izquierdo-Riera JA, Caballero-Cubedo RE, Perez-Vela JL, et al: Propofol versus midazolam: safety and efficacy for sedating the severe trauma patient. Anesth Analg. 1998; 86: 1219-24.

4) Camps AS, Riera JASI, Vazquez DT, et al: Midazolam and $2 \%$ propofol in long-term sedation of traumatized, critically ill patients: Efficacy and safety comparison. Crit Care Med. 2000; 28: 3612-9.

5) Hall RI, Sandham D, Cardinal P, et al: Propofol vs midazolam for ICU sedation: a Canadian multicenter randomized trial. Chest. 2001; 119: 1151-9.

6) Carson SS, Kress JP, Rodgers JE, et al: A randomized trial of intermittent lorazepam versus propofol with daily interruption in mechanically ventilated patients. Crit Care Med. 2006; 34: 1326-32.

7) Pandharipande PP, Pun BT, Herr DL, et al: Effect of sedation with dexmedetomidine vs lorazepam on acute brain dysfunction in mechanically ventilated patients: the MENDS randomized controlled trial. JAMA. 2007; 298: 2644-53.

8) Riker RR, Shehabi Y, Bokesch PM, et al: Dexmedetomidine vs midazolam for sedation of critically ill patients: a randomized trial. JAMA. 2009; 301: 489-99.

9) Mesnil M, Capdevila X, Bringuier S, et al: Long-term sedation in intensive care unit: a randomized comparison between inhaled sevoflurane and intravenous propofol or midazolam. Intensive Care Med. 2011; 37: 933-41.

10) Jakob SM, Ruokonen E, Grounds RM, et al: Dexmedetomidine vs midazolam or propofol for sedation during prolonged mechanical ventilation: two randomized controlled trials. JAMA. 2012; 307: 1151-60.

11) Zhou Y, Jin X, Kang Y, et al: Midazolam and propofol used alone or sequentially for long-term sedation in critically ill, mechanically ventilated patients: a prospective, randomized study. Crit Care. 2014; 18: R122.

12) MacLaren R, Preslaski CR, Mueller SW, et al: A randomized, double-blind pilot study of dexmedetomidine versus midazolam for intensive care unit sedation: patient recall of their experiences 
and short-term psychological outcomes. J Intensive Care Med. 2015; 30: 167-75.

13) Yu T, Peng X, Liu L, et al: Propofol increases preload dependency in septic shock patients. J Surg Res. 2015; 193: 849-55.

14) $\mathrm{Lu} \mathrm{X}, \mathrm{Li} \mathrm{J}, \mathrm{Li} \mathrm{T}$, et al: Clinical study of midazolam sequential with dexmedetomidine for agitated patients undergoing weaning to implement light sedation in intensive care unit. Chin J Traumatol. 2016; 19: 94-6.

15) Rhodes A, Evans LE, Alhazzani W, et al: Surviving Sepsis Campaign: International Guidelines for Management of Sepsis and Septic Shock: 2016. Intensive Care Med. 2017; 43: 304-77.

16）西田修, 小倉裕司, 井上茂亮, 他, 日本版敗血症診療ガイドラ イン 2016 作成特別委員会. 日本版敗血症診療ガイドライン 2016. 日集中医誌. 2017; 24: S1-232.

17）西田修, 小倉裕司, 井上茂亮, 他, 日本版敗血症診療ガイドラ イン 2016 作成特別委員会. 日本版敗血症診療ガイドライン 2016. 日救急医会誌. 2017; 28: S1-232.

18) Devlin JW, Skrobik Y, Gélinas C, et al: Clinical Practice Guidelines for the Prevention and Management of Pain, Agitation/Sedation, Delirium, Immobility, and Sleep Disruption in Adult Patients in the ICU. Crit Care Med. 2018; 46: e825-73.
CQ10-3 : 人工呼吸中の敗血症患者の鎮静薬調整 において, 1 日 1 回の鎮静薬中止やプロトコル を用いた鎮静薬の調整による light sedation を行 うか?

Answer: 敗血症患者の人工呼吸管理中の鎮静薬調整 において，1日 1 回の鎮静薬中止やプロトコルを用い た鎮静薬の調整によって light sedation を行うことを弱 く推奨する（GRADE 2C：エビデンスの確実性 $=$ 「低」)。

\section{（1）背景および本 $C Q$ の重要度}

Light sedation の実践は, 意識レベルの確認や不穏の 早期発見という観点から重要であるだけでなく, 人工 呼吸期間や ICU 滞在日数の短縮につながるとされて いる。よって, 敗血症患者におけるその効果を検討す ることは, 患者予後改善の観点からも不可欠であると 判断し，CQとして取り上げた。

\section{(2) PICO}

$P$ (患者) : 人工呼吸管理中の 18 歳以上の成人

I (介入) : Light sedation [1 日 1 回の鎮静薬の中断 またはプロトコルによる鎮静薬の調整, RASS -2 以上（もしくはそれに相当する）の鎮静深度を目 標とした管理]

C (対照) : Deep sedation

$\mathrm{O}$ (アウトカム) : 人工呼吸期間, ICU 滞在日数, 死 亡, 計画外抜管

（3）エビデンスの要約

システマティックレビューの結果, PICO に合致し たランダム化比較試験（RCT）が 2 件 1,2) 施行されて おり,これらを用いたメタ解析を実施した。

（4）益と害のバランス（Table 10-3-1） 望ましい効果：

Light sedationの実践により, 死亡（2 RCT: $\mathrm{n}=$ 257）は 1,000 人あたり 57 人少ない（135人少ない〜 60 人多い）と臨床的な差はない。しかし人工呼吸期 間（2 RCT: $\mathrm{n}=257 ）$ は平均（MD）2.49 日短い（4.43 日短い 0.54 日短い), ICU 滞在日数 $(2$ RCT: $n=$ 257）は MD 3.34 日短い（6.09 日短い〜0.60日短い） については, いずれも介入群が優位である。Light sedation の実践を支持するものであると考え, 望まし い効果は「中」とした。 
Table 10-3-1 エビデンスプロファイル

\begin{tabular}{|c|c|c|c|c|c|c|c|c|c|c|c|c|}
\hline \multicolumn{7}{|c|}{ 確実性の評価 } & \multicolumn{2}{|c|}{ 患者数 } & \multicolumn{2}{|c|}{ 効果 } & \multirow[b]{2}{*}{ 確実性 } & \multirow[b]{2}{*}{ 重要性 } \\
\hline 研究数 & $\begin{array}{c}\text { 研究 } \\
\text { デザイン }\end{array}$ & $\begin{array}{l}\text { バイアス } \\
\text { のリスク }\end{array}$ & 非一貫性 & 非直接性 & 不精確性 & $\begin{array}{l}\text { その他 } \\
\text { の検討 }\end{array}$ & Light sedation & Deep sedation & $\begin{array}{l}\text { 相対指標 } \\
(95 \% \mathrm{CI})\end{array}$ & $\begin{array}{l}\text { 絶対指標 } \\
(95 \% \text { CI }\end{array}$ & & \\
\hline \multicolumn{13}{|c|}{ 人工呼吸期間 } \\
\hline 2 & RCT & 深刻a & 深刻でない & 深刻でない & 深刻 b & なし & 133 & 124 & - & $\begin{array}{c}\text { 平均 } 2.49 \text { 日短い } \\
\text { (4. } 43 \text { 日短い } \\
0.54 \text { 低い) }\end{array}$ & $\underset{\text { 低 }}{\oplus \oplus \bigcirc \bigcirc}$ & 重大 \\
\hline \multicolumn{13}{|c|}{ ICU 滞在日数 } \\
\hline 2 & RCT & 深刻 a & 深刻でない & 深刻でない & 深刻 b & なし & 133 & 124 & - & $\begin{array}{c}\text { 平均 } 3.34 \text { 日短い } \\
\text { (6.09 短い 0. } \\
\text { 短い) }\end{array}$ & $\underset{\text { 低 }}{\oplus \oplus \bigcirc}$ & 重大 \\
\hline \multicolumn{13}{|l|}{ 死亡 } \\
\hline 2 & RCT & 深刻 a & 深刻でない & 深刻でない & 深刻 b & なし & $\begin{array}{l}36 / 133 \\
(27.1 \%)\end{array}$ & $\begin{array}{l}39 / 124 \\
(31.5 \%)\end{array}$ & $\begin{array}{c}\text { RR } 0.82 \\
(0.57 \text { to } 1.19)\end{array}$ & $\begin{array}{l}\text { 1, } 000 \text { 人あたり } 57 \\
\text { 人少ない (135人少 } \\
\text { ない 60人多い) }\end{array}$ & $\underset{\text { 低 }}{\oplus \oplus \bigcirc \bigcirc}$ & 重大 \\
\hline \multicolumn{13}{|c|}{ 計画外拢管 } \\
\hline 1 & RCT & 深刻 a & 深刻でない & 深刻でない & 非常に深刻 c & なし & $2 / 68 \quad(2.9 \%)$ & $4 / 60(6.7 \%)$ & $\begin{array}{c}\text { RR } 0.44 \\
(0.08 \text { to } 2.32)\end{array}$ & $\begin{array}{l}1,000 \text { 人あたり } 37 \\
\text { 人少ない (61 人少 } \\
\text { ない 88 人多い) }\end{array}$ & $\begin{array}{l}\oplus \bigcirc \bigcirc \bigcirc \\
\text { 非常に低 }\end{array}$ & 重大 \\
\hline
\end{tabular}

a：Kress20001)，Treggiari20092)共に盲検化での高いバイアスのリスクであり，Treggiari2009 については不完全アウトカム報告も高いバイアスのリスクでありアウトカムに対する影響は深刻と考え 1 段階グレードダウンとした。

$\mathrm{b}:$ 対象となる研究が 2 つであり，対象者数が十分でないため，1段階グレードを下げた。

c：対象となる研究が 1 つであり対象者数が十分でなく，信頼区間も大きく，効果推定值が不精確だと判断し，2段階グレードを下げた。

\section{望ましくない効果 :}

懸念される望ましくない効果である，計画外抜管 （1 RCT: $\mathrm{n}=128 ）$ は 1,000 人あたり 37 人少ない（61 人少ない〜 88 人多い）と両群で差はない。望ましく ない効果はわずかと判断した。

益と害のバランス :

死亡に関しては差がないものの，人工呼吸期間， ICU 滞在日数においては，介入によって有益な効果が 示されており，好ましくない効果である計画外抜管も 減少傾向であることから，おそらく介入が優位であ る。

（5）アウトカム全般に関するエビデンスの確実性

死亡と計画外抜管は減少する方向で，人工呼吸期間 と ICU 滞在日数は有意差を持って介入を支持する方 向で一致している。各アウトカムに対する確実性は 「低」から「非常に低」であり，全体的なエビデンス の確実性は，その中で高いほうの「低」とした。

\section{（6）価值観}

Light sedation の実践に対する患者・家族の価值観に 関するデータはない。しかしながら，死亡や人工呼吸 期間, ICU 滞在日数は，患者予後に直結するアウトカ ムであり， light sedationにより患者意識が確認できれ ば，家族にとっては大きなメリットになることを考慮 すると，その価值は高く，ばらつきは少ないものと推 察した。

\section{（7）容認性}

Light sedation の実践は，担当看護師の負担が増える 可能性は否定できないものの，計画外抜管といった望 ましくない効果を増やすことなく患者意識を確認する ことが可能であり，かつ人工呼吸期間や ICU 滞在日 数を短縮することから，おそらく患者・家族から許容 されるものと判断した。

\section{（8）実行可能性}

Light sedation 下で人工呼吸管理中からリハビリテー ションを実践することが，標準的治療になりつつある ことを考えれば，鎮静薬の調節や意識のある患者に対 する対応が負担になるとは考えにくく，計画外抜管な どの望ましくない効果にも影響がないことから，実行 は可能であると判断した。

（9）判断の要約（Table 10-3-2）

（10）推奨グレーディング決定の工程

修正 RAND 法を用いた投票によって，中央值 8, 見解不一致指数 0.164 の結果となり, 委員会で採択さ れた（7 点以上 : 91.7\%)。

\section{（11）関連する他の診療ガイドラインにおける推奨}

SSCG 20163) では，鎮静レベルの目標を決めて鎮静 薬の量を最小限に抑えることが推奨されており，投与 方法については，間欠的，持続的のいずれでも良いと している (best practice statement: BPS)。PADIS ガイド 
日本版敗血症診療ガイドライン 2020

Table 10-3-2 判断の要約

\begin{tabular}{|c|c|c|c|c|c|c|c|}
\hline & \multicolumn{7}{|c|}{ 判溇 } \\
\hline 問題 & いいえ & $\begin{array}{c}\text { おそらく、いい } \\
\text { え }\end{array}$ & おそらく、はい & はい & & さまざま & 分からない \\
\hline 望ましい効果 & わずか & 小さい & 中 & 大きい & & さまざま & 分からない \\
\hline 望ましくない効果 & 大きい & 中 & 小さい & わずか & & さまざま & 分からない \\
\hline エビデンスの確実性 & 非常に低 & 低 & 中 & 高 & & & 採用研究なし \\
\hline 価值覞 & $\begin{array}{c}\text { 重要な不確実性 } \\
\text { またはばらつき } \\
\text { あり }\end{array}$ & $\begin{array}{c}\text { 重要な不確実性 } \\
\text { またはばらつき } \\
\text { の可能性あり }\end{array}$ & $\begin{array}{l}\text { 重要な不確実性 } \\
\text { またはばらつき } \\
\text { はおそらくなし }\end{array}$ & $\begin{array}{c}\text { 重要な不確実性 } \\
\text { またはばらつき } \\
\text { はなし }\end{array}$ & & & \\
\hline 効果のバランス & 比較が優位 & $\begin{array}{c}\text { 比較がおそらく } \\
\text { 優位 }\end{array}$ & $\begin{array}{c}\text { 介入も比較もい } \\
\text { ずれも優位でな } \\
\text { い }\end{array}$ & $\begin{array}{c}\text { おそらく介入が } \\
\text { 優位 }\end{array}$ & 介入が優位 & さまざま & 分からない \\
\hline 容認性 & いいえ & $\begin{array}{c}\text { おそらく、いい } \\
\text { え }\end{array}$ & おそらく、はい & はい & & さまざま & 分からない \\
\hline 実行可能性 & いいえ & 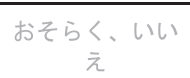 & おそらく、はい & はい & & さまざま & 分からない \\
\hline
\end{tabular}

ライン4）においては, light sedation の実践は死亡に影 響はないものの, 人工呼吸期間の短縮や気管切開施行 率の低下につながるとして推奨されている（条件付き 推奨，低い質のエビデンス)。

日本版敗血症診療ガイドライン（J-SSCG）2016

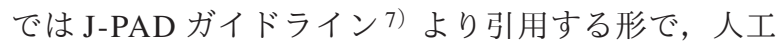
呼吸管理中の成人患者では，「毎日鎮静を中断する」 あるいは「浅い鎮静深度を目標とする」プロトコルの いずれかをルーチンに用いることを推奨している (1B)。

\section{（12）実施に関わる検討事項}

1 日 1 回の鎮静薬の中断とプロトコルによる鎮静薬 の調整では，どちらが有効でかつ安全に施行できるの か，鎮静のレベルについては鎮静スコアリングを用い てどのレベルを目標とすべきなのか，について日々お よび個々の患者で検討していく必要がある。

\section{（13）今後の研究の可能性}

今後は，敗血症患者のみを対象とした light sedation に対する有効性・安全性に関する検討や 1 日 1 回の鎮 静薬の中断とプロトコルによる鎮静薬の調整では，ど ちらが有効かつ安全に実践できるかに関する検討, RASS -2 以上の中でどの鎮静レベルが最も有効かつ 安全であるのかに対する検討が必要である。

\section{文 献}

1) Kress JP, Pohlman AS, O'Connor MF, et al: Daily interruption of sedative infusions in critically ill patients undergoing mechanical ventilation. N Engl J Med. 2000; 342: 1471-7.
2) Treggiari MM, Romand JA, Yanez ND, et al: Randomized trial of light versus deep sedation on mental health after critical illness. Crit Care Med. 2009; 37: 2527-34.

3) Rhodes A, Evans LE, Alhazzani W, et al: Surviving Sepsis Campaign: International Guidelines for Management of Sepsis and Septic Shock: 2016. Intensive Care Med. 2017; 43: 304-77.

4) Devlin JW, Skrobik Y, Gélinas C, et al: Clinical Practice Guidelines for the Prevention and Management of Pain, Agitation/Sedation, Delirium, Immobility, and Sleep Disruption in Adult Patients in the ICU. Crit Care Med. 2018; 46: e825-73.

5）西田修, 小倉裕司, 井上茂亮, 他, 日本版敗血症診療ガイドラ イン 2016 作成特別委員会. 日本版敗血症診療ガイドライン 2016. 日集中医誌. 2017; 24: S1-232.

6）西田修, 小倉裕司, 井上茂亮, 他, 日本版敗血症診療ガイドラ イン 2016 作成特別委員会. 日本版敗血症診療ガイドライン 2016. 日救急医会誌. 2017; 28: S1-232.

7）日本集中治療医学会 J-PAD ガイドライン作成委員会: 日本 版・集中治療室における成人重症患者に対する痛み・不穏・ せん妄管理のための臨床ガイドライン. 日集中医誌. 2014; 21: $539-79$. 


\section{CQ10-4：成人敗血症患者のせん妄予防に, 薬物 療法を行うか?}

Answer: 成人敗血症患者のせん妄予防にデクスメデ トミジンを投与することを弱く推奨する（GRADE $2 \mathrm{C}:$ エビデンスの確実性 $=\lceil$ 低」)。ハロペリドール を投与しないことを弱く推奨する（GRADE 2B：エビ デンスの確実性 $=\lceil$ 中」)。非定型抗精神病薬を投与し ないことを弱く推奨する（GRADE 2C：エビデンスの 確実性 $=「$ 低」）。スタチンを投与しないことを弱く推 奨する（GRADE 2D：エビデンスの確実性 $=$ 「非常に 低」)。

コメント : 鎮静が不必要な患者にデクスメデトミジン のルーチン投与を推奨するものではない。

また，デクスメデトミジンの投与は循環動態の変動 を来す恐れがあるため, 集中治療室で全身管理に熟練 した医師のもとで投与することが望ましい。

\section{（1）背景および本 CQの重要度}

敗血症患者の中枢神経系臓器障害の 1 つとしてせん 妄がある。集中治療室でのせん妄の持続日数は，集中 治療室退室後 3 か月と 12 か月の認知機能障害と関連 することが知られている。敗血症患者においてせん妄 を薬物により予防することができれば，患者の集中治 療後症候群（PICS）を軽減できる可能性があるため, 本 CQ を敗血症診療における重要な臨床課題として取 り上げた。

\section{(2) PICO}

$\mathrm{P}$ (患者): 敗血症, 呼吸不全, 心不全, 熱傷, 大侵 襲手術後などで人工呼吸中の成人重症患者

I（介入）: デクスメデトミジン，ハロペリドール， 非定型抗精神病薬，スタチンの投与

$\mathrm{C}$ (対照)：プラセボ投与

$\mathrm{O}$ (アウトカム ) : 死亡, 集中治療室退室後の認知機 能障害，せん妄，せん妄日数（報告がない場合 は，非せん妄日数)，ICU 滞在日数，重症有害事 象

\section{（3）エビデンスの要約}

システマティックレビューの結果, PICO に合致し たランダム化比較試験（RCT）がデクスメデトミジン 8 件 1-8)，ハロペリドール 7 件 1, 9-14)，非定型抗精神病 薬 3 件 10,15,16)，スタチン 2 件 17, 18）施行されており, これらを用いたメタ解析を実施した。
(4) 益と害のバランス（Table 10-4-1）

望ましい効果 :

デクスメデトミジンの予防投与は，せん妄（7 RCT: $\mathrm{n}=1,658)$ について 1,000 人あたり 155 人少ない（203 人少ない〜 83 人少ない）であり, 望ましい効果は「中」 であると判断した。他のハロペリドール，非定型抗精 神病薬，スタチンの予防投与については，それぞれせ ん妄 $(5$ RCT: $\mathrm{n}=2,159)$ が 1,000 人あたり 34 人少な い（92 人少ない～ 40 人多い），術後患者のみを対象と した $2 \mathrm{RCT}(\mathrm{n}=227 ）$ の 1,000人あたり 203 人少ない (225 人少ない〜 111 人少ない), $1 \mathrm{RCT}(\mathrm{n}=142)$ の 1,000 人あたり 9 人少ない（94人少ない〜 66 人多い） と，いずれも望ましい効果はわずかであった。 望ましくない効果 :

デクスメデトミジンの重症な有害事象は 1,000 人あ たり 53 人少ない $(69$ 人少ない〜 8 人多い), 八ロペリ ドールの重篤な有害事象は 1,000 人あたり 2 人少ない （6人少ない〜 13 人多い）であり，望ましくない効果 はわずかと考えた。非定型抗精神病薬，スタチンの予 防投与については, 重症な有害事象を調べた研究はな い，あるいは，介入群・対照群ともに有害事象の発生 はなく，望ましくない効果の推定值はわからなかっ た。

益と害のバランス :

デクスメデトミジンについては，望ましくない効果 発生に差はなく，集中治療室退室後の認知機能障害と せん妄について中程度の効果を認めるため, おそらく 介入が優位と判断した。

ハロペリドールについては，望ましい効果は限定的 であり，望ましくない効果も増えない可能性が高いこ とより，介入も比較対照のいずれも優位でないと判断 した。

非定型抗精神病薬については，せん妄を低下させた がその対象は術後患者のみであり，望ましい効果はわ ずかであると考えた。また，望ましくない効果は不明 である。以上より，敗血症患者に推奨するにはエビデ ンスが不足しており，介入も比較対照もいずれも優位 でないと判断した。

スタチンについては，望ましい効果は限定的で，望 ましくない効果もわずかであり，介入も比較もいずれ も優位でないと判断した。

（5）アウトカム全般に関するエビデンスの確実性

デクスメデトミジンについては，益と害の各アウト カムが同じ方向性を示しているため, 最も高いエビデ ンスである「低」を採用した。ハロペリドールについ 
Table 10-4-1エビデンスプロファイル

デクスメデトミジン

\begin{tabular}{|c|c|c|c|c|c|c|c|c|c|c|c|c|}
\hline \multicolumn{7}{|c|}{ 確実性の評価 } & \multicolumn{2}{|c|}{ 患者数 } & \multicolumn{2}{|c|}{ 勃果 } & \multirow[b]{2}{*}{ 碓実性 } & \multirow[b]{2}{*}{ 重要性 } \\
\hline 研究数 & $\begin{array}{l}\text { 研究 } \\
\text { デザイン }\end{array}$ & $\begin{array}{l}\text { パイス } \\
\text { のリスク }\end{array}$ & 非一貫性 & 非直接性 & 不精碓性 & $\begin{array}{l}\text { その他 } \\
\text { の检討 }\end{array}$ & デクスメデトミジン & プラセボ & $\begin{array}{l}\text { 相対指摽 } \\
(95 \% \text { cI) }\end{array}$ & $\begin{array}{l}\text { 絶対指標 } \\
(95 \% \mathrm{CI})\end{array}$ & & \\
\hline \multicolumn{13}{|l|}{ 死亡 } \\
\hline 4 & RCT & 深刻。 & 深刻でない & 深刻でない & 深刻 ${ }^{\circ}$ & なし & $148 / 530(27.9 \%)$ & $164 / 531 \quad(30.9 \%)$ & $\begin{array}{l}\text { RR } 0.91 \\
\text { (0.76 to } 1.09)\end{array}$ & $\begin{array}{l}\text { 1,000人おたり } 28 \\
\text { 人少ない (74人少 } \\
\text { ない 28人多い) }\end{array}$ & $\underset{\text { 低 }}{\oplus \oplus \bigcirc \bigcirc}$ & 重大 \\
\hline \multicolumn{13}{|c|}{ 集中治療空退室後の䛷知機能障害（modified Telephone Interview for Cognitive Status：TICS-m) } \\
\hline 1 & RCT & 深刻。 & 深刻でない & 深刻 d & 深刻 b & なし & 221 & 213 & - & $\begin{array}{l}\text { 平均 } 4.7 \text { 高い }(3.78 \\
\text { 高い } \\
\end{array}$ & $\begin{array}{l}\oplus \circ \\
\text { 非常に低 }\end{array}$ & 重大 \\
\hline \multicolumn{13}{|c|}{ 世ん安日数 } \\
\hline 1 & RCT & 深刻 a & 深刻でない & 深刻でない & 非常1深刻。 & なし & 50 & 50 & - & $\begin{array}{l}\text { 平均 } 0.2 \text { 日短い } \\
(0.86 \text { 日短い } \\
0.46 \text { 日長い) }\end{array}$ & $\begin{array}{l}\oplus \circ 0 \bigcirc \\
\text { 非常に低 }\end{array}$ & 重大 \\
\hline \multicolumn{13}{|l|}{ せん妄 } \\
\hline 7 & RCT & 深刻 ${ }^{f}$ & 深刻 : & 深刻でない & 深刻でない & なし & $128 / 829(15.4 \%)$ & $247 / 829(29.8 \%)$ & $\begin{array}{c}\text { RR } 0.48 \\
\text { (0. } 32 \text { to } 0.72)\end{array}$ & $\begin{array}{l}1,000 \text { 人あたり } 155 \\
\text { 少ない (203 人少 } \\
\text { ない 8い 人少ないい) }\end{array}$ & $\underset{\text { 低 }}{\oplus \oplus \bigcirc \bigcirc}$ & 重大 \\
\hline \multicolumn{13}{|c|}{ 重症な有害事象（機能不全に関わるもの：急性冠症候群、肺炎） } \\
\hline 2 & RCT & 深刻。 & 深刻でない & 深刻でない & 深刻 $\mathrm{h}$ & なし & $3 / 130(2.3 \%)$ & $10 / 131(7.6 \%)$ & $\begin{array}{l}\text { RR } 0.31 \\
\text { (0.09 to } 1.11)\end{array}$ & 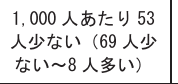 & $\underset{\text { 低 }}{\oplus \oplus \bigcirc \bigcirc}$ & 重大 \\
\hline \multicolumn{13}{|c|}{ ICU 滞在日数 } \\
\hline 5 & RCT & 深刻 a & 深刻 $\mathrm{B}$ & 深刻でない & 深刻 b & なし & 570 & 571 & - & $\begin{array}{c}\text { 平均 } 1.55 \text { 日短い } \\
(3.82 \text { 日短い } \\
0.72 \text { 長い) }\end{array}$ & $\begin{array}{l}\oplus \circ 0 \bigcirc \\
\text { 非常に低 }\end{array}$ & 重要 \\
\hline
\end{tabular}

a. 大多数の研究で，患者医療者の盲榆化ができていないため，一段階グレードを下げた。

b. 総サンプルサイズが小さいため,一段階グレードを下げた。

c. その他のバイアス (Zhang 20198) は, Su 2016)の fol low up study のため検出力低下が疑われる) のため, 一段階グレードを下げた。

d. 術後患者のみを対象としている研究のため一段階グレードを下げた。

1 1 件のRCT のみ。総サンプルサイズが小さいため, 二段階グレードを下げた。

f. 大多数の研究でバイアスのリスクの割付の隱蔽化，盲検化などの項目がバイアスリスクが高いあるいは不明であり，全体的なバイアスのリスクは高いと判断し，一段階グレードを下げた。

g. 異質性が高いため, 一段階グレードを下げた。

h. 総イベント数が少ないため, 一段階グレードを下げた。

ハロペリドール

\begin{tabular}{|c|c|c|c|c|c|c|c|c|c|c|c|c|}
\hline \multicolumn{7}{|c|}{ 確実性の評価 } & \multicolumn{2}{|c|}{ 患者数 } & \multicolumn{2}{|c|}{ 効果 } & \multirow[b]{2}{*}{ 確実性 } & \multirow[b]{2}{*}{ 重要性 } \\
\hline 研究数 & $\begin{array}{l}\text { 研究 } \\
\text { デザイン }\end{array}$ & $\begin{array}{l}\text { パイアス } \\
\text { のリスク }\end{array}$ & 非一貫性 & 非直接性 & 不精破性 & $\begin{array}{l}\text { その他 } \\
\text { の橹討 }\end{array}$ & ハロベリドール & プラセボ & $\begin{array}{l}\text { 相対指標 } \\
(95 \% \text { CI) }\end{array}$ & $\begin{array}{l}\text { 䋓対指標 } \\
(95 \% \text { CI) }\end{array}$ & & \\
\hline \multicolumn{13}{|c|}{ 死亡（最長のもの） } \\
\hline 7 & RCT & 深刻でない & 深刻てない & 深刻 a & 深刻でない & なし & $\begin{array}{l}190 / 1199 \\
(15.8 \%)\end{array}$ & $\begin{array}{c}192 / 1172 \\
(16.4 \%)\end{array}$ & $\begin{array}{c}\text { RR } 0.97 \\
\text { (0.81 to } 1.16)\end{array}$ & $\begin{array}{c}\text { 1, } 000 \text { 人あたり } 5 \\
\text { 少ない (31入 } \\
\text { 少ない } 26 \text { 人多 } \\
\text { (い) }\end{array}$ & $\underset{\text { 中 }}{\oplus \oplus \oplus \bigcirc}$ & 重大 \\
\hline \multicolumn{13}{|c|}{ せん妄日数 } \\
\hline 3 & RCT & 深刻てない & 深刻でない & 深刻 a & 深刻 b & なし & 174 & 173 & - & $\begin{array}{c}\text { 平均 } 0.02 \text { 日長い } \\
(0.23 \text { 日短い } \\
0.27 \text { 日長い) }\end{array}$ & $\underset{\text { 低 }}{\oplus \oplus \bigcirc \bigcirc}$ & 重大 \\
\hline \multicolumn{13}{|c|}{ 非世ん安（昏睡）日数（28日） } \\
\hline 2 & RCT & 深刻でない & 深刻でない & 深刻でない。 & 深刻 b & なし & 803 & 777 & - & $\begin{array}{c}\text { 平均 } 0.66 \text { 日短い } \\
(1.42 \text { 日短い } \\
0.11 \text { 日長い) }\end{array}$ & $\begin{array}{c}\oplus \oplus \oplus \bigcirc \\
\text { 中 }\end{array}$ & 重大 \\
\hline \multicolumn{13}{|l|}{ せん安 } \\
\hline 5 & RCT & 深刻でない & 深刻でない & 深刻 a & 深刻 d & なし & $\begin{array}{c}316 / 1093 \\
(28.9 \%)\end{array}$ & $\begin{array}{c}326 / 1066 \\
(30.6 \%)\end{array}$ & $\begin{array}{c}\text { RR } 0.89 \\
(0.70 \text { to } 1.13)\end{array}$ & $\begin{array}{c}\text { 1, } 000 \text { 人あたり } 34 \\
\text { 少ない } 992 \text { } \\
\text { 少ない } 40 \text { 人多 } \\
\text { い) }\end{array}$ & $\underset{\text { 低 }}{\oplus \oplus \bigcirc \bigcirc}$ & 重大 \\
\hline \multicolumn{13}{|c|}{ 重症な有害事象（致死的イベント、機能不全に関わるもの。著者らの定義） } \\
\hline 2 & RCT & 深刻でない & 深刻でない & 深刻てない。 & 非常1深刻。 & なし & $5 / 803(0.6 \%)$ & $6 / 777(0.8 \%)$ & $\begin{array}{c}\text { RR } 0.80 \\
\text { (0. } 24 \text { to } 2.66)\end{array}$ & $\begin{array}{c}\text { 1, 000人あたり } 2 \\
\text { 人少ない (6人少 } \\
\text { ない 13人多 } \\
\text { い) }\end{array}$ & $\underset{\text { 低 }}{\oplus \oplus \bigcirc}$ & 重大 \\
\hline \multicolumn{13}{|c|}{ ICU 滞在日数 } \\
\hline 7 & RCT & 深刻てない & 深刻でない & 深刻。 & 深刻でない & なし & 1180 & 1153 & - & $\begin{array}{c}\text { 平均 } 0.07 \text { 日短い } \\
(0.26 \text { 日短い } \\
0.11 \text { 日長い) }\end{array}$ & $\underset{\text { 中 }}{\oplus \oplus \oplus \bigcirc}$ & 重要 \\
\hline
\end{tabular}

集中治療室退室後の認知機能障害を検討した研究はなかった。

a. 対象集団の一部にせん妄（昏睡）患者を含んでいる研究を含むため、一段階グレードを下げた。

b. 総サンプルサイズが小さいため, 一段階グレードを下げた。

c. 対象集団の一部にせん妄（昏睡）患者を含んでいる研究を含むが，バイアスの影響が少ないアウトカムであるため,ダウングレードを行わなかった

. $95 \%$ CI が広く臨床決断の閾値をまたぐため, 一段階グレ一ドを下げた。

e. $95 \% \mathrm{CI}$ が広く臨床決断の闇值をまたぐため, 二段階グレードを下げた。 
日集中医誌 J Jpn Soc Intensive Care Med Vol. 28 Suppl

Table 10-4-1エビデンスプロファイル(つづき)

非定型抗精神病薬

\begin{tabular}{|c|c|c|c|c|c|c|c|c|c|c|c|c|}
\hline \multicolumn{7}{|c|}{ 確実性の評価 } & \multicolumn{2}{|c|}{ 患者数 } & \multicolumn{2}{|c|}{ 珓果 } & \multirow[b]{2}{*}{ 確実性 } & \multirow[b]{2}{*}{ 重要性 } \\
\hline 研究数 & $\begin{array}{l}\text { 研究 } \\
\text { テサイン }\end{array}$ & $\begin{array}{l}\text { ハイアス } \\
\text { のリスク }\end{array}$ & 非一貫栍 & 非直接性 & 不料礶性 & $\begin{array}{l}\text { その他 } \\
\text { の楥討 }\end{array}$ & 非定型抗精神 & プらゼ & $\begin{array}{l}\text { 相㸚指漂 } \\
(95 \% \text { CI) }\end{array}$ & $\begin{array}{l}\text { 䋓対指楼 } \\
(95 \% \text { GI) }\end{array}$ & & \\
\hline \multicolumn{13}{|c|}{ 死亡（最長のもの） } \\
\hline 1 & RCT & 深刻でない & 深刻でない & 深刻 a & 非常に深刻 b & なし & $4 / 30(13.3 \%)$ & $6 / 36(16.7 \%)$ & $\begin{array}{l}\text { RR } 0.80 \\
(0.25 \text { to } \\
2.57)\end{array}$ & $\begin{array}{l}1,000 \text { 人あた } \\
\text { 133 人少ない } \\
\text { (125 人少ない } \\
\sim 262 \text { 人多い) }\end{array}$ & $\begin{array}{l}\oplus \circ \\
\text { 非常に低 }\end{array}$ & 重大 \\
\hline \multicolumn{13}{|c|}{ せん安日数 } \\
\hline 2 & RCT & 深刻でない & 深刻でない & 深刻。 & 深刻 d & なし & 37 & 53 & - & $\begin{array}{c}\text { 平均 } 0.01 \text { 日 } \\
\text { 長い } \\
(1.13 \text { 日短い } \\
\sim 1.16 \text { 日長 } \\
\text { ( ) }\end{array}$ & $\underset{\text { 低 }}{\oplus \oplus \bigcirc \bigcirc}$ & 重大 \\
\hline \multicolumn{13}{|c|}{ 非せん妄（昏睡）日数（21 日） } \\
\hline 1 & RCT & 深刻でない & 深刻でない & 深刻 a & 非常に深刻 b & なし & 30 & 36 & - & $\begin{array}{c}\text { 平均 } 3.73 \text { 日長 } \\
\text { い } \\
(1.01 \text { 日短い } \\
\sim 8.47 \text { 日長 } \\
\text { () }\end{array}$ & $\begin{array}{l}\oplus \circ \\
\text { 非常に低 }\end{array}$ & 重大 \\
\hline \multicolumn{13}{|c|}{ せん安（術後患者のみを対象とした研究） } \\
\hline 2 & RCT & 深刻でない & 深刻でない & 深刻e & 深刻 d & なし & $\begin{array}{l}14 / 114 \\
(12.3 \%)\end{array}$ & $\begin{array}{l}37 / 113 \\
(32.7 \%)\end{array}$ & $\begin{array}{l}\text { RR } 0.38 \\
(0.22 \text { to } \\
0.66)\end{array}$ & $\begin{array}{c}1,000 \text { 人あた } \\
\text { り } 203 \text { 人少な } \\
\text { い } \\
(255 \text { 人少ない } \\
\sim 111 \text { 人少な } \\
\text { (1) }\end{array}$ & $\underset{\text { 低 }}{\oplus \oplus \bigcirc \bigcirc}$ & 重大 \\
\hline \multicolumn{13}{|c|}{ ICU 滞在日数 } \\
\hline 3 & RCT & 深刻でない & 深刻でない & 深刻 + & 深刻 d & なし & 100 & 116 & - & $\begin{array}{c}\text { 平均 } 0.03 \text { 日短 } \\
\text { い } \\
(0.67 \text { 日短い } \\
\sim 0.61 \text { 日長 } \\
\text { (い) }\end{array}$ & $\underset{\text { 低 }}{\oplus \oplus \bigcirc O}$ & 重要 \\
\hline
\end{tabular}

集中治療室退室後の認知機能障害，重症な有害事象を報告した研究はなかった。

a. 対象集団の一部にせん妄（昏睡）患者を含むため、一段階グレードを下げた。

b. 1 件の RCT。総サンプルサイズが小さいため，二段階グレードを下げた。

c. $1 / 2$ 件の RCT で術後患者を対象としているため, 一段階グレ一ドを下げた。

d. 総サンプルサイズが小さいため,一段階グレードを下げた。

e. $2 / 2$ 件のRCTで術後患者を対象としているため,一段階グレードを下げた。

f. $2 / 3$ 件の RCT で術後患者を対象としているため, 一段階グレードを下げた。

スタチン

\begin{tabular}{|c|c|c|c|c|c|c|c|c|c|c|c|c|}
\hline \multicolumn{7}{|c|}{ 確実性の評価 } & \multicolumn{2}{|c|}{ 患者数 } & \multicolumn{2}{|c|}{ 効果 } & \multirow[b]{2}{*}{ 確实性 } & \multirow[b]{2}{*}{ 重要性 } \\
\hline 研究数 & $\begin{array}{l}\text { 研究 } \\
\text { デザイン }\end{array}$ & $\begin{array}{l}\text { パイアス } \\
\text { のリスク }\end{array}$ & 非一貫性 & 非直接性 & 不精碓性 & $\begin{array}{l}\text { その他 } \\
\text { の检討 }\end{array}$ & スタチン & プラセボ & $\begin{array}{l}\text { 相対指摽 } \\
(955 \% \text { CI }\end{array}$ & $\begin{array}{l}\text { 絶対指㯖 } \\
(955 \% \text { CI }\end{array}$ & & \\
\hline \multicolumn{13}{|l|}{ 死亡 } \\
\hline 1 & RCT & 深刻てない & 深刻でない & 深刻でない & 深刻 a & なし & $30 / 71 \quad(42.3 \%)$ & $22 / 71(31.0 \%)$ & $\begin{array}{l}\text { RR } 1.36 \\
\text { (0.88 to } 2.12)\end{array}$ & $\begin{array}{c}\text { 1, 000 人あたり } 112 \\
\text { 人多い (37 少ない } \\
\text { ３47人多い) }\end{array}$ & $\underset{\text { 中 }}{\oplus \oplus \oplus \bigcirc}$ & 重大 \\
\hline \multicolumn{13}{|c|}{ 集中治療空退空後の認知機能障害 } \\
\hline 1 & RCT & 非常|=深刻 b & 深刻でない & 深刻。 & 非常|=深刻 d & なし & $19 / 53(35.8 \%)$ & $29 / 77 \quad(37.7 \%)$ & $\begin{array}{c}\text { RR } 0.95 \\
(0.60 \text { to } 1.51)\end{array}$ & $\begin{array}{c}1,000 \text { 人あたり } 19 \\
\text { 人少ない } 151 \text { (151 } \\
\text { 少ない } 192 \text { 人多 } \\
\text { い) }\end{array}$ & $\begin{array}{l}\oplus \bigcirc \bigcirc \bigcirc \\
\text { 非常に低 }\end{array}$ & 重大 \\
\hline \multicolumn{13}{|c|}{ 非世ん妄（昏睡）日数（28日） } \\
\hline 1 & RCT & 深刻てない & 深刻でない & 深刻でない & 深刻 a & なし & 71 & 71 & - & $\begin{array}{l}\text { 平均 } 1.1 \text { 日短い } \\
(4.74 \text { 日短い } \\
2.54 \text { 日長い) }\end{array}$ & $\underset{\text { 中 }}{\oplus \oplus \oplus \bigcirc}$ & 重大 \\
\hline \multicolumn{13}{|l|}{ せん妄 } \\
\hline 1 & RCT & 深刻でない & 深刻でない & 深刻でない & 深刻 a & なし & $66 / 71(93.0 \%)$ & $67 / 71(94.4 \%)$ & $\begin{array}{c}\text { RR } 0.99 \\
\text { (0.90 to } 1.07)\end{array}$ & $\begin{array}{l}\text { 1, 000人あたり } \\
\text { 人少ない (94人少 } \\
\text { ない 66人多い) }\end{array}$ & $\begin{array}{c}\oplus \oplus \oplus \bigcirc \\
\text { 中 }\end{array}$ & 重大 \\
\hline \multicolumn{13}{|c|}{ ICU 滞在日数 } \\
\hline 1 & RCT & 非常|=深刻 b & 深刻でない & 深刻。 & 深刻 a & なし & 164 & 165 & - & $\begin{array}{l}\text { 平均 } 1 \text { 日㷃い } \\
(0.84 \text { 日短い } \\
2.84 \text { 日長い) }\end{array}$ & $\begin{array}{l}\oplus \bigcirc \bigcirc \bigcirc \\
\text { 非常に低 }\end{array}$ & 重要 \\
\hline \multicolumn{13}{|c|}{ 重症な有害事象 } \\
\hline 1 & RCT & 深刻でない & 深刻でない & 深刻でない & 非常1深刻。” & なし & $0 / 71(0.0 \%)$ & $0 / 71 \quad(0.0 \%)$ & 推定不可 & & $\underset{\text { 低 }}{\oplus \oplus \bigcirc \bigcirc}$ & 重大 \\
\hline
\end{tabular}

a. 総サンプルサイズが少ないため, 一段階グレードを下げた。

b. バイアスのリスク（不完全なアウトカムデータ，助成金バイアス）が高く，二段階グレードを下げた。

c. 二次解析研究のため一段階グレ一ドを下げた。

d. 総サンプルサイズが少なく、信頼区間が臨床決断の闎値をまたぐため、二段階グレードを下げた。

e. 総イベント数が少ないため, 二段階グレードを下げた。 
ては，益と害の各アウトカムが同じ方向性を示してい るため，最も高いエビデンスである「中」を採用し た。非定型抗精神病薬については, 益と害の各アウト カムが同じ方向性を示しているため, 最も高いエビデ ンスである「低」を採用した。スタチンについては, 死亡率が高くなる方向であり, 益と害のアウトカムが 逆方向を示すと考えて最も低いエビデンスである「非 常に低」を採用した。

\section{（6）価値観}

成人敗血症患者のせん妄予防の薬物療法に対する, 各アウトカムに置く患者・家族の価值観に関するデー 夕はない。一般的に, 死亡, せん妄, せん妄日数など の臨床アウトカムに対して置く相対的価值は高く，ば らつきは少ないことが予想される。

\section{（7）容認性}

デクスメデトミジン $(200 \mu \mathrm{g} / 50 \mathrm{~mL}$ シリンジ価格 4,886 円）は集中治療における人工呼吸中および離脱 後の鎮静薬として広く使用されており，患者・家族の 個人的な負担を大きく増加するものではない。医療者 の仕事量に関しても，集中治療管理として薬剤の持続 投与は一般的な内容であり，容認可能である。八ロペ リドールは価格 5.7〜91 円とばらつきがあるが，患者 負担から考えて薬剤コストは容認できる。また，薬剤 内服は医療者への負担も限定的である。非定型抗精神 病薬は薬剤価格が比較的安価（リスペリドン 10.1〜 215.3 円，クエチアピン 10.6〜 68.6円）であり，おそ らく容認できる。また薬剤投与による医療関係者への
負担も十分容認できる。スタチンは先発品とジェネ リックを合わせると多数の種類があり，価格も 10.1 円〜328.4 円と様々である。しかし高額な薬剤ではな いため，患者にとっては容認可能である，また，薬剤 内服は医療者への負担も限定的である。

\section{（8）実行可能性}

敗血症を管理可能な医療施設であれば，介入は問題 なく実行可能である。ただし，八ロペリドール，非定 型抗精神病薬，スタチンをせん妄予防に使用する際 は，保険適用外の診療となる。

（9）判断の要約 (Table 10-4-2)

（10）推奨グレーディング決定の工程

デクスメデトミジン：修正 RAND 法を用いた投票 によって, 中央值 8, 見解不一致指数 0.015 の結果と なり，委員会で採択された（7点以上：83.3\%）。

ハロペリドール：修正 RAND 法を用いた投票に よって, 中央值 8 , 見解不一致指数 0.146 の結果とな り，委員会で採択された（7 点以上 : 91.7\%)。

非定型抗精神病薬 : 修正 RAND 法を用いた投票に よって, 中央值 7 , 見解不一致指数 0.164 の結果とな り，委員会で採択された（7 点以上 : 83.3\%)。

スタチン：修正 RAND 法を用いた投票によって， 中央值 8 , 見解不一致指数 0.164 の結果となり, 委員 会で採択された（7 点以上：91.7\%)。

Table 10-4-2 判断の要約

\begin{tabular}{|c|c|c|c|c|c|c|c|}
\hline & \multicolumn{7}{|c|}{ 半泮 } \\
\hline 問題 & いいえ & $\begin{array}{c}\text { おそらく、いい } \\
\text { え }\end{array}$ & おそらく、はい & はい & & さまざま & 分からない \\
\hline 望ましい効果 & わずか & 小さい & 中 & 大きい & & さまざま & 分からない \\
\hline 望ましくない勃果 & 大きい & 中 & 小さい & わずか & & さまざま & 分からない \\
\hline エビデンスの確実性 & 非常に低 & 低 & 中 & 高 & & & 採用研究なし \\
\hline 価値钼 & $\begin{array}{c}\text { 重要な不確実性 } \\
\text { またはばらつき } \\
\text { あり }\end{array}$ & $\begin{array}{c}\text { 重要な不確実性 } \\
\text { またはばらつき } \\
\text { の可能性あり }\end{array}$ & $\begin{array}{l}\text { 重要な不確実性 } \\
\text { またはばらつき } \\
\text { はおそらくなし }\end{array}$ & $\begin{array}{l}\text { 重要な不確実性 } \\
\text { またはばらつき } \\
\text { はなし }\end{array}$ & & & \\
\hline 効果のパランス & 比較が優位 & $\begin{array}{c}\text { 比較がおそらく } \\
\text { 優位 }\end{array}$ & $\begin{array}{c}\text { 介入も比較もい } \\
\text { ずれも優位でな } \\
\text { い }\end{array}$ & $\begin{array}{c}\text { おそらく介入が } \\
\text { 優位 }\end{array}$ & 介入が優位 & さまざま & 分からない \\
\hline 容認性 & いいえ & $\begin{array}{c}\text { おそらく、いい } \\
\text { え }\end{array}$ & おそらく、はい & はい & & さまざま & 分からない \\
\hline 実行可能性 & いいえ & $\begin{array}{c}\text { おそらく、いい } \\
\text { え }\end{array}$ & おそらく、はい & はい & & さまざま & 分からない \\
\hline
\end{tabular}


Table 10-4-2 判断の要約 (つづき)

\begin{tabular}{|c|c|c|c|c|c|c|c|}
\hline & \multicolumn{7}{|c|}{ 判断 } \\
\hline 問題 & いいえ & $\begin{array}{c}\text { おそらく、いい } \\
\text { え }\end{array}$ & おそらく、はい & はい & & さまざま & 分からない \\
\hline 望ましい効果 & わずか & 小さい & 中 & 大きい & & さまざま & 分からない \\
\hline 望ましくない効果 & 大きい & 中 & 小さい & わずか & & さまざま & 分からない \\
\hline エビデンスの確実性 & 非常に低 & 低 & 中 & 高 & & & 採用研究なし \\
\hline 価值钼 & $\begin{array}{c}\text { 重要な不確実性 } \\
\text { またははよらつき } \\
\text { あり }\end{array}$ & $\begin{array}{c}\text { 重要な不確実性 } \\
\text { またははよらつき } \\
\text { の可能性あり }\end{array}$ & $\begin{array}{l}\text { 重要な不確実性 } \\
\text { またはばらつき } \\
\text { はおそらくなし }\end{array}$ & $\begin{array}{l}\text { 重要な不確実性 } \\
\text { またはばらつき } \\
\text { はなし }\end{array}$ & & & \\
\hline 効果のバランス & 比較が優位 & $\begin{array}{c}\text { 比較がおそらく } \\
\text { 優位 }\end{array}$ & $\begin{array}{c}\text { 介入も比較もい } \\
\text { ずれも優位でな } \\
\text { い }\end{array}$ & $\begin{array}{c}\text { おそらく介入が } \\
\text { 優位 }\end{array}$ & 介入が優位 & さまざま & 分からない \\
\hline 容認性 & いいえ & $\begin{array}{c}\text { おそらく、いい } \\
\text { え }\end{array}$ & おそらく、はい & はい & & さまざま & 分からない \\
\hline 実行可能性 & いいえ & $\begin{array}{c}\text { おそらく、いい } \\
\text { え }\end{array}$ & おそらく、はい & はい & & さまざま & 分からない \\
\hline
\end{tabular}

\begin{tabular}{|c|c|c|c|c|c|c|c|}
\hline & \multicolumn{7}{|c|}{ 判断 } \\
\hline 問題 & いいえ & $\begin{array}{c}\text { おそらく、いい } \\
\text { え }\end{array}$ & おそらく、はい & はい & & さまざま & 分からない \\
\hline 望ましい勃果 & わずか & 小さい & 中 & 大きい & & さまざま & 分からない \\
\hline 望ましくない効果 & 大きい & 中 & 小さい & わずか & & さまざま & 分からない \\
\hline エビデンスの確実性 & 非常に低 & 低 & 中 & 高 & & & 採用研究なし \\
\hline 価值钼 & $\begin{array}{c}\text { 重要な不確実性 } \\
\text { またはばらつき } \\
\text { あり }\end{array}$ & $\begin{array}{l}\text { 重要な不確実性 } \\
\text { またはばらつさ } \\
\text { の可能性ありり }\end{array}$ & $\begin{array}{l}\text { 重要な不確実性 } \\
\text { またはばらつき } \\
\text { はおそらくなし }\end{array}$ & $\begin{array}{l}\text { 重要な不確実性 } \\
\text { またははららつき } \\
\text { はなしし }\end{array}$ & & & \\
\hline 勃果のパランス & 比較が優位 & $\begin{array}{c}\text { 比較がおそらく } \\
\text { 優位 }\end{array}$ & $\begin{array}{c}\text { 介入も比較もい } \\
\text { ずれも優位でな } \\
\text { い }\end{array}$ & $\begin{array}{c}\text { おそらく介入が } \\
\text { 優位 }\end{array}$ & 介入が優位 & さまざま & 分からない \\
\hline 容認性 & いいえ & $\begin{array}{c}\text { おそらく、いい } \\
\text { え }\end{array}$ & おそらく、はい & はい & & さまざま & 分からない \\
\hline 実行可能性 & いいえ & $\begin{array}{c}\text { おそらく、いい } \\
\text { え }\end{array}$ & おそらく、はい & はい & & さまざま & 分からない \\
\hline
\end{tabular}

スタチン

\begin{tabular}{|c|c|c|c|c|c|c|c|}
\hline & \multicolumn{7}{|c|}{ 判础 } \\
\hline 問題 & いいえ & $\begin{array}{c}\text { おそらく、いい } \\
\text { え }\end{array}$ & おそらく、はい & はい & & さまざま & 分からない \\
\hline 望ましい効果 & わずか & 小さい & 中 & 大きい & & さまざま & 分からない \\
\hline 望ましくない勃果 & 大きい & 中 & 小さい & わずか & & さまざま & 分からない \\
\hline エビデンスの確実性 & 非常に低 & 低 & 中 & 高 & & & 採用研究なし \\
\hline 価值観 & $\begin{array}{c}\text { 重要な不確実性 } \\
\text { またはばらつき } \\
\text { あり }\end{array}$ & $\begin{array}{c}\text { 重要な不確実性 } \\
\text { またはばらつき } \\
\text { の可能性ありり }\end{array}$ & $\begin{array}{l}\text { 重要な不確実性 } \\
\text { またははばらつき } \\
\text { はおそらくなし }\end{array}$ & $\begin{array}{c}\text { 重要な不確実性 } \\
\text { またはははらつつき } \\
\text { はなし }\end{array}$ & & & \\
\hline 効果のバランス & 比較が優位 & $\begin{array}{c}\text { 比較がおそらく } \\
\text { 優位 }\end{array}$ & $\begin{array}{c}\text { 介入も比較もい } \\
\text { ずれも優位でな } \\
\text { い }\end{array}$ & $\begin{array}{c}\text { おそらく介入が } \\
\text { 優位 }\end{array}$ & 介入が優位 & さまざま & 分からない \\
\hline 容認性 & いいえ & $\begin{array}{c}\text { おそらく、いい } \\
\text { え }\end{array}$ & おそらく、はい & はい & & さまざま & 分からない \\
\hline 実行可能性 & いいえ & $\begin{array}{c}\text { おそらく、いい } \\
\text { え }\end{array}$ & おそらく、はい & はい & & さまざま & 分からない \\
\hline
\end{tabular}




\section{（11）関連する他の診療ガイドラインにおける推奨}

日本版敗血症診療ガイドライン (J-SSCG) $2016^{19,20)}$ においては，J-PAD ガイドライン 21）より引用する形 で「薬理学的せん妄予防プロトコルを使用すべきとは いえない(データ不足)」となっている。また PADIS ガイドライン 22) において, 非定型抗精神病薬，八ロ ペリドール，デクスメデトミジン，スタチンをすべて の成人重症患者におけるせん妄の予防に使用しないこ とを提案している（条件付き推奨，非常に低い〜低い 質のエビデンス)。各診療ガイドラインによって，デ クスメデトミジンの推奨の方向性が若干異なることを 念頭に入れる必要がある。

\section{（12）実施に関わる検討事項}

薬剤をルーチンに使用するかについては，患者の年 齢・重症度・合併症も考慮する必要がある。デクスメ デトミジンは，国内で認可された投与量が海外の投与 量と異なり（デクスメデトミジンの維持量 0.2 $0.7 \mu \mathrm{g} / \mathrm{kg} / \mathrm{hr}$ は海外より少ない), 本邦での有効性およ び副作用の発生も考慮に入れた使用が望まれる。

本推奨は，鎮静が不必要な患者にデクスメデトミジ ンのルーチン投与を推奨するものではない。また，本 CQ では, “デクスメデトミジンの投与は循環動態の 変動を来す恐れがあるため，集中治療室で全身管理に 熟練した医師のもとで投与することが望ましい”とい うエキスパートコンセンサスを加えて提示することと した。

\section{（13）今後の研究の可能性}

今回含まれる研究は集中治療室の重症患者（場合に より術後患者）が対象となっているため，今後は敗血 症患者に限定したせん妄予防の研究が望まれる。

\section{文 献}

1) Abdelgalel EF: Dexmedetomidine versus haloperidol for prevention of delirium during non-invasive mechanical ventilation. Egypt J Anaesth. 2016; 32: 473-81.

2) Kawazoe Y, Miyamoto K, Morimoto T, et al: Effect of Dexmedetomidine on Mortality and Ventilator-Free Days in Patients Requiring Mechanical Ventilation With Sepsis: A Randomized Clinical Trial. JAMA. 2017; 317: 1321-8.

3) $\mathrm{Lu} \mathrm{X}, \mathrm{Li} \mathrm{J}, \mathrm{Li} \mathrm{T}$, et al: Clinical study of midazolam sequential with dexmedetomidine for agitated patients undergoing weaning to implement light sedation in intensive care unit. Chin J Traumatol. 2016; 19: 94-6.

4) Priye S, Jagannath $S$, Singh D, et al: Dexmedetomidine as an adjunct in postoperative analgesia following cardiac surgery: A randomized, double-blind study. Saudi J Anaesth. 2015; 9: 353-8.

5) Skrobik Y, Duprey MS, Hill NS, et al: Low-Dose Nocturnal Dexmedetomidine Prevents ICU Delirium. A Randomized, Placebo-controlled Trial. Am J Respir Crit Care Med. 2018; 197:
1147-56.

6) Su X, Meng ZT, Wu XH, et al: Dexmedetomidine for prevention of delirium in elderly patients after non-cardiac surgery: a randomised, double-blind, placebo-controlled trial. Lancet. 2016; 388: 1893-902.

7) Xuan Y, Fan R, Chen J, et al: Effects of dexmedetomidine for postoperative delirium after joint replacement in elderly patients: a randomized, double-blind, and placebo-controlled trial. Int J Clin Exp Med. 2018; 11: 13147-57.

8) Zhang DF, Su X, Meng ZT, et al: Impact of Dexmedetomidine on Long-term Outcomes After Noncardiac Surgery in Elderly: 3-Year Follow-up of a Randomized Controlled Trial. Ann Surg. 2019; 270: 356-63.

9) Al-Qadheeb NS, Skrobik Y, Schumaker G, et al: Preventing ICU Subsyndromal Delirium Conversion to Delirium With Low-Dose IV Haloperidol: A Double-Blind, Placebo-Controlled Pilot Study. Crit Care Med. 2016; 44: 583-91.

10) Girard TD, Pandharipande PP, Carson SS, et al: Feasibility, efficacy, and safety of antipsychotics for intensive care unit delirium: the MIND randomized, placebo-controlled trial. Crit Care Med. 2010; 38: 428-37

11) Khan BA, Perkins AJ, Campbell NL, et al: Preventing Postoperative Delirium After Major Noncardiac Thoracic Surgery-A Randomized Clinical Trial. J Am Geriatr Soc. 2018; 66: 2289-97.

12) Page V, Ely E, Gates S, et al: A randomised, double-blind, placebo-controlled trial to compare the early administration of intravenous haloperidol versus placebo in the prevention and treatment of delirium in critically ill ventilated patients (hope-Icu). Am J Respir Crit Care Med. 2013; 187: A6065.

13) van den Boogaard M, Slooter AJC, Brüggemann RJM, et al: Effect of Haloperidol on Survival Among Critically Ill Adults With a High Risk of Delirium: The REDUCE Randomized Clinical Trial. JAMA. 2018; 319: 680-90.

14) Wang W, Li HL, Wang DX, et al: Haloperidol prophylaxis decreases delirium incidence in elderly patients after noncardiac surgery: a randomized controlled trial*. Crit Care Med. 2012; 40: 731-9.

15) Hakim SM, Othman AI, Naoum DO: Early treatment with risperidone for subsyndromal delirium after on-pump cardiac surgery in the elderly: a randomized trial. Anesthesiology. 2012; 116: 987-97.

16) Prakanrattana U, Prapaitrakool S: Efficacy of risperidone for prevention of postoperative delirium in cardiac surgery. Anaesth Intensive Care. 2007; 35: 714-9.

17) Needham DM, Colantuoni E, Dinglas VD, et al: Rosuvastatin versus placebo for delirium in intensive care and subsequent cognitive impairment in patients with sepsis-associated acute respiratory distress syndrome: an ancillary study to a randomised controlled trial. Lancet Respir Med. 2016; 4: 203-12.

18) Page VJ, Casarin A, Ely EW, et al: Evaluation of early administration of simvastatin in the prevention and treatment of delirium in critically ill patients undergoing mechanical ventilation (MoDUS): a randomised, double-blind, placebo-controlled trial. Lancet Respir Med. 2017; 5: 727-37.

19）西田修, 小倉裕司, 井上茂亮, 他, 日本版敗血症診療ガイドラ イン 2016 作成特別委員会. 日本版敗血症診療ガイドライン 2016. 日集中医誌. 2017; 24: S1-232.

20）西田修, 小倉裕司, 井上茂亮, 他, 日本版敗血症診療ガイドラ イン 2016 作成特別委員会. 日本版敗血症診療ガイドライン 2016. 日救急医会誌. 2017; 28: S1-232.

21）日本集中治療医学会 J-PAD ガイドライン作成委員会：日本 版・集中治療室における成人重症患者に対する痛み・不穏・ せん妄管理のための臨床ガイドライン. 日集中医誌. 2014; 21: 539-79. 
22) Devlin JW, Skrobik Y, Gélinas C, et al: Clinical Practice Guidelines for the Prevention and Management of Pain, Agitation/Sedation, Delirium, Immobility, and Sleep Disruption in Adult Patients in the ICU. Crit Care Med. 2018; 46: e825-73.
CQ10-5：成人敗血症患者のせん妄治療に, 薬物 療法を行うか?

Answer : 成人敗血症患者のせん妄治療にデクスメデ トミジンを投与しないことを弱く推奨する（GRADE 2D：エビデンスの確実性＝「非常に低」)。ハロペリ ドールを投与しないことを弱く推奨する（GRADE $2 \mathrm{C}:$ エビデンスの確実性 $=$ 「低」)。非定型抗精神病 薬を投与しないことを弱く推奨する（GRADE 2B：エ ビデンスの確実性 $=\lceil$ 中」)。

コメント : 過活動型せん妄のため患者の生命または身 体が危険にさらされる可能性が高いと判断した場合 に，デクスメデトミジン，八ロペリドール，または非 定型抗精神病薬の使用を妨げるものではない。

\section{（1）背景および本 $C Q$ の重要度}

敗血症患者の中枢神経系藏器障害の 1 つにせん妄が ある。集中治療室でのせん妄持続日数が集中治療室退 室後 3 か月と 12 か月の認知機能障害と関連すること が知られている。敗血症患者においてせん妄を薬物に より治療することができれば，患者の集中治療後症候 群（PICS）を軽減できる可能性があるため，本 CQ を 敗血症診療における重要な臨床課題として取り上げ た。

(2) PICO

P (患者) : 敗血症, 呼吸不全, 心不全, 熱傷, 大侵 襲手術後などで人工呼吸中の成人重症患者

I（介入）：デクスメデトミジン，八ロペリドール， 非定型抗精神病薬の投与

$\mathrm{C}$ (対照) : プラセボ投与

$\mathrm{O}$ (アウトカム) : 死亡, 集中治療室退室後の認知機 能障害, せん妄, せん妄日数（報告がない場合 は, 非せん妄日数), ICU 滞在日数, 重症有害事 象

\section{（3）エビデンスの要約}

システマティックレビューの結果，PICO に合致し たランダム化比較試験（RCT）がデクスメデトミジン 1 件 1)，ハロペリドール 1 件 2)，非定型抗精神病薬 3 件 2-4）施行されており,これらを用いたメ久解析を実 施した。

（4）益と害のバランス（Table 10-5-1）

望ましい効果 :

術後患者を含むシステマティックレビューの結果, 
Table 10-5-1 エビデンスプロファイル

デクスメデトミジン

\begin{tabular}{|c|c|c|c|c|c|c|c|c|c|c|c|c|}
\hline \multicolumn{7}{|c|}{ 確実性の評価 } & \multicolumn{2}{|c|}{ 患者数 } & \multicolumn{2}{|c|}{ 効果 } & \multirow[b]{2}{*}{ 確実性 } & \multirow[b]{2}{*}{ 重要性 } \\
\hline 研究数 & $\begin{array}{l}\text { 研究 } \\
\text { デザイン }\end{array}$ & $\begin{array}{l}\text { パイアス } \\
\text { のリスク }\end{array}$ & 非一貫性 & 非直接性 & 不精破性 & $\begin{array}{l}\text { その他 } \\
\text { の検討 }\end{array}$ & $\begin{array}{c}\text { デクスメデトミ } \\
\text { ジン }\end{array}$ & プラセボ & $\begin{array}{l}\text { 相対指標 } \\
(95 \% \text { CI }\end{array}$ & $\begin{array}{l}\text { 絶対指標 } \\
(95 \% \text { CI })\end{array}$ & & \\
\hline \multicolumn{13}{|l|}{ 死亡 } \\
\hline 1 & RCT & 深刻 a & 深刻でない & 深刻でない & 非常に深刻 b & なし & $2 / 39 \quad(5.1 \%)$ & $0 / 32(0.0 \%)$ & $\begin{array}{c}\text { RR } 4.13 \\
\text { (0.21 to } 82.95)\end{array}$ & $\begin{array}{l}1,000 \text { 人あたり } 0 \\
\text { 人多い(0人少な } \\
\text { い 0人多い) }\end{array}$ & $\begin{array}{l}\oplus \bigcirc \bigcirc \bigcirc \\
\text { 非常に低 }\end{array}$ & 重大 \\
\hline \multicolumn{13}{|c|}{ ICU 滞在日数 } \\
\hline 1 & RCT & 深刻 a & 深刻でない & 深刻でない & 非常に深刻。 & なし & 39 & 32 & - & $\begin{array}{c}\text { 平均 } 1.37 \text { 日短い } \\
\text { (3.82 日短い } \\
1.08 \text { 日長い) }\end{array}$ & $\begin{array}{l}\oplus \bigcirc \bigcirc \bigcirc \\
\text { 非常に低 }\end{array}$ & 重要 \\
\hline
\end{tabular}

集中治療室退室後の認知機能障害，せん妄日数，重症な有害事象を報告した研究はなかった。

a. 患者医療者の盲検化が困難であるため, 一段階グレードを下げた。

a. 患者医療者の盲検化が困難であるため, 一段階グレードを下げた。
b. 1 件のRCTのみ。総イベント数が少なく, 段階グレードを下げた

c. 1 件の RCT のみ。総サンプルサイズが小さいため, 二段階グレードを下げた。

ハロペリドール

\begin{tabular}{|c|c|c|c|c|c|c|c|c|c|c|c|c|}
\hline \multicolumn{7}{|c|}{ 確実性の評価 } & \multicolumn{2}{|c|}{ 患者数 } & \multicolumn{2}{|c|}{ 効果 } & \multirow[b]{2}{*}{ 確実性 } & \multirow[b]{2}{*}{ 重要性 } \\
\hline 研究数 & $\begin{array}{c}\text { 研究 } \\
\text { デザイン }\end{array}$ & $\begin{array}{l}\text { バイアス } \\
\text { のリスク }\end{array}$ & 非一貫性 & 非直接性 & 不精確性 & $\begin{array}{l}\text { その他 } \\
\text { の検討 }\end{array}$ & ハロベリドール & プラセボ & $\begin{array}{l}\text { 相対指標 } \\
(95 \% \mathrm{CI})\end{array}$ & $\begin{array}{l}\text { 絶対指標 } \\
(95 \% \text { CI }\end{array}$ & & \\
\hline \multicolumn{13}{|c|}{ 死亡（最長のもの） } \\
\hline 1 & RCT & 深刻でない & 深刻でない & 深刻でない & 深刻 a & なし & $\begin{array}{l}73 / 192 \\
(38.0 \%)\end{array}$ & $63 / 184 \quad(34.2 \%)$ & $\begin{array}{c}\text { RR } 1.11 \\
(0.85 \text { to } 1.45)\end{array}$ & $\begin{array}{c}1,000 \text { 人あたり } 38 \\
\text { 人多い } 51 \text { 人少 } \\
\text { ない 154 人多 } \\
\text { (1) }\end{array}$ & $\begin{array}{c}\oplus \oplus \oplus \bigcirc \\
\text { 中 }\end{array}$ & 重大 \\
\hline \multicolumn{13}{|c|}{ せん妄日数 } \\
\hline 1 & RCT & 深刻でない & 深刻でない & 深刻でない & 深刻 a & なし & 192 & 184 & - & $\begin{array}{c}\text { 平均 } 0.34 \text { 日短い } \\
(1.18 \text { 日短い } \\
0.5 \text { 日長い) }\end{array}$ & $\begin{array}{c}\oplus \oplus \oplus \bigcirc \\
\text { 中 }\end{array}$ & 重大 \\
\hline \multicolumn{13}{|c|}{ 非せん妄（昏睡）日数（14 日） } \\
\hline 1 & RCT & 深刻でない & 深刻でない & 深刻でない & 非常に深刻 b & なし & 192 & 184 & - & $\begin{array}{c}\text { 平均 } 0.33 \text { 日長い } \\
\text { (1.33 日短い } \\
1.99 \text { 日長い) }\end{array}$ & $\underset{\text { 低 }}{\oplus \oplus \bigcirc \bigcirc}$ & 重大 \\
\hline \multicolumn{13}{|c|}{ ICU 滞在日数 } \\
\hline 1 & RCT & 深刻でない & 深刻でない & 深刻でない & 非常に深刻 b & なし & 192 & 184 & - & $\begin{array}{c}\text { 平均 } 0.33 \text { 日短い } \\
\text { (1.92 日短い } \\
1.26 \text { 日長い) }\end{array}$ & $\underset{\text { 低 }}{\oplus \oplus \bigcirc \bigcirc}$ & 重要 \\
\hline
\end{tabular}

集中治療室退室後の認知機能障害, 重症な有害事象を報告した研究はなかった。

a. 総サンプルサイズが小さいため,一段階グレードを下げた。

b. 1 つのRCT。総サンプルサイズが小さいため, 二段階グレードを下げた。

非定型抗精神病薬

\begin{tabular}{|c|c|c|c|c|c|c|c|c|c|c|c|c|}
\hline \multicolumn{7}{|c|}{ 確実性の評価 } & \multicolumn{2}{|c|}{ 患者数 } & \multicolumn{2}{|c|}{ 効果 } & \multirow[b]{2}{*}{ 確実性 } & \multirow[b]{2}{*}{ 重要性 } \\
\hline 研究数 & $\begin{array}{l}\text { 研究 } \\
\text { デサン }\end{array}$ & $\begin{array}{l}\text { バイアス } \\
\text { のリスク }\end{array}$ & 非一貫性 & 非直接性 & 不精確性 & $\begin{array}{l}\text { その他 } \\
\text { の検討 }\end{array}$ & $\begin{array}{c}\text { 非定型抗精神病 } \\
\text { 菜 }\end{array}$ & プラセボ & $\begin{array}{l}\text { 相対指標 } \\
(95 \% \mathrm{CI})\end{array}$ & $\begin{array}{l}\text { 䓳対指標 } \\
(95 \% \mathrm{CI})\end{array}$ & & \\
\hline \multicolumn{13}{|c|}{ 死亡（最長のもの） } \\
\hline 2 & RCT & 深刻でない & 深刻でない & 深刻でない & 非常に深刻 a & なし & $\begin{array}{l}67 / 208 \\
(32.2 \%)\end{array}$ & $66 / 202 \quad(32.7 \%)$ & $\begin{array}{c}\text { RR } 0.99 \\
\text { (0. } 75 \text { to } 1.30)\end{array}$ & $\begin{array}{c}\text { 1,000人あたり } 3 \\
\text { 人少ない } 82 \text { 人 } \\
\text { 少ない 98人多 } \\
\text { ( ) }\end{array}$ & $\underset{\text { 低 }}{\oplus \oplus \bigcirc}$ & 重大 \\
\hline
\end{tabular}

せん妄日数

\begin{tabular}{|c|c|c|c|c|c|c|c|c|c|c|c|c|}
\hline 2 & RCT & 深刻でない & 深刻 b & 深刻でない & 深刻。 & なし & 208 & 202 & - & $\begin{array}{c}\text { 平均 } 1.75 \text { 日短い } \\
(4.31 \text { 日短い } \\
0.81 \text { 日長い) }\end{array}$ & $\underset{\text { 低 }}{\oplus \oplus \bigcirc \bigcirc}$ & 重大 \\
\hline
\end{tabular}

非せん妄 (昏睡) 日数 (14 日)

\begin{tabular}{|c|c|c|c|c|c|c|c|c|c|c|c|c|}
\hline 1 & RCT & 深刻でない & 深刻でない & 深刻でない & 深刻。 & なし & 190 & 184 & - & $\begin{array}{l}\text { 平均 } 1 \text { 日長い } \\
(0.52 \text { 日短い } \\
2.52 \text { 日長い) }\end{array}$ & $\begin{array}{c}\oplus \oplus \oplus \bigcirc \\
\text { 中 }\end{array}$ & 重大 \\
\hline \multicolumn{13}{|c|}{ ICU 滞在日数 } \\
\hline 2 & RCT & 深刻でない & 深刻でない & 深刻でない & 深刻。 & なし & 208 & 202 & - & $\begin{array}{l}\text { 平均 } 1.1 \text { 日短い } \\
\text { (2.48 日短い } \\
0.28 \text { 日長い) }\end{array}$ & $\begin{array}{c}\oplus \oplus \oplus \bigcirc \\
\text { 中 }\end{array}$ & 重要 \\
\hline
\end{tabular}

集中治療室退出後の認知機能障害, 重症な有害事象を報告した研究はなかった。

a. $95 \%$ CI が広く臨床決断の閾値をまたぐため，二段階グレードを下げた。

b. 異質性が高い（（１2=77\%）ため,一段階グレードを下げた。

c. 総サンプルサイズが小さいため, 一段階グレードを下げた。 
デクスメデトミジン投与は死亡（1 RCT: $\mathrm{n}=71 ）$ に ついて 1,000 人あたり 0 人少ない $(0$ 人少ない〜 0 人 多い), ICU 滞在日数 (1 RCT: $\mathrm{n}=71)$ は 1.37 日短い (95\% CI: 3.82 日短い〜1.08 日長い) であり，ハロペ リドールについては, 死亡（1 RCT: $\mathrm{n}=376 ） 1,000$ 人あたり 38 人多い $(51$ 人少ない〜 154 人多い), せん 妄日数（1 RCT: $\mathrm{n}=376 ）$ は 0.34 日短い（1.18 日短い $\sim 0.5$ 日長い), ICU 滞在日数（1 RCT: $n=376 ）$ は 0.33 日短い（1.92 日短い〜1.26 日長い）であり，非定 型抗精神病薬については，死亡（2 RCT: $\mathrm{n}=410 ）$ 1,000 人あたり 3 人少ない $(82$ 人少ない〜 98 人多い $)$, せん妄日数（2 RCT: $n=410 ）$ は 1.75 日短い（4.31 日 短い 0.81 日長い), ICU 滞在日数 $(2$ RCT: $n=410)$ は 1.1 日短い（2.48 日短い〜 0.28 日長い）であり，い ずれの薬剤においても望ましい効果はわずかであると 判断した

\section{望ましくない効果：}

3 つの薬物共に, 重症な有害事象をアウトカムとし て報告した研究がなかった。

益と害のバランス :

3 つの薬物共に，望ましい効果はわずかであり，望 ましくない効果は不明である。効果のバランスは, 介 入も比較対照もいずれも優位でないと考えられる。

\section{（5）アウトカム全般に関するエビデンスの確実性}

デクスメデトミジンについては，死亡率が高くなる 方向性, ICU 滞在日数が短くなる方向性であり, 益と 害のアウトカムが逆方向を示すと考えて最も低いエビ デンスである「非常に低」を採用した。ハロペリドー ルについては, 死亡の効果推定值が高くなる方向性, せん妄日数と非せん妄日数，ICU 滞在日数は益となる 方向性を持つため「低」を採用した。非定型抗精神病 薬については，すべてのアウトカムが患者の益となる 方向性を示しているため, 最も高いエビデンスである 「中」を採用した。

\section{（6）価値観}

成人敗血症患者のせん妄治療の薬物療法に対する, 各アウトカムに置く患者・家族の価值観に関するデー 夕はない。一般的に, 死亡, せん妄, せん妄日数など の臨床アウトカムに対して置く相対的価值は高く，ば らつきは少ないことが予想される。

\section{（7）容認性}

デクスメデトミジン $(200 \mu \mathrm{g} / 50 \mathrm{~mL}$ シリンジ価格 4,886 円）は集中治療における人工呼吸中および離脱
後の鎮静薬として広く使用されており，患者・家族の 個人的な負担を大きく増加するものではない。医療者 の仕事量に関しても，集中治療管理として薬剤の持続 投与は一般的な内容であり，容認可能である。ハロペ リドールは価格 5.7〜91 円とばらつきがあるが，患者 負担から考えて薬剤コストは容認できる。また，薬剤 内服は医療者への負担も限定的である。非定型抗精神 病薬は薬剤価格が比較的安価（リスペリドン 10.1〜 215.3 円，クエチアピン 10.6〜 68.6 円）であり，おそ らく容認できる。また薬剤投与による医療関係者への 負担も十分容認できる。

\section{（8）実行可能性}

敗血症を管理可能な医療施設であれば，介入は問題 なく実行可能である。ただし，ハロペリドール，非定 型抗精神病薬をせん妄予防に使用する際は，保険適用 外の診療となる。

（9）判断の要約（Table 10-5-2）

（10）推奨グレーディング決定の工程

デクスメデトミジン：修正 RAND 法を用いた投票 によって, 中央值 7 , 見解不一致指数 0 の結果となり, 委員会で採択された（7点以上 : 87.5\%)。

ハロペリドール：修正 RAND 法を用いた投票に よって, 中央值 7 , 見解不一致指数 0.018 の結果とな り，委員会で採択された（7 点以上 : $87.5 \%)$ 。

非定型抗精神病薬 : 修正 RAND 法を用いた投票に よって, 中央值 7 , 見解不一致指数 0 の結果となり, 委員会で採択された（7点以上 : 87.5\%)。

\section{（11）関連する他の診療ガイドラインにおける推奨}

PADIS ガイドライン 5) において，人工呼吸管理中 の成人患者で不穏のためにウィーニング/抜管ができ ない場合，せん妄に対してデクスメデトミジンを使用 することを提案している（条件付き推奨，低い質のエ ビデンス)。しかし，J-PAD ガイドライン6）では，本 邦で承認された投与量でのデクスメデトミジンが，ベ ンゾジアゼピン系鎮静薬より望ましいかは不明である （0，C）と記載されており，注意が必要である。

また，PADIS ガイドライン5)では，せん妄治療に ハロペリドール，非定型抗精神病薬を日常的に用いな いことを提案している（条件付き推奨, 低い質のエビ デンス)。一方で，J-PAD ガイドライン 6）では，成人 集中治療患者のせん妄期間を短縮する有効な薬物治療 に関するデータは少ない（0，C）と記載されている。 
Table 10-5-2 判断の要約

\begin{tabular}{|c|c|c|c|c|c|c|c|}
\hline \multirow{2}{*}{ 問題 } & \multicolumn{7}{|c|}{ 判渚 } \\
\hline & いいえ & $\begin{array}{c}\text { おそらく、いい } \\
\text { え }\end{array}$ & おそらく、はい & はい & & さまざま & 分からない \\
\hline 望ましい索果 & わずか & 小さい & 中 & 大きい & & さまざま & 分からない \\
\hline 望ましくない効果 & 大きい & 中 & 小さい & わずか & & さまざま & 分からない \\
\hline エピデンスの確実性 & 非常に低 & 低 & 中 & 高 & & & 採用研究なし \\
\hline 価值钼 & $\begin{array}{c}\text { 重要な不確実性 } \\
\text { またはばらつり } \\
\text { あり }\end{array}$ & $\begin{array}{c}\text { 重要な不確実性 } \\
\text { またははよらつき } \\
\text { の可能性あり }\end{array}$ & $\begin{array}{l}\text { 重要な不確実性 } \\
\text { またはははらつき } \\
\text { はおそらくなし }\end{array}$ & $\begin{array}{c}\text { 重要な不確実性 } \\
\text { またははよらつき } \\
\text { はなし }\end{array}$ & & & \\
\hline 効果のバランス & 比較が優位 & $\begin{array}{c}\text { 比較がおそらく } \\
\text { 優位 }\end{array}$ & $\begin{array}{c}\text { 介入も比較もい } \\
\text { ずれも優位でな } \\
\text { い }\end{array}$ & $\begin{array}{c}\text { おそらく介入が } \\
\text { 優位 }\end{array}$ & 介入が優位 & さまざま & 分からない \\
\hline 容認性 & いいえ & $\begin{array}{c}\text { おそらく、いい } \\
\text { え }\end{array}$ & おそらく、はい & はい & & さまざま & 分からない \\
\hline 実行可能性 & いいえ & $\begin{array}{c}\text { おそらく、いい } \\
\text { え }\end{array}$ & おそらく、はい & はい & & さまざま & 分からない \\
\hline
\end{tabular}

\begin{tabular}{|c|c|c|c|c|c|c|c|}
\hline & \multicolumn{7}{|c|}{ 判断 } \\
\hline 問題 & いいえ & $\begin{array}{c}\text { おそらく、いい } \\
\text { え }\end{array}$ & おそらく、はい & はい & & さまざま & 分からない \\
\hline 望ましい効果 & わずか & 小さい & 中 & 大きい & & さまざま & 分からない \\
\hline 望ましくない効果 & 大きい & 中 & 小さい & わずか & & さまざま & 分からない \\
\hline エビデンスの確実性 & 非常に低 & 低 & 中 & 高 & & & 採用研究なし \\
\hline 価值钼 & $\begin{array}{l}\text { 重要な不確実性 } \\
\text { またはばらつき } \\
\text { あり }\end{array}$ & $\begin{array}{c}\text { 重要な不確実性 } \\
\text { またはばらつき } \\
\text { の可能性ありり }\end{array}$ & $\begin{array}{l}\text { 重要な不確実性 } \\
\text { またははばらつき } \\
\text { はおそらくなし }\end{array}$ & $\begin{array}{l}\text { 重要な不確実性 } \\
\text { またはばらつき } \\
\text { はなし }\end{array}$ & & & \\
\hline 効果のパランス & 比較が優位 & $\begin{array}{c}\text { 比較がおそらく } \\
\text { 優位 }\end{array}$ & $\begin{array}{c}\text { 介入も比較もい } \\
\text { ずれも優位でな } \\
\text { い }\end{array}$ & $\begin{array}{c}\text { おそらく介入が } \\
\text { 優位 }\end{array}$ & 介入が優位 & さまざま & 分からない \\
\hline 容認性 & いいえ & $\begin{array}{c}\text { おそらく、いい } \\
\text { え }\end{array}$ & おそらく、はい & はい & & さまざま & 分からない \\
\hline 実行可能性 & いいえ & $\begin{array}{c}\text { おそらく、いい } \\
\text { え }\end{array}$ & おそらく、はい & はい & & さまざま & 分からない \\
\hline
\end{tabular}

非定型抗精神病薬

\begin{tabular}{|c|c|c|c|c|c|c|c|}
\hline & \multicolumn{7}{|c|}{ 判断 } \\
\hline 問題 & いいえ & $\begin{array}{c}\text { おそらく、いい } \\
\text { え }\end{array}$ & おそらく、はい & はい & & さまざま & 分からない \\
\hline 望ましい効果 & わずか & 小さい & 中 & 大きい & & さまざま & 分からない \\
\hline 望ましくない勃果 & 大きい & 中 & 小さい & わずか & & さまざま & 分からない \\
\hline エビデンスの確実性 & 非常に低 & 低 & 中 & 高 & & & 採用研究なし \\
\hline 価值钼 & $\begin{array}{c}\text { 重要な不確実性 } \\
\text { またははららつき } \\
\text { あり }\end{array}$ & $\begin{array}{c}\text { 重要な不確実性 } \\
\text { またはばらつき } \\
\text { の可能性ありり }\end{array}$ & $\begin{array}{l}\text { 重要な不確実性 } \\
\text { またははばらつき } \\
\text { はおそらくなし }\end{array}$ & \begin{tabular}{|c} 
重要な不確実性 \\
またはばらつき \\
はなし
\end{tabular} & & & \\
\hline 効果のバランス & 比較が優位 & $\begin{array}{c}\text { 比較がおそらく } \\
\text { 優位 }\end{array}$ & $\begin{array}{c}\text { 介入も比較もい } \\
\text { ずれも優位でな } \\
\text { い }\end{array}$ & $\begin{array}{c}\text { おそらくく介入が } \\
\text { 優位 }\end{array}$ & 介入が優位 & さまざま & 分からない \\
\hline 容認性 & いいえ & $\begin{array}{c}\text { おそらく、いい } \\
\text { え }\end{array}$ & おそらく、はい & はい & & さまざま & 分からない \\
\hline 実行可能性 & いいえ & $\begin{array}{c}\text { おそらく、いい } \\
\text { え }\end{array}$ & おそらく、はい & はい & & さまざま & 分からない \\
\hline
\end{tabular}




\section{（12）実施に関わる検討事項}

薬剤をルーチンに使用するかについては，患者の年 齢・重症度・合併症も考慮する必要がある。デクスメ デトミジンは，国内で認可された投与量が海外の投与 量と異なり（デクスメデトミジンの維持量 0.2 $0.7 \mu \mathrm{g} / \mathrm{kg} / \mathrm{hr}$ は海外より少ない), 本邦での有効性およ び副作用の発生も考慮に入れた使用が望まれる。

また，過活動型せん妄のため患者の生命または身体 が危険にさらされる可能性が高いと判断した場合に， デクスメデトミジン，ハロペリドール，または非定型 抗精神病薬の使用を妨げるものではない。

\section{（13）今後の研究の可能性}

今回含まれる研究は集中治療室の重症患者（場合に より術後患者）が対象となっているため，今後は敗血 症患者に限定したせん妄治療の研究が望まれる。

\section{文 献}

1) Reade MC, Eastwood GM, Bellomo R, et al: Effect of dexmedetomidine added to standard care on ventilator-free time in patients with agitated delirium a randomized clinical trial. JAMA. 2016; 315: 1460-8.

2) Girard TD, Exline MC, Carson SS, et al: Haloperidol and ziprasidone for treatment of delirium in critical illness. N Engl J Med. 2018; 379: 2506-16.

3) Devlin JW, Roberts RJ, Fong JJ, et al: Efficacy and safety of quetiapine in critically ill patients with delirium: A prospective, multicenter, randomized, double-blind, placebo-controlled pilot study. Crit Care Med. 2010; 38: 419-27.

4) Devlin JW, Skrobik Y, Riker RR, et al: Impact of quetiapine on resolution of individual delirium symptoms in critically ill patients with delirium: A post-hoc analysis of a double-blind, randomized, placebo-controlled study. Crit Care. 2011; 15: R215.

5) Devlin JW, Skrobik Y, Gélinas C, et al: Clinical Practice Guidelines for the Prevention and Management of Pain, Agitation/Sedation, Delirium, Immobility, and Sleep Disruption in Adult Patients in the ICU. Crit Care Med. 2018; 46: e825-73.

6）日本集中治療医学会 J-PAD ガイドライン作成委員会: 日本 版・集中治療室における成人重症患者に対する痛み・不穏・ せん妄管理のための臨床ガイドライン. 日集中医誌. 2014; 21: 539-79.
CQ10-6：成人敗血症患者のせん妄予防に，非薬 物療法を行うか?

Answer：成人敗血症患者のせん妄予防に非薬物療法 を行うことを弱く推奨する（GRADE 2C：エビデンス の確実性 $=「$ 低」)。

\section{（1）背景および本 $C Q$ の重要度}

敗血症患者の中枢神経系臓器障害の 1 つにせん妄が ある。集中治療室でのせん妄持続日数が集中治療室退 室後 3 か月と 12 か月の認知機能障害と関連すること が知られている。敗血症患者において非薬物療法によ りせん妄を予防できれば，患者の集中治療後症候群 (PICS) も軽減できる可能性があり，本 CQ を重要な 臨床課題として取り上げた。

(2) $\mathrm{PICO}$

P (患者)：敗血症，呼吸不全，心不全，熱傷，大侵 襲手術後などで人工呼吸中の成人重症患者

I（介入）：睡眠の改善（アイマスク，耳栓，概日リ ズムの改善など), 覚醒の促進（眼鏡, 補聴器, 見当識改善など)，リラクゼーション（リハビリ テーション医療を除く）のいずれか

C (対照) : 非介入

$\mathrm{O}$ (アウトカム) : 死亡，集中治療室退室後の認知機 能障害，せん妄，せん妄日数（報告がない場合 は，非せん妄日数)，ICU 滞在日数，重症有害事 象

\section{（3）エビデンスの要約}

システマティックレビューの結果，PICO に合致し たランダム化比較試験（RCT）が 10 件 1-10）施行され ており，これらを用いたメタ解析を実施した。

\section{（4）益と害のバランス（Table 10-6-1）}

\section{望ましい効果：}

術後患者を含むシステマティックレビューの結果， 死亡（4 RCT: $\mathrm{n}=884 ）$ の効果推定值とその 95\% CI は, 1,000 人あたり 15 人少ない $(57$ 人少ない〜 42 人多い), 集中治療室退室後の認知機能（MMSE）（1 RCT: $\mathrm{n}=$ 32）は, 平均（MD） 0.2 高い（1.27 低い〜 1.67 高い), 非せん妄日数（2 RCT: $\mathrm{n}=799 ）$ は MD 0.01 日長い （1.22 日短い〜1.24 長い）であった。また，せん妄（6 RCT: $\mathrm{n}=1,028 ）$ は 1,000 人あたり 44 人少ない（149 人少ない〜 131 人多い), ICU 滞在日数 $(5$ RCT: $n=$ 904）は MD 0.14 日短い（1.06日短い〜0.79日長い） 
Table 10-6-1エビデンスプロファイル

\begin{tabular}{|c|c|c|c|c|c|c|c|c|c|c|c|c|}
\hline \multicolumn{7}{|c|}{ 確実性の評価 } & \multicolumn{2}{|c|}{ 患者数 } & \multicolumn{2}{|c|}{ 効果 } & \multirow[b]{2}{*}{ 確実性 } & \multirow[b]{2}{*}{ 重要性 } \\
\hline 研究数 & $\begin{array}{c}\text { 研究 } \\
\text { デザイン }\end{array}$ & $\begin{array}{l}\text { ハイイアス } \\
\text { のリスク }\end{array}$ & 非一貫性 & 非直接性 & 不精確性 & $\begin{array}{l}\text { その他 } \\
\text { の検討 }\end{array}$ & 非薬物療法 & 通常治療 & $\begin{array}{l}\text { 相対指標 } \\
(95 \% \text { cI) }\end{array}$ & $\begin{array}{l}\text { 絶対指標 } \\
(95 \% \text { CI })\end{array}$ & & \\
\hline \multicolumn{13}{|c|}{ 死亡（論文中で報告されている最長のもの） } \\
\hline 4 & RCT & 深刻 a & 深刻でない & 深刻でない & 深刻 b & なし & $\begin{array}{l}80 / 447 \\
(17.9 \%)\end{array}$ & $\begin{array}{l}83 / 437 \\
(19.0 \%)\end{array}$ & $\begin{array}{c}\text { RR } 0.92 \\
(0.70 \text { to } 1.22)\end{array}$ & $\begin{array}{c}1,000 \text { 人あたり } 15 \\
\text { 人少ない }(57 \text { 人 } \\
\text { 少ない 42 人多 } \\
\text { () }\end{array}$ & $\underset{\text { 低 }}{\oplus \oplus \bigcirc \bigcirc}$ & 重大 \\
\hline \multicolumn{13}{|c|}{ ICU 退室後の認知機能障害（評価：MMSE：スケール から：0 to 30） } \\
\hline 1 & RCT & 非常に深刻 c & 深刻でない & 深刻でない & 非常に深刻 d & なし & 18 & 14 & - & $\begin{array}{l}\text { 平均 } 0.2 \text { 高い } \\
(1.27 \text { 低い } \\
1.67 \text { 高い) }\end{array}$ & $\begin{array}{l}\oplus \bigcirc \bigcirc \bigcirc \\
\text { 非常に低 }\end{array}$ & 重大 \\
\hline \multicolumn{13}{|c|}{ 非せん妄（昏睡）日数 } \\
\hline 2 & RCT & 非常に深刻 e & 深刻でない & 深刻でない & 深刻 ${ }^{f}$ & なし & 404 & 395 & - & $\begin{array}{c}\text { 平均 } 0.01 \text { 日長い } \\
\text { (1.22 日短い } \\
1.24 \text { 日長い) }\end{array}$ & $\begin{array}{l}\oplus \bigcirc \bigcirc \bigcirc \\
\text { 非常に低 }\end{array}$ & 重大 \\
\hline \multicolumn{13}{|l|}{ せん妄 } \\
\hline 6 & RCT & 深刻 a & 深刻 g & 深刻でない & 深刻 b & なし & $\begin{array}{l}156 / 510 \\
(30.6 \%)\end{array}$ & $\begin{array}{l}151 / 518 \\
(29.2 \%)\end{array}$ & $\begin{array}{c}\text { RR } 0.85 \\
(0.49 \text { to } 1.45)\end{array}$ & $\begin{array}{c}1,000 \text { 人あたり } 44 \\
\text { 人少ない(149人 } \\
\text { 少ない 131 人多 } \\
\text { い) }\end{array}$ & $\begin{array}{l}\oplus \bigcirc \bigcirc \bigcirc \\
\text { 非常に低 }\end{array}$ & 重大 \\
\hline \multicolumn{13}{|c|}{ ICU 滞在日数 } \\
\hline 5 & RCT & 非常に深刻 e & 深刻でない & 深刻でない & 深刻 ${ }^{f}$ & なし & 457 & 447 & - & $\begin{array}{c}\text { 平均 } 0.14 \text { 日短い } \\
(1.06 \text { 日短い } \\
0.79 \text { 日長い) }\end{array}$ & $\begin{array}{l}\oplus \bigcirc \bigcirc \bigcirc \\
\text { 非常に低 }\end{array}$ & 重要 \\
\hline
\end{tabular}

重篤な有害事象の報告はなかった。

a. 大多数の研究で, バイアスのリスクが高い(患者医療者の盲検化はできていない)ため, 一段階グレードを下げた。

b. 総イベント数が少ないため, 一段階グレードを下げた。

c. 1 件の研究におけるバイアスのリスクが高い（患者医療者の盲検化は不可能，不完全アウトカムデータ）ため二段階グレードを下げた。

d. 1 件のみの研究における患者数は 32 例のみであるため, 二段階グレードを下げた。

e. 寄与率の高い研究のバイアスのリスクが高い（盲検化の欠如）ため, 二段階グレードを下げた。

g. 推定値の方向性がサブグループ間で異なり，異質性 (I'值は $46 \%)$ が中等度認められるため, 一段階グレードを下げた。

であった。以上より，介入による望ましい効果を小さ

いと判断した。

望ましくない効果 :

重症な有害事象を報告した研究がなかった。

益と害のバランス :

望ましい効果は小さく，望ましくない効果は不明で ある。しかし，介入内容から推測される望ましくない 効果はほとんどないと考えられる。以上より，おそら く介入が優位と判断した。

（5）アウトカム全般に関するエビデンスの確実性

介入に関する効果推定值は死亡を減少，集中治療室 退室後の認知機能スコアを増加など，益と害の方向性 は一致している。全体的なエビデンスの確実性は, 最 も高い「低」と判定した。

\section{（6）価値観}

成人敗血症患者のせん妄予防の非薬物療法に対する, 各アウトカムに置く患者・家族の価值観に関するデー タはない。一般的に死亡, せん妄に対して置く相対的 価值は高く，ばらつきは少ないことが予想される。
（7）容認性

非薬物療法として実施される睡眠の改善（アイマス ク, 耳栓, 概日リズムの改善など), 覚醒の促進（眼 鏡, 補聴器, 見当識改善など), リラクゼーション （リハビリテーション医療を除く）は患者・家族の個 人的な負担を増強するものではないが, 医療者の仕事 量は増加させる可能性がある。

\section{（8）実行可能性}

睡眠の改善（アイマスク, 耳栓, 概日リズムの改善 など), 覚醒の促進 (眼鏡, 補聴器, 見当識改善など), リラクゼーション（リハビリテーション医療を除く） は介入としてむずかしいことはなく, 問題なく実行可 能である。

（9）判断の要約（Table 10-6-2）

\section{（10）推奨グレーディング決定の工程}

修正 RAND 法を用いた投票によって, 中央值 8, 見解不一致指数 0.164 の結果となり, 委員会で採択さ れた（7 点以上 : 95.8\%)。 
Table 10-6-2 判断の要約

\begin{tabular}{|c|c|c|c|c|c|c|c|}
\hline & \multicolumn{7}{|c|}{ 判溇 } \\
\hline 問題 & いいえ & $\begin{array}{c}\text { おそらく、いい } \\
\text { え }\end{array}$ & おそらく、はい & はい & & さまざま & 分からない \\
\hline 望ましい効果 & わずか & 小さい & 中 & 大きい & & さまざま & 分からない \\
\hline 望ましくない効果 & 大きい & 中 & 小さい & わずか & & さまざま & 分からない \\
\hline エビデンスの確実性 & 非常に低 & 低 & 中 & 高 & & & 採用研究なし \\
\hline 価值钼 & $\begin{array}{c}\text { 重要な不確実性 } \\
\text { またはばらつき } \\
\text { あり }\end{array}$ & $\begin{array}{c}\text { 重要な不確実性 } \\
\text { またはばらつき } \\
\text { の可能性あり }\end{array}$ & $\begin{array}{l}\text { 重要な不確実性 } \\
\text { またはばらつき } \\
\text { はおそらくなし }\end{array}$ & $\begin{array}{c}\text { 重要な不確実性 } \\
\text { またはばらつき } \\
\text { はなし }\end{array}$ & & & \\
\hline 効果のバランス & 比較が優位 & $\begin{array}{c}\text { 比較がおそらく } \\
\text { 優位 }\end{array}$ & $\begin{array}{c}\text { 介入も比較もい } \\
\text { ずれも優位でな } \\
\text { い }\end{array}$ & $\begin{array}{c}\text { おそらく介入が } \\
\text { 優位 }\end{array}$ & 介入が優位 & さまざま & 分からない \\
\hline 容認性 & いいえ & $\begin{array}{c}\text { おそらく、いい } \\
\text { え }\end{array}$ & おそらく、はい & はい & & さまざま & 分からない \\
\hline 実行可能性 & いいえ & $\begin{array}{c}お そ ら く 、 い い ~ \\
\text { え }\end{array}$ & おそらく、はい & はい & & さまざま & 分からない \\
\hline
\end{tabular}

\section{（11）関連する他の診療ガイドラインにおける推奨}

日本版敗血症診療ガイドライン (J-SSCG) 2016 11, 12) においては，J-PAD ガイドライン 13) より引用する形 で「可能な場合はいつでも音楽を使った介入を行うこ とを弱く推奨する（2C）」となっている。またPADIS ガイドライン 14) では，成人重症患者において，修正 可能なせん妄の危険因子の減少, 認知機能の改善, 睡 眠や運動，聴力，視力の最適化に焦点を当てた（ただ しそれらに限定されない）多角的な非薬理学的介入法 を用いることを提案している（条件付き推奨，低い質 のエビデンス)。

\section{（12）実施に関わる検討事項}

非薬物療法として，睡眠の改善・覚醒の促進・認知 療法は，重症患者においても安全に実施できる可能性 が示唆されている。

\section{（13）今後の研究の可能性}

個別の介入に関してそれぞれに有効性を検討するこ とが望まれる。同時に，ABCDEFバンドルケアに代 表される複合的非薬物療法に関しても，今後考慮して いく必要がある。今回含まれる研究は集中治療室の重 症患者（場合により術後患者）が対象となっているた め, 今後は患者を敗血症に限定したせん妄予防の研究 が望まれる。

\section{文 献}

1) Brummel NE, Girard TD, Ely EW, et al: Feasibility and safety of early combined cognitive and physical therapy for critically ill medical and surgical patients: the Activity and Cognitive Therapy in ICU (ACT-ICU) trial. Intensive Care Med. 2014; 40: 370-9.

2) Demoule $A$, Carreira $S$, Lavault $S$, et al: Impact of earplugs and eye mask on sleep in critically ill patients: a prospective randomized study. Crit Care. 2017; 21: 284

3) Johnson K, Fleury J, McClain D: Music intervention to prevent delirium among older patients admitted to a trauma intensive care unit and a trauma orthopaedic unit. Intensive Crit Care Nurs. 2018; 47: 7-14.

4) Lee CH, Lee CY, Hsu MY, et al: Effects of Music Intervention on State Anxiety and Physiological Indices in Patients Undergoing Mechanical Ventilation in the Intensive Care Unit. Biol Res Nurs. 2017; 19: 137-44.

5) Litton E, Elliott R, Ferrier J, et al: Quality sleep using earplugs in the intensive care unit: The QUIET pilot randomised controlled trial. Crit Care Resusc. 2017; 19: 128-33.

6) Munro CL, Cairns P, Ji M, et al: Delirium prevention in critically ill adults through an automated reorientation intervention-A pilot randomized controlled trial. Hear Lung. 2017; 46: 234-8.

7) Potharajaroen $S$, Tangwongchai $S$, Tayjasanant $T$, et al: Bright light and oxygen therapies decrease delirium risk in critically ill surgical patients by targeting sleep and acid-base disturbances. Psychiatry Res. 2018; 261: 21-7.

8) Simons KS, Laheij RJF, van den Boogaard M, et al: Dynamic light application therapy to reduce the incidence and duration of delirium in intensive-care patients: a randomised controlled trial. Lancet Respir Med. 2016; 4: 194-202.

9) Taguchi T, Yano M, Kido Y: Influence of bright light therapy on postoperative patients: A pilot study. Intensive Crit Care Nurs. 2007; 23: 289-97.

10) Van Rompaey B, Elseviers MM, Van Drom W, et al: The effect of earplugs during the night on the onset of delirium and sleep perception: a randomized controlled trial in intensive care patients. Crit Care. 2012; 16: R73.

11）西田修, 小倉裕司, 井上茂亮, 他, 日本版敗血症診療ガイドラ イン 2016 作成特別委員会. 日本版敗血症診療ガイドライン 2016. 日集中医誌. 2017; 24: S1-232.

12）西田修, 小倉裕司, 井上茂亮, 他, 日本版敗血症診療ガイドラ イン 2016 作成特別委員会. 日本版敗血症診療ガイドライン 2016. 日救急医会誌. 2017; 28: S1-232.

13）日本集中治療医学会 J-PAD ガイドライン作成委員会: 日本 版・集中治療室における成人重症患者に対する痛み・不穞・ 
せん妄管理のための臨床ガイドライン. 日集中医誌. 2014; 21: 539-79.

14) Devlin JW, Skrobik Y, Gélinas C, et al: Clinical Practice Guidelines for the Prevention and Management of Pain, Agitation/Sedation, Delirium, Immobility, and Sleep Disruption in Adult Patients in the ICU. Crit Care Med. 2018; 46: e825-73. 


\section{CQ11：急性腎障害·血液浄化療法}

急性腎障害（acute kidney injury: AKI）は，急激に進 行する腎機能低下により生体の恒常性が破綻している 病態であり，幅広い疾患スペクトラムを有する症候群 である。2012 年に発表された Kidney Disease Improving Global Outcomes（KDIGO）による AKI 診療 ガイドラインにおいては，48 時間あるいは 1 週間の 期間における血清クレアチニン濃度の上昇, あるいは 6〜24 時間での尿量減少に基づく AKI 診断基準と重 症度分類が下表のとおり提示された 11 。広く臨床現場 において測定されている 2 つ臨床指標により簡便か つ迅速な AKI 診断が可能となり,この AKI 診断基準 を用いた臨床研究が数多く行われ，AKIの発症がど のような臨床場面においても有意に予後と関連するこ とが明らかとなった。

敗血症は AKI の原因疾患のなかでも高頻度に認め られるものの 1 つであり, 敗血症性 AKI の予後は不 良であることが広く認識されている2)。特に血液浄化 療法が必要となる重症 AKI が敗血症に合併した場合 の死亡率は高く，本邦の近年の DPC データを用いた 解析においては, 院内死亡率が $50 \%$ 程度であったと 報告されている3)。敗血症性 AKI の病態生理は複雑 であり, 血行動態の異常に加えて, 炎症反応の関与や ミトコンドリア機能異常などの細胞障害が想定されて (る4)。多くの基礎研究が行われているものの, AKI において腎組織保護作用が臨床的に証明された薬剤は いまだ存在しないとされている。一方, 臨床の場にお いては体液管理の観点から利尿薬投与が敗血症性 AKI
に対して行われている現実があり，本ガイドラインに おいてもフロセミド（CQ 11-1）および心房性ナトリ ウム利尿ペプチド（ANP）（CQ 11-2）の投与に関する $\mathrm{CQ}$ を採用した。血行動態の異常が敗血症性 AKI 発症 に大きく関与していることはまちがいがないと考えら れており，昇圧作用のある薬剤のうち腎血流増加作用 とナトリウム排泄作用を有するドパミン（CQ 11-3） が特に低用量（いわゆる renal dose）で用いられてき た。この十数年のエビデンスの蓄積により, 敗血症全 般に対してのドパミンの有用性が否定されてきている なかで, 敗血症性 AKIにおけるドパミンの状況を改 めて確認すべく, 本ガイドラインにおいてはドパミン に関する CQ も採用している。

血液浄化療法は, 血液体外循環により血液中の病因 物質を除去，不足している物質を補給する治療法であ る。なかでも腎蔵の機能を代替する治療である腎代替 療法（renal replacement therapy: RRT）が最も多く行わ れている血液浄化療法である。実際の臨床において は, AKI に対するRRTのモダリティや開始時期, 治 療量などは個々の症例の病態と医療体制により決めら れているが，確固たるエビデンスに支持された最適な 治療条件は未だ確立されていない状況である。一方, 高い死亡率を呈する敗血症性 AKI における生命維持 にRRT は必要不可欠な治療法であり, 種々の治療条 件の決定を求められる場面は多いと思われる。持続的 あるいは間欠的な RRT のどちらを選択すべきか（CQ 11-4)，予後改善が最も期待できる RRT 開始のタイミ ングはいつか (CQ 11-5), RRTにおける治療量を増 やすことで予後の改善が期待できるのか（CQ 11-6）,

$\mathrm{KDIGO}$ によるAKI診断基準と重症度分類

\begin{tabular}{|c|c|c|}
\hline \multirow[t]{2}{*}{ AKI の診断基準 } & \multicolumn{2}{|c|}{$\begin{array}{c}48 \text { 時間以内に } \mathrm{sCr} \text { 值が } 0.3 \mathrm{mg} / \mathrm{dL} \text { 以上増加した場合 } \\
\text { または } \\
\mathrm{sCr} \text { 值がそれ以前 } 7 \text { 日以内に判っていたか子予想される基礎值より } 1.5 \text { 倍の増加があった場合 } \\
\text { または } \\
\text { 尿量が } 6 \text { 時間にわたって }<0.5 \mathrm{~mL} / \mathrm{kg} / \text { 時間に減少した場合 }\end{array}$} \\
\hline & $\mathrm{sCr}$ 基準 & 尿量基準 \\
\hline ステージ 1 & $\begin{array}{c}\text { 基礎値の } 1.5-1.9 \text { 倍への上昇 } \\
\text { または } \\
0.3 \mathrm{mg} / \mathrm{dL} \text { 以上の増加 }\end{array}$ & 0.5 mL/kg/hr 未満(6 時間以上) \\
\hline ステージ 2 & 基礎值の 2.0-2.9 倍への上昇 & 0.5 mL/kg/hr 未満(12 時間以上) \\
\hline ステージ 3 & $\begin{array}{c}\text { 基礎値の } 3 \text { 倍以上への上昇 } \\
\text { または } \\
4.0 \mathrm{mg} / \mathrm{dL} \text { 以上への増加 } \\
\text { または } \\
\text { 腎代替療法の開始 } \\
\text { または } \\
18 \text { 歳未満患者の } \mathrm{eGFR}<35 \mathrm{~mL} / \mathrm{min} / 1.73 \mathrm{~m}^{2}\end{array}$ & $\begin{array}{c}0.3 \mathrm{~mL} / \mathrm{kg} / \mathrm{hr} \text { 未満(24 時間以上) } \\
\text { または } \\
12 \text { 時間以上の無尿 }\end{array}$ \\
\hline
\end{tabular}

AKI: 急性腎障害, eGFR: 推算糸球体濾過量, sCr: 血清クレアチニン值 
といった CQを本ガイドラインにおいて採用してい る。特に RRT 開始時期に関しては, 最大規模となる multi-national pragmatic open-label ランダム化比較試験 （RCT）である STARRT AKI 研究が本ガイドラインに おけるエビデンス評価作業後に発表された ${ }^{5)}$ 。Stage 2 あるいは Stage 3 の AKI に対して 12 時間以内に RRT を開始する群と古典的絶対適応にて開始する群の比較 が行われ，90 日生存率に差はなく血圧低下と低リン 血症の頻度は早期開始群に多いと報告された。この結 果は早期開始を支持しないものであり，本ガイドライ ンにおける推奨とは相反しないと判断した。

RRT 以外にも敗血症診療において血液浄化療法が 施行されている。1つはエンドトキシン吸着療法であ る。グラム陰性桿菌感染症においては, 血中エンドト キシン濃度およびエンドトキシン活性が上昇している ことが観察されており, 病原体関連分子パターン (pathogen-associated molecular patterns: PAMPs) の 1 つ であるエンドトキシンを血液中から除去する治療は理 にかなっており，本邦で開発されて 20 年以上にわた
り保険収載された治療として用いられている。近年, 欧米を中心として複数の RCT が施行されており, そ れらの結果をエビデンスとして評価すべく, 本ガイド ラインにおいて CQとして採用した（CQ 11-7）。もう 1 つはいわゆる“non-renal indication”などの表現で炎 症性メディエータの除去・制御を目的とした血液浄化 療法である。実際には PMMA 膜など血液吸着特性を 有する血液浄化膜を用いた RRT として，腎障害が高 度に進展するよりも前に開始するという治療が，本邦 においては積極的に行われてきている。2014 年に保 険適用を得た AN69ST 膜は, その適応疾患が重症敗 血症, 敗血症性ショックであり, AKI は必須ではな いことから注目された。その後, これらの血液浄化膜 について, いくつかの観察研究が報告されているが, RCT はいまだ施行されていない。2016 年のガイドラ インにおいては，血液浄化膜に関する $\mathrm{CQ}$ はなく，本 ガイドラインにおいても採用していない。今後のエビ デンスの蓄積を期待するとともに, 血液浄化膜に関す るCQについても検討していきたい。
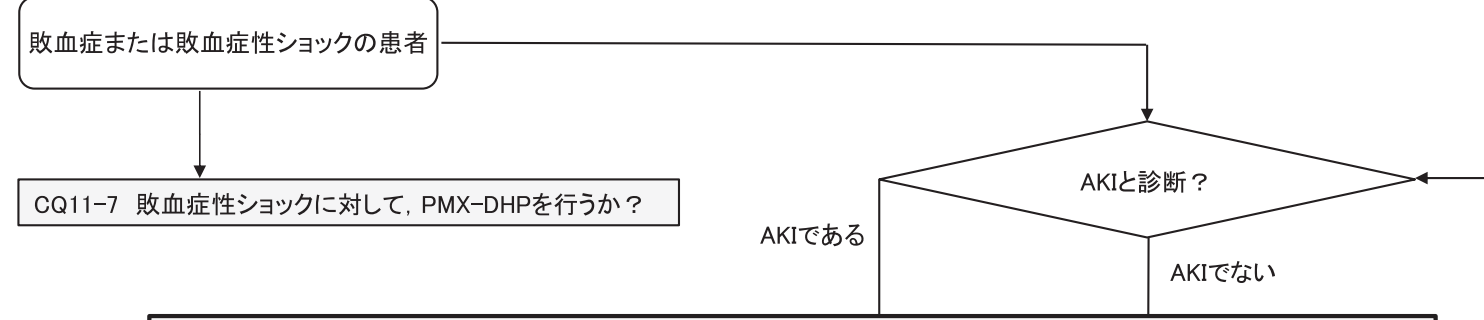

CQ11-1 敗血症性AKI の予防·治療目的にフロセミドの投与は行うか？

CQ11-2 敗血症性AKI の予防·治療目的に心房性ナトリウム利尿ペプチド(ANP)の投与は行うか? (保険適用外使用) CQ11-3 敗血症性AKI の予防·治療目的にドパミンの投与は行うか？

CQ11-4 敗血症性AKII対する腎代替療法では持続的治療を行うか?

CQ11-5 敗血症性AKIに対して早期の腎代替療法を行うか?

CQ11-6 敗血症性AKII対する腎代替療法において, 血液浄化量の増加を行うか?

急性腎障害・血液浄化療法 [診療フロー]

\section{文 献}

1) KDIGO AKI Working Group: KDIGO clinical practice guideline for acute kidney injury. Kidney Int Suppl. 2012; 2: 1-138.

2) Peerapornratana $S$, Manrique-Caballero CL, Gómez H, et al: Acute kidney injury from sepsis: current concepts, epidemiology, pathophysiology, prevention and treatment. Kidney Int. 2019; 96: 1083-99.

3) Miyamoto Y, Iwagami M, Aso S, et al: Temporal change in characteristics and outcomes of acute kidney injury on renal replacement therapy in intensive care units: analysis of a nationwide administrative database in Japan, 2007-2016. Crit Care. 2019; 23: 172.
4) Doi K: Role of kidney injury in sepsis. J Intensive Care. 2016; 4: 17.

5) Bagshaw SM, Wald R, Adhikari NKJ, et al: Timing of Initiation of Renal-Replacement Therapy in Acute Kidney Injury. N Engl J Med. 2020; 383: 240-51. 
CQ11-1：敗血症性 AKI の予防・治療目的にフロ セミドの投与は行うか?

Answer : 敗血症性 AKI に対して予防あるいは治療を 目的としてフロセミドを投与しないことを弱く推奨す る（GRADE 2C : エビデンスの確実性 $=「$ 低」）。

\section{（1）背景および本 $C Q$ の重要度}

フロセミドは，尿量の維持によって脱落した尿細管 上皮細胞による尿細管の閉塞を予防し，また尿細管の 酸素消費能を低下させることで腎障害に対して有益に 働きうるとの考えがある 1-3)。1980 年代からフロセミ ドによる腎保護効果あるいは腎障害治療効果を検討し た臨床研究が行われたが，結果の多くは有効性を示さ なかった4)。しかしながら，フロセミドは，敗血症診 療の体液管理において広く汎用されていることから， 引き続きガイドラインで取り上げられるべきと考えら れる。

なお，本 CQ は，敗血症性 AKI の予防・治療目的 に投与されるフロセミドに関するものであり，体液過 剩を補正する目的に関するものではない。体液過剩の 際には，フロセミドを含めた利尿薬などによる適切な 体液管理が望まれる。

\section{(2) PICO}

(1) 敗血症性 AKI の予防

P (患者)：成人の感染症，敗血症あるいは敗血症性 ショック患者および重症疾患患者

I（介入）:フロセミドの投与

C (対照)：プラセボまたは標準的治療, 治療なし

$\mathrm{O}$ (アウトカム)：院内死亡，腎代替療法（renal replacement therapy: RRT) 施行, AKI の発症, 合 併症発生

(2) 敗血症性 AKI の治療

P (患者)：成人の敗血症性 AKI 患者および重症疾 患による AKI 患者

I（介入）：フロセミドの投与

C（対照）：プラセボまたは標準的治療，治療なし

$\mathrm{O}$ (アウトカム) : 死亡, RRT 施行，AKI からの回 復, AKI 罹患期間

\section{（3）エビデンスの要約}

システマティックレビューの結果，敗血症性 AKI の予防目的の PICO に合致したランダム化比較試験 （RCT）は抽出されなかった。治療目的のPICOに合
致した RCT が 6 件施行されており $5-10)$ ，これらを用 いたメタ解析を実施した。

\section{（4）益と害のバランス（Table 11-1-1）}

\section{望ましい効果 :}

AKI 罹病期間においては，有用性が示唆されるも のの, 重大なアウトカムでは望ましい効果はみられ ず，明らかな望ましい効果があるかは不明である。

望ましくない効果 :

院内死亡（6 RCT: $\mathrm{n}=649 ） に$ 対する効果推定值は, 1,000 人あたり 39 人多い $(95 \%$ CI: 26 人少ない〜 122 人多い), RRT の導入（3 RCT: $\mathrm{n}=206 ）$ の効果推定 值は，1,000 人あたり 40 人多い $(95 \%$ CI: 103 人少な い〜299人多い）であった。望ましくない効果はわず かであると判断した。

益と害のバランス :

重大なアウトカムにおいて望ましい効果は明らかで はない一方で，院内死亡，RRT の導入などのアウト カムで望ましくない効果がわずかにみられた。以上か らフロセミド投与による明らかな有益性を示さなかっ た。

（5）アウトカム全般に関するエビデンスの確実性 重大なアウトカムにおいて，効果推定值の方向性は 一致している。そのため，全体としては一番高いアウ トカムの確実性を採用した。アウトカム全体における エビデンスの確実性は「低」である。

\section{（6）価值観}

患者および家族の価値観に関するデータはなく，死 亡という重大なアウトカムにおいては個々人の価值観 のばらつきは小さいと考えられる。

\section{（7）容認性}

フロセミドの投与は， 1 日あたり最大 $1,000 \mathrm{mg}$ まで 保険診療として認められている。フロセミド $(20 \mathrm{mg})$ 1 アンプルの薬価は約 60 円であり，フロセミドによ る 1 日あたりの最大コストは約 3,000 円である。個人 負担額を考元ると，患者・家族の個人の視点からは許 容範囲内と考えられる。また，医療従事者に対する業 務負荷量はわずかと考えられる。

（8）実行可能性

フロセミド投与において実行は容易である。

（9）判断の要約（Table 11-1-2） 
Table 11-1-1エビデンスプロファイル

\begin{tabular}{|c|c|c|c|c|c|c|c|c|c|c|c|c|}
\hline \multicolumn{7}{|c|}{ 確実性の評価 } & \multicolumn{2}{|c|}{ 患者数 } & \multicolumn{2}{|c|}{ 勃果 } & \multirow[b]{2}{*}{ 確实性 } & \multirow[b]{2}{*}{ 重要性 } \\
\hline 研究数 & $\begin{array}{c}\text { 研究 } \\
\text { デザイン }\end{array}$ & \begin{tabular}{|l} 
パイアス \\
のリスク
\end{tabular} & 非一貫性 & 非直接性 & 不精確性 & $\begin{array}{l}\text { その他 } \\
\text { の検討 }\end{array}$ & フロセミド & $\begin{array}{l}\text { コントロー } \\
\text { ル }\end{array}$ & $\begin{array}{l}\text { 相対指㯢 } \\
(95 \% \text { GI) }\end{array}$ & $\begin{array}{l}\text { 絶対指標 } \\
(95 \% \text { CI })\end{array}$ & & \\
\hline \multicolumn{13}{|l|}{ 院内死亡 } \\
\hline 6 & RCT & $\begin{array}{l}\text { 深刻で } \\
\text { ない }\end{array}$ & $\begin{array}{l}\text { 深刻で } \\
\text { ない }\end{array}$ & 深刻 a & 深刻 b & なし & $\begin{array}{l}124 / 338 \\
(36.7 \%)\end{array}$ & $\begin{array}{l}100 / 311 \\
(32.2 \%)\end{array}$ & $\begin{array}{c}\text { RR } 1.12 \\
\text { (0. } 92 \text { to } 1.38)\end{array}$ & $\begin{array}{c}1,000 \text { 人あたり } 39 \\
\text { 人多い } \\
\text { (26 人少ない } \\
122 \text { 人多い) }\end{array}$ & $\underset{\text { 低 }}{\oplus \oplus \bigcirc \bigcirc}$ & 重大 \\
\hline \multicolumn{13}{|c|}{ 腎代替療法 } \\
\hline 3 & RCT & $\begin{array}{l}\text { 深刻で } \\
\text { ない }\end{array}$ & 深刻。 & 深刻 a & $\begin{array}{l}\text { 非常に } \\
\text { 深刻 d }\end{array}$ & なし & $\begin{array}{l}35 / 105 \\
(33.3 \%)\end{array}$ & $\begin{array}{l}29 / 101 \\
(28.7 \%)\end{array}$ & $\begin{array}{c}\text { RR } 1.14 \\
\text { (0. } 64 \text { to } 2.04)\end{array}$ & $\begin{array}{c}1,000 \text { 人あたり } 40 \\
\text { 人多い } \\
\text { (103 人少ない } \\
299 \text { 人多い })\end{array}$ & $\begin{array}{l}\oplus \bigcirc \bigcirc \bigcirc \\
\text { 非常に低 }\end{array}$ & 重大 \\
\hline \multicolumn{13}{|c|}{ AKI からの回復 } \\
\hline 5 & RCT & $\begin{array}{l}\text { 深刻で } \\
\text { ない }\end{array}$ & $\begin{array}{l}\text { 深刻で } \\
\text { ない }\end{array}$ & 深刻 a & 深刻 b & なし & $\begin{array}{l}146 / 304 \\
(48.0 \%)\end{array}$ & $\begin{array}{l}158 / 298 \\
(53.0 \%)\end{array}$ & $\begin{array}{c}\text { RR } 0.91 \\
\text { (0. } 78 \text { to } 1.05)\end{array}$ & $\begin{array}{c}1,000 \text { 人あたり } 48 \\
\text { 人少ない } \\
(117 \text { 人少ない } \\
27 \text { 人多い })\end{array}$ & $\underset{\text { 低 }}{\oplus \oplus \bigcirc \bigcirc}$ & 重要 \\
\hline \multicolumn{13}{|c|}{ AKI 瞿病期間 (腎代替喗法依存期間) } \\
\hline 3 & RCT & $\begin{array}{l}\text { 深刻で } \\
\text { ない }\end{array}$ & $\begin{array}{l}\text { 深刻で } \\
\text { ない }\end{array}$ & 深刻 a & 深刻。 & なし & 234 & 229 & - & $\begin{array}{c}\text { 平均 } 0.67 \text { 日短い } \\
(2.36 \text { 日短い } \\
1.01 \text { 日長い) }\end{array}$ & $\underset{\text { 低 }}{\oplus \oplus \bigcirc \bigcirc}$ & 重要 \\
\hline \multicolumn{13}{|l|}{ 聴力障害 } \\
\hline 3 & RCT & $\begin{array}{l}\text { 深刻で } \\
\text { ない }\end{array}$ & $\begin{array}{l}\text { 深刻で } \\
\text { ない }\end{array}$ & 深刻 a & $\begin{array}{l}\text { 非常に } \\
\text { 深刻 d }\end{array}$ & なし & $\begin{array}{l}4 / 235 \\
(1.7 \%)\end{array}$ & $\begin{array}{l}2 / 230 \\
(0.9 \%)\end{array}$ & $\begin{array}{c}\text { RR } 1.68 \\
\text { (0. } 34 \text { to } 8.22)\end{array}$ & $\begin{array}{c}1,000 \text { 人あたり } 6 \\
\text { 人多い } \\
\text { (6 人少ない 63 } \\
\text { 人多い) }\end{array}$ & $\begin{array}{l}\oplus \bigcirc \bigcirc \bigcirc \\
\text { 非常に低 }\end{array}$ & 重要 \\
\hline
\end{tabular}

a. 敗血症性 AKI に限定した研究は抽出できなかった。

b. 95\%信頼区間が 1.0 をまたいでいる。

c. 非一貫性が高い $\left(I^{2}>50 \%\right)$ 。

d. $95 \%$ 信頼区間が 0.75 と 1.25 の両方をまたいでいる。

e. 95\%信頼区間が 0 をまたいでいる。

Table 11-1-2 判断の要約

\begin{tabular}{|c|c|c|c|c|c|c|c|}
\hline 問題 & いいえ & $\begin{array}{c}\text { おそらく、いい } \\
\text { え }\end{array}$ & おそらく、はい & はい & & さまざま & 分からない \\
\hline 望ましい効果 & わずか & 小さい & 中 & 大きい & & さまざま & 分からない \\
\hline 望ましくない効果 & 大きい & 中 & 小さい & わずか & & さまざま & 分からない \\
\hline エビデンスの確実性 & 非常に低 & 低 & 中 & 高 & & & 採用研究なし \\
\hline 価值钼 & $\begin{array}{c}\text { 重要な不確実性 } \\
\text { またはばらつき } \\
\text { あり }\end{array}$ & $\begin{array}{l}\text { 重要な不確実性 } \\
\text { またはばらつき } \\
\text { の可能性ありり }\end{array}$ & $\begin{array}{l}\text { 重要な不確実性 } \\
\text { またはばらつき } \\
\text { はおそらくなし }\end{array}$ & $\begin{array}{c}\text { 重要な不確実性 } \\
\text { またはばらつき } \\
\text { はなし }\end{array}$ & & & \\
\hline 勃果のパランス & 比較が優位 & $\begin{array}{c}\text { 比較がおそらく } \\
\text { 優位 }\end{array}$ & $\begin{array}{c}\text { 介入も比較もい } \\
\text { ずれも優位でな } \\
\text { い }\end{array}$ & $\begin{array}{c}\text { おそらく介入が } \\
\text { 優位 }\end{array}$ & 介入が優位 & さまざま & 分からない \\
\hline 容認性 & いいえ & $\begin{array}{c}\text { おそらく、いい } \\
\text { え }\end{array}$ & おそらく、はい & はい & & さまざま & 分からない \\
\hline 実行可能性 & いいえ & $\begin{array}{c}\text { おそらく、いい } \\
\text { え }\end{array}$ & おそらく、はい & はい & & さまざま & 分からない \\
\hline
\end{tabular}




\section{（10）推奨グレーディング決定の工程}

修正 RAND 法を用いた投票によって，中央值 7.5, 見解不一致指数 0.164 の結果となり, 委員会で採択さ れた（7点以上 : 83.3\%)。

\section{（11）関連する他の診療ガイドラインにおける推奨}

SSCG 2016 では，本 CQ については特に言及されて いない11)。本邦から出版された AKI（急性腎障害） 診療ガイドライン 2016 では，体液過剰を補正する目 的での使用を除き，AKIの予防および治療目的にルー プ利尿薬を投与することは推奨されていない（予防 : 推奨の強さ 1 , エビデンスの強さ $\mathrm{B}$ 。治療 : 推奨の強 さ2, エビデンスの強さ C) ${ }^{12)}$ 。また諸外国から出版 された AKI のガイドラインでも同様に，体液量を補 正する目的での使用を除き，ルーチンでの利尿薬の使 用は推奨されていない（KDIGO-予防：推奨の強さ 1 , エビデンスの強さ $\mathrm{B}$ 。 KDIGO-治療 : 推奨の強さ 2 , エビデンスの強さ C) 13,14)。

\section{（12）実施に関わる検討事項}

フロセミドの投与にあたっては，体液量，血管内容 量の評価を行う必要がある。

\section{（13）今後の研究の可能性}

フロセミドに対する反応性が AKI 重症化の指標と なりうる報告があり ${ }^{15)}$ ，フロセミド反応性に基づい た介入研究が行われることが望まれる。

\section{文 献}

1) Karajala V, Mansour W, Kellum JA: Diuretics in acute kidney injury. Minerva Anestesiol. 2009; 75: 251-7.

2) Ludens JH, Hook JB, Brody MJ, et al: Enhancement of renal blood flow by furosemide. J Pharmacol Exp Ther. 1968; 163 : 456-60.

3) Ludens JH, Williamson HE: Effect of furosemide on renal blood flow in the conscious dog. Proc Soc Exp Biol Med. 1970; 133: 513-5.

4) Ho KM, Power BM: Benefits and risks of furosemide in acute kidney injury. Anaesthesia. 2010; 65: 283-93.

5) Cantarovich F, Fernandez JC, Locatelli A, et al: Frusemide in high doses in the treatment of acute renal failure. Postgrad Med J. 1971; 47: 13-7.

6) Kleinknecht D, Ganeval D, Gonzalez Duque LA, et al Furosemide in acute oliguric renal failure; a controlled trial. Nephron. 1976; 17: 51-8.

7) Shilliday IR, Quinn KJ, Allison ME: Loop diuretics in the management of acute renal failure: A prospective, double-blind, placebo-controlled, randomized study. Nephrol Dial Transplant. 1997; 12: 2592-6.

8) Cantarovich F, Rangoonwala B, Lorenz H, et al: High-dose furosemide for established ARF: A prospective, randomized, double-blind, placebo-controlled, multicenter trial. Am J Kidney Dis. 2004; 44: 402-9.
9) van der Voort PH, Boerma EC, Koopmans M, et al: Furosemide does not improve renal recovery after hemofiltration for acute renal failure in critically ill patients: a double blind randomized controlled trial. Crit Care Med. 2009; 37: 533-8.

10) Bagshaw SM, Gibney RTN, Kruger P, et al: The effect of low-dose furosemide in critically ill patients with early acute kidney injury: a pilot randomized blinded controlled trial (the SPARK study). J Crit Care. 2017; 42: 138-46.

11) Rhodes A, Evans LE, Alhazzani W, et al: Surviving Sepsis Campaign: International Guidelines for Management of Sepsis and Septic Shock: 2016. Intensive Care Med. 2017; 43: 304-77.

12）寺田典生, 井関邦敏, 湯澤由紀夫, 他: AKI（急性腎障害）診 療ガイドライン 2016. 日腎会誌. 2017; 59: 419-533.

13) KDIGO AKI Working Group: KDIGO clinical practice guideline for acute kidney injury. Kidney Int Suppl. 2012; 2: 1-138.

14) National Institute for Health and Care Excellence (UK): National Institute for Health and Care Excellence: Clinical Guidelines. Acute Kidney Injury: Prevention, Detection and Management. 2019

15) Chen JJ, Chang CH, Huang YT, et al: Furosemode stress test as a predictive marker of acute kidney injury progression or renal replacement therapy: a systemic review and meta-analysis. Crit Care. 2020; 24: 202. 
CQ11-2 : 敗血症性 AKI の予防 ·治療目的に心房 性ナトリウム利尿ペプチド（ANP）の投与は行 うか?（保険適用外使用）

Answer : 敗血症性 AKI に対して予防あるいは治療を 目的として，心房性ナトリウム利尿ペプチド（ANP） を投与しないことを弱く推奨する（GRADE 2D : エビ デンスの確実性 $=$ 「非常に低」)。

\section{（1）背景および本 CQ の重要度}

ANP は，尿細管でのナトリウム再吸収を抑制し， 輸入細動脈の拡張および輸出細動脈の収縮を促すこと で, 系球体濾過量を増加させることから, AKIに対し て保護的に作用する可能性がこれまでの基礎実験から 示唆されている 1-3)。加えて, 本邦では同薬は急性心 不全に対する治療薬として承認されているという背景 があり, 主に心臓血管外科術後 AKI の予防や治療に おいて検討されてきた4)。しかしながら，敗血症性 AKI に対する効果については明らかにはされていな い。敗血症性 AKI の高い死亡率を考慮すれば，本薬 剂による敗血症性 AKI の治療効果が認められれば, 患者予後を改善する可能性があり, 重要な臨床課題と 考えられる5)。

\section{(2) PICO}

(1) 敗血症性 AKI の予防

$\mathrm{P}$ (患者) : 成人の感染症, 敗血症あるいは敗血症性 ショック患者および重症疾患患者

I（介入）：ANP の投与

$\mathrm{C}$ (対照) : プラセボまたは標準的治療, 治療なし

$\mathrm{O}$ (アウトカム) : 死亡, 腎代替療法 (renal replacement therapy: RRT）施行, AKI の発症, 合併症（低血圧） 発生

(2) 敗血症性 AKI の治療

P (患者)：成人の敗血症性 AKI 患者および重症疾 患による AKI 患者

I（介入）：ANP の投与

C (対照) : プラセボまたは標準的治療, 治療なし

$\mathrm{O}$ (アウトカム) : 死亡, RRT 施行, ICU 滞在日数, 腎機能の回復, 合併症（低血圧）発生

\section{（3）エビデンスの要約}

システマティックレビューの結果, 敗血症性 AKI の予防目的の PICOに合致したランダム化比較試験 （RCT）は抽出されなかった。治療目的のPICOに合
致した RCT が 3 件 6-8) 施行されており，これらを用 いたメタ解析を実施した。

\section{（4）益と害のバランス（Table 11-2-1）}

望ましい効果 :

RRT の導入（3 RCT: $\mathrm{n}=779 ）$ の効果推定值は, 1,000 人あたり 58 人少ない $(95 \% \mathrm{CI}: 157$ 人少ない〜 73 人多い）であった。望ましい効果はわずかと考え られる。

望ましくない効果 :

死亡アウトカム（3 RCT: $\mathrm{n}=779 ）$ の効果推定值は, 1,000 人あたり 18 人多い $(95 \% \mathrm{CI}: 57$ 人少ない〜 110 人多い）であった。望ましくない効果はわずかと考え られる。

益と害のバランス :

望ましい効果が「わずか」である一方で，望ましく ない効果も「わずか」であり，標準的治療として同薬 を投与することは，明らかに有益であるとはいえな い。重大なアウトカムに設定した低血圧の有害事象が 起こらない症例では, 同薬の投与が有益性をもたらす 可能性はあるが，重症敗血症では血圧が低下すること が多く，その有益性は限定的と考えられる。

\section{（5）アウトカム全般に関するエビデンスの確実性}

今回検討されたアウトカムでは，本薬剤投与による 望ましい効果, 望ましくない効果の方向性は一致して おらず，一番低いアウトカムの確実性を全体として採 用した。アウトカム全体におけるエビデンスの確実性 は「非常に低」である。

\section{（6）価値観}

各アウトカムに対する患者・家族の価值観に関する データはない。一般的に, 死亡や腎代替療法の導入に 対して置く相対的価值は高く, そのばらつきは少ない ことが予想される。

\section{（7）容認性}

体重 $50 \mathrm{~kg}$ の患者に対して $0.1 \mu \mathrm{g} / \mathrm{kg} / \mathrm{min}$ で投与され た場合, 介入に伴う 1 日あたりのコストは，14,544 円 (1,888 円/バイアル $\times 8$ バイアル $)$ である。個人負担 額を考えると, 患者・家族の個人の視点からは許容範 囲内と考えられる。投与に際しては精密投与が必要か つ, 配合禁忌の多い薬剤であり, 医療従事者の負荷に はなりうる。 
Table 11-2-1エビデンスプロファイル

\begin{tabular}{|c|c|c|c|c|c|c|c|c|c|c|c|c|}
\hline \multicolumn{7}{|c|}{ 確実性の評価 } & \multicolumn{2}{|c|}{ 患者数 } & \multicolumn{2}{|c|}{ 効果 } & \multirow[b]{2}{*}{ 確夷性 } & \multirow[b]{2}{*}{ 重要性 } \\
\hline 研究数 & $\begin{array}{c}\text { 研究 } \\
\text { デザイ }\end{array}$ & $\begin{array}{l}\text { パイアス } \\
\text { のリスク }\end{array}$ & 非一貫性 & 非直接性 & 不精碓性 & $\begin{array}{l}\text { その他 } \\
\text { の湌尉 }\end{array}$ & ANP & $\begin{array}{l}\text { コントロー } \\
\text { ル }\end{array}$ & $\begin{array}{l}\text { 相対指標 } \\
(95 \% \text { GI) }\end{array}$ & $\begin{array}{l}\text { 䋓対指䱜 } \\
(95 \% \text { GI) }\end{array}$ & & \\
\hline \multicolumn{13}{|l|}{ 死亡 } \\
\hline 3 & RCT & 深刻でない & $\begin{array}{c}\text { 深刻てな } \\
\text { い }\end{array}$ & 深刻 a & 深刻 b & なし & $\begin{array}{l}143 / 386 \\
(37.0 \%)\end{array}$ & $\begin{array}{l}139 / 393 \\
(35.46)\end{array}$ & $\begin{array}{c}\text { RR } 1.05 \\
\text { (0.84 to } 1.31)\end{array}$ & $\begin{array}{l}1,000 \text { 人あたり } 18 \\
\text { 人多い } \\
(57 \text { 人少ない } 110 \\
\text { 人多い) }\end{array}$ & $\underset{\text { 低 }}{\oplus \oplus \bigcirc}$ & 重大 \\
\hline \multicolumn{13}{|c|}{ 罗代替癔法 } \\
\hline 3 & RCT & 深刻てない & 深刻。 & 深刻 a & 深刻 b & なし & $\begin{array}{l}188 / 386 \\
(48.7 \%)\end{array}$ & $\begin{array}{l}206 / 393 \\
(52.4 \%)\end{array}$ & $\begin{array}{c}\text { RR } 0.89 \\
\text { (0.70 to } 1.14)\end{array}$ & $\begin{array}{l}\text { 1, 000 人あたりり } 58 \\
\text { 人少ない } \\
\text { (157 人少ない } 73 \\
\text { 人多い) }\end{array}$ & $\begin{array}{l}\oplus \bigcirc \bigcirc \bigcirc \\
\text { 非常に低 }\end{array}$ & 重大 \\
\hline \multicolumn{13}{|c|}{ 哃機能の回復 } \\
\hline 2 & RCT & 深刻でない & 深刻。 & 深刻 a & 深刻 b & なし & $\begin{array}{l}130 / 357 \\
(36.4 \%)\end{array}$ & $\begin{array}{l}138 / 371 \\
(37.2 \%)\end{array}$ & $\begin{array}{c}\text { RR } 1.05 \\
(0.70 \text { to } 1.59)\end{array}$ & $\begin{array}{c}\text { 1, 000人あたり } 19 \\
\text { 人多い } \\
\text { (112 人少ない } \\
\text { 219人多い) }\end{array}$ & $\begin{array}{l}\oplus \bigcirc 0 \bigcirc \\
\text { 非常に低 }\end{array}$ & 重要 \\
\hline \multicolumn{13}{|l|}{ 低血圧 } \\
\hline 3 & RCT & 深刻でない & 深刻。 & 深刻。 & $\begin{array}{l}\text { 深刻てな } \\
\text { い }\end{array}$ & なし & $\begin{array}{l}217 / 386 \\
(56.2 \%)\end{array}$ & $\begin{array}{l}109 / 393 \\
(27.76)\end{array}$ & $\begin{array}{c}\text { RR } 2.06 \\
\text { (1. } 37 \text { to } 3.09 \text { ) }\end{array}$ & $\begin{array}{c}1,000 \text { 人あたり } 294 \\
\text { 人多い } \\
\text { (103 人多い } 580 \text { 人 } \\
\text { 多い) }\end{array}$ & $\underset{\text { 低 }}{\oplus \oplus \bigcirc \bigcirc}$ & 重要 \\
\hline
\end{tabular}

a. 敗血症性AKIに限定した研究は抽出できなかった。

b. 95\% CI が 1.0 をまたいでいる。

c. 非一貫性が高い $\left(I^{2}>50 \%\right) 。$

Table 11-2-2 判断の要約

\begin{tabular}{|c|c|c|c|c|c|c|c|}
\hline & \multicolumn{7}{|c|}{ 判淇 } \\
\hline 問題 & いいえ & $\begin{array}{c}\text { おそらく、いい } \\
\text { え }\end{array}$ & おそらく、はい & はい & & さまざま & 分からない \\
\hline 望ましい勃果 & わずか & 小さい & 中 & 大きい & & さまざま & 分からない \\
\hline 望ましくない効果 & 大きい & 中 & 小さい & わずか & & さまざま & 分からない \\
\hline エビデンスの確実性 & 非常に低 & 低 & 中 & 高 & & & 採用研究なし \\
\hline 価值钼 & $\begin{array}{c}\text { 重要な不確実性 } \\
\text { またはばらつき } \\
\text { あり }\end{array}$ & $\begin{array}{l}\text { 重要な不確実性 } \\
\text { またはばらつき } \\
\text { の可能性あり }\end{array}$ & $\begin{array}{l}\text { 重要な不確実性 } \\
\text { またはばらつき } \\
\text { はおそらくなし }\end{array}$ & $\begin{array}{c}\text { 重要な不確実性 } \\
\text { またはばらつき } \\
\text { はなし }\end{array}$ & & & \\
\hline 効果のバランス & 比較が優位 & $\begin{array}{c}\text { 比較がおそらく } \\
\text { 優位 }\end{array}$ & $\begin{array}{c}\text { 介入も比較もい } \\
\text { ずれも優位でな } \\
\text { い }\end{array}$ & $\begin{array}{c}\text { おそらく介入が } \\
\text { 優位 }\end{array}$ & 介入が優位 & さまざま & 分からない \\
\hline 容認性 & いいえ & $\begin{array}{c}\text { おそらく、いい } \\
\text { え }\end{array}$ & おそらく、はい & はい & & さまざま & 分からない \\
\hline 実行可能性 & いいえ & $\begin{array}{c}\text { おそらく、いい } \\
\text { え }\end{array}$ & おそらく、はい & はい & & さまざま & 分からない \\
\hline
\end{tabular}

（8）実行可能性

本薬剤は，急性心不全に対する治療薬としては保険 収載されているが，腎障害に対する薬剤としては承認 されていない。腎障害の予防もしくは治療を目的とし て同薬を投与することは，適応外使用である。

(9) 判断の要約 (Table 11-2-2)

（10）推奨グレーディング決定の工程

修正 RAND 法を用いた投票によって，中央值 7,
見解不一致指数 0.178 の結果となり，委員会で採択さ れた（7 点以上 : $87.5 \%) 。$

（11）関連する他の診療ガイドラインにおける推奨

SSCG 2016 では，本 CQについては特に言及されて いない9）。本邦から出版された AKI（急性腎障害）診 療ガイドライン 2016 では, AKIの予防および治療目 的に低用量 ANP を投与することは, エビデンスレベ ルの低さから推奨されていない（推奨の強さなし, エビデンスの強さ D) 10)。また諸外国の AKI ガイドラ 
インでも，AKIの予防および治療目的に同薬を投与 しないことが推奨されている（推奨の強さ 2 , エビデ ンスの強さ B) ${ }^{11)}$ 。

\section{（12）実施に関わる検討事項}

本薬剤の投与にあたっては，血圧低下のリスクを十 分に評価したうえで投与を検討することが望まれる。

\section{（13）今後の研究の可能性}

敗血症性 AKI のみに限定した検討，また低用量（ミ $0.05 \mu \mathrm{g} / \mathrm{kg} / \mathrm{min}$ ）に限定した検討が期待される。

\section{文 献}

1) Potter LR, Abbey-Hosch S, Dickey DM: Natriuretic peptides, their receptors, and cyclic guanosine monophosphate-dependent signaling functions. Endocr Rev. 2006; 27: 47-72.

2) Kuwahara K, Nakao K: Regulation and significance of atrial and brain natriuretic peptides as cardiac hormones. Endocr J. 2010; 57: 555-65.

3) Marin-Grez M, Fleming JT, Steinhausen M: Atrial natriuretic peptide causes pre-glomerular vasodilatation and post-glomerular vasoconstriction in rat kidney. Nature. 1986; 324: 473-6.

4) Yamada H, Doi $K$, Tsukamoto $T$, et al: Low-dose atrial natriuretic peptide for prevention or treatment of acute kidney injury: a systematic review and meta-analysis. Crit Care. 2019; $23: 41$.

5) Alobaidi R, Basu RK, Goldstein SL, et al: Sepsis-associated acute kidney injury. Semin Nephrol. 2015; 35: 2-11.

6) Rahman SN, Kim GE, Mathew AS, et al: Effects of atrial natriuretic peptide in clinical acute renal failure. Kidney Int. 1994; 45: 1731-8.

7) Allgren RL, Marbury TC, Rahman SN, et al: Anaritide in acute tubular necrosis. Auriculin Anaritide Acute Renal Failure Study Group. N Engl J Med. 1997; 336: 828-34.

8) Lewis J, Salem MM, Chertow GM, et al: Atrial natriuretic factor in oliguric acute renal failure. Anaritide Acute Renal Failure Study Group. Am J Kidney Dis. 2000; 36: 767-74.

9) Rhodes A, Evans LE, Alhazzani W, et al: Surviving Sepsis Campaign: International Guidelines for Management of Sepsis and Septic Shock: 2016. Intensive Care Med. 2017; 43: 304-77.

10）寺田典生, 井関邦敏, 湯澤由紀夫, 他: AKI（急性腎障害）診 療ガイドライン 2016. 日腎会誌. 2017; 59: 419-533.

11) KDIGO AKI Working Group: KDIGO clinical practice guideline for acute kidney injury. Kidney Int Suppl. 2012; 2: 1-138.
CQ11-3：敗血症性 AKI の予防・治療目的にドパ ミンの投与は行うか?

Answer : 敗血症性 AKI に対して予防あるいは治療を 目的として，ドパミンを投与しないことを弱く推奨す る（GRADE 2C : エビデンスの確実性 $=$ 「低」）。

\section{（1）背景および本 CQ の重要度}

ドパミンは健常人に対して $1 \sim 3 \mu \mathrm{g} / \mathrm{kg} / \mathrm{min}$ の低用量 で投与すると, 腎血管拡張, 糸球体濾過量増加, ナト リウム利尿作用が得られることにより, 腎保護性の昇 圧薬として使用されてきたが，2000 年代に報告され たランダム化比較試験（RCT）を中心にその有益性は すでに否定されている1-3)。しかしながら, “renal dose” という呼称のもと長く使用されてきた歴史的経 緯から, 引き続き本 $\mathrm{CQ}$ を重要臨床課題として取り上 げた。

\section{(2) PICO}

(1) 敗血症性 AKI の予防

$\mathrm{P}$ (患者) : 成人の感染症, 敗血症あるいは敗血症性 ショック患者および重症疾患患者

I (介入) : ドパミンの投与

$\mathrm{C}$ (対照)：プラセボ投与または標準的治療，治療な U

$\mathrm{O}$ (アウトカム) : 死亡, 腎代替療法 (renal replacement therapy: RRT) 施行, AKI の発症, 合併症（不整脈） 発生

(2) 敗血症性 AKI の治療

P (患者) : 成人の敗血症性 AKI 患者および重症疾 患による AKI 患者

I（介入）: ドパミンの投与

$\mathrm{C}$ (対照)：プラセボ投与または標準的治療, 治療な U

$\mathrm{O}$ (アウトカム ) : 死亡, RRT 施行, AKI からの回 復, 合併症 (不整脈) 発生

（3）エビデンスの要約

システマティックレビューの結果, 敗血症性 AKI

の予防目的の PICO に合致した RCT は抽出されなかっ た。治療目的の PICO に合致した RCT が 1 件 4 ）施行 されていた。 
Table 11-3-1エビデンスプロファイル

\begin{tabular}{|c|c|c|c|c|c|c|c|c|c|c|c|c|}
\hline \multicolumn{7}{|c|}{ 確実性の評価 } & \multicolumn{2}{|c|}{ 患者数 } & \multicolumn{2}{|c|}{ 勃果 } & \multirow{2}{*}{ 確実性 } & \multirow{2}{*}{ 重要性 } \\
\hline 研究数 & $\begin{array}{c}\text { 研究 } \\
\text { デザイン }\end{array}$ & $\begin{array}{c}\text { パイアスの } \\
\text { リスク }\end{array}$ & 非一貫性 & 非直接性 & 不精確性 & $\begin{array}{l}\text { その他 } \\
\text { の検討 }\end{array}$ & ドパミン & コントロール & $\begin{array}{l}\text { 相対指樰 } \\
(95 \% \text { CI) }\end{array}$ & $\begin{array}{l}\text { 絶対指穓 } \\
(95 \% \text { CI) }\end{array}$ & & \\
\hline \multicolumn{13}{|c|}{ 死亡 (院内死亡) } \\
\hline 1 & RCT & 深刻でない & 深刻でない & 深刻でない & 深刻 a & なし & $69 / 161 \quad(42.9 \%)$ & $66 / 163(40.5 \%)$ & $\begin{array}{c}\text { RR } 1.06 \\
(0.82 \text { to } 1.37)\end{array}$ & $\begin{array}{c}1,000 \text { 人あたり } 24 \\
\text { 人多い } \\
(73 \text { 人少ない 150 } \\
\text { 人多い) }\end{array}$ & $\begin{array}{c}\oplus \oplus \oplus \bigcirc \\
\text { 中 }\end{array}$ & 重大 \\
\hline \multicolumn{13}{|c|}{ 死亡（ICU 死亡） } \\
\hline 1 & RCT & 深刻でない & 深刻でない & 深刻でない & 深刻 a & なし & $53 / 161 \quad(32.9 \%)$ & $58 / 163(35.6 \%)$ & $\begin{array}{c}\mathrm{RR} 0.93 \\
(0.68 \text { to } 1.25)\end{array}$ & $\begin{array}{c}1,000 \text { 人あたり } 25 \\
\text { 人少ない } \\
(114 \text { 人少ない 89 } \\
\text { 人多い) }\end{array}$ & $\begin{array}{c}\oplus \oplus \oplus \bigcirc \\
\text { 中 }\end{array}$ & 重大 \\
\hline \multicolumn{13}{|l|}{ RRT } \\
\hline 1 & RCT & 深刻でない & 深刻でない & 深刻でない & 非常に深刻 & なし & $35 / 161 \quad(21.7 \%)$ & $40 / 163(24.5 \%)$ & $\begin{array}{c}\text { RR } 0.89 \\
(0.60 \text { to } 1.32)\end{array}$ & $\begin{array}{c}1,000 \text { 人あたり } 27 \\
\text { 人少ない } \\
(98 \text { 人少ない 79 } \\
\text { 人多い })\end{array}$ & $\begin{array}{c}\oplus \oplus \bigcirc \bigcirc \\
\text { 低 }\end{array}$ & 重大 \\
\hline \multicolumn{13}{|c|}{ AKI の発生／AKI からの回復 - 未測定 } \\
\hline- & - & - & - & - & - & - & - & - & - & - & - & \\
\hline \multicolumn{13}{|c|}{ 合併症（不整脈） } \\
\hline 1 & RCT & 深刻でない & 深刻でない & 深刻でない & 非常に深刻 & なし & $53 / 161 \quad(32.9 \%)$ & $54 / 163(33.1 \%)$ & $\begin{array}{c}\text { RR } 0.99 \\
(0.73 \text { to } 1.35)\end{array}$ & $\begin{array}{c}1,000 \text { 人あたり } 3 \\
\text { 人少ない } \\
(89 \text { 人少ない 116 } \\
\text { 人多い) }\end{array}$ & $\begin{array}{c}\oplus \oplus \bigcirc \bigcirc \\
\text { 低 }\end{array}$ & 重要 \\
\hline
\end{tabular}

a. 95\%信頼区間が 1.0 をまたいでいる, かつ信頼区間が広い。

b. 95\%信頼区間が 1.0 をまたいでいる，かつ 0.75 と 1.25 の両方の䦣値を含む。

（4）益と害のバランス（Table 11-3-1）

望ましい効果 :

集中治療室退室時の死亡に対する効果推定值は, 1,000 人あたり 25 人少ない $(95 \% \mathrm{CI}: 114$ 人少ない〜 89 人多い) であった。また，RRTへの移行では, 1,000 人あたり 27 人少ない $(95 \% \mathrm{CI}: 98$ 人少ない〜 79 人多い）であり，ドパミンの望ましい効果はわずかと 考えられる。

望ましくない効果 :

院内死亡に対する効果推定值は，1,000 人あたり 24 人少ない $(95 \% \mathrm{CI}: 73$ 人少ない〜 150 人多い) であっ た。望ましくない効果はわずかと考えられる。

益と害のバランス :

望ましい効果が「わずか」である一方，望ましくな い効果も「わずか」と評価された。重大なアウトカム として院内死亡と ICU 死亡の 2 つを採用したが，方 向性が異なる結果であった。以上から，標準的治療と して同薬を投与することは，明らかに有益であるとは いえないと考えられた。

\section{（5）アウトカム全般に関するエビデンスの確実性}

望ましい効果と望ましくない効果の方向性が一致し ておらず，全体的なエビデンスの確実性は「低」とし た。ただし，1つの RCT に基づく推奨であることを
強調する必要がある。

\section{（6）価值観}

患者および家族の価値観に関するデータはなく，死 亡という重大なアウトカムにおいては個々人の価值観 のばらつきは小さいと考えられる。

\section{（7）容認性}

ドパミンのコストは安価であり，患者・家族の視点 からは容認できる範囲であると思われる。

（8）実行可能性

ドパミン投与において，実行は容易である。

（9）判断の要約（Table 11-3-2）

（10）推奨グレーディング決定の工程

修正 RAND 法を用いた投票によって，中央值 7, 見解不一致指数 0.164 の結果となり，委員会で採択さ れた（7 点以上 : 91.7\%)。

（11）関連する他の診療ガイドラインにおける推奨

SSCG 2016 では，腎保護目的に低用量ドパミンを投 与しないことを強く推奨されている（推奨の強さ強, 
Table 11-3-2 判断の要約

\begin{tabular}{|c|c|c|c|c|c|c|c|}
\hline & \multicolumn{7}{|c|}{ 判溇 } \\
\hline 問題 & いいえ & $\begin{array}{c}\text { おそらく、いい } \\
\text { え }\end{array}$ & おそらく、はい & はい & & さまざま & 分からない \\
\hline 望ましい勃果 & わずか & 小さい & 中 & 大きい & & さまざま & 分からない \\
\hline 望ましくない勃果 & 大きい & 中 & 小さい & わずか & & さまざま & 分からない \\
\hline エビデンスの確実性 & 非常に低 & 低 & 中 & 高 & & & 採用研究なし \\
\hline 価值覞 & $\begin{array}{c}\text { 重要な不確実性 } \\
\text { またはばらつき } \\
\text { あり }\end{array}$ & $\begin{array}{l}\text { 重要な不確実性 } \\
\text { またはばらつき } \\
\text { の可能性ありり }\end{array}$ & $\begin{array}{l}\text { 重要な不確実性 } \\
\text { またはばらつき } \\
\text { はおそらくなし }\end{array}$ & $\begin{array}{c}\text { 重要な不確実性 } \\
\text { またはばらつき } \\
\text { はなし }\end{array}$ & & & \\
\hline 効果のバランス & 比較が優位 & $\begin{array}{c}\text { 比較がおそらく } \\
\text { 優位 }\end{array}$ & $\begin{array}{c}\text { 介入も比較もい } \\
\text { ずれも優位でな } \\
\text { い }\end{array}$ & $\begin{array}{c}\text { おそらく介入が } \\
\text { 優位 }\end{array}$ & 介入が優位 & さまざま & 分からない \\
\hline 容認性 & いいえ & $\begin{array}{c}\text { おそらく、いい } \\
\text { え }\end{array}$ & おそらく、はい & はい & & さまざま & 分からない \\
\hline 実行可能性 & いいえ & 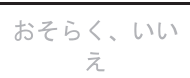 & おそらく、はい & はい & & さまざま & 分からない \\
\hline
\end{tabular}

エビデンスの強さ高) 5)。本邦から出版された AKI （急性腎障害）診療ガイドライン 2016 および諸外国の AKI ガイドラインでも，AKIの予防および治療目的 に同薬を投与しないことが推奨されている［AKI（急 性腎障害）診療ガイドライン: 推奨の強さ 1 , エビデ ンスの強さ $\mathrm{A}]$ （KDIGO : 推奨の強さ 1 , エビデンス

の強さA）6-8)。

（12）実施に関わる検討事項

なし。

（13）今後の研究の可能性

敗血症性 AKI のみに限定した RCT の実施が期待さ れる。

\section{文 献}

1) Denton MD, Chertow GM, Brady HR: "Renal-dose" dopamine for the treatment of acute renal failure: scientific rationale, experimental studies and clinical trials. Kidney Int. 1996; 50: 4-14.

2) Keir I, Kellum JA: Acute kidney injury in severe sepsis: pathophysiology, diagnosis, and treatment recommendations. J Vet Emerg Crit Care (San Antonio). 2015; 25: 200-9.

3) Friedrich JO, Adhikari N, Herridge MS, et al: Meta-analysis: low-dose dopamine increases urine output but does not prevent renal dysfunction or death. Ann Intern Med. 2005; 142: 510.

4) Bellomo R, Chapman M, Finfer S, et al: Low-dose dopamine in patients with early renal dysfunction: a placebo-controlled randomised trial. Australian and New Zealand Intensive Care Society (ANZICS) Clinical Trials Group. Lancet. 2000; 356: 2139-43.

5) Rhodes A, Evans LE, Alhazzani W, et al: Surviving Sepsis Campaign: International Guidelines for Management of Sepsis and Septic Shock: Intensive Care Med. 2017; 43: 304-77.

6）寺田典生, 井関邦敏, 湯澤由紀夫, 他: AKI（急性腎障害）診
療ガイドライン 2016. 日腎会誌. 2017; 59: 419-533.

7) KDIGO AKI Working Group: KDIGO clinical practice guideline for acute kidney injury. Kidney Int Suppl. 2012; 2: 1-138.

8) National Institute for Health and Care Excellence (UK): National Institute for Health and Care Excellence: Clinical Guidelines. Acute Kidney Injury: Prevention, Detection and Management. 2019 
CQ11-4：敗血症性 AKI に対する腎代替療法では 持続的治療を行うか?

Answer：敗血症性 AKI に対する腎代替療法は，持続 的治療・間欠的治療のどちらを選択しても構わない （GRADE 2C：エビデンスの確実性 =「低」）。ただし， 循環動態が不安定な症例については持続的治療を選択 する (Good Practice Statement)。

\section{（1）背景および本 $C Q$ の重要度}

敗血症性 AKI が高度に進展した場合，院内死亡率 は50\%にまで及ぶとされ，生命維持のためには腎代 替療法（renal replacement therapy: RRT）は必要不可欠 な治療方法である。治療時間に関する分類として持続 的あるいは間欠的な RRT があるが，どちらを敗血症 性 AKIに対して用いるのかは，病態のみならず治療 施設における経験や診療体制にも依存するため，施設 や症例において個別的な判断がなされており，その臨 床判断の振れ幅は大きいと思われる。一方，循環が不 安定な状態においては持続的な RRT が選択される傾 向にあることが観察研究で報告されている1)。した がって, この問題の優先度は高く, 臨床的に重要な選 択でもあるため, CQ として取り上げた。

\section{(2) PICO}

P (患者)：成人の敗血症性 AKI 患者および重症疾 患による AKI 患者
I（介入）：持続的腎代替療法（continuous renal replacement therapy: CRRT)

C (対照)：間欠的腎代替療法（intermittent renal replacement therapy: IRRT)

$\mathrm{O}$ (アウトカム) : 死亡, 透析依存, 両者の複合アウ トカム，合併症発生

\section{（3）エビデンスの要約}

システマティックレビューの結果，PICO に合致し たランダム化比較試験（RCT）が 5 件 2-6) 施行されて おり，これらを用いたメタ解析を実施した。なお， RCT 割り付け後の重症度（APACHE II および III スコ 了, 肝不全有無, 不全臟器数) に有意差を認めた RCT が1つあった2)。この RCT を含めた 5 RCT にお けるエビデンスの確実性は「非常に低」であり，この RCT を除いた 4 RCT におけるエビデンスの確実性は 「低」であったため，今回は $4 \mathrm{RCT}$ による解析結果を 用いた。

\section{（4）益と害のバランス（Table 11-4-1）}

\section{望ましい効果：}

死亡アウトカムの効果推定值 $(4 \mathrm{RCT}, \mathrm{n}=838)$ は 1,000 人あたり 6 人少ない $(95 \%$ CI: 69 人少ない〜 63 人多い)，透析依存アウトカム $(2 \mathrm{RCT}, \mathrm{n}=201)$ は 1,000 人あたり 28 人少ない $(95 \%$ CI: 61 人少ない〜 68 人多い)，透析依存と死亡の複合アウトカム（1 $\mathrm{RCT}, \mathrm{n}=125 ）$ は 1,000 人あたり 42 人少ない（95\%

Table 11-4-1エビデンスプロファイル

\begin{tabular}{|c|c|c|c|c|c|c|c|c|c|c|c|c|}
\hline \multicolumn{7}{|c|}{ 確実性の評価 } & \multicolumn{2}{|c|}{ 患者数 } & \multicolumn{2}{|c|}{ 勃果 } & \multirow[b]{2}{*}{ 確実性 } & \multirow[b]{2}{*}{ 重要性 } \\
\hline 研究数 & $\begin{array}{c}\text { 研究 } \\
\text { デザイン }\end{array}$ & $\begin{array}{l}\text { パイアス } \\
\text { のリスク }\end{array}$ & 非一其性 & 非直接性 & 不精確性 & $\begin{array}{l}\text { その他 } \\
\text { の検討 }\end{array}$ & CRRT & IRRT & $\begin{array}{l}\text { 相対指標 } \\
(95 \% \text { CI) }\end{array}$ & $\begin{array}{l}\text { 絶対指標 } \\
(95 \% \text { CI }\end{array}$ & & \\
\hline \multicolumn{13}{|l|}{ 死亡 } \\
\hline 4 & RCT & 深刻 a & 深刻でない & 深刻 b & 深刻でない & なし & $\begin{array}{c}256 / 419 \\
(61.1 \%)\end{array}$ & $\begin{array}{c}262 / 419 \\
(62.5 \%)\end{array}$ & $\begin{array}{l}\text { RR } 0.99 \\
(0.89 \text { to } \\
1.10)\end{array}$ & $\begin{array}{c}1.000 \text { 人あたり } \\
6 \text { 人少ない } \\
\text { (69人少ない } \\
63 \text { 人多い) }\end{array}$ & $\underset{\text { 低 }}{\oplus \oplus \bigcirc \bigcirc}$ & 重大 \\
\hline \multicolumn{13}{|l|}{ 透析依存 } \\
\hline 2 & RCT & 深刻。 & 深刻でない & 深刻 b & 非常に深刻 d & なし & $5 / 98(5.1 \%)$ & $8 / 103(7.8 \%)$ & $\begin{array}{l}\text { RR } 0.64 \\
(0.22 \text { to } \\
1.87)\end{array}$ & $\begin{array}{c}1,000 \text { 人あたり } \\
28 \text { 人少ない } \\
\text { (61 人少ない } \\
68 \text { 人多い) }\end{array}$ & $\begin{array}{l}\oplus \bigcirc \bigcirc \bigcirc \\
\text { 非常に低 }\end{array}$ & 重大 \\
\hline \multicolumn{13}{|c|}{ 透析依存と死亡（複合アウトカム） } \\
\hline 1 & RCT & 深刻。 & 深刻でない & 深刻 b & 非常に深刻。 & なし & $\begin{array}{c}34 / 70 \\
(48.6 \%)\end{array}$ & $\begin{array}{c}29 / 55 \\
(52.7 \%)\end{array}$ & $\begin{array}{c}\text { RR } 0.92 \\
(0.65 \text { to } \\
1.30)\end{array}$ & $\begin{array}{c}1.000 \text { 人あたり } \\
42 \text { 人少ない } \\
\text { (185 人少ない } \\
\sim 158 \text { 人多い) }\end{array}$ & $\begin{array}{l}\oplus \bigcirc \bigcirc \bigcirc \\
\text { 非常に低 }\end{array}$ & 重大 \\
\hline \multicolumn{13}{|c|}{ 合併症（出血） } \\
\hline 2 & RCT & 深刻。 & 深刻でない & 深刻 b & 非常に深刻 d & なし & $\begin{array}{l}16 / 297 \\
(5.4 \%)\end{array}$ & $\begin{array}{l}18 / 312 \\
(5.8 \%)\end{array}$ & $\begin{array}{l}\text { RR } 0.94 \\
(0.49 \text { to } \\
1.80)\end{array}$ & $\begin{array}{l}\text { 1. } 000 \text { 人あたり } \\
3 \text { 人少ない) } \\
\text { (29人少ない } \\
\sim 46 \text { 人多い) }\end{array}$ & $\begin{array}{l}\oplus \bigcirc \bigcirc \bigcirc \\
\text { 非常に低 }\end{array}$ & 重要 \\
\hline
\end{tabular}

a. 効果量の大きい研究において，介入のプロトコルでアウトカムに影響を及ぼしうるデザイン上の問題点がある。

b. 非敗血症 AKI を含む。

研究の寄与率が高い

0.75 と 1.25 の両方の決断の閾値を含み, 最適情報量も満たさない

e. 最適情報量を満たすが， $95 \%$ CI を満たさない。 
CI： 185 人少ない〜 158 人多い）であった。また，出 血合併症（2 RCT, $\mathrm{n}=609 ）$ は 1,000 人あたり 3 人少 ない $(95 \% \mathrm{CI}: 29$ 人少ない〜46人多い) であった。 したがって, CRRTによる望ましい効果はわずかであ ると判断した。

望ましくない効果 :

今回検討したアウトカムでは, 望ましくない効果は 認められず，明らかな望ましくない効果があるかは不 明である。

益と害のバランス :

望ましい効果が「わずか」であり，望ましくない効 果が「分からない」であった。したがって，効果のバ ランスは介入対象がおそらく優位と判断した。

\section{（5）アウトカム全般に関するエビデンスの確実性}

すべてのアウトカムにおいて CRRT の効果はわず かであると判断でき, 相反するものはなかったため, 全体的なエビデンスの確実性は「低」と判断した。

\section{（6）価值観}

患者および家族の価值観に関するデータはなく，死 亡という重大なアウトカムにおいては個々人の価值観 のばらつきは小さいと考えられる。

\section{（7）容認性}

本邦の保険診療において, CRRT とIRRT はともに 承認された治療であり, 患者・家族の視点からは容認 できる範囲であると思われる。一方で, CRRTという 介入の費用負担は IRRT と比較すると高いと考えられ, 回路凝固などの管理面で医療従事者の負担増大となり
うる。抗凝固薬の調整などで対応可能ではあるが, CRRT 施行に際しては医療スタッフの業務負荷が IRRT よりも増加することは明らかであり，望ましい効果が 乏しい場合には，施行は容認しがたいものとなりうる。

\section{（8）実行可能性}

本邦における急性期病院での観察研究の結果から は, 集中治療室において CRRT を行うことはほぼ可 能であると考えられる。非集中治療室環境において は, CRRT の施行は困難であると考えられる。

（9）判断の要約 (Table 11-4-2)

効果のバランスは介入対象がおそらく優位と判断し たが, アウトカム全般における確実性は「低」, 容認 性については「おそらく, いいえ」であると判断し た。以上から, CRRT と IRRT のどちらも他方よりも 勝るという結論には至らなかった。

\section{（10）推奨グレーディング決定の工程}

修正 RAND 法を用いた投票によって, 中央值 8, 見解不一致指数 0.164 の結果となり, 委員会で採択さ れた（7 点以上 : 91.7\%)。また, 循環動態が不安定な 患者を対象として, CRRT と IRRT を比較した RCT は 存在しなかったが，実際の臨床においては循環動態が 不安定な患者には CRRT が選択されることが多いた め, 委員会の判断で, このような状況においては CRRT を選択するという GPS を示すこととした。

（11）関連する他の診療ガイドラインにおける推奨 SSCG 2016 では, CRRT, IRRTのどちらを選択し

Table 11-4-2 判断の要約

\begin{tabular}{|c|c|c|c|c|c|c|c|}
\hline 問題 & いいえ & $\begin{array}{c}\text { おそらく、いい } \\
\text { え }\end{array}$ & おそらく、はい & はい & & さまざま & 分からない \\
\hline 望ましい効果 & わずか & 小さい & 中 & 大きい & & さまざま & 分からない \\
\hline 望ましくない效果 & 大きい & 中 & 小さい & わずか & & さまざま & 分からない \\
\hline エビデンスの確実性 & 非常に低 & 低 & 中 & 高 & & & 採用研究なし \\
\hline 価值钼 & $\begin{array}{c}\text { 重要な不確実性 } \\
\text { またはばらつき } \\
\text { あり }\end{array}$ & $\begin{array}{c}\text { 重要な不確実性 } \\
\text { またはばつ惨さ } \\
\text { の可能性あり }\end{array}$ & $\begin{array}{l}\text { 重要な不確実性 } \\
\text { またははつつき } \\
\text { はおそらくなし }\end{array}$ & $\begin{array}{c}\text { 重要な不確実性 } \\
\text { またははばらつき } \\
\text { はなし }\end{array}$ & & & \\
\hline 勃果のバランス & 比較が優位 & $\begin{array}{c}\text { 比較がおそらく } \\
\text { 優位 }\end{array}$ & $\begin{array}{l}\text { 介入も比較もいず } \\
\text { れも優位ではない }\end{array}$ & $\begin{array}{c}\text { おそらく介入が } \\
\text { 優位 }\end{array}$ & 介入が優位 & さまざま & 分からない \\
\hline 容認性 & いいえ & おそらく、いいえ & おそらく、はい & はい & & さまざま & 分からない \\
\hline 実行可能性 & いいえ & $\begin{array}{c}\text { おそらく、いい } \\
\text { え }\end{array}$ & おそらく、はい & はい & & さまざま & 分からない \\
\hline
\end{tabular}


てもよいが, 血行動態が不安定な患者については, CRRT を使用することを提案している（推奨の強さ 弱，エビデンスの強さ低）7）。本邦から出版された AKI（急性腎障害）診療ガイドライン 2016 および海 外の AKI ガイドラインでも, 同様に提案されている [AKI（急性腎障害）診療ガイドラインー血行動態安 定 : 推奨の強さ 2 , エビデンスの強さ $\mathrm{B}$ 。AKI（急性 腎障害）診療ガイドラインー血行動態不安定 : 推奨の 強さなし, エビデンスの強さ D。）（KDIGO : 推奨の 強さ 2 , エビデンスの強さ B $)^{8,9)}$ 。

\section{（12）実施に関わる検討事項}

循環動態が不安定な症例においては CRRT を選択 することが望ましいと考えられる。観察研究において も循環動態が不安定な症例では, CRRTが選択されて いることが報告されており，すでに標準治療となって いると思われる。

\section{（13）今後の研究の可能性}

費用対効果について検討した研究が期待される。

\section{文 献}

1) Iwagami M, Yasunaga H, Noiri E, et al: Choice of renal replacement therapy modality in intensive care units: data from a Japanese Nationwide Administrative Claim Database. J Crit Care. 2015; 30: 381-5.

2) Mehta RL, Mcdonald B, Gabbai FB, et al: A randomized clinical trial of continuous versus intermittent dialysis for acute renal failure. Kidney Int. 2001; 60: 1154-63.

3) Gasparović V, Filipović-Grcić I, Merkler M, et al: Continuous renal replacement therapy (CRRT) or intermittent hemodialysis (IHD)--what is the procedure of choice in critically ill patients? Ren Fail. 2003; 25: 855-62.

4) Uehlinger DE, Jakob SM, Ferrari P, et al: Comparison of continuous and intermittent renal replacement therapy for acute renal failure. Nephrology Dialysis Transplantation. 2005; 20: 1630-7.

5) Vinsonneau C, Camus C, Combes A, et al: Continuous venovenous haemodiafiltration versus intermittent haemodialysis for acute renal failure in patients with multiple-organ dysfunction syndrome: a multicentre randomised trial. Lancet. 2006; 368: 379-85.

6) Schefold JC, von Haehling S, Pschowski R, et al: The effect of continuous versus intermittent renal replacement therapy on the outcome of critically ill patients with acute renal failure (CONVINT): a prospective randomized controlled trial. Crit Care. 2014; 18: R11.

7) Rhodes A, Evans LE, Alhazzani W, et al: Surviving Sepsis Campaign: International Guidelines for Management of Sepsis and Septic Shock: 2016. Intensive Care Med. 2017; 43: 304-77.

8）寺田典生, 井関邦敏, 湯澤由紀夫, 他: AKI（急性腎障害）診 療ガイドライン 2016. 日腎会誌. 2017; 59: 419-533.

9) KDIGO AKI Working Group: KDIGO clinical practice guideline for acute kidney injury. Kidney Int Suppl. 2012; 2: 1-138.
CQ11-5-1：敗血症性 AKI に対して，早期の腎代 替療法を行うか? (Stage 2 vs Stage 3 または古 典的絶対適応)

Answer : 敗血症性 AKI に対して Stage 2 での早期の 腎代替療法を行うか否かについて，本ガイドラインで は推奨を提示しない。

\section{（1）背景および本 $C Q$ の重要度}

AKI を合併した敗血症患者に対して，いつ腎代替 療法（renal replacement therapy: RRT）を開始すべきか, 臨床現場では判断に悩むことが多い。いわゆる絶対適 応ではない段階での早期の RRTによって予後が改善 する可能性も示唆されている一方で, 不要な RRTを 行うことは患者を合併症のリスクに余計にさらす可能 性ももつ。いつRRTを行うかについては依然議論が 分かれており，重要な臨床課題として取り上げるべき と考えられる。なお，早期の定義が統一されていない 状況を鑑み, AKIの重症度で $\mathrm{CQ}$ を分けることとし た。

(2) PICO

P (患者)：成人の敗血症性 AKI 患者および重症疾 患による AKI 患者

I（介入）: RIFLE/AKIN/KDIGO Stage 2 で RRT 施 行

C (対照)：RIFLE/AKIN/KDIGO Stage 3 または古典 的な絶対適応で RRT 施行

$\mathrm{O}$ (アウトカム ) : 死亡, 透析依存, 両者の複合アウ トカム

\section{（3）エビデンスの要約}

システマティックレビューの結果，PICO に合致し たランダム化比較試験（RCT）が 1 件 ${ }^{1 ）}$ 施行されて おり，これらを用いたメタ解析を実施した。

\section{（4）益と害のバランス（Table 11-5-1-1）}

望ましい効果：

Stage 2 での開始の効果は, 死亡については 1,000 人 あたり 195 人少ない $(95 \%$ CI: 293 人少ない〜 70 人少 ない）であった。死亡または透析依存の複合アウトカ ムについては，1,000人あたり 190 人少ない $(95 \%$ CI: 292 人少ない〜 66 人少ない）であった。したがって， Stage 2 におけるRRT の開始における望ましい効果は 「中」と判断した。 
Table 11-5-1-1エビデンスプロファイル

Stage 2 vs Stage3 または古典的絶対適応

\begin{tabular}{|c|c|c|c|c|c|c|c|c|c|c|c|c|}
\hline \multicolumn{7}{|c|}{ 確実性の評価 } & \multicolumn{2}{|c|}{ 患者数 } & \multicolumn{2}{|c|}{ 勃果 } & \multirow[b]{2}{*}{ 確実性 } & \multirow[b]{2}{*}{ 重要性 } \\
\hline 研究数 & $\begin{array}{l}\text { 研究 } \\
\text { デザイン }\end{array}$ & $\begin{array}{l}\text { バイアス } \\
\text { のリスク }\end{array}$ & 非一貫性 & 非直接性 & 不精確性 & $\begin{array}{l}\text { その他 } \\
\text { の模詂 }\end{array}$ & Stage 2 & $\begin{array}{c}\text { Stage } 3 \text { または } \\
\text { 絶対道応 }\end{array}$ & $\begin{array}{l}\text { 相対指標 } \\
(95 \% \mathrm{CI})\end{array}$ & $\begin{array}{l}\text { 絶対指㯖 } \\
(95 \% \text { cI) }\end{array}$ & & \\
\hline \multicolumn{13}{|c|}{ 死亡（1 年以内の最長期間） } \\
\hline 1 & RCT & $\begin{array}{c}\text { 深刻てたな } \\
\text { い }\end{array}$ & 深刻でない & 深刻 a & 深刻 b & なし & $56 / 111(50.5 \%)$ & $83 / 119(69.7 \%)$ & $\begin{array}{c}\text { RR } 0.72 \\
(0.58 \text { to } \\
0.90)\end{array}$ & $\begin{array}{c}1,000 \text { 人あたり } 195 \\
\text { 人少ない } \\
\text { (293 人少ない 70 } \\
\text { 人少ない) }\end{array}$ & $\underset{\text { 低 }}{\oplus \oplus \bigcirc}$ & 重大 \\
\hline \multicolumn{13}{|c|}{ 透析依存（最長钼察期間） } \\
\hline 1 & RCT & $\begin{array}{c}\text { 深刻でな } \\
\quad い\end{array}$ & 深刻でない & 深刻 a & 非常に深刻。 & なし & $4 / 55 \quad(7.3 \%)$ & $4 / 36(11.1 \%)$ & $\begin{array}{l}\text { RR } 0.65 \\
(0.17 \text { to } \\
2.45)\end{array}$ & $\begin{array}{c}1,000 \text { 人あたり } 39 \\
\text { 人少ない } \\
(92 \text { 人少ない 161 } \\
\text { 人多い) }\end{array}$ & $\begin{array}{l}\oplus \bigcirc \bigcirc \bigcirc \\
\text { 非常に低 }\end{array}$ & 重要 \\
\hline \multicolumn{13}{|c|}{ 死亡または透析依存（最長钼察期間） } \\
\hline 1 & $\mathrm{RCT}$ & $\begin{array}{l}\text { 深刻でな } \\
\quad \text { い }\end{array}$ & 深刻でない & 深刻 a & 深刻 d & なし & $60 / 111(54.1 \%)$ & $87 / 119(73.1 \%)$ & $\begin{array}{c}\text { RR } 0.74 \\
(0.60 \text { to } \\
0.91)\end{array}$ & $\begin{array}{c}1,000 \text { 人あたり } 190 \\
\text { 人少ない } \\
(292 \text { 人少ない 66 } \\
\text { 人少ない) }\end{array}$ & $\underset{\text { 低 }}{\oplus \oplus \bigcirc \bigcirc}$ & 重大 \\
\hline
\end{tabular}

a. ステージ 3 と絶対適応が混在。

b. 信頼区間が広い。

c. 最適情報量を満たさず， 0.75 と 1.25 の両方の閜值を含むので 2 段階グレードダウンが適切。

d. 最適情報量を満たさないため 1 段階グレードダウンが適切。

望ましくない効果 :

採用された 1 つの RCT では出血合併症について報 告されていない。早期に RRT を開始すればブラッド アクセス挿入によるカテーテル感染が増加する可能性 が懸念されるが，本システマティックレビューにおい て対象となった RCT ではアウトカムには含まれてい ない。したがって，望ましくない効果は様々であると 判断した。

益と害のバランス :

Stage 2 における RRT の開始の望ましい効果は「中」 であり，おそらく介入が優位と判断される。しかしな がら，この望ましい効果は，1 施設で実施された 1 つ の RCT から得られた結果であり一般化の可能性は低 い。また，本研究結果に関連する大規模多施設研究が 2020 年 2 月の時点で完了しており，その結果により 推奨が変わる可能性がある。したがって，本ガイドラ インにおいては, 敗血症性 AKI に対して Stage 2 での 早期の RRT を行うか否かについて推奨を提示しない こととした。

\section{（5）アウトカム全般に関するエビデンスの確実性}

Stage 2 vs Stage 3 または古典的絶対適応の比較にお いて，1つの RCT で評価された 2 つの重大なアウト カムである, 死亡率と死亡または透析依存の複合エン ドポイントはともに Stage 2 での RRT 導入の有用性が 高いことを示したが，エビデンスの確実性は「低」と 判断されている。

\section{（6）価値観}

患者および家族の価值観に関するデータはなく，死 亡という重大なアウトカムにおいては個々人の価值観 のばらつきは小さいと考えられる。

\section{（7）容認性}

早期に RRT を開始すれば，カテーテル感染や出血 合併症の増加が懸念される。明確な利益が確定してい なければ，患者にとって不要な侵襲的処置の施行に関 する容認性は低いと思われる。また，早期の RRT の 実施に際しては医療スタッフの業務負荷は増加するた め, 望ましい効果が確定的でなければその施行は容認 しがたいものとなりうる。一方で，その実施における 治療費用は施行しない場合と比較すると高くなるが, 本邦において RRT は保険診療として用いられている 治療であり，患者・家族の視点からは費用負担は容認 できる範囲であると思われる。

\section{（8）実行可能性}

RRT を早期に開始すると，RRT を受ける患者数が 増える可能性があるため, 早期開始の妨げとなる要因 は設備および人的資源である。設備や人的資源が潤沢 な施設や敗血症診療の頻度が低い施設では，その実行 可能性は「おそらく，はい」である。しかし，設備や 人的資源が限られている施設や敗血症診療の頻度が高 い施設では，その実行可能性は「おそらく，いいえ」 である。本ガイドラインは一般診療を対象としたガイ ドラインであるため, 設備や人的資源が潤沢ではない 施設での状況を鑑み，実行可能性は「おそらく，いい 
Table 11-5-1-2 判断の要約

\begin{tabular}{|c|c|c|c|c|c|c|c|}
\hline & \multicolumn{7}{|c|}{ 半判湆 } \\
\hline 問題 & いいえ & $\begin{array}{c}\text { おそらく、いい } \\
\text { え }\end{array}$ & おそらく、はい & はい & & さまざま & 分からない \\
\hline 望ましい勃果 & わずか & 小さい & 中 & 大きい & & さまざま & 分からない \\
\hline 望ましくない効果 & 大きい & 中 & 小さい & わずか & & さまざま & 分からない \\
\hline エビデンスの確実性 & 非常に低 & 低 & 中 & 高 & & & 採用研究なし \\
\hline 価值钼 & $\begin{array}{c}\text { 重要な不確実性 } \\
\text { またはばらつき } \\
\text { あり }\end{array}$ & $\begin{array}{l}\text { 重要な不確実性 } \\
\text { またはばらつき } \\
\text { の可能性ありり }\end{array}$ & $\begin{array}{l}\text { 重要な不確実性 } \\
\text { またはばらつき } \\
\text { はおそらくなし }\end{array}$ & $\begin{array}{c}\text { 重要な不確実性 } \\
\text { またはばらつき } \\
\text { はなし }\end{array}$ & & & \\
\hline 効果のバランス & 比較が優位 & $\begin{array}{c}\text { 比較がおそらく } \\
\text { 優位 }\end{array}$ & $\begin{array}{c}\text { 介入も比較もい } \\
\text { ずれも優位では } \\
\text { ない }\end{array}$ & $\begin{array}{c}\text { おそらく介入が } \\
\text { 優位 }\end{array}$ & 介入が優位 & さまざま & 分からない \\
\hline 容認性 & いいえ & $\begin{array}{c}\text { おそらく、いい } \\
\text { え }\end{array}$ & おそらく、はい & はい & & さまざま & 分からない \\
\hline 実行可能性 & いいえ & $\begin{array}{c}\text { おそらく、いい } \\
\text { え }\end{array}$ & おそらく、はい & はい & & さまざま & 分からない \\
\hline
\end{tabular}

え」とした。

（9）判断の要約（Table 11-5-1-2）

（10）推奨グレーディング決定の工程

ワーキンググループからは，本 CQ である「Stage 2 vs Stage 3 または古典的絶対適応」と別 CQ である 「Stage 3 vs 古典的絶対適応」を統合した形でのエビデ ンスが提出されたが，委員会の判断において異なる AKI 重症度での開始を分けて推奨を提示するように 変更した。本 CQについては，修正 RAND 法を用い た投票によって，中央值 7 , 見解不一致指数 0.164 の 結果となり，委員会で採択された（7点以上： $87.5 \%$ )。

\section{（11）関連する他の診療ガイドラインにおける推奨}

SSCG 2016 では，透析療法の絶対的な適応がない乏 尿または血清クレアチニン高值の段階では，RRTを 行わないことを提案している（推奨の強さ 弱, エビ デンスの強さ 低) 2)。本邦から出版された AKI（急 性腎障害）診療ガイドライン 2016 では，「早期の血液 浄化療法開始が予後を改善するエビデンスは乏しく, 臨床症状や病態を広く考慮して開始の時期を決定すべ きである（推奨の強さ なし，エビデンスの強さ C)」と述べられている3)。一方，海外の AKI ガイド ラインでは, 「体液量, 電解質, 酸塩基平衡の致死的 になりうる変化がある場合に速やかに RRT を開始す る(グレードなし)」と記載されている4)。
（12）実施に関わる検討事項 なし。

\section{（13）今後の研究の可能性}

敗血症性 AKI に限定した解析，費用対効果に関す る検討が期待される。また，非早期開始群における緊 急的な RRT を害として評価する必要がある。

\section{文 献}

1) Zarbock A, Kellum JA, Schmidt C, et al: Effect of Early vs Delayed Initiation of Renal Replacement Therapy on Mortality in Critically Ill Patients With Acute Kidney Injury: The ELAIN Randomized Clinical Trial. JAMA. 2016; 315: 2190-9.

2) Rhodes A, Evans LE, Alhazzani W, et al: Surviving Sepsis Campaign: International Guidelines for Management of Sepsis and Septic Shock: 2016. Intensive Care Med. 2017; 43: 304-77.

3）寺田典生, 井関邦敏, 湯澤由紀夫, 他: AKI（急性腎障害）診 療ガイドライン 2016. 日腎会誌. 2017; 59: 419-533.

4) KDIGO AKI Working Group: KDIGO clinical practice guideline for acute kidney injury. Kidney Int Suppl. 2012; 2: 1-138. 
CQ11-5-2：敗血症性 AKI に対して，早期の腎代 替療法を行うか? (Stage 3 vs 古典的絶対適応)

Answer : 敗血症性 AKI に対して Stage 3 での早期の 腎代替療法を行わないことを弱く推奨する（GRADE 2D : エビデンスの確実性 $=$ 「非常に低」)。

\section{（1）背景および本 $C Q$ の重要度}

CQ11-2-1 と同様である。

(2) PICO

P (患者)：成人の敗血症性 AKI 患者および重症疾 患による AKI 患者

I（介入）：RIFLE/AKIN/KDIGO Stage 3 でRRT 施 行

C (対照) : 古典的な絶対適応で RRT 施行

$\mathrm{O}$ (アウトカム $)$ : 死亡, 透析依存, 両者の複合アウ トカム, 合併症（出血）

（3）エビデンスの要約

システマティックレビューの結果, PICO に合致し たランダム化比較試験（RCT）が 2 件 1, 2) 施行されて おり,これらを用いたメタ解析を実施した。
（4）益と害のバランス（Table 11-5-2-1）

望ましい効果 :

Stage 3 と古典的絶対適応での開始を比較した $2 つ$ の RCT で抗凝固薬投与による出血が害として報告さ れている。出血のリスクは 1,000 人あたり 22 人少な い（95\% CI: 45 人少ない〜 12人多い）であり，観察 された点推定值が 1 を下回っているということのみに 基づいて, 出血リスクが下がることを「望ましい効 果」と評価した場合に，その効果はわずかであると判 断した。

望ましくない効果 :

Stage 3 での開始と古典的絶対適応での開始を比較 し，死亡をアウトカムとした 2 つの RCT においては, Stage 3 での開始の効果は 1,000 人あたり 11 人多い （95\% CI: 48 人少ない〜 74 人多い）であった。死亡ま たは透析依存の複合アウトカムについては，1,000人 あたり 0 人の増減 $(95 \%$ CI: 59 人少ない 70人多い) であった。したがって， Stage 3 におけるRRT の開始 における望ましくない効果はわずかであると判断し た。

益と害のバランス :

Stage 3 における RRT の開始の望ましい効果も望ま しくない効果も，いずれかを支持するほどには示され ていない。

Table 11-5-2-1エビデンスプロファイル

Stage 3 vs 古典的絶対適応

\begin{tabular}{|c|c|c|c|c|c|c|c|c|c|c|c|c|}
\hline \multicolumn{7}{|c|}{ 確実性の評価 } & \multicolumn{2}{|c|}{ 费者数 } & \multicolumn{2}{|c|}{ 奻果 } & \multirow[b]{2}{*}{ 確実性 } & \multirow[b]{2}{*}{ 重要性 } \\
\hline 滦究数 & $\begin{array}{l}\text { 研究 } \\
\text { デイン }\end{array}$ & $\begin{array}{l}\text { ハイアス } \\
\text { のリスク }\end{array}$ & 非一貫性 & 非直接性 & 不精磼性 & 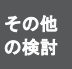 & Stage 3 & 䋓対通庶 & $\begin{array}{l}\text { 相対指檟 } \\
(95 \% \text { CI })\end{array}$ & $\begin{array}{l}\text { 絶対指檈 } \\
(95 \% \text { cI) }\end{array}$ & & \\
\hline \multicolumn{13}{|l|}{ 死亡 } \\
\hline 2 & RCT & 深刻でない & 深刻でない & 深刻てない & 深刻でない。 & なし & $\begin{array}{l}293 / 547 \\
(53.6 \%)\end{array}$ & $\begin{array}{l}287 / 543 \\
(52.96)\end{array}$ & $\begin{array}{c}R R 1.02 \\
\text { (0. } 91 \text { to } 1.14)\end{array}$ & $\begin{array}{c}1,000 \text { 人あたり } 11 \\
\text { ᄉ多い } \\
(48 \text { 人少ない 74 } \\
\text { 人多い) }\end{array}$ & $\begin{array}{c}\oplus \oplus \oplus \oplus \\
\text { 高 }\end{array}$ & 重大 \\
\hline \multicolumn{13}{|c|}{ 出血合併症 } \\
\hline 2 & $\mathrm{RCT}$ & 非常に深刻 b & 深刻でない & 深刻でない & 深刻。 & なし & $\begin{array}{l}39 / 557 \\
(7.0 \%)\end{array}$ & $\begin{array}{l}51 / 550 \\
(9.3 \%)\end{array}$ & $\begin{array}{c}\text { RR } 0.76 \\
\text { (0. } 51 \text { to } 1.13)\end{array}$ & $\begin{array}{c}\text { 1, } 000 \text { 人おたり } 22 \\
\text { 人少ない } \\
(45 \text { 人少ない 12 } \\
\text { 人多い) }\end{array}$ & $\begin{array}{l}\oplus \bigcirc \bigcirc \bigcirc \\
\text { 非常に低 }\end{array}$ & 重大 \\
\hline \multicolumn{13}{|c|}{ 透析依存 } \\
\hline 2 & RCT & 非常に深刻 b & 深刻でい & 深刻でない & 非常に深刻 d & なし & $\begin{array}{l}5 / 258 \\
(1.9 \%)\end{array}$ & $\begin{array}{l}11 / 265 \\
(4.2 \%)\end{array}$ & $\begin{array}{l}\text { RR } 0.47 \\
\text { (0. } 16 \text { to } 1.34)\end{array}$ & $\begin{array}{c}\text { 1, 000 人あたり } 22 \\
\text { 人少ない } \\
(35 \text { 人ない } \\
\text { 人多い) }\end{array}$ & $\begin{array}{l}\oplus \bigcirc 00 \\
\text { 非常に低 }\end{array}$ & 重要 \\
\hline \multicolumn{13}{|c|}{ 死亡または透析依存 } \\
\hline 2 & RCT & 非常に深刻 b & 深刻でない & 深刻でない & 深刻でない & なし & $\begin{array}{l}293 / 550 \\
(53.3 \%)\end{array}$ & $\begin{array}{l}292 / 546 \\
(53.5 \%)\end{array}$ & $\begin{array}{c}\text { RR } 1.00 \\
\text { (0.89 to } 1.13)\end{array}$ & $\begin{array}{c}1,000 \text { 人あたり } 0 \text { 人 } \\
\text { 少ない } \\
(59 \text { 少ない 70 } \\
\text { 人多い) }\end{array}$ & $\underset{\text { 低 }}{\oplus \oplus \bigcirc}$ & 重大 \\
\hline
\end{tabular}

a. 信頼区間が広い $\Rightarrow$ 狭いのでグレードダウンしなくてよい。

b. 主観的アウトカム，実行バイアス。

c. 信頼区間が広い。

d. 0.75 と 1.25 の両方を含むので不精確性は 2 段階グレードダウン。

e. 不精確性はグレードダウンなし。 
（5）アウトカム全般に関するエビデンスの確実性

重大なアウトカムである死亡と出血合併症のアウト カムが異なる方向性を示しており, 出血合併症に関す る確実性は「非常に低」と評価されていることから， 全体的な確実性を「非常に低」とする。

\section{（6）価値観}

患者および家族の価值観に関するデータはなく，死 亡という重大なアウトカムにおいては個々人の価值観 のばらつきは小さいと考えられる。

\section{（7）容認性}

RRT という介入の費用負担は施行しない場合と比 較すると当然高い。しかし，本邦において RRT は保 険診療として用いられている治療であり，患者・家族 の視点からは費用負担は容認できる範囲であると思わ れる。一方，RRT施行に際しては医療スタッフの業 務負荷は増加するため, 不必要な施行は容認しがたい ものとなりうるが，望ましい効果が明らかではないた め, 重要な利害関係者にとって妥当なものであるかど うか評価するに至っていない。

\section{（8）実行可能性}

RRT を早期に開始するに伴い，RRT を受ける患者 数が増える可能性があるため，早期開始の妨げとなる 要因は設備および人的資源である。臓器障害を伴う敗 血症患者の診療にあたる施設における，患者数の増加 に対応する RRT 実施体制についてのリサーチエビデ ンスはないため, 本 CQ での介入について実行可能性
の評価は困難である。

（9）判断の要約（Table 11-5-2-2）

（10）推奨グレーディング決定の工程

ワーキンググループからは，本 CQ である「Stage 2 vs Stage 3 または古典的絶対適応」と別 CQ である 「Stage 3 vs 古典的絶対適応」をまとめた形でのエビデ ンスが提出されたが，委員会の判断において異なる AKI 重症度での開始を分けて推奨を提示するように 変更した。本 CQについては，修正 RAND 法を用い た投票によって，中央值 7 ，見解不一致指数 0.164 の 結果となり，委員会で採択された（7点以上： $91.7 \%)$ 。

\section{（11）関連する他の診療ガイドラインにおける推奨}

SSCG 2016 では，透析療法の絶対的な適応がないそ 尿または血清クレアチニン高值の段階では，RRTを 行わないことを提案している（推奨の強さ弱, エビ デンスの強さ 低 ${ }^{3)}$ 。本邦から出版された AKI（急性 腎障害）診療ガイドライン 2016 では，「早期の血液浄 化療法開始が予後を改善するエビデンスは乏しく，臨 床症状や病態を広く考慮して開始の時期を決定すべき である（推奨の強さなし, エビデンスの強さ $\mathrm{C}$ )」と 述べられている4)。一方，海外の AKI ガイドライン では, 体液量, 電解質, 酸塩基平衡の致死的になりう る変化がある場合に速やかに RRT を開始する（グ レードなし）と記載されている5)。

Table 11-5-2-2 判断の要約

\begin{tabular}{|c|c|c|c|c|c|c|c|}
\hline & \multicolumn{7}{|c|}{ 判断 } \\
\hline 問題 & いいえ & $\begin{array}{c}\text { おそらく、いい } \\
\text { え }\end{array}$ & おそらく、はい & はい & & さまざま & 分からない \\
\hline 望ましい勃果 & わずか & 小さい & 中 & 大きい & & さまざま & 分からない \\
\hline 望ましくない効果 & 大きい & 中 & 小さい & わずか & & さまざま & 分からない \\
\hline エビデンスの確実性 & 非常に低 & 低 & 中 & 高 & & & 採用研究なし \\
\hline 価值钼 & $\begin{array}{c}\text { 重要な不確実性 } \\
\text { またはばらつき } \\
\text { あり }\end{array}$ & $\begin{array}{c}\text { 重要な不確実性 } \\
\text { またはばらつき } \\
\text { の可能性ありり }\end{array}$ & $\begin{array}{l}\text { 重要な不確実性 } \\
\text { またははばらつき } \\
\text { はおそらくなし }\end{array}$ & $\begin{array}{c}\text { 重要な不確実性 } \\
\text { またはばらつき } \\
\text { はなし }\end{array}$ & & & \\
\hline 効果のパランス & 比較が優位 & $\begin{array}{c}\text { 比較がおそらく } \\
\text { 優位 }\end{array}$ & $\begin{array}{c}\text { 介入も比較もい } \\
\text { ずれも優位でな } \\
\text { い }\end{array}$ & $\begin{array}{c}\text { おそらく介入が } \\
\text { 優位 }\end{array}$ & 介入が優位 & さまざま & 分からない \\
\hline 容認性 & いいえ & $\begin{array}{c}\text { おそらく、いい } \\
\text { え }\end{array}$ & おそらく、はい & はい & & さまざま & 分からない \\
\hline 実行可能性 & いいえ & $\begin{array}{c}\text { おそらく、いい } \\
\text { え }\end{array}$ & おそらく、はい & はい & & さまざま & 分からない \\
\hline
\end{tabular}


（12）実施に関わる検討事項

なし。

（13）今後の研究の可能性

費用対効果について検討した研究が期待される。

\section{文 献}

1) Gaudry S, Hajage D, Schortgen F, et al: Initiation Strategies for Renal-Replacement Therapy in the Intensive Care Unit. N Engl J Med. 2016; 375: 122-33.

2) Barbar SD, Clere-Jehl R, Bourredjem A, et al: Timing of RenalReplacement Therapy in Patients with Acute Kidney Injury and Sepsis. N Engl J Med. 2018; 379: 1431-42.

3) Rhodes A, Evans LE, Alhazzani W, et al: Surviving Sepsis Campaign: International Guidelines for Management of Sepsis and Septic Shock: 2016. Intensive Care Med. 2017; 43: 304-77.

4）寺田典生, 井関邦敏, 湯睪由紀夫, 他: AKI（急性腎障害）診 療ガイドライン 2016. 日腎会誌. 2017; 59: 419-533.

5) KDIGO AKI Working Group: KDIGO clinical practice guideline for acute kidney injury. Kidney Int Suppl. 2012; 2: 1-138.
CQ11-6：敗血症性 AKI に対する腎代替療法にお いて，血液浄化量の増加を行うか?

Answer : 敗血症性 AKI に対して, 血液浄化量を標準 量よりも増やさないことを弱く推奨する（GRADE $2 \mathrm{C}:$ エビデンスの確実性 $=\lceil$ 低」)。

\section{（1）背景および本 $C Q$ の重要度}

敗血症性 AKI 患者に腎代替療法（renal replacement therapy：RRT）を施行する際に，炎症性サイトカインや 種々のメディエータなどのクリアランスを上げること で予後を改善させることを期待し, 透析量・濾過量を 増やすことが検討されている。本邦の保険診療では $15 \mathrm{~mL} / \mathrm{kg} / \mathrm{hr}$ 程度の処方量が標準とされているが，国外 では $25 \mathrm{~mL} / \mathrm{kg} / \mathrm{hr}$ 程度が標準的な処方量とされている。 敗血症性 AKI に対して最も治療効果の高い処方量を設 定することは予後改善において重要であり, 検討すべ き $\mathrm{CQ} と し て$ 取り上げた。

(2) PICO

P (患者)：成人の敗血症性 AKI 患者および重症疾 患による AKI 患者

I（介入）：高用量での RRT

C (対照) : 標準量での RRT

$\mathrm{O}$ (アウトカム) : 死亡, 透析依存, 両者の複合アウ トカム, 副作用（低リン血症）発生

\section{（3）エビデンスの要約}

システマティックレビューの結果，PICO に合致し たランダム化比較試験（RCT）が 6 件抽出された ${ }^{1-6) 。}$ なお，3つの RCT において超高用量（ $50 \mathrm{~mL} / \mathrm{kg} / \mathrm{hr} \sim)$ と高用量（30〜35 $\mathrm{mL} / \mathrm{kg} / \mathrm{hr} ）$ での RRT の比較検討が 行われており 2, 5, 6), これらは,「(10) 推奨グレー ディング決定の工程」において述べる理由で推奨の作 成において除外した。

（4）益と害のバランス（Table 11-6-1）

望ましい効果 :

今回検討したアウトカムでは, 望ましい効果は認め られず，明らかな望ましい効果があるかは不明であ る。

\section{望ましくない効果 :}

死亡アウトカム（3 RCT, $\mathrm{n}=2,789$ ) の効果推定值 は 1,000 人あたり 22 人多い $(95 \%$ CI: 13 人少ない〜 58 人多い) であった。透析依存アウトカム (3 RCT, $\mathrm{n}=2,096)$, 透析依存と死亡複合アウトカム（3 RCT, 
Table 11-6-1エビデンスプロファイル

\begin{tabular}{|c|c|c|c|c|c|c|c|c|c|c|c|c|}
\hline \multicolumn{7}{|c|}{ 確実性の評価 } & \multicolumn{2}{|c|}{ 患者数 } & \multicolumn{2}{|c|}{ 勃果 } & \multirow[b]{2}{*}{ 確実性 } & \multirow[b]{2}{*}{ 重要性 } \\
\hline 研究数 & $\begin{array}{l}\text { 研究 } \\
\text { デザイン }\end{array}$ & $\begin{array}{l}\text { バイアス } \\
\text { のリスク }\end{array}$ & 非一页性 & 非直接性 & 不精確性 & $\begin{array}{l}\text { その他 } \\
\text { の検討 }\end{array}$ & 高用 & 標準耳 & $\begin{array}{l}\text { 相対指欜 } \\
(95 \% \mathrm{CI})\end{array}$ & $\begin{array}{l}\text { 絶対指橝 } \\
(95 \% \text { CI })\end{array}$ & & \\
\hline \multicolumn{13}{|l|}{ 死亡 } \\
\hline 3 & RCT & 深刻でない & 深刻でない & 深刻 b & 深刻でない & なし & $\begin{array}{c}644 / 1,385 \\
(46.5 \%)\end{array}$ & $\begin{array}{c}623 / 1,404 \\
(44.4 \%)\end{array}$ & $\begin{array}{c}\text { RR } 1.05 \\
(0.97 \text { to } \\
1.13)\end{array}$ & $\begin{array}{c}1,000 \text { 人あたり } \\
22 \text { 人多い } \\
(13 \text { 人少ない } 58 \\
\text { 人多い) }\end{array}$ & $\underset{\text { 低 }}{\oplus \oplus \bigcirc \bigcirc}$ & 重大 \\
\hline \multicolumn{13}{|c|}{ 透析依存 } \\
\hline 3 & RCT & 深刻 a & 深刻でない & 深刻 b & 深刻でない & なし & $\begin{array}{c}494 / 1,032 \\
(47.9 \%)\end{array}$ & $\begin{array}{c}468 / 1,064 \\
(44.0 \%)\end{array}$ & $\begin{array}{c}\text { RR } 1.05 \\
(0.98 \text { to } \\
1.13)\end{array}$ & $\begin{array}{c}1,000 \text { 人あたり } \\
22 \text { 人多い } \\
(9 \text { 人少ない } 57 \\
\text { 人多い) }\end{array}$ & $\underset{\text { 低 }}{\oplus \oplus \bigcirc \bigcirc}$ & 重大 \\
\hline \multicolumn{13}{|c|}{ 透析依存と死亡（複合アウトカム） } \\
\hline 3 & RCT & 深刻 a & 深刻でない & 深刻 b & 深刻でない & なし & $\begin{array}{c}889 / 1,382 \\
(64.3 \%)\end{array}$ & $\begin{array}{c}868 / 1,404 \\
(61.8 \%)\end{array}$ & $\begin{array}{c}\text { RR } 1.02 \\
(0.98 \text { to } \\
1.07)\end{array}$ & $\begin{array}{c}\text { 1, } 000 \text { 人あたり } \\
12 \text { 人多い } \\
(12 \text { 人少ない 43 } \\
\text { 人多い) }\end{array}$ & $\underset{\text { 低 }}{\oplus \oplus \bigcirc \bigcirc}$ & 重大 \\
\hline \multicolumn{13}{|c|}{ 副作用 (低リン血症) } \\
\hline 2 & RCT & 深刻 a & 深刻でない & 深刻 b & 深刻でない & なし & $\begin{array}{c}560 / 1,271 \\
(44.1 \%)\end{array}$ & $\begin{array}{c}457 / 1,294 \\
(35.3 \%)\end{array}$ & $\begin{array}{c}\text { RR } 1.35 \\
(1.01 \text { to } \\
1.81)\end{array}$ & $\begin{array}{c}\text { 1. } 000 \text { 人あたり } \\
124 \text { 人多い } \\
(4 \text { 人多い 286 } \\
\text { 人多い) }\end{array}$ & $\underset{\text { 低 }}{\oplus \oplus \bigcirc \bigcirc}$ & 重要 \\
\hline
\end{tabular}

a. 高バイアスのリスクの研究の寄与率が高い。

b. 敗血症でない症例を多く含んでいる。

$\mathrm{n}=2,786)$ はそれぞれ 1,000 人あたり 22 人多い $(95 \%$ CI: 9 人少ない〜 57 人多い), 1,000人あたり 12 人多 い（95\% CI：12人少ない〜43人多い）であった。望 ましくない効果は「わずか」であると判断した。

益と害のバランス :

望ましい効果は「分からない」であり，望ましくな い効果は「わずか」と判断された。したがって，効果 のバランスは「比較がおそらく優位」とした。なお， 超高用量（ $50 \mathrm{~mL} / \mathrm{kg} / \mathrm{hr} \sim)$ と高用量（30〜35mL/kg/hr） での RRTの比較検討が行われた 3 つの $\mathrm{RCT}^{2,5,6)}$ で は，エビデンスの確実性は「非常に低」であり，望ま しい効果も望ましくない効果も「わずか」と判断され, 介入も比較もいずれも優位でない結果が得られてい る。

（5）アウトカム全般に関するエビデンスの確実性 すべての重大なアウトカムにおいて「低」と評価さ れており, 方向性が同じであるため, 全体的なエビデ ンスの確実性も「低」とした。

\section{（6）価值観}

患者および家族の価值観に関するデータはなく，死 亡という重大なアウトカムにおいては個々人の価值観 のばらつきは小さいと考えられる。

\section{（7）容認性}

高用量の RRT という介入の費用負担は標準量より も当然高いが，透析液および置換液の費用負担は比較 的安価であり，患者・家族の視点からは容認できる範
囲であると思われる。しかし，頻回の透析液・置換液 の交換や，血液濾過量を増加させた場合における頻回 のフィルターおよび回路凝固は, 医療従事者の労力増 加につながる。

\section{（8）実行可能性}

技術的には抗凝固薬の調整やフィルターの選択を工 夫することで高用量の腎代替療法は実行可能である。

（9）判断の要約 (Table 11-6-2)

（10）推奨グレーディング決定の工程

修正 RAND 法を用いた投票によって，中央值 7, 見解不一致指数 0.164 の結果となり，委員会で採択さ

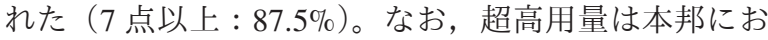
ける診療においては現実的にほぼ用いられていない治 療量であることに加え, 超高用量が高用量よりも優れ ている結果が前記の通り得られていないことから，標 準量からの増量が効果を示すとは考えにくいと委員会 が判断し，これら 3 つの RCT は対象に含めていない。

\section{（11）関連する他の診療ガイドラインにおける推奨}

SSCG 2016 では，解説文で血液浄化量について言及 されているが，明確な推奨はされていない7)。本邦か ら出版された AKI（急性腎障害）診療ガイドライン 2016 では, 至適な血液浄化量を推奨できる根拠とな るエビデンスがなく, 病態に応じた血液浄化量の設定 が必要であると述べられている（推奨の強さ 2 , エビ デンスの強さ B ) ${ }^{8}$ 。 一方, 海外の AKI ガイドライン 
Table 11-6-2 判断の要約

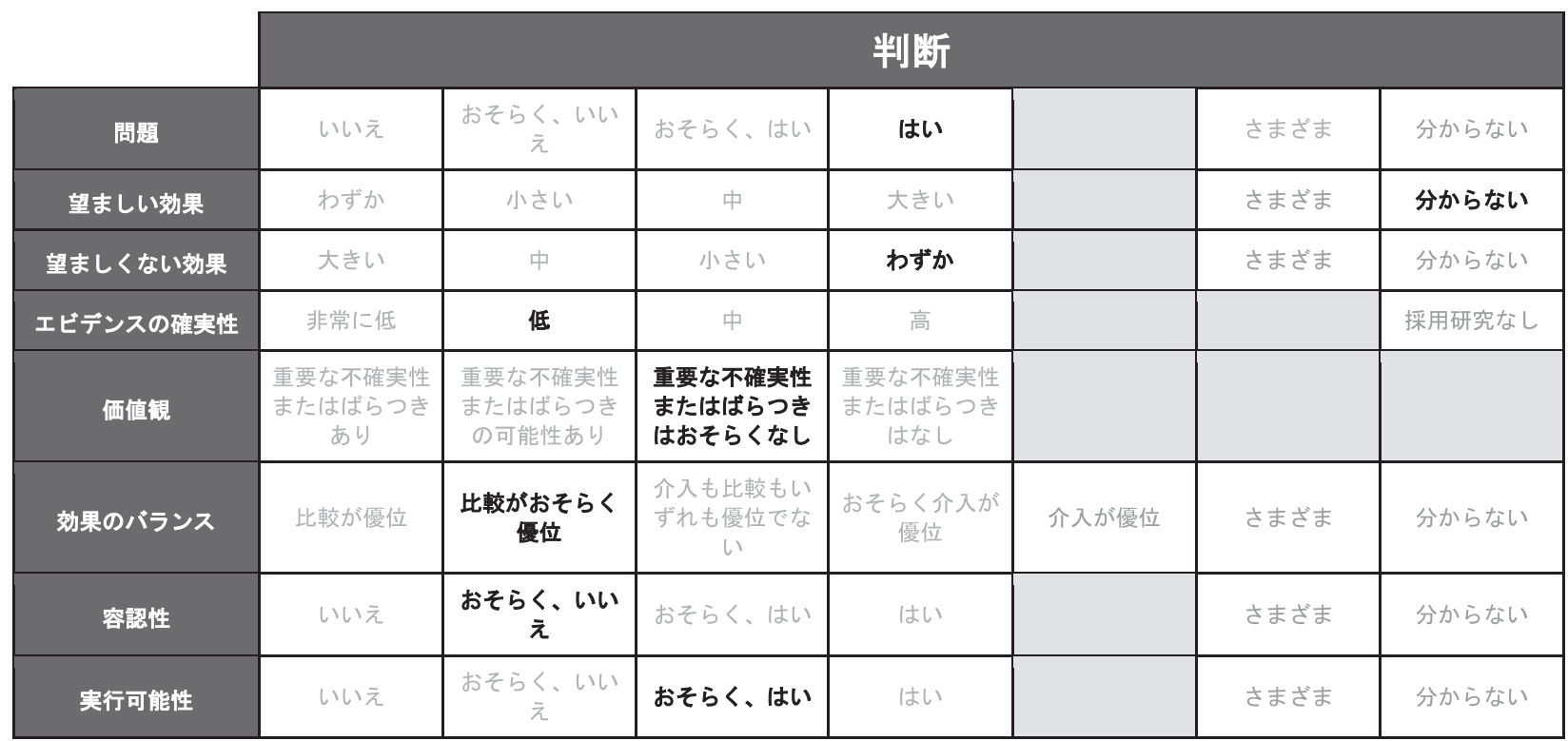

では，血液浄化量として $20 \sim 25 \mathrm{~mL} / \mathrm{kg} / \mathrm{hr}$ で行うこと が推奨されている（推奨の強さ 1 , エビデンスの強さ A) ${ }^{9)}$ 。

\section{（12）実施に関わる検討事項}

海外における血液浄化量の標準量は 20〜 $25 \mathrm{~mL} / \mathrm{kg} / \mathrm{hr}$ であるが，本邦における保険適用量は $10 \sim 15 \mathrm{~mL} / \mathrm{kg} / \mathrm{hr}$ であり乘離がある。

\section{（13）今後の研究の可能性}

本邦と海外で行われている血液浄化量の乘離に関し て検討した研究や, 費用対効果について検討した研究 が期待される。

\section{文 献}

1) Tolwani AJ, Campbell RC, Stofan BS, et al: Standard versus high-dose CVVHDF for ICU-related acute renal failure. J Am Soc Nephrol. 2008; 19: 1233-8.

2) Boussekey N, Chiche A, Faure K, et al: A pilot randomized study comparing high and low volume hemofiltration on vasopressor use in septic shock. Intensive Care Med. 2008; 34: 1646-53.

3) Palevsky PM, Zhang JH, O'Connor TZ, et al: Intensity of renal support in critically ill patients with acute kidney injury. N Engl J Med. 2008; 359: 7-20.

4) RENAL Replacement Therapy Study Investigators; Bellomo R, Cass A, Cole L, et al: Intensity of continuous renal-replacement therapy in critically ill patients. N Engl J Med. 2009; 361: 1627-38.

5) Joannes-Boyau O, HonoréPM, Perez P, et al: High-volume versus standard-volume haemofiltration for septic shock patients with acute kidney injury (IVOIRE study): a multicentre randomized controlled trial. Intensive Care Med. 2013; 39: 1535-46.

6) Ye J, Pu X, Chen X: Impacts of different hemofiltration methods on the prognosis of patients with sepsis. Biomed Res. 2017; 28: 5473-8.
7) Rhodes A, Evans LE, Alhazzani W, et al: Surviving Sepsis Campaign: International Guidelines for Management of Sepsis and Septic Shock: 2016. Intensive Care Med. 2017; 43: 304-77.

8）寺田典生, 井関邦敏, 湯澤由紀夫, 他: AKI（急性腎障害）診 療ガイドライン 2016. 日腎会誌. 2017; 59: 419-533.

9) KDIGO AKI Working Group: KDIGO clinical practice guideline for acute kidney injury. Kidney Int Suppl. 2012; 2: 1-138. 
CQ11-7：敗血症性ショックに対して, PMX-DHP を行うか?

Answer：敗血症性ショックの患者に対して, PMX-DHP を行わないことを弱く推奨する（GRADE 2B : エビデンスの確実性 $=\lceil$ 中)。

\section{（1）背景および本 $C Q$ の重要度}

エンドトキシンは，グラム陰性桿菌の細胞壁の構成 成分であるリポ多糖類であり，体内に侵入すると， 様々な炎症性サイトカインやメディエータ産生を誘導 することが知られている1,2)。エンドトキシンの吸着 を目的としてポリミキシン $\mathrm{B}$ 固定化カラムを用いた 直接血液灌流法 (direct hemoperfusion with polymyxin B immobilized fiber column: PMX-DHP）が開発され, 本邦において臨床応用された ${ }^{3)}$ 。本治療には, 敗血症 の病態を大きく改善させうる理論的背景がある一方 で，治療を行うにはカテーテル挿入，抗凝固薬の投与 などが必要であることから, 合併症のリスクも同時に はらんでおり，その有効性については議論が続いてい た 4 , 5)。加えて, 本治療で使用されるポリミキシン B 固定化カラムは，本邦で開発されたため国内での認知 度は非常に高く，また諸外国でも様々なランダム化比 較試験（RCT）が行われていることから，本 CQ を重 要な臨床課題として取り上げた ${ }^{6,7) 。}$
(2) PICO

$\mathrm{P}$ (患者)：成人の敗血症患者

I（介入）: PMX-DHP あり

C (対照)：PMX-DHP なし，または標準的治療

$\mathrm{O}$ (アウトカム) : 死亡 (最長観察期間), 副作用 (患者単位), 臓器障害スコア (72 時間), 昇圧薬 不使用日数

\section{（3）エビデンスの要約}

システマティックレビューの結果，PICO に合致し た RCT が 3 件 8-10）施行されており，これらを用いた メタ解析を実施した。

(4) 益と害のバランス（Table 11-7-1）

望ましい効果 :

昇圧薬の不使用日数は減少することが示唆された が，その他の重大なアウトカムでは，望ましい効果は みられず，明らかな望ましい効果があるかは不明であ る。

望ましくない効果 :

最長観察期間での全死亡は，3つの RCT で 1,000 人 あたり 12 人多い（95\% CI: 123 人少ない〜223 人多い） である。臨床試験で定められた何らかの副作用は，2 つの RCT で 1,000 人あたり 17 人多い $(95 \%$ CI: 19 人 少ない〜 58 人多い）である。望ましくない効果はわ ずかであると判断した。

Table 11-7-1エビデンスプロファイル

\begin{tabular}{|c|c|c|c|c|c|c|c|c|c|c|c|c|}
\hline \multicolumn{7}{|c|}{ 確実性の評価 } & \multicolumn{2}{|c|}{ 患者数 } & \multicolumn{2}{|c|}{ 勃果 } & \multirow[b]{2}{*}{ 碓夷性 } & \multirow[b]{2}{*}{ 重要性 } \\
\hline 研究数 & $\begin{array}{l}\text { 研究 } \\
\text { デサ1 } \\
\stackrel{2}{2}\end{array}$ & $\begin{array}{l}\text { パイアス } \\
\text { のリスク }\end{array}$ & 非一貫性 & 非直接性 & 不精確性 & $\begin{array}{l}\text { その他 } \\
\text { の检討 }\end{array}$ & $\begin{array}{c}\text { PMX } \\
\text { グルーフ }\end{array}$ & $\begin{array}{c}\text { 対腷 } \\
\text { グルーフ }\end{array}$ & $\begin{array}{l}\text { 相対指鲾 } \\
(95 \% \text { CI })\end{array}$ & $\begin{array}{l}\text { 絶対指㩖 } \\
(95 \% \text { CI })\end{array}$ & & \\
\hline \multicolumn{13}{|c|}{ 死亡（最長観察期間） } \\
\hline 3 & RCT & 深刻でない & 非常に深刻 a & 深刻でない & 深刻 b & なし & $\begin{array}{l}167 / 373 \\
(44.8 \%)\end{array}$ & $\begin{array}{l}138 / 359 \\
(38.4 \%)\end{array}$ & $\begin{array}{l}\text { RR } 1.03 \\
\text { (0.68 to } 1.58)\end{array}$ & $\begin{array}{c}1,000 \text { 人あたり } 12 \text { 人 } \\
\text { 多い } \\
\text { (123 人少ない 223 } \\
\text { 人多い) }\end{array}$ & $\begin{array}{l}\oplus \bigcirc \bigcirc \bigcirc \\
\text { 非常に低 }\end{array}$ & 重大 \\
\hline \multicolumn{13}{|c|}{ 副作用（副作用の起きた患者の割合） } \\
\hline 2 & RCT & 深刻でない & 深刻でない & 深刻。 & 深刻でない & なし & $\begin{array}{l}93 / 343 \\
(27.1 \%)\end{array}$ & $\begin{array}{l}82 / 339 \\
(24.2 \%)\end{array}$ & $\begin{array}{l}\text { RR } 1.07 \\
\text { (0.92 to } 1.24)\end{array}$ & $\begin{array}{c}1,000 \text { 人あたり } 17 \text { 人 } \\
\text { 多い } \\
(19 \text { 人少ない 58人 } \\
\text { 多い) }\end{array}$ & $\begin{array}{c}\oplus \oplus \oplus \bigcirc \\
\text { 中 }\end{array}$ & 重大 \\
\hline \multicolumn{13}{|c|}{ 膶器障害スコア（72 時間の変化または最終值） } \\
\hline 2 & RCT & 深刻でない & 深刻でない & 深刻でない & 深刻でない & なし & 343 & 339 & - & $\begin{array}{c}\text { 標準平均差 } 0.01 \text { 高 } \\
\text { い } \\
(0.37 \text { 低い 0.4 高 } \\
\text { (い) }\end{array}$ & 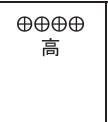 & 重要 \\
\hline \multicolumn{13}{|c|}{ 昇圧蕃不使用日数 } \\
\hline 1 & RCT & 深刻 d & 深刻でない & 深刻でない & 深刻 b & なし & 119 & 113 & - & $\begin{array}{c}\text { 平均 } 1.8 \text { 日 短い } \\
(4.14 \text { 日短い } 0.54 \\
\text { 日長い) }\end{array}$ & $\underset{\text { 低 }}{\oplus \oplus \bigcirc}$ & 重要 \\
\hline
\end{tabular}

，推定值の信頼区間がほぼ重ならない，異質性が高い。

b. 信頼区間が広い。

c. 具体的な症状ではない

d. 非盲検化試験のみ 
Table 11-7-2 判断の要約

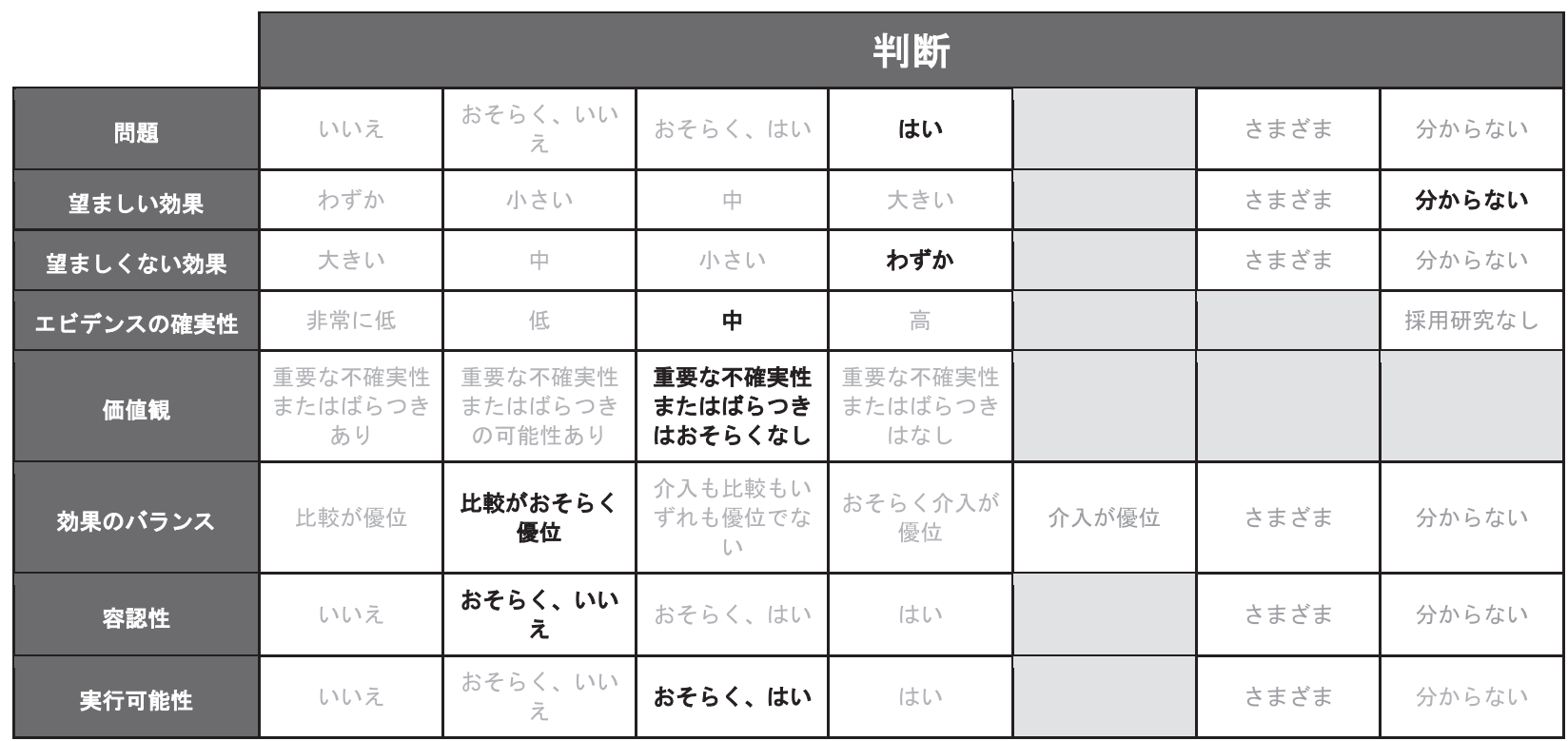

益と害のバランス :

効果のバランスは望ましくない効果が「わずか」で あり, 望ましい効果は分からないため,「比較対照が おそらく優位」と結論した。

（5）アウトカム全般に関するエビデンスの確実性 2 つの重大なアウトカムの方向性は同じであり，最 も高い確実性を採用して「中」とした。

\section{（6）価値観}

患者および家族の価值観に関するデータはなく，死 亡という重大なアウトカムにおいては個々人の価值観 のばらつきは小さいと考えられる。

\section{（7）容認性}

吸着カラムの価格約 30 万円/回，診療報酬 2,000 点 と高額であり，容認性が高い治療とはいいにくいた め,「おそらく，いいえ」と判断した。

\section{（8）実行可能性}

PMX-DHP 実行可能性を評価した臨床研究は存在し ないが，敗血症性ショックの患者診療にあたる施設で は，血液浄化装置を配備していることが想定され，本 治療の施行は可能であると思われるため，実行可能性 は「おそらく，はい」と判断した。

（9）判断の要約（Table 11-7-2）
（10）推奨グレーディング決定の工程

修正 RAND 法を用いた投票によって，中央值 7, 見解不一致指数 0.164 の結果となり, 委員会で採択さ れた（7点以上 : $87.5 \%) 。$

\section{（11）関連する他の診療ガイドラインにおける推奨}

SSCG 2016 では，本治療法については推奨が示され ていない11)。

\section{（12）実施に関わる検討事項}

なし。

\section{（13）今後の研究の可能性}

サブ解析において臓器障害スコアの高い患者 （MODS >9）に対する有効性，エンドトキシン活性 が高い患者での有効性が示唆されており，このような 患者群に特化した介入研究が期待される。

$$
\text { 文 献 }
$$

1) Rittirsch D, Flierl MA, Ward PA: Harmful molecular mechanisms in sepsis. Nat Rev Immunol. 2008; 8: 776-87.

2) Cavaillon JM: Exotoxins and endotoxins: Inducers of inflammatory cytokines. Toxicon. 2018; 149: 45-53.

3) Hanasawa K, Tani T, Oka T, et al: Selective removal of endotoxin from the blood by extracorporeal hemoperfusion with polymyxin B immobilized fiber. Prog Clin Biol Res. 1988; 264: 337-41.

4) Ronco C, Klein DJ: Polymyxin B hemoperfusion: a mechanistic perspective. Crit Care. 2014; 18: 309.

5) Yamashita $C$, Moriyama $K$, Hasegawa $D$, et al: Evidence and Perspectives on the Use of Polymyxin B-Immobilized Fiber Column Hemoperfusion among Critically Ill Patients. Contrib Nephrol. 2018; 196: 215-22.

6) Fujii T, Ganeko R, Kataoka Y, et al: Polymyxin B-immobilized 
hemoperfusion and mortality in critically ill adult patients with sepsis/septic shock: a systematic review with meta-analysis and trial sequential analysis. Intensive Care Med. 2018; 44: 167-78.

7) Terayama T, Yamakawa K, Umemura Y, et al: Polymyxin B Hemoperfusion for Sepsis and Septic Shock: A Systematic Review and Meta-Analysis. Surgical Infections. 2017; 18: 225-33.

8) Nakamura T, Ebihara I, Shoji H, et al: Treatment with polymyxin B-immobilized fiber reduces platelet activation in septic shock patients: Decrease in plasma levels of soluble P-selectin, platelet factor 4 and $\beta$-thromboglobulin. Inflamm Res. 1999; 48: 171-5.

9) Payen DM, Guilhot J, Launey Y, et al: Early use of polymyxin B hemoperfusion in patients with septic shock due to peritonitis: a multicenter randomized control trial. Intensive Care Med. 2015; 41: 975-84.

10) Dellinger RP, Bagshaw SM, Antonelli M, et al: Effect of Targeted Polymyxin B Hemoperfusion on 28-Day Mortality in Patients With Septic Shock and Elevated Endotoxin Level: The EUPHRATES Randomized Clinical Trial. JAMA. 2018; 320 : 1455-63.

11) Rhodes A, Evans LE, Alhazzani W, et al: Surviving Sepsis Campaign: International Guidelines for Management of Sepsis and Septic Shock: 2016. Intensive Care Med. 2017; 43: 304-77. 


\section{CQ12 : 栄養療法}

敗血症などの重症病態では, 神経内分泌の賦活化, サイトカインなどの炎症性メディエータによる免疫応 答により，異化克進をはじめとする代謝変動を来 す 1-3)。栄養障害が進行すると易感染性および生体機 能の低下を来し，感染率，人工呼吸期間，死亡率，病 院滞在日数などが増加する4)。適切な栄養介入は, こ れらの生体反応を制御し，予後を改善する可能性が示 唆されている5)。

本ガイドラインでは，敗血症患者に栄養投与を行う 場合の基本的な 8 つの CQ と, 近年注目されているビ タミン C とビタミン $\mathrm{D}$ に関する $\mathrm{CQ}$ の計 9 個の $\mathrm{CQ}$ を取り上げることとした。7つの CQについてシステ
マティックレビューを実施したが，敗血症患者に限定 したエビデンスは少ないため，敗血症に見合う程度の 重症患者を対象にしたランダム化比較試験（RCT）に 基づいて推奨を行っている。

CQ12-1 は, 経腸栄養と経静脈栄養のどちらを優先 するべきかに関するものである。栄養の経腸投与が, 腸内細菌叢と腸管粘膜の構造を維持し, 腸管関連リン パ組織（gut-associated lymphoid tissue: GALT）の機能 を維持することにより, bacterial translocation（生菌の みならず菌体成分を含む）を抑制すると考えられてい る。ヒトで生きた腸内細菌が腸管外へ translocationす る病態は多くないが，死菌でもその菌体成分は自然免 疫に関するレセプター（toll-like receptor など）を介し て生体に免疫応答を引き起こすことがわかっている

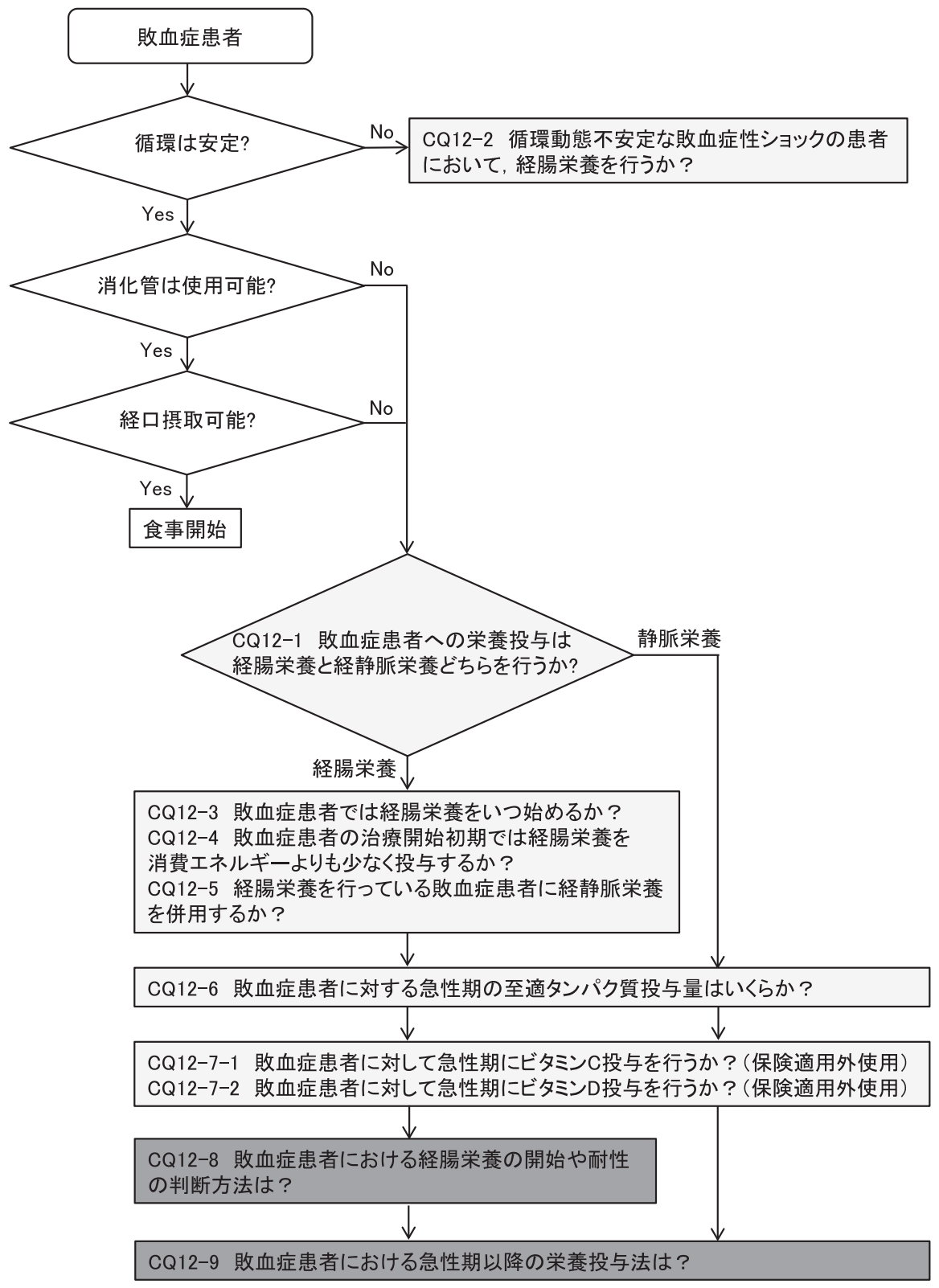

敗血症患者の栄養療法〔診療フロー〕 
[病原体関連分子パターン（pathogen-associated molecular patterns: PAMPs)］。そこで，経腸栄養が静脈 栄養に比較して実際に益があるかについて検討を行つ た。CQ12-2では, 循環動態が不安定な患者において 経腸栄養を開始することの益と害について, システマ ティックレビューを実施した。特に, 循環動態不安定 な患者における経腸栄養で問題となる腸管虚血・虚血 性腸炎など重篤な消化管系合併症を重大なアウトカム として設定した。CQ12-3 は, 早期, すなわち重症病 態への治療開始後 24〜 48 時間以内に経腸栄養を開始 することが，それ以降に開始する場合と比較して益と 害のバランスがどうかについて検討を行った。

CQ12-4 では, 経腸栄養の栄養投与量に関して検討 した。システマティックレビューでは, 消費エネル ギーよりも少ないエネルギー投与量と消費エネルギー 程度の投与量を行う群での比較を行った。前者には, 腸管粘膜や免疫能維持などを目的とした消費エネル ギー量の $1 / 4$ や $500 \mathrm{kcal} /$ 日（20kcal/hr）程度の低容量 投与（trophic feeding）や，酸化ストレスやオートファ ジー障害などを避ける目的で, 消費エネルギー量の 60〜 70\% 程度が投与される軽度エネルギー制限投与 (permissive underfeeding/hypofeeding) が含まれる。後 者には, 少量の投与から開始し, 最終的に消費エネル ギー量に見合う量を投与する場合や，投与開始時から 消費エネルギー量に見合う量の投与をめざし，胃残量 の増加や下㾥などの不耐性が出現したら減量する方法 が含まれている。CQ12-5 では, 経腸栄養のみでは目 標とするエネルギー量を投与できない場合に，補足的 な経静脈栄養を追加するかどうかについての検討を 行った。CQ12-6では, 急性期の至適タンパク質投与 量について検討を行った。本邦でのタンパク質投与量

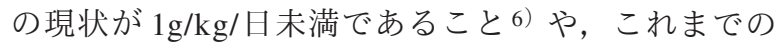
ガイドライン 7-9) での推奨の下限值が $1.2 \sim 1.3 \mathrm{~g} / \mathrm{kg}$ /日 であることを踏まえて，システマティックレビューで は $1 \mathrm{~g} / \mathrm{kg}$ /日未満の投与量と $1 \mathrm{~g} / \mathrm{kg} /$ 日以上の投与量での 比較を行った。

CQ12-7では，ビタミン C とビタミン D の投与に関 する検討を行った。ビタミンCについては，重症敗 血症, 敗血症性ショック患者に対してビタミン $\mathrm{C}$ を 投与することで院内死亡率が顕著に改善したとする報 告 10) がなされて以降，注目されるようになった。し かしながら，2020 年に発表された RCTでは，28 日死 亡，90 日死亡とも改善しないことが示された ${ }^{11) 。 ヒ ゙ ~}$ タミン Dについても，ビタミン D が欠乏した集中治 療患者では予後が悪いという報告 ${ }^{12)}$ があり, 補充す ることで死亡率を改善する傾向があったとする
RCT 13）もある。2019 年に発表された RCT では，ビ タミン D の有益性は否定される結果となった ${ }^{14)}$ 。そ こで，ビタミン C とビタミン $\mathrm{D}$ 投与の効果に関し, システマティックレビューを行い検証した。

CQ12-8 は経腸栄養の開始や耐性の判断方法につい て，CQ12-9 は急性期以降の栄養療法に関するそれぞ れ情報提供を行う BQ である。それぞれ栄養療法を実 施するうえで重要な臨床課題であり，敗血症の臨床現 場で知識として役立てていただければ幸いである。

\section{文 献}

1) Hasselgren PO: Catabolic response to stress and injury: Implications for regulation. World J Surg. 2000; 24: 1452-9.

2) Demling RH, Seigne P: Metabolic management of patients with severe burns. World J Surg. 2000; 24: 673-80.

3) Hill AG, Hill GL: Metabolic response to severe injury. Br J Surg. 1998; 85: 884-90.

4) Ali NA, O’Brien JM Jr, Hoffmann SP, et al: Acquired weakness, handgrip strength, and mortality in critically III patients. Am J Respir Crit Care Med. 2008; 178: 261-8.

5) Elamin EM, Camporesi E: Evidence-based nutritional support in the intensive care unit. Int Anesthesiol Clin. 2009; 47: 121-38.

6) Yatabe $\mathrm{T}$, Egi M, Sakaguchi $\mathrm{M}$, et al: Influence of nutritional management and rehabilitation on physical outcome in Japanese intensive care unit patients: A multicenter observational study. Ann Nutr Metab. 2019; 74: 35-43.

7) Singer P, Blaser AR, Berger MM, et al: ESPEN guideline on clinical nutrition in the intensive care unit. Clin Nutr. 2019; 38: 48-79.

8) McClave SA, Taylor BE, Martindale RG, et al: Guidelines for the Provision and Assessment of Nutrition Support Therapy in the Adult Critically Ill Patient: Society of Critical Care Medicine (SCCM) and American Society for Parenteral and Enteral Nutrition (A.S.P.E.N.). JPEN J Parenter Enteral Nutr. 2016; 40: 159-211.

9） 日本集中治療医学会重症患者の栄養管理ガイドライン作成 委員会: 日本版重症患者の栄養療法ガイドライン. 日集中医 誌. 2016; 23: 185-281.

10) Marik PE, Khangoora V, Rivera R, et al: Hydrocortisone, Vitamin $\mathrm{C}$, and Thiamine for the Treatment of Severe Sepsis and Septic Shock: A Retrospective Before-After Study. Chest. 2017; 151: 1229-38.

11) Fujii T, Luethi N, Young PJ, et al: Effect of Vitamin C, Hydrocortisone, and Thiamine vs Hydrocortisone Alone on Time Alive and Free of Vasopressor Support among Patients with Septic Shock: The VITAMINS Randomized Clinical Trial. JAMA. 2020; 323: 423-31.

12) Braun AB, Gibbons FK, Litonjua AA, et al: Low serum 25-hydroxyvitamin $\mathrm{D}$ at critical care initiation is associated with increased mortality. Crit Care Med. 2012; 40: 63-72.

13) Amrein K, Schnedl C, Holl A, et al: Effect of High-Dose Vitamin D 3 on Hospital Length of Stay in Critically Ill Patients With Vitamin D Deficiency. JAMA. 2014; 312: 1520-30.

14) Ginde AA, Brower RG, Caterino JM, et al: Early high-dose Vitamin D3 for critically ill, Vitamin D-deficient patients. N Engl J Med. 2019; 381: 2529-40. 
CQ12-1：敗血症患者への栄養投与は経腸栄養と 経静脈栄養のどちらを行うか?

Answer : 敗血症患者への栄養投与は経腸栄養で行う ことを弱く推奨する（GRADE 2D：エビデンスの確実 性 $=「$ 非常に低」)。

\section{（1）背景および本 $C Q$ の重要度}

食事摂取不可能な敗血症患者には栄養療法を計画す る必要があるが，経腸栄養は腸管機能と腸内細菌叢の 保全により免疫防御機構の維持に貢献し，患者の予後 や感染症発生率を改善させるといわれている。一方, 経静脈栄養は確実な栄養投与を行うことができ，循環 不安定な場合や腸閉塞などの状況でも栄養投与が可能 である。経腸栄養と経静脈栄養のいずれがより有益で あるかを明確にすることは，栄養計画の初期戦略を考 えるうえで重要であり，本ガイドラインに取り上げる ベき重要臨床課題であると考える。

\section{(2) PICO}

$P$ (患者)：成人集中治療患者

I（介入）：経腸栄養を行う

C (対照) : 経静脈栄養を行う
$\mathrm{O}$ (アウトカム ) : 死亡, 病院滞在日数, 人工呼吸期 間，すべての感染症発生

（3）エビデンスの要約

システマティックレビューの結果, PICO に合致し たランダム化比較試験（RCT）が 24 件 1-24）施行され ておりこれらを用いたメタ解析を実施した。

(4) 益と害のバランス（Table 12-1-1） 望ましい効果：

敗血症（血流感染）発生に関する効果推定值は，リ スク差（RD）1,000 人あたり19人少ない（95\% CI: 32 人少ない〜 4 人多い）であり（9 RCT， 2,976人), 肺炎に関する効果推定值は，RD 1,000人あたり 18 人 少ない $(95 \%$ CI: 41 人少ない〜 12 人多い) であり（8 RCT, 3,066 人), 腹部感染症に関する効果推定值は, RD 1,000 人あたり 39 人少ない $(95 \% \mathrm{CI}: 46$ 人少な い〜30 人少ない）であり（7 RCT， 3,159 人)，人工呼 吸期間に関する効果推定值は，平均（MD）0.36日短 い $(95 \%$ CI: 0.93 日短い〜 0.2 日長い) であり（4 RCT, 563 人), 病院滞在日数に関する効果推定值は, MD 2.51 日短い（95\% CI: 4.78 日短い〜 0.24 日短い）であ る (10 RCT, 5,515 人)。望ましい効果は「中」であ

Table 12-1-1エビデンスプロファイル

\begin{tabular}{|c|c|c|c|c|c|c|c|c|c|c|c|c|}
\hline \multicolumn{7}{|c|}{ 確実性の評価 } & \multicolumn{2}{|c|}{ 患者数 } & \multicolumn{2}{|c|}{ 効果 } & \multirow[b]{2}{*}{ 確実性 } & \multirow[b]{2}{*}{ 重要性 } \\
\hline 研究数 & $\begin{array}{c}\text { 研究 } \\
\text { デザイン }\end{array}$ & $\begin{array}{l}\text { バイアス } \\
\text { のリスク }\end{array}$ & 非一貫性 & 非直接性 & 不精確性 & $\begin{array}{l}\text { その他 } \\
\text { の検討 }\end{array}$ & EN & PN & $\begin{array}{l}\text { 相対指標 } \\
(95 \% \text { CI }\end{array}$ & $\begin{array}{l}\text { 絶対指標 } \\
(95 \% \mathrm{CI})\end{array}$ & & \\
\hline \multicolumn{13}{|l|}{90 日死亡 } \\
\hline 4 & RCT & 深刻 a & 深刻でない & 深刻でない & 深刻でない & なし & $\begin{array}{c}1015 / 2424 \\
(41.9 \%)\end{array}$ & $\begin{array}{c}962 / 2420 \\
(39.8 \%)\end{array}$ & $\begin{array}{c}\text { RR } 1.05 \\
\text { (0.95 to } 1.17)\end{array}$ & $\begin{array}{l}1,000 \text { 人あたり } 20 \\
\text { 人多い } 20 \text { 人少な } \\
\text { い 68人多い) }\end{array}$ & $\begin{array}{c}\oplus \oplus \oplus \bigcirc \\
\text { 中 }\end{array}$ & 重大 \\
\hline \multicolumn{13}{|c|}{ 病院滞在日数 } \\
\hline 10 & RCT & 非常に深刻 b & 非常に深刻 c & 深刻 d & 深刻 e & なし & 2767 & 2748 & - & $\begin{array}{c}\text { 平均 } 2.51 \text { 日短い } \\
(4.78 \text { 日短い } \\
0.24 \text { 日短い) }\end{array}$ & $\begin{array}{l}\oplus \bigcirc 00 \\
\text { 非常に低 }\end{array}$ & 重大 \\
\hline \multicolumn{13}{|c|}{ 人工呼吸期間 } \\
\hline 4 & RCT & 非常に深刻 b & 非常に深刻。 & 深刻でない & 深刻” & なし & 277 & 286 & - & $\begin{array}{c}\text { 平均 } 0.36 \text { 日短い } \\
(0.93 \text { 日短い } \\
0.2 \text { 日長い) }\end{array}$ & $\begin{array}{l}\oplus \bigcirc 00 \\
\text { 非常に低 }\end{array}$ & 重大 \\
\hline \multicolumn{13}{|c|}{ 敗血症（血流感染） } \\
\hline 9 & RCT & 非常に深刻 b & 深刻でない & 深刻でない & 深刻 e & なし & $\begin{array}{c}52 / 1,479 \\
(3.5 \%)\end{array}$ & $\begin{array}{c}82 / 1,497 \\
(5.5 \%)\end{array}$ & $\begin{array}{c}\text { RR } 0.66 \\
(0.41 \text { to } 1.07)\end{array}$ & $\begin{array}{c}1,000 \text { 人あたり } 19 \\
\text { 人少ない } \\
(32 \text { 人少ない 4 } \\
\text { 人多い) }\end{array}$ & $\begin{array}{l}\oplus \bigcirc 0 \bigcirc \\
\text { 非常に低 }\end{array}$ & 重大 \\
\hline \multicolumn{13}{|c|}{ 肺炎（人工呼吸器関連肺资）発生 } \\
\hline 8 & RCT & 深刻 a & 深刻でない & 深刻でない & 深刻 e & なし & $\begin{array}{c}150 / 1,520 \\
(9.9 \%)\end{array}$ & $\begin{array}{c}181 / 1,546 \\
(11.7 \%)\end{array}$ & $\begin{array}{c}\operatorname{RR~} 0.85 \\
(0.65 \text { to } 1.10)\end{array}$ & $\begin{array}{l}1,000 \text { 人あたり } 18 \\
\text { 人少ない (41 人少 } \\
\text { ない 12 人多い) }\end{array}$ & $\underset{\text { 低 }}{\oplus \oplus \bigcirc \bigcirc}$ & 重大 \\
\hline \multicolumn{13}{|c|}{ 腹部感染（腹腔内膿瘍，壊死性膵资） } \\
\hline 7 & RCT & 深刻 a & 深刻でない & 深刻でない & 深刻でない & なし & $\begin{array}{l}48 / 1,612 \\
(3.0 \%)\end{array}$ & $\begin{array}{c}100 / 1,547 \\
(6.5 \%)\end{array}$ & $\begin{array}{c}\text { RR } 0.39 \\
(0.29 \text { to } 0.53)\end{array}$ & $\begin{array}{c}\text { 1,000 人あたり } 39 \\
\text { 人少ない (46人少 } \\
\text { ない } 30 \text { 人少な } \\
\text { ( ) }\end{array}$ & $\begin{array}{c}\oplus \oplus \oplus \bigcirc \\
\text { 中 }\end{array}$ & 重大 \\
\hline
\end{tabular}

．患者医療者の盲検化が出来ていない：1レベルグレードダウン

b. 割付隱蔽化，ランダム化，患者医療者の盲検化が出来ていない：2 レベルグレードダウン

c. 点推定値のばらつきが大きく，信頼区間が広く，異質性検定で $P\left\langle 0.01\right.$, かつ $\mathrm{I}^{2}$ が大きい : 2 レベルグレードダウン

d. 病院滞在日数の平均と標準偏差が研究によってあまりにも異なる。病院滞在日数という概念は同じだが，意味するところは研究（国）によって大きく異なることを示している可能性がある。例えば, 本邦だと自宅退院可能程度まで入院継続してから退院となるが，アメリカなどは超急性期の根治的治療が終了したらすぐに療養施設へ退院することなり，そこで自宅退院可能な程度まで入院することに なる。したがって最初の施設の病院滞在日数はとても短くなる。このような影響があると考え 1 レベルグレードダウンとした。

e. 信頼区間が臨床的推奨非推罢決定領域を片側またいでいる：1レベルグレードダウン 
ると判断した。

望ましくない効果 :

90 日死亡に関する効果推定值は，RD 1,000 人あた り 20 人多い $(95 \% \mathrm{CI}: 20$ 人少ない〜 68 人多い) で あった（4 RCT，4,844人)。望ましくない効果はわず かであると判断した。

益と害のバランス :

アウトカムの相対的価值を考慮しない場合でも，ま た，死亡に関する相対的価值を 3 倍と考慮した場合に おいても対照群において害が多いため，おそらく介入 が優位であると判断する。

\section{（5）アウトカム全般に関するエビデンスの確実性}

各アウトカムが益と害の異なる方向性を示してお り，重大なアウトカムに関するエビデンスの確実性の 中でも最も低い GRADE を採用することになり，最も 低い「非常に低」とした。

\section{（6）価値観}

栄養療法におけるアウトカムに関する価值観につい てのデータはない。一般的に死亡に対して置く相対的 価值は高く，そのばらつきは少ないことが予想され る。

\section{（7）容認性}

経腸栄養剤は多くの場合，食事として提供されるた め食事療養標準負担額となる。経静脈栄養は 1 日の薬 価が約 1,000〜2,000 円である。いずれの場合でも容認 されると考えられる。経鼻胃管の留置はリスクが少な
く許容されるだろう。中心静脈カテーテルは循環作動 薬の投与などのために挿入されている場合は問題にな らないが，栄養療法のためだけに留置する場合は，リ スクを考慮する必要がある。

（8）実行可能性

一般的な処置であり，どの病院においても実行可能 性は高いといえる。

（9）判断の要約（Table 12-1-2）

（10）推奨グレーディング決定の工程

修正 RAND 法を用いた投票によって，中央值 8, 見解不一致指数 0.164 の結果となり, 委員会で採択さ れた（7 点以上：95.8\%）。

\section{（11）関連する他の診療ガイドラインにおける推奨}

他のガイドラインとして, American Society for Parenteral and Enteral Nutrition/Society of Critical Care Medicie（ASPEN/SCCM）ガイドライン, European Society for Clinical Nutrition and Metabolism (ESPEN) ガイドラインが挙げられる 25,26$) 。$

ASPEN/SCCM ガイドラインでは, 栄養サポートが 必要な重症患者に対して, 経静脈栄養よりも経腸栄養 を推奨している。ESPEN ガイドラインでは, 経口捸 取ができない場合，経静脈栄養よりも経腸栄養を 48 時間以内に投与することを推奨している。

Table 12-1-2 判断の要約

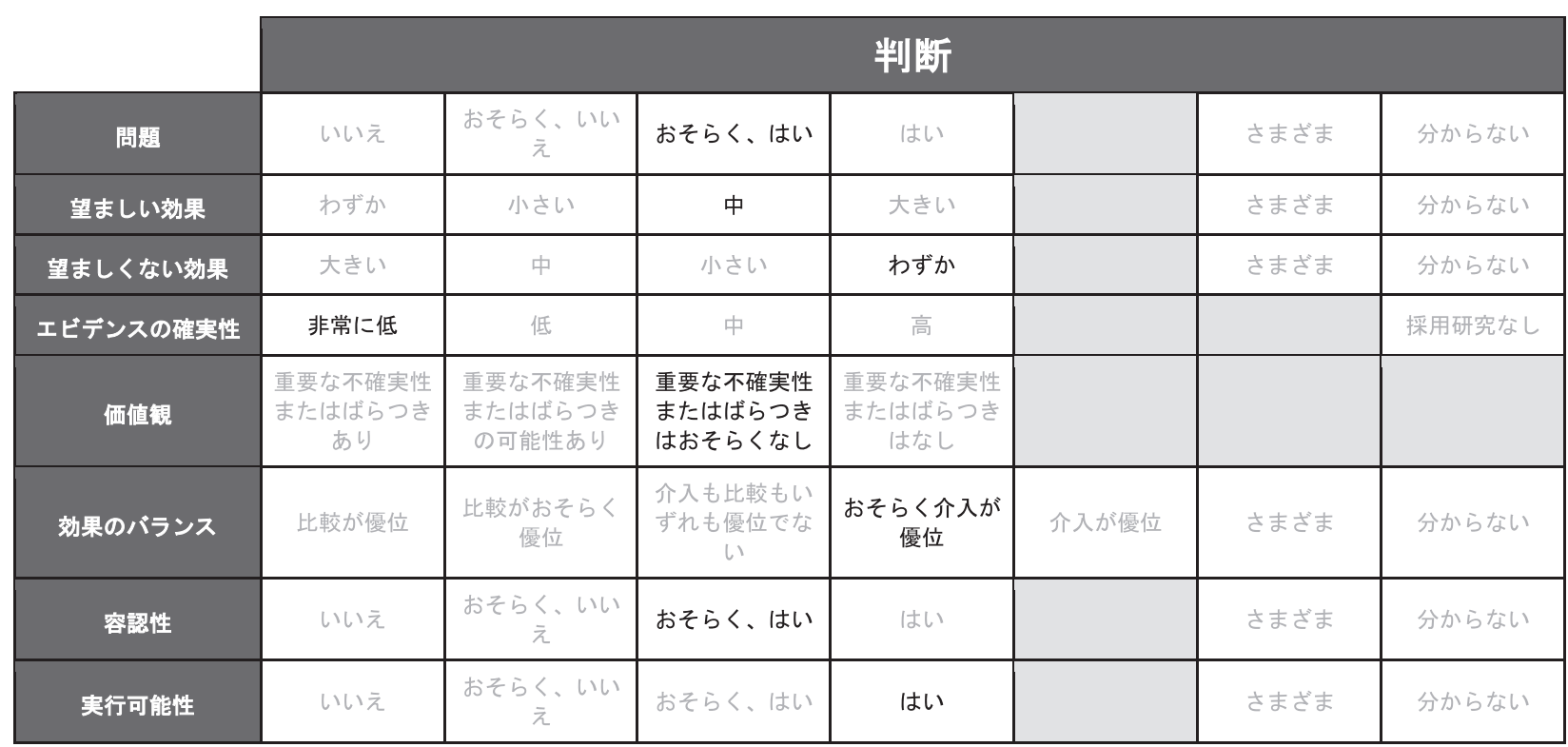




\section{（12）実施に関わる検討事項}

経腸栄養の実施にあたっては循環動態の安定ができ

ているかの検討が必要である。

\section{（13）今後の研究の可能性}

今後, 投与経路の違いが身体機能などのアウトカム に影響を与えるかに関する研究が行われることが望ま れる。

\section{文 献}

1) Rapp RP, Young B, Twyman D, et al: The favorable effect of early parenteral feeding on survival in head-injured patients. $\mathrm{J}$ Neurosurg. 1983; 58: 906-12.

2) Moore EE, Jones TN: Benefits of immediate jejunostomy feeding after major abdominal trauma -- a prospective, randomized study. J Traumac. 1986; 26: 874-81.

3) Young B, Ott L, Twyman D, et al: The effect of nutritional support on outcome from severe head injury Patient Population and Clinical Therapy. J Neurosurg. 1987; 67: 668-76.

4) Cerra FB, McPherson JP, Konstantinides FN, et al: Enteral nutrition does not prevent multiple organ failure syndrome (MOFS) after sepsis. Surgery. 1988; 104: 727-33.

5) Kudsk KA: Gut mucosal nutritional support - Enteral nutrition as primary therapy after multiple system trauma. Gut. 1994; 35: S52-4.

6) Hadfield RJ, Sinclair DG, Houldsworth PE, et al: Effects of enteral and parenteral nutrition on gut mucosal permeability in the critically ill. Am J Respir Crit Care Med. 1995; 152: 1545-8.

7) McClave SA, Greene LM, Snider HL, et al: Comparison of the safety of early enteral vs parenteral nutrition in mild acute pancreatitis. JPEN J Parenter Enteral Nutr. 1997; 21: 14-20.

8) Windsor AC, Kanwar S, Li AG, et al: Compared with parenteral nutrition, enteral feeding attenuates the acute phase response and improves disease severity in acute pancreatitis. Gut. 1998; 42: 431-5.

9) Pupelis G, Austrums E, Jansone A, et al: Randomised trial of safety and efficacy of postoperative enteral feeding in patients with severe pancreatitis: Preliminary report. Eur J Surg. 2000; 166: 383-7.

10) Bertolini G, Iapichino G, Radrizzani D, et al: Early enteral immunonutrition in patients with severe sepsis: Results of an interim analysis of a randomized multicentre clinical trial. Intensive Care Med. 2003; 29: 834-40.

11) Gupta R, Patel K, Calder PC, et al: A randomised clinical trial to assess the effect of total enteral and total parenteral nutritional support on metabolic, inflammatory and oxidative markers in patients with predicted severe acute pancreatitis (APACHE II > or =6). Pancreatology. 2003; 3: 406-13.

12) Louie BE, Noseworthy T, Hailey D, et al: 2004 MacLean-Mueller Prize Enteral or parenteral nutrition for severe pancreatitis: A randomized controlled trial and health technology assessment. Can J Surg. 2005; 48: 298-306.

13) Petrov MS, Kukosh MV, Emelyanov NV: A randomized controlled trial of enteral versus parenteral feeding in patients with predicted severe acute pancreatitis shows a significant reduction in mortality and in infected pancreatic complications with total enteral nutrition. Dig Surg. 2006; 23: 336-44.

14) Radrizzani D, Bertolini G, Facchini R, et al: Early enteral immunonutrition vs. parenteral nutrition in critically ill patients without severe sepsis: A randomized clinical trial. Intensive Care Med. 2006; 32: 1191-8.
15) Eckerwall GE, Axelsson JB, Andersson RG: Early nasogastric feeding in predicted severe acute pancreatitis: A clinical, randomized study. Ann Surg. 2006; 244: 959-65; discussion 965-7.

16) Wu XM, Ji KQ, Wang HY, et al: Total Enteral Nutrition in Prevention of Pancreatic Necrotic Infection in Severe Acute Pancreatitis. Pancreas. 2010; 39: 248-51.

17) Altintas ND, Aydin K, Türkoğlu MA, et al: Effect of enteral versus parenteral nutrition on outcome of medical patients requiring mechanical ventilation. Nutr Clin Pract. 2011; 26: $322-9$.

18) Justo Meirelles CM, de Aguilar-Nascimento JE: Nutrición enteral o parenteral en lesión traumatica cerebral: Un estudio prospectivo y randomizado. Nutr Hosp. 2011; 26: 1120-24.

19) Aydoğmuș MT, Tomak Y, Tekin M, et al: Glutamine supplemented parenteral nutritionto prevent ventilator-associated pneumonia in the intensive care unit. Balkan Med J. 2012; 29: 414-8.

20) Wang G, Wen J, Xu L, et al: Effect of enteral nutrition and ecoimmunonutrition on bacterial translocation and cytokine production in patients with severe acute pancreatitis. J Surg Res. 2013; 183: 592-7.

21) Harvey SE, Parrott F, Harrison DA, et al: Trial of the route of early nutritional support in Critically ill adults. N Engl J Med. 2014; 371: 1673-84.

22) Wan B, Fu H, Yin J, et al: Efficacy of rhubarb combined with early enteral nutrition for the treatment of severe acute pancreatitis: a randomized controlled trial. Scand J Gastroenterol. 2014; 49: 1375-84.

23) Reignier J, Boisramé-Helms J, Brisard L, et al: Enteral versus parenteral early nutrition in ventilated adults with shock: a randomised, controlled, multicentre, open-label, parallel-group study (NUTRIREA-2). Lancet. 2018; 391: 133-43.

24) Liu QY, Li JF, Liang X: Comparison of the clinical efficacy between the early enteral nutrition and parenteral nutrition on patients after liver transplantation. Acta Medica Mediterr. 2018; 34: 859-63.

25) McClave SA, Taylor BE, Martindale RG, et al: Guidelines for the Provision and Assessment of Nutrition Support Therapy in the Adult Critically Ill Patient: Society of Critical Care Medicine (SCCM) and American Society for Parenteral and Enteral Nutrition (A.S.P.E.N.). JPEN J Parenter Enteral Nutr. 2016; 40: 159-211.

26) Singer P, Blaser AR, Berger MM, et al: ESPEN guideline on clinical nutrition in the intensive care unit. Clin Nutr. 2019; 38: 48-79. 
CQ12-2：循環動態不安定な敗血症性ショックの 患者において, 経腸栄養を行うか?

Answer : 循環動態不安定な敗血症性ショックの患者 において，経腸栄養を行わないことを弱く推奨する (GRADE 2D : エビデンスの確実性 =「非常に低」)。

\section{（1）背景および本 $C Q$ の重要度}

敗血症患者では，早期経腸栄養が腸管免疫や予後に も重要と考えられ1,2), 経腸栄養の遅れはエネルギー 負債にも結びつく3)。しかし，不安定な循環動態のも とで経腸栄養を投与すると，腸管栄養不耐や虚血性腸 炎などの腸管トラブルを生じるリスクが考えられ4), 敗血症性ショック下の早期経腸栄養の是非に関しては 議論が必要である。

経腸栄養を開始できる循環動態の目安に関するコン センサスはなく，臨床現場では主治医判断や施設ごと の方針で経腸栄養を開始しており，何らかの基準が求 められている。したがって, 循環動態不安定な患者で 経腸栄養と経静脈栄養の益と害のバランスを明確にす ることは，重要臨床課題であると考える。
(2) PICO

P (患者)：血管作動薬を投与されている集中治療患 者，もしくは血圧が低い集中治療患者

I（介入）：経腸栄養を行う

C (対照) : 経静脈栄養を行う

$\mathrm{O}$ (アウトカム) : 死亡, 病院滞在日数, あらゆる重 篤な副作用，感染症発生，腸管虚血など重篤な消 化管系合併症

\section{（3）エビデンスの要約}

システマティックレビューの結果，PICO に合致し たランダム化比較試験（RCT）が 1 件 5) 施行されて おり，これを用いたメタ解析を実施した。

\section{（4）益と害のバランス（Table 12-2-1）}

望ましい効果：

集中治療室獲得感染症に関する効果推定值は，リス ク差（RD）1,000 人あたり 16 人少ない（95\% CI: 42 人少ない〜 13 人多い）であり, 病院滞在日数は平均 （MD）1 日短い（95\% CI: 2.42 日短い〜0.42 日長い） である（いずれも RCT 1，2,410人)。望ましい効果は わずかであると判断した。

望ましくない効果 :

Table 12-2-1エビデンスプロファイル

\begin{tabular}{|c|c|c|c|c|c|c|c|c|c|c|c|c|}
\hline \multicolumn{7}{|c|}{ 確実性の評価 } & \multicolumn{2}{|c|}{ 患者数 } & \multicolumn{2}{|c|}{ 効果 } & \multirow[b]{2}{*}{ 確実性 } & \multirow[b]{2}{*}{ 重要性 } \\
\hline 研究数 & $\begin{array}{l}\text { 研究 } \\
\text { デザイン }\end{array}$ & $\begin{array}{l}\text { バイアス } \\
\text { のリスク }\end{array}$ & 非一貫性 & 非直接性 & 不精確性 & $\begin{array}{l}\text { その他 } \\
\text { の検討 }\end{array}$ & $\begin{array}{l}\text { mortality on } \\
\text { day } 90\end{array}$ & placebo & $\begin{array}{l}\text { 相対指標 } \\
(95 \% \mathrm{Cl})\end{array}$ & $\begin{array}{l}\text { 絶対指標 } \\
(95 \% \text { CI) }\end{array}$ & & \\
\hline \multicolumn{13}{|c|}{ 病院滞在日数 } \\
\hline 1 & RCT & 深刻a & 深刻でない & 深刻でない & 深刻でない & なし & 1202 & 1208 & - & $\begin{array}{l}\text { 平均 } 1 \text { 日短い } \\
(2.42 \text { 日短い } \\
0.42 \text { 日長い) }\end{array}$ & $\begin{array}{c}\oplus \oplus \oplus \bigcirc \\
\text { 中 }\end{array}$ & 重大 \\
\hline \multicolumn{13}{|c|}{90 日死亡 } \\
\hline 1 & $\mathrm{RCT}$ & 深刻でないa & 深刻でない & 深刻でない & 深刻でない & なし & $\begin{array}{c}530 / 1202 \\
(44.1 \%)\end{array}$ & $\begin{array}{c}507 / 1208 \\
(42.0 \%)\end{array}$ & $\begin{array}{c}\text { RR } 1.05 \\
(0.96 \text { to } 1.15)\end{array}$ & $\begin{array}{l}1,000 \text { 人あたり } 21 \\
\text { 人多い (17 人少な } \\
\text { い〜 } 63 \text { 人多い) }\end{array}$ & 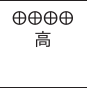 & 重大 \\
\hline \multicolumn{13}{|c|}{ 消化管偽性腸閉塞 } \\
\hline 1 & RCT & 深刻 a & 深刻でない & 深刻でない & 深刻 b & なし & $\begin{array}{c}11 / 1202 \\
(0.9 \%)\end{array}$ & $3 / 1208(0.2 \%)$ & $\begin{array}{c}\text { RR } 3.69 \\
\text { (1.03 to } 12.93)\end{array}$ & $\begin{array}{l}1,000 \text { 人あたり } 7 \\
\text { 人多い (0人少な } \\
\text { い〜30人多い) }\end{array}$ & $\begin{array}{c}\oplus \oplus \bigcirc \bigcirc \\
\text { 低 }\end{array}$ & 重大 \\
\hline \multicolumn{13}{|c|}{ 集中治療室獲得感染症 } \\
\hline 1 & $\mathrm{RCT}$ & 深刻 a & 深刻でない & 深刻でない & 深刻 b & なし & $\begin{array}{c}173 / 1202 \\
(14.4 \%)\end{array}$ & $\begin{array}{c}194 / 1208 \\
(16.1 \%)\end{array}$ & $\begin{array}{c}\text { RR } 0.90 \\
(0.74 \text { to } 1.08)\end{array}$ & $\begin{array}{l}\text { 1,000 人あたり } 16 \\
\text { 人少ない }(42 \text { 人少 } \\
\text { ない 13 人多い) }\end{array}$ & $\begin{array}{c}\oplus \oplus \bigcirc \bigcirc \\
\text { 低 }\end{array}$ & 重大 \\
\hline \multicolumn{13}{|l|}{ 腸管虚血 } \\
\hline 1 & RCT & 深刻 a & 深刻でない & 深刻でない & 非常に深刻 b & なし & $\begin{array}{c}19 / 1202 \\
(1.6 \%)\end{array}$ & $5 / 1208(0.4 \%)$ & $\begin{array}{c}\text { RR } 3.82 \\
\text { (1.43 to } 10.19)\end{array}$ & $\begin{array}{c}1,000 \text { 人あたり } 12 \\
\text { 人多い (2人多い〜 } \\
38 \text { 人多い) }\end{array}$ & $\begin{array}{l}\oplus \bigcirc \bigcirc \bigcirc \\
\text { 非常に低 }\end{array}$ & 重大 \\
\hline \multicolumn{13}{|l|}{ 嘔吐 } \\
\hline 1 & RCT & 深刻 a & 深刻でない & 深刻でない & 深刻でない & なし & $\begin{array}{c}406 / 1202 \\
(33.8 \%)\end{array}$ & $\begin{array}{c}246 / 1208 \\
(20.4 \%)\end{array}$ & $\begin{array}{c}\text { RR } 1.66 \\
(1.46 \text { to } 1.87)\end{array}$ & \begin{tabular}{|c|}
1,000 人あたり \\
134 人多い (94人 \\
多い〜 177 人多 \\
い)
\end{tabular} & $\begin{array}{c}\oplus \oplus \oplus \bigcirc \\
\text { 中 }\end{array}$ & 重要 \\
\hline \multicolumn{13}{|l|}{ 下痢 } \\
\hline 1 & $\mathrm{RCT}$ & 深刻 a & 深刻でない & 深刻でない & 深刻でない & なし & $\begin{array}{c}432 / 1202 \\
(35.9 \%)\end{array}$ & $\begin{array}{c}393 / 1208 \\
(32.5 \%)\end{array}$ & $\begin{array}{c}\text { RR } 1.10 \\
(0.99 \text { to } 1.23)\end{array}$ & $\begin{array}{l}1,000 \text { 人あたり } 33 \\
\text { 人多い (3 人少な } \\
\text { い〜 } 75 \text { 人多い) }\end{array}$ & $\begin{array}{c}\oplus \oplus \oplus \bigcirc \\
\text { 中 }\end{array}$ & 重要 \\
\hline
\end{tabular}


90 日死亡に関する効果推定值は，RD 1,000 人あた り 21 人多い $(95 \% \mathrm{CI}: 17$ 人少ない〜 63 人多い) であ り，消化管偽性腸閉塞に関する効果推定值は，RD 1,000 人あたり 7 人多い $(95 \% \mathrm{CI}: 0$ 人少ない〜 30 人 多い）であり，腸管虚血に関する効果推定值は，RD 1,000 人あたり 12 人多い $(95 \%$ CI: 2 人多い〜 38 人多 い）である（いずれも RCT 1，2,410人）。望ましくな い効果は小さいと判断した。

\section{益と害のバランス :}

アウトカムの相対的価值を考慮しない場合でも，ま た，死亡に関する相対的価值を 3 倍と考慮した場合に おいても害が益を上回るため，おそらく比較が優位で あると判断する。

\section{（5）アウトカム全般に関するエビデンスの確実性}

各アウトカムが益と害の異なる方向性を示してお り，重大なアウトカムに関するエビデンスの確実性の 中でも最も低い GRADE を採用することになり，最も 低い「非常に低」とした。

\section{（6）価値観}

栄養療法におけるアウトカムに関する価值観につい てのデータはない。一般的に死亡に対して置く相対的 価值は高く，そのばらつきは少ないことが予想され る。

\section{（7）容認性}

経腸栄養剤は多くの場合，食事として提供されるた め食事療養標準負担額となる。経静脈栄養は 1 日の薬
価が約 1,000〜2,000 円である。いずれの場合でも容認 されると考えられる。経鼻胃管の留置はリスクが少な く許容されるだろう。中心静脈カテーテルは, 循環作 動薬の投与などのために挿入されている場合は問題に ならないが，栄養療法のためだけに留置する場合は， リスクを考慮する必要があるものの，一般的な処置で あり，容認性は高い。

\section{（8）実行可能性}

一般的な処置であり，どの病院においても実行可能 性は高いといえる。

(9) 判断の要約 (Table 12-2-2)

（10）推奨グレーディング決定の工程

修正 RAND 法を用いた投票によって，中央值 8, 見解不一致指数 0.164 の結果となり，委員会で採択さ れた（7 点以上 : $95.8 \%) 。$

（11）関連する他の診療ガイドラインにおける推奨 ESPEN $^{6)}$ やASPEN/SCCM ${ }^{7)}$ によるガイドライン においても，循環不安定な場合は経腸栄養の実施を避 けるべきとしている。

\section{（12）実施に関わる検討事項}

採用した RCT は 1 つしかなく，エビデンスの確実 性も「非常に低」である。個々の症例ごとにショック が改善しているのか悪化しているのかなど，様々な状 況を考慮して，いずれの栄養療法を行うか検討する必

Table 12-2-2 判断の要約

\begin{tabular}{|c|c|c|c|c|c|c|c|}
\hline & \multicolumn{7}{|c|}{ 判断 } \\
\hline 問題 & いいえ & $\begin{array}{c}\text { おそらく、いい } \\
\text { え }\end{array}$ & おそらく、はい & はい & & さまざま & 分からない \\
\hline 望ましい勃果 & わずか & 小さい & 中 & 大きい & & さまざま & 分からない \\
\hline 望ましくない効果 & 大きい & 中 & 小さい & わずか & & さまざま & 分からない \\
\hline エビデンスの確実性 & 非常に低 & 低 & 中 & 高 & & & 採用研究なし \\
\hline 価值钼 & $\begin{array}{c}\text { 重要な不確実性 } \\
\text { またはばらつき } \\
\text { あり }\end{array}$ & $\begin{array}{l}\text { 重要な不確実性 } \\
\text { またはばらつき } \\
\text { の可能性ありり }\end{array}$ & $\begin{array}{l}\text { 重要な不確実性 } \\
\text { またはばらつき } \\
\text { はおそらくなし }\end{array}$ & $\begin{array}{c}\text { 重要な不確実性 } \\
\text { またはばらつき } \\
\text { はなし }\end{array}$ & & & \\
\hline 勃果のパランス & 比較が優位 & $\begin{array}{c}\text { 比較がおそらく } \\
\text { 優位 }\end{array}$ & $\begin{array}{c}\text { 介入も比較もい } \\
\text { ずれも優位でな } \\
\text { い }\end{array}$ & $\begin{array}{c}\text { おそらく介入が } \\
\text { 優位 }\end{array}$ & 介入が優位 & さまざま & 分からない \\
\hline 容認性 & いいえ & $\begin{array}{c}\text { おそらく、いい } \\
\text { え }\end{array}$ & おそらく、はい & はい & & さまざま & 分からない \\
\hline 実行可能性 & いいえ & $\begin{array}{c}\text { おそらく、いい } \\
\text { え }\end{array}$ & おそらく、はい & はい & & さまざま & 分からない \\
\hline
\end{tabular}


要がある。

\section{（13）今後の研究の可能性}

今後，昇圧薬の使用量の闇值，平均血圧の閾值や投 与量, 投与組成などに注目したさらなる研究が行われ ることが望まれる。

\section{文 献}

1) Lipman TO: Grains or veins: Is enteral nutrition really better than parenteral nutrition? A look at the evidence. JPEN J Parenter Enteral Nutr. 1998; 22: 167-82.

2) Marik PE, Zaloga GP: Early enteral nutrition in acutely ill patients: A systematic review. Crit Care Med. 2001; 29: 2264-70.

3) Villet S, Chiolero RL, Bollmann MD, et al: Negative impact of hypocaloric feeding and energy balance on clinical outcome in ICU patients. Clin Nutr. 2005; 24: 502-9.

4) Montejo JC: Enteral nutrition-related gastrointestinal complications in critically ill patients: a multicenter study. The Nutritional and Metabolic Working Group of the Spanish Society of Intensive Care Medicine and Coronary Units. Crit Care Med. 1999; 27: 1447-53.

5) Reignier J, Boisramé-Helms J, Brisard L, et al: Enteral versus parenteral early nutrition in ventilated adults with shock: a randomised, controlled, multicentre, open-label, parallel-group study (NUTRIREA-2). Lancet. 2018; 391: 133-43.

6) Singer P, Blaser AR, Berger MM, et al: ESPEN guideline on clinical nutrition in the intensive care unit. Clin Nutr. 2019; 38 48-79.

7) McClave SA, Taylor BE, Martindale RG, et al: Guidelines for the Provision and Assessment of Nutrition Support Therapy in the Adult Critically Ill Patient: Society of Critical Care Medicine (SCCM) and American Society for Parenteral and Enteral Nutrition (A.S.P.E.N.). JPEN J Parenter Enteral Nutr. 2016; 40: 159-211.
CQ12-3：敗血症患者では経腸栄養をいつ始める か?

Answer : 敗血症患者において, 早期（重症病態への 治療開始後 24〜48 時間以内） から経腸栄養を行うこ とを弱く推奨する（GRADE 2D：エビデンスの確実 性 $=$ 「非常に低」)。

\section{（1）背景および本 $C Q$ の重要度}

敗血症患者では，十分な栄養の自力摂取が多くの場 合不可能であり, 経腸栄養, 経静脈栄養などで補助を 行わないと栄養障害が生じる。また, 経腸栄養の投与 が遅れると, 腸管からの栄養素の吸収率が低下するこ とが知られている。さらに，経腸栄養を行わない状態 では, 腸管粘膜が菲薄化し腸管免疫が障害されるた め, 経腸栄養の施行の有無は全身の免疫能にも影響 し，予後に影響する可能性がある。したがって，経腸 栄養施行開始を早期とするか晚期とするかは，重要臨 床課題といえる。

(2) PICO

P (患者)：集中治療室で治療を受ける重症患者

I（介入）: 早期経腸栄養（重症病態への治療開始後 24〜48 時間以内）

C (対照)：晚期経腸栄養（それ以降）

$\mathrm{O}$ (アウトカム) : 死亡, 病院滞在日数, あらゆる重 篤な副作用, 感染症発生

\section{（3）エビデンスの要約}

システマティックレビューの結果，PICO に合致し たランダム化比較試験（RCT）が 13 件 1-13）施行され ており,これらを用いたメタ解析を実施した。

（4）益と害のバランス（Table 12-3-1）

望ましい効果 :

死亡に関する効果推定值は，リスク差（RD）1,000 人あたり 27 人少ない $(95 \% \mathrm{CI}: 63$ 人少ない〜 25 人多 い）（13 RCT, 709 人）であり，肺炎に関する効果推定 值は，RD 1,000 人あたり 85 人少ない $(95 \%$ CI: 173 人 少ない〜 41 人多い) $(6 \mathrm{RCT} ， 441$ 人）であった。望ま しい効果は「中」であると判断した。

望ましくない効果：

菌血症に関する効果推定值は, RD 1,000 人あたり 48 人多い $(95 \%$ CI: 69 人少ない 240 人多い) (6 RCT, 354 人）であり，病院滞在日数は平均（MD） 0.41 日 長い（95\% CI: 2.71 日短い〜3.53 日長い）（5 RCT，217 
日本版敗血症診療ガイドライン 2020

Table 12-3-1エビデンスプロファイル

\begin{tabular}{|c|c|c|c|c|c|c|c|c|c|c|c|c|}
\hline \multicolumn{7}{|c|}{ 確実性の評価 } & \multicolumn{2}{|c|}{ 患者数 } & \multicolumn{2}{|c|}{ 効果 } & \multirow[b]{2}{*}{ 確実性 } & \multirow[b]{2}{*}{ 重要性 } \\
\hline 研究数 & $\begin{array}{c}\text { 研究 } \\
\text { デザイン }\end{array}$ & $\begin{array}{l}\text { バイアス } \\
\text { のリスク }\end{array}$ & 非一貫性 & 非直接性 & 不精確性 & $\begin{array}{l}\text { その他 } \\
\text { の検討 }\end{array}$ & Early EN & Delayed EN & $\begin{array}{l}\text { 相対指標 } \\
(95 \% \mathrm{Cl})\end{array}$ & $\begin{array}{l}\text { 絶対指標 } \\
(95 \% \mathrm{Cl})\end{array}$ & & \\
\hline \multicolumn{13}{|l|}{ 死亡 } \\
\hline 13 & RCT & 深刻 b,c & 深刻でないd & 深刻でない & 深刻 d & $\begin{array}{c}\text { 出版バイア } \\
\text { スが強く示 } \\
\text { 唆される }\end{array}$ & $\begin{array}{c}34 / 350 \\
(9.7 \%)\end{array}$ & $\begin{array}{l}47 / 359 \\
(13.1 \%)\end{array}$ & $\begin{array}{c}\text { RR } 0.79 \\
(0.52 \text { to } 1.19)\end{array}$ & $\begin{array}{c}1,000 \text { 人あたり } \\
27 \text { 人少ない (63 } \\
\text { 人少ない〜 } 25 \text { 人 } \\
\text { 多い) }\end{array}$ & $\begin{array}{l}\oplus \bigcirc \bigcirc \bigcirc \\
\text { 非常に低 }\end{array}$ & 重大 \\
\hline \multicolumn{13}{|c|}{ 集中治療室死亡 } \\
\hline 2 & RCT & 深刻 b,c & 深刻でない & 深刻でない & 深刻 d,e & なし & $4 / 41(9.8 \%)$ & $5 / 39(12.8 \%)$ & $\begin{array}{c}\text { RR } 0.81 \\
(0.27 \text { to } 2.39)\end{array}$ & $\begin{array}{c}1,000 \text { 人あたり } \\
24 \text { 人少ない }(94 \\
\text { 人少ない〜 178 } \\
\text { 人多い) }\end{array}$ & $\begin{array}{l}\oplus \bigcirc \bigcirc \bigcirc \\
\text { 非常に低 }\end{array}$ & 重大 \\
\hline \multicolumn{13}{|c|}{ 院内死亡 } \\
\hline 2 & RCT & 深刻 b,c & 深刻でない & 深刻でない & 非常に深刻d,e & なし & $2 / 47(4.3 \%)$ & $1 / 48(2.1 \%)$ & $\begin{array}{c}\text { RR } 2.00 \\
\text { (0.19 to } 20.90 \text { ) }\end{array}$ & $\begin{array}{c}1,000 \text { 人あたり } \\
21 \text { 人多い }(17 \text { 人 } \\
\text { 少ない 415人 } \\
\text { 多い) }\end{array}$ & $\begin{array}{l}\oplus \bigcirc 0 \bigcirc \\
\text { 非常に低 }\end{array}$ & 重大 \\
\hline \multicolumn{13}{|c|}{ ICU 滞在日数 } \\
\hline 6 & RCT & 深刻 $a, b, c$ & 深刻 ${ }^{f}$ & 深刻でない & 深刻 d,e & なし & 118 & 115 & - & $\begin{array}{c}\text { 平均 } 0.38 \text { 日長い } \\
\text { (3.89 日短い〜 } \\
4.65 \text { 日長い) }\end{array}$ & $\begin{array}{l}\oplus \bigcirc 0 \bigcirc \\
\text { 非常に低 }\end{array}$ & 重大 \\
\hline \multicolumn{13}{|c|}{ 病院滞在日数 } \\
\hline 5 & RCT & 深刻 a,c & 深刻 ${ }^{f}$ & 深刻でない & 深刻 ${ }^{e}$ & なし & 107 & 110 & - & $\begin{array}{c}\text { 平均 } 0.41 \text { 日長い } \\
\text { (2.71 日短い〜 } \\
3.53 \text { 日長い) }\end{array}$ & $\begin{array}{l}\oplus \bigcirc \bigcirc \bigcirc \\
\text { 非常に低 }\end{array}$ & 重大 \\
\hline \multicolumn{13}{|l|}{ 肺炎 } \\
\hline 6 & RCT & 深刻 a,c & 深刻でない & 深刻でない & 深刻 d & なし & $\begin{array}{l}60 / 216 \\
(27.8 \%)\end{array}$ & $\begin{array}{l}83 / 225 \\
(36.9 \%)\end{array}$ & $\begin{array}{c}\text { RR } 0.77 \\
(0.53 \text { to } 1.11)\end{array}$ & $\begin{array}{c}1,000 \text { 人あたり } \\
85 \text { 人少ない (173 } \\
\text { 人少ない 41 人多 } \\
\text { い) }\end{array}$ & $\begin{array}{l}\oplus \bigcirc 0 \bigcirc \\
\text { 非常に低 }\end{array}$ & 重大 \\
\hline \multicolumn{13}{|l|}{ 菌血症 } \\
\hline 6 & RCT & 深刻 a,c & 深刻でない & 深刻でない & 深刻 d,g & なし & $\begin{array}{l}59 / 205 \\
(28.8 \%)\end{array}$ & $\begin{array}{l}38 / 149 \\
(25.5 \%)\end{array}$ & $\begin{array}{c}\text { RR } 1.19 \\
\text { (0.73 to } 1.94)\end{array}$ & $\begin{array}{c}1,000 \text { 人あたり } \\
48 \text { 人多い }(69 \text { 人 } \\
\text { 少ない〜240人 } \\
\text { 多い) }\end{array}$ & $\begin{array}{l}\oplus \bigcirc \bigcirc \bigcirc \\
\text { 非常に低 }\end{array}$ & 重大 \\
\hline
\end{tabular}

a. オープンラベル研究が多い。

b. 高いバイアスのリスクが 2 項目以上。

c. 不明なバイアスのリスクが多い研究が多い。

d. Clが 0.75 もしくは 1.25 をまたぐ。

e. 症例数が少ない。

f. Iが高い。

g. イベント数が少ない。

人）であった。望ましくない効果は「小さい」と判断 した。

益と害のバランス :

アウトカムの相対的価值を考慮しない場合でも，ま た，死亡に関する相対的価值を 3 倍と考慮した場合に おいても益が害を上回るため，おそらく介入が優位で あると判断する。

\section{（5）アウトカム全般に関するエビデンスの確実性}

重大なアウトカムに関するエビデンスの確実性は, いずれも「非常に低」であった。

\section{（6）価値観}

栄養療法におけるアウトカムに関する価値観につい てのデータはない。一般的に死亡に対して置く相対的 価值は高く，そのばらつきは少ないことが予想される。

\section{（7）容認性}

経腸栄養剂は多くの場合，食事として提供され食事 療養標準負担額となるため，コストについては，容認 されると考えられる。また，経鼻胃管の留置はリスク が少なく手技自体も許容されるだろう。

\section{（8）実行可能性}

一般的な処置であり，どの病院においても実行可能 性は高いといえる。

（9）判断の要約（Table 12-3-2）

（10）推奨グレーディング決定の工程

修正 RAND 法を用いた投票によって，中央值 7, 見解不一致指数 0.164 の結果となり, 委員会で採択さ れた（7 点以上 : 91.7\%)。 
Table 12-3-2 判断の要約

\begin{tabular}{|c|c|c|c|c|c|c|c|}
\hline & \multicolumn{7}{|c|}{ 判断 } \\
\hline 問題 & いいえ & $\begin{array}{c}\text { おそらく、いい } \\
\text { え }\end{array}$ & おそらく、はい & はい & & さまざま & 分からない \\
\hline 望ましい効果 & わずか & 小さい & 中 & 大きい & & さまざま & 分からない \\
\hline 望ましくない効果 & 大きい & 中 & 小さい & わずか & & さまざま & 分からない \\
\hline エビデンスの確実性 & 非常に低 & 低 & 中 & 高 & & & 採用研究なし \\
\hline 価值観 & $\begin{array}{c}\text { 重要な不確実性 } \\
\text { またはばらつき } \\
\text { あり }\end{array}$ & $\begin{array}{c}\text { 重要な不確実性 } \\
\text { またはばらつき } \\
\text { の可能性あり }\end{array}$ & $\begin{array}{l}\text { 重要な不確実性 } \\
\text { またはばらつき } \\
\text { はおそらくなし }\end{array}$ & $\begin{array}{c}\text { 重要な不確実性 } \\
\text { またはばらつき } \\
\text { はなし }\end{array}$ & & & \\
\hline 効果のパランス & 比較が優位 & $\begin{array}{c}\text { 比較がおそらく } \\
\text { 優位 }\end{array}$ & $\begin{array}{c}\text { 介入も比較もい } \\
\text { ずれも優位でな } \\
\text { い }\end{array}$ & $\begin{array}{c}\text { おそらく介入が } \\
\text { 優位 }\end{array}$ & 介入が優位 & さまざま & 分からない \\
\hline 容認性 & いいえ & $\begin{array}{c}\text { おそらく、いい } \\
\text { え }\end{array}$ & おそらく、はい & はい & & さまざま & 分からない \\
\hline 実行可能性 & いいえ & $\begin{array}{c}\text { おそらく、いい } \\
\text { え }\end{array}$ & おそらく、はい & はい & & さまざま & 分からない \\
\hline
\end{tabular}

\section{（11）関連する他の診療ガイドラインにおける推奨} 他のガイドラインとして，ASPEN/SCCM ガイドラ イン ${ }^{14)}$, ESPEN ガイドライン 15) が挙げられる。

ASPEN/SCCM ガイドラインならびに ESPEN ガイ ドラインでは，経口摂取ができない重症患者症例にお いては，経腸栄養を集中治療室入室後 24〜 48 時間以 内に開始することを推奨している。

\section{（12）実施に関わる検討事項}

経腸栄養の開始にあたっては循環動態にも考慮が必 要である。循環動態の不安定な患者における経腸栄養 については CQ12-2 で検討した。

\section{（13）今後の研究の可能性}

今後，最適な投与組成，投与量の検討，身体機能な どに注目したさらなる研究が行われることが望まれ る。

\section{文 献}

1) Chiarelli A, Enzi G, Casadei A, et al: Very early nutrition supplementation in burned patients. Am J Clin Nutr. 1990; 51: 1035-9.

2) Eyer SD, Micon LT, Konstantinides FN, et al: Early enteral feeding does not attenuate metabolic response after blunt trauma. J Trauma. 1993; 34: 639-43; discussion 643-4.

3) Singh G, Ram RP, Khanna SK: Early postoperative enteral feeding in patients with nontraumatic intestinal perforation and peritonitis. J Am Coll Surg. 1998; 187: 142-6.

4) Kompan L, Kremzar B, Gadzijev E, et al: Effects of early enteral nutrition on intestinal permeability and the development of multiple organ failure after multiple injury. Intensive Care Med. 1999; 25: 157-61

5) Pupelis G, Selga G, Austrums E, et al: Jejunal feeding, even when instituted late, improves outcomes in patients with severe pancre- atitis and peritonitis. Nutrition. 2001; 17: 91-4.

6) Kompan L, Vidmar G, Spindler-Vesel A, et al: Is early enteral nutrition a risk factor for gastric intolerance and pneumonia?. Clin Nutr. 2004; 23: 527-32.

7) Malhotra A, Mathur AK, Gupta S: Early enteral nutrition after surgical treatment of gut perforations: A prospective randomised study. J Postgrad Med. 2004; 50: 102-6.

8) Peck MD, Kessler M, Cairns BA, et al: Early enteral nutrition does not decrease hypermetabolism associated with burn injury. J Trauma. 2004; 57: 1143-8; discussion 1148-9.

9) Moses V, Mahendri NV, John G, et al: Early hypocaloric enteral nutritional supplementation in acute organophosphate poisoning A prospective randomized trial. Clin Toxicol (Phila). 2009; 47: 419-24.

10) Chourdakis M, Kraus MM, Tzellos T, et al: Effect of early compared with delayed enteral nutrition on endocrine function in patients with traumatic brain injury: An open-labeled randomized trial. JPEN J Parenter Enteral Nutr. 2012; 36: 108-16.

11) Nguyen NQ, Besanko LK, Burgstad C, et al: Delayed enteral feeding impairs intestinal carbohydrate absorption in critically ill Patients. Cri Care Med. 2012; 40: 50-4.

12) Petrov MS, McIlroy K, Grayson L, et al: Early nasogastric tube feeding versus nil per os in mild to moderate acute pancreatitis: A randomized controlled trial. Clin Nutr. 2013; 32: 697-703.

13) Sun JK, Mu XW, Li WQ, et al: Effects of early enteral nutrition on immune function of severe acute pancreatitis patients. World $\mathrm{J}$ Gastroenterol. 2013; 19: 917-22.

14) McClave SA, Taylor BE, Martindale RG, et al: Guidelines for the Provision and Assessment of Nutrition Support Therapy in the Adult Critically Ill Patient: Society of Critical Care Medicine (SCCM) and American Society for Parenteral and Enteral Nutrition (A.S.P.E.N.). JPEN J Parenter Enteral Nutr. 2016; 40: 159-211.

15) Singer P, Blaser AR, Berger MM, et al: ESPEN guideline on clinical nutrition in the intensive care unit. Clin Nutr. 2019; 38: 48-79. 
CQ12-4：敗血症患者の治療開始初期では経腸栄 養を消費エネルギーよりも少なく投与するか？

Answer : 敗血症患者に対する治療開始初期は経腸栄 養を消費エネルギーよりも少なく投与することを弱く 推奨する (GRADE 2B：エビデンスの確実性 =「中」)。

\section{（1）背景および本 $C Q$ の重要度}

敗血症患者では, 十分な栄養の自力摄取は不可能で あることが多く, 経腸栄養, 経静脈栄養などによる補 助を行わないと栄養障害が生じる。経腸栄養の投与が 遅れると腸管粘膜の菲薄化や腸管免疫の障害が生じ, 予後に影響する可能性がある。しかし, 少量の経腸栄 養でも腸管粘膜の保護には十分な可能性もあり, エネ ルギー投与量が過剩になった場合は overfeeding の害 も考えられる。

早期に経腸栄養を開始することがCQ12-3 のように 弱く推奨されているが, 敗血症患者に対するエネル ギー投与量の多葟による有効性・有害性については議 論があり，経腸栄養の初期投与量をどのように設定す るかは, 重要臨床課題であると考える。

(2) PICO

P (患者) : 集中治療室で治療を受ける重症患者

I（介入）: 消費エネルギーよりも少ないエネルギー 投与量

$\mathrm{C}$ (対照) : 消費エネルギー程度の投与量

$\mathrm{O}$ (アウトカム) : 死亡, 病院滞在日数, あらゆる重 篤な副作用, 感染症発生

\section{（3）エビデンスの要約}

システマティックレビューの結果, PICO に合致し たランダム化比較試験（RCT）が 18 件 1-18）施行され ており,これらを用いたメタ解析を実施した。

\section{（4）益と害のバランス（Table 12-4-1）}

\section{望ましい効果 :}

死亡に関する効果推定值は，リスク差（RD）1,000 人あたり 2 人少ない $(95 \%$ CI: 23 人少ない 21 人多い) (18 RCT, 12,679人) であり, 病院滞在日数は平均 (MD） 0.35 日短い (95\% CI: 2.68 日短い〜 1.99 日長い) (10 RCT，6,728 人）であり，全ての感染症に関する 効果推定值は, RD 1,000 人あたり 3 人少ない $(95 \%$ CI: 44 人少ない 47 人多い) $(11 \mathrm{RCT}, 6,245$ 人) で あり，肺炎に関する効果推定値は，RD 1,000 人あた り 25 人少ない $(95 \%$ CI: 50 人少ない 4 人多い)（10
RCT， 7,778 人）であり, 菌血症に関する効果推定値 は, RD 1,000 人あたり 6 人少ない $(95 \%$ CI: 18 人少な い〜11 人多い）（9 RCT, 10,768 人）であり, カテー テル関連血流感染に関する効果推定値は, RD 1,000 人あたり 19 人少ない $(95 \%$ CI: 34 人少ない〜 15 人多 い）（5 RCT，1,608人）であった。望ましい効果は 「小さい」と判断した。

望ましくない効果 :

重篤な副作用についての報告がなく, 望ましくない 効果については判断できない。

\section{効果のバランス :}

本 CQ においては，重要な害に関してはエビデンス がなく明らかではないが，小さいながら介入により望 ましい効果を認めるため, バランスは介入が優位であ ると判断した。

\section{（5）アウトカム全般に関するエビデンスの確実性}

今回採用したすべてのアウトカムの効果推定値の方 向性は一致しているため, 一番高いアウトカムの確実 性を全体としては採用した。アウトカム全体にわたる エビデンスの確実性は「中」である。

\section{（6）価值観}

栄養療法におけるアウトカムに関する価值観につい てのデータはない。一般的に死亡に対する価值は高 く，そのばらつきは少ないと考えられる。

\section{（7）容認性}

介入群では, エネルギーの消費量の $70 \%$ 程度まで 経腸栄養投与量が制限されており, 対照群では消費エ ネルギーに見合った経腸栄養投与量が投与されてい る。嘔吐などの潜在的なリスクにおいても介入群のほ うが容認しやすい。

経腸栄養剂は多くの場合, 食事として提供されて食 事療養標準負担額となるため, いずれもコストについ ては容認されると考えられる。

\section{（8）実行可能性}

経腸栄養は一般的な処置であり, その投与量の調整 はどの病院においても実行可能性は高いといえる。

（9）判断の要約（Table 12-4-2）

（10）推奨グレーディング決定の工程

修正 RAND 法を用いた投票によって, 中央值 7, 見解不一致指数 0.164 の結果となり, 委員会で採択さ 
日集中医誌 J Jpn Soc Intensive Care Med Vol. 28 Suppl

Table12-4-1エビデンスプロファイル

\begin{tabular}{|c|c|c|c|c|c|c|c|c|c|c|c|c|}
\hline \multicolumn{7}{|c|}{ 確実性の評価 } & \multicolumn{2}{|c|}{ 患者数 } & \multicolumn{2}{|c|}{ 効果 } & \multirow[b]{2}{*}{ 確実性 } & \multirow[b]{2}{*}{ 重要性 } \\
\hline 研究数 & $\begin{array}{l}\text { 研究 } \\
\text { デザイン }\end{array}$ & $\begin{array}{l}\text { バイアス } \\
\text { のリスク }\end{array}$ & 非一貫性 & 非直接性 & 不精確性 & $\begin{array}{l}\text { その他 } \\
\text { の検討 }\end{array}$ & Hypofeeding & Normofeeding & $\begin{array}{l}\text { 相対指標 } \\
(95 \% \mathrm{Cl})\end{array}$ & $\begin{array}{l}\text { 絶対指標 } \\
(95 \% \mathrm{Cl})\end{array}$ & & \\
\hline \multicolumn{13}{|l|}{ 全死亡 } \\
\hline 18 & $\mathrm{RCT}$ & 深刻でない & 深刻でない & 深刻でない & 深刻でない & なし & $\begin{array}{c}1,277 / 6,317 \\
(20.2 \%)\end{array}$ & $\begin{array}{c}1,297 / 6,262 \\
(20.7 \%)\end{array}$ & $\begin{array}{c}\text { RR } 0.99 \\
(0.89 \text { to } 1.10)\end{array}$ & $\begin{array}{c}1,000 \text { 人あたり } 2 \\
\text { 人少ない }(23 \text { 人 } \\
\text { 少ない〜21 人多 } \\
\text { () }\end{array}$ & $\begin{array}{c}\oplus \oplus \oplus \bigcirc \\
\text { 中 }\end{array}$ & 重大 \\
\hline \multicolumn{13}{|c|}{ 院内死亡 } \\
\hline 10 & RCT & 深刻でない & 深刻 a & 深刻でない & 深刻でない & なし & $\begin{array}{c}949 / 5,312 \\
(17.9 \%)\end{array}$ & $\begin{array}{c}978 / 5,269 \\
(18.6 \%)\end{array}$ & $\begin{array}{c}\text { RR } 0.96 \\
(0.83 \text { to } 1.12)\end{array}$ & $\begin{array}{c}1,000 \text { 人あたり } 7 \\
\text { 人少ない }(32 \text { 人 } \\
\text { 少ない〜22人多 } \\
\text { () }\end{array}$ & $\underset{\text { 低 }}{\oplus \oplus \bigcirc \bigcirc}$ & 重大 \\
\hline \multicolumn{13}{|c|}{ 病院滞在日数 } \\
\hline 10 & RCT & 深刻でない & 深刻 a & 深刻でない & 深刻でない & なし & 3,371 & 3,357 & - & $\begin{array}{c}\text { 平均 } 0.35 \text { 日短い } \\
\text { (2.68 日短い } \\
1.99 \text { 日長い) }\end{array}$ & $\begin{array}{c}\oplus \oplus \bigcirc \bigcirc \\
\text { 低 }\end{array}$ & 重大 \\
\hline \multicolumn{13}{|c|}{ 全ての感染症 } \\
\hline 11 & RCT & 深刻でない & 深刻 a & 深刻でない & 深刻でない & なし & $\begin{array}{c}751 / 3,144 \\
(23.9 \%)\end{array}$ & $\begin{array}{c}810 / 3,101 \\
(26.1 \%)\end{array}$ & $\begin{array}{c}\text { RR } 0.99 \\
(0.83 \text { to } 1.18)\end{array}$ & $\begin{array}{c}1,000 \text { 人あたり } 3 \\
\text { 人少ない }(44 \text { 人 } \\
\text { 少ない〜 } 47 \text { 人多 } \\
\text { い) }\end{array}$ & $\underset{\text { 低 }}{\oplus \oplus \bigcirc \bigcirc}$ & 重大 \\
\hline \multicolumn{13}{|l|}{ 肺炎 } \\
\hline 10 & RCT & 深刻でない & 深刻でない & 深刻でない & 深刻 c & なし & $\begin{array}{c}600 / 3,935 \\
(15.2 \%)\end{array}$ & $\begin{array}{c}686 / 3,843 \\
(17.9 \%)\end{array}$ & $\begin{array}{c}\text { RR } 0.86 \\
(0.72 \text { to } 1.02)\end{array}$ & $\begin{array}{c}1,000 \text { 人あたり } \\
25 \text { 人少ない（50 } \\
\text { 人少ない〜4 人多 } \\
\text { い) }\end{array}$ & $\begin{array}{c}\oplus \oplus \oplus \bigcirc \\
\text { 中 }\end{array}$ & 重大 \\
\hline \multicolumn{13}{|l|}{ 菌血症 } \\
\hline 9 & RCT & 深刻でない & 深刻でない & 深刻でない & 深刻でない & なし & $\begin{array}{c}460 / 5,416 \\
(8.5 \%)\end{array}$ & $\begin{array}{c}491 / 5,352 \\
(9.2 \%)\end{array}$ & $\begin{array}{c}\text { RR } 0.94 \\
(0.80 \text { to } 1.12)\end{array}$ & $\begin{array}{c}1,000 \text { 人あたり } 6 \\
\text { 人少ない }(18 \text { 人 } \\
\text { 少ない〜 } 11 \text { 人多 } \\
\text { い) }\end{array}$ & $\begin{array}{c}\oplus \oplus \oplus \bigcirc \\
\text { 中 }\end{array}$ & 重大 \\
\hline \multicolumn{13}{|c|}{ カテーテル関連血流感染 } \\
\hline 5 & RCT & 深刻でない & 深刻でない & 深刻でない & 非常に深刻hc & $\begin{array}{c}\text { 出版バイ } \\
\text { アスが強 } \\
\text { く示唆さ } \\
\text { れる }\end{array}$ & $\begin{array}{c}19 / 816 \\
(2.3 \%)\end{array}$ & $36 / 792(4.5 \%)$ & $\begin{array}{c}\text { RR } 0.59 \\
(0.26 \text { to } 1.33)\end{array}$ & $\begin{array}{c}\text { 1,000 人あたり } \\
19 \text { 人少ない (34 } \\
\text { 人少ない 15人 } \\
\text { 多い) }\end{array}$ & $\underset{\text { 低 }}{\oplus \oplus \bigcirc \bigcirc}$ & 重大 \\
\hline
\end{tabular}

a. $1^{2}$ が高い。

b. 症例数が少ない。

c. Clが 0.75 もしくは 1.25 をまたぐ。

Table 12-4-2 判断の要約

\begin{tabular}{|c|c|c|c|c|c|c|c|}
\hline 問題 & いいえ & $\begin{array}{c}\text { おそらく、いい } \\
\text { え }\end{array}$ & おそらく、はい & はい & & さまざま & 分からない \\
\hline 望ましい勃果 & わずか & 小さい & 中 & 大きい & & さまざま & 分からない \\
\hline 望ましくない効果 & 大きい & 中 & 小さい & わずか & & さまざま & 分からない \\
\hline エビデンスの確実性 & 非常に低 & 低 & 中 & 高 & & & 採用研究なし \\
\hline 価値钼 & $\begin{array}{c}\text { 重要な不確実性 } \\
\text { またはばらつき } \\
\text { あり }\end{array}$ & $\begin{array}{c}\text { 重要な不確実性 } \\
\text { またはばらつ } \\
\text { の可能性あり }\end{array}$ & $\begin{array}{l}\text { 重要な不確実性 } \\
\text { またはばらつき } \\
\text { はおそらくなし }\end{array}$ & $\begin{array}{c}\text { 重要な不確実性 } \\
\text { またはばらつき } \\
\text { はなし }\end{array}$ & & & \\
\hline 効果のパランス & 比較が優位 & $\begin{array}{c}\text { 比較がおそらく } \\
\text { 優位 }\end{array}$ & $\begin{array}{c}\text { 介入も比較もい } \\
\text { ずれも優位でな } \\
\text { い }\end{array}$ & $\begin{array}{c}\text { おそらく介入が } \\
\text { 優位 }\end{array}$ & 介入が優位 & さまざま & 分からない \\
\hline 容認性 & いいえ & $\begin{array}{c}\text { おそらく、いい } \\
\text { え }\end{array}$ & おそらく、はい & はい & & さまざま & 分からない \\
\hline 実行可能性 & いいえ & 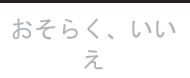 & おそらく、はい & はい & & さまざま & 分からない \\
\hline
\end{tabular}


れた（7 点以上： $87.5 \%) 。$

（11）関連する他の診療ガイドラインにおける推奨 他のガイドラインとして, ASPEN/SCCM ガイドラ イン 19), ESPEN ガイドライン 20) が挙げられる。 ASPEN/SCCM ガイドラインならびに ESPEN ガイ ドラインにおいて，栄養リスクがない症例では，集中 治療室入室後早期の消費エネルギーに相当するエネル ギーの投与は推奨しないとされている。

ASPEN/SCCM ガイドラインでは, 経口摂取ができ ない場合でも，重症度が低く栄養りスクが低い症例に は, 初期の 1 週間において積極的に経腸栄養を増量し ていくような特別な栄養療法は必要ないとされてい る。ただし, 解説において, 初期は軽症でも重症度や 代謝状態の悪化，ICU 滞在日数が長期化するなどの場 合は積極的な経腸栄養による利益が危険を上回るた め, 症例の状態を評価していくべきと述べられてい る。また，栄養リスクが高いか，もともと栄養障害が ある症例では, リフィーディング症候群に注意しなが ら，初期の 48〜 72 時間の間に目標投与エネルギーの 80\%を超える投与を行うように推奨している。

ESPEN ガイドラインでは, 初期の目標エネルギー は消費エネルギーの 70〜100\% とし，初期の 2 日間は 目標に達さないようにすること，3〜7日間で目標に 達することを推奨している。

\section{（12）実施に関わる検討事項}

経腸栄養の開始にあたっては循環動態にも考慮が必 要である。循環動態の不安定な患者における経腸栄養 についてはCQ12-2で検討した。

\section{（13）今後の研究の可能性}

今後, 最適な投与組成, 栄養リスクが高い（るいそ うが強い, 重症度が高いなど), 身体機能などに注目 したさらなる研究が行われることが望まれる。

\section{文 献}

1) Allingstrup MJ, Kondrup J, Wiis J, et al: Early goal-directed nutrition versus standard of care in adult intensive care patients: the single-centre, randomised, outcome assessor-blinded EAT-ICU trial. Intensive Care Med. 2017; 43: 1637-47.

2) Arabi YM, Tamim HM, Dhar GS, et al: Permissive underfeeding and intensive insulin therapy in critically ill patients: A randomized controlled trial. Am J Clin Nutr. 2011; 93: 569-77.

3) Braunschweig CA, Sheean PM, Peterson SJ, et al: Intensive nutrition in acute lung injury: A clinical trial (INTACT). JPEN J Parenter Enteral Nutr. 2015; 39: 13-20.

4) Casaer MP, Mesotten D, Hermans G, et al: Early versus late parenteral nutrition in critically ill adults. N Engl J Med. 2011; 365: 506-17.
5) Chapman M, Peake SL, Bellomo R, et al: Energy-dense versus routine enteral nutrition in the critically ill. N Engl J Med. 2018; 379: 1823-34.

6) Charles EJ, Petroze RT, Metzger R, et al: Hypocaloric compared with eucaloric nutritional support and its effect on infection rates in a surgical intensive care unit: A randomized controlled trial. Am J Clin Nutr. 2014; 100: 1337-43.

7) Desachy A, Clavel M, Vuagnat A, et al: Initial efficacy and tolerability of early enteral nutrition with immediate or gradual introduction in intubated patients. Intensive Care Med. 2008; 34 : 1054-9.

8) Doig GS, Simpson F, Heighes PT, et al: Restricted versus continued standard caloric intake during the management of refeeding syndrome in critically ill adults: A randomised, parallelgroup, multicentre, single-blind controlled trial. Lancet Respir Med. 2015; 3: 943-52.

9) Heidegger CP, Berger MM, Graf S, et al: Optimisation of energy provision with supplemental parenteral nutrition in critically ill patients: A randomised controlled clinical trial. Lancet. 2013; 381: 385-93.

10) Moses V, Mahendri NV, John G, et al: Early hypocaloric enteral nutritional supplementation in acute organophosphate poisoning A prospective randomized trial. Clin Toxicol (Phila). 2009; 47: 419-24.

11) Peake SL, Davies AR, Deane AM, et al: Use of a concentrated enteral nutrition solution to increase calorie delivery to critically ill patients: A randomized, double-blind, clinical trial. Am J Clin Nutr. 2014; 100: 616-25.

12) Petros S, Horbach M, Seidel F, et al: Hypocaloric vs Normocaloric Nutrition in Critically Ill Patients: A Prospective Randomized Pilot Trial. JPEN J Parenter Enteral Nutr. 2016; 40: 242-9.

13) Rice TW, Mogan S, Hays MA, et al: Randomized trial of initial trophic versus full-energy enteral nutrition in mechanically ventilated patients with acute respiratory failure. Crit Care Med. 2011; 39: $967-74$.

14) National Heart, Lung, and Blood Institute Acute Respiratory Distress Syndrome (ARDS) Clinical Trials Network, Rice TW, Wheeler AP, et al: Initial trophic vs full enteral feeding in patients with acute lung injury: The EDEN randomized trial. JAMA. 2012; 307: 795-803.

15) Rugeles S, Villarraga-Angulo LG, Ariza-Gutiérrez A, et al: High-protein hypocaloric vs normocaloric enteral nutrition in critically ill patients: A randomized clinical trial. J Crit Care. 2016; 35: 110-4.

16) Singer $P$, Anbar R, Cohen J, et al: The tight calorie control study (TICACOS): A prospective, randomized, controlled pilot study of nutritional support in critically ill patients. Intensive Care Med. 2011; 37: 601-9.

17) Wischmeyer PE, Hasselmann M, Kummerlen C, et al: A randomized trial of supplemental parenteral nutrition in underweight and overweight critically ill patients: The TOP-UP pilot trial. Crit Care. 2017; 21: 142.

18) Arabi YM, Aldawood AS, Haddad SH, et al: Permissive underfeeding or standard enteral feeding in critically ill adults. N Engl J Med. 2015; 372: 2398-408.

19) McClave SA, Taylor BE, Martindale RG, et al: Guidelines for the Provision and Assessment of Nutrition Support Therapy in the Adult Critically Ill Patient: Society of Critical Care Medicine (SCCM) and American Society for Parenteral and Enteral Nutrition (A.S.P.E.N.). JPEN J Parenter Enteral Nutr. 2016; 40: 159-211.

20) Singer P, Blaser AR, Berger MM, et al: ESPEN guideline on clinical nutrition in the intensive care unit. Clin Nutr. 2019; 38: 48-79. 
CQ12-5：経腸栄養を行っている敗血症患者に経 静脈栄養を併用するか?

Answer : 経腸栄養を行っているが投与エネルギー量 が不足している敗血症患者に補足的経静脈栄養を併用 することを弱く推奨する（GRADE 2D : エビデンスの 確実性 $=$ 「非常に低」）。

\section{（1）背景および本 $C Q$ の重要度}

経腸栄養が可能な集中治療患者に対しては早期経腸 栄養が推奨されている。経腸栄養を行っているが，そ の投与量が目標カロリーに対して不足している場合, 静脈栄養を併用することは，目標エネルギー量を充足 できる一方で，感染リスク，血糖コントロールの問題 を生じる可能性がある。そのため, 経腸栄養を行って いる患者に対して静脈栄養を併用する益と害を明らか にすることは重要であり，本ガイドラインに取り上げ るべき重要臨床課題であると考える。

\section{(2) PICO}

$P$ (患者)：集中治療室で治療を受ける重症患者

I（介入）：経静脈栄養を併用する

C (対照) : 経静脈栄養を併用しない

$\mathrm{O}$ (アウトカム $):$ 死亡，感染症発生

\section{（3）エビデンスの要約}

システマティックレビューの結果，PICO に合致し たランダム化比較試験（RCT）が 5 件 1-5) 施行されて おり，これらを用いたメタ解析を実施した。

（4）益と害のバランス（Table 12-5-1）

望ましい効果 :

90 日死亡に関する効果推定值は, リスク差（RD） 1,000 人あたり 18 人少ない $(95 \%$ CI: 138 人少ない〜 195 人多い)（1 RCT, 120 人）であり, 呼吸器感染に 関する効果推定值は，RD 1,000 人あたり 64 人少ない （95\% CI: 143 人少ない〜49人多い）（4 RCT，624人） である。望ましい効果は「中」であると判断した。

望ましくない効果 :

血流感染に関する効果推定值は，RD 1,000人あた り 6 人多い $(95 \%$ CI: 62 人少ない 293 人多い)（3 RCT, 504 人) であり，尿路感染に関する効果推定值 は，RD 1,000 人あたり 25 人多い $(95 \%$ CI: 40 人少な い〜199人多い）（3 RCT, 550 人）であり，腹部感染 に関する効果推定值は，RD 1,000 人あたり 52 人多い ( $95 \%$ CI: 28 人少ない 1,000 人多い) $(2$ RCT, 430 人) である。望ましくない効果は「中」であると判断し た。

益と害のバランス :

本 CQ においては，その効果のバランスは介入も比 較対照もいずれも優位ではない。しかし，死亡につい

Table 12-5-1エビデンスプロファイル

\begin{tabular}{|c|c|c|c|c|c|c|c|c|c|c|c|c|}
\hline \multicolumn{7}{|c|}{ 確実性の評価 } & \multicolumn{2}{|c|}{ 患者数 } & \multicolumn{2}{|c|}{ 効果 } & \multirow[b]{2}{*}{ 確実性 } & \multirow[b]{2}{*}{ 重要性 } \\
\hline 研究数 & $\begin{array}{l}\text { 研究 } \\
\text { デザイン }\end{array}$ & $\begin{array}{l}\text { パイアス } \\
\text { のリスク }\end{array}$ & 非一貫性 & 非直接性 & 不精碓性 & $\begin{array}{l}\text { その他 } \\
\text { の榆討 }\end{array}$ & $\begin{array}{c}\text { 経腸栄養に経静 } \\
\text { 脈栄養を併用す } \\
\text { る }\end{array}$ & 経腸栄養単独 & $\begin{array}{l}\text { 相対指標 } \\
(95 \% \text { CI) }\end{array}$ & $\begin{array}{l}\text { 䋓対指標 } \\
(95 \% \text { CI })\end{array}$ & & \\
\hline \multicolumn{13}{|l|}{90 日死亡 } \\
\hline 1 & RCT & 深刻でない & 深刻でない & 深刻でない & 非常に深刻 b & なし & $17 / 60 \quad(28.3 \%)$ & $18 / 60 \quad(30.0 \%)$ & $\begin{array}{c}\text { RR } 0.94 \\
\text { (0.54 to } 1.65)\end{array}$ & $\begin{array}{c}1,000 \text { 人あたり } 18 \\
\text { 人少ない(138人 } \\
\text { 少ない〜 } 195 \text { 人多 } \\
\text { い) }\end{array}$ & $\underset{\text { 低 }}{\oplus \oplus \bigcirc \bigcirc}$ & 重大 \\
\hline \multicolumn{13}{|l|}{ 血流感染 } \\
\hline 3 & RCT & 深刻 a & 深刻。 & 深刻でない & 非常に深刻 b & なし & $19 / 241 \quad(7.9 \%)$ & $22 / 263 \quad(8.4 \%)$ & $\begin{array}{c}\text { RR } 1.07 \\
\text { (0. } 26 \text { to } 4.50)\end{array}$ & $\begin{array}{l}1,000 \text { 人あたり } 6 \\
\text { 人多い (62人少な } \\
\text { い 293 人多い) }\end{array}$ & $\begin{array}{l}\oplus \bigcirc 00 \\
\text { 非常に低 }\end{array}$ & 重大 \\
\hline \multicolumn{13}{|c|}{ 呼吸器感染 } \\
\hline 4 & RCT & 深刻 a & 深刻でない & 深刻でない & 深刻 d & なし & $70 / 301 \quad(23.3 \%)$ & $98 / 323 \quad(30.3 \%)$ & $\begin{array}{c}\text { RR } 0.79 \\
(0.53 \text { to } 1.16)\end{array}$ & $\begin{array}{c}1,000 \text { 人あたり } 64 \\
\text { 人少ない (143人 } \\
\text { 少ない 49人多 } \\
\text { ( ) }\end{array}$ & $\underset{\text { 低 }}{\oplus \oplus \bigcirc \bigcirc}$ & 重大 \\
\hline \multicolumn{13}{|l|}{ 尿路感染 } \\
\hline 3 & RCT & 深刻 a & 深刻でない & 深刻でない & 非常に深刻 b & なし & $24 / 265 \quad(9.1 \%)$ & $23 / 285(8.1 \%)$ & $\begin{array}{c}\text { RR } 1.31 \\
(0.50 \text { to } 3.46)\end{array}$ & $\begin{array}{l}1,000 \text { 人あたり } 25 \\
\text { 人多い (40人少な } \\
\text { い 199人多い) }\end{array}$ & $\begin{array}{l}\oplus \bigcirc 00 \\
\text { 非常に低 }\end{array}$ & 重大 \\
\hline \multicolumn{13}{|c|}{ 腹部感染 } \\
\hline 2 & RCT & 深刻 a & 深刻でない & 深刻でない & 非常に深刻 b & なし & $12 / 205 \quad(5.9 \%)$ & $8 / 225 \quad(3.6 \%)$ & $\begin{array}{c}\text { RR } 2.47 \\
\text { (0. } 21 \text { to } 29.33)\end{array}$ & $\begin{array}{l}1,000 \text { 人あたり } 52 \\
\text { 人多い( } 28 \text { 人少な } \\
\text { い 1,000 人多い) }\end{array}$ & $\begin{array}{l}\oplus \bigcirc 00 \\
\text { 非常に低 }\end{array}$ & 重大 \\
\hline
\end{tabular}

a. 患者医療者の盲検化ができていない：1レベルグレードダウン

b. 信頼区間が臨床的推奨非推奖決定領域を両側またいでいる：2 2レベルグレードダウン

c. 点推定値のばらつきが大きく，信頼区間が広く，異質性検定で $P=0.03$ かつ $I^{2}$ が大きい：1レベルグレードダウン

d. 信䡩区間が臨床的推罣非推奨決定領域を片側またいでいる：1レベルグレードダウン 
ての相対的価值を設定した場合（3 倍と設定），介入 が優位になる可能性がある。

（5）アウトカム全般に関するエビデンスの確実性

各アウトカムが益と害の異なる方向性を示してお り，重大なアウトカムに関するエビデンスの確実性の 中でも最も低い「非常に低」とした。

\section{（6）価値観}

栄養療法におけるアウトカムに関する価值観につい てのデータはない。一般的に死亡に対して置く相対的 価值は高く，そのばらつきは少ないことが予想され る。

\section{（7）容認性}

経静脈栄養は 1 日の薬価が約 1,000〜2,000 円であ る。いずれの場合でも容認されると考えられる。中心 静脈カテーテルは循環作動薬の投与などのために挿入 されている場合は問題にならないが，栄養療法のため だけに留置する場合は，リスクを考慮する必要があ る。

\section{（8）実行可能性}

一般的な処置であり，どの病院においても実行可能 性は高いといえる。

（9）判断の要約（Table 12-5-2）
（10）推奨グレーディング決定の工程

修正 RAND 法を用いた投票によって，中央值 7, 見解不一致指数 0.164 の結果となり, 委員会で採択さ れた（7 点以上 : 79.2\%)。

\section{（11）関連する他の診療ガイドラインにおける推奨} 他のガイドラインとして, ASPEN/SCCM ガイドラ イン, ESPEN ガイドラインが挙げられる 6,7)。

ASPEN/SCCM ガイドラインでは，栄養リスクが高 い患者も低い患者も，経腸栄養が必要量の $60 \%$ に満 たない場合，集中治療室入室 7〜10 日後には補足的経 静脈栄養を考慮することを推奨している。それより前 の補足的経静脈栄養開始は，アウトカムの改善につな がらず，患者にとって害となる可能性がある。

ESPEN ガイドラインでは, 最初の週に適正量の経 腸栄養に満たない場合, 安全性や利点を考慮して症例 に応じて経静脈栄養を行う，としており，さらに経静 脈栄養は，経腸栄養を投与できるような方策を最大限 行うまでは始めるべきではないとしている。

\section{（12）実施に関わる検討事項}

本推奨に関するエビデンスの確実性が非常に低いこ となども鑑み，その実施においては，個々の患者の栄 養状態などから適応を考慮する必要がある。

\section{（13）今後の研究の可能性}

今後, もともと栄養不良のある患者における効果の バランス, 経静脈栄養の最適な併用量, 身体機能など に注目したアウトカムの設定といった課題について,

Table 12-5-2 判断の要約

\begin{tabular}{|c|c|c|c|c|c|c|c|}
\hline & \multicolumn{7}{|c|}{ 半粠 } \\
\hline 問題 & いいえ & $\begin{array}{c}\text { おそらく、いい } \\
\text { え }\end{array}$ & おそらく、はい & はい & & さまざま & 分からない \\
\hline 望ましい效果 & わずか & 小さい & 中 & 大きい & & さまざま & 分からない \\
\hline 望ましくない効果 & 大きい & 中 & 小さい & わずか & & さまざま & 分からない \\
\hline エビデンスの確実性 & 非常に低 & 低 & 中 & 高 & & & 採用研究なし \\
\hline 価值钼 & $\begin{array}{c}\text { 重要な不確実性 } \\
\text { またはばらつき } \\
\text { あり }\end{array}$ & $\begin{array}{c}\text { 重要な不確実性 } \\
\text { またはばらつき } \\
\text { の可能性あり }\end{array}$ & $\begin{array}{l}\text { 重要な不確実性 } \\
\text { またはばらつき } \\
\text { はおそらくなし }\end{array}$ & $\begin{array}{c}\text { 重要な不確実性 } \\
\text { またはばらつき } \\
\text { はなし }\end{array}$ & & & \\
\hline 効果のパランス & 比較が優位 & $\begin{array}{c}\text { 比較がおそらく } \\
\text { 優位 }\end{array}$ & $\begin{array}{c}\text { 介入も比較もい } \\
\text { ずれも優位でな } \\
\text { い }\end{array}$ & $\begin{array}{c}\text { おそらく介入が } \\
\text { 優位 }\end{array}$ & 介入が優位 & さまざま & 分からない \\
\hline 容認性 & いいえ & $\begin{array}{c}\text { おそらく、いい } \\
\text { え }\end{array}$ & おそらく、はい & はい & & さまざま & 分からない \\
\hline 実行可能性 & いいえ & $\begin{array}{c}\text { おそらく、いい } \\
\text { え }\end{array}$ & おそらく、はい & はい & & さまざま & 分からない \\
\hline
\end{tabular}


さらなる研究が行われることが望まれる。

\section{文 献}

1) Bauer $P$, Charpentier $C$, Bouchet $C$, et al: Parenteral with enteral nutrition in the critically ill. Intensive Care Med. 2000; 26: 893-900.

2) Heidegger $\mathrm{CP}$, Berger MM, Graf $\mathrm{S}$, et al: Optimisation of energy provision with supplemental parenteral nutrition in critically ill patients: A randomised controlled clinical trial. Lancet. 2013; 381: 385-93.

3) Wischmeyer PE, Hasselmann M, Kummerlen C, et al: A randomized trial of supplemental parenteral nutrition in underweight and overweight critically ill patients: The TOP-UP pilot trial. Crit Care. 2017; 21: 142.

4) Berger MM, Pantet O, Jacquelin-Ravel N, et al: Supplemental parenteral nutrition improves immunity with unchanged carbohydrate and protein metabolism in critically ill patients: The SPN2 randomized tracer study. Clin Nutr. 2019; 38: 2408-16.

5) Qin HL, Zheng JJ, Tong DN, et al: Effect of Lactobacillus plantarum enteral feeding on the gut permeability and septic complications in the patients with acute pancreatitis. Eur J Clin Nutr. 2008; 62: 923-30.

6) McClave SA, Taylor BE, Martindale RG, et al: Guidelines for the Provision and Assessment of Nutrition Support Therapy in the Adult Critically Ill Patient: Society of Critical Care Medicine (SCCM) and American Society for Parenteral and Enteral Nutrition (A.S.P.E.N.). JPEN J Parenter Enteral Nutr. 2016; 40: 159-211.

7) Singer P, Blaser AR, Berger MM, et al: ESPEN guideline on clinical nutrition in the intensive care unit. Clin Nutr. 2019; 38: 48-79.
CQ12-6：敗血症患者に対する急性期の至適タン パク質投与量はいくらか?

Answer : 敗血症患者に対して急性期に $1 \mathrm{~g} / \mathrm{kg} / \mathrm{day}$ 未満 のタンパク質（ペプチド，アミノ酸）を投与すること を弱く推奨する (GRADE 2D : エビデンスの確実性 = 「非常に低」)。

\section{（1）背景および本 $C Q$ の重要度}

タンパク質は重要な栄養素の 1 つであり, 代謝に必 要な各種アミノ酸の供給源でもある 1 。筋肉をはじめ とする体タンパクの維持のために, 十分量の投与が必 要であると考えられる2)。一方で, 急性期のアミノ酸 投与が autophagy を障害するなどの有害事象が懸念さ れる3)。以上のような背景から, 急性期のタンパク質 の投与推奨量は定まっていない。筋合成や窒素バラン スを考えると $2 \mathrm{~g} / \mathrm{kg} /$ 日程度まで増やすことがよいとさ れる2）が，実際の集中治療での投与は制限的栄養投 与の施行に伴い，投与量が少なくなることが多い4)。 したがって, 敗血症患者に対する急性期の至適タンパ ク質投与量は重要臨床課題であるといえる。

(2) PICO

$\mathrm{P}$ (患者) : 集中治療室で治療を受ける重症患者

I（介入）：ペプチド（タンパク質，アミノ酸）の急 性期の投与量が $1 \mathrm{~g} / \mathrm{kg} /$ 日以上

$\mathrm{C}$ (対照) : ペプチド（タンパク質,アミノ酸）の急 性期の投与量が $1 \mathrm{~g} / \mathrm{kg} /$ 日未満

$\mathrm{O}$ (アウトカム $)$ : 死亡, 病院滞在日数, 人工呼吸期 間，抗菌薬治療期間，ADL スコア・身体機能評 価，筋肉量

\section{（3）エビデンスの要約}

システマティックレビューの結果, PICO に合致し たランダム化比較試験（RCT）が 6 件 5-10) 施行され ており,これらを用いたメタ解析を実施した。

\section{（4）益と害のバランス（Table 12-6-1）}

\section{望ましい効果 :}

死亡に関する効果推定值は，リスク差（RD） 1,000 人あたり 4 人少ない $(95 \%$ CI: 51 人少ない 62 人多い) (5 RCT, 730 人) であり，身体機能評価に関する効果 推定値は, 平均 (MD) 0.45 高い (95\% CI: 4.57 低い〜 5.46 高い）（3 RCT，489人）であり，筋肉量に関する 効果推定値は, MD 0.2 高い (95\% CI: 0.56 低い 0.96 高い）（2 RCT，157 人）である。望ましい効果はわず 
Table 12-6-1エビデンスプロファイル

\begin{tabular}{|c|c|c|c|c|c|c|c|c|c|c|c|c|}
\hline \multicolumn{7}{|c|}{ 確実性の評価 } & \multicolumn{2}{|c|}{ 患者数 } & \multicolumn{2}{|c|}{ 効果 } & \multirow[b]{2}{*}{ 磪实性 } & \multirow[b]{2}{*}{ 重要性 } \\
\hline 研究数 & $\begin{array}{c}\text { 研究 } \\
\text { デサン }\end{array}$ & $\begin{array}{l}\text { パアス } \\
\text { のリスク }\end{array}$ & 非一貫性 & 非直接性 & 不精碓性 & $\begin{array}{l}\text { その他 } \\
\text { の检討 }\end{array}$ & prote in $>1 \mathrm{~g} / \mathrm{kg} /$ day & $<1 \mathrm{~g} / \mathrm{kg} / \mathrm{day}$ & $\begin{array}{l}\text { 相対指標 } \\
(95 \% \mathrm{CI})\end{array}$ & $\begin{array}{l}\text { 維対指摽 } \\
(95 \% \text { CI }\end{array}$ & & \\
\hline \multicolumn{13}{|l|}{ 死亡 } \\
\hline 5 & RCT & 深刻でない & 深刻てない & 深刻 。 & 深刻 b & なし & $65 / 366(17.8 \%)$ & $66 / 364(18.1 \%)$ & $\begin{array}{c}\text { RR } 0.98 \\
\text { (0.72 to } 1.34)\end{array}$ & $\begin{array}{l}1,000 \text { 人あたり } 4 \\
\text { 人少ない (51 人少 } \\
\text { ない 62人多い) }\end{array}$ & $\underset{\text { 低 }}{\oplus \oplus \bigcirc \bigcirc}$ & 重大 \\
\hline \multicolumn{13}{|c|}{ 病院滞在日数 } \\
\hline 5 & RCT & 深刻。 & 深刻てない & 深刻 a & 深刻でない & なし & 369 & 364 & - & $\begin{array}{c}\text { 平均 } 2.36 \text { 日長い } \\
(1.42 \text { 日短い } \\
6.15 \text { 日長い) }\end{array}$ & 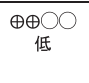 & 重大 \\
\hline \multicolumn{13}{|c|}{ 人工呼吸期間 } \\
\hline 5 & RCT & 深刻。 & 深刻でない & 深刻 " & 深刻でない & なし & 390 & 387 & - & $\begin{array}{c}\text { 平均 } 0.07 \text { 日長い } \\
(0.02 \text { 日短い } \\
0.16 \text { 長い) }\end{array}$ & $\begin{array}{l}\oplus \oplus \oplus \bigcirc \\
\text { 低 }\end{array}$ & 重大 \\
\hline \multicolumn{13}{|c|}{ 抗菌薬治療日数 } \\
\hline 1 & RCT & 深刻。 & 深刻でない & 深刻 a & 深刻でない & なし & 239 & 235 & - & $\begin{array}{c}\text { 平均 } 0.15 \text { 日長い } \\
0.07 \text { 日唇い } \\
0.23 \text { 日長い) }\end{array}$ & $\underset{\text { 低 }}{\oplus \oplus \bigcirc \bigcirc}$ & 重大 \\
\hline \multicolumn{13}{|c|}{ 身体機能評価 } \\
\hline 3 & RCT & 深刻。 & 深刻でない & 深刻a & 深刻 b & なし & 250 & 239 & - & $\begin{array}{c}\text { 平均 } 0.45 \text { 高い } \\
(4.57 \text { 低い } 5.46 \\
\text { 高い) }\end{array}$ & $\begin{array}{l}\oplus \bigcirc 0 \bigcirc \\
\text { 非常に低 }\end{array}$ & 重大 \\
\hline \multicolumn{13}{|l|}{ 筮肉量 } \\
\hline 2 & RCT & 深刻。 & 深刻でない & 深刻 。 & 深刻 d & なし & 77 & 80 & - & $\begin{array}{c}\text { 平均 } 0.2 \text { 高い } \\
(0.56 \text { 低い } \sim 0.96 \\
\text { 高(い) }\end{array}$ & 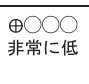 & 重大 \\
\hline
\end{tabular}

a.タンパク質だけを変化させた研究が少ないため，また全ての研究で集中治療患者全てを対象としており，敗血症患者に対する研究ではないため。

b. 信頼区間が大きいため。

d. サンプルサイズが小さいため。

かであると判断した。

望ましくない効果 :

病院滞在日数に関する効果推定值は，MD 2.36 日長 い（95\% CI：1.42 日短い〜6.15 日長い）（5 RCT，733 人）であり，人工呼吸期間に関する効果推定值は, MD 0.07 日長い（95\% CI: 0.02 日短い〜 0.16 日長い） （5 RCT， 777 人）であり，抗菌薬治療期間に関する効 果推定值は，MD 0.15 日長い（95\% CI：0.07 日長い〜 0.23 日長い）（1 RCT，474人）である。望ましくない 効果は「小さい」と判断した。

益と害のバランス :

本 CQ においては，望ましい効果はわずかであり， 望ましくない効果は小さいため, 比較がおそらく優位 と考えられる。

（5）アウトカム全般に関するエビデンスの確実性

各アウトカムが益と害の異なる方向性を示してお り，重大なアウトカムに関するエビデンスの確実性の 中でも最も低い「非常に低」とした。

\section{（6）価值観}

栄養療法におけるアウトカムに関する価值観につい てのデータはない。一般的に死亡に対して置く相対的 価值は高く，そのばらつきは少ないことが予想され る。
（7）容認性

経腸栄養剂は多くの場合，食事として提供されるた め食事療養標準負担額となる。経静脈栄養からアミノ 酸を投与する場合, 最も高い高カロリ一輸液を使用し たとしても 1 日の薬価が約 1,000〜2,000 円である。い ずれの場合でも容認されると考えられる。

\section{（8）実行可能性}

一般的な処置であり, どの病院においても実行可能 性は高いといえる。

（9）判断の要約（Table 12-6-2）

（10）推奨グレーディング決定の工程

修正 RAND 法を用いた投票によって，中央值 7, 見解不一致指数 0.018 の結果となり, 委員会で採択さ れた（7 点以上 : $79.2 \%) 。$

（11）関連する他の診療ガイドラインにおける推奨

ESPEN ガイドラインでは集中治療患者において漸 増して $1.3 \mathrm{~g} / \mathrm{kg} /$ 日のタンパク質量を目標とすることを 推奨 ${ }^{11)}$, ASPEN/SCCM ガイドラインでは $1.2 \sim 2.0 \mathrm{~g} / \mathrm{kg}$ のタンパク質量が必要であることを見込むとしてい る12)。ただし，これらのガイドラインにおける推奨 は，急性期と急性期以降に分けたものではないので， 本 CQ（急性期）には直接当てはまらない。 
Table 12-6-2 判断の要約

\begin{tabular}{|c|c|c|c|c|c|c|c|}
\hline & \multicolumn{7}{|c|}{ 判溇 } \\
\hline 問題 & いいえ & $\begin{array}{c}\text { おそらく、いい } \\
\text { え }\end{array}$ & おそらく、はい & はい & & さまざま & 分からない \\
\hline 望ましい効果 & わずか & 小さい & 中 & 大きい & & さまざま & 分からない \\
\hline 望ましくない効果 & 大きい & 中 & 小さい & わずか & & さまざま & 分からない \\
\hline エビデンスの確実性 & 非常に低 & 低 & 中 & 高 & & & 採用研究なし \\
\hline 価值覞 & $\begin{array}{c}\text { 重要な不確実性 } \\
\text { またはばらつき } \\
\text { あり }\end{array}$ & $\begin{array}{c}\text { 重要な不確実性 } \\
\text { またはばらつき } \\
\text { の可能性ありり }\end{array}$ & $\begin{array}{l}\text { 重要な不確実性 } \\
\text { またはばらつき } \\
\text { はおそらくなし }\end{array}$ & $\begin{array}{c}\text { 重要な不確実性 } \\
\text { またはばらつ } \\
\text { はなし }\end{array}$ & & & \\
\hline 効果のバランス & 比較が優位 & $\begin{array}{c}\text { 比較がおそらく } \\
\text { 優位 }\end{array}$ & $\begin{array}{c}\text { 介入も比較もい } \\
\text { ずれも優位でな } \\
\text { い }\end{array}$ & $\begin{array}{c}\text { おそらく介入が } \\
\text { 優位 }\end{array}$ & 介入が優位 & さまざま & 分からない \\
\hline 容認性 & いいえ & $\begin{array}{c}\text { おそらく、いい } \\
\text { え }\end{array}$ & おそらく、はい & はい & & さまざま & 分からない \\
\hline 実行可能性 & いいえ & $\begin{array}{c}\text { おそらく、いい } \\
\text { え }\end{array}$ & おそらく、はい & はい & & さまざま & 分からない \\
\hline
\end{tabular}

\section{（12）実施に関わる検討事項}

エビデンスの確実性が「非常に低」であり，個々の 患者において，益を優先するか害を優先するかでその 判断は変わると考えられる。

\section{（13）今後の研究の可能性}

今後，エネルギー量は同じでタンパク質の量の多寡 を比較したデザイン，タンパク質の投与タイミング, 経静脈的なアミノ酸投与併用の至適量といった課題に ついて, さらなる研究が行われることが望まれる。

\section{文 献}

1) Di Girolamo FG, Situlin R, Biolo G: What factors influence protein synthesis and degradation in critical illness?. Curr Opin Clin Nutr Metab Care. 2017; 20: 124-30.

2) Allingstrup MJ, Esmailzadeh N, Wilkens Knudsen A, et al: Provision of protein and energy in relation to measured requirements in intensive care patients. Clin Nutr. 2012; 31: 462-8.

3) Casaer MP, Langouche L, Coudyzer W, et al: Impact of early parenteral nutrition on muscle and adipose tissue compartments during critical Illness. Crit Care Med. 2013; 41: 2298-309.

4) Lambell KJ, King SJ, Forsyth AK, et al: Association of Energy and Protein Delivery on Skeletal Muscle Mass Changes in Critically Ill Adults: A Systematic Review. JPEN J Parenter Enteral Nutr. 2018; 42: 1112-22.

5) Fetterplace K, Deane AM, Tierney A, et al: Targeted Full Energy and Protein Delivery in Critically Ill Patients: A Pilot Randomized Controlled Trial (FEED Trial). JPEN J Parenter Enteral Nutr. 2018; 42: 1252-62.

6) Doig GS, Simpson F, Bellomo R, et al: Intravenous amino acid therapy for kidney function in critically ill patients: a randomized controlled trial. Intensive Care Med. 2015; 41: 1197-208.

7) Ferrie S, Allman-Farinelli M, Daley M, et al: Protein Requirements in the Critically Ill: A Randomized Controlled Trial Using Parenteral Nutrition. JPEN J Parenter Enteral Nutr. 2016; 40: 795-805.
8) van Zanten ARH, Petit L, De Waele J, et al: Very high intactprotein formula successfully provides protein intake according to nutritional recommendations in overweight critically ill patients: A double-blind randomized trial. Crit Care. 2018; 22: 156.

9) Yeh DD, Ortiz LA, Lee JM, et al: PEP uP (Enhanced ProteinEnergy Provision via the Enteral Route Feeding Protocol) in Surgical Patients - A Multicenter Pilot Randomized Controlled Trial. JPEN J Parenter Enteral Nutr. 2020; 44: 197-204.

10) Rugeles SJ, Rueda JD, Díaz CE, et al: Hyperproteic hypocaloric enteral nutrition in the critically ill patient: A randomized controlled clinical trial. Indian J Crit Care Med. 2013; 17: 343-9.

11) Singer P, Blaser AR, Berger MM, et al: ESPEN guideline on clinical nutrition in the intensive care unit. Clin Nutr. 2019; 38 48-79.

12) McClave SA, Taylor BE, Martindale RG, et al: Guidelines for the Provision and Assessment of Nutrition Support Therapy in the Adult Critically Ill Patient: Society of Critical Care Medicine (SCCM) and American Society for Parenteral and Enteral Nutrition (A.S.P.E.N.). JPEN J Parenter Enteral Nutr. 2016; 40: 159-211. 
CQ12-7-1：敗血症患者に対して，急性期にビタ ミン C 投与を行うか? (保険適用外使用)

Answer : 敗血症患者に対して, ビタミンC の投与を 行うことを弱く推奨する（GRADE 2D：エビデンスの 確実性 $=\lceil$ 非常に低」)。

\section{（1）背景および本 $C Q$ の重要度}

ビタミン $\mathrm{C}$ は, 水溶性ビタミンに分類され, 生体 内で合成できない。近年，敗血症患者においてビタミ ン C を投与することで生存率を改善できる可能性が 報告され，注目されている。一方で，ビタミンCの 投与による腎障害の発生も懸念される。以上により, ビタミンCの投与の敗血症患者における益と害のバ ランスを明らかにすることは, 本ガイドラインに取り 上げるべき重要臨床課題であると考える。

\section{(2) PICO}

P (患者) : 集中治療室で治療を受ける重症患者

I（介入）:ビタミンC 投与

$\mathrm{C}$ (対照) : プラセボまたはビタミン $\mathrm{C}$ 非投与

$\mathrm{O}$ (アウトカム) : 死亡, 病院滞在日数, 急性腎障害 (AKI) 発生

\section{（3）エビデンスの要約}

システマティックレビューの結果, PICO に合致し
たランダム化比較試験（RCT）が 11 件 1-11）施行され ておりここれらを用いたメタ解析を実施した。

（4）益と害のバランス（Table 12-7-1-1）

望ましい効果 :

死亡に関する効果推定值は 28 日死亡リスク差 $(\mathrm{RD})$ 1,000 人あたり 55 人少ない $(95 \%$ CI: 131 人少ない〜 52 人多い）(5 RCT，1,646 人), 院内死亡 RD 1,000 人あ たり 25 人少ない $(95 \%$ CI: 105 人少ない 83 人多い) （7 RCT，1,798 人）である。ICU 滞在日数に関する効 果推定值は, 平均 (MD) 0.58 日短い (95\% CI: 1.45 日短い〜 0.28 日長い)（6 RCT，1,394人）である。 AKI に関する効果推定值は, RD 1,000 人あたり 18 人 少ない（95\% CI: 111 人少ない〜92 人多い）（2 RCT, 248 人) である。この AKI をアウトカムとした 2 編 のRCT (Tanaka 2000²), Fujii 202011) のうち, Tanaka 20002) は小規模（37 人）かつ AKI 発生率が介 入, 対照とも $0 \%$ であった。AKIに関する効果推定値 は Fujii 202011）の報告によるところが大きい。28日 死亡および 90 日死亡のいずれもわずかに減少させる 傾向かつ患者にとって非常に重大なアウトカムの改善 と考えられるため，望ましい効果は「小さい」と判断 した。

望ましくない効果 :

病院滞在日数に関する効果推定值は, MD 0.64 日長 い（95\% CI: 1.24 日短い〜2.52 日長い）（5 RCT，1,556

Table 12-7-1-1エビデンスプロファイル

\begin{tabular}{|c|c|c|c|c|c|c|c|c|c|c|c|c|}
\hline \multicolumn{7}{|c|}{ 確実性の評価 } & \multicolumn{2}{|c|}{ 患者数 } & \multicolumn{2}{|c|}{ 勃果 } & \multirow[b]{2}{*}{ 確実性 } & \multirow[b]{2}{*}{ 重要性 } \\
\hline 研究数 & $\begin{array}{c}\text { 研究 } \\
\text { デザイン }\end{array}$ & $\begin{array}{l}\text { パイアス } \\
\text { のリスク }\end{array}$ & 非一貫性 & 非直接性 & 不精確性 & $\begin{array}{l}\text { その他 } \\
\text { の検討 }\end{array}$ & Vitamin C & $\mathrm{Pl}$ acebo & $\begin{array}{l}\text { 相対指標 } \\
(95 \% \mathrm{CI})\end{array}$ & $\begin{array}{l}\text { 䋓対指標 } \\
(95 \% \text { CI })\end{array}$ & & \\
\hline \multicolumn{13}{|c|}{28 日死亡 } \\
\hline 5 & RCT & 深刻でない & 深刻 a & 深刻でない & 深刻 b & なし & $248 / 837(29.6 \%)$ & $\begin{array}{l}246 / 809 \\
(30.4 \%)\end{array}$ & $\begin{array}{c}\text { RR } 0.82 \\
(0.57 \text { to } 1.17)\end{array}$ & $\begin{array}{c}1,000 \text { 人あたり } 55 \\
\text { 人少ない(131人 } \\
\text { 少ない 52人多 } \\
\text { () }\end{array}$ & $\underset{\text { 低 }}{\oplus \oplus \bigcirc \bigcirc}$ & 重大 \\
\hline \multicolumn{13}{|l|}{ 院内死亡 } \\
\hline 7 & RCT & 深刻。 & 深刻 d & 深刻でない & 深刻 b & なし & $321 / 923(34.8 \%)$ & $\begin{array}{l}317 / 875 \\
(36.2 \%)\end{array}$ & $\begin{array}{c}\text { RR } 0.93 \\
(0.71 \text { to } 1.23)\end{array}$ & $\begin{array}{c}\text { 1,000人あたり } 25 \\
\text { 人少ない(105人 } \\
\text { 少ない 83人多 } \\
\text { ( ) }\end{array}$ & $\begin{array}{l}\oplus \bigcirc 0 \bigcirc \\
\text { 非常に低 }\end{array}$ & 重大 \\
\hline \multicolumn{13}{|c|}{ ICU 滞在日数 } \\
\hline 6 & RCT & 深刻。 & 深刻でない & 深刻でない & 深刻でない & なし & 717 & 677 & - & $\begin{array}{c}\text { 平均 } 0.58 \text { 日短い } \\
(1.45 \text { 日短い } \\
0.28 \text { 日長い) } \\
\end{array}$ & $\begin{array}{c}\oplus \oplus \oplus \bigcirc \\
\text { 中 }\end{array}$ & 重大 \\
\hline \multicolumn{13}{|c|}{ 病院滞在日数 } \\
\hline 5 & RCT & 深刻。 & 深刻でない & 深刻でない & 深刻でない & なし & 802 & 754 & - & $\begin{array}{c}\text { 平均 } 0.64 \text { 日長い } \\
\text { (1.24 日短い } \\
\text { 2.52 日長い) }\end{array}$ & $\begin{array}{c}\oplus \oplus \oplus \bigcirc \\
\text { 中 }\end{array}$ & 重大 \\
\hline \multicolumn{13}{|c|}{ 急性腎障害 } \\
\hline 2 & RCT & 深刻。 & 深刻でない & 深刻でない & 深刻 e & なし & $75 / 126 \quad(59.5 \%)$ & $75 / 122 \quad(61.5 \%)$ & $\begin{array}{c}\text { RR } 0.97 \\
(0.82 \text { to } 1.15)\end{array}$ & $\begin{array}{c}1,000 \text { 人あたり } 18 \\
\text { 人少ない(111 } \\
\text { 少ない 92 人多 } \\
\text { (1) }\end{array}$ & $\underset{\text { 低 }}{\oplus \oplus \bigcirc \bigcirc}$ & 重大 \\
\hline
\end{tabular}

a. $I^{2}=62 \%$ と中等度の異質性があり，その原因について明確な理由を抽出することはできないため，2段階のグレードダウンとした。

b. 信頼区間が臨床的推奨非推奖決定領域を片側またいでいる：1レベルグレードダウン。

c. 定量的バイアスのリスク評価基準により，1段階グレードダウン。

d. $I^{2}=64 \%$ と中等度の異質性があり，その原因について明確な理由を抽出することはできないため，2段階のグレードダウンとした。

e. サンプルサイズが小さい。 
人）である。介入により病院滞在日数が延長する傾向 ではあるものの，非常に短期間であると考えられる。 上記から, 望ましくない効果は,「わずか」と考えら れる。

益と害のバランス :

本 CQ においては，望ましい効果は小さいながらも 介入が優位であり，介入に対する望ましくない効果も わずかである。さらに死亡についての相対的価值を考 慮すると，介入が優位と考えられる。

\section{（5）アウトカム全般に関するエビデンスの確実性}

各アウトカムは異なる方向性を示しており，重大な アウトカムに関するエビデンスの確実性の中でも最も 低い「非常に低」とした。

\section{（6）価値観}

栄養療法におけるアウトカムに関する，価值観につ いてのデータはない。一般的に死亡に対して置く相対 的価值は高く，そのばらつきは少ないことが予想され る。

\section{（7）容認性}

ビタミン $\mathrm{C}$ を経静脈的に投与した場合，本邦の承 認量の上限である $2,000 \mathrm{mg}$ を投与したとしても，1 日 の薬価が約 80〜1,600 円であり，容認されると考えら れる。

\section{（8）実行可能性}

一般的な薬剤であり, どの病院においても実行可能
性は高いといえるが，適用外使用と判断される場合， 倫理委員会の承認などの院内手続きが必要な施設もあ ると考えられる。

(9) 判断の要約 (Table 12-7-1-2)

（10）推奨グレーディング決定の工程

修正 RAND 法を用いた投票によって，中央值 7, 見解不一致指数 0.018 の結果となり, 委員会で採択さ れた（7 点以上 : 91.7\%)。

\section{（11）関連する他の診療ガイドラインにおける推奨}

日本版敗血症診療ガイドライン（J-SSCG）2016 12), SSCG 2016 13), ASPEN/SCCM 栄養ガイドライン ${ }^{14)}$, 日本版重症患者の栄養療法ガイドライン 15) のいずれ においても，ビタミン全般に対する記載はあるものの 個別にビタミン Cについて詳細に言及されたものは ない。

\section{（12）実施に関わる検討事項}

メタ解析に採用した RCT のうち，ビタミン C 投与 量が本邦の保険適用内の研究が 5 つ, 保険適用以上の

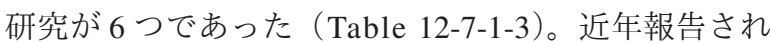
ている研究は，いずれも介入群として保険適用外の投 与量が用いられている傾向がある。しかしながら，最 適なビタミン $\mathrm{C}$ 投与量は現時点では不明であり，本 邦の保険適用上限である $2,000 \mathrm{mg} /$ 日を超えて投与す ることについては注意が必要である。また保険診療上 の適応疾患は, 消耗性疾患などでビタミン Cの需要

Table 12-7-1-2 判断の要約

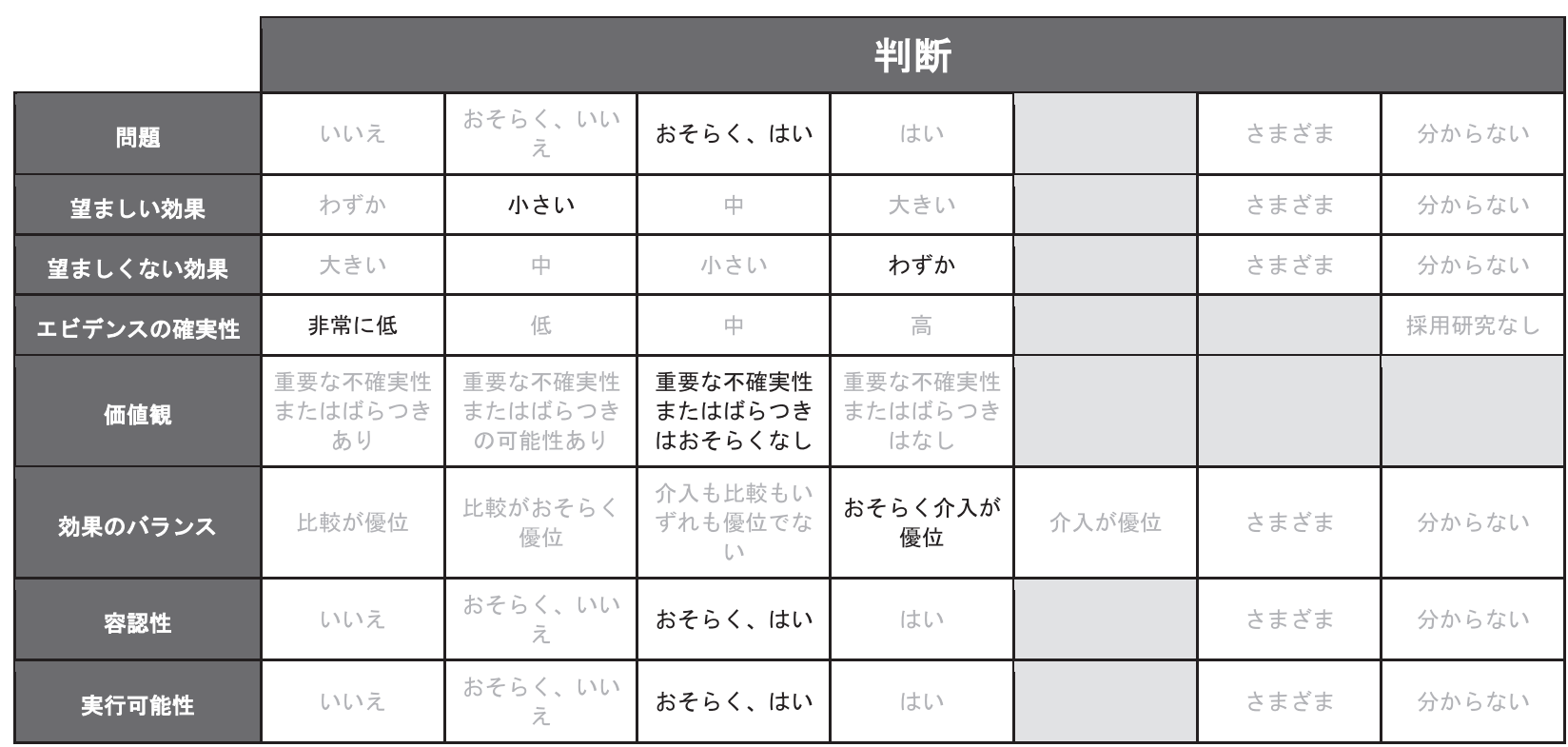


日本版敗血症診療ガイドライン 2020

Table 12-7-1-3 メタ解析に用いたRCTでの投与量

\begin{tabular}{lllc}
\hline Author, Year & Year & 対象患者 & 1 日投与量* $(\mathrm{mg})$ \\
\hline Porter, 1999 1) & 1999 & 外傷患者 & 300 \\
\hline Tanaka, 2000 2) & 2000 & 熱傷患者 & 79,200 \\
\hline Crimi, 2004 3) & 2004 & 重症患者 & 500 \\
\hline Ferrón-Celma, 20094) & 2009 & 敗血症患者 & 450 \\
\hline Nogueira, 2013 5) & 2013 & 重症患者 & 600 \\
\hline Heyland, 2013 6) & 2013 & 多藏器不全患者 & 1,500 \\
\hline Fowler, 20147) & 2014 & 敗血症・敗血症性ショック患者 & $2,500,10,000$ \\
\hline Howe, 2015 8) & 2015 & 人工呼吸患者 & 3,000 \\
\hline Zabet, 2016 9) & 2016 & 敗血症性ショック患者 & 5,000 \\
\hline Fowler, 2019 10) & 2019 & 敗血症患者とARDS 患者 & 10,000 \\
\hline Fujii, 2020 11) & 2020 & 敗血症性ショック患者 & 6,000 \\
\hline *50kg 換算 & & &
\end{tabular}

が増大し，食事からの掑取が不十分な際の補給である ことにも十分に留意する必要がある。各施設で適用外 使用と判断される場合や保険承認用量を超えて投与す る場合には，倫理委員会の承認など各施設が定める院 内手続きを適正に踏んだうえで実施する。

\section{（13）今後の研究の可能性}

今後, 適切な投与のタイミングや投与経路などを解 明するさらなる大規模研究が行われることが望まれ る。

\section{文 献}

1) Porter JM, Ivatury RR, Azimuddin K, et al: Antioxidant therapy in the prevention of organ dysfunction syndrome and infectious complications after trauma: Early results of a prospective randomized study. Am Surg. 1999; 65: 478-83.

2) Tanaka H, Matsuda T, Miyagantani $Y$, et al: Reduction of resuscitation fluid volumes in severely burned patients using ascorbic acid administration: A randomized, prospective study. Arch Surg. 2000; 135: 326-31.

3) Crimi E, Liguori A, Condorelli M, et al: The beneficial effects of antioxidant supplementation in enteral feeding in critically III patients: A prospective, randomized, double-blind, placebocontrolled trial. Anesth Analg. 2004; 99: 857-63.

4) Ferrón-Celma I, Mansilla A, Hassan L, et al: Effect of Vitamin C Administration on Neutrophil Apoptosis in Septic Patients After Abdominal Surgery. J Surg Res. 2009; 153: 224-30.

5) Nogueira CR, Borges F, Lameu E, et al: Efectos de la suplementación con vitaminas antioxidantes y la peroxidación lipídica en pacientes críticos. Nutr Hosp. 2013; 28: 1666-72.

6) Heyland D, Muscedere J, Wischmeyer PE, et al: A randomized trial of glutamine and antioxidants in critically Ill patients. N Engl J Med. 2013; 368: 1489-97.

7) Fowler AA 3rd, Syed AA, Knowlson S, et al: Phase I safety trial of intravenous ascorbic acid in patients with severe sepsis. J Transl Med. 2014; 12: 32.

8) Howe KP, Clochesy JM, Goldstein LS, et al: Mechanical ventilation antioxidant trial. Am J Crit Care. 2015; 24: 440-5.

9) Zabet MH, Mohammadi M, Ramezani M, et al: Effect of high-dose Ascorbic acid on vasopressor's requirement in septic shock. J Res Pharm Pract. 2016; 5: 94-100.

10) Fowler AA 3rd, Truwit JD, Hite RD, et al: Effect of Vitamin C
Infusion on Organ Failure and Biomarkers of Inflammation and Vascular Injury in Patients with Sepsis and Severe Acute Respiratory Failure: The CITRIS-ALI Randomized Clinical Trial. JAMA. 2019; 322: 1261-70.

11) Fujii T, Luethi N, Young PJ, et al: Effect of Vitamin C, Hydrocortisone, and Thiamine vs Hydrocortisone Alone on Time Alive and Free of Vasopressor Support among Patients with Septic Shock: The VITAMINS Randomized Clinical Trial. JAMA. 2020; 323: 423-31.

12) Nishida O, Ogura H, Egi M, et al: The Japanese Clinical Practice Guidelines for Management of Sepsis and Septic Shock 2016 (J-SSCG 2016). J Intensive Care. 2018; 6: 7.

13) Rhodes A, Evans LE, Alhazzani W, et al: Surviving Sepsis Campaign: International Guidelines for Management of Sepsis and Septic Shock: 2016. Intensive Care Med. 2017; 43: 304-77.

14) Taylor BE, McClave SA, Martindale RG, et al: Guidelines for the Provision and Assessment of Nutrition Support Therapy in the Adult Critically Ill Patient: Society of Critical Care Medicine (SCCM) and American Society for Parenteral and Enteral Nutrition (A.S.P.E.N.). Crit Care Med. 2016; 44: 390-438.

15）日本集中治療医学会重症患者の栄養管理ガイドライン作成 委員会: 日本版重症患者の栄養療法ガイドライン. 日集中医 誌. 2016; 23: 185-281. 
CQ12-7-2：敗血症患者に対して，急性期にビタ ミン D 投与を行うか?（保険適用外使用）

Answer : 敗血症患者に対して，ビタミン D 投与を行 わないことを弱く推奨する（GRADE 2D：エビデンス の確実性 $=$ 「非常に低」)。

\section{（1）背景および本 CQの重要度}

ビタミン D は, 脂溶性ビタミンに分類され，生体 内で合成できない。ビタミン D は，カルシウム・リ ン代謝の調節，心筋収縮力の増大および細胞増殖の制 御などの重要な役割を担う。近年, ビタミン D 欠乏 が敗血症の発症や死亡率に関与することが報告され， 注目されている。以上により，敗血症患者に対して急 性期にビタミン D 投与を行うか否かは，本ガイドラ インに取り上げるべき重要臨床課題であると考える。

\section{(2) PICO}

$\mathrm{P}$ (患者) : 集中治療室で治療を受ける重症患者
$\mathrm{I}$ (介入 $):$ ビタミン D 投与
$\mathrm{C}$ (対照) : プラセボまたはビタミン D 非投与
$\mathrm{O}$ (アウトカム $):$ 死亡, 病院滞在日数, 高カルシウ
么血症発生

（3）エビデンスの要約

システマティックレビューの結果, PICO に合致し たランダム化比較試験（RCT）が 11 件 1-11）施行され ており，これらを用いたメタ解析を実施した。

(4) 益と害のバランス（Table 12-7-2-1）

望ましい効果：

死亡に関する効果推定值は，28日または 30 日死亡 のリスク差（RD）1,000人あたり 8 人少ない $(95 \% \mathrm{CI}:$ 50 人少ない〜 46 人多い) $\left(6 \mathrm{RCT}^{3-5,7,10,11)}, 1,966\right.$ 人), 90 日死亡の RD 1,000 人あたり 28 人多い $(95 \%$ CI: 18 人少ない〜 85 人多い) $\left(3 \mathrm{RCT}^{6,7,10)}, 1,157\right.$ 人), 院内 死亡の RD 1,000 人あたり 95 人少ない $(95 \%$ CI: 180 人 少ない〜41 人多い) $\left(4 \mathrm{RCT}^{1,2,4,9)}, 632\right.$ 人）である。 病院滞在日数に関する効果推定值は, 平均（MD） 0.32 日短い $(95 \%$ CI: 2.15 日短い〜1.5日長い) (9 $\mathrm{RCT}^{1,3-8,10,11)}, 1,886$ 人）である。90 日死亡について 介入により増加, 28 日または 30 日死亡は効果なし, 院内死亡は低下という結果であった。死亡に関するエ ビデンスの確実性は 28 日または 30 日死亡が「低」，他

Table 12-7-2-1エビデンスプロファイル

\begin{tabular}{|c|c|c|c|c|c|c|c|c|c|c|c|c|}
\hline \multicolumn{7}{|c|}{ 確実性の評価 } & \multicolumn{2}{|c|}{ 患者数 } & \multicolumn{2}{|c|}{ 効果 } & \multirow[b]{2}{*}{ 確実性 } & \multirow[b]{2}{*}{ 重要性 } \\
\hline 研究数 & $\begin{array}{l}\text { 研究 } \\
\text { デサン }\end{array}$ & $\begin{array}{l}\text { パイアス } \\
\text { のリスク }\end{array}$ & 非一貫性 & 非直接性 & 不精確性 & $\begin{array}{l}\text { その他 } \\
\text { の検討 }\end{array}$ & Vitamind & Placebo & $\begin{array}{l}\text { 相対指標 } \\
(95 \% \text { CI })\end{array}$ & $\begin{array}{l}\text { 絶対指標 } \\
(95 \% \mathrm{CI})\end{array}$ & & \\
\hline \multicolumn{13}{|c|}{28 日または 30 日死亡 } \\
\hline 6 & RCT & 深刻でない & 深刻でない & 深刻a & 深刻。 & なし & $\begin{array}{l}166 / 991 \\
(16.8 \%)\end{array}$ & $161 / 975 \quad(16.5 \%)$ & $\begin{array}{c}\mathrm{RR} 0.95 \\
(0.70 \text { to } 1.28)\end{array}$ & $\begin{array}{l}1,000 \text { 人あたり } 8 \\
\text { 人少ない (50人少 } \\
\text { ない 46人多い) }\end{array}$ & $\underset{\text { 低 }}{\oplus \oplus \bigcirc \bigcirc}$ & 重大 \\
\hline \multicolumn{13}{|c|}{90 日死亡 } \\
\hline 3 & RCT & 深刻でない & 深刻でない & 非常に深刻 d & 深刻き & なし & $\begin{array}{l}132 / 584 \\
(22.6 \%)\end{array}$ & $113 / 573 \quad(19.7 \%)$ & $\begin{array}{c}\text { RR } 1.14 \\
(0.91 \text { to } 1.43)\end{array}$ & $\begin{array}{l}1,000 \text { 人あたり } 28 \\
\text { 人多い (18 人少な } \\
\text { い 85 人多い) }\end{array}$ & $\begin{array}{l}\oplus \bigcirc 00 \\
\text { 非常に低 }\end{array}$ & 重大 \\
\hline \multicolumn{13}{|l|}{ 院内死亡 } \\
\hline 4 & RCT & 深刻 ${ }^{\dagger}$ & 深刻でない & 深刻a & 深刻。 & なし & $\begin{array}{l}78 / 317 \\
(24.6 \%)\end{array}$ & $107 / 315 \quad(34.0 \%)$ & $\begin{array}{c}\text { RR } 0.72 \\
(0.47 \text { to } 1.12)\end{array}$ & $\begin{array}{c}1,000 \text { 人あたり } 95 \\
\text { 人少ない }(180 \text { 人 } \\
\text { 少ない 41 人多 } \\
\text { () }\end{array}$ & $\begin{array}{l}\oplus \bigcirc \bigcirc \bigcirc \\
\text { 非常に低 }\end{array}$ & 重大 \\
\hline \multicolumn{13}{|c|}{ ICU 滞在日数 } \\
\hline \begin{tabular}{|l|}
6 \\
\end{tabular} & RCT & 深刻でない & 深刻 g & 深刻 a & 深刻でない & なし & 358 & 337 & - & $\begin{array}{c}\text { 平均 } 0.24 \text { 日短い } \\
\text { (3.72 日短い } \\
3.23 \text { 日長い) }\end{array}$ & $\underset{\text { 低 }}{\oplus \oplus \bigcirc \bigcirc}$ & 重大 \\
\hline \multicolumn{13}{|c|}{ 病院滞在日数 } \\
\hline 9 & RCT & 深刻 f & 非常に深刻 h & 深刻 a & 深刻でない & なし & 948 & 938 & - & $\begin{array}{c}\text { 平均 } 0.32 \text { 日短い } \\
\text { (2.15 日短い } \\
1.5 \text { 日長い) }\end{array}$ & $\begin{array}{l}\oplus \bigcirc \bigcirc \bigcirc \\
\text { 非常に低 }\end{array}$ & 重大 \\
\hline \multicolumn{13}{|c|}{ 高カルシウム血症 } \\
\hline 5 & RCT & 深刻でない & 深刻 ' & 深刻 b & 非常に深刻 j & なし & $\begin{array}{l}15 / 637 \\
(2.4 \%)\end{array}$ & $15 / 639 \quad(2.3 \%)$ & $\begin{array}{c}\text { RR } 0.70 \\
(0.13 \text { to } 3.77)\end{array}$ & $\begin{array}{l}\text { 1, } 000 \text { 人あたり } 7 \\
\text { 人少ない }(20 \text { 人少 } \\
\text { ない } 65 \text { 人多い) }\end{array}$ & $\begin{array}{l}\text { @O○O } \\
\text { 非常に低 }\end{array}$ & 重大 \\
\hline
\end{tabular}

a. 対象患者は重症患者であり，敗血症は少ない。

サンプルサイズが小さい。

信頼区間が臨床的推奨非推奖決定領域を両側またいでいるもののわずかであるため, 1レベルグレードダウン

対象患者は重症患者のみである。

信頼区間が臨床的推粱非推奨決定領域を片側またいでいる：1レベルグレードダウン

定量的バイアスのリスク評価基準により，1段階グレードダウン

$\mathrm{I}^{2}=63 \%$ と中等度の異質性があり，その原因について明確な理由を抽出することはできないため，2段階のグレードダウンとした

$\mathrm{I}^{2}=70 \%$ と中等度の異質性があり，その原因について明確な理由を抽出することはできないため，2段階のグレードダウンとした。

$\mathrm{I}^{2}=58 \%$ と中等度の異質性があり，その原因について明確な理由を抽出することはできないため，2段階のグレードダウンとした。

信頼区間が臨床的推奨非推奨決定領域を両側またいでいる : 2 レベルグレードダウン 
は「非常に低」であった。エビデンスの確実性の最も 高い28日または30日死亡の結果から介入の効果は 「ない」あるいはあっても「わずか」と判断する。

\section{望ましくない効果 :}

高カルシウム血症に関する効果推定值は, RD 1,000 人あたり 7 人少ない $(95 \% \mathrm{CI}: 20$ 人少ない〜 65 人多い) $\left(5 \mathrm{RCT}^{1,3}, 4,7,10\right) ， 1,276$ 人) である。望ましくない効 果はわずかであると判断した。

益と害のバランス :

本 CQ においては，望ましい効果は介入において 「ない」かあっても「わずか」である。したがって， 介入も比較もいずれも優位ではないと判断する。

（5）アウトカム全般に関するエビデンスの確実性

各アウトカムは異なる方向性を示しており，重大な アウトカムに関するエビデンスの確実性の中でも最も 低い「非常に低」とした。

\section{（6）価値観}

栄養療法におけるアウトカムに関する，価值観につ いてのデータはない。一般的に死亡に対して置く相対 的価值は高く，そのばらつきは少ないことが予想され る。

\section{（7）容認性}

本邦で使用可能なビタミン D 製剤は数種類存在し, 内服あるいは経静脈の投与が可能である。しかしなが ら, 敗血症への使用は適用外使用となる。保険適用内 の使用では，1 日あたり約 100 円〜2,000 円/日のコス
トがかかりばらつきがある。上記から，説明によって は容認できない患者・家族がいることが想定されるた め，容認性は様々とした。

\section{（8）実行可能性}

適応外使用となるため，倫理委員会など病院規定の 承認を得る必要があるなど, 実行可能性には疑念があ る。

（9）判断の要約（Table 12-7-2-2）

（10）推奨グレーディング決定の工程

修正 RAND 法を用いた投票によって，中央值 7, 見解不一致指数 0.164 の結果となり, 委員会で採択さ れた（7 点以上 : $95.8 \%) 。$

\section{（11）関連する他の診療ガイドラインにおける推奨}

日本版敗血症診療ガイドライン（J-SSCG）2016 ${ }^{12)}$, SSCG 2016 13), ASPEN/SCCM 栄養ガイドライン 14), 日本版重症患者の栄養療法ガイドライン15) のいずれ においても，ビタミン全般に対する記載はあるものの 個別にビタミン D について詳細に言及されたものは ない。

\section{（12）実施に関わる検討事項}

ビタミン D 欠乏状態の患者を対象にした RCT のみ でサブグループ解析を実施した。28日または 30 日死 亡については $\left.3 \mathrm{RCT}^{4}, 10,11\right)$ が該当し， RD 1,000人あ たり 3 人少ない $(95 \% \mathrm{CI}: 60$ 人少ない〜 82 人多い),

Table 12-7-2-2 判断の要約

\begin{tabular}{|c|c|c|c|c|c|c|c|}
\hline 問題 & いいえ & $\begin{array}{c}\text { おそらく、いい } \\
\text { え }\end{array}$ & おそらく、はい & はい & & さまざま & 分からない \\
\hline 望ましい効果 & わずか & 小さい & 中 & 大きい & & さまざま & 分からない \\
\hline 望ましくない効果 & 大きい & 中 & 小さい & わずか & & さまざま & 分からない \\
\hline エビデンスの確実性 & 非常に低 & 低 & 中 & 高 & & & 採用研究なし \\
\hline 価值観 & $\begin{array}{c}\text { 重要な不確実性 } \\
\text { またはばらつき } \\
\text { あり }\end{array}$ & $\begin{array}{c}\text { 重要な不確実性 } \\
\text { またはばらつき } \\
\text { の可能性あり }\end{array}$ & $\begin{array}{l}\text { 重要な不確実性 } \\
\text { またはばらつき } \\
\text { はおそらくなし }\end{array}$ & $\begin{array}{c}\text { 重要な不確実性 } \\
\text { またはばらつき } \\
\text { はなし }\end{array}$ & & & \\
\hline 勃果のバランス & 比較が優位 & $\begin{array}{c}\text { 比較がおそらく } \\
\text { 優位 }\end{array}$ & $\begin{array}{c}\text { 介入も比較もい } \\
\text { ずれも優位でな } \\
\text { い }\end{array}$ & $\begin{array}{c}\text { おそらく介入が } \\
\text { 優位 }\end{array}$ & 介入が優位 & さまざま & 分からない \\
\hline 容認性 & いいえ & $\begin{array}{c}\text { おそらく、いい } \\
\text { え }\end{array}$ & おそらく、はい & はい & & さまざま & 分からない \\
\hline 実行可能性 & いいえ & $\begin{array}{c}\text { おそらく、いい } \\
\text { え }\end{array}$ & おそらく、はい & はい & & さまざま & 分からない \\
\hline
\end{tabular}


90 日死亡については $1 \mathrm{RCT}{ }^{10 ）}$ が該当し， RD 1,000人 あたり 29 人多い $(95 \% \mathrm{CI}: 19$ 人少ない〜89人多い) と方向性に変わりはなかった。

また，採用した RCT のビタミン D の投与方法は一 定でない。また，使用量は本邦の保険適用量よりも著 しく多い量であることを考慮する必要がある。ビタミ ン $\mathrm{D}$ 投与は適用外使用となるため，施設において適 切な手続きの後に実施することが求められる。

なお，本推奨は，通常の経腸栄養剂や高カロリー輸 液製剤によるビタミン D 投与を妨げるものではない。

\section{（13）今後の研究の可能性}

今後, 適切な投与のタイミングや投与経路などを解 明するさらなる大規模研究が行われることが望まれ る。

\section{文 献}

1) Amrein K, Sourij H, Wagner G, et al: Short-term effects of high-dose oral vitamin D3 in critically ill vitamin D deficient patients: A randomized, double-blind, placebo-controlled pilot study. Crit Care. 2011; 15: R104.

2) Aminmansour B, Nikbakht H, Ghorbani A, et al: Comparison of the administration of progesterone versus progesterone and vitamin D in improvement of outcomes in patients with traumatic brain injury: A randomized clinical trial with placebo group. Adv Biomed Res. 2012; 1: 58.

3) Leaf DE, Raed A, Donnino MW, et al: Randomized controlled trial of calcitriol in severe sepsis. Am J Respir Crit Care Med. 2014; 190: 533-41.

4) Amrein K, Schnedl C, Holl A, et al: Effect of High-Dose Vitamin D 3 on Hospital Length of Stay in Critically Ill Patients With Vitamin D Deficiency: the VITdAL-ICU randomized clinical trial. JAMA .2014; 312: 1520-30.

5) Quraishi SA, De Pascale G, Needleman JS, et al: Effect of Cholecalciferol Supplementation on Vitamin D Status and Cathelicidin Levels in Sepsis: A Randomized, Placebo-Controlled Trial. Crit Care Med. 2015; 43: 1928-37.

6) Han JE, Jones JL, Tangpricha V, et al: High dose Vitamin D administration in ventilated intensive care unit patients: A pilot double blind randomized controlled trial. J Clin Transl Endocrinol. 2016; 4: 59-65.

7) Parekh D, Dancer RCA, Scott A, et al: Vitamin D to Prevent Lung Injury Following Esophagectomy-A Randomized, PlaceboControlled Trial. Crit Care Med. 2018; 46: e1128-35.

8) Jokar A, Ahmadi K, Taherinia A, et al: The effects of injected Vitamin D on prognosis of patients with urosepsis. Horm Metab Res. 2018; 50: 383-8.

9) Hasanloei MAV, Rahimlou M, Eivazloo A, et al: Effect of Oral Versus Intramuscular Vitamin D Replacement on Oxidative Stress and Outcomes in Traumatic Mechanical Ventilated Patients Admitted to Intensive Care Unit. Nutr Clin Pract. 2019; 35 548-58.

10) National Heart, Lung, and Blood Institute PETAL Clinical Trials Network, Ginde AA, Brower RG, Caterino JM, et al: Early high-dose Vitamin D3 for critically ill, Vitamin D-deficient patients. N Engl J Med. 2019; 381: 2529-40.

11) Karsy M, Guan J, Eli I, et al: The effect of supplementation of vitamin D in neurocritical care patients: RandomizEd Clinical
TrIal oF hYpovitaminosis D (RECTIFY). J Neurosurg. 2019; 13: $1-10$.

12) Nishida O, Ogura H, Egi M, et al: The Japanese Clinical Practice Guidelines for Management of Sepsis and Septic Shock 2016 (J-SSCG 2016). J Intensive Care. 2018; 6: 7.

13) Rhodes A, Evans LE, Alhazzani W, et al: Surviving Sepsis Campaign: International Guidelines for Management of Sepsis and Septic Shock: 2016. Intensive Care Med. 2017; 43: 304-77.

14) Taylor BE, McClave SA, Martindale RG, et al: Guidelines for the Provision and Assessment of Nutrition Support Therapy in the Adult Critically Ill Patient: Society of Critical Care Medicine (SCCM) and American Society for Parenteral and Enteral Nutrition (A.S.P.E.N.). Crit Care Med. 2016; 44: 390-438.

15）日本集中治療医学会重症患者の栄養管理ガイドライン作成 委員会: 日本版重症患者の栄養療法ガイドライン. 日集中医 誌. 2016; 23: 185-281. 


\section{CQ12-8：敗血症患者における経腸栄養の開始や 耐性の判断方法は?}

Answer : 経腸栄養開始に腸蠕動音など腸管が働いて いる所見は必要でないとされる。一方，経腸栄養開始 後の不耐性を示す所見は, 腸音欠如または異常腸音, 嘔吐, 腸拡張, 下痢, 消化管出血, 胃内残留物過多な ど，様々である。胃内残留物過多は不耐性を示唆する が，耐性の有無を判断するための胃内残留量の基準は 不明である (BQに対する情報提示)。

\section{（1）背景および本 $C Q$ の重要度}

経腸栄養は集中治療患者の栄養療法において標準的 な治療となっている。しかし，どのような状態になれ ば経腸栄養を開始することができるか，また，経腸栄 養の継続をどのように判断するかの具体的な基準は不 明である。したがって，その背景にある知識について 解説する本 CQ の重要度は高い。

\section{（2）解説}

敗血症患者を対象とした研究は少ないため, 重症患 者からの知見をもとに経腸栄養の開始，耐性の判断に ついて概説する。循環動態が安定している症例におい て，消化管が使用可能である際には経腸栄養を開始す る。循環動態の安定の基準に関しては CQ12-2に，経 腸栄養の開始時期に関しては CQ12-3 に詳述する。

経腸栄養開始を検討する際，腸蠕動音や放屁の有無 が慣習的にモニタリングされてきた。しかし，腸蝡動 音の有無は, 腸が動いていることを示してはいるが, 腸管の健常性（腸管透過性，バリア機能，吸収能な ど）の評価にはならない。胃静止の改善を待って経腸 栄養を開始した群と, 待たずに開始した群を比較し, 予後に差がなかったとの報告 1）もある。一方，経腸 栄養開始が遅れると吸収能が低下する2）と指摘され ており，少なくとも腸蠕動音などを経腸栄養開始の必 須条件とする必要はないと考えられる。

経腸栄養の投与に伴い消化器症状が出現し, 栄養剂 が十分に投与できない状況を腸管不耐性という3)。腸 管不耐性は胃静止や腸閉塞，腸管虚血などに起因する 嘔吐, 腹痛, 胃内残留物過多, 腹部膨満, 鼓腸, 消化 管出血, 蠕動六進や吸収能低下から来る下痢など様々 な症状で示される。しかし，腸管不耐性の明確な基準 はなく，その症状の原因となる疾患を鑑別し，原疾患 の治療や腸管蝡動薬の使用, 経腸栄養の減量, 中止な どを個々で判断する必要がある。

胃内容残留量についても腸管不耐性の所見として使
用されてきた。しかし, 胃内容残留量は肺炎の発症 率 4), 胃排出能 5), 逆流や誤嚥の発症率 6) と相関しな いことが示されている。また, 胃内容残留量の測定に より嘔吐は減る7）が，栄養チューブの閉塞 [測定時 に逆流した胃内容物中のタンパク質がカード化（固形 化）することも一因と考えられる] や不必要な経腸栄 養の中断（臨床的に問題ない量の胃内容残留でも中断 するなど）を増やし，結果として経腸栄養投与量が減 り，予後には影響しないとの報告 ${ }^{8)}$ もある。1 回の吸 引で $500 \mathrm{~mL}$ 以上引けた場合は経腸栄養を中止し，原

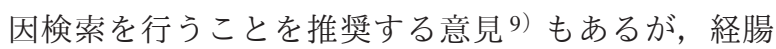
栄養を減量ないし中止するべき胃内容残留量の基準は 不明であり，胃内容残留量の測定を行うことをルーチ ンの業務として支持するデータは乏しいといえる。

\section{文 献}

1) Minard G, Kudsk KA, Melton S, et al: Early versus delayed feeding witn an immune-enhancing diet in patients with severe head injuries. J Parenter Enter Nutr. 2000; 24: 145-9.

2) Nguyen N, Besanko LK, Burgstad C, et al: Delayed enteral feeding impairs intestinal carbohydrate absorption in critically ill Patients. Crit Care Med. 2011; 40: 50-4.

3) Elke G, Felbinger TW, Heyland DK: Gastric residual volume in critically ill patients: A dead marker or still alive?. Nutr Clin Pract. 2015; 30: 59-71.

4) Montejo JC, Miñambres E, BordejéL, et al: Gastric residual volume during enteral nutrition in ICU patients: The REGANE study. Intensive Care Med. 2010; 36: 1386-93.

5) Landzinski J, Kiser TH, Fish DN, et al: Gastric motility function in critically ill patients tolerant vs intolerant to gastric nutrition. J Parenter Enter Nutr. 2008; 32: 45-50.

6) McClave SA, Lukan JK, Stefater JA, et al: Poor validity of residual volumes as a marker for risk of aspiration in critically ill patients. Crit Care Med. 2005; 33: 324-30.

7) Reignier J, Mercier E, Gouge AL, et al: Effect of not monitoring residual gastric volume on risk of ventilator-associated pneumonia in adults receiving mechanical ventilation and early enteral feeding: A randomized controlled trial. JAMA. 2013; 309: 249-56.

8) Poulard F, Dimet J, Martin-Lefevre L, et al: Impact of not measuring residual gastric volume in mechanically ventilated patients receiving early enteral feeding: A prospective before-after study. J Parenter Enter Nutr. 2010; 34: 125-30.

9) McClave SA, Taylor BE, Martindale RG, et al: Guidelines for the Provision and Assessment of Nutrition Support Therapy in the Adult Critically Ill Patient: Society of Critical Care Medicine (SCCM) and American Society for Parenteral and Enteral Nutrition (A.S.P.E.N.). J Parenter Enter Nutr. 2016; 40: 159-211. 


\section{CQ12-9：敗血症患者における急性期以降の栄養 投与法は？}

Answer : 病態が急性期を乗り越えた場合，あるいは 1 週間程度を超えた時期からは，必要エネルギー（タ ンパク質を含めて 25〜30kcal/ kg/日程度）を満たす投 与量が必要と考えられている。同時期のタンパク質も $1 \mathrm{~g} / \mathrm{kg}$ /日以上の投与量が望ましいとの考えがある。た だし，重症化前から栄養障害のある患者ではより早期 に投与量を増やすほうがよいとの意見もある（BQに 対する情報提示)。

\section{（1）背景および本 CQの重要度}

急性期の栄養療法に関してはランダム化比較試験 （RCT）を含む多くの臨床研究が施行されており，本 ガイドラインでも CQ として取り上げられている。し かし，急性期以降の栄養投与の方法や内容，投与量な どに関しては言及されていない。実際の治療にあたっ ては, 急性期以降の栄養療法も重要であり, 本 CQ は 有用であると考える。

\section{（2）解説}

CQ12-4 において弱く推奨されているように，急性 期に意図して消費エネルギーよりも少なく栄養投与す る場合や，不可抗力により栄養投与量が少なくなる場 合があるが，その際に生じるエネルギー負債に配慮す る必要がある。エネルギー負債は消費エネルギー量と 投与エネルギー量の差の累積であるが，エネルギー負 債が大きくなるほど予後が悪化するといわれてい る 1,2)。エネルギー負債と予後との関係を示した研究 は観察研究に限られており，その結果には考慮すべき 交絡因子が介在すると考えられる。しかし，大きなエ ネルギー負債が患者の免疫や体組成に悪影響を与える のは自明であり，急性期から回復期に移行した際には 十分なエネルギー投与を行う必要があると考えられて いる。

急性期から回復期への移行は患者の病態ごとに大き く異なり，臨床的に急性期を脱したと判断されれば回 復期の栄養療法に切り替える。多くの急性期栄養療法 の臨床試験が 7 日前後を目安に介入期限としてお り 3-6), 先のエネルギー負債も鑑みて 7 日を目途に必 要エネルギー（タンパク質を含めて 25〜 30kcal $/ \mathrm{kg}$ /日 程度）を満たす栄養投与を行う戦略とするのが一般的 である7,8)。参考として，急性肺傷害を対象とした $\mathrm{RCT}^{9)}$ において，7 日目以前まではエネルギー投与量 の多い患者群で死亡率が高いのに対し，8日目以降は
エネルギー投与量が多いと逆に死亡率が低くなる傾向 がみられた。これらの研究結果は, 急性期から回復期 への移行にあたって栄養療法の見直しが必要となるこ とを示唆している。

タンパク質投与に関しても同様に急性期を越えた時 点で，十分なタンパク質の投与量を確保することが必 要かもしれない。急性期のタンパク質投与量を具体的 に何 $\mathrm{g} / \mathrm{kg} /$ 日とすべきかは CQ12-6で議論されている ようにエビデンスが不足しているが，健常時の推奨タ ンパク質摂取量を考えて最低でも $1 \mathrm{~g} / \mathrm{kg}$ /日以上必要と 考えるのが一般的である。

なお，低体重や筋肉量減少など栄養不良のある患者 は急性期から十分なエネルギー投与を考慮したほうが よいとの意見もある。ただし，極度の栄養不良の患者 に対する急速なエネルギー投与はリフィーディング症 候群を来す可能性があり，栄養の際にはリン，カリウ ム, マグネシウムおよび他の電解質の厳重なモニタリ ングが必要である。

\section{文 献}

1) Bartlett RH, Dechert RE, Mault JR, et al: Measurement of metabolism in multiple organ failure. Surgery. 1982: 92: 771-9.

2) Berger MM, Pichard C: Best timing for energy provision during critical illness. Crit Care. 2012; 16: 215.

3) Casaer MP, Mesotten D, Hermans G, et al: Early versus late parenteral nutrition in critically ill adults. N Engl J Med. 2011; 365: 506-17.

4) Wischmeyer PE, Hasselmann M, Kummerlen C, et al: A randomized trial of supplemental parenteral nutrition in underweight and overweight critically ill patients: the TOP-UP pilot trial. Crit Care. 2017; 21: 142.

5) Allingstrup MJ, Kondrup J, Wiis J, et al: Early goal-directed nutrition versus standard of care in adult intensive care patients: the single-centre, randomised, outcome assessor-blinded EAT-ICU trial. Intensive Care Med. 2017; 43: 1637-47.

6) Rice TW, Wheeler AP, Thompson BT, et al: Initial trophic vs full enteral feeding in patients with acute lung injury: the EDEN randomized trial: JAMA. 2012; 307: 795-803.

7) Singer P, Blaser AR, Berger MM, et al: ESPEN Guideline on Clinical Nutrition in the Intensive Care Unit. Clin Nutr. 2019; 38: 48-79.

8) McClave SA, Taylor BE, Martindale RG, et al: Guidelines for the Provision and Assessment of Nutrition Support Therapy in the Adult Critically Ill Patient: Society of Critical Care Medicine (SCCM) and American Society for Parenteral and Enteral Nutrition (A.S.P.E.N.). JPEN J Parenter Enteral Nutr. 2016; 40: 159-211.

9) Braunschweig CL, Freels S, Sheean PM, et al; Role of timing and dose of energy received in patients with acute lung injury on mortality in the Intensive Nutrition in Acute Lung Injury Trial (INTACT): a post hoc analysis. Am J Clin Nutr. 2017; 105: 411-6. 


\section{CQ13：血糖管理}

高血糖の発生は免疫能に影響を与え，感染症を増悪 させるなど, 予後を悪化させる可能性があり, 敗血症 患者における血糖管理は重要である。インスリンを使 用した血糖管理の重要な害として低血糖があり，低血

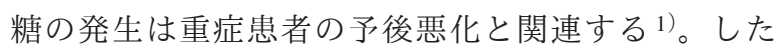
がって，目標血糖值の設定には益と害のバランスを考 慮する必要がある。また, 誤った血糖測定はインスリ ンの不適切な使用の要因となる。以上から, 目標血糖 值と血糖測定方法の 2 つを重要臨床課題（CQ）とし た。

\section{目標血糖値}

心臓外科集中治療室での単独施設ランダム化比較試 験（RCT）では，目標血糖值を $80 \sim 110 \mathrm{mg} / \mathrm{dL}$ とする 強化インスリン療法を行うことで，集中治療室での死 亡率が低下することが報告された ${ }^{2)}$ 。続いて内科系集 中治療室で ICU 滞在日数が 3 日以上と見積もられた 患者を対象とした RCT が行われたが，強化インスリ ン療法の使用によって全患者群の死亡率は減少しな かった ${ }^{3)}$ 。集中治療患者における血糖管理の目標值を 検証した RCTのうち, 最大規模の研究である NICE-SUGAR trial では, 強化インスリン療法は 90 日 死亡率と低血糖の発生を増加させた ${ }^{4)}$ 。敗血症患者を 対象にしたSong らのメタ解析では, 強化インスリン 療法と通常の血糖管理を比較して死亡率に両群で差は なく, 強化インスリン療法は低血糖の危険性が高いと 報告している5)。これらの知見により, SSCG 2016 6) では，2 回の連続する血糖測定值が $180 \mathrm{mg} / \mathrm{dL}$ を超え た場合にインスリンを開始し，目標血糖值の上限は
$110 \mathrm{mg} / \mathrm{dL}$ 以下ではなく，180mg/dL 以下とするべきと している。

目標血糖值 110 $180 \mathrm{mg} / \mathrm{dL}$ は幅広く, 110〜 $144 \mathrm{mg} / \mathrm{dL}, \quad 144 \sim 180 \mathrm{mg} / \mathrm{dL}$ の 2 つ目標血糖值を考 えた場合, 死亡率や低血糖の発生率に差がないのかと いった疑問がある。しかし，この $110 〜 144 \mathrm{mg} / \mathrm{dL}$ と 144〜 180mg/dL を直接比較した研究は極めて少なく, この 2 つの目標血糖值のいずれがより至適であるかは 不明であった。日本版敗血症診療ガイドライン （J-SSCG）2016 の血糖班において，ネットワークメタ 解析（NMA）により目標血糖值 $110 \mathrm{mg} / \mathrm{dL}$ 以下, $110 \sim 144 \mathrm{mg} / \mathrm{dL}, \quad 144 \sim 180 \mathrm{mg} / \mathrm{dL}, 180 \mathrm{mg} / \mathrm{dL}$ 以上のい ずれが最も益と害のバランスにおいて優れているかに ついて検討した結果, 病院死亡率, 感染症発生率は, 直接比較可能な 4 群間において差を認めなかったが, 低血糖の危険性は $110 \mathrm{mg} / \mathrm{dL}$ 以下と $110 \sim 144 \mathrm{mg} / \mathrm{dL}$ で は，144〜 $180 \mathrm{mg} / \mathrm{dL}$ と $180 \mathrm{mg} / \mathrm{dL}$ 以上と比較して有意 に高かった7)。この結果より，J-SSCG 2016 では $144 \sim 180 \mathrm{mg} / \mathrm{dL}$ 目標とすることを弱く推奨し た8,9)。J-SSCG 2020 においても J-SSCG 2016 に引き 続き，NMAの手法を用いて目標血糖值を CQ13-2 で 検討した。

\section{血糖測定方法}

集中治療室における血糖測定は簡易血糖測定器や血 液ガス分析器を使用して行われることが多いが，使用 機器や採血法によって結果が異なることがある。多く の集中治療室で簡易血糖測定が行われるが，その測定 值は不正確でしばしば高く見積もられるため, 低血糖 の発生を見逃す可能性がある10)。過去のメタ解析に おいても毛細管血を使用した簡易血糖測定は，静脈血

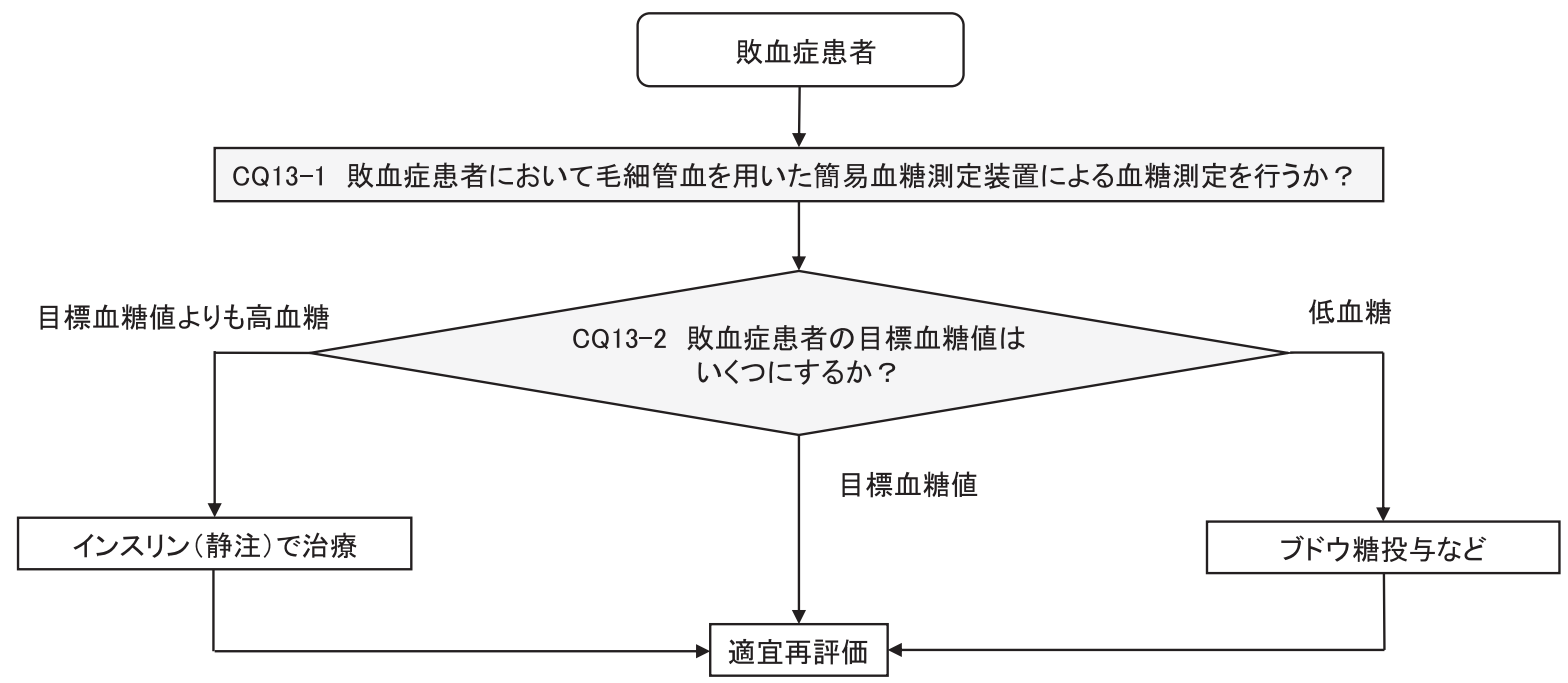

敗血症における血糖管理〔診療フロー〕 
を使用した簡易血糖測定，あるいは血液ガス分析器に よる血糖測定と比較して有意に不正確であることが報 告されている 10)。特に低血糖带（血糖值 $72 \mathrm{mg} / \mathrm{dL}$ 以 下）では，この毛細管血を使用した簡易血糖測定の測 定誤差は臨床上大きな問題となり, 血液ガス分析器に よる血糖測定のほうがより正確である ${ }^{10)}$ 。血糖值の 測定誤差は, 採血部位と測定器の種類以外にも, サン プルのヘマトクリットや酸素分圧, 薬剤など様々な要 因により影響を受ける。特に血糖測定範囲を逸脱した 患者 ${ }^{10)}$ ，貧血を呈した患者 ${ }^{11)}$ ，低血圧患者 ${ }^{12)}$ ，カテ コラミン使用中の患者 ${ }^{13)}$, 中心静脈カテーテルから の採血 ${ }^{14)}$ では, 血糖值の測定誤差が大きくなりやす い。本委員会では採血部位と測定機器に注目して CQ13-1 で血糖測定方法について検討した。

血糖測定の頻度について，SSCG 2016 ではインスリ ン治療を行う患者では血糖值やインスリン投与速度が 安定するまでは $1 \sim 2$ 時間後ごと, その後は 4 時間ご との血糖測定を best practice statement として推奨して いる ${ }^{6)}$ 。過去の急性期血糖管理の研究でも, 血糖值は 少なくとも 4 時間ごとに測定されている。このことょ り, 病態が変化している場合や栄養投与の予期せぬ中 断時などはさらなる注意が必要となるが，少なくとも 4 時間ごとの血糖測定が望ましいといえる。また，人 工膵臓など持続血糖管理装置に関する $\mathrm{CQ}$ について も，本委員会では $\mathrm{CQ}$ としての立案を見送ったが，敗 血症領域における研究が待たれる。

\section{文 献}

1) Finfer $S$, Liu B, Chittock DR, et al: Hypoglycemia and risk of death in critically ill patients. N Engl J Med. 2012; 367: 1108-18.

2) van den Berghe G, Wouters $P$, Weekers $F$, et al: Intensive insulin therapy in critically ill patients. N Engl J Med. 2001; 345: 1359-67.

3) van den Berghe G, Wilmer A, Hermans G, et al: Intensive insulin therapy in the medical ICU. N Engl J Med. 2006; 354: 449-61.

4) NICE-SUGAR Study Investigators, Finfer $S$, Chittock DR, et al: Intensive versus conventional glucose control in critically Ill patients. N Engl J Med. 2009; 360: 1283-97.

5) Song F, Zhong LJ, Han L, et al: Intensive insulin therapy for septic patients: A meta-analysis of randomized controlled trials. Biomed Res Int. 2014; 2014: 698265.

6) Rhodes A, Evans LE, Alhazzani W, et al: Surviving Sepsis Campaign: International Guidelines for Management of Sepsis and Septic Shock: 2016. Intensive Care Med. 2017; 43: 304-77.

7) Yatabe $T$, Inoue $S$, Sakaguchi $M$, et al: The optimal target for acute glycemic control in critically ill patients: a network metaanalysis. Intensive Care Med. 2017; 43: 16-28.

8）西田修, 小倉裕司, 井上茂亮, 他, 日本版敗血症診療ガイドラ イン 2016 作成特別委員会. 日本版敗血症診療ガイドライン 2016. 日集中医誌. 2017; 24: S1-232.

9）西田修, 小倉裕司, 井上茂亮, 他, 日本版敗血症診療ガイドラ イン 2016 作成特別委員会. 日本版敗血症診療ガイドライン 2016. 日救急医会誌. 2017; 28: S1-232.

10) Kanji S, Buffie J, Hutton B, et al: Reliability of point-of-care testing for glucose measurement in critically ill adults. Crit Care Med. 2005; 33: 2778-85.

11) Inoue S, Egi M, Kotani J, et al: Accuracy of blood-glucose measurements using glucose meters and arterial blood gas analyzers in critically ill adult patients: Systematic review. Crit Care. 2013; 17: R48.

12) Ghys T, Goedhuys W, Spincemaille K, et al: Plasma-equivalent glucose at the point-of-care: evaluation of Roche Accu-Chek Inform ${ }^{\circledR}$ and Abbott Precision PCx ${ }^{\circledR}$ glucose meters. Clin Chim Acta. 2007; 386: 63-8.

13) Fekih Hassen M, Ayed S, Gharbi R, et al: Bedside capillary blood glucose measurements in critically ill patients: Influence of catecholamine therapy. Diabetes Res Clin Pract. 2010; 87: 87-91.

14) Pereira AJ, Corrêa TD, de Almeida FP, et al: Inaccuracy of venous point-of-care glucose measurements in critically ill patients: A cross-sectional study. PLoS One. 2015; 10: e0129568. 
CQ13-1：敗血症患者において毛細管血を用いた 簡易血糖測定装置による血糖測定を行うか?

Answer : 敗血症患者において毛細管血を用いた簡易 血糖測定装置による血糖測定を行わないことを弱く推 奨する（GRADE 2A：エビデンスの確実性＝「高」）。

\section{（1）背景および本 $C Q$ の重要度}

集中治療室における血糖測定は，簡易血糖測定器や 動脈血血液ガス分析器を使用して行われることが多い が，使用機器や採血法によって結果が異なることがあ る。また，毛細管血を使用した簡易血糖測定は，動脈 血・静脈血を使用した簡易血糖測定，あるいは血液ガ ス分析器による血糖測定と比較して有意に不正確であ る可能性が高い。このように，血糖測定方法の選択 は，その後の治療にも関わる重要な臨床課題である。
(2) PECO

$P$ (患者)：成人集中治療患者

$\mathrm{E}$ (曝露)：簡易血糖測定装置（毛細管血）

C (対照): 血液ガス分析装置（動脈血・静脈血）, 簡易血糖測定装置（動脈血・静脈血）

$\mathrm{O}$ (アウトカム)：(患者や集団にとっての重要なア ウトカム) 死亡，感染症，低血糖

（代理アウトカム）許容範囲外の測定誤差

（3）エビデンスの要約

システマティックレビューの結果，PECO に合致し た研究が 43 件施行されており, これらを用いたメタ 解析を実施した。許容範囲外の測定誤差は，一致度に おいて検査室の血糖値 $20 \%$ を誤差の許容範囲と定義 して評価した。

Table 13-1-1エビデンスプロファイル

血液ガス分析装置（動脈血・静脈血）と簡易血糖測定装置（毛細管血）の比較

\begin{tabular}{|c|c|c|c|c|c|c|c|c|c|c|c|c|}
\hline \multicolumn{7}{|c|}{ 確実性の評価 } & \multicolumn{2}{|c|}{ 患者数 } & \multicolumn{2}{|c|}{ 効果 } & \multirow[b]{2}{*}{ 確実性 } & \multirow[b]{2}{*}{ 重要性 } \\
\hline 研究数 & $\begin{array}{l}\text { 研究 } \\
\text { デザイン }\end{array}$ & $\begin{array}{l}\text { バイアス } \\
\text { のリスク }\end{array}$ & 非一貫性 & 非直接性 & 不精確性 & $\begin{array}{l}\text { その他 } \\
\text { の検討 }\end{array}$ & $\begin{array}{l}\text { 簡易血糖測定装 } \\
\text { 置（毛細管血） }\end{array}$ & $\begin{array}{l}\text { 血液ガス分析装 } \\
\text { 置 (動脈血・静 } \\
\text { 脈血) }\end{array}$ & $\begin{array}{l}\text { 相対指標 } \\
(95 \% \mathrm{Cl})\end{array}$ & $\begin{array}{l}\text { 絶対指標 } \\
(95 \% \text { CI) }\end{array}$ & & \\
\hline \multicolumn{13}{|c|}{ 許容範囲外の測定誤差 } \\
\hline 3 & 観察研究 & 深刻でない & 深刻でない & 深刻でない & 深刻でない & なし & $\begin{array}{c}79 / 1,888 \\
(4.2 \%)\end{array}$ & $2 / 912(0.2 \%)$ & $\begin{array}{c}\text { RR } 21.56 \\
\text { (6.15 to } 75.57)\end{array}$ & $\begin{array}{c}1,000 \text { 測定あたり } \\
45 \text { 多い (11多い } \\
164 \text { 多い) }\end{array}$ & 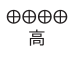 & 重大 \\
\hline
\end{tabular}

血液ガス分析装置（動脈血・静脈血）と簡易血糖測定装置（動脈血・静脈血）の比較

\begin{tabular}{|c|c|c|c|c|c|c|c|c|c|c|c|c|}
\hline \multicolumn{7}{|c|}{ 確実性の評価 } & \multicolumn{2}{|c|}{ 患者数 } & \multicolumn{2}{|c|}{ 効果 } & \multirow[b]{2}{*}{ 確実性 } & \multirow[b]{2}{*}{ 重要性 } \\
\hline 研究数 & $\begin{array}{l}\text { 研究 } \\
\text { デザイン }\end{array}$ & $\begin{array}{l}\text { パイアス } \\
\text { のリスク }\end{array}$ & 非一貫性 & 非直接性 & 不精碓性 & $\begin{array}{l}\text { その他 } \\
\text { の検討 }\end{array}$ & 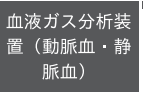 & $\begin{array}{l}\text { 簡易血糖測定装 } \\
\text { 動脈血·静 } \\
\text { 脈血） }\end{array}$ & $\begin{array}{l}\text { 相対指標 } \\
(95 \% \mathrm{Cl})\end{array}$ & $\begin{array}{l}\text { 䋓対指標 } \\
(95 \% \text { Cl) }\end{array}$ & & \\
\hline \multicolumn{13}{|c|}{ 許容範囲外の測定誤差 } \\
\hline 5 & 観察研究 & 深刻でない & 深刻でない & 深刻でない & 深刻 a & なし & $3 / 1,232(0.2 \%)$ & $\begin{array}{c}38 / 3,089 \\
(1.2 \%)\end{array}$ & $\begin{array}{l}\text { RR } 0.18 \\
\text { (0.03 to } 1.02)\end{array}$ & $\begin{array}{c}1,000 \text { 測定あたり } \\
10 \text { 少ない }(12 \text { 少な } \\
\text { い〜0 少ない) }\end{array}$ & $\begin{array}{c}\oplus \oplus \oplus \bigcirc \\
\text { 中 }\end{array}$ & 重大 \\
\hline
\end{tabular}

a. RR の 95\%Cl のカットオフ值を 20\%として評価した際, 95\%Cl 0.03-1.02 であるため。

簡易血糖測定装置（動脈血・静脈血）と簡易血糖測定装置（毛細管血）の比較

\begin{tabular}{|c|c|c|c|c|c|c|c|c|c|c|c|c|}
\hline & & & 確実性の語 & & & & 患裳 & 当数 & & 棵 & & \\
\hline 研究数 & $\begin{array}{l}\text { 研究 } \\
\text { デザイン }\end{array}$ & $\begin{array}{l}\text { バイアス } \\
\text { のリスク }\end{array}$ & 非一貫性 & 非直接性 & 不精確性 & $\begin{array}{l}\text { その他 } \\
\text { の検討 }\end{array}$ & $\begin{array}{l}\text { 簡易血糖測定装 } \\
\text { 晋 (毛細管血) }\end{array}$ & $\begin{array}{l}\text { 簡易血糖測定装 } \\
\text { 置 (動脈血・静 } \\
\text { 腿血) }\end{array}$ & $\begin{array}{l}\text { 相対指標 } \\
(95 \% \text { l) }\end{array}$ & $\begin{array}{l}\text { 絶対指標 } \\
(95 \% \text { I })\end{array}$ & 確実性 & 重要性 \\
\hline 許容範囲 & 外の測定誤 & & & & & & & & & & & \\
\hline 8 & 観察研究 & 深刻でない & 深刻でない & 深刻でない & 深刻でない & なし & $\begin{array}{c}249 / 2,759 \\
(9.0 \%)\end{array}$ & $\begin{array}{c}164 / 3,165 \\
(5.2 \%)\end{array}$ & $\begin{array}{c}\text { RR } 2.11 \\
\text { (1.23 to } 3.59)\end{array}$ & $\begin{array}{c}1,000 \text { 測定あたり } \\
58 \text { 多い (12 多い〜 } \\
134 \text { 多い) }\end{array}$ & $\begin{array}{c}\oplus \oplus \oplus \oplus \\
\text { 高 }\end{array}$ & 重大 \\
\hline
\end{tabular}

血液ガス分析装置 - 簡易血糖測定装置（動脈血・静脈血）と簡易血糖測定装置（毛細管血）の比較

\begin{tabular}{|c|c|c|c|c|c|c|c|c|c|c|c|c|}
\hline \multicolumn{7}{|c|}{ 確実性の評価 } & \multicolumn{2}{|c|}{ 患者数 } & \multicolumn{2}{|c|}{ 効果 } & \multirow[b]{2}{*}{ 確実性 } & \multirow[b]{2}{*}{ 重要性 } \\
\hline 研究数 & $\begin{array}{c}\text { 研究 } \\
\text { デザイン }\end{array}$ & $\begin{array}{l}\text { パイアス } \\
\text { のリスク }\end{array}$ & 非一貫性 & 非直接性 & 不精確性 & $\begin{array}{l}\text { その他 } \\
\text { の検討 }\end{array}$ & $\begin{array}{l}\text { 簡易血糖測定装 } \\
\text { 置（毛細管血） }\end{array}$ & $\begin{array}{c}\text { 血液ガス分析装 } \\
\text { 置・簡易血糖測 } \\
\text { 定装置（動脈 } \\
\text { 血・静脈血） }\end{array}$ & $\begin{array}{l}\text { 相対指標 } \\
(95 \% \text { Cl) }\end{array}$ & $\begin{array}{l}\text { 絶対指標 } \\
(95 \% \mathrm{Cl})\end{array}$ & & \\
\hline \multicolumn{13}{|c|}{ 許容範囲外の測定誤差 } \\
\hline 3 & 観察研究 & 深刻でない & 深刻でない & 深刻でない & 深刻でない & なし & $\begin{array}{c}79 / 1,888 \\
(4.2 \%)\end{array}$ & $\begin{array}{c}30 / 3,187 \\
(0.9 \%)\end{array}$ & $\begin{array}{c}\text { RR } 5.12 \\
\text { (2.47 to } 10.59 \text { ) }\end{array}$ & $\begin{array}{c}1,000 \text { 測定あたり } \\
39 \text { 多い (14多い〜 } \\
90 \text { 多い) }\end{array}$ & 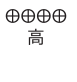 & 重大 \\
\hline
\end{tabular}


（4）益と害のバランス（Table 13-1-1）

\section{望ましい効果 :}

毛細管血を用いた簡易血糖測定装置による測定は, 動脈血・静脈血を用いた血液ガス分析装置あるいは簡 易血糖測定装置による血糖測定と比較して, 後述のよ うに $95 \%$ CI を考慮しても許容範囲外の測定誤差が多 くなるため，望ましい効果はあったとしても「わず か」であると判断する。

\section{望ましくない効果 :}

ゴールドスタンダードである血清を用いた生化学検 查器による血糖測定と比較して, 許容範囲外（誤差 $20 \%$ 以上）の測定誤差発生に関する効果推定值 $(1,000$ 測定あたり）は，簡易血糖測定装置（毛細管血）は血 液ガス分析装置（動脈血・静脈血）と比較して，リス ク差（RD）1,000 測定あたり45 多い（95\% CI: 11 多 い〜164 多い）（3 観察研究，2,800 測定 ${ }^{1-3)}$ ，簡易血 糖測定装置（毛細管血）は簡易血糖測定装置（動脈 血・静脈血）と比較して，RD 1,000 測定あたり 58 多 い (95\% CI: 12 多い〜134多い)（8 観察研究，5,924 測定 $)^{1-8)}$ ，簡易血糖測定装置（毛細管血）は，血液ガ 又分析装置・簡易血糖測定装置（動脈血・静脈血）と 比較して，RD 1,000 測定あたり 39 多い（95\% CI: 14 多い〜90 多い）（3 観察研究，5,075 測定） 1-3)，血液ガ 又分析装置（動脈血・静脈血）は簡易血糖測定装置 （動脈血・静脈血）と比較して，RD 1,000 測定あたり 10 少ない（95\% CI: 12 少ない〜0 少ない）（5 観察研 究，4,321 測定) 1-3, 9, 10) である。

高血糖の発生は重要なアウトカムである死亡や感染 症発生増加に関与し，低血糖の発生は神経障害や死亡 に関与する。測定が大きく誤っていた場合には，迅速 に治療を受ける機会が失われたり，著しい血糖異常を 見過ごされたりする可能性がある。毛細管血を用いて 簡易血糖測定装置で測定する方法は，動脈血・静脈血 を用いて血液ガス分析装置または簡易血糖測定装置で 測定する方法と比較して 1,000 測定あたり 39〜58 回, 許容範囲外の測定誤差が多くなるため，望ましくない 効果は「中」であると判断した。

\section{益と害のバランス :}

毛細管血を用いて簡易血糖測定装置で測定する方法 と比較して, 動脈血・静脈血を用いて血液ガス分析装 置または簡易血糖測定装置で測定する方法がおそらく 優位であると判断する。

\section{（5）アウトカム全般に関するエビデンスの確実性}

各アウトカムが全て同じ方向性を示しているため, アウトカムに関するエビデンスの確実性の中でも最も
高いGRADE を採用するため「高」とした。

\section{（6）価值観}

血糖異常が見過ごされたり，発見が遅れたりするこ とを防ぐことの価值は高く，そのばらつきは少ないこ とが予想される。それに影響を与える可能性のある許 容範囲外の測定誤差に関する価值も高く，また，ばら つきが少ないことが予想される。

\section{（7）容認性}

毛細管血を採取することと動脈血・静脈血を採取す ることの違いが医療従事者の大きな負担になることは ないだろう。特に，急性期で観血的動脈圧ラインが留 置されている場合，容認性は高いと考えられる。

\section{（8）実行可能性}

敗血症診療を行う医療機関においては，血液ガス分 析器を院内に有していることがほとんどであると考え られる。また，ない場合でも動脈血・静脈血を用いた 簡易血糖測定の実施を代替手段として提示しており， 実行可能性は高いといえる。

\section{（9）判断の要約（Table 13-1-2）}

\section{（10）推奨グレーディング決定の工程}

修正 RAND 法を用いた投票によって，中央值 8, 見解不一致指数 0.164 の結果となり, 委員会で採択さ れた（7点以上 : 91.7\%)。

\section{（11）関連する他の診療ガイドラインにおける推奨}

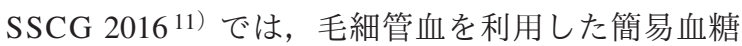
測定は動脈血や血漿グルコース值を正確に推定できな い可能性があるため, 解釈に注意するようにと best practice statement として提示している。また, 動脈力 テーテルが挿入されている患者では, 簡易血糖測定器 での測定に毛細管血より動脈血を使用することを提案 している。

\section{（12）実施に関わる検討事項}

ベッドサイドから離れた場所に血液ガス分析装置が ある場合, 頻回の血液ガス分析装置での測定に伴う, 検体の輸送の負担を考慮する必要がある。動脈血・静 脈血を用いた血液ガス分析装置および簡易血糖測定装 置による血糖測定の測定誤差の発生率の相違はわずか であり，動脈血・静脈血を用いた簡易血糖測定装置に よる血糖測定を選択してもよい。しかし，これらの方 
Table 13-1-2 判断の要約

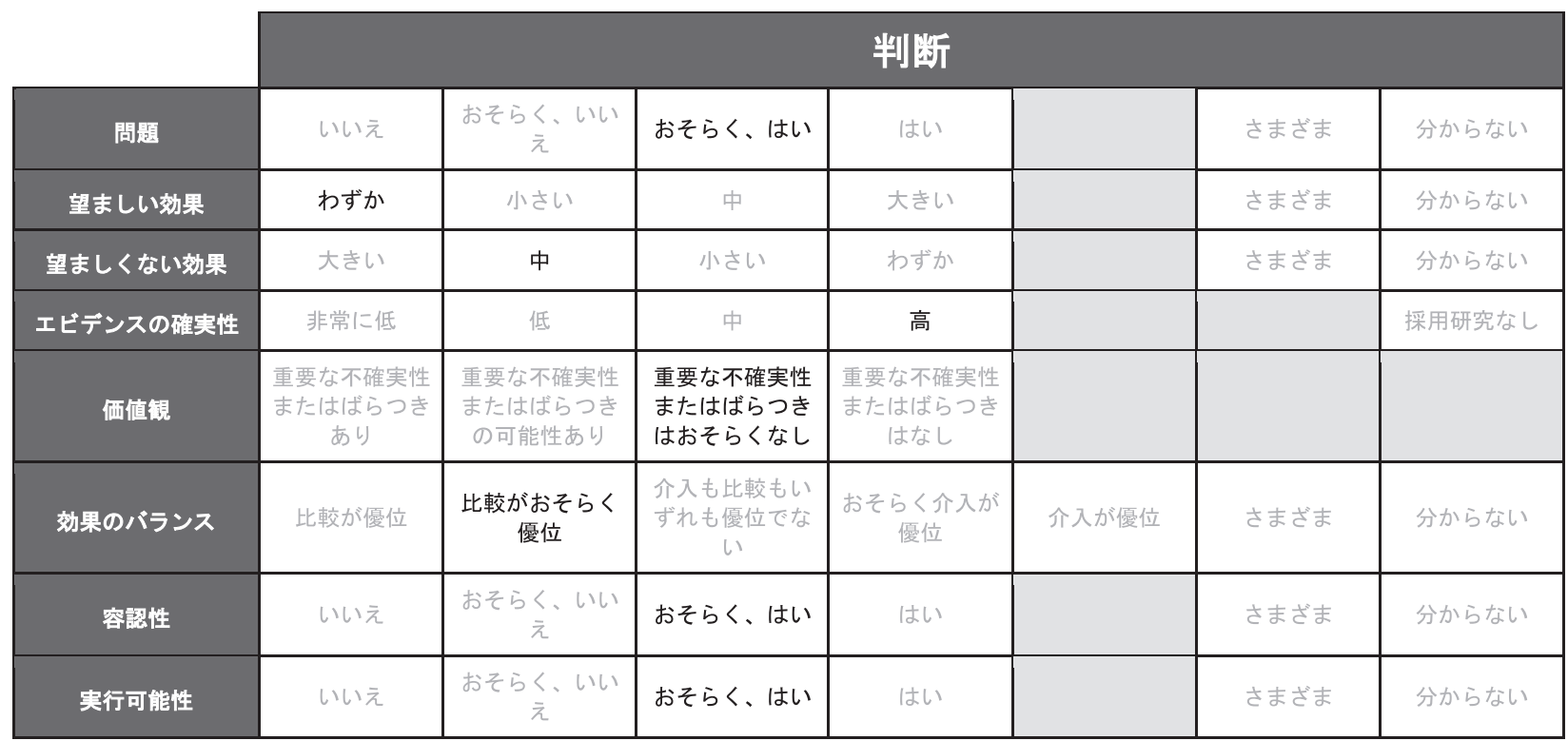

法であっても測定誤差が生じうるため，適宜，中央検 査室での血糖測定を行い，その正確性を確認する必要 がある。なお，本推奨は集中治療患者を対象とした研 究に基づく推奨であり，一般病床における血糖測定方 法については検討できていない。

\section{（13）今後の研究の可能性}

今後，敗血症患者などの重症病態における持続血糖 モニタリング装置の測定誤差に関する研究が望まれ る。

\section{文 献}

1) Kanji S, Buffie J, Hutton B, et al: Reliability of point-of-care testing for glucose measurement in critically ill adults. Crit Care Med. 2005; 33: 2778-85.

2) Petersen JR, Graves DF, Tacker DH, et al: Comparison of POCT and central laboratory blood glucose results using arterial, capillary, and venous samples from MICU patients on a tight glycemic protocol. Clin Chim Acta. 2008; 396: 10-3.

3) Slater-MacLean L, Cembrowski G, Chin D, et al: Accuracy of glycemic measurements in the critically ill. Diabetes Technol Ther. 2008; 10: 169-77.

4) Desachy A, Vuagnat AC, Ghazali AD, et al: Accuracy of bedside glucometry in critically ill patients: Influence of clinical characteristics and perfusion index. Mayo Clin Proc. 2008; 83: 400-5.

5) Ellis MF, Benjamin K, Cornell M, et al: Suitability of capillary blood glucose analysis in patients receiving vasopressors. Am J Crit Care. 2013; 22: 423-9.

6) Karon BS, Gandhi GY, Nuttall GA, et al: Accuracy of Roche Accu-Chek Inform whole blood capillary, arterial, and venous glucose values in patients receiving intensive intravenous insulin therapy after cardiac surgery. Am J Clin Pathol. 2007; 127: 919-26.

7) Lonjaret L, Claverie V, Berard E, et al: Relative accuracy of arterial and capillary glucose meter measurements in critically ill patients. Diabetes Metab. 2012; 38: 230-5.
8) Pulzi Júnior SA, de Assunção MSC, Mazza BF, et al: Accuracy of different methods for blood glucose measurement in critically ill patients. Sao Paulo Med J. 2009; 127: 259-65.

9) Claerhout H, De Prins M, Mesotten D, et al: Performance of stripbased glucose meters and cassette-based blood gas analyzer for monitoring glucose levels in a surgical intensive care setting. Clin Chem Lab Med. 2016; 54:169-80.

10) Watkinson PJ, Barber VS, Amira E, et al: The effects of precision, haematocrit, $\mathrm{pH}$ and oxygen tension on point-of-care glucose measurement in critically ill patients: A prospective study. Ann Clin Biochem. 2012; 49: 144-51.

11) Rhodes A, Evans LE, Alhazzani W, et al: Surviving Sepsis Campaign: International Guidelines for Management of Sepsis and Septic Shock: 2016. Intensive Care Med. 2017; 43: 304-77. 
CQ13-2：敗血症患者の目標血糖值はいくつにす るか?

Answer : 敗血症患者の目標血糖値を $144 \sim 180 \mathrm{mg} / \mathrm{dL}$ とすることを弱く推奨する（GRADE 2D：エビデンス の確実性 $=$ 「非常に低」)。

\section{（1）背景および本 $C Q$ の重要度}

高血糖は, 感染症の増加などから予後の悪化につな がる可能性がある。一方で, 高血糖を是正するために インスリンを使用した場合，鎮静下の患者では低血糖 の発見がむずかしく，不可逆的な神経障害を招く危険 がある。そのため, 低血糖の危険を回避して, 感染症 の低下などの益を得るための適切な血糖目標值はいく らかということは重要な臨床課題である。

\section{(2) PICO}

P (患者)：成人集中治療患者

I（介入）：目標血糖值帯 $110 \mathrm{mg} / \mathrm{dL}$ 未満，110～ $144 \mathrm{mg} / \mathrm{dL}, 144 \sim 180 \mathrm{mg} / \mathrm{dL}, 180 \mathrm{mg} / \mathrm{dL}$ 以上

C (対照)：上記各 4 群間の比較

$\mathrm{O}$ (アウトカム) : 死亡，感染症，低血糖

\section{（3）エビデンスの要約}

システマティックレビューの結果，PICO に合致し たランダム化比較試験（RCT）が 35 件 1-35）施行され ており，これらを用いたネットワークメタ解析を実施 した。

(4) 益と害のバランス（Table 13-2-1, 13-2-2, 13-2-3)

望ましい効果 :

死亡に関する効果推定值は， $110 \mathrm{mg} / \mathrm{dL}$ 未満に対し て，110 144mg/dL では，リスク差（RD）1,000人あ たり 40 人少ない $(95 \%$ CI: 100 人少ない〜 30 人多い) （1 RCT，90人）であり，144 180mg/dLでは，RD 1,000 人あたり 27 人少ない $(95 \% \mathrm{CI}: 45$ 人少ない〜 8 人少ない）（5 RCT，7,323 人）であり， $180 \mathrm{mg} / \mathrm{dL}$ 以 上では，RD 1,000 人あたり 4 人多い $(95 \%$ CI: 22 人少 ない〜35人多い) (12 RCT, 8,027 人) であった。 $110 \sim 144 \mathrm{mg} / \mathrm{dL}$ に対しては, $144 \sim 180 \mathrm{mg} / \mathrm{dL}$ では, RD 1,000 人あたり 6 人多い (95\% CI: 104 人少ない〜 147 人多い）（1 RCT，20 人）であり，180mg/dL 以上 では，RD 1,000 人あたり 28 人多い $(95 \%$ CI: 14 人少 ない〜81 人多い）（8 RCT，884人）であった。144〜 $180 \mathrm{mg} / \mathrm{dL}$ に対しては, $180 \mathrm{mg} / \mathrm{dL}$ 以上は, RD 1,000
人あたり 1 人多い（95\% CI: 0 人多い〜3 人多い）（1 RCT，212人）であった。

感染症に関する効果推定值は, $110 \mathrm{mg} / \mathrm{dL}$ 未満に対 して, $144 \sim 180 \mathrm{mg} / \mathrm{dL}$ では, RD 1,000 人あたり 5 人 少ない $(95 \%$ CI: 19 人少ない〜 10 人多い)（3 RCT, 6,185 人)，180mg/dL 以上では，RD 1,000 人あたり 25 人多い $(95 \%$ CI: 8 人多い〜 43 人多い) $(8$ RCT，6,104 人)であった。

$110 \sim 144 \mathrm{mg} / \mathrm{dL}$ に対して，180 $\mathrm{mg} / \mathrm{dL}$ 以上では，RD 1,000 人あたり 62 人多い $(95 \%$ CI: 3 人多い〜 135 人 多い)（5 RCT，485人）であった。 $110 \mathrm{mg} / \mathrm{dL}$ 未満と $110 \sim 144 \mathrm{mg} / \mathrm{dL}, \quad 110 \sim 144 \mathrm{mg} / \mathrm{dL}$ と $144 \sim 180 \mathrm{mg} / \mathrm{dL}$, $144 \sim 180 \mathrm{mg} / \mathrm{dL}$ と $180 \mathrm{mg} / \mathrm{dL}$ 以上，では直接比較がな かった。

望ましくない効果 :

低血糖に関する効果推定值は, $110 \mathrm{mg} / \mathrm{dL}$ 未満に対

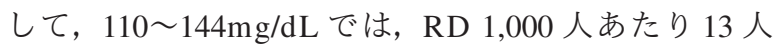
多い $(95 \%$ CI: 42 人少ない 103 人多い)（1 RCT，90 人）であり，144〜 $180 \mathrm{mg} / \mathrm{dL}$ では, RD 1,000 人あたり 63 人少ない $(95 \%$ CI: 67 人少ない 58 人少ない) $(5$ RCT, 7,331 人) であり， $180 \mathrm{mg} / \mathrm{dL}$ 以上では，RD 1,000 人あたり 85 人少ない $(95 \% \mathrm{CI}: 94$ 人少ない〜 75 人少 ない）（12 RCT，8,342人）であった。110 144mg/dL に対して，144〜180mg/dL では，RD 1,000 人あたり 66 人少ない $(95 \% \mathrm{CI}: 72$ 人少ない 58 人少ない)（1 RCT，302 人）であり，180mg/dL 以上では，RD 1,000 人あたり 88 人少ない $(95 \% \mathrm{CI}: 121$ 人少ない〜 37 人少 ない）（7 RCT，730 人）であった。144〜 180mg/dL に 対して， $180 \mathrm{mg} / \mathrm{dL}$ 以上では，RD 1,000人あたり 0 人 多い $(95 \%$ CI: 0 人多い 0 人多い，※対照群の発生率 が 0 であるため)（1 RCT，212人）であった。

益と害のバランス :

各群間の効果のバランスは以下の通りである。

$110 \mathrm{mg} / \mathrm{dL}$ 未満に対して $110 \sim 144 \mathrm{mg} / \mathrm{dL} ， 144 \sim$ $180 \mathrm{mg} / \mathrm{dL}, 180 \mathrm{mg} / \mathrm{dL}$ 以上のいずれも優位である。

110 144m $/ \mathrm{dL}$ に対して 144〜 180mg/dL は優位, $180 \mathrm{mg} / \mathrm{dL}$ 以上は優位ではない。

144 180mg/dL に対して $180 \mathrm{mg} / \mathrm{dL}$ 以上は優位では ない。

以上をまとめると 144〜 180mg/dL が最も優位であ るといえる。

（5）アウトカム全般に関するエビデンスの確実性

各アウトカムが益と害の異なる方向性を示している 群間もあり，重大なアウトカムに関するエビデンスの 確実性の中でも最も低い GRADE を採用するため「非 
Table 13-2-1エビデンスプロファイル

死亡

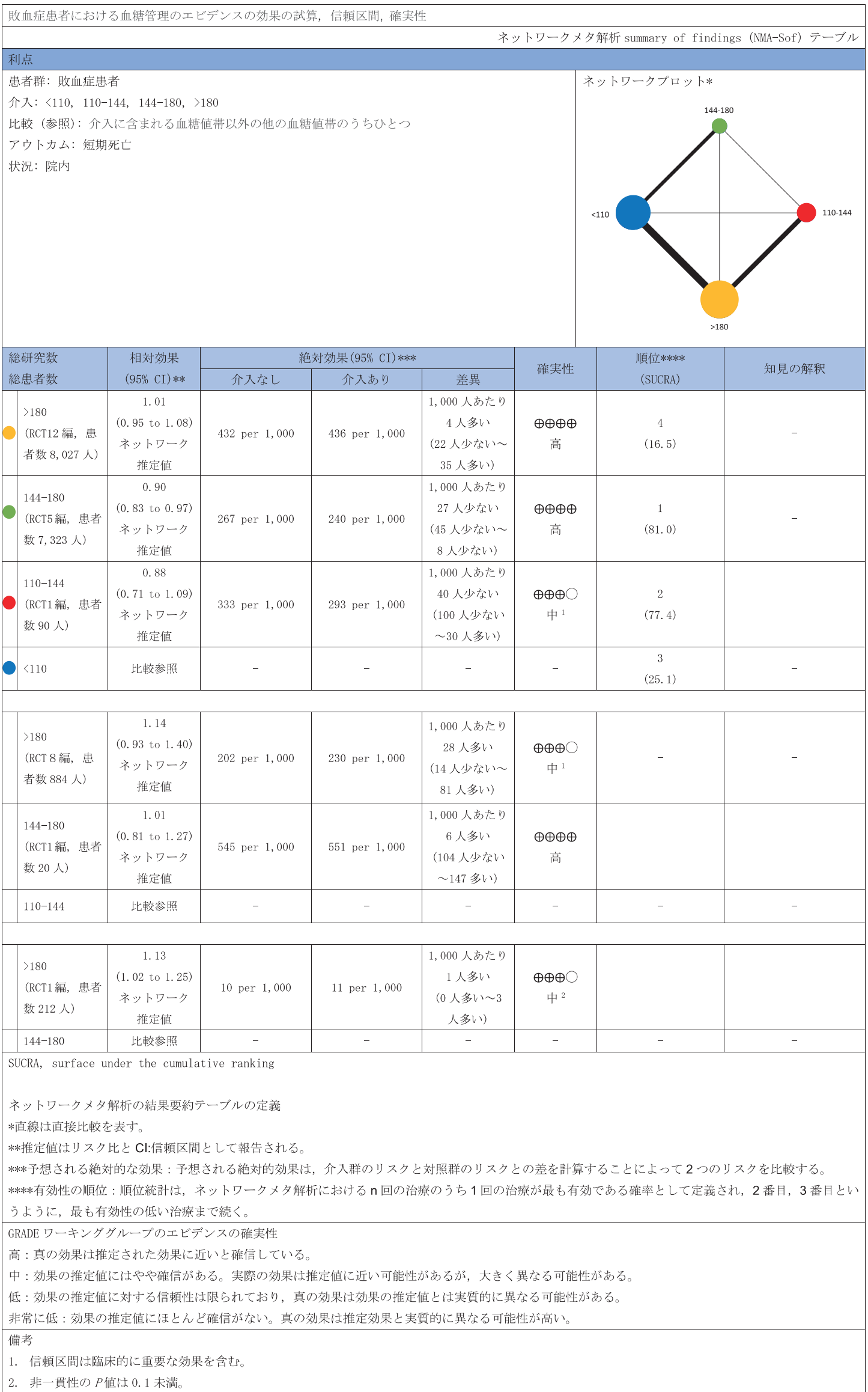


Table 13-2-2 エビデンスプロファイル

感染症

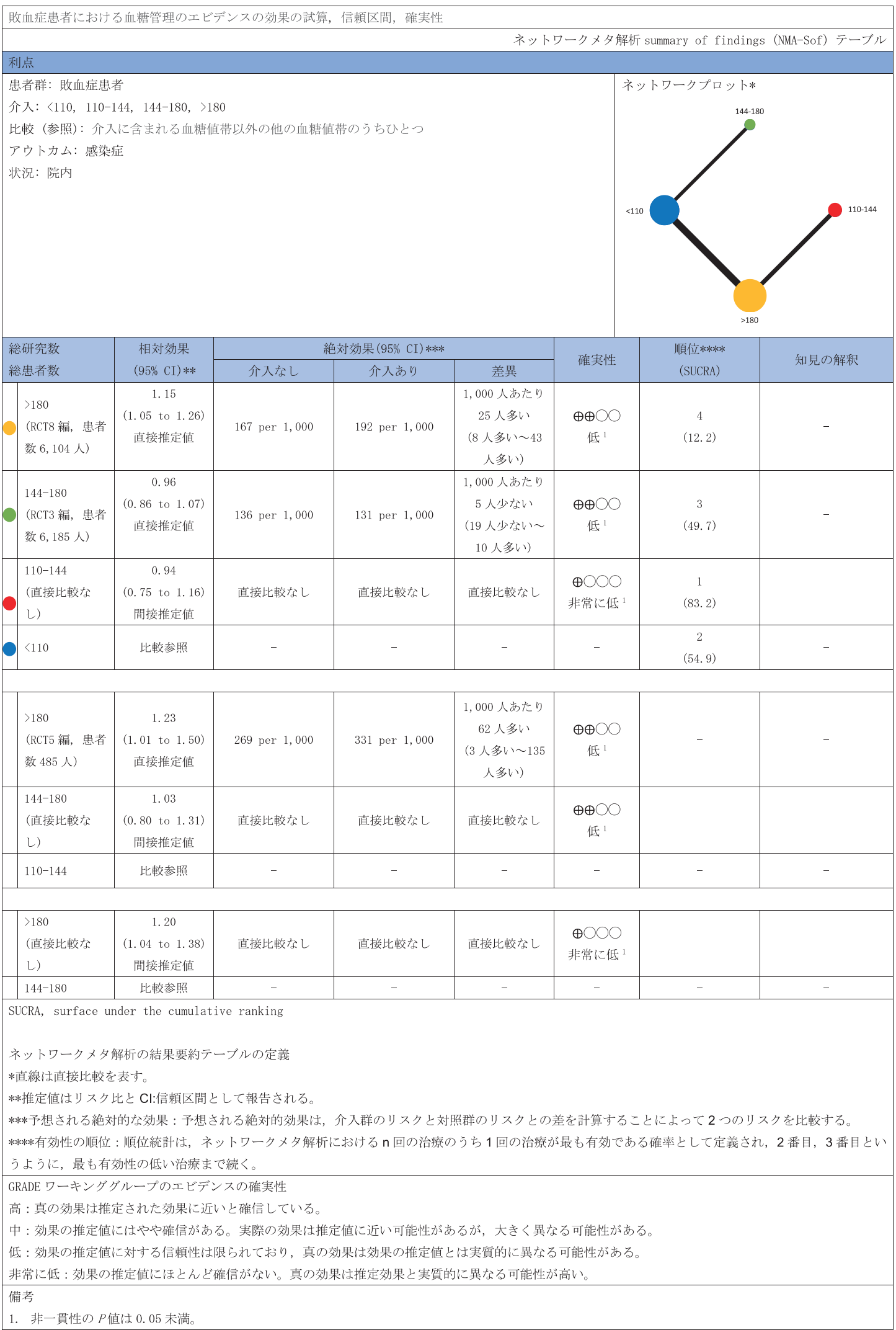


Table 13-2-3 エビデンスプロファイル

低血糖

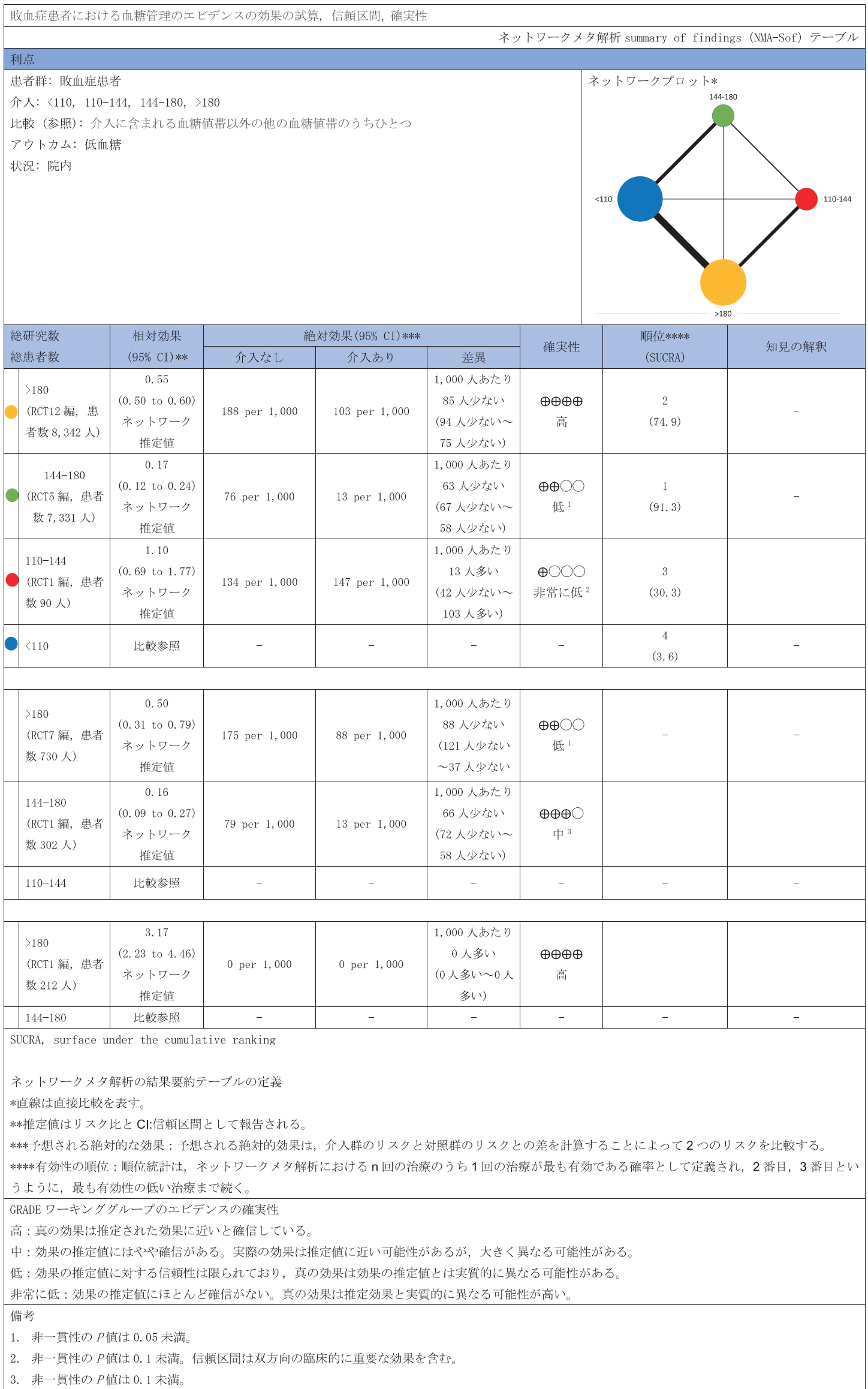


常に低」とした。

（6）価值観

血糖管理のアウトカムに関する価值観についての データはない。一般的に死亡に対して置く相対的価值 は高く, そのばらつきは少ないことが予想される。

\section{（7）容認性}

インスリンの薬価は約 300 円/100 単位とコストに 関する容認性は高いと思われる。血糖測定が頻回に なった場合, 看護師の労力は増加する。

\section{（8）実行可能性}

一般的な薬剤を用いた治療であり，どの病院におい ても実行可能性は高いといえる。

（9）判断の要約（Table 13-2-4）

\section{（10）推奨グレーディング決定の工程}

修正 RAND 法を用いた投票によって，中央值 8, 見解不一致指数 0 の結果となり，委員会で採択された (7 点以上 : 100\%)。

\section{（11）関連する他の診療ガイドラインにおける推奨}

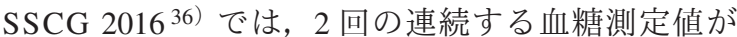
$180 \mathrm{mg} / \mathrm{dL}$ を超えた場合にインスリンを開始し，目標 血糖值の上限は $110 \mathrm{mg} / \mathrm{dL}$ 以下よりは $180 \mathrm{mg} / \mathrm{dL}$ 以下 とすべきであるとしている。

\section{（12）実施に関わる検討事項}

使用する血糖測定装置に関しては CQ13-1 に記載し た。

\section{（13）今後の研究の可能性}

今後, 糖尿病患者における最適な血糖值帯や持続血 糖モニタリング装置あるいは Closed-loop 方式の血糖 管理装置を使用した場合の最適な血糖值帯に関する研 究が望まれる。

\section{文 献}

1) Annane D, Cariou A, Maxime V, et al: Corticosteroid treatment and intensive insulin therapy for septic shock in adults: A randomized controlled trial. JAMA. 2010; 303: 341-8.

2) Arabi YM, Dabbagh OC, Tamim HM, et al: Intensive versus conventional insulin therapy: A randomized controlled trial in medical and surgical critically ill patients. Crit Care Med. 2008; 36: 3190-7.

3) Arabi YM, Tamim HM, Dhar GS, et al: Permissive underfeeding and intensive insulin therapy in critically ill patients: A randomized controlled trial. Am J Clin Nutr. 2011; 93: 569-77.

4) Bilotta F, Spinelli A, Giovannini F, et al: The effect of intensive insulin therapy on infection rate, vasospasm, neurologic outcome, and mortality in neurointensive care unit after intracranial aneurysm clipping in patients with acute subarachnoid hemorrhage: A randomized prospective pilot trial. J Neurosurg Anesthesiol. 2007; 19: 156-60.

5) Bilotta F, Caramia R, Cernak I, et al: Intensive insulin therapy after severe traumatic brain injury: A randomized clinical trial. Neurocrit Care. 2008; 9: 159-66.

6) Bilotta F, Caramia R, Paoloni FP, et al: Safety and efficacy of intensive insulin therapy in critical neurosurgical patients. Anesthesiology. 2009; 110: 611-9.

7) Bland DK, Fankhanel Y, Langford E, et al: Intensive versus modified conventional control of blood glucose level in medical intensive care patients: A pilot study. Am J Crit Care. 2005; 14: 370-6.

8) Brunkhorst FM, Engel C, Bloos F, et al: Intensive insulin therapy

Table 13-2-4 判断の要約

\begin{tabular}{|c|c|c|c|c|c|c|c|}
\hline & \multicolumn{7}{|c|}{ 判溇 } \\
\hline 問題 & いいえ & $\begin{array}{c}\text { おそらく、いい } \\
\text { え }\end{array}$ & おそらく、はい & はい & & さまざま & 分からない \\
\hline 望ましい効果 & わずか & 小さい & 中 & 大きい & & さまざま & 分からない \\
\hline 望ましくない効果 & 大きい & 中 & 小さい & わずか & & さまざま & 分からない \\
\hline エビデンスの確実性 & 非常に低 & 低 & 中 & 高 & & & 採用研究なし \\
\hline 価值観 & $\begin{array}{c}\text { 重要な不確実性 } \\
\text { またはばらつき } \\
\text { あり }\end{array}$ & $\begin{array}{c}\text { 重要な不確実性 } \\
\text { またはばらつき } \\
\text { の可能性あり }\end{array}$ & $\begin{array}{l}\text { 重要な不確実性 } \\
\text { またはばらつき } \\
\text { はおそらくなし }\end{array}$ & $\begin{array}{c}\text { 重要な不確実性 } \\
\text { またははよらつき } \\
\text { はなし }\end{array}$ & & & \\
\hline 効果のバランス & 比較が優位 & $\begin{array}{c}\text { 比較がおそらく } \\
\text { 優位 }\end{array}$ & $\begin{array}{c}\text { 介入も比較もい } \\
\text { ずれも優位でな } \\
\text { い }\end{array}$ & $\begin{array}{c}\text { おそらくく入が } \\
\text { 優位 }\end{array}$ & 介入が優位 & さまざま & 分からない \\
\hline 容認性 & いいえ & $\begin{array}{c}\text { おそらく、いい } \\
\text { え }\end{array}$ & おそらく、はい & はい & & さまざま & 分からない \\
\hline 実行可能性 & いいえ & $\begin{array}{c}\text { おそらく、いい } \\
\text { え }\end{array}$ & おそらく、はい & はい & & さまざま & 分からない \\
\hline
\end{tabular}


and pentastarch resuscitation in severe sepsis. N Engl J Med. 2008; 358: 125-39.

9) Bruno A, Kent TA, Coull BM, et al: Treatment of hyperglycemia in ischemic stroke (THIS): A randomized pilot trial. Stroke. 2008; 39: 384-9.

10) Cappi SB, Noritomi DT, Velasco IT, et al: Dyslipidemia: A prospective controlled randomized trial of intensive glycemic control in sepsis. Intensive Care Med. 2012; 38: 634-41.

11) Chan RP, Galas FR, Hajjar LA, et al: Intensive perioperative glucose control does not improve outcomes of patients submitted to open-heart surgery: A randomized controlled trial. Clinics (Sao Paulo). 2009; 64: 51-60.

12) Coester A, Neumann CR, Schmidt MI: Intensive insulin therapy in severe traumatic brain injury: A randomized trial. J Trauma. 2010; 68: 904-11.

13) Davies RR, Newton RW, McNeill GP, et al: Metabolic control in diabetic subjects following myocardial infarction: Difficulties in improving blood glucose levels by intravenous insulin infusion. Scott Med J. 1991; 36: 74-6.

14) de Azevedo JR, de Araujo LO, da Silva WS, et al: A carbohydraterestrictive strategy is safer and as efficient as intensive insulin therapy in critically ill patients. J Crit Care. 2010; 25: 84-9.

15) De La Rosa Gdel C, Donado JH, Restrepo AH, et al: Strict glycaemic control in patients hospitalised in a mixed medical and surgical intensive care unit: A randomised clinical trial. Crit Care. 2008; 12: R120.

16) Farah R, Samokhvalov A, Zviebel F, et al: Insulin therapy of hyperglycemia in intensive care. Isr Med Assoc J. 2007; 9: 140-2.

17) Finfer S, Chittock DR, Su SYS, et al: Intensive versus conventional glucose control in critically Ill patients. N Engl J Med. 2009; 360: 1283-97.

18) Giakoumidakis K, Eltheni R, Patelarou E, et al: Effects of intensive glycemic control on outcomes of cardiac surgery. Heart \& Lung. 2013; 42: 146-51.

19) Green DM, O'Phelan KH, Bassin SL, et al: Intensive versus conventional insulin therapy in critically ill neurologic patients. Neurocrit Care. 2010; 13: 299-306.

20) Grey NJ, Perdrizet GA: Reduction of nosocomial infections in the surgical intensive-care unit by strict glycemic control. Endocr Pract. 2004; 10 Suppl 2: 46-52.

21) Hsu CW, Sun SF, Lin SL, et al: Moderate glucose control results in less negative nitrogen balances in medical intensive care unit patients: A randomized, controlled study. Crit Care. 2012; 16 : R56.

22) Iapichino G, Albicini M, Umbrello M, et al: Tight glycemic control does not affect asymmetric-dimethylarginine in septic patients. Intensive Care Med. 2008; 34: 1843-50.

23) Kalfon P, Giraudeau B, Ichai C, et al: Tight computerized versus conventional glucose control in the ICU: A randomized controlled trial. Intensive Care Med. 2014; 40: 171-81.

24) McMullin J, Brozek J, McDonald E, et al: Lowering of Glucose in Critical care: a randomized pilot trial. J Crit Care. 2007; 22: 112-8; discussion 118-9.

25) Mitchell I, Knight E, Gissane J, et al: A phase II randomised controlled trial of intensive insulin therapy in general intensive care patients. Crit Care Resusc. 2006; 8: 289-93.

26) Oksanen T, Skrifvars MB, Varpula T, et al: Strict versus moderate glucose control after resuscitation from ventricular fibrillation. Intensive Care Med. 2007; 33: 2093-100.

27) Plummer MP, Notkina N, Timofeev I, et al: Cerebral metabolic effects of strict versus conventional glycaemic targets following severe traumatic brain injury. Crit Care. 2018; 22: 16.

28) Preiser JC, Devos P, Ruiz-Santana S, et al: A prospective randomised multi-centre controlled trial on tight glucose control by intensive insulin therapy in adult intensive care units: The
Glucontrol study. Intensive Care Med. 2009; 35: 1738-48.

29) Savioli M, Cugno M, Polli F, et al: Tight glycemic control may favor fibrinolysis in patients with sepsis. Crit Care Med. 2009; 37: 424-31.

30) Stefanidis A, Melidonis A, Tournis S, et al: Intensive insulin treatment reduces transient ischaemic episodes during acute coronary events in diabetic patients. Acta Cardiol. 2002; 57: 357-64.

31) Umpierrez G, Cardona S, Pasquel F, et al: Randomized controlled trial of intensive versus conservative glucose control in patients undergoing coronary artery bypass graft surgery: GLUCOCABG trial. Diabetes Care. 2015; 38: 1665-72.

32) van den Berghe G, Wouters P, Weekers F, et al: Intensive insulin therapy in critically ill patients. N Engl J Med. 2001; 345: 1359-67.

33) Van den Berghe G, Wilmer A, Hermans G, et al: Intensive insulin therapy in the medical ICU. N Engl J Med. 2006; 354: 449-61.

34) Walters MR, Weir CJ, Lees KR: A randomised, controlled pilot study to investigate the potential benefit of intervention with insulin in hyperglycaemic acute ischaemic stroke patients. Cerebrovasc Dis. 2006; 22: 116-22.

35) Wang Y, Li JP, Song YL, et al: Intensive insulin therapy for preventing postoperative infection in patients with traumatic brain injury: A randomized controlled trial. Medicine (Baltimore). 2017; 96: e6458.

36) Rhodes A, Evans LE, Alhazzani W, et al: Surviving Sepsis Campaign: International Guidelines for Management of Sepsis and Septic Shock: 2016. Intensive Care Med. 2017; 43: 304-77. 


\section{CQ14：体温管理}

体温は日常的に測定するバイタルサインである。そ の異常は集中治療患者において最も高率に認める徵候 の 1 つであり, 発熱あるいは低体温を契機に新たな診 療がしばしば開始される1,2)。本邦における敗血症患 者を対象としたレジストリー研究でも, 集中治療室入 室時における体温は $36{ }^{\circ} \mathrm{C}$ 未満 $11.1 \%, 36 \sim 38^{\circ} \mathrm{C}$ $49.4 \%,>38^{\circ} \mathrm{C} 39.4 \%$ であることが報告されてい る ${ }^{3)}$ 。体温は測定部位により異なるため, 可能な限り 信頼性の高い部位で測定する必要がある。脳・肺・心 臓・肝臓・腎臓など主要臓器の温度が生体活動には重 要であり, 深部体温測定が推奨される。深部体温の ゴールドスタンダードは血液温度であるとされている が，血液温度測定のためには肺動脈カテーテルなどの 挿入が必要であり，日常的には用いることはできな い。American College of Critical Care Medicine と Infectious Diseases Society of America のガイドラインで は, 血液・膀胱・食道・直腸温度は深部体温を正確に 反映するとして，これらの測定を推奨している1)。一 方, 鼓膜 ・腋窩 ·未梢血管温度 (末梢動脈カテーテル で測定される血液温度）測定による評価の信頼性は低 く，集中治療室での使用は推奨されていない。膀胱温 は，尿道カテーテルを挿入する患者のほぼ全例で測定 可能であると共に正確性が高いため, 重症患者での体 温測定に適している1)。

本邦と韓国の 25 施設で行われた多施設前向き観察 研究である FACE study では, $38.5^{\circ} \mathrm{C}$ 以上の発熱は集 中治療室患者の $40.5 \% ， 39.5^{\circ} \mathrm{C}$ 以上は $11.5 \%$ の患者で 認められていた ${ }^{4)}$ 。一般に体温は視床下部の制御に よって $37 \pm 0.5^{\circ} \mathrm{C}$ 程度の狭い範囲にコントロールされ, 発熱は感染や生体侵襲に対する適応反応の 1 つとして 捉えることができる5)。発熱は, 抗体産生の増加, $\mathrm{T}$ 細胞の活性化, サイトカインの合成, 好中球およびマ クロファージの活性化を惹起する生体防御反応であ り，重症感染症患者における発熱は死亡率低下との関

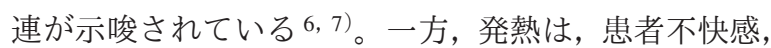
呼吸需要および心筋酸素需要の増大, 中枢神経障害な どを生じ，負の側面もある ${ }^{2)}$ 。

\section{発熱と解熱療法}

発熱患者に対して解熱療法を行うことにより，脈拍 や酸素消費量低下が期待できる。また，分時換気量の 減少や不快感軽減も期待されるため, 発熱を伴う重症 患者に対する解熱療法は一般的に施行されていると考 えられる。解熱療法は，発熱に関連する有害事象を軽
減あるいは予防する目的に行われることもあるが，日 常的には解熱そのものを目的として施行されていると の報告もみられる4)。一方，解熱療法により，生体に 有益な適応・防御反応が抑制される可能性もある。ま た，解熱薬には胃腸障害，肝障害，腎障害や血圧低下 などの副作用もある ${ }^{8,9) 。 ~}$

発熱患者に解熱処置を考慮する際，その方法は大き く“薬物による解熱”と体表などの“冷却による解 熱”に分けられる。薬物による解熱では, 非ステロイ ド性抗炎症薬あるいはアセトアミノフェンが使用され る。両者は, $\mathrm{PGE}_{2}$ 合成阻害を介して視床下部体温調 節中枢のセットポイントを低下させることによって解 熱効果を得るとされている。

冷却による解熱には，体表クーリングや氷囊を体幹 部にあてる表面冷却が使用される。鎮静は寒冷反応 （シバリング・立毛筋収縮）を抑制し，冷却による解 熱に併用することで効果的な体温低下をもたらすとさ れている10,11)。しかし, 患者が鎮静下でない場合, 冷却による解熱は寒冷反応を惹起する。寒冷反応を生 じた場合，特に表面冷却での解熱は困難となり，むし ろ, 酸素消費量や分時換気量は増加する ${ }^{12)}$ 。解熱療 法の目的が患者の酸素消費量・脈拍・分時換気量の低 下あるいは寒冷反応に伴う不快感の軽減である場合, 非鎮静下における表面冷却は逆効果であり，避けるべ きである。

このように，発熱はその原因検索のための診断や治 療法変更へとつながる徵候であると共に, 患者不快感, 呼吸および心筋を含む全身の酸素需要増大，中枢神経 障害などを生じる。一方, 病原微生物の除去促進も関 連する防御反応でもある。解熱療法は頻繁に施行され ているものの，前記防御反応が抑制される可能性もあ り，その有効性・有害性の評価は定まっていない。以 上より，体温管理の項における第 1 の $\mathrm{CQ}$ は，「発熱を 伴う敗血症患者に解熱療法を行うか?」とした。

\section{体温低下と復温療法}

敗血症患者の体温低下は，生体の体温維持機能の喪 失や鎮静・筋弛緩，体外循環の施行などによって生じ ると考えられ, 発熱と比較して, より重篤な患者で生 じやすい。APACHE II スコア，敗血症，あるいは感 染関連性人工呼吸器関連合併症の定義においては, $36^{\circ} \mathrm{C}$ 未満が低体温とされている 13-15)。本邦における 敗血症レジストリーによる解析でも，集中治療室入室 時における $36^{\circ} \mathrm{C}$ 未満の低体温は $10 \%$ を超える患者で 生じており, 敗血症患者のうち入室 24 時間以内に低 体温を呈した患者は死亡率が高いことが明らかにされ 


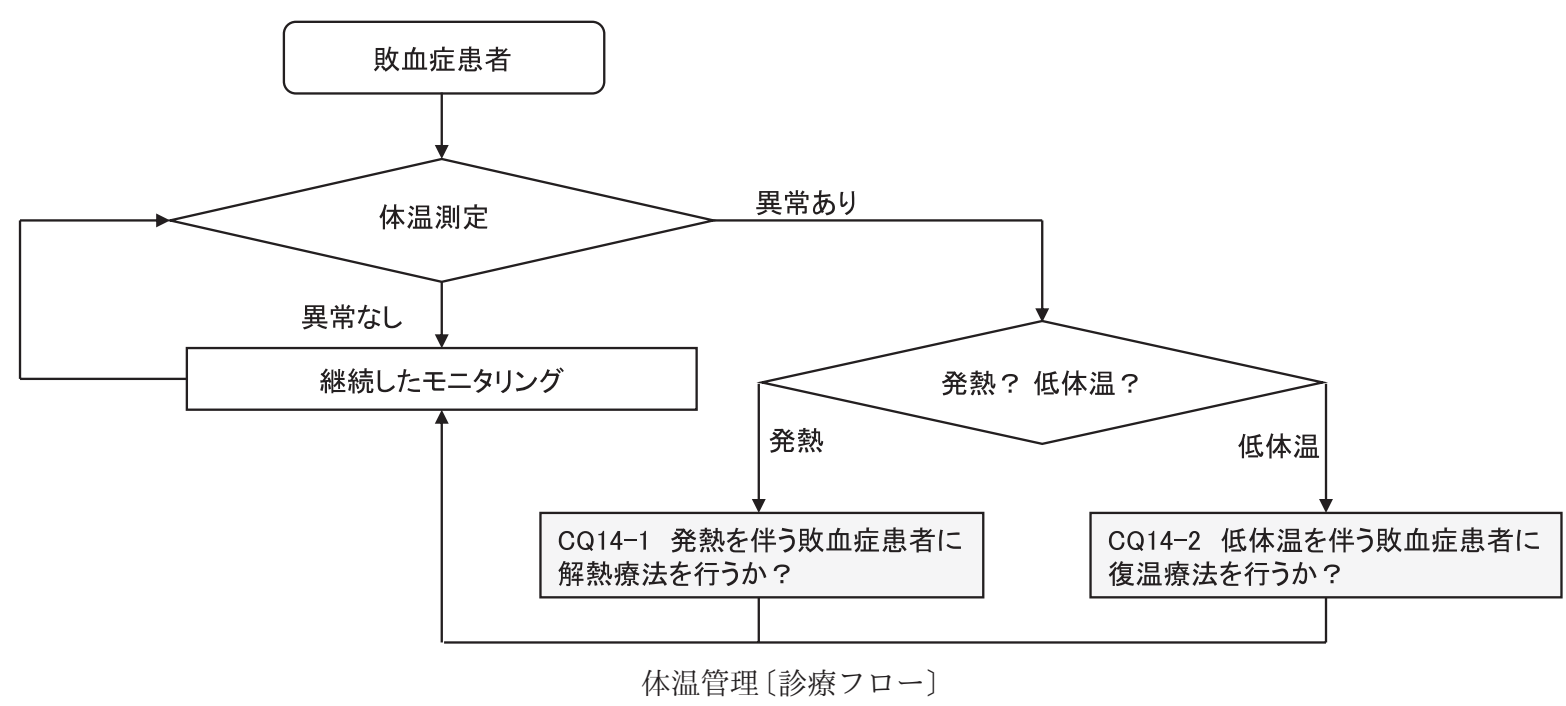

ている3,16)。

低体温は感染防御能の低下に関連し，徐脈，心収縮 力低下, 不整脈, 換気応答の低下, 高血糖, 高カリウ ム血症などの副作用がある。また, 深部体温 $35^{\circ} \mathrm{C}$ 未 満の低体温症においては, 心収縮力低下 · 心拡張能低 下・凝固異常が生じ， $33^{\circ} \mathrm{C}$ 以下では血小板数の低下が 生じる 17-21)。

このように，低体温に伴うデメリットと共に，低体 温を呈する敗血症患者の予後は不良である。低体温を 伴う敗血症患者に対する復温療法は，転帰改善が期待 される治療法である可能性がある。したがって，敗血 症治療開始時に低体温を呈している患者の体温を復温 するかは重要な問題と考えられるが，その有効性・有 害性の評価は定まっていない。以上より，本項におけ る 2 番目の $\mathrm{CQ}$ は, 「低体温を伴う敗血症患者に復温 療法を行うか?」とした。

\section{文 献}

1) O'Grady NP, Barie PS, Bartlett JG, et al: Guidelines for evaluation of new fever in critically ill adult patients: 2008 update from the American College of Critical Care Medicine and the Infectious Diseases Society of America. Crit Care Med. 2008; 36: 1330-49.

2) Laupland KB: Fever in the critically ill medical patient. Crit Care Med. 2009; 37(7 Suppl) : S273-8.

3) Kushimoto $\mathrm{S}$, Abe T, Ogura $\mathrm{H}$, et al: Impact of Body Temperature Abnormalities on the Implementation of Sepsis Bundles and Outcomes in Patients with Severe Sepsis: A Retrospective Sub-Analysis of the Focused Outcome Research on Emergency Care for Acute Respiratory Distress Syndrome, Sepsis and Trauma Study. Crit Care Med. 2019; 47: 691-9.

4) Lee BH, Inui D, Suh GY, et al: Association of body temperature and antipyretic treatments with mortality of critically ill patients with and without sepsis: multi-centered prospective observational study. Crit Care. 2012; 16: R33.

5) Dantzer R, Wollman E: Molecular mechanisms of fever: the missing links. Eur Cytokine Netw. 1998; 9: 27-31.

6) Swenson BR, Hedrick TL, Popovsky K, et al: Is fever protective in surgical patients with bloodstream infection? J Am Coll Surg. 2007; 204: 815-21.

7) Rumbus Z, Matics R, Hegyi P, et al: Fever is associated with reduced, hypothermia with increased mortality in septic patients: a meta-analysis of clinical trials. PLoS One. 2017; 12: e0170152.

8) Plaisance KI, Mackowiak PA: Antipyretic therapy: physiologic rationale, diagnostic implications, and clinical consequences. Arch Intern Med. 2000; 160: 449-56.

9) Schell-Chaple HM, Liu KD, Matthay MA, et al: Effects of IV Acetaminophen on Core Body Temperature and Hemodynamic Responses in Febrile Critically Ill Adults: A Randomized Controlled Trial. Crit Care Med. 2017; 45: 1199-207.

10) Axelrod P: External cooling in the management of fever. Clin Infect Dis. 2000; 31(Suppl 5) : S224-9.

11) Sessler DI: Perioperative heat balance. Anesthesiology. 2000; 92: 578-96.

12) Gozzoli V, Treggiari MM, Kleger GR, et al: Randomized trial of the effect of antipyresis by metamizol, propacetamol or external cooling on metabolism, hemodynamics and inflammatory response. Intensive Care Med. 2004; 30: 401-7.

13) Knaus WA, Draper EA, Wagner DP, et al: APACHE II: a severity of disease classification system. Crit Care Med. 1985; 13: 818-29.

14) American College of Chest Physicians/Society of Critical Care Medicine Consensus Conference: definitions for sepsis and organ failure and guidelines for the use of innovative therapies in sepsis. Crit Care Med. 1992; 20: 864-74.

15) Levy MM, Fink MP, Marshall JC, et al: 2001 SCCM/ESICM/ ACCP/ATS/SIS International Sepsis Definitions Conference. Crit Care Med. 2003; 31: 1250-6.

16) Kushimoto S, Gando S, Saitoh D, et al: The impact of body temperature abnormalities on the disease severity and outcome in patients with severe sepsis: an analysis from a multicenter, prospective survey of severe sepsis. Crit Care. 2013; 17: R271.

17) Valeri CR, MacGregor H, Cassidy G, et al: Effects of temperature on bleeding time and clotting time in normal male and female volunteers. Crit Care Med. 1995; 23: 698-704.

18) Watts DD, Trask A, Soeken K, et al: Hypothermic coagulopathy in trauma: effect of varying levels of hypothermia on enzyme speed, platelet function, and fibrinolytic activity. J Trauma. 1998; 44: 846-54.

19) Brown DJA, Brugger H, Boyd J, et al: Accidental hypothermia. N Engl J Med. 2012; 367: 1930-8.

20) Epstein E, Anna K: Accidental hypothermia. BMJ. 2006; 332: 
706-9.

21) Wolberg AS, Meng ZH, Monroe DM 3rd, et al: A systematic evaluation of the effect of temperature on coagulation enzyme activity and platelet function. J Trauma. 2004; 56: 1221-8.
CQ14-1：発熱を伴う敗血症患者に解熱療法を行 うか?

Answer: 発熱を伴う敗血症患者に対して, 解熱療法 を行わないことを弱く推奨する（GRADE 2A：エビデ ンスの確実性 $=$ 「高」)。

\section{（1）背景および本 $C Q$ の重要度}

敗血症患者では発熱は頻繁に生じる。発熱は，その 原因検索のための診断や治療法変更へとつながる徴候 であると共に, 患者不快感, 呼吸および心筋を含む全 身の酸素需要増大, 中枢神経障害などを生じる。一 方, 抗体産生増加, $\mathrm{T}$ 細胞活性化, サイトカイン産生 促進, 好中球およびマクロファージの活性化を惹起さ せ, 病原微生物の除去促進に関連する防御反応でもあ る。解熱療法は, 患者不快感の軽減, 酸素需要増大の 低減，中枢神経障害予防を目的に頻繁に施行されてい る。しかし, 解熱療法により前記防御反応が抑制され る可能性もある。その有効性・有害性の評価は定まっ ておらず，本 CQ の優先度は高いと考える。

(2) PICO

P (患者) : 感染症, 敗血症あるいは敗血症性ショッ ク患者

I（介入）：あらゆる種類および投与量の解熱薬投 与，体表あるいは体内クーリングデバイスの使用

C (対照)：プラセボ投与あるいは非介入

$\mathrm{O}$ (アウトカム ) : 病院死亡, ICU 滞在日数, あらゆ る重篤な副作用，感染性合併症

\section{（3）エビデンスの要約}

敗血症診断基準を満たした患者のみを対象としたラ ンダム化比較試験（RCT）７論文を用いたメタ解析を 行った 1-7)。死亡アウトカムに関しては，事前設定に 基づいて検索し得た全 RCT を対象としたもの，なら びに，バイアスリスクが低い RCTに限定したもの （Low RoB）の 2 通りを行った。エビデンスの確実性 が高い解析を用いることと事前に設定していたため, Low RoB RCT に限定した解析の死亡アウトカムを採 用した $\left.{ }^{1-5}, 7\right)$ 。

（4）益と害のバランス（Table 14-1-1）

望ましい効果 :

低いバイアスのリスクの 6 つの RCT から得られる病 院死亡に関する効果推定值は，リスク差（RD）1,000 人あたり 14 人少ない $(95 \% \mathrm{CI}: 52$ 人少ない〜 30 人多い) 
Table 14-1-1エビデンスプロファイル

\begin{tabular}{|c|c|c|c|c|c|c|c|c|c|c|c|c|}
\hline \multicolumn{7}{|c|}{ 確実性の評価 } & \multicolumn{2}{|c|}{ 患者数 } & \multicolumn{2}{|c|}{ 効果 } & \multirow{2}{*}{ 確実性 } & \multirow{2}{*}{ 重要性 } \\
\hline 研究数 & $\begin{array}{l}\text { 研究 } \\
\text { デザイン }\end{array}$ & $\begin{array}{l}\text { パイアス } \\
\text { のリスク }\end{array}$ & 非一貫性 & 非直接性 & 不精確性 & $\begin{array}{l}\text { その他 } \\
\text { の検討 }\end{array}$ & 解熱療法 & プラセボ & $\begin{array}{l}\text { 相対指標 } \\
(95 \% \text { CI }\end{array}$ & $\begin{array}{l}\text { 絶対指標 } \\
(95 \% \text { CI })\end{array}$ & & \\
\hline \multicolumn{13}{|c|}{ 病院死亡（全ての RCT） } \\
\hline 7 & RCT & 深刻 a & 深刻でないb & 深刻でない & 深刻。 & なし & $\begin{array}{c}208 / 752 \\
(27.7 \%)\end{array}$ & $\begin{array}{c}205 / 752 \\
(27.3 \%)\end{array}$ & $\begin{array}{c}\text { RR } 1.08 \\
(0.83 \text { to } 1.41)\end{array}$ & $\begin{array}{l}1,000 \text { 人あたり } 22 \\
\text { 人多い (46人少な } \\
\text { い 112 人多い) }\end{array}$ & $\underset{\text { 低 }}{\oplus \oplus \bigcirc \bigcirc}$ & 重大 \\
\hline \multicolumn{13}{|c|}{ 病院死亡 (バイアスリスクの低いRCT のみ) } \\
\hline 6 & RCT & 深刻でない & 深刻でないd & 深刻でない & 深刻でない & なし & $\begin{array}{l}187 / 718 \\
(26.0 \%)\end{array}$ & $\begin{array}{l}197 / 721 \\
(27.3 \%)\end{array}$ & $\begin{array}{c}\text { RR } 0.95 \\
\text { (0.81 to } 1.11)\end{array}$ & $\begin{array}{l}\text { 1,000 人あたり } 14 \\
\text { 人少ない (52人少 } \\
\text { ない 30 人多い) }\end{array}$ & 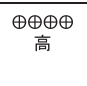 & 重大 \\
\hline \multicolumn{13}{|c|}{ ICU 滞在日数 } \\
\hline 2 & RCT & 深刻 e & 深刻でないd & 深刻でない & 深刻 f & なし & 446 & 443 & - & $\begin{array}{c}\text { 平均 } 0.26 \text { 日短い } \\
(0.99 \text { 日短い } \\
0.46 \text { 日長い) }\end{array}$ & $\underset{\text { 低 }}{\oplus \oplus \bigcirc \bigcirc}$ & 重大 \\
\hline \multicolumn{13}{|c|}{ あらゆる重篤な副作用 } \\
\hline 2 & RCT & 深刻 e & 深刻でないd & 深刻でない & 深刻 c & なし & $9 / 569(1.6 \%)$ & $17 / 575 \quad(3.0 \%)$ & $\begin{array}{c}\operatorname{RR} 0.56 \\
\text { (0.26 to } 1.22)\end{array}$ & $\begin{array}{l}1,000 \text { 人あたり } 13 \\
\text { 人少ない (22人少 } \\
\text { ない 7 人多い) }\end{array}$ & $\underset{\text { 低 }}{\oplus \oplus \bigcirc \bigcirc}$ & 重大 \\
\hline \multicolumn{13}{|c|}{ 感染性合併症 } \\
\hline 3 & RCT & 深刻 e & 深刻でないd & 深刻でない & 非常に深刻 \& & なし & $21 / 254(8.3 \%)$ & $29 / 256(11.3 \%)$ & $\begin{array}{c}\text { RR } 0.75 \\
\text { (0.38 to } 1.48)\end{array}$ & $\begin{array}{l}1,000 \text { 人あたり } 28 \\
\text { 人少ない (70人少 } \\
\text { ない 54 人多い) }\end{array}$ & $\begin{array}{l}\oplus \bigcirc \bigcirc \bigcirc \\
\text { 非常に低 }\end{array}$ & 重要 \\
\hline
\end{tabular}

a. 1 つの RCT が高いバイアスのリスクでその寄与率が 11.5\%ある。この研究が異質性や不精確性にも影響を与えている。

b. $1^{2}$ 值=45\%と中等度の非一貫性は認めるが, 高いバイアスのリスクの研究を除外した場合、 $1^{2}$ 值=0\%となる。このことから研究方法により説明可能と判断しダウングレードしなかった。

c. サンプルサイズが最適情報量より少ない。さらに $95 \% \mathrm{CI}$ が相当な益を含む。

d. $1^{2}$ 値<40\%より非一貫性は低いと判断した。

中間のバイアスのリスクの研究を含むため。

サンプルサイズが最適情報量より少ない。

g. サンプルサイズが最適情報量より少ない。さらに $95 \%$ CI が相当な益と害を含む。

（6 RCT，1,439人）であり，ICU 滞在日数に関する効 果推定值は，平均（MD）0.26日短い（95\% CI: 0.99 日 短い〜 0.46 日長い）（2 RCT，889人）であった。望ま しい効果はわずかであると判断した。

望ましくない効果：

あらゆる重篤な副作用に関する効果推定值は，RD 1,000 人あたり 13 人少ない $(95 \% \mathrm{CI}: 22$ 人少ない〜7 人多い）（2 RCT, 1,144人）であった。望ましくない 効果はわずかであると判断した。

益と害のバランス :

本 CQ においては，病院死亡についての相対的価值 の設定によらず，その効果のバランスは介入も比較対 照もいずれも優位ではなかった。

\section{（5）アウトカム全般に関するエビデンスの確実性}

今回採用したすべてのアウトカムの効果推定值の方 向性は一致していた（効果なし）ため，一番高いアウ トカムの確実性を全体としては採用した。アウトカム 全体にわたるエビデンスの確実性は「高」である。

\section{（6）価値観}

発熱を伴う敗血症患者に対する解熱療法において, 各アウトカムに対する患者・家族の価值観に関する データはない。死亡アウトカムに対する相対的価值は 高く，そのばらつきは少ないことが予想される。

\section{（7）容認性}

解熱薬の中で最も高価であり，かつ静脈注射薬とし て標準的に使用されるアセトアミノフェン静注薬 (1,000mg) の薬価は 323 円であり, 薬物的介入を行っ たとしてもその費用は容認されるものであると考えら れる。仕事量も軽微な増加であり, 通常の臨床業務範 囲内で行うことができる。ウォーターパッド体温管理 装置を含む体表・体内デバイスの使用により作業量は 増加するものの, 集中治療室における通常の診療業務 範囲内であると思われる。ウォーターパッド体温管理 用ジェルパッドは，全身装着の際には約 10 万円と高 額であるが（再使用禁止）, 敗血症患者に対する適用 は限定的であると考えられる。

\section{（8）実行可能性}

多くの医療施設において実行可能である。

(9) 判断の要約（Table 14-1-2）

（10）推奨グレーディング決定の工程

修正 RAND 法を用いた投票によって，中央值 8, 見解不一致指数 0.164 の結果となり, 委員会で採択さ れた（7点以上 : $87.5 \%) 。$

（11）関連する他の診療ガイドラインにおける推奨 SSCG 2016 ${ }^{8)}$ を含む国際ガイドラインなどにおい 
Table 14-1-2 判断の要約

\begin{tabular}{|c|c|c|c|c|c|c|c|}
\hline 問題 & いいえ & $\begin{array}{c}\text { おそらく、いい } \\
\text { え }\end{array}$ & おそらく、はい & はい & & さまざま & 分からない \\
\hline 望ましい効果 & わずか & 小さい & 中 & 大きい & & さまざま & 分からない \\
\hline 望ましくない効果 & 大きい & 中 & 小さい & わずか & & さまざま & 分からない \\
\hline エビデンスの確実性 & 非常に低 & 低 & 中 & 高 & & & 採用研究なし \\
\hline 価值観 & $\begin{array}{c}\text { 重要な不確実性 } \\
\text { またはばらつき } \\
\text { あり }\end{array}$ & $\begin{array}{c}\text { 重要な不確実性 } \\
\text { またはばらつき } \\
\text { の可能性あり }\end{array}$ & $\begin{array}{l}\text { 重要な不確実性 } \\
\text { またはばらつき } \\
\text { はおそらくなし }\end{array}$ & $\begin{array}{c}\text { 重要な不確実性 } \\
\text { またはばらつき } \\
\text { はなし }\end{array}$ & & & \\
\hline 効果のバランス & 比較が優位 & $\begin{array}{c}\text { 比較がおそらく } \\
\text { 優位 }\end{array}$ & $\begin{array}{c}\text { 介入も比較もい } \\
\text { ずれも優位でな } \\
\text { い }\end{array}$ & $\begin{array}{c}\text { おそらく介入が } \\
\text { 優位 }\end{array}$ & 介入が優位 & さまざま & 分からない \\
\hline 容認性 & いいえ & 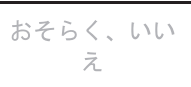 & おそらく、はい & はい & & さまざま & 分からない \\
\hline 実行可能性 & いいえ & $\begin{array}{c}\text { おそらく、いい } \\
\text { え }\end{array}$ & おそらく、はい & はい & & さまざま & 分からない \\
\hline
\end{tabular}

て，本 CQ は取り上げられていない。日本版敗血症診 療ガイドライン（J-SSCG）20169,10）においてはじめ て採用したものであり，ルーチンの解熱療法を実施し ないことを弱く推奨する（2C）とされ，本ガイドラ インと同様の「弱い非推奨」となっている。

\section{（12）実施に関わる検討事項}

発熱を伴う敗血症患者全例に対して解熱療法を行わ ないことを弱く推奨するが，容認性，実行可能性とも に問題ないことから，著しい高体温への対応や発熱に 伴う症状改善のためにはその限りではない。

\section{（13）今後の研究の可能性}

解熱療法の適応，開始時期と期間，維持体温の設 定, 解熱方法のさらなる研究が期待される。

\section{文 献}

1) Bernard GR, Wheeler AP, Russell JA, et al: The effects of ibuprofen on the physiology and survival of patients with sepsis. N Engl J Med. 1997; 336: 912-8.

2) Janz DR, Bastarache JA, Rice TW, et al: Randomized, placebocontrolled trial of acetaminophen for the reduction of oxidative injury in severe sepsis: The acetaminophen for the reduction of oxidative injury in severe sepsis trial. Crit Care Med. 2015; 43: $534-41$

3) Haupt MT, Jastremski MS, Clemmer TP, et al: Effect of ibuprofen in patients with severe sepsis: A randomized, double-blind, multicenter study. The Ibuprofen Study Group. Crit Care Med. 1991; 19: 1339-47.

4) Niven DJ, Stelfox HT, Léger C, et al: Assessment of the safety and feasibility of administering antipyretic therapy in critically ill adults: A pilot randomized clinical trial. J Crit Care. 2013; 28: 296-302.

5) Schortgen F, Charles-Nelson A, Bouadma L, et al: Respective impact of lowering body temperature and heart rate on mortality in septic shock: mediation analysis of a randomized trial. Intensive Care Med. 2015; 41: 1800-8.

6) Yang YL, Liu DW, Wang XT, et al: Body temperature control in patients with refractory septic shock: Too much may be harmful. Chin Med J (Engl). 2013; 126: 1809-13.

7) Young P, Saxena M, Bellomo R, et al: Acetaminophen for fever in critically III patients with suspected infection. N Engl J Med. 2015 ; 373: 2215-24.

8) Rhodes A, Evans LE, Alhazzani W, et al: Surviving Sepsis Campaign: International Guidelines for Management of Sepsis and Septic Shock: 2016. Intensive Care Med. 2017; 43: 304-77.

9）西田修, 小倉裕司, 井上茂亮, 他, 日本版敗血症診療ガイドラ イン 2016 作成特別委員会. 日本版敗血症診療ガイドライン 2016. 日集中医誌. 2017; 24: S1-232.

10）西田修, 小倉裕司, 井上茂亮, 他, 日本版敗血症診療ガイドラ イン 2016 作成特別委員会. 日本版敗血症診療ガイドライン 2016. 日救急医会誌. 2017; 24: S1-232. 


\section{CQ14-2：低体温を伴う敗血症患者に復温療法を} 行うか?

Answer : 低体温（深部体温 $<35^{\circ} \mathrm{C}$ ）を呈する敗血症 患者において, 低体温に伴う循環障害や凝固異常など を認めるときには, 循環動態の安定化に配慮して復温 療法を行うことを弱く推奨する（エキスパートコンセ ンサス：エビデンス不十分）。

\section{（1）背景および本 CQ の重要度}

敗血症の定義に使用されてきた systemic inflammatory response syndrome（SIRS）基準にも体温 $36^{\circ} \mathrm{C}$ 未満が含まれているように，低体温は敗血症患者に生 じる体温異常の 1 つである。本邦の敗血症患者を対象 とした多施設観察研究 1) では, 集中治療室入室時に おける $36^{\circ} \mathrm{C}$ 未満の低体温は $11.1 \%$ の患者で生じてい た。低体温は感染防御能の低下に関連し，心機能低 下・不整脈・電解質異常などの合併症を生じうる。前 述の多施設観察研究では, 集中治療室入室時体温 $38^{\circ} \mathrm{C}$ を超える患者群に対する $36^{\circ} \mathrm{C}$ 未満患者群の病院 死亡非調整オッズ比は 1.760 (95\% CI: 1.134〜2.732) であり，低体温を呈した敗血症患者の予後は不良であ る。また，低体温（深部体温 $<35^{\circ} \mathrm{C}$ ）においては, 心収縮力低下 - 心拡張能低下 ・ 凝固異常が生じう る 2-4)。低体温を伴う敗血症患者に対する復温療法は, 転帰改善が期待される治療法である可能性がある5) が，その有効性・有害性の評価は定まっておらず，本 $\mathrm{CQ}$ の優先度は高いと考える。

\section{(2) PICO}

$\mathrm{P}$ (患者)：体温低下を伴う成人敗血症あるいは敗血 症性ショック患者

I（介入）：あらゆる薬物, 体表あるいは体内デバイ スの使用による復温療法（目標值および時間など の制限はない)

C (対照) : 非介入

$\mathrm{O}$ (アウトカム ) : 病院死亡, ICU 滞在日数，あらゆ る重篤な副作用, 感染性合併症, 血圧低下

\section{（3）エビデンスの要約}

“rewarming”, “sepsis”, “septic shock”を基本とし て検索式を立案した。検索エンジンは, PubMed, CENTRAL，医中誌 Web を用い，254 文献が抽出され た。重複を除いた 203 文献をスクリーニングし，体温 低下を伴う成人敗血症あるいは敗血症性ショック患者 を対象としたランダム化比較試験（RCT）が存在しな
いことを確認した。

\section{(4) 益と害のバランス}

望ましい効果 :

低体温時には心収縮力低下 · 心拡張能低下 · 凝固異 常が生じることがあり，これらの低体温によると考え られる合併症を認めた際には，緩徐な復温を試みたほ うが患者に益する可能性が高いと考える。望ましい効 果は「小さい」と判断した。

望ましくない効果 :

低体温からの復温の際には, 血圧低下・循環血液量 の相対的減少など, 循環動態が不安定化する可能性が あることに十分留意する必要がある。望ましくない効 果は「小さい」と判断した。

益と害のバランス :

PICO に合致する RCT は存在せず不明であるが，患 者の状態によってそのバランスは異なると考えられ る。少なくとも高度低体温により循環不全を伴う場合 は，復温に伴う益が害を上回るものと考えられる。

（5）アウトカム全般に関するエビデンスの確実性

システマティックレビューを行ったが PICO に合致 する RCT は存在しなかった。

\section{（6）価値観}

死亡率が低下することは，患者・家族は一般的に重 視すると考えられ，不確実性やばらつきはないと思わ れる。

\section{（7）容認性}

ウォーターパッド体温管理用ジェルパッドは，全身 装着の際には約 10 万円と高額であるが(再使用禁止), 敗血症患者に対する適用は限定的であると考えられ る。エアーブランケットや毛布を使用することによる コストは低いと考えられる。

ウオーターパッド体温管理装置，エアーブランケッ トや毛布を使用することにより，医療従事者の仕事量 が若干増加することが予想される。しかし, 集中治療 室における通常の診療業務範囲内であり，その影響は 小さいと考えられる。また，これらの装置などは多く の集中治療室で利用可能である。復温のためにこれら の介入を行うことに関して, 患者・家族・コメディカ ル・医師における評価と容認性に違いがないものと思 われる。 
Table 14-2-1 判断の要約

\begin{tabular}{|c|c|c|c|c|c|c|c|}
\hline & \multicolumn{7}{|c|}{ 判䱚 } \\
\hline 問題 & いいえ & $\begin{array}{c}\text { おそらく、いい } \\
\text { え }\end{array}$ & おそらく、はい & はい & & さまざま & 分からない \\
\hline 望ましい効果 & わずか & 小さい & 中 & 大きい & & さまざま & 分からない \\
\hline 望ましくない効果 & 大きい & 中 & 小さい & わずか & & さまざま & 分からない \\
\hline エビデンスの確実性 & 非常に低 & 低 & 中 & 高 & & & 採用研究なし \\
\hline 価值钼 & $\begin{array}{c}\text { 重要な不確実性 } \\
\text { またはばらつき } \\
\text { あり }\end{array}$ & $\begin{array}{c}\text { 重要な不確実性 } \\
\text { またはばらつき } \\
\text { の可能性あり }\end{array}$ & $\begin{array}{l}\text { 重要な不確実性 } \\
\text { またはばらつき } \\
\text { はおそらくなし }\end{array}$ & $\begin{array}{c}\text { 重要な不確実性 } \\
\text { またはばらつき } \\
\text { はなし }\end{array}$ & & & \\
\hline 効果のバランス & 比較が優位 & $\begin{array}{c}\text { 比較がおそらく } \\
\text { 優位 }\end{array}$ & $\begin{array}{c}\text { 介入も比較もい } \\
\text { ずれも優位でな } \\
\text { い }\end{array}$ & $\begin{array}{c}\text { おそらく介入が } \\
\text { 優位 }\end{array}$ & 介入が優位 & さまざま & 分からない \\
\hline 容認性 & いいえ & $\begin{array}{c}\text { おそらく、いい } \\
\text { え }\end{array}$ & おそらく、はい & はい & & さまざま & 分からない \\
\hline 実行可能性 & いいえ & $\begin{array}{c}\text { おそらく、いい } \\
\text { え }\end{array}$ & おそらく、はい & はい & & さまざま & 分からない \\
\hline
\end{tabular}

\section{（8）実行可能性}

ウォーターパッド体温管理装置，エアーブランケッ トや毛布などは，多くの集中治療室で利用可能である と考えられる。

（9）判断の要約（Table 14-2-1）

\section{（10）推奨グレーディング決定の工程}

修正 RAND 法を用いた投票によって，中央值 8 , 見解不一致指数 0.164 の結果となり，委員会で採択さ れた（7点以上 : $87.5 \%) 。$

\section{（11）関連する他の診療ガイドラインにおける推奨}

SSCG 2016 6) を含む国際ガイドラインなどにおい て，本 CQ は取り上げられていない。日本版敗血症診 療ガイドライン（J-SSCG）2016においてはじめて採 用したものであり，「低体温に伴う心収縮力低下・心 拡張能低下・凝固異常などの合併症を認める敗血症患 者では, 循環動態の安定化に配慮して緩徐に復温療法 を行うことを弱く推奨する」とされている。

\section{（12）実施に関わる検討事項}

低体温の重症度とこれに伴う症状の重篤度により, 復温による益と害のバランスが異なる可能性がある。

\section{（13）今後の研究の可能性}

低体温を伴う敗血症患者の復温に関する RCT がな いことが明らかとなり，復温が死亡率に与える影響， 復温に伴う循環動態への影響などを検証する RCT の
早期実施が望まれる。

$$
\text { 文 献 }
$$

1) Kushimoto $\mathrm{S}$, Abe $\mathrm{T}$, Ogura $\mathrm{H}$, et al: Impact of Body Temperature Abnormalities on the Implementation of Sepsis Bundles and Outcomes in Patients with Severe Sepsis: A Retrospective Sub-Analysis of the Focused Outcome Research on Emergency Care for Acute Respiratory Distress Syndrome, Sepsis and Trauma Study. Crit Care Med. 2019; 47: 691-99.

2) Brown DJA, Brugger H, Boyd J, et al: Accidental hypothermia. $\mathrm{N}$ Engl J Med. 2012 ; 367: 1930-8.

3) Epstein E, Anna K: Accidental hypothermia. BMJ. 2006; 332: 706-9.

4) Wolberg AS, Meng ZH, Monroe DM, et al: A systematic evaluation of the effect of temperature on coagulation enzyme activity and platelet function. J Trauma. 2004; 56: 1221-8.

5) Young PJ, Bellomo R: Fever in sepsis: Is it cool to be hot? Crit Care. 2014; 18: 109

6) Rhodes A, Evans LE, Alhazzani W, et al: Surviving Sepsis Campaign: International Guidelines for Management of Sepsis and Septic Shock: 2016. Intensive Care Med. 2017; 43: 304-77. 


\section{CQ15 : DIC 診断と治療}

敗血症における凝固・線溶状態の変化と DIC の合併 凝固・線溶状態の変化は, 敗血症が重症化していく 過程において早期から認められ, 全身性の凝固異常で ある播種性血管内凝固 (disseminated intravascular coagulation: DIC）を合併すると多臓器障害による死亡 リスクは著しく増加することが知られている1)。これ は敗血症性 DIC の本態は全身性の著しい凝固活性化 状態であり，血管内凝固による微小循環障害が蔵器障 害の発現に関与しているからである ${ }^{2)}$ 。DICでは凝固 の活性化に応じて線溶機能も活性化されるが, 線溶機 能の程度は基礎疾患によって異なるため, DIC は線溶 抑制型と線溶㐫進型に大別されている。敗血症性 DIC においては, 凝固六進に対して線溶機能の活性化が十 分に行われず，線溶抑制パターンを示すため，臓器障 害の合併が多く，予後不良であることが知られてい る3)。

敗血症性 DIC の診断, 鑑別診断, 治療のフローチャート 敗血症における DIC 診断は，重症度評価と治療介 入の必要性を判断するうえで必須である。診断基準と しては本邦では日本救急医学会が提唱する「急性期 DIC 診断基準」が広く用いられており 1)，海外では国 際血栓止血学会が提唱する「overt-DIC 診断基準」が 標準とされている4)。前者は急性 DIC の診断に特化 した診断基準で，簡便性や早期診断に優れる。一方，
後者はより厳密にDICを捉えようとしているため, 多少煩雑であり, 診断のタイミングが遅くなることが 指摘されている5)。このため国際血栓止血学会は, 新 たに sepsis-induced coagulopathy の診断基準を策定して この批判に応えている5)。一方，DICではない症例に 対する抗凝固療法は効果が期待できないばかりでな

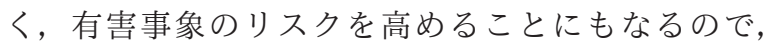
DIC の鑑別診断は重要である6)。

実際の診療にあたっては, 凝固・線溶状態をリアル タイムに把握し，DIC 診断に基づいて適切に治療介入 を行う必要がある。敗血症において臨床症状や検査所 見で凝固異常が認められる際には, 診療フロー（下 図）を参考にすることがスムーズな診療につながるで あろう。まず診断では, CQ15-1 を参考にして診断基 準を選択し，それぞれの基準に基づいて診断を進め る。そして DIC，もしくはその疑い症例においては CQ15-2 に基づいて鑑別を実施する。その結果，他疾 患が除外され，DICであると判断された場合は治療実 施の是非を判断することになる。一方，DIC 診断基準 を満たさない場合でも, 凝固異常は転帰と関連するこ とを意識して適宜再検討を行い, 治療が遅れないよう 留意する必要がある。DIC 治療としては, 原因となっ ている病態への対処が必須であるが，同時に抗凝固療 法を実施することにより病態の改善が期待できる場合 もある。ガイドラインでは代表的な治療薬のエビデン スに基づく評価を CQ15-3〜 6に提示してあるので選 択の参考にされたい。なお, 抗凝固療法の実施に際し ては，いずれの治療薬に関してもエビデンスの確実性

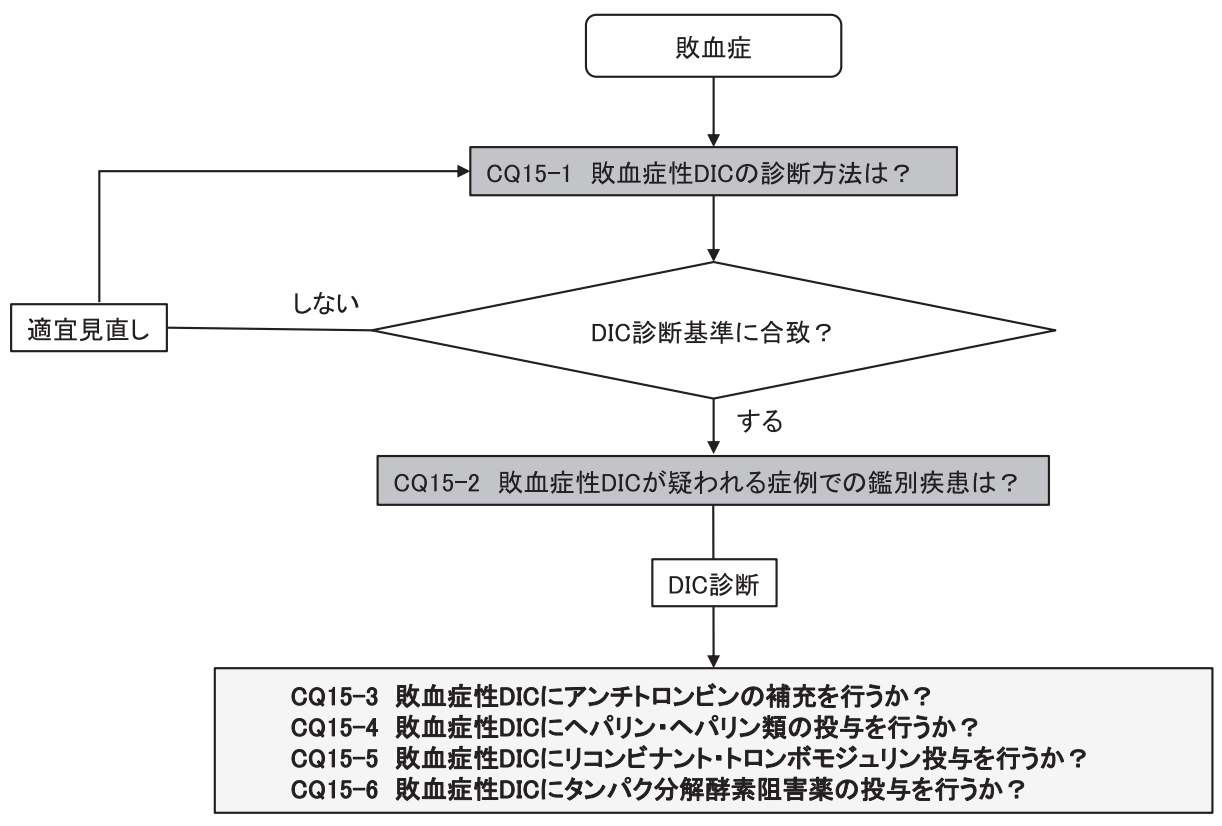

DIC 診断と治療〔診療フロー〕 
は低く, 海外においては積極的に抗凝固療法を実施し ている例はむしろ少数であることも念頭に置いておく 必要がある。

\section{文 献}

1) Gando $S$, Iba T, Eguchi $Y$, et al: A multicenter, prospective validation of disseminated intravascular coagulation diagnostic criteria for critically ill patients: comparing current criteria. Crit Care Med. 2006; 34: 625-31.

2) Levi M, van der Poll $\mathrm{T}$ : A short contemporary history of disseminated intravascular coagulation. Semin Thromb Hemost. 2014; 40: 874-80.

3) Asakura H: Classifying types of disseminated intravascular coagulation: clinical and animal models. J Intensive Care. 2014; 2 : 20

4) Taylor FB Jr, Toh CH, Hoots WK, et al: Towards definition, clinical and laboratory criteria, and a scoring system for disseminated intravascular coagulation. Thromb Haemost. 2001; 86: 1327-30.

5) Iba T, Umemura $Y$, Watanabe E, et al: Diagnosis of sepsisinduced disseminated intravascular coagulation and coagulopathy. Acute Med Surg. 2019; 6: 223-32.

6) Iba T, Levy JH, Warkentin TE, et al: Diagnosis and management of sepsis-induced coagulopathy and disseminated intravascular coagulation. J Thromb Haemost. 2019; 17: 1989-94.

\section{CQ15-1：敗血症性 DIC の診断方法は？}

Answer : DIC の診断を行うために複数の診断基準が 存在する。国内では急性期 DIC 診断基準が広く用い られており, 海外では ISTH overt-DIC 診断基準が標準 として使用されている。診断基準間の優劣を判断する ことは困難であり，目的に応じて使い分ける（BQに 対する情報提示)。

\section{（1）背景および本 CQ の重要度}

すべての生体侵襲は DICを引き起こしうるが，特 に敗血症に起因するDIC は，その頻度と重症度の高 さから最重要臨床課題と考えられる。また，近年の研 究から抗凝固療法の有効性が十分に発揮されるのは, 敗血症の中でも DIC などの一部の患者群に限られる ことが報告され，DIC 診断は抗凝固療法の適応を判断 し，患者の転帰に影響しうる重要な要素として改めて 注目されている。一方, 複数の DIC 診断基準が存在 する現状において，臨床上，それらをどのように使い 分け，どのようにDIC を診断するかに関しては統一 した見解はない。したがって，国内外のエビデンスを 集約し，各診断基準の意義を評価する必要があり，本 ガイドラインの臨床疑問の 1 つとして取り上げた。

\section{（2）解説}

敗血症では，活性化した自然免疫系と血小板，血管 内皮の相互作用によって，早期から凝固線溶障害が引 き起こされ，それが生理的な制御範囲を逸脱し，全身 性に著しい凝固障害が引き起こされた状態が DIC で ある。敗血症性 DIC は, その頻度と重症度の高さか ら敗血症診療における最重要な臨床的課題の 1 つと考 えられてきた。実際，本邦で行われた敗血症患者に関 する 2 つの大規模観察研究では, 敗血症患者全体の死 亡率と比較して敗血症性 DIC 患者の死亡率は有意に 高いことが報告された1,2)。このような背景から， DIC 診断は本邦の敗血症診療において特に重要視され てきた。

さらに近年, 複数の研究から, 敗血症の中でも抗凝 固療法によって生存転帰の改善が期待できるのは, DIC を発症した症例に限られることが示された3,4)。 また, 本邦の大規模観察研究では, 敗血症症例に対し て DIC 診断を行うこと自体が患者転帰の改善に関連 し, DIC 診断を繰り返し行うことで生存転帰の改善が

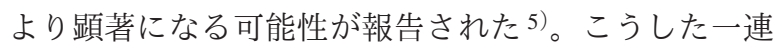
の研究結果から, 敗血症診療における DIC 診断は, 早期に DIC 症例を見極女, 適切な治療介入の可能性 
を検討することにより，患者転帰の改善に寄与しうる プロセスであることが示唆される。

一方，複数の DIC 診断基準をどのように使い分け るかに関しては，未だ統一した見解は示されていな い。DIC 診断基準は，1979年に発表された本邦の旧 厚生省 DIC 診断基準に始まり，国際血栓止血学会 （ISTH）の overt-DIC 診断基準，日本救急医学会より 発表された急性期 DIC 診断基準, 産科的 DIC 診断基 準，日本血栓止血学会 DIC 診断基準など，様々な基 準が公表されてきた。

この中で, 現在, 敗血症性 DIC の診断を目的とし て最も広く用いられている基準は, 急性期 DIC 診断 基準と ISTH overt-DIC 診断基準である 6,7)。急性期 DIC 診断基準は，炎症に伴う凝固線溶異常を鋭敏に感 知するために，診断項目に全身性炎症反応症候群 （SIRS）スコアや血小板の経日的な減少率を含めてお り，本邦の敗血症性 DIC 診断では最も普及している と考えられる。一方，国際的な標準的診断基準である ISTH overt-DIC 診断基準は, 急性期 DIC 診断基準と比 較してより厳密な診断基準であり，過剩診断を回避で きる一方で早期診断には適していない。

DIC 診断は正診の gold standard となる指標が存在し ないため, いずれの基準が優れているか判断すること は困難である。利益と害の観点で両者の明確な優劣を 示すためには, 敗血症症例を対象として, いずれかの DIC 診断基準を使用して診療を行った群間で，患者転 帰の差が示される必要があるが，こうしたエビデンス は現時点では示されていない。

両基準の診断特性の差は, その目的に起因してい る。これらの基準を適切に使用するためには，本邦と 諸外国の間で敗血症性 DIC 治療に対する考え方の相 違があることを理解する必要がある。すなわち，本邦 の臨床家の多くは敗血症性 DICを治療対象と考え, 早期治療介入の指標を必要としているのに対し, 諸外 国では敗血症性 DIC を特異的な治療の対象としてい ないため, 病態の正確な評価を目的とした厳密な診断 基準が適切と考えられている。したがって，現時点で は診断基準間の優劣を判断するのではなく，それらの 特性を十分に理解したうえで目的に応じて使い分ける ことが重要である。例えば, 多くの症例の中から真に 敗血症性 DIC である可能性の高い症例のみをリスト アップしたい場合は，ISTH overt-DIC 診断基準を用い ることで過剩診断を避けることができ，逆に過剩診断 を許容してでも敗血症性 DIC 診断症例を見落としな く抽出したい場合には, 急性期 DIC 診断基準の使用 が適切である。
以上の DIC 診断に関する見解は，本ガイドライン 作成委員会の DIC 診療に関するワーキンググループ によって考察され, その詳細は総説として公表されて いる ${ }^{8)}$ 。

\section{文 献}

1) Gando $S$, Saitoh $D$, Ogura $H$, et al: A multicenter, prospective validation study of the Japanese Association for Acute Medicine disseminated intravascular coagulation scoring system in patients with severe sepsis. Crit Care. 2013; 17: R111.

2) Gando $S$, Shiraishi $A$, Yamakawa $K$, et al: Role of disseminated intravascular coagulation in severe sepsis. Thromb Res. 2019; 178: $182-8$

3) Umemura $Y$, Yamakawa $\mathrm{K}$, Ogura $\mathrm{H}$, et al: Efficacy and safety of anticoagulant therapy in three specific populations with sepsis: a meta-analysis of randomized controlled trials. J Thromb Haemost. 2016; 14: 518-30.

4) Yamakawa $K$, Umemura $Y$, Hayakawa M, et al: Benefit profile of anticoagulant therapy in sepsis: a nationwide multicentre registry in Japan. Crit Care. 2016; 20: 229.

5) Umemura Y, Yamakawa K, Hayakawa M, et al: Screening itself for disseminated intravascular coagulation may reduce mortality in sepsis: A nationwide multicenter registry in Japan. Thromb Res. 2018; 161: 60-6.

6) Taylor FB Jr, Toh CH, Hoots WK, et al: Towards definition, clinical and laboratory criteria, and a scoring system for disseminated intravascular coagulation. Thromb Haemost. 2001; 86: 1327-30.

7) Gando S, Iba T, Eguchi Y, et al: A multicenter, prospective validation of disseminated intravascular coagulation diagnostic criteria for critically ill patients: comparing current criteria. Crit Care Med. 2006; 34: 625-31.

8) Iba T, Umemura $Y$, Watanabe E, et al: Diagnosis of sepsisinduced disseminated intravascular coagulation and coagulopathy. Acute Med Surg. 2019; 6: 223-32. 


\section{CQ15-2：敗血症性 DIC が疑われる症例での鑑別 疾患は?}

Answer : DIC 類似病態として，血栓性血小板減少性 紫斑病 (thrombotic thrombocytopenic purpura: TTP) や 溶血性尿毒症症候群（hemolytic uremic syndrome: HUS）, ペリン起因性血小板減少症（heparin-induced thrombocytopenia: HIT) などが存在し，鑑別を要する これらの疾患においてはDIC とは異なる対応が必要 になる（BQ に対する情報提示）。

\section{（1）背景および本 CQの重要度}

敗血症を含む重症生体侵襲の多くが DIC を引き起 こしうる一方で, 慢性肝障害に伴う凝固因子の低下 や, 薬剤誘発性の血小板減少症, 血栓性微小血管障害 症（thrombotic microangiopathy: TMA）など, 類似の 血液検査異常を来しながらも DIC とは一線を画す病 態が存在する。この中には, 敗血症性 DIC とは異な る, 特異的な治療アルゴリズムが必要な病態も含まれ ている。こうした背景から，敗血症性 DIC と診断し た場合でも類似病態を鑑別する必要があるため，本ガ イドラインの CQ として取り上げた。

\section{（2）解説}

DIC の本態は，基礎疾患の存在下における全身的な 凝固活性化状態である。日本救急医学会による本邦に おける調査では, DIC 発生率は敗血症の $50 \%$ を超え るという報告もあり ${ }^{1)}$, 発症頻度は極めて高い。DIC から鑑別するべき疾患の中で, 迅速に特異的な対応を 行うことによって, 救命あるいは重篤な後遺症発症の 防止につながりうるものとして，TMA が挙げられる。 TMA は, 微小血管障害性溶血性貧血（microangiopathic hemolytic anemia: MAHA), 消費性血小板減少, 微小 血管内血小板血栓による臓器機能障害を 3 主徵とする 病態であり，志賀毒素を産生する病原性大腸菌（Shiga toxin-producing Escherichia coli: STEC) による HUS, von Willebrand 因子 (vWF) の切断酵素である ADAMTS13 (a disintegrin-like and metalloproteinase with thrombospondin type 1 motif, member 13）の活性が 先天的に (Upshaw-Schulman 症候群)，あるいは自己 抗体により後天的に低下する TTP, 補体の異常な活 性化による非典型溶血性尿毒症症候群（atypical HUS: aHUS), その他の原因（自己免疫性疾患, 移植関連, 感染症，薬剤など）による二次性 TMA に分類され る 2)。TMAの発生頻度は, DIC と比べて約 $1 / 150$ と の報告もある ${ }^{3)}$ 。しかし, DIC と診断されても, 実際
には TMA であったり, TMA が並存している可能性 は否定できない。

TMA に関しては, 最近様々な診断フローが提唱さ れている 4-6）が，多くはDIC との鑑別が大きな分岐点 となる。これらの急性期鑑別診断においては, 第 1 段 階で，凝固障害 6）あるいは溶血 ${ }^{4,5)}$ の有無のうち，ど ちらを先にスクリーニングするかという方針上の違い が注目される。これはまずDICを治療対象として想定 するか TMA を想定するかにより，第 1 段階のスクリー ニングが異なることを反映しているといえる。治療を 要するような敗血症性 DIC に対する診断は, 迅速に行 う必要があるが, 当初は敗血症性 DIC と診断したもの の, その治療に反応性がそしい場合, あるいは臨床徴 候が非典型的な場合には，その背景に潜む TMA を念 頭に置き，迅速な鑑別に基づき血漿治療，あるいは分 子標的治療などの特異的治療へ速やかに切り替える必 要がある7)。また, TMA 以外の重要な類似疾患の 1 つ である HIT は，4Ts スコアリング8）によるスクリーニ ングや抗体検査などによる診断精度向上も相まって, 早期にDIC と鑑別できるようになってきた。一方, HELLP (hemolysis, elevated liver enzymes and low platelets）症候群9）は, 妊娠高血圧症候群の重症型で あり，分婏により速やかに改善するため，臨床診断に よって比較的容易に鑑別できる。しかしながら，先天 性 TTP や aHUS が，妊娠中の vWF の増加により顕在 化する場合があり，その場合は HELLP 症候群との鑑 別が困難となる場合があるので注意を要する ${ }^{10)}$ 。

以上は，最近の鑑別診断フローにはいずれも取り上 げられている主要な DIC 類似病態である。それらを 勘案して, 本ガイドライン作成委員会の DIC 診療に 関するワーキンググループから公表した総説でも, DIC 早期鑑別診断のための鑑別診断フローの 1 案を提 唱した 7)。

\section{文 献}

1) Gando $S$, Shiraishi A, Yamakawa $K$, et al: Role of disseminated intravascular coagulation in severe sepsis. Thromb Res. 2019; 178: $182-8$

2) Kato H, Nangaku M, Hataya $H$, et al: Clinical guides for atypical hemolytic uremic syndrome in Japan. Pediatr Int. 2016; 58: 549-55.

3) Wada H, Matsumoto T, Suzuki K, et al: Differences and similarities between disseminated intravascular coagulation and thrombotic microangiopathy. Thromb J. 2018; 16: 14.

4) Azoulay E, Knoebl P, Garnacho-Montero J, et al: Expert statements on the standard of care in critically ill adult patients with atypical hemolytic uremic syndrome. Chest. 2017; 152: 424-34.

5) Vincent JL, Castro P, Hunt BJ, et al: Thrombocytopenia in the ICU: disseminated intravascular coagulation and thrombotic microangiopathies-what intensivists need to know. Crit Care. 2018; 22: 158. 
6) Iba T, Levy JH, Wada H, et al: Differential diagnoses for sepsisinduced disseminated intravascular coagulation: communication from the SSC of the ISTH. J Thromb Haemost. 2019; 17: 415-9.

7) Iba $T$, Watanabe E, Umemura $Y$, et al: Sepsis-associated disseminated intravascular coagulation and its differential diagnoses. J Intensive Care. 2019; 7: 32.

8) Warkentin TE: Clinical picture of heparin-induced thrombocytopenia (HIT) and its differentiation from non-HIT thrombocytopenia. Thromb Haemost. 2016; 116: 813-22.

9) Weinstein L: Syndrome of hemolysis, elevated liver enzymes, and low platelet count: a severe consequence of hypertension in pregnancy. Am J Obstet Gynecol. 1982; 142: 159-67.

10) Hulstein JJJ, van Runnard Heimel PJ, Franx A, et al: Acute activation of the endothelium results in increased levels of active von Willebrand factor in hemolysis, elevated liver enzymes and low platelets (HELLP) syndrome. J Thromb Haemost. 2006; 4: 2569-75.
CQ15-3 : 敗血症性 DIC にアンチトロンビンの補 充を行うか?

Answer : 敗血症性 DIC 患者に対して, アンチトロン ビンの補充療法を行うことを弱く推奨する（GRADE $2 \mathrm{C}:$ エビデンスの確実性 $=「$ 低」)。

\section{（1）背景および本 CQ の重要度}

すべての生体侵襲はDICを引き起こしうるが，特 に敗血症に起因するDIC は，その頻度と重症度の高 さから最重要臨床課題と考えられる。アンチトロンビ ンは，主にトロンビンと活性化第 X因子を阻害する ことで抗凝固作用を有するだけでなく，血管内皮細胞 のプロスタサイクリン産生を介した抗炎症作用を有す ることから ${ }^{1)}$, 敗血症性 DIC の病態を制御できる可 能性が期待され, 本邦の臨床現場でも幅広く使われて いる。しかし, 過去の研究では, アンチトロンビンが 敗血症性 DIC の予後に与える影響に関して相反する 結果が公表されており, 明確なエビデンスが確立され ていない。このような背景から, 敗血症性 DICに対 してアンチトロンビン投与を行うかは, 本邦の敗血症 診療における重要な課題であり, 本ガイドラインの臨 床疑問の 1 つとして取り上げた。

(2) PICO

P (患者) : 成人の敗血症性 DIC 患者

I (介入)：アンチトロンビン製剤投与

$\mathrm{C}$ (対照)：プラセボ投与あるいはアンチトロンビン 非投与

$\mathrm{O}$ (アウトカム ) : 死亡, 出血性合併症, DIC 離脱

\section{（3）エビデンスの要約}

システマティックレビューの結果, PICO に合致し たランダム化比較試験（RCT）が 5 件 2-6）施行されて おり,これらを用いたメタ解析を実施した。

（4）益と害のバランス（Table 15-3-1）

本 CQ で推奨作成のために最終的に採用した重大な アウトカムは「死亡」と「出血性合併症」の 2 件で あった。

望ましい効果 :

アンチトロンビン製剤投与によって予期される有益 な効果は, 死亡アウトカムの減少である。 5 つの RCT から得られた死亡アウトカムの効果推定值とその信頼 区間は，1,000人あたり 134 人少ない（192人少ない ～ 58 人少ない）であり，アンチトロンビン製剤投与 
Table 15-3-1エビデンスプロファイル

\begin{tabular}{|c|c|c|c|c|c|c|c|c|c|c|c|c|}
\hline \multicolumn{7}{|c|}{ 確実性の評価 } & \multicolumn{2}{|c|}{ 患者数 } & \multicolumn{2}{|c|}{ 効果 } & \multirow[b]{2}{*}{ 確実性 } & \multirow[b]{2}{*}{ 重要性 } \\
\hline 研究数 & $\begin{array}{l}\text { 研究 } \\
\text { デザイン }\end{array}$ & $\begin{array}{l}\text { バイアス } \\
\text { のリスク }\end{array}$ & 非一貫性 & 非直接性 & 不精確性 & $\begin{array}{l}\text { その他 } \\
\text { の検討 }\end{array}$ & AT & Placebo & $\begin{array}{l}\text { 相対指標 } \\
(95 \% \mathrm{CI})\end{array}$ & $\begin{array}{l}\text { 絶対指摽 } \\
(95 \% \text { cI) }\end{array}$ & & \\
\hline \multicolumn{13}{|l|}{ 死亡 } \\
\hline 5 & RCT & 深刻でない & 深刻でない & 深刻でない & 深刻 a & なし & $62 / 201 \quad(30.8 \%)$ & $86 / 193 \quad(44.6 \%)$ & $\begin{array}{c}R R 0.70 \\
\text { (0.57 to } 0.87)\end{array}$ & $\begin{array}{c}1,000 \text { 人あたり } 134 \\
\text { 人少ない }(192 \text { 人 } \\
\text { 少ない 58 人少な } \\
\text { い) }\end{array}$ & $\begin{array}{c}\oplus \oplus \oplus \bigcirc \\
\text { 中 }\end{array}$ & 重大 \\
\hline \multicolumn{13}{|c|}{ 出血性合併症 } \\
\hline 3 & RCT & 深刻でない & 深刻でない & 深刻でない & 非常に深刻 b & なし & $8 / 158 \quad(5.1 \%)$ & $7 / 163 \quad(4.3 \%)$ & $\begin{array}{l}\text { RR } 1.20 \\
\text { (0. } 45 \text { to } 3.19)\end{array}$ & $\begin{array}{l}1,000 \text { 人あたり } 9 \\
\text { 人多い }(24 \text { 人少な } \\
\text { い 94 人多い) }\end{array}$ & $\underset{\text { 低 }}{\oplus \oplus \bigcirc}$ & 重大 \\
\hline \multicolumn{13}{|l|}{ DIC 離脱 } \\
\hline 3 & RCT & 深刻でない & 深刻でない & 深刻でない & 深刻 a & なし & $32 / 54 \quad(59.3 \%)$ & $8 / 55 \quad(14.5 \%)$ & $\begin{array}{c}\text { RR } 3.39 \\
\text { (1. } 74 \text { to } 6.59)\end{array}$ & $\begin{array}{l}1,000 \text { 人あたり } 348 \\
\text { 人多い (108人多 } \\
\text { い 813人多い) }\end{array}$ & $\begin{array}{c}\oplus \oplus \oplus \bigcirc \\
\text { 中 }\end{array}$ & 重要 \\
\hline
\end{tabular}

a. 相対リスク減少を 20 30\%とした場合の最適情報量基準を満たさないが，信頼区間が効果なし（RR=1）を含まない

b. 相対リスク減少を 20 30\%とした場合の最適情報量基準を满たさず，また信頼区間が効果なし（RR=1）を含み，かつ重要な利益（RR=0.80）と重要な害（RR=1.20）の双方を含む。

による望ましい効果は大きいと判断した。

望ましくない効果 :

採用した重大アウトカムの中で，アンチトロンビン 製剂投与によって予期される有害な効果は，出血性合 併症アウトカムの増加である。3つの RCT から得ら れた出血性合併症アウトカムの効果推定值とその信頼 区間は，1,000人あたり 9 人多い（24 人少ない〜94人 多い）であり，アンチトロンビン製剤投与による望ま しくない効果はわずかであると判断した。

益と害のバランス :

死亡と出血性合併症の効果推定值は，1,000 人あた り死亡 134 人減少に対して出血性合併症 9 人増加であ り，相対的価值を無視しても 125 名の正味の利益が得 られる。また望ましい効果（死亡の減少）の相対的価 值は, 望ましくない効果（出血の増加）に比べて一般 的に高く，これを考慮しても利益が害を上回っている 可能性が高い。

（5）アウトカム全般に関するエビデンスの確実性 本 CQ で採用した 2 つの重大なアウトカムの効果推 定值の方向性は相反しているため，その中で一番低い アウトカムの確実性を全体としては採用した。した がって，アウトカム全体にわたるエビデンスの確実性 は「低」である。

\section{（6）価值観}

敗血症患者に対するアンチトロンビン製剤投与にお いて，採用された 2 つ重大なアウトカム（死亡と出 血性合併症）の，患者・家族から見た価值観（相対的 重要性）に関しては質の高いエビデンスはない。一般 的に, 出血アウトカムに対して死亡アウトカムの相対 的重要性は高く，そのばらつきは少ないことが予想さ
れる。

\section{（7）容認性}

アンチトロンビン製剤投与に伴う医療者の仕事量の 増加はわずかである。アンチトロンビン製剂投与に伴 うコストは約 181,200 円（製剂 1,500 単位の平均的な 薬価約 60,400 円を 3 日間投与の場合）である。その 薬価は高価ではあるが，利益と害のバランスを患者・ 家族の個人の視点から考えると，おそらく許容できる だろう。

\section{（8）実行可能性}

アンチトロンビン製剤の投与は本邦の多くの医療機 関において実行可能であり，その実行可能性はおそら く高い。

(9) 判断の要約（Table 15-3-2）

（10）推奨グレーディング決定の工程

修正 RAND 法を用いた投票によって，中央値 8, 見解不一致指数 0.164 の結果となり，委員会で採択さ れた（7 点以上 : $87.5 \%) 。$

\section{（11）関連する他の診療ガイドラインにおける推奨}

SSCG 2016 では「弱い非推奨」である。本邦の「科 学的根拠に基づいた感染症に伴う DIC 治療のエキス パートコンセンサス」7）では推奨度 B1 で投与を推奨 されている。日本版敗血症診療ガイドライン (J-SSCG) 2016 では投与することを弱く推奨していた。

\section{（12）実施に関わる検討事項}

敗血症患者における出血性合併症の頻度とそれによ 
Table 15-3-2 判断の要約

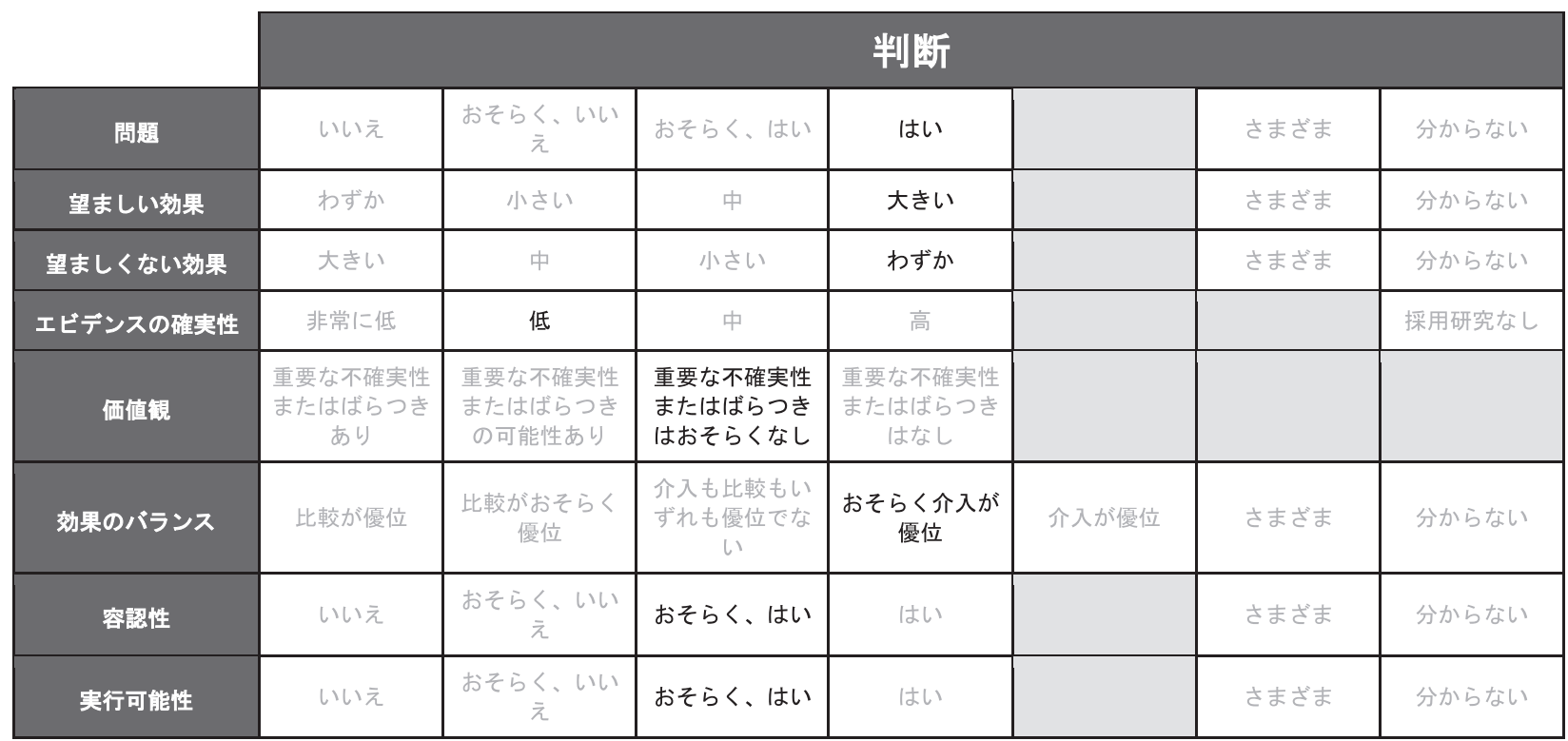

るリスクは，病態や手術治療の有無によって大きく異 なる。特に出血リスクの高いと判断される症例に対す る使用方法は注意を要する。

\section{（13）今後の研究の可能性}

以下の内容に関する検討が求められるだろう。

・本邦で認可された投与量 $(30$ 単位 $/ \mathrm{kg} /$ 日 $\times 3$ 日間)

\section{による有効性の検証}

・より有効性が期待できる患者群を明らかにするこ と

・出血性合併症のベースラインリスクに応じた利益 と害のバランスの検証

\section{文 献}

1) Levi M, Schouten M, van der Poll T: Sepsis, coagulation, and antithrombin: old lessons and new insights. Semin Thromb Hemost. 2008; 34: 742-6.

2) Fourrier F, Chopin C, Huart JJ, et al: Double-blind, placebocontrolled trial of antithrombin III concentrates in septic shock with disseminated intravascular coagulation. Chest. 1993; 104: 882-8.

3) Inthorn D, Hoffmann JN, Hartl WH, et al: Antithrombin III supplementation in severe sepsis: beneficial effects on organ dysfunction. Shock. 1997; 8: 328-34.

4) Baudo F, Caimi TM, de Cataldo F, et al: Antithrombin III (AT III) replacement therapy in patients with sepsis and/or postsurgical complications: a controlled double-blind, randomized, multicenter study. Intensive Care Med. 1998; 24: 336-42.

5) Kienast J, Juers M, Wiedermann CJ, et al: Treatment effects of high-dose antithrombin without concomitant heparin in patients with severe sepsis with or without disseminated intravascular coagulation. J Thromb Haemost. 2006; 4: 90-7.

6) Gando S, Saitoh D, Ishikura H, et al: A randomized, controlled, multicenter trial of the effects of antithrombin on disseminated intravascular coagulation in patients with sepsis. Crit Care. 2013;
17: R297.

7）日本血栓止血学会学術標準化委員会 DIC 部会: 科学的根拠 に基づいた感染症に伴う DIC 治療のエキスパートコンセン サス. 日血栓止血会誌. 2009; 20: 77-113. 


\section{CQ15-4：敗血症性 DIC にヘパリン・ヘパリン類 の投与を行うか?}

Answer : 敗血症性 DIC 患者に対して，ヘパリン・ヘ パリン類投与を標準治療として行わないことを弱く推 奨する（GRADE 2D : エビデンスの確実性 =「非常に 低」)。

\section{（1）背景および本 $C Q$ の重要度}

敗血症性 DIC 患者は, 過度の凝固活性化が微小循 環障害をもたらし，これが臟器不全を招くという理解 から，敗血症性 DIC 患者に対して抗凝固療法の投与 が評価されてきた。近年のメタ解析では, 敗血症全般 では抗凝固療法の効果は期待できず，その有効性は敗 血症性 DIC に限られることが報告されている ${ }^{1) 。 へ ~}$ パリンは本邦で最も古くから敗血症性 DIC の治療目 的に使用されてきた薬剤の 1 つであるが，現在のとこ ろ臨床転帰の改善効果に関しては評価が定まっていな い。

本邦における実臨床に即し，敗血症性 DIC に対す るヘパリン・ヘパリン類投与の評価を改めて行うこと を目的に設定した本 $\mathrm{CQ}$ は，重要度の高いものと考え られる。

\section{(2) PICO}

P (患者)：成人の敗血症性 DIC 患者

I（介入）：ヘパリン・ヘパリン類投与.
$\mathrm{C}$ (対照)：プラセボ投与あるいはヘパリン・ヘパリ ン類非投与

$\mathrm{O}$ (アウトカム)：全原因死亡, 出血性合併症, DIC 離脱

(3) エビデンスの要約

システマティックレビューの結果，PICO に合致し たランダム化比較試験（RCT）が 2 件 2,3) 施行されて おり，これらを用いたメタ解析を実施した。

（4）益と害のバランス（Table 15-4-1）

本 CQ で推奨作成のために最終的に採用した重大な アウトカムは「全原因死亡」と「出血性合併症」の 2 件であった。

望ましい効果 :

ヘパリン・ヘパリン類投与によって予期される望ま しい効果は，死亡アウトカムの減少である。2つの RCT から得られた死亡アウトカムの効果推定值とそ の信頼区間は，1,000 人あたり 58 人少ない（99人少 ない〜27 人多い）であり，信頼区間の上限と下限で 大きく効果の方向性が異なる。したがって，ヘパリ ン・ヘパリン類投与による望ましい効果はわずかと判 断した。

望ましくない効果 :

ヘパリン・ヘパリン類投与によって予期される望ま

しくない効果は, 出血性合併症アウトカムの増加であ る。1 つの RCT から得られた出血性合併症アウトカ

Table 15-4-1エビデンスプロファイル

\begin{tabular}{|c|c|c|c|c|c|c|c|c|c|c|c|c|}
\hline \multicolumn{7}{|c|}{ 確央性の評価 } & \multicolumn{2}{|c|}{ 患者数 } & \multicolumn{2}{|c|}{ 奻果 } & \multirow{2}{*}{ 碓奏性 } & \multirow{2}{*}{ 重要性 } \\
\hline 研究数 & $\begin{array}{c}\text { 研究 } \\
\text { デザイン }\end{array}$ & $\begin{array}{l}\text { バイアス } \\
\text { のリスク }\end{array}$ & 非一貫性 & 非直接性 & 不精磼性 & $\begin{array}{l}\text { その他 } \\
\text { の检討 }\end{array}$ & Heparin群 & Placebo群 & $\begin{array}{l}\text { 相対指瞟 } \\
(95 \% \mathrm{Cl})\end{array}$ & $\begin{array}{l}\text { 絶対指標 } \\
(95 \% \text { Cl) }\end{array}$ & & \\
\hline
\end{tabular}

全原因死亡

\begin{tabular}{|c|c|c|c|c|c|c|c|c|c|c|c|c|}
\hline 2 & RCT & 深刻 a & 深刻でない & 深刻でない & 非常に深刻 b & なし & $12 / 127(9.4 \%)$ & $\begin{array}{l}18 / 134 \\
(13.4 \%)\end{array}$ & $\begin{array}{c}\text { RR } 0.57 \\
\text { (0.26 to } 1.20)\end{array}$ & $\begin{array}{l}1,000 \text { 人あたり } 58 \\
\text { 人少ない (99 人少 } \\
\text { ない〜27 人多い) }\end{array}$ & $\begin{array}{l}\oplus \bigcirc 0 \bigcirc \\
\text { 非常に低 }\end{array}$ & 重大 \\
\hline
\end{tabular}

出血性合併症

\begin{tabular}{|c|c|c|c|c|c|c|c|c|c|c|c|c|}
\hline 1 & RCT & 深刻 a & 深刻でない & 深刻でない & 非常に深刻 b & 深刻 a & $\begin{array}{l}5 / 105 \\
(4.8 \%)\end{array}$ & $\begin{array}{l}12 / 119 \\
(10.1 \%)\end{array}$ & $\begin{array}{c}\text { RR } 0.48 \\
\text { (0.16 to } 1.27 \text { ) }\end{array}$ & $\begin{array}{l}1,000 \text { 人あたり } 52 \\
\text { 人少ない }(85 \text { 人少 } \\
\text { ない〜 } 27 \text { 人多い) }\end{array}$ & $\begin{array}{l}\oplus \bigcirc 0 \bigcirc \\
\text { 非常に低 }\end{array}$ & 重大 \\
\hline
\end{tabular}

DIC 離脱 $\mathrm{d}$

\begin{tabular}{|c|c|c|c|c|c|c|c|c|c|c|c|c|}
\hline 1 & RCT & 深刻 a & 深刻でない & 深刻でない & 深刻 c & なし & $\begin{array}{l}20 / 22 \\
(91 \%)\end{array}$ & $\begin{array}{l}6 / 15 \\
(40 \%)\end{array}$ & $\begin{array}{c}\text { RR } 0.11 \\
\text { (0.02 to } 0.53 \text { ) }\end{array}$ & $\begin{array}{l}1,000 \text { 人あたり } \\
356 \text { 人少ない } \\
(392 \text { 人少ない } \\
188 \text { 人少ない) }\end{array}$ & $\begin{array}{c}\oplus \oplus \bigcirc \bigcirc \\
\text { 低 }\end{array}$ & 重要 \\
\hline
\end{tabular}

a. 採用研究の多くにおいて盲検化またはアウトカム報告に関する記載が不十分である。

b. 相対リスク減少を $20 \sim 30 \%$ とした場合の最適情報量（OIS）基準を満たさず，信頼区間が勃果なし（RR=1）を含み，かつ重要な利益（RR=0.80）と重要な害（RR=1.20）の双方を含む。

c. 相対リスク減少を 20〜30\%とした場合の最適情報量（OIS）基準を満たさないが，信頼区間が効果なし（RR=1）を含まない。

d. pre-DIC からの DIC 発症 
ムの効果推定值とその信頼区間は，1,000人あたり 52 人の出血性合併症減少（ 85 人少ない〜 27 人多い）で あり，信頼区間の上限と下限で大きく効果の方向性が 異なる。したがって, ヘパリン・ヘパリン類投与によ る望ましくない効果もまたわずかと判断した。

益と害のバランス :

死亡と出血性合併症の効果推定值は，1,000 人あた り死亡 58 人の減少に対して出血性合併症は 52 人の減 少で, 相対的価值を無視しても 110 名の正味の利益が 得られる。しかし，いずれのアウトカムに関しても不 確実性が非常に強く，信頼区間の上限と下限で大きく 効果の方向性が異なる。したがって，望ましい効果と 望ましくない効果のバランスに関して, 介入と比較対 照のいずれも優位とはいえない。

（5）アウトカム全般に関するエビデンスの確実性

本 $\mathrm{CQ}$ で採用した 2 つの重大なアウトカムの効果推 定值の方向性は一致していたため，その中で一番高い アウトカムの確実性を全体としては採用した。した がって，アウトカム全体にわたるエビデンスの確実性 は「非常に低」である。

\section{（6）価値観}

敗血症患者に対するヘパリン・ヘパリン類投与にお いて, 採用された 2 つ重大なアウトカム（死亡と出 血性合併症）に関する患者・家族から見た価值観（相 対的重要性）を評価した質の高いエビデンスはない。 一般的に, 出血アウトカムに対して死亡アウトカムの 相対的重要性は高く, そのばらつきは少ないことが予
想される。

（7）容認性

ヘパリン・ヘパリン類投与に伴う医療者の仕事量の 増加はわずかである。ヘパリン・ヘパリン類投与に伴 うコストは約 1,600 円（製剤 10,000 単位の平均的な薬 価約 320 円を 5 日間投与の場合）である。その個人負 担額は安価であり，おそらく許容できるだろう。

\section{（8）実行可能性}

介入は多くの医療施設において実行可能である。

（9）判断の要約（Table 15-4-2）

\section{（10）推奨グレーディング決定の工程}

修正 RAND 法を用いた投票によって，中央值 8, 見解不一致指数 0.164 の結果となり, 委員会で採択さ れた（7 点以上 : $83.3 \%) 。$

\section{（11）関連する他の診療ガイドラインにおける推奨}

SSCG 2016 では，敗血症性 DIC に対するへパリン・ ヘパリン類の使用についての記載はない。一方，日本 版敗血症診療ガイドライン（J-SSCG）2016では, DIC 担当班から「敗血症性 DIC に対するへパリン投与に ついては，効果や有害性を裏づけるエビデンスにそし く, 現時点での評価は不能である (unknown)」とい う意見文が提案され，委員 19 名中の 16 名の同意によ り可決された。ガイドライン作成委員会で行動につな がる意見文の変更が促され，「敗血症性 DICに対して，

Table 15-4-2 判断の要約

\begin{tabular}{|c|c|c|c|c|c|c|c|}
\hline & \multicolumn{7}{|c|}{ 判溇 } \\
\hline 問題 & いいえ & $\begin{array}{c}\text { おそらく、いい } \\
\text { え }\end{array}$ & おそらく、はい & はい & & さまざま & 分からない \\
\hline 望ましい効果 & わずか & 小さい & 中 & 大きい & & さまざま & 分からない \\
\hline 望ましくない効果 & 大きい & 中 & 小さい & わずか & & さまざま & 分からない \\
\hline エビデンスの確実性 & 非常に低 & 低 & 中 & 高 & & & 採用研究なし \\
\hline 価值钫 & $\begin{array}{c}\text { 重要な不確実性 } \\
\text { またはばらつき } \\
\text { あり }\end{array}$ & $\begin{array}{c}\text { 重要な不確実性 } \\
\text { またはばらつき } \\
\text { の可能性あり }\end{array}$ & $\begin{array}{l}\text { 重要な不確実性 } \\
\text { またはばらつき } \\
\text { はおそらくなし }\end{array}$ & $\begin{array}{c}\text { 重要な不確実性 } \\
\text { またはばらつき } \\
\text { はなし }\end{array}$ & & & \\
\hline 効果のバランス & 比較が優位 & $\begin{array}{c}\text { 比較がおそらく } \\
\text { 優位 }\end{array}$ & $\begin{array}{c}\text { 介入も比較もい } \\
\text { ずれも優位でな } \\
\text { い }\end{array}$ & $\begin{array}{c}\text { おそらく介入が } \\
\text { 優位 }\end{array}$ & 介入が優位 & さまざま & 分からない \\
\hline 容認性 & いいえ & $\begin{array}{c}\text { おそらく、いい } \\
\text { え }\end{array}$ & おそらく、はい & はい & & さまざま & 分からない \\
\hline 実行可能性 & いいえ & $\begin{array}{c}\text { おそらく、いい } \\
\text { え }\end{array}$ & おそらく、はい & はい & & さまざま & 分からない \\
\hline
\end{tabular}


ヘパリン・ヘパリン類を標準治療としては投与しない ことを弱く推奨する（エキスパートコンセンサス）」 が選択された。

\section{（12）実施に関わる検討事項}

標準的治療としてヘパリン・ヘパリン類投与を行う ことは好ましくないが, 症例に応じた適応判断を否定 するものではない。

\section{（13）今後の研究の可能性}

敗血症性 DIC 患者に対するヘパリン・ヘパリン類 投与の有用性を評価した RCT が 2 つのであること が明らかとなった。敗血症性 DIC 患者に対するへパ リン・ヘパリン類投与の有効性や有害事象を検証する さらなる RCT の実施が望まれる。また，アンチトロ ンビンやリコンビナント・トロンボモジュリンとの併 用による有効性, 有害事象の検証も望まれる。

\section{文 献}

1) Umemura $Y$, Yamakawa $K$, Ogura $H$, et al: Efficacy and safety of anticoagulant therapy in three specific populations with sepsis: a meta-analysis of randomized controlled trials. J Thromb Haemost. 2016; 14: 518-30.

2) Liu XL, Wang $X Z$, Liu $X X$, et al: Low-dose heparin as treatment for early disseminated intravascular coagulation during sepsis: A prospective clinical study. Exp Ther Med. 2014; 7: 604-8.

3) Yang $C$, Chen $X$, Zheng D, et al: Impacts of early anticoagulant therapy on tissue perfusion in patients with sepsis. Int J Clin Exp Med. 2016; 9: 20074-9.
CQ15-5 : 敗血症性 DIC にリコンビナント ・トロ ンボモジュリン投与を行うか?

Answer : 敗血症性 DIC 患者に対して，リコンビナン ト・トロンボモジュリン製剤を投与することを弱く推 奨する（GRADE 2C：エビデンスの確実性 $=「$ 低」）。

\section{（1）背景および本 $C Q$ の重要度}

すべての生体侵襲は DIC を引き起こしうるが，特 に敗血症に起因する DIC は，その頻度と重症度の高 さから最重要臨床課題と考えられる。リコンビナン ト・トロンボモジュリンは, 主にトロンビンに結合し て，プロテイン C の活性化を促進することで抗凝固 作用を有するだけでなく，そのレクチン様ドメインを

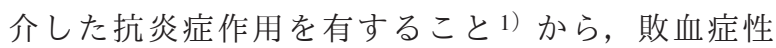
DIC の病態を制御できる可能性が期待され，2008 年 の上市以降，本邦の臨床現場でも幅広く使われてい る。

しかし，これまでの研究ではリコンビナント・トロ ンボモジュリンが敗血症性 DIC の予後に与える影響 に関して相反する結果が公表されており, 明確なエビ デンスが確立されていない。2019年に最新の多国籍 間第 3 相試験（SCARLET 試験）が終了し結果が公表 されたことを踏まえ ${ }^{2)}$, 敗血症性 DICに対してリコ ンビナント・トロンボモジュリン製剤投与を行うかは 本邦の敗血症診療における重要な課題であり, 本ガイ ドラインの臨床疑問の 1 つとして取り上げた。

(2) $\mathrm{PICO}$

P (患者) : 成人の敗血症性 DIC 患者

I（介入）：リコンビナント・トロンボモジュリン製 剂投与

$\mathrm{C}$ (対照)：プラセボ投与あるいはリコンビナント・ トロンボモジュリン非投与

$\mathrm{O}$ (アウトカム) : 死亡, 出血性合併症, DIC 離脱

（3）エビデンスの要約

システマティックレビューの結果, PICO に合致し たランダム化比較試験（RCT）が 3 件 2-4）施行されて おり，これらを用いたメタ解析を実施した。

\section{（4）益と害のバランス（Table 15-5-1）}

本 CQ で推奨作成のために最終的に採用した重大な アウトカムは「死亡」と「出血性合併症」の 2 件で あった。 
Table 15-5-1 エビデンスプロファイル

\begin{tabular}{|c|c|c|c|c|c|c|c|c|c|c|c|c|}
\hline \multicolumn{7}{|c|}{ 確実性の評価 } & \multicolumn{2}{|c|}{ 患者数 } & \multicolumn{2}{|c|}{ 効果 } & \multirow[b]{2}{*}{ 確実性 } & \multirow[b]{2}{*}{ 重要性 } \\
\hline 研究数 & $\begin{array}{c}\text { 研究 } \\
\text { デザイン }\end{array}$ & $\begin{array}{l}\text { バイアス } \\
\text { のリスク }\end{array}$ & 非一貫性 & 非直接性 & 不精確性 & $\begin{array}{l}\text { その他 } \\
\text { の検討 }\end{array}$ & TM 製剂 & Placebo & $\begin{array}{l}\text { 相対指標 } \\
(95 \% \text { CI })\end{array}$ & $\begin{array}{l}\text { 絶対指標 } \\
(95 \% \mathrm{CI})\end{array}$ & & \\
\hline \multicolumn{13}{|l|}{ 死亡 } \\
\hline 3 & RCT & 深刻でない & 深刻でない & 深刻でない & 深刻 a & なし & $\begin{array}{l}156 / 725 \\
(21.5 \%)\end{array}$ & $\begin{array}{l}192 / 742 \\
(25.9 \%)\end{array}$ & $\begin{array}{c}\text { RR } 0.84 \\
(0.70 \text { to } 1.01)\end{array}$ & $\begin{array}{l}1,000 \text { 人あたり } 41 \\
\text { 人少ない (78 人少 } \\
\text { ない 3 人多い) }\end{array}$ & $\begin{array}{c}\oplus \oplus \oplus \bigcirc \\
\text { 中 }\end{array}$ & 重大 \\
\hline \multicolumn{13}{|c|}{ 出血性合併症 } \\
\hline 3 & RCT & 深刻 ${ }^{b}$ & 深刻でない & 深刻でない & 深刻” & なし & $44 / 813 \quad(5.4 \%)$ & $34 / 820 \quad(4.1 \%)$ & $\begin{array}{c}\text { RR } 1.30 \\
(0.84 \text { to } 2.02)\end{array}$ & $\begin{array}{l}1,000 \text { 人あたり } 12 \\
\text { 人多い(7人少な } \\
\text { い 42 人多い) }\end{array}$ & $\underset{\text { 低 }}{\oplus \oplus \bigcirc \bigcirc}$ & 重大 \\
\hline \multicolumn{13}{|l|}{ DIC 離脱 } \\
\hline 2 & RCT & 深刻 b & 深刻でない & 深刻でない & 深刻 d & なし & $40 / 92(43.5 \%)$ & $27 / 95 \quad(28.4 \%)$ & $\begin{array}{c}\text { RR } 1.45 \\
(0.99 \text { to } 2.11)\end{array}$ & $\begin{array}{c}1,000 \text { 人あたり } 128 \\
\text { 人 (3人少ない } \\
315 \text { 人多い) }\end{array}$ & $\underset{\text { 低 }}{\oplus \oplus \bigcirc}$ & 重要 \\
\hline
\end{tabular}

a. 相対リスク減少を 20 30\%とした場合の最適情報量基準を満たさないが，信頼区間が効果なし（RR=1）を含み，かつ重要な利益（RR=0.80）を含む。 b. 採用研究の多くにおいて盲検化またはアウトカム報告に関する記載が不十分である。

c. 相対リスク減少を20〜30\%とした場合の最適情報量基隻を満たさず，信頼区間が効果なし（RR=1）を含み，かつ重要な害（RR=1.20）を含む。

望ましい効果 :

リコンビナント・トロンボモジュリン製剤投与に よって予期される有益な効果は, 死亡アウトカムの減 少である。採用試験の 1 つ(SCARLET 試験：2019 年) では，薬剤投与時に DIC 基準を満たしたサブグルー プの結果を採用した。3つの RCT から得られた死亡 アウトカムの効果推定値とその信頼区間は，1,000人 あたり 41 人少ない（78 人少ない〜3 人多い）であり， リコンビナント・トロンボモジュリン製剤投与による 望ましい効果は小さいと判断した。

望ましくない効果 :

採用した重大アウトカムの中で，リコンビナント． トロンボモジュリン製剂投与によって予期される有害 な効果は, 出血性合併症アウトカムの増加である。3 つの RCT から得られた出血性合併症アウトカムの効 果推定值とその信頼区間は，1,000 人あたり 12 人多い （7人少ない〜 42 人多い）であり，リコンビナント・ トロンボモジュリン製剂投与による望ましくない効果 はわずかであると判断した。

益と害のバランス :

死亡と出血性合併症の効果推定值は, 1,000 人あた り死亡 41 人減少に対して出血性合併症 12 人増加であ り, 相対的価值を無視しても29名の正味の利益が得 られる。また望ましい効果（死亡の減少）の相対的価 值は, 望ましくない効果（出血の増加）に比べて一般 的に高く，これを考慮しても利益が害を上回っている 可能性が高い。

（5）アウトカム全般に関するエビデンスの確実性

本 CQ で採用した 2 つの重大なアウトカムの効果推 定值の方向性は相反しているため，その中で一番低い
アウトカムの確実性を全体としては採用した。した がって，アウトカム全体にわたるエビデンスの確実性 は「低」である。

\section{（6）価值観}

敗血症患者に対するリコンビナント・トロンボモ

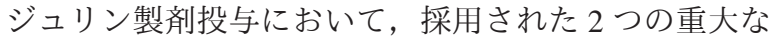
アウトカム（死亡と出血性合併症）に対する患者・家 族から見た価值観（相対的重要性）に関して質の高い エビデンスはない。一般的に, 出血アウトカムに対し て死亡アウトカムの相対的重要性は高く，そのばらつ きは少ないことが予想される。

\section{（7）容認性}

リコンビナント・トロンボモジュリン製剂投与に伴 う医療者の仕事量の増加はわずかである。リコンビナ ント・トロンボモジュリン製剤投与に伴うコストは約 236,400 円（製剂 12,800 単位の薬価約 39,400 円を 6 日 間投与の場合）である。その薬価は高価ではあるが費 用対効果に関しては現時点で質の高い研究は報告され ていない。しかし，死亡を回避するという患者・家族 が最も重視する利益と，費用，害のバランスを考える と，おそらく許容できるだろう。

\section{（8）実行可能性}

リコンビナント・トロンボモジュリン製剤の投与 は，本邦の多くの医療機関において実行可能である。

(9) 判断の要約 (Table 15-5-2) 
Table 15-5-2 判断の要約

\begin{tabular}{|c|c|c|c|c|c|c|c|}
\hline & \multicolumn{7}{|c|}{ 半判湆 } \\
\hline 問題 & いいえ & $\begin{array}{c}\text { おそらく、いい } \\
\text { え }\end{array}$ & おそらく、はい & はい & & さまざま & 分からない \\
\hline 望ましい効果 & わずか & 小さい & 中 & 大きい & & さまざま & 分からない \\
\hline 望ましくない効果 & 大きい & 中 & 小さい & わずか & & さまざま & 分からない \\
\hline エビデンスの確実性 & 非常に低 & 低 & 中 & 高 & & & 採用研究なし \\
\hline 価值钼 & $\begin{array}{c}\text { 重要な不確実性 } \\
\text { またはばらつき } \\
\text { あり }\end{array}$ & $\begin{array}{l}\text { 重要な不確実性 } \\
\text { またはばらつき } \\
\text { の可能性あり }\end{array}$ & $\begin{array}{l}\text { 重要な不確実性 } \\
\text { またはばらつき } \\
\text { はおそらくなし }\end{array}$ & $\begin{array}{c}\text { 重要な不確実性 } \\
\text { またはばらつき } \\
\text { はなし }\end{array}$ & & & \\
\hline 効果のパランス & 比較が優位 & $\begin{array}{c}\text { 比較がおそらく } \\
\text { 優位 }\end{array}$ & $\begin{array}{c}\text { 介入も比較もい } \\
\text { ずれも優位でな } \\
\text { い }\end{array}$ & $\begin{array}{c}\text { おそらく介入が } \\
\text { 優位 }\end{array}$ & 介入が優位 & さまざま & 分からない \\
\hline 容認性 & いいえ & $\begin{array}{c}\text { おそらく、いい } \\
\text { え }\end{array}$ & おそらく、はい & はい & & さまざま & 分からない \\
\hline 実行可能性 & いいえ & $\begin{array}{c}お そ ら く 、 い い ~ \\
\text { え }\end{array}$ & おそらく、はい & はい & & さまざま & 分からない \\
\hline
\end{tabular}

（10）推奨グレーディング決定の工程

修正 RAND 法を用いた投票によって，中央值 7, 見解不一致指数 0.164 の結果となり，委員会で採択さ れた（7 点以上：75\%）。

\section{（11）関連する他の診療ガイドラインにおける推奨}

本邦の「科学的根拠に基づいた感染症に伴う DIC 治療のエキスパートコンセンサス」5）では推奨度 B1 で投与を推奨されている。また SSCG 2016，日本版敗 血症診療ガイドライン（J-SSCG）2016においては, 2016 年の時点で SCARLET 試験が進行中であったこ とから，共に推奨を保留していた。

\section{（12）実施に関わる検討事項}

敗血症患者における出血性合併症の頻度とそれによ るリスクは病態や手術など侵襲的治療の有無によって 大きく異なる。特に出血リスクの高いと判断される症 例に対する使用方法は注意を要する。

\section{（13）今後の研究の可能性}

以下の内容に関する検討が求められるだろう。

・出血性合併症のベースラインリスクに応じた利益 と害のバランスの検証

・より有効性が期待される患者群を明らかにするこ と

・リコンビナント・トロンボモジュリンの費用対効 果の検証

\section{文 献}

1) Van de Wouwer M, Collen D, Conway EM: Thrombomodulinprotein C-EPCR system: integrated to regulate coagulation and inflammation. Arterioscler Thromb Vasc Biol. 2004; 24: 1374-83.

2) Vincent JL, Francois B, Zabolotskikh I, et al: Effect of a Recombinant Human Soluble Thrombomodulin on Mortality in Patients With Sepsis-Associated Coagulopathy: The SCARLET Randomized Clinical Trial. JAMA. 2019; 321: 1993-2002.

3) Vincent JL, Ramesh MK, Ernest D, et al: A randomized, doubleblind, placebo-controlled, Phase $2 \mathrm{~b}$ study to evaluate the safety and efficacy of recombinant human soluble thrombomodulin, ART-123, in patients with sepsis and suspected disseminated intravascular coagulation. Crit Care Med. 2013; 41: 2069-79.

4) Hagiwara A, Tanaka N, Uemura T, et al: Can recombinant human thrombomodulin increase survival among patients with severe septic-induced disseminated intravascular coagulation: a singlecentre, open-label, randomised controlled trial. BMJ Open. 2016; 6: $\mathrm{e} 012850$

5）日本血栓止血学会学術標準化委員会 DIC 部会: 科学的根拠 に基づいた感染症に伴う DIC 治療のエキスパートコンセン サス. 日血栓止血会誌. 2009; 20: 77-113. 
CQ15-6 : 敗血症性 DIC にタンパク分解酵素阻害 薬の投与を行うか?

Answer：敗血症性 DIC 患者に対して，タンパク分解 酵素阻害薬投与を標準治療としては行わないことを弱 く推奨する（GRADE 2D：エビデンスの確実性 =「非 常に低」)。

\section{（1）背景および本 $C Q$ の重要度}

すべての生体侵襲は DIC を引き起こしうるが，特 に敗血症に起因するDIC は, その頻度と重症度の高 さから最重要臨床課題と考えられる。タンパク分解醏 素阻害薬は, DIC における過剩な凝固活性のみならず 線溶活性化を抑制するため, 他の抗凝固薬と比較して 出血性合併症のリスクが少ないとされる。本邦の臨床 現場では，敗血症を含む様々な基礎疾患に起因する DIC に対して長きにわたって使用されており，現在で も抗凝固療法の選択肢の重要な一角を担っているが, 現在のところ臨床転帰の改善効果に関しては評価が定 まっていない。このような背景から，敗血症性 DIC に対してタンパク分解酵素阻害薬の投与を行うかは本 邦の敗血症診療において重要であり, 本ガイドライン の臨床疑問の 1 つとして取り上げた。

\section{(2) PICO}

P (患者)：成人の敗血症性 DIC 患者

I（介入）：タンパク分解酵素阻害薬投与

$\mathrm{C}$ (対照)：プラセボ投与あるいはタンパク分解䤉素 阻害薬非投与

$\mathrm{O}$ (アウトカム) : 死亡, 出血性合併症, DIC 離脱

（3）エビデンスの要約

システマティックレビューの結果, PICO に合致し たランダム化比較試験（RCT）が 2 件 1, 2) 施行されて
おり，これらを用いたメタ解析を実施した。

（4）益と害のバランス（Table 15-6-1）

本 $\mathrm{CQ}$ で推奨作成のために最終的に採用した重大な アウトカムは「死亡」と「出血性合併症」の 2 件で あった。

望ましい効果 :

タンパク分解酵素阻害薬投与によって予期される有 益な効果は，死亡アウトカムの減少である。2つの RCT から得られた死亡アウトカムの効果推定值とそ の信頼区間は，1,000 人あたり 39 人少ない（181 人少 ない〜217 人多い）であり，信頼区間の上限と下限で 大きく効果の方向性が異なる。したがって，タンパク 分解䤉素阻害薬による望ましい効果はわずかであると 判断した。

望ましくない効果 :

採用した重大アウトカムの中で，タンパク分解醭素 阻害薬投与によって予期される有害な効果は, 出血性 合併症アウトカムの増加である。1 つの RCT から得 られた出血性合併症アウトカムの効果推定値とその信 頼区間は， 1,000 人あたり 161 人少ない $(223$ 人少な い〜120人多い）であり，信頼区間の上限と下限で大 きく効果の方向性が異なる。したがって，タンパク分 解酵素阻害薬投与による望ましくない効果もまたわず かであると判断した。

益と害のバランス :

死亡と出血性合併症の効果推定值は，1,000 人あた り死亡 39 人の減少に対して出血性合併症は 161 人の 減少で, 相対的価値を無視しても 200 名の正味の利益 が得られる。しかし，いずれのアウトカムに関しても 研究数や症例数が少ないため不確実性が非常に強く, 信頼区間の上限と下限で大きく効果の方向性が異な る。したがって，望ましい効果と望ましくない効果の バランスに関して，介入と比較対照のいずれも優位と

Table 15-6-1エビデンスプロファイル

\begin{tabular}{|c|c|c|c|c|c|c|c|c|c|c|c|c|}
\hline \multicolumn{7}{|c|}{ 確夷性の䛨価 } & \multicolumn{2}{|c|}{ 患者数 } & \multicolumn{2}{|c|}{ 勃果 } & \multirow[b]{2}{*}{ 碓実性 } & \multirow[b]{2}{*}{ 重要性 } \\
\hline 研究数 & $\begin{array}{l}\text { 研究 } \\
\text { テザイン }\end{array}$ & $\begin{array}{l}\text { パイアス } \\
\text { のリスク }\end{array}$ & 非一貫性 & 非直接性 & 不精確性 & $\begin{array}{l}\text { その他 } \\
\text { の㛟討 }\end{array}$ & $\begin{array}{l}\text { Protease } \\
\text { Inhibitors }\end{array}$ & Placebo & $\begin{array}{l}\text { 相対指標 } \\
(95 \% \text { cI) }\end{array}$ & $\begin{array}{l}\text { 䋫対指標 } \\
(95 \% \text { CI) }\end{array}$ & & \\
\hline \multicolumn{13}{|l|}{ 死亡 } \\
\hline 2 & RCT & 深刻 a & 深刻でない & 深刻てない & 非常に深刻 b & なし & $14 / 45(31.18)$ & $16 / 45(35.6 \%)$ & $\begin{array}{c}\text { RR } 0.89 \\
\text { (0. } 49 \text { to } 1.61)\end{array}$ & $\begin{array}{c}1,000 \text { 人あたり } 39 \\
\text { 人少ない (181 } \\
\text { 少ないて217人多 } \\
\text { (1) }\end{array}$ & $\begin{array}{l}\oplus \circ 0 \bigcirc \\
\text { 非常に低 }\end{array}$ & 重大 \\
\hline \multicolumn{13}{|c|}{ 出血性合併症 } \\
\hline 1 & RCT & 深刻 & 深刻でな & 深刻てない & 非常に深刻 ‘ & なし & $2 / 25 \quad(8.0 \%)$ & $6 / 25(24.0 \%)$ & $\begin{array}{c}\text { RR } 0.33 \\
(0.07 \text { to } 1.50)\end{array}$ & $\begin{array}{c}1,000 \text { 人あたり } 161 \\
\text { 人少ない (223 } \\
\text { 少ない〜120人多 } \\
\text { (1) }\end{array}$ & $\begin{array}{l}\oplus \circ 00 \\
\text { 非常に=低 }\end{array}$ & 重大 \\
\hline
\end{tabular}

a. 採用研究の多くにおいて割り付け，盲検化またはアウトカム報告に関するバイアスがある，またバイアスに関する記載が不十分である。

b. 相対リスク減少を 20 30\%とした場合の最適情報量基準を満たさず，また信頼区間が効果なし（RR=1）を含み、かつ重要な利益（RR=0.80）と重要な害（RR=1.20）の双方を含む。 
はいえない。

（5）アウトカム全般に関するエビデンスの確実性

本 $\mathrm{CQ}$ で採用した 2 つの重大なアウトカムの効果推 定值の方向性は一致していたため，その中で一番高い アウトカムの確実性を全体としては採用した。した がって，アウトカム全体にわたるエビデンスの確実性 は「非常に低」である。

\section{（6）価値観}

敗血症患者に対するタンパク分解酵素阻害薬投与に

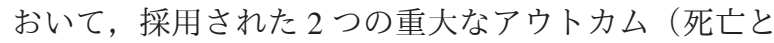
出血性合併症）の，患者・家族から見た価值観（相対 的重要性）に関しては質の高いエビデンスはない。一 般的に, 出血アウトカムに対して死亡アウトカムの相 対的重要性は高く，そのばらつきは少ないことが予想 される。

\section{（7）容認性}

タンパク分解酵素阻害薬投与に伴う医療者の仕事量 の増加はわずかである。タンパク分解酵素阻害薬投与 に伴うコストは約 16,500 円（各製剂の保険使用量に おける平均的な薬価約 3,300 円を 5 日間投与の場合） である。その薬価を考慮すると，おそらく許容できる だろう。

\section{（8）実行可能性}

タンパク分解酵素阻害薬の投与は, 本邦の多くの医 療機関において実行可能である。
（9）判断の要約（Table 15-6-2）

（10）推奨グレーディング決定の工程

修正 RAND 法を用いた投票によって, 中央值 8, 見解不一致指数 0.164 の結果となり, 委員会で採択さ れた（7 点以上 : 91.7\%）。

（11）関連する他の診療ガイドラインにおける推奨 本邦の「科学的根拠に基づいた感染症に伴う DIC 治療のエキスパートコンセンサス」3) では推奨度 B2 で投与を推奨されている。SSCG 2016 では敗血症に対 する推奨に関して記載はない。日本版敗血症診療ガイ ドライン（J-SSCG）2016においては，標準治療とし ては投与しないことを弱く推奨していた。

\section{（12）実施に関わる検討事項}

敗血症患者における出血性合併症の頻度とそれによ るリスクは，病態や手術治療の有無によって大きく異 なる。特に出血リスクの高いと判断される症例に対す る使用方法は注意を要する。

（13）今後の研究の可能性

以下の内容に関する検討が求められるだろう。 ・死亡アウトカムに関する効果のさらなる検証 ・出血アウトカムに関する効果のさらなる検証

文 献

1) Nishiyama $T$, Matsukawa $T$, Hanaoka K: Is protease inhibitor a choice for the treatment of pre- or mild disseminated intravascular coagulation? Crit Care Med. 2000; 28: 1419-22.

Table 15-6-2 判断の要約

\begin{tabular}{|c|c|c|c|c|c|c|c|}
\hline & \multicolumn{7}{|c|}{ 半粠 } \\
\hline 問題 & いいえ & $\begin{array}{c}\text { おそらく、いい } \\
\text { え }\end{array}$ & おそらく、はい & はい & & さまざま & 分からない \\
\hline 望ましい効果 & わずか & 小さい & 中 & 大きい & & さまざま & 分からない \\
\hline 望ましくない効果 & 大きい & 中 & 小さい & わずか & & さまざま & 分からない \\
\hline エビデンスの確実性 & 非常に低 & 低 & 中 & 高 & & & 採用研究なし \\
\hline 価值钼 & $\begin{array}{c}\text { 重要な不確実性 } \\
\text { またはばらつき } \\
\text { あり }\end{array}$ & $\begin{array}{c}\text { 重要な不確実性 } \\
\text { またはばらつき } \\
\text { の可能性あり }\end{array}$ & $\begin{array}{l}\text { 重要な不確実性 } \\
\text { またはばらつき } \\
\text { はおそらくなし }\end{array}$ & $\begin{array}{c}\text { 重要な不確実性 } \\
\text { またはばらつき } \\
\text { はなし }\end{array}$ & & & \\
\hline 効果のパランス & 比較が優位 & $\begin{array}{c}\text { 比較がおそらく } \\
\text { 優位 }\end{array}$ & $\begin{array}{c}\text { 介入も比較もい } \\
\text { ずれも優位でな } \\
\text { い }\end{array}$ & $\begin{array}{c}\text { おそらく介入が } \\
\text { 優位 }\end{array}$ & 介入が優位 & さまざま & 分からない \\
\hline 容認性 & いいえ & $\begin{array}{c}\text { おそらく、いい } \\
\text { え }\end{array}$ & おそらく、はい & はい & & さまざま & 分からない \\
\hline 実行可能性 & いいえ & $\begin{array}{c}\text { おそらく、いい } \\
\text { え }\end{array}$ & おそらく、はい & はい & & さまざま & 分からない \\
\hline
\end{tabular}


2) Hsu JT, Chen HM, Chiu DF, et al: Efficacy of gabexate mesilate on disseminated intravascular coagulation as a complication of infection developing after abdominal surgery. J Formos Med Assoc. 2004; 103: 678-84.

3) 日本血栓止血学会学術標準化委員会 DIC 部会: 科学的根拠 に基づいた感染症に伴う DIC 治療のエキスパートコンセン サス. 日血栓止血会誌. 2009; 20: 77-113. 


\section{CQ16 : 静脈血栓塞栓症 （venous thromboembolism: VTE）対策}

静脈血栓塞栓症（venous thromboembolism: VTE）は 深部静脈血栓症（deep vein thrombosis: DVT）と肺血 栓塞栓症（pulmonary embolism: PE）の両方を含み, 入院中の生命に関わる合併症として注意が必要な病態 である。2017 年, 本邦では医療事故調査・支援セン ター, 日本医療安全調査機構が「医療事故の再発防止 に向けた提言」としてVTEのリスク評価と予防，診 断，治療，院内体制の整備に関する提言を発表してお り, VTEの予防は医療安全の観点からも不可欠な対 策となっている1)。

本邦におけるVTE の発症率は，1996 年の調査では 人口 100 万人あたり 28 人だったが， 2011 年の調査で は人口 100 万人あたり 126 人と 15 年間で 4.6 倍に増 加している 2,3$)$ 。VTE の発症率が増加している原因と して, 生活習慣の欧米化や高齢者の増加といった要因 の他に，本疾患に対する認識やVTE 診断法の向上が 影響していると考えられている。

入院中の PEについては, 日本麻酔科学会で行われ た周術期のアンケート調査（JSA-PTE study）があり, この中で, 手術 1 万件あたりの PE 発症率は 2002 年 の 4.4 人から 2011 年には 3.0 人と減少したと報告され ている ${ }^{4)}$ 。PE 発症率が減少した要因として, 2004 年 に出された「肺血栓塞栓症および深部静脈血栓症の診 断, 治療, 予防に関するガイドライン」やそれに伴う VTE 予防管理料の診療報酬加算認定が影響しており, これ以降, 周術期患者に対するVTEのリスク評価や 予防対策が行われ，PEの発症が減少したと考えられ ている5)。

本邦におけるVTE の報告としては，成人患者 1,087 人 [女性 $58.8 \%$, 平均年齢 65.3 歳, 平均 BMI（body mass index）23.3]を対象とした観察研究がある 6)。 この中で, DVT 単独の発症は68.6\%, PE 単独は $17 \%$ ，DVT とPEの両者の合併は $14.4 \%$ だったと報告
されている。VTE 発症のリスクとしては, 担癌状態 が $27.0 \%$ と最も多く, 次いで 3 か月以内の外科手術 $17.8 \%$ ，心疾患 6.7\%, VTE の既往 $6.1 \%$ となり，重症 感染症は $2.8 \%$ と低かった。

これらの結果をもとに，本邦では「肺血栓塞栓症お よび深部静脈血栓症の診断, 治療, 予防に関するガイ ドライン (2017 年改訂版)」が出されており, VTEの 発症リスクに応じた予防法が示されている7)。このガ イドラインにおいて, 重症感染症はVTE 発症の付加 的な危険因子として, 高齢, 長期臥床, 心 ·肺疾患, 担癌状態と並ぶ中等度リスクに挙げられている。

重症感染症や敗血症患者を対象としたVTEの研究 は少なく, 日本版敗血症診療ガイドライン（J-SSCG） 2016 で採用した Kaplan らによる報告以来，まとまっ た報告はない ${ }^{8-10)}$ 。彼らの報告によると，敗血症や敗 血症性ショックで集中治療室に入院している患者 113 人の前向き調查において，全例にVTE 予防を行って いたにもかかわらず, VTEの発生率は $37.2 \%, \mathrm{PE}$ $3.5 \%$ と極めて高率であった。特に中心静脈カテーテ ルの留置（OR 4.37）と人工呼吸器管理（OR 2.35）を 必要とした患者では発症率が高かった。また，米国で 300 万人以上の担癌患者を対象とした調査研究では, 合併症が増えるに従いVTEの発症率は増加するが, 最も影響の大きい合併症は敗血症を含む感染症（敗血 症 14\%, 侵襲性カンジダ症 $16 \%$, 肺炎 $11 \%$, 静脈留 置針感染 14\%）であったと報告されている11）。

このように感染症では炎症による凝固无進状態にお いてVTEの発症リスクが増加するため, 抗凝固療法 や理学療法によるVTE予防を行うことが共通のコン センサスとなっているが，より重篤な凝固障害や播種 性血管内凝固症候群 (disseminated intravascular coagulation: DIC）を伴う敗血症における VTEの発症率につ いてはまだ研究が少なく, 効果的な予防法についても 議論が続いている。VTEの予防は医療安全の観点か らも不可欠ではあるが, 敗血症の患者においては凝固 障害の程度を鑑みた慎重な対応が必要であるため，本

敗血症(あるいは疑い)

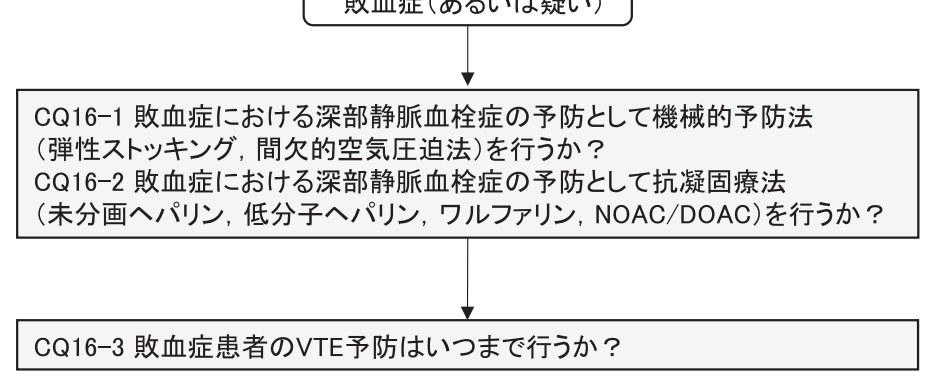

静脈血栓塞栓症 (venous thromboembolism: VTE) 対策 [診療フロー〕 
項では敗血症患者を対象としたVTE 対策の CQ を立 案した。

\section{文 献}

1）医療事故調査・支援センター, 日本医療安全調査機構: 急性 肺血栓塞栓症に係る死亡事例の分析. 日本医療安全調査機 構, 東京, 2017.

2) Kumasaka N, Sakuma M, Shirato K: Incidence of pulmonary thromboembolism in Japan. Jpn Circ J. 1999; 63: 439-41.

3) Nakamura M, Yamada N, Ito M: Current management of venous thromboembolism in Japan: Current epidemiology and advances in anticoagulant therapy. J Cardiol. 2015; 66: 451-9.

4) Kuroiwa M, Morimatsu H, Tsuzaki K, et al: Changes in the incidence, case fatality rate, and characteristics of symptomatic perioperative pulmonary thromboembolism in Japan: Results of the 2002-2011 Japanese Society of Anesthesiologists Perioperative Pulmonary Thromboembolism (JSA-PTE) Study. J Anesth. 2015; 29: 433-41.

5) 日本循環器学会, 日本心臓病学会, 日本胸部外科学会, 他: 肺 血栓塞栓症および深部静脈血栓症の診断・治療・予防に関 するガイドライン. Circ J. 2004; 68 (Suppl IV): 1079-134.

6) Nakamura M, Miyata T, Ozeki Y, et al: Current Venous Thromboembolism Management and Outcomes in Japan. Circ J. 2014; 78: 708-17.

7) 日本循環器学会, 日本医学放射線学会, 日本胸部外科学会, 他: 肺血栓塞栓症および深部静脈血栓症の診断, 治療, 予防 に関するガイドライン (2017 年改訂版). Available online at: https://j-circ.or.jp/old/guideline/pdf/JCS2017_ito_h.pdf. Accessed November 3, 2020.

8）西田修, 小倉裕司, 井上茂亮, 他, 日本版敗血症診療ガイドラ イン 2016 作成特別委員会. 日本版敗血症診療ガイドライン 2016. 日集中医誌. 2017; 24: S1-232.

9）西田修, 小倉裕司, 井上茂亮, 他, 日本版敗血症診療ガイドラ イン 2016 作成特別委員会. 日本版敗血症診療ガイドライン 2016. 日救急医会誌. 2017; 28: S1-232.

10) Kaplan D, Casper TC, Elliott CG, et al: VTE incidence and risk factors in patients with severe sepsis and septic shock. Chest. 2015; 148: 1224-30.

11) Lyman GH, Culakova E, Poniewierski MS, et al: Morbidity, mortality and costs associated with venous thromboembolism in hospitalized patients with cancer. Thromb Res. 2018; 164 Suppl 1: S112-8.
CQ16-1：敗血症における深部静脈血栓症の予防 として機械的予防法（弾性ストッキング, 間欠 的空気圧迫法）を行うか?

Answer : 敗血症患者において, 深部静脈血栓症（deep vein thrombosis: DVT) の予防として機械的予防法（弾 性ストッキング，間欠的空気圧迫法）を行うことを弱 く推奨する（エキスパートコンセンサス：エビデンス 不十分）。

\section{（1）背景および本 $C Q$ の重要度}

静脈血栓塞栓症（venous thromboembolism: VTE）は 集中治療室患者において肺血栓塞栓症（pulmonary embolism: PE）のように致死的な合併症となることが ある。また，敗血症患者におけるVTEのリスクは， その他の集中治療室患者より高いという報告があり, VTEに関連した死亡も急性感染症で高いとも報告さ れている1)。米国集中治療医学会の SSCG 2016 では 「VENOUS THROMBOEMBOLISM PROPHYLAXIS」 の項目で抗凝固療法, 機械的予防法が推奨されてお り 2), 日本版敗血症診療ガイドライン (J-SSCG) 2016 でも, リスクレベルに応じて抗凝固療法, 機械 的予防法を行うことを“エキスパートコンセンサス/

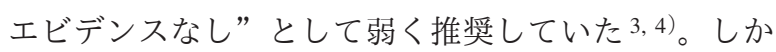
し, これらのガイドラインは, 術後患者や集中治療室 に入院した多種多様な重症患者を対象とした文献から 導かれており，敗血症患者を対象とした各予防法の有 効性，有害性についてエビデンスに基づいた見解は得 られていない。

以上より, VTE 予防に機械的予防法 (弾性ストッ キング，間欠的空気圧迫法）を行うかどうか, 敗血症 患者に限定して解析することが，本ガイドラインにお いて重要であると考える。

\section{(2) PICO}

P (患者) : 敗血症および敗血症性ショック患者

I (介入)：機械的予防法（弾性ストッキング, 間欠 的空気圧迫法）を行う

$\mathrm{C}$ (対照)：非介入

$\mathrm{O}$ (アウトカム) : DVT の発症, PE の発症

\section{（3）エビデンスの要約}

システマティックレビューを行ったが，PICO に合 致するランダム化比較試験（RCT）は存在しなかっ た。対象患者を集中治療室の重症患者としたシステマ ティックレビューや，外傷患者を対象とした RCTに 
おいては，機械的予防法の低分子ヘパリン（LMWH） に対する非劣性を示した報告がある 5,6$) 。 一$ 方で, 出 血リスクのある重症患者を対象とした RCT や, 重症 患者を対象とした抗凝固療法との併用療法での RCT においては, 間欠的空気圧迫法の有効性を認めなかっ たという報告もある ${ }^{7,8)}$ 。

（4）益と害のバランス

\section{望ましい効果 :}

敗血症患者ではVTEの発症リスクが高いことが報 告されており, PEのような致死的合併症を，機械的 予防により防ぐことができる可能性がある。したがっ て，望ましい効果は「中」であると判断した。

\section{望ましくない効果 :}

機械的圧迫による皮膚損傷や, 糖尿病, 閉塞性動脈 硬化症を持つ患者では血流障害が発生しうることを考 慮して，望ましくない効果は「小さい」と判断した。 益と害のバランス :

機械的圧迫法によるVTE 予防の益が害を上回ると 考えられる。

\section{（5）アウトカム全般に関するエビデンスの確実性}

システマティックレビューを行ったが，PICO に合 致する RCT は存在しなかった。

\section{（6）価値観}

VTEを予防することについて，患者・家族共に重 要視すると考えられるが，期待される効果以上に合併 症を恐れる患者・家族もいる可能性がある。

\section{（7）容認性}

間欠的空気圧迫法や弾性ストッキング着用にかかる 医療従事者の仕事量は，若干増加する。コストについ ては，弾性ストッキングは医療用として安価に入手可 能だが，間欠的空気圧迫のための機器を対象患者すべ てに導入することは高額となり，病院によっては困難 であることが予想される。以上から容認性は「おそら く，はい」であると判断した。

\section{（8）実行可能性}

弾性ストッキングは医療用としてどこでも安価に入 手可能であり，利用もできる。間欠的空気圧迫のため の機器は多くの病院が所有しており，いずれも使用は 簡便であるため実行可能性は高いと考えられるが，病 院によってはすべての対象患者に導入することは困難 である可能性がある。

（9）判断の要約 (Table 16-1-1)

（10）推奨グレーディング決定の工程

修正 RAND 法を用いた投票によって，中央值 7.5, 見解不一致指数 0.164 の結果となり，委員会で採択さ れた（7 点以上 : $83.3 \%) 。$

\section{（11）関連する他の診療ガイドラインにおける推奨} SSCG 2016 の「VENOUS THROMBOEMBOLISM PROPHYLAXIS」の項目では，可能であれば下腿の機 械的予防法を抗凝固療法に併用することを“weak recommendation, low quality of evidence”として推奨し

Table 16-1-1 判断の要約

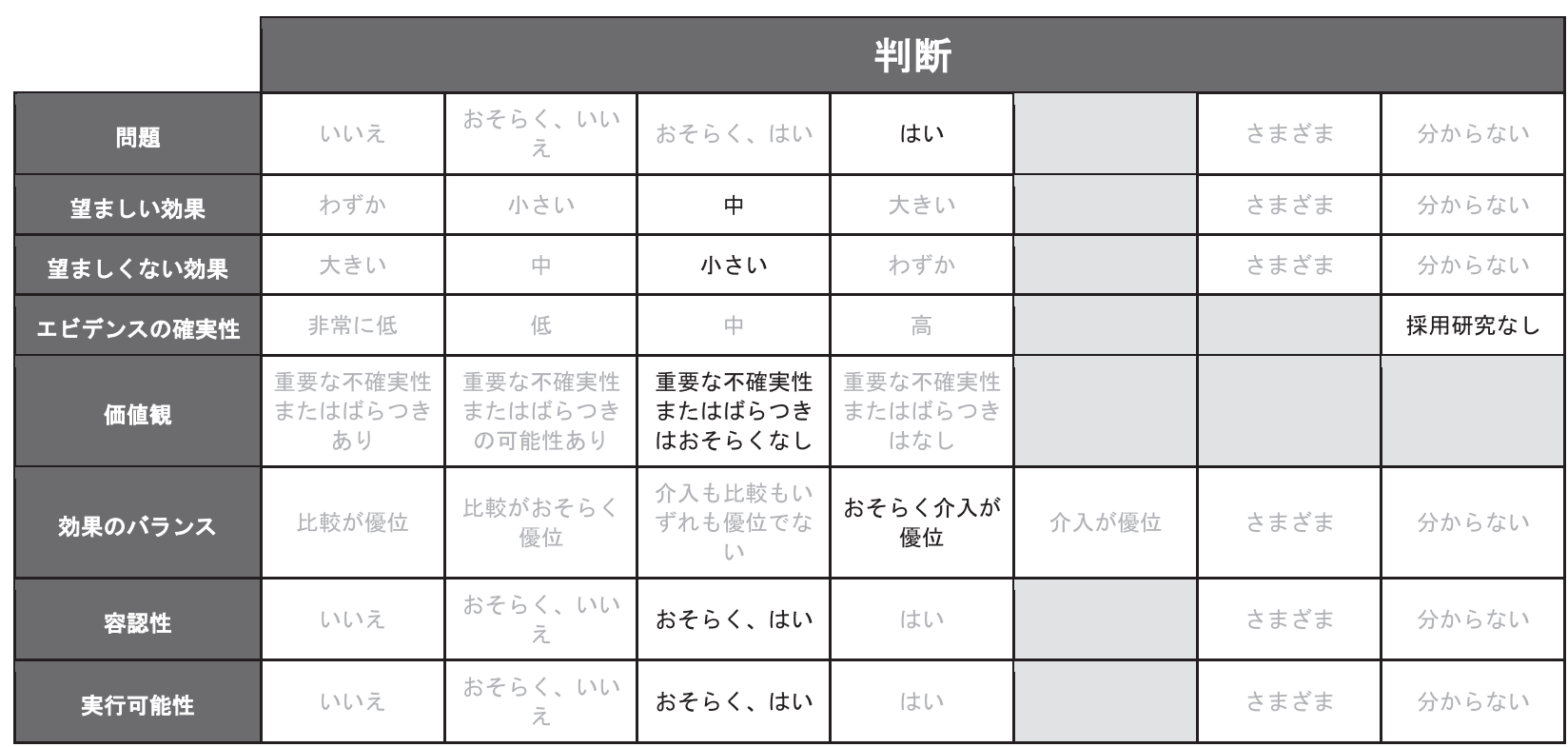


ている。また，抗凝固療法が禁忌の場合には機械的予 防法を施行することを“weak recommendation, low quality of evidence”として推奨している ${ }^{2) 。}$

本邦においては「肺血栓塞栓症および深部静脈血栓 症の診断, 治療, 予防に関するガイドライン（2017 年改訂版）」9）および「肺血栓塞栓症 / 深部静脈血栓症 (静脈血栓塞栓症）予防ガイドライン」10）の中で, DVTを発症するリスク分類とそれに応じた予防法が 述べられている。いずれも敗血症患者を対象としたエ ビデンスはなく，解釈には注意が必要である。

\section{（12）実施に関わる検討事項}

実施に際して，機械的圧迫による皮膚損傷や，糖尿 病, 閉塞性動脈硬化症を持つ患者では血流障害に注意 する必要がある。

\section{（13）今後の研究の可能性}

敗血症患者に対する機械的予防法によるVTE 予防 の RCT は存在しない。今後, 機械的予防法による VTE 予防効果，生命予後に関する RCT の早期実施が 望まれる。

\section{文 献}

1) Kaplan D, Casper C, Elliott G, et al: VTE incidence and risk factors in patients with severe sepsis and septic shock. Chest. 2015; 148: 1224-30

2) Rhodes A, Evans LE, Alhazzani W, et al: Surviving Sepsis Campaign: International Guidelines for Management of Sepsis and Septic Shock: 2016. Crit Care Med. 2017; 45: 486-552.

3）西田修, 小倉裕司, 井上茂亮, 他, 日本版敗血症診療ガイドラ イン 2016 作成特別委員会. 日本版敗血症診療ガイドライン 2016. 日集中医誌. 2017; 24: S1-232.

4）西田修, 小倉裕司, 井上茂亮, 他, 日本版敗血症診療ガイドラ イン 2016 作成特別委員会. 日本版敗血症診療ガイドライン 2016. 日救急医会誌. 2017; 28: S1-232.

5) Limpus A, Chaboyer W, McDonald E, et al: Mechanical thromboprophylaxis in critically ill patients: A systematic review and meta-analysis. Am J Crit Care. 2006; 15: 402-10.

6) Ginzburg E, Cohn SM, Lopez J, et al: Randomized clinical trial of intermittent pneumatic compression and low molecular weight heparin in trauma. Br J Surg. 2003; 90: 1338-44.

7) Vignon $P$, Dequin $P F$, Renault $A$, et al: Intermittent pneumatic compression to prevent venous thromboembolism in patients with high risk of bleeding hospitalized in intensive care units: The CIREA1 randomized trial. Intensive Care Med. 2013; 39: 872-80.

8) Arabi YM, Al-Hameed F, KEA Burns, et al: Adjunctive intermittent pneumatic compression for venous thromboprophylaxis. $\mathrm{N}$ Engl J Med. 2019; 380: 1305-15.

9) 日本循環器学会, 日本医学放射線学会, 日本胸部外科学会, 他: 肺血栓塞栓症および深部静脈血栓症の診断, 治療, 予防 に関するガイドライン (2017 年改訂版). 2018.

10）肺血栓塞栓症 / 深部静脈血栓症（静脈血栓塞栓症）予防ガ イドライン作成委員会: 肺血栓塞栓症 / 深部静脈血栓症（静 脈血栓塞栓症）予防ガイドライン.メディカルフロントイン ターナショナルリミテッド, 東京, 2004.
CQ16-2：敗血症における深部静脈血栓症の予防 として抗凝固療法（未分画ヘパリン，低分子へ パリン, ワルファリン, NOAC/DOAC）を行う か?

Answer : 敗血症患者において, 深部静脈血栓症の予 防として抗凝固療法を行うことを弱く推奨する（エキ スパートコンセンサス：エビデンス不十分）。

\section{（1）背景および本 CQ の重要度}

CQ16-1 の背景と同様に, 静脈血栓塞栓症（venous thromboembolism: VTE) 予防に抗凝固療法を行うかど うか, 敗血症患者に限定して解析することが，本ガイ ドラインにおいて重要であると考える。

(2) PICO

P (患者) : 敗血症および敗血症性ショック患者

I (介入): 抗凝固療法 [未分画ヘパリン (UFH), 低分子ヘパリン (LMWH), ワルファリン, nobel oral anticoagulants (NOAC)/direct oral anticoagulants (DOAC) ] を行う

$\mathrm{C}$ (対照)：非介入

O (アウトカム ) : DVT の発症, pulmonary embolism (PE) の発症

\section{（3）エビデンスの要約}

システマティックレビューを行ったが，PICO に合 致するランダム化比較試験（RCT）は存在しなかっ た。対象患者を集中治療室の重症患者とした RCT や メタ解析では, LMWH， UFH，または fondaparinuxに よるVTE 予防で, VTE の発生率が約 40〜60\% 減少し

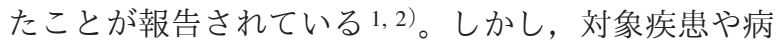
態によってVTEの発生率が約 22〜80\% と大きく異 なっており ${ }^{3)}$, 結果を敗血症まで一般化するかどうか は慎重な解釈が必要である。

\section{(4) 益と害のバランス}

望ましい効果 :

敗血症患者ではVTE の発症リスクが高く,PEのよ うな致死的合併症を，抗凝固療法により防ぐことがで きる可能性があり，望ましい効果は「中」であると判 断した。

望ましくない効果：

抗凝固療法による出血リスクやヘパリンの使用にお いては, heparin-induced thrombocytopenia（HIT）発症 のリスクがある。しかし, 多くの報告例では有意な出 
血増加はなく，あっても重篤なものはわずかである。 したがって, 望ましくない効果は「小さい」と判断し た。

\section{益と害のバランス :}

PICO に合致する RCT が存在しないため不明である が，抗凝固療法によるVTE 予防の益は害を上回ると 判断した。

\section{（5）アウトカム全般に関するエビデンスの確実性}

システマティックレビューを行ったが，PICO に合 致する RCT は存在しなかった。

\section{（6）価値観}

VTEを予防することについて，患者・家族共に重 要視すると考えられ，不確実性やばらつきはないと考 えるが，一部，期待される効果以上に合併症を恐れる 患者・家族がいる可能性もある。

\section{（7）容認性}

抗凝固療法に用いる薬剤は，一般臨床で用いる抗凝 固薬で，多くの病院で採用されており，コストも比較 的安価であるため，容認性は妥当なものと考える。し かし，一部には合併症への懸念から抗凝固薬の使用に 否定的な意見を持つ医療従事者や患者・家族がいる可 能性がある。

\section{（8）実行可能性}

抗凝固療法に用いる薬剤は，一般臨床で用いる抗凝 固薬で, 多くの病院で採用され, 投与方法や投与量も
よく認知されており，実行可能性は高いと考える。

（9）判断の要約（Table 16-2-1）

（10）推奨グレーディング決定の工程

修正 RAND 法を用いた投票によって，中央值 7, 見解不一致指数 0.164 の結果となり, 委員会で採択さ れた（7 点以上 : $83.3 \%) 。$

\section{（11）関連する他の診療ガイドラインにおける推奨}

SSCG 2016 の「VENOUS THROMBOEMBOLISM PROPHYLAXIS」の項目では，禁忌事項がなければ LMWH または UFH の予防投与を“strong recommendation, moderate quality of evidence” として強く推奨し ている。なかでも LMWHを“strong recommendation, moderate quality of evidence” として UFHよりも強く 推奨している4)。

本邦においては「肺血栓塞栓症および深部静脈血栓 症の診断，治療，予防に関するガイドライン（2017 年改訂版)」5）および「肺血栓塞栓症 / 深部静脈血栓症 （静脈血栓塞栓症）予防ガイドライン」6）の中で, DVTを発症するリスク分類とそれに応じた予防法が 述べられている。いずれも敗血症患者を対象としたエ ビデンスはなく，解釈には注意が必要である。

\section{（12）実施に関わる検討事項}

抗凝固療法による出血や, ヘパリンの使用において はHIT 発症のリスクがあり，実施に際して注意を要 する。

Table 16-2-1 判断の要約

\begin{tabular}{|c|c|c|c|c|c|c|c|}
\hline & \multicolumn{7}{|c|}{ 半粠 } \\
\hline 問題 & いいえ & $\begin{array}{c}\text { おそらく、いい } \\
\text { え }\end{array}$ & おそらく、はい & はい & & さまざま & 分からない \\
\hline 望ましい効果 & わずか & 小さい & 中 & 大きい & & さまざま & 分からない \\
\hline 望ましくない効果 & 大きい & 中 & 小さい & わずか & & さまざま & 分からない \\
\hline エビデンスの確実性 & 非常に低 & 低 & 中 & 高 & & & 採用研究なし \\
\hline 価值観 & $\begin{array}{c}\text { 重要な不確実性 } \\
\text { またはばらつき } \\
\text { あり }\end{array}$ & $\begin{array}{c}\text { 重要な不確実性 } \\
\text { またはばらつき } \\
\text { の可能性あり }\end{array}$ & $\begin{array}{l}\text { 重要な不確実性 } \\
\text { またはばらつき } \\
\text { はおそらくなし }\end{array}$ & $\begin{array}{c}\text { 重要な不確実性 } \\
\text { またはばらつき } \\
\text { はなし }\end{array}$ & & & \\
\hline 効果のバランス & 比較が優位 & $\begin{array}{c}\text { 比較がおそらく } \\
\text { 優位 }\end{array}$ & $\begin{array}{c}\text { 介入も比較もい } \\
\text { ずれも優位でな } \\
\text { い }\end{array}$ & $\begin{array}{c}\text { おそらく介入が } \\
\text { 優位 }\end{array}$ & 介入が優位 & さまざま & 分からない \\
\hline 容認性 & いいえ & $\begin{array}{c}\text { おそらく、いい } \\
\text { え }\end{array}$ & おそらく、はい & はい & & さまざま & 分からない \\
\hline 実行可能性 & いいえ & $\begin{array}{c}\text { おそらく、いい } \\
\text { え }\end{array}$ & おそらく、はい & はい & & さまざま & 分からない \\
\hline
\end{tabular}




\section{（13）今後の研究の可能性}

敗血症患者に対する抗凝固療法によるVTE 予防の RCT がないことが明らかとなり, 今後, 抗凝固療法 によるVTE 予防効果，生命予後に関する RCT の早期 実施が望まれる。

\section{文 献}

1) Nisio MD, Porreca E: Prevention of venous thromboembolism in hospitalized acutely ill medical patients: Focus on the clinical utility of (low-dose) fondaparinux. Drug Des Devel Ther. 2013; 7 : 973-80.

2) Alhazzani W, Lim W, Jaeschke RZ, et al: Heparin thromboprophylaxis in medical-surgical critically ill patients: A systematic review and meta-analysis of randomized trials. Crit Care Med. 2013; 41: 2088-98.

3) Attia J, Ray JG, Cook DJ, et al: Deep vein thrombosis and its prevention in critically ill adults. Arch Intern Med. 2001; 161: 1268-79.

4) Rhodes A, Evans LE, Alhazzani W, et al: Surviving Sepsis Campaign: International Guidelines for Management of Sepsis and Septic Shock: 2016. Crit Care Med. 2017; 45: 486-552.

5) 日本循環器学会, 日本医学放射線学会, 日本胸部外科学会, 他: 肺血栓塞栓症および深部静脈血栓症の診断, 治療, 予防 に関するガイドライン (2017 年改訂版). 2018.

6) 肺血栓塞栓症 / 深部静脈血栓症（静脈血栓塞栓症）予防ガ イドライン作成委員会: 肺血栓塞栓症 / 深部静脈血栓症（静 脈血栓塞栓症）予防ガイドライン.メディカルフロントイン ターナショナルリミテッド, 東京, 2004.
CQ16-3：敗血症患者のVTE 予防はいつまで行 うか?

Answer：敗血症患者において, 静脈血栓塞栓症 (venous thromboembolism: VTE) の予防（機械的予防 法または抗凝固療法）は，歩行が可能になるまで，あ るいは退院するまで行うことを弱く推奨する（エキス パートコンセンサス：エビデンス不十分）。

\section{（1）背景および本 CQ の重要度}

米国集中治療医学会の SSCG 2016 ${ }^{1)}$ ，日本版敗血症 診療ガイドライン（J-SSCG）20162,3) でも，機械的 圧迫や抗凝固薬によるVTEの予防が推奨されている が，敗血症患者に対する各予防法の実施期間について エビデンスに基づいた見解は得られていない。VTE 予防として用いられる機械的予防法は圧迫部の血行障 害を起こすリスクがあり, 抗凝固療法は出血性合併症 を起こすリスクがある。このことから，漫然とVTE 予防を行うべきではないが，敗血症患者に対する VTE 予防の至適期間は定まっておらず, 臨床現場で も中止時期の判断は施設や担当医によって様々であ る。

以上より, 敗血症患者に対してVTE 予防をいつま で行うかという本 CQ の重要度は高いと考える。

(2) PICO

P (患者)：敗血症および敗血症性ショック患者

I（介入）：機械的予防法（弾性ストッキング，間欠 的空気圧迫法）または抗凝固療法を離床まで，ま たは入院期間中のみ行う

$\mathrm{C}$ (対照)：機械的予防法（弾性ストッキング，間欠 的空気圧迫法）または抗凝固療法を離床後または 退院後も行う

O (アウトカム) : deep vein thrombosis（DVT）の発 症, pulmonary embolism (PE) の発症

（3）エビデンスの要約

システマティックレビューを行ったが，PICO に合 致するランダム化比較試験（RCT）は存在しなかっ た。

\section{（4）益と害のバランス}

望ましい効果 :

離床が困難な時期には機械的予防法や抗凝固療法に よりVTEを予防し, 離床が可能になった段階で中止 することで，機械的予防法による圧迫部の血行障害や 
抗凝固療法による出血性合併症のリスクを最小限に留 めることができると考えられる。したがって，望まし い効果は「中」であると判断した。

\section{望ましくない効果 :}

離床後や退院後にVTE を発症し，肺塞栓症のよう な致死的合併症を発症する可能性があるため, 望まし くない効果は「小さい」と判断した。

益と害のバランス :

PICO に合致する RCT が存在しないため不明である が，VTEの予防効果と合併症を発症するリスクのバ ランスから，機械的予防法および抗凝固療法を離床ま で，または入院期間中のみ行うことは，離床後または 退院後も行う場合と比較して, 益が害を上回ると判断 した。

（5）アウトカム全般に関するエビデンスの確実性 システマティックレビューを行ったが，PICOに合 致する RCT は存在しなかった。

\section{（6）価値観}

VTEを予防することは，患者・家族共に重要視す ると考えられ，離床後や退院後にも弾性ストッキング による機械的予防法や抗凝固療法によるVTE 予防の 継続を望む場合もあると考えられ，価值観はばらつく 可能性がある。

\section{（7）容認性}

機械的予防法や抗凝固療法にかかる医療従事者の仕 事量とそれらにかかるコストを考慮すると，機械的予
防法および抗凝固療法を離床まで，または入院期間中 のみ行うことの容認性は妥当なものである。

\section{（8）実行可能性}

機械的予防法および抗凝固療法を離床まで，または 入院期間中のみ行うことは実行可能である。

（9）判断の要約 (Table 16-3-1)

（10）推奨グレーディング決定の工程

修正 RAND 法を用いた投票によって，中央值 7, 見解不一致指数 0.164 の結果となり, 委員会で採択さ れた（7 点以上 : $87.5 \%) 。$

\section{（11）関連する他の診療ガイドラインにおける推奨}

米国集中治療医学会のSSCG 2016 ${ }^{1)}$ ，および J-SSCG 2016 2,3) では, VTE 予防をいつまで行うかに ついての記載はない。「肺血栓塞栓症 / 深部静脈血栓

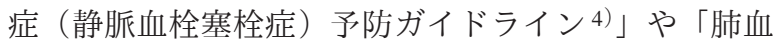
栓塞栓症および深部静脈血栓症の診断, 治療, 予防に

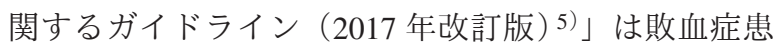
者を対象にしたものではないが，いずれのガイドライ ンでも, 弾性ストッキングは手術予定患者の術前, 術 中，術後を通してリスクが続く限り終日着用する，間 久的空気圧迫法は十分な歩行が可能となるまで装着す る，低用量未分画へパリンは少なくとも十分な歩行が 可能となるまで継続する，と記載されている。

また，米国胸部医学会のガイドライン6)では，急 性期の内科疾患で入院し, VTE 予防が実施された患

Table 16-3-1 判断の要約

\begin{tabular}{|c|c|c|c|c|c|c|c|}
\hline & \multicolumn{7}{|c|}{ 判溇 } \\
\hline 問題 & いいえ & $\begin{array}{c}\text { おそらく、いい } \\
\text { え }\end{array}$ & おそらく、はい & はい & & さまざま & 分からない \\
\hline 望ましい効果 & わずか & 小さい & 中 & 大きい & & さまざま & 分からない \\
\hline 望ましくない効果 & 大きい & 中 & 小さい & わずか & & さまざま & 分からない \\
\hline エビデンスの確実性 & 非常に低 & 低 & 中 & 高 & & & 採用研究なし \\
\hline 価値䚇 & $\begin{array}{c}\text { 重要な不確実性 } \\
\text { またはばらつき } \\
\text { あり }\end{array}$ & $\begin{array}{c}\text { 重要な不確実性 } \\
\text { またはははららさ } \\
\text { の可能性あり }\end{array}$ & $\begin{array}{l}\text { 重要な不確実性 } \\
\text { またはばらつき } \\
\text { はおそらくなし }\end{array}$ & $\begin{array}{c}\text { 重要な不確実性 } \\
\text { またはばらつき } \\
\text { はなし }\end{array}$ & & & \\
\hline 効果のパランス & 比較が優位 & $\begin{array}{c}\text { 比較がおそらく } \\
\text { 優位 }\end{array}$ & $\begin{array}{c}\text { 介入も比較もい } \\
\text { ずれも優位でな } \\
\text { い }\end{array}$ & $\begin{array}{c}\text { おそらく介入が } \\
\text { 優位 }\end{array}$ & 介入が優位 & さまざま & 分からない \\
\hline 容認性 & いいえ & $\begin{array}{c}\text { おそらく、いい } \\
\text { え }\end{array}$ & おそらく、はい & はい & & さまざま & 分からない \\
\hline 実行可能性 & いいえ & $\begin{array}{c}\text { おそらく、いい } \\
\text { え }\end{array}$ & おそらく、はい & はい & & さまざま & 分からない \\
\hline
\end{tabular}


者に対して，安静臥床や急性期入院の時期を過ぎた後 まで予防期間を延長しないことが提案されている

(GRADE 2B)。

\section{（12）実施に関わる検討事項}

一部の患者（自力歩行が不可能, 人工呼吸患者のリ ハビリテーション目的の転院など）では，VTE 予防

の延長が必要な可能性がある。

\section{（13）今後の研究の可能性}

敗血症患者に対するVTE 予防期間の RCT がないた め, 今後, VTE 予防期間の違いによる VTE 発症率や PE など致死的合併症の発症率に関する RCT の実施が 望まれる。

\section{文 献}

1) Rhodes A, Evans LE, Alhazzani W, et al: Surviving Sepsis Campaign: International Guidelines for Management of Sepsis and Septic Shock: 2016. Crit Care Med. 2017; 45: 486-552.

2）西田修, 小倉裕司, 井上茂亮, 他, 日本版敗血症診療ガイドラ イン 2016 作成特別委員会. 日本版敗血症診療ガイドライン 2016. 日集中医誌. 2017; 24: S1-232.

3）西田修, 小倉裕司, 井上茂亮, 他, 日本版敗血症診療ガイドラ イン 2016 作成特別委員会. 日本版敗血症診療ガイドライン 2016. 日救急医会誌. 2017; 28: S1-232.

4）肺血栓塞栓症 / 深部静脈血栓症（静脈血栓塞栓症）予防力゙ イドライン作成委員会: 肺血栓塞栓症 / 深部静脈血栓症（静 脈血栓塞栓症）予防ガイドライン.メディカルフロントイン ターナショナルリミテッド,東京, 2004.

5) 日本循環器学会, 日本医学放射線学会, 日本胸部外科学会, 他: 肺血栓塞栓症および深部静脈血栓症の診断, 治療, 予防 に関するガイドライン (2017 年改訂版). 2018.

6) Kahn SR, Lim W, Dunn AS, et al: Prevention of VTE in nonsurgical patients. Antithrombotic therapy and prevention of thrombosis, 9th ed: American College of Chest Physicians evidencebased clinical practice guidelines. Chest. 2012; 141: e195S-e226S. 


\section{CQ17 : Post-intensive care syndrome (PICS) と ICU-acquired weakness (ICU-AW)}

集中治療室退室後の亜急性期・慢性期の身体的 · 心 理的な諸問題が注目されるなか, 2010 年に Society of Critical Care Medicine が post-intensive care syndrome （PICS）および ICU-acquired weakness（ICU-AW）とい う概念を提唱した 1,2)。PICS とは，集中治療室在室 中あるいは退室後, さらには退院後に生じる身体機 能, 認知機能, 精神の障害である。PICS の要因とし ては大きく以下の 4 つに分類可能である。(1)患者の疾 患および重症度，(2)医療・ケア介入，(3)集中治療室環 境要因 (アラーム音, 光), (4)患者の精神的要因（種々 のストレス, 自分の疾患や経済面, 家族の不安)。こ れらの要因が複雑に絡み合い, PICS 発症にかかわっ ているとされる。2000 年に Nelson らは，急性肺障害 の患者において鎮静薬や筋弛緩薬の使用がうつ病や PTSD (post-traumatic stress disorder) の発症と関係し ていることを報告しており ${ }^{3)}$, 薬剤, 輸血, 輸液, 人 工呼吸器, 血液浄化療法などの治療因子も PICS の発 症に寄与する可能性がある。また，治療以外に喀痰の 吸引や体位変換などのケア因子でも, 同様に PICS の 発症との関連があるといわれている。精神因子として は, せん妄, 不眠, 不穏, 精神的ストレス, 環境因子 として，モニター音やアラーム音，集中治療室の閉鎖 的な環境などがある。さらに，早期リハビリテーショ ンや active mobilization が PICS 予防策として期待され ている ${ }^{4,5)}$ 。PICS は敗血症とも関連しうる病態で, 重症敗血症生存患者は非重症敗血症患者と比較して 1
年間の福祉利用が増加することも報告されている 6)。

ICU-AW は，PICS の身体機能障害の 1 つであり，集 中治療室入室後に発症する急性の左右対称性の四肢筋 力低下を呈する症候群であり，近年注目されている7)。 この概念は, critical illness polyneuropathy（CIP）や critical illness myopathy（CIM）を原因とするびまん性 筋力低下症候群の総体である。敗血症, 多臓器不全, 長期人工呼吸などの重症患者のうち，実に $46 \%$ に ICU-AW が発症していると報告されている ${ }^{8)}$ 。ICU-AW のうち CIP と CIM 両者の合併したカテゴリーが最も多 く, 次に CIM 単独, 最も少ないのは CIP 単独であっ た 9)。ICU-AW による四肢麻痺を呈しても，CIM は数 週から月の単位で回復するが, CIP はときに年の単位 で身体機能に後遺症を残すとされる10)。従来, 重症患 者に発症する筋力低下の原因はポリニューロパチーと 考えられていたが，実は多蔵器不全を呈する敗血症は ミオパチーとも密接に関連している11,12)。Stevens ら 8) のシステマティックレビューにおいても, 敗血症, 多 臓器不全は ICU-AW 発症のリスク因子であった。しか し，これまでの敗血症と筋力低下に関する研究の多く は，呼吸筋，とりわけ横隔膜に関する検討であり，四 肢の筋力に関する検討は少ない11)。2014年に American Thoracic Society から ICU-AW の診断に関す るガイドラインが発表された ${ }^{13)}$ 。このガイドラインで は，絞り込まれた 31 編の文献のシステマティックレ ビューが行われており，ICU-AW の診断には，身体所 見 $(84 \%: 26 / 31)$, 筋電図 (electromyography: EMG) （90\%:28/31）, 神経伝導検査 (nerve conduction study: NCS）（84\%：26/31）が採用されていた。身体所見で

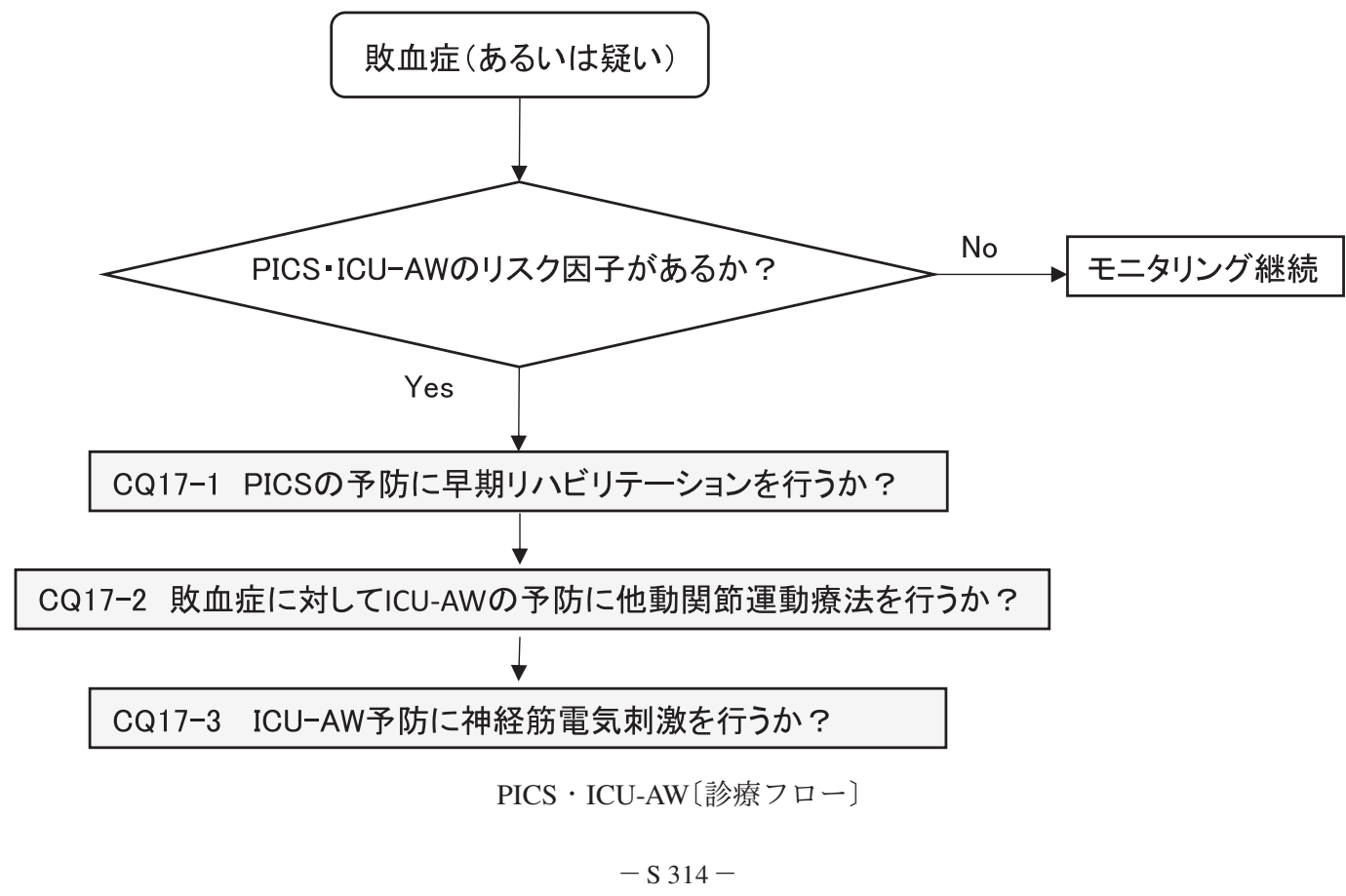


は, ベッドサイドでの徒手筋力テスト（manual muscle test: MMT）が用いられ，さらに複数箇所をまとめて数 值化した MRC (medical research council) 合計スコ ア14）も頻用されていた。MMT と MRC 合計スコアは, EMG や NCS との相関が確認されており, MRC 合計ス コア 60 点満点中, 48 点以下が重度の筋力低下と定義 されることが多かった。これらの身体所見による診断 は, 覚醒状態が重要であり, 鎮静中止によって適切な 意識状態を維持していなければ正確な判定を行うこと はできない。特にせん妄や敗血症性脳症の状態では不 適切となるため, 注意が必要と考えられる。ICU-AW の関連因子として, 敗血症, 不動化, 高血糖, ステロ イド薬の使用, 筋弛緩薬の使用などが挙げられる ${ }^{15)}$ 。 特に前記ガイドラインによると, 重症敗血症患者を対 象とした研究（合計 262 人）で重度の筋力低下を合併 した患者の割合は，他の患者群を対象とした研究（合 計 504 人）よりも有意に高かった（64\% vs. $30 \%, P<$ $0.001)^{13)}$ 。また，人工呼吸器装着期間が長期に及ぶほ うが，ICU-AW を発症する割合が高いことも指摘され ている。敗血症患者は循環動態が不安定なため，初期 にはベッド外での早期リハビリテーションの実施が困 難な場合が多く, ベッド上でのリハビリテーション介 入として他動関節運動療法や神経筋電気刺激療法が選 択されることがある5)。

PICS と ICU-AW のどちらもが集中治療患者の長期 予後のみならず，患者・家族の精神にも影響を及ぼす ものとして広く認識され始めている。近年, この PICS や ICU-AW などの亜急性期から慢性期の病態が, 集中治療室における敗血症患者にも密接に関与してい るという報告がなされるようになり，日本版敗血症診 療ガイドライン（J-SSCG）2016より独立した章とし

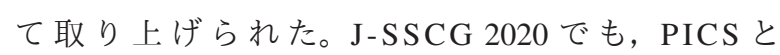
ICU-AW の予防は臨床的重要事項と考え, 早期リハビ リテーション, 他動関節運動療法, 神経筋電気刺激療 法の 3 つを入として CQを提示した。PICSや ICU-AW の理解とそれに対する介入は, 集中治療を受 ける患者の救命の先にある社会復帰を目標とすべきも のであり, 集中治療に関わらない医療従事者との連携 も必要である。そのどちらも, 集中治療領域の新たな 課題として注目されており, その発症予防と治療に関 する最新知見を共有することが重要である。

\section{文 献}

1) Needham DM, Davidson J, Cohen H, et al: Improving long-term outcomes after discharge from intensive care unit: Report from a stakeholders' conference. Crit Care Med. 2012; 40: 502-9.

2) Elliott D, Davidson JE, Harvey MA, et al: Exploring the scope of post-intensive care syndrome therapy and care: engagement of non-critical care providers and survivors in a second stakeholders meeting. Crit Care Med. 2014; 42: 2518-26.

3) Nelson BJ, Weinert CR, Bury CL, et al: Intensive care unit drug use and subsequent quality of life in acute lung injury patients. Crit Care Med. 2000; 28: 3626-30.

4) Fuke R, Hifumi T, Kondo Y, et al: Early rehabilitation to prevent postintensive care syndrome in patients with critical illness: a systematic review and meta-analysis. BMJ Open. 2018; 8: e019998.

5) Tipping CJ, Harrold M, Holland A, et al: The effects of active mobilisation and rehabilitation in ICU on mortality and function: a systematic review. Intensive Care Med. 2017; 43: 171-83.

6) Prescott HC, Langa KM, Liu V, et al: Increased 1-year healthcare use in survivors of severe sepsis. Am J Respir Crit Care Med. 2014; 190: 62-9.

7) Kress JP, Hall JB: ICU-acquired weakness and recovery from critical illness. N Engl J Med. 2014; 370: 1626-35.

8) Stevens RD, Dowdy DW, Michaels RK, et al: Neuromuscular dysfunction acquired in critical illness: a systematic review. Intensive Care Med. 2007; 33: 1876-91.

9) Koch S, Spuler S, Deja M, et al: Critical illness myopathy is frequent: accompanying neuropathy protracts ICU discharge. J Neurol Neurosurg Psychiatry. 2011; 82: 287-93.

10) Koch S, Wollersheim T, Bierbrauer J, et al: Long-term recovery In critical illness myopathy is complete, contrary to polyneuropathy. Muscle Nerve. 2014; 50: 431-6.

11) Callahan C, Fox K, Fox A: The small acid soluble proteins (SASP alpha and SASP beta) of Bacillus weihenstephanensis and Bacillus mycoides group 2 are the most distinct among the Bacillus cereus group. Mol Cell Probes. 2009; 23: 291-7.

12) Deconinck N, Van Parijs V, Beckers-Bleukx G, et al: Critical illness myopathy unrelated to corticosteroids or neuromuscular blocking agents. Neuromuscul Disord. 1998; 8: 186-92.

13) Fan E, Cheek F, Chlan L, et al: An official American Thoracic Society Clinical Practice guideline: the diagnosis of intensive care unit-acquired weakness in adults. Am J Respir Crit Care Med. 2014; 190: 1437-46.

14) Kleyweg RP, van der Meché FG, Meulstee J: Treatment of Guillain-Barre syndrome with high-dose gammaglobulin. Neurology. 1988; 38: 1639-41.

15) Schefold JC: Measurement of monocytic HLA-DR (mHLA-DR) expression in patients with severe sepsis and septic shock: assessment of immune organ failure. Intensive Care Med. 2010; 36: $1810-2$. 


\section{CQ17-1：PICS の予防に早期リハビリテーショ ンを行うか?}

Answer : 敗血症患者において, PICS の予防に早期リ ハビリテーションを行うことを弱く推奨する(GRADE 2D：エビデンスの確実性 $=$ 「非常に低」)。

\section{（1）背景および本 CQ の重要度}

集中治療患者における早期リハビリテーションは, 患者の筋肉量増加, 運動機能改善, 早期離床の促進, ADL 改善などが数多く報告されており，PICS を予防 しうると考えられる。しかしながら，敗血症患者に対 する早期リハビリテーションの有効性・有害性の評価 は定まっておらず，臨床現場でも早期リハビリテー ションの定義・種類・開始時期・実施期間などについ ては多様性がある。本 CQ では，早期リハビリテー ションを下記(1)〜 (4)と定義し, PICSへの予防効果に ついて検証する。

(1)理学療法かつ/または作業療法（認知療法などは 除く)。

(2)ベッド外でのリハビリテーションを含む。

(3)対照群よりも早期に開始されている。

(4)集中治療室入室から 1 週間以内に開始されてい る。

\section{(2) PICO}

$\mathrm{P}$ (患者)：成人集中治療患者

I（介入）: 早期リハビリテーションを実施する

$\mathrm{C}$ (対照)：早期リハビリテーションを実施しない

$\mathrm{O}$ (アウトカム) : 院内死亡, 病院滞在日数, 6 か月時 点の the Medical Outcomes Study 36-Item Short Form Health Survey Physical Function scale (SF-36 PF), 病院滞在時の Medical Research Council (MRC), 6 か月時点の Hospital Anxiety and Depression scale（HADS），6 か月時点の Mini-Mental State Examination（MMSE）, あらゆる有害事象

\section{（3）エビデンスの要約}

文献検索の結果，1,403 論文を抽出し，重複を削除 した 1,085 論文のタイトルと抄録を確認した。このう ち，対象論文の可能性がある 34 論文の全文原稿を確 認し, 対象論文として 11 編のランダム化比較試験 (RCT) 1-11）にメタ解析を実施した。
(4) 益と害のバランス（Table 17-1-1）

望ましい効果：

病院滞在日数（10 RCT: $n=1,224 ） に$ 対する効果推 定值は 2.86 日短い（5.51日短い〜0.21 日短い)，6 6 月時点の SF-36PF（3 RCT: $n=241 ） に$ 対する効果推 定值は平均（MD）4.65 高い（16.13 低い～25.43 高 い), 病院滞在時の MRC（3 RCT: $\mathrm{n}=196 ）$ に対する 効果推定值は MD 4.84 高い（0.36 高い～9.31 高い), 6 か月時点の HADS（1 RCT: $n=37 ）$ に対する効果推 定值は 0.3 高い（4.92 低い〜 5.52 高い)，6 か月時点の MMSE（1 RCT: $\mathrm{n}=165 ）$ に対する効果推定值は MD 0.6 多い（0.25 少ない〜1.45 多い), 院内死亡（7 RCT: $\mathrm{n}=924 ）$ に対する効果推定值とその信頼区間（CI） は 1,000 人あたり 15 人多い $(24$ 人少ない〜 71 人多い $)$ であった。死亡は増加傾向であるが，臨床的な差はな いと考えられる，望ましい効果は「小さい」と判断し た。

望ましくない効果：

有害事象発生（5 RCT: $\mathrm{n}=706 ） に$ 対する効果推定 值は， 1,000 人あたり 14 人少ない（38 人少ない〜 55 人多い）である。望ましくない効果はわずかであると 判断した。

益と害のバランス :

早期リハビリテーションは, 病院滞在日数の短縮 と, 病院滞在時の MRC の増加を認めた。一方で，早 期リハビリテーションは院内死亡を増加させる傾向を 示した。以上により，介入優位であるが，院内死亡の 重要度を考慮し, 効果バランスはおそらく介入が優位 と判断した。

（5）アウトカム全般に関するエビデンスの確実性

「非常に低」から「低」に分類されている。異なる 方向性を示すアウトカムがあるため, 重大なアウトカ ムに関するエビデンスの確実性の中で最も低い GRADEである「非常に低」を全体的なエビデンスの 確実性とした。

\section{（6）価値観}

PICS 予防に対する早期リハビリテーションにおけ る各アウトカムに置く患者・家族の価值観に関する データはない。一般的に死亡や病院滞在日数に対して 置く相対的価值は高い。さらに近年，本邦の医療政策 として推進されている地域包括ケアシステム構築や健 康寿命延伸の文脈において，身体機能・認知機能・精 神状態などの機能回復や QOL 向上に対して置く相対 的価值が高まっている。以上により，そのばらつきは 
Table 17-1-1 エビデンスプロファイル

\begin{tabular}{|c|c|c|c|c|c|c|c|c|c|c|c|c|}
\hline \multicolumn{7}{|c|}{ 確実性の議価 } & \multicolumn{2}{|c|}{ 患者数 } & \multicolumn{2}{|c|}{ 効果 } & \multirow[b]{2}{*}{ 碓実性 } & \multirow[b]{2}{*}{ 重要性 } \\
\hline 研究数 & $\begin{array}{l}\text { 研究 } \\
\text { デザイン }\end{array}$ & $\begin{array}{l}\text { バイアス } \\
\text { のリスク }\end{array}$ & 非一貫性 & 非直接性 & 不精磼性 & $\begin{array}{l}\text { その他 } \\
\text { の湌討 }\end{array}$ & $\begin{array}{l}\text { 早期リハの } \\
\text { 施行 }\end{array}$ & $\begin{array}{c}\text { 早期リハの } \\
\text { 非施行 }\end{array}$ & $\begin{array}{l}\text { 相对指標 } \\
(95 \% \mathrm{CI})\end{array}$ & $\begin{array}{l}\text { 䖻対指標 } \\
(95 \% \text { Cl) }\end{array}$ & & \\
\hline \multicolumn{13}{|c|}{ 院内死亡 } \\
\hline 7 & RCT & 深刻でない & 深刻でない & 深刻でない & 深刻a & なし & $\begin{array}{l}64 / 466 \\
(13.7 \%)\end{array}$ & $\begin{array}{l}56 / 458 \\
(12.2 \%)\end{array}$ & $\begin{array}{c}\text { RR } 1.12 \\
\text { (0.80 to } 1.58 \text { ) }\end{array}$ & $\begin{array}{c}1,000 \text { 人あたり } \\
15 \text { 人多い (24 } \\
\text { 少ない〜71 人多 } \\
\text { い) }\end{array}$ & $\underset{\text { 低 }}{\oplus \oplus \bigcirc \bigcirc}$ & 重大 \\
\hline \multicolumn{13}{|c|}{ 病院滞在日数 } \\
\hline 10 & RCT & 深刻 ${ }^{b}$ & 深刻 c & 深刻 ${ }^{d}$ & 深刻でない & なし & 613 & 611 & & $\begin{array}{c}\text { 平均 } 2.86 \text { 日短い } \\
(5.51 \text { 日短い } \\
0.21 \text { 短い) }\end{array}$ & $\begin{array}{l}\oplus \circ \bigcirc \bigcirc \\
\text { 非常に低 }\end{array}$ & 重大 \\
\hline \multicolumn{13}{|c|}{ 6か月時点の SF-36PF } \\
\hline 3 & RCT & 深刻 & 深刻 & 深刻でない & 深刻 $\mathrm{B}$ & なし & 119 & 122 & - & $\begin{array}{l}\text { 平均 } 4.65 \text { 高い } \\
\text { (16.13 低い } \\
25.43 \text { 高い) }\end{array}$ & $\begin{array}{l}\oplus \circ \bigcirc \bigcirc \\
\text { 非常に低 }\end{array}$ & 重大 \\
\hline \multicolumn{13}{|c|}{ 病院滞在時の MRC } \\
\hline 3 & RCT & 深刻 ${ }^{b}$ & 深刻でない & 深刻でない & 深刻 $\mathrm{g}$ & なし & 97 & 99 & - & $\begin{array}{c}\text { 平均 } 4.84 \text { 高い } \\
\text { (0.36 高い } \\
9.31 \text { 高い) }\end{array}$ & $\begin{array}{l}\oplus \circ \bigcirc \bigcirc \\
\text { 非常に低 }\end{array}$ & 重大 \\
\hline \multicolumn{13}{|c|}{ 6か月時点の HADS } \\
\hline 1 & RCT & 深刻 b & 深刻でない & 深刻でない & 深刻 ${ }^{n}$ & なし & 21 & 16 & - & $\begin{array}{l}\text { 平均 } 0.3 \text { 高い } \\
\text { (4.92 低い } \\
5.52 \text { 高い) }\end{array}$ & $\begin{array}{l}\oplus \circ \bigcirc \bigcirc \\
\text { 非常に低 }\end{array}$ & 重大 \\
\hline \multicolumn{13}{|c|}{ 6か月時点の MMSE } \\
\hline 1 & RCT & 深刻 b & 深刻でない & 深刻でない & 深刻 ${ }^{n}$ & なし & 84 & 81 & - & $\begin{array}{c}\text { 平均 } 0.6 \text { 高い } \\
(0.25 \text { 低い } \\
1.45 \text { 高い) }\end{array}$ & $\begin{array}{l}\oplus \circ \bigcirc \bigcirc \\
\text { 非常に低 }\end{array}$ & 重大 \\
\hline \multicolumn{13}{|c|}{ 有害事象 } \\
\hline 5 & RCT & 深刻 b & 深刻 & 深刻でない & 深刻 a & なし & $\begin{array}{l}13 / 358 \\
(3.6 \%)\end{array}$ & $17 / 348(4.9 \%)$ & $\begin{array}{c}\text { RR } 0.71 \\
\text { (0.23 to } 2.13)\end{array}$ & $\begin{array}{c}1,000 \text { 人あたり } \\
14 \text { 人少ない (38 } \\
\text { 人少ない } 55 \text { 人 } \\
\text { 多い) }\end{array}$ & $\begin{array}{l}\oplus \circ \bigcirc \bigcirc \\
\text { 非常に低 }\end{array}$ & 重大 \\
\hline
\end{tabular}

a. サンプルサイズが $n=2,000$ より下回るため $(\alpha=0.05, \beta=0.2, E v e n t=20 \%, R R R=25 \%$ を元に最適情報量を計算, $n=2,000)$ 。

b. 実行バイアスが存在するため。

c. 統計学的に非一貫性が認められる。( $\left.\left.\right|^{2}: 85 \%\right)$

d. 心臓血管外科，予定手術の患者を対象といた研究が複数以上含まれているため (集団の差異)

e. $95 \%$ CI に効果なしが含まれている。

f. 統計学的に非一貫性が認められる。(1 $2: 90 \%)$

g. サンプルサイズが $n=400$ より下回るため (経験的な閾值 ; $\alpha=0.05, \beta=0.2, d=0.2 \sim 0.3$ を元に最適情報量を計算, $\mathrm{n}=400$ )

h. 単一研究のみ。サンプルサイズが $n=400$ より下回るため(経験的な閾値； $\alpha=0.05, \beta=0.2, d=0.2 \sim 0.3$ を元に最適情報量を計算, $n=400) 。$

i. 点推定值が研究間で異なり，その相違がかなり大きい。

少ないことが予想される。

\section{（7）容認性}

患者が負担する費用は，特定集中治療室管理料にお ける早期離床・リハビリテーション加算で算定した場 合は 1 日あたり「500 点」, 疾患別リハビリテーショ ン料で算定した場合は 1 単位（20 分）あたり「疾患 別リハビリテーション料 200 点前後十早期リハビリ テーション加算 30 点 + 初期加算 45 点」である。ど ちらの場合も, 患者の個人の視点からおそらく許容で きると考える。また，本 CQにおける早期リハビリ テーションにおいて新たに購入が必要な医療器具など は少なく, 医療機関の経営者側の視点からもおそらく 許容できると考える。一方で，早期リハビリテーショ ンの実施によって医療者の仕事量が増えることが予測 されるが，現行の診療報酬における人員配置などの施
設基準上では許容可能と考える。

\section{（8）実行可能性}

医師または医師の指示のもとで看護師や理学療法 士・作業療法士によって実行可能であるが，安全性や 実践内容を担保するための基準やプロトコルなどを各 施設で整備する必要がある。集中治療領域での経験が ある医療従事者と, 早期リハビリテーションの基準や プロトコルなどの整備が確保できれば，すべての集中 治療室において実行可能と考える。

(9) 判断の要約 (Table 17-1-2)

（10）推奨グレーディング決定の工程

修正 RAND 法を用いた投票によって，中央值 8, 見解不一致指数 0.178 の結果となり，委員会で採択さ 
Table 17-1-2 判断の要約

\begin{tabular}{|c|c|c|c|c|c|c|c|}
\hline & \multicolumn{7}{|c|}{ 判溇 } \\
\hline 問題 & いいえ & $\begin{array}{c}\text { おそらく、いい } \\
\text { え }\end{array}$ & おそらく、はい & はい & & さまざま & 分からない \\
\hline 望ましい効果 & わずか & 小さい & 中 & 大きい & & さまざま & 分からない \\
\hline 望ましくない効果 & 大きい & 中 & 小さい & わずか & & さまざま & 分からない \\
\hline エビデンスの確実性 & 非常に低 & 低 & 中 & 高 & & & 採用研究なし \\
\hline 価值覞 & $\begin{array}{c}\text { 重要な不確実性 } \\
\text { またはばらつき } \\
\text { あり }\end{array}$ & $\begin{array}{c}\text { 重要な不確実性 } \\
\text { またはばらつき } \\
\text { の可能性ありり }\end{array}$ & $\begin{array}{l}\text { 重要な不確実性 } \\
\text { またはばらつき } \\
\text { はおそらくなし }\end{array}$ & $\begin{array}{c}\text { 重要な不確実性 } \\
\text { またはばらつき } \\
\text { はなし }\end{array}$ & & & \\
\hline 効果のバランス & 比較が優位 & $\begin{array}{c}\text { 比較がおそらく } \\
\text { 優位 }\end{array}$ & $\begin{array}{c}\text { 介入も比較もい } \\
\text { ずれも優位でな } \\
\text { い }\end{array}$ & $\begin{array}{c}\text { おそらく介入が } \\
\text { 優位 }\end{array}$ & 介入が優位 & さまざま & 分からない \\
\hline 容認性 & いいえ & $\begin{array}{c}\text { おそらく、いい } \\
\text { え }\end{array}$ & おそらく、はい & はい & & さまざま & 分からない \\
\hline 実行可能性 & いいえ & $\begin{array}{c}\text { おそらく、いい } \\
\text { え }\end{array}$ & おそらく、はい & はい & & さまざま & 分からない \\
\hline
\end{tabular}

れた（7点以上 : 95.8\%)。

\section{（11）関連する他の診療ガイドラインにおける推奨}

日本版敗血症診療ガイドライン (J-SSCG) 2016 12, 13)

では，敗血症，あるいは集中治療患者において，PICS の予防に早期リハビリテーションを行うことを弱く推 奨（2C）している。

PADIS ガイドライン 14) では，成人重症患者に早期 リハビリテーションを行うことが提案されている（条 件付き推奨, 低い質のエビデンス)。また，BQとし て，深刻な有害事象は一般的には早期リハビリテー ション中には発生しないこと, 安全に早期リハビリ テーションを開始するための主な指標には，心血管 系・呼吸器系・神経系の状態の安定性などがあり，血 管作動薬の持続投与や人工呼吸器の装着は，患者がそ れらの使用によって安定している場合には，早期リハ ビリテーションの開始の妨げにはならないこと，早期 リハビリテーションを中止するための主要な指標に は，心血管系・呼吸器系または神経系などの不安定性 の新規出現があることが解説されている。

\section{（12）実施に関わる検討事項}

敗血症患者への標準的治療として早期リハビリテー ションを行うことが望まれるが，学会などで示されて いる開始基準や中止基準などに照らし，各施設の人員 配置や構造，利用可能な機器などに適した基準やプロ トコルを作成して行うことを考慮する必要がある。

\section{（13）今後の研究の可能性}

敗血症患者を限定とした研究が望まれる。また，早 期リハビリテーションの開始時期や継続期間による有 用性，早期リハビリテーションの強度や時間，頻度に よる有用性，対象者の特徵（重症度，疾患，年齢，栄 養状態, 従前の ADL など）に対する早期リハビリテー ションの有用性について検証した研究が求められる。

\section{文 献}

1) Dong Z, Yu B, Zhang Q, et al: Early rehabilitation therapy is beneficial for patients with prolonged mechanical ventilation after coronary artery bypass surgery a prospective random study. Int Heart J. 2016; 57: 241-6.

2) Hodgson CL, Bailey M, Bellomo R, et al: A binational multicenter pilot feasibility randomized controlled trial of early goaldirected mobilization in the ICU. Crit Care Med. 2016; 44: 1145-52.

3) Kayambu G, Boots R, Paratz J: Early physical rehabilitation in intensive care patients with sepsis syndromes: a pilot randomised controlled trial. Intensive Care Med. 2015; 41: 865-74.

4) Maffei P, Wiramus $S$, Bensoussan L, et al: Intensive Early Rehabilitation in the Intensive Care Unit for Liver Transplant Recipients: A Randomized Controlled Trial. Arch Phys Med Rehabil. 2017; 98: 1518-25.

5) Moradian ST, Najafloo M, Mahmoudi H, et al: Early mobilization reduces the atelectasis and pleural effusion in patients undergoing coronary artery bypass graft surgery: A randomized clinical trial. J Vasc Nurs. 2017; 35: 141-5.

6) Morris PE, Berry MJ, Files DC, et al: Standardized rehabilitation and hospital length of stay among patients with acute respiratory failure a randomized clinical trial. JAMA. 2016; 315: 2694-702.

7) Moss M, Nordon-Craft A, Malone D, et al: A Randomized Trial of an Intensive Physical Therapy Program for Patients with Acute Respiratory Failure. Am J Respir Crit Care Med. 2016; 193: 1101-10.

8) Patman S, Sanderson D, Blackmore M: Physiotherapy following cardiac surgery: Is it necessary during the intubation period? 
Aust J Physiother. 2001; 47: 7-16.

9) Schaller SJ, Anstey M, Blobner M, et al: Early, goal-directed mobilisation in the surgical intensive care unit: a randomised controlled trial. Lancet. 2016; 388: 1377-88.

10) Tariq MI, Khan AA, Khalid Z, et al: Effect of early $\leq 3$ Mets (Metabolic Equivalent of Tasks) of physical activity on patient's outcome after cardiac surgery. J Coll Physicians Surg. Pak. 2017; 27: 490-4.

11) Schweickert WD, Pohlman MC, Pohlman AS, et al: Early physical and occupational therapy in mechanically ventilated, critically ill patients: a randomised controlled trial. Lancet. 2009; 373: 1874-82.

12）西田修, 小倉裕司, 井上茂亮, 他: 日本版敗血症診療ガイドラ イン 2016 作成特別委員会. 日本版敗血症診療ガイドライン 2016. 日集中医誌. 2017; 24: S1-232.

13）西田修, 小倉裕司, 井上茂亮, 他: 日本版敗血症診療ガイドラ イン 2016 作成特別委員会. 日本版敗血症診療ガイドライン 2016. 日救急医会誌. 2017; 28: S1-232.

14) Devlin JW, Skrobik Y, Gélinas C, et al: Clinical Practice Guidelines for the Prevention and Management of Pain, Agitation/Sedation, Delirium, Immobility, and Sleep Disruption in Adult Patients in the ICU. Crit Care Med. 2018; 46: e825-73.

\section{CQ17-2 : 敗血症に対してICU-AW の予防に他動 関節運動療法を行うか?}

Answer：敗血症患者に対して，標準治療として他動 関節運動療法を行うことを弱く推奨する（GRADE 2D : エビデンスの確実性 $=「$ 非常に低」)。

\section{（1）背景および本 CQ の重要度}

ICU-AW 発症は患者の予後不良と関連があり ${ }^{1-4)}$, ICU-AW 発症予防のために早期よりリハビリテーショ ン介入が開始される5)。重症な敗血症患者では早期に は積極的運動療法が困難な場合が多く, 他動関節運動 療法が主体となることが多い。そのため, 敗血症患者 における他動関節運動療法の ICU-AW の発症予防に 対する有効性を明らかにすることは，リハビリテー ション介入計画を考えるうえで重要である。

(2) PICO

$P$ (患者)：成人集中治療患者

I (介入) : 他動関節運動療法（または通常のリハビ リテーション介入に加えた集中的な他動関節運動 療法の実施）

C (対照)：他動関節運動療法の非実施（または通常 のリハビリテーション介入）

$\mathrm{O}$ (アウトカム $)$ : 筋力 [握力, medical research council (MRC) ], 運動耐容能 [6 min walk test（6 MWD)], 日常生活動作 [functional independence measure (FIM)], ICU 滞在日数または病院滞在 日数，人工呼吸期間，あらゆる有害事象

\section{（3）エビデンスの要約}

システマティックレビューの結果，PICO に合致し たランダム化比較試験（RCT）が 6 件 6-11）施行され ており,これらを用いたメタ解析を実施した。

\section{（4）益と害のバランス（Table 17-2-1）}

望ましい効果 :

MRC スコアに関する効果推定值は, 平均（MD） 0.96 少ない $(95 \%$ CI: 4.13 少ない〜2.21 多い) (3 RCT: 366 人) であり，6 MWD に関する効果推定值は MD $10.5 \mathrm{~m}$ 長い（63.45m 短い〜84.46m 長い）（2 RCT: 173 人）である。FIMにする効果推定值は, MD 3 多い (5.42 少ない〜11.42 多い)（1 RCT: 115 人）であり, ICU 滞在日数に関する効果推定值は，MD 0.36 日長い (1.79 日短い〜2.51 日長い)（4 RCT: 277 人）である。 病院滞在日数に関する効果推定值は, MD 0.74 日長い 
Table 17-2-1エビデンスプロファイル

\begin{tabular}{|c|c|c|c|c|c|c|c|c|c|c|c|c|}
\hline \multicolumn{7}{|c|}{ 確実性の評価 } & \multicolumn{2}{|c|}{ 患者数 } & \multicolumn{2}{|c|}{ 効果 } & \multirow[b]{2}{*}{ 確実性 } & \multirow[b]{2}{*}{ 重要性 } \\
\hline 研究数 & $\begin{array}{l}\text { 研究 } \\
\text { デザイン }\end{array}$ & $\begin{array}{l}\text { パイアス } \\
\text { のリスク }\end{array}$ & 非一貫性 & 非直接性 & 不精確性 & $\begin{array}{l}\text { その他 } \\
\text { の検討 }\end{array}$ & $\begin{array}{c}\text { 他動関節運動 } \\
\text { 療法 }\end{array}$ & 標準療法 & $\begin{array}{l}\text { 相対指標 } \\
(95 \% \mathrm{CI})\end{array}$ & $\begin{array}{l}\text { 絶対指標 } \\
(95 \% \mathrm{CI})\end{array}$ & & \\
\hline \multicolumn{13}{|c|}{ 筋力 (MRC スコア) } \\
\hline 3 & RCT & 深刻 a & 深刻でない & 深刻 b & 深刻。 & なし & 182 & 184 & - & $\begin{array}{c}\text { 平均 } 0.96 \text { 低い } \\
(4.13 \text { 低い 2.21 } \\
\text { 高い) }\end{array}$ & $\begin{array}{l}\oplus \bigcirc 00 \\
\text { 非常に低 }\end{array}$ & 重大 \\
\hline \multicolumn{13}{|c|}{ 運動耐容能（6 分間歩行テスト） } \\
\hline 2 & RCT & 深刻でない & 深刻 d & 深刻 b & 深刻。 & なし & 84 & 89 & - & $\begin{array}{l}\text { 平均 } 10.5 \mathrm{~m} \text { 長い } \\
(63.45 \mathrm{~m} \text { 短い } \\
84.46 \mathrm{~m} \text { 長い) }\end{array}$ & $\begin{array}{l}\oplus \bigcirc 00 \\
\text { 非常に低 }\end{array}$ & 重大 \\
\hline \multicolumn{13}{|c|}{ 日常生活動作（FIM） } \\
\hline 1 & RCT & 深刻でない & 深刻でない & 深刻 b & 深刻。 & なし & 58 & 57 & - & $\begin{array}{c}\text { 平均 } 3 \text { 高い }(5.42 \\
\text { 低い 11. } 42 \text { 高 } \\
\text { (1) }\end{array}$ & $\underset{\text { 低 }}{\oplus \oplus \bigcirc \bigcirc}$ & 重大 \\
\hline \multicolumn{13}{|c|}{ ICU 滞在日数 } \\
\hline 4 & RCT & 深刻 a & 深刻でない & 深刻 b & 深刻。 & なし & 142 & 135 & - & $\begin{array}{c}\text { 平均 } 0.36 \text { 日長い } \\
\text { (1.79日短い } \\
\text { 2. } 51 \text { 日長い) }\end{array}$ & $\begin{array}{l}\oplus \bigcirc 00 \\
\text { 非常に低 }\end{array}$ & 重大 \\
\hline \multicolumn{13}{|c|}{ 病院滞在日数 } \\
\hline 4 & RCT & 深刻でない & 深刻でない & 深刻 b & 深刻。 & なし & 142 & 135 & - & $\begin{array}{c}\text { 平均 } 0.74 \text { 日長い } \\
\text { (3.68 日短い } \\
5.15 \text { 日長い) }\end{array}$ & $\underset{\text { 低 }}{\oplus \oplus \bigcirc \bigcirc}$ & 重大 \\
\hline \multicolumn{13}{|c|}{ 人工呼吸期間 } \\
\hline 4 & RCT & 深刻 a & 深刻でない & 深刻 b & 深刻。 & なし & 274 & 257 & - & $\begin{array}{c}\text { 平均 } 0.14 \text { 日長い } \\
\text { (1.03 日短い } \\
1.31 \text { 日長い) }\end{array}$ & $\begin{array}{l}\oplus \bigcirc 00 \\
\text { 非常に低 }\end{array}$ & 重大 \\
\hline \multicolumn{13}{|c|}{ 有害事象 } \\
\hline 3 & RCT & 深刻。 & 深刻でない & 深刻 b & 非常|=深刻 af & なし & $9 / 216 \quad(4.2 \%)$ & $12 / 200 \quad(6.0 \%)$ & $\begin{array}{c}\operatorname{RR} 0.70 \\
(0.30 \text { to } 1.63)\end{array}$ & $\begin{array}{c}1,000 \text { 人あたり } 18 \\
\text { 人少ない } 42 \text { 人 } \\
\text { 少ない 38人多 } \\
\text { (1) }\end{array}$ & $\begin{array}{l}\oplus \bigcirc 00 \\
\text { 非常に低 }\end{array}$ & 重大 \\
\hline
\end{tabular}

a. 2 論文で割付の隠蔽のバイアスのリスクが不明，かつ全論文で参加者と研究者の盲検化のバイアスのリスクが高。

b. 対象患者をICU 入室患者としており，敗血症患者に限定していない。

c. サンプルサイズが不足。

d. 採用 2 論文の結果の方向性が違い, $\mathrm{I}^{2}=61 \%$

. 2 論文で割付の隠蔽のバイアスのリスクが不明,

（3.68 日短い〜 5.15 日長い）（4 RCT: 277 人）であり， 人工呼吸期間に関する効果推定值は，MD 0.14 日長い （1.03 日短い〜 1.31 日長い）（4 RCT: 531 人）である。 望ましい効果は「小さい」と判断した。

望ましくない効果 :

あらゆる有害事象の効果推定值は，リスク差（RD） 1,000 人あたり 18 人少ない $(42$ 人少ない〜 38 人多い) （3 RCT : n = 416）である。望ましくない効果はわず かであると判断した。

益と害のバランス :

望ましい効果は小さく，望ましくない効果はわずか であった。患者が置く相対的価值の設定によらず，お そらく介入が優位であると考える。

（5）アウトカム全般に関するエビデンスの確実性

異なる方向性を示すアウトカムがあるため，重大な アウトカムに関するエビデンスの確実性の中で最も低 いGRADEである「非常に低」を, 全体的なエビデン スの確実性とした。

\section{（6）価値観}

敗血症患者に対する他動関節運動療法におけるアウ トカムに関する，患者の価值観についてのデータはな い。一般的に，ICU-AW の診断基準の 1 つである筋力 や ICU 滞在日数に対して置く相対的価值は高く，そ のばらつきは少ないことが予想される。

\section{（7）容認性}

他動関節運動療法は集中治療室での早期リハビリ テーションの一部であり, 通常の日常診療範囲のもの である。患者が負担する費用は，早期離床・リハビリ テーション加算算定施設においては 1 日あたり 500 点 である。集中治療室で疾患別リハビリテーション料を 算定している場合，施設基準 I の施設において 20 分 あたり 175 点から 245 点の疾患別リハビリテーション 料と初期加算 75 点の費用となる。どちらの場合も, 患者の個人の視点からおそらく許容できるだろう。他 動関節運動療法によって医療者の仕事量が増加するこ とが予測されるが，その労働負担は多くないと考えら れる。 
（8）実行可能性

多くの施設において，医師，看護師，リハビリテー ション関連職種による徒手的な他動関節運動療法であ れば実行可能である。

\section{（9）判断の要約（Table 17-2-2）}

\section{（10）推奨グレーディング決定の工程}

修正 RAND 法を用いた投票によって，中央值 7.5, 見解不一致指数 0.164 の結果となり，委員会で採択さ れた（7点以上 : 91.7\%)。

\section{（11）関連する他の診療ガイドラインにおける推奨} なし。

\section{（12）実施に関わる検討事項}

本介入における医師，看護師，リハビリテーション 関連職種の労働負担は多くないと考えられる。ただ し, 研究で示されているようなベッド上でのリハビリ テーション器具の新たな購入費も考慮する必要があ る。

\section{（13）今後の研究の可能性}

今後, 敗血症や循環動態不安定のためベッド外での 早期離床・リハビリテーションが困難な患者の ICU-AW 発生に対して, 他動関節運動療法の有効性に 関する研究が望まれる。

\section{文 献}

1) Ali NA, O’Brien JM Jr, Hoffmann SP, et al: Acquired weakness, handgrip strength, and mortality in critically ill patients. Am J Respir Crit Care Med. 2008; 178: 261-8.

2) Sharshar T, Bastuji-Garin S, Stevens RD, et al: Presence and severity of intensive care unit-acquired paresis at time of awakening are associated with increased intensive care unit and hospital mortality. Crit Care Med. 2009; 37: 3047-53.

3) Hermans G, Van Mechelen H, Clerckx B, et al: Acute outcomes and 1-year mortality of intensive care unit-acquired weakness. A cohort study and propensity-matched analysis. Am J Respir Crit Care Med. 2014; 190: 410-20.

4) Dinglas VD, Aronson Friedman L, Colantuoni E, et al: Muscle weakness and 5-year survival in acute respiratory distress syndrome survivors. Crit Care Med. 2017; 45: 446-53.

5) Fuke R, Hifumi T, Kondo $Y$, et al: Early rehabilitation to prevent postintensive care syndrome in patients with critical illness: a systematic review and meta-analysis. BMJ Open. 2018; 8: e019998.

6) Burtin C, Clerckx B, Robbeets C, et al: Early exercise in critically ill patients enhances short-term functional recovery. Crit Care Med. 2009; 37: 2499-505.

7) Karadas C, Ozdemir L: The effect of range of motion exercises on delirium prevention among patients aged 65 and over in intensive care units. Geriatr Nurs. 2016; 37: 180-5.

8) Machado ADS, Pires-Neto RC, Carvalho MTX, et al: Effects that passive cycling exercise have on muscle strength, duration of mechanical ventilation, and length of hospital stay in critically ill patients: a randomized clinical trial. J Bras Pneumol. 2017; 43: 134-9.

9) Fossat G, Baudin F, Courtes L, et al: Effect of In-Bed Leg Cycling and Electrical Stimulation of the Quadriceps on Global Muscle Strength in Critically Ill Adults: A Randomized Clinical Trial. JAMA. 2018; 320: 368-78.

10) Eggmann S, Verra ML, Luder G, et al: Effects of early, combined endurance and resistance training in mechanically ventilated, critically ill patients: A randomised controlled trial. PLoS One. 2018; 13: e0207428.

11) Kho ME, Molloy AJ, Clarke FJ, et al: Multicentre pilot randomised clinical trial of early in-bed cycle ergometry with ventilated patients. BMJ Open Respir Res. 2019; 6: e000383.

Table 17-2-2 判断の要約

\begin{tabular}{|c|c|c|c|c|c|c|c|}
\hline & \multicolumn{7}{|c|}{ 半判断 } \\
\hline 問題 & いいえ & $\begin{array}{c}\text { おそらく、いい } \\
\text { え }\end{array}$ & おそらく、はい & はい & & さまざま & 分からない \\
\hline 望ましい效果 & わずか & 小さい & 中 & 大きい & & さまざま & 分からない \\
\hline 望ましくない効果 & 大きい & 中 & 小さい & わずか & & さまざま & 分からない \\
\hline エビデンスの確夷性 & 非常に低 & 低 & 中 & 高 & & & 採用研究なし \\
\hline 価值钼 & $\begin{array}{l}\text { 重要な不確実性 } \\
\text { またはばらつき } \\
\text { あり }\end{array}$ & $\begin{array}{c}\text { 重要な不確実性 } \\
\text { またはばらつき } \\
\text { の可能性あり }\end{array}$ & $\begin{array}{l}\text { 重要な不確実性 } \\
\text { またはばらつき } \\
\text { はおそらくなし }\end{array}$ & $\begin{array}{c}\text { 重要な不確実性 } \\
\text { またはばらつき } \\
\text { はなし }\end{array}$ & & & \\
\hline 効果のパランス & 比較が優位 & $\begin{array}{c}\text { 比較がおそらく } \\
\text { 優位 }\end{array}$ & $\begin{array}{c}\text { 介入も比較もい } \\
\text { ずれも優位でな } \\
\text { い }\end{array}$ & $\begin{array}{c}\text { おそらく介入が } \\
\text { 優位 }\end{array}$ & 介入が優位 & さまざま & 分からない \\
\hline 容認性 & いいえ & $\begin{array}{c}\text { おそらく、いい } \\
\text { え }\end{array}$ & おそらく、はい & はい & & さまざま & 分からない \\
\hline 実行可能性 & いいえ & $\begin{array}{c}\text { おそらく、いい } \\
\text { え }\end{array}$ & おそらく、はい & はい & & さまざま & 分からない \\
\hline
\end{tabular}


CQ17-3：ICU-AW 予防に神経筋電気刺激を行う か?

Answer：敗血症患者に対して，標準的治療として ICU-AW 予防に神経筋電気刺激を行わないことを弱く 推奨する（GRADE 2D：エビデンスの確実性 $=$ 「非常 に低」)。

\section{（1）背景および本 $C Q$ の重要度}

ICU-AW は, 生命予後, 身体機能低下や健康関連 QOL 低下と関連している。敗血症や昇圧薬の使用は ICU-AW 発症のリスク因子とされている ${ }^{1)}$ 。神経筋電 気刺激は重症患者の筋力低下予防の効果が期待されて いるが，敗血症患者や昇圧薬の使用患者，浮腫のある 患者では有効な筋収縮が得られにくいという報告もあ り 1)，敗血症患者に対する神経筋電気刺激の有効性は 明らかではない。日本版敗血症診療ガイドライン （J-SSCG）2016では，敗血症患者あるいは集中治療患 者に対して，ICU-AW 予防として神経筋電気刺激を実 施しないことが弱く推奨した ${ }^{2,3)}$ 。その後の知見を踏 まえて本 CQ では神経筋電気刺激の ICU-AW の発症予 防効果について検証する。
(2) PICO

$P$ (患者)：成人集中治療患者

I (介入) : 神経筋電気刺激

$\mathrm{C}$ (対照) : 神経筋電気刺激の非実施

$\mathrm{O}$ (アウトカム)：ICU 退室時の ICU-AW，ICU 退室 時の筋力（MRC スコア）, 人工呼吸期間, 院内死 亡, ICU 滞在日数

\section{（3）エビデンスの要約}

システマティックレビューの結果，PICO に合致し たランダム化比較試験（RCT）が 10 件施行されてお り 4-13)，これらを用いたメタ解析を実施した。

（4）益と害のバランス（Table 17-3-1）

望ましい効果 :

ICU 退室時の ICU-AW（1 RCT: $\mathrm{n}=28 ）$ に対する効 果推定值は 1,000 人あたり 0 人の増減（183 人少な い〜 665 人多い), ICU 退室時の筋力（MRC スコア） （1 RCT: $\mathrm{n}=28 ）$ は, 平均（MD） 1.00 高い（4.19 低 い〜 6.19 高い)，人工呼吸期間（7 RCT: $\mathrm{n}=262 ） に$ ついては MD 1.56 日短い（3.12 日短い〜0.01 日長い)，

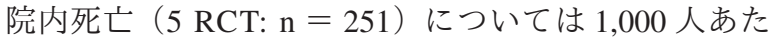

Table 17-3-1エビデンスプロファイル

\begin{tabular}{|c|c|c|c|c|c|c|c|c|c|c|c|c|}
\hline \multicolumn{7}{|c|}{ 確実性の評価 } & \multicolumn{2}{|c|}{ 患者数 } & \multicolumn{2}{|c|}{ 勃果 } & \multirow[b]{2}{*}{ 碓实性 } & \multirow[b]{2}{*}{ 重要性 } \\
\hline 研究数 & $\begin{array}{l}\text { 研究 } \\
\text { テザイン }\end{array}$ & $\begin{array}{l}\text { パイア } \\
\text { のリスク }\end{array}$ & 非一貫性 & 非直接性 & 不精確性 & $\begin{array}{l}\text { その他 } \\
\text { の检討 }\end{array}$ & 神経筋電気刺澈 & 通常ケア & 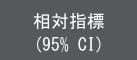 & $\begin{array}{l}\text { 絶対指摽 } \\
(95 \% \text { cI) }\end{array}$ & & \\
\hline \multicolumn{13}{|c|}{ ICU 退空時のICU-AW } \\
\hline 1 & RCT & 深刻 a & 深刻氏ない口 & 深刻てない。 & 非常1深刻 d & なし & $3 / 12(25.0 \%)$ & $4 / 16 \quad(25.0 \%)$ & $\begin{array}{c}\text { RR } 1.00 \\
\text { (0.27 to } 3.66)\end{array}$ & $\begin{array}{c}\text { 1, } 000 \text { 人あたり0 } \\
\text { 人少ない (183 } \\
\text { 少ない } 665 \text { 人多 } \\
\text { い) }\end{array}$ & $\begin{array}{l}\oplus \circ 0 \bigcirc \\
\text { 非常に低 }\end{array}$ & 重大 \\
\hline \multicolumn{13}{|c|}{ ICU 退坴時の筋力（MRC スコア） } \\
\hline 1 & RCT & 深刻 & 深刻てない口 & 深刻でい。 & 非常1深刻。 & なし & 12 & 16 & - & $\begin{array}{l}\text { 平均 } 1.00 \text { 高い } \\
(4.19 \text { 低い } \\
6.19 \text { 高い) }\end{array}$ & $\begin{array}{l}\oplus \circ O \bigcirc \\
\text { 非常に低 }\end{array}$ & 重大 \\
\hline \multicolumn{13}{|c|}{ 人工呼吸期間 } \\
\hline 7 & RCT & 深刻 $\mathrm{f}$ & 深刻てないる & 深刻でい。 & 非常1深刻。 & なし & 132 & 130 & - & $\begin{array}{c}\text { 平均 } 1.56 \text { 日短い } \\
(3.12 \text { 日短い } \\
0.01 \text { 日長い) }\end{array}$ & $\begin{array}{l}\oplus \circ 0 \bigcirc \\
\text { 非常に低 }\end{array}$ & 重大 \\
\hline \multicolumn{13}{|c|}{ 院内死亡 } \\
\hline 5 & RCT & 深刻 h & 深刻てない & 深刻てない。 & 非常|深刻 $\mathrm{d}$ & なし & $\begin{array}{l}39 / 127 \\
(30.7 \%)\end{array}$ & $\begin{array}{l}40 / 124 \\
(32.3 \%)\end{array}$ & $\begin{array}{c}\text { RR } 0.88 \\
\text { (0. } 46 \text { to } 1.68)\end{array}$ & $\begin{array}{c}1,000 \text { 人あたり } 39 \\
\text { 人少ない (174人 } \\
\text { 少ない 219人多 } \\
\text { (1) }\end{array}$ & $\begin{array}{l}\oplus \oplus^{\oplus 0} \\
\text { 非常に低 }\end{array}$ & 重大 \\
\hline \multicolumn{13}{|c|}{ ICU 滞在日数 } \\
\hline 5 & RCT & 深刻 & 深刻 k & 深刻てない。 & 非常1深刻。 & なし & 99 & 113 & - & $\begin{array}{c}\text { 平均 } 3.23 \text { 日長い } \\
(3.35 \text { 日短い } \\
9.81 \text { 日長い) }\end{array}$ & $\begin{array}{l}\oplus \circ 0 \bigcirc \\
\text { 非常に=低 }\end{array}$ & 重大 \\
\hline
\end{tabular}

a. バイアスのリスクが高。

b. 1 つの研究のみ。

c. 敗血症と非敗血症で介入のインパクトに差がない。

d. 患者数 4,000 人未満。

患者数 400 人未渶。

$I^{2} 20 \%$

． $63 \%$ を占める。選択バイアスが高か不明。

i. $\mathrm{I}^{2} 39 \%$

j. 2 つのアウトカムで, バイアスのリスクが 2 つ以上。

$\mathrm{I}^{2} 88 \%$ 
り 39 人少ない（174 人少ない〜 219 人多い, ICU 滞在 日数（5 RCT: $\mathrm{n}=212 ）$ は MD 3.23 日長い（3.35 日短 い〜9.81 日長い）であった。望ましい効果はわずかで あると判断した。

望ましくない効果 :

アウトカムの 1 つとしてあらゆる有害事象（疼痛, 不快感，パッドのアレルギー）を設定したが，論文の 結果に記載がないため, 評価できなかった。望ましく ない効果については不明である。

（5）アウトカム全般に関するエビデンスの確実性

今回採用したすべてのアウトカムの効果推定值の方 向性は一致しているため, 一番高いアウトカムの確実 性を全体としては採用した。アウトカム全体にわたる エビデンスの確実性は「非常に低」である。

\section{（6）価値観}

ICU-AW 予防に神経筋電気刺激における, 各アウト カムに置く患者・家族の価值観に関するデータはな い。一般的に， ICU-AW の診断基準の 1 つである筋力 に対して置く相対的価值は高く，そのばらつきは少な いことが予想される。

\section{（7）容認性}

神経筋電気刺激実施によって医療者の仕事量が増加 することが予測されるが，その労働負担は多くないと 考えられる。

\section{（8）実行可能性}

介入には “神経筋電気刺激装置”といった機器を要 するため, 機器を有さない施設での施行は機器の購入 などを要する。したがって, その実行可能性は「おそ らく, いいえ」であると判断した。

(9) 判断の要約 (Table 17-3-2)

（10）推奨グレーディング決定の工程

修正 RAND 法を用いた投票によって，中央值 7.5, 見解不一致指数 0.164 の結果となり，委員会で採択さ れた（7 点以上 : 100\%)。

\section{（11）関連する他の診療ガイドラインにおける推奨} なし。

\section{（12）実施に関わる検討事項}

重症患者全例に対する標準的治療としては行わない ことが望まれる。

（13）今後の研究の可能性

以下の内容に関するさらなる検討が求められるであ ろう。

・敗血症に限定した研究

・電気筋刺激導入による理学療法士の負担の軽減の検 討

・電気筋刺激導入による早期リハビリテーション開始 の検討

・電気筋刺激導入によるリハビリテーション施行患者

Table 17-3-2 判断の要約

\begin{tabular}{|c|c|c|c|c|c|c|c|}
\hline & \multicolumn{7}{|c|}{ 判断 } \\
\hline 問題 & いいえ & $\begin{array}{c}\text { おそらく、いい } \\
\text { え }\end{array}$ & おそらく、はい & はい & & さまざま & 分からない \\
\hline 望ましい勃果 & わずか & 小さい & 中 & 大きい & & さまざま & 分からない \\
\hline 望ましくない効果 & 大きい & 中 & 小さい & わずか & & さまざま & 分からない \\
\hline エビデンスの確実性 & 非常に低 & 低 & 中 & 高 & & & 採用研究なし \\
\hline 価值钼 & $\begin{array}{c}\text { 重要な不確実性 } \\
\text { またはばらつき } \\
\text { あり }\end{array}$ & $\begin{array}{c}\text { 重要な不確実性 } \\
\text { またはばちう } \\
\text { の可能性ありり }\end{array}$ & $\begin{array}{l}\text { 重要な不確実性 } \\
\text { またはばらつき } \\
\text { はおそらくなし }\end{array}$ & $\begin{array}{c}\text { 重要な不確実性 } \\
\text { またはばらつき } \\
\text { はなし }\end{array}$ & & & \\
\hline 効果のバランス & 比較が優位 & $\begin{array}{c}\text { 比較がおそらく } \\
\text { 優位 }\end{array}$ & $\begin{array}{c}\text { 介入も比較もい } \\
\text { ずれも優位でな } \\
\text { い }\end{array}$ & $\begin{array}{c}\text { おそらく介入が } \\
\text { 優位 }\end{array}$ & 介入が優位 & さまざま & 分からない \\
\hline 容認性 & いいえ & $\begin{array}{c}\text { おそらく、いい } \\
\text { え }\end{array}$ & おそらく、はい & はい & & さまざま & 分からない \\
\hline 実行可能性 & いいえ & $\begin{array}{c}\text { おそらく、いい } \\
\text { え }\end{array}$ & おそらく、はい & はい & & さまざま & 分からない \\
\hline
\end{tabular}


数の検討

\section{文 献}

1) Van Aerde N, Meersseman $P$, Debaveye $Y$, et al: Five-year impact of ICU-acquired neuromuscular complications: a prospective, observational study. Intensive Care Med. 2020; 46: 1184-93.

2) Nishida O, Ogura H, Egi M, et al: The Japanese Clinical Practice Guidelines for Management of Sepsis and Septic Shock 2016 (J-SSCG 2016). Acute Med Surg. 2018; 5: 3-89.

3) Nishida O, Ogura H, Egi M, et al: The Japanese Clinical Practice Guidelines for Management of Sepsis and Septic Shock 2016 (J-SSCG 2016). J Intensive Care. 2018; 6: 7.

4) Akar O, Gunay E, Sarinc Ulasli S, et al: Efficacy of neuromuscular electrical stimulation in patients with COPD followed in intensive care unit. Clin Respir J. 2017; 11: 743-50.

5) Dos Santos FV, Cipriano G, Jr, Vieira L, et al: Neuromuscular electrical stimulation combined with exercise decreases duration of mechanical ventilation in ICU patients: A randomized controlled trial. Physiother Theory Pract. 2020; 36: 580-8.

6) Gerovasili V, Stefanidis K, Vitzilaios K, et al: Electrical muscle stimulation preserves the muscle mass of critically ill patients: a randomized study. Crit Care. 2009; 13: R161.

7) Gruther W, Kainberger F, Fialka-Moser V, et al: Effects of neuromuscular electrical stimulation on muscle layer thickness of knee extensor muscles in intensive care unit patients: a pilot study. J Rehabil Med. 2010; 42: 593-7.

8) Kho ME, Truong AD, Zanni JM, et al: Neuromuscular electrical stimulation in mechanically ventilated patients: a randomized, sham-controlled pilot trial with blinded outcome assessment. J Crit Care. 2015; 30: 32-9.

9) Koutsioumpa E, Makris D, Theochari A, et al: Effect of Transcutaneous Electrical Neuromuscular Stimulation on Myopathy in Intensive Care Patients. Am J Crit Care. 2018; 27: 495-503.

10) Ojima M, Takegawa R, Hirose T, et al: Hemodynamic effects of electrical muscle stimulation in the prophylaxis of deep vein thrombosis for intensive care unit patients: a randomized trial. J Intensive Care. 2017; 5: 9.

11) Routsi C, Gerovasili V, Vasileiadis I, et al: Electrical muscle stimulation prevents critical illness polyneuromyopathy: a randomized parallel intervention trial. Crit Care. 2010; 14: R74.

12) Abu-Khaber HA, Abouelela AMZ, Abdelkarim EM: Effect of electrical muscle stimulation on prevention of ICU acquired muscle weakness and facilitating weaning from mechanical ventilation. Alexandria J Med. 2013; 49: 309-15.

13) Shen SY, Lee CH, Lin RL, et al: Electric Muscle Stimulation for Weaning from Mechanical Ventilation in Elder Patients with Severe Sepsis and Acute Respiratory Failure - A Pilot Study. Int J Gerontol. 2017; 11: 41-5. 


\section{CQ18：小児}

\section{背景}

小児敗血症は現在も罹患者 10〜20\% が死亡する重篤 な病態であり，敗血症性ショックではさらに死亡率は 高い 1, 2)。2005 年に Goldstein らにより systemic inflammatory response syndrome（SIRS）とともに小児敗血症 が国際的に初めて定義され ${ }^{3)}$ ， $\mathrm{SSCG}^{4}$ ) や Global Sepsis Alliance（GSA）5, 6) といった活動を通じて, 臨床的な 重要性の認識が広まった。SSCG は2008 年版7)と 2012 年版 ${ }^{8)}$ において “Pediatric considerations”という セクションを設けて小児敗血症診療に関する推奨を掲 載している。しかし, Goldstein らによる小児のSIRS 基準や敗血症の診断基準 3 ) は多くの批判を受け，日本 版敗血症診療ガイドライン（J-SSCG）2016では小児 敗血症に関して 15 件の CQ が立案されたが，そのうち 4 件を定義に関する疑問が占めた 9,10$)$ 。

その後, 2016 年に成人領域において, 敗血症の定 義は, SOFA スコア11) による臟器障害の評価をべー スとする Sepsis-3に移行した ${ }^{12) 。 し か し ， S O F A ~ ス コ ~}$ アは小児に適用する妥当性が証明されていないこと や，成人とは致死率が異なることを理由に小児の定義 変更は見送られ，SSCG 2016 でも小児敗血症には言及 されなかった ${ }^{13)}$ 。過去 4 年間に複数の小览 SOFA ス コアが提唱されており 14-16)，現在それらを統一しょ うとする国際的な動きが活発になっている。

\section{$\mathrm{CQ}$ 設定と推奨作成}

J-SSCG 2016 発刊後の使用実態調査では，小児に関 する項目の遵守状況は $5 \%$ 未満にとどまることが報告

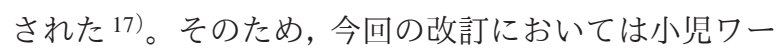
キンググループ (WG) として“使ってもらえるガイ ドライン”を目標に掲げ，小児敗血症診療の流れを精 查し, 臨床家が決断を迷いやすいと思われる場面を再 検討することから作業を開始した。なお，本ガイドラ インでは，近い将来，小児領域でも Sepsis-3 ${ }^{12 ）}$ に準 じた定義変更が行われることを見越して，J-SSCG $2016^{9}$ ，10）で積極的に取り上げた定義に関する疑問は $\mathrm{CQ}$ 立案を見送った。

当初は 14 件の $\mathrm{CQ}$ が立案されたが，このうち初期 輸液蘇生に不応の敗血症の管理方針に関する $\mathrm{CQ}$ は委 員会において成人・小児を問わない共通性が指摘さ れ, GPS（Good Practice Statement）として推奨が決定 された（CQ21-3を参照）。その結果，小児 WGでは 残りの 13 件に関してさらなる検討が進められた。こ れらのうち，5件については BQ として情報提供を
行った（経験的抗菌薬，抗ヘルペスウイルス薬，血圧 の管理目標值, 輸液に対する反応の評価方法, 初期輸 液の速度と量)。また， 1 件についてはシステマティッ クレビューにより適切なランダム化比較試験（RCT） が得られず，エキスパートコンセンサスとして推奨を 作成した (免疫グロブリン療法)。さらに, 残りの 7 件についてはGRADEの方法論に則ってシステマ ティックレビュー結果を受ける形で推奨を作成した （診療アルゴリズムの適用, 循環作動薬の第一選択, バソプレシン, ステロイド, 赤血球輸血, 急性血液浄 化療法, 厳密な血糖管理)。

また， 2020 年 5 月現在，小児敗血症の定義は厳密 には Goldstein らによる SIRS 基準を踏まえた診断基準 のままである3）が，成人領域の CQ との一貫性も考 慮し, 小児領域の CQ でも臟器機能障害を伴う感染症 を“敗血症”，その中で循環不全を伴う敗血症を “敗 血症性ショック”と表記した。ただし, システマ ティックレビューにあたっては, Goldstein らの定義 した “重症敗血症 (severe sepsis)”という用語 ${ }^{3)} も$ 含 めて検討した。

システマティックレビューの結果，依然として小児 に特化したエビデンスは非常に乏しいことが明らかに なったものの，一部の疑問に対して新たに RCT が行

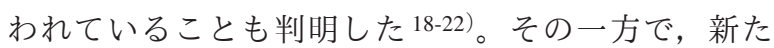
な研究がまったく行われていない疑問も少なくなく, 成人領域でのエビデンスの動向も加味しながら慎重に 推奨を検討する必要があった。

\section{注意点}

まず重要なポイントとして，J-SSCG 20169，10）と同 じく, 本ガイドラインにおける小児敗血症に関連した $\mathrm{CQ}$ は，その診療に関わるすべての問題を網羅的に取 り上げることを目的とはせず，小児敗血症の診療現場 において決断を迷いやすいと思われる項目に的を絞っ て立案されていることに留意されたい。

次に，小児集中治療室（PICU）で診療する対象は， 主として乳児および小児患者であるが，なかには生後 28 日未満の新生児も含まれる。新生児でも早産児・ 未熟児, あるいは出生直後の胎児期からの移行期にお ける問題は新生児集中治療室 (NICU) の担当領域で あるため，本ガイドラインのスコープには含まず，新 生児のみに関連した $\mathrm{CQ}$ は作成しなかった。ただし， データ解析あるいは解説文に（正期産・成熟）新生児 が含まれたものが存在することはありうる。一方で, “小児” の年齢定義は, 論文ごと, あるいは国や地域 ごとに思春期層を含めるかどうかなどで異なることも 
あり，厳密に定義しなかった。より厳密には，年齢層 による感染症や基礎疾患の差違が存在するため, 年齢 層別の検討が行われる余地はあるものの, 前述の通り 知見に乏しいうえ，非直接性を増すリスクに鑑み，行 わなかった。
さらに，成人領域との整合性についても言及する。 小児領域のみを対象とした良質な科学的根拠があれば これを優先し，一方で明確な根拠がない場合は，推奨 度合いなども含め, 成人領域との整合性を図った。こ れは，他の多くの診療ガイドラインでもみられる通

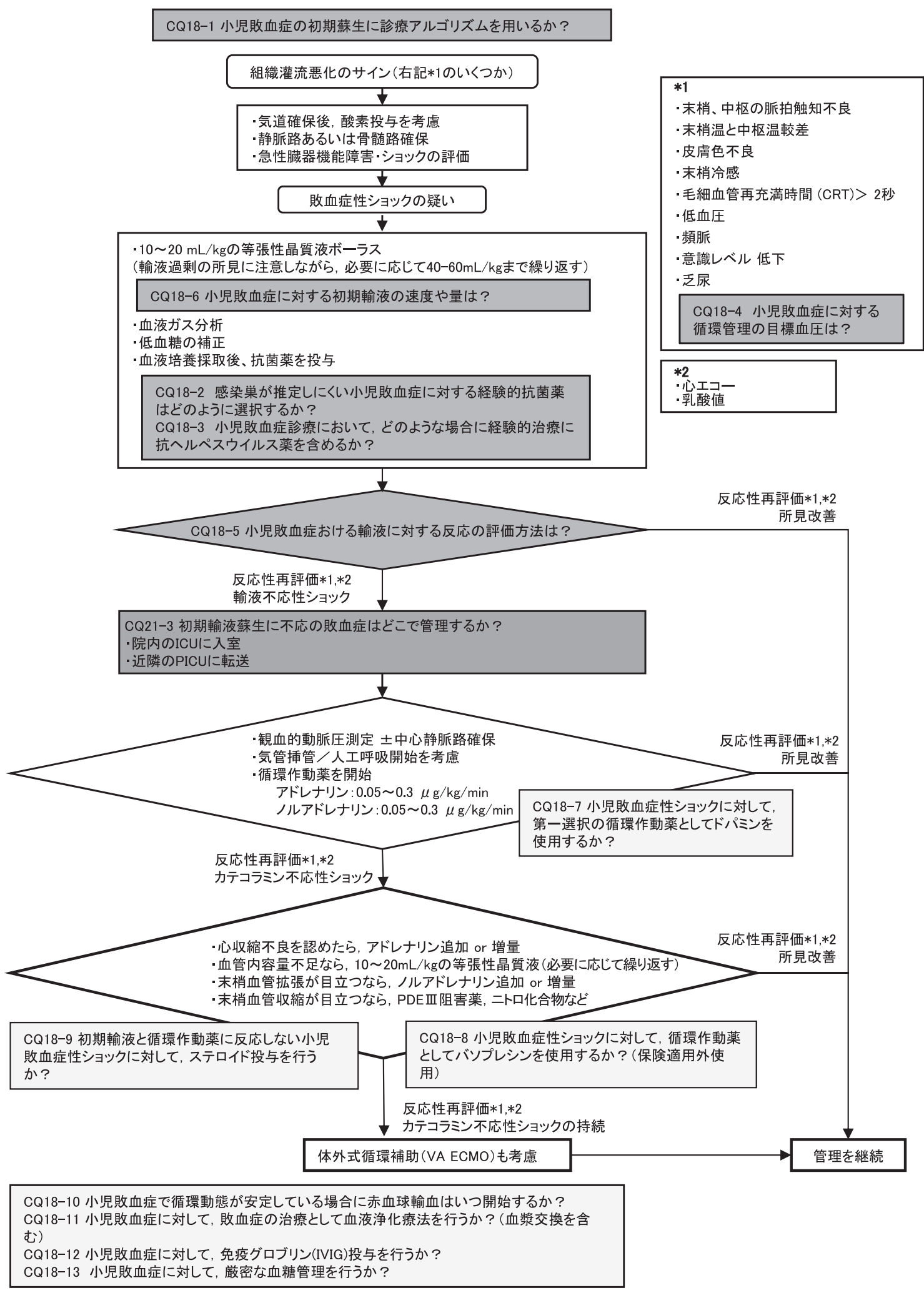

小児敗血症性ショック〔診療フロー〕 
り, 成人の根拠や推奨の整理を踏まえたうえで小児で の知見を補足することが，科学的にも現実的にも妥当 な手段であると考慮したためである。実臨床におい て, 解剖学的にも生理学的にも, 思春期層の病態は成 人と同様に考えて診療して良いであろうが，幼児から 乳児へと若年になるほどその年齢層特有の相違が大き くなることに留意する。

J-SSCG 2016 で揭載した小児敗血症の初期診療アル ゴリズム9,10) に関しても，今回のガイドラインにお ける推奨を反映させる形で, 担当グループ専門家によ る提案として若干の改定を行った。このアルゴリズム のすべての内容が今回の CQ に取り挙げられているわ けではなく, 科学的根拠に乏しいものも含まれてお り，かつ本アルゴリズム自体の妥当性も確認されては いないが，診療の参考になれば幸甚である。

最後に, 敗血症や敗血症性ショックはあくまでも症 候群である。臨床現場において当初は敗血症の可能性 を含めて診療を開始する場合でも, 原因が本当に感染 症によるものか, そうでないのか（川崎病や血球荟食 性リンパ組織球症などの，いわゆる “sepsis-mimicker, sepsis-mimicking diseases”）を見極めることがむずか しい状況も少なくない。そのような場合には, 本ガイ ドラインの推奨だけにとらわれず，柔軟に方針を決定 されるようお願いしたい。

\section{展望}

今回のシステマティックレビューの過程で新たに収 集された RCT も含めて ${ }^{18-22)}$ ，特に大規模な小児敗血 症の RCT は少なからず途上国や新興国から出版され ているという現状がある ${ }^{23)}$ 。途上国では依然として 市中における感染症や敗血症がヘルスケアの中心課題 であることや，患者リクルートが容易であることなど がその要因と考えられるが, 途上国で行われた研究結 果を本邦の医療環境に外指する際には, 非直接性の点 から慎重な吟味を要すると思われる。

また，転帰指標として短中期的な生命予後のみなら ず，小児患者だからこその長期的な生命予後や機能予 後の検討は非常に重要であろう。現在, 生存患者の集 中治療後症候群 (post-intensive care syndrome: PICS) が話題になっている24-27) が，小児の PICS (PICS-p) の各領域の問題は相互に関連し合いながら最終的にす べて発達予後に影響を与えることが指摘されてい る 28-30)。小児生存患者の機能予後や発達予後の評価 方法は至難を極めるが，今後の知見の集積を切望した い。

\section{文 献}

1) Weiss SL, Fitzgerald JC, Pappachan J, et al: Global Epidemiology of Pediatric Severe Sepsis: The Sepsis Prevalence, Outcomes, and Therapies Study. Am J Respir Crit Care Med. 2015; 191 : 1147-57.

2) Shime N, Kawasaki T, Saito O, et al: Incidence and risk factors for mortality in paediatric severe sepsis: results from the national paediatric intensive care registry in Japan. Intensive Care Med. 2012; 38: 1191-7.

3) Goldstein B, Giroir B, Randolph A, et al: International pediatric sepsis consensus conference: definitions for sepsis and organ dysfunction in pediatrics. Pediatr Crit Care Med. 2005; 6: 2-8.

4) Society of Critical Care Medicine: Surviving Sepsis Campaign (SSC). Available online at: https://www.sccm.org/SurvivingSepsi sCampaign/Home. Accessed May16, 2020.

5) Global Sepsis Alliance. Available online at: https://www.globalsepsis-alliance.org/. Accessed May 16, 2020.

6) 日本集中治療医学会, 日本救急医学会: 敗血症. com. Available online at: http:// 敗血症. com/. Accessed May16, 2020.

7) Dellinger RP, Levy MM, Carlet JM, et al: Surviving Sepsis Campaign: international guidelines for management of severe sepsis and septic shock: 2008. Intensive Care Med. 2008; 34 : 17-60.

8) Dellinger RP, Levy MM, Rhodes A, et al: Surviving sepsis campaign: international guidelines for management of severe sepsis and septic shock: 2012. Crit Care Med. 2013; 41: 580-637.

9）西田修, 小倉裕司, 井上茂亮, 他: 日本版敗血症診療ガイドラ イン 2016 作成特別委員会. 日本版敗血症診療ガイドライン 2016. 日集中医誌. 2017; 24: S1-232.

10）西田修, 小倉裕司, 井上茂亮, 他: 日本版敗血症診療ガイドラ イン 2016 作成特別委員会. 日本版敗血症診療ガイドライン 2016. 日救急医会誌. 2017; 28: S1-232.

11) Vincent JL, Moreno R, Takala J, et al: The SOFA (Sepsis-related Organ Failure Assessment) score to describe organ dysfunction/ failure. On behalf of the Working Group on Sepsis-Related Problems of the European Society of Intensive Care Medicine. Intensive Care Med. 1996; 22: 707-10.

12) Singer M, Deutschman CS, Seymour CW, et al: The Third International Consensus Definitions for Sepsis and Septic Shock (Sepsis-3). JAMA. 2016; 315: 801-10.

13) Rhodes A, Evans LE, Alhazzani W, et al: Surviving Sepsis Campaign: International Guidelines for Management of Sepsis and Septic Shock: 2016. Crit Care Med. 2017; 45: 486-552.

14) Matics TJ, Sanchez-Pinto LN: Adaptation and Validation of a Pediatric Sequential Organ Failure Assessment Score and Evaluation of the Sepsis-3 Definitions in Critically Ill Children. JAMA Pediatr. 2017; 171: e172352.

15) Shime N, Kawasaki T, Nakagawa S: Proposal of a New Pediatric Sequential Organ Failure Assessment Score for Possible Validation. Pediatr Crit Care Med. 2017; 18: 98-9.

16) Schlapbach LJ, Straney L, Bellomo R, et al: Prognostic accuracy of age-adapted SOFA, SIRS, PELOD-2, and qSOFA for in-hospital mortality among children with suspected infection admitted to the intensive care unit. Intensive Care Med. 2018; 44: 179-88.

17）日本版敗血症診療ガイドライン 2016 作成特別委員会: 日本 版敗血症診療ガイドライン 2016 の使用に関する実態調査報 告. 日集中医誌. 2018; 25: 271-7.

18) Ramaswamy KN, Singhi S, Jayashree M, et al: Double-Blind Randomized Clinical Trial Comparing Dopamine and Epinephrine in Pediatric Fluid-Refractory Hypotensive Septic Shock. Pediatr Crit Care Med. 2016; 17: e502-12.

19) Menon K, McNally D, O’Hearn K, et al: A Randomized Controlled Trial of Corticosteroids in Pediatric Septic Shock: A 
Pilot Feasibility Study. Pediatr Crit Care Med. 2017; 18: 505-12.

20) El-Nawawy A, Khater D, Omar H, et al: Evaluation of Early Corticosteroid Therapy in Management of Pediatric Septic Shock in Pediatric Intensive Care Patients: A Randomized Clinical Study. Pediatr Infect Dis J. 2017; 36: 155-9.

21) Akyildiz B, Ulgen Tekerek N, Pamukcu O, et al: Comprehensive Analysis of Liberal and Restrictive Transfusion Strategies in Pediatric Intensive Care Unit. J Trop Pediatr. 2018; 64: 118-25.

22) Agus MS, Wypij D, Hirshberg EL, et al: Tight glycemic control in critically Ill children. N Engl J Med. 2017; 376: 729-41.

23) Maitland K, Kiguli S, Opoka RO, et al: Mortality after Fluid Bolus in African Children with Severe Infection. N Engl J Med. 2011; 364: 2483-95.

24) Needham DM, Davidson J, Cohen H, et al: Improving long-term outcomes after discharge from intensive care unit: report from a stakeholders' conference. Crit Care Med. 2012; 40: 502-9.

25) Elliott D, Davidson JE, Harvey MA, et al: Exploring the Scope of Post-Intensive Care Syndrome Therapy and Care: Engagement of Non-Critical Care Providers and Survivors in a Second Stakeholders Meeting. Crit Care Med. 2014; 42: 2518-26.

26) Inoue S, Hatakeyama J, Kondo Y, et al: Post-intensive care syndrome: its pathophysiology, prevention, and future directions. Acute Med Surg. 2019; 6: 233-46.

27）日本集中治療医学会: PICS 集中治療後症候群. Available online at: https://www.jsicm.org/provider/pics.html. Accessed May 19, 2020.

28) Watson RS, Choong K, Colville G, et al: Life after Critical Illness in Children-Toward an Understanding of Pediatric Post-intensive Care Syndrome. J Pediatr. 2018; 198: 16-24.

29) Manning JC, Pinto NP, Rennick JE, et al: Conceptualizing Post Intensive Care Syndrome in Children-The PICS-p Framework. Pediatr Crit Care Med. 2018; 19: 298-300.

30) Fink EL, Watson RS: PICS-p: It Is About Time (and Family) ! But How Did Adult Medicine Beat Pediatrics to a Holistic View of the Patient? Pediatr Crit Care Med. 2018; 19: 375-7.

\section{CQ18-1：小児敗血症の初期蘇生に診療アルゴリ ズムを用いるか?}

Answer : 小児敗血症の初期蘇生に診療アルゴリズム を使用することを弱く推奨する（GRADE 2D：エビデ ンスの確実性 $=「$ 非常に低」)。

\section{（1）背景および本 CQ の重要度}

小児敗血症患者の致死率は高く，治療成績を向上さ せる介入方法の確立は急務である。小児敗血症性 ショックの治療に際して, 系統的なアプローチで評価 と介入を行い, 可能な限り早急にショックから回復さ せることが重要である。小児敗血症に対する American College of Critical Care Medicine - Pediatric Advanced Life Support（ACCM-PALS）アルゴリズム 1-3）は世界的に 普及している 4-6）が，その妥当性と信頼性の検証が必 要であると考えられる。

(2) $\mathrm{PICO}$

P (患者): Goldstein 定義での敗血症性ショック, 重症敗血症, または感染症による臓器障害を来し た小児患者（新生児領域を除く）

I（介入）：診療アルゴリズム（ACCM-PALS アルゴ リズム, early goal-directed therapy（EGDT）を含 む）を利用した管理

$\mathrm{C}$ (対照) : 診療アルゴリズムに依らない管理

$\mathrm{O}$ (アウトカム ) : 死亡，ショック離脱期間

\section{（3）エビデンスの要約}

システマティックレビューの結果, PICO に合致し たものは，1 件の観察研究のみであった ${ }^{7) 。}$

\section{（4）益と害のバランス（Table 18-1-1）}

望ましい効果 :

本 CQ に対するランダム化比較試験（RCT）は存在 せず， 1 件の観察研究を採用し 7), ROBINS-I に則っ て効果とバイアスの評価を行った。採用された 1 件の 観察研究では, ACCM-PALS アルゴリズム 1) が介入 としてコホート比較で検討されていた。死亡アウトカ ム（1 観察研究 : $n=91 ）$ に対する効果推定值はリス ク差（RD）1,000人あたり 303 人少ない（95\% CI: 357 人少ない〜 107 人少ない）であり，望ましい効果が期 待された。なお，ショック離脱期間のアウトカムにつ いてはそれを検討した文献が得られず，介入の効果は 推定できなかった。 
Table 18-1-1 エビデンスプロファイル

\begin{tabular}{|c|c|c|c|c|c|c|c|c|c|c|c|c|}
\hline \multicolumn{7}{|c|}{ 碓実性の評価 } & \multicolumn{2}{|c|}{ 患者数 } & \multicolumn{2}{|c|}{ 勃果 } & \multirow[b]{2}{*}{ 碓実性 } & \multirow[b]{2}{*}{ 重要性 } \\
\hline 研究数 & $\begin{array}{l}\text { 研究 } \\
\text { デサイン }\end{array}$ & $\begin{array}{l}\text { パイアス } \\
\text { のリスク }\end{array}$ & 非一其性 & 非直接性 & 不精磼性 & $\begin{array}{l}\text { その他 } \\
\text { の梌詂 }\end{array}$ & $\begin{array}{c}\text { New } \\
\text { Comparison }\end{array}$ & Placebo & $\begin{array}{l}\text { 相対指懵 } \\
(95 \%, 0 I)\end{array}$ & 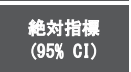 & & \\
\hline \multicolumn{13}{|l|}{ 死亡 } \\
\hline 1 & 観察研究 & 非常|深刻a & 深刻てない & 深刻でい & 深刻 b & $\begin{array}{c}\text { 全てのありそ } \\
\text { うな残余交絡 } \\
\text { が, 効果が観 } \\
\text { 察されていな } \\
\text { いのに, 誤っ } \\
\text { た効果を示唆 } \\
\text { している }\end{array}$ & $2 / 27 \quad(7.4 \%)$ & $\begin{array}{l}24 / 64 \\
(37.5 \%)\end{array}$ & $\begin{array}{l}\text { OR } 0.13 \\
(0.03 \text { to } \\
0.61)\end{array}$ & $\begin{array}{c}1,000 \text { 人あた } \\
\text { り } 303 \text { 人少な } \\
\text { い } \\
(357 \text { 人少な } \\
\text { い〜107 人少 } \\
\text { ない) } \\
\text { ない }\end{array}$ & $\underset{\text { 低 }}{\oplus \oplus \bigcirc}$ & 重大 \\
\hline
\end{tabular}

a. 診療ガイドライン群は軽症となるが交絡因子の調整をしていないため。

b、最適情報量を満たさない。

\section{望ましくない効果 :}

望ましくない効果となる重大なアウトカムの評価は 事前に計画されなかった。診療アルゴリズムを用いて 初期蘇生を実施することにより輸夜過剩を来すことが 懸念されるが，その影響は死亡率の上昇に反映される と予測できるため，それ以外の望ましくない効果をも たらすアウトカムを重大なものとしては検討しなかっ た。

\section{益と害のバランス :}

本 CQ においては望ましくない効果をもたらすアウ トカムが検討されていないが，望ましい効果は大き く，介入が優位と推定するのが妥当であろう。

\section{（5）アウトカム全般に関するエビデンスの確実性}

採用されたのは 1 件の観察研究のみである7)。診療 アルゴリズム群が比較よりも軽症となりうるが，重症 度などの交絡因子の調整は行われていなかった。唯一 検討されたアウトカムに対するエビデンスの確実性は 「低」であるが， 1 件の観察研究のみに基づく非常に 深刻なバイアスのリスクと，イベント数が小さいこと に起因する深刻な不精確さを加味し，エビデンス総体 としては「非常に低」と判断した。

\section{（6）価値観}

小児敗血症患者に対して, 診療ガイドラインを利用 した管理における各アウトカムに置く患者・家族の価 值観に関するデータはない。一般的に，死亡アウトカ ムに対して置く相対的価值は高く，そのばらつきは少 ないことが予想される。

\section{（7）容認性}

本介入に伴うコストは通常の敗血症診療に伴う介入 と同等である。早期の昇圧薬使用などが実施されたと しても，そのコストは患者・家族の個人の視点からお そらく許容できる。一方, 診療アルゴリズムを利用し た介入は来院後短時間で多くのバンドル化された介入
を実施する必要がある。小児敗血症性ショックの発生 頻度が成人より低いにしても, 特に人手が乏しい施設 での医療者にとっては労力の増加は免れ得ないが，介 入を否定するほどではないと考える。

\section{（8）実行可能性}

診療アルゴリズムにバンドル化された個々の介入は 短時間のうちに実施する必要があり，広く世界に普及 しているアルゴリズムとはいえ，人手やスキルの問題 などにより本介入を実行できない施設が存在する可能 性がある。

\section{（9）判断の要約（Table 18-1-2）}

採用された研究は 1 件の観察研究のみであり 7$)$, ACCM-PALS アルゴリズム 1) に基づいた介入が検討 されていた。介入に関して望ましい効果が期待できる にせよ，非常に深刻なバイアスも含むことからエビデ ンスの確実性は「非常に低」である。したがって，介 入に対する強い推奨はできない。

なお，小児敗血症の診療アルゴリズムの主体となる 介入は初期輸夜蘇生である。初期輸液蘇生に限定した 介入効果を検討した多施設非盲検 RCT (FEAST trial） ${ }^{8)}$ では，急速輸液なし群と比較して急速輸液群 で死亡率が高い結果となった。これは輸液過剩に対す る警鐘ともいえるが，本邦と診療環境が異なることに 留意する必要がある。また，成人の EGDT を検討し た 3 つの大規模 $\mathrm{RCT}^{9-111)}$ では，いずれも生命予後は 改善しなかったが，EGDTに依らない通常管理群でも 割り付け開始前に比較的充分量の初期輸液蘇生がなさ れていたことを考慮する必要がある。それらを総合的 に判断し，条件付きの推奨とした。

\section{（10）推奨グレーディング決定の工程}

修正 RAND 法を用いた投票によって，中央值 7, 見解不一致指数 0.164 の結果となり, 委員会で採択さ れた（7 点以上 : 91.7\%)。 
Table 18-1-2 判断の要約

\begin{tabular}{|c|c|c|c|c|c|c|c|}
\hline & \multicolumn{7}{|c|}{ 判断 } \\
\hline 問題 & いいえ & $\begin{array}{c}\text { おそらく、いい } \\
\text { え }\end{array}$ & おそらく、はい & はい & & さまざま & 分からない \\
\hline 望ましい効果 & わずか & 小さい & 中 & 大きい & & さまざま & 分からない \\
\hline 望ましくない効果 & 大きい & 中 & 小さい & わずか & & さまざま & 分からない \\
\hline エビデンスの確実性 & 非常に低 & 低 & 中 & 高 & & & 採用研究なし \\
\hline 価值襀 & $\begin{array}{c}\text { 重要な不確実性 } \\
\text { またははららつき } \\
\text { あり }\end{array}$ & $\begin{array}{c}\text { 重要な不確実性 } \\
\text { またはばらつき } \\
\text { の可能性あり }\end{array}$ & $\begin{array}{l}\text { 重要な不確実性 } \\
\text { またはばらつき } \\
\text { はおそらくなし }\end{array}$ & $\begin{array}{c}\text { 重要な不確実性 } \\
\text { またはばらつき } \\
\text { はなし }\end{array}$ & & & \\
\hline 効果のバランス & 比較が優位 & $\begin{array}{c}\text { 比較がおそらく } \\
\text { 優位 }\end{array}$ & $\begin{array}{c}\text { 介入も比較もい } \\
\text { ずれも優位でな } \\
\text { い }\end{array}$ & $\begin{array}{c}\text { おそらく介入が } \\
\text { 優位 }\end{array}$ & 介入が優位 & さまざま & 分からない \\
\hline 容認性 & いいえ & $\begin{array}{c}\text { おそらく、いい } \\
\text { え }\end{array}$ & おそらく、はい & はい & & さまざま & 分からない \\
\hline 実行可能性 & いいえ & $\begin{array}{c}\text { おそらく、いい } \\
\text { え }\end{array}$ & おそらく、はい & はい & & さまざま & 分からない \\
\hline
\end{tabular}

\section{（11）関連する他の診療ガイドラインにおける推奨}

日本版敗血症診療ガイドライン（J-SSCG）2016 で は，「小児敗血症診療においては，ACCM-PALS 初期 治療アルゴリズムを，患者の状態や現場の必要性に応 じて用いうる（エキスパートコンセンサス/エビデン スなし)」と記載されている12,13)。

SSCG in children 2020 では, ACCM-PALS や EGDT など特定の診療アルゴリズムを推奨していない。ただ し， best practice statement として，敗血症の小児に対 してバンドル的なプロトコルやガイドラインを用いて 診療することを推奨している ${ }^{14)}$ 。

\section{（12）実施に関わる検討事項}

小児敗血症の初期蘇生においては，末梢循環不全や 臓器灌流の改善所見をこまめに評価すると同時に，湿 性ラ音や新たな努力呼吸, 肝腫大といった輸液過剩の 所見の出現を見逃さないように注意する13,14）。

\section{（13）今後の研究の可能性}

既に広く世界に普及している診療アルゴリズムであ り，本邦と同等の診療環境下での RCT 実施は困難で あることが予想される。しかしながら，輸液過剰に対 して警鐘的な示唆が報告される $8,15,16)$ など，小児敗 血症の初期蘇生アルゴリズムを構成する個々の介入要 素については今後も慎重な検討が必要である。

\section{文 献}

1) Carcillo JA, Fields AI: American College of Critical Care Medicine Task Force Committee Members: Clinical practice parameters for hemodynamic support of pediatric and neonatal patients in septic shock. Crit Care Med. 2002; 30: 1365-78.

2) Brierley J, Carcillo JA, Choong K, et al: Clinical practice parameters for hemodynamic support of pediatric and neonatal septic shock: 2007 update from the American College of Critical Care Medicine. Crit Care Med. 2009; 37: 666-88.

3) Davis AL, Carcillo JA, Aneja RK, et al: American College of Critical Care Medicine Clinical Practice Parameters for Hemodynamic Support of Pediatric and Neonatal Septic Shock. Crit Care Med. 2017; 45: 1061-93.

4) Oliveira CF, Nogueira de SáFR, Oliveira DS, et al: Time- and Fluid-Sensitive Resuscitation for Hemodynamic Support of Children in Septic Shock. Barriers to the Implementation of the American College of Critical Care Medicine / Pediatric Advanced Life Support Guidelines in a Pediatric Intensive Care Unit in a developing world. Pediatr Emerg Care. 2008; 24: 810-5.

5) Carcillo JA, Kuch BA, Han YY, et al: Mortality and Functional Morbidity After Use of PALS/APLS by Community Physicians. Pediatrics. 2009; 124: 500-8.

6) Cruz AT, Perry AM, Williams EA, et al: Implementation of Goal-Directed Therapy for Children With Suspected Sepsis in the Emergency Department abstract. Pediatrics. 2011; 127: e758-66.

7) Han YY, Carcillo JA, Dragotta MA, et al: Early Reversal of Pediatric-Neonatal Septic Shock by Community Physicians Is Associated With Improved Outcome. Pediatrics. 2003; 112: 793-9.

8) Maitland K, Kiguli S, Opoka RO, et al: Mortality after Fluid Bolus in African Children with Severe Infection. N Engl J Med. 2011; 364: 2483-95.

9) Yealy DM, Kellum JA, Huang DT, et al: A randomized trial of protocol-based care for early septic shock. N Engl J Med. 2014; 370: 1683-93.

10) The ARISE Investigators and The ANZICS Clinical Trials Group, Peake SL, Delaney A, et al: Goal-Directed Resuscitation for Patients with Early Septic Shock. N Engl J Med. 2014; 371: 1496-506

11) Mouncey PR, Osborn TM, Power GS, et al: Trial of early, goaldirected resuscitation for septic shock. N Engl J Med. 2015; 372: 1301-11.

12）西田修, 小倉裕司, 井上茂亮, 他, 日本版敗血症診療ガイドラ イン 2016 作成特別委員会. 日本版敗血症診療ガイドライン 2016. 日集中医誌. 2017; 24: S1-232. 
13）西田修, 小倉裕司, 井上茂亮, 他, 日本版敗血症診療ガイドラ イン 2016 作成特別委員会. 日本版敗血症診療ガイドライン 2016. 日救急医会誌. 2017; 28: S1-232.

14) Weiss SL, Peters MJ, Alhazzani W, et al: Surviving sepsis campaign international guidelines for the management of septic shock and sepsis-associated organ dysfunction in children. Intensive Care Med. 2020; 46: 10-67.

15) Sankar J, Ismail J, Sankar MJ, et al: Fluid bolus over 15-20 versus 5-10 minutes each in the first hour of resuscitation in children with septic shock: A randomized controlled trial. Pediatr Crit Care Med. 2017; 18: e435-45.

16) Alobaidi R, Morgan C, Basu RK, et al: Association between fluid balance and outcomes in critically ill children: A systematic review and meta-analysis. JAMA Pediatr. 2018; 172: 257-68.

\section{CQ18-2 : 感染巣が推定しにくい小児敗血症に対 する経験的抗菌薬はどのように選択するか?}

Answer: 発生場所（市中, 院内, 集中治療室など), 患者背景（免疫状態, 治療歴など）を考慮して, 想定 されうる微生物をカバーできる抗菌薬を選択する (BQ に対する情報提示)。

\section{（1）背景および本 $C Q$ の重要度}

敗血症には原因となる感染巣が存在する。原因微生 物が同定されていない段階での経験的治療では, 感染 巣を推定した後に頻度の高い微生物をカバーする抗菌 薬を選択することが基本である。しかし, 実際の臨床 の場面では迅速に感染巣を推定することが困難なこと も多いことから，本 CQ はそのような場合の抗菌薬選 択を重要な課題として位置づけた。

\section{（2）解説 (Table 18-2-1)}

抗菌薬の選択は, 患者の年齢や発生場所, 患者背景 と想定される臓器への移行性を加味して決定され る 1)。感染症の発生場所は, 原因微生物を考える際の 重要な要素である。市中発症の場合, 小児の細菌感染 症としては肺炎球菌やインフルエンザ桿菌, 黄色ブド ウ球菌, 大腸菌などの腸内細菌科細菌の頻度が高い。 通常, これらの細菌は第 3 世代セファロスポリンであ るセフォタキシムが感性であることが多い。しかし， 生後 1 か月未満の敗血症の場合にはリステリアが関与 している頻度が比較的高い2）ため, アンピシリンの 追加を考慮する。さらに生後 1 か月以降で髄膜炎の可 能性が高い場合, セファロスポリンおよびカルバペネ ムの耐性株の肺炎球菌を考慮して ${ }^{3,4)}$, バンコマイシ ンの追加を検討する 5)。最終的には, 患者背景として 基礎疾患, 原発性免疫不全や無脾症などの免疫状態, 周囲流行歴などを参考に抗菌薬を選択する。

特に近年, 腸内細菌科細菌における ESBL (extended spectrum $\beta$-lactamases）産生菌の頻度が上昇してきて いる ${ }^{6)}$ 。尿路や腹腔内, 新生児髄膜炎など, 腸内細菌 科細菌が原因微生物と考えられる感染巣の敗血症にお いて，抗菌薬の先行投与や医療曝露歴があるなど，リ スクが高い場合7）には, ESBL 産生菌を念頭においた カルバペネムの選択も検討する ${ }^{8)}$ 。

一般病棟や集中治療室内で発症した小児敗血症も， 同様の考え方により抗菌薬を決定する。グラム陰性桿 菌に関しては, 腸内細菌科細菌に加えて, 緑膿菌やア シネトバクターなどのブドウ糖非発酵菌も原因微生物 となることがあり ${ }^{9)}$, MRSA（methicillin-resistant 
Table 18-2-1 抗菌薬の選択

\begin{tabular}{|c|c|c|c|c|}
\hline \multicolumn{3}{|c|}{ 抗菌薬 } & 想定する微生物 & 注記 \\
\hline \multicolumn{3}{|c|}{$\begin{array}{l}\text { 市中発症 } \\
\text { セフォタキシム (セフトリアキソン) } \\
\text { 《髄膜炎の可能性が高い生後 } 1 \text { か月未満》 } \\
\text { リステリアを考慮してアンピシリンを追加 } \\
\text { 《髄膜炎の可能性が高い生後 } 1 \text { か月以上》 } \\
\text { バンコマイシンを追加 } \\
\text { 《ESBL 産生菌のリスクが高い場合》 } \\
\text { メロペネムに変更 }\end{array}$} & $\begin{array}{l}\text { 肺炎球菌, } \\
\text { インフルエンザ桿菌, } \\
\text { 黄色ブドウ球菌, } \\
\text { 大腸菌など }\end{array}$ & $\begin{array}{l}\text { 基礎疾患, 免疫不全の有無, 周囲流行歴などを考慮 } \\
\text { する。 }\end{array}$ \\
\hline \multicolumn{3}{|c|}{$\begin{array}{l}\text { 院内発症 } \\
\text { セフォタキシム(セフトリアキソン) } \\
\text { or セフェピム } \\
\text { or ピペラシリンタゾバクタム } \\
\text { or メロペネム } \\
\text { (十バンコマイシン }) \\
\text { (十抗真菌薬 })\end{array}$} & $\begin{array}{l}\text { 腸内細菌科細菌, } \\
\text { 緑膿菌などのブドウ糖非発酵菌, } \\
\text { MRSA を含む黄色ブドウ球菌, } \\
\text { 真菌など }\end{array}$ & $\begin{array}{l}\text { ·基礎疾患, 治療歴, 免疫不全の有無, 耐性菌検出歴, } \\
\text { 院内アンチバイオグラムなどを考慮する。 } \\
\text { • バンコマイシンや抗真菌薬はリスクに応じて追加 } \\
\text { する。 }\end{array}$ \\
\hline 投与量 & $\begin{array}{l}\text { セフォタキシム } \\
\text { アンピシリン } \\
\text { セフェピム } \\
\text { ピペラシリンタゾバクタム } \\
\text { メロペネム } \\
\text { バンコマイシン }\end{array}$ & $\begin{array}{l}200 \mathrm{mg} / \mathrm{kg} / \text { 日 } \\
200 \mathrm{mg} / \mathrm{kg} / \text { 日 } \\
150 \mathrm{mg} / \mathrm{kg} / \text { 日 } \\
337.5 \mathrm{mg} / \mathrm{kg} / \text { 日 } \\
120 \mathrm{mg} / \mathrm{kg} / \text { 日 } \\
60 \mathrm{mg} / \mathrm{kg} / \text { 日 }\end{array}$ & 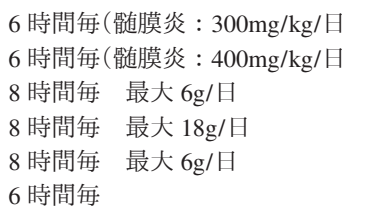 & $\begin{array}{ll}6 \text { 時間毎） } & \text { 最大 } 12 \mathrm{~g} / \text { 日 } \\
6 \text { 時間毎） } & \text { 最大 } 12 \mathrm{~g} / \text { 日 }\end{array}$ \\
\hline
\end{tabular}

Staphylococcus aureus) や真菌もリスクと重症度に合 わせてカバーすることを検討する (CQ4-3を参照)。 患者本人の過去の耐性菌検出歴や抗菌薬の曝露歴は, 原因微生物が耐性菌や真菌である可能性を高める 10）。 各薬剤の微生物に対する感受性は施設ごとに異なるた め, 院内のアンチバイオグラムも参考に抗菌薬を選択 する。

\section{文 献}

1) Guzman-Cottrill JA, Vaz LE: The Systemic Inflammatory Response Syndrome (SIRS), Sepsis, and Septic Shock. In: Long SS, Prober CG, Fischer M, eds. Princ Pract Pediatr Infect Dis. 5th ed. Elsevier, Amsterdam, 2017, p98-102.

2) Thigpen MC, Whitney CG, Messonnier NE, et al: Bacterial meningitis in the United States, 1998-2007. N Engl J Med. 2011; 364: 2016-25.

3) Okada T, Sato Y, Toyonaga Y, et al: Nationwide survey of Streptococcus pneumoniae drug resistance in the pediatric field in Japan. Pediatr Int. 2016; 58: 192-201.

4) Nakano S, Fujisawa T, Ito Y, et al: Spread of MeropenemResistant Streptococcus pneumonia Serotype 15A-ST63 Clone in Japan, 2012-2014. Emerg Infect Dis. 2018; 24: 275-83.

5) Olarte L: Vancomycin should be part of empiric therapy for suspected bacterial meningitis. J Pediatric Infect Dis Soc. 2019; 8 : 187-8.

6) Lukac PJ, Bonomo RA, Logan LK: Extended-spectrum $\beta$ lactamase-producing enterobacteriaceae in children: Old foe, emerging threat. Clin Infect Dis. 2015; 60: 1389-97.

7) Kizilca O, Siraneci R, Yilmaz A, et al: Risk factors for community-acquired urinary tract infection caused by ESBL-producing bacteria in children. Pediatr Int. 2012; 54 : 858-62.

8) Leber WJA: Klebsiella and Raultella species. In: Long SS, Prober CG, Fischer M, eds. Princ Pract Pediatr Infect Dis. 5th ed Elsevier, Amsterdam, 2017, p819-22.

9) Niedner MF, Huskins WC, Colantuoni E, et al: Epidemiology of
Central Line-Associated Bloodstream Infections in the Pediatric Intensive Care Unit. Infect Control Hosp Epidemiol. 2011; 32: $1200-8$.

10) Zaoutis TE, Prasad PA, Localio AR, et al: Risk Factors and Predictors for Candidemia in Pediatric Intensive Care Unit Patients: Implications for Prevention. Clin Infect Dis. 2010; 51: e38-45. 
CQ18-3：小児敗血症診療において，どのような 場合に経験的治療に抗ヘルペスウイルス薬を含 めるか?

Answer : 単純ヘルペスウイルスの罹患率が高く罹患 すると重症化しやすい生後 1 か月未満で, 中枢神経感 染症が疑われる場合，もしくは細菌感染巣が特定でき ない場合がある（BQに対する情報提示）。

\section{（1）背景および本 CQ の重要度}

成人と比較して小児の敗血症では起因微生物がウイ ルスである割合が高く，その中で治療可能なウイルス としては, 単純ヘルペスウイルス（herpes simplex virus: HSV）が挙げられる。治療の遅れは, 死亡や重 篤な後遺症の増加を招くことも報告されている 1,2$) 。$ しかし，HSVによる敗血症は臨床症状が非特異的で あり, 臨床像や迅速検査から病原微生物が HSV かど うかを見分けることは困難なため, 確定診断を待たず に抗ヘルペスウイルス薬の投与を開始することを検討 しなくてはならない。

一方, 抗ヘルペスウイルス薬の過剩な使用が, 特に 日齢 30 以上の児で増えていることも海外では報告さ れており ${ }^{3)}$ ，抗ヘルペスウイルス薬は，その副作用や コストといった面でも懸念が残るため，小児敗血症患 者に対する経験的治療に抗ヘルペスウイルス薬を含め ることが合理的であるのかを検討することは重要であ ると考えた。

\section{（2）解説}

患者がHSVによる敗血症に罹患している場合には, 経験的治療として早期から抗ヘルペスウイルス薬を投 与することにより, 予後の改善が期待される。しかし ながら, HSVによる敗血症は決して頻度の高いもの ではない。北米で行われた大規模な観察研究では, 救 急外来を受診した 26,533 人（敗血症患者数の記載な し）の日齢 60 未満児のうち，HSV 感染症患者は 112 人 $(0.42 \%)$ にとどまり，このうち敗血症を併発する と考えられる中枢神経型は 36 人 $(0.14 \%, 95 \% \mathrm{CI}$ : $0.10 \% \sim 0.19 \%)$ ，全身型は 32 人 $(0.12 \%, 95 \% \mathrm{CI}$ : $0.08 \% \sim 0.17 \%$ ）と報告されている ${ }^{4)}$ 。

すなわち，その発生頻度は極めて低く, 経験的治療 としての抗ヘルペスウイルス薬投与が望ましい効果を もたらす患者の割合は, 非常に限定的といえる。実 際，上記の研究においては，日齢 60 未満の中枢神経 型と全身型の HSV 感染症患者 1 人を治療するために 588 人 (95\% CI: 435 人〜 769 人) に経験的治療として
の抗ヘルペスウイルス薬が投与開始された。HSV 感 染症患者の日齢中央值は 14 日（IQR 9 日〜24日）, 日 齢 0〜28 児は日齢 29〜60 児より罹患頻度は高かった (オッズ比 3.9, 95\% CI: 2.4〜 6.2)。そのため, 1 人の 日歯令 0〜 28, および日齢 29〜60 の HSV 感染症患者を 治療するために，それぞれ 152 人 $(95 \% \mathrm{CI}: 123$ 人〜 185 人）と 583 人（ $95 \%$ CI: 384 人〜909人）に経験的 治療としての抗ヘルペスウイルス薬が投与開始された ことになる4)。したがって，抗ヘルペスウイルス薬の 経験的投与による望ましい効果は, 日齢 $0 \sim 28$ の年齢 層の児においてより期待できる。

抗ヘルペスウイルス薬の使用時には, 腎機能障害 5) や血球減少, 精神神経症状などの重篤な副作用が出現 することがある。また，血管の細い乳幼児においては 血管外漏出による組織障害の危険も無視できない。さ らに, 抗ヘルペスウイルス薬の希釈に要する多量の水 分が輸液負荷にもなりうる。加えて, PCR 法などに より HSV 感染の診断を確定するには多くの施設で数 日間を要するため, HSV 感染でない患者においては, 経験的治療として開始された抗ヘルペスウイルス薬を 終了できるまで病院滞在日数の延長をもたらす可能性 がある 6)。

現時点で, 小児敗血症の経験的治療として抗ヘルペ スウイルス薬を含めるか否かを検討したランダム化比 較試験（RCT）は存在しないが，上述のように日歯令 29 以降では害を受ける患者の割合がより増加すると 考える。また, 明らかに肺炎や尿路感染症といった感 染巣が明確に推定できる小児敗血症患者に対して, 抗 ヘルペスウイルス薬を経験的に開始することも不適切 である。したがって, 概ね生後 1 か月未満で, 感染巣 として中枢神経感染症が疑われるか, 感染巣が確定で きない患者において, 抗ヘルペスウイルス薬を経験的 治療に含めることが妥当であると考える。

なお，年齢層にかかわらず，経験的治療とは異な り, 少なくとも HSV 感染が確定した患者においては, 可及的速やかに抗ヘルペスウイルス薬を投与すること の必要性は論をまたない1,2)。

\section{文 献}

1) Raschilas F, Wolff M, Delatour F, et al: Outcome of and prognostic factors for herpes simplex encephalitis in adult patients: results of a multicenter study. Clin Infect Dis. 2002; 35: 254-60.

2) Shah SS, Aronson PL, Mohamad Z, et al: Delayed acyclovir therapy and death among neonates with herpes simplex virus infection. Pediatrics. 2011; 128: 1153-60.

3) Gaensbauer JT, Birkholz M, Pfannenstein K, et al: Herpes PCR testing and empiric acyclovir use beyond the neonatal period. Pediatrics. 2014; 134: e651-6. 
4) Cruz AT, Freedman SB, Kulik DM, et al: Herpes simplex virus infection in infants undergoing meningitis evaluation. Pediatrics. 2018; 141: e20171688.

5) Rao S, Abzug MJ, Carosone-Link $P$, et al: Intravenous acyclovir and renal dysfunction in children: a matched case control study. J Pediatr. 2015; 166: 1462-1468.e1-4.

6) Shah SS, Volk J, Mohamad Z, et al: Herpes simplex virus testing and hospital length of stay in neonates and young infants. J Pediatr. 2010; 156: 738-43.

\section{CQ18-4：小児敗血症に対する循環管理の目標血 圧は?}

Answer : 適切な目標血圧は不明であり, 年齢や臟器循環 などを考慮して設定する。健康小児の平均血圧の中央值 $\lceil 55+$ 年齢 $\times 1.5 \mathrm{mmHg}$ と 5 パーセンタイル值 $\lceil 40+$ 年 齢 $\times 1.5 \mathrm{mmHg} 」$ が参考になる (BQ に対する情報提示)。

\section{（1）背景および本 $C Q$ の重要度}

敗血症診療において，その治療効果，あるいは治療 方針変更などの意思決定を行う際に血圧（低血圧）を 評価指標の 1 つとすることは一般的である。小児の敗 血症診療においても「低血圧」が組織灌流低下の 1 つ のサインとして明示されている1-3)。しかし, 至適血 圧は年齢，体重などに大きく依存し，さらに全身状態 や臓器障害, それに対して必要な組織灌流圧などを加 味する必要があり，一様に論じることはむずかしい。 その一方で, 基準となる值についてその背景を理解 し，その元となるエビデンスを整理しておくことは有 意義であり，CQ として取り上げた。

\section{（2）解説}

必要な臓器循環を維持することを念頭に，平均血圧 に基づいて個別的に目標設定することが望ましいが， 現時点において収縮期血圧に基づく管理との優劣は明 らかでない。数值目標に関しては参照できる文献が存 在せず，本ガイドラインの作成にあたった専門家の間 でも，意見の一致をみなかった。参考として海外の健 康小児の血圧の正常範囲に関する大規模な調査報告が ある4）。収縮期血圧, 拡張期血圧のみならず平均血圧 についても年齢を考慮した指標が記載されており，管 理目標值や許容下限值を設定する際に参考にできる。 ただし, 個々の病態やそれに応じた必要な臓器循環な どを評価しながら，管理目標となる血圧を個別に設定 する必要があることをつけ加える。

\section{文 献}

1）西田修, 小倉裕司, 井上茂亮, 他, 日本版敗血症診療ガイドラ イン 2016 作成特別委員会. 日本版敗血症診療ガイドライン 2016. 日集中医誌. 2017; 24: S1-232.

2）西田修, 小倉裕司, 井上茂亮, 他, 日本版敗血症診療ガイドラ イン 2016 作成特別委員会. 日本版敗血症診療ガイドライン 2016. 日救急医会誌. 2017; 28: S1-232.

3) Davis AL, Carcillo JA, Aneja RK, et al: American College of Critical Care Medicine Clinical Practice Parameters for Hemodynamic Support of Pediatric and Neonatal Septic Shock. Crit Care Med. 2017; 45: 1061-93.

4) Haque IU, Zaritsky AL: Analysis of the evidence for the lower limit of systolic and mean arterial pressure in children. Pediatr Crit care Med. 2007; 8: 138-44. 


\section{CQ18-5：小児敗血症における輸液に対する反応 の評価方法は?}

Answer : 輸液に対する反応の評価には, 臨床所見［脈 拍数, 血圧, 末梢 - 中枢の温度較差や脈の触知, 毛細 血管再充満時間（capillary refill time: CRT）］や検査值 （乳酸クリアランスや心エコー所見など）が参考にな る（BQに対する情報提示）。

\section{（1）背景および本 CQ の重要度}

成人と同じく小児においても適切な全身管理と感染 症治療は敗血症治療の両輪であり, 特に初期診療での 前負荷の適正化は, 心拍出量を増加させ循環動態を安 定化する過程の基礎である1-3)。しかしながら，前負 荷が適正であるかどうかを評価することは容易ではな く, その一方で過剰な輸液は臓器機能の回復を妨げる 可能性も指摘されている4)。したがって, 輸液を行う ことで循環動態が改善するかを事前に予測したり，投 与した輸液により循環動態が改善したかを事後に評価 したりするのに臨床上有用な指標を整理することは, 小児敗血症診療の質を高めるために重要な課題である と考えられる。

\section{（2）解説}

輸液蘇生に対する反応性の評価法には，(1)輸液蘇生 を実施したら心拍出量が増加するかどうかを事前に予 測するための指標, (2)蘇生輸液を投与した後に心拍出 量が増加したかどうかを事後に評価するための指標の 2 つがある。

本ガイドラインでは，(1)に対して「輸液反応性予 測」という用語を充てているが，小児領域において十 分な信頼に足る輸液反応性の予測指標は現在までのと ころ存在しない5)。Gan らは，様々な背景の小児重症 患者を対象としたシステマティックレビューにおい て, 信頼できる静的指標はなく, 動的指標の中でも ドップラー心エコーにより計測される respiratory variation in aortic blood flow peak velocity $\left(\triangle \mathrm{V}_{\text {peak }}\right.$ : 大動 脈弁から駆出された血流の最高流速の呼吸性変動）を 唯一信頼できるとした 5)。しかし, Desgrangesらは, 集中治療室と手術室の小児患者を対象としたより最近 のシステマティックレビュー・メタ解析においてその 知見を確認しながらも, 研究間で導かれたカットオフ 值が 7〜20\% と幅広いことを指摘し, 臨床判断への利 用は時期尚早との見解を示した ${ }^{6)}$ 。なお, 成人領域で 輸液反応性の予測指標として有用性が確立している stroke volume variation (SVV) や pulse pressure variation
(PPV)，下大静脈径のエコー評価は小児を対象とした 複数の研究において信頼性が確認されておらず5), passive leg raising（PLR）は有用性を示唆されながらも 報告は未だ 1 件に留まっている7)。また，これらのシ ステマティックレビューに組み入れられた研究は, い ずれも敗血症に特化したものではないことに留意され たい。

一方，(2)に関しては, 初期輸液蘇生の過程では, 10〜 20mL/kg の細胞外液組成の輸液をボーラス投与す るたびに，その効果を複数の指標を組み合わせて再評 価することが望まれる。輸液により心拍出量が増加し たか否かを経時的に再評価せず，漫然と輸液投与を継 続すると，思わぬ輸液過剰につながる。評価に際し て, 頻脈や低血圧の是正, 脈の触知の改善, 未梢・ 中 枢の温度較差の縮小といった臨床所見は, 1 回拍出量 や心拍出量の増加を示唆する。また, 臓器低灌流に起 因した意識障害や乏尿といった所見が改善するかを観 察することも重要である3)。

毛細血管再充満時間（capillary refill time: CRT）は, 指趾または体幹の皮膚を圧迫阻血した後にすばやく圧 迫を解除し，何秒間で皮膚の血色が改善するかを計測 し, 未梢循環を評価する臨床所見である。通常 2 秒を 超えると皮膚灌流の低下が示唆され, 未梢循環不全の 可能性が疑われる 8, 9)。CRT は非侵襲的であり, 反復 して経時的に評価が可能な循環管理指標として汎用さ れており ${ }^{3)}, \mathrm{PICU}$ 入室中の小児において 2 秒以内の $\mathrm{CRT}$ が $\mathrm{S}_{\mathrm{CVO}} \geqq 70 \%$ と相関すること 10）や， 3 秒以上 の CRT と死亡との関連を示唆する報告もある ${ }^{11) 。 そ ~}$ の一方で, CRT は患者年齢や測定部位, 圧迫時間, 気温, 皮膚温といった種々の因子の影響を受けること が知られており ${ }^{8)}$, ストップウォッチを利用するなど して評価方法を一定にする必要があることに留意す

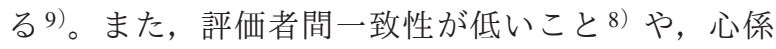
数などの侵襲的な循環動態指標との相関が低いとする 指摘もあり 12,13), CRT 単独で循環動態を評価するこ とは避けるべきである。

乳酸值の上昇は主として組織低酸素を反映し, Sepsis-3では成人領域の敗血症性ショックの定義にも 採用されている14)。小児領域でも複数の観察研究に おいて, 診断時の高乳酸血症が死亡率の上昇と関連す ること15-17）や，輸液や循環作動薬による介入で乳酸 值が低下しないことが死亡と関連すること ${ }^{18,19)}$, 乳 酸值の正常化が臓器機能の回復と関連すること20）が 報告されている。一方, 臨床所見から診断された小児 敗血症性ショック症例では, 代償性であれ非代償性 （低血圧性）であれ，必ずしも高乳酸血症を伴ってい 
るとは限らないことも指摘されている3)。したがって, 初診時から乳酸值が上昇している症例に限り, 輸液に よりその值が低下するかどうかを効果判定の評価指標 として参照できると考えられるが，有効と判断できる 乳酸クリアランスのカットオフ值は明らかでなく, CRT と同様に他の循環動態指標と組み合わせて判断 する必要がある。なお，敗血症性ショックの循環管理 目標として CRT 正常化と乳酸クリアランスとを比較 した近年の成人領域のランダム化比較試験（RCT）で は, 28 日死亡に対する両者の優劣は認められなかっ た ${ }^{21)}$ 。

心エコーはベッドサイドで非侵襲的に繰り返し評価 が可能であり, 前負荷や収縮性を判断する客観的な情 報を与えてくれるうえ, 先天性心疾患や肺高血圧症 · 右心不全の合併の有無も確認できる ${ }^{3)}$ 。輸液により適 切な左室拡張末期容量が確保されたかどうかを評価す るとともに，房室弁逆流を来すほどの輸液は過負荷と 判断する根拠となる。Ranjit らは，標準的な小児敗血 症性ショックの管理に加えて, 診断後 6 時間以内に心 エコーによる評価を実施することにより，多くの患者 で輸液や循環作動薬の調整が可能であったと報告して いる22)。しかしながら, 本研究も含めて, 心エコー による循環動態評価を管理に加えることで予後が改善 するかどうかは依然として不明であることにも留意さ れたい。

最後に，成人領域と同様に小児領域でも，輸液過剩 のもたらす害が多数報告されている。Alobaidiらは, 小児集中治療患者を対象としたシステマティックレ ビューにおいて, 輸液過剰が死亡率上昇や人工呼吸期 間の長期化，急性腎障害の増加などと関連することを 示しており ${ }^{4)}$ ，輸液過剰を回避する努力は不可欠であ る。初期輸液蘇生の施行中に, 努力呼吸の増悪や湿性 ラ音, 肝腫大, ギャロップ音が出現した際には速やか に輸液投与を中断し ${ }^{3)}$ ，輸液過剰を疑って心エコーな どを利用し前負荷の状態を再評価することが重要であ る。

\section{文 献}

1）西田修, 小倉裕司, 井上茂亮, 他, 日本版敗血症診療ガイドラ イン 2016 作成特別委員会. 日本版敗血症診療ガイドライン 2016. 日集中医誌. 2017; 24: S1-232.

2）西田修, 小倉裕司, 井上茂亮, 他, 日本版敗血症診療ガイドラ イン 2016 作成特別委員会. 日本版敗血症診療ガイドライン 2016. 日救急医会誌. 2017; 28: S1-232.

3) Davis AL, Carcillo JA, Aneja RK, et al: American College of Critical Care Medicine Clinical Practice Parameters for Hemodynamic Support of Pediatric and Neonatal Septic Shock. Crit Care Med. 2017; 45: 1061-93.

4) Alobaidi R, Morgan C, Basu RK, et al: Association between fluid balance and outcomes in critically ill children: A systematic review and meta-analysis. JAMA Pediatr. 2018; 172: 257-68.

5) Gan H, Cannesson M, Chandler JR, et al: Predicting fluid responsiveness in children: a systematic review. Anesth Analg. 2013; 117: $1380-92$

6) Desgranges FP, Desebbe O, Pereira de Souza Neto E, et al: Respiratory variation in aortic blood flow peak velocity to predict fluid responsiveness in mechanically ventilated children: a systematic review and meta-analysis. Paediatr Anaesth. 2016; 26: 37-47.

7) Lukito V, Djer MM, Pudjiadi AH, et al: The role of passive leg raising to predict fluid responsiveness in pediatric intensive care unit patients. Pediatr Crit Care Med. 2012; 13: e155-60.

8) Pickard A, Karlen W, Ansermino JM: Capillary Refill Time: Is It Still a Useful Clinical Sign? Anesth Analg. 2011; 113: 120-3.

9) Fleming S, Gill P, Jones C, et al: Validity and reliability of measurement of capillary refill time in children: a systematic review. Arch Dis Child. 2015; 100: 239-49.

10) Raimer PL, Han YY, Weber MS, et al: A Normal Capillary Refill Time of $\leq 2$ Seconds is Associated with Superior Vena Cava Oxygen Saturations of $\geq 70 \%$. J Pediatr. 2011; 158: 968-72.

11) Fleming S, Gill P, Jones C, et al: The Diagnostic Value of Capillary Refill Time for Detecting Serious Illness in Children: A Systematic Review and Meta-Analysis. PLoS One. 2015; 10: $\mathrm{e} 0138155$.

12) Tibby SM, Hatherill M, Murdoch IA: Capillary refill and coreperipheral temperature gap as indicators of haemodynamic status in paediatric intensive care patients. Arch Dis Child. 1999; 80: 163-6.

13) Lobos AT, Lee S, Menon K: Capillary refill time and cardiac output in children undergoing cardiac catheterization. Pediatr Crit Care Med. 2012; 13: 136-40.

14) Singer M, Deutschman CS, Seymour CW, et al: The Third International Consensus Definitions for Sepsis and Septic Shock (Sepsis-3). JAMA. 2016; 315: 801-10.

15) Hatherill M, Waggie Z, Purves L, et al: Mortality and the nature of metabolic acidosis in children with shock. Intensive Care Med. 2003; 29: 286-91.

16) Scott HF, Brou L, Deakyne SJ, et al: Association Between Early Lactate Levels and 30-Day Mortality in Clinically Suspected Sepsis in Children. JAMA Pediatr. 2017; 171: 249-55.

17) Scott HF, Donoghue AJ, Gaieski DF, et al: The utility of early lactate testing in undifferentiated pediatric systemic inflammatory response syndrome. Acad Emerg Med. 2012; 19: 1276-80.

18) Kim YA, Ha EJ, Jhang WK, et al: Early blood lactate area as a prognostic marker in pediatric septic shock. Intensive Care Med. 2013; 39: 1818-23.

19) Munde A, Kumar N, Beri RS, et al: Lactate clearance as a marker of mortality in pediatric intensive care unit. Indian Pediatr. 2014; 51: 565-7.

20) Scott HF, Brou L, Deakyne SJ, et al: Lactate Clearance and Normalization and Prolonged Organ Dysfunction in Pediatric Sepsis. J Pediatr. 2016; 170: 149-155. e1-4.

21) Hernández G, Ospina-Tascón GA, Damiani LP, et al: Effect of a Resuscitation Strategy Targeting Peripheral Perfusion Status vs Serum Lactate Levels on 28-Day Mortality Among Patients With Septic Shock: The ANDROMEDA-SHOCK Randomized Clinical Trial. JAMA. 2019; 321: 654-64.

22) Ranjit S, Aram G, Kissoon N, et al: Multimodal Monitoring for Hemodynamic Categorization and Management of Pediatric Septic Shock. Pediatr Crit Care Med. 2014; 15: e17-26. 


\section{CQ18-6：小児敗血症に対する初期輸液の速度や} 量は?

Answer : 心不全を合併していない小児敗血症の初期 輸液として，輸液に対する反応を評価しながら 10〜 $20 \mathrm{~mL} / \mathrm{kg}$ ずつボーラス投与を反復する方法がある。一 方, 輸液過剰を示唆する臨床所見の出現や輸液に対す る反応の鈍化があれば，輸液蘇生中断の参考になる。 輸液速度や輸液量の上限についての質の高いエビデン スはない（BQに対する情報提示）。

\section{（1）背景および本 $C Q$ の重要度}

敗血症診療における適切な初期輸液は重要である。 小児敗血症性ショックに対する初期治療アルゴリズム においては, 敗血症性ショックの早期認識と急速輸液 の開始が強調されている1-3)。しかし, 輸液過剰への 警鐘もあり，適切な初期輸液に関する本 $\mathrm{CQ}$ は小児敗 血症診療の質を高めるために重要な課題であると考え られる。

\section{（2）解説}

小児敗血症性ショック初期治療アルゴリズム1,2) お よび American College of Critical Care Medicine-Pediatric Advanced Life Support（ACCM-PALS）アルゴリズム ${ }^{3)}$ では, 敗血症性ショックを疑った際には $20 \mathrm{~mL} / \mathrm{kg}$ の等 張晶質液を 5〜10 分かけてボーラス投与し, ショック の徵候が持続すれば必要に応じて最初の 1 時間に計 40 60mL/kg まで反復してもよいと示されている。ま た，ACCM-PALS アルゴリズム4-6）やその他の急速輸 液を含む初期治療アルゴリズム7-12)に従った治療によ り, 生命予後が改善したとする報告や, 病院滞在日数 が短縮したとする報告がある。

しかし, 敗血症性ショック患者が含まれる循環不全 を合併した重症小児熱性疾患に対する初期輸液蘇生の 効果を検討した多施設非盲検ランダム化比較試験 （RCT）（FEAST trial）では，急速輸液なし群と比較し て急速輸液群で死亡率が高かった ${ }^{13)}$ 。本邦とは異な る人工呼吸を含む集中治療管理が不可能な診療環境で の検討であるが, 敗血症診療における輸液過剰の危険 を認識する必要性を示唆している。また，小児敗血症 性ショック患者に対して, $20 \mathrm{~mL} / \mathrm{kg}$ の輸液負荷を 15〜20 分ごとに行う群と 5 10 分ごとに行う群の RCT では, 5〜10 分ごとに行う群で気管抻管，人工呼 吸管理となる割合が増加したとの報告があり ${ }^{14)}$, 輸 液負荷の 1 回投与量としての $20 \mathrm{~mL} / \mathrm{kg}$ が輸液過剰を 招く可能性も検討されている15)。
これらの知見を考慮に入れると，本邦の集中治療管 理が可能な医療環境においては, 急速輸液による初期 蘇生は依然として小児敗血症診療の基本であるもの の, 従来の $20 \mathrm{~mL} / \mathrm{kg}$ 単位よりもやや控えめな等張晶 質液 $10 \sim 20 \mathrm{~mL} / \mathrm{kg}$ 単位でのボーラス投与が妥当であ ろう。そして，ボーラス投与中や投与後にもその都 度, 輸液過剰や輸液に対する反応の鈍化を評価するこ とが重要である。

輸液過剩の可能性を示唆する湿性ラ音・呼吸窮迫・ 肝腫大などを認めれば, 輸液蘇生中断の参考になる。 また，輸液に対する反応は，未梢・中枢の温度較差の 縮小などの未梢循環の改善, 血圧上昇, 心拍数低下, 尿量増加, 意識状態改善などで評価できるが（CQ18-5 参照), ボーラス輸液を断続的に繰り返すなかでその 反応がそしくなれば, 輸液蘇生の中断や輸液投与の減 速を考慮する $1-3)$ 。なお, 輸液速度や輸液量の上限に ついての質の高いエビデンスはない。

\section{文 献}

1）西田修, 小倉裕司, 井上茂亮, 他, 日本版敗血症診療ガイドラ イン 2016 作成特別委員会. 日本版敗血症診療ガイドライン 2016. 日集中医誌. 2017; 24: S1-232.

2）西田修, 小倉裕司, 井上茂亮, 他, 日本版敗血症診療ガイドラ イン 2016 作成特別委員会. 日本版敗血症診療ガイドライン 2016. 日救急医会誌. 2017; 28: S1-232.

3) Davis AL, Carcillo JA, Aneja RK, et al: American College of Critical Care Medicine Clinical Practice Parameters for Hemodynamic Support of Pediatric and Neonatal Septic Shock. Crit Care Med. 2017; 45: 1061-93.

4) Han YY, Carcillo JA, Dragotta MA, et al: Early Reversal of Pediatric-Neonatal Septic Shock by Community Physicians is Associated with Improved Outcome. Pediatrics. 2003; 112: 793-9.

5) Oliveira CF, Nogueira de Sá FR, Oliveira DSF, et al: Time- and Fluid-Sensitive Resuscitation for Hemodynamic Support of Children in Septic Shock: Barriers to the Implementation of the American College of Critical Care Medicine/Pediatric Advanced Life Support Guidelines in a Pediatric Intensive Care Unit in a Developing World. Pediatr Emerg Care. 2008; 24: 810-5.

6) Carcillo JA, Kuch BA, Han YY, et al: Mortality and Functional Morbidity After Use of PALS/APLS by Community Physicians. Pediatrics. 2009; 124: 500-8.

7) Booy R, Habibi P, Nadel S, et al: Reduction in case fatality rate from meningococcal disease associated with improved healthcare delivery. Arch Dis Child. 2001; 85: 386-90.

8) Cruz AT, Perry AM, Williams EA, et al: Implementation of Goal-Directed Therapy for Children with Suspected Sepsis in the Emergency Department. Pediatrics. 2011; 127: e758-66.

9) Paul R, Neuman MI, Monuteaux MC, et al: Adherence to PALS Sepsis Guidelines and Hospital Length of Stay. Pediatrics. 2012; 130: e273-80.

10) van Paridon BM, Sheppard C, G GG, et al: Timing of antibiotics, volume, and vasoactive infusions in children with sepsis admitted to intensive care. Crit Care. 2015; 19: 293.

11) Lane RD, Funai T, Reeder R, et al: High Reliability Pediatric Septic Shock Quality Improvement Initiative and Decreasing Mortality. Pediatrics. 2016; 138: e1-9.

12) Evans IVR, Phillips GS, Alpern ER, et al: Association between 
the New York sepsis care mandate and in-hospital mortality for pediatric sepsis. JAMA. 2018; 320: 358-67.

13) Maitland K, Kiguli S, Opoka RO, et al: Mortality after Fluid Bolus in African Children with Severe Infection. N Engl J Med. 2011; 364: 2483-95.

14) Sankar J, Ismail J, Sankar MJ, et al: Fluid bolus over $15-20$ versus 5-10 minutes each in the first hour of resuscitation in children with septic shock: A randomized controlled trial. Pediatr Crit Care Med. 2017; 18: e435-45.

15) Inwald DP, Canter R, Woolfall K, et al: Restricted fluid bolus volume in early septic shock: results of the Fluids in Shock pilot trial. Arch Dis Child. 2019; 104: 426-31.
CQ18-7：小児敗血症性ショックに対して，第一 選択の循環作動薬としてドパミンを使用する か?

Answer：小児敗血症性ショックに対して，第一選択 の循環作動薬としてドパミンを使用せず，循環動態に 応じてアドレナリンかノルアドレナリンを選択するこ とを弱く推奨する（アドレナリンに対しては GRADE 2D : エビデンスの確実性 $=$ 「非常に低」, ノルアドレ ナリンに対してはエキスパートコンセンサス : エビデ ンス不十分)。

\section{（1）背景および本 CQ の重要度}

日本版敗血症診療ガイドライン（J-SSCG）2016 1, 2) では,「小児敗血症性ショックに対する循環作動薬は, どのようにするか?」という CQ に対して，「小児の 敗血症性ショック患者に対する昇圧薬は，アドレナリ ンを第一選択とする（エキスパートコンセンサス/エ ビデンスの質「C」)」という意見が提示されている。 また, 成人の敗血症性ショックでドパミンではなくノ ルアドレナリンを第一選択としているように，血管拡 張性ショックの病態で $\alpha$ 受容体刺激作用を求める場合 であっても，ノルアドレナリンに優先してドパミンを 用いる根拠は乏しいと考元られる。しかし，J-SSCG 2016 では，ドパミンの使用に関する意見が明示され ていないため, 本邦の臨床現場では小児敗血症性 ショックに対して，依然ドパミンが多く使用されてい ることが推測される3）。上上り，本 $\mathrm{CQ}$ は本ガイド ラインで取り上げるべき重要臨床課題であると考え る。

(2) PICO

P (患者)：Goldstein 定義での敗血症性ショック小 児患者

I（介入）: 初期循環管理におけるあらゆる投与量, 投与期間のドパミン投与

$\mathrm{C}$ (対照) : 初期循環管理におけるあらゆる投与量, 投与期間のアドレナリン投与またはノルアドレナ リン投与

$\mathrm{O}$ (アウトカム) : 全原因死亡, ショック離脱期間, ICU 滞在日数, あらゆる重篤な副作用（院内感染 症など)

\section{（3）エビデンスの要約}

システマティックレビューの結果，PICO に合致し たランダム化比較試験（RCT）が 2 件施行されてお 
り 4, 5), これらを用いたメタ解析を実施した。詳細な 検索過程は付録を参照されたい。

（4）益と害のバランス（Table 18-7-1）

【対アドレナリン】

望ましい効果 :

今回採用された 2 つ RCT では，いずれもアドレ ナリンが比較に設定されていた ${ }^{4,5)}$ 。ICU 滞在日数の アウトカム（1 RCT: $\mathrm{n}=60$ ）に対する効果推定值は, 平均（MD）1.00 日短かかった（95\% CI: 3.95 日短い〜 1.95 日長い) 5)。以上から，望ましい効果はわずかで あると考えられた

望ましくない効果 :

全原因死亡の代わりに 28 日死亡をアウトカム（2 RCT: $\mathrm{n}=180$ ）として検討したところ，介入に対する 効果推定值はリスク差（RD） 1,000 人あたり 136 人多 かった (95\% CI: 61 人少ない〜 590 人多い) 4 , 5)。また, ショック離脱のアウトカムについては, 1 時間以内の ショック離脱（1 RCT: $\mathrm{n}=60 ）$ と循環作動薬離脱日 数（1 RCT: $\mathrm{n}=120 ）$ を検討したが, 前者の効果推定 值は RD 1,000 人あたり 286 人少なく（95\% CI: 368 人 少ない〜 58 人少ない) $)^{5)}$, 後者の効果推定值は MD 4.8 日短かかった（95\% CI: 8.44 日短い〜1.16日短い） 4$)$ 。 さらに，重篤な副作用（医療関連感染十虚血）のア
ウトカム（2 RCT: $\mathrm{n}=180 ）$ に関する効果推定值は RD 1,000 人あたり 126 人多かった（95\% CI: 50 人少な い〜764人多い) 4, 5)。以上から，望ましくない効果は 「中」であると判断した。

益と害のバランス :

第一選択薬としてドパミンを使用する介入に対する 望ましい効果はわずかで, 望ましくない効果は中等度 であるため，望ましい効果と望ましくない効果のバラ ンスは比較のアドレナリンが優位であると判断した。

【対ノルアドレナリン】

望ましい効果 :

第一選択薬としてドパミンとノルアドレナリンを比 較した RCT は存在しなかったことから，死亡率低減 やショック離脱のアウトカムに関してドパミンに望ま しい効果があるかどうかは不明である。しかしなが ら, 未梢血管拡張性ショックの循環動態を呈する患者 においては， $\alpha$ 受容体刺激作用が主体となるノルアド レナリンを第一選択として使用することは, 薬理学的 に合理的な選択といえる。介入の望ましい効果はわず かであると考えられた。

望ましくない効果 :

第一選択薬としてドパミンとノルアドレナリンを比 較した RCT は存在しなかったため, 重篤な副作用 (医療関連感染 + 虚血) のアウトカムに関してドパミ

Table 18-7-1エビデンスプロファイル

\begin{tabular}{|c|c|c|c|c|c|c|c|c|c|c|c|c|}
\hline \multicolumn{7}{|c|}{ 確実性の評価 } & \multicolumn{2}{|c|}{ 患者数 } & \multicolumn{2}{|c|}{ 奻果 } & \multirow[b]{2}{*}{ 確実性 } & \multirow[b]{2}{*}{ 重要性 } \\
\hline 研究数 & $\begin{array}{c}\text { 研究 } \\
\text { デザイン }\end{array}$ & $\begin{array}{l}\text { バイアス } \\
\text { のリスク }\end{array}$ & 非一貫性 & 非直接性 & 不精確性 & $\begin{array}{l}\text { その他 } \\
\text { の検討 }\end{array}$ & Dopamine & Epinephrine & $\begin{array}{l}\text { 相対指標 } \\
(95 \% \text { CI) }\end{array}$ & $\begin{array}{l}\text { 絶対指標 } \\
(95 \% \mathrm{Cl})\end{array}$ & & \\
\hline \multicolumn{13}{|c|}{28 日死亡 } \\
\hline 2 & RCT & 深刻でない & 深刻でない & 深刻でない & 非常に深刻 a & なし & $\begin{array}{c}31 / 94 \\
(33.0 \%)\end{array}$ & $\begin{array}{c}18 / 86 \\
(20.9 \%)\end{array}$ & $\begin{array}{c}\text { RR } 1.65 \\
\text { (0.71 to } 3.82)\end{array}$ & $\begin{array}{l}1,000 \text { 人あた } \\
\text { り136 人多い } \\
\text { (61 人少ない } \\
\sim 590 \text { 人多い) }\end{array}$ & $\begin{array}{c}\oplus \oplus \bigcirc \bigcirc \\
\text { 低 }\end{array}$ & 重大 \\
\hline \multicolumn{13}{|c|}{1 時間以内のショック離脱 } \\
\hline 1 & $\mathrm{RCT}$ & 深刻でない & 深刻でない & 深刻でない & 深刻b & なし & $4 / 31(12.9 \%)$ & $\begin{array}{c}12 / 29 \\
(41.4 \%)\end{array}$ & $\begin{array}{c}\text { RR } 0.31 \\
\text { (0.11 to } 0.86)\end{array}$ & $\begin{array}{c}1,000 \text { 人あた } \\
\text { り } 286 \text { 人少な } \\
\text { い } \\
\text { (368 人少ない } \\
\sim 58 \text { 人少な } \\
\text { い) }\end{array}$ & $\begin{array}{c}\oplus \oplus \oplus \bigcirc \\
\text { 中 }\end{array}$ & 重大 \\
\hline \multicolumn{13}{|c|}{ 循環作動薬離脱日数 } \\
\hline 1 & $\mathrm{RCT}$ & 深刻でない & 深刻でない & 深刻でない & 非常に深刻 a & なし & 63 & 57 & - & $\begin{array}{c}\text { 平均 } 4.80 \text { 日 } \\
\text { 短い }(8.44 \text { 日 } \\
\text { 短い 1.16日 } \\
\text { 短い) }\end{array}$ & $\begin{array}{c}\oplus \oplus \bigcirc \bigcirc \\
\text { 低 }\end{array}$ & 重大 \\
\hline \multicolumn{13}{|c|}{ ICU 滞在日数 } \\
\hline 1 & $\mathrm{RCT}$ & 深刻でない & 深刻でない & 深刻でない & 深刻 b & なし & 31 & 29 & - & $\begin{array}{c}\text { 平均 } 1.00 \text { 日 } \\
\text { 短い }(3.95 \text { 日 } \\
\text { 短い 1.95 日 } \\
\text { 長い) }\end{array}$ & $\begin{array}{c}\oplus \oplus \oplus \bigcirc \\
\text { 中 }\end{array}$ & 重大 \\
\hline \multicolumn{13}{|c|}{ 重篤な副作用 } \\
\hline 2 & RCT & 深刻でない & 深刻でない & 深刻でない & 非常に深刻 a & なし & $\begin{array}{c}25 / 94 \\
(26.6 \%)\end{array}$ & $\begin{array}{c}10 / 86 \\
(11.6 \%)\end{array}$ & $\begin{array}{c}\text { RR } 2.08 \\
\text { (0.57 to } 7.57)\end{array}$ & $\begin{array}{l}1,000 \text { 人あた } \\
\text { り126人多い } \\
\text { (50人少ない } \\
\sim 764 \text { 人多い) }\end{array}$ & $\begin{array}{c}\oplus \oplus \bigcirc \bigcirc \\
\text { 低 }\end{array}$ & 重大 \\
\hline
\end{tabular}


ンに望ましくない効果があるかどうかは不明である。 しかしながら，両薬骫とも $\alpha$ 受容体刺激作用と $\beta$ 受容 体刺激作用を併せ持つ一方で, ドパミン受容体に対す る作用はドパミンに限られていることから，プロラク チン分泌抑制を介した免疫抑制による医療関連感染症 のリスクはドパミンにだけ存在する可能性は否定でき ない。以上から，望ましくない効果は小さいと考えら れた

\section{益と害のバランス :}

末梢血管拡張性ショックの循環動態を呈する患者に おいては，第一選択薬としてノルアドレナリンに対し てドパミンは，望ましい効果はわずかで，望ましくな い効果は小さく, 比較のノルアドレナリンがおそらく 優位と判断した。

\section{（5）アウトカム全般に関するエビデンスの確実性}

\section{【対アドレナリン】}

各アウトカムの効果推定值の方向性は一定ではな く, 最も低いアウトカムの確実性を採用し，全体的な エビデンスの確実性は「低」である。また，いずれの アウトカムに関しても深刻か非常に深刻な不精確さを 内包しており，かつ採用された研究におけるドパミン とアドレナリンの力価が相当していないことが懸念さ れる。したがって，最終的にアウトカム全体にわたる エビデンスの確実性は「非常に低」とした。

【対ノルアドレナリン】

設定した PICO に合致するような，第一選択薬とし てドパミンとノルアドレナリンを比較した RCT は存 在しなかった。なお，アドレナリンとノルアドレナリ ンを比較した RCT も存在しなかった。

\section{（6）価值観}

\section{【対アドレナリン】}

小児敗血症性ショックに対する循環作動薬におけ る, 各アウトカムに置く患者・家族の価值観に関する データはない。一般的に, 死亡アウトカムに対して置 く相対的価值は高く，そのばらつきは少ないことが予 想される。

\section{【対ノルアドレナリン】}

小児敗血症性ショックに対する循環作動薬におけ る，各アウトカムに置く患者・家族の価值観に関する データはない。一般的に, 死亡アウトカムに対して置 く相対的価值は高く，そのばらつきは少ないことが予 想される。

\section{（7）容認性}

【対アドレナリン】

ドパミンの薬価は非常に低く, 患者・個人の視点か らは許容できると考えられる。また，アドレナリンよ りもドパミンのほうが使い慣れている医療従事者もい ると考えられるが，薬剤の準備や使用の労力に差はな いと考えられる。

【対ノルアドレナリン】

ドパミンの薬価は非常に低く, 患者・個人の視点か らは許容できると考えられる。また，ノルアドレナリ ンよりもドパミンのほうが使い慣れている医療従事者 もいると考えられるが, 薬剤の準備や使用の労力に差 はないと考えられる。

\section{（8）実行可能性}

【対アドレナリン】

介入は多くの医療施設において実行可能である。 【対ノルアドレナリン】

介入は多くの医療施設において実行可能である。

（9）判断の要約（Table 18-7-2, Table 18-7-3）

第一選択の循環作動薬としてドパミンを使用する介 入の望ましい効果は，比較のアドレナリンに対してわ ずかであり，望ましくない効果は中等度である。ま た，第一選択の循環作動薬としてドパミンとノルアド レナリンを比較した RCT は存在しない。しかし，ド パミンはノルアドレナリンょりも $\alpha$ 受容体刺激作用の 割合が小さく，ドパミン受容体を介したプロラクチン 分泌抑制による免疫抑制作用も懸念されるため，末梢 血管拡張性ショックの循環動態を呈する患者において はノルアドレナリンを選択することがおそらく優位と 考えられる。

これらを総合的に考慮し，小児敗血症性ショックに 対する第一選択の循環作動薬としてのドパミンの使用 を条件付きの非推奨とした。

\section{（10）推奨グレーディング決定の工程}

修正 RAND 法を用いた投票によって，中央值 7, 見解不一致指数 0.164 の結果となり, 委員会で採択さ れた（7 点以上 : $87.5 \%) 。$

\section{（11）関連する他の診療ガイドラインにおける推奨}

J-SSCG 2016 では，「小児敗血症性ショックに対す る循環作動薬は，どのようにするか？」という $\mathrm{CQ}$ に 対して，「小児の敗血症性ショック患者に対する昇圧 薬は，アドレナリンを第一選択とする（エキスパート 
日本版敗血症診療ガイドライン 2020

Table 18-7-2 判断の要約 (対アドレナリン)

\begin{tabular}{|c|c|c|c|c|c|c|c|}
\hline & \multicolumn{7}{|c|}{ 判㴪 } \\
\hline 問題 & いいえ & $\begin{array}{c}\text { おそらく、いい } \\
\text { え }\end{array}$ & おそらく、はい & はい & & さまざま & 分からない \\
\hline 望ましい効果 & わずか & 小さい & 中 & 大きい & & さまざま & 分からない \\
\hline 望ましくない効果 & 大きい & 中 & 小さい & わずか & & さまざま & 分からない \\
\hline エビデンスの確実性 & 非常に低 & 低 & 中 & 高 & & & 採用研究なし \\
\hline 価值観 & $\begin{array}{c}\text { 重要な不確実性 } \\
\text { またはばらつき } \\
\text { あり }\end{array}$ & $\begin{array}{c}\text { 重要な不確実性 } \\
\text { またはばらつき } \\
\text { の可能性あり }\end{array}$ & $\begin{array}{l}\text { 重要な不確実性 } \\
\text { またはばらつき } \\
\text { はおそらくなし }\end{array}$ & $\begin{array}{c}\text { 重要な不確実性 } \\
\text { またはばらつき } \\
\text { はなし }\end{array}$ & & & \\
\hline 効果のパランス & 比較が優位 & $\begin{array}{c}\text { 比較がおそらく } \\
\text { 優位 }\end{array}$ & $\begin{array}{c}\text { 介入も比較もい } \\
\text { ずれもも優位でな } \\
\text { い }\end{array}$ & $\begin{array}{c}\text { おそらく介入が } \\
\text { 優位 }\end{array}$ & 介入が優位 & さまざま & 分からない \\
\hline 容認性 & いいえ & $\begin{array}{c}\text { おそらく、いい } \\
\text { え }\end{array}$ & おそらく、はい & はい & & さまざま & 分からない \\
\hline 実行可能性 & いいえ & $\begin{array}{c}\text { おそらく、いい } \\
\text { え }\end{array}$ & おそらく、はい & はい & & さまざま & 分からない \\
\hline
\end{tabular}

Table 18-7-3 判断の要約 (対ノルアドレナリン)

\begin{tabular}{|c|c|c|c|c|c|c|c|}
\hline & \multicolumn{7}{|c|}{ 半棌 } \\
\hline 問題 & いいえ & $\begin{array}{c}\text { おそらく、いい } \\
\text { え }\end{array}$ & おそらく、はい & はい & & さまざま & 分からない \\
\hline 望ましい効果 & わずか & 小さい & 中 & 大きい & & さまざま & 分からない \\
\hline 望ましくない効果 & 大きい & 中 & 小さい & わずか & & さまざま & 分からない \\
\hline エビデンスの確実性 & 非常に低 & 低 & 中 & 高 & & & 採用研究なし \\
\hline 価值钼 & $\begin{array}{c}\text { 重要な不確実性 } \\
\text { またはばらつき } \\
\text { あり }\end{array}$ & $\begin{array}{c}\text { 重要な不確実性 } \\
\text { またはばらつき } \\
\text { の可能性あり }\end{array}$ & $\begin{array}{l}\text { 重要な不確実性 } \\
\text { またはばらつき } \\
\text { はおそらくなし }\end{array}$ & $\begin{array}{c}\text { 重要な不確実性 } \\
\text { またはばらつき } \\
\text { はなし }\end{array}$ & & & \\
\hline 効果のバランス & 比較が優位 & $\begin{array}{c}\text { 比較がおそらく } \\
\text { 優位 }\end{array}$ & $\begin{array}{c}\text { 介入も比較もい } \\
\text { ずれも優位でな } \\
\text { い }\end{array}$ & $\begin{array}{c}\text { おそらく介入が } \\
\text { 優位 }\end{array}$ & 介入が優位 & さまざま & 分からない \\
\hline 容認性 & いいえ & $\begin{array}{c}\text { おそらく、いい } \\
\text { え }\end{array}$ & おそらく、はい & はい & & さまざま & 分からない \\
\hline 実行可能性 & いいえ & $\begin{array}{c}\text { おそらく、いい } \\
\text { え }\end{array}$ & おそらく、はい & はい & & さまざま & 分からない \\
\hline
\end{tabular}

コンセンサス/エビデンスの質「C」)」と記されてい る 1,2)。

SSCG in children 2020 では, ドパミンよりもアドレ ナリン（弱い推奨，低いエビデンスの質), またはノ ルアドレナリン（弱い推奨，非常に低いエビデンスの 質）を使用することが提案されている 6)。

\section{（12）実施に関わる検討事項}

アドレナリンもノルアドレナリンも $\alpha$ 受容体刺激作 用と $\beta$ 受容体刺激作用の両方を併せ持つが，アドレナ リンに比ベてノルアドレナリンは相対的に $\alpha$ 受容体刺
激作用が強い。したがって，十分な輸液後の臨床的な 評価において，末梢血管拡張性ショックと考えられる 場合にはノルアドレナリンの選択も考慮される。な お，本 CQ で採用された 2 つの RCTにおいて，ドパ ミンとアドレナリンの用量調整プロトコルは同一では ないことに留意する ${ }^{4,5)}$ 。また，本推奨は，アドレナ リンやノルアドレナリンが使用できない状況などにお いて，ドパミンの使用を否定するものではない。

（13）今後の研究の可能性

今回採用された 2 つの RCT はいずれもサンプル数, 
イベント数が小さく，各アウトカムの検討結果は不精 確である ${ }^{4,5)}$ 。小览敗血症性ショックに対する循環作 動薬の第一選択を検討するより大規模な RCT の実施 が必要である。また，その研究実施の際には，より臨 床現場の実態に即した薬剂用量の調整プロトコルの検 討が望まれる。

\section{文 献}

1）西田修, 小倉裕司, 井上茂亮, 他: 日本版敗血症診療ガイドラ イン 2016 作成特別委員会. 日本版敗血症診療ガイドライン 2016. 日集中医誌. 2017; 24: S1-232.

2）西田修, 小倉裕司, 井上茂亮, 他: 日本版敗血症診療ガイドラ イン 2016 作成特別委員会. 日本版敗血症診療ガイドライン 2016. 日救急医会誌. 2017; 28: S1-232.

3）横川真里, 笠井正志, 志馬伸朗: 本邦小児集中治療領域にお ける敗血症性ショック管理の現状. 日集中医誌. 2018; 25: 115-20

4) Ventura AMC, Shieh HH, Bousso A, et al: Double-Blind Prospective Randomized Controlled Trial of Dopamine Versus Epinephrine as First-Line Vasoactive Drugs in Pediatric Septic Shock. Crit Care Med. 2015; 43: 2292-302.

5) Ramaswamy KN, Singhi S, Jayashree M, et al: Double-Blind Randomized Clinical Trial Comparing Dopamine and Epinephrine in Pediatric Fluid-Refractory Hypotensive Septic Shock. Pediatr Crit Care Med. 2016; 17: e502-12.

6) Weiss SL, Peters MJ, Alhazzani W, et al: Surviving sepsis campaign international guidelines for the management of septic shock and sepsis-associated organ dysfunction in children. Intensive Care Med. 2020; 46: 10-67.
CQ18-8：小児敗血症性ショックに対して，循環 作動薬としてバソプレシンを使用するか?（保 険適用外使用）

Answer：小児敗血症性ショックに対して，循環作動 薬としてバソプレシンを使用しないことを弱く推奨す る(GRADE 2D : エビデンスの確実性 =「非常に低」)。

\section{（1）背景および本 $C Q$ の重要度}

日本版敗血症診療ガイドライン（J-SSCG）2016で は, 「小児敗血症性ショックに対する循環作動薬は, どのようにするか?」という CQ に対して，「小児の 敗血症性血管拡張性ショックに対して，バソプレシン を使用しない（エキスパートコンセンサス/エビデン スの質「C」)」という意見が提示されており，カテコ ラミン不応性ショックでは, バソプレシン以外の追加 治療を行ったうえでVA-ECMO も考慮可とされてい る1,2)。バソプレシンは, 他のカテコラミンと異なる メカニズムによる昇圧作用によって，小児敗血症性 ショック患者の循環動態を改善し ECMO を回避でき る可能性があり, 特に VA-ECMO の導入が容易でない 臨床現場では，現場の判断でバソプレシンが用いられ ている可能性がある。一方で, 虚血や生命予後の悪化 などの害がある可能性もあり，その利益と害のバラン スは明らかではない。よって本ガイドラインに取り上 げるべき重要臨床課題であると考える。

(2) PICO

P (患者)：Goldstein 定義での敗血症性ショックま たは血管拡張性ショック小児患者

I（介入）：あらゆる投与量，投与期間のバソプレシ ン投与

$\mathrm{C}$ (対照)：あらゆる投与量，投与期間のノルアドレ ナリン投与またはプラセボ投与

$\mathrm{O}$ (アウトカム) : 全原因死亡, ショック離脱期間, ICU 滞在日数, あらゆる重篤な副作用（虚血・壊 死など)

\section{（3）エビデンスの要約}

システマティックレビューの結果，PICO に合致し たランダム化比較試験（RCT）が 2 件施行されてお り 3,4)，これらを用いたメタ解析を実施した。

（4）益と害のバランス（Table 18-8-1）

望ましい効果 :

本 CQ では 2 つの RCT が採用されたが，介入とし 
Table 18-8-1エビデンスプロファイル

\begin{tabular}{|c|c|c|c|c|c|c|c|c|c|c|c|c|}
\hline \multicolumn{7}{|c|}{ 確実性の評価 } & \multicolumn{2}{|c|}{ 患者数 } & \multicolumn{2}{|c|}{ 効果 } & \multirow[b]{2}{*}{ 確実性 } & \multirow[b]{2}{*}{ 重要性 } \\
\hline 研究数 & $\begin{array}{c}\text { 研究 } \\
\text { デザイン }\end{array}$ & $\begin{array}{l}\text { パイアス } \\
\text { のリスク }\end{array}$ & 非一貫性 & 非直接性 & 不精確性 & $\begin{array}{l}\text { その他 } \\
\text { の検討 }\end{array}$ & Vasopressin & Control & $\begin{array}{l}\text { 相対指標 } \\
(95 \% \mathrm{CI})\end{array}$ & $\begin{array}{l}\text { 絶対指標 } \\
(95 \% \text { CI }\end{array}$ & & \\
\hline \multicolumn{13}{|l|}{ 死亡 } \\
\hline 2 & RCT & 深刻 a & 深刻でない & 深刻 b & 非常に深刻・ & なし & $30 / 63(47.6 \%)$ & $25 / 60(41.7 \%)$ & $\begin{array}{c}\text { RR } 1.17 \\
(0.60 \text { to } 2.26)\end{array}$ & $\begin{array}{c}1,000 \text { 人あたり } 60 \\
\text { 人多い(130人少 } \\
\text { ない 250 人多 } \\
\text { (1) }\end{array}$ & $\begin{array}{l}\oplus \bigcirc \bigcirc \bigcirc \\
\text { 非常に低 }\end{array}$ & 重大 \\
\hline \multicolumn{13}{|c|}{ 循環作動藥離脱までの時間 } \\
\hline 1 & RCT & 深刻 a & 深刻でない & 深刻 d & 非常に深刻。 & なし & 33 & 32 & - & $\begin{array}{c}\text { 平均 } 2.60 \text { 時間長い } \\
\text { (49. } 95 \text { 時間短い } \\
\sim 55.15 \text { 時間長 } \\
\text { ( ) }\end{array}$ & $\begin{array}{l}\oplus \bigcirc \bigcirc \bigcirc \\
\text { 非常に低 }\end{array}$ & 重大 \\
\hline \multicolumn{13}{|c|}{ ICU 滞在日数 } \\
\hline 2 & RCT & 深刻 a & 深刻でない & 深刻 b & 非常に深刻。 & なし & 63 & 60 & - & $\begin{array}{l}\text { 平均 } 3.64 \text { 日短い } \\
\text { (9.82 日短い } \\
2.53 \text { 日長い) }\end{array}$ & $\begin{array}{l}\oplus \bigcirc \bigcirc \bigcirc \\
\text { 非常に低 }\end{array}$ & 重大 \\
\hline \multicolumn{13}{|c|}{ 重篤な副作用 } \\
\hline 2 & RCT & 深刻 a & 深刻でない & 深刻 b & 非常に深刻。 & なし & $8 / 63(12.7 \%)$ & $5 / 60(8.3 \%)$ & $\begin{array}{c}\text { RR } 1.52 \\
(0.53 \text { to } 4.36)\end{array}$ & $\begin{array}{l}1,000 \text { 人あたり } 40 \\
\text { 人多い (60人少な } \\
\text { い 140人多い) }\end{array}$ & $\begin{array}{l}\oplus \bigcirc 0 \bigcirc \\
\text { 非常に低 }\end{array}$ & 重大 \\
\hline
\end{tabular}

a. Yi Idizdas20084)は，非ブラインド化試験で，割り付けの隠蔽化バイアスが不明，評価者盲検化の記載なし，研究プロトコルの事前登録は確認できない。

b. Choong20093) では血管拡張性ショックが対象であり，敗血症性ショック以外の患者も含まれる。Yildizdas20084)はバソプレシンではなくテルリプレシンが用いられている。

c. 最適情報量を満たさず信頼区間が広い。

d. 血管拡張性ショックが対象であり，敗血症性ショック以外の患者も含まれる。

て 1 つはバソプレシン ${ }^{3)}$ ，もう 1 つはその誘導体であ るテルリプレシンが使用され4)，比較はそれぞれプラ セボと通常治療であった。ICU 滞在日数（2 RCT: $\mathrm{n}=$ 123）のアウトカムに対する効果推定值は平均（MD） 3.64 日短かかった（95\% CI: 9.82 日短い〜2.53日長 い)。上記より，望ましい効果は小さいと考えられた。 望ましくない効果 :

死亡アウトカム（2 RCT: $\mathrm{n}=123 ）$ に関する効果推 定值はリスク差（RD）1,000人あたり 60 人多い（95\% CI: 130 人少ない〜250人多い) であった ${ }^{3,4)}$ 。また, 循環作動薬離脱までの時間（1 RCT: $\mathrm{n}=65 ）$ に関す る効果推定值は MD 2.60 時間長かった（95\% CI: 49.95 時間短い〜 55.15 時間長い) ${ }^{3)}$ 。さらに, 重篤な副作用 （指趾虚血，血栓，心停止，消化管出血）のアウトカ 厶（2 RCT: $\mathrm{n}=123 ）$ に関する効果推定值は, RD 1,000 人あたり 40 人多い $(95 \% \mathrm{CI}: 60$ 人少ない〜 140 人多い）であり 3,4$)$ ，バソプレシンによる望ましくな い効果は「中」であると判断した。

益と害のバランス :

介入による望ましい効果は小さく，望ましくない効 果は中等度である。患者・家族が置くアウトカムの相 対的価值の設定によらず，その効果のバランスはおそ らく比較が優位である。

\section{（5）アウトカム全般に関するエビデンスの確実性}

検討したすべてのアウトカムにおいて，バイアスのリ スクと非直接性は深刻で，かつ不精確さは非常に深刻 であり, 各々のエビデンスの確実性は非常に低い。効果 推定值の方向性も一致していない。よってアウトカム全
体にわたるエビデンスの確実性は「非常に低」である。

\section{（6）価値観}

小児敗血症性ショックに対する循環作動薬におけ る，各アウトカムに置く患者・家族の価值観に関する データはない。一般的に，死亡アウトカムに対して置 く相対的価值は高く，そのばらつきは少ないことが予 想される。

\section{（7）容認性}

ピトレシン注射液 20 の薬価は 658 円/アンプルと高 くなく, 患者・家族の個人の視点から許容できる。バ ソプレシン投与に関わる医療関係者の労力も限定的で ある。この選択肢は重要な利害関係者にとっておそら く妥当なものである。

\section{（8）実行可能性}

介入は多くの医療施設において実行可能である。

（9）判断の要約 (Table 18-8-2)

介入による望ましい効果は小さく，望ましくない効 果は中等度であり，アウトカム全般にわたるエビデン スの確実性は「非常に低」である。標準的治療として バソプレシン投与を行うことは好ましくないが，症例 に応じた適応判断を否定するものではない。それらを 総合的に判断し，条件付きの非推奨とした。

（10）推奨グレーディング決定の工程

修正 RAND 法を用いた投票によって, 中央值 8 , 
Table 18-8-2 判断の要約

\begin{tabular}{|c|c|c|c|c|c|c|c|}
\hline 問題 & いいえ & $\begin{array}{c}\text { おそらく、いい } \\
\text { え }\end{array}$ & おそらく、はい & はい & & さまざま & 分からない \\
\hline 望ましい効果 & わずか & 小さい & 中 & 大きい & & さまざま & 分からない \\
\hline 望ましくない勃果 & 大きい & 中 & 小さい & わずか & & さまざま & 分からない \\
\hline エビデンスの確実性 & 非常に低 & 低 & 中 & 高 & & & 採用研究なし \\
\hline 価值観 & $\begin{array}{c}\text { 重要な不確実性 } \\
\text { またはばらつき } \\
\text { あり }\end{array}$ & $\begin{array}{c}\text { 重要な不確実性 } \\
\text { またはばらつき } \\
\text { の可能性あり }\end{array}$ & $\begin{array}{l}\text { 重要な不確実性 } \\
\text { またはばらつき } \\
\text { はおそらくなし }\end{array}$ & $\begin{array}{c}\text { 重要な不確実性 } \\
\text { またはばらつき } \\
\text { はなし }\end{array}$ & & & \\
\hline 効果のパランス & 比較が優位 & $\begin{array}{c}\text { 比較がおそらく } \\
\text { 優位 }\end{array}$ & $\begin{array}{c}\text { 介入も比較もい } \\
\text { ずれも優位でな } \\
\text { い }\end{array}$ & $\begin{array}{c}\text { おそらく介入が } \\
\text { 優位 }\end{array}$ & 介入が優位 & さまざま & 分からない \\
\hline 容認性 & いいえ & $\begin{array}{c}\text { おそらく、いい } \\
\text { え }\end{array}$ & おそらく、はい & はい & & さまざま & 分からない \\
\hline 実行可能性 & いいえ & おそらく、いい & おそらく、はい & はい & & さまざま & 分からない \\
\hline
\end{tabular}

見解不一致指数 0.164 の結果となり，委員会で採択さ れた（7 点以上：95.8\%）。

\section{（11）関連する他の診療ガイドラインにおける推奨}

J-SSCG 2016 では，「小児敗血症性ショックに対す る循環作動薬は，どのようにするか？」という CQ に 対して，「小児の敗血症性血管拡張性ショックに対し て，バソプレシンを使用しない（エキスパートコンセ ンサス/エビデンスの質「C」)」という意見が提示さ れている1,2)。

SSCG in children 2020 では, 高用量のカテコラミン を必要とする敗血症性ショックの小児患者において， バソプレシンの追加またはカテコラミンのさらなる調 節が提案されている（弱い推奨, 低いエビデンスの 質) 5)。ただしこの提案は, 血液分布異常性ショック の成人を対象にしたメタ解析 ${ }^{6)}$ において, バソプレ シンが追加された患者で腎代替療法の必要性が少ない 傾向があったことを加味している点に注意が必要であ る。

\section{（12）実施に関わる検討事項}

バソプレシン投与を考慮する際には，指趾虚血など の重篤な副作用に注意し，望ましい効果が期待できる か否かを個々の患者で評価し，漫然と投与しないよう にする。

\section{（13）今後の研究の可能性}

本 CQ で検討した 2 件の RCT のうち， 1 件は敗血 症性ショック以外の血管拡張性ショックの患者も含ま
れ 3), もう 1 件は敗血症性ショックの患者が対象だが, 介入薬は国内未発売のバソプレシンアナログであるテ ルリプレシンを介入薬としていた4)。よって，小児敗 血症性ショック患者のみを対象として, バソプレシン の効果を評価する RCT が望まれる。

\section{文 献}

1）西田修, 小倉裕司, 井上茂亮, 他: 日本版敗血症診療ガイドラ イン 2016 作成特別委員会. 日本版敗血症診療ガイドライン 2016. 日集中医誌. 2017; 24: S1-232.

2）西田修, 小倉裕司, 井上茂亮, 他: 日本版敗血症診療ガイドラ イン 2016 作成特別委員会. 日本版敗血症診療ガイドライン 2016. 日救急医会誌. 2017; 28: S1-232.

3) Choong K, Bohn D, Fraser DD, et al: Vasopressin in pediatric vasodilatory shock: a multicenter randomized controlled trial. Am J Respir Crit Care Med. 2009; 180: 632-9.

4) Yildizdas D, Yapicioglu H, Celik U, et al: Terlipressin as a rescue therapy for catecholamine-resistant septic shock in children. Intensive Care Med. 2008; 34: 511-7.

5) Weiss SL, Peters MJ, Alhazzani W, et al: Surviving sepsis campaign international guidelines for the management of septic shock and sepsis-associated organ dysfunction in children. Intensive Care Med. 2020; 46 (Suppl 1): 10-67.

6) McIntyre WF, Um KJ, Alhazzani W, et al: Association of vasopressin plus catecholamine vasopressors vs catecholamines alone with atrial fibrillation in patients with distributive shock: a systematic review and meta-Analysis. JAMA. 2018; 319: 1889-900. 
CQ18-9：初期輸液と循環作動薬に反応しない小 児敗血症性ショックに対して, ステロイド投与 を行うか?

Answer : 初期輸液と循環作動薬に反応しない小児敗 血症性ショックに対して, ルーチンのステロイド投与 を行わないことを弱く推奨する（GRADE 2D：エビデ ンスの確実性 $=$ 「非常に低」)。

\section{（1）背景および本 $C Q$ の重要度}

小児敗血症患者の致死率は依然として高く, 治療成 績を向上させる介入法の確立は急務である。現在まで 小児患者に対するルーチンのステロイド使用について は様々な議論がなされ，関連する質の高い研究も少な からず存在している ${ }^{1-3)}$ 。しかし，現状では，ルーチ ンのステロイド投与の有効性・有害性の評価は定まっ ておらず，臨床現場でもその投与判断については多様 性がある。日本版敗血症診療ガイドラン（J-SSCG） 2016 策定における本課題に対するシステマティック レビューにおいても，ランダム化比較試験（RCT）が 十分に存在せず，本邦で対象となるような小児患者に ルーチンでステロイドを使用しないことが弱く推奨さ れている 4,5$)$ 。ステロイドのルーチン使用の是非は, その薬効特性上, 生命予後改善などの予想される益と 関連合併症（二次感染など）などの害を他薬剤にもま して注意深く評価する必要があり, 最新のエビデンス を集約し理解しておくことは大変重要であると考え る。ここでは「敗血症性ショック」に対するルーチン のステロイド使用を $\mathrm{CQ}$ として扱うこととした。

\section{(2) PICO}

P (患者)：Goldstein 定義での敗血症性ショックで, 初期輸液と循環作動薬に不応である小児（新生児 を除くすべて，18 歳未満）患者

I（介入）: 定期的（ルーチン）なステロイドの全身 投与（投与方法，体重あたりの量は限定しない）

$\mathrm{C}$ (対照) : 定期的（ルーチン）なステロイドを行わ ない（ルーチン以外，例えばステロイド全身投与 の適応が広く認められている疾患などへの敗血症 ショック離脱を目的としない使用は C に含む。)

$\mathrm{O}$ (アウトカム) : ICU 死亡, 病院滞在日数, ショッ ク離脱日数, 人工呼吸期間, 二次感染など [ventilator-associated pneumonia（VAP）やカテーテル関 連を含む］の合併症

\section{（3）エビデンスの要約}

システマティックレビューの結果，PICO に合致し た RCT が 3 件 6-8) 施行されており，これらを用いた メタ解析を実施した。

\section{（4）益と害のバランス（Table 18-9-1）}

望ましい効果 :

死亡アウトカムに関しては事前設定に基づいて検索 した結果，3 件の RCT（n=155）が解析対象とな り 6-8), 効果推定值はリスク差（RD）1,000 人あたり 40 人少ない $(95 \%$ CI: 167 人少ない〜 130 人多い) で あった。また，ショック離脱期間は 2 件の RCT が解 析対象となった 6,7)。1 件の RCT $(\mathrm{n}=68)^{5)}$ では平 均 60.0 時間（ルーチンステロイド投与群）と 139.2 時 間（比較対照群），他方の 1 件の RCT $(\mathrm{n}=38) 7)$ で は中央值 49.5 時間（ルーチンステロイド投与群）と 70 時間（比較対照群）と一定の効果が推定された。 したがって, 望ましい効果は小さいと考えられた。

望ましくない効果 :

二次感染合併症（2 RCT: $\mathrm{n}=87 ）$ のアウトカムに 対しては, 介入による効果推定值は, RD 1,000 人あ たり 41 人多い $(95 \%$ CI: 73 人少ない 284人多い) と推定された 6-8)。また, 病院滞在日数は 2 件の RCT が解析対象となり 5, 7) 1 件の RCT $\left.(\mathrm{n}=68)^{6}\right)$ では平 均 11.4 日（ルーチンステロイド投与群）と 8.2 日（比 較対照群)，他のもう 1 件の RCT $\left.(\mathrm{n}=49)^{8}\right)$ では中 央值 10.7 日（ルーチンステロイド投与群）と 9.6 日 （比較対照群）と，わずかながら介入群での延長が推 定された。したがって, 望ましくない効果は小さいと 考えられた。

益と害のバランス :

介入による望ましい効果は小さく，望ましくない効 果も小さいと考元られ，患者・家族が置くアウトカム の相対的価值の設定によらず，介入も比較もいずれも 優位でない。

（5）アウトカム全般に関するエビデンスの確実性

各アウトカムの効果の方向性は一定しておらず，全 体的なエビデンスの確実性は「非常に低」とした。ま た, 評価可能であったすべてのアウトカムにおいてサ ンプル数，イベント数ともに極端に少なく不精確であ ることを勘案し，最終的にアウトカム全体にわたるエ ビデンスの確実性は「非常に低」とした。

\section{（6）価值観}

小児敗血症患者に対するルーチンのステロイド投与 
Table 18-9-1エビデンスプロファイル

\begin{tabular}{|c|c|c|c|c|c|c|c|c|c|c|c|c|}
\hline \multicolumn{7}{|c|}{ 確実性の評価 } & \multicolumn{2}{|c|}{ 患者数 } & \multicolumn{2}{|c|}{ 効果 } & \multirow[b]{2}{*}{ 確実性 } & \multirow[b]{2}{*}{ 重要性 } \\
\hline 研究数 & $\begin{array}{l}\text { 研究 } \\
\text { デサイン }\end{array}$ & $\begin{array}{l}\text { パイアス } \\
\text { のリスク }\end{array}$ & 非一貫性 & 非直接性 & 不精確性 & $\begin{array}{l}\text { その他 } \\
\text { の梌討 }\end{array}$ & $\begin{array}{c}\text { ルチンのステロ } \\
\text { イド投与 }\end{array}$ & \begin{tabular}{|l} 
ルチンなステロ \\
イド投与をしな \\
い
\end{tabular} & $\begin{array}{l}\text { 相対指摽 } \\
(95 \%, \mathrm{I})\end{array}$ & $\begin{array}{l}\text { 䋫対指摽 } \\
(95 \% \text { CI) }\end{array}$ & & \\
\hline \multicolumn{13}{|l|}{ 死亡* } \\
\hline 3 & RCT & 深刻。 & 深刻でない & 深刻でない & 非常|=深刻 b & なし & $22 / 74 \quad(29.780)$ & $27 / 81 \quad(33.3 \%)$ & $\begin{array}{c}\text { RR } 0.88 \\
(0.50 \text { to } 1.39)\end{array}$ & $\begin{array}{l}\text { 1, 000 人あたり } 40 \\
\text { イ少ない } 167 \text { 人 } \\
\text { 少ない 130人多 } \\
\text { い) }\end{array}$ & $\begin{array}{l}\oplus \bigcirc \bigcirc \bigcirc \\
\text { 非常に低 }\end{array}$ & 重大 \\
\hline \multicolumn{13}{|c|}{ 病院滞在日数 } \\
\hline 2 & RCT & 深刻 a & 深刻でない & 深刻でない & 深刻でない & なし & \multicolumn{4}{|c|}{ 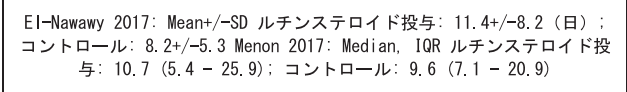 } & $\underset{\text { 中 }}{\oplus \oplus \oplus \bigcirc}$ & 重大 \\
\hline \multicolumn{13}{|c|}{ ショック離眖期間 } \\
\hline 2 & RCT & 深刻。 & 深刻でない & 深刻 d & 深刻。 & なし & \multicolumn{4}{|c|}{ 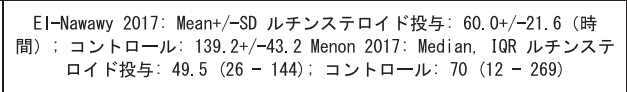 } & $\begin{array}{l}\oplus \bigcirc \bigcirc \bigcirc \\
\text { 非常に低 }\end{array}$ & 重大 \\
\hline \multicolumn{13}{|c|}{ 二次感染合併症 } \\
\hline 2 & RCT & 深刻。 & 深刻 ${ }^{+}$ & 深刻てない & 非常|=深刻 b & なし & $7 / 42 \quad(16.7 \%)$ & $6 / 45 \quad(13.3 \%)$ & $\begin{array}{c}\text { RR } 1.31 \\
\text { (0. } 45 \text { to } 3.13)\end{array}$ & $\begin{array}{l}\text { 1, 000人あたり } 41 \\
\text { イ多い(73人少 } \\
\text { ない〜284人多 } \\
\text { (1) }\end{array}$ & $\begin{array}{l}\oplus \bigcirc \bigcirc \bigcirc \\
\text { 非常に低 }\end{array}$ & 重大 \\
\hline
\end{tabular}

a. El-Nawawy 20176) はGroupC と GroupD の比較のみアウトカムが提示されている。つまりランダム化ののち.グループA と B の患者の中でステロイドを実際に投与された人だけが母数になっている。 すなわち,グループDはそもそも患者背景がRCT の counterfactual principle を満たさないすでにかなりバイアスのかかったコホートということになってしまう。Valoor20097は死亡についてはどの 時点までの死亡かが記載されていない。

b. 相対効果 $95 \%$ CI が 1.0 を跨いでおりかつ非常に最大値，最小値比が非常に大きい。

ショック離脱期間は時間ではなく「日にち」単位で記録されており，離脱期間平均值が非常に短いことを考慮すると重大なバイアスをもたらしている可能性がある。

d. 特にコントロール群での差がおよそ3日間となっている。

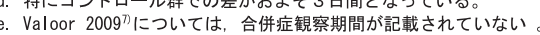

f. 設定が先進国と途上国となっており，その合併症発生率も大きく異なっている。

*死亡はそれぞれ30日死亡，ICU 死亡，全死亡（期間不記載）となっているが，概ね遠隔期までの死亡を考慮していると判断できる。

における，各アウトカムに置く患者・家族の価值観に 関するデータはない。一般的に，死亡アウトカムに対 して置く相対的価值は高く，そのばらつきは少ないこ とが予想される。

\section{（7）容認性}

本介入に伴うコストは，ヒドロコルチゾン $1 \mathrm{mg} / \mathrm{kg}$ を 4 回/日投与した場合，100mg（瓶）が 200〜 400 円 であることから 1 日あたり約 800〜1,600 円となる。 患者・家族の個人の視点からはおそらく許容できるで あろう。また，ヒドロコルチゾン投与に際しての医療 者の労力もわずかである。

\section{（8）実行可能性}

本介入は多くの施設において実行可能である。

\section{(9) 判断の要約 (Table 18-9-2)}

初期輸液と循環作動薬に反応しない小児敗血症性 ショックに対するステロイド投与に関しては，ショッ ク離脱を早めるかもしれないという望ましい効果と, 二次感染症の合併を増やして病院滞在日数を延長させ るかもしれないという望ましくない効果とが，いずれ も小さい程度で拮抗している。また，アウトカム全般 にわたるエビデンスの確実性は非常に低い。初期輸液 と循環作動薬に反応しない小児敗血症性ショック患者
に対してルーチンのステロイド投与を行うことは好ま しくないが，症例に応じた適応判断を否定するもので はない。それらを総合的に判断し，条件付きの非推奨 とした。

（10）推奨グレーディング決定の工程

修正 RAND 法を用いた投票によって，中央值 7, 見解不一致指数 0.164 の結果となり, 委員会で採択さ れた（7 点以上 : $91.7 \%) 。$

\section{（11）関連する他の診療ガイドラインにおける推奨}

J-SSCG 2016 では，「小児敗血症性ショックにおい て，標準治療としてはステロイドを投与しないことを 弱く推奨する（2D）」という推奨がなされている。こ のときは 1 件の RCT のみが検討対象とされた7）が, さらに 2 件の RCT が追加された 6,8$)$ 今回も最終的な 推奨は同等なものとなった。

SSCG in children 20209）でも初期輸液と循環作動薬 で回復可能な小児敗血症性ショックと，不応な場合の 小児敗血症性ショックに分けてステロイド使用の評価 を行っている。回復可能な場合には，使用をしないこ とが弱く推奨されている（低いエビデンスの質）。一 方，不応性の場合については，使用することが弱く推 奨されている（低いエビデンスの質）。 
日本版敗血症診療ガイドライン 2020

Table 18-9-2 判断の要約

\begin{tabular}{|c|c|c|c|c|c|c|c|}
\hline & \multicolumn{7}{|c|}{ 判溇 } \\
\hline 問題 & いいえ & $\begin{array}{c}\text { おそらく、いい } \\
\text { え }\end{array}$ & おそらく、はい & はい & & さまざま & 分からない \\
\hline 望ましい効果 & わずか & 小さい & 中 & 大きい & & さまざま & 分からない \\
\hline 望ましくない効果 & 大きい & 中 & 小さい & わずか & & さまざま & 分からない \\
\hline エビデンスの確実性 & 非常に低 & 低 & 中 & 高 & & & 採用研究なし \\
\hline 価值覞 & $\begin{array}{c}\text { 重要な不確実性 } \\
\text { またはばらつき } \\
\text { あり }\end{array}$ & $\begin{array}{l}\text { 重要な不確実性 } \\
\text { またはばらつき } \\
\text { の可能性ありり }\end{array}$ & $\begin{array}{l}\text { 重要な不確実性 } \\
\text { またはばらつき } \\
\text { はおそらくなし }\end{array}$ & $\begin{array}{c}\text { 重要な不確実性 } \\
\text { またはばらつきき } \\
\text { はなし }\end{array}$ & & & \\
\hline 勃果のパランス & 比較が優位 & $\begin{array}{c}\text { 比較がおそらく } \\
\text { 優位 }\end{array}$ & $\begin{array}{c}\text { 介入も比較もい } \\
\text { ずれも優位でな } \\
\text { い }\end{array}$ & $\begin{array}{c}\text { おそらく介入が } \\
\text { 優位 }\end{array}$ & 介入が優位 & さまざま & 分からない \\
\hline 容認性 & いいえ & $\begin{array}{c}\text { おそらく、いい } \\
\text { え }\end{array}$ & おそらく、はい & はい & & さまざま & 分からない \\
\hline 実行可能性 & いいえ & 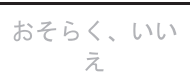 & おそらく、はい & はい & & さまざま & 分からない \\
\hline
\end{tabular}

\section{（12）実施に関わる検討事項}

先天性副腎皮質過形成症を基礎に持つ患者や，長期 間にわたってステロイド投与を受けている患者が敗血 症に罹患した際には，ショックの有無に関係なくステ ロイドカバーが不可欠である。

\section{（13）今後の研究の可能性}

以下の内容に関する検討が求められるであろう。

・二次感染，高血糖を含む合併症に関して

・患者因子あるいは感染源などによる効果の不均質 性に関して

・長期予後また機能予後に関して

- 持続的腎代替療法や血管作動薬の使用（必要性） に関して

・コストに関して

なお， 2020 年現在 28 日死亡をプライマリーアウト カムとした RCT が行われている10)。

\section{文 献}

1) Zimmerman JJ: A history of adjunctive glucocorticoid treatment for pediatric sepsis: moving beyond steroid pulp fiction toward evidence-based medicine. Pediatr Crit Care Med. 2007; 8: 530-9.

2) Zimmerman JJ, Williams MD: Adjunctive corticosteroid therapy in pediatric severe sepsis: Observations from the RESOLVE study. Pediatr Crit Care Med. 2011; 12: 2-8.

3) Atkinson SJ, Cvijanovich NZ, Thomas NJ, et al: Corticosteroids and pediatric septic shock outcomes: a risk stratified analysis. PLoS One. 2014; 9: e112702.

4）西田修, 小倉裕司, 井上茂亮, 他: 日本版敗血症診療ガイドラ イン 2016 作成特別委員会. 日本版敗血症診療ガイドライン 2016. 日集中医誌. 2017; 24: S1-232.

5）西田修, 小倉裕司, 井上茂亮, 他: 日本版敗血症診療ガイドラ イン 2016 作成特別委員会. 日本版敗血症診療ガイドライン
2016. 日救急医会誌. 2017; 28: S1-232.

6) El-Nawawy A, Khater D, Omar H, et al: Evaluation of Early Corticosteroid Therapy in Management of Pediatric Septic Shock in Pediatric Intensive Care Patients: A Randomized Clinical Study. Pediatr Infect Dis J. 2017; 36: 155-9.

7) Valoor HT, Singhi S, Jayashree M: Low-dose hydrocortisone in pediatric septic shock: an exploratory study in a third world setting. Pediatr Crit Care Med. 2009; 10: 121-5.

8) Menon K, McNally D, O'Hearn K, et al: A Randomized Controlled Trial of Corticosteroids in Pediatric Septic Shock: A Pilot Feasibility Study. Pediatr Crit Care Med. 2017; 18: 505-12.

9) Weiss SL, Peters MJ, Alhazzani W, et al: Surviving sepsis campaign international guidelines for the management of septic shock and sepsis-associated organ dysfunction in children. Intensive Care Med. 2020; 46: 10-67.

10) Zimmerman J: Stress Hydrocortisone In Pediatric Septic Shock (SHIPSS). Available online at: https://clinicaltrials.gov/ct2/show/ study/NCT03401398. Accessed April 21, 2020. 
CQ18-10：小児敗血症で循環動態が安定してい る場合に赤血球輸血はいつ開始するか？

Answer : 循環動態の安定している重篤な小児敗血症 患者において，へモグロビン（Hb）值 $7.0 \mathrm{~g} / \mathrm{dL}$ を閾值 として赤血球輸血を開始することを弱く推奨する $($ GRADE 2C：エビデンスの確実性 $=\lceil$ 低」）。

\section{（1）背景および本 $C Q$ の重要度}

重篤な疾患の入室患者は, 凝固能異常や造血能抑制 などから貧血を来すことは少なくない。疾患背景の多 㥞性あるいは幅広い年齢・体重の患者を扱うことなど から，小児集中治療においては成人患者にもまして慎 重に輸血閾値を勘案する必要がある。近年では，特に 必要以上の輸血曝露を避けるという観点から，より低 い目標赤血球輸血閾值を中心にその是非についての検 討がなされており 1-3)，その診療における最新のエビ デンスを整理しておくことは非常に有益であると考え られる。そのため本ガイドラインにおいて重要臨床課 題として取り上げることとした。

なお，循環動態が安定している状況では，敗血症患 者と非敗血症患者とで赤血球輸血の意義に大きな違い があるとは考えにくく，本 CQ では広く循環動態が安 定している小児重症患者を対象とした。

\section{(2) PICO}

$\mathrm{P}$ (患者)：敗血症に限らず重篤な疾患（循環動態が 安定している場合）の小児患者（新生児領域を除 $<)$

I（介入）: 低めの $\mathrm{Hb}$ 閾值での輸血開始

$\mathrm{C}$ (対照) : 高めの $\mathrm{Hb}$ 閾值での輸血開始

$\mathrm{O}$ (アウトカム) : 全原因死亡, ICU 滞在日数, 病院 滞在日数，人工呼吸期間，赤血球輸血合併症

\section{（3）エビデンスの要約}

システマティックレビューの結果，PICO に合致し たランダム化比較試験（RCT）が 2 件施行されてお り ${ }^{4,5)}$ ，これらを用いたメタ解析を実施した。詳細な 検索過程は付録を参照されたい。組み入れられた 2 件 4, 5) の RCT ではいずれも, 介入群では赤血球輸血 を開始する $\mathrm{Hb}$ 閾值が低めに（両研究とも $7 \mathrm{~g} / \mathrm{dL}$ ), 対 照群では高めに（Lacroix 2007 では $9.5 \mathrm{~g} / \mathrm{dL}^{4)}$, Akyildiz 2018 では $\left.10 \mathrm{~g} / \mathrm{dL}^{5)}\right)$ 設定されていた。この うち 1 件の RCT では目標 $\mathrm{Hb}$ 值も介入群では低め $(8.5 \sim 9.5 \mathrm{~g} / \mathrm{dL})$, 対照群では高め $(11 \sim 12 \mathrm{~g} / \mathrm{dL})$ に設 定されていた4) が，もう1 件の RCT では両群とも目
標 $\mathrm{Hb}$ 值が設定されていなかった 5)。

（4）益と害のバランス（Table 18-10-1）

望ましい効果 :

全原因死亡（2 RCT: $\mathrm{n}=797 ）$ のアウトカムに関し ては, 介入の効果推定值はリスク差（RD）1,000 人あ たり 6 人少ない $(95 \%$ CI: 28 人少ない 38 人多い) であった 4, 5)。また，ICU 滞在日数（2 RCT: $\mathrm{n}=797 ）$ と人工呼吸期間（2 RCT: $\mathrm{n}=797 ）$ のアウトカムに関 しては，それぞれに対する介入の効果推定值は平均 （MD）0.62 日短い（95\% CI: 1.76 日短い 0.51日長 い)，ならびに MD 0.00 日長い（95\% CI: 0.84 日短い〜 0.84 日長い）であった 4,5$)$ 。したがって，介入による 望ましい効果はわずかであると考えられた。

望ましくない効果 :

赤血球輸血合併症として，ヒト由来であるため, 感 染症やアナフィラキシーなどの副作用が挙げられる。 また，赤血球輸血が水分負荷や肺障害を引き起こすこ ともありうる。

赤血球輸血合併症のアウトカム（1 RCT: $\mathrm{n}=637)$ に関しては，介入の効果推定值はRD 1,000 人あたり 28 人多い $(95 \%$ CI: 62 人少ない 153 人多い）と, 望 ましくない効果は増えない可能性が高い4)。したがっ て，望ましくない効果はわずかであると考えられた。 益と害のバランス :

本 CQ では，赤血球輸血を開始する $\mathrm{Hb}$ 闇值を低め に設定してもすべてのアウトカムにおいて効果なしと いう結果であったため, 患者・家族が置くアウトカム の相対的価值の設定によらず，その効果のバランスは 介入も比較もいずれも優位でない。

（5）アウトカム全般に関するエビデンスの確実性

今回採用したすべてのアウトカムの効果推定値の方 向性は一致している（効果なし）ため，一番高いアウ トカムの確実性を全体としては採用した。アウトカム 全体にわたるエビデンスの確実性は「低」である。

\section{（6）価值観}

赤血球輸血における各アウトカムに置く患者・家族 の価値観に関するデータはない。救命可否や合併症の アウトカムに関する価值観の相違は考えづらいが，そ れでも輸血忌避の宗教的信条を優先する患者や家族も あり，価值観と意向は不確実である。

\section{（7）容認性}

有害事象のリスクは低く，介入に伴うコストは約 
Table 18-10-1エビデンスプロファイル

\begin{tabular}{|c|c|c|c|c|c|c|c|c|c|c|c|c|}
\hline \multicolumn{7}{|c|}{ 確実性の評価 } & \multicolumn{2}{|c|}{ 患者数 } & \multicolumn{2}{|c|}{ 効果 } & \multirow[b]{2}{*}{ 碓夷性 } & \\
\hline 研究数 & $\begin{array}{c}\text { 研究 } \\
\text { デザイン }\end{array}$ & $\begin{array}{l}\text { バイアス } \\
\text { のリスク }\end{array}$ & 非一貫性 & 非直接性 & 不精確性 & $\begin{array}{l}\text { その他 } \\
\text { の检討 }\end{array}$ & 介入群 & Control 群 & $\begin{array}{l}\text { 相对指摽 } \\
(95 \% \mathrm{Cl})\end{array}$ & $\begin{array}{l}\text { 絗対指標 } \\
(95 \% \text { Cl) }\end{array}$ & & 重要性 \\
\hline
\end{tabular}

全原因死亡

\begin{tabular}{|c|c|c|c|c|c|c|c|c|c|c|c|c|}
\hline 2 & RCT & 深刻でない & 深刻でない & 深刻 a & 非常に深刻 b & なし & $17 / 391(4.3 \%)$ & $21 / 406(5.2 \%)$ & $\begin{array}{c}\text { RR } 0.89 \\
\text { (0.46 to } 1.74 \text { ) }\end{array}$ & $\begin{array}{l}1,000 \text { 人あたり } 6 \\
\text { 人少ない }(28 \text { 人少 } \\
\text { ない 38 人多い) }\end{array}$ & $\begin{array}{l}\oplus \bigcirc 0 \bigcirc \\
\text { 非常に低 }\end{array}$ & 重大 \\
\hline
\end{tabular}

ICU 滞在日数

\begin{tabular}{|c|c|c|c|c|c|c|c|c|c|c|c|}
\hline 2 & RCT & 深刻でない & 深刻 c & 深刻でない & 非常に深刻 d & なし & 391 & 406 & $\begin{array}{c}\text { 平均 } 0.62 \text { 日短い } \\
(1.76 \text { 日短い } \\
0.51 \text { 日長い) }\end{array}$ & $\begin{array}{l}\oplus \bigcirc \bigcirc \bigcirc \\
\text { 非常に低 }\end{array}$ & 重大 \\
\hline
\end{tabular}

人工呼吸期間

\begin{tabular}{|c|c|c|c|c|c|c|c|c|c|c|c|}
\hline 2 & RCT & 深刻でない & 深刻e & 深刻でない & 非常に深刻 & なし & 391 & 406 & & $\begin{array}{c}\text { 平均 } 0.00 \text { 日長い } \\
(0.84 \text { 日短い } \\
0.84 \text { 日長い) }\end{array}$ & $\begin{array}{c}\oplus 000 \\
\text { 非常に低 }\end{array}$ \\
\hline
\end{tabular}

赤血球輸血合併症

\begin{tabular}{|c|c|c|c|c|c|c|c|c|c|c|c|c|}
\hline 1 & RCT & 深刻でない & 深刻でない & 深刻でない & 非常に深刻 B & なし & $\begin{array}{l}97 / 320 \\
(30.3 \%)\end{array}$ & $\begin{array}{l}90 / 317 \\
(28.3 \%)\end{array}$ & $\begin{array}{c}\text { RR } 1.10 \\
\text { (0.78 to } 1.54 \text { ) }\end{array}$ & $\begin{array}{l}1,000 \text { 人あたり } 28 \\
\text { 人多い (62 人少な } \\
\text { い〜 } 153 \text { 人多い) }\end{array}$ & $\begin{array}{c}\oplus \oplus \bigcirc \bigcirc \\
\text { 低 }\end{array}$ & 重大 \\
\hline
\end{tabular}

a. Lacroix $2007^{4)}$ は 28 日死亡を採用している。

b. 総イベント数が 38 と非常に少なく，RR1.25 をまたいでいる。

c. $I^{2}=36 \%$

d. 信頼区間の幅が大きく，非一貫性と併せて判断。

e. $l^{2}=54 \%$

f.信頼区間の幅が大きく，非一貫性と併せて判断。

g. 総イベント数が 187 と少なく, RR 1.25 をまたいでいる。

なお，病院滞在日数に関してはアウトカムの報告がなかった。

17,000 円（赤血球液 2 単位）である。また，介入を実 施するにあたっての医療者の労力は減少する。した がって，本介入は許容できる。

\section{（8）実行可能性}

輸血を制限する介入のほうが多くの医療施設では実 行が容易である。

\section{（9）判断の要約（Table 18-10-2）}

望ましい効果と望ましくない効果にはいずれも差が なく，アウトカム全般にわたるエビデンスの確実性は 「低」である。循環動態の安定している重篤な小児患 者において，介入に関わるコストや拾い切れていない 長期合併症などを考慮すると, 高めの $\mathrm{Hb}$ 閾值での赤 血球輸血は推奨されないが，症例に応じた適応判断を 否定するものではない。それらを総合的に判断し，条 件付きの推奨とした。

\section{（10）推奨グレーディング決定の工程}

修正 RAND 法を用いた投票によって，中央值 7, 見解不一致指数 0.018 の結果となり, 委員会で採択さ
れた（7 点以上 : $87.5 \%) 。$

\section{（11）関連する他の診療ガイドラインにおける推奨}

日本版敗血症診療ガイドライン（J-SSCG）2016で は，CQ19-9 で目標 Hb 值に関する CQ が挙げられて おり，「患者の状態によって対処は異なるが，ショッ ク，低酸素血症より離脱した循環が安定した状態では $\mathrm{Hgb}>7 \mathrm{~g} / \mathrm{dL}$ を目標にできる」ことがエキスパート コンセンサスで記載されている6,7)。

SSCG in children 2020 では循環動態の安定している 重篤な小児敗血症患者において, $\mathrm{Hb}>7.0 \mathrm{~g} / \mathrm{dL}$ を閾 值として赤血球輸血を開始することが弱く推奨されて いる(低いエビデンスの質) 8)。

また，循環動態が不安定な小児敗血症患者での赤血 球輸血の閾值は定められていない。

2018 年に発表されたPediatric Critical Care Transfusion and Anemia Expertise Initiative (TAXI) にお いては，重症小児患者に対する赤血球輸血に関して複 数の推奨が行われている9)。すなわち，「重症または 重症化リスクのある小児患者において, $\mathrm{Hb}<5.0$ $\mathrm{g} / \mathrm{dL}$ の場合には，赤血球輸血を行うことを推奨する 
Table 18-10-2 判断の要約

\begin{tabular}{|c|c|c|c|c|c|c|c|}
\hline & \multicolumn{7}{|c|}{ 判溇 } \\
\hline 問題 & いいえ & $\begin{array}{c}\text { おそらく、いい } \\
\text { え }\end{array}$ & おそらく、はい & はい & & さまざま & 分からない \\
\hline 望ましい勃果 & わずか & 小さい & 中 & 大きい & & さまざま & 分からない \\
\hline 望ましくない効果 & 大きい & 中 & 小さい & わずか & & さまざま & 分からない \\
\hline エビデンスの確実性 & 非常に低 & 低 & 中 & 高 & & & 採用研究なし \\
\hline 価值覞 & $\begin{array}{c}\text { 重要な不確実性 } \\
\text { またはばらつき } \\
\text { あり }\end{array}$ & $\begin{array}{c}\text { 重要な不確実性 } \\
\text { またはばらつき } \\
\text { の可能性あり }\end{array}$ & $\begin{array}{l}\text { 重要な不確実性 } \\
\text { またはばらつき } \\
\text { はおそらくなし }\end{array}$ & $\begin{array}{c}\text { 重要な不確実性 } \\
\text { またはばらつき } \\
\text { はなし }\end{array}$ & & & \\
\hline 効果のバランス & 比較が優位 & $\begin{array}{c}\text { 比較がおそらく } \\
\text { 優位 }\end{array}$ & $\begin{array}{c}\text { 介入も比較もい } \\
\text { ずれも優位でな } \\
\text { い }\end{array}$ & $\begin{array}{c}\text { おそらく介入が } \\
\text { 優位 }\end{array}$ & 介入が優位 & さまざま & 分からない \\
\hline 容認性 & いいえ & $\begin{array}{c}\text { おそらく、いい } \\
\text { え }\end{array}$ & おそらく、はい & はい & & さまざま & 分からない \\
\hline 実行可能性 & いいえ & $\begin{array}{c}お そ ら く 、 い い ~ \\
\text { え }\end{array}$ & おそらく、はい & はい & & さまざま & 分からない \\
\hline
\end{tabular}

[強い推奨，低い質の小児エビデンス $(1 \mathrm{C})] 」$,「重症 または重症化リスクのある小児患者において，循環動 態が安定しておりかつ $\mathrm{Hb} \geqq 7.0 \mathrm{~g} / \mathrm{dL}$ の場合には，赤 血球輸血を行わないことを推奨する [強い推奨, 中等 度の質の小児エビデンス (1B)]」,「Hb $5.0 \sim 7.0 \mathrm{~g} / \mathrm{dL}$ の重症小児患者に対しては，輸血閾值に関する推奨を 作成するためのエビデンスが不十分である。しかしな がら，患者の状態を臨床的に判断し輸血を検討するこ とが妥当である(専門家パネルによるコンセンサス)」, 「循環動態が安定している重症または重症化リスクの ある小児患者において, 輸血後の $\mathrm{Hb}$ 目標值は輸血適 応を解消するものであるべきだが，必ずしも年齢の正 常值を達成する必要はないと推奨する。輸血後の妥当 な $\mathrm{Hb}$ 目標值は 7.0 から $9.5 \mathrm{~g} / \mathrm{dL}$ の間であろう $[$ 弱い

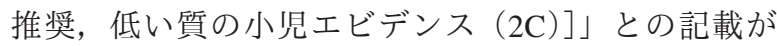
ある9）。さらに，同じ TAXIによる非出血性ショック の重症小児患者に限定した赤血球輸血に関する検討で は，「循環動態が安定した重症敗血症または敗血症性 ショックの重症小児患者において, $\mathrm{Hb} \geqq 7 \mathrm{~g} / \mathrm{dL}$ の場 合には，赤血球輸血を行わないことを推奨する[弱い 推奨，低い質の小児エビデンス $(2 \mathrm{C})] 」$ と記載され ている10)。

\section{（12）実施に関わる検討事項}

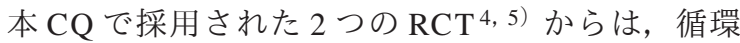
動態の安定している重篤な小児敗血症患者において, $\mathrm{Hb}$ 值 $7 \mathrm{~g} / \mathrm{dL}$ 以下に至ったら赤血球輸血を開始するこ とが妥当と考えられる。また，チアノーゼ性心疾患な どの基礎疾患を持つ患者では，より高めの閾值での赤
血球輸血の開始を考慮する必要があるかもしれない。

\section{（13）今後の研究の可能性}

今後の研究として, 小児敗血症患者に限定した赤血 球輸血を開始する $\mathrm{Hb}$ 閾值設定の検証が強く望まれる。

\section{文 献}

1) Hébert PC, Wells G, Blajchman MA, et al: A multicenter, randomized, controlled clinical trial of transfusion requirements in critical care. Transfusion Requirements in Critical Care Investigators, Canadian Critical Care Trials Group. N Engl J Med. 1999; 340: 409-17.

2) Carson JL, Stanworth SJ, Roubinian N, et al: Transfusion thresholds and other strategies for guiding allogeneic red blood cell transfusion. Cochrane Database Syst Rev. 2016; 10: CD002042.

3) Rygård SL, Holst LB, Wetterslev J, et al: Long-term outcomes in patients with septic shock transfused at a lower versus a higher haemoglobin threshold: the TRISS randomised, multicentre clinical trial. Intensive Care Med. 2016; 42: 1685-94.

4) Lacroix J, Hébert PC, Hutchison JS, et al: Transfusion strategies for patients in pediatric intensive care units. N Engl J Med. 2007; 356: 1609-19.

5) Akyildiz B, Tekerek NU, Pamukcu O, et al: Comprehensive Analysis of Liberal and Restrictive Transfusion Strategies in Pediatric Intensive Care Unit. J Trop Pediatr. 2018; 64: 118-25.

6）西田修, 小倉裕司, 井上茂亮, 他: 日本版敗血症診療ガイドラ イン 2016 作成特別委員会. 日本版敗血症診療ガイドライン 2016. 日集中医誌. 2017; 24: S1-232.

7）西田修, 小倉裕司, 井上茂亮, 他: 日本版敗血症診療ガイドラ イン 2016 作成特別委員会. 日本版敗血症診療ガイドライン 2016. 日救急医会誌. 2017; 28: S1-232.

8) Weiss SL, Peters MJ, Alhazzani W, et al: Surviving sepsis campaign international guidelines for the management of septic shock and sepsis-associated organ dysfunction in children. Intensive Care Med. 2020; 46: 10-67.

9) Doctor A, Cholette JM, Remy KE, et al: Recommendations on RBC Transfusion in General Critically Ill Children Based on 
Hemoglobin and/or Physiologic Thresholds From the Pediatric Critical Care Transfusion and Anemia Expertise Initiative. Pediatr Crit Care Med. 2018; 19: S98-113.

10) Muszynski JA, Guzzetta NA, Hall MW, et al: Recommendations on RBC Transfusions for Critically Ill Children With Nonhemorrhagic Shock From the Pediatric Critical Care Transfusion and Anemia Expertise Initiative. Pediatr Crit Care Med. 2018; 19: S121-6.
CQ18-11：小児敗血症に対して，敗血症の治療 として血液浄化療法を行うか?（血漿交換を含 む)

Answer : 小児敗血症に対して, 敗血症の治療として 血液浄化療法を行わないことを弱く推奨する (GRADE 2D : エビデンスの確実性 =「非常に低」)。

コメント：血漿交換などによる治療適応がある原疾患 （血栓性血小板減少性紫斑病など）の治療や, 高カリ ウム血症などを伴う重篤な急性腎障害や，利尿薬に不 応の滑水の管理に対する腎代替療法の施行を否定する ものではない。

\section{（1）背景および本 $C Q$ の重要度}

小児敗血症患者の死亡率は依然として高く, 救命率 を向上させる治療・介入方法の確立は重要な命題であ る。日本版敗血症診療ガイドライン (J-SSCG) 2016 では小児敗血症に対する治療目的の血液浄化療法の施 行について推奨の提示はできない, と結論づけた 1, 2) が, 実臨床の現場においては小児敗血症患者に対する 治療目的での血液浄化療法施行の可否に関する判断に 多様性がある。小児における血液浄化療法の導入は, 体格などの問題からブラッドアクセス確保の困難性な どの小児特有の問題点を有する。以上により, 本ガイ ドラインに取り上げるべき重要臨床課題であると考え る。

\section{(2) PICO}

P (患者)：Goldstein 定義での重症敗血症，または 感染症による臟器障害として定義される敗血症小 児患者

I（介入）：血液透析, 血液濾過, 血液吸着, 血漿交 換などの血液浄化療法施行（ただし腹膜透析は含 まない)

$C$ (対照)：血液浄化療法非施行

$\mathrm{O}$ (アウトカム) : 全原因死亡, ICU 滞在日数, 人工 呼吸期間, ショック離脱期間, あらゆる重篤な副 作用

（3）エビデンスの要約

システマティックレビューの結果, PICO に合致し たランダム化比較試験（RCT）が 1 件施行されてお り 3), これらを用いたメタ解析を実施した。 
（4）益と害のバランス（Table 18-11-1）

望ましい効果 :

今回の事前設定に基づいた検索により対象となった 研究は 1 件のみであった ${ }^{3)}$ 。ICU 滞在日数，人工呼吸 期間，ショック離脱期間という各アウトカムに関して はデータがなく評価できなかったが，全原因死亡は増 加すると推定されるため，望ましい効果はわずかであ ると考えられた。

\section{望ましくない効果：}

全原因死亡というアウトカム（1 RCT: $\mathrm{n}=48 ） に$ 関して，効果推定值は RD 1,000 人あたり 377 人多い （95\% CI: 30 人少ない 1,000 人多い）であるが，小規 模な 1 件の RCT のみのデータであることから，介入 による望ましくない効果は中等度と判断した ${ }^{3)}$ 。なお, あらゆる重篤な副作用というアウトカムに関しては データがなかったため評価できなかった。

\section{益と害のバランス :}

エビデンスの示せる主要アウトカムにおいて, 血液 浄化療法を施行することに関する望ましい効果はわず かである。その一方で, 望ましくない効果は中等度と 考えられた。効果のバランスは比較がおそらく優位で ある。

\section{（5）アウトカム全般に関するエビデンスの確実性}

今回採用されたすべてのアウトカムのうち, 効果推 定值を得られたアウトカムは 1 件のみであり，そのバ イアスのリスクは深刻と判断した。また，検討された アウトカムにおける不精確さも非常に深刻であったこ とから，そのアウトカムのエビデンスの確実性は「非 常に低」である。したがって，アウトカム全体にわた るエビデンスの確実性は「非常に低」である。

\section{（6）価值観}

小児敗血症患者に対する血液浄化療法に関して，主 要アウトカムに対する患者・家族の価值観についての
データはない。しかしながら，一般的に，救命の可否 に対して置かれる相対的価值は高く，そのばらつきは 少ないことが予想される。

\section{（7）容認性}

2019 年 10 月現在，本邦では，敗血症に対して持続 緩徐式血液滤過（1 日につき 1,990 点）の診療報酬算 定は認められているが，血漿交換療法（1 日につき 42,000 点）は保険適用外である。血液浄化療法を施行 するためには血液透析カテーテルの㨂入が必要とな る。血液透析カテーテル 14,800～21,600 円，血液透析 用モジュール 24,100〜26,500 円，血漿交換用モジュー ル 24,900 円，血液浄化用回路 7,000 円であり，そのう え抗凝固薬や多量の置換液 $(5 \%$ アルブミンや新鮮凍 結血漿), 各種検査も必要となる。また，小児の血液 浄化症例が乏しい施設で, 各年齢層に応じたサイズの デバイス一式を常備することは現実的とはいえない。

一方，体格の小さな小児患者，特に乳幼児へのカ テーテル挿入の際には少なからず鎮痛・鎮静・不動 化・気管挿管・人工呼吸管理が必要であり，かつ安定 した血液浄化療法を継続的に実施するために要する看 護師や臨床工学技士の労力は多大である。

以上から，相当の効果が期待できない限り，本介入 は容認しがたい。

\section{（8）実行可能性}

血液浄化療法を施行するには血液透析用カテーテル の挿入が必要であり, 体格の小さな小児患者へのカ テーテル挿入は習熟した技術を要する。また，体格の 小さな小児患者，特に乳幼児で安定して体外補助循環 を稼働させることは，かなりの経験を要する。小児集 中治療に習熟した医師を含む医療者がいれば実行可能 であるが，すべての医療施設に同様の集中治療医が従 事しているわけではないため，実行可能性について多 様性が生じると考えられる。

Table 18-11-1エビデンスプロファイル

\begin{tabular}{|c|c|c|c|c|c|c|c|c|c|c|c|c|}
\hline \multicolumn{7}{|c|}{ 確実性の評価 } & \multicolumn{2}{|c|}{ 患者数 } & \multicolumn{2}{|c|}{ 効果 } & \multirow[b]{2}{*}{ 確実性 } & \multirow[b]{2}{*}{ 重要性 } \\
\hline 研究数 & $\begin{array}{c}\text { 研究 } \\
\text { デザイン }\end{array}$ & $\begin{array}{l}\text { ハイアス } \\
\text { のリスク }\end{array}$ & 非一貫性 & 非直接性 & 不精確性 & $\begin{array}{l}\text { その他 } \\
\text { の㛟討 }\end{array}$ & 介入群 & Control 群 & $\begin{array}{l}\text { 相対指椤 } \\
(95 \% \% \text { II) }\end{array}$ & $\begin{array}{l}\text { 絶対指禋 } \\
(95 \% \text { II) }\end{array}$ & & \\
\hline
\end{tabular}

全原因死亡

\begin{tabular}{|c|c|c|c|c|c|c|c|c|c|c|c|c|}
\hline 1 & RCT & 深刻 & 深刻でない & 深刻でない & 非常|深刻 $b$ & なし & $10 / 25(40.0 \%)$ & $4 / 23(17.4 \%)$ & $\begin{array}{c}\text { RR } 3.17 \\
\text { (0.83 to } 12.13 \text { ) }\end{array}$ & $\begin{array}{l}\text { 1, 000 人あたり } 377 \\
\text { 人多い(30人少な } \\
\text { い 1, 000人多い) }\end{array}$ & $\begin{array}{l}\oplus \bigcirc 0 \bigcirc \\
\text { 非常に低 }\end{array}$ & 重大 \\
\hline
\end{tabular}

ロバイアスのリスクが高 1 つ，不明 2 つ。

$\mathrm{b}$ 総イベント数が 14 と極めて少なく，益と害の両方をまたいでいる。

なお，ICU 滞在日数，人工呼吸期間，ショック離脱期間，あらゆる重篤な副作用に関してはアウトカムの報告がなかった。 


\section{(9) 判断の要約 (Table 18-11-2)}

敗血症の治療として血液浄化療法を実施することに よる望ましくない効果は中等度で, 介入による望まし い効果はわずかであり, 血液浄化療法をしないことの 効果が優位であると考えられる。アウトカム全般にわ たるエビデンスの確実性は「非常に低」であり，介入 の容認性や実行可能性も乏しい。小児敗血症に対する 標準的治療として血液浄化療法を施行することは好ま しくないが，症例に応じた適応判断を否定するまでの 効果のバランスの優位は示されないため, 条件付きの 非推奨とした。なお，本 CQ の推奨は，適応のある原 疾患に対して血漿交換などを施行したり，重篤な急性 腎障害や利尿薬に不応の溢水に対して腎代替療法を実 施したりすることを否定するものではない。

\section{（10）推奨グレーディング決定の工程}

修正 RAND 法を用いた投票によって，中央值 7, 見解不一致指数 0.164 の結果となり，委員会で採択さ れた（7点以上 : 91.7\%）。

\section{（11）関連する他の診療ガイドラインにおける推奨}

J-SSCG 2016 では「小児敗血症性ショック治療の目 的で血液浄化療法を行うか?」という CQに対して, 小児敗血症性ショック治療目的の血液浄化療法に対し て, 現時点では十分なエビデンスがなく推奨の提示は できない（エキスパートコンセンサス/エビデンスな し）としている ${ }^{1,2)}$ 。なお，同ガイドラインと本ガイ ドラインの推奨の相違に関しては，今回は GRADEに よる評価を行ったことに注意されたい。
また，SSCG in children 2020 では，血液浄化療法に 関して以下の 4 つの記載がある4)。

「血小板減少を伴わない敗血症性ショックやその他 の敗血症関連藏器機能障害の小児患者において，血漿 交換を行わないことを提案する（弱い推奨，非常に低 い質のエビデンス）」

「血小板減少を伴う敗血症性ショックやその他の敗 血症関連藏器機能障害の小児患者において，血漿交換 を行うことに関して賛成も反対も表明できない」

「輸液制限や利尿療法に反応しない敗血症性ショッ クやその他の敗血症関連臓器機能障害の小児患者にお いて，体液過剰を予防したり治療したりするために腎 代替療法を行うことを提案する（弱い推奨，非常に低 い質のエビデンス)」

「腎代替療法による治療を受けている敗血症性 ショックやその他の敗血症関連臓器機能障害の小児患 者において，標準的な血液濾過を上回る高容量血液濾 過を行わないことを提案する（弱い推奨, 低い質のエ ビデンス)」

\section{（12）実施に関わる検討事項}

敗血症の治療として血液浄化療法を行わないことが 望まれる。その一方で，本 CQ の推奨は，血漿交換な どによる治療適応がある原疾患（血栓性血小板減少性 紫斑病など）に対する治療を目的とした施行や，重篤 な急性腎障害（無尿や高カリウム血症などを伴うも の）や保存的治療で管理できない溢水状態に対する腎 代替療法としての施行を否定するものではない。

Table 18-11-2 判断の要約

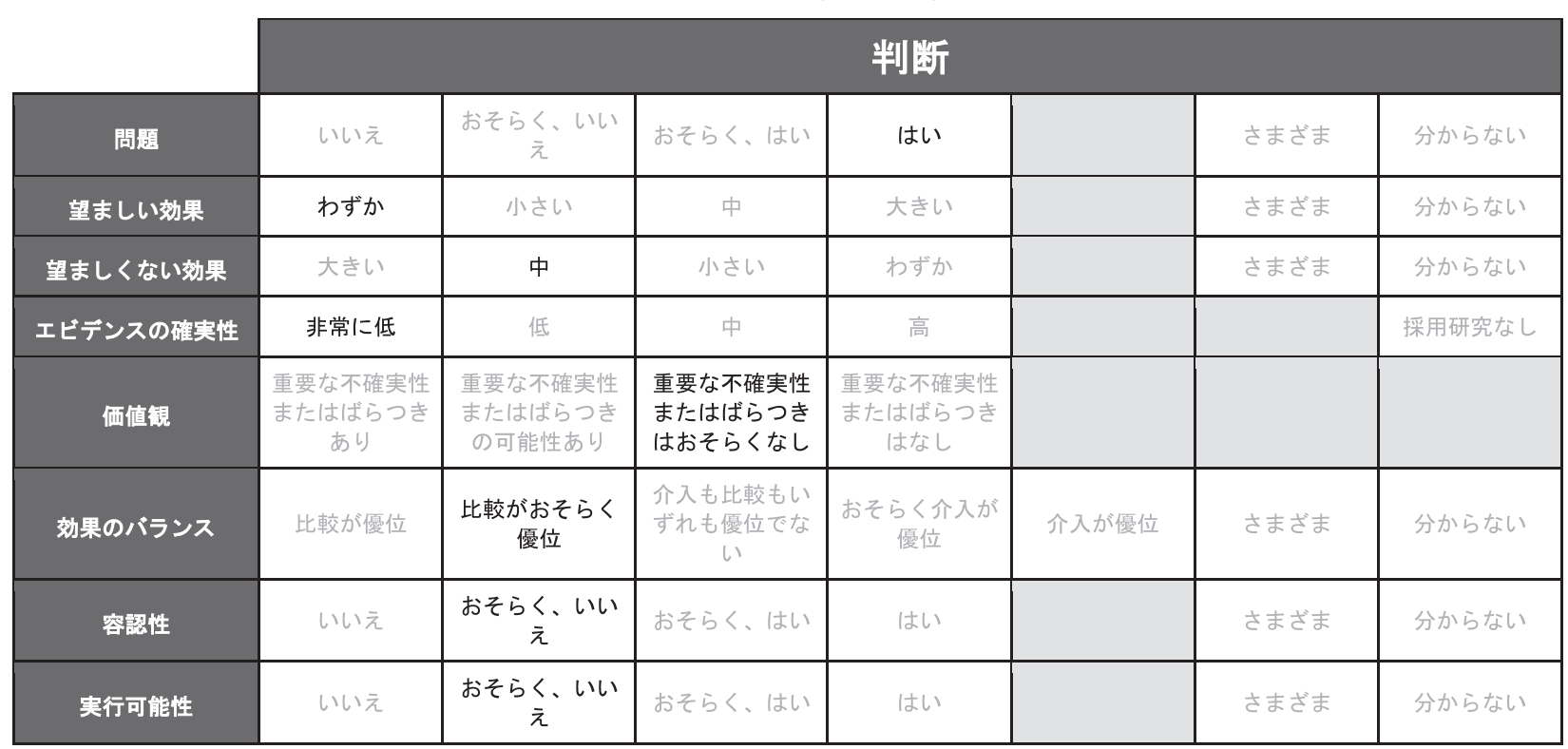




\section{（13）今後の研究の可能性}

近年，成人領域において，敗血症の治療目的での血 液浄化療法の効果に関して否定的な方向に傾きつつあ

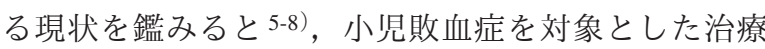
目的での血液浄化療法の研究は実施しづらいと考えら れる。

\section{文 献}

1）西田修, 小倉裕司, 井上茂亮, 他: 日本版敗血症診療ガイドラ イン 2016 作成特別委員会. 日本版敗血症診療ガイドライン 2016. 日集中医誌. 2017; 24: S1-232.

2）西田修, 小倉裕司, 井上茂亮, 他: 日本版敗血症診療ガイドラ イン 2016 作成特別委員会. 日本版敗血症診療ガイドライン 2016. 日救急医会誌. 2017; 28: S1-232.

3) Long EJ, Taylor A, Delzoppo C, et al: A randomised controlled trial of plasma filtration in severe paediatric sepsis. Crit care Resusc. 2013; 15: 198-204.

4) Weiss SL, Peters MJ, Alhazzani W, et al: Surviving sepsis campaign international guidelines for the management of septic shock and sepsis-associated organ dysfunction in children. Intensive Care Med. 2020; 46: 10-67.

5) Joannes-Boyau O, Honoré PM, Perez P, et al: High-volume versus standard-volume haemofiltration for septic shock patients with acute kidney injury (IVOIRE study): a multicentre randomized controlled trial. Intensive Care Med. 2013; 39: 1535-46.

6) Clark E, Molnar AO, Joannes-Boyau O, et al: High-volume hemofiltration for septic acute kidney injury: a systematic review and meta-analysis. Crit Care. 2014; 18: R7.

7) Borthwick EM, Hill CJ, Rabindranath KS, et al: High-volume haemofiltration for sepsis in adults. Cochrane Database Syst Rev. 2017; 1: CD008075.

8) Dellinger RP, Bagshaw SM, Antonelli M, et al: Effect of Targeted Polymyxin B Hemoperfusion on 28-Day Mortality in Patients With Septic Shock and Elevated Endotoxin Level: The EUPHRATES Randomized Clinical Trial. JAMA. 2018; 320 : $1455-63$.
CQ18-12 : 小児敗血症に対して, 免疫グロブリ

ン（IVIG）投与を行うか?

Answer：小児敗血症に対して，免疫グロブリン （IVIG）投与を行わないことを弱く推奨する（エキス パートコンセンサス：エビデンス不十分）。

\section{（1）背景および本 $C Q$ の重要度}

本邦では重症感染症に対する免疫グロブリン （IVIG）の投与が健康保険適用となっており，臨床予 後の改善効果が不明なまま，広く投与されている。一 方, 海外では免疫修飾（immunomodulation）を目的と した，より大量の投与が試みられているが，その効果 は研究によって一貫性がなく，新生児を除く小児領域 での質の高いランダム化比較試験（RCT）も不足して いる 1-4)。成人領域では IVIG を投与しないことが弱 く推奨されているが5,6)，小児領域では IVIG 投与の 有効性・有害性の評価は定まっていない。また，血漿 分画製剤である IVIG は高額であり，その臨床効果を 明確にする意義は大きい。小児敗血症患者の致死率は 高く, 治療成績を向上させる介入方法の確立は重要で あり，小児敗血症診療における IVIG 投与に臨床現場 での判断にも多様性があるため，本 CQ の優先度は高 いといえる。

\section{(2) $\mathrm{PICO}$}

P (患者) : Goldstein 定義での敗血症性ショック, 重症敗血症，または感染症による臓器障害を来し た小児患者（新生児領域，先天性免疫不全・低ガ ンマグロブリン血症を除く）

I（介入）: すべての IVIG 投与

C (対照)：IVIG 非投与，プラセボ群

$\mathrm{O}$ (アウトカム ) : 死亡, ショック離脱期間, 人工呼 吸期間，ICU 滞在日数，副作用

\section{（3）エビデンスの要約}

システマティックレビューの結果，PICO に合致し た RCT が 1 件抽出された ${ }^{7)}$ が，非常に小規模でバイ アスの強い論文であるため，そのエビデンスだけを利 用した推奨作成を回避することが，委員会議論にて全 会一致で同意された。

\section{(4) 益と害のバランス}

\section{望ましい効果：}

IVIGにより病原微生物や毒素に対する中和抗体が 供給され，大量投与すると免疫調整作用を通じて炎症 
を軽減する薬理作用が期待されている。しかし，成人 領域ではその効果は否定的であり (CQ5-1 参照)，か つ本ガイドラインの対象外とはいえ, NICU 領域で早 産児を主体に実施された質の高い大規模多施設 RCT (INIS trial) 4) やそれを含む义夕解析において1,8)，重 症感染症に対する IVIG の治療効果が明確に否定され たことを考慮すると，その間の年齢層である小児領域 においても IVIG に望ましい効果はわずかであると推 定される。

望ましくない効果 :

IVIG の重篤な副作用としてアナフィラキシーや急 性腎障害, 肝機能障害, 無菌性髄膜炎, 血管外漏出な どが挙げられるが，重大なものは少なく頻度も低いた め，望ましくない効果はわずかと考えられる。

益と害のバランス :

望ましい効果も望ましくない効果もわずかであり, 効果のバランスとしては介入も比較もいずれも優位で ないと考えられる。

\section{（5）アウトカム全般に関するエビデンスの確実性}

本 $\mathrm{CQ}$ においては 1 件の RCT が検索された7) が, 小規模でバイアスの非常に強い論文であるため，その エビデンスだけを利用した推奨作成を回避すること が，委員会議論にて全会一致で同意された。したがっ て, 本 $\mathrm{CQ}$ の EtD の作成にあたって採用された RCT は存在しない。

\section{（6）価值観}

一般的に死亡アウトカムに対する相対的価值は高
く，そのばらつきは少ないことが予想されるが，血漿 分画製剂であるため，宗教的信条などを優先させて投 与を望まない患者や家族もいる可能性がある。

\section{（7）容認性}

免疫グロブリン製剤 $5 \mathrm{~g}$ で約 40,000 円と高価である。 一方，薬剂投与に特別な手技を必要とせず， 1 日 1 回 3 日間の投与であり, 医療者の仕事量の増加は著しく ない。効果のバランスを勘案すると，医療経済の観点 より，本介入はおそらく容認されない。

\section{（8）実行可能性}

IVIG は入手困難な薬剤ではなく，ほとんどの施設 で投与可能である。

\section{（9）判断の要約（Table 18-12-1）}

推奨内容を検討するうえで判断の根拠となりうるエ ビデンスは存在しない。しかしながら，NICU 領域で 早産児を主体に実施された質の高い大規模多施設 $\mathrm{RCT}^{4}$ ) やそれを含む义夕解析 1 1,8) において重症感染 症に対する IVIG の治療効果が明確に否定されたこと， また成人領域でも IVIG の効果が否定されていること （CQ5-1 参照）を考えると，その間の年齢層の小览領 域においてのみ敗血症に対する IVIG 投与に害を上回 る益は期待しづらいと推定された。さらに，高額なコ ストに関わる容認性を考慮すると，本介入を推奨する ことは妥当ではないと判断した。

ただし，症例に応じた IVIG 投与の適応を否定する ものではない。それらを総合的に判断し，介入への反

Table 18-12-1 判断の要約

\begin{tabular}{|c|c|c|c|c|c|c|c|}
\hline & \multicolumn{7}{|c|}{ 判溇 } \\
\hline 問題 & いいえ & $\begin{array}{c}\text { おそらく、いい } \\
\text { え }\end{array}$ & おそらく、はい & はい & & さまざま & 分からない \\
\hline 望ましい勃果 & わずか & 小さい & 中 & 大きい & & さまざま & 分からない \\
\hline 望ましくない効果 & 大きい & 中 & 小さい & わずか & & さまざま & 分からない \\
\hline エビデンスの確実性 & 非常に低 & 低 & 中 & 高 & & & 採用研究なし \\
\hline 価值観 & $\begin{array}{c}\text { 重要な不確実性 } \\
\text { またはばらつき } \\
\text { あり }\end{array}$ & $\begin{array}{c}\text { 重要な不確実性 } \\
\text { またははばつき } \\
\text { の可能性あり }\end{array}$ & $\begin{array}{l}\text { 重要な不確実性 } \\
\text { またはばらつき } \\
\text { はおそらくなし }\end{array}$ & $\begin{array}{c}\text { 重要な不確実性 } \\
\text { またはばらつき } \\
\text { はなし }\end{array}$ & & & \\
\hline 勃果のバランス & 比較が優位 & $\begin{array}{c}\text { 比較がおそらく } \\
\text { 優位 }\end{array}$ & $\begin{array}{c}\text { 介入も比較もい } \\
\text { ずれも優位でな } \\
\text { い }\end{array}$ & $\begin{array}{c}\text { おそらく介入が } \\
\text { 優位 }\end{array}$ & 介入が優位 & さまざま & 分からない \\
\hline 容認性 & いいえ & $\begin{array}{c}\text { おそらく、いい } \\
\text { え }\end{array}$ & おそらく、はい & はい & & さまざま & 分からない \\
\hline 実行可能性 & いいえ & $\begin{array}{c}\text { おそらく、いい } \\
\text { え }\end{array}$ & おそらく、はい & はい & & さまざま & 分からない \\
\hline
\end{tabular}


対を条件付きで推奨することとした。

\section{（10）推奨グレーディング決定の工程}

修正 RAND 法を用いた投票によって，中央值 7, 見解不一致指数 0.164 の結果となり，委員会で採択さ れた（7点以上 : 100\%)。

\section{（11）関連する他の診療ガイドラインにおける推奨}

日本版敗血症診療ガイドライン（J-SCCG）2016に おいては，「小児敗血症に対して免疫グロブリン療法 を行うか？」という CQ に対して，「小児敗血症に対 して，標準治療としては免疫グロブリン療法を行わな いことを推奨する（エキスパートコンセンサス/エビ デンスなし)」と記載している9,10)。

SSCG in children 2020 においても，「敗血症性ショッ クまたは敗血症関連臟器機能障害の小児患者に対して ルーチンで IVIG を投与しないことを提案する（弱い 推奨, 低いエビデンスの質)」としている ${ }^{11) 。}$

\section{（12）実施に関わる検討事項}

感染症全例に対して IVIG を標準的治療として行う ことは推奨されない。

\section{（13）今後の研究の可能性}

小児敗血症における IVIG 投与に対する質の高い RCT が実施されることが望まれる。その際には，投 与前の低ガンマグロブリン血症の有無に応じた層別化 が行われることが理想的であろう。

なお，今回推奨内容を検討するうえで 1 件の RCT が検索された7)が，小規模でバイアスが非常に強い ものであったことからエビデンスとしての採択を見 送った。しかし，小児敗血症に対する IVIG の要否を 検討する新たな RCT が将来出版された後には，今回 採択しなかった RCT 7) をそれらの研究と統合しメタ 解析を行うことを排除するものではない。

\section{文 献}

1) Alejandria MM, Lansang MA, Dans LF, et al: Intravenous immunoglobulin for treating sepsis, severe sepsis and septic shock. Cochrane Database Syst Rev. 2013; 2013: CD001090.

2) Busani S, Damiani E, Cavazzuti I, et al: Intravenous immunoglobulin in septic shock: review of the mechanisms of action and meta-analysis of the clinical effectiveness. Minerva Anestesiol. 2016; 82: 559-72.

3) Aubron C, Berteau F, Sparrow RL: Intravenous immunoglobulin for adjunctive treatment of severe infections in ICUs. Curr Opin Crit Care. 2019; 25: 417-22

4) INIS Collaboration Group: Treatment of neonatal sepsis with intravenous immune globulin. N Engl J Med. 2011; 365: 1201-11.

5) Dellinger RP, Levy MM, Rhodes A, et al: Surviving sepsis campaign: international guidelines for management of severe sepsis and septic shock: 2012. Crit Care Med. 2013; 41: 580-637.

6) Rhodes A, Evans LE, Alhazzani W, et al: Surviving Sepsis Campaign: International Guidelines for Management of Sepsis and Septic Shock: 2016. Crit Care Med. 2017; 45: 486-552.

7) El-Nawawy A, El-Kinany H, Hamdy El-Sayed M, et al: Intravenous polyclonal immunoglobulin administration to sepsis syndrome patients: a prospective study in a pediatric intensive care unit. J Trop Pediatr. 2005; 51: 271-8.

8) Ohlsson A, Lacy JB: Intravenous immunoglobulin for suspected or proven infection in neonates. Cochrane Database Syst Rev. 2020; 1: CD001239.

9）西田修, 小倉裕司, 井上茂亮, 他: 日本版敗血症診療ガイドラ イン 2016 作成特別委員会. 日本版敗血症診療ガイドライン 2016. 日集中医誌. 2017; 24: S1-232.

10）西田修, 小倉裕司, 井上茂亮, 他: 日本版敗血症診療ガイドラ イン 2016 作成特別委員会. 日本版敗血症診療ガイドライン 2016. 日救急医会誌. 2017; 28: S1-232.

11) Weiss SL, Peters MJ, Alhazzani W, et al: Surviving sepsis campaign international guidelines for the management of septic shock and sepsis-associated organ dysfunction in children. Intensive Care Med. 2020; 46: 10-67. 
CQ18-13：小児敗血症に対して，厳密な血糖管 理を行うか?

Answer：小児敗血症に対して，㛜密な血糖管理を行 わないことを弱く推奨する（GRADE 2C：エビデンス の確実性 $=「$ 低」)。

\section{（1）背景および本 $C Q$ の重要度}

高血糖の発生は，成人と同様に小児においても免疫 能に影響を与え感染症を増悪させ，高い死亡率や病院 滞在日数の長さとの関連など予後を悪化させる可能性 があり 1-4)，敗血症患者における血糖管理は重要な治 療法の 1 つと考えられている。インスリンを使用した 血糖管理の重要な害として低血糖があり，低血糖の発 生は重症患者の予後悪化と関連する2,5)。このため, 小児敗血症患者に対する厳密な血糖管理の是非に関し て，本ガイドラインに取り上げるべき重要臨床課題で あると考える。なお，厳密な血糖管理の意義は，小児 敗血症患者とその他の集中治療管理を要する小児患者 とで違いがあるとは考えにくいため，本 CQ の対象は 敗血症に限定しなかった。

\section{(2) PICO}

$P$ (患者) : 集中治療管理中の小照患者

I（介入）：厳密な血糖管理
C (対照)：通常の血糖管理

$\mathrm{O}$ (アウトカム ) : 全原因死亡, ICU 滞在日数, 人工 呼吸期間，低血糖

（3）エビデンスの要約

システマティックレビューの結果，PICO に合致し たランダム化比較試験（RCT）が 5 件施行されてお り 6-10)，これらを用いたメタ解析を実施した。

\section{（4）益と害のバランス（Table 18-13-1）}

望ましい効果 :

全原因死亡（5 RCT: $\mathrm{n}=3,923 ）$ というアウトカム に関して，効果推定值はリスク差（RD）1,000人あた り 1 人少ない $(95 \% \mathrm{CI}: 14$ 人少ない〜 17 人多い) で あり ${ }^{6-10)}$, ICU 滞在日数（3 RCT: $\mathrm{n}=3,049$ ) は平均 (MD) 0.50 日短い（95\% CI：0.52 日短い〜0.48 日短 い) $6,8,9)$ であり，人工呼吸期間（3 RCT: $\mathrm{n}=3,049 ）$ は MD 0.30 日短い（95\% CI: 0.32 日短い〜 0.27 日短い） であった。介入による望ましい効果はわずかであると 考えられた。

望ましくない効果 :

インスリンによる有害事象である低血糖は，特に発 達中でエネルギー要求の高い小児の中枢神経系に不可 逆的悪影響を起こしうる重大な合併症である。低血糖 （5 RCT: $\mathrm{n}=3,933 ）$ は, 効果推定值は RD 1,000 人あ

Table 18-13-1エビデンスプロファイル

\begin{tabular}{|c|c|c|c|c|c|c|c|c|c|c|c|c|}
\hline \multicolumn{7}{|c|}{ 確実性の評価 } & \multicolumn{2}{|c|}{ 患者数 } & \multicolumn{2}{|c|}{ 効果 } & \multirow[b]{2}{*}{ 磪実性 } & \\
\hline 研究数 & $\begin{array}{c}\text { 研究 } \\
\text { デザイン }\end{array}$ & $\begin{array}{l}\text { ハイアス } \\
\text { のリスク }\end{array}$ & 非一貫性 & 非直接性 & 不精磼性 & $\begin{array}{l}\text { その他 } \\
\text { の検討 }\end{array}$ & 介入群 & Control群 & $\begin{array}{l}\text { 相対指標 } \\
(95 \% \text { cI })\end{array}$ & $\begin{array}{l}\text { 絶対指摽 } \\
(95 \% \mathrm{CI})\end{array}$ & & 重要任 \\
\hline
\end{tabular}

全原因死亡

\begin{tabular}{|c|c|c|c|c|c|c|c|c|c|c|c|c|}
\hline 5 & RCT & 深刻でない & 深刻 a & 深刻でない & 深刻 ${ }^{b}$ & なし & $98 / 1928 \quad(5.1 \%)$ & $\begin{array}{c}107 / 1995 \\
(5.4 \%)\end{array}$ & $\begin{array}{c}\text { RR } 0.98 \\
(0.73 \text { to } 1.31)\end{array}$ & $\begin{array}{l}1,000 \text { 人あたり } 1 \text { 人 } \\
\text { 少ない (14 人少ない } \\
\sim 17 \text { 人多い) }\end{array}$ & $\begin{array}{c}\oplus \oplus \bigcirc \bigcirc \\
\text { 低 }\end{array}$ & 重大 \\
\hline
\end{tabular}

ICU 滞在日数

\begin{tabular}{|c|c|c|c|c|c|c|c|c|c|c|c|}
\hline 3 & RCT & 深刻でない & 深刻 ${ }^{\circ}$ & 深刻でない & 深刻でない & なし & 1533 & 1516 & $\begin{array}{c}\text { 平均 } 0.50 \text { 日短い } \\
(0.52 \text { 日短い } 0.48 \\
\text { 日短い) }\end{array}$ & $\begin{array}{c}\oplus \oplus \oplus \bigcirc \\
\text { 中 }\end{array}$ & 重大 \\
\hline
\end{tabular}

人工呼吸期間

\begin{tabular}{|c|c|c|c|c|c|c|c|c|c|c|c|}
\hline 3 & RCT & 深刻でない & 深刻 d & 深刻でない & 深刻でない & なし & 1533 & 1516 & 平均 0.30 日 \\
$(0.32$ 日短い 0.27 \\
日短い)
\end{tabular}

低血糖

\begin{tabular}{|c|c|c|c|c|c|c|c|c|c|c|c|c|}
\hline 5 & RCT & 深刻でない & 深刻 ${ }^{8}$ & 深刻でない & 深刻 ${ }^{b}$ & なし & $185 / 1931$ & $39 / 2002$ & $\begin{array}{c}\text { RR } 6.37 \\
\text { (4. } 41 \text { to } 9.21)\end{array}$ & $\begin{array}{c}1,000 \text { 人あたり } 105 \\
\text { 人多い（66人多い } \\
166 \text { 人多い） }\end{array}$ & $\begin{array}{c}\oplus \oplus \bigcirc \bigcirc \\
\text { 低 }\end{array}$ & 重大 \\
\hline
\end{tabular}

a. I $I^{2}=57 \%$, b. 総イベント数 300 末満，c. $I^{2}=82 \% ，$ d. $I^{2}=97 \% ，$ e. $I^{2}=73 \%$ 
たり 105 人多い $(95 \% \mathrm{CI}: 66$ 人多い〜 166 人多い）で あった 6-10)。したがって，介入による望ましくない効 果は大きいと考えられた。

益と害のバランス :

厳密な血糖管理の望ましい効果はわずかであり，一 方，望ましくない効果は大きいと考えられた。した がって, 効果のバランスとしては比較がおそらく優位 であると考える。

\section{（5）アウトカム全般に関するエビデンスの確実性}

介入により ICU 滞在日数と人工呼吸期間はわずか ながら短縮する効果が予期される一方で, 低血糖は増 加する効果が予期されるため, 各アウトカムの効果の 方向性は異なっている。したがって，アウトカム全般 にわたる全体的なエビデンスの確実性は「低」であ る。

\section{（6）価値観}

小児敗血症患者に対する厳密な血糖管理に関して, 主要アウトカムに対する患者・家族の価值観について のデータはない。一般的に，救命の可否に対して置か れる相対的価值は高く，そのばらつきは少ないことが 予想される。

\section{（7）容認性}

高血糖に対する降下療法として頻用されるインスリ ンのコストは, 約 300 円 /100 単位であり, 患者・家 族の個人の視点から許容できると考えられる。一方, インスリン持続投与を導入すると，低血糖の合併症を
回避するために，医療者は頻繁な血糖值の確認を余儀 なくされ，労力は確実に増加する。これらを総合的に 勘案すると, 明らかな利益が認められない限り，本介 入はおそらく容認できない。

（8）実行可能性

介入は多くの医療施設において実行可能である。

\section{(9) 判断の要約 (Table 18-13-2)}

望ましい効果はわずかで，望ましくない効果は大き く，アウトカム全般にわたるエビデンスの確実性は 「低」である。小児敗血症に対する厳密な血糖管理は 好ましくないが，症例に応じた適応判断を否定するま での効果のバランスの優位は示されないため, 条件付 きの非推奨とした。

\section{（10）推奨グレーディング決定の工程}

修正 RAND 法を用いた投票によって，中央值 8, 見解不一致指数 0.164 の結果となり, 委員会で採択さ れた（7 点以上 : 100\%)。

\section{（11）関連する他の診療ガイドラインにおける推奨}

日本版敗血症診療ガイドライン（J-SSCG）2016で は同 CQ を取り上げ，小児敗血症において厳密な血糖 管理を行わないことを推奨する（1B：効果の推定值 に中程度の確信がある推奨）としている11，12）。また, SSCG in children 2020 では, 血糖值を $140 \mathrm{mg} / \mathrm{dL}$ 以下 を目標值とするインスリン療法を行わないことを推奨 している（強い推奨, 中程度のエビデンスの質）が,

Table 18-13-2 判断の要約

\begin{tabular}{|c|c|c|c|c|c|c|c|}
\hline 問題 & いいえ & $\begin{array}{c}\text { おそらく、いい } \\
\text { え }\end{array}$ & おそらく、はい & はい & & さまざま & 分からない \\
\hline 望ましい効果 & わずか & 小さい & 中 & 大きい & & さまざま & 分からない \\
\hline 望ましくない効果 & 大きい & 中 & 小さい & わずか & & さまざま & 分からない \\
\hline エビデンスの確実性 & 非常に低 & 低 & 中 & 高 & & & 採用研究なし \\
\hline 価值観 & $\begin{array}{c}\text { 重要な不確実性 } \\
\text { またははららつき } \\
\text { あり }\end{array}$ & $\begin{array}{c}\text { 重要な不確実性 } \\
\text { またはばらつき } \\
\text { の可能性あり }\end{array}$ & $\begin{array}{l}\text { 重要な不確実性 } \\
\text { またはばらつき } \\
\text { はおそらくなし }\end{array}$ & $\begin{array}{c}\text { 重要な不確実性 } \\
\text { またははよらつき } \\
\text { はなし }\end{array}$ & & & \\
\hline 勃果のバランス & 比較が優位 & $\begin{array}{c}\text { 比較がおそらく } \\
\text { 優位 }\end{array}$ & $\begin{array}{c}\text { 介入も比較もい } \\
\text { ずれも優位でな } \\
\text { い }\end{array}$ & $\begin{array}{c}\text { おそらく介入が } \\
\text { 優位 }\end{array}$ & 介入が優位 & さまざま & 分からない \\
\hline 容認性 & いいえ & $\begin{array}{c}\text { おそらく、いい } \\
\text { え }\end{array}$ & おそらく、はい & はい & & さまざま & 分からない \\
\hline 実行可能性 & いいえ & $\begin{array}{c}\text { おそらく、いい } \\
\text { え }\end{array}$ & おそらく、はい & はい & & さまざま & 分からない \\
\hline
\end{tabular}


Table 18-13-3 採用された各研究における血糖值の管理目標值

\begin{tabular}{lll}
\hline Trial & Intervention & Control \\
\hline Vlasselaers 20096) & $\begin{array}{l}\text { Infant: } 50-80 \mathrm{mg} / \mathrm{dL} \\
\text { Children: } 70-100 \mathrm{mg} / \mathrm{dL}\end{array}$ & $\leqq 214 \mathrm{mg} / \mathrm{dL}$ \\
\hline Jeschke 20107) & $80-110 \mathrm{mg} / \mathrm{dL}$ & $140-180 \mathrm{mg} / \mathrm{dL}$ \\
\hline Agus 20128) & $80-110 \mathrm{mg} / \mathrm{dL}$ & “standard care” (担当医の判断) \\
\hline Macrae 20149) & $72-126 \mathrm{mg} / \mathrm{dL}$ & $<216 \mathrm{mg} / \mathrm{dL}$ \\
\hline Agus 2017 10) & $80-110 \mathrm{mg} / \mathrm{dL}$ & $150-180 \mathrm{mg} / \mathrm{dL}$ \\
\hline
\end{tabular}

具体的な目標血糖值の範囲を設定することに関する推 奨は論じられない，と結論づけている13)。

一方，重症小児の栄養ガイドラインでのこの問題の 扱いは，欧州小児新生児集中治療学会（European Society of Pediatric and Neonatal Intensive Care: ESPNIC) による 2020 年版のガイドラインにおいて，「低血糖を 回避するのに十分, かつ高血糖を予防できるだけの過 剩でない量のブドウ糖を経静脈的に投与すべきであ る。(推奨度 D, 強いコンセンサス)」とだけ記載され ており，具体的な血糖值の管理目標や厳密な管理に関 しては言及されていない14)。なお，米国集中治療医 学会（Society of Critical Care Medicine: SCCM）と米国 静脈経腸栄養学会 (American Society for Parenteral and Enteral Nutrition: ASPEN）による 2017 年版の重症小児 患者の栄養ガイドラインにおいては, 血糖管理に関し て全く言及されていない15)。

\section{（12）実施に関わる検討事項}

厳密な血糖管理については行わないことを推奨した が，浸透圧利尿を来すとされる $180 \mathrm{mg} / \mathrm{dL}$ を超える高 血糖が持続する場合におけるインスリン使用を制限す るものではない。

なお，採用された RCT における血糖值の管理目標 值が参考になる（Table 18-13-3）。

\section{（13）今後の研究の可能性}

小児敗血症患者に限定した厳密な血糖管理の研究が 行われることが理想的ではあるが，本 CQ の検討結果 や，成人領域において厳密な血糖管理の有効性を疑問 視する見方を踏まえると, 研究実施は現実的ではない かもしれない。

\section{文 献}

1) Branco RG, Garcia PC, Piva JP, et al: Glucose level and risk of mortality in pediatric septic shock. Pediatr Crit Care Med. 2005; 6: 470-2.

2) Wintergerst KA, Buckingham B, Gandrud L, et al: Association of hypoglycemia, hyperglycemia, and glucose variability with morbidity and death in the pediatric intensive care unit. Pediatrics. 2006; 118: 173-9.
3) Hirshberg E, Larsen G, Van Duker H: Alterations in glucose homeostasis in the pediatric intensive care unit: Hyperglycemia and glucose variability are associated with increased mortality and morbidity. Pediatr Crit Care Med. 2008; 9: 361-6.

4) Yung M, Wilkins B, Norton L, et al: Glucose control, organ failure, and mortality in pediatric intensive care. Pediatr Crit Care Med. 2008; 9: 147-52.

5) Faustino EV, Bogue CW: Relationship between hypoglycemia and mortality in critically ill children. Pediatr Crit Care Med. 2010; 11: 690-8.

6) Vlasselaers D, Milants I, Desmet L, et al: Intensive insulin therapy for patients in paediatric intensive care: a prospective, randomised controlled study. Lancet. 2009; 373: 547-56.

7) Jeschke MG, Kulp GA, Kraft R, et al: Intensive insulin therapy in severely burned pediatric patients: a prospective randomized trial. Am J Respir Crit Care Med. 2010; 182: 351-9.

8) Agus MSD, Steil GM, Wypij D, et al: Tight glycemic control versus standard care after pediatric cardiac surgery. $N$ Engl J Med. 2012; 367: 1208-19.

9) Macrae D, Grieve R, Allen E, et al: A randomized trial of hyperglycemic control in pediatric intensive care. N Engl J Med. 2014; 370: 107-18.

10) Agus MSD, Wypij D, Hirshberg EL, et al: Tight glycemic control in critically Ill children. N Engl J Med. 2017; 376: 729-41.

11）西田修, 小倉裕司, 井上茂亮, 他: 日本版敗血症診療ガイドラ イン 2016 作成特別委員会. 日本版敗血症診療ガイドライン 2016. 日集中医誌. 2017; 24: S1-232.

12）西田修, 小倉裕司, 井上茂亮, 他: 日本版敗血症診療ガイドラ イン 2016 作成特別委員会. 日本版敗血症診療ガイドライン 2016. 日救急医会誌. 2017; 28: S1-232.

13) Weiss SL, Peters MJ, Alhazzani W, et al: Surviving sepsis campaign international guidelines for the management of septic shock and sepsis-associated organ dysfunction in children. Intensive Care Med. 2020; 46: 10-67.

14) Tume LN, Valla FV, Joosten K, et al: Nutritional support for children during critical illness: European Society of Pediatric and Neonatal Intensive Care (ESPNIC) metabolism, endocrine and nutrition section position statement and clinical recommendations. Intensive Care Med. 2020; 46: 411-25.

15) Mehta NM, Skillman HE, Irving SY, et al: Guidelines for the Provision and Assessment of Nutrition Support Therapy in the Pediatric Critically Ill Patient: Society of Critical Care Medicine and American Society for Parenteral and Enteral Nutrition. Pediatr Crit Care Med. 2017; 18: 675-715. 


\section{CQ19：神経集中治療}

敗血症は様々な臓器障害を引き起こすが，脳も障害 される臓器の一つであり, 様々な症状を呈することが 知られている1)。また，脳障害を合併した敗血症患者 は, 脳障害を合併しない敗血症患者と比較して，有意 に死亡率が高くなることが報告されている2)。敗血症 における脳障害の原因は様々で, 病態生理学的な発生 機序は複合的であり ${ }^{3)}$, 敗血症関連脳障害と脳神経疾 患の合併の鑑別が必要である。治療可能な原因への早 期介入を行い，神経学的な予後を改善することができ る可能性がある1）ため，敗血症における脳障害の鑑 別と診断は重要である。

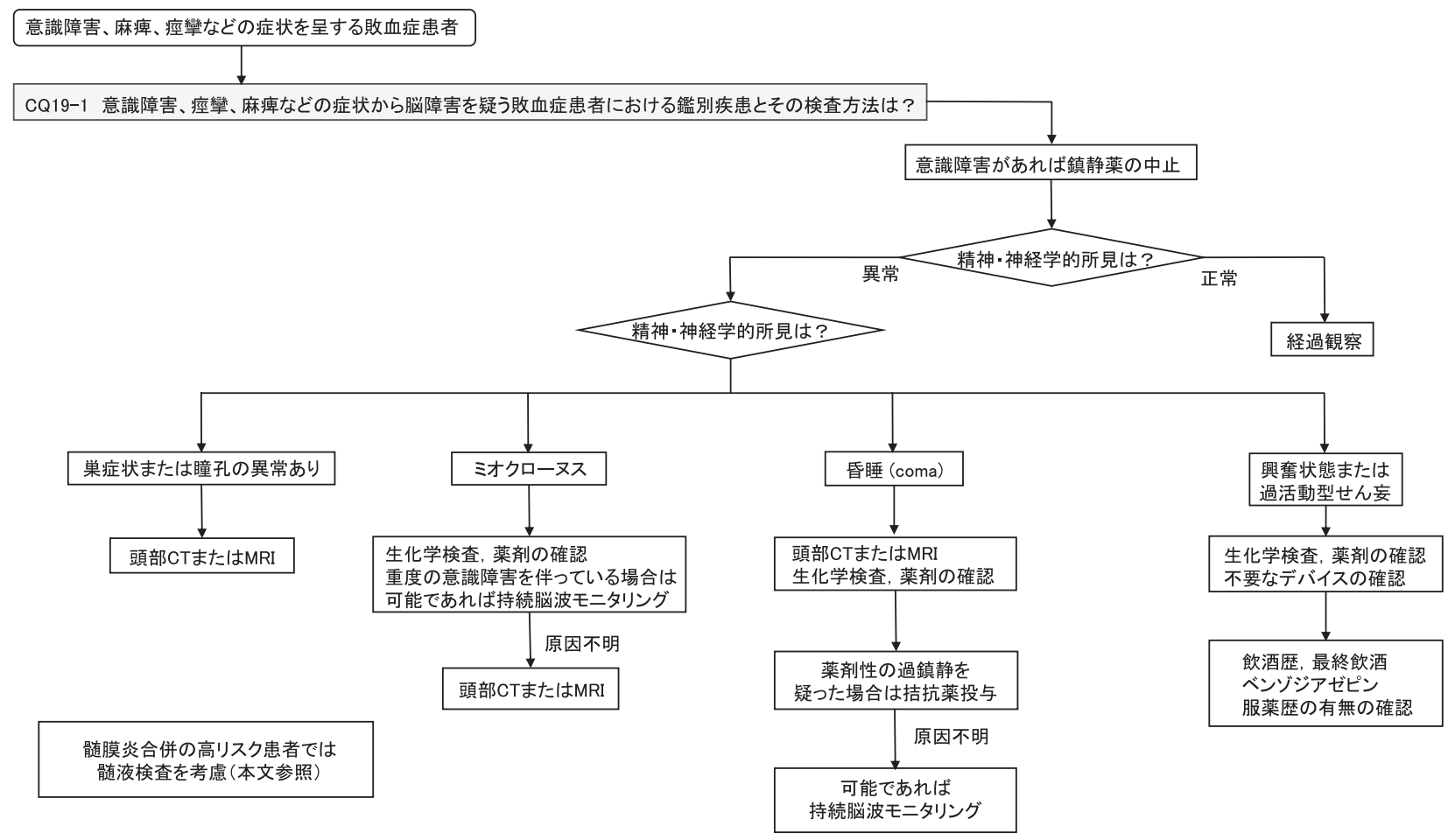

敗血症における脳障害の鑑別診断〔診療フロー〕

Crit Care Med. 2009; 37 (10 Suppl): S331-6. を参照して作成 
CQ19-1：意識障害, 痮攣, 麻痺などの症状から 脳障害を疑う敗血症患者における鑑別疾患とそ の検査方法は?

Answer : 脳障害の原因が複合していることも想定し, まず頭蓋内病変（脳卒中など）および潜在的原因（代 謝異常など）を鑑別する。検査には，頭部画像検査， 持続脳波モニタリング, 生化学検査, 原因となる薬剂 の確認, そして, 必要に応じて髄液検査がある。なか でも巣症状が認められれば, 頭部画像検査が優先され る (BQに対する情報提示)。

\section{（1）背景および本 $C Q$ の重要度}

敗血症患者では, 神経学的異常所見を伴うことは珍 しくない。神経学的異常への対応として, 敗血症の治 療が中心となる狭義の敗血症関連脳障害以外に, 脳梗 塞, 非痓攣性てんかん重積状態, 薬剂性脳症, 続発性 髄膜炎など, 治療の追加や治療内容の変更が必要とな る脳障害を見逃さないことが重要であり，本ガイドラ インの CQ として取り上げる必要があると考えた。

\section{（2）解説}

敗血症における脳障害の原因は，A）狭義の敗血症 関連脳障害，B）広義の敗血症関連脑障害，そして C) 敗血症に合併した脳神経疾患に分けることができ る1,4) が，実際はこれらの病態生理が複合している ことが多い5)。特に B）およびC）は特異的な治療が 必要な場合があるため, 鑑別を考えることが重要であ る。敗血症による脳障害は, せん妄, 軽度の意識障害 から昏睡まで多様な症状を呈する4)。

1）敗血症における脳障害の分類

A）狭義の敗血症関連脳障害

炎症性メディエータによる脳への直接的影響で あり，いわゆる敗血症関連脳症 (sepsis-associated encephalopathy）と呼ばれる病態である4)。敗血 症に伴い増加した炎症性メディエータにより，血 管内皮細胞の活性化，血液脳関門の破綻，血管自 己調節機能の破綻, 脳組織への好中球の遊走, ミ クログリアの活性化, 神経伝達物質の調節障害, ミトコンドリア不全などが生じ, びまん性の脳障 害が引き起こされる。重症の場合, MRI 上では 白質脳症の像を呈することがある6,7)。

B）広義の敗血症関連脳障害

低血圧，低酸素，腎機能障害による尿毒症や電 解質異常, 肝機能障害による高アンモニア血症な どの敗血症による脳以外の臟器障害, または薬剤
などによって間接的に引き起こされる脳障害であ る1, 4, 6)。

C）敗血症に合併した脳神経疾患

感染性心内膜炎に合併した髄膜炎, 感染性脳動 脈瘤の破裂によるくも膜下出血, 脳膿瘄, 脳灌流 低下による脳梗塞や，てんかん重積など，敗血症 に合併した新たな中枢神経系における病態のこと である。

2）敗血症における脳障害の鑑別疾患とその検査方法 敗血症における脳障害のうち, 狭義の敗血症関連脳 障害以外は, 敗血症の治療に加えて何らかの介入が必 要となる場合があるため, 敗血症における脳障害の分 類と診断を考えることは重要である。可能であれば鎮 静薬を中止または減量し, 薬剤による影響を最小限に したうえで身体所見をとることから鑑別診断を開始す る。身体所見に基づいた鑑別の進め方の 1 例として, (1)巣症状または瞳孔の異常があるか? (2)ミオクロー ヌスがあるか? (3)昏睡か? (4)興莴状態または過活 動型せん妄か? の 4 つの状態に分類して鑑別を進め る方法がある 4,8$)$ 。

(1)巣症状または瞳孔の異常があれば, 低血圧や低灌 流による脳梗塞, 凝固障害による脳出血など, 器質的 な異常が鑑別の上位に挙がるため, CT や MRI などの 頭部画像検査を優先することを考慮する。

(2)ミオクローヌスがあり, 意識障害が軽度の場合, 電解質異常, 尿毒症, 肝性脳症などの代謝異常, また は抗菌薬による薬剤性脳症などが原因である可能性を 考慮し, 生化学検查および使用している薬剂の確認が 優先される。腎不全や肝障害による代謝異常がある患 者で, ミオクローヌスと重度の意識障害を認めた場合 は, 非痓攣性てんかん重積状態を合併している可能性 を考慮し，持続脳波モニタリングを行うことをヨー ロッパ神経集中治療医学会は推奨している99。

(3)患者が昏睡である場合, 非痤攣性てんかん重積状 態, 代謝異常, 薬剤などが鑑別の上位に挙がる。しか し, 緊急の介入が必要となる可能性がある頭蓋内出血 などの器質的疾患の合併を最初に否定することが重要 である。頭部の画像検査を行った後, 血液検査, 薬剂 を確認する。それでも原因が不明な場合は, 可能であ れば持続脳波モニタリングを施行する。鎮痛・鎮静薬 の過剩投与や効果の遷延が疑われる場合はフルマゼニ ルやナロキソンなどの拮抗薬を投与し, 意識が改善す るかを確認する。脳波上, 発作波と解釈されるような 所見が認められず, 徐波, シータ波またはサプレッ ションパターンが優位に認められた場合は, 意識障害 の原因として狭義の敗血症関連脳障害，または低灌流 
によるびまん性の脳虚血状態，鎮静薬の過剩投与や効 果の遷延などの広義の敗血症関連脳障害が鑑別に挙が る3)。

(4)興奮状態または過活動型せん妄と判断した場合, 電解質異常，代謝異常の有無の確認と，せん妄を助長 する薬剤や不必要なデバイスの有無を確認する。ま た，せん妄の原因がアルコール離脱やベンゾジアゼピ ン離脱であることが見逃されていることが多く，過去 の服薬歴や飲酒量, 最終飲酒を確認することが重要で ある4)。

上記の (1)〜 (4)の中で挙げられた鑑別以外にも，敗血 症に合併した脳神経疾患の合併を考えることが重要で ある。その中でも髄膜炎の合併は抗菌薬の種類や投与 量の変更が必要となる場合があるため，特に診断が重 要である。様々な中枢神経系以外の感染源による敗血 症の中で，髄膜炎を合併することが稀ではないもの は, 細菌性肺炎, 中耳炎, 副鼻腔炎, そして感染性心 内膜炎である 10$)$ 。感染性心内膜炎と髄膜炎の合併に ついては，どちらが続発性であるかの区別が不可能な 場合が多く，感染性心内膜炎に髄膜炎を合併する頻度 は研究によって 0〜20\%とばらつきがある 10,11)。遠 隔の感染源からの続発性髄膜炎の起因菌として頻度が 高いものは，黄色ブドウ球菌と肺炎球菌である ${ }^{10,11) 。 ~}$ 1,025 人の髄膜炎患者を調査した後ろ向き研究では, 感染性心内膜炎と髄膜炎を合併した症例のうち，原因 菌として黄色ブドウ球菌（33\%）と肺炎球菌（54\%）

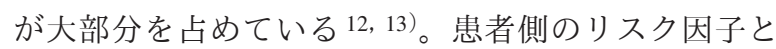
して，アルコール依存患者，免疫不全患者が報告され ている。

\section{文 献}

1) Oddo M, Taccone FS: How to monitor the brain in septic patients? Minerva Anestesiol. 2015; 81: 776-88.

2) Eidelman LA, Putterman D, Putterman C, et al: The spectrum of septic encephalopathy. Definitions, etioloqies, and mortalities. JAMA. 1996; 275: 470-3.

3) Sonneville R, Verdonk F, Rauturier C, et al: Understanding brain dysfunction in sepsis. Ann. Intensive Care. 2013; 3: 15.

4) Iacobone E, Bailly-Salin J, Polito A, et al: Sepsis-associated encephalopathy and its differential diagnosis. Crit Care Med. 2009; 37(10 Suppl): S331-6.

5) Gofton TE, Bryan Young G: Sepsis-associated encephalopathy. Nat Rev Neurol. 2012; 8: 557-66.

6) Polito A, Eischwald F, Maho AL, et al: Pattern of brain injury in the acute setting of human septic shock. Crit Care. 2013; 17: R204.

7) Sharshar T, Gray F, Poron F, et al: Multifocal necrotizing leukoencephalopathy in septic shock. Crit Care Med. 2002; 30: 2371-5.

8) Tokuda Y, Nakazato N, Stein GH: Pupillary evaluation for differential diagnosis of coma. Postgra Med J. 2003; 79: 49-51.

9) Claassen J, Taccone FS, Horn P, et al: Recommendations on the use of EEG monitoring in critically ill patients: Consensus statement from the neurointensive care section of the ESICM. Intensive Care Med. 2013; 39: 1337-51.

10) van de Beek D, de Gans J, Spanjaard L, et al: Clinical features and prognostic factors in adults with bacterial meningitis. N Engl J Med. 2004; 351: 1849-59.

11) Angstwurm K, Halle E, Wetzel K, et al: Isolated bacterial meningitis as the key syndrome of infective endocarditis. Infection. 2004; 32: 47-50.

12) Kanakadandi V, Annapureddy N, Agarwal SK, et al: The Austrian syndrome: A case report and review of the literature. Infection. 2013; 41: 695-700.

13) Lucas MJ, Brouwer MC, van der Ende A, et al: Endocarditis in adults with bacterial meningitis. Circulation. 2013; 127: 2056-62. 


\section{CQ20 : Patient- and Family-Centered Care}

集中治療医学の発展とエビデンスの集積, 診療ガイ ドラインの普及などにより, 敗血症患者における比較 的短期の生命予後は近年目覚ましく改善している ${ }^{1)}$ 。 一方で, 敗血症患者を対象にした多国間共同ランダム 化比較試験（RCT） 2) では，入院前の生活が自立して いた 2,130 名の患者のうち約 3 分の 1 が 6 か月後以内 に死亡し，6 か月後に QOL の測定を実施できた 580 名のうち $41.6 \%$ の患者が自立した生活を送ることが できない状況にあったと報告している。このような状 況などを鑑み，米国集中治療医学会は，2012 年に集 中治療後症候群 (post intensive care syndrome: PICS) という重要な概念を提唱した ${ }^{3)}$ 。PICS とは, 集中治 療室滞在中あるいは集中治療室退室後, さらには退院 後に生じる身体機能・認知機能・精神の障害で, 敗血 症などの集中治療を必要とする重症患者の長期予後は もとより，家族の精神にも影響を及ぼす病態である。 特に本邦は, 総人口に占める 65 歳以上の高齢者の割 合が $25 \%$ を超える世界でも類を見ない高齢化国家で ある4)。救命率が上がるにつれ要介護者が増え続ける 構図は社会的にみても決して健全な状態とはいえず, 本邦における重要政策課題である健康寿命延伸の実現 のためには, PICS をいかに予防・改善するのかが敗 血症診療において今後ますます重要になることは明白 である。

集中治療室に入室した呼吸不全またはショック患者
406 名を対象にした多施設前向き観察研究 5)による と, 退院後 12 か月後に身体機能・認知機能・精神の いずれかに障害があった患者の割合は $56.1 \%$ であり， 身体機能障害があった患者の $62.0 \%$ では，精神障害 または認知機能障害が併存していた。精神障害に関し て，集中治療室で 24 時間以上の診療を受けた患者 13,155 名を対象にした郵送法による質問紙調査 6）の 結果では, 集中治療室退室後 3 か月または 12 か月後 に不安・うつ・心的外傷後ストレス障害 (post-traumatic stress disorder: PTSD）のいずれかがあった患者の割合 は回答者 4,943 名の $55.2 \%$ にのぼり，そのうちの $64.8 \%$ の患者では2つ以上の精神障害が併存していた。 また, 家族の精神障害である PICS-F（post intensive care syndrome-family) の発生率（1～12 か月）は 5〜 $49 \%$ とされており 7 ), 患者の精神障害の重症度と家族 の精神障害の重症度は相関することが報告されてい る ${ }^{8)}$ 。以上のように PICS は，身体・認知・精神それ ぞれのドメイン間, 患者・家族間などが影響し合い構 成される複雑多様な病態であり, 効果的な予防・対策 方法については未だ明らかになっておらず，画一的な 介入ではなく, 有用性が示唆された複数の介入を束ね て実施する ABCDEFGH バンドル9）をはじめとする 包括的ケアが提案されている。

$\mathrm{ABCDEFGH}$ バンドルにおける痛み・不穏・せん妄 管理の向上などに関連し, 集中治療室滞在中の早期離 床・リハビリテーション, 療養環境の調整, 医療者と 患者や家族との関わりなどに係る課題が浮き彫りにな

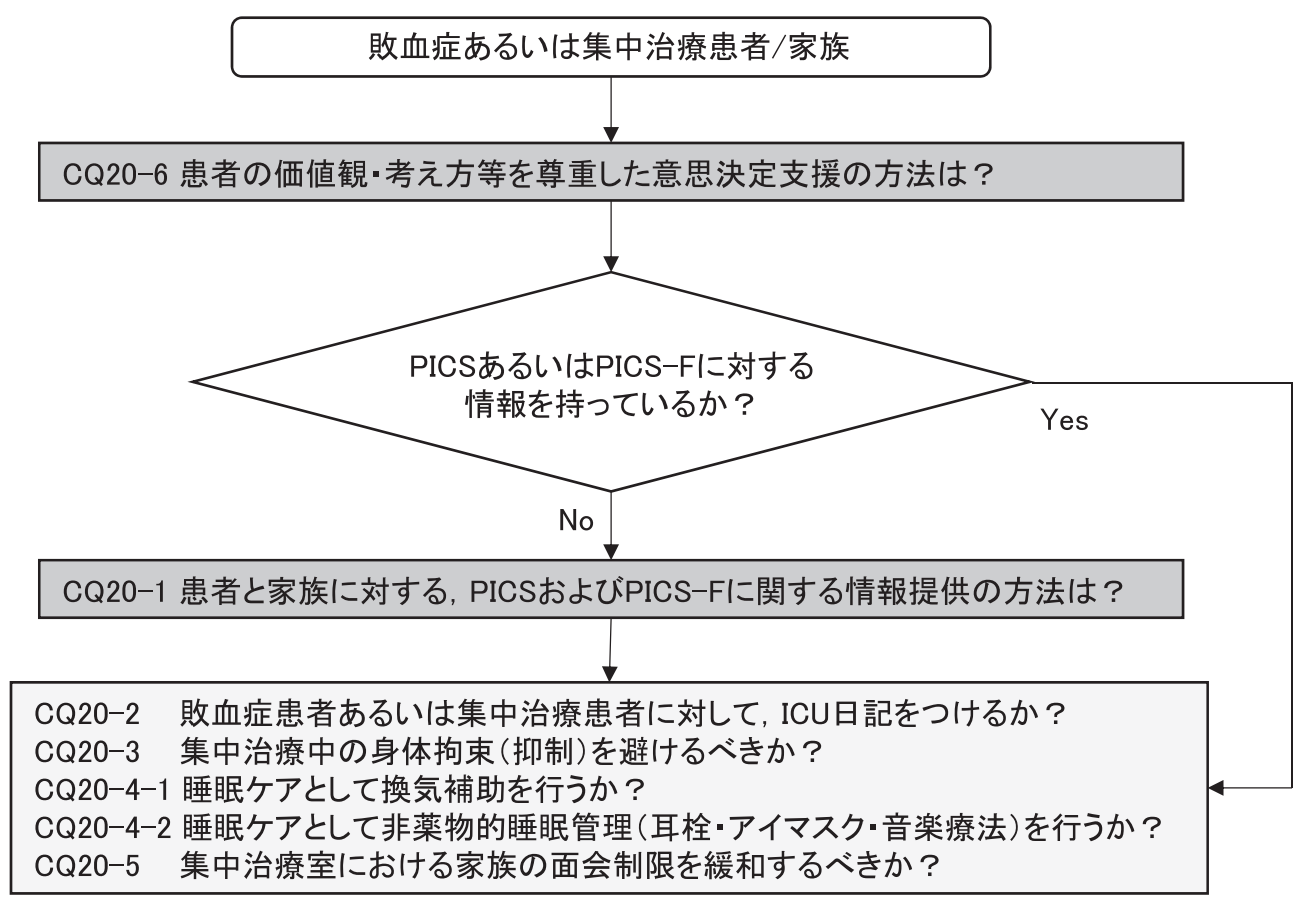

Patient-and Family-Centered Care[診療フロー] 
りつつある。日本版敗血症診療ガイドライン (J-SSCG)

2016 10）では世界に先駆けて PICS を独立した章とし て取り上げ, PICS 予防のための早期リハビリテーショ ンに係る推奨について記載している。ガイドラインな どでの推奨や，早期離床・リハビリテーション加算の 新設による診療報酬上の後押しもあり，日本集中治療 医学会会員を対象にした調査（回答者 453 名）による と，回答者の $92.1 \%$ の施設で早期リハビリテーショ ンが実施されていた ${ }^{11)}$ 。一方で, 回答者の約 4 割の 施設では, PICS や ABCDEF バンドルという用語が周 知・使用されていなかった11)。集中治療の対象は, 生活者たる人間である。また，集中治療室は集中治療 の場であるが, 患者にとっての療養生活の場でもあ る。多様な価值観や考え方をもつ患者の人間性を尊重 した診療のために，集中治療室滞在中からどのような 配慮が必要なのか, 患者や家族との関わりはどうある ベきなのか, 彼らの精神的なサポートのためには医療 従事者は何を行うべきなのかなど，考えるべき臨床的 課題は多い。これらの背景をもとに，J-SSCG 2020 で は，「Patient- and Family-Centered Care」を新たに独立 した章として取り上げた。「ICU-AW・PICS ・早期リ ハビリテーション」の章では主に身体機能に関連した 内容を扱い,「Patient- and Family-Centered Care」の章 では，患者と家族の精神に関連した内容，集中治療室 における療養環境や意思決定支援などに関する内容を 扱う領域と位置づけている。本章では，多職種から成 るワーキンググループでの議論により，20 を超える $\mathrm{CQ}$ 案の中から厳選を重ね，2つの $\mathrm{BQ}$ を含む 6 つの CQを取り上げた。これらはエビデンスに乏しい領域 であるが，今後の敗血症診療，および集中治療の質を 向上しうる，非常に重要な領域である。個々の患者と 家族を前に，その人の人間性を尊重した「Patient- and Family-Centered Care」はどのようにあるべきかを模索 するための礎となることを期待している。

\section{文 献}

1) Rudd KE, Johnson SC, Agesa KM, et al: Global, regional, and national sepsis incidence and mortality, 1990-2017: analysis for the Global Burden of Disease Study. Lancet. 2020; 395: 200-11.

2) Yende $S$, Austin $S$, Rhodes $A$, et al: Long-Term Quality of Life Among Survivors of Severe Sepsis: Analyses of Two International Trials. Crit Care Med. 2016; 44: 1461-7.

3) Needham DM, Davidson J, Cohen H, et al: Improving long-term outcomes after discharge from intensive care unit: report from a stakeholders'conference. Crit Care Med. 2012; 40: 502-9.

4) Nomura K, Koizumi A: Strategy against aging society with declining birthrate in Japan. Ind Health. 2016; 54: 477-9.

5) Marra A, Pandharipande PP, Girard TD, et al: Co-Occurrence of Post-Intensive Care Syndrome Problems Among 406 Survivors of Critical Illness. Crit Care Med. 2018; 46: 1393-401.
6) Hatch R, Young D, Barber V, et al: Anxiety, Depression and Post Traumatic Stress Disorder after critical illness: a UK-wide prospective cohort study. Crit Care. 2018; 22: 310.

7) Inoue S, Hatakeyama J, Kondo Y, et al: Post-intensive care syndrome: its pathophysiology, prevention, and future directions. Acute Med Surg. 2019; 6: 233-46.

8) Fumis RR, Ranzani OT, Martins PS, et al: Emotional disorders in pairs of patients and their family members during and after ICU stay. PLoS One. 2015; 10: e0115332.

9) Davidson JE, Harvey MA, Schuller J, et al: Post-intensive care syndrome: What is it and how to help prevent it. Am Nurse Today. 2013; 8: 32-8.

10) Nishida O, Ogura H, Egi M, et al: The Japanese Clinical Practice Guidelines for Management of Sepsis and Septic Shock 2016 (J-SSCG 2016). J Intensive Care. 2018; 6: 7.

11）日本集中治療医学会 PICS 対策·生活の質改善検討委員会: 本邦の診療現場における post-intensive care syndrome (PICS) の実態調査. 日集中医誌. 2019; 26: 467-75. 


\section{CQ20-1：患者と家族に対する, PICSおよび PICS-F に関する情報提供の方法は?}

Answer : 患者と家族等に, PICS および PICS-Fに関 する情報を正確に，かつ継続して提供することが重要 と考えられている。患者に関わるメディカルスタッフ は，集中治療室入退室時にリーフレットを渡すなど， 適宜情報を提供する動きが広まりつつある。さらに， 集中治療室退室後の回診やフォローアップ外来の開設 など，継続して情報を提供する取り組みが始まってい る (BQに対する情報提示)。

\section{（1）背景および本 $C Q$ の重要度}

日本集中治療医学会の会員を対象にした調査による と, PICS という用語や疾患概念が集中治療室で周知・ 使用されている割合は $61 \%$ であった 1 )。集中治療室 で従事する多くの医療者が PICS を知らない状況にお いて，患者や家族が PICS や PICS-Fに関する情報を 得ることは困難である。一方で, PICS や PICS-F は敗 血症患者とその家族に高率に発症する2)。そのため, 多くの患者と家族は不十分な情報のなかで PICS と PICS-Fに対峙し, 様々な苦痛や不安・恐怖, 治療に 対する葛藤などを抱えながら生活を送っていると推察 される。患者や家族に対して PICS や PICS-Fに関す る情報を正確に，かつ継続して提供することは, PICS や PICS-F が自分または大切な人だけに生じる特 別な異常ではないことの理解や, 安心などにつながる 可能性がある ${ }^{3)}$ 。また， PICS や PICS-Fに関する事前 の予測や早期発見, 迅速な対応につながる可能性もあ る3)。このように，PICS および PICS-F に関する情報 提供は重要であると考元られるが，どのような方法が 効果的であるのかは明らかになっていない。しかし， 今後の普及の可能性を考え，本ガイドラインの CQ と して取り上げた。

\section{（2）解説}

集中治療室入退室時にリーフレットを渡すことは非 常に簡便な情報提供の方法である。PICS や PICS-F の 概要や症状，相談先などを記載したリーフレットをあ らかじめ作成しておき, 集中治療室入退室時などに患 者や家族に手渡すことで適宜情報を提供する。その際 に，一方向からの情報提供で終わることがないよう， 患者・家族・医療者の双方向のコミュニケーションが 重要となる。集中治療室の概要や医療機器などに関す る情報を記載したリーフレットの提供が家族の理解や 満足度を向上させたとする多施設ランダム化比較試験
（RCT）がある 4）が，PICS や PICS-F に関する情報を 記載したリーフレットの提供について検証した研究は なく, 今後の研究が待たれる。

集中治療室退室後の回診や訪問は，集中治療室の医 師や看護師などが集中治療室退室後患者の病床に訪問 して情報を提供する方法である。集中治療室退室後患 者の $46 \%$ が，悪夢や幻覚などの真実ではない妄想的 記憶をもっていたことが報告されている5)。集中治療 室退室後の回診や訪問は, 集中治療室での体験や治療 の理解に関する齟齙や不明点を補うだけではなく, 病 状や機能障害について評価し，主治医などとの連携の もと, 集中治療室への再入室の必要性や適切な専門外 来などへの受診を早期に調整できる効果も期待され る。集中治療室退室後訪問が集中治療室での体験につ いての理解を助けたと報告する質的研究 6) や, 集中 治療室退室後訪問に記憶のゆがみを補正するための支 援プログラムを用いることによって，退院後の不安や うつ，ストレス障害を有意に改善させたとの報告7) がある。

集中治療室退室後のフォローアップ外来は，この 20 年でヨーロッパを中心に広がっている。2006 年時 点で英国の 30\% の集中治療室では, 集中治療室に3 4 日以上在室した患者を主な対象とし，フォローアッ プ外来が設置されていた ${ }^{8)}$ 。フォローアップ外来で提 供される主な医療は，スクリーニングッールを用いた 身体・精神・認知機能や QOL などの評価, リハビリ テーション, 精神・認知機能のサポート, 適切な専門 外来の紹介, 服薬管理などがある。フォローアップ外 来の有用性については, 英国の 3 施設での RCTに よって検証されているが, 退院 12 か月後の QOL や 不安・うつ・PTSD など，いずれにおいても有意な改 善を認めなかった9)。フォローアップ外来の形態や方 法，対象患者などは十分に検証されておらず，今後の 詳細な検証が必要である。また，本邦において普及す るためには, 診療報酬を始めとした医療制度の整備も 不可欠である。

患者と家族に対する，PICS および PICS-Fに関する 情報提供の有用性は，未だ十分に検証されていない。 本邦の集中治療室における実施率も $10 \%$ 未満と低率 である11) が，今後の研究次第によっては，実施が拡 大されていくものと考える。

\section{文 献}

1）日本集中治療医学会 PICS 対策 ·生活の質改善検討委員会: 本邦の診療現場における post-intensive care syndrome（PICS） の実態調査. 日集中医誌. 2019; 26: 467-75.

2) Inoue $\mathrm{S}$, Hatakeyama J, Kondo $\mathrm{Y}$, et al: Post-intensive care 
syndrome: its pathophysiology, prevention, and future directions. Acute Med Surg. 2019; 6: 233-46.

3) Davidson JE, Harvey MA, Schuller J, et al: Post-intensive care syndrome: What is it and how to help prevent it. American Nurse Today. 2013; 8: 32-8.

4) Azoulay E, Pochard F, Chevret S, et al: Impact of a family information leaflet on effectiveness of information provided to family members of intensive care unit patients: a multicenter, prospective, randomized, controlled trial. Am J Respir Crit Care Med. 2002; 165: 438-42.

5) Myhren H, Tøien K, Ekeberg O, et al: Patients' memory and psychological distress after ICU stay compared with expectations of the relatives. Intensive Care Med. 2009; 35: 2078-86.

6) Engström A, Andersson S, Söderberg S: Re-visiting the ICU experiences of follow-up visits to an ICU after discharge: a qualitative study. Intensive Crit Care Nurs. 2008; 24: 233-41.

7）木下佳子: 記憶のゆがみをもつ ICU 退室後患者への看護支 援プログラム開発とその有効性に関する研究. 日クリティ カルケア看会誌. 2011; 7: 20-35.

8) Griffiths JA, Barber VS, Cuthbertson BH, et al: A national survey of intensive care follow-up clinics. Anaesthesia. 2006; 61: 950-5.

9) Cuthbertson BH, Rattray J, Campbell MK, et al: The PRaCTICaL study of nurse led, intensive care follow-up programmes for improving long term outcomes from critical illness: a pragmatic randomised controlled trial. BMJ. 2009; 339: b3723.
CQ20-2：敗血症患者あるいは集中治療患者に対 して, ICU日記をつけるか?

Answer : 成人の敗血症患者あるいは集中治療患者に 対して，ICU日記をつけることを弱く推奨する (GARDE 2D : エビデンスの確実性 $=$ 「非常に低」)。

\section{（1）背景および本 $C Q$ の重要度}

集中治療室入室中の重症患者は深鎮静状態や強い侵 襲下にあるため, 集中治療室での記憶の一部ならびに 全部が欠損することがある。実際にはなかったできご とが鮮明な記憶として思い起こされる妄想的記憶に悩 まされることもある。これらは患者が集中治療室を退 室した後も遷延し, 心的外傷後ストレス障害（post traumatic stress disorder: PTSD）や急性ストレス障害 (acute stress disorder: ASD）の発生に関連するとされ る1)。これら記憶障害に対する介入として ICU 日記 ${ }^{2)}$ が提唱され，患者・家族における PTSD や不安，うつ 症状の軽減や健康関連 $\mathrm{QOL}$ の改善が報告されてい る3)。しかし, 現状では敗血症患者に対する ICU 日 記の有効性・有害性については定まっておらず, 臨床 現場でも介入方法に多様性がある。以上により，これ ら患者に対する ICU 日記の有効性・有害性を明らか にすることは重要臨床課題であるといえる。

(2) PICO

$\mathrm{P}$ (患者)：18 歳以上の敗血症患者あるいは集中治 療患者

I（介入）：ICU 日記介入の実施

C (対照)：ICU 日記介入の非実施

O (アウトカム)：患者の PTSD および ASD 発症, 患者の不安 (Hospital Anxiety and Depression Scale: HADS), 患者のうつ (HADS), 家族の PTSD お よび ASD 発症, 家族の不安 (HADS), 家族のう つ（HADS），あらゆる有害事象（患者のストレ ス，日記記載に関する負担）

\section{（3）エビデンスの要約}

システマティックレビューの結果, PICO に合致し たランダム化比較試験（RCT）が 3 件 4-6) 施行されて おり，これらを用いたメタ解析を実施した。なお，敗 血症患者に限定した RCT は見つけられなかったため, 対象患者は敗血症患者あるいは集中治療患者とした。 
（4）益と害のバランス（Table 20-2-1）

望ましい効果 :

患者の PTSD 発症の効果推定值は 1,000 人あたり 51 人少ない $(95 \%$ CI: 123 人少ない 41 人多い）となる。 また, HADS anxiety スコアが平均 0.82 少ない（95\% CI: 2.45 少ない 0.82 多い), HADS depression スコア が平均 1.01 少ない (95\% CI: 3.55 少ない〜1.53 多い) となる。したがって, 介入は, 患者のPTSD，うつ， 不安に対して小さな望ましい効果があるといえる。 望ましくない効果 :

1 つの RCT において，有害事象として ICU 日記が どれほど面倒かという項目を評価している。面倒さの 度合いを 10 段階評価して，全く面倒でない場合を 0 , 最も面倒である場合は 10 として計測し, 家族 $(\mathrm{n}=$ 78）では mean (SD) が $0.69(1.46)$, 友人 $(\mathrm{n}=4)$ では $2.0 （ 2.45)$, 看護師 $(\mathrm{n}=98)$ では $1.6(0.19)$, 医師 $(\mathrm{n}=12)$ では 1.75 (1.48), 看護師以外のメディ カルスタッフ $(\mathrm{n}=6)$ では 1.0（0.63）という結果と なり，あまり面倒ではないという結果となっている。 したがって，介入の望ましくない効果はわずかである と考えられた

\section{益と害のバランス :}

本 $\mathrm{CQ}$ においては, 効果推定值が広く確実性は低い ものの患者の PTSD, 不安, うつ, 家族の PTSD で ICU 日記に優位な結果である一方, 望ましくない効果 が限定的であるため, おそらく介入が優位と判断し た。

（5）アウトカム全般に関するエビデンスの確実性

今回採用したすべてのアウトカムの効果推定值にば らつきがあるため, アウトカム全体にわたるエビデン スの確実性は「非常に低」である。

\section{（6）価值観}

敗血症患者, 集中治療を要する患者に対する ICU 日記の介入における, 各アウトカムに置く患者・家族 の価値観に関するデータはない。本 $\mathrm{CQ}$ のアウトカム は患者・家族の PTSD，不安，うつであり，重視する か否かの価值観にはばらつきが想定される。

\section{（7）容認性}

有害事象はリスクが低い可能性が高い。介入に伴う

Table 20-2-1エビデンスプロファイル

\begin{tabular}{|c|c|c|c|c|c|c|c|c|c|c|c|c|}
\hline \multicolumn{7}{|c|}{ 碓実性の評価 } & \multicolumn{2}{|c|}{ 患者数 } & \multicolumn{2}{|c|}{ 勃果 } & \multirow[b]{2}{*}{ 確実性 } & \multirow[b]{2}{*}{ 重要性 } \\
\hline 研究数 & 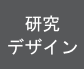 & $\begin{array}{l}\text { パイアス } \\
\text { のリスク }\end{array}$ & 非一貫性 & 非直接性 & 不精確性 & $\begin{array}{l}\text { その他 } \\
\text { の㛟討 }\end{array}$ & $\begin{array}{l}\text { ICU 日記を } \\
\text { つける }\end{array}$ & $\begin{array}{l}\text { ICU 日記を } \\
\text { つけない }\end{array}$ & $\begin{array}{l}\text { 相対指標 } \\
(95 \% \text { CI })\end{array}$ & $\begin{array}{l}\text { 絶対指摽 } \\
(95 \% \mathrm{CI})\end{array}$ & & \\
\hline \multicolumn{13}{|c|}{ 患者のPISD およびASD 発症 } \\
\hline 3 & RCT & 深刻 a & 深刻てない & 深刻てない & 深刻 ' & なし & $\begin{array}{l}60 / 216 \\
(27.8 \%)\end{array}$ & $\begin{array}{l}71 / 208 \\
(34.1 \%)\end{array}$ & $\begin{array}{l}\text { RR } 0.85 \\
\text { (0.64 to } 1.12)\end{array}$ & $\begin{array}{c}1,000 \text { 人あたり } 51 \\
\text { 人少ない (123人 } \\
\text { 少ないい } 14 \text { 人多 } \\
\text { (1) }\end{array}$ & $\underset{\text { 低 }}{\oplus \oplus \circ \bigcirc}$ & 重大 \\
\hline \multicolumn{13}{|c|}{ 患者の不安 (HADS) } \\
\hline 2 & RCT & 深刻 a & 深刻でない & 深刻てない & 深刻 b & なし & 189 & 184 & - & $\begin{array}{l}\text { 平均 } 0.82 \text { 低い } \\
(2.45 \text { 低い } \\
0.82 \text { 高い) }\end{array}$ & $\underset{\text { 低 }}{\oplus \oplus \circ}$ & 重大 \\
\hline \multicolumn{13}{|c|}{ 患者のうつ (HADS) } \\
\hline 2 & RCT & 深刻 a & 深刻。 & 深刻てない & 深刻 b & なし & 189 & 184 & - & $\begin{array}{l}\text { 平均 } 1.01 \text { 低い } \\
\text { (3.55 低い } \\
1.53 \text { 高い) }\end{array}$ & $\begin{array}{l}\oplus \circ 0 \bigcirc \\
\text { 非常に=低 }\end{array}$ & 重大 \\
\hline \multicolumn{13}{|c|}{ 家族のPSDD およびASD 発症 } \\
\hline 2 & RCT & 深刻 a & 深刻。 & 深刻てない & 非常1深刻 的 & なし & $\begin{array}{l}148 / 324 \\
(45.76)\end{array}$ & $\begin{array}{l}150 / 328 \\
(45.7 \%)\end{array}$ & $\begin{array}{c}\text { RR } 0.88 \\
\text { (0.56 to } 1.40)\end{array}$ & $\begin{array}{c}1,000 \text { 人あたり } 55 \\
\text { 人少ない (201 } \\
\text { 少ない } 183 \text { 人多 } \\
\text { (い) }\end{array}$ & $\begin{array}{l}\oplus \circ \bigcirc \bigcirc \\
\text { 非常に=低 }\end{array}$ & 重要 \\
\hline \multicolumn{13}{|c|}{ 家族の不安（HADS） } \\
\hline 1 & RCT & 深刻 a & 深刻てない & 深刻てない & 深刻 b & なし & 286 & 286 & - & 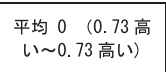 & $\underset{\text { 低 }}{\oplus \oplus \bigcirc}$ & 重要 \\
\hline \multicolumn{13}{|c|}{ 家族のうつ (HADS) } \\
\hline 1 & RCT & 深刻。 & 深刻てない & 深刻てない & 深刻 ' & なし & 286 & 286 & - & $\begin{array}{l}\text { 平均 } 0 \quad(0.73 \text { 低 } \\
\text { い 0.73高(い) }\end{array}$ & $\underset{\text { 低 }}{\oplus \oplus \bigcirc \bigcirc}$ & 重要 \\
\hline
\end{tabular}

a. blind できていないことが結果に大きく影響を与えると考えられるため。

b. 信頼区間が広く臨床的にみて有効かそうでないかの判断ができないから。

c. 研究間での効果推定値において，臨床的に差があると考えられる程度のばらつきがあると考えられるため。

d. RR が 0.75 と 1.25 の両方の間值を含むため。

・あらゆる有害事象に関して

Kredentser 2018 において，唯一，有害事象として ICU 日記がどれほど面倒かという項目を評価している。面倒さの度合いを 10 段階評価して，全く面倒でない場合を0，もっとも面倒である場合は 10 として計測。家族 $(n=78)$ では mean $(S D)$ が $0.69(1.46)$ ，友人 $(n=4)$ では $2.0(2.45)$ ，看護師 $(n=98)$ では $1.6(0.19)$ ，医師（ $\mathrm{n}=12 ）$ では 1.75(1.48)，看護師以外のコメディカルスタッフ $(\mathrm{n}=6)$ では $1.0(0.63)$ という結果となり，あまり面倒ではないという結果となっている。 
コストは人件費のみである。その個人負担額を考える

と, 患者・家族の個人の視点からおそらく許容できる だろう。

\section{（8）実行可能性}

介入は多くの医療施設において実行可能である。

（9）判断の要約（Table 20-2-2）

\section{（10）推奨グレーディング決定の工程}

修正 RAND 法を用いた投票によって，中央值 7, 見解不一致指数 0.164 の結果となり, 委員会で採択（7 点以上 : $91.7 \%$ )。

\section{（11）関連する他の診療ガイドラインにおける推奨}

日本版敗血症診療ガイドライン（J-SSCG）2016 7,8$)$ において，ICU 日記はPICS の予防方法としての記載に とどまっていた。また, 新生児, 小児, 成人集中治療室 における患者家族のためのガイドライン9）において， 家族の不安，抑うつ，PTSD を軽減するために ICU 日記 介入を実施することを提案している（2C）。しかし，集 中治療患者そのものに対する ICU 日記介入の実施の推 奨を検討するガイドラインは, 現時点では存在しない。

\section{（12）実施に関わる検討事項}

ICU 日記介入の実施や評価の方法, 医療スタッフの トレーニング・教育などの今後の検討が必要である。

\section{（13）今後の研究の可能性}

以下の内容に関する検討が求められると考えられる。

・集中治療を要する患者の中で敗血症患者に限定し た ICU 日記による有効性の検証

・サンプル数が多い研究における有害事象の検証

$$
\text { 文 献 }
$$

1) Hatch R, Young D, Barber V, et al: Anxiety, Depression and Post Traumatic Stress Disorder after critical illness: A UK-wide prospective cohort study. Crit Care. 2018; 22: 310.

2) Bäckman CG, Walther SM: Use of a personal diary written on the ICU during critical illness. Intensive Care Med. 2001; 27: 426-9.

3) McIlroy PA, King RS, Garrouste-Orgeas M, et al: The Effect of ICU Diaries on Psychological Outcomes and Quality of Life of Survivors of Critical Illness and Their Relatives: A Systematic Review and Meta-Analysis. Crit Care Med. 2019; 47: 273-9.

4) Garrouste-Orgeas M, Flahault $C$, Vinatier I, et al: Effect of an ICU Diary on Posttraumatic Stress Disorder Symptoms Among Patients Receiving Mechanical Ventilation: A Randomized Clinical Trial. JAMA. 2019; 322: 229-39.

5) Kredentser MS, Blouw M, Marten N, et al: Preventing posttraumatic stress in ICU survivors: A single-center pilot randomized controlled trial of ICU diaries and psychoeducation. Crit Care Med. 2018; 46: 1914-22.

6) Nielsen AH, Angel S, Egerod I, et al: The effect of familyauthored diaries on posttraumatic stress disorder in intensive care unit patients and their relatives: A randomised controlled trial (DRIP-study). Aust Crit Care. 2020; 33: 123-9.

7）西田修, 小倉裕司, 井上茂亮, 他, 日本版敗血症診療ガイドラ イン 2016 作成特別委員会. 日本版敗血症診療ガイドライン 2016. 日集中医誌. 2017; 24: S1-232.

8）西田修, 小倉裕司, 井上茂亮, 他, 日本版敗血症診療ガイドラ イン 2016 作成特別委員会. 日本版敗血症診療ガイドライン 2016. 日救急医会誌. 2017; 28: S1-232.

9) Davidson JE, Aslakson RA, Long AC, et al: Guidelines for Family-Centered Care in the Neonatal, Pediatric, and Adult ICU. Crit Care Med. 2017; 45: 103-28.

Table 20-2-2 判断の要約

\begin{tabular}{|c|c|c|c|c|c|c|c|}
\hline 問題 & いいえ & $\begin{array}{c}\text { おそらく、いい } \\
\text { え }\end{array}$ & おそらく、はい & はい & & さまざま & 分からない \\
\hline 望ましい効果 & わずか & 小さい & 中 & 大きい & & さまざま & 分からない \\
\hline 望ましくない効果 & 大きい & 中 & 小さい & わずか & & さまざま & 分からない \\
\hline エビデンスの確実性 & 非常に低 & 低 & 中 & 高 & & & 採用研究なし \\
\hline 価值観 & $\begin{array}{c}\text { 重要な不確実性 } \\
\text { またはばらつき } \\
\text { あり }\end{array}$ & $\begin{array}{c}\text { 重要な不確実性 } \\
\text { またはばらつき } \\
\text { の可能性あり }\end{array}$ & $\begin{array}{l}\text { 重要な不確実性 } \\
\text { またはばらつき } \\
\text { はおそらくなし }\end{array}$ & $\begin{array}{c}\text { 重要な不確実性 } \\
\text { またはばらつき } \\
\text { はなし }\end{array}$ & & & \\
\hline 効果のバランス & 比較が優位 & $\begin{array}{c}\text { 比較がおそらく } \\
\text { 優位 }\end{array}$ & $\begin{array}{c}\text { 介入も比較もい } \\
\text { ずれも優位でな } \\
\text { い }\end{array}$ & $\begin{array}{c}\text { おそらく介入が } \\
\text { 優位 }\end{array}$ & 介入が優位 & さまざま & 分からない \\
\hline 容認性 & いいえ & $\begin{array}{c}\text { おそらく、いい } \\
\text { え }\end{array}$ & おそらく、はい & はい & & さまざま & 分からない \\
\hline 実行可能性 & いいえ & $\begin{array}{c}\text { おそらく、いい } \\
\text { え }\end{array}$ & おそらく、はい & はい & & さまざま & 分からない \\
\hline
\end{tabular}




\section{CQ20-3：集中治療中の身体拘束（抑制）を避け るべきか?}

Answer：成人の敗血症患者あるいは集中治療患者に 対して, 集中治療中の身体拘束（抑制）を避けること を弱く推奨する（GARDE 2C：エビデンスの確実性 $=「$ 低」)。

\section{（1）背景および本 $C Q$ の重要度}

身体拘束（抑制）とは「抑制帯等，患者の身体又は 衣服に触れる何らかの用具を使用して，一時的に当該 患者の身体を拘束し，その運動を抑制する行動の制 限」をいう（厚生労働省通知令和 2 年 3 月 5 日付保医 発 0305 第 1 号別添 1)。身体抑制は基本的人権や人間 の尊㛜を守ることを妨げる行為であり，倫理的に大き な問題とされながらも，多くの集中治療室で頻繁に実 施されている介入である 1,2$)$ 。敗血症患者あるいは集 中治療患者は生命維持に係る種々の医療機器などを装 着する患者が多く，身体抑制はこれらの医療デバイス の計画外抜去などから患者の安全を守るために実施さ れている3,4）が，それに関して検証したランダム化 比較試験（RCT）はなく，身体抑制の有用性は明らか になっていない。一方で，身体抑制は，抑制部位の皮 膚損傷などの身体障害5）や，不動化や裖瘡，院内感 染 6), せん妄 7,8$)$, PTSD などの精神障害9), 認知症 等の認知機能障害 10) などの有害事象と関連すること が報告されているが，その影響についても明らかでは ない。身体抑制は，その益も害も十分に検証されない まま，臨床において一般的に実施されている特殊な介 入である。以上により，集中治療中の身体抑制につい ては Patient-and Family-Centered Care において取り上 げるべき重要臨床課題であり, 本 CQ では集中治療中 の身体抑制を避けるべきかについて検証した。

\section{(2) PICO}

P (患者)：18 歳以上の敗血症患者あるいは集中治 療患者

I（介入）：集中治療室入室中に身体拘束（抑制）を 行わない

C (対照)：集中治療室入室中に身体拘束（抑制）を 行う

$\mathrm{O}$ (アウトカム ) : せん妄発症, 人工呼吸期間, ICU 滞在日数, デバイスの計画外抜去発生，身体抑制 に対する患者や家族の思い，身体抑制に対する医 療者の思い, 身体抑制の代替法

\section{（3）エビデンスの要約}

MEDLINE, CENTRAL, CINAHL, 医学中央雑誌を用 いた文献検索の結果，897 論文を抽出し，重複を削除 した 557 論文のタイトルと抄録を確認した。このうち, 対象論文の可能性がある 84 論文の全文原稿を確認し, 16 編の質的研究 11-26）と, 15 編の観察研究 8, 27-40) を対象論文として選択した。質的研究に対しては Confidence in the Evidence from Reviews of Qualitative research（CERQual）アプローチによる質的エビデンス の統合を実施した。また, 観察研究に対してはメタ解 析を実施した。なお，敗血症患者に限定した研究は見 つけられなかったため, 対象患者は敗血症患者あるい は集中治療患者とした。

\section{（4）益と害のバランス（Table 20-3-1）}

CERQualによる質的エビデンス統合の結果，集中 治療室で身体抑制を実施された患者は身体抑制につい て, 覚えていない, 安全確保のため問題ないとする一 方で，人権や人間の尊厳を侵害するため実施すべきで ないと考えていた（エビデンスの確信性：低）。家族 は身体抑制を仕方ないと考えながらもかわいそうと感 じ，医療者の丁寧な説明や身体抑制を最小限にする配 慮をありがたいと感じていた（エビデンスの確信性 : 非常に低)。医療者は身体抑制の有害事象を危惧しな がらも, 安全確保のために, ジレンマのなかで無力感 を感じながら実施していた（エビデンスの確信性 : 高)。医療者は身体抑制の代替法として, 手厚い人員 配置などの体制整備とともに，施設の体制によらな い, 生活者としての個人を尊重するケアが重要と考え ていた（エビデンスの確信性 : 高)。

観察研究のメタ解析の結果, せん妄発症 (10 観察 研究: $n=2,184 ）$ のオッズ比 $(95 \% \mathrm{CI})$ は 0.09 $(0.04 \sim 0.19)$, 人工呼吸期間 $(2$ 観察研究 $: n=1,132)$ の差は 0.8 日短い (95\% CI: 6.71 日短い〜 5.12 日長い), ICU 滞在日数（4 観察研究 $: n=1,105 ）$ の差は 3.99 日短い（95\% CI: 7.91 日短い〜0.07 日短い）と，デバ イスの計画外抜去発生は 1,000 人あたり 64 人少ない （95\% CI: 89 人少ない〜 2 人少ない）であり, 介入群 に優位な相関を示したが，ほとんどの一次研究のバイ アスリスクは非常に深刻であったことから，介入とア ウトカムの因果関係を示すことは困難である。

CERQualの結果では，集中治療中の身体抑制の実 施は, 患者の人権や尊厳の侵害, 医療者の無力感や葛 藤などの精神的負担に影響を与える可能性があるた め, 身体抑制を避けることは小さな益に資すると考え られる。望ましい効果は小さく, 望ましくない効果は 
Table 20-3-1エビデンスプロファイル

【CERQual】

\begin{tabular}{|c|c|c|c|c|c|c|c|}
\hline レビュー所見 & $\begin{array}{l}\text { レビュー所 } \\
\text { 見に寄与しし } \\
\text { た } 1 \text { 次研究 }\end{array}$ & 方法論的限界 & 整合性 & 適切性 & 関連性 & $\begin{array}{l}\text { 全体的 } \\
\text { CERQual } \\
\text { 確信的評価 }\end{array}$ & CERQual 評価の説明 \\
\hline \multicolumn{8}{|l|}{ 身体拘束（抑制）に対する患者や家族の思い } \\
\hline 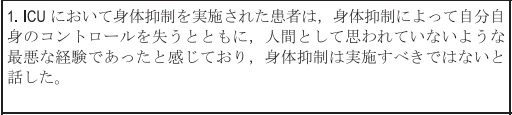 & 研究 4,15 & $\begin{array}{l}\text { 中程度の方法論的限 } \\
\text { 界 (不明確な募集と } \\
\text { サンンプング戦略, } \\
\text { 再帰性なしし, 不明確 } \\
\text { な結果) }\end{array}$ & \begin{tabular}{|l|} 
整合性に関する非 \\
常に小さい奬念 \\
\\
\end{tabular} & 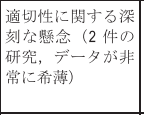 & 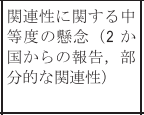 & $\begin{array}{l}\text { 磪信性： } \\
\text { 低」 }\end{array}$ & 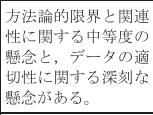 \\
\hline $\begin{array}{l}\text { 2.1CUにこおいて身体抑制を実施された患者は，身体抑制を実施されたこ } \\
\text { とを党えていなかった。 }\end{array}$ & 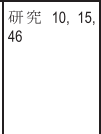 & $\begin{array}{l}\text { 小さな方法論的限界 } \\
\text { (不明確な募集とサ } \\
\text { ンブリング戰略) }\end{array}$ & $\begin{array}{l}\text { 整合性に関する樑 } \\
\text { 刻な獎念(いずれ } \\
\text { の研究にむレビュ } \\
\text { 一所見と買なるデ } \\
\text { 一タがある }\end{array}$ & $\begin{array}{l}\text { 適切性に関する中 } \\
\text { 等度な睌念 (3 件 } \\
\text { の研究, データが } \\
\text { 希薄) }\end{array}$ & 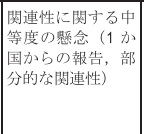 & 䂾售珄: & 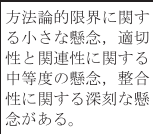 \\
\hline 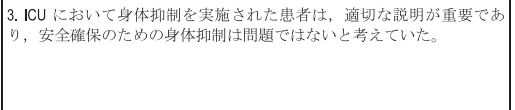 & 研究 10, 46 & $\begin{array}{l}\text { 小さな方法論的限界 } \\
\text { (不明確な募集とサ } \\
\text { ンプリング戦略) }\end{array}$ & \begin{tabular}{|l|} 
整合性に関する非 \\
常に小さい獎念
\end{tabular} & \begin{tabular}{|l} 
適切性に関する深 \\
刻な縣念 (2 件の \\
研究, データが非 \\
常に希薄)
\end{tabular} & $\begin{array}{l}\text { 関連性に関する媣 } \\
\text { 刻の獎念( } \text { か国 } \\
\text { からの報告, 非常 } \\
\text { に部分的な関連 } \\
\text { 性) }\end{array}$ & 礔信性： & 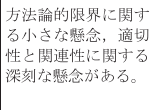 \\
\hline 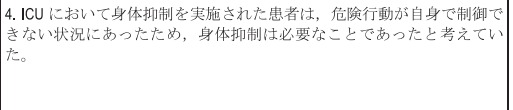 & 研究 10, 46 & 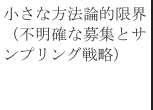 & \begin{tabular}{|l|} 
整合性に関する非 \\
常に小さい奬念
\end{tabular} & 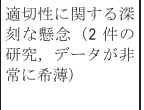 & $\begin{array}{l}\text { 関連性に関する樑 } \\
\text { 刻の獎念( } \text { か国 } \\
\text { からの報告, 非常 } \\
\text { に部分的な関連 } \\
\text { 性) }\end{array}$ & 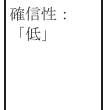 & 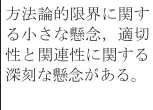 \\
\hline 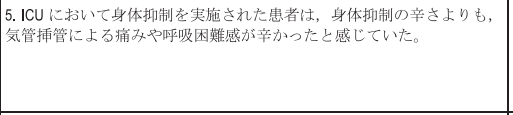 & 研究 10,46 & $\begin{array}{l}\text { 小さな方法論的限界 } \\
\text { (不明確な募集とサ } \\
\text { ンプリング戦䀩) }\end{array}$ & $\mid$\begin{tabular}{|c|c|} 
整合性に関する非 \\
常に小さい獎念
\end{tabular} & \begin{tabular}{|l} 
適切性に関する深 \\
刻な懸念 $(2$ 件 0 \\
研究, デーダーダ \\
常に布薄)
\end{tabular} & \begin{tabular}{|l} 
関連性に関する樑 \\
刻の懸念(本邦か \\
らの報告だが, 1 \\
研究のみ。非常に \\
部分的な関連性)
\end{tabular} & [確信性! & 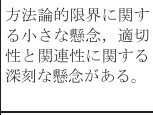 \\
\hline 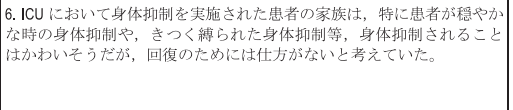 & 研究 82 & 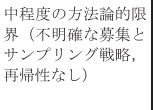 & 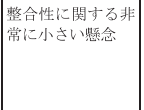 & $\begin{array}{l}\text { 適切性に関する深 } \\
\text { 刻な曗念(1 件の } \\
\text { 研究, データが非 } \\
\text { 常に希薄) }\end{array}$ & $\begin{array}{l}\text { 関連性に関する樑 } \\
\text { 刻の獎念( } \text { か国 } \\
\text { からの報告, 非常 } \\
\text { に部分的な関連 } \\
\text { 性) }\end{array}$ & $\begin{array}{l}\text { 確信性 : } \\
\text { 常 に } \\
\text { 低」 }\end{array}$ & 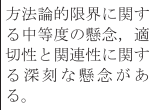 \\
\hline 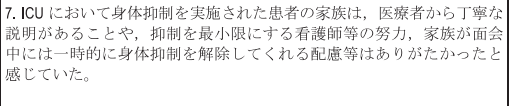 & 研究 82 & 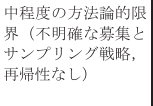 & 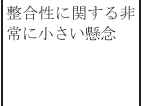 & \begin{tabular}{|l} 
適切性に関する深 \\
刻な㝥念 (1 件の \\
研究, データが非 \\
常に希薄)
\end{tabular} & \begin{tabular}{|l} 
関連性に関する深 \\
刻の奬念(本邦か \\
らの報告だが, 1 \\
研究のみ。非常に \\
部分的な関連性)
\end{tabular} & $\begin{array}{l}\text { 確信性 : } \\
\text { 常 に } \\
\text { 低」 }\end{array}$ & 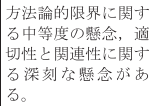 \\
\hline
\end{tabular}

\section{身体拘束（狮制）に対する医療者の思い}

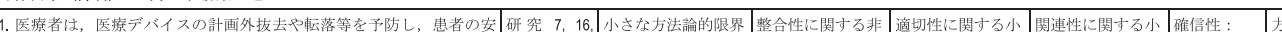

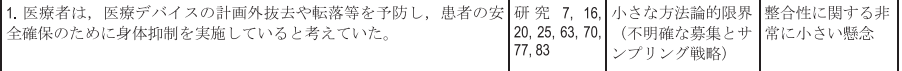

適切性に関する小

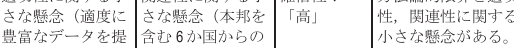

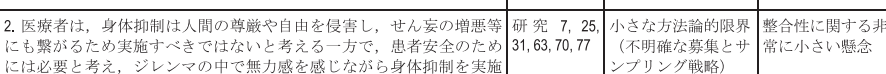
には必要と考え,

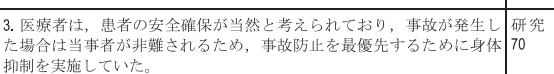

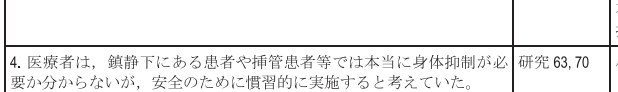
( \begin{tabular}{l|l} 
十分な対象者の選 & $\begin{array}{l}1 \text { 次研究のデータ } \\
\text { がある }\end{array}$ \\
\hline
\end{tabular} 8つ硏 報告

適切性红閣する小

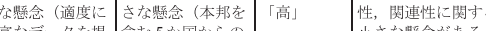

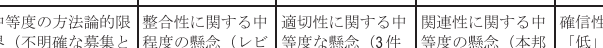

希薄)

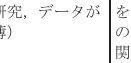

郝告, 部分的的 連性)

さな彩念がある。

\begin{tabular}{|c|c|c|c|c|c|c|c|}
\hline 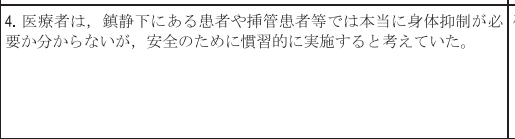 & 研究 63,70 & $\begin{array}{l}\text { 小さな方法論的限界 } \\
\text { (不明確な募集とササ } \\
\text { ンプリグ栈略) }\end{array}$ & 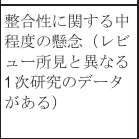 & \begin{tabular}{|l|} 
適切性に関する深 \\
刻な彩念 (2件の \\
研究, データが非 \\
常に希薄)
\end{tabular} & \begin{tabular}{|l} 
関連性に関する中 \\
等度の懸念 (本邦 \\
を含む 2か国から \\
の報告, 部分的な \\
関連性)
\end{tabular} & $\begin{array}{l}\text { 磼信性 } \\
\text { 「低」 }\end{array}$ & 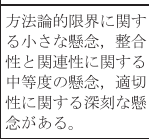 \\
\hline 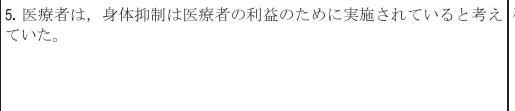 & 研究 25, 31 & $\begin{array}{l}\text { 中等度の方法論的限 } \\
\text { 界 (不明確な募集と } \\
\text { サンプリンク戰略, } \\
\text { 不十分な対象若の選 } \\
\text { 択) }\end{array}$ & 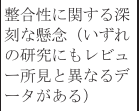 & 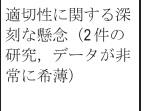 & \begin{tabular}{|l} 
関連性に関する深 \\
刻の嶈念 (2か国 \\
からの報告, 非常 \\
に部分的な関連 \\
性)
\end{tabular} & $\begin{array}{l}\text { 確信性： } \\
\text { 「非常江 } \\
\text { 低」 }\end{array}$ & 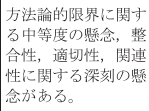 \\
\hline $\begin{array}{l}\text { 6. 医療者は，身体抑制を実施すると重大な傷害が起こりうると考えてて } \\
\text { いた。 }\end{array}$ & $\mid \begin{array}{l}\text { 研究 } 16,31, \\
63\end{array}$ & $\begin{array}{l}\text { 小さな方法論的限界 } \\
\text { (不明確な募集とサ } \\
\text { ンプリング被略) }\end{array}$ & 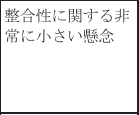 & 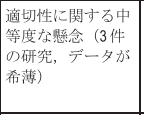 & 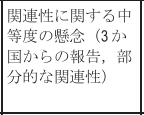 & 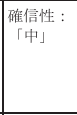 & 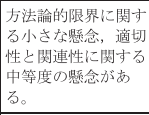 \\
\hline $\begin{array}{l}\text { 7. 医療者は，患者の安全だけではなく，医療者の保護のためにも身体 } \\
\text { 抑制が必要であと考えてい。 }\end{array}$ & 研究 25 & $\begin{array}{l}\text { 中等度の方法論的限 } \\
\text { 界 (不明確な募集と } \\
\text { サンブリング略, } \\
\text { 不十分な対象若の選 } \\
\text { 択) } \\
\end{array}$ & 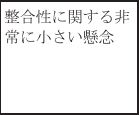 & \begin{tabular}{|l|} 
適切性に関する深 \\
刻な奬念(1件の \\
研究, データが非 \\
常に希薄)
\end{tabular} & 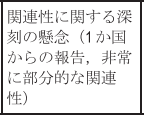 & $\begin{array}{l}\text { 確信性： } \\
\text { 「非常目 } \\
\text { 低」 }\end{array}$ & $\begin{array}{l}\text { 方法論的限界に関す } \\
\text { る中等度の奬念, 適 } \\
\text { 切性と関連性に関す } \\
\text { る深刻な牀念があ } \\
\text { る。 }\end{array}$ \\
\hline 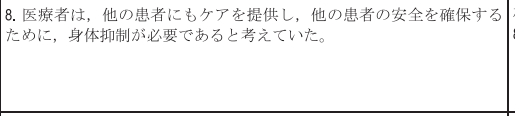 & $\mid \begin{array}{l}83 \\
83\end{array}$ & $\begin{array}{l}\text { 小さな方法論的限界 } \\
\text { (不明確な募集とサ } \\
\text { ンブリング临略) }\end{array}$ & 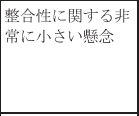 & \begin{tabular}{|l} 
適切性に関する中 \\
等度な獎念 (3件 \\
の研究, データが \\
希薄)
\end{tabular} & \begin{tabular}{|l} 
関連性に関する中 \\
等度の懸 (すぐ \\
て本邦からの報 \\
告, 部分的な関連 \\
性)
\end{tabular} & $\begin{array}{l}\text { 磪信性: } \\
\text { 「中」 }\end{array}$ & 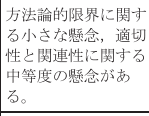 \\
\hline 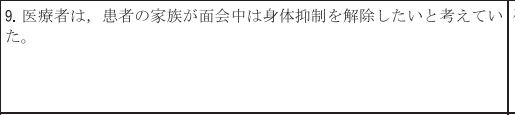 & 研究 $7,63,77 \mid$ & $\begin{array}{l}\text { 小さな方法論的限界 } \\
\text { (不明確な募集とササ } \\
\text { ンブリング羢略) }\end{array}$ & 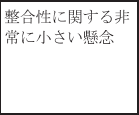 & $\begin{array}{l}\text { 適切性に関する中 } \\
\text { 等度な獎念 (3件 } \\
\text { の研究, データが } \\
\text { 希薄) }\end{array}$ & 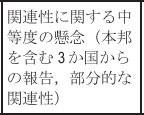 & \begin{tabular}{|l} 
础信性: \\
「中」
\end{tabular} & 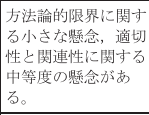 \\
\hline 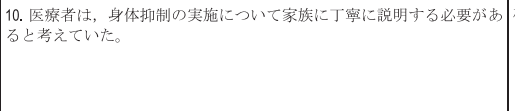 & 研究 7, 25, 63 & 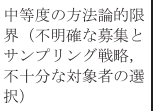 & 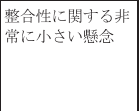 & 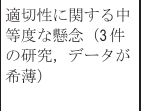 & 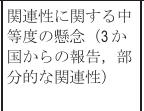 & $\begin{array}{l}\text { 磼信性 : } \\
\text { 「中」 }\end{array}$ & 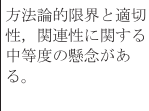 \\
\hline $\begin{array}{l}\text { 11. 医潦者は，職種間で身体抑制比対する考え方が異なると考えてい } \\
\text { た。 }\end{array}$ & $\mid \begin{array}{l}\text { 研究 } 7,31, \\
63,70\end{array}$ & $\begin{array}{l}\text { 小さな方法論的限界 } \\
\text { (不明確な募集とササ } \\
\text { ンプリング戦略) }\end{array}$ & 整合性江闒する非 & 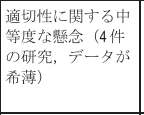 & 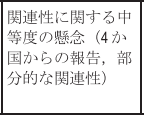 & 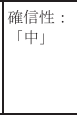 & $\begin{array}{l}\text { 方法論的限界に関す } \\
\text { る小さ奬念, 適切 } \\
\text { 性と関連性に関する } \\
\text { 中等度の將念があ } \\
\text { る。 }\end{array}$ \\
\hline 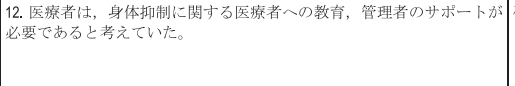 & 研究 31, 63 & 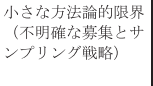 & 整合性に闒する非 & 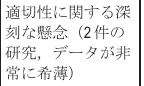 & 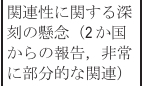 & $\begin{array}{l}\text { 確信性 : } \\
\text { 「低」 }\end{array}$ & 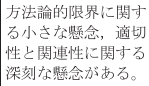 \\
\hline
\end{tabular}




\begin{tabular}{|c|c|c|c|c|c|c|c|}
\hline 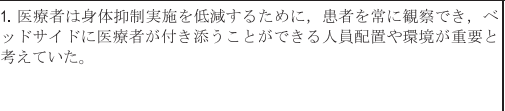 & $\begin{array}{l}\text { 研究 } 13,16 \\
20,25,63,77 \\
83\end{array}$ & \begin{tabular}{|l} 
小さな方法論的限界 \\
(不明確な幕集とサ \\
ンブリンク戦略)
\end{tabular} & \begin{tabular}{|l|} 
整合性に関する非 \\
常に小さい徆念 \\
\end{tabular} & 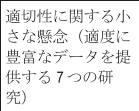 & 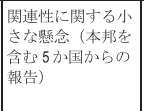 & 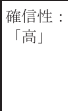 & 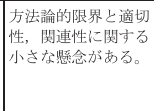 \\
\hline 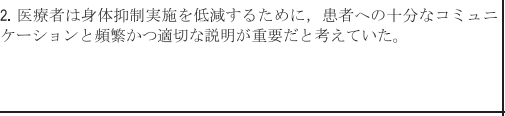 & $\mid \begin{array}{l}\text { 研究 } 13,20, \\
31,84\end{array}$ & $\begin{array}{l}\text { 小さな方法論的限界 } \\
\text { (不明確な募集とサ } \\
\text { ンブリンク戦略) }\end{array}$ & \begin{tabular}{|l|} 
整合性に関する非 \\
常に小い獎念
\end{tabular} & 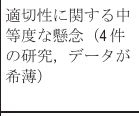 & 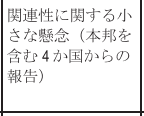 & $\begin{array}{l}\text { 確信性 : } \\
\text { 「中」 }\end{array}$ & 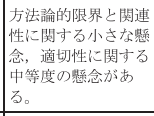 \\
\hline 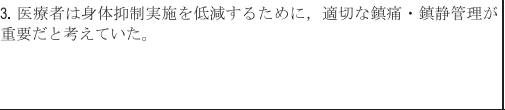 & $\left|\begin{array}{l}\text { 研究 } 13,16, \mid \\
20,31\end{array}\right|$ & \begin{tabular}{|l} 
小さな方法論的限界 \\
(不明確な募集とサ \\
ンプリング戦略)
\end{tabular} & \begin{tabular}{|l|} 
慗合性に関する非 \\
常に小さい䁛念
\end{tabular} & 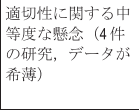 & 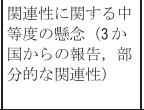 & $\begin{array}{l}\text { 確信性 } \\
\text { 「中」 }\end{array}$ & $\begin{array}{l}\text { 方法論的限界に関す } \\
\text { る小さな䝮念, 適切 } \\
\text { 性と関連性に関するる } \\
\text { 中等度の䁖念があ } \\
\text { る。 }\end{array}$ \\
\hline 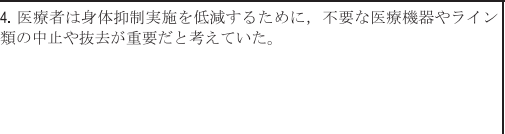 & 研究 16,77 & $\begin{array}{l}\text { 小さな方法論的限界 } \\
\text { (不明確な募集とサ } \\
\text { ンブリング戦略) }\end{array}$ & 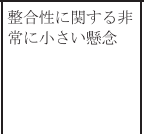 & 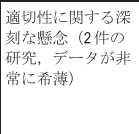 & $\begin{array}{l}\text { 関連性に関する中 } \\
\text { 等度の懸 (本邦 } \\
\text { を含む } 2 \text { か国から } \\
\text { の報告, 部分的な } \\
\text { 関連性) }\end{array}$ & $\begin{array}{l}\text { 確信性 : } \\
\text { 「中」 }\end{array}$ & 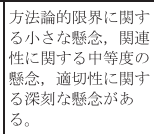 \\
\hline 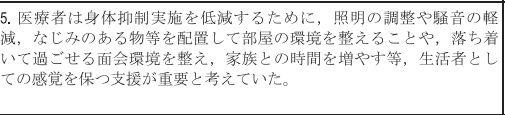 & 研究 13,16, & $\begin{array}{l}\text { 小さな方法論的限界 } \\
\text { ( 不明稚な募集とササ } \\
\text { ンプリンク戦略) }\end{array}$ & \begin{tabular}{|l|} 
整合性に関する非 \\
常に小さい獎念 \\
\end{tabular} & 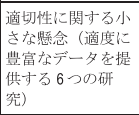 & \begin{tabular}{|l|} 
関連性に関する小 \\
さな愳念(本邦を \\
含む 4 か国からの \\
報告)
\end{tabular} & 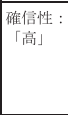 & $\begin{array}{l}\text { 方法論的限界と適切 } \\
\text { 性, 関連性に関する } \\
\text { 小さな懸念がある。 }\end{array}$ \\
\hline 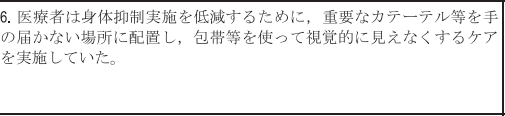 & 研究 13,20, & \begin{tabular}{|l|} 
小さな方法論的限界 \\
(不明確な募集とサ \\
ンプリンク戦略)
\end{tabular} & 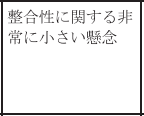 & 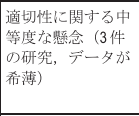 & 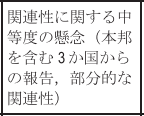 & $\begin{array}{l}\text { 確信性 : } \\
\text { 「中」 }\end{array}$ & 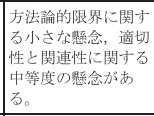 \\
\hline 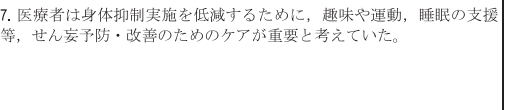 & 20 & $\begin{array}{l}\text { 中等度の方法論的限 } \\
\text { 界(不明確な募集と } \\
\text { サンプリング践略, } \\
\text { 不十分な対象者の選 } \\
\text { 択) }\end{array}$ & \begin{tabular}{|l|} 
整合性に関する非 \\
常に小さい㝥念 \\
\end{tabular} & 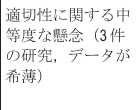 & 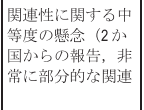 & $\begin{array}{l}\text { 確信性： } \\
\text { 「中」 }\end{array}$ & 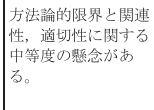 \\
\hline 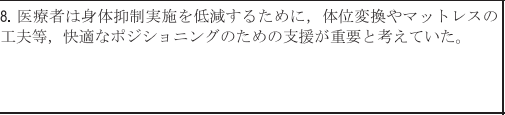 & 研究 13, 20 & $\begin{array}{l}\text { 中等度の方法論的限 } \\
\text { 界 (不明確な募集と } \\
\text { サンプリング戟略, } \\
\text { 不十分な対象者の選 } \\
\text { 択) } \\
\end{array}$ & \begin{tabular}{|l|} 
整合性に関する非 \\
常に小さい墏念 \\
\end{tabular} & 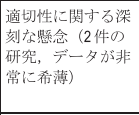 & 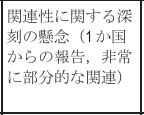 & $\begin{array}{l}\text { 確信性： } \\
\text { 「低」 }\end{array}$ & 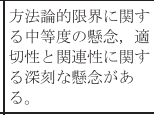 \\
\hline 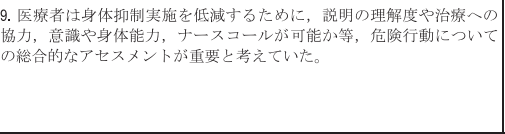 & 研究 77,83 & \begin{tabular}{|l|} 
小さな方法論的限界 \\
(不明確な募集とサ \\
ンプリンク戦略)
\end{tabular} & 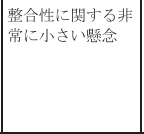 & 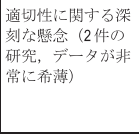 & \begin{tabular}{|l|} 
関逨性に関する中 \\
等度の懸念 (本邦 \\
かららの報告, 部分 \\
的な関連)
\end{tabular} & $\begin{array}{l}\text { 確信性 : } \\
\text { 「中」 }\end{array}$ & 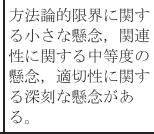 \\
\hline 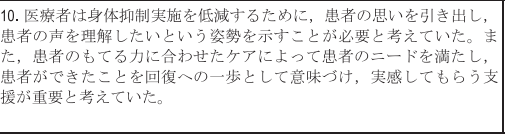 & 研究 31, 84 & \begin{tabular}{|l|} 
小さな方法論的限界 \\
(不明確な募集とサ \\
ンプリング戦略)
\end{tabular} & 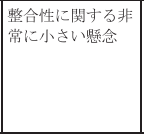 & 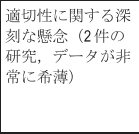 & $\begin{array}{l}\text { 関連性に関する中 } \\
\text { 等度の懸 (本邦 } \\
\text { を含む 2か国から } \\
\text { の報告, 部分的な } \\
\text { 関連) }\end{array}$ & $\begin{array}{l}\text { 碓信性 : } \\
\text { 「中」 }\end{array}$ & 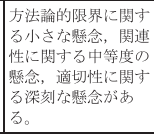 \\
\hline 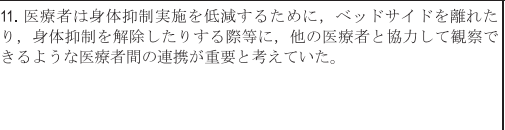 & 研究 77, 83 & \begin{tabular}{|l|} 
小さな方法論的限界 \\
(不明確な募集とサ \\
ンプリンク戦略)
\end{tabular} & 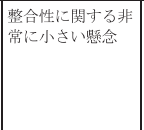 & 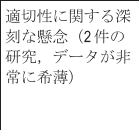 & 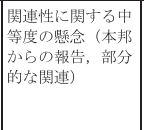 & $\begin{array}{l}\text { 磪信性 : } \\
\text { 「中」 }\end{array}$ & 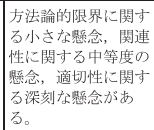 \\
\hline
\end{tabular}

【観察研究】

\begin{tabular}{|c|c|c|c|c|c|c|c|c|c|c|c|c|}
\hline \multicolumn{7}{|c|}{ 確実性の評価 } & \multicolumn{2}{|c|}{ 患者数 } & \multicolumn{2}{|c|}{ 効果 } & \multirow[b]{2}{*}{ 確実性 } & \multirow[b]{2}{*}{ 重要性 } \\
\hline 研究数 & $\begin{array}{l}\text { 研究 } \\
\text { デザイン }\end{array}$ & $\begin{array}{l}\text { パイアス } \\
\text { のリスク }\end{array}$ & 非一貫性 & 非直接性 & 不精確性 & $\begin{array}{l}\text { その他 } \\
\text { の検討 }\end{array}$ & $\begin{array}{c}\text { 身体拘束（抑 } \\
\text { 制）を行わない }\end{array}$ & $\begin{array}{l}\text { 身体拘束（抑 } \\
\text { 制）を行う }\end{array}$ & $\begin{array}{l}\text { 相対指標 } \\
(95 \% \mathrm{CI})\end{array}$ & $\begin{array}{l}\text { 絶対指標 } \\
(95 \% \text { CI })\end{array}$ & & \\
\hline \multicolumn{13}{|c|}{ せん妄発症 } \\
\hline 10 & $\begin{array}{l}\text { 観察研究 } \\
\end{array}$ & 非常に深刻 a & 深刻でないb & 深刻でない & 深刻でない & なし & $\begin{array}{l}256 / 1351 \\
(18.9 \%)\end{array}$ & $\begin{array}{l}538 / 833 \\
(64.6 \%)\end{array}$ & $\begin{array}{c}\text { OR } 0.09 \\
(0.04 \text { to } 0.19)\end{array}$ & $\begin{array}{c}1,000 \text { 人あたり } 505 \\
\text { 人少ない (578 } \\
\text { 少ない 389人少 } \\
\text { ない) }\end{array}$ & $\underset{\text { 低 }}{\oplus \oplus \bigcirc \bigcirc}$ & 重大 \\
\hline \multicolumn{13}{|c|}{ 人工呼吸期間 } \\
\hline 2 & 钼察研究 & 非常に深刻 a & 非常に深刻 c & 深刻でない & 深刻 d & なし & 430 & 702 & - & $\begin{array}{c}\text { 平均 } 0.8 \text { 日短い } \\
\text { (6.71 日短い } \\
5.12 \text { 日長い) }\end{array}$ & $\begin{array}{l}\oplus \bigcirc \bigcirc \bigcirc \\
\text { 非常に低 }\end{array}$ & 重要 \\
\hline \multicolumn{13}{|c|}{ ICU 滞在日数 } \\
\hline 4 & 钼察研究 & 非常に深刻 a & 深刻でないb & 深刻でない & 深刻でない & なし & 341 & 764 & - & $\begin{array}{c}\text { 平均 } 3.99 \text { 日短い } \\
\text { (7. } 91 \text { 日短い } \\
0.07 \text { 日短い) }\end{array}$ & $\underset{\text { 低 }}{\oplus \oplus \bigcirc \bigcirc}$ & 重要 \\
\hline \multicolumn{13}{|c|}{ デバイスの計画外抜去発生 } \\
\hline 5 & 観察研究 & 非常に深刻 a & 深刻 e & 深刻 ${ }^{f}$ & 深刻でない & なし & $\begin{array}{l}100 / 2524 \\
(4.0 \%)\end{array}$ & $\begin{array}{c}244 / 2354 \\
(10.4 \%)\end{array}$ & $\begin{array}{c}\text { OR } 0.36 \\
(0.13 \text { to } 0.98)\end{array}$ & $\begin{array}{c}1,000 \text { 人あたり } 64 \\
\text { 人少ない (89人少 } \\
\text { ない 2 人少な } \\
\text { (1) }\end{array}$ & $\begin{array}{l}\oplus \bigcirc \bigcirc \bigcirc \\
\text { 非常に低 }\end{array}$ & 重大 \\
\hline
\end{tabular}

a. 大多数の研究で交絡が調整されておらず，患者選択や群分け，介入からの选脱に関するバイアスに懸念があったため，2段階グレードを下げた。

b. 非常に大きい異質性があるが，組み込まれた研究の点推定值は同じ方向であるため(統計的異質性)、グレードを下げない。

c. 非常に大きい異質性があり，組み込まれた研究の点推定值は同じ方向にないため(臨床的異質性)，2段階グレードを下げた。

d. 信頼区間が害と利益の双方を含んでいるため, 1段階グレードを下げた

e. 非常に大きい異質性があり，組み込まれた研究の点推定值は同じ方向にない (臨床的異質性)。人工呼吸患者のみを対象にしたサブグループ解析では，デバイスの計画外拔去発生率の減少を示唆し，

異質性は低下した。そのため,1段階グレードを下げた。

f. 1 つの研究で，身体抑制の定義にサイドレールが含まれていた。また，1つの研究で，アウトカムの単位が人*シフトであった。そのため, 1 段階グレードを下げた。 
明らかではないため，効果のバランスはおそらく介入 が優位と判断した。

\section{（5）アウトカム全般に関するエビデンスの確実性}

CERQual の各レビュー所見のエビデンスの確信性 は，「非常に低」から「高」に分類されている。異な る方向性を示すアウトカムはないため，重大なアウト カムに関するエビデンスの確実性における平均的なグ レードである「低」を全体的なエビデンスの確実性と した。なお，観察研究のシステマティックレビューの 結果からは介入とアウトカムの因果関係を示すことは 困難であったため，推奨判断の根拠から除外した。

\section{（6）価値観}

患者や家族，医療者の多くが，安全確保のためには 身体抑制は致し方ないと考えながらも，身体抑制はす ベきではない，できる限り解除したい（してほしい） と考えていた。これは，身体抑制を避けることや，そ れによる人権や尊厳の堅持に対して置く相対的価値が 高いことを示唆している。さらに近年，身体抑制は倫 理的に問題とする考えが拡大しつつあり，診療報酬に おいても，身体抑制を避けた場合を評価する加算や， 身体抑制を避ける取り組みを実施していることを入院 基本料等加算の要件に追加するなど，これを後押しし ている。以上により，そのばらつきは少ないことが予 想される。

\section{（7）容認性}

集中治療中の身体抑制を避けることに際して，新た
な薬剂の使用や医療器具などの購入は必要なく, 診療 報酬点数にも変わりがないため, 患者の視点からも, 医療機関の経営者側の視点からも，おそらく許容でき ると考える。一方で，身体抑制を避けることによっ て, 短期的には医療者の仕事量が増える可能性が考え られるが，身体抑制の代替法を各施設の実情に合わせ て実施することにより，ある程度は許容可能と考えら れる。

\section{（8）実行可能性}

CERQual の各レビュー所見における医療者が考え る身体抑制の代替法は，各施設の実情によって実施可 能な範囲が異なることが予測されるものの，各施設の 実情に合わせてこれらの代替法を実施することで，現 状以上に集中治療中の身体抑制を避けることは実行可 能と考える。

（9）判断の要約（Table 20-3-2）

（10）推奨グレーディング決定の工程

修正 RAND 法を用いた投票によって，中央值 7, 見解不一致指数 0.164 の結果となり，委員会で採択さ れた（7 点以上 : $83.3 \% ） 。$

\section{（11）関連する他の診療ガイドラインにおける推奨}

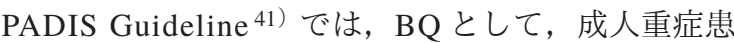
者における身体抑制の実施率，根拠およびアウトカム （益と害）について解説しているが，推奨の判断はし ていない。

Table 20-3-2 判断の要約

\begin{tabular}{|c|c|c|c|c|c|c|c|}
\hline & \multicolumn{7}{|c|}{ 半粠 } \\
\hline 問題 & いいえ & $\begin{array}{c}\text { おそらく、いい } \\
\text { え }\end{array}$ & おそらく、はい & はい & & さまざま & 分からない \\
\hline 望ましい効果 & わずか & 小さい & 中 & 大きい & & さまざま & 分からない \\
\hline 望ましくない効果 & 大きい & 中 & 小さい & わずか & & さまざま & 分からない \\
\hline エビデンスの確実性 & 非常に低 & 低 & 中 & 高 & & & 採用研究なし \\
\hline 価值钼 & $\begin{array}{c}\text { 重要な不確実性 } \\
\text { またははららつき } \\
\text { あり }\end{array}$ & $\begin{array}{c}\text { 重要な不確実性 } \\
\text { またはばらつき } \\
\text { の可能性あり }\end{array}$ & $\begin{array}{l}\text { 重要な不確実性 } \\
\text { またはばらつき } \\
\text { はおそらくなし }\end{array}$ & $\begin{array}{c}\text { 重要な不確実性 } \\
\text { またはばらつき } \\
\text { はなし }\end{array}$ & & & \\
\hline 効果のパランス & 比較が優位 & $\begin{array}{c}\text { 比較がおそらく } \\
\text { 優位 }\end{array}$ & $\begin{array}{c}\text { 介入も比較もい } \\
\text { ずれも優位でな } \\
\text { い }\end{array}$ & $\begin{array}{c}\text { おそらく介入が } \\
\text { 優位 }\end{array}$ & 介入が優位 & さまざま & 分からない \\
\hline 容認性 & いいえ & $\begin{array}{c}\text { おそらく、いい } \\
\text { え }\end{array}$ & おそらく、はい & はい & & さまざま & 分からない \\
\hline 実行可能性 & いいえ & $\begin{array}{c}\text { おそらく、いい } \\
\text { え }\end{array}$ & おそらく、はい & はい & & さまざま & 分からない \\
\hline
\end{tabular}




\section{（12）実施に関わる検討事項}

重症患者全般における標準的な患者・家族中心のケ アとして身体抑制を避けることが望まれるが，各施設 の実情に合わせて代替法を実施するとともに，マニュ アルなどを作成して行うことを考慮する必要がある。 また，医療デバイスの計画外抜去などの有害事象に関 するモニタリングが必要である。

\section{（13）今後の研究の可能性}

集中治療中の身体抑制を避けることの有用性や有害 事象に関して検証した RCT が望まれる。また，集中 治療中の身体抑制を避けることがむずかしい患者や療 養環境の特徵，集中治療中の身体抑制を避けるために 効果的な代替法に関して検証した研究が期待される。 質的研究については，集中治療室において身体抑制を 実施された患者やその家族を対象にした研究が少ない ため,さらなる研究が求められる。

\section{文 献}

1) Unoki $T$, Sakuramoto H, Ouchi A, et al: Physical restraints in intensive care units: a national questionnaire survey of physical restraint use for critically ill patients undergoing invasive mechanical ventilation in Japan. Acute Med Surg. 2019; 6: 68-72.

2) Azizpour M, Moosazadeh M, Esmaeili R: Use of physical restraints in intensive care unit: A systematic review study. Acta Medica Mediterr. 2017; 33: 129.

3）池添志乃, 田井雅子, 中野綾美, 他: 倫理的判断を基盤とした 抑制についての調査一抑制実施時の倫理的判断と「説明」 を重視する看護者の特徵一. 日看倫理会誌. 2011; 3: 64-70.

4) Benbenbishty J, Adam S, Endacott R: Physical restraint use in intensive care units across Europe: The PRICE study. Intensive Crit Care Nurs. 2010; 26: 241-5.

5) Kandeel NA, Attia AK: Physical restraints practice in adult intensive care units in Egypt. Nurs Heal Sci. 2013; 15: 79-85.

6) Baumgarten M, Margolis DJ, Localio AR, et al: Extrinsic risk factors for pressure ulcers early in the hospital stay: a nested casecontrol study. J Gerontol A Biol Sci Med Sci. 2008; 63: 408-13.

7) Mehta S, Cook D, Devlin JW, et al: Prevalence, Risk Factors, and Outcomes of Delirium in Mechanically Ventilated Adults. Crit Care Med. 2015; 43: 557-66.

8) Van Rompaey B, Elseviers MM, Schuurmans MJ, et al: Risk factors for delirium in intensive care patients: a prospective cohort study. Crit Care. 2009; 13: R77.

9) Jones C, Bäckman C, Capuzzo M, et al: Precipitants of posttraumatic stress disorder following intensive care: a hypothesis generating study of diversity in care. Intensive Care Med. 2007; 33: $978-85$.

10) Brummel NE, Balas MC, Morandi A, et al: Understanding and reducing disability in older adults following critical illness. Crit Care Med. 2015; 43: 1265-75.

11) Chang CW, Chen YM, Su CC: Care needs of older patients in the intensive care units. J Clin Nurs. 2012; 21: 825-32.

12) Choe K, Kang Y, Park Y: Moral distress in critical care nurses: a phenomenological study. J Adv Nurs. 2015; 71: 1684-93.

13) Clukey L, Weyant RA, Roberts M, et al: Discovery of Unexpected Pain in Intubated and Sedated Patients. Am J Crit Care. 2014; 23: 216-20.
14) Dolan J, Dolan Looby SE: Determinants of nurses'use of physical restraints in surgical intensive care unit patients. Am J Crit Care. 2017; 26: 373-9.

15) Fowler SB: Impaired verbal communication during short-term oral intubation. Nurs Diagn. 1997; 8: 93-8.

16) Freeman S, Hallett C, McHugh G: Physical restraint: Experiences, attitudes and opinions of adult intensive care unit nurses. Nurs Crit Care. 2016; 21: 78-87.

17) Happ MB: Preventing treatment interference: The nurse's role in maintaining technologic devices. Heart Lung. 2000; 29: 60-9.

18) Jiang H, Li C, Gu Y, et al: Nurses'perceptions and practice of physical restraint in China. Nurs Ethics. 2015; 22: 652-60.

19) Langley G, Schmollgruber S, Egan A: Restraints in intensive care units - A mixed method study. Intensive Crit Care Nurs. 2011; 27: 67-75.

20) Minnick A, Leipzig RM, Johnson ME: Elderly patients' reports of physical restraint experiences in intensive care units. Am J Crit Care. 2001; 10: 168-71.

21) Via-Clavero G, Sanjuán-Naváis M, Romero-García M, et al: Eliciting critical care nurses' beliefs regarding physical restraint use. Nurs Ethics. 2019; 26: 1458-72.

22) Sasaki R, Sekido K: Dilemmas Experienced by ICU Nurses When They Care for Patients with Symptoms of Delirium, Int Nurs Care Res. 2016; 15: 19-30.

23）桑原美香: ICU 患者の身体抑制に影響する看護師の判断要 因. 日クリティカルケア看会誌. 2015; 11: 57-65.

24）至極友香子, 町田美佳, 岡眞由美, 他: 急性期に抑制を受ける 患者家族の苦痛に影響する因子. 徳島赤十字病医誌. 2007; 12: 168-72.

25）長澤静代, 黒田裕子: 集中治療室における患者管理の 1 つと しての身体抑制を取り巻く看護師の判断と行動. 日クリ ティカルケア看会誌. 2009; 5: 25-32.

26）長谷川沙希, 原祥子, 沖中由美, 他: ICUにおいて抑制を受け る高齢患者に対する看護ケア. 老年看. 2012; 17: 28-36.

27) Chang LY, Wang KWK, Chao YF: Influence of physical restraint on unplanned extubation of adult intensive care patients: A casecontrol study. Am J Crit Care. 2008; 17: 408-15.

28) Chuang ML, Lee CY, Chen YF, et al: Revisiting Unplanned Endotracheal Extubation and Disease Severity in Intensive Care Units. PLoS One. 2015; 10: e0139864.

29) Gu T, Wang $X$, Deng N, et al: Investigating influencing factors of physical restraint use in China intensive care units: A prospective, cross-sectional, observational study. Aust Crit Care. 2019; 32: 193-8.

30) Hamilton D, Griesdale D, Mion LC: The prevalence and incidence of restraint use in a Canadian adult intensive care unit: A prospective cohort study. Can J Crit Care Nurs. 2017; 28: 25-33.

31) Kwizera A, Nakibuuka J, Ssemogerere L, et al: Incidence and risk factors for delirium among mechanically ventilated patients in an African intensive care setting: An observational multicenter study. Crit Care Res Pract. 2015; 2015: 491780.

32) Limpawattana P, Panitchote A, Tangvoraphonkchai K, et al: Delirium in critical care: a study of incidence, prevalence, and associated factors in the tertiary care hospital of older Thai adults. Aging Ment Health. 2016; 20: 74-80.

33) Luk E, Sneyers B, Rose L, et al: Predictors of physical restraint use in Canadian intensive care units. Crit Care. 2014; 18: R46.

34) Micek ST, Anand NJ, Laible BR, et al: Delirium as detected by the CAM-ICU predicts restraint use among mechanically ventilated medical patients. Crit Care Med. 2005; 33: 1260-5.

35) Öztürk Birge A, Bedük T: The relationship of delirium and risk factors for cardiology intensive care unit patients with the nursing workload. J Clin Nurs. 2018; 27: 2109-19.

36) Perren A, Corbella D, Iapichino E, et al: Physical restraint in the 
ICU: does it prevent device removal? Minerva Anestesiol. 2015; 81: 1086-95.

37) Rose L, Burry L, Mallick R, et al: Prevalence, risk factors, and outcomes associated with physical restraint use in mechanically ventilated adults. J Crit Care. 2016; 31: 31-5.

38) Sanson G, Khlopenyuk Y, Milocco S, et al: Delirium after cardiac surgery. Incidence, phenotypes, predisposing and precipitating risk factors, and effects. Heart Lung. 2018; 47: 408-17.

39) van der Kooi AW, Peelen LM, Raijmakers RJ, et al: Use of Physical Restraints in Dutch Intensive Care Units: A Prospective Multicenter Study. Am J Crit Care. 2015; 24: 488-95.

40) Wang J, Ji Y, Wang N, et al: Risk factors for the incidence of delirium in cerebrovascular patients in a Neurosurgery Intensive Care Unit: A prospective study. J Clin Nurs. 2018; 27: 407-15.

41) Devlin JW, Skrobik Y, Gélinas C, et al: Clinical Practice Guidelines for the Prevention and Management of Pain, Agitation/Sedation, Delirium, Immobility, and Sleep Disruption in Adult Patients in the ICU. Crit Care Med. 2018; 46: e825-73.
CQ20-4-1：睡眠ヶアとして換気補助を行うか？

Answer : 成人の敗血症患者あるいは集中治療患者に 対して，睡眠ケアとして換気補助の追加を行うことを 弱く推奨する（GRADE 2D：エビデンスの確実性 $=$ 「非常に低」)。

\section{（1）背景および本 $C Q$ の重要度}

重症患者は，集中治療室という特殊な環境や昼夜を 問わない医療介入，騒音，光など様々なストレスを受 けている。これら環境要因のみならず，病態や薬剤な ど複合的な要因が，睡眠障害や不安，せん妄発症のリ スクとなる。特に睡眠障害は，せん妄と関連し，長期 にわたる認知機能障害と関連している可能性があり, PADIS ガイドライン1) においても睡眠ケアの重要性 が強調されている。人工呼吸管理中に換気補助の追加 を行うことで，睡眠障害が改善するかどうかは不明で あり, 本ガイドラインに取り上げるべき重要臨床課題 であるといえる。

(2) PICO

$P$ (患者) : 18 歳以上の敗血症患者あるいは集中治 療患者

I（介入）：換気補助の追加をする

C (対照)：換気補助の追加をしない

$\mathrm{O}$ (アウトカム) : 客観的睡眠（量）

\section{（3）エビデンスの要約}

MEDLINE，CENTRAL，医学中央雑誌を用いた文 献検索の結果，451 論文を抽出し論文のタイトルと抄 録を確認した。このうち，対象論文の可能性がある 47 論文の全文原稿を確認し，PICO に合致した 5 編の ランダム化比較試験（RCT） 2-6）をメタ解析した。な お，敗血症患者に限定した RCT は見つけられなかっ たため, 対象患者は敗血症患者あるいは集中治療患者 とした。

\section{（4）益と害のバランス（Table 20-4-1-1）}

\section{望ましい効果：}

客観的睡眠（量）（total sleep time / total recording time など）に関する効果推定值は，平均 12.2 高い （4.12 高い〜20.28 高い）であり，望ましい効果は「小 さい」と考えられた

望ましくない効果 :

今回の PICO に合致した 5 編の RCT において，人 工呼吸管理中に換気補助を追加することの害について 
論じている論文がなく評価困難である。

益と害のバランス :

介入による害を論じている論文がないが，臨床上， 介入による害の発生は小さいと考えると, おそらく介 入が優位ではないかと考える。

\section{（5）アウトカム全般に関するエビデンスの確実性}

今回採用したアウトカムは客観的睡眠（量）のみで あり，エビデンスは「非常に低」であるためアウトカ ム全体にわたるエビデンスの確実性は「非常に低」で ある。

\section{（6）価値観}

敗血症患者あるいは集中治療患者において, 睡眠ケ アとしての人工呼吸器設定に関する患者・家族の価值 観にばらつきはないと考えた。

\section{（7）容認性}

多くの人工呼吸器には換気補助を追加するモード （A/C，PCVなど）が搭載されており，追加費用はか
からないことが予想される。J-PAD ガイドライン 7) では，目標鎮静深度を RASS $-2 \sim 0$ としており，比較 的浅い鎮静管理となるため, 換気補助を追加するモー ド (A/C, PCV, PAVなど) と追加しないモード （PSV，吹き流し）を比較した場合に，医療従事者の 労力には差がないと考える。

\section{（8）実行可能性}

多くの人工呼吸器で換気補助を追加するモード （A/C，PCV など）が搭載されており，実行可能と考 える。

（9）判断の要約（Table 20-4-1-2）

（10）推奨グレーディング決定の工程

修正 RAND 法を用いた投票によって，中央值 7.5, 見解不一致指数 0.164 の結果となり，委員会で採択さ れた（7 点以上 : $95.8 \%) 。$

Table 20-4-1-1エビデンスプロファイル

\begin{tabular}{|c|c|c|c|c|c|c|c|c|c|c|c|c|}
\hline \multicolumn{7}{|c|}{ 確実性の評価 } & \multicolumn{2}{|c|}{ 患者数 } & \multicolumn{2}{|c|}{ 勃果 } & \multirow[b]{2}{*}{ 確実性 } & \multirow[b]{2}{*}{ 重要性 } \\
\hline 研究数 & $\begin{array}{l}\text { 研究 } \\
\text { デザイン }\end{array}$ & $\begin{array}{l}\text { バイアス } \\
\text { のリスク }\end{array}$ & 非一貫性 & 非直接性 & 不精確性 & $\begin{array}{l}\text { その他 } \\
\text { の検討 }\end{array}$ & $A / C$ & PSV & $\begin{array}{l}\text { 相対指標 } \\
(95 \% \text { CI }\end{array}$ & $\begin{array}{l}\text { 絶対指標 } \\
(95 \% \text { CI })\end{array}$ & & \\
\hline \multicolumn{13}{|c|}{ 客観的睡眠（量） } \\
\hline 5 & RCT & 深刻a & 深刻でない & 深刻 b & 深刻 c. & なし & 79 & 79 & - & $\begin{array}{c}\text { 平均 } 12.2 \text { 高い } \\
\text { (4.12 高い } \\
20.28 \text { 高い) }\end{array}$ & $\begin{array}{l}\oplus \bigcirc \bigcirc \bigcirc \\
\text { 非常に低 }\end{array}$ & 重大 \\
\hline
\end{tabular}

a. 研究方法により盲検化ができないため，すべての研究を高いバイアスのリスクと判断した。

b. 研究間で介入方法が異なり異質性が高いと判断した。

c. サンプルサイズが小さく $95 \%$ CI が広い。

Table 20-4-1-2 判断の要約

\begin{tabular}{|c|c|c|c|c|c|c|c|}
\hline & \multicolumn{7}{|c|}{ 判湆 } \\
\hline 問題 & いいえ & $\begin{array}{c}\text { おそらく、いい } \\
\text { え }\end{array}$ & おそらく、はい & はい & & さまざま & 分からない \\
\hline 望ましい効果 & わずか & 小さい & 中 & 大きい & & さまざま & 分からない \\
\hline 望ましくない効果 & 大きい & 中 & 小さい & わずか & & さまざま & 分からない \\
\hline エビデンスの確実性 & 非常に低 & 低 & 中 & 高 & & & 採用研究なし \\
\hline 価值観 & $\begin{array}{c}\text { 重要な不確実性 } \\
\text { またはばらつき } \\
\text { あり }\end{array}$ & $\begin{array}{c}\text { 重要な不確実性 } \\
\text { またはばらつき } \\
\text { の可能性ありり }\end{array}$ & $\begin{array}{l}\text { 重要な不確実性 } \\
\text { またはばらつき } \\
\text { はおとらくなし }\end{array}$ & $\begin{array}{c}\text { 重要な不確実性 } \\
\text { またはばらつき } \\
\text { はなし }\end{array}$ & & & \\
\hline 効果のパランス & 比較が優位 & $\begin{array}{c}\text { 比較がおそらく } \\
\text { 優位 }\end{array}$ & $\begin{array}{c}\text { 介入も比較もい } \\
\text { ずれも優位でな } \\
\text { い }\end{array}$ & $\begin{array}{c}\text { おそらく介入が } \\
\text { 優位 }\end{array}$ & 介入が優位 & さまざま & 分からない \\
\hline 容認性 & いいえ & $\begin{array}{c}\text { おそらく、いい } \\
\text { え }\end{array}$ & おそらく、はい & はい & & さまざま & 分からない \\
\hline 実行可能性 & いいえ & $\begin{array}{c}\text { おそらく、いい } \\
\text { え }\end{array}$ & おそらく、はい & はい & & さまざま & 分からない \\
\hline
\end{tabular}


（11）関連する他の診療ガイドラインにおける推奨

PADIS ガイドライン 1) では，成人重症患者の睡眠 を改善するために，夜間に［圧支持換気（PSV）に対 して）補助/調整換気（A/C）が使用されるべきか? という CQ に対して，夜間は（PSVに対して） A/C を 使用することを提案する（条件付き推奨，低い質のエ ビデンス）となっている。

\section{（12）実施に関わる検討事項}

推奨の実施においては，換気補助として人工呼吸器 のどのモードを採用したのか，換気補助の介入時間， 客観的睡眠時間を測定することが望まれる。

\section{（13）今後の研究の可能性}

以下の内容に関する検討が求められると考えられる。 ・アウトカムとして客観的睡眠（質）の評価や問診 票を用いた睡眠の主観的評価の検証

・換気補助の追加としてどの人工呼吸器モードが有 用なのか $(\mathrm{PCV}, \mathrm{A} / \mathrm{C}$ など）

・換気補助を行うことによる害（換気補助を行うこ とでの横隔膜機能不全の発症率など）

\section{文 献}

1) Devlin JW, Skrobik Y, Gélinas C, et al: Clinical Practice Guidelines for the Prevention and Management of Pain, Agitation/Sedation, Delirium, Immobility, and Sleep Disruption in Adult Patients in the ICU. Crit Care Med. 2018; 46: e825-73.

2) Alexopoulou C, Kondili E, Vakouti E, et al: Sleep during proportional-assist ventilation with load-adjustable gain factors in critically ill patients. Intensive Care Med. 2007; 33: 1139-47.

3) Andréjak C, Monconduit J, Rose D, et al: Does using pressurecontrolled ventilation to rest respiratory muscles improve sleep in ICU patients? Respir Med. 2013; 107: 534-41.

4) Bosma K, Ferreyra G, Ambrogio C, et al: Patient-ventilator interaction and sleep in mechanically ventilated patients: Pressure support versus proportional assist ventilation. Crit Care Med. 2007; 35: 1048-54.

5) Cabello B, Thille AW, Drouot X, et al: Sleep quality in mechanically ventilated patients: Comparison of three ventilatory modes. Crit Care Med. 2008; 36: 1749-55

6) Roche-Campo F, Thille AW, Drouot X, et al: Comparison of Sleep Quality With Mechanical Versus Spontaneous Ventilation During Weaning of Critically Ill Tracheostomized Patients. Crit Care Med. 2013; 41: 1637-44.

7）日本集中治療医学会 J-PAD ガイドライン作成委員会: 日本 版・集中治療室における成人重症患者に対する痛み・不穏・ せん妄管理のための臨床ガイドライン. 日集中医誌. 2014; 21: 539-79.
CQ20-4-2：睡眠ケアとして非薬物的睡眠管理 （耳栓·アイマスク・音楽療法）を行うか?

Answer：成人の敗血症患者あるいは集中治療患者に 対して，睡眠ケアとして非薬物的睡眠管理を行うこと を弱く推奨する（GRADE 2D：エビデンスの確実性 $=$ 「非常に低」)。

\section{（1）背景および本 $C Q$ の重要度}

重症患者は，集中治療室という特殊な環境や昼夜を 問わない医療介入，騷音，光など様々なストレスを受 けている。これら環境要因のみならず，病態や薬剤な ど複合的な要因が，睡眠障害や不安，せん妄発症のリ スクとなる。特に睡眠障害は，せん妄と関連し，長期 に渡る認知機能障害と関連している可能性があり, PADIS ガイドライン 1）においても睡眠ケアの重要性 が強調されている。睡眠障害の予防として，耳栓やア イマスク，音楽療法，騒音低減プログラムなどの非薬 物的睡眠管理が期待されており，せん妄予防には一定 の効果が示されているが，睡眠促進効果やその他の PICS 予防の有用性は不明である。また，不安は闘病 意欲を低下させるとともに，鎮静薬の投与量を増加さ せるが，この不安の軽減に音楽療法などが試みられ， 一定の効果が示されている。以上により，本ガイドラ インに取り上げるべき重要臨床課題であると考える。

\section{(2) PICO}

$\mathrm{P}$ (患者)：18 歳以上の敗血症患者あるいは集中治 療患者

I（介入）: 非薬物的睡眠管理（耳栓・アイマスク • 音楽療法）

C (対照)：通常のケア

$\mathrm{O}$ （アウトカム）：主観的評価，客観的睡眠（量）

\section{（3）エビデンスの要約}

MEDLINE，CENTRAL，医学中央雑誌を用いた文 献検索の結果，451 論文を抽出し論文のタイトルと抄 録を確認した。このうち，対象論文の可能性がある 47 論文の全文原稿を確認し，PICO に合致した 4 編の ランダム化比較試験（RCT） 2-5）をメタ解析した。な お，敗血症患者に限定した RCT は見つけられなかっ たため, 対象患者は敗血症患者あるいは集中治療患者 とした。 
（4）益と害のバランス（Table 20-4-2-1）

望ましい効果 :

主観的評価 (Verran and Snyder-Halpern Sleep Scale などを用いた患者へのアンケートなど）の効果推定値 は，標準化平均（SMD）1.5 高い（95\% CI: 1.11 高い 〜1.9高い）である。客観的睡眠（量）（total sleep time / total recording time など) の効果推定值は, 平均 （MD） 2.46 少ない（95\% CI: 9.94 少ない〜 5.01 多い） である。したがって, 望ましい効果は「小さい」と考 えられた。

望ましくない効果 :

今回の PICO に合致した 4 編の RCT において, 睡 眠ケアとしてアイマスク・耳栓・音楽療法を用いるこ との害について論じている論文がなく評価困難であ る。

益と害のバランス :

介入による害を論じている論文がないが，臨床上， 介入による害の発生はわずかであると考えると，介入 がおそらく優位ではないかと考える。

\section{（5）アウトカム全般に関するエビデンスの確実性}

今回採用したアウトカムの効果推定值は, 1 つは効 果あり，1つは効果なしであるが，方向性は一致して いる（効果ありの方向）ため, 効果ありの主観的評価 のアウトカムの確実性を全体としては採用した。アウ トカム全体にわたるエビデンスの確実性は「非常に 低」である。

（6）価值観

敗血症患者あるいは集中治療患者において, 睡眠ヶ アとしての非薬物的睡眠管理に関する患者・家族の価 值観は不確実であり,ばらつきの可能性はあると考える。
（7）容認性

耳栓やアイマスク, 音楽療法に必要な機材は高価で はなく, また介入方法も比較的容易である。

\section{（8）実行可能性}

耳栓やアイマスク, 音楽療法に必要な機材は高価で はないため実行可能と考える。

（9）判断の要約（Table 20-4-2-2）

（10）推奨グレーディング決定の工程

修正 RAND 法を用いた投票によって, 中央値 7.5, 見解不一致指数 0.164 の結果となり, 委員会で採択さ れた（7点以上: $91.7 \%) 。$

\section{（11）関連する他の診療ガイドラインにおける推奨}

PADIS ガイドライン 1) では, 成人重症患者の睡眠 を改善するために, 騒音と光を低減する方法, 音楽が 夜間に（使用なしに対して）使用されるべきか？とい う $\mathrm{CQ}$ に対して, 騒音と光の低隇策を用いることを提 案する (条件付き推奨, 低い質のエビデンス), 音楽 を夜間に用いないことを提案する（非常に低い質のエ ビデンス）となっている。

\section{（12）実施に関わる検討事項}

推奨の実施においては, 介入時間, 客観的睡眠時間 や問診票を用いた睡眠評価を測定することが望まれ る。

\section{（13）今後の研究の可能性}

以下の内容に関する検討が求められると考えられる。 ・睡眠の質の評価として問診票を用いた主観的評価 のみならず，客観的睡眠の質を測定するパラメー タの確立

Table 20-4-2-1エビデンスプロファイル

\begin{tabular}{|c|c|c|c|c|c|c|c|c|c|c|c|c|}
\hline \multicolumn{7}{|c|}{ 確実性の評価 } & \multicolumn{2}{|c|}{ 患者数 } & \multicolumn{2}{|c|}{ 効果 } & \multirow[b]{2}{*}{ 確実性 } & \multirow[b]{2}{*}{ 重要性 } \\
\hline 研究数 & $\begin{array}{c}\text { 研究 } \\
\text { デザイン }\end{array}$ & $\begin{array}{l}\text { バイアス } \\
\text { のリスク }\end{array}$ & 非一貫性 & 非直接性 & 不精確性 & $\begin{array}{l}\text { その他 } \\
\text { の検討 }\end{array}$ & $\begin{array}{l}\text { music/eye } \\
\text { mask/earplug }\end{array}$ & usual care & $\begin{array}{l}\text { 相対指標 } \\
(95 \% \mathrm{CI})\end{array}$ & $\begin{array}{l}\text { 絶対指標 } \\
(95 \% \mathrm{CI})\end{array}$ & & \\
\hline \multicolumn{13}{|c|}{ 主钼的評価 } \\
\hline 3 & RCT & 深刻 a & 深刻 b & 深刻でない & 深刻。 & なし & 68 & 68 & - & $\begin{array}{l}\text { 平均 } 1.5 \text { 高い } \\
\text { (1. } 11 \text { 高い 1.9 } \\
\text { 高い) }\end{array}$ & $\begin{array}{l}\oplus \bigcirc \bigcirc \bigcirc \\
\text { 非常に低 }\end{array}$ & 重大 \\
\hline \multicolumn{13}{|c|}{ 客観的睡眠（量） } \\
\hline 2 & RCT & 深刻 a & $\begin{array}{c}\text { 深刻ては } \\
\text { ない }\end{array}$ & 深刻でない & 深刻。 & なし & 37 & 42 & - & $\begin{array}{c}\text { 平均 } 2.46 \text { 少ない } \\
(9.94 \text { 少ない } \\
5.01 \text { 多い) }\end{array}$ & $\underset{\text { 低 }}{\oplus \oplus \bigcirc}$ & 重大 \\
\hline
\end{tabular}

a. 研究方法により盲検化ができないため，すべての研究を高いバイアスのリスクと判断した。

b. 異質性は $\mathrm{I}^{2}=83 \%$ と高く，非一貫性に関する深刻なバイアスが示唆される。

c. サンプルサイズが小さい。 
Table 20-4-2-2 判断の要約

\begin{tabular}{|c|c|c|c|c|c|c|c|}
\hline 問題 & いいえ & $\begin{array}{c}\text { おそらく、いい } \\
\text { え }\end{array}$ & おそらく、はい & はい & & さまざま & 分からない \\
\hline 望ましい勃果 & わずか & 小さい & 中 & 大きい & & さまざま & 分からない \\
\hline 望ましくない勃果 & 大きい & 中 & 小さい & わずか & & さまざま & 分からない \\
\hline エビデンスの確実性 & 非常に低 & 低 & 中 & 高 & & & 採用研究なし \\
\hline 価值钼 & $\begin{array}{c}\text { 重要な不確実性 } \\
\text { またはばらつき } \\
\text { あり }\end{array}$ & $\begin{array}{c}\text { 重要な不確実性 } \\
\text { またはばらつき } \\
\text { の可能性あり }\end{array}$ & $\begin{array}{l}\text { 重要な不確実性 } \\
\text { またはばらつき } \\
\text { はおそらくなし }\end{array}$ & $\begin{array}{c}\text { 重要な不確実性 } \\
\text { またはばらつき } \\
\text { はなし }\end{array}$ & & & \\
\hline 効果のパランス & 比較が優位 & $\begin{array}{c}\text { 比較がおそらく } \\
\text { 優位 }\end{array}$ & $\begin{array}{c}\text { 介入も比較もい } \\
\text { ずれも優位でな } \\
\text { い }\end{array}$ & $\begin{array}{c}\text { おそらく介入が } \\
\text { 優位 }\end{array}$ & 介入が優位 & さまざま & 分からない \\
\hline 容認性 & いいえ & $\begin{array}{c}\text { おそらく、いい } \\
\text { え }\end{array}$ & おそらく、はい & はい & & さまざま & 分からない \\
\hline 実行可能性 & いいえ & $\begin{array}{c}\text { おそらく、いい } \\
\text { え }\end{array}$ & おそらく、はい & はい & & さまざま & 分からない \\
\hline
\end{tabular}

・非薬物的睡眠管理を用いることによる害の評価

$$
\text { 文 献 }
$$

1) Devlin JW, Skrobik Y, Gélinas C, et al: Clinical Practice Guidelines for the Prevention and Management of Pain, Agitation/Sedation, Delirium, Immobility, and Sleep Disruption in Adult Patients in the ICU. Crit Care Med. 2018; 46: e825-73.

2) Demoule $A$, Carreira $S$, Lavault $S$, et al: Impact of earplugs and eye mask on sleep in critically ill patients: a prospective randomized study. Crit Care. 2017; 21: 284.

3) Ryu MJ, Park JS, Park H: Effect of sleep-inducing music on sleep in persons with percutaneous transluminal coronary angiography in the cardiac care unit. J Clin Nurs. 2012; 21: 728-35.

4) Su CP, Lai HL, Chang ET, et al: A randomized controlled trial of the effects of listening to non-commercial music on quality of nocturnal sleep and relaxation indices in patients in medical intensive care unit. J Adv Nurs. 2013; 69: 1377-89.

5) Yazdannik AR, Zareie A, Hasanpour M, et al: The effect of earplugs and eye mask on patients' perceived sleep quality in intensive care unit. Iran J Nurs Midwifery Res. 2014; 19: 673-8. 


\section{CQ20-5：集中治療室における家族の面会制限を 緩和するべきか?}

Answer : 成人の敗血症患者あるいは集中治療患者に 対して, 家族の面会制限を緩和することを弱く推奨す る（GRADE 2D：エビデンスの確実性 $=$ 「非常に 低」)。

\section{（1）背景および本 CQ の重要度}

集中治療室に入室中の患者は, 心身ともに重篤な状 態であり, 家族の存在は大きく, 患者と家族が接する ための面会の機会は重要である。面会は患者のみなら ず家族のメンタルヘルスにも影響を与えており，面会 時間を緩和することは, post intensive care syndromefamily（PICS-F）などの予防に有効である可能性があ る。一方で, 面会時間に寛容であることは, 処置やケ アを行うにあたり医療スタッフの負担が増加すること となる。また, 感染症予防の観点から, 面会時間を制 限している施設もみられており, 面会制限を緩和する ことに対して一定の見解は得られていない。以上によ り, 本ガイドラインに取り上げるべき重要臨床課題で あると考える。

\section{(2) PICO}

P (患者)：18 歳以上の敗血症患者あるいは集中治 療患者, およびその家族

I（介入）：面会時間の制限なし

C (対照)：面会時間の制限あり

$\mathrm{O}$ (アウトカム) : 集中治療室感染患者のせん妄発 症, ICU 滞在日数, 患者の抑うつ状態, 家族の抑 うつ状態・不安・満足度, 集中治療室滞在中の新 規感染症発症

\section{（3）エビデンスの要約}

PubMed, CENTRAL，医学中央雑誌を用いて文献検 索を行い, 1,259 論文を抽出, それらのタイトルと抄 録を確認した。このうち, 対象論文の可能性がある 43 論文の全文を確認したところ，2 編 1 1,2) のランダ 厶化比較試験（RCT）が本 CQ の PICO に合致した。 また, 工程の途中, 本 $\mathrm{CQ}$ の $\mathrm{PICO}$ に合致する 1 編 3$)$ の RCT が新たに出版された。それも含め, 最終的に 計 3 編の論文からデータを抽出・統合した。なお，敗 血症患者に限定した RCT は見つけられなかったため, 対象患者は敗血症患者あるいは集中治療患者とした。

\section{（4）益と害のバランス（Table 20-5-1）}

\section{望ましい効果 :}

介入により，せん妄発症は 1,000 人あたり 68 人少な い $(95 \%$ CI: 148 人少ない 132 人多い)。ICU 滞在日 数は介入群, 対照群いずれも中央値 5.0 (四分位範囲 3.0 8.0）と同等である。また, 患者の抑うつ状態に関 する介入による効果は Hospital Anxiety and Depression Scale（HADS）スコア mean 0 （95\% CI: 0 0）である。 家族の抑うつ状態に関し, HADS depression スコアの 中央值（四分位範囲）は介入群/対照群の順で 4.0 $(2.0 \sim 8.0) / 5.0(2.0 \sim 9.0)$, 家族の不安に関して HADS anxiety スコアの中央值（四分位範囲）は6.0（3.0〜 8.2)/ 7.0 (4.0〜11.0) であった。HADS スコアが，0〜 $7=$ normal, $8 \sim 10=$ borderline abnormal, $11 \sim 21=$ abnormal と段階的に判定することを考虑すると，この median の差は, 臨床的な望ましい効果とは考えること ができない。上記を統合すると，介入による望ましい 効果は小さいと考えられた。

\section{望ましくない効果 :}

望ましくない効果として集中治療室滞在中の新規感 染症発症が評価されている。2つの RCT（総症例数 1,908 例）に基づき，面会制限を緩和することによる 集中治療室滞在中の新規感染症発症の可能性は 1,000 人あたり 4 人少ない $(95 \% \mathrm{CI}: 20$ 人少ない〜 20 人多 い）であり，望ましくない効果はわずかであると考え られた。

\section{益と害のバランス :}

面会制限の緩和により「せん妄発症率」に望ましい 効果が小さいながら期待される。一方, この介入によ る望ましくない効果はわずかであると示唆される。エ ビデンスの確実性は非常に低いものの, 以上から, お そらく介入（面会制限の緩和）が優位であると考えら れる。

\section{（5）アウトカム全般に関するエビデンスの確実性}

今回採用したアウトカムのうち, 効果推定値の方向 性は一致していないため, 最も低いアウトカムの確実 性である「非常に低」を選択した。

\section{（6）価值観}

集中治療室における面会制限を緩和することによる 望ましい効果は, 今回採用したアウトカムのうち「せ 儿妄発症率」において予期される。しかしながら，そ の効果は一部限定的であり, どの程度この効果を期待 するかは，価值観によってばらつきがあると想定され る。 
Table 20-5-1エビデンスプロファイル

\begin{tabular}{|c|c|c|c|c|c|c|c|c|c|c|c|c|}
\hline \multicolumn{7}{|c|}{ 確実性の評価 } & \multicolumn{2}{|c|}{ 患者数 } & \multicolumn{2}{|c|}{ 効果 } & \multirow[b]{2}{*}{ 確実性 } & \multirow[b]{2}{*}{ 重要性 } \\
\hline 研究数 & $\begin{array}{l}\text { 研究 } \\
\text { デザイン }\end{array}$ & $\begin{array}{l}\text { バイアス } \\
\text { のリスク }\end{array}$ & 非一貫性 & 非直接性 & 不精確性 & $\begin{array}{l}\text { その他 } \\
\text { の検討 }\end{array}$ & 面会制限なし & コントロール群 & $\begin{array}{l}\text { 相対指標 } \\
(95 \% \text { CI })\end{array}$ & $\begin{array}{l}\text { 絶対指標 } \\
(95 \% \mathrm{CI})\end{array}$ & & \\
\hline \multicolumn{13}{|c|}{ 集中治療室感染 } \\
\hline 2 & RCT & 深刻 a & 深刻でない & 深刻でない & 深刻 b & なし & $50 / 951 \quad(5.3 \%)$ & $54 / 957 \quad(5.6 \%)$ & $\begin{array}{c}\text { RR } 0.93 \\
\text { (0.64 to } 1.35)\end{array}$ & $\begin{array}{c}1,000 \text { 人あたり } 4 \\
\text { 人少ない } 20 \text { 人 } \\
\text { 少ない〜20人多 } \\
\text { () }\end{array}$ & $\underset{\text { 低 }}{\oplus \oplus \bigcirc \bigcirc}$ & 重大 \\
\hline \multicolumn{13}{|c|}{ 患者のせん妄発症 } \\
\hline 2 & RCT & 深刻 a & 深刻。 & 深刻でない & 非常に深刻 d & なし & $\begin{array}{l}161 / 865 \\
(18.6 \%)\end{array}$ & $\begin{array}{l}181 / 879 \\
(20.6 \%)\end{array}$ & $\begin{array}{c}\text { RR } 0.67 \\
\text { (0.28 to } 1.64)\end{array}$ & $\begin{array}{c}1,000 \text { 人あたり } 68 \\
\text { 人少ない }(148 \text { 人 } \\
\text { 少ない 132 人多 } \\
\text { い) }\end{array}$ & $\begin{array}{l}\oplus \bigcirc \bigcirc \bigcirc \\
\text { 非常に低 }\end{array}$ & 重大 \\
\hline \multicolumn{13}{|c|}{ ICU 滞在日数 } \\
\hline 1 & RCT & 深刻 a & 深刻でない & 深刻でない & 深刻でない & なし & 837 & 848 & - & $\begin{array}{c}\text { 平均 } 0.02 \text { 日短い } \\
(0.15 \text { 日短い } \\
0.09 \text { 日長い) }\end{array}$ & $\begin{array}{c}\oplus \oplus \oplus \bigcirc \\
\text { 中 }\end{array}$ & 重大 \\
\hline \multicolumn{13}{|c|}{ 家族の満足度 } \\
\hline 1 & RCT & 深刻 a & 深刻でない。 & 深刻でない & 深刻でない & なし & 493 & 483 & - & $\begin{array}{l}\text { 平均 } 13.5 \text { 高い } \\
\text { (10.87 高い } \\
16.13 \text { 高い) }\end{array}$ & $\begin{array}{c}\oplus \oplus \oplus \bigcirc \\
\text { 中 }\end{array}$ & 重要 \\
\hline \multicolumn{13}{|c|}{ 家族の抑うつ状態 } \\
\hline 1 & RCT & 深刻 a & 深刻でない。 & 深刻でない & 深刻でない & なし & 529 & 525 & - & $\begin{array}{c}\text { 平均 } 1.2 \text { 低い (2 } \\
\text { 低い 4 低い) }\end{array}$ & $\begin{array}{c}\oplus \oplus \oplus \bigcirc \\
\text { 中 }\end{array}$ & 重大 \\
\hline \multicolumn{13}{|c|}{ 家族の不安 } \\
\hline 1 & RCT & 深刻 a & 深刻でない & 深刻でない & 深刻でない & なし & 529 & 525 & - & $\begin{array}{l}\text { 平均 } 1.6 \text { 低い } \\
\text { (2.3 低い } 0.9 \\
\quad \text { 低い) }\end{array}$ & $\begin{array}{c}\oplus \oplus \oplus \bigcirc \\
\text { 中 }\end{array}$ & 重大 \\
\hline \multicolumn{13}{|c|}{ 患者の抑うつ状態 } \\
\hline 1 & RCT & 非常に深刻 ${ }^{\dagger}$ & 深刻でない。 & 深刻でない & 深刻 g & なし & 115 & 111 & - & $\begin{array}{c}\text { 平均 } 0 \\
(0 \sim 0)\end{array}$ & $\begin{array}{l}\oplus \bigcirc \bigcirc \bigcirc \\
\text { 非常に低 }\end{array}$ & 重大 \\
\hline
\end{tabular}

a. 2/7 項目でバイアスリスクの高い研究からのデータが大多数を占めるので, 1 段階ダウン。

b. リスク比が 1 を超えているので, 1 段階ダウン。

c. $I^{2}=68 \%$ ( $\mathrm{I}^{2}=50-90 \%$ は実質的な非一貫性があるので, 1 段階ダウン)。

d. リスク比が 0.75 と 1.25 の両方をまたいでいるので，2段階ダウン。

e.1文献からのサンプルのため評価できない

f. 3/7 項目に高リスクの研究からのデータが大多数を占めるので，2段階ダウン

g. 連続変数で示されたアウトカムで，サンプル数が 400 に満たないので，1段階ダウン

（7）容認性

面会制限の有無そのものでは，費用に差は生じない

ことが予想される。

\section{（8）実行可能性}

介入は実行可能であるが，面会制限の有無による診 療上の支障やリスク，医療スタッフヘの負担は，施 設・症例によって様々であることが想定される。ま た，緩和により診療やケアに支障を来す可能性があ る。

（9）判断の要約（Table 20-5-2）

\section{（10）推奨グレーディング決定の工程}

修正 RAND 法を用いた投票によって，中央值 7, 見解不一致指数 0.164 の結果となり，委員会で採択さ れた（7点以上 : 91.7\%）。
（11）関連する他の診療ガイドラインにおける推奨

PADIS ガイドラインで4）は，患者ストレスの減少， せん妄予防と管理のための非薬理学的介入における家 族の役割について，さらなる研究の必要性について言 及しているが，面会制限に関する具体的な推奨の判断 はしていない。

（12）実施に関わる検討事項 なし。

\section{（13）今後の研究の可能性}

以下の内容に関する検討が求められると考えられる。 ・患者に関する望ましいアウトカム（せん妄発症, ICU 滞在日数，患者の抑うつ状態）に対する有効 性のさらなる検証

・サンプル数が多い研究における有害事象の検証

$$
\text { 文 献 }
$$

1) Eghbali-Babadi M, Shokrollahi N, Mehrabi T: Effect of 
Table 20-5-2 判断の要約

\begin{tabular}{|c|c|c|c|c|c|c|c|}
\hline 問題 & いいえ & $\begin{array}{c}\text { おそらく、いい } \\
\text { え }\end{array}$ & おそらく、はい & はい & & さまざま & 分からない \\
\hline 望ましい効果 & わずか & 小さい & 中 & 大きい & & さまざま & 分からない \\
\hline 望ましくない効果 & 大きい & 中 & 小さい & わずか & & さまざま & 分からない \\
\hline エビデンスの確実性 & 非常に低 & 低 & 中 & 高 & & & 採用研究なし \\
\hline 価值観 & $\begin{array}{c}\text { 重要な不確実性 } \\
\text { またはばらつき } \\
\text { あり }\end{array}$ & $\begin{array}{c}\text { 重要な不確実性 } \\
\text { またはばらつき } \\
\text { の可能性あり }\end{array}$ & $\begin{array}{l}\text { 重要な不確実性 } \\
\text { またはばらつき } \\
\text { はおそらくなし }\end{array}$ & $\begin{array}{c}\text { 重要な不確実性 } \\
\text { またはばらつき } \\
\text { はなし }\end{array}$ & & & \\
\hline 効果のバランス & 比較が優位 & $\begin{array}{c}\text { 比較がおそらく } \\
\text { 優位 }\end{array}$ & $\begin{array}{c}\text { 介入も比較もい } \\
\text { ずれも優位でな } \\
\text { い }\end{array}$ & $\begin{array}{c}\text { おそらく介入が } \\
\text { 優位 }\end{array}$ & 介入が優位 & さまざま & 分からない \\
\hline 容認性 & いいえ & $\begin{array}{c}\text { おそらく、いい } \\
\text { え }\end{array}$ & おそらく、はい & はい & & さまざま & 分からない \\
\hline 実行可能性 & いいえ & おそらく、いい & おそらく、はい & はい & & さまざま & 分からない \\
\hline
\end{tabular}

family - patient communication on the incidence of delirium in hospitalized patients in cardiovascular surgery ICU. Iran J Nurs Midwifery Res. 2017; 22: 327-31.

2) Fumagalli S, Boncinelli L, Nostro AL, et al: Reduced cardiocirculatory complications with unrestrictive visiting policy in an intensive care unit: Results from a pilot, randomized trial. Circulation. 2006; 113: 946-52.

3) Rosa RG, Falavigna M, da Silva DB, et al: Effect of Flexible Family Visitation on Delirium Among Patients in the Intensive Care Unit: The ICU Visits Randomized Clinical Trial. JAMA. 2019; 322: 216-28.

4) Devlin JW, Skrobik Y, Gélinas C, et al: Clinical Practice Guidelines for the Prevention and Management of Pain, Agitation/Sedation, Delirium, Immobility, and Sleep Disruption in Adult Patients in the ICU. Crit Care Med. 2018; 46: e825-73. 


\section{CQ20-6：患者の価值観・考え方等を尊重した意 思決定支援の方法は?}

Answer : 患者や家族等を含めた多職種カンファレン スなどで議論を重ね，患者の価值観や意向を尊重した 意思決定を支援するなどの方法がある。患者の意思が 不明確な場合には，家族等の代理意思推定者を慎重に 見極め, 患者本人の意思を推定する方法などが提案さ れている。患者の意思を尊重すると同時に，患者・家 族等に医学的に正確な情報を提供することも重要であ る (BQ に対する情報提示)。

\section{（1）背景および本 CQの重要度}

医療の複雑化や患者の価值観・考え方, ライフスタ イルの多様化に伴い, 意思決定支援の重要性が増して きている。患者の知る権利 ·自己決定権 - 自律の原則 の尊重が重要視され, 従前の医療者主導のパターナリ スティックな意思決定支援から，患者の意思を尊重し たインフォームド・コンセントや事前指示書 (advance directive: AD）による意思決定支援が推進された。し かし, 特に救急・集中治療領域においては, 病状や環 境の変化が急激であることから，患者の価值観や意向 も変化することが考えられ，これらの意思決定支援方 法では十分な対応は困難であることが明らかになって きた。このような背景のなか，近年では，患者や家族 等と医療者が治療・療養について話し合うプロセスで ある「共同意思決定（shared decision making: SDM）」 と「人生会議（advance care planning: ACP)」が提案さ れている。SDM や ACP の話し合いが家族の不安など を軽減させた報告もあり，今後の普及の可能性を考 え，本ガイドラインの CQ として取り上げた。

\section{（2）解説}

本邦における調査では，多くの国民が自身の治療方 針について医師との相談または説明を受けたうえで, 自身で決定したいと望んでいた ${ }^{1)}$ 。一方，本人や代理 意思推定者によって治療方針が意思決定されたにもか かわらず，別の家族の意向が優先され，治療方針が変 更となる事例も報告された 2)。このような背景を受け て，インフォームド・コンセントや ADによる意思決 定支援が推進されたが，ADの有用性を検証した大規 模クラスターランダム化比較試験（RCT）では，ケア の質や患者の転帰などに有意な改善を認めなかっ た ${ }^{3)}$ 。その理由として, 実際の状況が複雑なため患者 が予想すること自体が困難であること，その時点の意 思決定が現在も同じであるか分からないことなどが挙
げられた。特に救急・集中治療領域においては, 病状 や環境の変化が急激であることから，この傾向が顕著 であることが予測される。そのため, 一時点でのイン フォームド・コンセントや AD ではなく，経時的な話 し合いが重要視されるようになった。

近年では，SDM と ACP が提案されている。これら の方法は，患者や家族等（家族だけではなく，患者が 信頼して自身の治療・療養を決めてほしいと思う知 人・友人を含む）の意思決定を支えるプロセスであ り，医療者は患者の状態と治療の選択肢・方法などの エビデンスとなる正確な情報を提供し，患者と家族等 は患者自身の価值観や意向などの情報を提供すると いった双方向の継続的な過程である。この過程では, 患者本人による意思決定を基本とし, 多職種カンファ レンスなどで議論を重ね，方針の決定を行うことが提 案されている4)。患者にとっての最善について対話し, 考えるプロセスが SDM であり， ACP の根幹を成す。 患者の意思確認ができない場合には，家族等の代理意 思推定者を慎重に見極め, 患者の推定意思を尊重し, 患者にとっての最善の方針をとる方法が提案されてい る。また，家族等が患者の意思を推定できない場合に は，患者にとっての最善の方針をとることを基本と し，家族等を含めた多職種カンファレンスなどで十分 に話し合う方法がある ${ }^{4)}$ 。これらの方法は，一度意思 決定されたら終了ではなく，時間の経過，心身の状態 の変化, 医学的評価の変更などに応じて, このプロセ スを繰り返し行うことが重要とされる。また，このプ ロセスにおいて話し合った内容は，その都度，文書に まとめておくことが提案されている4)。

なお, 救急・集中治療医学の発展により, 従来では 救命不可能であった敗血症患者を救命できるように なってきている5)。これに伴い, 救急・集中治療領域 における終末期も変遷してきており，終末期の判断の ためには，主治医を含む複数の医師（複数科であるこ とが望ましい）と看護師等からなる医療チームでの十 分な検討が必要である6)。終末期か否かの線引きはむ ずかしいが，明らかに救命可能な命を終末期に持ち込 んだり, 明らかな延命治療を救命と誤認したりするこ とがないよう，患者と家族等へ医学的に正確な情報を 提供することが重要である。

このような SDM や ACP の話し合いは，死別後の 家族のストレス・うつ・不安などを低減すると報告さ れている7，8)。SDM や ACP の有用性は，未だ十分に 検証されていないが，今後の研究や医療制度によっ て，実施が拡大されていくものと考える。 
1）江口成美, 出口真弓: 第 5 回日本の医療に関する意識調査. 日医総研ワーキングペーパー. 2014; 331: 18-9. Available online at: http://www.jmari.med.or.jp/download/WP331.pdf. Accessed October 26, 2019.

2) Molloy DW, Clarnette RM, Braun EA, et al: Decision making in the incompetent elderly: "The Daughter from California Syndrome”. J Am Geriatr Soc. 1991; 39: 396-9.

3) Connors AF, Dawson NV, Desbiens NA, et al: A controlled trial to improve care for seriously ill hospitalized patients. The study to understand prognoses and preferences for outcomes and risks of treatments (SUPPORT). The SUPPORT Principal Investigators. JAMA. 1995; 274: 1591-8.

4）厚生労働省: 人生の最終段階における医療・ケアの決定プ ロセスに関するガイドライン. Available online at: https:// www.mhlw.go.jp/file/04-Houdouhappyou-10802000-IseikyokuShidouka/0000197701.pdf. Accessed October 26, 2019.

5) Kaukonen KM, Bailey M, Suzuki S, et al: Mortality related to severe sepsis and septic shock among critically ill patients in Australia and New Zealand, 2000-2012. JAMA. 2014; 311: 1308-16.

6) 日本集中治療医学会, 日本救急医学会, 日本循環器学会: 救 急・集中治療における終末期医療に関するガイドライン〜3 学会からの提言〜. Available online at: https://www.jsicm. org/pdf/1guidelines1410.pdf. Accessed October 26, 2019.

7) Detering KM, Hancock AD, Reade MC, et al: The impact of advance care planning on end of life care in elderly patients: randomised controlled trial. BMJ. 2010; 340: c1345.

8) Lautrette A, Darmon M, Megarbane B, et al: A communication strategy and brochure for relatives of patients dying in the ICU. N Engl J Med. 2007; 356: 469-78. 


\section{CQ21 : Sepsis treatment system}

国内外で敗血症が注目され，臨床現場では重篤な感 染症を診療する体制の構築が求められている。日本版 敗血症診療ガイドライン（J-SSCG）2020では，この ような診療体制の変化に対応するために新たに敗血症 診療システム（sepsis treatment system: STS）という項 目を掲げ，敗血症の診療体制についての CQ を提示す ることとした。STS の基本的な考え方は，敗血症を早 期に認識・覚知し，適切な体制での診療が受けられる ことを可能にすることで，治療成績を向上させること にある。また，同時に一般市民や敗血症診療には普段 関わらない一般医療従事者に対しても，敗血症という 疾患の重篤性や適切な診療体制を構築する意義などを 認知，認識するような啓発活動もガイドラインとして の重要な役割である。さらに, 敗血症の診断と治療に おける質を担保するために，敗血症診療に関する評価 をどのように行うべきかも重要である。本章ではこれ らに関する CQ を提示する。

敗血症の早期認識のシステムに関する CQとして, 「一般病棟, ER で敗血症を早期発見する方法は?」と 「一般病棟で敗血症を疑う患者の病状変化に対応する rapid response system (RRS) の役割とはどのようなも のか?」の2つを提示した。敗血症の早期発見が可能 になれば，輸液蘇生や抗菌薬投与などの早期の介入が でき，患者の転帰を改善する可能性がある 1)。早期発 見ツールとして quick SOFA ${ }^{2)}$ や national early warning score (NEWS) ${ }^{3)}$ などのいくつかの早期警告スコアが 提唱されている。各スコアには利点と欠点があること を理解したうえで, より現場で使いやすいスコアとし て，敗血症早期発見システムの導入が望まれる4)。敗
血症早期発見システムを導入しても，主治医や担当医 のみが使用するのでは早期発見には限界がある。これ らのシステムを有効に活用するためには医師のみなら ず，すべてのメディカルスタッフが早期発見ツールを 駆使できる必要がある。特に患者に接することの多い 一般病棟の看護師, 理学療法士, 臨床工学技士, 薬剤 師, 栄養士などは敗血症の早期発見の重要なポジショ ンである。バイタルサインの異常や何かおかしいなど といった懸念を感じるなかに敗血症が隠れている可能 性もあり，患者の病状の変化を確実に報告し，その報 告にすぐに対応できるシステムの構築が必要である。 そのようなシステムの一つとして RRS があり, 敗血 症診療にも利用できる。

敗血症を早期に疑い，集中治療を開始する診療体制 などについて「初期輸液蘇生に不応の敗血症はどこで 管理するか?」という CQ を重要な臨床課題として提 示した。本邦では 10 万人あたりの集中治療室ベッド 数が欧米の 10〜30 床に対し，5床と著しく少な $<5,6)$, 集中治療専門医も集中治療室ベッド数から算 出した適正な 4,000 人に対し半分程度の充足率である。 したがって, 敗血症患者の生命予後, 機能予後を改善 するためには集中治療室に限定せずに集中治療が可能 な施設や体制での診療が必要である。また，治療対象 となる患者を選定するうえで質の高いエビデンスはな く,「初期輸液蘇生に不応」の場合を集中治療が可能 な場所への搬送を検討する基準としたが，「不応」に ついては厳格な基準を設けず，各施設の医療資源（診 療体制）で判断することとした。また，小児でも初期 輸液蘇生に不応と判断された時点で人工呼吸管理や循 環作動薬の導入を考慮することが示唆されているよう に4,7)，成人から小児にまで適応できる基準として提

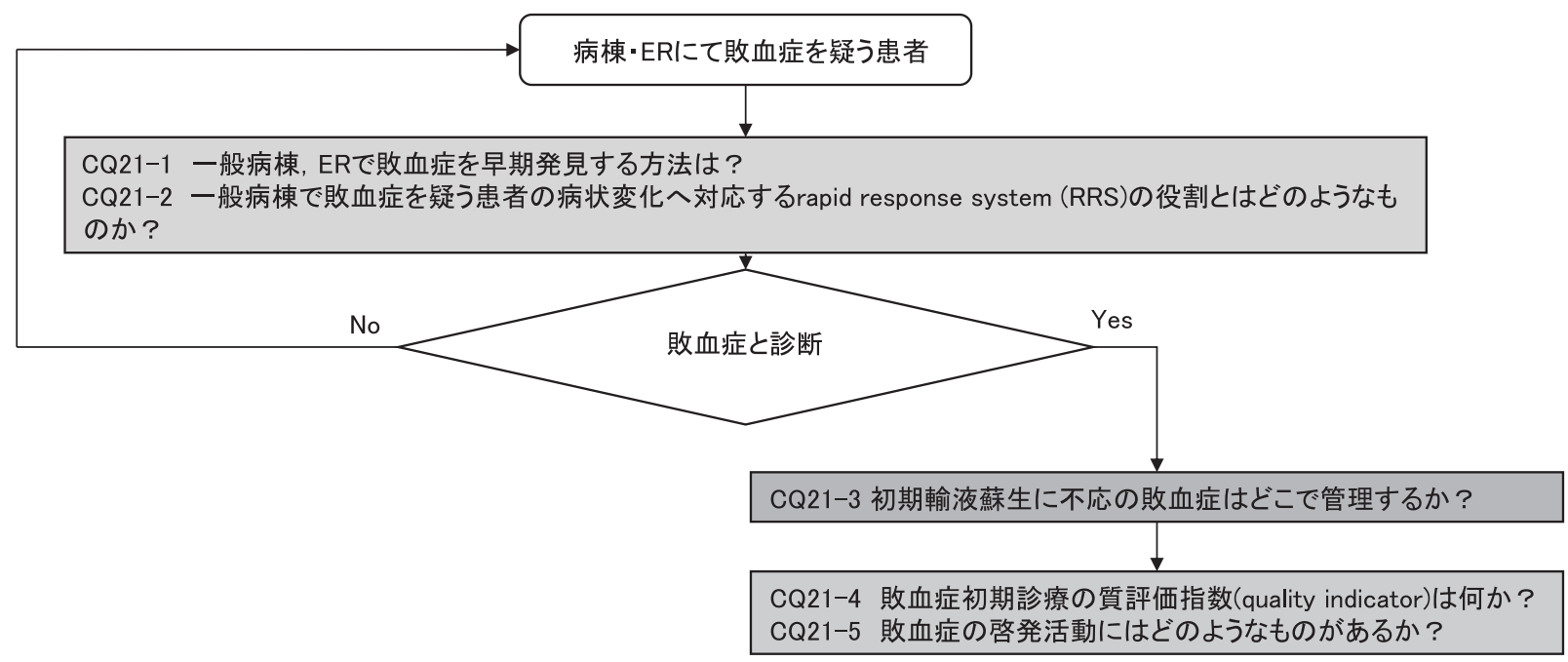

Sepsis treatment system [診療フロー〕 
示した。熟練したチームによる病院間搬送は治療戦略 の一つであり, 重症小児では搬送数の増加と良好な治 療成績の関連が知られている。敗血症における転院搬 送については，今後の検討課題である ${ }^{8-14) 。 ~}$

集中治療室での加療の有効性については, 観察研究 ではあるが，重症敗血症/敗血症性ショックにおいて 来院から集中治療室入室までの時間が 1 時間遅れるご とに死亡率の調整オッズ比が 1.11 上昇すると報告さ れている15)。「集中治療ができる場所」の定義は患者 因子と環境因子の相対的なものであるため明文化する ことはむずかしい。集中治療医の関わりと治療成績に 関しては, high intensity モデルでは low intensity モデ ルに比べ，院内死亡率の低下や入院期間の短縮が期待 されることが報告されている16,17)。しかし，集中治 療医の介入と院内死亡率の上昇の関連を指摘する報告 もある ${ }^{18) 。}$

敗血症診療における適切な治療の実施について, 敗 血症の早期認知と早期治療介入の観点から評価しなけ ればならない。敗血症の初期診療における質評価指数 （quality indicator: QI）を明確にし, 診療プロセスを適 切に評価することは，敗血症診療全体における質の向 上に繋がる。そのため「敗血症初期診療の質評価指数 (quality indicator) は何か?」という CQを提示した。 本邦では敗血症に特化した QI は十分には検討されて いない。現在，米国連邦政府の保険福祉省が Hospital Inpatient Quality Reporting Program (IQRP) の中で, Severe Sepsis and Septic Shock Early Management Bundle (SEP-1) を唯一敗血症診療での QI として取り上げて いる ${ }^{19)}$ 。SEP-1 では, 従来の治療のプロトコル遵守率 という評価ではなく, 治療バンドルとして達成度から 評価している。バンドルの項目として SEP-1 には 6 項 目あるが，適宜修正変更されている。現在，3時間以 内の広域抗菌薬投与以外には敗血症の予後改善と関連 する項目がみられず20)，バンドルの項目を新たに修 正してさらにQI としての質の向上を行う過程にあ る21)。本邦で行われた FORECAST 研究では closed ICU のほうが敗血症の 3 時間バンドルの遵守率が高い とも報告されているように22)，本邦においても QI 評 価を目的とした検討が期待される。

以上のような敗血症の概念や早期発見・早期治療の 重要性について, 医療従事者および一般市民も広く認 識していることが，敗血症の予防と予後の改善には重 要と考えられ, 世界的に敗血症の啓発活動が行われて いる。本ガイドラインでは「敗血症の啓発活動にはど のようなものがあるか? という CQ を提示し，世界 敗血症連盟（Global Sepsis Alliance: GSA） ${ }^{23)}$ と世界保
健機関（World Health Organization: WHO） ${ }^{24)}$ との連携, そして本邦における学会の取り組みについて言及す る。

\section{文 献}

1) Bhattacharjee P, Edelson DP, Churpek MM: Identifying Patients With Sepsis on the Hospital Wards. Chest. 2017; 151: 898-907.

2) Seymour CW, Liu VX, Iwashyna TJ, et al: Assessment of clinical criteria for sepsis for the third international consensus definitions for sepsis and septic shock (sepsis-3). JAMA. 2016; 315: 762-74.

3) Royal College of Physicians: National early warning score (NEWS) 2. Available online at: https://www.rcplondon.ac.uk/projects/ outputs/national-early-warning-score-news-2. Accessed December 31, 2020.

4) Dellinger RP, Levy MM, Rhodes A, et al: Surviving sepsis campaign: international guidelines for management of severe sepsis and septic shock: 2012. Intensive Care Med. 2013; 39: 165-228.

5) 橋本悟: わが国の集中治療医学の現況とこれからの課題: 新 専門医制度をふまえて（特集集中治療医学の課題と将来の 展望). ICUと CCU. 2013; 37: 113-8.

6) 内野滋彦: わが国の集中治療室は適正利用されているのか. 日集中医誌. 2010; 17: 141-4.

7) Davis AL, Carcillo JA, Aneja RK, et al: The American College of Critical Care Medicine Clinical Practice Parameters for Hemodynamic Support of Pediatric and Neonatal Septic Shock: Executive Summary. Pediatr Crit Care Med. 2017; 18: 884-90.

8) Tilford JM, Simpson PM, Green JW, et al: Volume-outcome relationships in pediatric intensive care units. Pediatrics. 2000; 106: 289-94.

9) Marcin JP, Song J, Leigh JP: The impact of pediatric intensive care unit volume on mortality: A hierarchical instrumental variable analysis. Pediatr Crit Care Med. 2005; 6: 136-41.

10) Pearson G, Shann F, Barry P, et al: Should paediatric intensive care be centralised? Trent versus Victoria. Lancet. 1997; 349: 1213-7.

11) Markovitz BP, Kukuyeva I, Soto-Campos G, et al: PICU Volume and Outcome: A Severity-Adjusted Analysis. Pediatr Crit Care Med. 2016; 17: 483-9

12) Ramnarayan P, Thiru K, Parslow RC, et al: Effect of specialist retrieval teams on outcomes in children admitted to paediatric intensive care units in England and Wales: A retrospective cohort study. Lancet. 2010; 376: 698-704.

13) Moynihan K, McSharry B, Reed P, et al: Impact of Retrieval, Distance Traveled, and Referral Center on Outcomes in Unplanned Admissions to a National PICU. Pediatr Crit Care Med. 2016; 17: e34-42.

14) Hamrin TH, Berner J, Eksborg S, et al: Characteristics and outcomes of critically ill children following emergency transport by a specialist paediatric transport team. Acta Paediatr. 2016; 105: 1329-34.

15) Li Q, Wang J, Liu G, et al: Prompt admission to intensive care is associated with improved survival in patients with severe sepsis and/or septic shock. J Int Med Res. 2018; 46: 4071-81

16) Pronovost PJ, Angus DC, Dorman T, et al: Physician Staffing Patterns and Clinical Outcomes in Critically Ill Patients A Systematic Review. JAMA. 2002; 288: 2151-62.

17) Wilcox ME, Chong CA, Niven DJ, et al: Do intensivist staffing patterns influence hospital mortality following ICU admission? A systematic review and meta-analyses. Crit Care Med. 2013; 41: 2253-74.

18) Levy MM, Rapoport J, Lemeshow S, et al: Association between critical care physician management and patient mortality in the intensive care unit. Ann Intern Med. 2008; 148: 801-9. 
19) Faust JS, Weingart SD: The Past, Present, and Future of the Centers for Medicare and Medicaid Services Quality Measure SEP-1: The Early Management Bundle for Severe Sepsis/Septic Shock. Emerg Med Clin North Am. 2017; 35: 219-31.

20) Seymour CW, Gesten F, Prescott HC, et al: Time to treatment and mortality during mandated emergency care for sepsis. N Engl J Med. 2017; 376: 2235-44.

21) Marik PE, Farkas JD, Spiegel R, et al: POINT: Should the Surviving Sepsis Campaign Guidelines Be Retired? Yes. Chest. 2019; 155: 12-4.

22) Abe T, Ogura H, Shiraishi A, et al: Characteristics, management, and in-hospital mortality among patients with severe sepsis in intensive care units in Japan: the FORECAST study. Crit Care. 2018; $22: 322$.

23) Global Sepsis Alliance: Available online at: https://www.globalsepsis-alliance.org/.

24）WHO: WHO 第 70 回決議（A70/13 13 April 2017）. Available online at: http://apps.who.int/gb/e/e_wha70.html. Accessed December 31, 2020
CQ21-1：一般病棟, ER で敗血症を早期発見す る方法は?

Answer：一般病棟，ER で敗血症を早期に発見する方 法として, quick SOFA（qSOFA）や早期警告スコアな どを用いたスクリーニング法がある（Table 21-1-1〜 21-1-3）（BQに対する情報提示）。

\section{（1）背景および本 $C Q$ の重要度}

敗血症を早期に発見し治療を開始することで，予後 が改善する可能性がある 1 )。特に一般病棟や ER では 敗血症を想起して発見することで, 治療開始のタイミ ングを逃さないようにするべきである。敗血症の早期 発見は, 患者の予後を左右する敗血症診療の重要なポ イントであり，本 CQを取り上げた。

\section{（2）解説}

敗血症の早期発見と早期介入は, 死亡率改善には不 可欠である。敗血症の早期発見が可能になれば，輸液 蘇生や抗菌薬投与などの早期の介入ができ，患者の転 帰を改善する可能性がある 2)。しかし, 敗血症と敗血 症以外の感染症で病態生理が大きく異なるわけではな く, 時系列で変化するものである。よって, 敗血症患 者のみを抽出するような診断基準は極めてむずかし い。そのため, 死亡率の高い, 高度な医療を必要とす る感染症群をどのように検出するかという観点で診断 基準が作成されている。1991 年に全身性炎症反応症 候群 (systemic inflammatory response syndrome: SIRS) をもとにした敗血症の定義が提唱された。

SIRS は敗血症の早期発見のツールとしての特異度 が低い点 ${ }^{3)}$ ，また病棟の患者で SIRS の 2 項目を満た す症例は約半数である点 4$)$ などの問題点が指摘され た。2016 年に Sepsis-3 の定義とともに, 病棟や ER で 敗血症を疑うスクリーニングツールとして SIRS より 項目数を減らした qSOFA が提唱された5)。qSOFA は, SIRS, logistic organ dysfunction system (LODS) や SOFA と比較して, 敗血症の早期発見や院内死亡をよ り良く予測するスコアであると報告されている5)。 qSOFA は, 病棟やERにおける敗血症患者の院内死亡 率, 急性臟器障害, 集中治療室緊急入室に関して高い

Table 21-1-1 quick SOFA

\begin{tabular}{lll}
\hline \multicolumn{1}{c}{ 項目 } & \multicolumn{1}{c}{ 測定值 } & 点数 \\
\hline 収縮期血圧 & $\leqq 100 \mathrm{mmHg}$ & 1 \\
\hline 呼吸数 & $\geqq 22$ 回/分 & 1 \\
\hline 意識の変容 & & 1 \\
\hline
\end{tabular}

3 項目の中で 2 点以上は敗血症を疑う 
Table 21-1-2 早期警告スコア national early warning score(NEWS)

\begin{tabular}{|c|c|c|c|c|c|c|c|}
\hline 項目 点数 & 3 & 2 & 1 & 0 & 1 & 2 & 3 \\
\hline 呼吸 & $\leqq 8$ & & $9 \sim 11$ & $12 \sim 20$ & & $21 \sim 24$ & $\geqq 25$ \\
\hline $\mathrm{SpO}_{2}$ & $\leqq 91$ & $92 \sim 93$ & $94 \sim 95$ & $\geqq 96$ & & & \\
\hline 酸素投与 & & あり & & なし & & & \\
\hline 体温 & $\leqq 35.0$ & & $35.1 \sim 36.0$ & $36.1 \sim 38.0$ & $38.1 \sim 39.0$ & $\geqq 39.1$ & \\
\hline 血圧 & $\leqq 90$ & $91 \sim 100$ & $101 \sim 110$ & $111 \sim 219$ & & & $\geqq 220$ \\
\hline 脈拍 & $\leqq 40$ & & $41 \sim 50$ & $51 \sim 90$ & $91 \sim 110$ & $111 \sim 130$ & $\geqq 131$ \\
\hline 意識 & & & & 覚醒 & & & 覚醒以外 \\
\hline
\end{tabular}

Table 21-1-3 NEWS のスコアリング後の対応

\begin{tabular}{|c|c|c|}
\hline NEWS スコアリング & モニタリング頻度 & 臨床的介入 \\
\hline 0 点 & 最低 12 時間ごと & とりあえず経過観察 \\
\hline $1 \sim 4$ 点 & 最低 $4 \sim 6$ 時間ごと & $\begin{array}{c}\text { リーダーに報告・相談 } \\
\text { 観察強化の指示 }\end{array}$ \\
\hline $\begin{array}{c}\quad 5 \sim 6 \text { 点 } \\
\text { もしくは } 1 \text { 項目でも } \\
3 \text { 点以上がある場合 }\end{array}$ & 最低 1 時間ごと & $\begin{array}{c}\text { 急変対応チームの要請 } \\
\text { 急変しうる病態かどうかを判断 } \\
\text { high care unit }(\mathrm{HCU}) \text { への移動 }\end{array}$ \\
\hline 7 点以上 & 持続的モニタリング & $\begin{array}{c}\text { 熟練した急変対応チームを即座に呼ぶ } \\
\text { 緊急性の強化を行う } \\
\text { ICU などの高度ユニットへ }\end{array}$ \\
\hline
\end{tabular}

診断特異性を示した6)。また，院内死亡率の予測因子 を評価した 10 件の研究のメタ解析ではSIRSより qSOFA が有用と報告されている[リスク比 (RR) 0.03, 95\% CI: 0.01 多い〜0.05 多い, $P=0.002)]$ 7)。一方, qSOFA が敗血症を認識するのには感度が低い可能性 もある ${ }^{8)}$ 。さらに, rapid response system（RRS）は, 院内における敗血症を含む急変事例を早期に発見・対 応するシステムであり, その起動ツールのうちいくつ かの指標を組み合わせ，スコア化して英国で発表され た national early warning score (NEWS) も敗血症の早 期発見のツールとして評価されている ${ }^{9)}$ 。Redfern ら は, 一時感染患者の院内死亡の予測（area under ROC curve）ではNEWS が優れている（NEWS: 0.805 vs. qSOFA: 0.677）と報告 10) している。現時点では, 早 期発見のためのスクリーニングにはそれぞれの施設で 実施可能なスコアリングを用いるのがよい。

\section{文 献}

1) Kadri SS, Rhee C, Strich JR, et al: Estimating Ten-Year Trends in Septic Shock Incidence and Mortality in United States Academic Medical Centers Using Clinical Data. Chest. 2017; 151: 278-85.

2) Bhattacharjee P, Edelson DP, Churpek MM: Identifying Patients With Sepsis on the Hospital Wards. Chest. 2017; 151: 898-907.

3) Kaukonen KM, Bailey M, Pilcher D, et al: Systemic inflammatory response syndrome criteria in defining severe sepsis. $\mathrm{N}$ Engl $\mathrm{J}$ Med. 2015; 372: 1629-38.

4) Churpek MM, Zadravecz FJ, Winslow C, et al: Incidence and prognostic value of the systemic inflammatory response syndrome and organ dysfunctions in ward patients. Am J Respir Crit Care
Med. 2015; 192: 958-64.

5) Seymour CW, Liu VX, Iwashyna TJ, et al: Assessment of clinical criteria for sepsis: for the third international consensus definitions for sepsis and septic shock (Sepsis-3). JAMA. 2016; 315: 762-74.

6) Song JU, Sin CK, Park HK, et al: Performance of the quick Sequential (sepsis-related) Organ Failure Assessment score as a prognostic tool in infected patients outside the intensive care unit: A systematic review and meta-analysis. Crit Care. 2018; 22: 28.

7) Serafim R, Gomes JA, Salluh J, et al: A Comparison of the Quick-SOFA and Systemic Inflammatory Response Syndrome Criteria for the Diagnosis of Sepsis and Prediction of Mortality: A Systematic Review and Meta-Analysis. Chest. 2018;153: 646-55.

8) Anand V, Zhang Z, Kadri SS, et al: Epidemiology of Quick Sequential Organ Failure Assessment Criteria in Undifferentiated Patients and Association With Suspected Infection and Sepsis. Chest. 2019; 156: 289-97.

9) Royal College of Physicians: National Early Warning Score (NEWS) 2. Available online at: https://www.rcplondon.ac.uk/ projects/outputs/national-early-warning-score-news-2.

10) Redfern OC, Smith GB, Prytherch DR, et al: A Comparison of the Quick Sequential (Sepsis-Related) Organ Failure Assessment Score and the National Early Warning Score in Non-ICU Patients With/Without Infection. Crit Care Med. 2018; 46: 1923-33. 


\section{CQ21-2：一般病棟で敗血症を疑う患者の病状変 化に対応する rapid response system (RRS) の 役割とはどのようなものか?}

Answer : Rapid response system（RRS）は，院内患者 の病状変化を早期に覚知・対応するシステムであり, その導入により敗血症においても生命予後の改善が期 待されるとの意見がある (BQに対する情報提示)。

\section{（1）背景および本 $C Q$ の重要度}

敗血症を早期に覚知し治療介入することは，患者生 命予後の改善に強く影響する重要課題である。病院の 規模や診療体制にかかわらず，ER 患者や入院患者を 注意深く観察し, 敗血症へと進展している可能性を早 期に認識できるシステムの構築が望ましい。実際に は，種々のバイタルサインを含めた病状の変化を早期 に認識し，対応するシステムであるRRS を用いた敗 血症スクリーニングとその後の治療介入が有用である と考え，本 CQを取り上げた。

\section{（2）解説}

敗血症の死亡率は，SSCG による治療の標準化の普 及などにより着実に低下している1)。今後，さらに死 亡率の軽隇を図るためには, 標準治療の遵守に加え, それ以外のアプローチも必要になってくる。

敗血症の標準治療の普及や遵守と共に重要なこと は, 早期の敗血症の認知と治療介入であり, 予後改善 には必要不可欠なものである2)。2016 年の敗血症診 断基準の変更により, 敗血症は感染症を基礎として臓 器障害へと進展した病態と定義されている(Sepsis-3)。 Sepsis-3 では臟器障害の評価に SOFA スコアを用いる ため, 血液検査や血液ガス分析なども必要とし診断に は時間を要するため，スクリーニングとしての使用は 煩雑である。したがって，一般病棟や ER のベッドサ イドで簡便にスクリーニングする何らかの方法が必要 となる。このような臟器障害へと進展する患者は, 早 期から何らかのバイタルサインの異常を示すことが多 いため, 敗血症を疑うためのベッドサイドでのスク リーニングツールとして単純なバイタルサイン（収縮 期血圧，呼吸数，意識の変容）に基づいて評価する qSOFA が推奨されている。

一方, 敗血症を含めた重症患者のバイタルサインの 異常といった病状変化を早期に認知, 介入し, 重症 化，特に心肺停止への進展を予防するシステムが RRS である。一般にRRS は, 医師以外にも看護師, 理学療法士, 薬剤師, 臨床工学技士といった多職種医
療スタッフや医学生, 患者家族などにより, 患者の病 状変化を早期発見・介入するシステムである。海外で は 1980 年代から導入されてきたが，本邦では 2000 年 代に入り，医療安全全国共同行動 “いのちをまもる パートナーズ” 運動の行動目標に院内急変時の迅速対 応システムの構築が推奨され，ようやく普及しつつあ る。

RRS 起動基準は各医療施設で異なることが予想さ れるが，呼吸，循環，意識などの単一あるいは複数の バイタルサインの異常を認知することで起動される。 この中には, 収縮期血圧, 呼吸数, 意識の変容といっ た qSOFA の項目が含まれることが多い。したがって, 感染症を疑う場合の RRS 起動により敗血症のスク リーニングも可能である。また, RRS 起動基準には, 複数のバイタルサインにそれぞれ固有の重みづけをし てスコアリングするEWS が用いられることも多い。 英国の国民保健サービス（National Health Service: NHS）が提唱するRRS に用いられる NEWS では，感 染症が疑われる患者において合計 5 点以上，あるいは 1 項目でも 3 点以上がある場合, 敗血症を疑うことを 提案している ${ }^{3)}$ 。RRS と敗血症スクリーニングの有用 性について検討したランダム化比較試験（RCT）は存 在しないが，RRS 導入により早期に敗血症/敗血症性 ショックに対する治療介入が可能となり, 予後の改善 につながった報告もみられる4)。また，ERあるいは 一般病棟で感染症を疑う患者の生命予後や ICU への 緊急入室を予測するスコアとして, RRS 起動で用い られる modified early warning score (MEWS) やNEWS が, qSOFA や SIRS 項目と比べて優れているという報 告もされている5)。

RRS により一般病棟や ER で早期に敗血症を認識す ることで, 1 時間バンドルなどの推奨治療の達成を可 能とし, その結果, 敗血症の生命予後の改善につなが る可能性が考えられる。

\section{文 献}

1) Kaukonen KM, Bailey M, Suzuki S, et al: Mortality Related to Severe Sepsis and Septic Shock Among Critically Ill Patients in Australia and New Zealand, 2000-2012. JAMA. 2014; 311 : 1308-16.

2) Dellinger RP, Levy MM, Rhodes A, et al: Surviving sepsis campaign: international guidelines for management of severe sepsis and septic shock: 2012. Intensive Care Med. 2013; 39: 165-228.

3) NHS England: Sepsis Guidance implementation advice for adults. 2017.

4) Sebat F, Musthafa AA, Johnson D, et al: Effect of a rapid response system for patients in shock on time to treatment and mortality during 5 years. Crit Care Med. 2007; 35: 2568-75.

5) Churpek MM, Snyder A, Han X, et al: Quick Sepsis-related 
Organ Failure Assessment, Systemic Inflammatory Response Syndrome, and Early Warning Scores for Detecting Clinical Deterioration in Infected Patients Outside the Intensive Care Unit. Am J Respir Crit Care Med. 2017; 195: 906-11.
CQ21-3 : 初期輸液蘇生に不応の敗血症はどこで 管理するか？

Answer : 初期輸液蘇生に不応の敗血症は集中治療が できる場所で管理する（Good Practice Statement）。

\section{（1）背景および本 $C Q$ の重要度}

敗血症はどの診療科, 医療施設でも遭遇しうる頻度 の高い病態であり，様々な医療者が診療に携わる。患 者が重症化した場合は高度な集中治療が必要となる が, 敗血症の症状や重症度の幅は広く，その線引きは 容易ではない。我が国では欧米に比べて集中治療医も 集中治療病床数も少ないことが指摘されており 1,2$)$, 一般病床で昇圧薬管理や人工呼吸管理などの重症患者 管理が行われる例もある。適切な医療資源が提供され ることにより, 患者の生命予後, 機能予後を改善する 可能性があることを鑑み，本 CQ を取り上げた。

\section{（2）解説}

敗血症は罹患率の高い疾患であるがゆえに, 集中治 療を専門としていない医療者も治療にあたる必要があ る。一般病床でも治療可能な軽症例もあるが, 重症化 するとケアレベルの高い病床への移動が必要になり, 患者の重症度を評価して適切な病床を選択する必要が ある。診療に必要な医療資源（相応の診療スキルを備 えたスタッフの人的配置や，モニタリング，人工呼吸 器を含む機器など）が十分に提供できない環境では, 患者の予後に悪影響が及ぶことが懸念される。適切な 病床選択は, 各施設の機能, 規模, 病床使用状況に よって異なる相対的なものとなるため, 一概に重症度 と適切な病床区分を対応させることはできない3）が, 必要な集中治療を適切に提供するために, 委員会では 本 $\mathrm{CQ}$ を GPS として推奨するに至った。なお, 院外 への搬送では移動中のリスク・距離・方法なども勘案 する必要がある。

本推奨は初期輸液蘇生に不応の患者を対象とした が，対象を選定するうえで質の高いエビデンスは見当 たらなかった。米国集中治療医学会の ICU admission, discharge, and triage guidelines（ADT ガイドライン）で は, 集中治療室入室の推奨度 $2 \mathrm{C}$ (弱い推奨, 低いエ ビデンスレベル）の例として生命の危険がある敗血症 を挙げている4)。本ガイドラインは集中治療室がない 環境で診療している一般診療医療者も対象としている こと, 敗血症の表現型が多様であるため可能な限りシ ンプルな基準でなければ実用性がないことを考慮し て,「初期輸液蘇生に不応の場合」を集中治療が可能 
な場所へ搬送を検討する基準とした。敗血症性ショッ クを想定したが，定義上必要となる乳酸值測定ができ ない施設も多い状況も考慮した。また,「不応」は曖 昧な表現であるが，各施設が持っている医療資源に応 じて幅が必要であると判断して推奨文に使用した。不 応という範疇には, 持続性低血圧, 意識障害の遷延, 呼吸状態の悪化, 乳酸クリアランス不良などが含まれ る。ただし, 重症度のみならず, 必要となる医療資源 や回復の見込みなどを総合的に判断することが重要で ある4)。

また, 小児の敗血症管理では, 各種の診療アルゴリ ズムにおいて, 初期輸液蘇生に不応と判断された時点 で気管挿管・人工呼吸管理の開始や, 中心静脈ライン を確保して循環作動薬の導入を考慮することが示唆さ れている 5,6$)$ 。敗血症は多くの臟器系に機能障害を来 す致死率の高い病態であり，本ガイドラインの小児章 においても同様の診療アルゴリズムを提示したよう に,「初期輸液蘇生に不応」という目安をもって集中 治療管理への移行を判断するのは妥当であろう。すな わち, 院内の集中治療が可能な病床へ患者を転床する なり, 重症小児の管理に長けた集中治療室が近隣に存 在するのであれば，そこへの院外搬送を検討する。敗 血症に限らず，重症小児患者の診療成績に関しては患 者数の増加と良好な治療成績の関連が知られてい る7-10)。また，重症小児患者を搬送するスキルと装備 を備えたチームが従事すれば, 生命予後は悪化しない とも報告されており ${ }^{11-13)}$, 病院間搬送の適否や手段 を検討する際に考虑されたい。

集中治療室での治療のメリットについてのエビデン スは観察研究に限られる。敗血症に限らない患者で は, 集中治療室満床により 1 時間入室が遅れるごとに 集中治療室死亡の調整リスク比（RR）が 1.015 多い (95\% CI: 1.006 多い〜1.023多い), 一般病棟での病状 悪化から集中治療室チームへの相談が遅れた群（> 7.7 時間) は遅れない群（<1 時間）に比べ 30 日死亡 率が上昇し［調整オッズ比（OR） 1.8 多い $(95 \%$ CI: 1.1 多い〜 1.9 多い)], EWS で重症と判定されてから 集中治療室への移送が 6 時間以上かかると院内死亡率 が上昇（33.2\% vs. $24.5 \%, P<0.001 ） し ， 1$ 時間ごと に院内死亡の OR が $3 \%$ 上昇する，などといった報告 が散見される 14-20)。この領域ではランダム化比較試 験（RCT）が実質的に不可能であり, 現時点のエビデ ンスにより ADT ガイドラインでも重症患者を集中治 療室で管理することのコンセンサスが得られてい る4)。敗血症に関してはさらに限定的になるが, 重症 敗血症/敗血症性ショックにおいて来院から集中治療
室入室までの時間が 1 時間遅れるごとに死亡の調整 ORが 1.11 上昇（95\% CI: 1.006 多い〜1.017多い）す ると報告されている211。

「集中治療ができる場所」の条件, 特に集中治療医 の関わり方について委員会で議論されたが, 患者因子 と環境因子の相対的なもので明文化することはむずか しい。本邦の特定集中治療室管理料, 小览特定集中治 療室管理料, 救命救急入院料の要件などは, 1 つの基 準となりうる。集中治療医の関わりについては，シス テマティックレビューで high intensity モデル（集中治 療医が決定権を持つ closed ICU，ないし全症例で集中 治療医へのコンサルトが必須）で low intensity モデル （各科が独自に管理する open ICU または集中治療医が 不在）に比べ，院内死亡の低下（RR 0.83,95\% CI: 0.70 多い 0.99 多い), 入院期間の短縮（加重平均の 差 0.17 日少ない, $95 \%$ CI: 0.31 日少ない 0.03 日多い) が報告されている22, 23)。ただし，集中治療医の介入 と院内死亡率の上昇の関連を指摘する報告もあり, 集 中治療医による過剩な検查や手技, 患者情報の不十分 な申し送りによる集中治療医の治療の質低下のリスク などが指摘されている24)。また, high intensity モデル の効果は, 集中治療室の専門性, 地域, 研究された年 代で差が見られる ${ }^{23)}$ 。敗血症に関してのデータは極 めて限定的だが, 本邦の多施設研究 (FORECAST) では closed ICU のほうが 3 時間バンドルの遵守率が 高い（調整 OR: 2.84 多い, 95\% CI: 1.28 多い〜6.28 多 い）と報告されている ${ }^{25) 。 ~}$

\section{文 献}

1）橋本悟: わが国の集中治療医学の現況とこれからの課題一 新専門医制度をふまえて一. ICU と CCU. 2013; 37: 113-8.

2）内野滋彦: わが国の集中治療室は適正利用されているのか. 日集中医誌. 2010; 17: 141-4.

3) Marshall JC, Bosco L, Adhikari NK, et al: What is an intensive care unit? A report of the task force of the World Federation of Societies of Intensive and Critical Care Medicine. J Crit Care. 2017; 37: 270-6.

4) Nates JL, Nunnally M, Kleinpell R, et al: ICU Admission, Discharge, and Triage Guidelines: A Framework to Enhance Clinical Operations, Development of Institutional Policies, and Further Research. Crit Care Med. 2016; 44: 1553-602.

5) Dellinger RP, Levy MM, Rhodes A, et al: Surviving Sepsis Campaign: International Guidelines for Management of Severe Sepsis and Septic Shock, 2012. Intensive Care Med. 2013; 39: 165-228.

6) Davis AL, Carcillo JA, Aneja RK, et al: The American College of Critical Care Medicine Clinical Practice Parameters for Hemodynamic Support of Pediatric and Neonatal Septic Shock: Executive Summary. Pediatr Crit Care Med. 2017; 18: 884-90.

7) Tilford JM, Simpson PM, Green JW, et al: Volume-outcome relationships in pediatric intensive care units. Pediatrics. 2000; 106: 289-94.

8) Marcin JP, Song J, Leigh JP: The impact of pediatric intensive 
care unit volume on mortality: A hierarchical instrumental variable analysis. Pediatr Crit Care Med. 2005; 6: 136-41.

9) Pearson G, Shann F, Barry P, et al: Should paediatric intensive care be centralised? Trent versus Victoria. Lancet. 1997; 346: 1213-7.

10) Markovitz BP, Kukuyeva I, Soto-Campos G, et al: PICU Volume and Outcome: A Severity-Adjusted Analysis. Pediatr Crit Care Med. 2016; 17: 483-9.

11) Ramnarayan P, Thiru K, Parslow RC, et al: Effect of specialist retrieval teams on outcomes in children admitted to paediatric intensive care units in England and Wales: A retrospective cohort study. Lancet. 2010; 376: 698-704.

12) Moynihan K, McSharry B, Reed P, et al: Impact of Retrieval, Distance Traveled, and Referral Center on Outcomes in Unplanned Admissions to a National PICU. Pediatr Crit Care Med. 2016; 17: e34-42.

13) Hamrin TH, Berner J, Eksborg S, et al: Characteristics and outcomes of critically ill children following emergency transport by a specialist paediatric transport team. Acta Paediatr. 2016; 105 : 1329-34.

14) Mardini L, Lipes J, Jayaraman D: Adverse outcomes associated with delayed intensive care consultation in medical and surgical inpatients. J Crit Care. 2012; 27: 688-93.

15) Hersch M, Sonnenblick M, Karlic A, et al: Mechanical ventilation of patients hospitalized in medical wards vs the intensive care unit--an observational, comparative study. J Crit Care. 2007; 22 13-7.

16) Young MP, Gooder VJ, McBride K, et al: Inpatient transfers to the intensive care unit: delays are associated with increased mortality and morbidity. J Gen Intern Med. 2003; 18: 77-83.

17) Chalfin DB, Trzeciak S, Likourezos A, et al: Impact of delayed transfer of critically ill patients from the emergency department to the intensive care unit. Crit Care Med. 2007; 35: 1477-83.

18) Churpek MM, Wendlandt B, Zadravecz FJ, et al: Association between intensive care unit transfer delay and hospital mortality: A multicenter investigation. J Hosp Med. 2016; 11: 757-62.

19) Cardoso LT, Grion CM, Matsuo T, et al: Impact of delayed admission to intensive care units on mortality of critically ill patients: a cohort study. Crit Care. 2011; 15: R28.

20) Robert R, Reignier J, Tournoux-Facon C, et al: Refusal of intensive care unit admission due to a full unit: impact on mortality. Am J Respir Crit Care Med. 2012; 185: 1081-7.

21) Li Q, Wang J, Liu G, et al: Prompt admission to intensive care is associated with improved survival in patients with severe sepsis and/or septic shock. J Int Med Res. 2018; 46: 4071-81.

22) Pronovost PJ, Angus DC, Dorman T, et al: Physician Staffing Patterns and Clinical Outcomes in Critically Ill Patients: A Systematic Review. JAMA. 2002; 288: 2151-62.

23) Wilcox ME, Chong CA, Niven DJ, et al: Do intensivist staffing patterns influence hospital mortality following ICU admission? A systematic review and meta-analyses. Crit Care Med. 2013; 41: 2253-74.

24) Levy MM, Rapoport J, Lemeshow S, et al: Association between critical care physician management and patient mortality in the intensive care unit. Ann Intern Med. 2008; 148: 801-9.

25) Abe T, Ogura H, Shiraishi A, et al: Characteristics, management, and in-hospital mortality among patients with severe sepsis in intensive care units in Japan: the FORECAST study. Crit Care. 2018; 22: 322 .
CQ21-4：敗血症初期診療の質評価指標（quality indicator）は何か?

Answer: 敗血症初期診療の質評価指標（quality indicator）として, 血液培養の採取, 乳酸值の測定, 早期抗菌薬投与，初期輸液蘇生，反復した血管内容量 と心機能の評価などの各項目の実施率がある（BQに 対する情報提示)。

\section{（1）背景および本 $C Q$ の重要度}

敗血症初期診療においては，早期発見と早期治療介 入が重要である。そのため, 敗血症に対する治療が適 切に実施されているかどうかを, 早期発見と早期治療 介入の観点から評価する必要がある。敗血症初期診療 における質評価指標（quality indicator: QI）を明らか にするために本 CQ を取り上げた。

\section{（2）解説}

診療の質を改善するためには, 適切な診療プロセス や望ましいアウトカムによって構成される診療の QI を 用いて評価することが重要である。敗血症の従来の初 期診療では, 敗血症をより早期に発見し, early goaldirected therapy（EGDT）プロトコルに従った治療を進 めることが有効と考えられ, 過去のガイドラインでも 推奨されてきた1)。しかし，2014年に報告された ProCESS trial などでEGDT プロトコルでは予後が改善 しないことが確認された 2-4)。その結果を重視し，2015 年に米国連邦政府の保健福祉省 (Department of Health and Human Services: HHS）内にあるメディケア・メディ ケイドサービスセンター（Centers for Medicare \& Medicaid Services: CMS) は, hospital inpatient quality reporting program (IQRP) において, severe sepsis and septic shock early management bundle (SEP-1) を敗血症 診療における QI として取り上げた ${ }^{5)}$ 。以降, 従来のよ うなプロトコルによる治療戦略ではなく, 治療バンド ルの達成を進めるという戦略に変更されている。した がって，バンドルとして取り上げられる各項目は，敗 血症における治療の質をモニタリングする点からも重 要である。SEP-1 の QI はは 6 項目あり，敗血症発症か ら 3 時間以内の (1)血液培養実施, (2)乳酸測定, (3)適切 な抗菌薬投与，そして敗血症性ショックの場合は(4) $30 \mathrm{~mL} / \mathrm{kg}$ の輸液蘇生, さらに初期乳酸值が $2.0 \mathrm{mmol} / \mathrm{L}$ を超える場合は 6 時間以内において (5)乳酸值の反復測 定，低血圧が遷延する場合の6血管作動薬の使用であ る6)。また, SEP-1には入っていないが, 敗血症性 ショックの初期対応では輸液だけでなく，超音波検査 
などによる血管内容量と心機能の評価も必要な可能性 がある 7)

近年の報告では，抗菌薬投与をより早い 1 時間以内

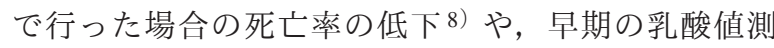
定が早期治療介入を促して患者の予後改善につながる 可能性も指摘されている9)。しかし，SEP-1の各項目 の達成度と敗血症の予後について調査した報告では, 3 時間以内の広域抗菌薬投与 10) 以外の QI に関しては, 治療効果改善の根拠に乏しいとされている11)。また, 早期の抗菌薬投与に関しても, 適切な抗菌薬か否かの 検証も今後必要である12)。以上のように，国際的に も未だ適切な QI は明らかになっていないのが現状で ある。本邦においては敗血症診療に特化した QI の設 定とその評価は十分に行われておらず，今後の課題と いえる。

\section{文 献}

1) Dellinger RP, Levy MM, Rhodes A, et al: Surviving sepsis campaign: International guidelines for management of severe sepsis and septic shock, 2012. Intensive Care Med. 2013; 39: 165-228.

2) Yealy DM, Kellum JA, Huang DT, et al: A randomized trial of protocol-based care for early septic shock. N Engl J Med. 2014; 370: 1683-93

3) Peake SL, Delaney A, Bailey M, et al: Goal-directed resuscitation for patients with early septic shock. N Engl J Med. 2014; 371: 1496-506.

4) Mouncey PR, Osborn TM, Power GS, et al: Trial of early, goaldirected resuscitation for septic shock. N Engl J Med. 2015; 372: 1301-11.

5) Faust JS, Weingart SD: The Past, Present, and Future of the Centers for Medicare and Medicaid Services Quality Measure SEP-1: The Early Management Bundle for Severe Sepsis/Septic Shock. Emerg Med Clin North Am. 2017; 35: 219-31.

6) The Joint Commission: Chart Abstracted Measures. Available online at: https://www.sepsiscoordinatornetwork.org/wp-content/ uploads/2018/05/Sepsis-Alliance-SEP-1-Core-Measure.pdf Accessed September 1, 2020.

7) Marik P, Bellomo R: A rational approach to fluid therapy in sepsis. Br J Anaesth. 2016; 116: 339-49.

8) Levy MM, Evans LE, Rhodes A: The surviving sepsis campaign bundle: 2018 update. Crit Care Med. 2018; 46: 997-1000.

9) Han X, Edelson DP, Snyder A, et al: Implications of Centers for Medicare \& Medicaid Services Severe Sepsis and Septic Shock Early Management Bundle and Initial Lactate Measurement on the Management of Sepsis. Chest. 2018; 154: 302-8.

10) Seymour CW, Gesten F, Prescott HC, et al: Time to treatment and mortality during mandated emergency care for sepsis. N Engl J Med. 2017; 376: 2235-44

11) Marik PE, Farkas JD, Spiegel R, et al: POINT: Should the Surviving Sepsis Campaign Guidelines be Retired? Yes. Chest. 2019; 155: 12-4.

12) Septimus EJ, Coopersmith CM, Whittle J, et al: Sepsis National Hospital Inpatient Quality Measure (SEP-1): Multistakeholder Work Group Recommendations for Appropriate Antibiotics for the Treatment of Sepsis. Clin Infect Dis. 2017; 65: 1565-9.
CQ21-5：敗血症の啓発活動にはどのようなもの があるか？

Answer : Global Sepsis Alliance と世界保健機関(WHO) を中心に，一般市民向けの「世界敗血症デー」のイベ ントや医療従事者向けのセミナーなどが行われている (BQに対する情報提示)。

\section{（1）背景および本 $C Q$ の重要度}

敗血症診療ガイドラインを医療従事者や一般市民へ 伝えることは，ガイドラインの作成と並ぶ重要な課題 である。敗血症の知識を医療従事者や一般市民へ伝え る啓発活動がどのように行われているのかを本ガイド ラインの利用者が知ることは, 本ガイドラインと敗血 症の知識のさらなる普及につながると考え, CQ とし て取り上げた。

\section{（2）解説}

2002 年から始まった Surviving Sepsis Campaign は, 2004 年以降の SSCG を通して敗血症の概念や標準治 療を世界に広めているが，ガイドラインだけでは敗血 症の予防や早期発見には至らず，敗血症と気づかれな いまま，多くの人々が命を落としていることが課題と されていた。2010 年に敗血症の概念と予防・早期発 見について，医療従事者だけでなく一般市民にも広く 伝えることを目的として, ヨーロッパを中心に「Global Sepsis Alliance: GSA（世界敗血症連盟) 1)」が結成さ れた。

GSA では「Stop sepsis, Save lives!」のスローガンの もと，2020 年までの 5 つの目標，(1)敗血症の罹患率 を $20 \%$ 下げる，(2)敗血症の救命率を $10 \%$ 上げる, (3)医療従事者, 一般市民の敗血症の理解と認知度を高 める，(4)敗血症のリハビリテーションを世界中で普及 させる，(5)敗血症の予防と治療の効果を正確に評価す る，を掲げて啓発活動を行ってきた。SSCG が標準治 療の普及を目的とするのに対し，GSA では敗血症の 予防・早期発見から治療までを一般市民や集中治療室 以外の医療従事者にもわかりやすく伝えることを目的 としている。このため, GSA は 9 月 13 日を「世界敗 血症デー」と定め, この日に世界中で敗血症に関する イベントを開催してきた。GSA は世界保健機関(World Health Organization: WHO）にも協力を呼びかけ，2017 年には, WHOの総会において，敗血症が「世界的に 解決すべき緊急課題」として認定されている。

2020 年に GSA は 2030 年までの新たな 6 つの目標, (1)感染症予防により敗血症の発症を減らす，(2)各国が 
政策として感染制御の 3 本柱（感染予防，抗菌薬適正 使用支援，敗血症の早期認知と管理）に取り組む, (3)敗血症の早期発見と標準治療により子供から大人ま での生存率を改善させる, (4)世界中の人々が適切なリ ハビリテーションを受けられるようにする，(5)一般市 民から医療従事者まで, 敗血症の認知度を上げる, (6)敗血症による社会的負担と敗血症対策の評価を改善 する,を示した。今後, この新たな目標に向けて, WHO と共に各国へ感染症予防と敗血症の対策を呼び かけていくことになる。

日本集中治療医学会では, GSA 委員会が中心とな り，2013 年より「世界敗血症デー」に合わせた市民 公開イベントや医療従事者を対象とした「敗血症セミ ナー」を開催してきた。2018 年からは日本救急医学 会が GSA の活動に加わり，2019 年には日本感染症学 会も加わった 3 学会合同の「Japan Sepsis Alliance (JaSA)」へと発展している。JaSA では, 敗血症セミ ナーや市民公開講座，ホームページ「敗血症. com $^{2)} 」$ などを通して，医療従事者と市民へ敗血症診療ガイド ラインや敗血症の知識を伝える活動を行っている。

\section{文 献}

1) Global Sepsis Alliance. Available online at: https://www.globalsepsis-alliance.org/. Accessed August 31, 2020.

2）日本集中治療医学会, 日本救急医学会, 日本感染症学会: 敗 血症.com. Available online at: http://xn--ucvv97al2n.com/index. html. Accessed August 31, 2020. 


\section{CQ22 : ストレス潰瘍}

敗血症患者などの重症患者においては，ストレス潰 瘍に伴う上部消化管出血が問題となる。近年，全身管 理の質の向上に伴い, 上部消化管出血の発生率は 2 $5 \%$ まで低下してきた ${ }^{1)}$ 。しかし，上部消化管出血の 発生は死亡率の増加との関連が示唆されているた め 2), ストレス潰瘍の予防は重要である。その予防方 法として, 胃酸分泌抑制薬, 胃酸中和薬, 胃粘膜防御 因子増強薬といった抗潰瘍薬の投与がある。しかし, 抗潰瘍薬の投与により, 胃酸の $\mathrm{pH}$ の上昇に伴い胃内 の細菌叢に変化が起こり, 人工呼吸器関連肺炎の原因 となる病原菌の胃や気管, 気管支への定着が促進さ れ, 人工呼吸器関連肺炎の発症リスクが増加する可能 性がある3)。また，胃酸分泌抑制薬の中でもプロトン ポンプ阻害薬（PPI）では, Clostridioides difficile 感染 症のリスクが上昇する可能性もある3)。このように抗 潰瘍薬による予防にも益と害が存在するため, CQ22-1「敗血症患者に消化管出血の予防を目的とし た抗潰瘍薬の投与を行うか?」においてその検証を 行った。今回のシステマティックレビューでは, ヒス タミン $\mathrm{H}_{2}$ 受容体拮抗薬，PPI，スクラルファートが抗 潰瘍薬として含まれているが，そのいずれが優れてい るかについては検討を行っていない。このうちどれが 優れているかについては, ネットワークメタ解析にお いて, PPI が最も上部消化管出血の予防効果が高いと されているが, 肺炎のリスクを増加させる可能性も報 告されているので参考にされたい4)。

また，開始した抗潰瘍薬による予防をいつまで続け るべきかについても臨床上の重要な疑問である。そこ でBQ として CQ22-2「敗血症患者に対する抗潰瘍薬 の中止の判断はどのようにするか?」を策定した。こ の CQ では, 消化性潰瘍のリスクと抗潰瘍薬の必要性,
抗潰瘍薬の副作用, 経腸栄養と抗潰瘍薬との関係に着 目して情報提供を行った。

最後に, 抗潰瘍薬の予防投与はすべての患者で一律 に行われるべきものではない。SSCG 20165）や日本版 重症患者の栄養療法ガイドライン6) でも述べられて いるように, 出血リスクの少ない患者においては, 抗 潰瘍薬の予防投与は推奨されていない。CQ22-2 にお いて消化性潰瘍のリスク因子についても情報提供を 行っているので, 臨床の場で予防投与を行うべき患者 かを検討する際に, 役立てていただければ幸いであ る。

\section{文 献}

1) Zhou $X$, Fang H, Xu J, et al: Stress ulcer prophylaxis with proton pump inhibitors or histamine 2 receptor antagonists in critically ill adults - a meta-analysis of randomized controlled trials with trial sequential analysis. BMC Gastroenterol. 2019; 19: 193.

2) Krag M, Perner A, Wetterslev J, et al: Prevalence and outcome of gastrointestinal bleeding and use of acid suppressants in acutely ill adult intensive care patients. Intensive Care Med. 2015; 41: 833-45.

3) Toews I, George AT, Peter JV, et al: Interventions for preventing upper gastrointestinal bleeding in people admitted to intensive care units. Cochrane Database Syst Rev. 2018; 6: CD008687.

4) Alhazzani W, Alshamsi F, Belley-Cote E, et al: Efficacy and safety of stress ulcer prophylaxis in critically ill patients: a network meta-analysis of randomized trials. Intensive Care Med. 2018; 44: 1-11.

5) Rhodes A, Evans LE, Alhazzani W, et al: Surviving Sepsis Campaign: International Guidelines for Management of Sepsis and Septic Shock: 2016. Intensive Care Med. 2017; 43: 304-77.

6）日本集中治療医学会重症患者の栄養管理ガイドライン作成 委員会: 日本版重症患者の栄養療法ガイドライン. 日集中医 誌. 2016; 23: 185-281.

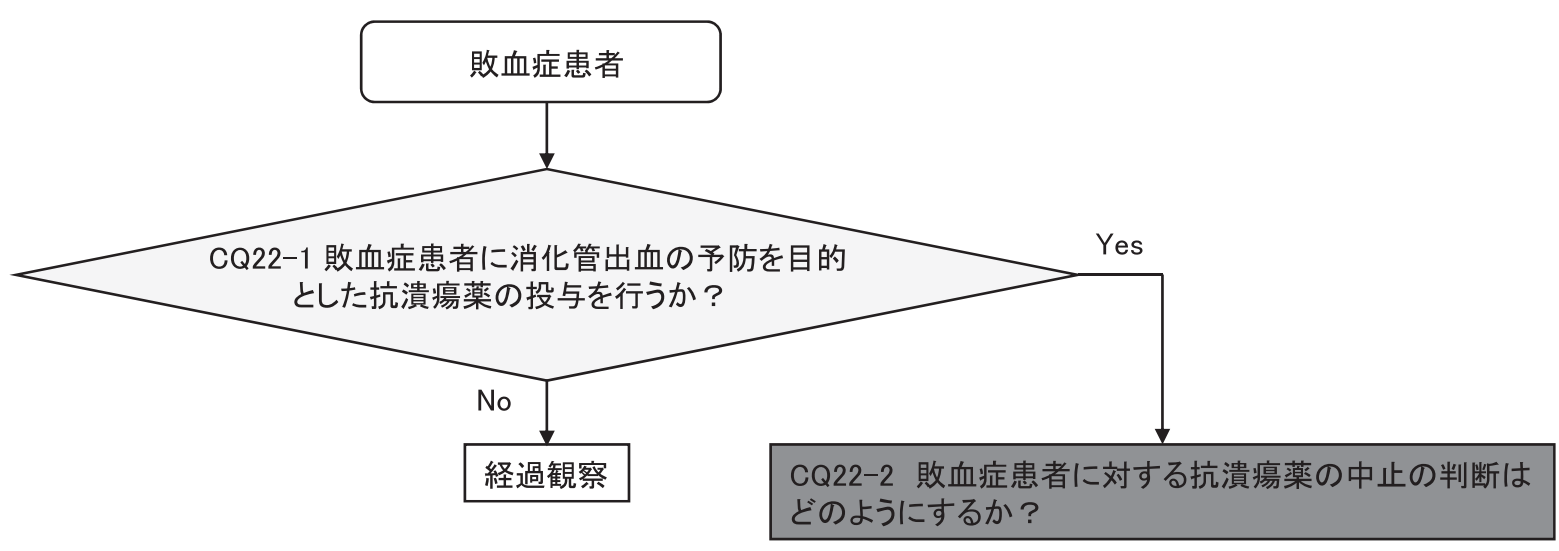

ストレス潰瘍〔診療フロー〕 
CQ22-1：敗血症患者に消化管出血の予防を目的 とした抗潰瘍薬の投与を行うか?

Answer : 敗血症患者に消化管出血の予防を目的とし た抗潰瘍薬の投与を行うことを弱く推奨する (GRADE 2B：エビデンスの確実性 $=\lceil$ 「」)。

\section{（1）背景および本 $C Q$ の重要度}

敗血症患者など重症患者では，侵襲に伴うストレス 潰瘍やそれに伴う出血を生じることがある。ストレス 潰瘍の予防として，ヒスタミン $\mathrm{H}_{2}$ 受容体拮抗薬，プ ロトンポンプ阻害薬（PPI），スクラルファートといっ た抗潰瘍薬が投与されるが，出血の予防という益があ る一方で, 肺炎, Clostridioides difficile 感染症の増加, 薬剂の副作用としての汎血球減少といった害も懸念さ れる。したがって，敗血症患者において，ストレス潰 瘍による出血の予防のために抗潰瘍薬を投与するかど うかを検証することは重要と考えられ，臨床課題とし て取り上げた。

(2) PICO

$$
\mathrm{P} \text { (患者) : 成人集中治療患者 }
$$

I (介入) : 抗潰瘍薬の投与

C (対照) : プラセボまたは抗潰瘍薬の非投与

$\mathrm{O}$ (アウトカム) : 消化管出血, 病院死亡・全死亡,
肺炎, Clostridioides difficile 感染症，あらゆる重 篤な副作用

（3）エビデンスの要約

システマティックレビューの結果，PICO に合致し たランダム化比較試験（RCT）が 30 編施行 1-30) され ており，これらを用いたメタ解析を実施した。アウト カムに関しては，事前設定に基づいて検索し得た全 RCT を対象としたもの，ならびにバイアスリスクが 低い RCT に限定したものの 2 通りを行った。エビデ ンスの確実性が高い解析を用いることと事前に設定し ていたため，バイアスリスクが低い RCT に限定した アウトカムを採用した。

（4）益と害のバランス（Table 22-1-1）

望ましい効果：

消化管出血に関する効果推定值は，リスク差（RD） 1,000 人あたり 44 人少ない $(95 \%$ CI: 54 人少ない〜 28 人少ない）（14 RCT，4,884 人）であり，死亡に関す る効果推定值は，RD 1,000 人あたり 3 人多い $(95 \%$ CI: 22 人少ない 33 人多い) (8 RCT，4,314人）であ る。介入による望ましい効果は「小さい」と考えられ る。

望ましくない効果：

肺炎に関する効果推定值は，RD 1,000 人あたり 4

Table 22-1-1エビデンスプロファイル

\begin{tabular}{|c|c|c|c|c|c|c|c|c|c|c|c|c|}
\hline \multicolumn{7}{|c|}{ 碓実性の評価 } & \multicolumn{2}{|c|}{ 患者数 } & \multicolumn{2}{|c|}{ 効果 } & \multirow[b]{2}{*}{ 碓実性 } & \multirow[b]{2}{*}{ 重要性 } \\
\hline 研究数 & $\begin{array}{l}\text { 研究 } \\
\text { デサン }\end{array}$ & $\begin{array}{l}\text { バイアス } \\
\text { のリスク }\end{array}$ & 非一貫性 & 非直接性 & 不精確性 & $\begin{array}{l}\text { その他 } \\
\text { の㮥討 }\end{array}$ & 抗清場薬 & プラセボ & $\begin{array}{l}\text { 相対指摽 } \\
(95 \% \text { cI }\end{array}$ & $\begin{array}{l}\text { 絶対指標 } \\
(95 \% \text { cI })\end{array}$ & & \\
\hline \multicolumn{13}{|c|}{ 消化管出血 } \\
\hline 28 & RCT & 深刻 a & 深刻 b.o & 深刻でない & 深刻でない & なし & $\begin{array}{c}202 / 3,530 \\
(5.7 \%)\end{array}$ & $\begin{array}{c}285 / 2,955 \\
(9.6 \%)\end{array}$ & $\begin{array}{l}\text { RR } 0.50 \\
\text { (0. } 37 \text { to } 0.68)\end{array}$ & $\begin{array}{l}\text { 1,000 人あたり } 48 \\
\text { 人少ない } 661 \text { 人少 } \\
\text { ない 31 人少ないい }\end{array}$ & $\underset{\text { 低 }}{\oplus \oplus \bigcirc}$ & 重大 \\
\hline \multicolumn{13}{|c|}{ 消化管出血 } \\
\hline 14 & RCT & 深刻でない & 深刻 ' & 深刻でない & 深刻でない & なし & $\begin{array}{c}81 / 2,558 \\
(3.2 \%)\end{array}$ & $\begin{array}{c}169 / 2,326 \\
(7.3 \%)\end{array}$ & $\begin{array}{c}\text { RR } 0.39 \\
\text { (0. } 25 \text { to } 0.62)\end{array}$ & $\begin{array}{l}\text { 1,000人あたり } 44 \\
\text { 人少ない } \\
\text { ない } 54 \text { 人少 } \\
\text { (1) }\end{array}$ & $\underset{\text { 中 }}{\oplus \oplus \oplus \bigcirc}$ & 重大 \\
\hline \multicolumn{13}{|l|}{ 肺炎 } \\
\hline 8 & RCT & 深刻でない & 深刻でない & 深刻でない & 深刻でない & なし & $\begin{array}{c}328 / 2,244 \\
(14.6 \%)\end{array}$ & $\begin{array}{c}302 / 2,042 \\
(14.8 \%)\end{array}$ & $\begin{array}{c}\text { RR } 1.03 \\
\text { (0.89 to } 1.19)\end{array}$ & $\begin{array}{c}1 \text { 1.000 人あたり } 4 \text { 人 } \\
\text { 多い (16 人少ない } \\
\text { ２8人多い) }\end{array}$ & $\begin{array}{c}\oplus \oplus \oplus \oplus) \\
\text { 高 }\end{array}$ & 重大 \\
\hline \multicolumn{13}{|l|}{ 死亡 } \\
\hline 8 & RCT & 深刻でない & 深刻でない & 深刻でない & 深刻でない & なし & $\begin{array}{c}593 / 2,243 \\
(26.4 \%)\end{array}$ & $\begin{array}{c}562 / 2,071 \\
(27.1 \%)\end{array}$ & $\begin{array}{c}\text { RR } 1.01 \\
\text { (0.92 to } 1.12)\end{array}$ & $\begin{array}{c}1 \text { 1, 000 人あたり } 3 \text { 人 } \\
\text { 多い (22 人少ない } \\
\sim 33 \text { 人多い) }\end{array}$ & 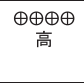 & 重大 \\
\hline \multicolumn{13}{|c|}{ 重篤な副作用 } \\
\hline 7 & RCT & 深刻でない & 深刻でない & 深刻でない & 深刻 d & なし & $\begin{array}{c}84 / 2,156 \\
(3.9 \%)\end{array}$ & $\begin{array}{c}72 / 1,987 \\
(3.6 \%)\end{array}$ & $\begin{array}{c}\text { RR } 1.13 \\
\text { (0.83 to } 1.54)\end{array}$ & $\begin{array}{l}1,000 \text { 人あたり } 5 \text { 人 } \\
\text { 多い (6人仦ない } \\
20 \text { 人多い) }\end{array}$ & $\begin{array}{c}\oplus \oplus \oplus \bigcirc \\
\text { 中 }\end{array}$ & 重大 \\
\hline \multicolumn{13}{|c|}{ Clostridioides difficile 感染症 } \\
\hline 3 & RCT & 深刻てない & 深刻でない & 深刻でない & 深刻 d & なし & $\begin{array}{c}21 / 1,807 \\
(1.2 \%)\end{array}$ & $\begin{array}{c}28 / 1,800 \\
(1.6 \%)\end{array}$ & $\begin{array}{c}\text { RR } 0.75 \\
\text { (0. } 42 \text { to } 1.31)\end{array}$ & $\begin{array}{l}1,000 \text { 人あたり } 4 \text { 人 } \\
\text { 少ない (9人少ない } \\
\sim 5 \text { 人多い) }\end{array}$ & $\begin{array}{c}\oplus \oplus \oplus \bigcirc \\
\text { 中 }\end{array}$ & 重大 \\
\hline
\end{tabular}

a. 深刻なバイアスのリスクの研究を含むため深刻と判断した。

b. 点推定值が各研究で異なり，信頼区間の重なりもあり， $\mathrm{I}^{2}$ 值も40\%を超えているため深刻と判断した。

c. 点推定値，信頼区間，かなり大きい I²值より非一貫性は高いが，PPI vs プラセボでは非一貫性を認めない。そのため介入の違いなどが影響を与えている可能性もあり，2段階ダウングレードはせず 深刻とした。

d. CIに益と害の可能性が含まれているため深刻と判断した。 
人多い $(95 \%$ CI: 16 人少ない〜 28 人多い) $(8 \mathrm{RCT}$, 4,286 人), Clostridioides difficile 感染症に関する効果 推定值は，RD 1,000 人あたり 4 人少ない $(95 \%$ CI: 9 人少ない〜 5 人多い)（3 RCT，3,607 人), あらゆる重 篤な副作用に関する効果推定值は，RD 1,000 人あた り 5 人多い $(95 \%$ CI: 6 人少ない 20人多い) (7 RCT，4,143 人）である。介入による望ましくない効 果はわずかであると考えられる。

益と害のバランス :

アウトカムの相対的価值を考慮しない場合でも，死 亡に関する相対的価値を考慮した場合においても利益 が害を上回っているため，おそらく介入が優位である と判断する。

\section{（5）アウトカム全般に関するエビデンスの確実性}

各アウトカムが益と害の異なる方向性を示してお り，重大なアウトカムに関するエビデンスの確実性の 中でも最も低いグレードを採用するため「中」とし た。

\section{（6）価值観}

抗潰瘍薬の投与におけるアウトカムに関する価值観 についてのデータはない。一般的に死亡や消化管出血 に対して置く相対的価值は高く，そのばらつきは少な いことが予想される。

\section{（7）容認性}

ヒスタミン $\mathrm{H}_{2}$ 受容体拮抗薬，PPI，スクラルファー トは 1 日の薬価が先発品で約 80〜850 円であり，容認
されると考えられる。また，本薬剤を 1～2 回/日，経 静脈あるいは経管（経口）投与する労力もわずかであ り，容認されると考えられる。

\section{（8）実行可能性}

一般的な薬剤であり，どの病院においても実行可能 性は高いといえる。

（9）判断の要約（Table 22-1-2）

（10）推奨グレーディング決定の工程

修正 RAND 法を用いた投票によって，中央値 8, 見解不一致指数 0.015 の結果となり，委員会で採択さ れた（7点以上：100\%）。

\section{（11）関連する他の診療ガイドラインにおける推奨}

SSCG 2016 ${ }^{31)}$ では，消化管出血のリスク因子を有 する敗血症または敗血症性ショック患者に対して，ス トレス潰瘍予防の実施が強く推奨されている。一方 で，消化管出血のリスク因子のない患者は，ストレス 潰瘍予防を行わないことを best practice statement とし て提示している。

\section{（12）実施に関わる検討事項}

いつまで抗潰瘍薬の投与を続けるかについては，各 症例ごとに考慮する必要がある。その判断にどのよう なものがあるかについては，CQ22-2に記載した。

Table 22-1-2 判断の要約

\begin{tabular}{|c|c|c|c|c|c|c|c|}
\hline & \multicolumn{7}{|c|}{ 判断 } \\
\hline 問題 & いいえ & $\begin{array}{c}\text { おそらく、いい } \\
\text { え }\end{array}$ & おそらく、はい & はい & & さまざま & 分からない \\
\hline 望ましい效果 & わずか & 小さい & 中 & 大きい & & さまざま & 分からない \\
\hline 望ましくない効果 & 大きい & 中 & 小さい & わずか & & さまざま & 分からない \\
\hline エビデンスの確実性 & 非常に低 & 低 & 中 & 高 & & & 採用研究なし \\
\hline 価値観 & $\begin{array}{c}\text { 重要な不確実性 } \\
\text { またはばらつき } \\
\text { あり }\end{array}$ & $\begin{array}{c}\text { 重要な不確実性 } \\
\text { またはばらつき } \\
\text { の可能性あり }\end{array}$ & $\begin{array}{l}\text { 重要な不確実性 } \\
\text { またはばらつき } \\
\text { はおそらくなし }\end{array}$ & $\begin{array}{c}\text { 重要な不確実性 } \\
\text { またはばらつき } \\
\text { はなし }\end{array}$ & & & \\
\hline 効果のパランス & 比較が優位 & $\begin{array}{c}\text { 比較がおそらく } \\
\text { 優位 }\end{array}$ & $\begin{array}{c}\text { 介入も比較もい } \\
\text { ずれも優位でな } \\
\text { い }\end{array}$ & $\begin{array}{c}\text { おそらく介入が } \\
\text { 優位 }\end{array}$ & 介入が優位 & さまざま & 分からない \\
\hline 容認性 & いいえ & $\begin{array}{c}\text { おそらく、いい } \\
\text { え }\end{array}$ & おそらく、はい & はい & & さまざま & 分からない \\
\hline 実行可能性 & いいえ & $\begin{array}{c}\text { おそらく、いい } \\
\text { え }\end{array}$ & おそらく、はい & はい & & さまざま & 分からない \\
\hline
\end{tabular}




\section{（13）今後の研究の可能性}

今後, 抗潰瘍薬の投与終了時期に関する研究が行わ れることが望まれる。

\section{文 献}

1) Selvanderan SP, Summers MJ, Finnis ME, et al: Pantoprazole or Placebo for Stress Ulcer Prophylaxis (POP-UP): Randomized Double-Blind Exploratory Study. Crit Care Med. 2016; 44: 1824-50.

2) Lin CC, Hsu YL, Chung CS, et al: Stress ulcer prophylaxis in patients being weaned from the ventilator in a respiratory care center: A randomized control trial. J Formos Med Assoc. 2016; 115: 19-24.

3) Kaushal S, Midha V, Sood A, et al: A comparative study of the effects of famotidine and sucralfate in prevention of upper gastrointestinal bleeding in patients of head injury. Indian J Pharmacol. 2000; 32: 246-9.

4) El-Kersh K, Jalil B, McClave SA, et al: Enteral nutrition as stress ulcer prophylaxis in critically ill patients: A randomized controlled exploratory study. J Crit Care. 2018; 43: 108-13.

5) Nourian A, Mohammadi M, Beigmohammadi MT, et al: Comparing efficacy of enteral nutrition plus ranitidine and enteral nutrition alone as stress ulcer prophylaxis. J Comp Eff Res. 2018; 7: 493-501

6) Groll A, Simon JB, Wigle RD, et al: Cimetidine prophylaxis for gastrointestinal bleeding in an intensive care unit. Gut. 1986; 27: 135-40.

7) Apte NM, Karnad DR, Medhekar TP, et al: Gastric colonization and pneumonia in intubated critically ill patients receiving stress ulcer prophylaxis: a randomized, controlled trial. Crit Care Med. 1992; 20: 590-3.

8) van den Berg B, van Blankenstein M: Prevention of stress-induced upper gastrointestinal bleeding by cimetidine in patients on assisted ventilation. Digestion. 1985; 31: 1-8.

9) Zinner MJ, Zuidema GD, Smith PL, et al: The prevention of upper gastrointestinal tract bleeding in patients in an intensive care unit. Surg Gynecol Obstet. 1981; 153: 214-20.

10) Hanisch EW, Encke A, Naujoks F, et al: A randomized, doubleblind trial for stress ulcer prophylaxis shows no evidence of increased pneumonia. Am J Surg. 1998; 176: 453-7.

11) Burgess P, Larson GM, Davidson P, et al: Effect of ranitidine on intragastric $\mathrm{pH}$ and stress-related upper gastrointestinal bleeding in patients with severe head injury. Dig Dis Sci. 1995; 40: 645-50.

12) Hastings PR, Skillman JJ, Bushnell LS, et al: Antacid titration in the prevention of acute gastrointestinal bleeding: a controlled, randomized trial in 100 critically ill patients. N Engl J Med. 1978; 298: 1041-5.

13) Metz CA, Livingston DH, Smith JS, et al: Impact of multiple risk factors and ranitidine prophylaxis on the development of stressrelated upper gastrointestinal bleeding: a prospective, multicenter, double-blind, randomized trial. Crit Care Med. 1993; 21: 1844-9.

14) Cloud ML, Offen W: Continuous infusions of nizatidine are safe and effective in the treatment of intensive care unit patients at risk for stress gastritis. The Nizatidine Intensive Care Unit Group. Scand J Gastroenterol Suppl. 1994; 206: 29-34.

15) Karlstadt RG, Iberti TJ, Silverstein J, et al: Comparison of Cimetidine and Placebo for the Prophylaxis of Upper Gastrointestinal Bleeding Due to Stress-related Gastric Mucosal Damage in the Intensive Care Unit. J Intensive Care Med. 1990; 5: 26-32.

16) Halloran LG, Zfass AM, Gayle WE, et al: Prevention of acute gastrointestinal complications after severe head injury: a controlled trial of cimetidine prophylaxis. Am J Surg. 1980; 139: 44-8.
17) Rixen D, Livingston DH, Loder P: Ranitidine improves lymphocyte function after severe head injury: Results of a randomized, double-blind study. Crit Care Med. 1996; 24: 1787-92.

18) Ben-Menachem T, Fogel R, Patel RV, et al: Prophylaxis for stressrelated gastric hemorrhage in the medical intensive care unit. A randomized, controlled, single-blind study. Ann Intern Med. 1994; 121: 568-75.

19) Martin LF, Booth FV, Karlstadt RG, et al: Continuous intravenous cimetidine decreases stress-related upper gastrointestinal hemorrhage without promoting pneumonia. Crit Care Med. 1993; 21: 19-30.

20) Reusser P, Gyr K, Scheidegger D, et al: Prospective endoscopic study of stress erosions and ulcers in critically ill neurosurgical patients: Current incidence and effect of acid-reducing prophylaxis. Crit Care Med. 1990; 18: 270-4.

21) Eddleston JM, Pearson RC, Holland J, et al: Prospective endoscopic study of stress erosions and ulcers in critically ill adult patients treated with either sucralfate or placebo. Crit Care Med. 1994; 22: 1949-54.

22) Krag M, Marker S, Perner A, et al: Pantoprazole in patients at risk for gastrointestinal bleeding in the ICU. N Engl J Med. 2018; 379 : 2199-208.

23) Ruiz-Santana S, Ortiz E, Gonzalez B, et al: Stress-induced gastroduodenal lesions and total parenteral nutrition in critically ill patients: frequency, complications, and the value of prophylactic treatment. A prospective, randomized study. Crit Care Med. 1991; 19: 887-91.

24) Chan KH, Lai EC, Tuen H, et al: Prospective double-blind placebo-controlled randomized trial on the use of ranitidine in preventing postoperative gastroduodenal complications in highrisk neurosurgical patients. J Neurosurg. 1995; 82: 413-7.

25) Powell H, Morgan M, Li SK, et al: Inhibition of gastric acid secretion in the intensive care unit after coronary artery bypass graft. A pilot control study of intravenous omeprazole by bolus and infusion, ranitidine and placebo. Theor Surg. 1993; 8: 125-30.

26) Darlong V, Jayalakhsmi TS, Kaul HL, et al: Stress ulcer prophylaxis in patients on ventilator. Trop Gastroenterol. 2003; 24: 124-8.

27) Basso N, Bagarani M, Materia A, et al: Cimetidine and antacid prophylaxis of acute upper gastrointestinal bleeding in high risk patients. Controlled, randomized trial. Am J Surg. 1981; 141: $339-41$.

28) Kantorova I, Svoboda P, Scheer P, et al: Stress ulcer prophylaxis in critically ill patients: a randomized controlled trial. Hepatogastroenterology. 2004; 51:757-61.

29) Pinilla JC, Oleniuk FH, Reed D, et al: Does antacid prophylaxis prevent upper gastrointestinal bleeding in critically ill patients? Crit Care Med. 1985; 13: 646-50.

30）大塚敏文, 八木義弘, 島崎修次, 他: 脳血管障害, 頭部外傷に よる胃酸分泌充進に対するファモチジン（F）注の抑制効 果の検討 プラセボを対照とした二重盲検比較試験. 診療と 新薬. 1991; 28: 1-12.

31) Rhodes A, Evans LE, Alhazzani W, et al: Surviving Sepsis Campaign: International Guidelines for Management of Sepsis and Septic Shock: 2016. Intensive Care Med. 2017; 43: 304-77. 


\section{CQ22-2：敗血症患者に対する抗潰瘍薬の中止の} 判断はどのようにするか?

Answer : 抗潰瘍薬中止の具体的な判断基準は不明で ある。臨床上の判断材料として, 出血りスク因子が軽 減した場合，汎血球減少や肝機能異常などの副作用を 認めた場合，十分な経腸栄養が投与可能となった場合 などが挙げられる（BQに対する情報提示）。

\section{（1）背景および本 $C Q$ の重要度}

抗潰瘍薬投与により胃内 $\mathrm{pH}$ が上昇し, 消化管内の細 菌叢に変化が生じることなどから, 肺炎やClostridioides difficile 感染症のリスクが上昇することが報告されてい る1-3)。したがって，抗潰瘍薬を漫然と継続することは 避けるべきであり，コストの面も考慮し ${ }^{3)}$ ，不要と判 断した場合は速やかに中止することが望ましい。しか し，現時点で，抗潰瘍薬中止の具体的な判断基準は不 明であり，その背景知識について解説する本 $\mathrm{CQ}$ の重 要度は高い。

\section{（2）解説}

１）消化性潰瘍のリスクと抗潰瘍薬の必要性

生体にストレスが加わることによって消化性潰瘍が 生じる。敗血症などの侵襲に伴って血小板減少や DIC など，止血凝固機能障害を伴うことも多く，潰瘍が形 成されると出血を生じるリスクが高まる。消化管出血 のリスク因子を Table 22-2-1 に示す4)。病態が改善し て回復期に入った場合，潰瘍形成のリスクが低減した 場合, 止血凝固機能障害が改善して出血のリスク因子 が軽減した場合が，抗潰瘍薬の投与中止の一つの臨床 上の判断材料になるかもしれない。一方で，ステロイ ドや非ステロイド性抗炎症薬（NSAIDs）など，潰瘍 形成の副作用のある薬剤を投与している場合，抗凝固 薬・抗血小板薬を投与している場合，潰瘍の既往のあ る場合，胃・十二指腸の血流障害が懸念される場合な どは，抗潰瘍薬の中止は慎重に判断すべきであろう5)。

Table 22-2-1 消化管出血のリスク因子 4)

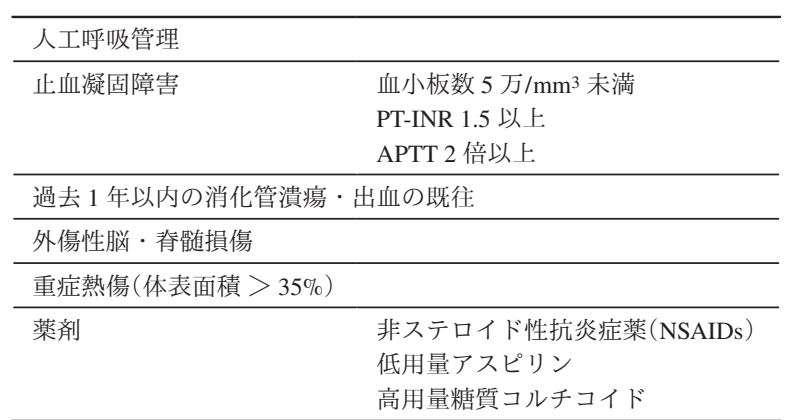

(2)抗潰瘍薬の副作用

抗潰瘍薬のうち，プロトンポンプ阻害薬（PPI）や ヒスタミン $\mathrm{H}_{2}$ 受容体拮抗薬などの薬剤の副作用とし て, 汎血球減少や肝機能異常などが臨床的に問題とな る 2, 6)。重症患者では同様の症状を呈する他の要因も 存在するため鑑別を要する。PPI やヒスタミン $\mathrm{H}_{2}$ 受 容体拮抗薬が原因と考えられる場合は，薬剤投与の中 止によって比較的速やかに回復することが多く，薬剤 の中止から平均 7 日で回復したとの報告もある 6)。こ のように，薬剂の副作用を認めた場合も中止の判断材 料となるだろう。抗潰瘍薬による副作用が生じても, 消化性潰瘍のリスクが高いと判断される場合には，別 の系統の薬剤に変更 $\left(\mathrm{PPI} \rightarrow\right.$ ヒスタミン $\mathrm{H}_{2}$ 受容体拮 抗薬など）し，リスクが低いと判断される場合には副 作用が比較的少ない薬剂（胃粘膜保護剂など）に変更 するなどの対応が必要である。

(3)経腸栄養と抗潰瘍薬との関係

胃内 $\mathrm{pH}$ は空腹時に低下し，食事摄取後に上昇する。 敗血症などの重症患者では様々なストレスに加えて, 絶食に伴って胃内 $\mathrm{pH}$ が上昇しなくなることが消化性 潰瘍形成の一因になると考えられる。したがって，絶 食中や経胃投与での経腸栄養投与量が少量にとどまっ ている時期には胃内 $\mathrm{pH}$ が上昇しにくいため，抗潰瘍 薬の投与は理にかなっている。食事と同様に胃内投与 の経腸栄養にも胃酸を緩衝する効果があり，重症患者 では経腸栄養剤の持続投与がヒスタミン $\mathrm{H}_{2}$ 受容体拮 抗薬やPPI よりも $\mathrm{pH}$ を上昇させる可能性も報告され ている3)。このことから，十分な経腸栄養が経胃投与 できていれば胃内 $\mathrm{pH}$ の上昇が見込まれるため，抗潰 瘍薬の中止の判断材料になるだろう。実際，ICU 患者 において，経腸栄養のみと経腸栄養に抗潰揚薬を併用 した場合の消化管出血の割合に有意差はなく，むしろ 抗潰瘍薬を併用した群で肺炎の危険性が有意に高いこ とが最近のメタ解析で報告されている1)。一方で，経 腸栄養を経空腸投与する場合には，栄養剤による胃内 $\mathrm{pH}$ の上昇は生じにくいと考えられるため，抗潰瘍薬 の投与が必要となる可能性はあるが，明らかなエビデ ンスはない。

\section{文 献}

1) Huang HB, Jiang W, Wang CY, et al: Stress ulcer prophylaxis in intensive care unit patients receiving enteral nutrition: A systematic review and meta-analysis. Crit Care. 2018; 22: 1-9.

2) Barletta JF, Bruno JJ, Buckley MS, et al: Stress ulcer prophylaxis. Crit Care Med. 2016; 44: 1395-405.

3) Plummer MP, Blaser AR, Deane AM: Stress ulceration: Prevalence, pathology and association with adverse outcomes. 
Crit Care. 2014; 18: 213.

4）日本集中治療医学会重症患者の栄養管理ガイドライン作成 委員会: 日本版重症患者の栄養療法ガイドライン: 病態別栄 養療法. 日集中医誌. 2017; 24: 569-91.

5) Buendgens L, Koch A, Tacke F: Prevention of stress-related ulcer bleeding at the intensive care unit: Risks and benefits of stress ulcer prophylaxis. World J Crit Care Med. 2016; 5: 57-64.

6) Priziola JL, Smythe MA, Dager WE: Drug-induced thrombocytopenia in critically ill patients. Crit Care Med. 2010; 38(6 Suppl): S145-54. 

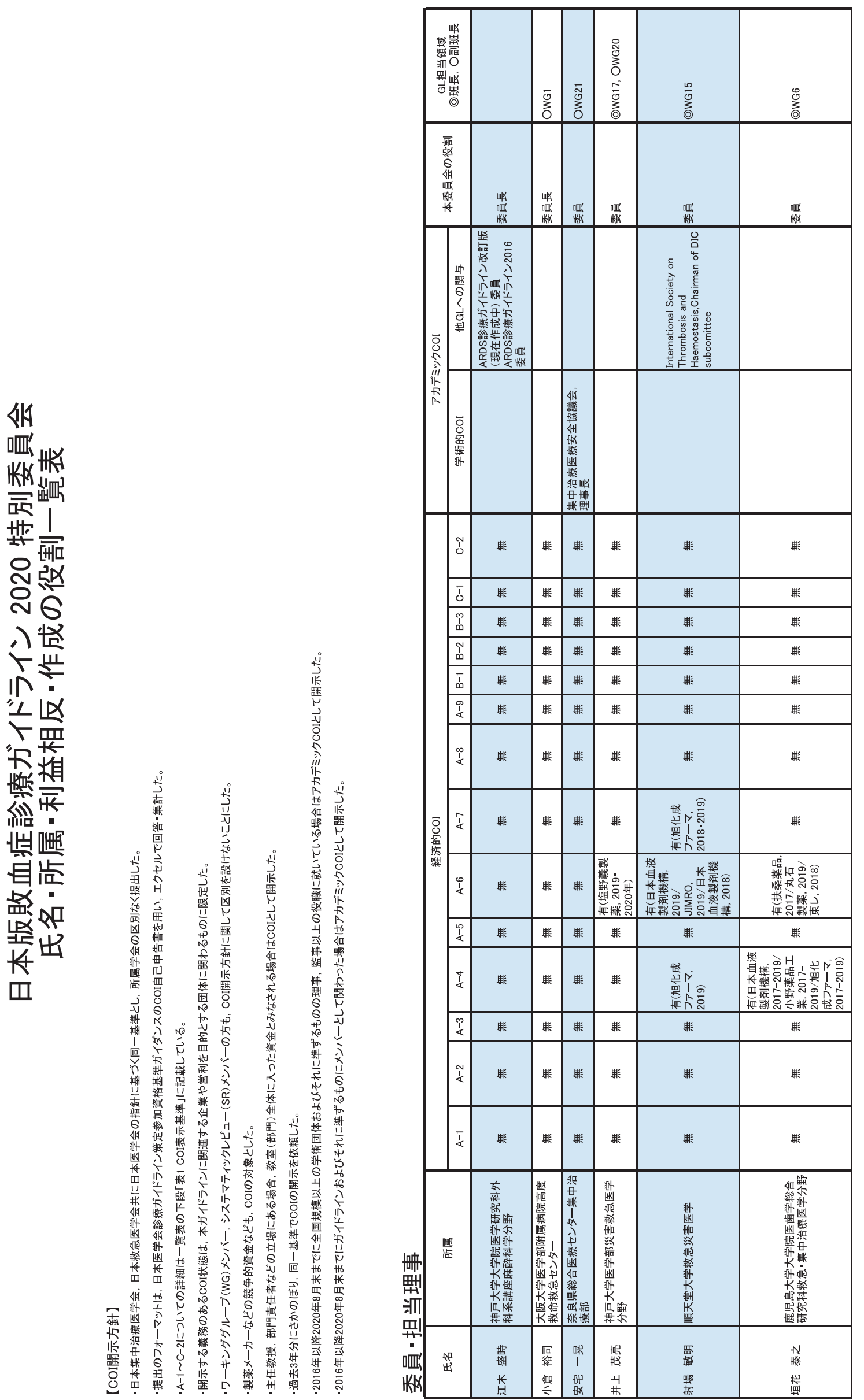


\begin{tabular}{|c|c|c|c|c|c|c|c|c|c|c|c|c|c|c|}
\hline 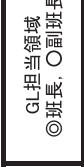 & $\begin{array}{l}\frac{\infty}{0} \\
\stackrel{0}{0} \\
\end{array}$ & 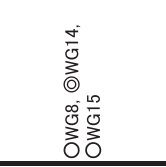 & $\begin{array}{l}\frac{0}{0} \\
\text { ऐo } \\
0\end{array}$ & 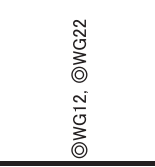 & 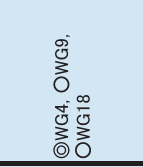 & 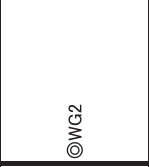 & $\begin{array}{l}\frac{0}{0} \\
03 \\
0 \\
0 \\
0 \\
0 \\
0 \\
0\end{array}$ & $\begin{array}{l}\overline{5} \\
0 \\
0 \\
0\end{array}$ & $\begin{array}{l}0 \\
\frac{0}{0} \\
03 \\
0\end{array}$ & 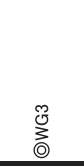 & 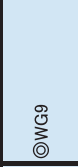 & 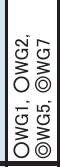 & 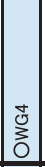 & 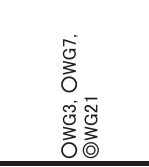 \\
\hline 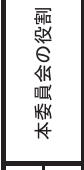 & 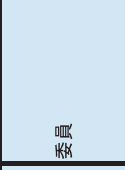 & 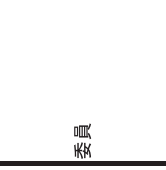 & 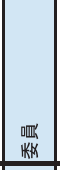 & $\begin{array}{l}\text { 㴓 } \\
\text { 粈 }\end{array}$ & 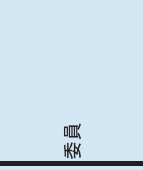 & 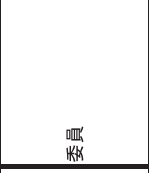 & 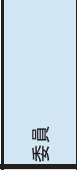 & $\begin{array}{l}\text { 吅 } \\
\text { 粉 } \\
\end{array}$ & 喠 & $\begin{array}{l}\text { 响 } \\
\text { 粈 }\end{array}$ & 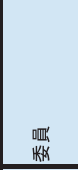 & 㕰 & 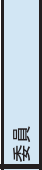 & 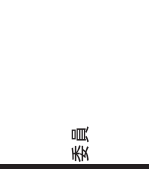 \\
\hline 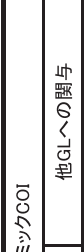 & 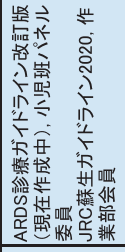 & 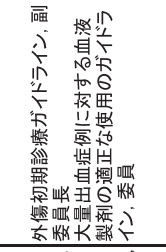 & 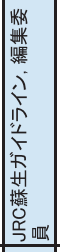 & 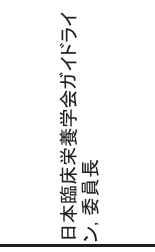 & 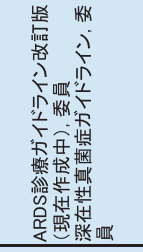 & & & 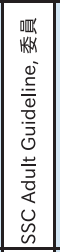 & & & 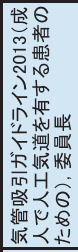 & & & \\
\hline 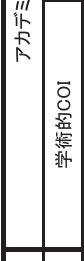 & & 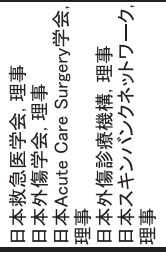 & 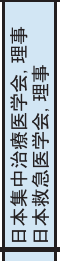 & 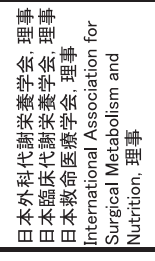 & 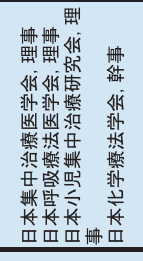 & & & & 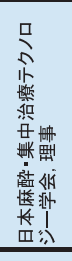 & 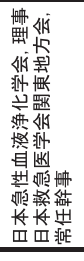 & & & 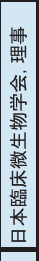 & 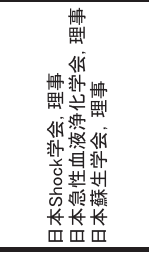 \\
\hline$\tilde{0}$ & 粠 & 粠 & 粕 & 糕 & 粠 & 叛 & 标 & 夥 & 楼 & 夥 & 夥 & 敤 & 糕 & 糕 \\
\hline 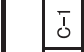 & 粠 & 楼 & 楼 & 粠 & 桻 & 楼 & 敤 & 标 & 果 & 楼 & 粀 & 敤 & 标 & 夥 \\
\hline $\begin{array}{ll}\infty \\
p \\
\infty\end{array}$ & 茟 & 楼 & 楼 & 楼 & 粠 & 粠 & 果 & 果 & 粠 & 夥 & 粠 & 敤 & 果 & 粠 \\
\hline \begin{tabular}{|c|c}
$\tilde{N}$ \\
$\tilde{\omega}$ \\
\end{tabular} & 楼 & 粠 & 楼 & 夥 & 粍 & 粠 & 桙 & 夥 & 踈 & 夥 & 敤 & 楼 & 彞 & 楼 \\
\hline \begin{tabular}{|l|} 
\\
$\infty$ \\
\end{tabular} & 粠 & 楼 & 楼 & 夥 & 粠 & 粠 & 夥 & 标 & 糕 & 粀 & 夥 & 敤 & 标 & 夥 \\
\hline$\frac{i}{<}$ & 桻 & 楼 & 粠 & 粠 & 粠 & 粠 & 粯 & 耤 & 楼 & 糕 & 楼 & 楼 & 㮆 & 糕 \\
\hline $\begin{array}{l}\infty \\
\vdots \\
\alpha\end{array}$ & 粠 & 粠 & 粠 & 野 & 楼 & 楼 & 楼 & 敤 & 楼 & 桻 & 敤 & 夥 & 桻 & 夥 \\
\hline 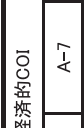 & 标 & 粠 & 粠 & 桻 & 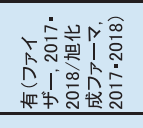 & 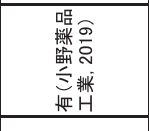 & 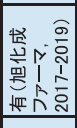 & 踈 & 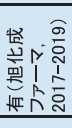 & 夥 & 桻 & 楼 & 标 & 夥 \\
\hline 慗 & 果 & 粠 & 粠 & 桻 & 标 & 楼 & 标 & 梌 & 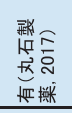 & 夥 & 桻 & 桻 & 糕 & 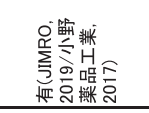 \\
\hline \begin{tabular}{|l|l|} 
\\
$<$
\end{tabular} & 粠 & 粠 & 粠 & 桻 & 标 & 果 & 粗 & 标 & 粠 & 夥 & 桻 & 敤 & 糕 & 楼 \\
\hline $\begin{array}{l}4 \\
\\
\end{array}$ & 粠 & 粠 & 粠 & 粠 & 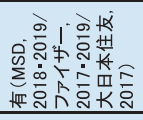 & 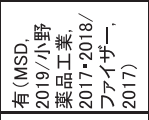 & 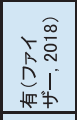 & 标 & 粠 & 粠 & 楼 & 桻 & 粍 & 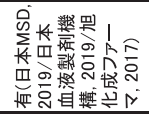 \\
\hline $\begin{array}{l}0 \\
\dot{\alpha} \\
\end{array}$ & 粠 & 粠 & 楼 & 粠 & 野 & 夥 & 枆 & 枟 & 粠 & 粠 & 敤 & 敤 & 夥 & 粠 \\
\hline$\frac{N}{<}$ & 粠 & 粠 & 粠 & 粠 & 枟 & 标 & 果 & 粠 & 粠 & 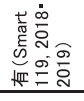 & 枟 & 夥 & 楼 & 糕 \\
\hline$\frac{T}{\alpha}$ & 粠 & 楼 & 楼 & 楼 & 楼 & 敤 & 粠 & 标 & 果 & 楼 & 夥 & 粘 & 粠 & 夥 \\
\hline 穏 & 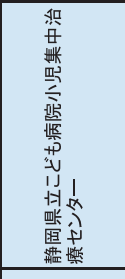 & 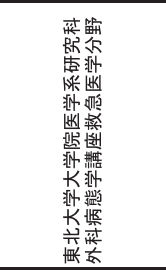 & 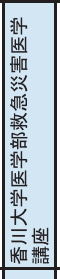 & 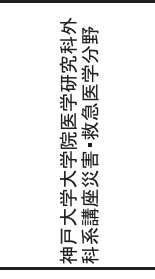 & 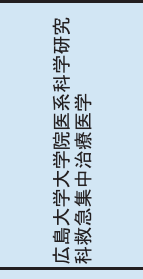 & 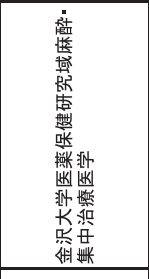 & 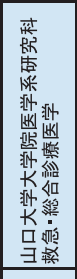 & 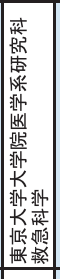 & 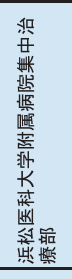 & 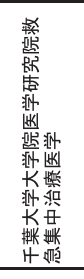 & 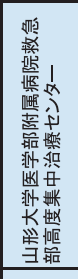 & 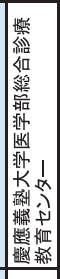 & 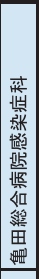 & 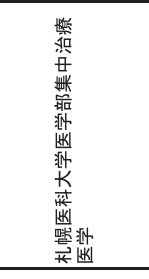 \\
\hline 崛 & 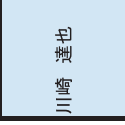 & 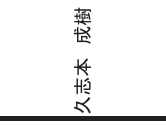 & 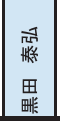 & 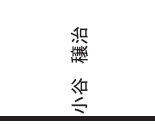 & 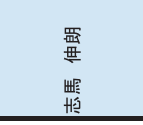 & $\begin{array}{l}\text { 倔 } \\
\text { 品 } \\
\text { 得 }\end{array}$ & 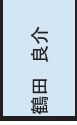 & $\begin{array}{l}\prec \\
\text { 点 } \\
\text { 苏 } \\
\text { H } \\
\end{array}$ & $\begin{array}{l}\text { 榭 } \\
\text { 出 } \\
\text { 苏 } \\
\text { H } \\
\end{array}$ & $\begin{array}{l}\text { 箵 } \\
\text { 田 } \\
\text { 田 }\end{array}$ & 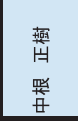 & 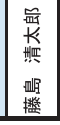 & 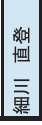 & 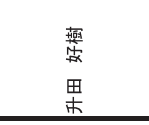 \\
\hline
\end{tabular}


日集中医誌 J Jpn Soc Intensive Care Med Vol. 28 Suppl

\begin{tabular}{|c|c|c|c|c|c|c|}
\hline 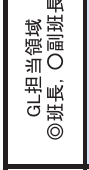 & 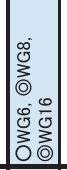 & 产 & 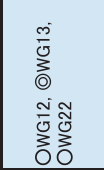 & 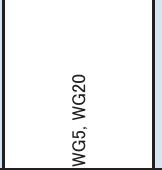 & 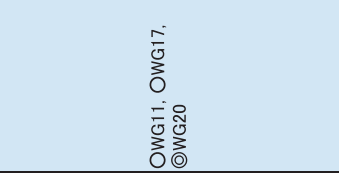 & \\
\hline 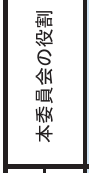 & 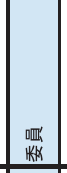 & 踩 & 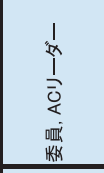 & 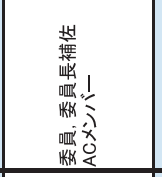 & 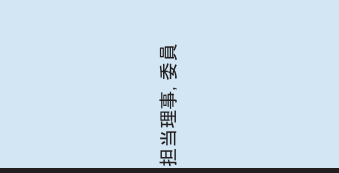 & 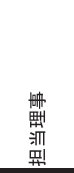 \\
\hline 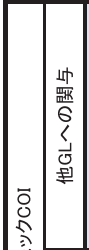 & 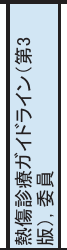 & & 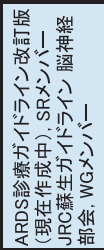 & 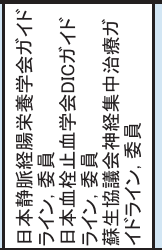 & 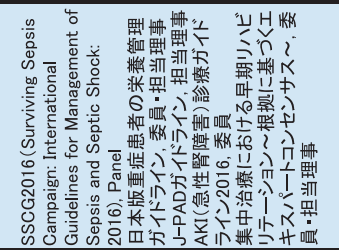 & \\
\hline 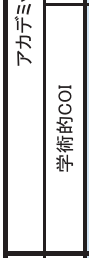 & & 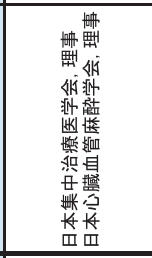 & & & 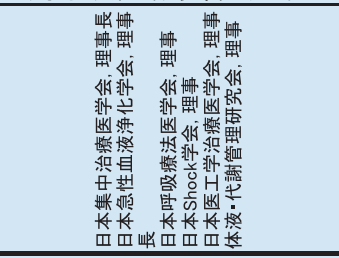 & 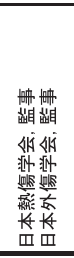 \\
\hline$\tilde{0}$ & 粠 & 楼 & 楼 & 梧 & 彞 & 楼 \\
\hline \begin{tabular}{|l|}
$\bar{j}$ \\
\end{tabular} & 楼 & 䊅 & 彞 & 粍 & 粍 & 些 \\
\hline 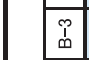 & 䊀 & 枟 & 楼 & 米 & 楼 & 米 \\
\hline \begin{tabular}{|l|}
$\tilde{\omega}$ \\
\\
\end{tabular} & 夥 & 粪 & 楼 & 楼 & 粠 & 粕 \\
\hline \begin{tabular}{|l|}
$\overline{1}$ \\
\end{tabular} & 粠 & 枟 & 楼 & 楼 & 楼 & 楼 \\
\hline \begin{tabular}{|l|l|}
9 \\
\end{tabular} & 夥 & 枟 & 㐘 & 业 & 楼 & 慗 \\
\hline$\left|\begin{array}{ll}\infty \\
0 \\
⿱ \\
1\end{array}\right|$ & 粠 & 楼 & 夥 & 桻 & 楼 & 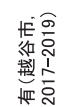 \\
\hline 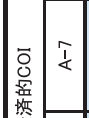 & 粠 & 晊 & 夥 & 桻 & 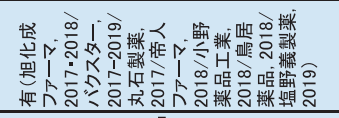 & 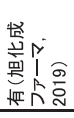 \\
\hline $\begin{array}{l}1 \\
0 \\
⿱ 亠 乂\end{array}$ & 粠 & 桧 & 跮 & 桻 & 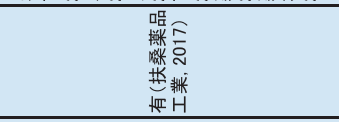 & 晊 \\
\hline \begin{tabular}{|l|l|} 
\\
\\
\end{tabular} & 粠 & 楼 & 楼 & 楼 & 楼 & 楼 \\
\hline$\frac{d}{d}$ & 糧 & 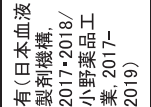 & 粭 & 楼 & 夥 & 格 \\
\hline \begin{tabular}{|l|l|l|l|l} 
\\
\end{tabular} & 耤 & 楼 & 楼 & 米 & 楼 & 楼 \\
\hline $\mid \begin{array}{l}\mid \\
\dot{\alpha} \\
\mid\end{array}$ & 枟 & 楼 & 踈 & 糕 & 楼 & 楼 \\
\hline$\frac{T}{4}$ & 粀 & 楼 & 糧 & 粠 & 粠 & 楼 \\
\hline 䏆 & 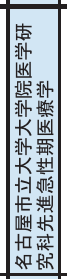 & 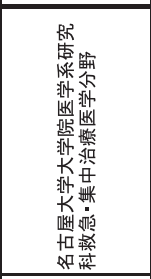 & 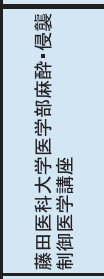 & 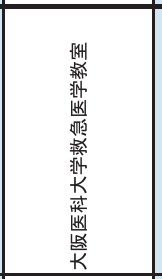 & 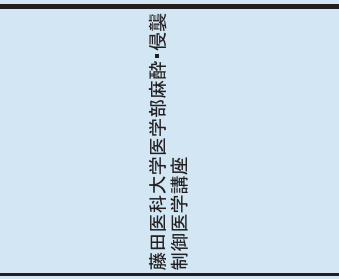 & 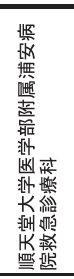 \\
\hline 嵒 & $\begin{array}{l}\text { 笂 } \\
\text { 啨 } \\
\end{array}$ & 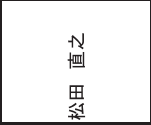 & 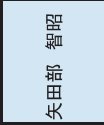 & $\begin{array}{l}\text { 堲 } \\
\overline{\bar{\Xi}}\end{array}$ & $\begin{array}{l}\text { 䴎 } \\
\end{array}$ & $\begin{array}{l}\text { 琣 } \\
\text { 畐 }\end{array}$ \\
\hline
\end{tabular}

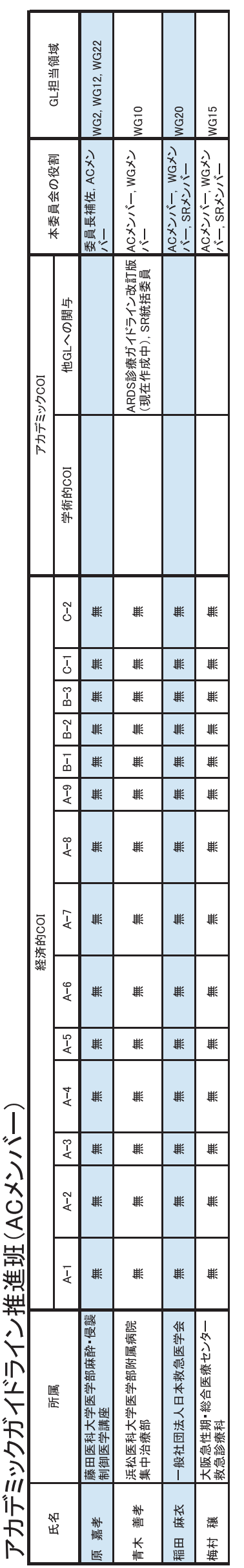




\begin{tabular}{|c|c|c|c|c|c|c|c|c|c|c|c|c|c|c|c|c|}
\hline 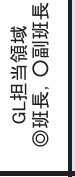 & $\stackrel{8}{3}$ & 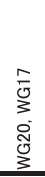 & 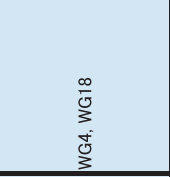 & $\tilde{\Xi}$ & 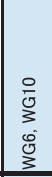 & $\begin{array}{l}\overline{0} \\
3 \\
\frac{j}{0} \\
\frac{0}{3} \\
\end{array}$ & $\frac{\circ}{\bar{\varpi}}$ & $\overline{\bar{\sigma}}$ & $\frac{m}{0}$ & 壳 & 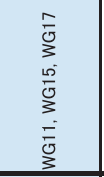 & $\stackrel{\tilde{J}}{3}$ & $\stackrel{\Xi}{\Xi}$ & 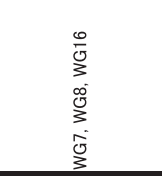 & 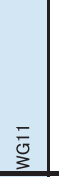 & $\stackrel{\overline{\bar{\sigma}}}{\bar{\xi}}$ \\
\hline 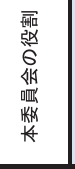 & 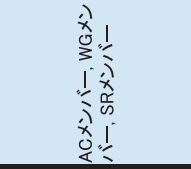 & 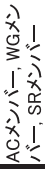 & 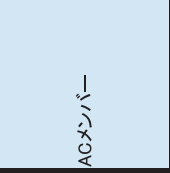 & 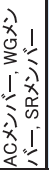 & 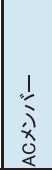 & 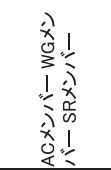 & 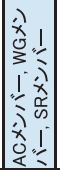 & 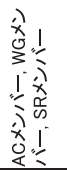 & 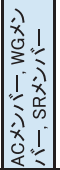 & 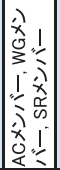 & $\begin{array}{l}1 \\
\vdots \\
0 \\
0 \\
0\end{array}$ & 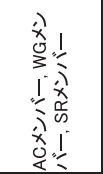 & 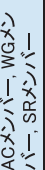 & 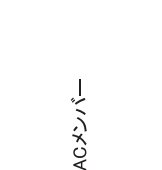 & 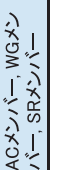 & 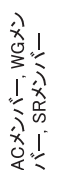 \\
\hline 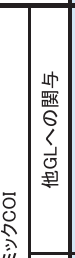 & 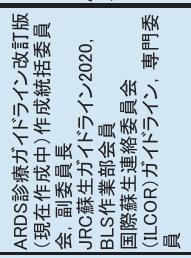 & & 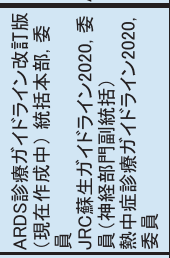 & & 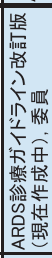 & 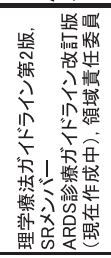 & & 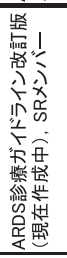 & & & 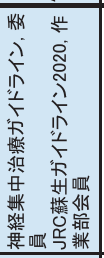 & 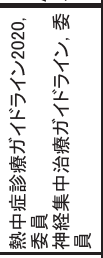 & & 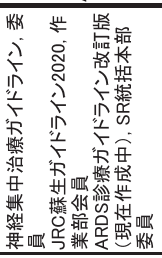 & & 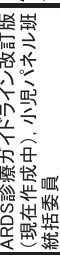 \\
\hline 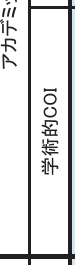 & 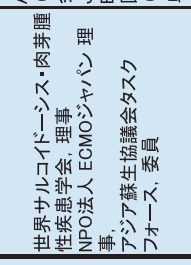 & & & & & & & & & & & & & & & \\
\hline$\hat{0}$ & 粠 & 粠 & 楼 & 夥 & 楼 & 楼 & 楼 & 夥 & 夥 & 夥 & 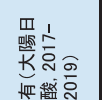 & 糧 & 粠 & 楼 & 楼 & 粠 \\
\hline \begin{tabular}{|l|} 
\\
\end{tabular} & 楼 & 粠 & 糧 & \begin{tabular}{l|l|} 
夥 \\
\end{tabular} & 桻 & 楼 & 楼 & 夥 & 夥 & 桻 & 粆 & 輁 & 粠 & 曲 & 楼 & 楼 \\
\hline \begin{tabular}{|l|}
$?$ \\
m \\
\end{tabular} & 彞 & 标 & 夥 & 夥 & 格 & 栏 & 楼 & 枟 & \begin{tabular}{l|l} 
夥 \\
\end{tabular} & 格 & 粎 & 楼 & 楼 & 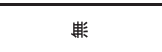 & 楼 & 楼 \\
\hline \begin{tabular}{|l|}
$\tilde{\omega}$ \\
\end{tabular} & 楼 & 楼 & 标 & $\begin{array}{l}\text { 夥 } \\
\end{array}$ & 格 & 楼 & 楼 & 格 & 夥 & 䊅 & 楼 & 楼 & 枟 & 楼 & 粍 & 楼 \\
\hline \begin{tabular}{|l|}
\multicolumn{1}{|l|}{} \\
\multicolumn{1}{|l|}{}
\end{tabular} & 䊝 & 夥 & 粸 & \begin{tabular}{l|l} 
夥 \\
\end{tabular} & 粠 & 夥 & 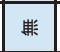 & 格 & \begin{tabular}{|l|} 
格 \\
\end{tabular} & \begin{tabular}{|l|} 
夥 \\
\end{tabular} & 粎 & 䊝 & 楼 & 格 & 格 & 楼 \\
\hline \begin{tabular}{|l|}
9 \\
\end{tabular} & 格 & 枟 & 楼 & 夥 & 桻 & 楼 & 楼 & 粀 & 格 & \begin{tabular}{|l|} 
显 \\
\end{tabular} & 楼 & 夥 & 标 & 楼 & 楼 & 楼 \\
\hline $\mid \begin{array}{l}0 \\
\dot{q} \\
\end{array}$ & 輁 & 桻 & 梪 & 夥 & 桻 & 楼 & 楼 & 晊 & 夥 & 桻 & 楼 & 夥 & 楼 & 桻 & 粠 & 顆 \\
\hline \begin{tabular}{l|l}
$\overrightarrow{0}$ & \{ \\
\end{tabular} & 楼 & 糧 & 格 & 楼 & 夥 & 楼 & 粠 & 楼 & 夥 & 桻 & 桻 & 楼 & 楼 & 桻 & 楼 & 粠 \\
\hline $\begin{array}{l}9 \\
\frac{1}{2}\end{array}$ & 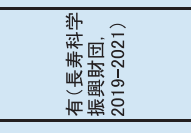 & 楼 & 楼 & 楼 & 㭋 & 楼 & 邦 & 夥 & 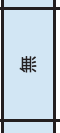 & 夥 & 楼 & 楼 & 楼 & 楼 & 楼 & 粠 \\
\hline \begin{tabular}{|l|} 
是 \\
\end{tabular} & 楼 & 楼 & 楼 & 楼 & \begin{tabular}{|l|l} 
䊉 \\
\end{tabular} & 粠 & 䊀 & 榧 & 格 & \begin{tabular}{|l|l|} 
粠 \\
\end{tabular} & 䊀 & 楼 & 楼 & 䊉 & 彞 & 楼 \\
\hline $\mid \frac{1}{1}$ & 䊉 & 踈 & 楼 & 夥 & 粘 & 楼 & 䊉 & 楼 & 楼 & 桻 & 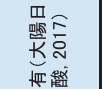 & 粀 & 楼 & 桻 & 粍 & 楼 \\
\hline \begin{tabular}{|l|} 
\\
\end{tabular} & 精 & 秚 & 楼 & 楼 & 楼 & 楼 & 楼 & 楼 & 㮫 & \begin{tabular}{|l|l|} 
粞 \\
\end{tabular} & 帮 & 敤 & 楼 & 楼 & 楼 & 楼 \\
\hline $\mid$\begin{tabular}{|l|}
$\mid \frac{1}{x}$ \\
\end{tabular} & 楼 & 粠 & 楼 & 楼 & 桻 & 粠 & 粠 & 楼 & 䊅 & 夥 & 夥 & 株 & 輁 & 䊏 & 楼 & 䊅 \\
\hline$\frac{T}{4}$ & 糧 & 桧 & 楼 & 楼 & 梧 & 楼 & 楼 & 夥 & 糧 & 楼 & 楼 & 楼 & 楼 & 楼 & 楼 & 粠 \\
\hline 咴 & 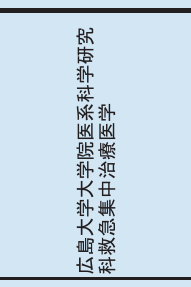 & 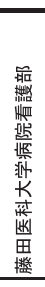 & 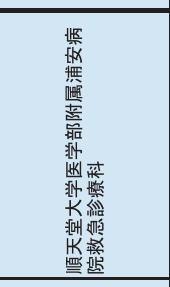 & 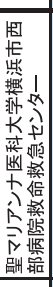 & 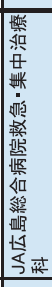 & 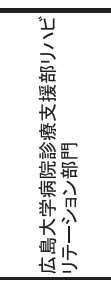 & 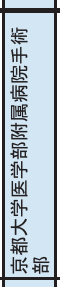 & 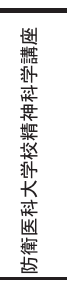 & 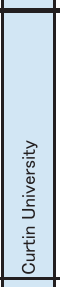 & 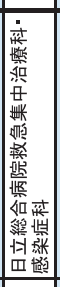 & 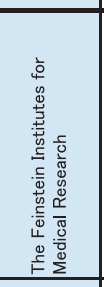 & 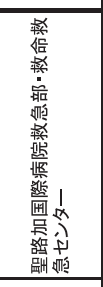 & 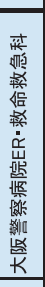 & 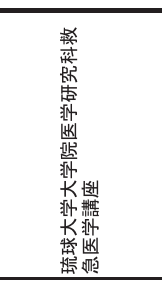 & 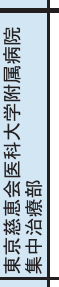 & 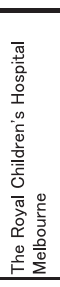 \\
\hline 虽 & 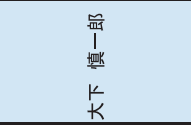 & 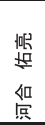 & 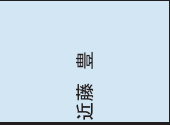 & 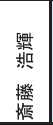 & 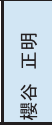 & 亜 & 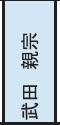 & 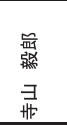 & 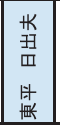 & 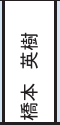 & $\begin{array}{l}\text { 異 } \\
\end{array}$ & $\begin{array}{l}\text { 肿 } \\
\text { III } \\
11 \\
1\end{array}$ & 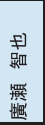 & 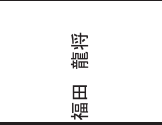 & 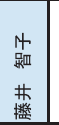 & $\begin{array}{l}\text { 瑟 } \\
\text { 橆 }\end{array}$ \\
\hline
\end{tabular}


日集中医誌 J Jpn Soc Intensive Care Med Vol. 28 Suppl

\begin{tabular}{|c|c|}
\hline 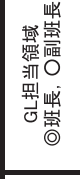 & 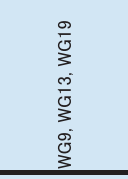 \\
\hline 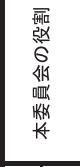 & $\begin{array}{l}\frac{1}{3} \\
\mathbf{x} \\
0 \\
0 \\
\end{array}$ \\
\hline 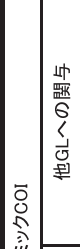 & 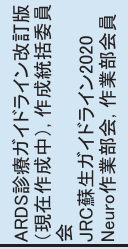 \\
\hline 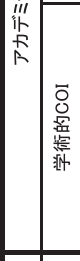 & 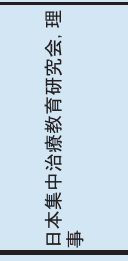 \\
\hline$\tilde{0}$ & 敤 \\
\hline j. & 判 \\
\hline $\begin{array}{l}m \\
\dot{\omega}\end{array}$ & 夥 \\
\hline$\tilde{\omega}$ & 粘 \\
\hline $\bar{\omega}$ & 夥 \\
\hline \multirow{3}{*}{ 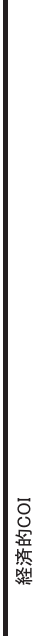 } & 夥 \\
\hline & 枟 \\
\hline & 粀 \\
\hline $\begin{array}{l}0 \\
\dot{4}\end{array}$ & 野 \\
\hline \begin{tabular}{|l} 
\\
4 \\
\end{tabular} & 叛 \\
\hline$\frac{\pi}{4}$ & 楼 \\
\hline$\frac{m}{4}$ & 枟 \\
\hline$\frac{N}{\alpha}$ & 楼 \\
\hline T & 䛶 \\
\hline 箇 & 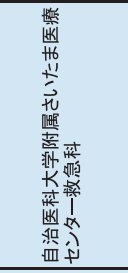 \\
\hline 召 & $\begin{array}{l}\prec \\
\text { 墒 } \\
\text { 田 } \\
\text { tWX }\end{array}$ \\
\hline
\end{tabular}

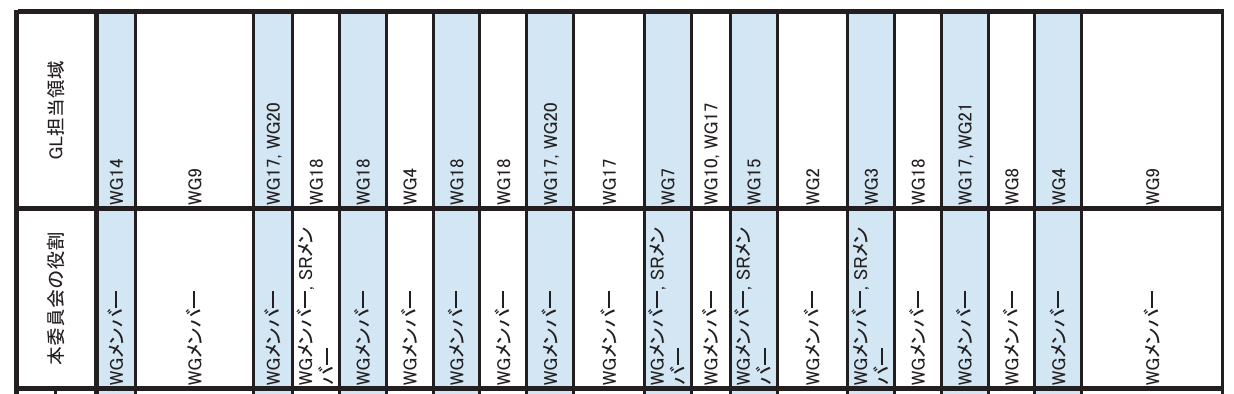

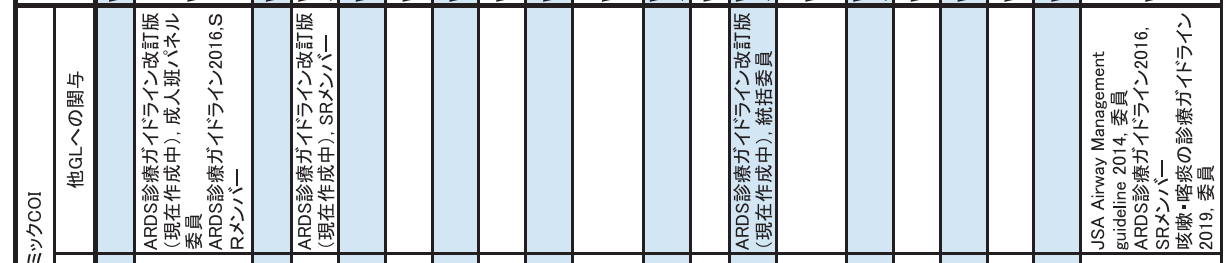

侦

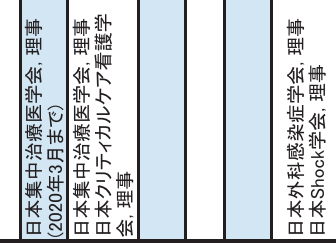

\begin{tabular}{|c|c|c|c|c|c|c|c|c|c|c|c|c|c|c|c|c|c|c|c|c|}
\hline$\tilde{u}$ & 夥 & 粠 & 楼 & 楼 & 桻 & 楼 & 楼 & 桻 & 楼 & 桻 & 楼 & 楼 & 楼 & 楼 & 輠 & 柾 & 粞 & 楼 & 楼 & 粠 \\
\hline J & 夥 & 粯 & 彞 & 楼 & 桻 & 标 & 楼 & 夥 & 糧 & 夥 & 楼 & 粎 & 格 & 敤 & 夥 & 楼 & 标 & 楼 & 楼 & 楼 \\
\hline ? & 夥 & 䊅 & 䉽 & 楼 & 夥 & 枟 & 秚 & 夥 & 粠 & 标 & 穑 & 楼 & 楼 & 敤 & 敤 & 标 & 枟 & 楼 & 敤 & 踈 \\
\hline$\stackrel{\sim}{\tilde{\omega}}$ & 夥 & 楼 & 䊉 & 粕 & 夥 & 䊎 & 䉽 & 夥 & 枟 & 夥 & 楼 & 楼 & 楼 & 格 & 格 & 柾 & 枟 & 标 & 格 & 楼 \\
\hline $\bar{\omega}_{\infty}$ & 夥 & 标 & 䉽 & 楼 & 桻 & 栏 & 䉽 & 顆 & 标 & 枟 & 标 & 粎 & 楼 & 敤 & 格 & 粘 & 敤 & 楼 & 栏 & 粠 \\
\hline$\frac{9}{4}$ & 格 & 夥 & 彞 & 夥 & 桻 & 夥 & 楼 & 敤 & 标 & 枟 & 楼 & 夥 & 夥 & 敤 & 标 & 野 & 䛶 & 夥 & 栏 & 楼 \\
\hline & 楼 & 显 & 彞 & 楼 & 格 & 䊎 & 夥 & 敤 & 夥 & 夥 & 敤 & 楼 & 楼 & 楼 & 夥 & 楼 & 敤 & 标 & 楼 & 格 \\
\hline
\end{tabular}

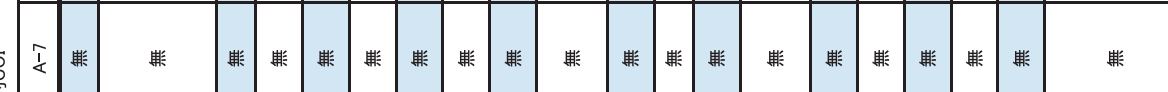

整

\begin{tabular}{|c|c|c|c|c|c|c|c|c|c|c|c|c|c|c|c|c|c|c|c|c|}
\hline$\frac{T}{<}$ & 夥 & 栏 & 枟 & 楼 & 楼 & 夥 & 粈 & 桻 & 桻 & 栏 & 夥 & 夥 & 䊉 & 楼 & 栏 & 栏 & 粈 & 粈 & 夥 & 栏 \\
\hline $\bar{x}$ & 粘 & 楼 & 叛 & 标 & 敤 & 楼 & 楼 & 格 & 格 & 楼 & 桻 & 粈 & 楼 & 敤 & 桻 & 格 & 夥 & 桻 & 桻 & 楼 \\
\hline 跕 & 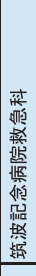 & 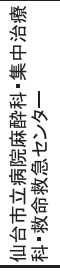 & 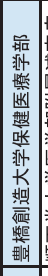 & 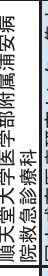 & 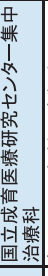 & 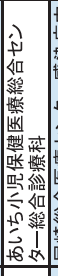 & 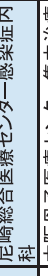 & 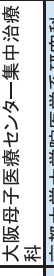 & 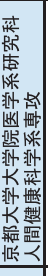 & 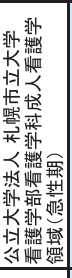 & 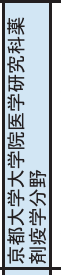 & 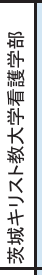 & 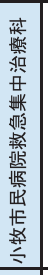 & 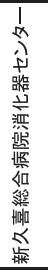 & 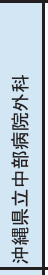 & 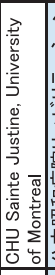 & 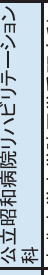 & 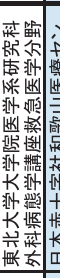 & 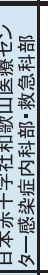 & 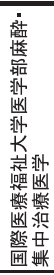 \\
\hline 趉 & 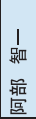 & 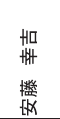 & 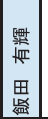 & 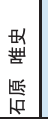 & 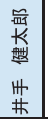 & 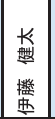 & 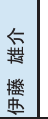 & 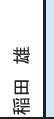 & 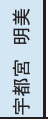 & 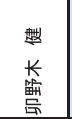 & 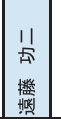 & 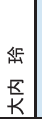 & 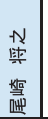 & 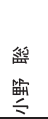 & 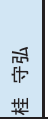 & 标 & 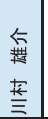 & 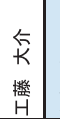 & 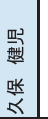 & 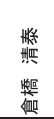 \\
\hline
\end{tabular}




\begin{tabular}{|c|c|c|c|c|c|c|c|c|c|c|c|c|c|c|c|c|c|c|c|c|c|c|c|c|c|c|c|c|c|}
\hline 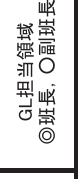 & $\begin{array}{l}1 \\
\overline{0} \\
0 \\
0 \\
0 \\
3 \\
\end{array}$ & $\stackrel{8}{3}$ & $\begin{array}{l}\frac{0}{0} \\
\frac{0}{3}\end{array}$ & $\tilde{丶}_{\underline{3}}$ & $\stackrel{\square}{\underline{g}}$ & ¿ & 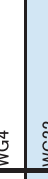 & స్ & $\stackrel{1}{3}$ & $\stackrel{\S}{3}$ & $\begin{array}{l}\frac{0}{0} \\
3 \\
3\end{array}$ & $\begin{array}{l}\text { ָิ } \\
\stackrel{3}{3}\end{array}$ & $\begin{array}{l}\frac{\infty}{0} \\
\frac{0}{3} \\
\end{array}$ & $\sum_{3}^{N}$ & $\varliminf_{3}^{\infty}$ & 气ू & $\overline{\bar{j}}$ & స్ & $\begin{array}{l}N \\
\bar{N} \\
3\end{array}$ & $\overbrace{3}^{3}$ & $\begin{array}{l}\frac{0}{0} \\
\frac{0}{3}\end{array}$ & $\frac{0}{0}$ & $\overbrace{3}^{3}$ & ฐั๊ & స్త్ & 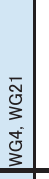 & $\frac{N}{\tilde{N}}$ & $\begin{array}{l}\frac{m}{0} \\
\frac{0}{3}\end{array}$ & $\begin{array}{l}\text { స్ } \\
3 \\
\infty \\
0 \\
\vdots \\
\vdots\end{array}$ \\
\hline 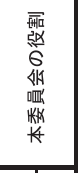 & 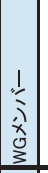 & 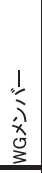 & $\begin{array}{l}1 \\
\vdots \\
\hat{x} \\
0 \\
3 \\
\end{array}$ & 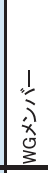 & 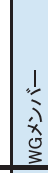 & 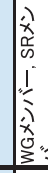 & 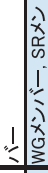 & 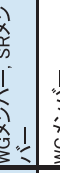 & 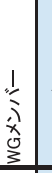 & $\begin{array}{l}1 \\
\vdots \\
\\
0 \\
3 \\
3 \\
\end{array}$ & $\begin{array}{l}1 \\
\vdots \\
\\
0 \\
3 \\
3 \\
\end{array}$ & $\begin{array}{l}1 \\
\vdots \\
\\
0 \\
3 \\
3 \\
\end{array}$ & $\begin{array}{l}1 \\
\vdots \\
\vdots \\
0 \\
3 \\
3 \\
\end{array}$ & 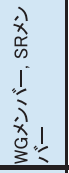 & 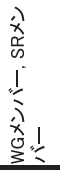 & \begin{tabular}{|c|} 
\\
$\vdots$ \\
$\lambda$ \\
0 \\
3 \\
\\
\end{tabular} & $\begin{array}{l}1 \\
\vdots \\
0 \\
0 \\
3 \\
3\end{array}$ & 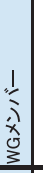 & 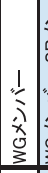 & 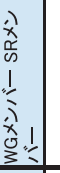 & $\begin{array}{l}\frac{1}{3} \\
\stackrel{x}{x} \\
0 \\
3\end{array}$ & $\begin{array}{r}1 \\
3 \\
3 \\
3 \\
3 \\
3\end{array}$ & \begin{tabular}{|c|} 
\\
$\vdots$ \\
$x$ \\
0 \\
3 \\
\end{tabular} & 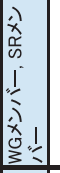 & 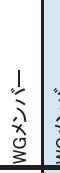 & 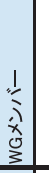 & $\begin{array}{l}1 \\
3 \\
\hat{x} \\
0 \\
3\end{array}$ & 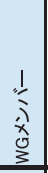 & $\begin{array}{l}1 \\
\vdots \\
0 \\
0 \\
3 \\
3\end{array}$ \\
\hline 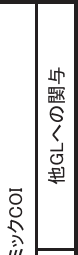 & & & & & 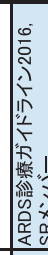 & & & & 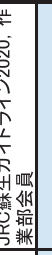 & & & & & 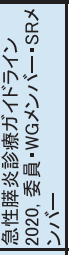 & & & & & & 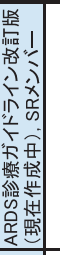 & & 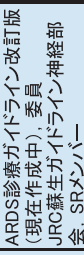 & 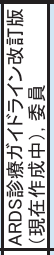 & & & & 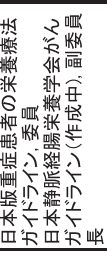 & & \\
\hline 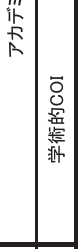 & & & & & & & & & & & & & & & & & & & & & 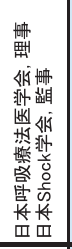 & & 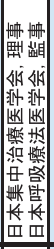 & & & & & & \\
\hline$\tilde{0}$ & 楼 & 粠 & 粠 & 夥 & 敤 & 敤 & 此 & 楼 & 标 & 䉽 & 格 & 夥 & 夥 & 桻 & 夥 & 标 & 粠 & 显 & 枟 & 标 & 粠 & 粠 & 粠 & 夥 & 夥 & 夥 & 楼 & 夥 & 粠 \\
\hline $\bar{j}$ & 夥 & 楼 & 楼 & 昣 & 敤 & 标 & 咀 & 夥 & 标 & 䊏 & 粘 & 格 & 楼 & 夥 & 粀 & 桻 & 粠 & 标 & 枟 & 䊀 & 楼 & 桻 & 格 & 䊀 & 格 & 楼 & 粕 & 敤 & 桻 \\
\hline $\begin{array}{l}m \\
m \\
m\end{array}$ & 标 & 䊏 & 粠 & 夥 & 枟 & 标 & 林 & 枟 & 标 & 䊏 & 粘 & 夥 & 夥 & 粠 & 昣 & 楼 & 粠 & 标 & 枟 & 标 & 夥 & 格 & 楼 & 枟 & 格 & 标 & 楼 & 敤 & 粠 \\
\hline \begin{tabular}{|l|}
$\tilde{\omega}$ \\
$\tilde{\omega}$
\end{tabular} & 枟 & 粠 & 粍 & 夥 & 敤 & 敤 & 林 & 楼 & 楼 & 粍 & 粠 & 夥 & 夥 & 楼 & 夥 & 粸 & 楼 & 桻 & 夥 & 些 & 柾 & 显 & 显 & 踈 & 楼 & 标 & 楼 & 夥 & 楼 \\
\hline $\bar{\omega}$ & 夥 & 楼 & 楼 & 楼 & 标 & 标 & 粀 & 标 & 桻 & 粘 & 粘 & 格 & 楼 & 䊝 & 粀 & 粸 & 䌸 & 夥 & 枟 & 䊀 & 楼 & 桻 & 楼 & 踈 & 夥 & 标 & 桻 & 敤 & 粠 \\
\hline$\frac{9}{4}$ & 夥 & 格 & 夥 & 格 & 敤 & 夥 & 虾 & 楼 & 粠 & 楼 & 格 & 桻 & 楼 & 糧 & 粀 & 枟 & 䌸 & 标 & 格 & 标 & 桻 & 夥 & 楼 & 糧 & 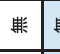 & 标 & 夥 & 楼 & 野 \\
\hline $\begin{array}{l}\infty \\
\dot{\alpha} \\
\end{array}$ & 枟 & 夥 & 粠 & 桻 & 枟 & 敤 & 林 & 些 & 桻 & 粍 & 粘 & 夥 & 桻 & 楼 & 夥 & 粎 & 楼 & 夥 & 夥 & 桻 & 楼 & 桻 & 粠 & 楼 & 格 & 标 & 夥 & 格 & 果 \\
\hline 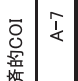 & 格 & 夥 & 格 & 格 & 敤 & 敤 & 林 & 些 & 果 & 䊏 & 粘 & 夥 & 柾 & 楼 & 夥 & 夥 & 䌸 & 桻 & 颗 & 桻 & 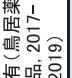 & 耤 & 楼 & 楼 & 格 & 桻 & 楼 & 敤 & 敤 \\
\hline $\begin{array}{l}0 \\
\dot{x}\end{array}$ & 耤 & 枆 & 桻 & 夥 & 堁 & 楼 & 林 & 夥 & 标 & 䊏 & 䊏 & 格 & 显 & 楼 & 粀 & 格 & 敤 & 桻 & 枟 & 桻 & 䊉 & 楼 & 䊝 & 夥 & 格 & 桻 & 粘 & 格 & 楼 \\
\hline $\begin{array}{l}5 \\
< \\
\end{array}$ & 桻 & 楼 & 楼 & 楼 & 枟 & 标 & 粬 & 楼 & 楼 & 楼 & 格 & 楼 & 粀 & 楼 & 夥 & 踈 & 楼 & 格 & 敤 & 果 & 桧 & 夥 & 显 & 楼 & 桻 & 踈 & 桻 & 敤 & 鋉 \\
\hline$\frac{⿱}{\dot{t}}$ & 夥 & 格 & 楼 & 格 & 粘 & 标 & 距 & 楼 & 夥 & 夥 & 夥 & 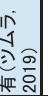 & 穑 & 跮 & 粀 & 䉽 & 野 & 粘 & 标 & 标 & 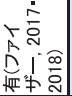 & 梪 & 楼 & 夥 & 桻 & 楼 & 糧 & 夥 & 粠 \\
\hline $\begin{array}{l}0 \\
\end{array}$ & 夥 & 格 & 格 & 格 & 敤 & 标 & 㯲 & 格 & 粠 & 格 & 粘 & 枟 & 楼 & 糧 & 夥 & 桻 & 粠 & 标 & 敤 & 夥 & 楼 & 糕 & 粠 & 夥 & 楼 & 楼 & 楼 & 敤 & 楼 \\
\hline$\frac{\pi}{<}$ & 标 & 彞 & 彞 & 格 & 敤 & 夥 & 旅 & 夥 & 粠 & 桧 & 䊏 & 楼 & 桻 & 楼 & & 彞 & 夥 & 标 & 颗 & 粠 & 粠 & 粀 & 夥 & 䊒 & 栟 & 踈 & 楼 & 敤 & 楼 \\
\hline$\frac{T}{\alpha}$ & 桻 & 彞 & 楼 & 格 & 夥 & 粕 & 林 & 桻 & 䊏 & 楼 & 夥 & 业 & 楼 & 楼 & 粀 & 格 & 䌸 & 楼 & 枟 & 粠 & 䊉 & 粠 & 楼 & 楼 & 格 & 标 & 标 & 夥 & 楼 \\
\hline 政 & 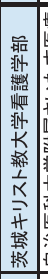 & 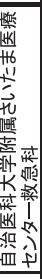 & 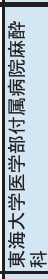 & 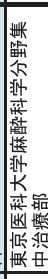 & 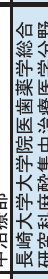 & 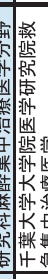 & 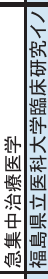 & 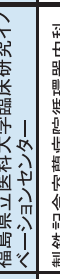 & 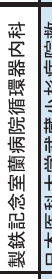 & 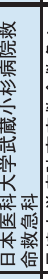 & 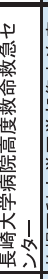 & 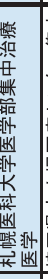 & 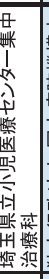 & 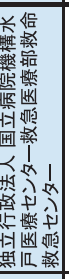 & 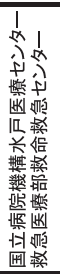 & 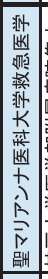 & 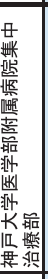 & 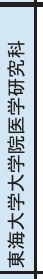 & 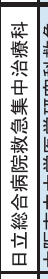 & 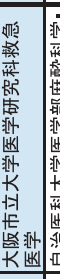 & 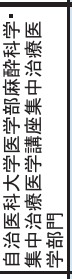 & 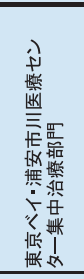 & 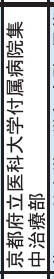 & 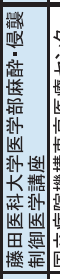 & 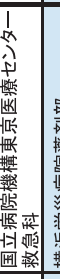 & 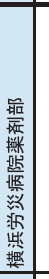 & 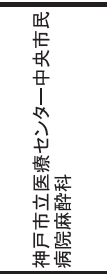 & 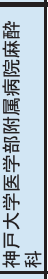 & 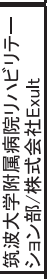 \\
\hline 虽 & 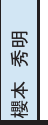 & $\begin{array}{c}\text { 齿 } \\
\exists \\
\bar{F} \\
\end{array}$ & 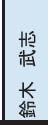 & 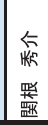 & 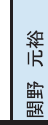 & 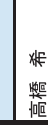 & 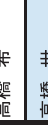 & 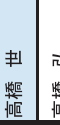 & 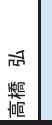 & $\begin{array}{l}\text { 幽 } \\
\text { ب } \\
\text { 田 }\end{array}$ & 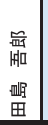 & 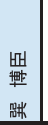 & 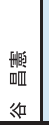 & 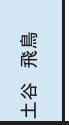 & $\begin{array}{l}\text { 雒 } \\
\text { 哭 }\end{array}$ & 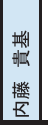 & 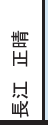 & 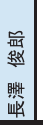 & 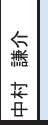 & 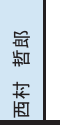 & 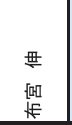 & 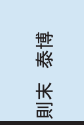 & 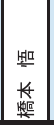 & 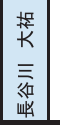 & 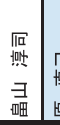 & 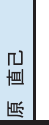 & 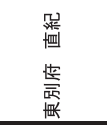 & 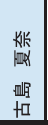 & 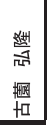 \\
\hline
\end{tabular}




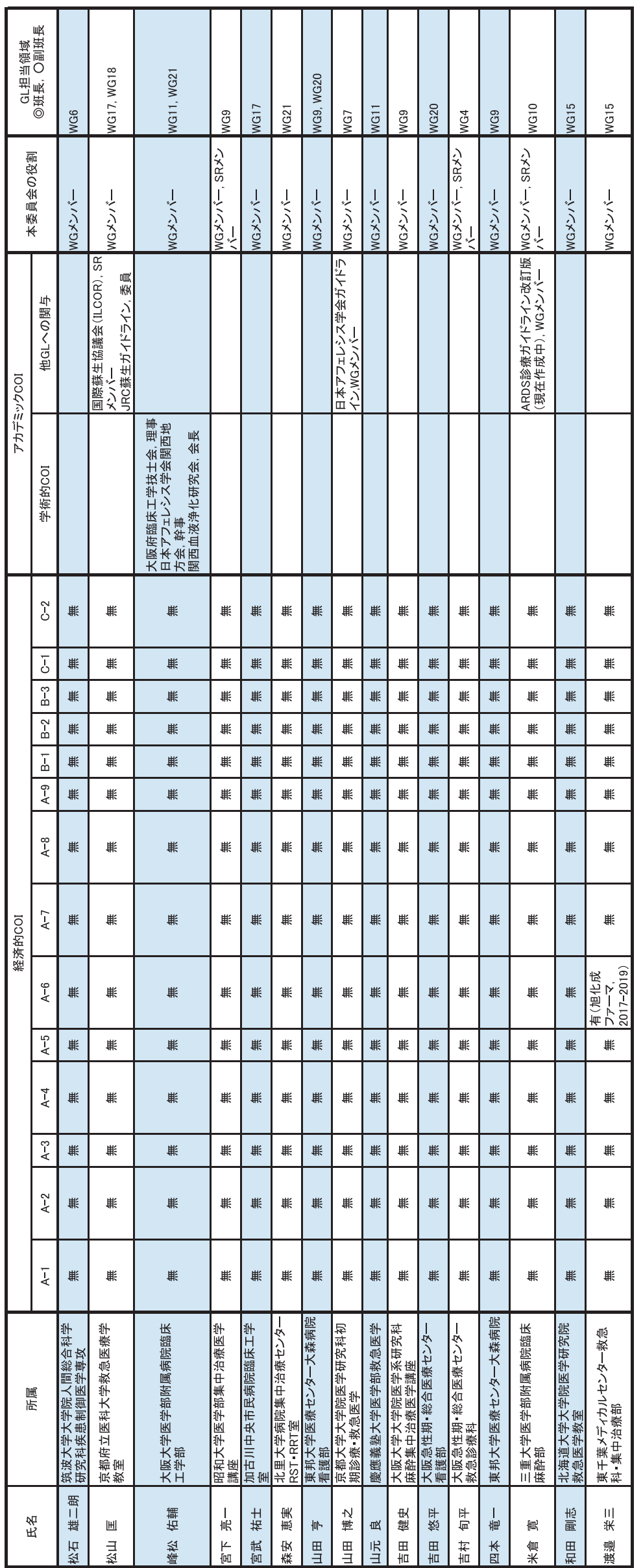

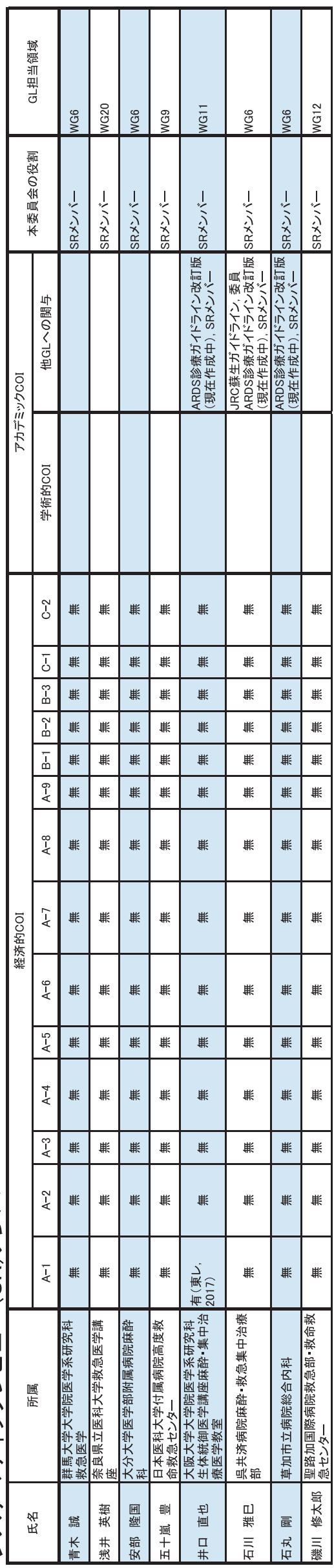




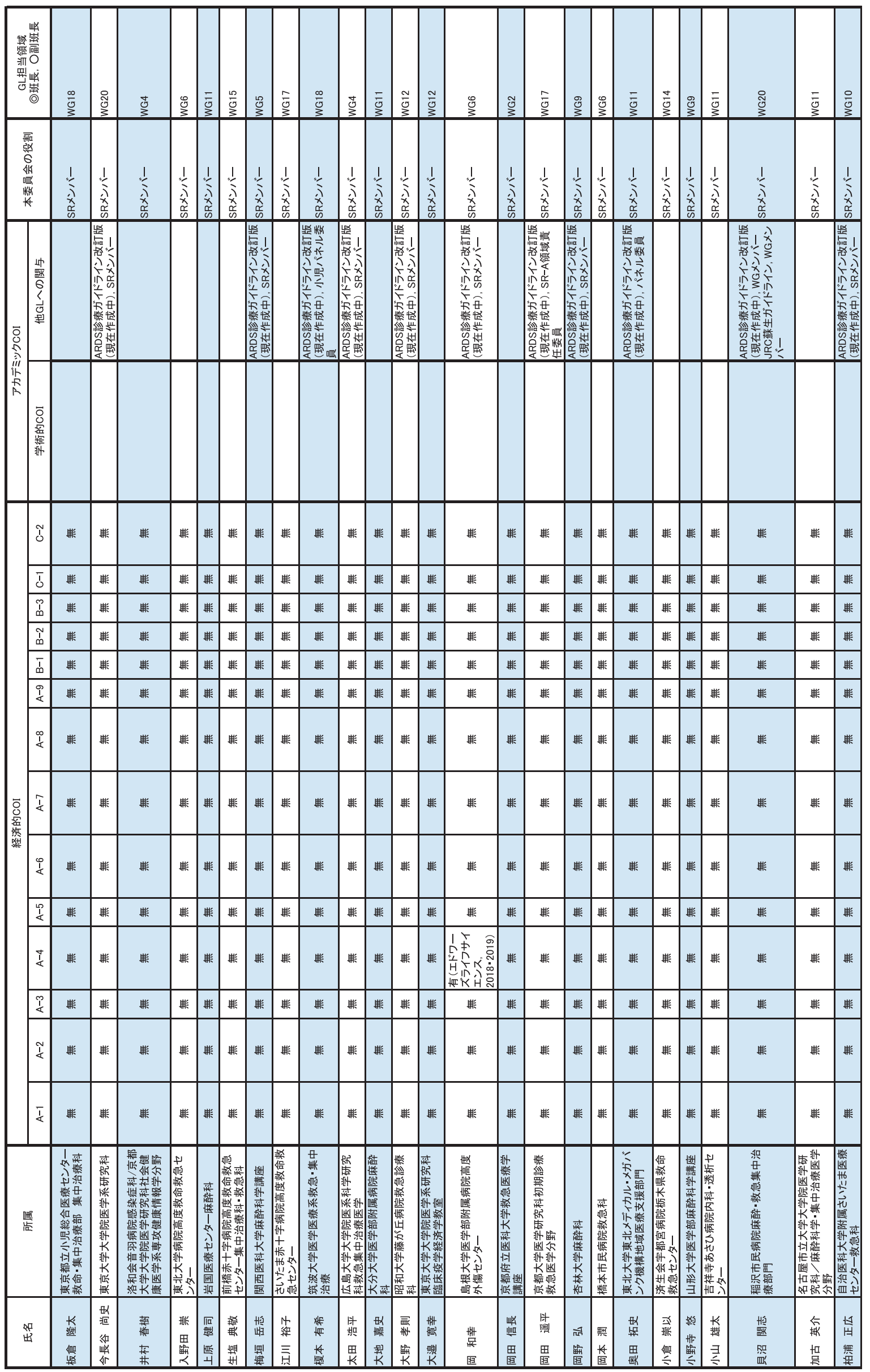




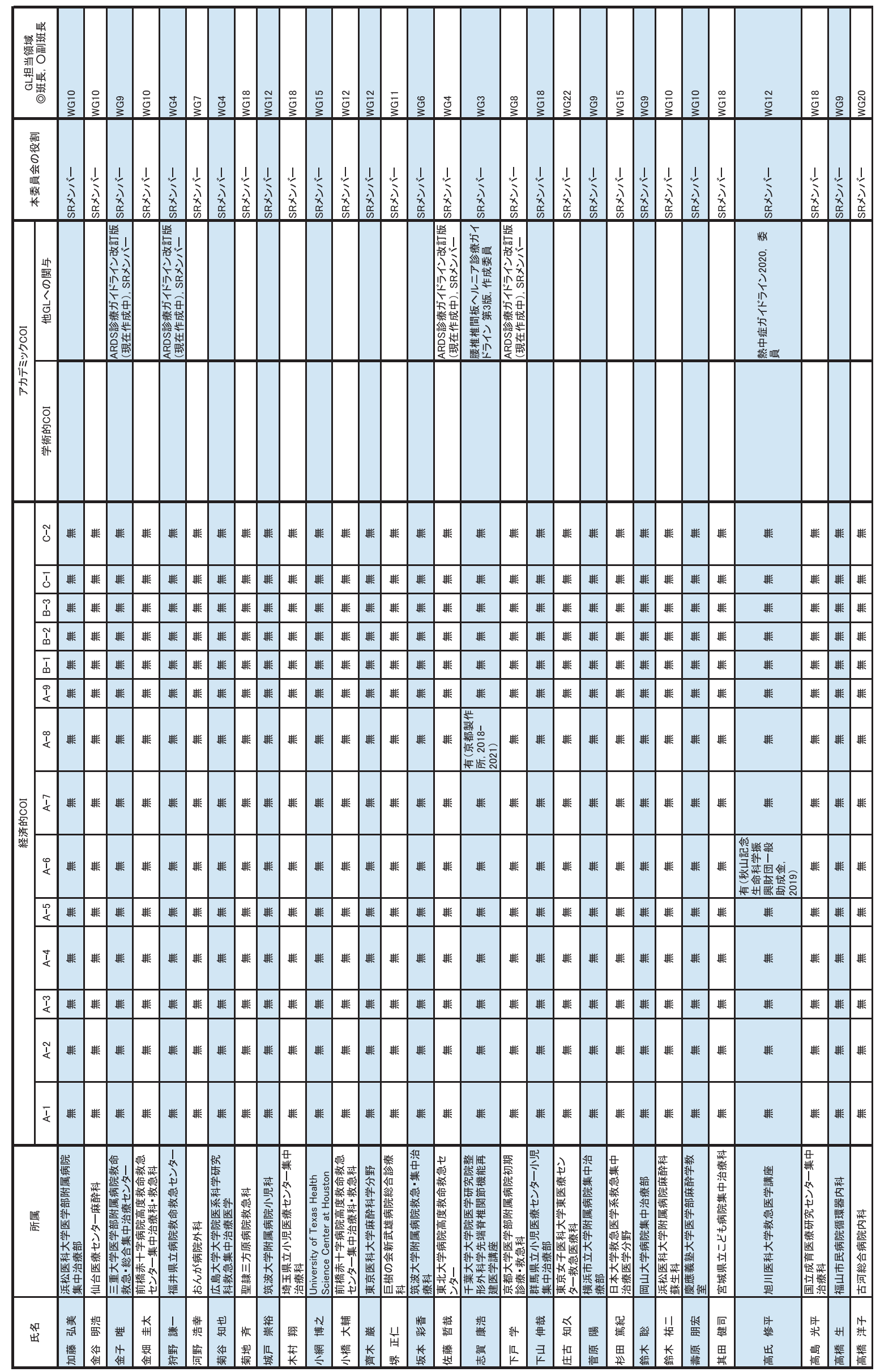




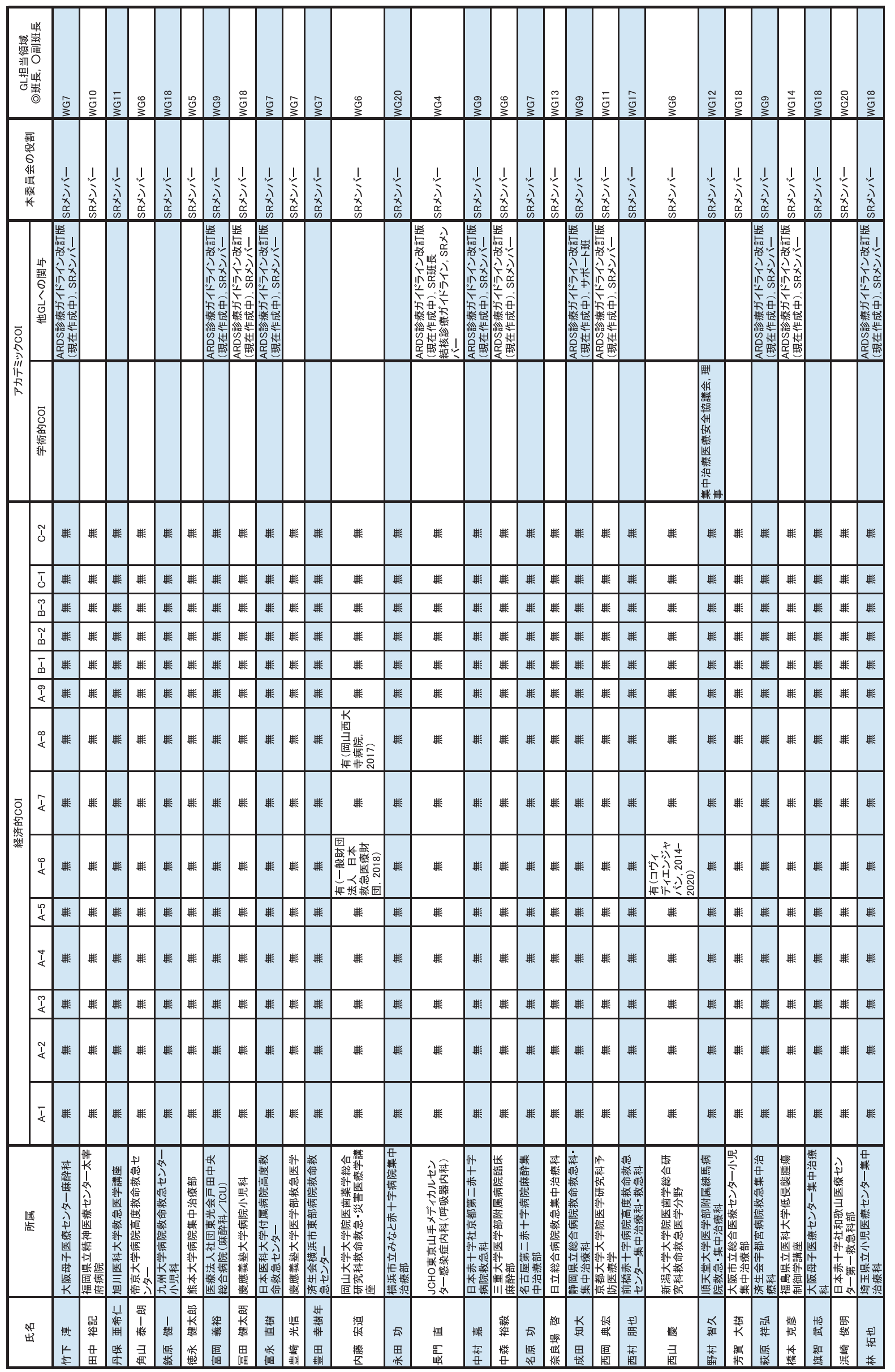




\begin{tabular}{|c|c|c|c|c|c|c|c|c|c|c|c|c|c|c|c|c|c|c|c|c|c|c|c|}
\hline 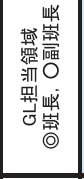 & $\begin{array}{c}\overline{0} \\
\sum\end{array}$ & \begin{tabular}{|l}
0 \\
0 \\
3
\end{tabular} & $\stackrel{8}{3}$ & $\stackrel{\Xi}{3}$ & $\frac{\frac{m}{j}}{3}$ & $\begin{array}{l}\frac{0}{3} \\
\frac{3}{3}\end{array}$ & $\begin{array}{l}\frac{\circ}{3} \\
\frac{3}{3}\end{array}$ & $\begin{array}{l}\stackrel{0}{0} \\
3\end{array}$ & $\begin{array}{l}\frac{0}{5} \\
3 \\
3\end{array}$ & $\begin{array}{l}0 \\
\frac{0}{3} \\
3\end{array}$ & No & $\stackrel{\infty}{5}_{3}^{\infty}$ & $\stackrel{8}{3}$ & 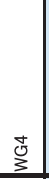 & $\stackrel{\S}{\xi}$ & $\begin{array}{l}\frac{10}{0} \\
3\end{array}$ & $\varliminf_{3}$ & $\begin{array}{l}\frac{m}{5} \\
\frac{5}{3}\end{array}$ & $\overline{\overline{0}}$ & $\begin{array}{l}0 \\
\vdots \\
\end{array}$ & $\begin{array}{l}0 \\
3 \\
3\end{array}$ & $\tilde{\widetilde{\tau}}$ & $\stackrel{\S}{3}$ \\
\hline 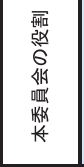 & 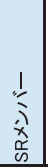 & 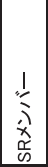 & 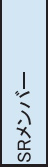 & 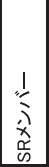 & 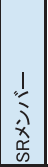 & 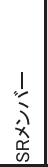 & 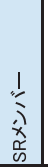 & 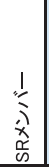 & $\begin{array}{l}\frac{1}{3} \\
\vdots \\
\frac{x}{0} \\
\frac{x}{0} \\
\end{array}$ & 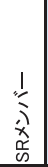 & 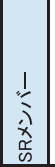 & 卒 & 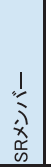 & 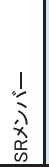 & 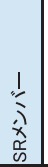 & 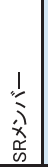 & 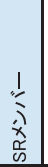 & 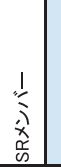 & 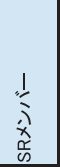 & 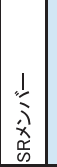 & 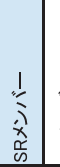 & 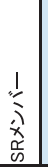 & 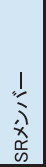 \\
\hline 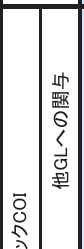 & & & & & & & & & & 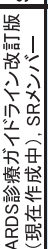 & 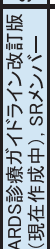 & & 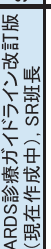 & & & & & & 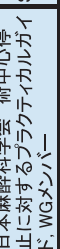 & 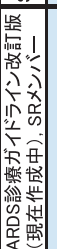 & & & 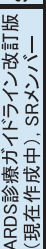 \\
\hline 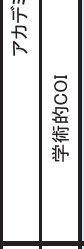 & & & & & & & & & & & & & & & 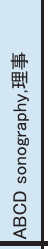 & & & & & & & & \\
\hline$\tilde{0}$ & 夥 & 桻 & 梧 & 楼 & 楼 & 楼 & 夥 & 夥 & 夥 & 楼 & 桻 & 栏 & 粘 & 楼 & 楼 & 楼 & 夥 & 桻 & 糧 & 夥 & 桻 & 格 & 格 \\
\hline $\bar{\jmath}$ & 堁 & 桻 & 粎 & 楼 & 踈 & 踈 & 粘 & 夥 & 夥 & 粈 & 桻 & 格 & 格 & 桻 & 楼 & 楼 & 踈 & 夥 & 夥 & 格 & 标 & 夥 & 敤 \\
\hline \begin{tabular}{l|l} 
\\
$\dot{m}$ \\
$\dot{m}$
\end{tabular} & 夥 & 楼 & 䊎 & 楼 & 楼 & 輠 & 楼 & 夥 & 夥 & 敤 & 柾 & 楼 & 楼 & 粎 & 标 & 枟 & 粘 & 楼 & 䉽 & 格 & 䊎 & 夥 & 格 \\
\hline \begin{tabular}{|c|}
$\tilde{\omega}$ \\
$\tilde{\omega}$
\end{tabular} & 格 & 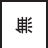 & 敤 & 楼 & 楼 & 楼 & 踈 & 楼 & 夥 & 楼 & 楼 & 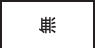 & 楼 & 楼 & 楼 & 楼 & 䉽 & 夥 & 粈 & 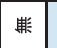 & 楼 & 桻 & 敤 \\
\hline $\bar{\infty}$ & 夥 & 楼 & 夥 & 楼 & 楼 & 粠 & 踈 & 敤 & 夥 & 敤 & 粠 & 楼 & 楼 & 夥 & 桻 & 夥 & 糧 & 夥 & 夥 & 夥 & 夥 & 夥 & 夥 \\
\hline$\frac{9}{4}$ & 夥 & 桻 & 格 & 夥 & 楼 & 楼 & 楼 & 夥 & 夥 & 敤 & 彞 & 楼 & 楼 & 楼 & 楼 & 夥 & 粎 & 夥 & 粠 & 格 & 枟 & 桻 & 敤 \\
\hline $\begin{array}{l}\infty \\
< \\
<\end{array}$ & 夥 & 楼 & 桻 & 桻 & 楼 & 夥 & 楼 & 夥 & 夥 & 敤 & 桻 & 桻 & 楼 & 楼 & 楼 & 桻 & 楼 & 夥 & 桻 & 夥 & 夥 & 桻 & 夥 \\
\hline T & 夥 & 桻 & 桻 & 楼 & 桻 & 夥 & 楼 & 粘 & 夥 & 楼 & 格 & 楼 & 楼 & 夥 & 楼 & 夥 & 格 & 桻 & 桻 & 敤 & 輠 & 标 & 彞 \\
\hline $\begin{array}{l}0 \\
<\end{array}$ & 夥 & 夥 & 格 & 楼 & 楼 & 楼 & 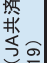 & 敤 & 楼 & 敤 & 标 & 楼 & 粎 & 楼 & 桻 & 桻 & 楼 & 桻 & 糧 & 夥 & 楼 & 标 & 夥 \\
\hline$\frac{8}{8}$ & 枟 & 粎 & 粎 & 楼 & 标 & 楼 & 粘 & 䌸 & 格 & 楼 & 楼 & 楼 & 桧 & 楼 & 䏝 & 枟 & 枟 & 楼 & 粭 & 显 & 楼 & 楼 & 楼 \\
\hline$\frac{1}{d}$ & 格 & 格 & 粈 & 楼 & 楼 & 楼 & 䊀 & 夥 & 夥 & 夥 & 楼 & 楼 & 格 & 粎 & 桻 & 桻 & 格 & 粗 & 䊝 & 夥 & 桻 & 桻 & 格 \\
\hline$\frac{m}{4}$ & 夥 & 桻 & 粎 & 楼 & 楼 & 楼 & 楼 & 楼 & 夥 & 敤 & 夥 & 楼 & 槕 & 粎 & 桻 & 夥 & 敤 & 楼 & 楼 & 格 & 格 & 夥 & 格 \\
\hline$\frac{T}{<}$ & 夥 & 桻 & 夥 & 楼 & 楼 & 楼 & 楼 & 夥 & 夥 & 敤 & 桻 & 桻 & 敤 & 楼 & 楼 & 楼 & 楼 & 夥 & 粠 & 格 & 夥 & 夥 & 格 \\
\hline$\frac{T}{\alpha}$ & 夥 & 楼 & 糧 & 楼 & 楼 & 楼 & 楼 & 夥 & 夥 & 夥 & 粠 & 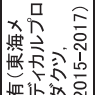 & 夥 & 夥 & 果 & 夥 & 夥 & 格 & 桻 & 夥 & 夥 & 夥 & 格 \\
\hline 些 & 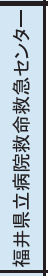 & 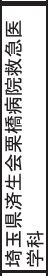 & 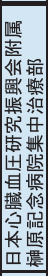 & 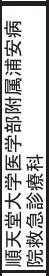 & 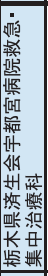 & 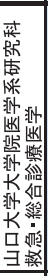 & 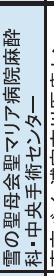 & 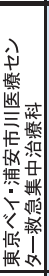 & 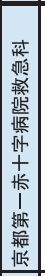 & 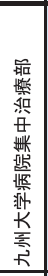 & 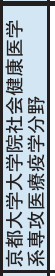 & 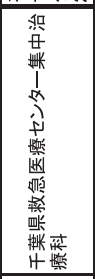 & 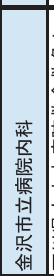 & 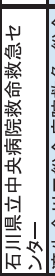 & 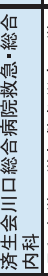 & 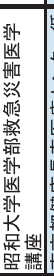 & 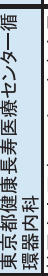 & 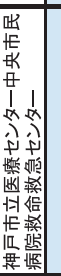 & 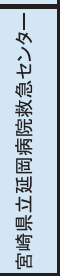 & 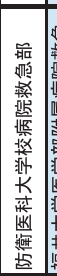 & 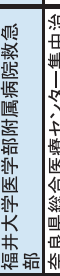 & 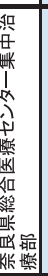 & 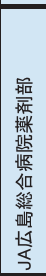 \\
\hline 架 & 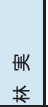 & 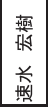 & 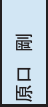 & 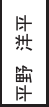 & $\begin{array}{l}\text { 慗 } \\
\text { 楁 } \\
\end{array}$ & 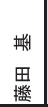 & 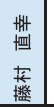 & $\begin{array}{l}\text { 禁 } \\
\text { 篦 }\end{array}$ & 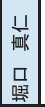 & $\begin{array}{l}\text { 地 } \\
\ldots\end{array}$ & 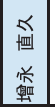 & $\begin{array}{l}\text { 無 } \\
\text { 䓛 }\end{array}$ & 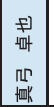 & 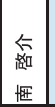 & 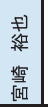 & 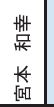 & 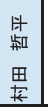 & 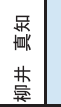 & 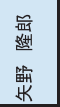 & $\begin{array}{l}\text { 昌 } \\
\text { 捛 } \\
\text { 田 }\end{array}$ & 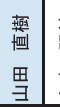 & 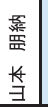 & 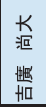 \\
\hline
\end{tabular}




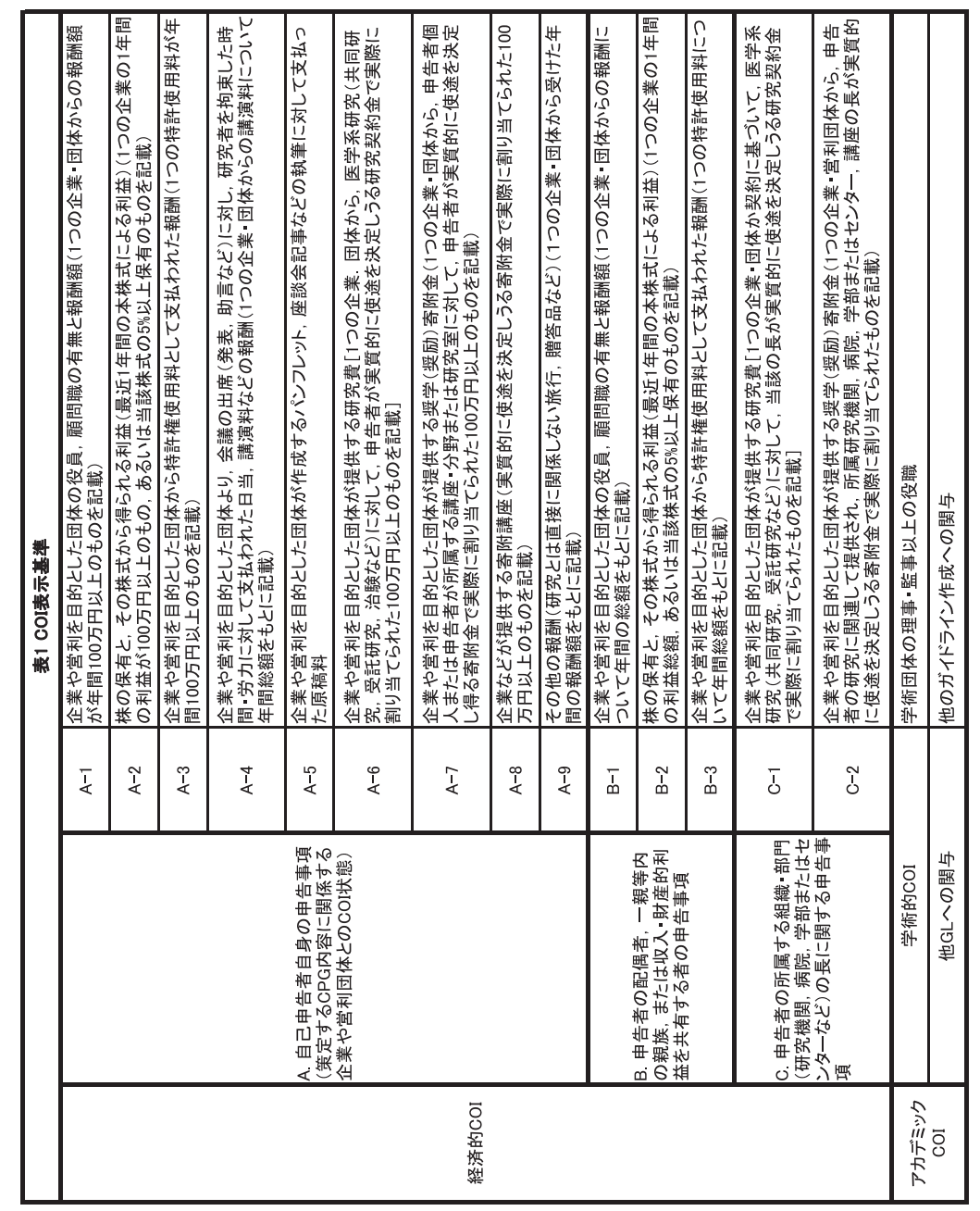

